\title{
Environmental \\ Characterization of Two \\ Potential Locations at \\ Hanford for a New \\ Production Reactor
}

September 1984

Prepared for the U.S. Department of Energy under Contract DE-AC06-76RLO 1830

Pacific Northwest Laboratory

Operated for the U.S. Department of Energy by Battelle Memorial Institute 


\title{
DISCLAIMER
}

This report was prepared as an account of work sponsored by an agency of the United States Government. Neither the United States Government nor any agency thereof, nor any of their employees, makes any warranty, express or implied, or assumes any legal liability or responsibility for the accuracy, completeness, or usefulness of any information, apparatus, product, or process disclosed, or represents that its use would not infringe privately owned rights. Reference herein to any specific commercial product, process, or service by trade name, trademark, manufacturer, or otherwise, does not necessarily constitute or imply its endorsement, recommendation, or favoring by the United States Government or any agency thereof. The views and opinions of authors expressed herein do not necessarily state or reflect those of the United States Government or any agency thereof.

\author{
PACIFIC NORTHWEST LABORATORY \\ operated by \\ BATTELLE \\ for the \\ UNITED STATES DEPARTMENT OF ENERGY \\ under Contract DE-AC06-76RLO 1830
}

\begin{tabular}{|c|c|}
\hline \multirow{2}{*}{\multicolumn{2}{|c|}{ Printed in the United States of America }} \\
\hline & \\
\hline \multicolumn{2}{|c|}{$\begin{array}{l}\text { Available from } \\
\text { National Technical Information Service }\end{array}$} \\
\hline \multicolumn{2}{|c|}{$\begin{array}{l}\text { National Technical Information Service } \\
\text { United States Department of Commerce }\end{array}$} \\
\hline \multicolumn{2}{|c|}{5285 Port Royal Road } \\
\hline \multicolumn{2}{|c|}{ Springfield, Virginia 22161} \\
\hline \multirow{2}{*}{\multicolumn{2}{|c|}{$\begin{array}{l}\text { NTIS Price Codes } \\
\text { Microfiche A01 }\end{array}$}} \\
\hline & \\
\hline \multicolumn{2}{|c|}{ Printed Copy } \\
\hline Pages & Price \\
\hline & \\
\hline $001-025$ & $\mathrm{~A} 02$ \\
\hline 026-050 & $\mathrm{A} 03$ \\
\hline $051-075$ & A04 \\
\hline $076-100$ & A05 \\
\hline $101-125$ & A06 \\
\hline $126-150$ & $\mathrm{~A} 07$ \\
\hline $151-175$ & $\mathrm{~A} 08$ \\
\hline $176-200$ & $\mathrm{~A} 09$ \\
\hline $201-225$ & A010 \\
\hline $226-250$ & A011 \\
\hline $251-275$ & A012 \\
\hline $276-300$ & A013 \\
\hline
\end{tabular}


ENYIRONMENTAL CHARACTERIZATION OF TWO POTENTIAL LOCATIONS AT HANFORD FOR A NEW PRODUCTION REACTOR
E. C. Watson
J. V. Ramsdej 1
C. D. Becker
D. G. Rice
R. E. Fitzner
D. L. Schreiber (b)
K. A. Gano
L. A. Skumatz
K. L. Imhoff
D. J. Sommer
R. F. McCa]Tum
J. J. Tawil
D. A. Myers
R. W. Wallace
T. L. Page
D. G. Watson
K. R. Price

September 1984

Prepared for

the U.S. Department of Energy

under Contract DE-AC06-76RLO 1830

Pacific Northwest Laboratory Richland, Washington 99352

(a) Oavid G. Rice Consulting Service, Seattle, Washington 98102

(b) Dr. David L. Schreiber, P.E., Schreiber Consultants, Inc., Coeur d'Alene, Idaho 83814 
CONTENTS

1.0 INTRODUCTION

2.0 GEOGRAPHY AND DEMOGRAPHY . . . . . . . . . . . . . . . 2.1

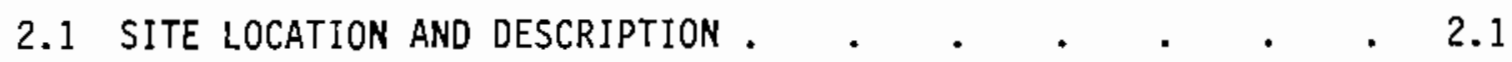

2.1 .1 Skagit/Hanford Site . . . . . . . . . 2.3

2.1 .2 Firehouse Site . . . . . . . . . 2.4

2.2 POPULATION DISTRIBUTION • . . . . . . . . . . 2.5

2.2.1 Population Within Ten Miles . . . . . . . $\quad$. 2.8

2.2.2 Population Between Ten and Fifty Miles . . . 2.10

2.2.3 Transient Population . . . . . . . . . 2.18

2.3 REFERENCES . . . . . . . . . . . . . . . 2.27

3.0 ECOLOGY

3.1 TERRESTRIAL ECOLOGY . $. \quad . \quad+\quad \cdot \quad \cdot \quad \cdot \quad \cdot \quad \cdot 3.1$

3.1.1 Plants and Habitat Description of the Skagit/Hanford Site . . . . . . . . 3.1

3.1.2 Soils of the Skagit/Hanford Site . . . . 3.3

3.1.3 Wildlife of the Skagit/Hanford Site . . . . 3.5

3.1.4 Important Species of the Skagit/Hanford Site . . 3.14

3.1.5 Unique and Sensitive Habitats of the Skagit/
Hanford Site . . . . 3.14

3.1.6 Threatened or Endangered Species of the
Skagit/Hanford Site

3.1.7 Plants and Habitat Description of the

3.1.8 Soils of the Firehouse Site . . . . . 3.16

3.1.9 Wildlife of the Firehouse Site . . . . . 3.17

3.1.10 Important Species of the Firehouse Site . . . 3.18 
3.1.11 Unique and Sensitive Habitats of the Firehouse Site . . . . . . . . . . 3.18

3.1.12 Theatened or Endangered Species of the Firehouse Site . $. \quad . \quad . \quad . \quad . \quad . \quad .3 .19$

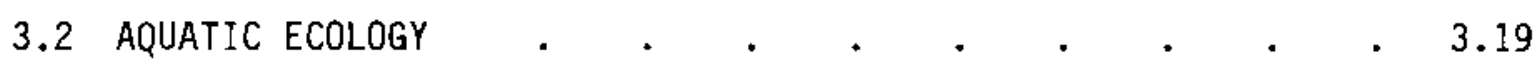

3.2.1 Habitats . . . . . . . . . . 3.19

3.2.2 Plants and Invertebrates of the Hanford Reach . . 3.23

3.2.3 Biota of Ponds and Small Streams . . . . . 3.38

3.2 .4 Fish Populations . . . . . . . . . . . 3.41

3.3 REFERENCES . . . . . . . . . . . . . 3.85

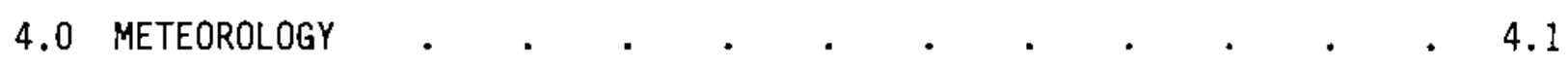

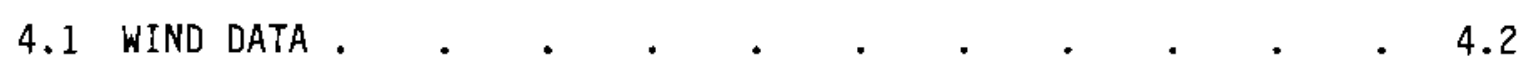

4.2 TEMPERATURE, PRECIPITATION AND HUMIDITY . . . . . . 4.4

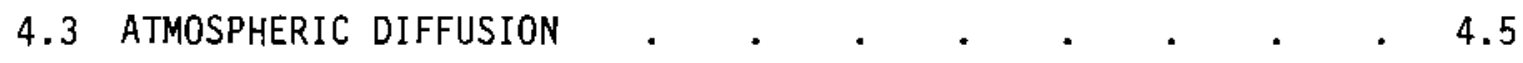

4.4 AIR QUALITY . . . . . . . . . . . . . . 4.6

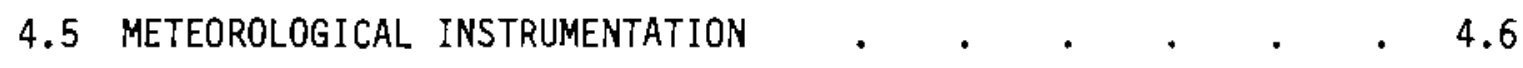

4.6 REFERENCES . . . . . . . . . . . . . . . . 4.7

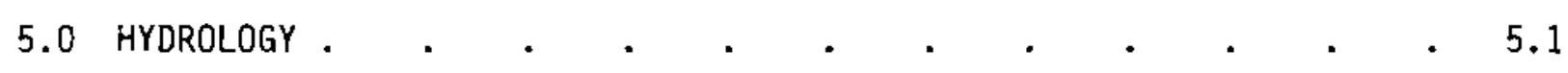

5.1 SURFACE WATER HYDROLOGY.$\quad \cdot \quad \cdot \quad \cdot \quad \cdot \quad \cdot \quad \cdot \quad \cdot 5.1$

5.1.1 Columbia River Hydrologic and Physical
Characteristics . . . . . . . . . 5.1

5.1 .2 Local Site Watershed Characteristics ..$\quad$. 5.23

5.1.3 Columbia River Quality. . . . . . . . . 5.23

5.1.4 Effluents Discharged to the Hanford. Reach of
the Columbia River . . . . . 5.44

5.2 GROUNOWATER . $. \quad . \quad . \quad . \quad . \quad . \quad . \quad . \quad . \quad 5.53$

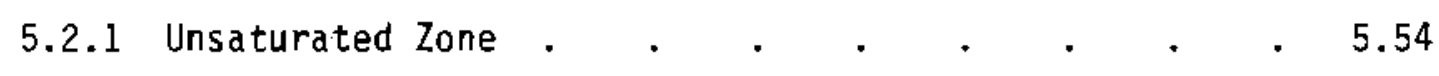

5.2 .2 Unconfined Aquifer . . . . . . . 5.58 
5.2.3 Confined Aquifers . . . . . . . . . 5.62

5.2.4 Alternate Site . . . . . . . . 5.68

5.2 .5 Groundwater Usage . . . . . . . . . . 5.68

5.2 .6 Groundwater Quality . . . . . . . 5.70

5.3 REFERENCES $\quad . \quad$. . . . . . . . . . . . 5.70

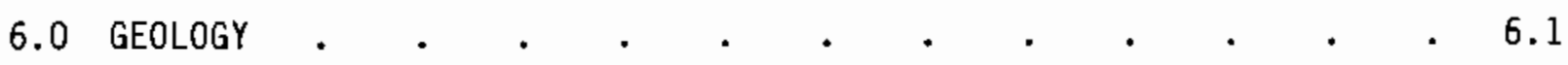

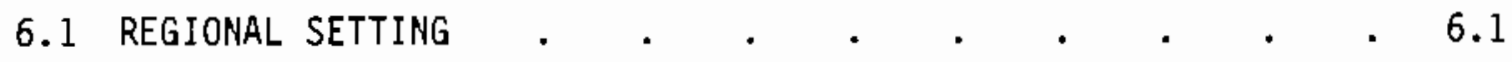

6.2 SITE TOPOGRAPHY $. \quad . \quad . \quad . \quad . \quad . \quad . \quad . \quad 6.3$

6.3 STRUCTURE . $. \quad . \quad . \quad . \quad . \quad . \quad . \quad . \quad . \quad .6 .3$

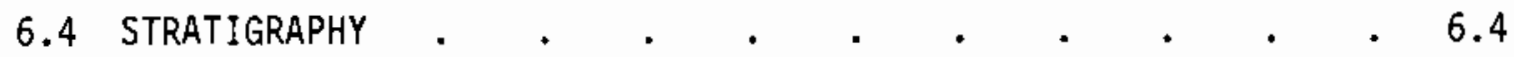

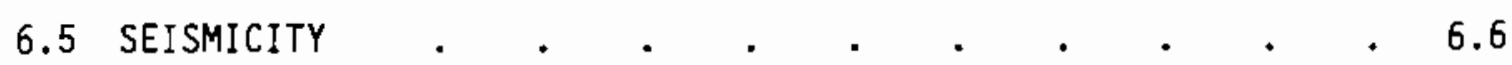

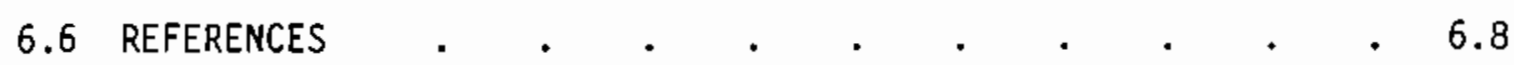

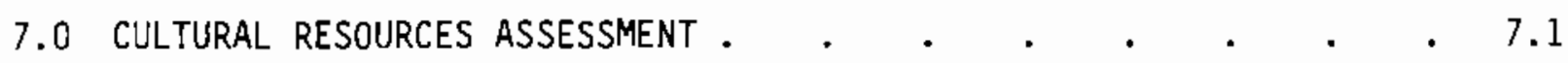

7.1 FIREHOUSE SITE . . . . . . . . . . . . . . 7.2

7.2 SKAGIT/HANFORD SITE . . . . . . . . . . . 7.5

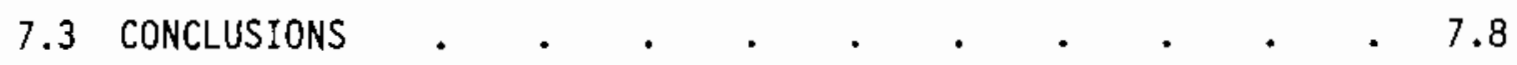

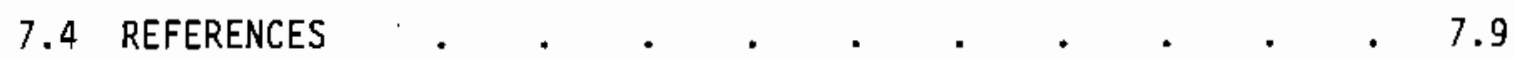

8.0 BASELINE ECONOMIC AND SOCIAL CONDITIONS FOR THE NPR
IMPACT AREA
.

8.1 HISTORICAL SOCIOECONOMIC DATA FOR THE IMPACT AREA . $\quad 8.1$

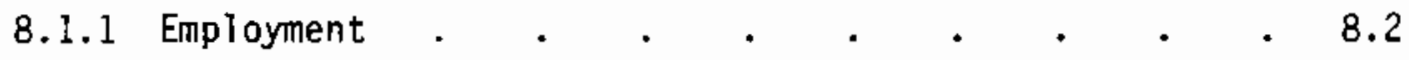

8.1.2 Labor Force Characteristics . . . . . . . . 8.8

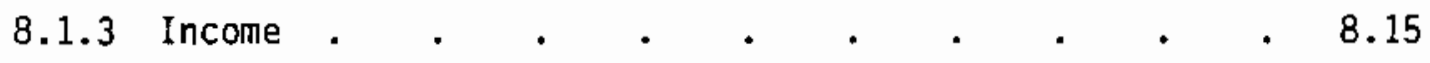

8.1 .4 Housing . $\quad . \quad$. $\quad . \quad$. . . . 8.20

8.1 .5 Education . . . . . . . . . . . 8.24

8.1.6 Public Services . . . . . . . . . 8.25

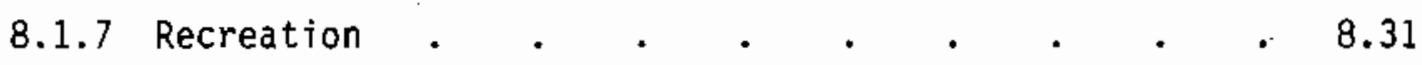


8.1.8 Transportation . . . . . . . . . 8.35

8.1 .9 Public Revenues . . . . . . . . . 8.37

8.2 ALTERNATIVE BASELINE SCENARIOS . . . . . . 8.52

8.2.1 Methodology and Assumptions . . . . . . 8.52

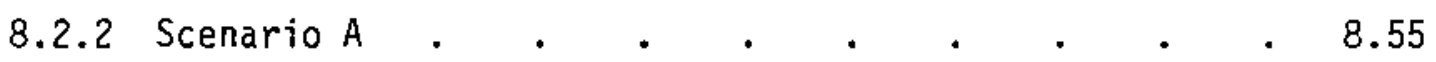

8.2 .3 Scenario B . . . . . . . . . . . 8.57

8.2 .4 Scenario C . . . . . . . . . . 8.60

8.2 .5 Scenario D $. \quad . \quad . \quad . \quad . \quad . \quad . \quad . \quad .8 .63$

8.3 REFERENCES . . . . . . . . . . . . . . 8.67

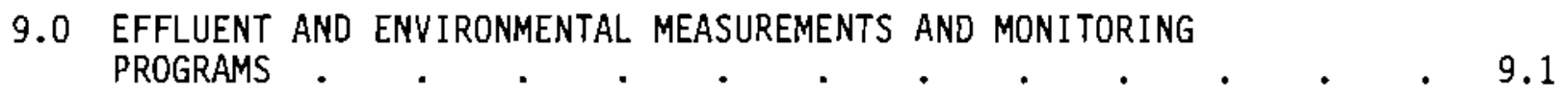

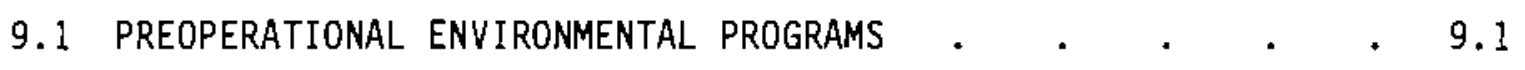

9.1 .1 Surface Water . . . . . . . . . 9.2

9.1 .2 Groundwater . . . . . . . . . 9.20

$9.1 .3 \mathrm{Air} \quad . \quad . \quad . \quad . \quad . \quad . \quad . \quad . \quad . \quad .9 .21$

9.1 .4 Land . . . . . . . . . . . . . 9.54

9.1 .5 Radiological Monitoring $\quad . \quad$. $\quad . \quad$. $\quad . \quad 9.61$

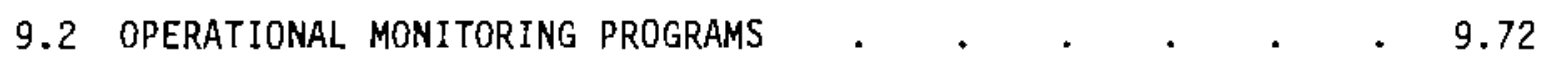

9.2.1 Radiological Monitoring . . . . . . 9.72

9.2.2 Chemical Effluent Monitoring . . . . . 9.73

9.2.3 Thermal Effluent Monitoring . . . . . $\quad 9.74$

9.2.4 Meteorological Monitoring . . . . . . . $\quad . \quad 9.75$

9.2 .5 Ecological Monitoring . . . . . . . 9.75

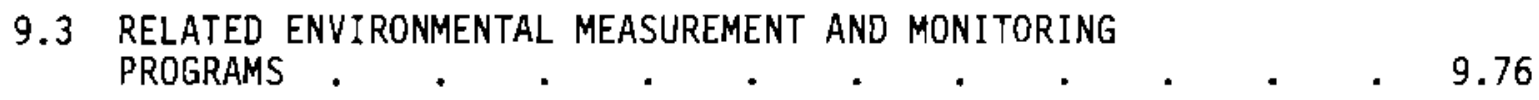

9.3.1 Hydrological and water Quality Studies in
Progress
. 
9.3.2 Ecological Parameters . . . . . . . . 9.78

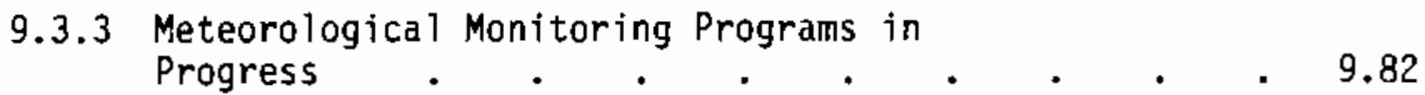

9.3.4 Radiological Studies in Progress . . . . . 9.83

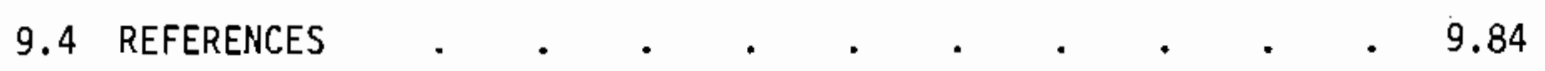

APPENDIX A - DETAILED ECOLOGICAL DATA . . . . . . . . . . A.I

APPENDIX B - WIND DATA SUMMARIES FOR THE SKAGIT/HANFORD SITE • • • B.1

APPENDIX C - MIXING LAYER THICKNESS CLIMATOLOGY FOR THE

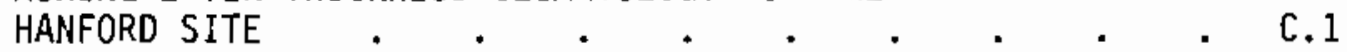

APPENDIX D - GEOTECHNICAL PROPERTIES: PARTIALLY SATURATED ZONE CHARACTERISTICS OF THE SKAGIT/HANFORD SITE . . . D.I

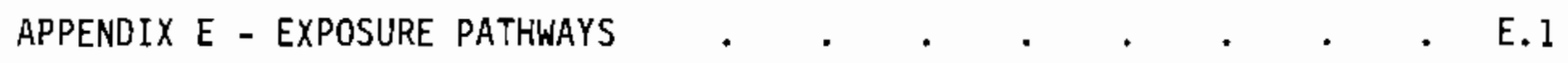

APPENDIX F - ENVIRONMENTAL PERMITS . . . . . . . . • . . F.l 



\section{FIGURES}

2.1 Location of Skagit/Hanford and Firehouse Sites Within the

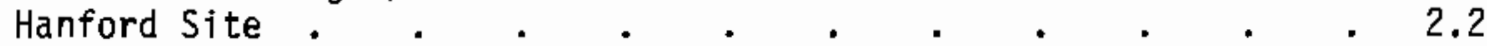

2.2 Communities Within a 50-Mile Radius of the Hanford Site a . 2.6

2.3 Population Within 10 Miles of the Skagit/Hanford Site,

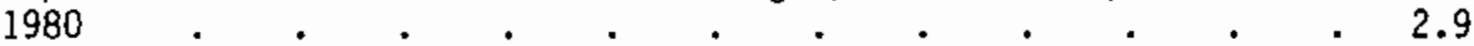

2.4 Population Within 10 Miles of the Skagit/Hanford Site, 2.11

2.5 Population Within 10 Miles of the Skagit/Hanford Site, 2000

2.6 Population Within 10 Miles of the Skagit/Hanford Site,

2.7 Population Within 10 Miles of the Skagit/Hanford Site, 2020

2.8 Population Within 10 Miles of the Skagit/Hanford Site, 2030

2.9 Population Between 10 and 50 Miles from the Skagit/Hanford

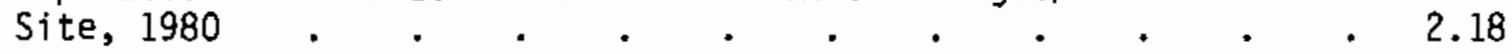

2.10 Population Between 10 and 50 Miles from the Skagit/Hanford Site, 1990

2.11 Population Between 10 and 50 Miles from the Skagit/Hanford Site, 2000

2.12 Population Between 10 and 50 Miles from the Skagit/Hanford Site, 2010

2.13 Population Between 10 and 50 Miles from the Skagit/Hanford Site, 2020

2.14 Population Between 10 and 50 Miles from the Skagit/Hanford Site, 2030

3.1 Major Vegetation Types of the Hanford Site . . . . . . . 3.2

3.2 Soil Types of the Hanford Reservation . . . . . . . . . 3.4

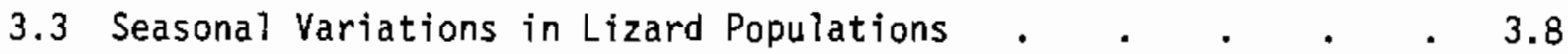

3.4 Surface water Bodies Including Ephemeral Streams on the Hanford Site 
3.5 Gable Mountain Pond . . . . . . . . . . . 3.22

3.6 B-Pond, and B-3-3 and A-29 Ditches . . . . . . . 3.23

3.7 U-Pond, and Z-19 and U-14 Ditches . . . . . . . . . 3.24

3.8 West Pond . . . . . . . . . . . . . . . . . . 3.25

3.9 Phytoplankton Densities in the Hanford Reach of the

3.10 Species Diversity Index, the Index of Relative Abundance, and Species Richness for Phytoplankton Samples at RM 352, September 1978 - March 1980 . . . . . . . . . . 3.30

3.11 ReTative Abundance of Dominant Zooplankton Specjes in the Columbia River at RM 352 . $\quad . \quad . \quad . \quad . \quad . \quad . \quad . \quad 3.34$

3.12 Columbia River Zooplankton Density, RM 352 and RM 380 . . 3.35

3.13 Seasonat Densities of Columbia River Macrobenthic Fauna . . . . . . . . . . . . . 3.37

3.14 Food Web of Gable Mountain Pond and U-Pond . . . . . 3.39

3.15 Seasonal Gross and Net Primary Producitivity and Respiration Rates for Rattlesnake Springs . . . . . . 3.41

3.16 Timing of Salmonid Migrations Near the Hanford Site Columbia River . . . . . . . . . . . . . 3.44

\begin{tabular}{l}
3.17 Hanford Reach Fall Chinook Salmon Redd Observations, \\
1947 Through 1979 . \\
\hline
\end{tabular}

3.18 Fall Chinook Salmon Spawning Areas Within the Hanford
Reach . . . . . . . . . 3.51

5.1 Columbia River Drainage Basin and Major Dams $\quad$ • $\quad$ • $\quad$ • 5.2

5.2 Schematic Representation of the Hydraulic Regime of the Columbia River Showing Major Dams . $\quad$ • $\quad$. $\quad$. 5.5

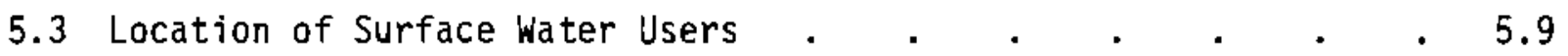

5.4 Adjusted Average Monthly Flow Below Priest Rapids Dam . . . 5.13

5.5 Adjusted Monthly and Annual Flow Duration Below Priest
Rapids Dam .. .5.
.

5.6 Flow Frequency Below Priest Rapids Dam . . . . . . . 5.15 
5.7 Flood Frequency Curves for the Columbia River at Trinidad • • 5.20

5.8 Water Elevation in Columbia River at River Mile 361.5 . . . 5.21

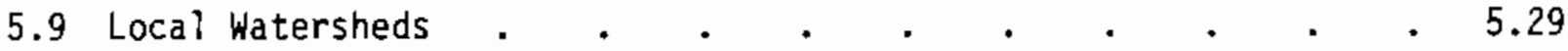

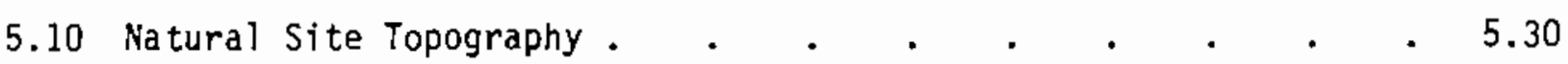

5.11 Skagit/Hanford Nuclear Project Watershed . . . . . . 5.31

5.12 Pasco Basin Location Map $\quad . \quad$. $\quad . \quad$. $\quad . \quad$. . . 5.54

5.13 Selected Hanford Well Locations . . . . . . . . . 5.56

5.14 Generalized Geological and Geohydrologic Column . . . . 5.57

5.15 Water Table Map for the Hanford Reservation for 1980 • • $\quad 5.63$

5.16 Water Table Map for the Hanford Reservation for 1978 . $\quad$. 5.64

5.17 Water Table Map for the Hanford Reservation for 1973 • • 5.65

5.18 Water Table Map for the Hanford Reservation for 1968 . . 5.66

5.19 Water Table Map for the Hanford Reservation for 1944 • • • 5.67

5.20 Uppermost Confined Aquifer Potential Map . . . . . . . 5.69

5.21 Nitrate Ion Distribution in Unconfined Ground Water . 5.71

5.22 Tritium Distribution in Unconfined Ground Water . . . . 5.72

6.1 Principal Physiographic Elements of the Pacific Northwest . . 6.2

6.2 Late Cenozoic Stratigraphy of the Coiumbia Plateau $\quad$ • $\quad$ • $\quad 6.5$

7.1 01d Indian Trail Passing Through the Firehouse Site . . . 7.3

\begin{tabular}{l}
7.2 Relationship of Firehouse Site to Identified Cultural \\
Resources \\
\hline
\end{tabular}

7.3 Relationship of Skagit/Hanford Site to Identified Cultural
Resources

7.4 Survey Units Selected and Walked by ERTEC Northwest in
Late 1981 Using 50 -foot Interval Transects

7.5 Significant Cultural Resources in the Skagit/Hanford Site
Vicinity...
.

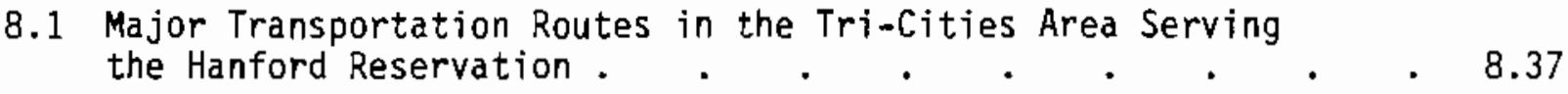


9.1 Location of Water Quality Sampling Stations in the Preoperational Monitoring Program . . . . . . . . . $\quad .9 .7$

9.2 Aquatic Biological Sampling Stations for the Preoperational Monitoring Program . . . . . . . . 9.17

9.3 Annual Chi/Q at Site Boundary . . . . . . . 9.41

9.4 Site Annual $\mathrm{Chi} / \mathrm{Q}$ at $3.2 \mathrm{~km}(2 \mathrm{mi})$. . . . . . 9.50

9.5 Plant Boundary Monitoring Locations . . . . . . 9.65

9.6 Monitoring Locations Beyond the Site Boundary . . . . $\quad$. 9.67 
TABLES

2.1 Historical Population Estimates for the Tri-Cities SMSA, 1970-1982

2.2 Age Distribution for the Tri-Cities SMSA, 1970 and 1980 . . 2.8

2.3 Distribution of 1980 Population Within a 50-Mile Radius of the Firehouse Site . . . . . . . . . 2.16

2.4 Projected 1990 Population Distribution Within a 50-Mile Radius of the Firehouse Site . . . . . . . 2.24

2.5 Transient Population Within 10 Miles of the Skagit/

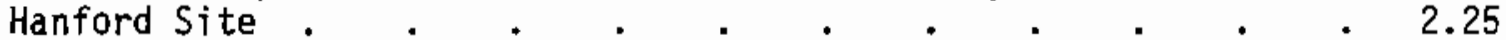

3.1 Relative Abundance (Percent) of Insect Taxa Collected from Sagebrush, Rabbitbrush, and Hopsage $\quad$. $\quad . \quad$. 3.6

3.2 Amphibian and Reptile Species Observed on the Hanford

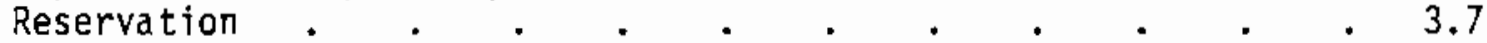

3.3 Mammals of the Hanford Reservation . . . . . . . . . 3.9

3.4 Percentage Composition of Small Mammal Population Inhabiting Conmon Habitat Types of the Hanford Site

3.5 Botanical Composition of Fecal Pellets Collected from Mule Deer During 1976 from Three Habitats on the Hanford Site. . . . . . . . . . . 3.12

3.6 Animal Species of Concern for Washington State . . . . 3.16

3.7 Species Composition, Canopy-Cover and Frequency of Vascular Plants on Gently Undulating Topography Typical of Firehouse Site $. \quad . \quad . \quad . \quad . \quad . \quad . \quad . \quad 3.17$

3.8 Physical and Chemical Characteristics of Ponds on the Hanford Site. . . . . . . . . . . 3.21

3.9 Macrophytes Identified in the Hanford Reach, Columbia River

3.10 Fish Species Designated as Important for the Hanford Reach, Columbia River

3.11 Median (Peak) Outmigration Dates for Juvenile Salmon Passing Priest Rapids Dam 
3.12 Annual Estimates of Adult Fall Chinook Using the Hanford

3.13 Calculation of Average Fall Chinook Interdam Population and Estimate of the Number of Fish Utilizing Hanford Reach 1962-1980

3.14 Fall Chinook Salmon Redd Distribution in the Hanford Reach by Spawning Area, 1947 Through 1982

3.15 Relative Utilization of Major Fall Chinook Spawning Grounds in the Hanford Reach.

3.16 Adult Salmon Counts at the Priest Rapids Dam Fishway . . . 3.63

5.1 Location of Significant Structures and Landmarks on the Columbia River. . 5.3

5.2 Surface Water Rights Claims 50 Miles Downstream from Skagit/Hanford Site

5.3 Surface Water Permits 50 Miles Downstream from Skagit/ Hanford Site.

5.4 Surface Water Applications as of May 18, 1981 . $\quad . \quad . \quad .5 .8$

5.5 Historical Discharge Data . . . . . . . . . 5.11

5.6 Surmary of Historical Flow Data (1929-1968) for the Columbia River Dam Adjusted to the 1980 Level of Irrigation Depletion and Dam Regulation

5.7 Dependable Yield for Columbia River Below Priest Rapids Dam . . . . . . . . . . . . 5.16

5.8 Low Flow Data for Columbia River Below Priest Rapids Dam .

5.9 Low Flow Recurrence Intervals for the Columbia River Below Priest Rapids Dam .

5.10 Particle-Size Distribution of Undispersed and Dispersed Sediments from Columbia River Size Classes. . . . . 5.24

5.11 Mineral Composition of Bottom Sediments from Columbia
River Reservoirs

5.12 Chemical Composition of Bottom Sediments from Columbia River Reservoirs 
5.13 Cation-Exchange Capacities (in milliequivalent per 100 grams) of Sized Sediments from Columbia River and Tributary Locations

5.14 Washington State Water Quality Standards for the Hanford Reach of the Columbia River . . . . . . . 5.32

5.15 Columbia River Water Quality ..$\quad$. . . . . . . . 5.33

5.16 Monthly Average Values of Dissolved Oxygen (mg/l) at Vernita Bridge and at 300 Area/Richland . . . . 5.36

5.17 Monthiy Numerical Average Vaiues of pH at Vernita Bridge and at 300 Area/Richland

5.18 Monthly Average Values of Turbidity (NTU) at Vernita Bridge and at 300 Area/Richland

5.19 Mean and Extreme Concentrations of Metals and Other Water Quality Parameters Measured at Vernita Bridge and Richland During Water Years 1979-1980

5.20 Seasonal Changes in the Concentration of Particulate Matter $\left(<53_{\mu}\right)$ in River Water . . . . . . . 5.43

5.21 Seasonal Changes in the Size Distribution of Particulate Matter Isolated from River Water . . . . . . . 5.43

5.22 Seasonal Changes in the Carbon Content of Particulate Matter $(<53 \mu)$ Isolated from River Water . . . . 5.44

5.23 Relative Abundance of Minerals in Size Fractions of Suspended Particulate Matter Isolated from River Water . $\quad 5.45$

5.24 Monthly Average Water Temperature in ${ }^{\circ} \mathrm{C}$ at Vernita Bridge, Washington . $. \quad . \quad . \quad . \quad . \quad . \quad 5.46$

5.25 Monthly Average Water Temperature in ${ }^{\circ} \mathrm{C}$ at Richland, Washington

5.26 Oischarge Lines to Columbia River from Hanford Reservation . . . . . . . . . . . . . . 5.48

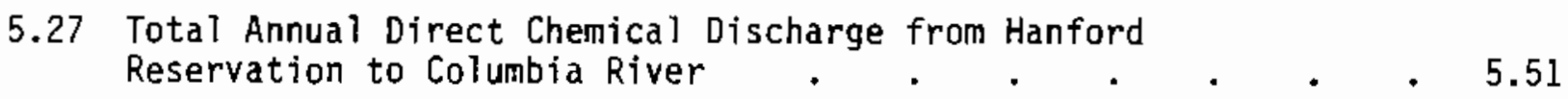

5.28 Summary of NPOES Monitoring Report Data from 100-N and $100-K$ Areas

5.29 Low-Volume Waste Sampled at the Hanford Generating Project (March 1980 - February 1981) 
5.30 Major Geologic Units in the Hanford Region and Their Hydrologic Character . . . . . . . . 5.55

5.31 Results of Pumping Tests Completed Within the Unconfined Aquifer . . . . . . . . . . . . 5.59

5.32 Representative Hydraulic Properties of the Unconfined Aquifer . . . . . . . . . . . 5.60

8.1 Employment by Type and Broad Industriat Categories for the Tri-Cities SMSA, 1969-1981 . . . . . . . 8.3

8.2 Calculated Average Annual Growth in Employment: Tri-Cities

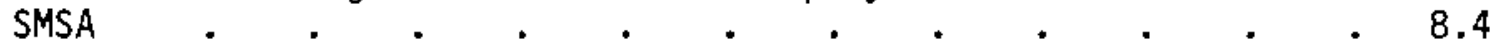

8.3 Irrigated Acreage in Benton and Franklin Counties, 1969-1982

8.4 Tri-Cities DOE and Supply System Employment, 1973-1982 • • 8.5

8.5 Resident Civilian Labor Force by Age, Sex, and Race for Benton, Franklin, and Walla Walla Counties. . . . . 8.9

8.6 Total Tri-Cities Civilian Labor Force Unemployment, 1973-1982

8.7 Applicants and Job Openings for Selected 0ccupations in the Tri-Cities Job Service Centers . . . . . 8.12

8.8 Applicants and Job Openings for Selected Occupations in Walla Walla Job Service Center . . . . . . . 8.13

8.9 Seasonality of Employment: Covered Agriculture in Benton and Franklin Counties, 1979-1981 . . . . . . . 8.16

8.10 Total Labor and Proprietors Personal Income by Major Source for the Tri-Cities SMSA . . . . . . 8.17

8.11 Calculated Growth in Income: Tri-Cities SMSA . . . . 8.18

8.12 Number of Housing Units for Benton and Frankl in Counties, $1970-1982$

8.13 Number of Housing Units in Richland, Kennewick, and Pasco, $1975-1982$

8.14 Vacancy Rates for the Tri-Cities, 1975-1983 . . . . . 8.23

8.15 Public School Enrollment in the Tri-Cities SMSA, 1970-1983 . . 8.24 
8.16 Enrollments and Capacities of School Districts in the

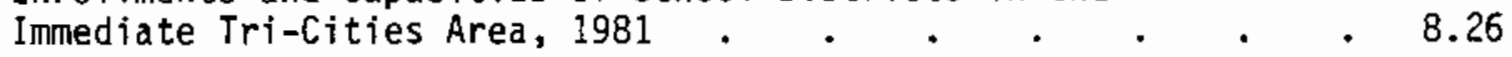

8.17 School District Expenditures in Benton and Franklin

Counties, 1970 to 1981 . $. \quad . \quad . \quad . \quad . \quad . \quad . \quad .8 .26$

8.18 Police Personnet in the Tri-Cities Area, 1981 . . . . 8.28

8.19 Type and Number of Crimes in the Tri-Cities SMSA, 1980 . $\quad 8.29$

8.2D Fire Protection Personnel Within the Tri-Cities Area, 1981 . 8.30

8.21 Examples of Human Services Facilities and Organizations in
the Tri-Cities SMSA . . . . . . . 8.32

8.22 Washington State Register of Historic Places in Counties Adjacent to the Hanford Site. . . . . . . . 8.33

8.23 Examples of Physical Recreational Facilities Available in 8.34 the Tri-Cities Area . . . . . . . . . . 8.34

8.24 Estimated Revenues and Expenditures, All Funds 1983 Budget for Tri-Cities Dollars and Percent of Total Receipts and Expenditures. . . . . . . . . . . . 8.38

8.25 Tri-Cities Police and Fire Protection, 1978 and 1983 . . . 8.40

8.26 City of Richland General Fund Revenues and Expenditures . 8.41

8.27 City of Kennewick, Current Fund Revenues and Expenditures . $\quad 8.42$

8.28 City of Pasco, General Fund Revenues and Expenditures . . . 8.43

8.29 Per Capita Revenue for the Tri-Cities, 1975-1981 . . . . 8.45

8.30 Revenue Source Share: 1975-1981, Richland, Pasco, . . . . . 8.48
Kennewick . . . . . . . . . . .

8.31 County Budgets: Benton and Franklin Counties, Current $\quad 8.49$

B.32 Per Capita Revenue for Benton/Franklin Counties, 1975-1981 . $\quad 8.50$

8.33 Benton/Franklin County Revenue Source Shares, 1975-1981 • . 8.51

8.34 Projected Primary and Secondary Employment in Benton and
FrankT in Counties: $1981-1985$. . . . . . 8.54

8.35 Baseline Employment and Population Using Scenario A, . . . 8.56
$1985-2010 .+$. 
8.36 Baseline Employment and Population Using Scenario B, $1985-2010$. . . . . . . . . . 8.59

8.37 Baseline Employment and Population Using Scenario C, 1985-2010

8.38 DOE EmpToyment for Scenario C, $1985-2010$. $\quad$. . . . $\quad$. 8.62

8.39 Baseline Employment and Population Using Scenario D, $1985-2010$

8.40 DOE Employment for Scenario D, 1985-2010 . . . . . . 8.66

9.1 Water Quality Sampling Stations for Site Preparation and Construction Monitoring Program . . . . . . . . . . 9.6

9.2 Analytical Methods and Levels of Detection for Water Characteristics to be Measured During the Construction

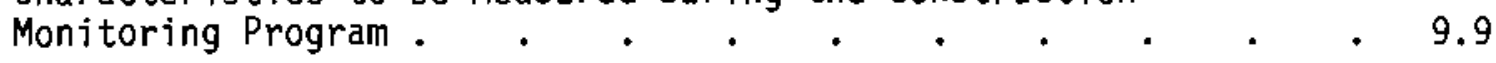

9.3 Analytical Methods, Detection Limits, and Preservation Techniques for the Water Quality Parameters to be Surveyed in the Preoperational Monitoring Program . . . 9.11

9.4 Water Quality Sampling Stations for the Preoperational Monitoring Program . . . . . . . . . . 9.12

9.5 Benthic Invertebrate Sampling Stations for the Preoperational Monitoring Program . . . . . . . . . . 9.19

9.6 Proposed Fish Sampling Frequency, by Station and Method, for the Preoperational Monitoring Program . . . . . . 9.20

9.7 Annual Distribution of Variable Winds . . . . . . . 9.25

9.8 Realistic Short-Term Chi/Qs by Sector for the Facility at the Exclusion Area Boundary and the Low Population Zone Boundary. . . . . . . . . . . . 9.29

9.9 Realistic Short-Term Accident Chi/Qs by Sector for Facility at Standard Distances . . . . . . . . 9.30

9.10 Annual Average Atmospheric Disperson and Deposition Parameters for NPR . . . . . . . . . . . 9.42

9.11 Annual Average Atmospheric Dispersion and Deposition
Parameters for the Facility. . . . . 9.44

9.12 Annual Average Atmospheric Dispersion Parameters and
Deposition Estimates at Selected Locations . . . . 9.45 
9.13 Annual Average Disperson Parameters and Deposition Estimates at Standard Distances for the Facility.

9.14 Summary of Procedures for Monitoring Wildiife Occurrence at the 01d Hanford Townsite . . . . . . . . 9.60

9.15 Radiological Environmental Monitoring Program . . . . 9.62

9.16 Maximum Value for the Lower Limit of Detection (LLD) . . . 9.64 



\section{ENVIRONMENTAL CHARACTERIZATION OF TWO POTENTIAL LOCATIONS AT HANFORD FOR A NEW PRODUCTION REACTOR}

\subsection{INTRODUCTION}

This report describes various environmental aspects of two areas on the Hanford Site that are potential locations for a New Production Reactor (NPR). The area known as the Skagit Hanford Site is considered the primary or reference site. The second area, termed the Firehouse Site, is considered the al ternate site.

The scope of this report encompasses an environmental characterization of these two potential NPR locations. It does not include an assessment of impacts of locating an NPR at either area. The information contained in this report witl likely be used, along with similar data being developed for the Idaho Falls and Savannah River sites, in a follow-on study evaluating the siting of various reactor types at each of the three government reservations (Hanford, Idaho Falis, and Savannah River).

The body of this environmental characterization report covers eight subject areas, each in a separate chapter:

- geography and demography

- ecology

- meteorology

- hydrology

- geology

- cultural resources assessment

- economic and social effects of station construction and operation

- environmental monitoring.

Each chapter addresses both the Skagit/Hanford and Firehouse sites, where appropriate (i.e., environmental monitoring is a Hanford Site-wide activity and would not necessarily differ significantly between the two Tocations). In 
addition, to the degree possible, the most recent information available on the various environmental aspects is presented. References are listed at the end of each chapter. (a)

In addition, two documents are referred to throughout this report. These had been prepared to support a license application (later withdrawn) by Puget Sound Power \& Light Company for construction of two commercial reactors at Hanford:

- Puget Sound Power \& Light Company. 1981. Skagit/Hanford Units 1 and 2, Application for Site Certification/Environmental Report. Docket Nos. 50-522 and STN 50-523, Seattle, Washington.

- U.S. Nuclear Regulatory Conanission and Washington State Energy Facility Site Evaluation Counci1. 1982. Draft Environmental Statement Related to the Construction of Skagit/Hanford Nuclear Project, Units 1 and 2. NUREG/0894, Washington, D.C. Various appendixes are also included in this environmental characterization report. The material provides extensive supplemental information likely to be useful in the follow-on site characterization study.

(a) In some cases a copy of the reference document has been included when it was more efficient to do so than to incorporate the information contained in the reference in the text of the chapter. 


\subsection{GEOGRAPHY AND DEMOGRAPHY}

In this chapter, geographic and demographic characteristics of the reference Skagit/Hanford Site and the alternate Firehouse Site are described.

\subsection{SITE LOCATION AND DESCRIPTION}

Both the Skagit/Hanford and the Firehouse sites are located on the U.S. Department of Energy's (DOE) Hanford Site, as shown in Figure 2.1. The Hanford Site is situated within the semiarid Pasco Basin, which makes up part of the Columbia Plateau in southeastern Washington State. The site occupies an area of about $1,480 \mathrm{~km}^{2}\left(570 \mathrm{mi}^{2}\right)$ and is approximately $48 \mathrm{~km}(30 \mathrm{mi})$ north to south and $38 \mathrm{~km}(24 \mathrm{mi})$ east to west. The Hanford Site overlies the structural low point of the Pasco Basin and is bounded to the southwest, west, and north by large ridges that trend eastward and southeasterly from the Cascade Range, enter the Pasco Basin and die out within its confines. The site is bounded to the north and east by the Columbia River and the steep bluffs of the Ringold Formation. The Yakima River flows near the southern boundary of the site.

A thin mantle of wind-blown silts and sands covering layers of coarse sands and gravels constitutes the Hanford Formation underlying the site. The Hanford Formation, which is up to $60 \mathrm{~m}(200 \mathrm{ft})$ thick, resulted from catastrophic floods (Tallman et al. 1979) that occurred during the last ice age (Pleistocene). Sands, silts, and gravels of the Ringold Formation lying beneath the Hanford Formation gravels were deposited up to $300 \mathrm{~m}(1000 \mathrm{ft})$ thick during the Pleistocene. Beneath these younger sediments lies an accumulation of basaltic lava of the Columbia River basalt group that extruded over periods extending from 6 to 16 million years ago. Borehold measurements indicate the total basaltic lava accumulation beneath the Hanford Site is greater than $3,650 \mathrm{~m}(12,000 \mathrm{ft})$ thick (U.S. DOE 1982b).

On the Hanford Site, principal DOE operational areas are identified by area numbers; access to these areas is controlled and 1 imited (U.S. DOE 1982a). The five major areas are as follows: 


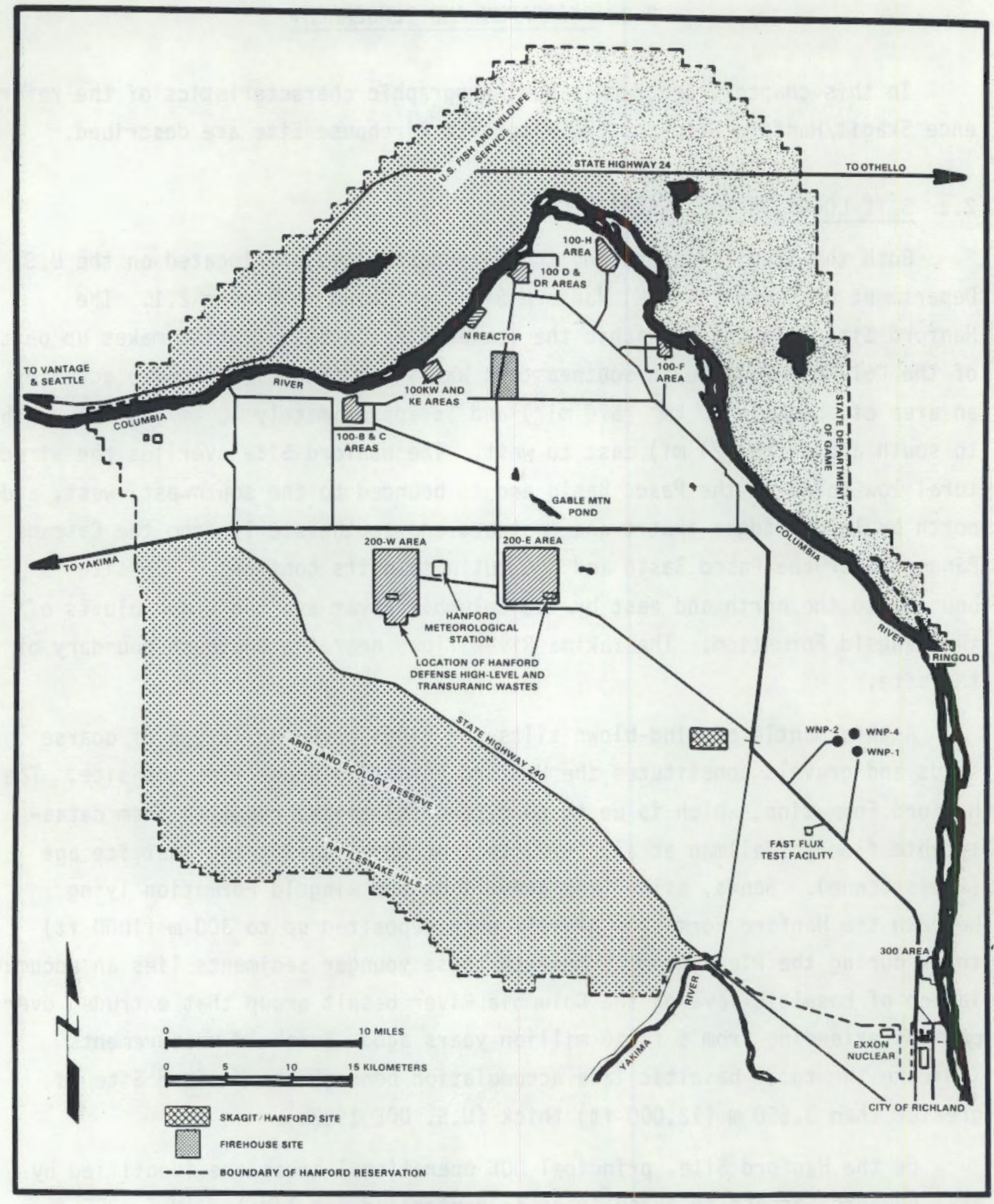

FIGURE 2.1. Location of Skagit/Hanford and Firehouse Sites Within the Hanford Site 
- The 100 Areas, bordered to the north by the south shore of the Columbia River, house eight nonoperating plutonium production reactors and one operating dual-purpose (electrical power generation and plutonium production) reactor. The 100 Areas occupy about 1,090 ha $(2,690$ acres $)$.

- The 200 Areas, located on a plateau about $11 \mathrm{~km}$ (7 mi) from the Columbia River, are the sites of fuel reprocessing as well as waste processing and management facilities. The 200 Areas cover about 1,560 ha $(3,860$ acres $)$.

- The 300 Area, located $9 \mathrm{~km}$ (6 mi) north of the City of Richland, is the site of nuclear research and development and fuel fabrication. The 300 Area covers 152 ha (375 acres).

- The 400 Area is about $11 \mathrm{~km}$ (7 mi) north of the 300 Area and is the site of the Fast Flux Test Facility used in the testing of breeder reactor systems.

- The 600 Area includes all of the Hanford Site not occupied by the $100,200,300$, or 400 areas. The 600 Area covers 145,000 ha (358,000 acres). Both the Skagit/Hanford and the Firehouse Sites are located within the 600 Areas.

Land use in areas surrounding the Hanford Site includes urban and industrial development, irrigated and dry-land farming, and grazing. Principal agricultural crops include hay, wheat, potatoes, corn, apples, soft fruit, hops, grapes, and vegetables. In recent years wine grapes have gained in importance. Industries in the nearby Tri-Cities are mainly those related to agriculture and energy production.

\section{1 .1 Skagit/Hanford Site}

The reference Skagit/Hanford Site is the location of the now abandoned Puget Sound Power \& Light Company (PSP\&L) Skagit/Hanford Nuclear Project $(S / H N P)$. Because the S/HNP envisioned twin reactors, the location of the NPR was taken to be the midpoint between the two reactors. Coordinates of that portion are: 


\begin{tabular}{|c|c|c|}
\hline $\begin{array}{l}\text { Latitude } \\
\text { and } \\
\text { Longitude } \\
\end{array}$ & $\begin{array}{l}\text { Universal } \\
\text { Transverse } \\
\text { Mercator } \\
\end{array}$ & $\begin{array}{c}\text { Lambert Coordinates } \\
\text { (State of Washington) } \\
\text { (ft) }\end{array}$ \\
\hline $\mathrm{N} 46^{\circ} 29^{\prime} 15^{\prime \prime}$ & N5150900M & N422710 \\
\hline W119 $25^{\prime} 57^{\prime \prime}$ & E313300 M & E2268840 \\
\hline
\end{tabular}

The Skagit/Hanford Site is legally described as Section 33, the south half of Section 28, the west quarter of Section 34, and the west half of the southwest quarter of Section 27, all within Township 12N, Range 27E, Benton County. The site is approximately $8 \mathrm{~km}(5 \mathrm{mi})$ west of the Washington Public Power Supply System's Nuclear Project No. 2 Unit. It is approximately $13 \mathrm{~km}$ ( $8 \mathrm{mi}$ ) west of the Columbia River at River Mile $352,11 \mathrm{~km}(7 \mathrm{mi})$ north of the Yakima River Horn Rapids Dam, and $19 \mathrm{~km}$ (12 mi) northwest of the City of Richland.

The Skagit/Hanford Site grade level varies between approximately $158 \mathrm{~m}$ $(520 \mathrm{ft})$ and $165 \mathrm{~m}(540 \mathrm{ft})$ above mean sea level. This site has no major features; further, no public roads or railroads cross the site. The total area of the site is roughly $3.2 \mathrm{~km}^{2}\left(2.0 \mathrm{mi}^{2}\right)$.

Additional information on the Skagit/Hanford Site can be found in Section 4.2 of the draft environmental statement on the S/HNP (U.S. NRC 1982) and in Section 2.1.1 of the application for site certification/environmental report for the S/HNP (PSP\&L 1981).

\subsubsection{Firehouse Site}

The alternative location for the NPR is the Firehouse Site, so-named because of the firehouse situated in the southwestern corner that serves the northern part of the Hanford Site.

A specific detailed survey to locate the midpoint of this site has not been performed. However, the approximate coordinates are $\mathrm{N}^{\circ} 6^{\circ} 36^{\prime}$ (1atitude) and $1119^{\circ} 33^{\prime}$ (1ongitude). The legal description of the site is Section 3 within Township 13N, Range 26E, Benton County, and Section 34, Township 14N, Range 26, Benton County.

The site is bordered on the south by Route 1, and Route $4 \mathrm{~N}$ passes from the southwestern corner through the northern border in a north-northeasterly 
direction. The site is located approximately $4.8 \mathrm{~km}(3 \mathrm{mi})$ south of the Columbia River at River Mile $380,4.8 \mathrm{~km}(3 \mathrm{mi})$ west of the White Bluffs Townsite, and $14 \mathrm{~km}(9 \mathrm{mi})$ northwest of the Hanford Townsite.

The Firehouse Site grade level varies between $158 \mathrm{~km}(520 \mathrm{ft})$ and $134 \mathrm{~km}$ (440 ft) above mean sea level; the terrain is gently sloping in a north-south direction. There are no major features on the site, although the Hanford Ditch (a canal constructed to provide irrigation water for orchards in and around the White Bluffs Townsite) cuts through the northwest corner. No public roads or railroads cross the site. The area of the Firehouse site is $3.2 \mathrm{~km}^{2}\left(20 \mathrm{mi}^{2}\right)$.

\subsection{POPULATION DISTRIBUTION}

The major population centers within a 50-mile radius of the Hanford Site are shown in Figure 2.2. The Tri-Cites area of Richland, Kennewick, Pasco, and West Richland lies southeast of Hanford and is both the largest population center and the center nearest to the site. Other major population centers include Yakima and the Yakima Valley towns to the west, Umatilla to the south, and Moses Lake to the north. The cities of Ellensburg and Walla Walla lie just beyond the 50-mile radius. Portions of Adams, Benton, Franklin, Grant, Kittitas, Walla Walla, Yakima, Morrow, and Umatilla Counties are contained within 50 miles of the Hanford Site. Both the primary and second NPR sites are indicated in Figure 2.2.

Because of the highly developed transportation network between the TriCities and the Hanford Site, the Tri-Cities Standard Metropolitan Statistical Area (SMSA) is the area most likely to exhibit population impacts for both the primary and secondary NPR sites. Historical population figures for the TriCities SMSA, which consists of Benton and Franklin Counties, are presented in Table 2.1. Population in the area grew 54.8 percent between the 1970 and 1980 census years, and growth continued through 1981. In 1982 the population declined, following the end of several thousand construction jobs at the WPPSS plants. During the period shown in Table 2.1, most of the population growth occurred in Benton County, with the population of the City of Kennewick more 


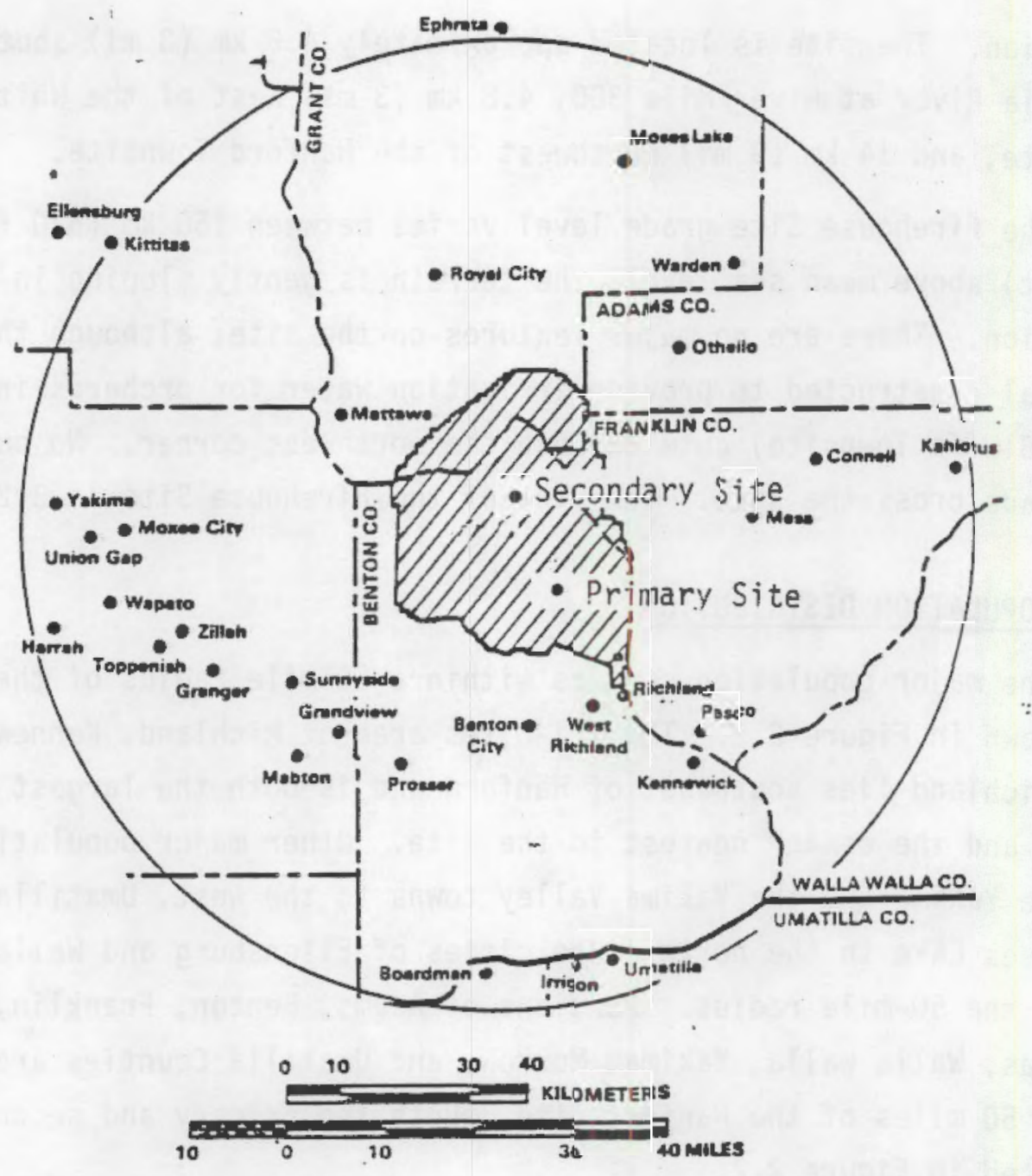

FIGURE 2.2. Communities Within a 50-Mile Radius of the Hanford Site 
TABLE 2.1. Historical Population Estimates for the Tri-Cities SMSA, 1970-1982 (a)

\begin{tabular}{|c|c|c|c|c|c|c|c|c|c|c|c|c|c|}
\hline & 1970 & 1971 & 1972 & 1973 & 1974 & 1975 & 1976 & 1977 & 1978 & 1979 & 1980 & 1981 & 1982 \\
\hline Tri-Cities SMSA & 93,356 & 93,499 & 93,722 & 95,289 & 99,319 & 104,922 & 114,040 & 120,169 & 130,805 & 139,203 & 144,469 & 148,260 & 143,910 \\
\hline Benton County & 67,540 & 67,069 & 67,214 & 64 & 350 & 054 & 341 & 65 & 238 & 104,941 & 109,444 & 112,010 & 72 \\
\hline Kennewick & 15,212 & 15,400 & 15,580 & 16,200 & 16,800 & 18,253 & 21,301 & 23,638 & 26,564 & 29,810 & 34,397 & 34,700 & 35,35 \\
\hline Prosser & 2,954 & 2,975 & 2,990 & 3,050 & 3,100 & 3,104 & 3,150 & 3,335 & 3,400 & 3,788 & 4,049 & 4,120 & 4,17 \\
\hline West Richl and & 1,143 & 1,143 & 1,159 & 1,225 & 1,247 & 1,477 & 1,561 & 2,024 & 2,311 & 2,641 & 2,938 & 3,783 & 3,93 \\
\hline Frankl in County & 25,816 & 26,430 & 26,508 & 27,025 & 27,469 & 27,868 & 29,699 & 29,804 & 32,567 & 34,262 & 35,025 & 36,250 . & 35,18 \\
\hline Pasco & 13,920 & 13,920 & 14,000 & 14,050 & 14,100 & 14,450 & 14,618 & 15,375 & 16,000 & 16,370 & 18,425 & 18,700 & 19,050 \\
\hline
\end{tabular}

(a) The use of HARC data for intercensual figures is necessary for consistency with mandated scenarios. Intercensual estimates are also available from the Washington State Office of Financial Management (1980).

Source: Bureau of the Census $(1972,1982)$ for 1970 and 1980.

Battelle, Human Affairs Research Centers for other years. 
than doubling for the period. Franklin County had slower, but steady, growth during the 1970 to 1981 period, and, like Benton County, exhibited a slight decline in population in 1982.

Table 2.2 gives the age distribution for the Tri-Cities SMSA for the census years 1970 and 1980. The most significant changes over the period are the decrease in the number of school-aged children and the increase in adults between 25 and 34 years old as percentages of total population. The increase in the adults was probably tied to the construction job activity that occurred at Hanford in the 1970s.

TABLE 2.2. Age Distribution for the Tri-Cites SMSA, 1970 and 1980 (percent of total population)

\begin{tabular}{llll} 
Age Range & $\underline{1970}$ & $\underline{1980}$ \\
\hline 0 to 14 years & 31 & 26 \\
15 to 24 years & 18 & 18 \\
25 to 34 years & 12 & 19 \\
35 to 44 years & 12 & 12 \\
45 to 54 years & 12 & 10 \\
55 to 64 years & 9 & 8 \\
65 to 74 years & 2 & 5 \\
75 years and over & 2 & 2
\end{tabular}

Source: Bureau of the Census $(1972,1982)$.

\subsubsection{Population Within Ten Miles}

Figure 2.3 shows the estimated 1980 population within a 10 -mile radius that uses the Skagit/Hanford Site as the geographic center of reference. Population estimates are shown for 16 compass direction sections and for rings representing distances of $1,2,3,4,5$, and 10 miles from the site. The estimates shown for 1980 are based on a house count conducted in 1981 (PSP\&L 1981). As these data indicate, the nearest residence was 7.5 miles away. Based on average household data for the area, it was estimated that 357 people 


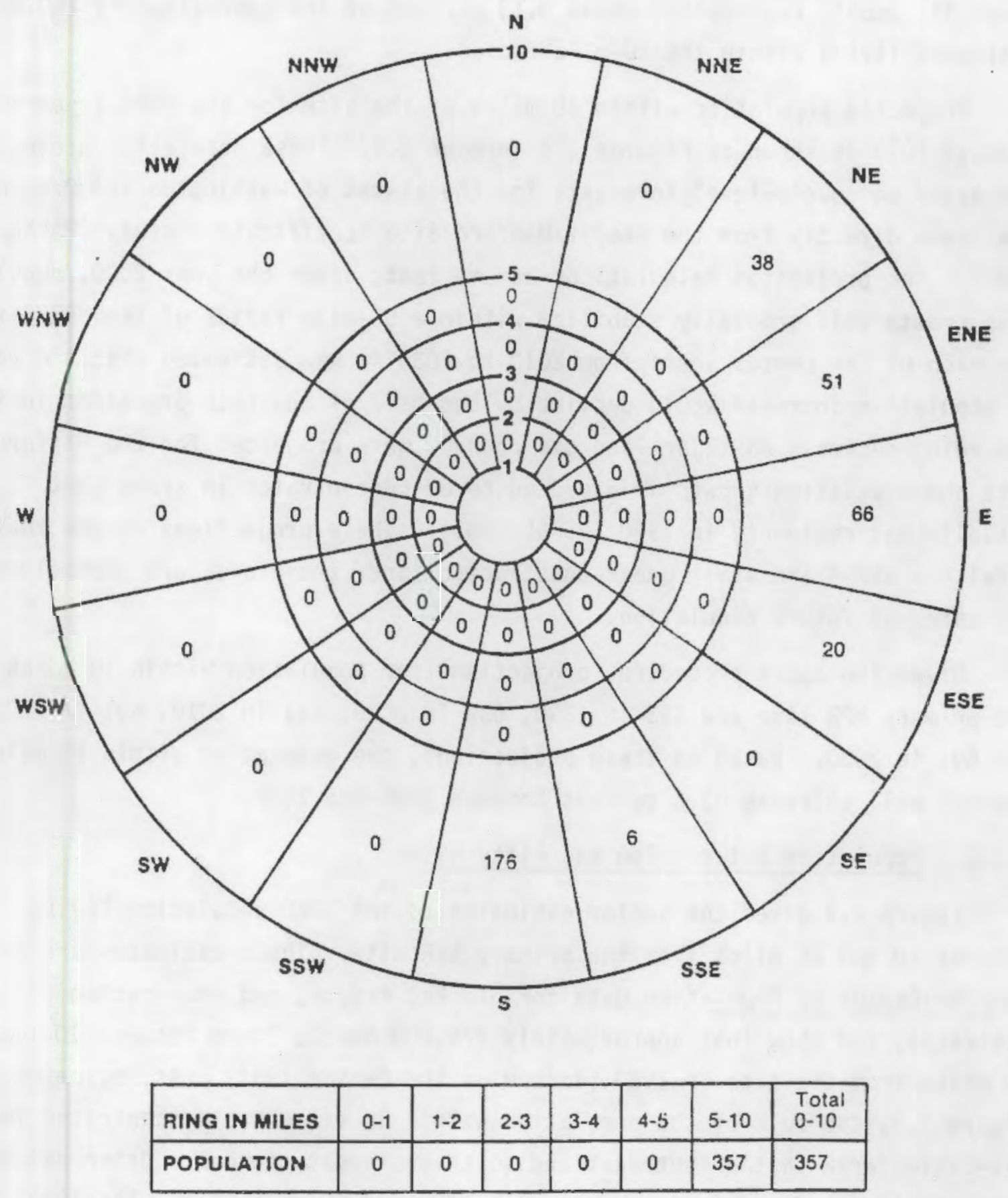

Source: Puget Sound Power \& Light Company (1981).

FIGURE 2.3. Population Within 10 Miles of the Skagit/Hanford Site, 1980 
resided within 10 miles of the site, all in southerly to easterly directions. These 357 people represented about 0.13 percent of the approximately 280,000 residents living within the $50-$ mile radius.

Projected population within 10 miles of the site for the census years 1990 through 2030 is shown in Figures 2.4 through 2.8. These population projections are based on county-level forecasts for the states of Washington and Oregon and are taken directly from the Skagit/Hanford Site certification study (PSP\&L 1981). The projection calculations assume that, after the year 2000, population growth will gradually stabilize within a 50-mile radius of the NPR Site. For each of the census years from 2010 to 2030 it was estimated that the rate of population increase would decline by one-half of the rate prevalent in the preceding decade. No major land use changes were projected for the Hanford Site and population growth is expected to be concentrated in areas that actually had residents in 1980 (PSP\&L 1981). These projections assume that WNP-1 and WNP-4 are still under construction and, therefore, are probably high estimates of future population.

Given the above procedure, projections for population within 10 miles of the primary NPR site are 513 in 1990, 639 in 2000,683 in 2010,691 in 2020, and 691 in 2030. Based on these projections, the population within 10 miles of the NPR will increase 93.6 percent between 1980 and 2030 .

\subsubsection{Population Between Ten and Fifty Miles}

Figure 2.9 gives the sector estimates of the 1980 population living between 10 and 50 miles from the primary NPR site. These estimates are based on 1980 Census of Population data for blocks, tracts, and enumeration districts, and show that approximately 279,000 people lived between 10 and 50 miles from the site in 1980 (Bureau of the Census 1982). As indicated in Figure 2.9, the bulk of the population within 30 miles was concentrated in the Tri-Cities area in the southeast and south-southeast sectors. Other major concentrations of population were in the 40- and 50-mile ring. The 1980 population distribution for the Firehouse Site is given in Table 2.3. 


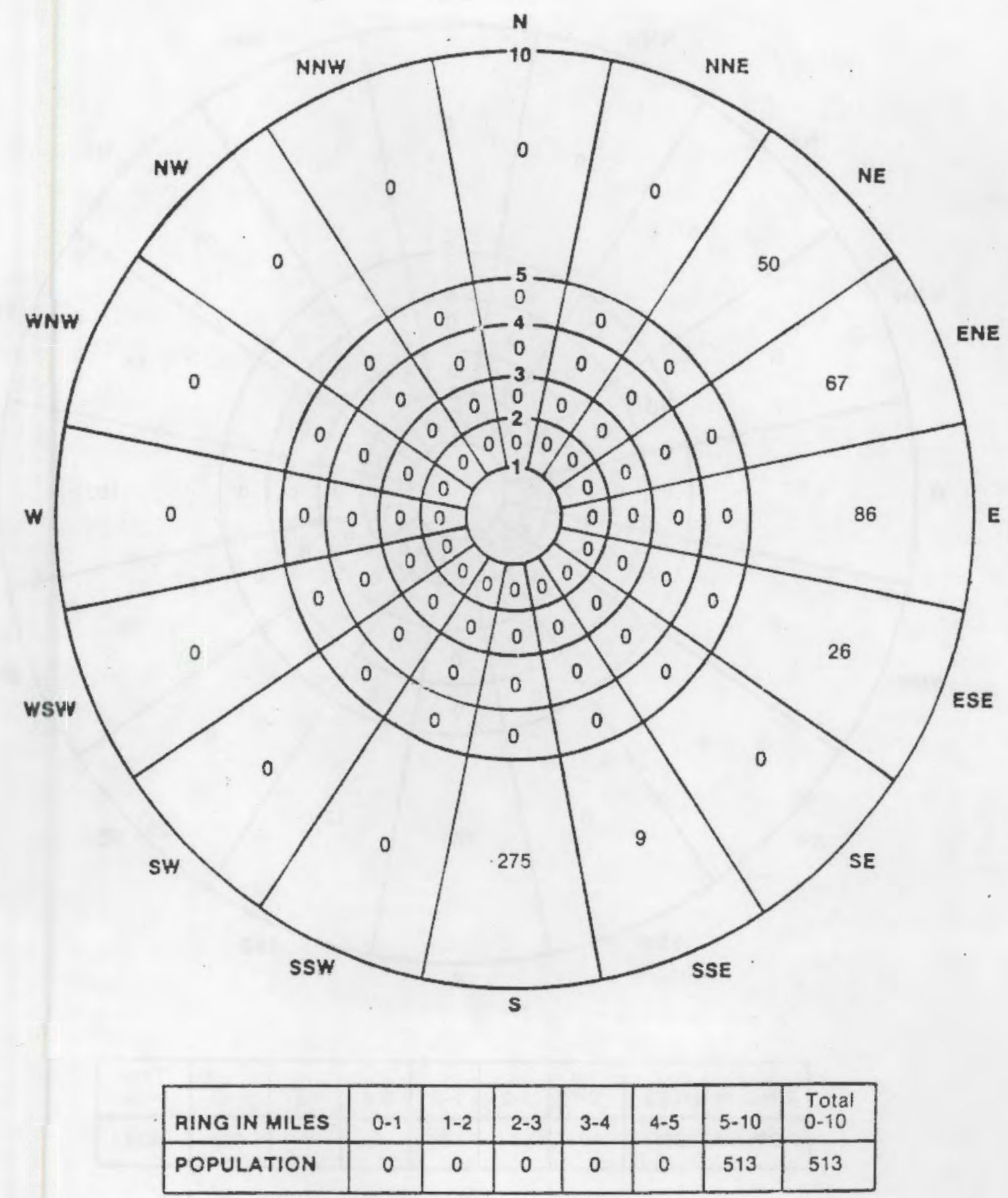

Source: Puget Sound Power \& Light Company (1981).

FIGURE 2.4. Population Within 10 Miles of the Skagit/Hanford Site, 1990 


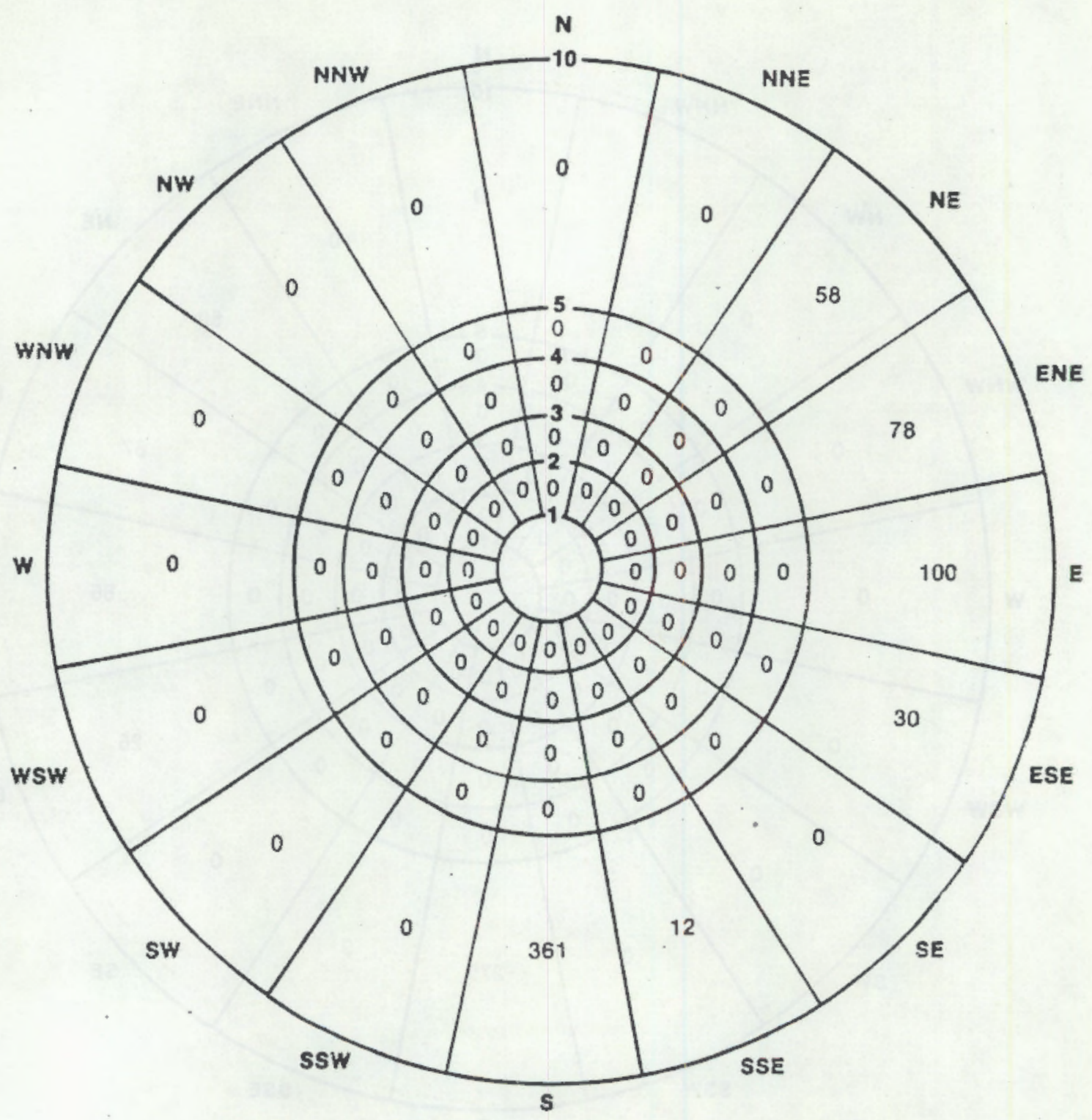

\begin{tabular}{|l|c|c|c|c|c|c|c|}
\hline RING IN MILES & $0-1$ & $1-2$ & $2-3$ & $3-4$ & $4-5$ & $5-10$ & $\begin{array}{l}\text { Total } \\
0-10\end{array}$ \\
\hline FOPULATION & 0 & 0 & 0 & 0 & 0 & 639 & 639 \\
\hline
\end{tabular}

Source: Puget Sound Power \& Light Company (1981).

FIGURE 2.5. Population Within 10 Miles of the Skagit/Hanford Site, 2000 


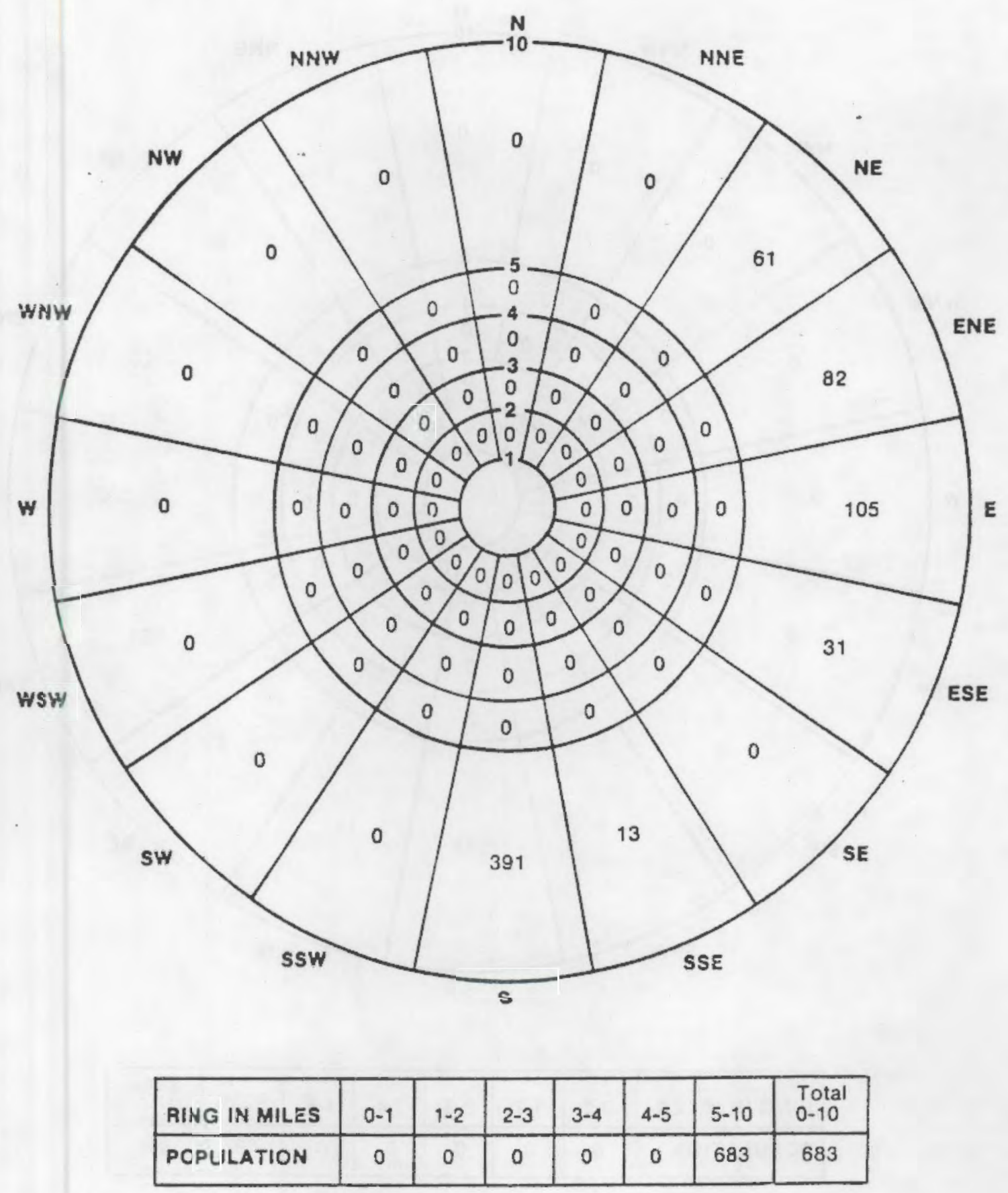

Source: Puget Sound Power \& Light Company (1981).

FIGURE 2.6. Population Within 10 Miles of the Skagit/Hanford Site,2010 


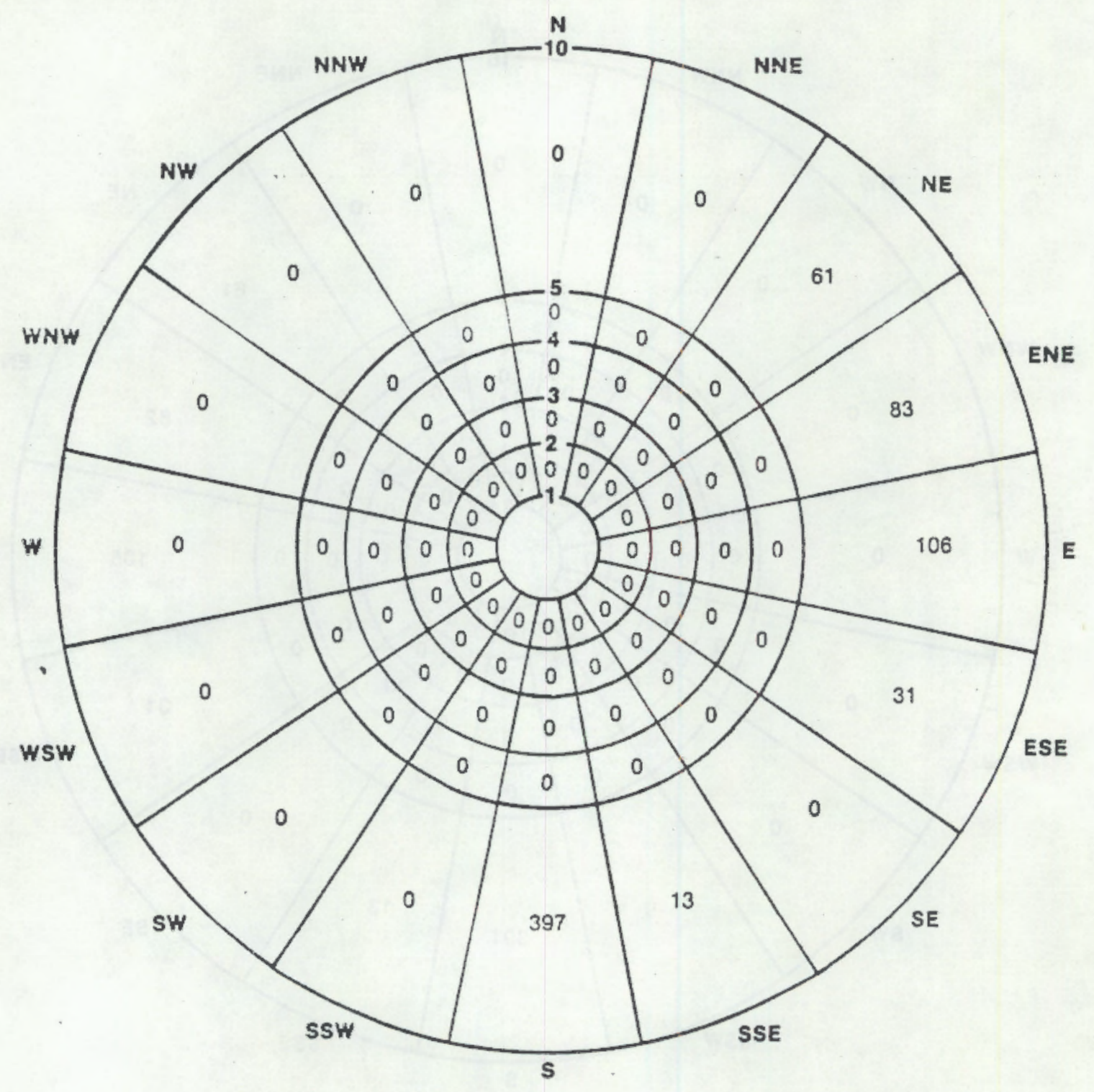

\begin{tabular}{|l|c|c|c|c|c|c|c|}
\hline RING IN MILES & $0-1$ & $1-2$ & $2-3$ & $3-4$ & $4-5$ & $5-10$ & $\begin{array}{c}\text { Total } \\
0-10\end{array}$ \\
\hline POPULATION & 0 & 0 & 0 & 0 & 0 & 691 & 691 \\
\hline
\end{tabular}

Source: Puget Sound Power \& Light Company (1981).

FIGURE 2.7. Population Within 10 Miles of the Skagit/Hanford Site, 2020 


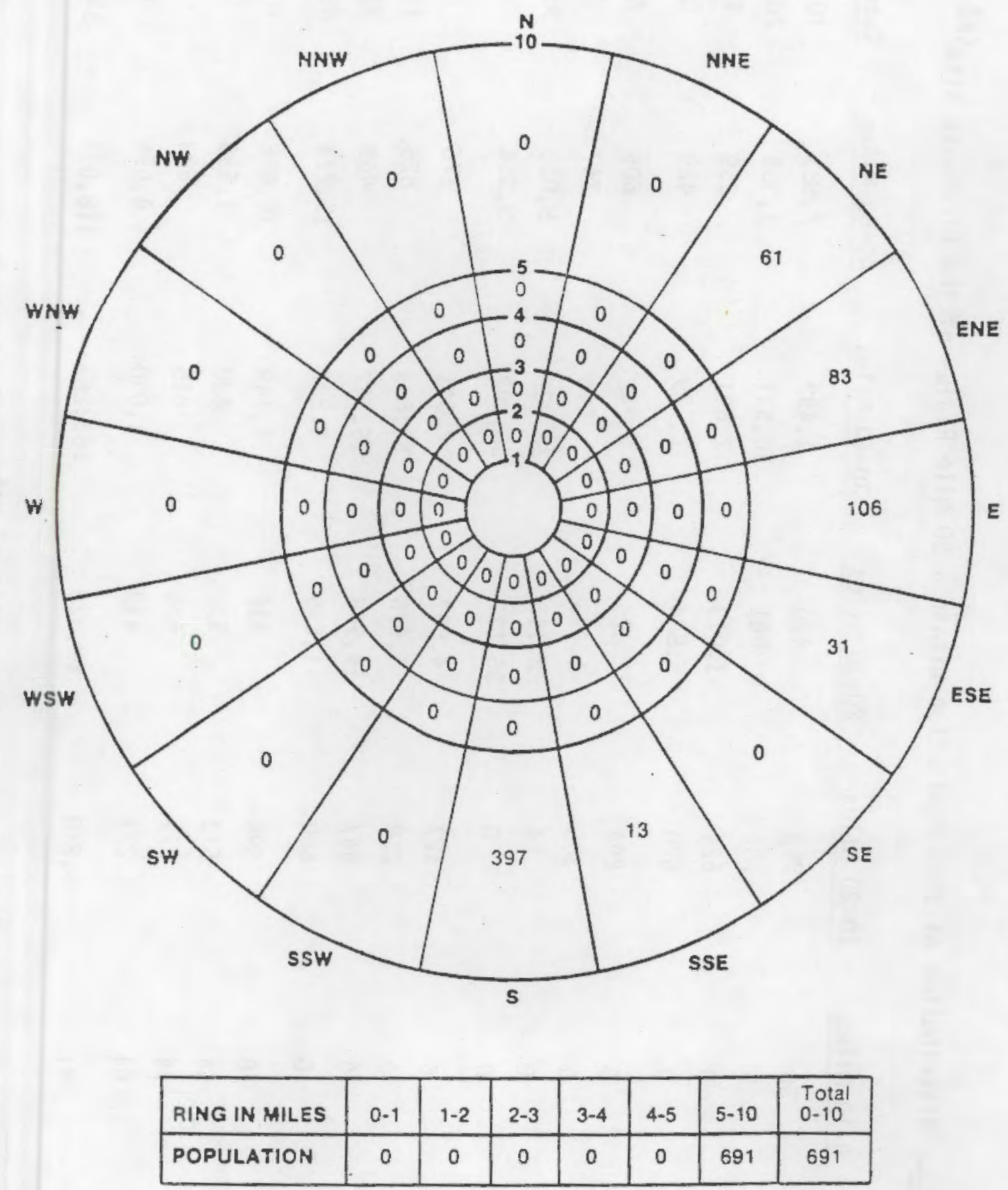

Source: Puget Sound Power \& Light Company (1981).

FIGURE 2.8. Population Within 10 Miles of the Skagit/Hanford Site, 2030 
TABLE 2.3. Distribution of 1980 Population Within a 50-Mile Radius of the Firehouse Site (a)

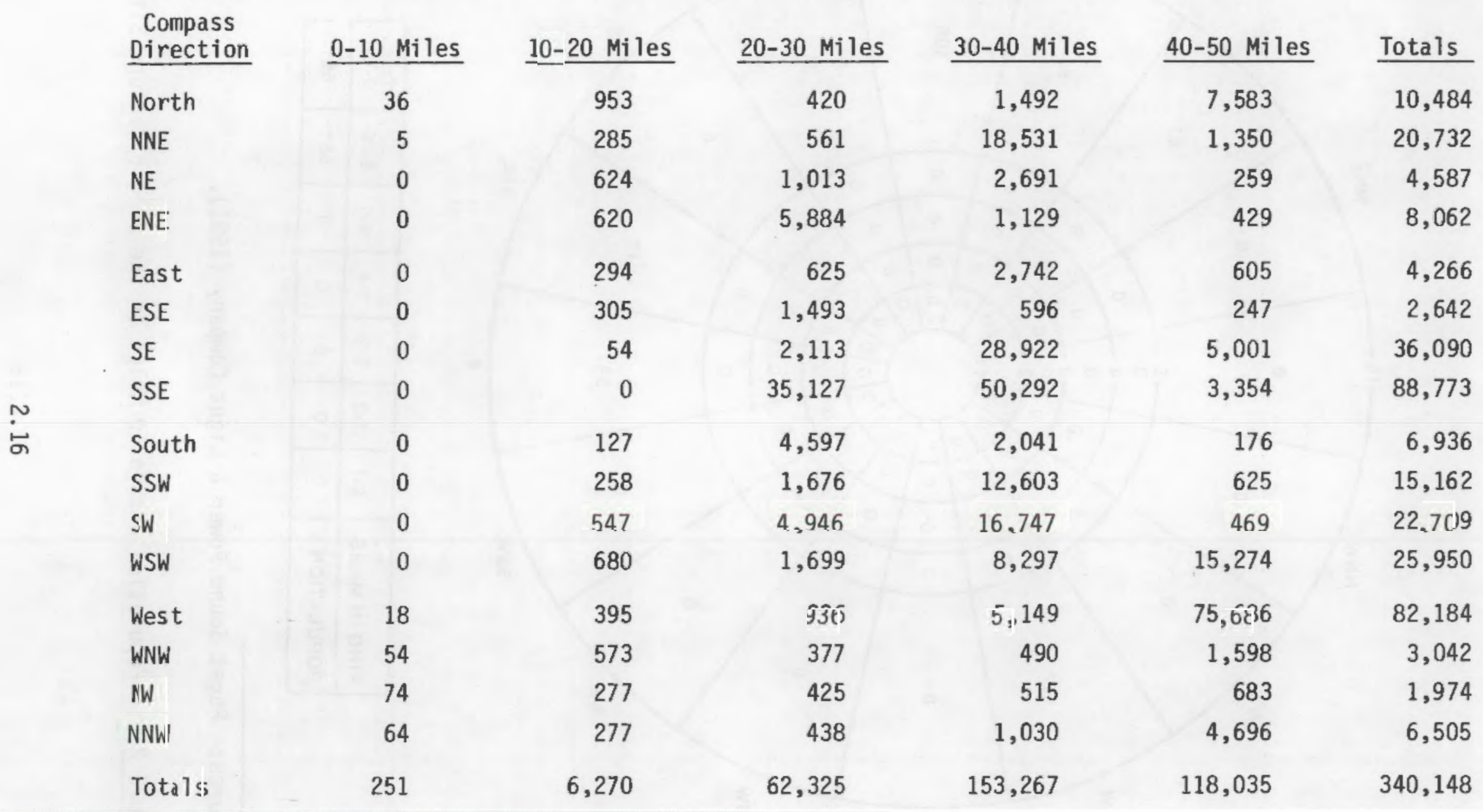

(a) The 100-N Reactor was used as the geographic center of reference.

Source: Sommer, Rau and Robinson (1981). 


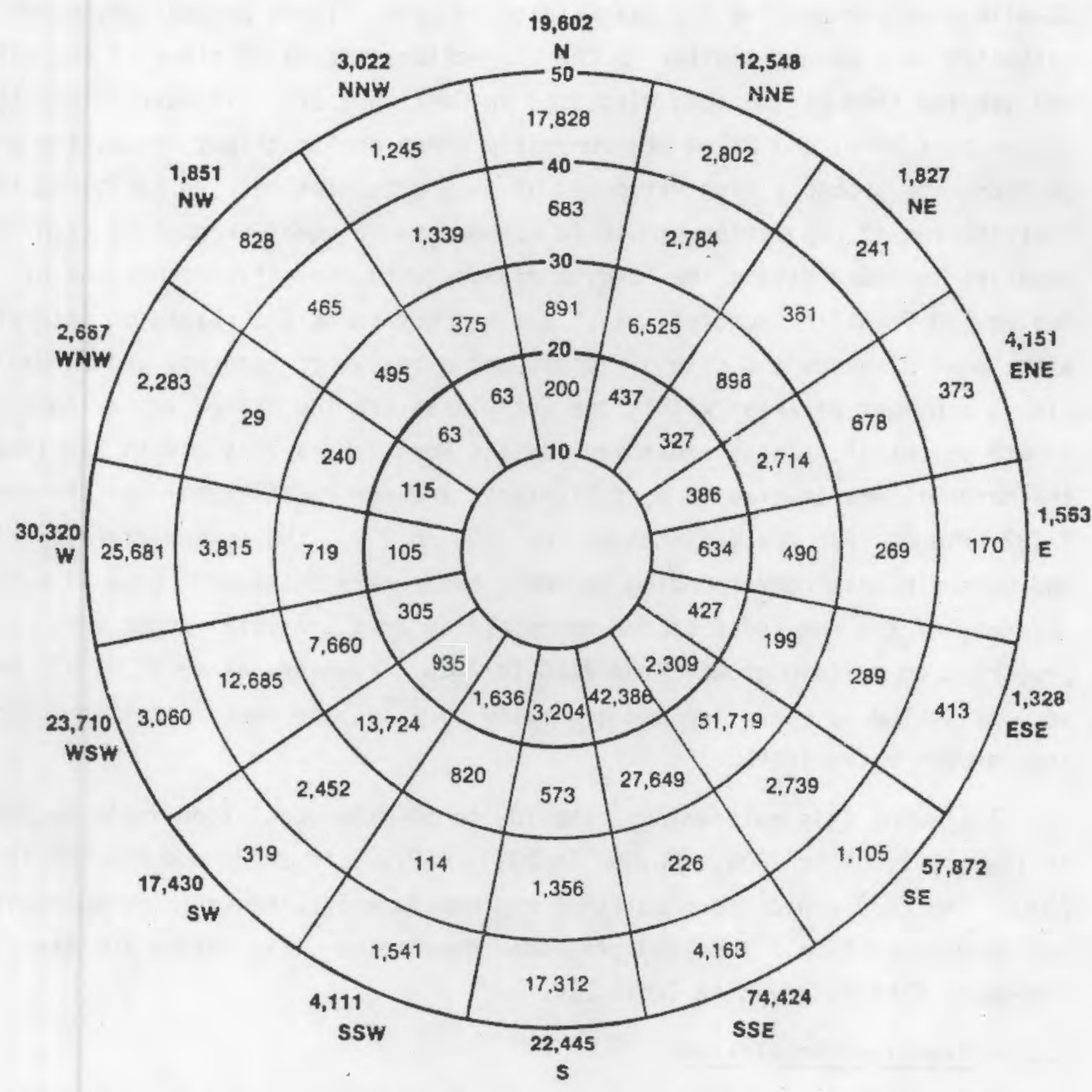

\begin{tabular}{|l|c|c|c|c|c|c|}
\hline RING IN MILES & $10-20$ & $20-30$ & $30-40$ & $40-50$ & $\begin{array}{c}\text { Total } \\
10-50\end{array}$ & $\begin{array}{c}\text { Total } \\
0-50\end{array}$ \\
\hline POPULATION & 53,532 & 115,691 & 30,284 & 79,364 & 278,871 & 279,228 \\
\hline
\end{tabular}

Source: Puget Sound Power \& Light Company (1981).

FIGURE 2.9. Population Between 10 and 50 Miles from the Skagit/Hanford Site, 1980 
Figures 2.10 through 2.14 give the population projections for the 10 - to 50-mile area surrounding the Skagit/Hanford Site. These projections were estimated in a manner similar to the projections within 10 miles of the site, and use the same assumptions discussed in Section 2.2.1. In particular, they assume that WNP-1 and WNP-4 are currently under construction; hence, the projections are probably high estimates of future population. In addition, the distribution of population growth is assumed to be equal throughout each of the counties included within the 50-mile radius, with the major exceptions of Benton and Franklin Counties, which are nearest the site. Based on interviews with local planners and city officials and a review of land use and annexation plans, a number of areas within the Tri-Cities are identified as having high growth potential. These areas include the Horn Rapids Triangle in Richland, the Horn-Willamette area in West Richland, and northwest Pasco near the new I-182 bridge. For the projections for 1990 to 2030, the enumeration districts and census blocks corresponding to these areas were assumed to grow at twice the rate of the remainder of the metropolitan area. Several areas were projected to sustain growth from 2000 to 2010. However, after 2010, a11 areas were projected to stabilize and generally parallel the overall metropolitan area growth rates (PSP\&L 1981).

Following this methodology, the 10 - to 50 -mile population would be 339,000 in $1990,393,000$ in $2000,426,000$ in $2010,432,000$ in 2020 , and 433,000 in 2030. The 2030 projected population represents a 55.2 percent increase over the 1980 population. The 1990 projected population distribution for the Firehouse Site is given in Table 2.4.

\subsubsection{Transient Population}

The transient population of both the Skagit/Hanford and Firehouse sites consists of agricultural workers, industrial and construction workers, and sportspersons engaged in hunting and fishing. The transiency of agricultural workers and sportspersons is seasonal, while the transiency of industrial and construction workers varies daily and by the amount of available work. Table 2.5 lists the total transient population within 10 miles of the Skagit/Hanford Site by location, direction, and distance. Industrial and construction workers make up the bulk of the transient population and are the 


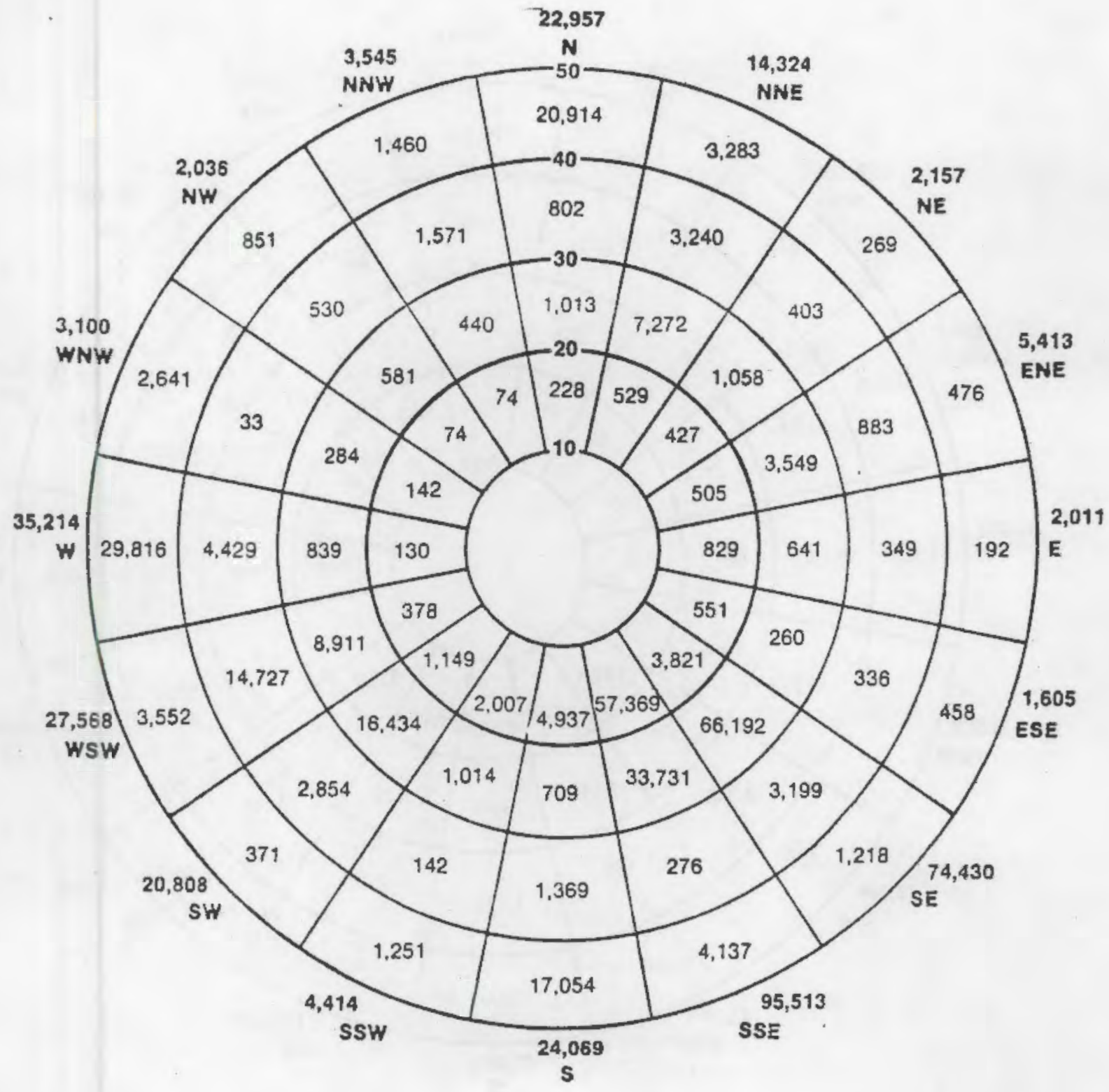

\begin{tabular}{|l|c|c|c|c|c|c|}
\hline RING IN MILES & $10-20$ & $20-30$ & $30-40$ & $40-50$ & $\begin{array}{c}\text { Total } \\
10-50\end{array}$ & $\begin{array}{c}\text { Total } \\
0-50\end{array}$ \\
\hline POPULATION & 73,150 & 142,928 & 35,143 & 87,943 & 339,164 & 339,677 \\
\hline
\end{tabular}

Source: Puget Sound Power \& Light Company (1981).

FIGURE 2.10. Population Between 10 and 50 Miles from the Skagit/Hanford Site, 1990 


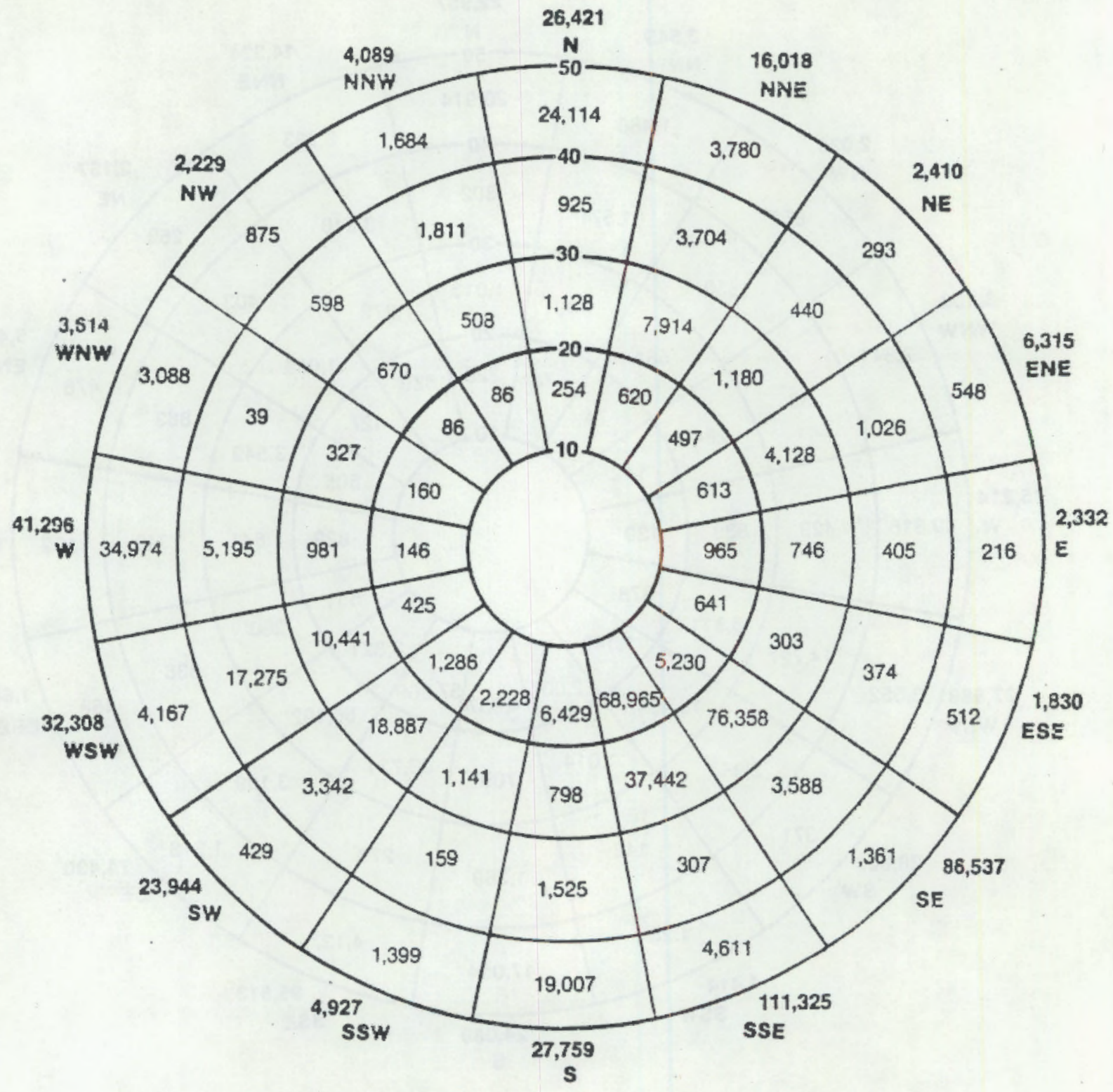

\begin{tabular}{|l|c|c|c|c|c|c|}
\hline RING IN MILES & $10-20$ & $20-30$ & $30-40$ & $40-50$ & $\begin{array}{c}\text { Total } \\
10-50\end{array}$ & $\begin{array}{c}\text { Total } \\
0-50\end{array}$ \\
\hline POPULATION & 88,631 & 162,952 & 40,713 & 101,058 & 393,354 & 393,993 \\
\hline
\end{tabular}

Source: Puget Sound Power \& Light Company (1981).

FIGURE 2.11. Population Between 10 and 50 Miles from the Skagit/Hanford Site, 2000 


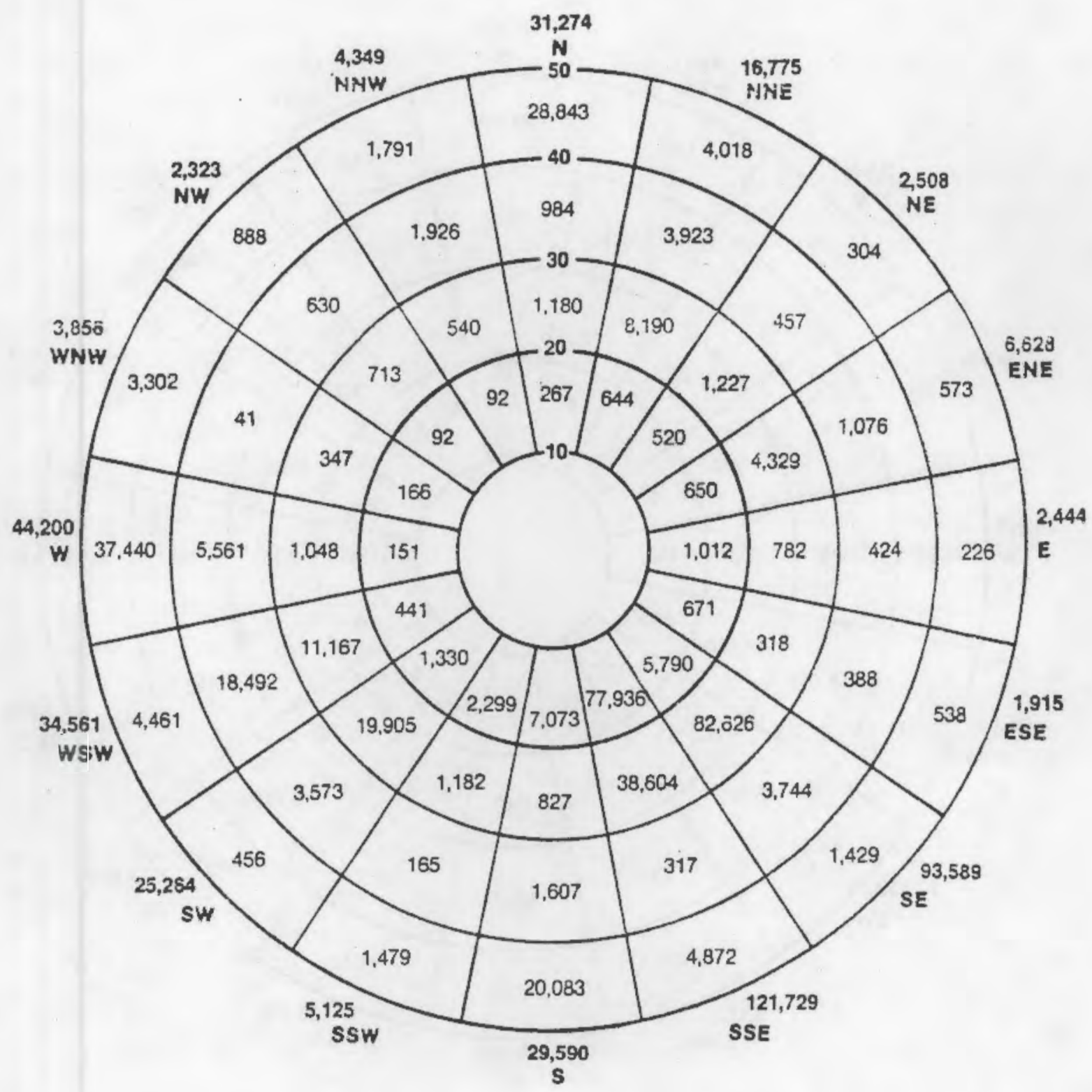

\begin{tabular}{|l|c|c|c|c|c|c|}
\hline RING IN MILES & $10-20$ & $20-30$ & $30-40$ & $40-50$ & $\begin{array}{c}\text { Total } \\
10-50\end{array}$ & $\begin{array}{c}\text { Total } \\
0-50\end{array}$ \\
\hline POPULATION & 99,134 & 172,985 & 43,308 & 110,703 & 426,130 & 426,813 \\
\hline
\end{tabular}

Source: Puget Sound Power \& Light Company (1981).

FIGURE 2.12. Population Between 10 and 50 Miles from the Skagit/Hanford Site, 2010 


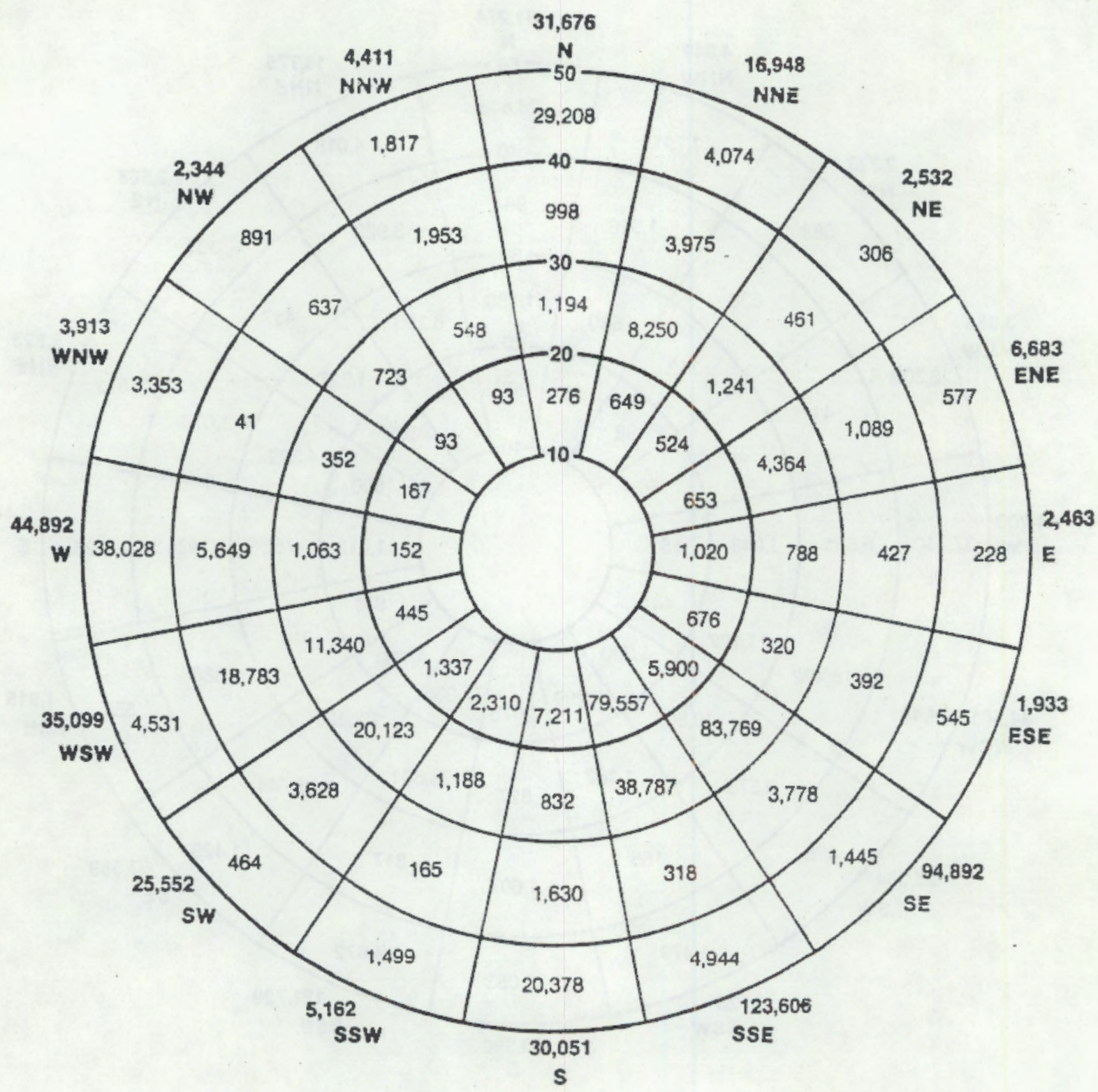

\begin{tabular}{|c|c|c|c|c|c|c|}
\hline RING IN MILES & $10-20$ & $20-30$ & $30-40$ & $40-50$ & $\begin{array}{c}\text { Total } \\
10-50\end{array}$ & $\begin{array}{c}\text { Total } \\
0-50\end{array}$ \\
\hline POPULATION & 101,063 & 174,882 & 43,924 & 112,288 & 432,157 & 432,848 \\
\hline
\end{tabular}

Source: Puget Sound Power \& Light Company (1981).

FIGURE 2.13. Population Between 10 and 50 Miles from the Skagit/Hanford Site, 2020 


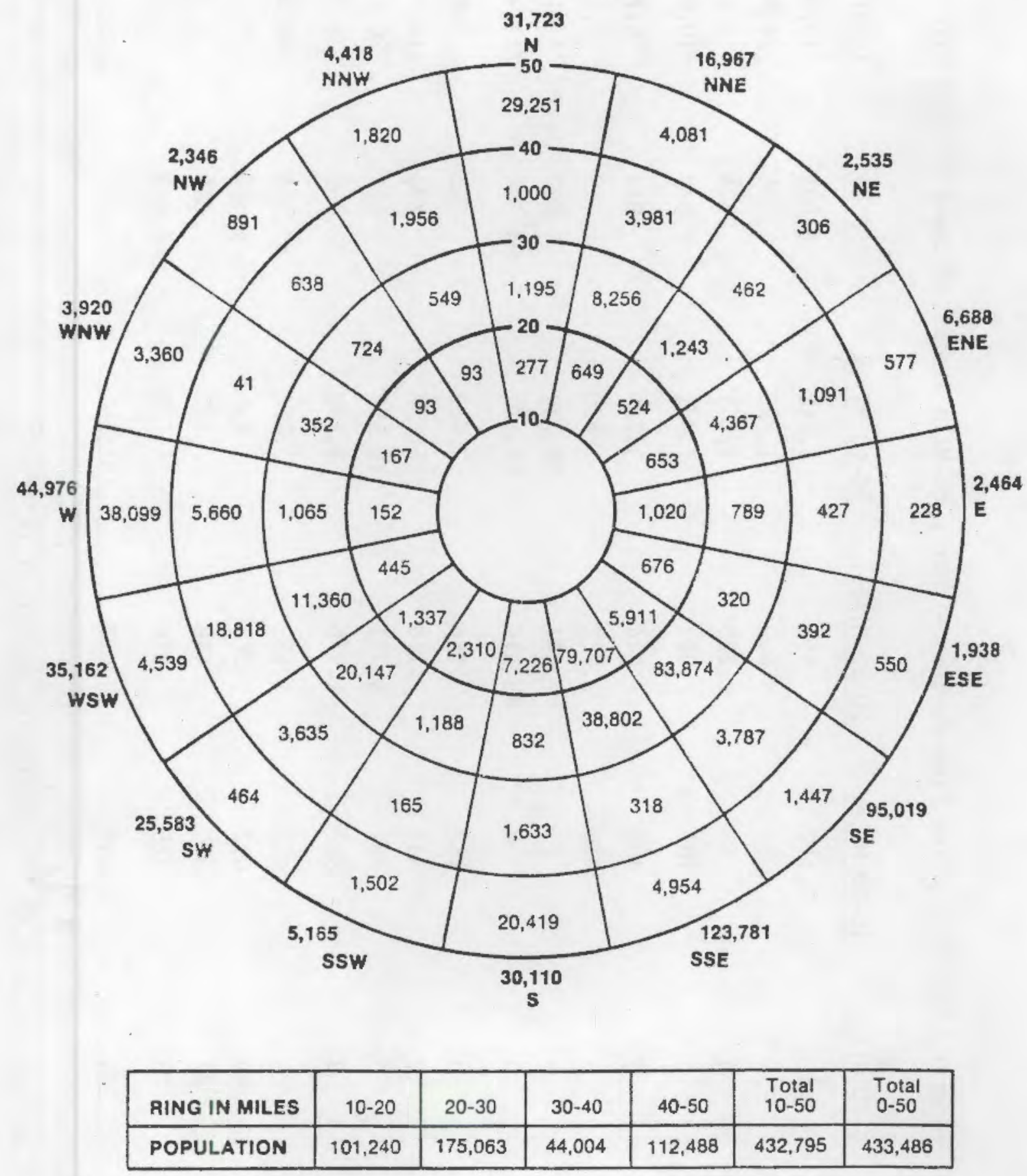

Source: Puget Sound Power \& Light Company (1981).

FIGURE 2.14. Population Between 10 and 50 Miles from the Skagit/Hanford Site, 2030 
TABLE 2.4. Projected 1990 Population Distribution Within a 50-Mile Radius of the Firehouse Site ${ }^{\text {(a) }}$

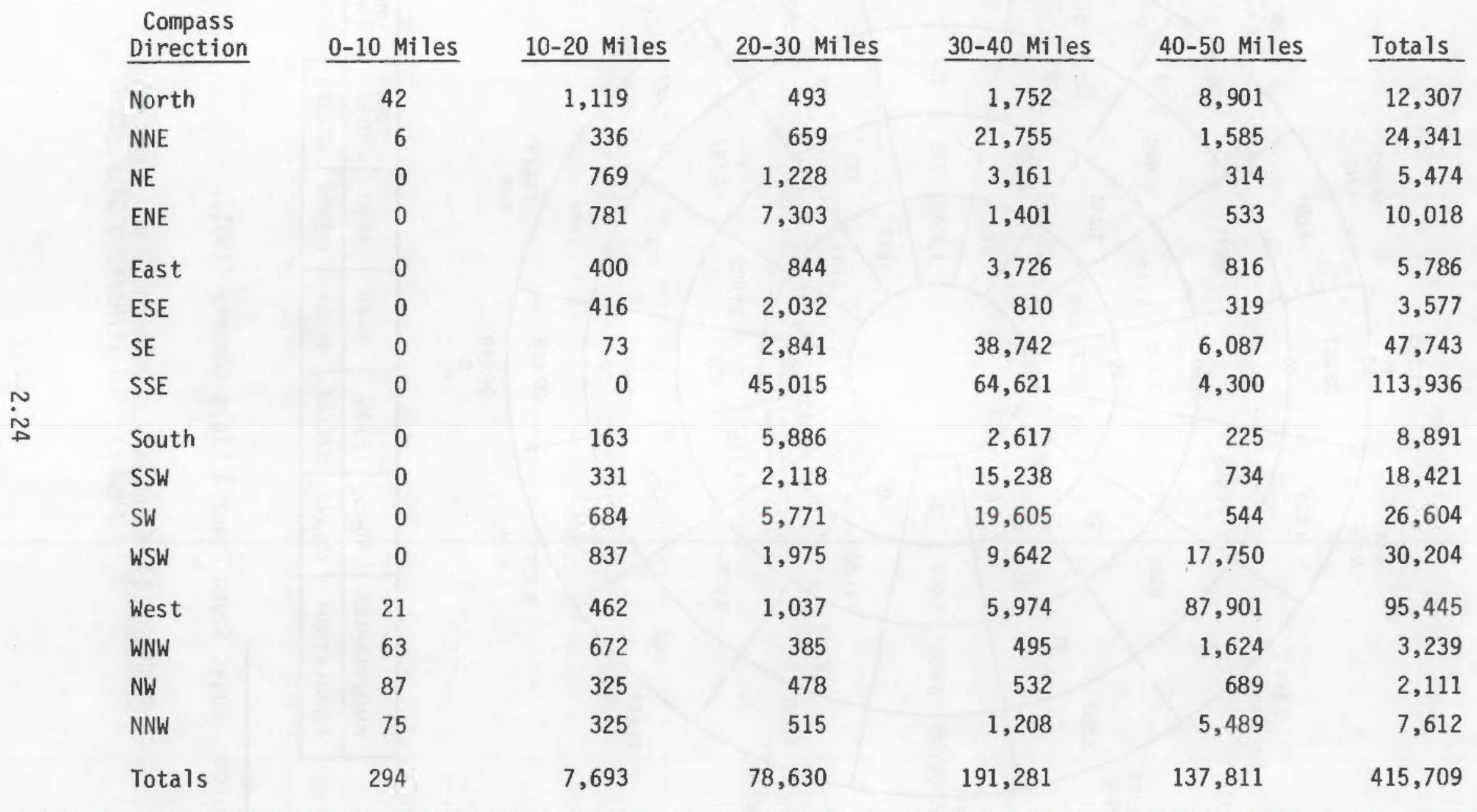

(a) The 100-N Reactor was used as the geographic center of reference.

Source: Sommer, Rau and Robinson (1981). 
TABLE 2.5. Transient Population Within 10 Miles of the Skagit/Hanford Site

Location

\begin{tabular}{|c|c|c|c|}
\hline $\begin{array}{l}\text { Peak } \\
\text { Transient } \\
\text { Population }\end{array}$ & $\begin{array}{l}\text { Equivalent } \\
\text { Permanent } \\
\text { Population }\end{array}$ & $\begin{array}{l}\text { Distance } \\
\text { in Miles } \\
\end{array}$ & Direction \\
\hline $\begin{array}{l}295 \\
200\end{array}$ & $\begin{array}{l}76 \\
14\end{array}$ & $4.5-5$ & ESE \\
\hline 1,187 & 305 & $4.5-5$ & SE \\
\hline 2,069 & 533 & $5-8.8$ & $\mathrm{NW}$ \\
\hline 1,361 & 351 & $8.5-10$ & WNW \\
\hline $1^{(a)}$ & $<1$ & 5 & $E$ \\
\hline 2 & $<1$ & 2 & NW \\
\hline 24 & 6 & $8.5-10$ & SW \\
\hline 35 & 12 & $8.5-10$ & SW \\
\hline 300 & 75 & $8.5-10$ & NNE-ESE \\
\hline $14,000^{\text {(b) }}$ & 14 & $6-10$ & $N E-2$ \\
\hline $2,910^{(b)}$ & 3 & $8.5-10$ & ENE-E \\
\hline
\end{tabular}

(a) Nine crew members report daily to the substation for work assignment.

(b) Person days per year.

Source: Puget Sound Power \& Light Company (1981).

group whose numbers are the most variable over time. The $100-\mathrm{N}$ reactor is the major source of industrial employment within 5 miles of the Firehouse Site, with 993 workers in 1981.

With the delay of WNP-1 and the termination of WNP-4, WNP-2 is the remaining Washington Public Power Supply System plant attracting transient workers. If WNP-1 were restarted, however, about 5500 construction workers could be expected within 10 miles of the Skagit/Hanford Site until plant completion, when transient population figures would be similar to those for WNP-2. No increase in workers is projected for WNP-4. The Fast Flux Test Facility (FFTF), operated by Westinghouse Hanford Company for OOE, has a transient work 
force of 1,187. The 200-East and 200-West Areas in the northwest quadrant of Hanford employ a total of 3,430 persons. Workers in these two areas are employed by DOE or its contractors.

The Arid Lands Ecology (ALE) Reserve and the Rattlesnake Mountain observatory are located southwest of the Skagit/Hanford Site. The ALE Reserve employs 24 persons, while the observatory has a normal daytime staff of 19 persons. However, as many as 35 people may be present at the observatory on a given day, and several persons may be staying overnight (PSP\&L 1981). The H. J. Ashe Electrical Substation is located 4.5 miles east of the Skagit/Hanford Site, and is operated by the Bonneville Power Administration as part of its transmission system. Workers at the substation consist of one operator who works eight hours per day, five days per week, and nine additional crew members who report daily for work assignments. The central landfill located 2.5 miles northnorthwest of the site employs two workers eight hours per day, five days per week (PSP\&L 1981).

No agricultural activity exists on the Hanford Site itself but there is farming across the Columbia River to the northeast and southeast of the Skagit/Hanford Site. Migrant farm workers may be present in these areas within 8 to 10 miles. Most of the migrant workers are present in the spring and early summer; a 1981 survey (PSP\&L) indicated that up to 300 migrants may be working within the 10-mile radius during those months.

Fishing and hunting are the primary recreational activities found within 10 miles of the Skagit/Hanford Site, and are focused on the Columbia and Yakima Rivers. The number of sportspersons varies with the season, weather, day of the week, and time of day. The area is used most heavily for both hunting and fishing on weekends and holidays in the early morning hours. The main hunting season is from mid-0ctober through January; it was estimated that during the season, 10 hunters are present on weekdays and 50 hunters are present on weekends and holidays, on average. Most of the hunters are in the 8- to 10-mile range from the site, east and east-northeast at the Wahluke Game Hunting Area. The main fishing season is from June to November; and it was estimated that 50 people on weekdays and 100 people on weekends are fishing within 10 miles of the Skagit/Hanford Site. Some fishing takes place on the Columbia River south 
of the Ringold Fish Hatchery toward Richland. It was estimated that the peak number of persons hunting or fishing in the area did not exceed 1000 at a given time (PSP\&L 1981).

\subsection{REFERENCES}

Bureau of the Census. 1972. 1970 Census of Population: Characteristics of the Population. Volume 1, Part 49, U.S. Department of Commerce. Washington, D.C.

Bureau of the Census 1982. 1980 Census of Population: General Population

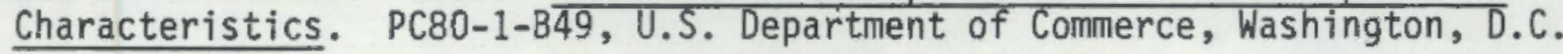

Office of Financial Management. 1980. State of Washington Population Trends. State of Washington, OTympia, Washington.

Puget Sound Power \& Light Company. 1981. Skagit/Hanford Units 1 and 2, Application for Site Certification/Environmental Report. Docket Nos. 50-522 and STN 50-523, Seattle, Washington.

Sommer, D. J., R. G. Rau, and D. C. Robinson. 1981. Population Estimates for the Areas within a 50-Mile Radius of Four Reference Points on the Hanford Site. PNL-4010, Pacific Northwest Laboratory, Richland, Washington.

Tallman, A. M., et al. 1979. Geology of the Separations Area, Hanford Site, South-Central Washington. RHO-ST-23, Rockwell Hanford Dperations, Richland, Washington.

U.S. Department of Energy. 1982a. Operation of PUREX and Uranium Oxide Plant Facilities: Draft Environmental Impact Statement. D0E/EIS-0089D, Washington, D.C.

U.S. Department of Energy. 1982b. Site Characterization Report for the Basalt Waste Isolation Project. DOE/RL 82-3, Washington, D.C.

U.S. Nuclear Regulatory Commission. 1982. Draft Environmental Statement Related to the Construction of Skagit/Hanford Nuclear Project, Units 1 and 2. NUREG-0894, Washington, D.C. 

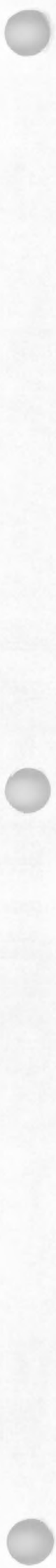


\subsection{ECOLOGY}

This chapter presents a detailed description of the terrestriā and aquatic plants and animals found on the Hanford Site and in the nearby Columbia River. Species known in inhabit both the Skagit/Hanford and Firehouse sites are characterized in terms of their abundance, habitats, interrelationships, and subjectivity to human intervention.

\subsection{TERRESTRIAL ECOLOGY}

\subsubsection{Plants and Habitat Description of the Skagit/Hanford Site}

The Skagit/Hanford (primary) site is located mostly in the sagebrush-bitterbrush/ cheatgrass plant community and extends slightly into the sagebrush/ cheatgrass community (Figure 3.1). The sagebrush-bitterbrush/ cheatgrass community occurs on sandy soils and stabilizes old sand dunes. Sagebrush dominates low areas between sand dunes, while bitterbrush occurs primarily on the dune tops. Associated shrubs of this community are gray rabbitbrush, green rabbitbrush, hopsage, and snowy buckwheat. The grasses include Sandberg bluegrass, Indian rice grass, thick-spike wheatgrass and needle-and-thread grass. The common forbs include terpentine cymopterus, long-leaf phlox, stalked-pod milkvetch, Lyall's milkvetch, Carey's balsamroot, pale evening primrose, lance-leaf scurf-pea, winged cryptantha, spring draba, and western tansy mustard. Starvation cactus is also common in the sagebrush-bitterbrush/cheatgrass community (PSP\&L 1981).

The western edge of the primary site extends into the sagebrush/ cheatgrass plant community. This community is dominated by sagebrush and cheatgrass, with scattered hopsage and rabbitbrush interspersed with sagebrush. The understory is dominated by cheatgrass with Sandberg bluegrass being common. The most abundant perennial forbs are long-leaf phlox and Carey's balsamroot. The annuals include six-week fescue, spring draba, jagged chickweed, Indian-wheat and western tansy mustard (PSP\&L 1981). The important plant species associated with the primary site are tabulated in Appendix A. Cline et al. (1977) report on the plants and soil of a sagebrush community on the Hanford Site. They also characterized the sagebrush/cheatgrass community. 


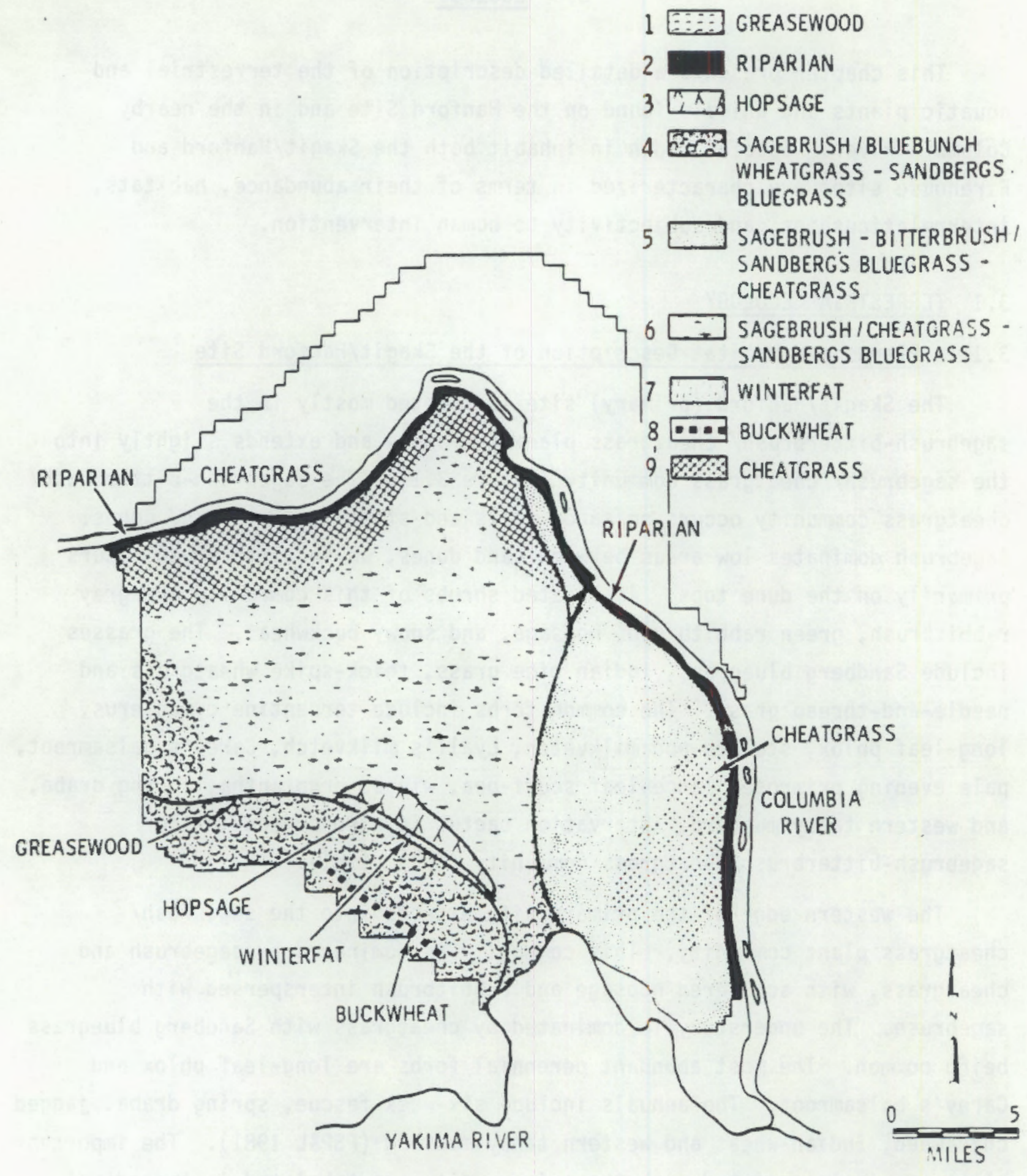

FIGURE 3.1. Major Vegetation Types of the Hanford Site (from Cline et al. 1977) 
The average understory cover was 38 percent. Cheatgrass, an annual grass, was the dominant species, providing 18 percent of the herbaceous cover. Sagebrush was the conspicuous shrub, providing 15 to 20 percent of the total cover. Biomass production of the herbaceous species was approximately $40 \mathrm{~g} / \mathrm{m}^{2}$.

Much of the primary site has been burned in the past. These range fires have eliminated sagebursh, bitterbrush, and hopsage. The resulting plant communities are strongly dominated by cheatgrass. Species that were found in the sagebrush or sagebrush-bitterbrush dominated communities before fires are usually well represented, but diversity appears lower in burned-over areas (PSP\&L 1981, p 2.2-2).

In the past, some of the primary site consisted of active sand dunes. Vegetation has stabilized most of these dunes but, in some areas, vegetation is sparse and the sand is actively moving. The blowouts are distinctive in the types of plants they contain. Perennial forbs predominate, including gray cryptantha, Franklin's sandwort, sand-dune penstemon, silverleaf phacelia, and lance-leaf scurf-pea. These areas are not dominated by cheatgrass or shrubs, although small amounts of cheatgrass may be present, and an occasional bitterbrush may be found. A few annual forbs, such as annual burweed, are found in this community (PSP\&L 1981, p. 2.2-2).

\subsubsection{Soils of the Skagit/Hanford Site}

Hajeck (1966) provides a detailed description of the soils on the Hanford Site; specific soil types are presented in Figure 3.2. The soils in the vicinity of the primary site are generally sandy with little potential for cropland use without irrigation. Four types are found: Rugers sand, Burbank loam sand, ephrata sandy loam, and dune sand. Detailed characteristics of these soils are presented in Appendix A.

The soils in the sagebrush/cheatgrass community are sandy loams dominated by sand, followed by silt and clay. Clay-sized particles are scarce, making up only 1 percent of the texture size classes. This implies that the moisture-holding capacity and cation exchange of the site's soil profile are low. Also, sandy soils are subject to serious wind erosion when disturbed. The pH of the surface soils is alkaline, and alkalinity increases with profile depth. Soluble salts are low, indicating that salinity (excess salts) is not 


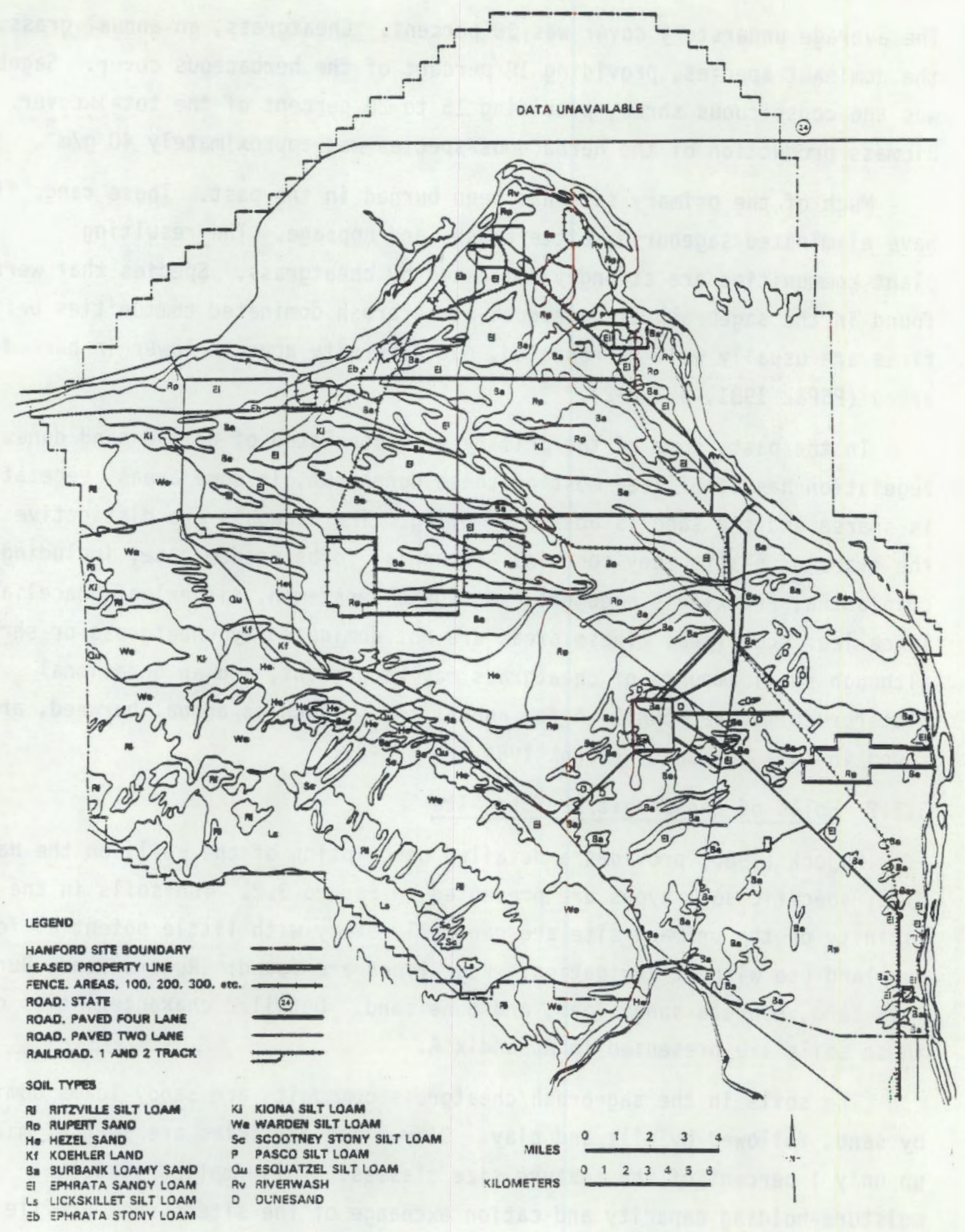

FIGURE 3.2. Soil Types of the Hanford Reservation 
a hindrance to plant growth, at least in the upper soil. Organic matter is low, indicative of low soil nitrogen levels.

Glad (1981) described the soil chemistry of the sagebrush-bitterbrush/cheatgrass vegetation community as characteristic of Rupert sand with scattered dune sand. Data on sixteen parameters, including $\mathrm{pH}$, bicarbonate, conductivity, sulfate, chlorine, fluoride and ten elemental concentrations, are summarized in Appendix A.

\subsubsection{Wildlife of the Skagit/Hanford Site}

\subsubsection{Invertebrates}

Numerous studies have been conducted on invertebrate inhabiting the Hanford Site (Rogers and Woodley 1978; Rogers et al. 1977; Rogers and Rickard 1975; Rogers 1979; Fitzner et al. 1979; Rogers and Fitzner 1980). Table 3.1 provides a list of the major insect taxa and the shrubs with which they are most commonly associated on the 200-Area plateau.

Rogers (1978) studied darking beetles and provides extensive data on their abundance across the Hanford Site. Rogers and Fitzner (1980) provide additional data on darkling beetles within 2 miles of the primary site and near Washington Public Power Supply System's nuclear power plant site No. 1 . The plant community here was a sagebrush-bitterbrush/cheatgrass community. Additional data were collected in a sagebrush/cheatgrass community on the 200 Area plateau. The data on darkling beetles from these two plant comnunities probably typify the species expected on the primary site. Because all naturally occurring animal populations are dynamic (ever-changing), the studies conducted today would not necessarily yield data of the same nature as that coliected by Rogers and Fitzner (1980). Year-to-year variations in temperature and humidity will affect abundance and distribution of insects.

The ant populations of the Hanford 300 area waste burial grounds were characterized by Fitzner et al. (1979). The species encountered were Solenops is molesta, Pogonomyrmex owyheei, Formica subpolita, and Formica manni. The habits of each species are provided in Fitzner et aT. (1979). Ants are of some concern in radioactive waste management, since they can 
TABLE 3.1. Relative Abundance (Percent) of Insect Taxa Collected from Sagebrush, Rabbitbrush, and Hopsage (Rogers 1979)

\begin{tabular}{|c|c|c|c|}
\hline Taxa & Sagebrush & Rabbitbrush & Hospage \\
\hline Hemiptera (true bugs) & 44.6 & 11.7 & 6.4 \\
\hline Homoptera (bugs) & 33.0 & 31.2 & 6.1 \\
\hline Orthoptera (grasshoppers) & 7.3 & 24.0 & 21.8 \\
\hline Araneida (spiders) & 6.5 & 20.7 & 21.3 \\
\hline Hymenoptera (ants, bees, wasps) & 4.2 & 2.9 & 5.8 \\
\hline Coleoptera (beetles) & 1.7 & 1.9 & 27.4 \\
\hline Lepidoptera (butterflies, moths) & 1.2 & 6.1 & 5.3 \\
\hline Oiptera (flies) & 1.1 & 1.2 & 5.3 \\
\hline Neuroptera (lace wings) & 0.3 & 0.3 & 0.3 \\
\hline Other & 0.1 & 0.1 & 0.3 \\
\hline
\end{tabular}

excavate soil to a depth of several meters. Buried waste can thus be transported from shallow waste burial sites to the surface. Grasshopper abundance has been examined by Rogers (1976).

Specific details on insect abundance and location are noted in Appendix A (Tables A.5 through A.7).

\subsubsection{Reptiles and Amphibians}

The Hanford Site is not rich in cold-blooded vertebrates. Table 3.2 lists 21 species that may occur on the site; of these, only 11 have been observed (Rogers and Rickard 1977, p. 3.37). Trapping studies using drift fencing and pit-traps indicate that green racers (Coluber constrictor mormon) and gopher snakes (Pituophis melanoleucus) occur in about equal numbers on the 200 Area Plateau. Striped whipsnake (Masticophis taeniatus), desert night snake (Hypsiglena torquata) and Northern Pacific rattlesnake (Crotalus viridus) also can be expected on the primary site; however, these species have fairly specific habitat requirements that limit their distribution.

Lizards may be the most important group of cold-blooded vertebrates from a density and biomass consideration. Species observed on the 200 Area Plateau (Rogers and Rickard 1977, p. 3.35) are the side-blotched lizard (Uta stansburiana), sagebrush lizard (Sceloporus graciosus) and pigmy short-horned 
TABLE 3.2. Amphibian and Reptile Species Observed on the Hanford Reservation (Rogers and Rickard 1977)

Common Name

Amphibians

Great Basin Spadefoot Toad

Western Toad

Pacific Treefrog

Reptiles

Sagebrush Lizard

Side-blotched Lizard

Pigmy Short-horned Lizard

Striped Whipsnake

Western Yellow-bellied Racer

Gopher Snake

Desert Night Snake

Northern Pacific Rattlesnake
Scientific Name

Occurrence

Scaphiopus intermontanus

Bufo Boreas

Hyla regilla $u^{(a)}$

$\mathrm{U}$

Sceloporus graciosus

Uta stansburiana

Phrynosoma douglassi

Masticophis taeniatus

Coluber constrictor

pituophis melanoleucus

Hypsiglena torguata

Crotalus viridus

U
C
U
0
C
C
R
C

Reptiles and amphibians for which sightings have not yet occurred

Long-toed Salamander
Tiger Salamander
Woodhouse's Toad
Leopard Frog
Bullfrog
Painted Turtle
Western Fence Lizard
Western Skink
Common Garter Snake
Western Terrestrial Garter
Snake

Long-toed Salamander

Leopard Frog

Bullfrog

Painted Turtle

Western Fence Lizard

Common Garter Snake

Snake
Ambys toma macrodacty 1 um

Ambystoma tigrinum

Bufo woodhousei

Rana pipiens

Rana catesbejana

Chrysemys picta

Sceloporus occidental is

Eumesces skijtonianus

Thamnophis sirtalis

Thamnophis elegans

(a) U=Uncommon, $\mathrm{C}=$ Common, $\mathrm{R}=$ Rare

lizard (Phrynosoma douglassi). The sagebrush and pigmy short-horned lizard are restricted primarily to sandy areas, while the side-blotched lizard is more widespread. Figure 3.3 provides a graphic representation of population levels, hatching dates, and dates of hibernation for the sagebrush and side-blotched lizard. By using $20 \times 20 \mathrm{~m}\left(400-\mathrm{m}^{2}\right)$ pit-trapping grids, density estimates of side-blotched lizards on the 200 Area Plateau were estimated to range from 15 to 25 lizards per hectare. Because the average weight of an 


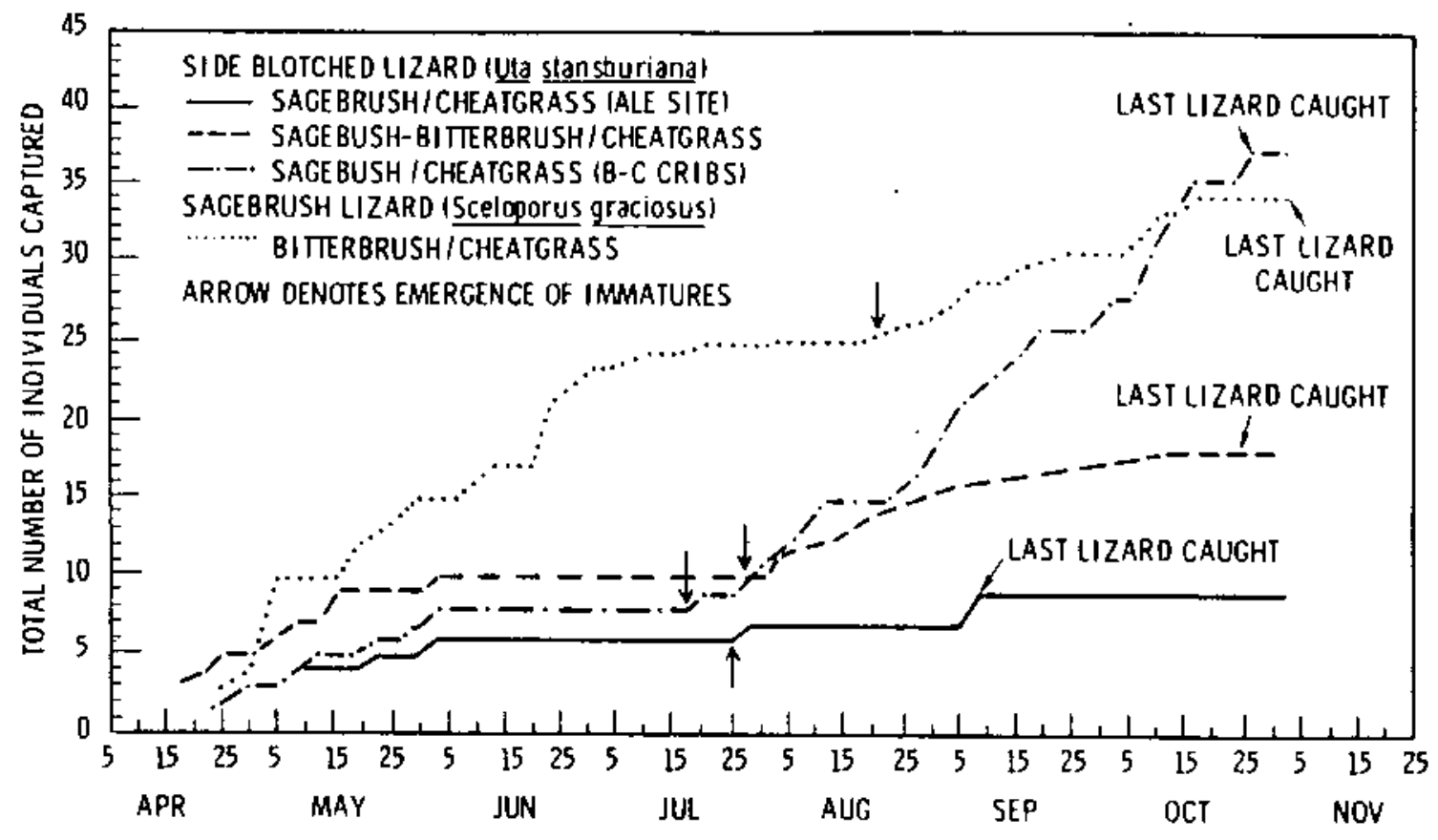

FIGURE 3.3. Seasonal Variations in Lizard Populations (Rogers and Rickard 1977)

individual lizard was $3.5 \mathrm{~g}$, density estimates ranged from 52.5 to $87.5 \mathrm{~g}$ of lizard biomass per hectare.

Amphibians on the Hanford Site are found primarily on the Columbia River shoreline and near waste ponds associated with the 200 Areas.

\subsubsection{Mamma]s}

Thirty-nine mammalian species, listed in Table 3.3, are reported to inhabit the Hanford Site; twelve of these are bats.

Small manmals have been studied intensively on the 200 Area Plateau near the B-C crib and a nearby control area (Hedlund and Rogers 1976). The Great Basin pocket mouse is by far the most pervasive species found on the Skagit/Hanford site. Table 3.4 provides the percentage composition of small mammal populations inhabiting a sagebrush-bitterbrush/cheatgrass community near the Washington Public Power Supply System's nuclear power plants and populations inhabiting a sagebrush/cheatgrass association on the 200 Area 
TABLE 3.3. Mammals of the Hanford Reservation (Rogers and Rickard 2977)

\begin{tabular}{l}
\multicolumn{1}{c}{ Common Name } \\
\hline Vagrant shrew \\
Black-tailed hare \\
White-tailed hare \\
Nuttall cottontail \\
Townsend ground squirrel \\
Northern pocket gopher \\
Great Basin pocket mouse \\
Beaver \\
Western harvest mouse \\
Deer mouse \\
Northern grasshopper mouse \\
Bushy-tailed wood rat \\
Sagebrush vole \\
Montana meadow mouse \\
Muskrat \\
Norway rat \\
House mouse \\
Porcupine \\
Coyote \\
Raccoon \\
Mink \\
Long-tailed weasel \\
Badger \\
Striped skunk \\
Bobcat \\
Mule deer \\
ETk \\
Little brown myotis bat \\
Fringed myotis bat \\
California myotis bat \\
Small-footed myotis bat \\
Hairy-winged myotis bat \\
Long-eared myotis \\
Hoary bat \\
Silvery-hajred bat \\
Big brown bat \\
Western pipistrelle bat \\
Pallid bat \\
Lump-nosed bat
\end{tabular}

Plateau. Additional data pertinent to the primary site are available in Rickard and Gano (1979).

Eight medium-sized mammals are known to inhabit the Hanford Site. These are muskrat, beaver, porcupine, jackrabbit, cottontail, coyote, badger, and 
TABLE 3.4. Percentage Composition of Small Mammal Populations Inhabiting Common Habitat Types of the Hanford Site

Habitat

\begin{tabular}{|c|c|c|}
\hline & $\begin{array}{l}\text { Sagebrush } \\
\text { Cheatgrass } \\
\end{array}$ & $\begin{array}{c}\text { Sagebrush-Bitterbursh/ } \\
\text { Cheatgrass }\end{array}$ \\
\hline $\begin{array}{l}\text { Pocket Mouse } \\
\text { (Perognathus parvus) }\end{array}$ & $93 \%(c)$ & $83 \% / 418^{(d)}$ \\
\hline $\begin{array}{l}\text { Deer Mouse } \\
\text { (Peromyscus maniculatus) }\end{array}$ & $6 \%$ & $13 \% / 65$ \\
\hline $\begin{array}{l}\text { N. Grasshopper mouse } \\
\text { (Onychomys leucogaster) }\end{array}$ & $1 \%$ & $3 \% / 15$ \\
\hline $\begin{array}{l}\text { W. Harvest Mouse } \\
\text { (Reithrodontomys megalotis) }\end{array}$ & --- & $2 \% / 8$ \\
\hline $\begin{array}{l}\text { Sagebrush vole } \\
\text { (Lagurus curtatus) }\end{array}$ & $4 \%$ & $\cdots$ \\
\hline $\begin{array}{l}\text { Mountain vole } \\
\text { (Microtus montanus) }\end{array}$ & --- & --- \\
\hline
\end{tabular}

(a) Adapted from Rogers and Rickard 1977.

(b) References adapted from WPPSS 1980.

(c) Percent of total capture; actual numbers captured not presented.

(d) Percent of total capture/actual numbers captured.

raccoon (Rogers and Rickard 1977, p. 3.10-3.11). The muskrat, beaver, and raccoon are associated with riparian habitats and the Columbia River. Porcupines occur throughout the Hanford Site but are most abundant in areas containing trees. The Columbia River shoreline and waste ponds contain trees used by this species.

Jackrabbits occur over most of the Hanford Site, and are abundant in the primary site. This species has been documented as a vector of radioactive materials away from waste burial sites. During the late 1950 s or early $60 \mathrm{~s}$, burrowing animals (probably badgers or coyotes) exposed buried radioactive salts, creating a salt lick for other wild life species. Jackrabbits were attracted to this salt lick and thus injested radioactivity. This radioactive material was excreted in urine and deposited as fecal pellets over distances 
up to $1.6 \mathrm{~km}$ from the waste burial sites (0'Farrell et aT. 1973). Uresk et a7. (1975) provide data on the foods eaten by jackrabbits.

Cottontail rabbits occur throughout the 200 Area Plateau (Rogers and Rickard 1977, p. 3.11). They are less abundant than jackrabbits and are associated more with riparian habitats and irrigated areas. They are conmonly associated with the irrigated lawns of the 100-N Area.

Coyotes and badgers are often observed on the primary site. They both dig burrows and are potential agents for uncovering buried radioactive wastes. Both species feed primarily on small manmals. Springer (1977) and Stoel (1976) provide information on movement patterns and food habits of coyotes. Coyote movements vary seasonally, with individuals sometimes being very limited in range while at other times their movements are extensive. The foods of coyotes are predominately small rodents (Great Basin pocket mice, microtines) and lagomorphs.

Two large mammals, the mule deer and elk, occur on the Hanford Site. Elk are found primarily on the ALE reserve (Rattlesnake Hills) while deer range over the entire site. Oeer are abundant within certain habitats, especially aiong the Columbia River, near Gable Mountain, and in Snively Canyon. The Hanford herd is not totally confined to the site boundaries; one deer was shot by a hunter $113 \mathrm{~km}$ north of the Hanford Site (Eberhardt et al. 1979).

Oietary habits of Hanford deer are reported by Uresk and Uresk (1980). They identified 44 food items in fecal pellets. The composition of pellets collected for three study sites on the 200 Area Plateau are iisted in Table 3.5. These data suggest that mule deer inhabiting the Hanford Reservation can serve as a pathway for movement of radioactive material from low-Tevel radioactive waste management areas to man. Uresk and Uresk (1980) found maximum levels of ${ }^{137} \mathrm{Cs}$ in fecal pellets of $100 \mathrm{pCi} / \mathrm{g}$ and $128 \mathrm{pCi} / \mathrm{g}$ for the B-Pond and Gable Mountain Pond areas, respectively. Maximum ${ }^{90} \mathrm{Sr}$ values found in deer pellets at 8-Pond were $107 \mathrm{pCj} / \mathrm{g}$ and $184 \mathrm{pCi} / \mathrm{g}$ at Gable Mountain Pond. These values indicate that mule deer can consume radioactive materials through forage plants growing in radioactive waste management sites. 


\section{TABLE 3.5. Botanical Composition of Fecal Pellets Collected from Mule Deer During 1976 from Three Habitats on the Hanford Site (Uresk and Uresk 1980)}

Crasses and Grass-like PTants

Needle-and-thread (Stipa comata)

Sandberg bluegrass (Poa sandbergii)

Bivebunch wheatgrass (Agropyron spicatum)

Canary grass (Phalaris arundinacea)

Three-awn (Aristida spp.)

Cheatgrass (Bromus tectorum)

Carex (Carex spp.)

Horsetail (Equisetum spp.)

Barnyard grass (Echinochloa crusgallii)

Muhly grass (MuhTenbergia sp.)

Indian ricegrass (Oryzopsis hymenoides)

oid withchgrass (Panicum sp.)

Cattail (Typha latifolia)

Sand dropseed (Sporobolus cryptandrus)

Forbs

Astragalus (Astragalus spp.)

Bassia (Bassia hyssopsfolia)

Tansy mustard (Descurainia pinnata)

wild lettuce (Lactuca serriola)

Bladderpod (Lesquerrella sp.)

Lupine (Lupinus spp.)

White sweet clover (Melitotus alba)

Microsteris (Microsteris sp.)

Evening-primrose (Oenothera spp.)

Phlox (Phlox longiflora)

Prickly pear (Opuntia polycantha)

Indian wheat (Plantago purshii)

Witlow-weed (Epilobium paniculatum)

Russian thistle (Salsola kali)

jim Hill mustard (Sisymbrium altissimum)

Coldenrod (Soldidago spp.)

Ciobe mallow (Sphaeralcea munroana)

Buttercup (Ranunculus sop.)

Common mullen (Verbascum thapsus)

Shrubs

Big sagebrush (Artemisia tridentata)

Bitterbrush (Purshia tridentata)

Cray Rabbitbrush (Chrysothamnus nauseosus)

Hopsage (Atriplex spinosa)

willow (Salix spp.) $\bar{x} \pm S E \quad \bar{x} \pm S E \quad \bar{x} \pm S E$

$<0.5$

$<0.5$

$0.6 \pm 0.3<0.5$

$<0.5$

$0.6 \pm 0.6$

$<0.5$

$<0.5$

$1.7 \pm 0.6$

$3.4 \pm 1.1$

$<0.5<0.5$

$<0.5 \quad 2.1 \pm 1.1$

$6.8 \pm 1.3$

$<0.5$

$<0.5$

$<0.5<0.5$

$<0.5$

$<0.5$

$<0.5<0.5 \quad 1.9 \pm 1.7$

$4.4 \pm 1.6$

$<0.5$

$1.9 \pm 0.7$

$<0.5$

$3.5 \pm 2.2^{(a)}$

$<0.5<0.5$

$23.2 \pm 3.9$

$<0.5$

$8.7 \pm 3.5 \quad 0.9 \pm 0.7<0.5$

$<0.5$

$<0.5$

$2.9 \pm 0.7 \quad 75.5 \pm 4.0 \quad 5.2 \pm 2.2$

$<0.5$

$1.4 \pm 0.4^{(\text {a })} \quad 6.1 \pm 1.9 \quad 39.7 \pm 5.4$

$<0.5 \quad 10.9 \pm 4.4 \quad 1.8 \pm 1.0$

(a)

$1.9 \pm 1.9$

$<0.5$

$79.4 \pm 7.3 \quad 2.2 \pm 2.2$

$<0.5$

$<0.5$

$18.1 \pm 5.8^{(\mathrm{a})} \quad 8.3 \pm 2.8 \quad 32.3 \pm 5.3$

a. These plants are not expected to occur in the $B-C$ Cribs area, which indicates deer moutd move into this area primarily from the B Pond site. 


\section{TABLE 3.5. (contd)}

B-C Cribs $(N-20)$

B Pond $(1+40)$

Cable Pond $(N=40)$

Trees

Russian Olive (Elaeagnus angustifolia)

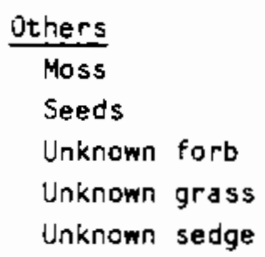

\section{1 .3 .4 Birds}

The primary site is totally dry land and thus provides no habitat for birds associated with wetland habitats. Rogers and Rickard (1977) 1ist only 29 species known to breed in the shrub-steppe habitat of the Hanford Reservation (Appendix A). Three additional species were listed as winter residents. Only three of the breeding species are abundant enough to be considered an important part of the functioning of the shrub-steppe ecosystem. These include the horned lark, western meadow lark and sage sparrow. The sage sparrow is rare in the primary site, due to the low density of big sagebrush, an important plant necessary for nesting.

The low numbers of species present limits the complexity of the primary site bird community. This lack of complexity is probably due to the hot, dry summers and cold, wet winters characteristic of Hanford. Rickard and Gano (1979) provide some additional data on relative abundances of birds near the primary site. Their study was conducted adjacent to the Washington Public Power and Supply System's nuclear power plants 1 and 4 . It indicated that the three most common breeding bird species were the western meadowlark, horned larks and white-crowned sparrows which were abundant during the winter. Sage sparrows were common, but less than half as abundant as the former species. Surveys revealed that the next most abundant species were loggerhead shrike, common nighthawk, mourning dove, burrowing owl, and long-billed curlew. 


\subsubsection{Important Species of the Skagit/Hanford Site}

A species is considered to be "important" if one or more of the following criteria applies: 1) the species is commercially or recreationally valuable, 2) the species is threatened or endangered, 3) the species affects the well-being of some important species within the first two criteria, and 4) the species is critical to the structure and function of the ecological system or is a biological indicator of radionuclides in the environment (U.S. NRC 1976, pp. 2.3-2.4).

The only important species providing sport hunting is the mule deer. Other huntable species occur on the primary site (i.e. cottontail, chukar, pheasant, California quai1, mourning dove) but in low numbers, and are not Tikely to travel offsite where they would be available to hunters. Eberhardt et al. (1979) reveal that deer from Hanford do travel offsite and are occasionally shot by hunters.

Mule deer are also the most important species to consider regarding transfer of radioactivity to man. Eberhardt et al. (1982) provide a discussion of the potential transfer of radionuclide contaminated deer meat to man. There appears to be "little potential for ingestion by man of ${ }^{137}$ Cs originating from the 200 Areas."

Several animal species have been involved in the nuisance spread of radioactivity on the Hanford Site. Section 3.1.3.3 of this report discusses mammalian species. Fitzner et al. (1980) report on several cases where birds of prey injested contaminated prey and carried their remains to the bird nest site or roosting area.

\subsubsection{Unique and Sensitive Habitats of the Skagit/Hanford Site}

The primary site has been examined for rare and endangered plant and animal species. Two plant species listed as sensitive ${ }^{(a)}$ by the Washington

(a) The designation "sensitive" includes species with small populations or localized distribution within the state whose populations and habitats will be jeopardized if current land use practices continue. 
Natural Heritage Program (1981) are Astragalus sclerocarpus and Cryptantha leucophaea; these plants occur in the primary site (PSP\&L 1981). These species occur in sandy habitats such as sand blowouts. These habitats are important to the preservation of these plant species.

Three pairs of nesting curlews were observed at two locations on the primary site (PSP\&L 1981). Curlews utilize shortgrass habitats dominated by cheatgrass and Poa. These habitats are not unique botanically; however, the integrity of the plant community is important for curlew nesting. The long-billed curlew is a candidate for threatened or endangered status by the U.S. Fish and Wildlife Service (Federal Register, 50 CFR Part 17, 1982). Nesting areas should be afforded protection due to the rarity of this species.

\subsubsection{Threatened or Endangered Species of the Primary Site}

The only federally listed threatened or endangered species known to occur on the primary site is the bald eagle (Haliaeetus leucacephalus alascanus). Three species common to the Hanford Site--the Swainson's Hawk (Buteo swainsoni), ferruginous hawk (Buteo regalis) and long-billed curlew (Numenius americanus)--are being reviewed for listing as threatened or endangered species (Federal Register, 1982). The Swainson's hawk and long-billed curlew are common on the primary site and nest within it.

Species of concern to the Washington State Department of Game, and which are known to occur on the Skagit/Hanford Site, are listed in Table 3.6 .

\subsubsection{Plants and Habitat Description of the Firehouse Site}

The sagebrush/cheatgrass-sandberg-bluegrass plant community occurs over most of the proposed secondary site. This plant community is dominant over most of the 200 Area Plateau (Rogers and Rickard 1977). A list of plants occurring on the 200 Area Plateau was compiled by Price and Rickard (1973), and additional species were identified by $C l$ ine et al. (1975). These species are listed in Appendix A. Climatic influences, fire, man's past activities and microtopography alter structure of vegetation in the secondary site. Scars from past fires, vehicle traffic, and grazing have altered plant communities by favoring cheatgrass (Bromus tectorum).

Microhabitat influences are evident on the northeast end of the firehouse site. This part of the site includes a portion of a 600 -acre area of knob and kettle 
TABLE 3.6. Animal Species of Concern for Washington State (Washington State Department of Game 1983)

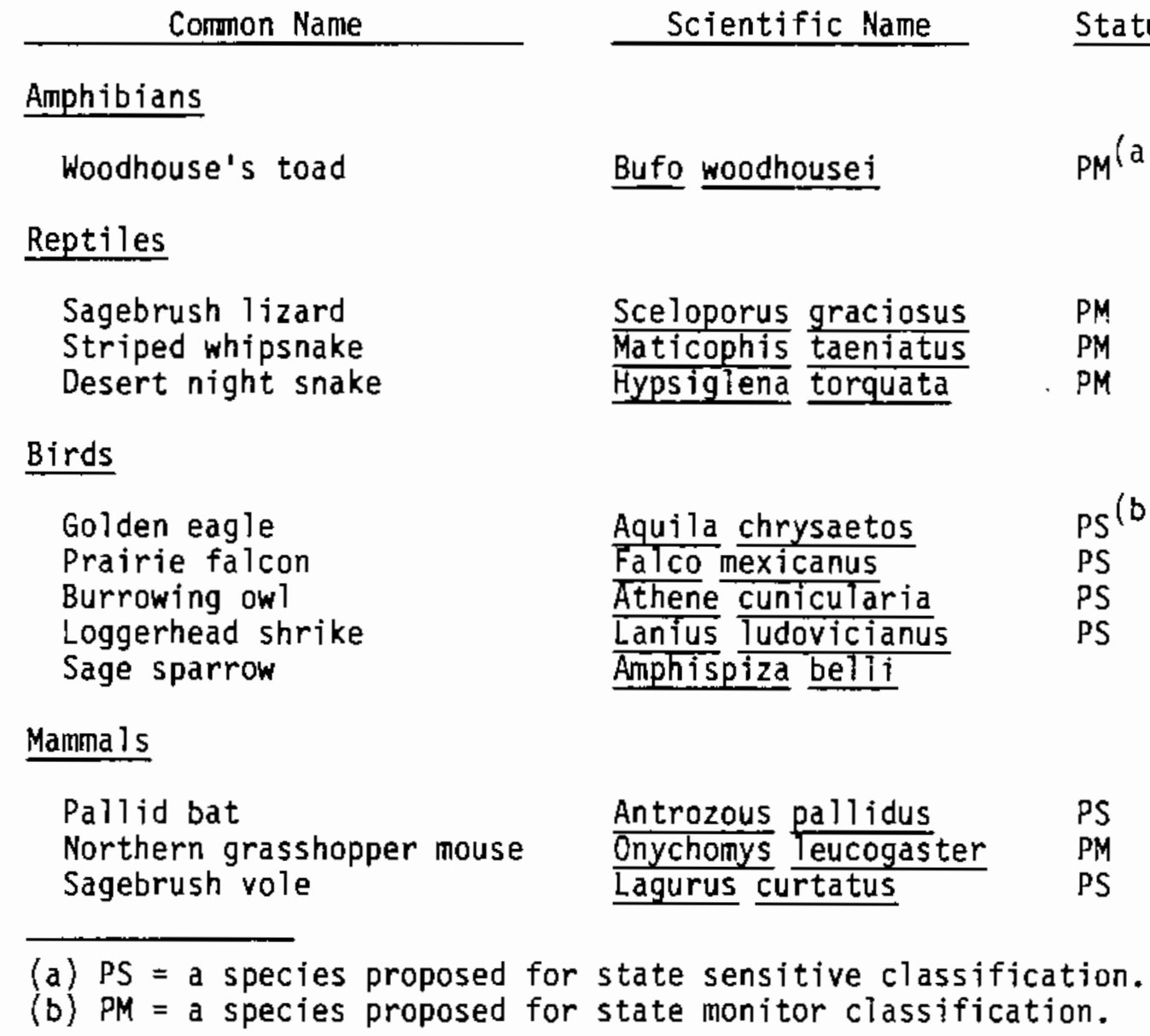

topography. Rickard (1975) described this site as a thin veneer of fine textured soil mixed with large amounts of river-washed gravels, cobbles, and boulders. These knobs rise 15-20 feet higher than the swales or kettles. This topography scarcely reaches the proposed secondary site, but is worth mentioning due to the influence it may have on vegetation structure and plant community composition. Table 3.7 lists the species composition, canopy-cover and frequency of vascular plants in the undulating topography.

\subsubsection{Soils of the Firehouse Site}

The soils associated with the secondary site are sandier than soils at higher elevations on the Hanford Reservation (Hajek 1966). The sandy soils 
TABLE 3.7. Species Composition, Canopy-cover and Frequency of Vascular Plants on Gently Undulating Topography Typical of Firehouse Site (Rickard 1975)

\begin{tabular}{|c|c|c|c|}
\hline & Species & $\propto$ Frequency & \% Cover \\
\hline Cheatgrass & Bromus tectorum & 100 & 39 \\
\hline Sandberg's Bluegrass & Poa sandbergii & 100 & 17 \\
\hline Microsteris & Miscrosteris gracilis & 48 & 1 \\
\hline Jim Hill Mustard & Sisymbrium altissimum & 16 & 2 \\
\hline Draba & Draba verna & 28 & 0.7 \\
\hline Tansy Mustard & Desurainia pinnata & 48 & 1 \\
\hline Russian Thistle & Salsola Kalj & 48 & 1 \\
\hline Total Cover $\%$ & & --- & 62 \\
\hline
\end{tabular}

(a) seedlings

have low water holding capacity and limited cation exchange capacity. The low water holding capacity provides for deeper penetration of water than would occur if the soils were less sandy. On the Hanford Reservation, water penetration seldom exceeds $g$ feet. Because plant roots rarely grow in the absence of moisture, one can expect that roots will not penetrate much beyond this 9-foot level (Rickard and Klepper 1976). The low cation exchange capacity of the soils reveal that only small quantities of minerals are held in the root zone for plant growth and thus play only a minor role in growth.

The dispersal of radioactive wastes can potentially occur through resuspension by wind, especially with soils that are very sandy, wind erodible, and where vegetation cover is sparse, and by action of soil water.

\subsubsection{Wildlife of the Firehouse Site}

\subsubsection{Invertebrates}

The most comprehensive study dealing with the insects most likely associated with shrubs on the secondary site was conducted several miles south on the 200 Area Plateau (Rogers 1979). In this report, insect taxa collected 
from sagebrush, rabbitbrush, and hopsage are listed according to their relative abundance (Table 3.1). Rogers (1978) also provides abundance data for darkling beetles, an important group of ground dwelling beetles common throughout the Hanford Reservation (Appendix A). The darkling beetle data were collected nearby on the 200 Area Plateau at the B-C Crib waste burial site and the REDOX pond area. Grasshopper abundance was examined at these same sites; data on population density for 16 species are found in Appendix A.

\subsubsection{Reptiles and Amphibians}

The reptiles and amphibians at both the primary and secondary sites are expected to be comparable and typical of those found throughout the Hanford Reservation. Section 3.1.3.2 provides a discussion of the reptiles and amphibians of the Hanford Reservation; Table 3.2 provides a list of species observed.

\subsubsection{Mammals}

A good discussion of the mammals expected on the Firehouse Site is presented in Section 3.1.3.3 of this report.

\subsubsection{Birds}

Section 3.1.3.4 of this report provides a discussion of the bird species known to inhabit the shrub-steppe habitat of the Hanford Reservation. Table A. 8 provides a list of 32 species of birds present during the different seasons of the year.

\subsubsection{Important Species of the Firehouse Site}

Important species of the Firehouse Site are the same as those of the Skagit/Hanford Site. These are discussed in Section 3.1 .4 of this report.

\subsubsection{Unique and Sensitive Habitats of the Firehouse Site}

No unique or sensitive habitats are known to occur directly within the Firehouse site. This site, however, has not been thoroughly examined for rare or endangered plant species. Thus, small pockets of habitat containing a rare and endangered plant may be present. Field reconnaisance is suggested for 1984. The area should be walked by several botanists skilled at identifying rare species. 


\subsubsection{Threatened or Endangered Species of the Firehouse Site}

Section 3.1.6 of this report lists the federally threatened or endangered species that occur on the Hanford Reservation. That discussion applies also to the secondary site wildlife species.

\subsection{AQUATIC ECOLOGY}

\subsubsection{Habitats}

The Columbia River is the major surface water and aquatic habitat on the Hanford Reservation. The physical and hydrological characteristics of the Columbia are described in Section 5.1.1 of this report.

Other surface waters on the Hanford Site include several artificial ponds and ditches used for the disposal of low-level radioactive liquid wastes, certain industrial pollutants, and process cooling water (U.S. ERDA 1975, p. 11.3-16). These waters are located mainly in or near the 200 Areas. They lie northwest of the Skagit/Hanford Site and to the south of the Firehouse Site. The major aquatic habitats are Gable Mountain Pond, B-Pond, U-Pond, and West Pond (Figure 3.4). The physical and chemical characteristics of these ponds are given in Table 3.8 and their dimensions are shown in Figures 3.5 through 3.8 .

Gable Mountain Pond, shown in Figure 3.5, is the largest [ 71 acres (28.7 ha)] and was created in 1957 to receive cooling water from the PUREX Plant in 200 West Area. It contains low levels of actinides and mixed fission products.

B-Pond was constructed in 1945 to receive cooling water from 200 East encapsulation facility and the PUREX plant. This pond, shown in Figure 3.6, has an area of about 40 acres ( 16.2 ha) and contains small amounts of actinides and mixed fission products.

U-Pond (Figure 3.7) has an area of 14 acres ( $5.7 \mathrm{ha}$ ) and was built in 1944 to receive low-level liquid effluents from plutonium processing facilities. It has also received contaminated laundry effluents and 


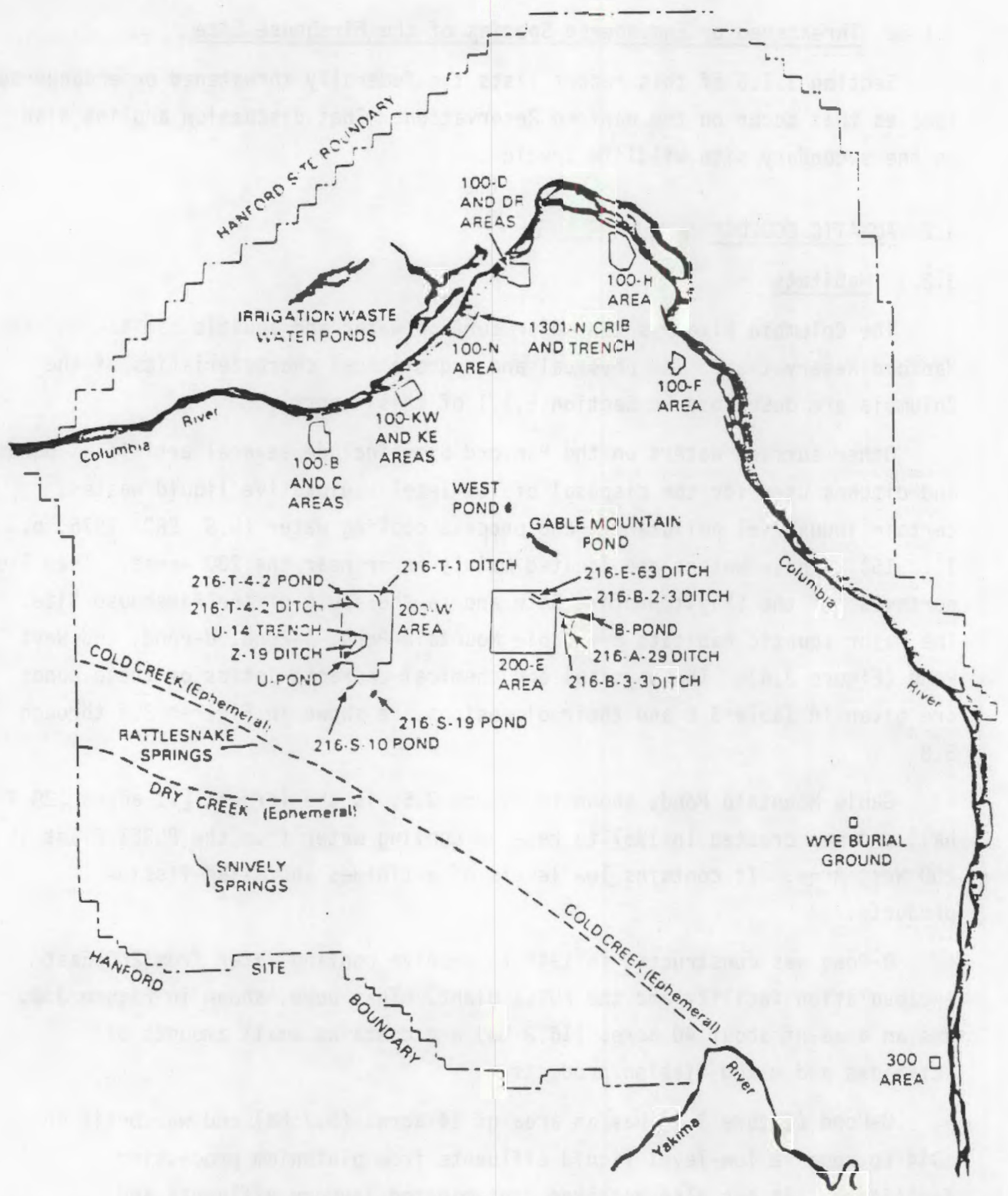

FIGURE 3.4. Surface Water Bodies Including Ephemeral Streams on the Hanford Site (U.S. DOE 1982; Meinhardt and Frostenson 1979) 
TABLE 3.8. Physical and Chemical Characteristics of Ponds on the Hanford Site (Emery and McShane 1980)

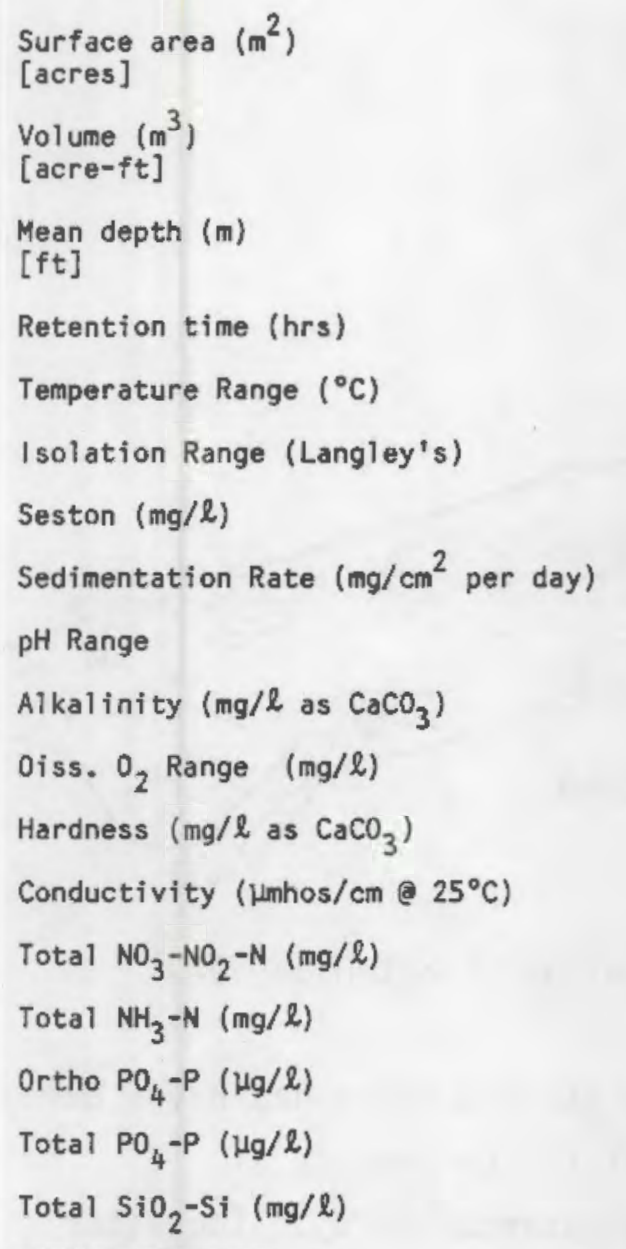

\begin{tabular}{|c|c|c|c|}
\hline Gable Pond & B-Pond & U-Pond & West Pond \\
\hline $\begin{array}{l}287,300 \\
{[71.0]}\end{array}$ & $\begin{array}{l}149,200 \\
{[36.9]}\end{array}$ & $\begin{array}{l}56,700 \\
{[14.0]}\end{array}$ & $\begin{array}{l}77,800 \\
{[19.2]}\end{array}$ \\
\hline $\begin{array}{l}431,000 \\
{[350]}\end{array}$ & $\begin{array}{l}233,200 \\
{[190]}\end{array}$ & $\begin{array}{l}22,700 \\
{[18,4]}\end{array}$ & $\begin{array}{l}31,100 \\
{[25.1]}\end{array}$ \\
\hline $\begin{array}{l}1.5 \\
{[4.9]}\end{array}$ & $\begin{array}{l}1.6 \\
{[5.2]}\end{array}$ & $\begin{array}{l}0.4 \\
{[1.3]}\end{array}$ & $\begin{array}{l}0.4 \\
{[1.3]}\end{array}$ \\
\hline $504 \pm 211$ & $424 \pm 183$ & $37 \pm 4$ & $\ldots(a)$ \\
\hline $0-25.3$ & $0-25.0$ & $0-28.4$ & $0-25.5$ \\
\hline $20-253$ & $20-253$ & $20-253$ & $20-253$ \\
\hline $14.5 \pm 10.9$ & $12.2 \pm 17.4$ & $24.0 \pm 8.9$ & $21.6 \pm 9.6$ \\
\hline $2.43 \pm 0.76$ & $0.81 \pm 0.51$ & $2.24 \pm 1.42$ & $11.20 \pm 6.50$ \\
\hline $7.8-8.7$ & $7.0-9.0$ & $7.0-9.5$ & $9.7-10.0$ \\
\hline $58.4 \pm 6.1$ & $57.1 \pm 4.8$ & $95.2 \pm 6.5$ & $9009 \pm 1923$ \\
\hline $7.9-12.7$ & $8.1-13.8$ & $9.0-13.00$ & $8.0-13.8$ \\
\hline $67.4 \pm 6.0$ & $68.0 \pm 4.2$ & $72.4 \pm 14.1$ & $121.8 \pm 7.6$ \\
\hline $1327 \pm 104$ & $1251 \pm 170$ & $1553 \pm 132$ & $229,698 \pm 42,292$ \\
\hline $0.18 \pm 0.07$ & $3.65 \pm 1.33$ & $0.28 \pm 0.08$ & -- \\
\hline $0.38 \pm 0.10$ & $1.04 \pm 0.51$ & $0.45 \pm 0.20$ & $2.61 \pm 0.40$ \\
\hline $1.0 \pm 0.1$ & $4.5 \pm 4.2$ & $57.8 \pm 25.1$ & $2050 \pm 180$ \\
\hline $38.0 \pm 10.0$ & $40.0 \pm 10.0$ & $123.0 \pm 56.0$ & $2160 \pm 140$ \\
\hline $0.99 \pm 0.22$ & $1.53 \pm 0.41$ & $0.80 \pm 0.43$ & $0.23 \pm 0.21$ \\
\hline
\end{tabular}

(a) No data available

Note: Means are shown with $95 \%$ confidence values (i.e., mean \pm confidence value $=95 \%$ confidence interval about the mean).

evaporator water. The radioactive materials in this pond include transuranic elements and other actinides, along with activation and mixed fission products.

The ponds and ditches in the 200 Areas have contributed to the rise in the water table; West Pond (Figure 3.8) was created in 1957 by the flooding 


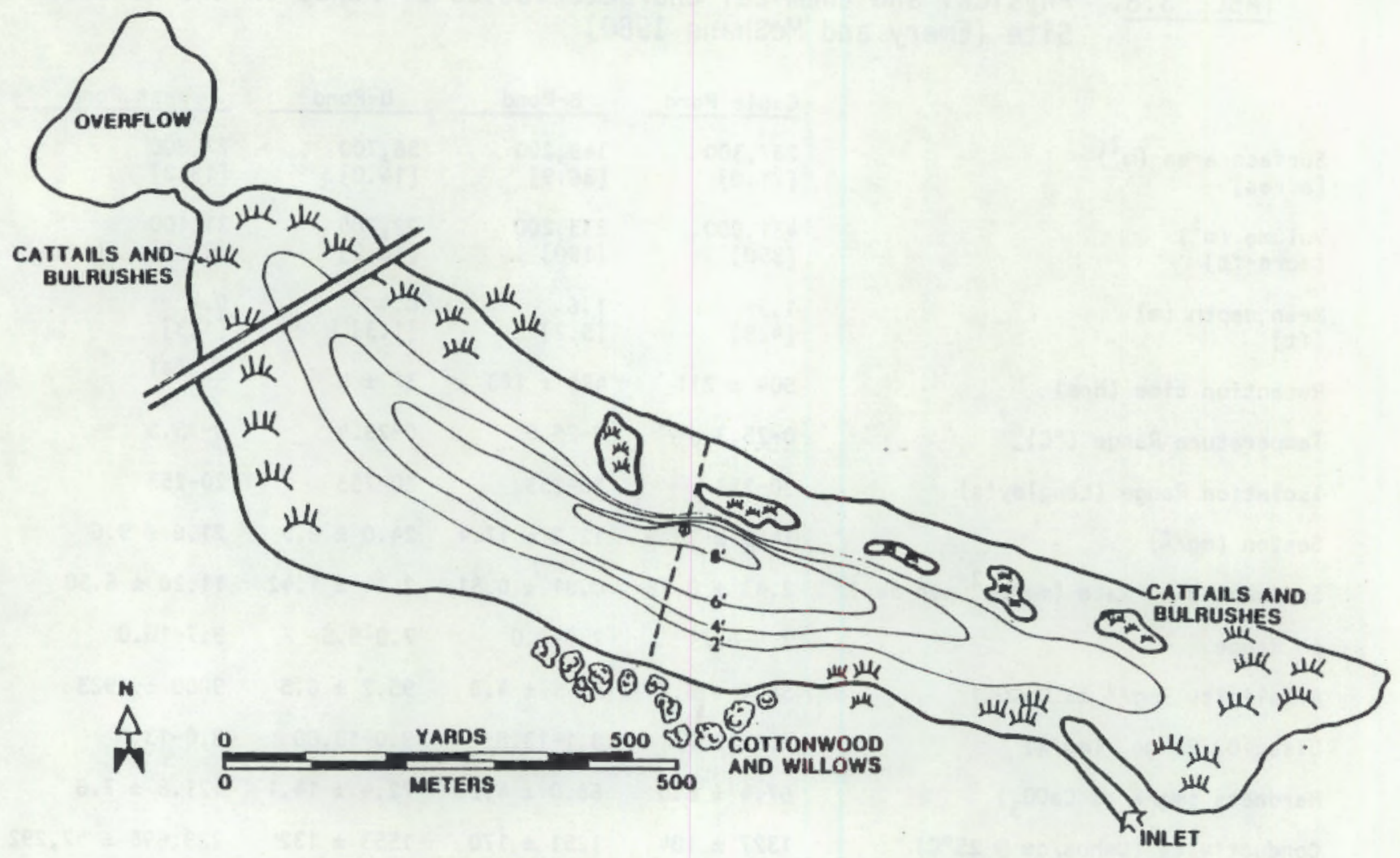

FIGURE 3.5. Gable Mountain Pond (Meinhardt and Frostenson 1979)

of a depression by groundwater. Wastewater from the 200 Areas has never been discharged directly to this pond but it does contain low amounts of radioactivity of unknown origin (Meinhardt and Frostenson 1979). The water quality of this pond differs from that of the other ponds in its much higher conductivity, alkalinity, phosphorous levels, and pH (see Table 3.8). The area of West Pond is about 19 acres (7.7 ha).

Rattlesnake Springs on the western side of the Hanford Reservation forms a small surface stream that flows for about $2.5 \mathrm{~km}(1.6 \mathrm{mi})$ before disappearing into the ground, as a result of seepage and evapotranspiration. Base flow of this stream is about $0.01 \mathrm{~m}^{3} / \mathrm{sec}(0.4 \mathrm{cfs}$ ) (Cushing and Wolf 1982 , p. 404). Water temperature ranges from 2 to $22^{\circ} \mathrm{C}\left(36\right.$ to $\left.72^{\circ} \mathrm{F}\right)$. Mean annual total alkalinity (as $\mathrm{CaCO}_{3}$ ), nitrate nitrogen, phosphate phosphorous, and total dissolved solids are 127, 0.3, 0.18, and $217 \mathrm{mg} / 1$ (Cushing et al. 


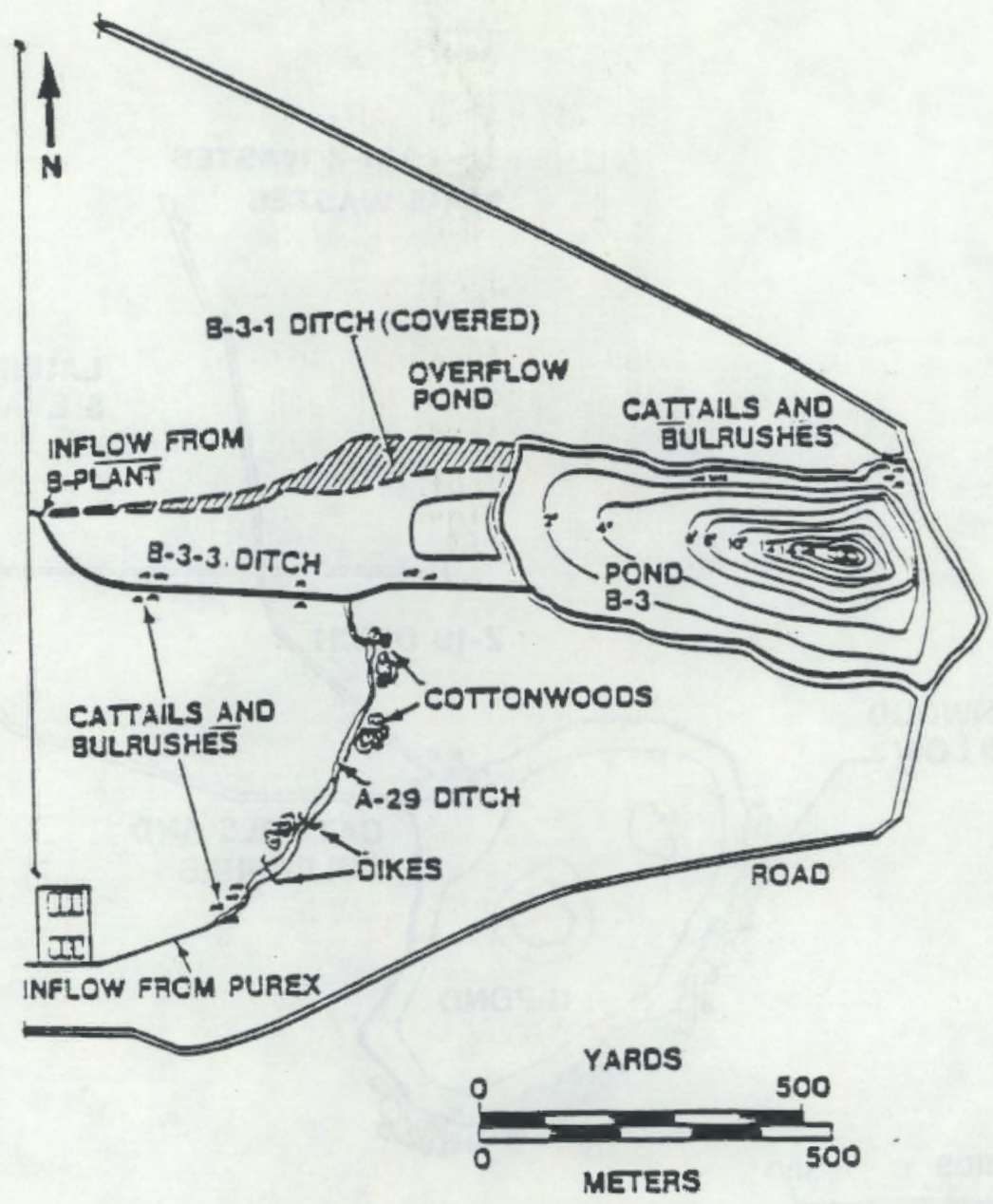

FIGURE 3.6. B-Pond, and B-3-3 and A-29 Ditches (Meinhardt and Frostenson 1979)

1980; Cushing and Wolf in press). The sodium content of the spring water is about 7 ppm (Brown 1970, p. 27).

\subsubsection{Plants and Invertebrates of the Hanford Reach}

Two groups of aquatic biota--plankton and benthic organisms--are discussed in this section.

\subsubsection{Plankton}

Plankton populations in the flowing Hanford Reach of the Columbia River are generally divided into four communities:

- phytoplankton - small, mostly microscopic aquatic plants (e.g., photosynthetic organisms) floating or drifting in the water column. 


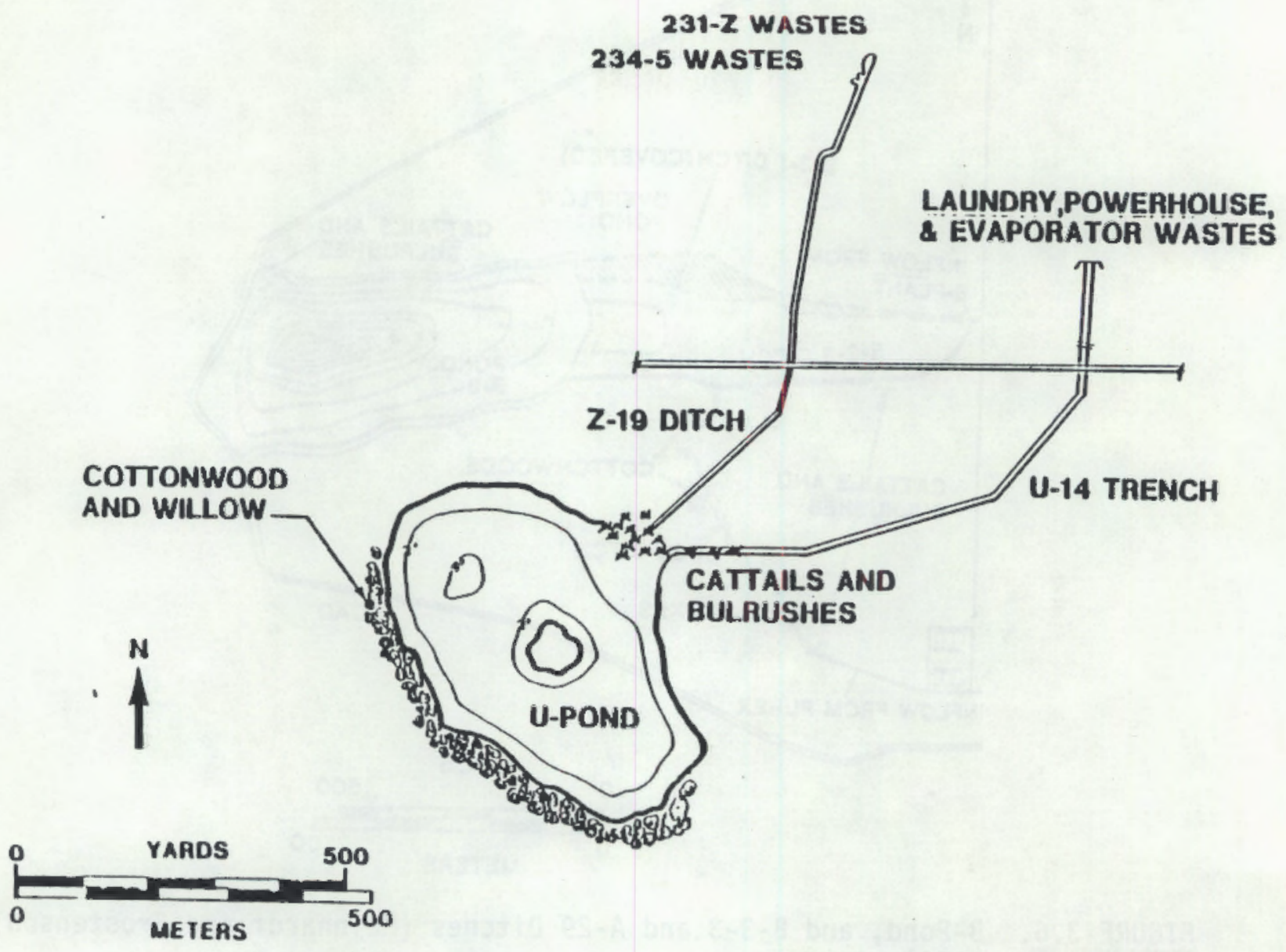

FIGURE 3.7. U-Pond, and Z-19 and U-14 Ditches (Meinhardt and Frostenson 1979)

- periphyton - a mixture of organisms, usually small but densely set, attached to underwater substrates, objects, or rooted aquatic plants associated with the river bottom or margins. This community is not planktonic but contributes to the phytoplankton in the Hanford Reach.

- macrophytes - large, mostly macroscopic aquatic plants (e.g., photosynthetic organisms), usually rooted to the river bottom or margins, and either submerged, emergent or floating. Again, this group is not part of the plankton, but is included here for case in discussion. 

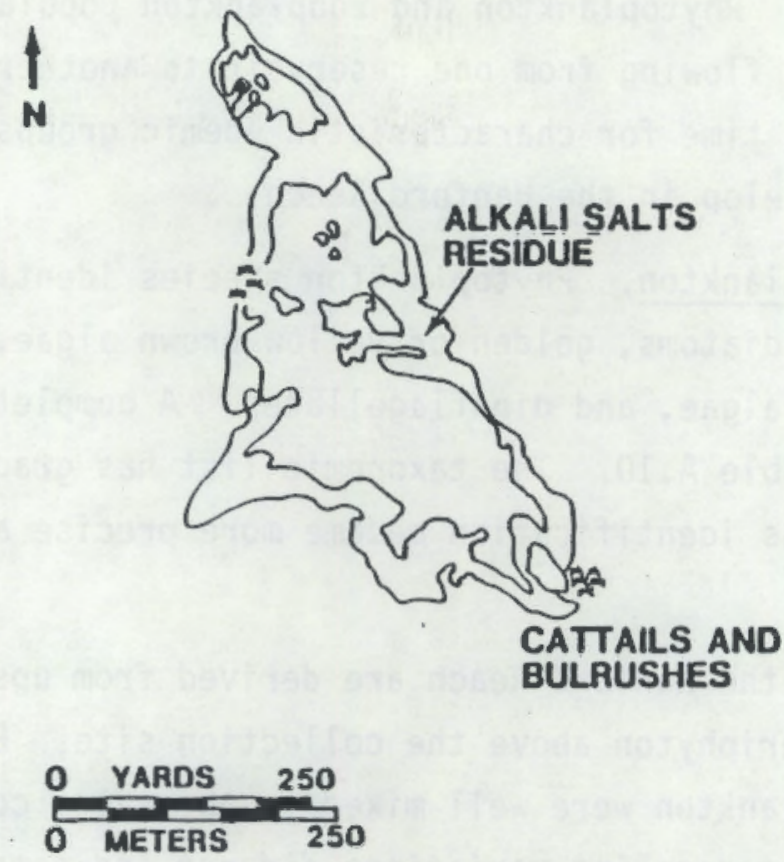

FIGURE 3.8. West Pond (Meinhardt and Frostenson 1979)

- zooplankton - small, mostly microscopic animals (e.g., nonphotosynthetic) floating or drifting in the water column.

Plankton populations generally represent a low-trophic level in aquatic ecosystems, and are predominately primary producers. However, lower trophic levels must obtain their energy from exogenous and/or endogenous sources. Streams in general, and espeically smaller ones, depend greatly on allochthonus (outside the system) input of organic matter to drive the energetics of the system. Large rivers, particularly the present-day Columbia River with its interconnected reservoir series, contain a large population of autochthonus (inside the system) primary producers such as phytoplankton and periphyton that contribute the basic energy needs (WPPSS 1977, p. 2.2-3 and 4). The primary producers, in turn, are utilized by secondary producers (e.g., benthic invertebrates, zooplankton, and fish).

Plankton populations in the Hanford Reach are influenced by communities that develop in the reservoirs of upstream dams, particularly Priest Rapids Reservoir, and manipulation of water levels, below by dam operations in 
downstream reservoirs. Phytoplankton and zooplankton populations at Hanford are largely transient, flowing from one reservoir to another. There is generally insufficient time for characteristic edemic groups of phytoplankton and zooplankton to develop in the Hanford Reach.

\subsection{Phytoplankton. Phytoplankton species identified from the} Hanford Reach include diatoms, golden or yellow-brown algae, green algae, blue-green algae, red algae, and dinoflagellates. A complete list of these species is shown in Table A.10. The taxonomic list has gradually increased over the last decade as identification became more precise and less common species were added.

Phytoplankton in the Hanford Reach are derived from upstream reservoirs and from periphyton above the collection site. Early studies indicated that phytoplankton were well mixed in the water column in the Hanford Reach, and that sampling variations did not indicate meaningful differences in the phytoplankton community (Wolf et al. 1976, p. 2-9). Thus, phytoplankton sampling is not a problem in terms of station or depth.

Diatoms (Chrysophyta, Bacillariophyceae) is the dominant algal group in the Columbia River, usually representing over $90 \%$ of the algae (PSP\&L 1981, p. 2.2-17; WPPSS 1977, p. 2.2-4; Neitzel et a1. 1982a, p. 498). The main genera include Asterionella, Cyclotella, Fragilaria, Melosira, Stephanodiscus and Synedra (Neitzel et al. 1982a, p. 498). Diatoms not only contribute the greatest number of species, but account for the highest percentage of total unit densities among the major algae divisions (Table A.11).

The diatoms of the phytoplankton community in the Hanford Reach are dominated by lentic forms that originate in upstream impoundments. The phytoplankton also contains a number of species derived from the periphyton or sessile algae. Daily fluctuations of water level from the operation of Priest Rapids Dam above the Hanford Reach (Becker et al. 1981, Figure 8; Fickeisen et al. 1980a, p. 4-24) may explain the presence of many periphytic algae in phytoplankton drift samples. Periphytic algae attached to rocks and other substrates along the river margin may be exposed when water levels fall, 
become partially dried, and then detach and be carried away when the water level rises.

Green algae (Chloroplyta) and blue-green algae (Cyanophyta) occasionally occur in the phytoplankton community during warmer months, but in substantially fewer numbers than the diatoms. Characteristically, the composition of phytoplanktonic species will vary from season to season and from year to year as indicated in Figure 3.9.

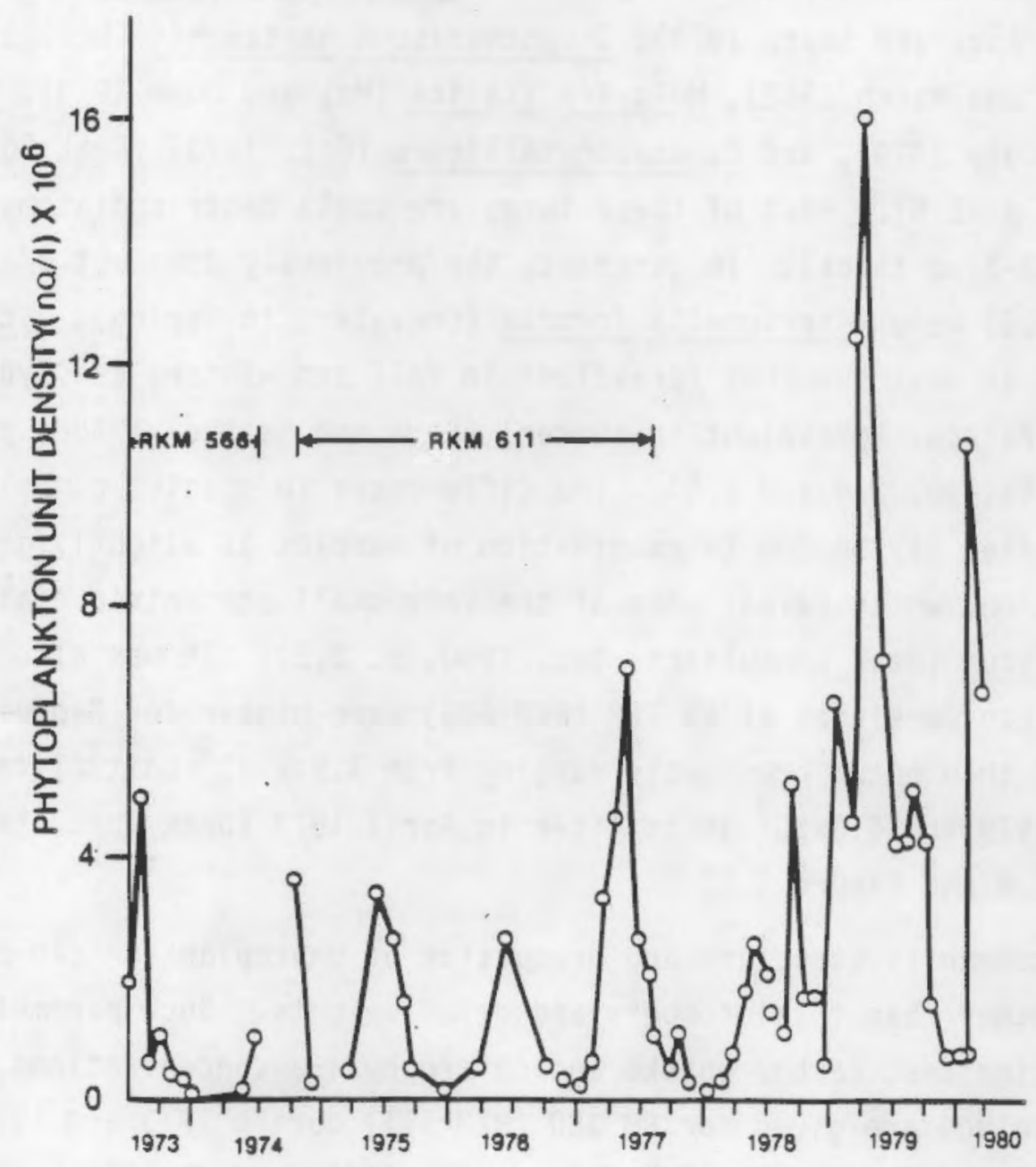

FIGURE 3.9. Phytoplankton Unit Densities in the Hanford Reach of the Columbia River, September 1974 - March 1980. Data from September 1974 through July 1978 from Page and Neitzel (1978) and Page et a1. (1979); from September 1978 through March 1980 from Beak Consultants, Inc. (1980) 
The spring pulse in phytoplankton density is probably related to increasing light and water temperature rather than to availability of nutrients as $\mathrm{PO}_{4}$ and $\mathrm{NO}_{3}$ (WPPSS 1977, p. 2.2-4; PSP\&L 1981, p. 2.2-17). Although these nutrients decrease in the spring due to both phytoplankton uptake and increased dilution associated with spring flows, they do not appear to decrease to concentrations limiting growth of algae at any time of the year (loc. cit.).

The most recent data on phytoplankton in the Hanford Reach were collected at RM 352 (RKM 566) from September 1978 to March 1980. During this period the five most abundant species of algae were Cyclotella glomerata (Sept., Oct. and Nov. 1978; Aug. and Sept. 1979), Stephanodiscus hantzschii (Dec. 1978; Apr., Jan., Feb. and March 1980), Melosira italica (May and June 1979), Cyclotella camensis (July 1979), and $\underline{C}$. pseudostelligera (Oct. 1979) (Beak Consultants Inc. 1980 , p. 2.5). Most of these forms are small centric diatoms (5-15 $\mu \mathrm{m}$ diameter, 2-3 $\mu \mathrm{m}$ thick). In contrast, the previously dominant diatoms, at RM 352 (RKM 566) were Asterionella formosa (prevalent in spring), Cyclotella spp. (prevalent in most summers) (prevalent in fall and winter) and Synedra spp. and Melosira spp. (prevalent in summer) (Page and Neitzel 1978a, p. 2.5; Page et al. 1979a, pp. 2.4 and 2.5). The differences in species composition in recent studies may be due to examination of samples at slightly greater magnification, which reveal more of the very small concentric diatoms such as Stephanodiscus (Beak Consultants Inc. 1980, p. 2.5). It was also noted that phytoplankton densities at RM 352 (RKM 566) were higher for September 1978 to March 1980 than noted previously ranging from $7.9 \times 10^{5}$ units/liter in November 1979 to $16.0 \times 10^{6}$ units/liter in April 1979 (Beak Consultants Inc. 1980 , p. 2.5 and Figure 2.1).

The community structure and production of phytoplankton can be measured in units other than total numbers and dried weights. Such parameters include diversity indices, carbon uptake and chlorophyll a concentrations. Information on these values are given for RM 380 (RKM 611) during 1973 and 1974 by Wolf et al. (1976), and for RM 352 (RKM 566) during 1973 through 1980 by Beak Consultants Inc. (1980) and Neitzel et al. (1982). Phytoplankton production values will fluctuate seasonally with such factors as light intensity, water temperature, and current velocities and may show wide year to year variations. 
The diversity index is based primarily on the number of species and their relative abundance. The diversity index, and two of its associated parameters (index of relative abundance and species richness) through 1979 at RM 352 (RKM 566 ) is shown in Figure 3.10, as an example. Diversity indices were higher in the summer, fall and early winter and spring when phytoplankton densities were highest (Beak Consultants Inc. 1980, p. 2.7).

Carbon uptake is essentially a measurement of photosynthetic activity (i.e.,. productivity); hence, it is influenced by light and temperature. Rate of carbon uptake at RM 352 (RKM 566) can be used to indicate general values for the Hanford Reach. Carbon uptake was measured on 12 dates from 1974 through 1976. Productivity ranged from 0.020 to less than $0.001 \mathrm{mg}{ }^{14} \mathrm{C} /$ hour (Neitzel et al. 1982, pp. 498-501). Carbon uptake is near zero during the winter (January, February, and March) but reaches $0.033 \mathrm{mg} \mathrm{C} / 1$ iter hour in June and September (loc. cit.). Uptake data are typical of rivers in a temperate climate. Uptake values increase seasonally at the surface of the river in late February, rise steadily to peak in July, remain high through midSeptember, and then decline to the winter minimum. Mid-depth and bottom uptake values are less than those at surface because of the influence of depth on light penetration, attenuation of light by particulate materials, and other physical properties of the water (loc. cit.).

Peak chlorophyll a concentrations at RM 380 (RKM 611) occurred in June and July. Unlike primary productivity, the summer chlorophyll a peak did not last long. Even though the chlorophyll a decreased in August, September and October, primary productivity was relatively stable. Apparently, during this period, phytoplankton organisms were more efficient in fixing carbon per gram of available chlorophyll a (Neitzel et al. 1982, p. 501).

Chlorophyll a concentration estimates at RM 352 (RKM 566) ranged from less than $1 \mathrm{mg} / \mathrm{m}^{3^{3}}$ to greater than $24 \mathrm{mg} / \mathrm{m}^{3}$. Chlorophy 11 a concentrations peaked in late spring-early summer and were lowest in late fall-early winter (Neitzel et al. 1982, p. 502). A11 maximum chlorophyl1 a concentrations measured at RM 352 (RKM 566) were greater than concentrations measured at RM 380 (RKM 611). 


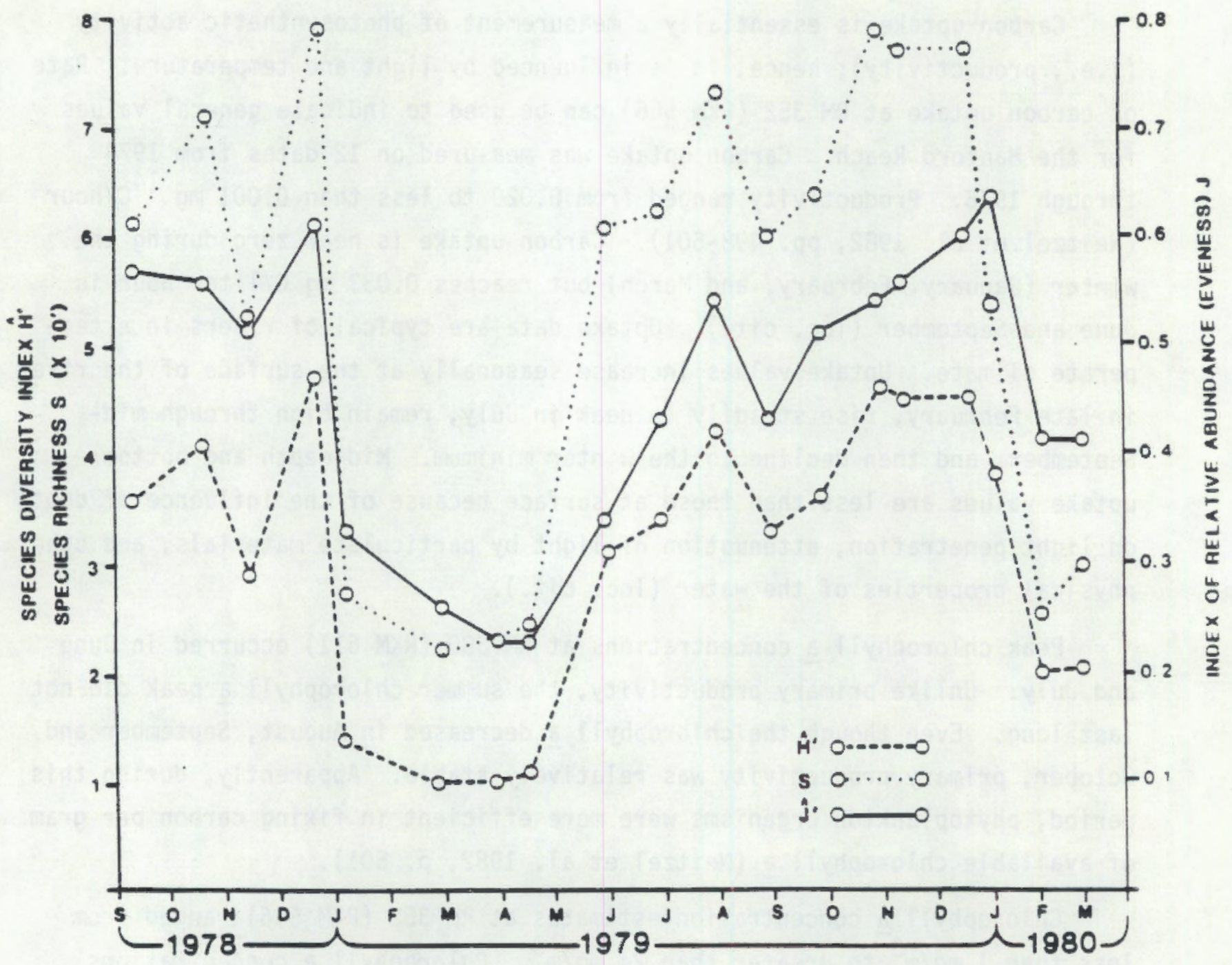

FIGURE 3.10. Species Diversity Index $\left(H^{\prime}\right)$, the Index of Relative Abundance $\left(\mathrm{J}^{\prime}\right)$, and Species Richness (S) for Phytoplankton Samples at RM352 (RKM566), September 1978March 1980 (Beak Consultants, Inc. 1980) 
3.2.2.1.2 Periphyton. The periphyton community in the Hanford Reach occurs on solid substrates wherever light is sufficient for photosynthesis; hence, they are often called "benthic microflora". This community is composed primarily of diatoms, which may be attached, or entangled from the river drift. Dominant genera are the diatoms Achnanthes, Asterionella, Cocconeis, Fragillaria, Gomphonema, Melosira, Nitzchia, Stephanadiscus and Synedra (Page and Neitzel 1978b, p. 4.1-4.36; Page et al. 1979b, p. 4.1-4.27; Beak Consultants Inc. 1980 , p. 4.7-4.12; Neitzel et al. 1982). One set of samples taken in June 1979 was dominated by filamentous blue-green algae, genera Schizothrix and Entophysalis (Beak Consultants Inc. 1980, p. 4.9; Neitzel et al. 1982, p. 502).

In studies conducted at RM 352 (RKM 566) from March 1977 to March 1980, the number of periphyton (microflora) units $/ \mathrm{cm}^{2}$ varied seasonally, with maxima in winter and minima in summer. The lowest average density was 4,652 units $/ \mathrm{cm}^{2}$ in June 1977, and the higher average density was $1,146,250$ units $/ \mathrm{cm}^{2}$ in March 1979 (Neitzel et a1. 1982, p. 502). Organic matter estimates also varied seasonally, with a low of $0.2 \mathrm{~g} / \mathrm{m}^{2}$ in June 1978 and a high of $21.0 \mathrm{~g} / \mathrm{m}^{2}$ in September 1977 (loc. cit.). However, chlorophy11 a estimates did not show clear seasonal trends (1oc. cit.).

Comparisons were made at RM 352 (RKM 566) between productivity of phytoplankton and periphyton. There was no obvious relationship between dominant taxa in phytoplankton or periphyton samples on 13 comparable dates. However, practically all taxa were present in samples of both communities. Chlorophyl1 a estimates from periphyton were generally higher than those from phytoplankton, ranging from 0.1 to 31 times greater and averaging 6 times greater (Neitzel et al. 1982, p. 502-503). The comparisons indicated greater production of periphyton than phytoplankton even though phytopiankton densities were greater. A possible cause was that more dead algae cells from planktonic and benthic origin were present in the drifting phytoplankton community due to mixing by river currents and diurnal river level fluctuations (loc. cit.).

In past years during operation of plutonium production reactors at Hanford (1944-1971), concentrations of radionuclides in the Columbia River 
were monitored in planktonic and benthic communities (Coopey 1953a; Cushing and Watson 1966; Cushing 1967a; Watson et al. 1971; Cushing et al. 1981). Primary emphasis was on uptake and cycling of radionuclides between Columbia River biota, but some early data on phytoplankton and periphyton production are given in these reports.

\subsection{Macrophytes. Fluctuating water levels, strong currents, and} rocky substrates inhibit the development of a rooted macrophyte community in the Hanford Reach. Rooted macrophytes are generally restricted to isolated slack-water areas in the main river channel and to muddy bottom areas of sloughs. Where they exist, macrophytes have considerable ecological value. They provide food and shelter for juvenile fish and spawning areas for some species of warm-water game fish. Macrophyte species that have been identified in the Hanford Reach are listed in Table 3.9. A comprehensive discussion of riparian zone vegetation, portions of which are innundated by periodic high flows, is given by Fickeisen et al. (1980a, Section 4), and Fickeisen et al. (1980b, Section 4).

The most common macrophyte likely to occur along the shoreline at Hanford is the curled leaf pondweed, Potamogeton crispus. Pondweed is common among quiet pools and is most visible at reduced flows after summer growth. Patches of emergent macrophytes, including rushes (Juncus spp.), sedges (Carex spp.), and cattails (Typha latifolia) also occur at various shoreline locations where currents and silt deposits permit. Isolated pools may contain green floating mats of duckweed (Lemna spp.)

3.2.2.1.4 Zooplankton. A complete list of zooplankton species known to occur in the Hanford Reach is given in Table A.12. Many organisms may be encountered in zooplankton samples. From a strict viewpoint, "zooplankton" includes only the Rotifera and Arthropoda while the other organisms listed belong with the benthic fauna although they may enter the river drift. Information on zooplankton in the Hanford Reach is provided by Coopey (1953a, 1953b; Page and Neitze1 1976, Section 3; Page and Neitzel 1978c, Section 3; Beak Consultants Inc. 1980, Section 3; Neitzel et a1. 1982b). Zooplankton species identified in McNary Reservoir, which may be typical of reservoir populations in the mid-Columbia River, are listed by Scarola (1968). 
TABLE 3.9. Macrophytes Identified in the Hanford Reach, Columbia River (Fickeisen et al. 1980a; PSP\&L 1981)

\begin{tabular}{|c|c|c|}
\hline Family & Species & Common Name \\
\hline Ceratophyllaceae & Ceratophyi ium demersum & Coontail \\
\hline Cruciferae & 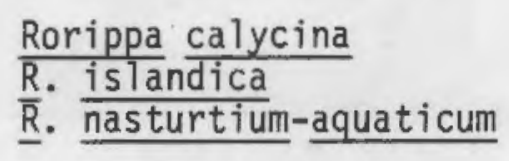 & $\begin{array}{l}\text { Rorippa (watercress) } \\
\text { Rorippa (watercress) } \\
\text { Rorippa (watercress) }\end{array}$ \\
\hline Cyperaceae & $\frac{\text { Carex }}{\underline{\text { Scirpur }} \text { athrostachya }}$ & $\begin{array}{l}\text { Carex (sedge) } \\
\text { Bulrush }\end{array}$ \\
\hline Halogaceae & Myriophyllum spp. & Water milfoil \\
\hline Hydrocharitaceae & Elodea canadensis & Elodea, waterweed \\
\hline Juncaceae & $\frac{\text { Juncus articulatus }}{\text { J. balticus }}$ & $\begin{array}{l}\text { Rush } \\
\text { Rush }\end{array}$ \\
\hline Lemnaceae & Lemina spp. & Duckweed \\
\hline Jajadaceae & $\frac{\text { Potomogetan }}{\text { p. pectinatus }}$ & $\begin{array}{l}\text { Curly pondweed, } \\
\text { curled leaf pondweek } \\
\text { pondweed }\end{array}$ \\
\hline Polygonaceae & Polygonum persicara & Buckweat \\
\hline Typhaceae & Typha latifolia & Cattail \\
\hline
\end{tabular}

The crustacean-zooplankton community at RM 380 (RKM 611) consisted of 12 identified species during 1973 and 1974 (Page and Neitzel 1976, Table 3.5). Bosmina longirostrus was the most abundant cladoceran and dominant zooplankter from June to October when Diaptomus ashlandi became dominant, and remained so until June 1974. Before January 1974, Cyclops bicuspidatus thomasi was third in abundance, but it increased to second in abundance during the JanuaryFebruary thaw and became dominant in June 1974. Daphnia spp. were fourth most abundant, but at only about $10 \%$ of the total zooplankton community present (Figure 3.11).

Other invertebrates than crustacea were taken in zooplankton samples. Larvae of aquatic insects usually were less than $5 \%$ of the organisms collected, peaking in mid-July at about 7 larvae $/ \mathrm{m}^{3}$ (Neitzel et al. 1982b, p. 

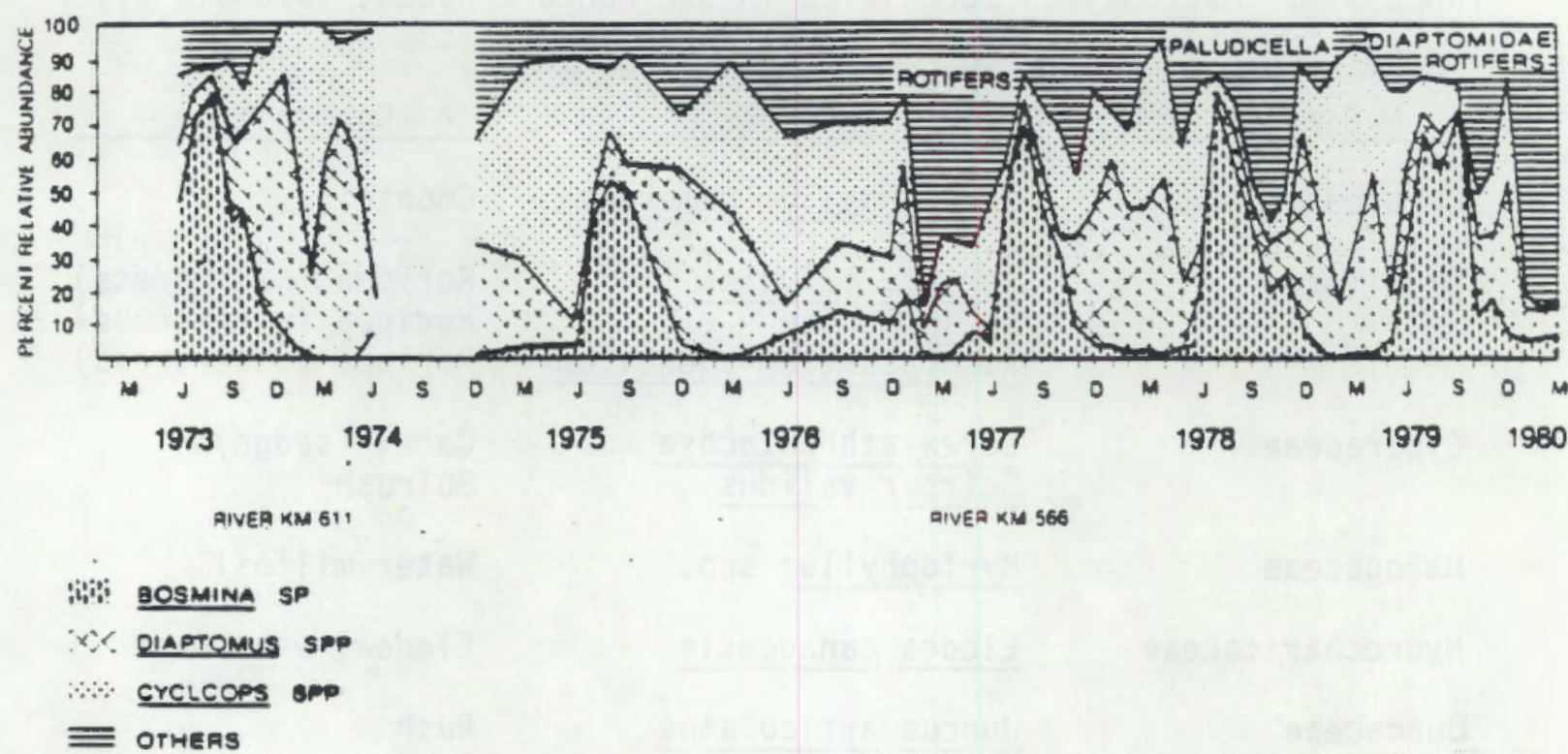

FIGURE 3.11. Relative Abundance of Dominant Zooplankton Species in the Columbia River at RM352 (RKM522) and RM380 (RKM611)

(PSP\&L 1981; Neitzel et a1. 1982b)

114). This peak corresponded with maximum abundance of insect larvae in the benthos. Drift insects represented only about $0.08 \%$ of all zooplankton.

The zooplankton community at RM 352 (RKM 566) consisted of 58 identified taxa from 1974 to March 1980. Three crustacean genera dominated: Bosmina, Diaptomus and Cyclops (Figure 3.11). Bosmina generally dominated in July, August and September samples; Diaptomus in December and January; and Cyclops in March and June. Insect larvae were numerically significant only in March 1975 and September 1976 samples.

Part of the increased taxa at RM 352 (RKM 566) was probably due to improvements in identification from 1975 to 1980 , which permitted more organisms to be identified to lower taxonomic levels, and not to an actual higher species diversity (Beak Consultants Inc. 1980).

Zooplankton densities generally followed a trend of winter minimums, and late spring and early-summer maximums (Figure 3.12). Average number of zooplankters ranged from 1500 organisms $/ \mathrm{m}^{3}$ in mid-july to less than 30 


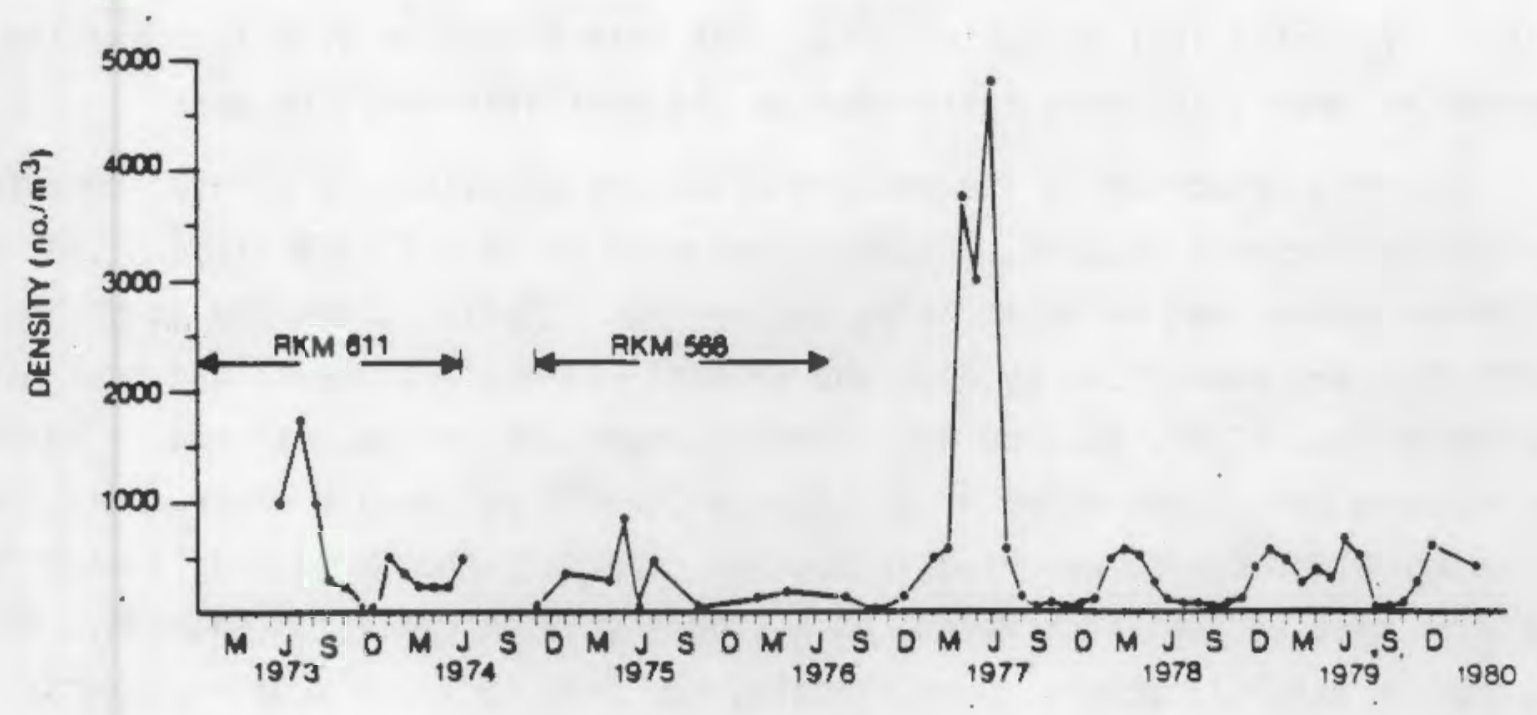

FIGURE 3.12. Columbia River Zooplankton Density RM352 (RKM566) and RM 380 (RKM611) (PSP\&L 1981; Neitzel et al. 1982b)

organisms $/ \mathrm{m}^{3}$ in November and December at RM 380 (RKM 611). Average numbers of zooplankters ranged from less than 10 organisms $/ \mathrm{m}^{3}$ in December 1974 to 4702 organisms $/ \mathrm{m}^{3}$ in June 1977 at RM 352 (RKM 566).

Zooplankton densities may be affected by total river flow. The density increase in 1977 (Figure 3.12) was likely influenced by extremely low river discharges that year (Beak Consultants Inc. 1980, p. 3.5). Reduced flows caused higher plankton densities by increasing residence time of water in reservoirs, so that reproduction was enhanced and net export of cells was decreased.

\subsubsection{Benthic Organisms}

Benthic organisms are those that live in or on the bottom substrates of lakes, reservoirs, and streams. Benthic communities are divided into macrofauna and microflora. The macrofauna, discussed in this section, are large nonphotosynthetic organisms such as insect larvae, annelids, and snails. The microflora are small photosynthetic organisms representing primarily the periphyton. The benthic communities of the river are a primary food source for many macroinvertebrates and fish.

Early studies of benthic organisms in the Hanford Reach were conducted by Davis and Cooper (1951) from Fall 1948 to Spring 1950 and by Roebuck et al. 
(1954) in Spring 1951 to Spring 1953. The data collected were from shallow shoreline areas, and were restricted by the available sampling gear.

Benthic organisms in the Hanford Reach are discussed in several reports on site assessment studies. Studies conducted at RM 380 (RKM 611) in 1973 and 1974 are summarized by Wolf (1976, Section 4). Studies conducted at RM 352 (RKM 566) are summarized by Page and Neitzel (1978c, Section 4) and Beak Consultants Inc. (1980, Section 4). Benthic organisms can be measured in terms of numbers per square meter or in biomass (grams) per square meter. Considerable variation can be expected in species diversity, numbers, and biomass from site to site at a given time and at a single site at different seasons. This is due to natural factors. For example, the life cycle of aquatic insects includes egg deposition, larval feeding and growth, pupation and adult emergence. Some insects pass through this cycle only once annually; others repeat it twice or more annually. Their peak abundance in the benthos occurs after eggs hatch and larvae are present in bottom substrates.

The macrofaunal composition of the Hanford Reach is diverse (Table A.13). Two taxa dominate: midge fly larvae (Chironomidae) and caddisfly larvae (Trichoptera). Other taxa include black fly larvae (Simuliidae), arnelids, molluscs, a crayfish (Pacifasticus leniusculus), a freshwater sponge (Spongilla lacustris), and water mites.

Population densities change seasonally and annually. Total numbers are usually lowest in June and July (corresponding with the spring emergence of adult aquatic insects), increase dramatically in September and October (aquatic insects eggs hatch into larvae), and are moderately high from December through April (overwintering population levels). Average numerical densities for September, December, March and June in samples collected between 1973-1980 were $53,656 / \mathrm{m}^{2}, 33,580 / \mathrm{m}^{2}, 6,984 / \mathrm{m}^{2}$ and $5,944 / \mathrm{m}^{2}$, respectively (Figure 3.13). Precise comparisons between years are usually unfeasible because of differences in sample sites, collection dates, duration of colonization (of collection units), and methods of collection.

Mean total biomass of benthic macrofauna usually peaks in December while the lowest biomass occurs in March, and coincides with high December and low March populations of Trichoptera (primarily hydropsyche cockerelli). On 


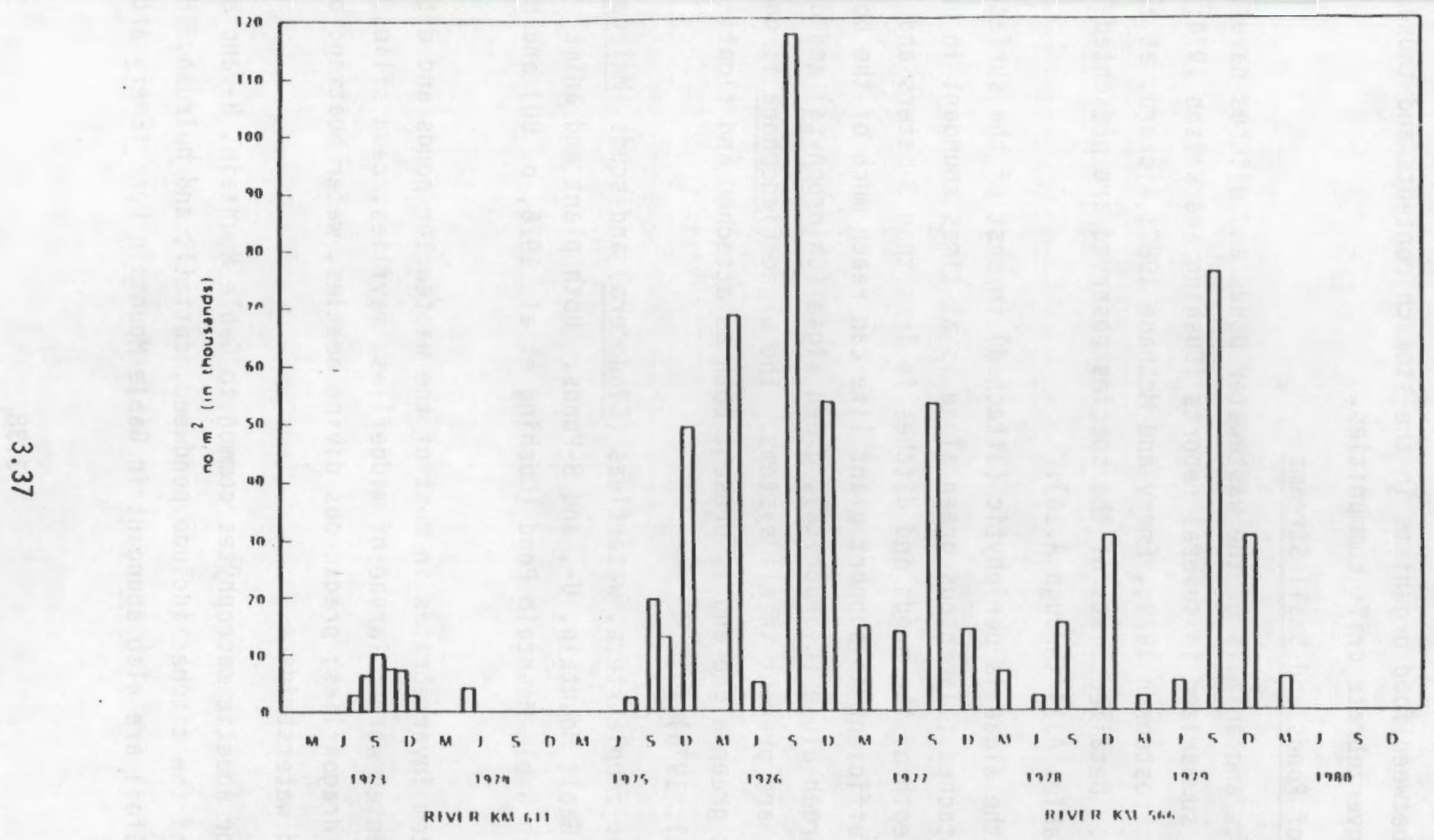

FIGURE 3.13. Seasonal Densities of Columbia River Macrobenthic Fauna (PSP\&L 1982) 
occasions, Simuliidae, Chironomidae, and molluscs will constitute significant portions of the benthic biomass.

Stomach contents of fish collected in the Hanford Reach from June 1973 through March 1980 (See Section 3.2.4) that benthic invertebrates are important food items for nearly all juvenile and adult fish. There is a close relationship between food organisms in the stomach contents and those in the benthic and invertebrate drift communities.

\subsubsection{Biota of Ponds and Small Streams}

The plants and animals of the wastewater ponds and ditches have been described and summarized in several reports (Cushing and Watson 1974; Meinhardt and Frostenson 1979;, Emery and McShane 1980; Rickard, et al. 1981; Jamison 1982). Detailed lists of the species observed are presented in Appendix A (Tables A.14 through A.16).

Most of the algae is periphytic (attached) in most of the surface waters although unattached filamentous green algae is at times abundant in U-Pond. The average depth of the ponds and ditches is less than 3 meters and light penetration sufficient to support plant life can reach much of the bottom area. Blue-green algae (Cyanophyta), green algae (Chlorophyta) and diatoms (Chrysophyta) are present in all systems. The algae Cladophora is one of the more abundant green algae and is present both as attached and floating masses (Cushing et al. 1976).

Among the zooplankters, waterfleas (Cladocera) and scuds (Malacostraca) are found in Gable Mountain, U-, and B-Ponds. Both plant and animal plankton were sparse in Gable Mountain Pond (Cushing et al. 1976, p. 8D) and U-Pond and B-Pond.

The bottom invertebrates in most of the wastewater ponds and ditches include segmented worms; larvae of midgeflies, mayflies, caddisflies, damselflies, dragonflies; predaceous diving beetles, water boatmen; backswimmers; and waterstriders.

The major aquatic macrophytes common to Gable Mountain, B- and U-Ponds and several of the ditches include pondweed, cattail, and bulrush. Hornwort and water milfoil are also abundant in Gable Mountain Pond (Emery and McShane 
1980). Cottonwoods (Populus) grow along shore at Gable Mountain Pond and U-Pond; willows (Salix) are found along U-Pond.

The aquatic food web is shown schematically in Figure 3.14. The ponds and ditches serve as food and water sources for birds and mammals, and can potentially contribute to the transfer of pollutants to the human food chain.

Rattlesnake Springs, near the western side of the Hanford Reservation, creates a small stream about $2.5 \mathrm{~km}$ long. It is of ecological importance because it provides a source of water to terrestrial animals in an otherwise arid part of the reservation. Snively Springs, located further west and at a higher elevation than Rattlesnake Springs apparently does not contribute to

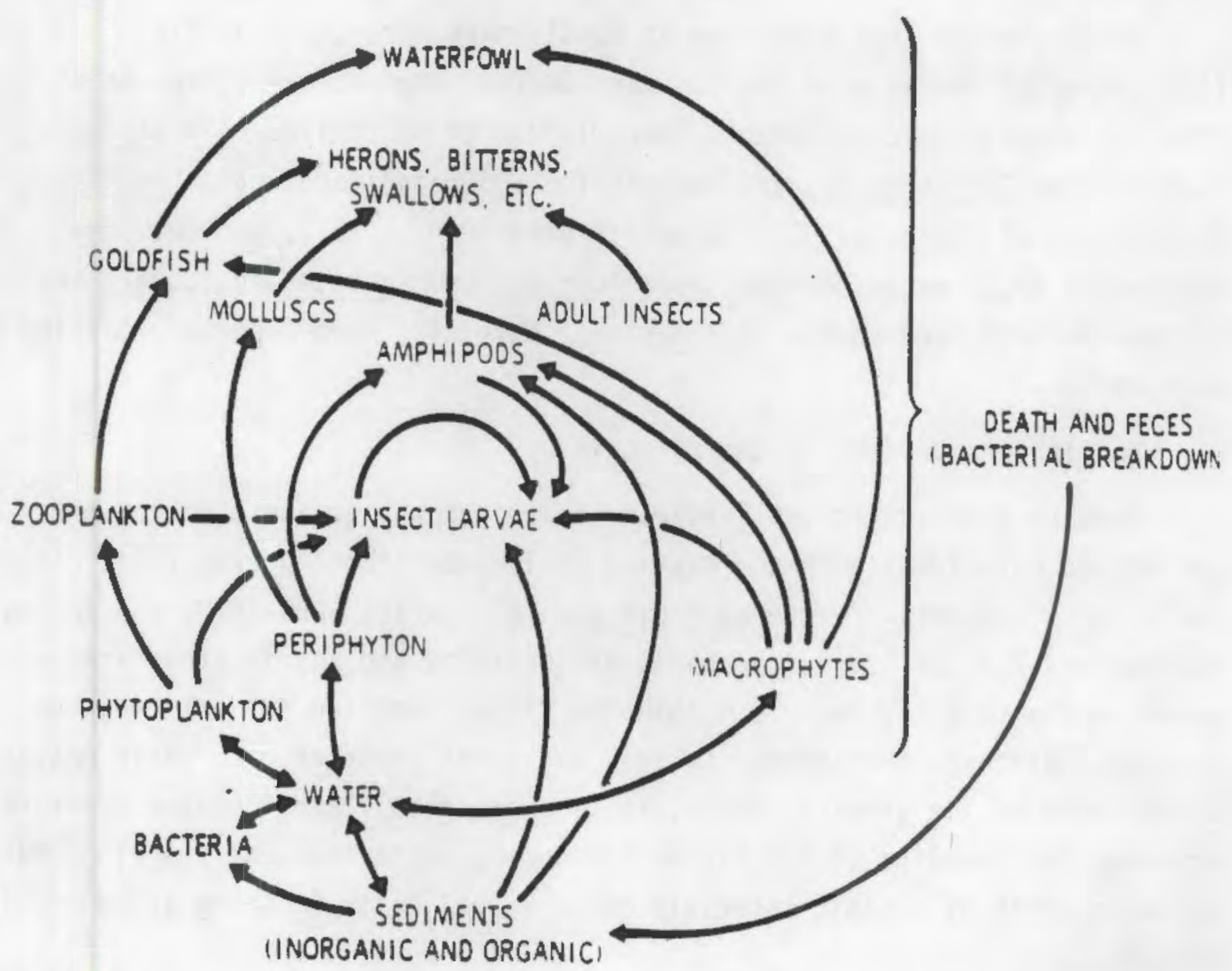

FIGURE 3.14. Food Web of Gable Mountain Pond and U Pond (U.S. ERDA 1975) 
the flow of Rattlesnake Springs, (Brown 1970, p. 26) but probabiy flows to the west and off the Reservation.

The autotrophic communities in the spring system are primarily periphytic; diatoms are the primary algae group (Cushing and Wolf, in press). Achnanthes lanceolata, Gomphonema intricatum and Melosira varians are the most abundant. A total of 90 algal species have been identified from the springs, with Chrysophyta (diatoms) the most abundant (49 species) and Chloroplyta (green algae) the next most abundant (23 species) (Lippert and Cushing 1973, p. 6.15). The major rooted aquatic plant, which in places may cover the entire width of the stream, is watercress (Rorippa nasturtium-aquatica). Isolated patches of bulrush (Scirpus sp.), spike rush (Eleocharis sp.), and cattail (Typha latifolia) occupy less than 5 percent of the streambed.

In studies of leaf breakdown at Rattlesnake Springs, midgefly (Chironomudae) larvae were the dominant benthic organisms (Cushing et al. 1974, p. 91-94); also represented were larvae of blackflies (Simuliidae), caddisflies (Trichoptera), and damselflies (Odonata); and scuds (Amphipoda) (Cushing et al. 1973, p. 93). Waterstriders (Gerris sp.), backswimmers (Notonecta sp.), water beetles (Hydaticus $\mathrm{sp}$. and Agabetes $\mathrm{sp.}$ ), mayflies (Ephemeroptera), and snails (Tyrolus sp.) have also been reported (Cushing and Wolf 1971).

No fish are present in the springs.

Primary productivity at Rattlesnake Springs was greatest during the spring and coincident with the maximum periphyton standing crop (10c. cit.). Net primary productivity averaged $0.9 \mathrm{gCm}^{-2} \mathrm{~d}^{-1}$ during 1969-1970; the spring maximum was $2.2 \mathrm{gCm}^{-2} \mathrm{~d}^{-1}$. Seasonal productivity and respiration rates are shown in Figure 3.15, and are within the ranges reported for arid region streams. Although Rattlesnake Springs was a net exporter of organic matter during much of the growing season, it is subject to flash floods and severe scouring and denuding of the stream bed during winter and early spring, making it an importer of organic materials on an annual basis (Cushing and Wolf, in press). 


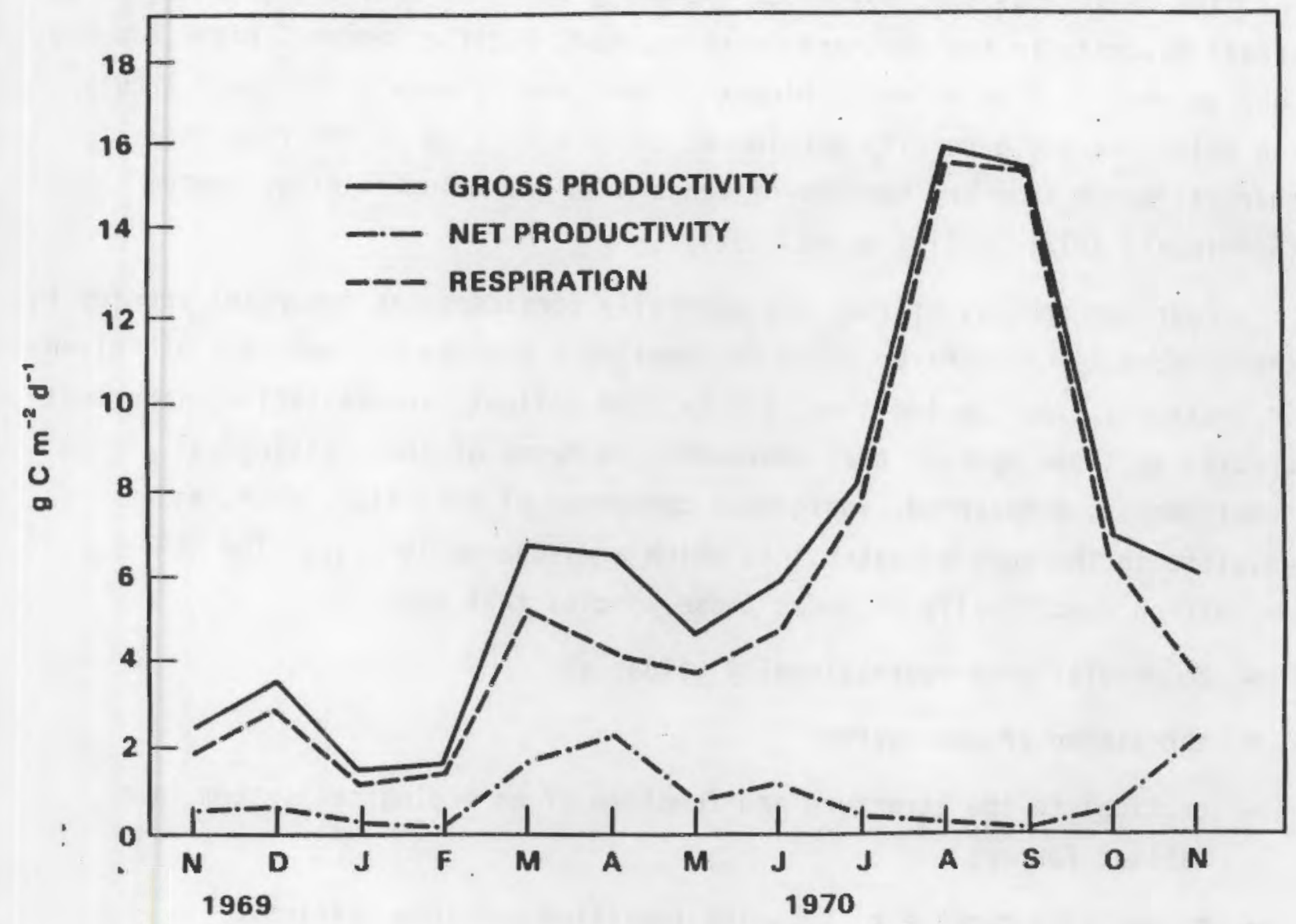

FIGURE 3.15. Seasonal Gross $\left(P_{q}\right)$ and net $\left(P_{n}\right)$ Primary Productivity and Respiration ( $R$ ) Rates for Rattlesnake Springs (Cushing and Wolf, in press)

\subsubsection{Fish Populations}

\subsubsection{Species Present}

Forty-four species of fish have been identified from the free-flowing Hanford Reach of the Columbia River (Gray and Dauble, 1977, p. 211-212). Of these, 39 are resident species present during the entire year, while seven are anadromous species present only during certain seasons and stages of their life cycle. The indigenous species native to the Columbia River are limited. Fifteen of the fish species listed were introduced to the Columbia River from other areas, many before 1900 (Smith 1896; Wydoski and Whitney 1979). Fish species found in the Hanford Reach are listed in Table A.17. 
The anadromous species, which typically spawn in fresh water but grow to sexual maturity in the sea, are American shad, Pacific lamprey, river lamprey, coho salmon, sockeye salmon, chinook salmon, and rainbow (steelhead) trout. The salmonids are generally considered to be sensitive to environmental changes; hence they are species of concern in the Columbia River system (Schwiebert 1977; Collins et al. 1975).

Fourteen species of fish are generally considered as important species in the Hanford Reach. Criteria for designating a species as important are given in Section 3.1.4. In addition, 316 (a) EPA defines representative, important species as those species that represent, in terms of their biological requirements, a balanced, indigenous community of shellfish, fish, and wildlife in the body of water into which a discharge is made. The EPA definition specifically includes those species that are:

- commercially or recreationally valuable

- threatened or endangered

- critical to the structure and function of an ecological system (e.g., habitat formers)

- potentially capable of becoming localized nuisance species

- necessary (e.g., in the food chain) for the well-being of species listed immediately above

- representative of the thermal requirements of important species but which themselves may not be important.

Although other species of fish found in the Hanford Reach may qualify for designation as "important", the species listed in Table 3.10 closely conform to these criteria.

\subsubsection{Important Anadromous Fishes}

Important anadromous fish utilizing the Hanford Reach include chinook, coho and sockeye salmon, steelhead trout (a seaward migrating form of rainbow trout), and American shad. These species are regionally important as recreational and commercial resources. The salmonids are also internationally important because of their extensive feeding migrations in the sea where they enter the commercial fisheries of Canada and Japan. 
TABLE 3.10. Fish Species Designated as Important for the Hanford Reach, Columbia River

\begin{tabular}{|c|c|}
\hline Common Name & Scientific Name \\
\hline $\begin{array}{l}\text { Adadromous Species } \\
\text { chinook salmon } \\
\text { coho salmon } \\
\text { sockeye salmon } \\
\text { rainbow (steelhead trout) }\end{array}$ & $\begin{array}{l}\frac{\text { Oncorhynchus }}{\text { Oncorhynchus }} \\
\frac{\text { tshawytscha }}{\text { Oncorhynchus }} \\
\frac{\text { Salmo gairdner }}{\text { nerka }} \\
\underline{\text { Salmo }}\end{array}$ \\
\hline $\begin{array}{l}\text { Resident Species, Indigenous } \\
\text { white sturgeon } \\
\text { largescale sucker } \\
\text { prickly sculpin } \\
\text { northern squawfish } \\
\text { mountain whitefish }\end{array}$ & $\begin{array}{l}\frac{\text { Acipenser }}{\text { Catostomus }} \text { transmontanus } \\
\frac{\text { Cottus asper }}{\text { Ptychocheilus }} \\
\frac{\text { Prosopium will wilamsoni }}{\text { Prosons }}\end{array}$ \\
\hline $\begin{array}{l}\text { Resident Species, Int } \\
\text { smallmouth bass } \\
\text { yellow perch }\end{array}$ & $\frac{\text { Micropterus }}{\text { Perca flavescens }} \frac{\text { dolomieu }}{\text { Perca }}$ \\
\hline
\end{tabular}

Sources: U.S. DOE (1982), PSP\&L (1981)

The free-flowing Hanford Reach serves as a migration route for salmon and steelhead that spawn upstream. In addition, it is the last major spawning ground for fall chinook salmon and steelhead trout in the main-stem Columbia River. Shad also spawn in the Hanford Reach.

Considerable research has been conducted on salmonid resources of the Columbia River, and runs are partly maintained with an extensive artificial propagation (hatchery) program supported by the federal government and the states of Idaho, Oregon and Washington. In recent years, an average of 123,500 adult salmonids produce 14 million outmigrants that originate in or pass through the Hanford Reach annualiy. These fish represent a combined sport and commercial value of $\$ 3$ million annually (Fickeisen et al. 1980, p. 2-15).

Anadromous salmonids have similar life cycles, but each species and often races within a species mature at different rates, resulting in differences in timing of the upriver spawning migration (Figure 3.16). Some adult salmon will be in the Hanford Reach each month of the year. The greatest numbers pass through during spring to early fall. The fewest occur from December 

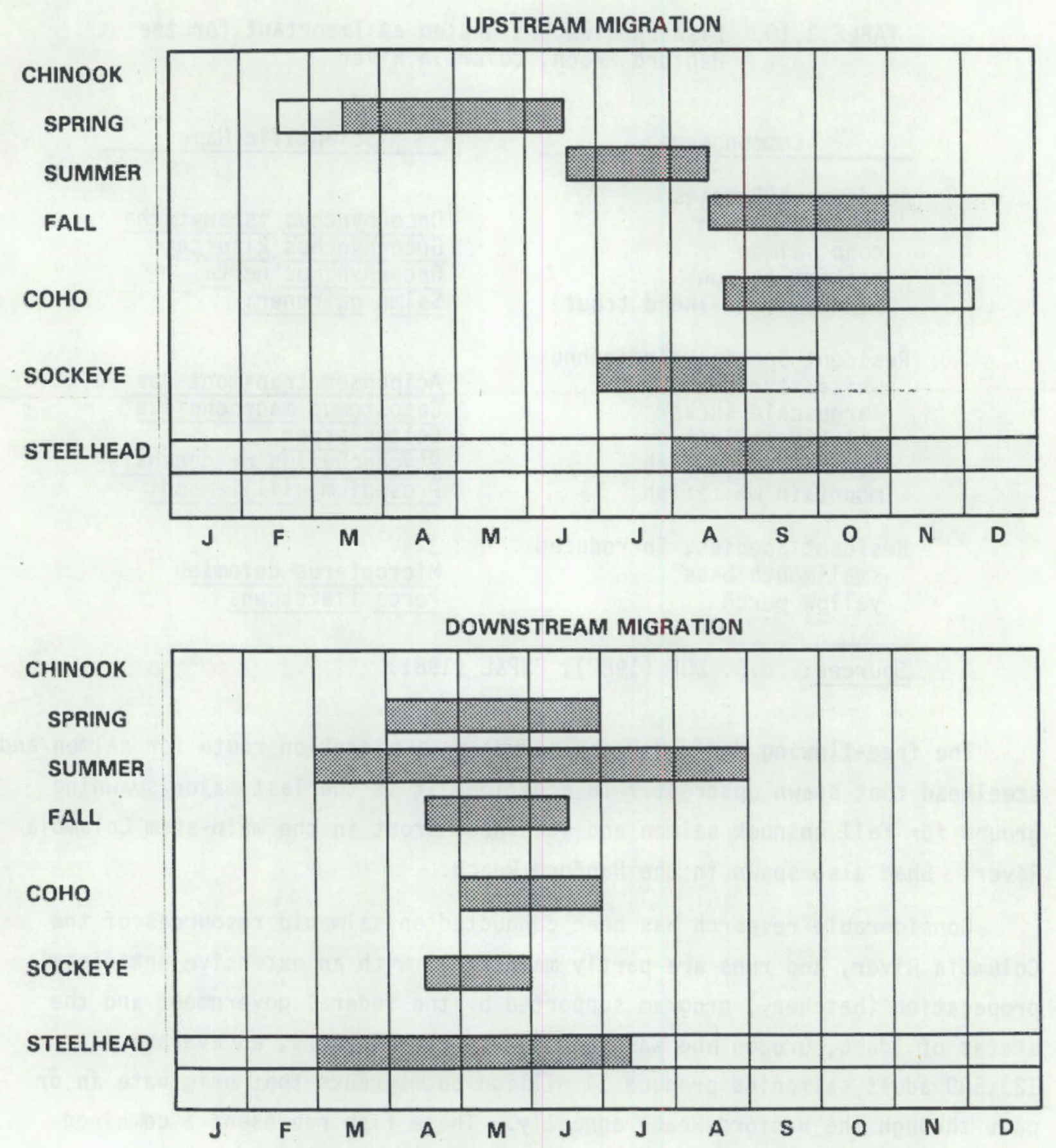

RANGE OF OCCURANCE

PEAK MOVEMENT

FIGURE 3.16. Timing of Salmonid Migrations Near the Hanford Site Columbia River (Adapted from PSP\&L 1981, Amendment 4) 
through February when only adult steelhead are present. Peak adult upstream migration periods at Hanford are normally as follows:

Sockeye: June-August

Chinook:

Spring: April to mid-June

Summer: mid-June to mid-August

Fal1: mid-August to November

Coho: September-October

Steelhead: August-October

Adult salmonids generally migrate upstream close to the banks of large rivers. Studies of migration routes in the Hanford Reach show that the fish usually prefer the east-northeast shore (left bank), which is opposite the intake and discharge ports of the closed and currently operating Hanford plants (Monan et al. 1970; Coutant 1973, p. 7-13; Becker 1973, p. 856). This migration path generally persists from Richland upstream to Priest Rapids Dam.

Chinook salmon: Spring and summer races of chinook salmon pass through the Hanford Reach to spawn primarily in tributaries of the mainstem river above Hanford, including the Wenatchee, Okanogan, Entiat and Methow Rivers (Fulton 1968). Adult spring- and summer-run chinook salmon move through the Hanford Reach from April through mid-June and mid-June to mid-August, respectively. Part of the adult fall chinook pass through the Hanford Reach to upstream spawning areas in mid-August to November; another portion of the run spawns in the Hanford Reach during September, October, and November.

Generally, juvenile spring and summer chinook salmon produced above Hanford migrate seaward as large fingerlings in their second year of life (1-age group), while juvenile fall chinook above and in the Hanford area migrate seaward as small fingerlings in their first year of life (0-age group) (Major and Mighel1 1969, p. 352-353; Bell 1973, Chapter 5, p. 4-6). Downstream movement of 1-age group spring chinook salmon through Hanford occurs from April to September but peaks in May (Table 3.11). An estimated 170,000 (in 1965) to 1.6 million (in 1975) spring chinook salmon fingerlings and 1.4 to 2.3 million summer and fall chinook salmon fingerlings pass downstream of Priest Rapids Dam annually (Sims and Miller 1976, Table 1). Hatchery releases contribute the major part of the spring chinook salmon 
TABLE 3.11. Median (Peak) Outmigration Dates for Juvenile Salmon Passing Priest Rapids Dam (from Hovland et al. 1982, p. 9; Weitkamp and McEntree 1982, p.12)

\begin{tabular}{|c|c|c|c|c|c|}
\hline Year & $\begin{array}{l}\text { Spring } \\
\text { Chinook } \\
\end{array}$ & $\begin{array}{l}\text { Fall \& } \\
\text { Sumner } \\
\text { Chinook } \\
\end{array}$ & Sockeye & Coho & Steelhead \\
\hline 1965 & May 19 & Aug. 11 & May 3 & May 12 & May 20 \\
\hline 1966 & May 17 & Aug. 12 & May 1 & April 29 & May 25 \\
\hline 1967 & May 23 & Aug. 8 & May 1 & May 20 & May 18 \\
\hline 1976 & May 14 & Aug. 11 & May 19 & May 19 & May 14 \\
\hline 1977 & May 17 & & May 14 & May 25 & May 17 \\
\hline 1979 & May 19 & & May 21 & May 23 & May 18 \\
\hline 1980 & May 12 & & May 14 & May 25 & May 10 \\
\hline 1981 & May 15 & Aug. 12 & May 14 & May 21 & May 15 \\
\hline 1982 & May 7 & & May 18 & May 19 & May 11 \\
\hline
\end{tabular}

outmigration originating above Priest Rapids Dam. Juvenile salmon from upriver areas travel from Priest Rapids Dam to McNary Dam (the Hanford Reach plus Lake Wallula) in 7 to 15 days, depending on river flow (Faurat 1979, p. 8). The fall run of chinook salmon ascending fishways at Bonneville Dam (RM 145) has been about 200,000 individuals annually the last ten years (1969-1978). Nearly half of these are harvested by the Indian fishery between Bonneville and McNary Dams (RM 2929) (Fickeisen et al. 1980, p. 2-4).

Total numbers of fall chinook salmon passing McNary Dam averaged 44,000 fish from 1968 to 1978 , but declined to $31,200,29,900$ and 21,100 fish in 1979, 1980, and 1981, respectively. Above McNary Dam the run may enter the Snake River and pass Ice Harbor Dam, pass on up the Columbia River over Priest Rapids Dam, or spawns in the Hanford Reach (fall chinook salmon only). Total numbers of fall chinook salmon passing Ice Harbor Dam averaged 7,300 fish from 1968 to 1978, but declined drastically after 1973 to less than 1,200 fish in 1979, 1980, and 1981, respectively. Total numbers of fall chinook salmon 
passing Priest Rapids Dam averaged 6,300 fish from 1968 to 1978, and was $4,900,6,000$ and 3,800 fish in 1979, 1980 and 1981, respectively (ODFW and WDF 1983, Table 26). Additionally, some fish enter the Yakima River. Estimates of numbers of adult fall chinook salmon using the mid-Columbia area are in Table 3.12.

Fall chinook salmon spawn primarily in tributaries of the lower Columbia River and main river in the Hanford Reach. Spawning at Hanford takes place from September to mid-November, peaking in late October and early November (Watson 1976, p. 4-6). Fall chinook salmon spawning in the Hanford Reach has increased markedly since 1960 with the construction of Priest Rapids Dam, probably as a result of the barrier to upstream movement created by the dam and the upstream translocation of main-stem spawning populations whose spawning grounds were eliminated by dams constructed below Hanford (Watson 1970 , p. 36).

Annual surveys of fall chinook salmon redds have been made at Hanford since 1947 (Figure 3.17). The number of redds increased dramatically from 1960 to 1969 and, except for greatly reduced abundance in 1972 and 1974, has remained relatively consistent since then. There is no evidence that maximum use of available spawning grounds has been reached in the Hanford area, thereby limiting further increase in the spawning population. Estimates of the total number of fall chinook salmon using the Hanford Reach annually are in Table 3.13 .

Several separate areas in the Hanford Reach have suitable substrates and currents for spawning of adult salmonids (Figure 3.18). The numbers of redds counted annually at each spawning area are in Table 3.14. Major spawning areas are at Vernita Bar ( $36 \%$ average contribution) below Priest Rapids Dam (RM 396), a possible partial barrier to upstream migration, and near Locke Island (RM 375) (20\% average contribution) (Table 3.15).

Eggs develop in the gravel of the Hanford Reach from late fall through the winter, when seasonal water temperatures are low. Fry typically emerge from March through June. Peak numbers of 0-age fall chinook salmon fry occur in shoreline areas at Hanford from April through May (Becker 1970, p. 6; Gray 
FIGURE 3.12. Annual Estimates of Adult Fall Chinook Using the Hanford Reach

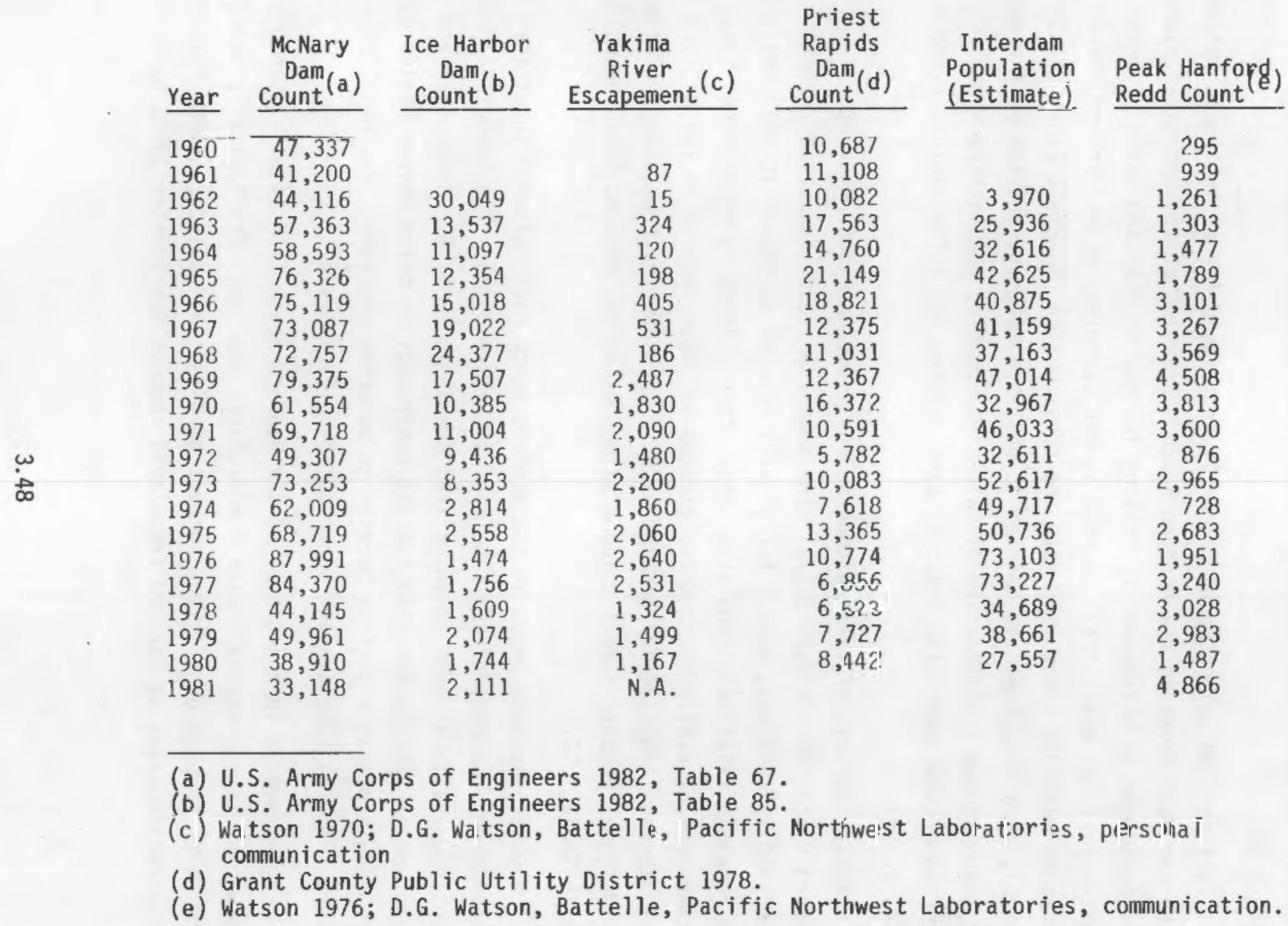




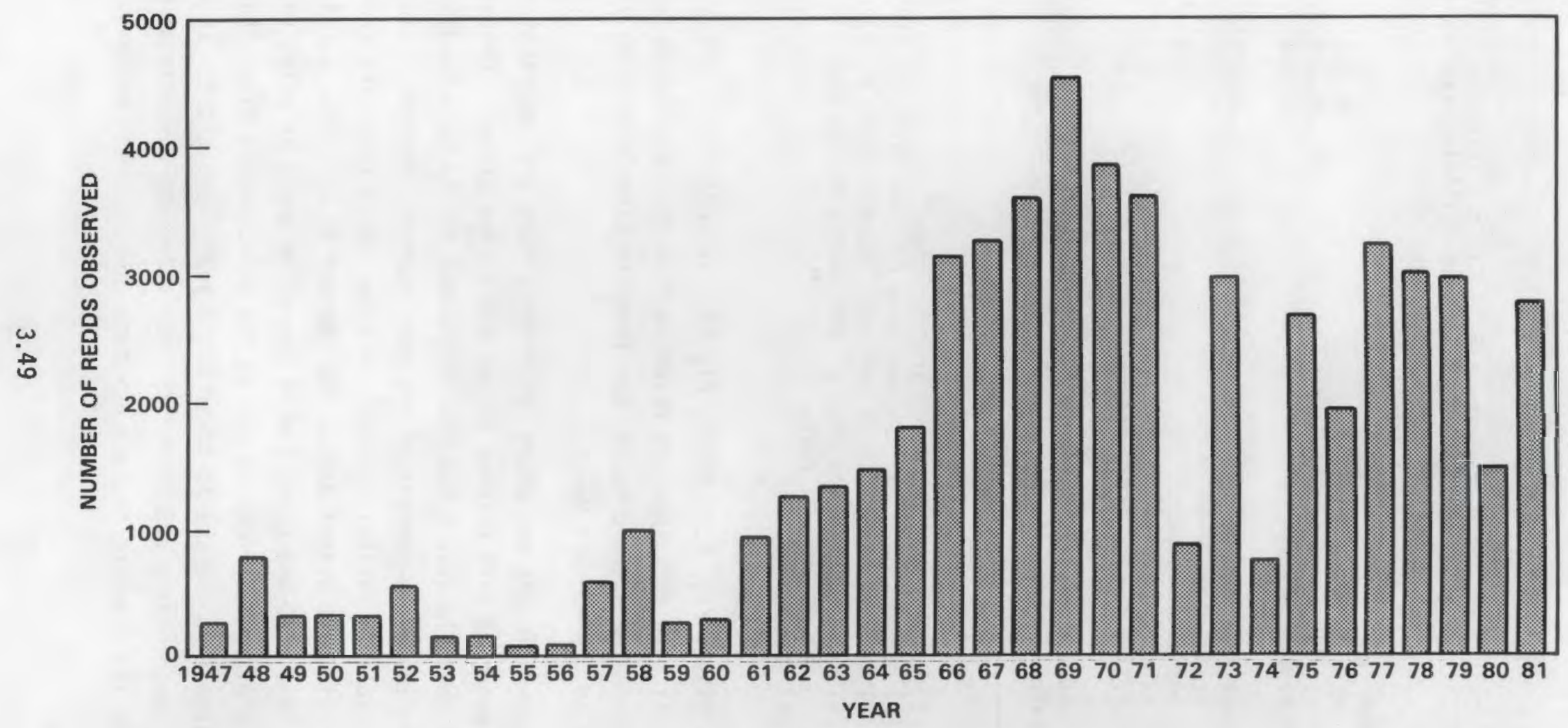

FIGURE 3.17. Hanford Reach Fall Chinook Salmon Redd Observations, 1947 Through 1979 (Based on Watson 1970, 1976 and D.G. Watson personal communication, Pacific Northwest Laboratory) 
TABLE 3.13. Calculation of Average Fall Chinook Interdam Population and Estimate of the Number of Fish Utilizing Hanford Reach 19621980 (Modified from PSP\&L 1981)

\begin{tabular}{lc} 
Dam Counts & \\
McNary & 64,562 \\
Ice Harbor & 10,325 \\
Priest Rapids & 11,699 \\
& \\
Interdam Population (5) & 42,225 \\
Yakima Spawners & 1,313 \\
Hanford spawners & 17,548 \\
Ringold Springs & 500 \\
Priest Rapids (volunteers) & 380 \\
Unaccounted (including sports catch and & \\
natural mortalities) & \\
& \\
\hline Note: & \\
\hline & \\
(1) Numbers with inherent inaccuracies. & \\
(2) Assumption of 3 fish per redd (Watson 1970, p. 4). & $(1,4)$ \\
(3) Assumption of 7 fish per redd (Watson 1970, p. 4). \\
(4) Represents 35 percent of the McNary count, but \\
varies from to year. \\
(5) From Table 3.12 .
\end{tabular}

and Dauble 1979a, Fig. 5.2, 1979b, Fig 2). In addition to these fish, juvenile fall chinook salmon are released from the hatchery and rearing facility above the Hanford Reach, and from the Ringold rearing station at the lower part of the Hanford Reach.

Backwater sloughs and shoreline indentations are important rearing sites for newly emergent fall chinook salmon fry ( 0 -age group). Currents are reduced in these locations and food organisms may be more readily available to fry than in the swift current of the main stream. However, chinook fry are also vulnerable to periodic changes in water level resulting from peaking power operations at Priest Rapids Dam (Becker et a1. 1981, p. 44). The residence time of 0 -age group fry in shoreline areas is relatively brief because fry of fall chinook salmon in the mid-Columbia River characteristically migrate to the sea in their first year (10c. cit.). In June, increased temperatures and high flows may stimulate down-stream movement of 0-age group fry from the Hanford environs. While small numbers of chinook 


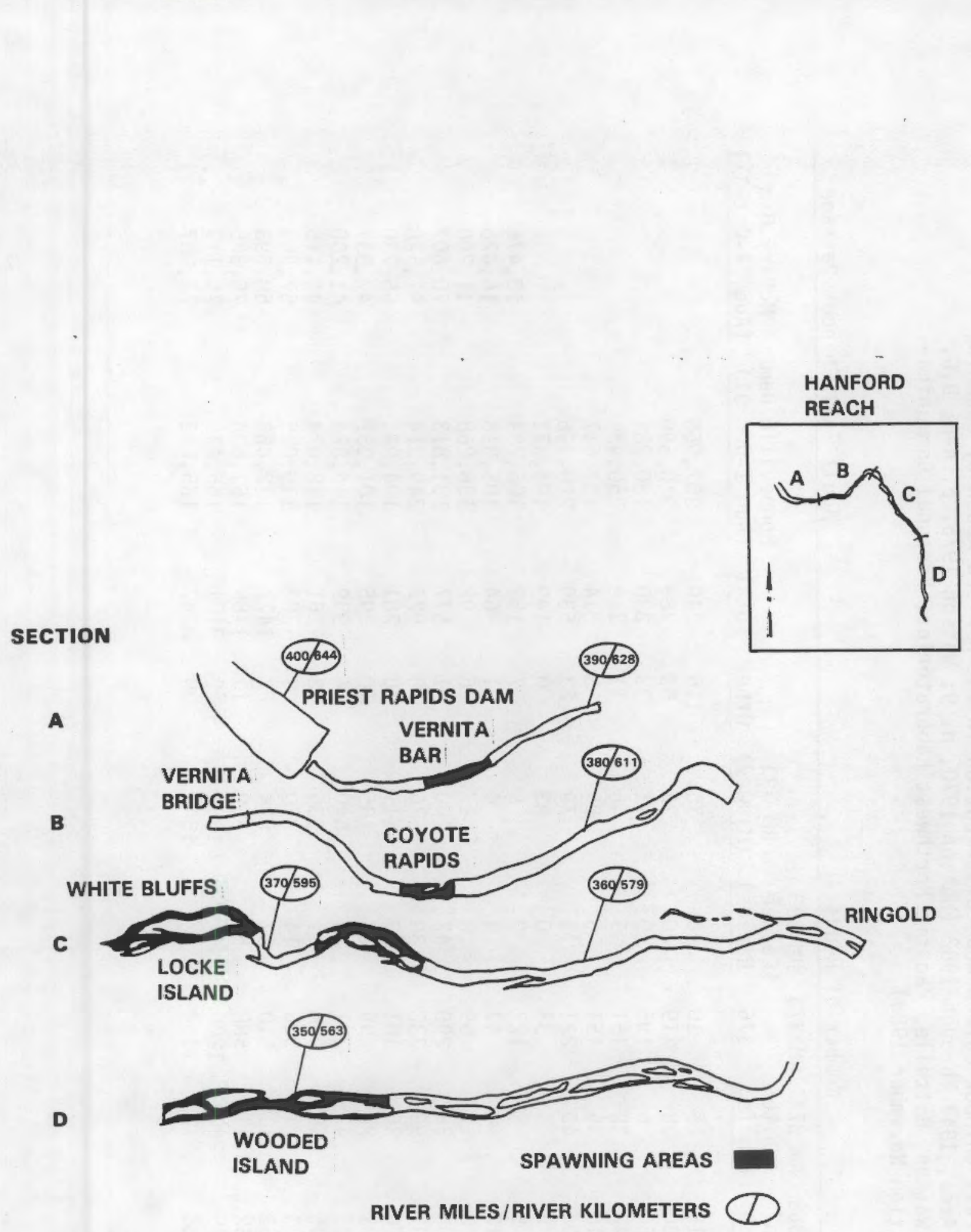

FIGURE 3.18. Fall Chinook Salmon Spawning Areas Within the Hanford Reach (Based on Watson 1976) 
TABLE 3.14. Fall Chinook Salmon Redd Distribution in the Hanford Reach by Spawning Area, 1947 Through 1982 (Watson 1970, p. 9; Watson 1976, p. 4-6; D.G. Watson, Battelle, Pacific Northwest Laboratories, Personal Communication November 1983)

Number of Redds

$\begin{array}{lllll} & \text { RM } 365 & \text { RM } 371 & \text { RM } 373 & \text { RM } 383 \\ \text { RM } 354 & \text { RM } 370 & \text { (White } & \end{array}$

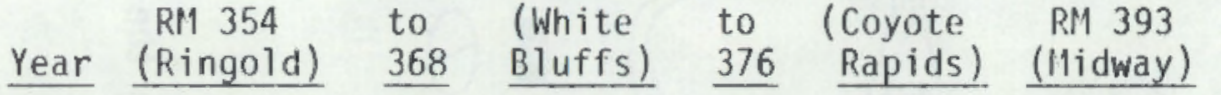

\begin{tabular}{|c|c|c|}
\hline 1947 & 0 & 15 \\
\hline 1948 & 120 & 330 \\
\hline 1949 & 45 & 50 \\
\hline 1950 & 24 & 43 \\
\hline 1951 & 5 & 10 \\
\hline 1952 & 73 & 101 \\
\hline 1953 & 7 & 5 \\
\hline 1954 & 4 & 5 \\
\hline 1955 & 0 & $1 ?$ \\
\hline $1956(1)$ & 0 & 3 \\
\hline $1957(1)$ & 17 & 88 \\
\hline $1958^{(1)}$ & 32 & 105 \\
\hline 1959 & 1 & 0 \\
\hline 1960 & 0 & 31 \\
\hline 1961 & 0 & 2.7 \\
\hline $196 ?$ & 6 & 195 \\
\hline 1963 & 0 & 283 \\
\hline 1964 & 5 & 163 \\
\hline 1965 & 4 & 262 \\
\hline 1966 & 10 & 279 \\
\hline 1967 & 28 & 388 \\
\hline
\end{tabular}

$\begin{array}{rr}25 & 10 \\ 38 & 219 \\ 6 & 195 \\ 38 & 151 \\ 45 & 151 \\ 40 & 221 \\ 16 & 38 \\ 8 & 127 \\ 0 & 47 \\ 7 & 59 \\ 39 & 290 \\ 99 & 332 \\ 36 & 101 \\ 2 ? & 99 \\ 43 & 201 \\ 66 & 456 \\ 127 & 506 \\ 111 & 510 \\ 211 & 588 \\ 267 & 1206 \\ 273 & 119 ?\end{array}$

Adult Fall Chinook Passage

Bonneville Dam McNary Dam (Aug 1-Dec 31) (Aug 14-0ct 31) other Total

$\begin{array}{rr}115 & 240 \\ 53 & 785\end{array}$

785

330

$$
316
$$$$
314
$$$$
539
$$$$
149
$$$$
\begin{aligned}
& 149 \\
& 157
\end{aligned}
$$$$
64
$$$$
\begin{array}{r}
64 \\
92 \\
577
\end{array}
$$$$
577
$$$$
922
$$$$
281
$$$$
295
$$$$
939
$$$$
1261
$$$$
1303
$$

1477

$11 \quad 1789$

11 3101

1206

$\begin{array}{ll}307,955 & \\ 310,590 & \\ 180,981 & \\ 250,482 & \\ 137,617 & \\ 220,396 & \\ 104,371 & \\ 106,784 & 13,476 \\ 105,318 & 16,426 \\ 136,268 & 11,290 \\ 131,813 & 70,607 \\ 249,314 & 97,528 \\ 194,943 & 55,730 \\ 101,232 & 47,337 \\ 116,824 & 41,200 \\ 118,024 & 44,116 \\ 139,075 & 57,363 \\ 172,463 & 58,593 \\ 157,694 & 76,326 \\ 155,445 & 75,119 \\ 185,643 & 73,087\end{array}$


TABLE 3.14. (contd)

Hutiber of Redds

\begin{tabular}{|c|c|c|c|c|c|c|c|c|c|c|c|}
\hline \multirow[b]{2}{*}{ ear } & & \\
\hline & $\begin{array}{c}\text { RM } 354 \\
\text { (Ringold) } \\
\end{array}$ & $\begin{array}{c}\text { RI' } 365 \\
\text { to } \\
368 \\
\end{array}$ & $\begin{array}{l}\text { RH } 371 \\
\text { (White } \\
\text { Bluffs) }\end{array}$ & $\begin{array}{c}\text { Rel } 373 \\
\text { to } \\
376 \\
\end{array}$ & $\begin{array}{l}\text { RM } 383 \\
\text { (Coyote } \\
\text { Rapids) } \\
\end{array}$ & $\begin{array}{c}\text { RM } 393 \\
\text { (Midway) }\end{array}$ & Other & Tota1 & $\begin{array}{l}\text { Bonneville } \\
\text { (Aug 1-Dec }\end{array}$ & $\begin{array}{l}\text { Dam } \\
31) \\
\end{array}$ & $\begin{array}{c}\text { McNary Dam } \\
\text { (Aug 14-0ct 31) }\end{array}$ \\
\hline 1968 & 117 & 595 & 188 & 1069 & $5 ?$ & 1520 & 39 & 3595 & 159,048 & & 72,757 \\
\hline 1969 & 265 & 820 & 42.7 & 1446 & 50 & 1500 & 0 & 4508 & 231,828 & & 79,375 \\
\hline 1970 & 107 & 615 & 302 & 1180 & 72 & 1528 & 9 & 3813 & 208,902 & & 61,554 \\
\hline 1971 & 182 & 560 & 416 & 1071 & 10 & 1361 & 0 & 3600 & 202,274 & & 69,718 \\
\hline 1972 & 88 & 247 & 147 & 259 & 4 & 131 & D & 876 & 137,486 & & 49,307 \\
\hline 1973 & 137 & 458 & 179 & 1273 & 62 & 856 & 0 & 2965 & 211,127 & & 73,253 \\
\hline 1974 & 104 & 156 & 49 & 238 & 5 & 173 & 3 & 728 & 186,328 & & 62,009 \\
\hline 1975 & 95 & 458 & 291 & 752 & 91 & 995 & 1 & 2683 & 277,111 & & 68,719 \\
\hline 1976 & 25 & 313 & 185 & 647 & 182 & 599 & 0 & 1951 & 325,312 & & 87,991 \\
\hline 1977 & 15 & 473 & 355 & 1577 & 48 & 772 & 0 & 3240 & 206,126 & 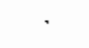 & 84,370 \\
\hline 1978 & 18 & 216 & $3 ? 6$ & 1389 & $8 D$ & 999 & 0 & 3028 & 200,414 & & 44,145 \\
\hline 1979 & 67 & 396 & 297 & 1151 & 92 & 980 & 0 & 2983 & 190,627 & & 49,961 \\
\hline 1980 & 30 & 157 & 64 & 346 & 35 & 855 & 0 & 1487 & 153,466 & & 38,910 \\
\hline 1981 & 82 & 421 & 275 & 1875 & 80 & 2132 & 0 & 4866 & 193,712 & & 33,148 \\
\hline 1982 & 9 & 368 & 290 & 1978 & 168 & 2159 & 16 & 4988 & 219,923 & & 56,869 \\
\hline
\end{tabular}

(1) 1957 and 1958 counts were corrected. The original values were the sum of all redds observed, i.e. the sum of all survey counts. 
TABLE 3.15. Relative Utilization of Major Fatl Chinook Spawining Grounds in the Hanford Reach

\begin{tabular}{|c|c|c|c|}
\hline Spawning Area & Section & $\begin{array}{c}10 \text { Year } \\
\text { Average } \\
* \text { Redds } \\
(1967-1976) \\
\end{array}$ & $\begin{array}{c}\text { Contribution } \\
\text { Per Area }\end{array}$ \\
\hline $\begin{array}{l}\text { 1. Wooded Island/ } \\
\text { Ringold }\end{array}$ & RM $347-354^{\circ}$ & 103 & 3.9 \\
\hline 2. -- & RM 365-368 & 2.59 & 9.8 \\
\hline 3. White Bluffs & RM 371 & 183 & 6.9 \\
\hline 4. -- & RM $373-374$ & 235 & 8.9 \\
\hline 5. Locke Island & RM 375 & 530 & 20.1 \\
\hline $6 .--$ & Rir 376 & 111 & 4.2 \\
\hline 7. -- & RM 377 & 226 & 8.6 \\
\hline 8. Coyote Rapids & RM 383 & 51 & 1.9 \\
\hline 9. Vernita Bar & RM 393-395 & 943 & 35.7 \\
\hline \multicolumn{2}{|c|}{ TOTAL 10 Year Average } & 2,639 & 100.0 \\
\hline Range & & $\begin{array}{r}3-3,981 \\
\text { Redds }\end{array}$ & \\
\hline
\end{tabular}

Source: PSP\&L (1981, Amendment 4)

salmon these fry may be present in nearshore areas in July, virtually all are absent in August when seasonal water temperatures peak.

Peak movement through the Hanford Reach of 0 -age group fall and summer chinook salmon from upstream tributaries and hatcheries typically occurs in August (Sims and Miller 1976, Table 2; Hovland et al. 1982, p. 9). Peak outmigration of 1-age group spring chinook salmon from upstream occurs near mid-May (Hoveland et al. 1982). Outmigrants passing through the Hanford Reach from upriver tributaries and hatcheries are typically larger than those produced locally. These upriver fish generally pass through the area rapidly and do not linger at nearshore sites. 
Two rearing facilities contribute juvenile fall chinook directly to the Hanford Reach: the hatchery and spawning channel at Priest Rapids Dam, above Hanford, and the Ringold Rearing Ponds in the lower reaches of Hanford. Available production data from these facilities are given in Figures A.1 and A.2.

Feeding and growth is important for 0-age fall chinook salmon in the Hanford Reach. Based on frequency of occurrance and volume, various stages of aquatic insects, mainly caddisfly (Trichoptera) and midge fly (Chironomidae) are the major food items (Becker 1972 p. 391; Gray and Dauble 1977a, p. 5.7; Gray and Dauble 1978, p. 5.5). Feeding trends are related to seasonal availability of various food organisms.

Because 1-age fingerlings are larger than 0-age fry, their food habits may differ. Adult caddisfly and midge fly pupae represent the greatest food $i$ tems by number and volume of transitory spring chinook salmon smolts (Gray and Dauble 1979a, p. 5.7; Gray and Dauble 1977b, p. 5.6). Caddisfly larvae, fish, spiders and midge fly larvae and adults are also taken. Salmon smolts may prey on salmon fry (10c. cit.).

Columbia River salmonids are cold-water species and are relatively sensitive to water temperatures exceeding $20^{\circ} \mathrm{C}$. Preferred temperatures are reported to range from $12.0^{\circ} \mathrm{C}\left(53.6^{\circ} \mathrm{F}\right)$ to $13.0^{\circ} \mathrm{C}\left(55.4^{\circ} \mathrm{F}\right)$ for juvenile chinook salmon acclimated to $20.0^{\circ} \mathrm{C}\left(68^{\circ} \mathrm{F}\right)$ (Brett $1952, \mathrm{p} .291$ ) and $17.3^{\circ} \mathrm{C}\left(63.1^{\circ} \mathrm{F}\right.$ ) for adults (Spigarelli 1975). The incipient upper lethal temperature ( 1 week exposure) for juvenile chinook salmon is $25.1^{\circ} \mathrm{C}\left(77.2^{\circ} \mathrm{F}\right.$ ) (Brett 1952, p. 305). Chinook salmon may be able to avoid temperatures that exceed the preferred temperatures. Juvenile chinook salmon in laboratory tests avoid simulated thermal discharges at a current velocity of $2.0 \mathrm{fps}$ when the thermal discharge greatiy exceed ambient temperatures (Gray et al. 1977, p. 369). Other observations suggest that adult chinook salmon in the Columbia River will cease upstream migration at water temperatures above $21.1^{\circ} \mathrm{C}\left(70.0^{\circ} \mathrm{F}\right.$ ) (EPA 1971, p. 17).

Median (50\% mortality) resistant times to death for young spring chinook salmon range from $205 \mathrm{~min}$ at a $22.5^{\circ} \mathrm{C}\left(72.5^{\circ} \mathrm{F}\right)$ exposure and $5^{\circ} \mathrm{C}\left(41^{\circ} \mathrm{F}\right)$ acclimation to 12,300 min at $25^{\circ} \mathrm{C}\left(77.0^{\circ} \mathrm{F}\right)$ exposure and $24^{\circ} \mathrm{C}\left(75.2^{\circ} \mathrm{F}\right)$ 
acclimation (Brett 1952, p. 316). The lethal threshold (10\% mortality) of $19.5^{\circ} \mathrm{C}\left(67.7^{\circ} \mathrm{F}\right)$ at $13.0^{\circ} \mathrm{C}\left(55.4^{\circ} \mathrm{F}\right)$ acclimation for chinook salmon fingerlings at 2-wk exposures (Snyder and Blahm 1970, p. 893). Another study lists an upper letha] threshold (50\% mortality) of $24.2-24.4^{\circ} \mathrm{C}\left(75.6^{\circ}-76.1^{\circ} \mathrm{F}\right.$ ) at acclimations of $11.0-20.0^{\circ} \mathrm{C}\left(51.8-68.0^{\circ} \mathrm{F}\right)$ (Blahm and McConnel 1970).

Precise upper limits have not been defined for adult chinook salmon, but experiments with precocious males (jack salmon) suggest that the incipient lethat temperature for fish acclimated to $15.3-19.6^{\circ} \mathrm{C}\left(59.5-67.3^{\circ} \mathrm{F}\right)$ ambient Columbia River water is $21.0-22.0^{\circ} \mathrm{C}\left(69.8-71.6^{\circ} \mathrm{F}\right)$ (Coutant 1970a). For adult chinook salmon in the Hanford Reach, water temperatures are crucial during spawning. Temperatures are normally about $15.0-16.0^{\circ} \mathrm{C}\left(59.0-60.8^{\circ} \mathrm{F}\right)$ when spawning begins in the fall, but they were as high as $19.3^{\circ} \mathrm{C}\left(66.8^{\circ} \mathrm{F}\right)$ during early October 1958 when spawning had apparently started.

The effect of a thermal effluent discharge in midstream on juvenile chinook salmon outmigrants will depend on several factors including the timing of the outmigration, distribution of the fish in the water column, the thermal increment encountered, and the duration of exposure.

Data on the timing of the chinook salmon outmigration from the Hanford Reach were presented previously. Peak numbers of 0-age fry occur in shoreline areas from late Aprit through May (Becker 1970, p. 6; Gray and Dauble 1979a, Fig. 5.2, 1979b, Fig. 5.2). Oownstream movement of i-age chinook fingerlings over Priest Rapids Oam occurred from April to September in 1967. The timing of the outmigration is now somewhat later than the timing before extensive dam construction. For example, the 1-age group outmigrants appeared at Byers Landing (RM 346) in June 1955 and composed 93\% of the catch in July (Mains and Smith 1964, p. 28-29). Impoundment of the upper Columbia River is considered responsible for delayed outmigration rates in recent years (Park 1969, p. 315-317; Raymond 1968, p. 358).

Most (60-75\%) movement of chinook salmon smolts occurred at night at Priest Rapids Oam (Sims and Miller 1977, p. 12), as it did in 1955 (70\%) at Beyers Landing (Mains and Smith 1964, p. 29-30). However, some outmigrants pass downriver at all times of the day. Horizontal and vertical distribution of outmigrants in the water column of the Hanford Reach is known primarity 
from 1955 studies of Mains and Smith (1964), before construction of Priest Rapids Dam. Stations closest to the banks accounted for the heaviest catches per unit of effort $(50-60 \%)$, although numerous fish were taken at all stations across the rest of the river $(40-50 \%)$. The outmigrant chinooks also preferred the surface zone, with $44 \%$ of the catch near the surface, $28 \%$ at mid-depth and $30 \%$ at the bottom (Mains and Smith 1964, p. 42). Recent (1983) studies on the distribution of 1-age salmonids passing seaward at Hanford were conducted at PNL, and these data are being analyzed.

The duration of exposure is related to an acute encounter when a fish enters a thermal effluent in a flowing river, passes downstream through the effluent and returns to ambient river temperature. Experimental data on this phenomena is given by Dean (1973) for juveniles of three salmonid species, including chinook salmon. Additional experimental studies on plume exposures were conducted at PNL in 1983, and these data are being analyzed. Coutant (1972) discussed the scientific basis for water temperature standards at power plants, including the relationship between effects and duration of exposure of fish entrained in themal discharge plumes.

\subsection{Coho salmon}

Coho salmon do not spawn in the Hanford Reach but migrate through it to and from upstream spawning areas, primarily the Wenatchee River system. Generally, coho spawning and fry development occurs in smaller rivers and moderately-sized tributary streams in the lower Columbia River (Fulton 1970, p. 12). After hatching, juvenile coho salmon remain in freshwater nursery area for one to three years before migrating to the sea as smolts measuring 4-7 inches (Wydowski and whitney 1979, p. 56-58).

From 1954 through 1981, the main adult coho salmon spawning migration at McNary Dam occurred from August through October, with the peak movement in September (U.S. Army Corps of Engineers, 1982 Table 69). Adult counts at Priest Rapids Dam have declined significantly in recent years. Counts ranged from 1,336 to 11,648 adults annually from 1966 to 1976, but dropped to less than a thousand for most years after that time. The coho saimon run characteristically contains a high proportion of precocious males ("jacks") (Bilton et a]. 1982). 
Outmigrant coho salmon, primarily 1-age fish, appear at Priest Rapids Dam from April to September with peaks occurring usually in May (Sims and Miller 1976, p. 9; Faurot 1979, p. 9; 01son 1981, p. 17). Coho move into gatewe11 collectors at Priest Rapids Dam primarily at night (01son 1981, p. 18-19). Downstream migration rate of a 11 salmonids including coho from Priest Rapids Dam to McNary Dam ranged from 7 to 15 days in 1977 with fastest trave $7^{-}$at higher river flows (Faurot 1979, p. 8). Passage through the Hanford Reach must be relatively rapid since outmigration would be slowed by Lake Wallula, the impoundment behind McNary Dam.

Some coho salmon smolts may stay in the Hanford Reach, a tendency noted only recently. In Spring 1978, several coho salmon were collected at Hanford that appeared to be 2-year old residents (Gray and Dauble 1979b, p. 5.10). However, these fish may have moved up from Lake Wallula, downstream of Hanford.

Numbers of coho salmon smolts passing through the Hanford Reach are variable, and depend on fluctuations in natural production and on artificial propagation, primarily at the Leavenworth Hatchery, Wenatchee River system in recent years (Sims and Miller 1976, p. 9). Annual gatewell catches at Priest Rapids Dam, a program now supported by Grant County Public Utility District, do not accurately indicate the size of the outmigration. This is because gatewell sampling does not collect outmigrants passing over the spillway, and spillway discharges vary widely from year to year. Also, collecting effort has been inconsistent from year to year. However, an estimated 600,000 juvenile coho salmon passed Priest Rapids Dam in 1976 (Sims and Miller 1976, p. 6). This estimate is only about half that of the runs that occurred in the late 1960s (Park and Bentley 1968).

Analys is of stomach contents of juvenile coho salmon collected at Hanford showed a varied diet consisting of fish larvae, midge fly larvae and pupae, and caddisfly larvae and adults (Gray and Dauble 1979b, p. 5.11).

Adult coho salmon generally prefer temperatures from 11.4 to $16.6^{\circ} \mathrm{C}(52.5$ to $61.9^{\circ} \mathrm{F}$ ) (Brett 1952, p. 293; Reutter and Herdendorf 1974, Spigarelli 1975). Coho salmon, like other species of Pacific salmon, generally avoid temperatures above $15^{\circ} \mathrm{C}\left(59^{\circ} \mathrm{F}\right)$ (Brett 1952 , p. 293). Elevation of 
environmental temperatures above $21.0^{\circ} \mathrm{C}\left(69.8^{\circ} \mathrm{F}\right)$ may be directly lethal to adult salmon and steelhead during long-term (about 1 week) exposures (Coutant 1970a, p. 10). Geometric mean time to death for adult coho salmon ranged from 13 minutes at $30^{\circ} \mathrm{C}\left(86^{\circ} \mathrm{F}\right)$ to $42 \mathrm{~min}$ at $26^{\circ} \mathrm{C}\left(78.8^{\circ} \mathrm{F}\right)$ (Coutant $1970 \mathrm{a}$, Figure 5).

The upper incipient lethal temperature for juvenile coho salmon acclimated at 5 to $23^{\circ} \mathrm{C}\left(41\right.$ to $73.2^{\circ} \mathrm{F}$ ) is 22.9 to $25^{\circ} \mathrm{C}\left(73.2\right.$ to $77.0^{\circ} \mathrm{F}$ ) (Brett 1952, Figure 24). Median times to death (50\% mortalitiy) range from 1000 min at exposure to $23^{\circ} \mathrm{C}\left(73.4^{\circ} \mathrm{F}\right)$ to $9000 \mathrm{~min}$ at exposure to $25^{\circ} \mathrm{C}\left(77.0^{\circ} \mathrm{F}\right)$, depending on acclimation level (Brett 1952, Figure 8, Table 4). The lethai threshold ( $10 \%$ mortality) for juvenile coho salmon acclimated at temperatures of 10 to $14^{\circ} \mathrm{C}\left(50\right.$ to $57.2^{\circ} \mathrm{F}$ ) ranged from 14 to $23.7^{\circ} \mathrm{C}\left(57.2\right.$ to $74.7^{\circ} \mathrm{F}$ ) (Blahm and McConnel 1970).

Loss of equilibrium and lethal temperatures of juvenile coho salmon acclimated to 5 and $15^{\circ} \mathrm{C}\left(41.0\right.$ and $\left.59^{\circ} \mathrm{F}\right)$ and exposed to progressively increasing temperatures will vary with the rate of increase (Becker and Genoway 1979, P. 248). Resistance times of juvenile coho salmon acciimated to 10,15 and $20^{\circ} \mathrm{C}\left(50,59\right.$ and $\left.68^{\circ} \mathrm{F}\right)$ varied from 100,000 to less than 100 minutes (Oean 1973, p. 38).

Elevated temperatures also produce secondary effects among coho salmon. For example, rheotactic response may be altered by sudden small changes in temperature during fry and smolt outmigration (Keeniyside and Hoare 1954, $\mathrm{p}$. 82). As it does with other anadromous species of salmonids, temperature influences the growth and smolting of juvenile coho salmon (Clarke et al. 1981 , p. 113; Wedemeyer et a1. 1980, p. 6-7). Also, sublethal heat stress results in a number of physiological responses (Wedemeyer 1973). Outbreaks of a number of fish diseases, including the bacterial disease columnaris (Holt et a]. 1975; Becker and Fujihara 1978, p. 25-27) are influenced by elevated temperatures.

\subsection{Sockeye saimon}

Sockeye salmon do not spawn in the hanford Reach but migrate through it to upstream spawning areas. Adults typically spawn in tributary or outlet streams of lakes, or along lake shores, from August through November. 
Juveniles live 1 to 3 years in lakes before migrating seaward in early spring. Virtually all sockeye salmon adults entering the Columbia River are destined for its upper reaches where the main production areas are Lake Wenatchee, on the Wenatchee River and Lake Osoyoos on the Okanogan River (Allen 1977, p. 29). Adult sockeye salmon typically migrate upriver in relatively shallow water near the shore (Becker 1962), but there is little knowledge of their migration routes in the mid-Columbia River.

The last large runs of adult sockeye salmon passed McNary Dam in 1966, 1967 and 1968 when the run averaged 127,000 fish. Since that time McNary Dam counts have averaged 40,000 fish (U.S. Army Corps of Engineers 1982, Table 68). There has been no meaningful commercial harvest in the lower Columbia River in recent years. Discrepencies exist between the counts of adult sockeye salmon at Priest Rapids Dam and the counts at McNary Dam. Adult sockeye salmon pass through the Hanford Reach primarily from June to early September, with the upstream migration peaking in July (U.S. Army Corps of Engineers 1982, Table 68).

Sockeye salmon fry emerge in April and May and enter lakes to feed. Peak outmigration of juvenile sockeye salmon at Priest Rapids Dam occurs in May (Table 3.11). Juveniles enter the gatewells at Priest Rapids Dam at all hours of the day, but in greatest numbers during the afternoon (01son 1981, Figure 6). In terms of relative abundance, the numbers of juvenile sockeye salmon outmigrants are close to that of juvenile chinook salmon outmigrants in gatewell collections at Priest Rapids Dam (0lson 1981, Table 2).

Numbers of sockeye salmon juveniles passing downstream each year through the Hanford Reach depends on natural reproduction of upstream stocks. Estimates of sockeye salmon juveniTes passing Priest Rapids Dam ranged from 1.0 to 4.0 million from 1965 to 1967 , and were $1.6 \mathrm{million}$ in 1976 (Sims and Miller 1976, Table 1). A few juvenile sockeye salmon have been collected in the Hanford Reach have been made in June and July (Gray and Dauble 1978, p. 515; Page et al. 1982, Table 2). The Hanford area is transitory habitat for juvenile sockeye salmon and this section of the river is not an important feeding area for outmigrants. 
Sockeye salmon juveniles feed primarily on zooplankton and phytoplankton in their lake nursery areas (Foerster 1968, p. 166-167). They feed on plankton more than juveniles of other species of Pacific salmon. Analysis of gut contents of a few sockeye salmon outmigrants taken at Hanford (RM 352) showed. primarily midge fly and caddisfly pupae (Gray and Dauble 1979a, Table 5.5).

Juvenile sockeye salmon prefer temperatures of 12 to $14^{\circ} \mathrm{C}(53.6$ to $57.2^{\circ} \mathrm{F}$ ) regardless of acclimation level, and generally avoid temperatures above $15^{\circ} \mathrm{C}\left(59^{\circ} \mathrm{C}\right)$, as do other species of Pacific Salmon (Brett 1952, p. 293). One field study showed a preferred range of 10.6 to $12.8^{\circ} \mathrm{C}\left(51.1\right.$ to $\left.55.0^{\circ} \mathrm{F}\right)$ (Horak and Tanner, 1964). The optimum temperature for growth of fingerling sockeye salmon is near $15^{\circ} \mathrm{C}\left(59^{\circ} \mathrm{F}\right)$ (Brett 1971 , p. 99). The temperature preference for kokanee salmon (landlocked sockeye salmon) is $10-15^{\circ} \mathrm{C}\left(50-59^{\circ} \mathrm{C}\right.$ ) (Scott and Crossman 1973, p. 169.).

The upper incipient lethal temperature for juvenile sockeye salmon acclimated from 5 to $23^{\circ} \mathrm{C}\left(41\right.$ to $\left.73.2^{\circ} \mathrm{F}\right)$ is 22 to $24^{\circ} \mathrm{C}\left(71.6\right.$ to $75.2^{\circ} \mathrm{F}$ ) (Brett 1952, Figure 22). Medium times to death (50\% mortality) range from 100 minutes at $5^{\circ} \mathrm{C}\left(41^{\circ} \mathrm{F}\right)$ acclimation and exposure to $22.5^{\circ} \mathrm{C}\left(72.5^{\circ} \mathrm{F}\right)$ to 675 minutes at $23^{\circ} \mathrm{C}\left(73.4^{\circ} \mathrm{F}\right.$ ) acclimation and exposure to $26.5^{\circ} \mathrm{C}\left(79.7^{\circ} \mathrm{F}\right.$ ) (Brett 1952, Table 4). Adult sockeye salmon can survive an average of 3.2 days at $22.2^{\circ} \mathrm{C}\left(72^{\circ} \mathrm{F}\right)$ and 11.7 days at $20.0^{\circ} \mathrm{C}\left(68^{\circ} \mathrm{F}\right)$ (EPA 1971, p. 41-42).

Elevated temperatures may delay the upstream migration of sockeye salmon. Adults congregate in colder tributary streams near Bonneville and Rock Island Dams when Columbia River temperatures reached 21.7 to $23.9^{\circ} \mathrm{C}\left(71.1\right.$ to $\left.75.0^{\circ} \mathrm{F}\right)$ (Fish and Hanavan 1948). Water temperatures above $21.1^{\circ} \mathrm{C}\left(70^{\circ} \mathrm{F}\right)$ block migration of sockeye salmon into the Okanogan River (Major and Mighell 1967, p. 145).

Elevated temperatures also produce secondary effects among sockeye salmon. In the Columbia River system, high temperatures are related to outbreaks of a bacterial disease, columnaris (Holt et al. 1975, Becker and Fujihara 1978 , p. 25-27). Juvenile sockeye salmon stressed by abrupt exposure to elevated temperatures are more susceptible to predation (Sylvester 1972). 


\subsection{Steelhead or rainbow trout. The steelhead trout is an}

anadromous form of the rainbow trout. Resident and anadromous forms both occur in the Hanford Reach. The steelhead trout spawns in freshwater but may not die afterward as do Pacific salmon (genus Oncorhynchus). Steelhead and rainbow trout both have sport and commercial value, and the former contributes to the Indian gill net fishery in the lower Columbia River on its return from the ocean.

On the basis of the timing of the aduTt migration in the lower Columbia River, steelhead trout are classified either as winter or summer run. The summer run, which enters the river from May to October, migrates upriver to tributaries above Bonnevilie Dam (Fulton 1970, p. 3).

Adult steelhead trout show peak periods of migration through the Hanford Reach, but a sizeable population is present the year around An upriver run of steelhead occurs over McNary Dam from April through October, but the peak movement occurs in August and September (U.S. Army Corps of Engineers 1982, Table 70). The average migration of steelhead trout over the McNary Dam from 1971 to 1981 was 11,000 in August and 24,000 in September (1oc. cit.). Many of these fish are destined for the Snake River as well as the mid-Columbia River. In some months (October, April, May) more steelhead pass over Priest Rapids and Ice Harbor Dams then come upriver over McNary Dam. This may indicate late fall and winter residence in Lake Wallula and the Hanford Reach (Watson 1973, p. 3).

Numbers of adult steelhead trout passing Priest Rapids Dam ranged from 2,000 to 11,000 from 1971 to 1980 and averaged 7,000 fish (Table 3.16). The average number from 1962 to 1971 at the same location was 9,700 (Watson 1973, Table 1), indicating sustained population levels with some year-to-year variations. The peak run of adult steelhead trout over Priest Rapids Dam occurs in September of most years. Steelhead and rainbow trout have been collected in small numbers from the Hanford Reach at RM 366 (RKM 588) and 352 (RKM 566) during most months (Gray and Dauble 1976a, Figure 5.13; Gray and Dauble 1979b, Figure 5.14). In addition to McNary and Ice Harbor runs, each year about 10,000 to 15,000 steelhead trout enter the Yakima River, about 4,000 to 5,000 enter the Walla Walla River, and about 2,700 are taken by sport 
TABLE 3.16. Adult Salmon Counts at the Priest Rapids Dam Fishway (01son 1981, p. 40)

\begin{tabular}{|c|c|c|c|c|c|c|c|}
\hline Yeax & $\begin{array}{l}\text { Spring } \\
\text { Chinook }\end{array}$ & $\begin{array}{l}\text { Summer } \\
\text { Chinook }\end{array}$ & $\begin{array}{c}\text { Fal } 1 \\
\text { Chinook } \\
\end{array}$ & Sockaye & Coho & Steelhead & $\begin{array}{c}\text { Total } \\
\text { Salmonids }\end{array}$ \\
\hline $\begin{array}{l}1960 \\
1961 \\
1962 \\
1963 \\
1964\end{array}$ & $\begin{array}{l}8,534 \\
9,395 \\
7,993 \\
7.597 \\
9,814\end{array}$ & $\begin{array}{l}20,852 \\
18,245 \\
20,824 \\
18,511 \\
26,489\end{array}$ & $\begin{array}{l}10,687 \\
11,108 \\
10,082 \\
17,563 \\
14,760\end{array}$ & $\begin{array}{l}58,201 \\
19,793 \\
28,575 \\
64,883 \\
79,072\end{array}$ & $\begin{array}{r}59 \\
89 \\
601 \\
29 \\
60\end{array}$ & $\begin{array}{l}7,827 \\
6,559 \\
9,324 \\
9,344 \\
6,009\end{array}$ & $\begin{array}{r}66,133 \\
66,179 \\
77,399 \\
177,927 \\
136,204\end{array}$ \\
\hline $\begin{array}{l}1969 \\
1966 \\
1967 \\
1968 \\
1969\end{array}$ & $\begin{array}{r}5,719 \\
13,358 \\
10,307 \\
10,739 \\
7,142\end{array}$ & $\begin{array}{l}24,936 \\
29,736 \\
26,256 \\
26,544 \\
21,277\end{array}$ & $\begin{array}{l}21,149 \\
18,921 \\
12,375 \\
11,031 \\
12,367\end{array}$ & $\begin{array}{r}48,340 \\
170,071 \\
123,786 \\
109,308 \\
39,240\end{array}$ & $\begin{array}{r}440 \\
21,903 \\
8,879 \\
13,212 \\
1,351\end{array}$ & $\begin{array}{r}9,041 \\
13,006 \\
7,354 \\
10,524 \\
6,650\end{array}$ & $\begin{array}{r}209,632 \\
252,930 \\
188,937 \\
180,358 \\
89,027\end{array}$ \\
\hline $\begin{array}{l}1970 \\
1971 \\
1972 \\
1973 \\
1974\end{array}$ & $\begin{array}{r}5,789 \\
5,086 \\
8,775 \\
9,967 \\
11,127\end{array}$ & $\begin{array}{l}21,641 \\
20,481 \\
18,083 \\
14,351 \\
13,703\end{array}$ & $\begin{array}{r}16,372 \\
10,591 \\
5,792 \\
10,083 \\
7,619\end{array}$ & $\begin{array}{l}77,419 \\
73,937 \\
44,927 \\
54,480 \\
35,434\end{array}$ & $\begin{array}{l}4,971 \\
7,738 \\
5,225 \\
1,576 \\
1,781\end{array}$ & $\begin{array}{r}5,550 \\
11,102 \\
6,429 \\
6,999 \\
3,089\end{array}$ & $\begin{array}{r}131,750 \\
129,835 \\
99,221 \\
97,456 \\
72,752\end{array}$ \\
\hline $\begin{array}{l}1975 \\
1976 \\
1977 \\
1978 \\
1979 \\
1980\end{array}$ & $\begin{array}{r}8,170 \\
13,306 . \\
21,217 \\
21,427 \\
7,750 \\
11,136\end{array}$ & $\begin{array}{l}22,205 \\
19,344 \\
19,605 \\
22,580 \\
22,609 \\
18,708\end{array}$ & $\begin{array}{r}13,865 \\
10,774 \\
6,856 \\
6,523 \\
7,727 \\
8,441\end{array}$ & $\begin{array}{l}55,210 \\
32,810 \\
95,413 \\
17,529 \\
45,662 \\
52,039\end{array}$ & $\begin{array}{r}2,193 \\
2,275 \\
370 \\
597 \\
311 \\
318\end{array}$ & $\begin{array}{l}2,462 \\
9,248 \\
9,803 \\
4,545 \\
8,409 \\
8,524\end{array}$ & $\begin{array}{r}103,605 \\
87,757 \\
153,264 \\
73,201 \\
86,947 \\
99,166\end{array}$ \\
\hline $1981 *$ & 14,467 & 11,633 & 5,417 & 51,460 & 300 & 8,925 & 92,202 \\
\hline $1982 \star$ & 8,664 & 8,762 & 12,462 & 40,461 & $\uparrow, 631$ & 10,893 & 82,873 \\
\hline
\end{tabular}

* Condensed Daily Fish Count Report,

U. S. Army Engineer District, Portland, $O R$

fishermen. Assuming a 20\% mortality also, for fish unaccounted for, the average annual number of steelhead trout spawning in the Hanford Reach was about 10,000 for the 1962-1971 period (Watson 1973, p. 6-7). In recent years, steelhead trout are also reared and released at the Ringold Hatchery [RM 354 (RKM 569)] and a significant sport fishery occurs on returns to this facility (Allen 1977, p. 25, 27).

Steelhead trout mature in the ocean at ages of 3 to 6 years, spawn in the Columbia River from late December through May and eggs incubate in the gravel through June (Be11 1973, Chapter 5, p. 12-13). Steelhead spawn from February through May from the mouth of the Yakima River to Priest Rapids Dam (Fickeisen 
et a1. 1980, p. 2-19). Gravid females have been collected in late April and early May, spent males in August, and a spent female in February in the Hanford Reach (Gray and Dauble 1976a, p. 5-20; Gray and Dauble 1977b, p. 5.8. Steelhead may survive spawning. Repeat spawnings ranging from 5 to 31.3 percent are reported in some British Columbia streams (Withler 1966, p. 365). Repeat spawners in Washington State compose from 4.4 to $14 \%$ of the run (Wydowski and Whitney 1979, p. 44-45).

Only a few steethead trout redds have been observed in the Hanford Reach. However, there are several sites with apparently suitable conditions for successful spawning. Few emergent steelhead trout fry have been coilected despite extensive effort (Fickeisen et al. 1980, p. 2-19). On the basis of the best avajlable information for the Hanford Reach, the estimated natura] production of steelhead trout fry is 1.6 million (loc. cit.).

Estimates of steelhead trout spawners in the Hanford Reach by direct observation and redd enumeration is complicated by high flows and turbidities during the late winter spawning season. Possible spawning areas for steelhead trout are scattered throughout the area (Figure 3.18 ).

Releases of juvenile steelhead trout occur annually at Ringold rearing facility operated by the Washington State Departments of Game and Fisheries. About 160,000 smolts are released each year from the Ringold facility (RM 354). The releases represent about $25 \%$ of the of steelhead trout reared artificialiy from the Hanford area upstream to Wenatchee (Washington State Department of Game, 1971 to 1979). Most releases from Ringold facilities remain in the general area for about a month, and a few overwinter in the Hanford Reach (Gray and Dauble 1978, p. 5.12).

Juvenile steelhead trout characteristically spend one to three years in freshwater and move seaward through the Columbia River during the spring and summer (Bell 1973, p. 12-13). The outmigration of juvenile steelhead trout from above Priest Rapids Dam generally occurs from mid-April to early July, with a peak movement in May (Table 3.11). Juvenile outmigrants were collected at Hanford from April through June with peak catches in May (Gray and Dauble 1977a, Fig. 5.12; 1978, Fig. 5.11; 1979a, Fig. 5.11). However, markings indicated that most of these fish were produced at upriver hatcheries. The 
hatchery contribution may be reflected in outmigration patterns (Park and Bentley 1968). Estimated of steelhead trout outmigrants at Priest Rapids Dam in 1965, 1966, 1967 and 1976 were 270,000, 240,000, 266,000 and 400,000, respectively (Sims and Miller 1976, Table 1).

Therefore, the total number of juvenile steelhead trout passing seaward from the Hanford Reach each year is between 2.0 and 2.2 million (sum of natural and artificial production at Hanford plus the outmigration at Priest Rapids Dam) (Fickeisen et al. 1980, p. 2-21). The variation in this estimate reflects changes in abundance of juveniles passing Priest Rapids Dam and of juveniles produced at the Ringold facilities.

Diel movements of juvenile salmonid outmigrants tends to very, for reasons that remain unclear. Catches at Priest Rapids Dam first indicated that most (61\%) entered the intake gatewells after dark (Sims and Miller 1977, p. 13). Recent studies indicate variable movement rates at night and a strong movement after sunrise (01son 1981, p. 19-20). Most outmigration (76\%) of stee ihead trout smolts from impounded waters occurs at night, and the portion of fish collected in the lighted surface zone $(0-7.3 \mathrm{~m})$ declines from day $(74 \%)$ to night $(36 \%)$, reflecting this movement (Smith 1974, p. 42-45). Most steelhead smolts passing Priest Rapids Dam probably move directly through the free-flowing Hanford Reach to Lake Wallula.

Juvenile steelhead and rainbow trout in freshwater streams exist on foods associated with the bottom, such as aquatic insects, amphipods, aquatic worms, fish eggs, and occasionally small fish. Diets change seasonally depending on availability of food items (Wydoski and Whitney 1979, p. 46). At Hanford, fish and caddisfilies (adults and larvae) were food major items of juvenile rainbow trout collected near the $\mathrm{N}$-Reactor (Gray and Dauble 1976a, Table 5.3), as well terrestrial insects (spiders and beetles). Analysis of stomach contents from fish collected near RM 352 revealed caddisfly larvae, pupae, and adults, midgefly pupae, other insects and fish as major food items (Gray and Dauble 1979b, Table 5.14). The summer emergence of adutt caddisflies in the Hanford Reach is reflected in stomach contents of these fish. Adult steelhead trout do not actively feed during their upstream migration, but they will take salmon eggs, worms and artificial Tures. Guts of adult steelhead collected at Hanford were empty and atrophied. 
Most adult steelhead trout collected at Hanford were 3 to 4 years old. Except for hatchery releases (Ringold), most fish displayed two freshwater annuali on their scales, indicating that they wintered 2 years in the river before outmigrating as smolts. Most fish returning to Washington streams have been at sea for 2 years and weigh 5 to 10 pounds (Wydowski and Whitney 1979, p. 44). Adult size is generally related to the length of residence and feeding conditions in the ocean.

Adult rainbow trout prefer temperatures ranging from 10.8 to $22.5^{\circ} \mathrm{C}(52.1$ to $72.5^{\circ} \mathrm{F}$ ) depending on acclimation temperature, season and life stage. In one early study, the final preferred temperature was $13^{\circ} \mathrm{C}\left(55.4^{\circ} \mathrm{F}\right.$ ) (Garside and Tate 1958, p. 565).

Juvenile rainbow trout prefer temperatures between 11.6 to $22.0^{\circ} \mathrm{C}(57.8$ to $\left.71.6^{\circ} \mathrm{F}\right)$ at acclimation temperatures between $6.0^{\circ}$ to $24.0^{\circ} \mathrm{C}\left(42.8\right.$ to $\left.75.2^{\circ} \mathrm{F}\right)$ (Cherry et al. 1975, Table 1).

Given a choice, rainbow trout (and other salmonids) may avoid potentially lethal temperatures. The upper avoidance temperature of adult rainbow trout is $25^{\circ} \mathrm{C}\left(77^{\circ} \mathrm{F}\right)$ when they are acc 1 imated to $24^{\circ} \mathrm{C}\left(75.2^{\circ} \mathrm{F}\right)$, and $13^{\circ} \mathrm{C}\left(55.4^{\circ} \mathrm{F}\right)$ when acclimated to $6^{\circ} \mathrm{C}\left(42.8^{\circ} \mathrm{F}\right)$ (Cherry et al. 1975, Tabie 2); fingerlings avoid $22.0^{\circ} \mathrm{C}\left(71.6^{\circ} \mathrm{F}\right)$ when reared at $15-20^{\circ} \mathrm{C}\left(29-68^{\circ} \mathrm{F}\right)$ (McCauley and Pond 1971, p. 1802-1804). The upper lethal temperature limit for steelhead and rainbow trout will vary with acclimation level, physiological condition of the fish, and environmental factors. In one study, juvenile rainbow trout acclimated to $11^{\circ} \mathrm{C}\left(51.8^{\circ} \mathrm{F}\right)$ died at $24^{\circ} \mathrm{C}\left(75.2^{\circ}\right)$ at exposures of 24 hours, but all survived at $22^{\circ} \mathrm{C}\left(71.6^{\circ} \mathrm{F}\right)(\mathrm{Black} 1953, \mathrm{p} .199)$. In another study, juvenite rainbow trout acclimated to $20^{\circ} \mathrm{C}\left(68^{\circ} \mathrm{F}\right)$ exposed to $27^{\circ} \mathrm{C}\left(80.6^{\circ} \mathrm{F}\right)$ died in 423 or 363 minutes, depending on whether they were reared in soft or hard water (Craigie 1963 , p. 828 ). The maximum acclimation temperature is $17^{\circ} \mathrm{C}$ $\left(80.6^{\circ} \mathrm{F}\right.$ ) (Charlon et al. 1970, p. 88). The apparent upper lethal threshold for adult steelhead trout in the Hanford Reach is $21^{\circ} \mathrm{C}\left(69.8^{\circ} \mathrm{F}\right.$ ) (Coutant 1970a, p. 10).

Elevated temperatures will generally increase the rate of embryonic development of eggs deposited by most species of salmonids, as long the 
temperature does not exceed lethal limits. Rainbow trout eggs hatch at the following rate when incubated at increasing temperatures: 80 days at $4.4^{\circ} \mathrm{C}$ $\left(40^{\circ} \mathrm{F}\right), 48$ days $7.2^{\circ} \mathrm{C}\left(45^{\circ} \mathrm{F}\right), 31$ days at $10^{\circ} \mathrm{C}\left(50^{\circ} \mathrm{F}\right), 24$ days at $12.8^{\circ} \mathrm{C}$ $\left(55^{\circ} \mathrm{F}\right)$, and 19 days at $15.6^{\circ} \mathrm{C}\left(60^{\circ} \mathrm{F}\right)$ (Leitritz and Lewis 1976, p. 76).

Secondary effects of high water temperatures have also been reported. Migrating steelhead trout (and other adult salmonids) may cease upstream movement in the Columbia River when temperatures exceed $21.1^{\circ} \mathrm{C}\left(70^{\circ} \mathrm{F}\right.$ ) (EPA 1971, p. 17). The migration paths of adult steelhead in the Snake River remained the same with seasonal changes of river temperature from 3.0 to $23.5^{\circ} \mathrm{C}\left(37.4\right.$ to $\left.74.3^{\circ} \mathrm{F}\right)$ however, migration rates increased from $1 \mathrm{~km} /$ day at $0-11^{\circ} \mathrm{C}\left(32-51.9^{\circ} \mathrm{F}\right)$ to $5 \mathrm{~km} /$ day at $18.5^{\circ} \mathrm{C}\left(65.3^{\circ} \mathrm{F}\right)$ and to $16 \mathrm{~km} /$ day at $21^{\circ} \mathrm{C}$ $\left(69.8^{\circ} \mathrm{F}\right.$ ) (Falter and Ringe 1974, p. 55-56). A rapid increase in temperature from 10 to $20^{\circ} \mathrm{C}\left(50-68^{\circ} \mathrm{F}\right)$ in three minutes can cause a number of sublethal physiological effects but recovery occurs in 24-28 hours (Wedemeyer 1973, p. 831-834). Exposure to thermal shock may induce selective predation on juvenile rainbow trout over different exposure times. The highest temperatures showed effects after the shortest exposures. The lowest temperature of $26^{\circ} \mathrm{C}$ induced significant predation after exposures of 64, 90 and 120 minutes but not after 16 to 32 min (Coutant 1973, p. 968-969).

Temperature is also a factor in susceptibility of salmonids to many infectious pathogens. In one study, experimental infections of juvenile steelhead trout with the bacterial disease columnaris was related to temperature. No mortality occurred below $9.4^{\circ} \mathrm{C}\left(49^{\circ} \mathrm{F}\right)$, but 96 to $100 \%$ mortality occurred in groups held at different temperatures above $12.2^{\circ} \mathrm{C}$ $\left(54^{\circ} \mathrm{F}\right.$ ) (Holt et al. 1975, p. 1555). The same study found that all steelhead trout held as controls at $23.3^{\circ} \mathrm{C}\left(74^{\circ} \mathrm{F}\right)$ died in 13 days with no evidence of infection (10c. cit).

\subsubsection{Important Resident Species}

Important resident species in the Hanford Reach include the white sturgeon, large scale sucker, prickly sculpin, northern squawfish, mountain whitefish, smalimouth bass and yellow perch.

3.2.4.3.1 White Sturgeon. The white sturgeon is the Targest North American freshwater fish. It occurs along the Pacific Coast from Monterey, 
California, to Cook Inlet in northwestern Alaska (Wydoski and Whitney 1979, $\mathrm{p}$. 17). White sturgeon occur throughout most of the Columbia River and its tributaries (Scott and Crossman 1973, p. 97). Although some individuals are found in the ocean and ascend rivers to spawn, white sturgeon are not truly anadromous. In earlier years, sturgeon in the Columbia River appeared to migrate upstream during the fall and early winter, and downstream in late winter and spring (Bajkov 1951, p. 20). However, many individuals rema in in freshwater throughout their long life; movement of those in the Columbia River above Bonneville Oam is now restricted by hydroelectric dams, although some may more upstream or downstream through the navigation locks.

Female white sturgeon do not mature until 15 years old at a length of about 64 inches $(165 \mathrm{~cm}$ ) and a weight of 60-70 lbs (Stockley 1981, p. 2). White sturgeon spawn primarily in May and June when temperatures reach between 8.9 and $16.7^{\circ} \mathrm{C}\left(48\right.$ and $62^{\circ} \mathrm{F}$ ) (10C. cit). Adults survive spawning but spawn again only after increasing intervals of 2-11 years. White sturgeon spawn in fast-flowing rocky areas of river at least $10 \mathrm{ft}$ ( 3 meters) deep and broadcast their eggs in large grayish masses. The eggs become sticky when exposed to water and adhere to any material contacted (loc. cit).

A female sturgeon can produce several million eggs, and the number of eggs produced increases geometrically as the fish grows (Stockley 1981, Figure 1). A female sturgeon with maturing ovaries, if subjected to stress, may absorb her eggs and lose a spawning cycle (Stockley 1981, p. 2). Eggs hatch in 1 to 2 weeks depending on water temperature. Collections of post-larval white sturgeon in the Columbia River, including the Hanford Reach, are rare. In the lower Columbia River, yolk-sac fry were collected in May 1979, 1980 and 1981 with drift trawels in from 30 to 65 feet (g to 20 meters) of water (Stockley 1981, p. 2). In the Hanford Reach, catches of inmature white sturgeon near RM 352 occurred in Apri1, May and August (Gray and DaubTe 1979b. Only one juvenile white sturgeon was collected on traveling screens during various impingement studies conducted at the Washington Public Power Supply Systems Hanford Generating Plant and N Reactor from 1974 through 1977 (Gray et a1. 1975, Page et al. 1975, 1976a, 1977a). A study of sturgeon movement in 
the Snake River failed to locate fish less than 18 inches (46 cm long, although effort to locate small individuals was 1 imited (Coon et a1. 1977, p. 34).

No spawning white sturgeon spawning has been detected in the Hanford Reach, 'but all botton types and currents generally reported as favorable for spawning are present (Fickeisen et al. 1980, p. 2-25). White sturgeon are found in deeper holes in the Columbia River (Wydoski and Whitney 1979, p. 17), and may spawn in certain areas of the Hanford Reach: below Priest Rapids Dam (RM 396), below Coyote Rapids (RM 383), at White Bluffs (RM 370), and below Ringold (Fickeisen et a1. 1980, Figure 10).

Sturgeon fry begin to search for small planktonic crustaceans as soon as their yolk sac is absorbed, then seak various insect larvae as they become larger. When about 1 year old $(7-9$ inches long; $18-23 \mathrm{~cm}$ ). They became bottom feeders and eat organisms such as molluscs, crayfish, fish and carrion. Sturgeon have poor eyesite and feed by touch and smel1. They are equiped with four sensitive barbels and root in the mud with their snouts when feeding a) though food consists mainly of animal matter, sturgeon are opportunistic and will try any available food (Galbreath 1979, p. 5). White sturgeon in the Snake River have had reduced growth rates in recent years, presumably because dams have eliminated or greatly reduced upriver runs of anadromous salmonids and lampreys. The spawned-out carcasses of these fish are important sturgeon food (Coon et a]. 1977, p. 60-61). Because of lesser amounts of food available, white sturgeon above Bonneyille Dam grow more slowly than those below (Galbreath 1979, p. 6).

Stomach contents of white sturgeon collected in the Hanford Reach show a variety of bottom organisms. In one study, fish collected near the $\mathrm{N}$-Reactor (RM 380) and showed that crayfish and snails were commonly ingested (Gray and Dauble 1976a, Table 5.24). In another study, fish collected at RM 352 showed that the main food items were fish, midge-fly larvae, caddisfly larvae, and crayfish (Gray and Dauble 1977a, Table 5.21.

White sturgeon collected in the Hanford Reach from 1973 through 1978 ranged from 45 to $158 \mathrm{~cm}$ long. A small white sturgeon about $20 \mathrm{~cm}$ long was observed just above Wooded Island (RM 350). Young sturgeon reach a length of 
$51 \mathrm{~cm}$ is about 5 years. All evidence indicates that a viable spawning population of white sturgeon is present in the Hanford Reach (Fickejsen et al. 1980, p. 2-27).

White sturgeon movement in the Hanford Reach was studied in 1975 and 1976. Water temperatures appeared to influence diel and seasonal movements. As temperatures dropped below $13^{\circ} \mathrm{C}\left(55.4^{\circ} \mathrm{F}\right)$ in october, sturgeon long-distant movement slowed and only local movement occurred until temperatures increased above $13^{\circ} \mathrm{C}\left(55.4^{\circ} \mathrm{F}\right)$ in June (Haynes 1978 , p. 59). During summer, sturgeon moved into warmed shallow areas in late afternoon and evening, and back to cool, main-channel areas in early morning (loc. cit.). These movements were probably related to feeding.

No thermal studies have been conducted with white sturgeon. Temperature preference is inferred only from movement data (Haynes 1978, 1oc. cit.) and spawning timing. In Sacramento River, California, sturgeon spawn when temperatures range from 7.8 to $17.8^{\circ} \mathrm{C}\left(46.0\right.$ to $\left.64.0^{\circ} \mathrm{F}\right)$, with a peak at $14.4^{\circ} \mathrm{C}$ $\left(57.9^{\circ} \mathrm{F}\right.$ ) (Kohlhorst 1976 , p. 352). Spawning in the Columbia River occurs from May through July at 8.9 to $17.2^{\circ} \mathrm{C}$ (48 to $63^{\circ} \mathrm{F}$ ) (Wydowski and Whitney 1979, p. 18). White sturgeon have been caught at temperatures of 0 to $23.3^{\circ} \mathrm{C}(32$ to $74^{\circ} \mathrm{F}$ ) (Scott and Crossman 1973, p. 98). For assessment purposes, the thermal tolerance of white sturgeon may be similar to that of chinook and coho salmon.

3.2.4.3.2 Largescale sucker. The largescale sucker is an abundant and highty prolific resident of Pacific Coast drainage systems in Oregon, Washington and British Columbia (Scott and Crossman 1973, p. 545). The largescale sucker inhabits both lakes and streams throughout the state of Washington Wydowski and Whitney 1979, p. 97), and is often considered to be a nuisance when abundant. The largescale sucker is very comonon in the Hanford Reach. It was the fourth most abundant species collected near the N-Reactor (RM 380) in 1973 to 1974 (Gray and Dauble 1976a, Figure 5.5). It was the second most common resident fish species collected in other parts of the Columbia River at Hanford (Gray and Dauble 1979b, Figure 5.7). In other studies, the largescale sucker was the most abundant resident species (by number) collected by boat electroshocker is other parts of the Columbia River at Hanford (Beak 1980, Page et a1, 1982). The largescale sucker apparently resides and feeds throughout the various widths and depths of the columbia 
River at Hanford. Mark-recapture studies at RM 361 in 1981 gave a population estimate of $\pm 4.961 \pm 9,422 \mathrm{fish}$ per $1000 \mathrm{M}$ of shoreline in June and 12,343 \pm 6,721 in July (Page et al. 1982, p. 20). Their large numbers could constitute serious food competition with young and adults of salmonid fishes (Scott and Crossman 1973, p. 546).

The largescale sucker spawns in the spring throughout its range, usually in deeper sandy areas of streams but at times on gravelly or sandy shoals in lakes (Scott and Crossman 1973, p. 545). In the Hanford Reach, wide variation occurs in spawning condition adults collected near the $\mathrm{N}$ Reactor from 1975 through 1977 (Gray and Dauble 1979a, Figure 5.3). Water temperatures at Hanford ranged from 6.0 to $10.0^{\circ} \mathrm{C}\left(42.8\right.$ to $\left.50^{\circ} \mathrm{F}\right)$ at initiation of spawning and were 12.0 to $15 .{ }^{\circ} \mathrm{C}\left(53.6\right.$ to $\left.59^{\circ} \mathrm{F}\right)$ at peak spawning in May and June. A female may deposit as many as 20,000 eggs, which are adhesive, demersal, and about $2.5 \mathrm{~mm}$ diameter before fertilization (Scott and Crossman 1973, p. 545-546).

Eggs of the largescale sucker hatch in about 2 weeks. Fry remain in the gravel or near the surface of sand for a few weeks until they become pelagic (Scott and Crossman 1973, p. 546; Wydowskj and Whitney 1979, p. 98). In the Hanford Reach, fry appear near the shoreline at sizes of 12 to $18 \mathrm{~mm}$ at depths less than $1 \mathrm{~m}$. Inshore water temperatures in locations sheltered from the current are wamer than those in mid-channel and these areas are sought by juvenile suckers. Largescale sucker fry and juveniles are collected in shoreline pools where water temperatures range to $23.3^{\circ} \mathrm{C}\left(73.9^{\circ} \mathrm{F}\right)$. Yearling largescale suckers are common in large slough areas rather than the main river (Dauble 1978, p. 6I-69).

Sucker fry, when they are pelagic, eat small zooplankton but they change their diet to insect larvae and some diatoms and other plant material when they become bottom dwellers (Wydowski and Whitney 1979, p. 98). Adults feed on a variety of bottom organisms including algae and plant remains, cladocerans, copepods, and aquatic insect larvae. Periphyton (attached algae) is the primary dietary component of largescale sucker of all ages at Hanford (Dauble 1978, Table 7, 9, Figure 18; Gray and Dauble 1976a, p. 5-13) in contrast to an apparent larger invertebrate diet component elsewhere in its range. 
Depending on geographical location, the largescale sucker matures in 3 to 6 years; males mature about 1 year earlier than females (Scott and Crossman 1973, p. 546; Brown 1971, p. 126). A largescale sucker can live as long as 11 years and reach a length of 24 inches and a weight of 7 pounds (Wydowski and Whitney 1979, p. 98). In the Hanford Reach, most females mature in 6 or 7 years at about $40 \mathrm{~cm}$ length, while males mature 1 year earlier at about $37 \mathrm{~cm}$ length (Dauble 1978, p. 17-26). Growth rates decline rapidly after maturity. The maximum age of largescale sucker collected at Hanford was 15 years (10c. cit.).

For juvenile largescale sucker acclimated to $19^{\circ} \mathrm{C}\left(66.2^{\circ} \mathrm{F}\right)$ and abruptly exposed to various temperature increases for 24 hours, the median death point (50\% mortality) is $29.4^{\circ} \mathrm{C}\left(84.9^{\circ} \mathrm{F}\right.$ ) (Black 1953 , p. 207). Largescale sucker were collected at Hanford and exposed to a gradual temperature increase to determine critical thermal maximum (CTM) values. The CTM values for adults acclimated from 4.5 to $21.0^{\circ} \mathrm{C}\left(40.1\right.$ to $\left.69.8^{\circ} \mathrm{F}\right)$ ranged from 26.9 to $32.6^{\circ} \mathrm{C}$ $\left(80.4\right.$ to $90.6^{\circ} \mathrm{F}$ ) (Dauble 1978, p. $71-72$ ).

Prickly sculpin. The prickly sculpin is generaliy found along coastal areas of Washington State, but penetrates more than 400 miles upstream in the Columbia River (Scott and Crossman 1973, p. 824; Wydowski and Whitney 1979, p. 160). It is generally found on bottoms of sand, gravel or rubble. At Hanford, adult prickly sculpin are common in nearshore areas, particularly among crevices in cobble bottoms.

The prickly sculpin has been collected near the $\mathrm{N}$-Reactor throughout the year, and was the sixth most common species at this site, with peak numbers observed in June (Gray and Dauble 1976a, Figure 5.7). At RM 252 (RKM 566) sculpins were collected mainly by hoop net in late spring (Gray and Dauble 1979b, Figure 5.5). The prickly sculpin uses its protective coloration for concealment and is often in open areas; small specimens are generally in vegetated areas in shallow water (Wydowski and Whitney 1979, p. 160).

Sculpin larvae appear in the Hanford Reach from mid-April through July at temperatures from 9.0 to $17.0^{\circ} \mathrm{C}\left(48.2\right.$ to $62.6^{\circ} \mathrm{F}$ ) (Page et a T. 1982, p. 21). The temperature range for naturally spawning prickly sculpin is 8.0 to $13.0^{\circ} \mathrm{C}\left(46.4\right.$ to $55.4^{\circ} \mathrm{F}$ ) (Krejsa 1967$)$. Nests are usually under rocks and logs 
in areas with low water velocities (_ 1 cfs), and often in man-made objects such as cans, sheet metal, car bodies etc. (Wydowski and Whitney 1979, p. 161). The adhesive eggs are deposited on the under-surface of objects and fertilized. After spawning, the female leaves and the male guards the eggs. Fecundity varies with size of the female, ranging from 280 to 7,410 eggs for mature females from 60 to $160 \mathrm{~mm}$ long (loc. cit.).

The eggs hatch in 15 to 16 days at $12^{\circ} \mathrm{C}\left(53.6^{\circ} \mathrm{F}\right)$, and the larvae are 5-7 am long (Scott and Crossman 1973, p. 825). Larvae remain pelagic for 30 to 35 days before metamorphosis when they sink to the bottom (loc. cit.). In rivers, these pelagic larvae are carried downstream by currents. Sculpin larvae dominate midstream ichthyoplankton drift in the Hanford Reach. Larvae of the prickly sculpin comprised more than $95 \%$ of the total larvae fish collected at RM 352 in 1979 (Beak Consultants Inc. 1981; Table 3.5) and at RM 361 (RKM 581) in 1981 (Page et a). 1982, p. 21). Peak densities, however, were relatively low, up to only 0.18 larvae/m ${ }^{3}$ (Page et al. 1982, Figure $5.31)$.

Prickly sculpin fry occur in nearshore areas at Hanford in mid-summer. Typical habitat is mud or sand bottom with some submerged or emergent vegetative cover.

Aquatic insect larvae, especially midgefly and caddisfly larvae, and other bottom invertebrates form the major food supply of prickly sculpin (Scott and Crossman 1979, p. 825). Planktonic crustaceans are also important for small fish about $30 \mathrm{~mm}$ long. In the Hanford Reach, prickly sculpin feed primarily on caddisfly and midgefly larvae, but also eat crayfish and other benthic invertebrates (Gray and Dauble 1976a, p. 5-15; Gray and Dauble 1979b, p. 5.7). Prickly sculpin also feed on fish eggs, and on young salmonids and other small fish. Several fish species, including white sturgeon, smallmouth bass, squawfish, and bullheads also feed on prickly sculpin (Gray and Dauble 1976a, Section 5).

Prickly sculpin may reach a maximum of 10 years age, but normal life expectancy is probably 5 to 6 years (Bond 1963, p. 30-31). They mature as early as 2 years, but some may not spawn until 4 years old (Wydowski and Whitney 1979 , p. 161). 
Prickly sculpin, in various parts of their range, are usually found at 10.0 to $17.8^{\circ} \mathrm{C}$ (50 to $64^{\circ} \mathrm{F}$ ), but they have been found at temperatures as high as $27.8^{\circ} \mathrm{C}\left(82^{\circ} \mathrm{F}\right)(10 \mathrm{c}$. cit. p. 160$)$. The species may be relatively sensitive to elevated temperatures. Prickly sculpins acclimated to $19.0^{\circ} \mathrm{C}\left(66.2^{\circ} \mathrm{F}\right)$ died after 24 hour exposure to water heated to $26.5^{\circ} \mathrm{C}\left(79.7^{\circ} \mathrm{F}\right)$; all fish survived at $22.8^{\circ} \mathrm{C}\left(73^{\circ} \mathrm{F}\right)$ but half of the test group died at $24.1^{\circ} \mathrm{C}\left(75.4^{\circ} \mathrm{F}\right)(\mathrm{Bl}$ ack 1954, p. 199). Sculpins acclimated to $14.0^{\circ} \mathrm{C}\left(57.2^{\circ} \mathrm{F}\right)$ and exposed to a $1^{\circ} \mathrm{C}$ daily increase in temperature underwent first mortality at $30.2^{\circ} \mathrm{C}\left(86.4^{\circ} \mathrm{F}\right)$ (Bond 1963, p. 57-58). Prickly sculpin eggs reared in the laboratory underwent over $50 \%$ mortality at $15.0^{\circ} \mathrm{C}\left(59.0^{\circ} \mathrm{F}\right)$ and total mortality at $18.0^{\circ} \mathrm{C}\left(64.4^{\circ} \mathrm{F}\right)$ (Krejsa 1967$)$.

3.2.4.3.4 Northern squawfish. The northern squawfish is abundant in the Columbia River system. They inhabit lakes and areas of slow to moderate currents in streams (Wydowski and Whitney 1979, p. 85). Northern squawfish are present throughout the year near the $\mathrm{N}$-Reactor (RM 380) (Gray and Dauble 1976a, Figure 5.22) and RM 352 (Gray and Dauble 1979b, Figure 5.23). Depending on collection method, they rank first to third in abundance of all species captured in the Hanford Reach.

Northern squawfish spawn in the Hanford Reach from late June to early August when water temperatures range from about 14.0 to $18.0\left(57.2\right.$ to $\left.64.4^{\circ} \mathrm{F}\right)$ (Gray and Oauble 1977a, p. 5.10; Gray and Dauble 1978, p. 5.6; Gray and Dauble 1979a, p. 5.10; Gray and Dauble 1979b, p. 5.3).

Spawning northern squawfish may gather in large numbers but build no nests. Eggs and sperm are released near the bottom over gravelly areas in lakes and streams and the eggs, which are adhesive and demersal, settle in the gravel (Scott and Crossman 1973, p. 489; Brown 1971, p. 105; Patten and Rodman 1969, p. 109-111). The eggs hatch in about 1 week at 15.6 to $20^{\circ} \mathrm{C}(60.1$ to $68^{\circ} \mathrm{F}$ ) (10c. cit., Jeppson and Platts 1959, p. 201). A female will produce 6,700 to 83,000 eggs, depending on size.

Based on collections from 1974 through 1978, fry of northern squawfish first appear at Hanford in late July with a peak abundance in September or October (Gray and Dauble 1976a, Figure 5.22; Gray and Oauble 1979b, Figure $5.23)$. 
Population levels appear highest after spawning and after fry enter the population in late summer. Fry abundance near the $\mathrm{N}$-Reactor peaked in September 1973 and yẹrling abundance occurred in May 1973 and 1974 (10c. cit.). Northern squawfish fry are conmon in shallow vegetated pools with mud and rock botton where temperatures are warmer than in main river channel. Large numbers of fry occur in slough areas at Hanford durting the spring and summer, frequently in association with fry of the redside shiner and peamouth chub.

Small northern squawfish 4-10 inches (25-102 mm) long feed primarily on insects. Adults are piscivorous and large individuais feed exclusively on fish and crayfish (Wydowski and Whitney 1979, p. 86); they can be serious predators on juvenile salmonids (Thompson 1959, p. 57-58) and may compete with trout and salmon for food (Jeppson and Platts 1959, p. 199). Because of this habit and their low food value, the northern squawfish is often considered an undesireable species.

The major food items of 311 fjsh taken at Hanford near the $N$-Reactor were adult caddisflies (13\% occurrence), crayfish $6 \%$ and fish 5\% (Gray and Dauble 1976a, Table 5.3). Analysis of gut contents from northern squawfish collected at other sites in the Hanford Reach showed that fish, caddisfly adults and larvae, and crayfish were the most abundant food items. There was evidence of northern squawfish predation on juvenile percids, catostomids, cottids, centrarchids, cyprinids, percopsids and salmonids (Gray and Dauble 1977b, 1978a). Northern squawfish fry $(2.0$ to $3.4 \mathrm{~cm}$ fork length) seined in 0ctober and November 1976 near RM 352 contained chironomid pupae in $70 \%$ of the stomachs examined; chironomid aduits (22\%) and chironomid larvae (17\%) were the next most comanon itens (Gray and Daubie 1978b p. 5.7).

Northern squawfish are reported to 7 ive 19 years, and to reach a length of 25 inches $(360 \mathrm{~mm}$ ) and a weight up to 29 lbs $(13 \mathrm{~kg}$ ) (Brown 1971, p. 106; Wydowski and Whitney 1979, p. 85; Scott and Crossman 1973, p. 489). They reportedly become sexually mature in 5 to 6 years. At Hanford, northern squawfish up to 15 years old were collected near RM 352. Females mature in 5 to 6 years at $32 \mathrm{~cm}$ fork length, and males mature about 1 year earlier at 25 cml fork length (Gray and Dauble 1977b, p. 5.10). Most large squawfish in the Hanford area are females. Annual growth rates are greatest from 1 to 5 years. 
The northern squawfish is relatively tolerant of warmed water. They prefer the highest temperatures 20.0 to $22.8^{\circ} \mathrm{C}\left(68-73^{\circ} \mathrm{F}\right)$ that occur in Lake Washington (Wydowski and whitney 1979, p. 85). All northern squawfish acclimated to $19-22^{\circ} \mathrm{C}\left(66.2-71.6^{\circ} \mathrm{F}\right)$ died after 24 hour exposure to water heated to $32^{\circ} \mathrm{C}\left(89.6^{\circ} \mathrm{F}\right)$; all fish survived at $26.4^{\circ} \mathrm{C}\left(79.5^{\circ} \mathrm{F}\right)$, but half of the test group died at $29.3^{\circ} \mathrm{C}\left(84.8^{\circ} \mathrm{F}\right)(B$ lack 1954, p. 199). Juvenile northern squawfish are regularly seen at Hanford in nearshore areas where temperatures reach $23.3^{\circ} \mathrm{C}\left(73.9^{\circ} \mathrm{F}\right)$.

\subsection{Mountain whitefish. The mountain whitefish is cormon in} Washington (Wydowski and Whitney 1979, p. 35). In the Hanford Reach, the mountain whitefish is abundant and present the year around. They are not fished commercially, and sport fishing is usually limited to the winter (Fickeisen et al. 1980, p. 2-23). The area above Vernita Bridge (RM 392) where mountain whitefish spawn in winter, is a popular fishing sport (loc. cit.). Whitefish reportedly make up nearly $14 \%$ of the sport catch in the lower Hanford Reach (Honstead et a1. 1971).

Mountain whitefish spawn in the late fall or early winter over gravel or grave 1 and rubble, but the exact time of spawning varies over its range (Scott and Crossman 1973, p. 293). In the Hanford Reach, spawning occurs from late November through early January when water temperatures average 3 to $8^{\circ} \mathrm{C}(37.4$ to $46.4^{\circ} \mathrm{F}$ ) (Gray and Dauble 1977b, p. 5.7; Gray and Dauble 1978, p. 5.9; Gray and Dauble 1979a, p. 5.1); this is somewhat later than spawning times reported elsewhere (Gray and Dauble 1979b, p. 5.8). Specific spawning sites have not been documented at Hanford. Mountain whitefish spawn over gravel or rubble riffle areas of streams (Brown 1952, p. 110-111) but little preference of bottom type was found in laboratory tests (Stalnaker and Gresswell 1974, p. 13). Eggs are deposited adjacent to strong currents at depths of 0.1 to $1.2 \mathrm{~m}$ or more, usually at dusk or night (Brown 1952, p. 111; Stalnaker and Gresswell 1974, p. 10-11). Based on substrate composition and collection of gravid females, several potential spawning areas have been visualized for the Hanford Reach (Fickeisen et al. 1980, Figure 9).

Mountain whitefish tend to move upstream to spawn. Before construction of Priest Rapids Dam, mountain whitefish migrated upstream from Hanford as far 
as Crab Creek (RM 411). Upstream movement above Priest Rapids Dam is not welI defined but they do migrate up to the dam and from the Columbia River into the lower Yakima River (Cushing and Watson 1966, p. 564-568). Mountain whitefish become sexually mature when 3 to 4 years old. A gravid female produces, on the average, 5,000 eggs but the number of eggs increase with female size. One female 19.5 inches (495 $\mathrm{mm}$ ) long weighed 3 pounds and carried 24,000 eggs (Scott and Crossman 1971, p. 293). The eggs are adhesive and stick to sand and gravel. Eggs hatch in 35 to 40 days at $11.1^{\circ} \mathrm{C}\left(52^{\circ} \mathrm{F}\right)$. In nature, most eggs hatch in March (Brown 1971, p. 45).

Mountain whitefish fry usually appear annually in the Hanford Reach from early April through May (Gray and Dauble 1979a, p. 5.1; Gray and Dauble 1979b, p. 5.8). Fry measuring 14 to $23 \mathrm{~mm}$ are found in shallow nearshore pools in early April. However, they disappear from these areas by early June when approaching $40 \mathrm{mon}$ in length. Extensive collections in the Hanford Area from 1973 through 1978 revealed no $0+$ to 1-year mountain whitefish (Fickeisen et al. 1980 , p. 2-25). They may move downstream into Lake Wallula or may be in areas of the river that can not affectively be sampled. In other areas juveniles tend to move downstream before the end of their first year (Pettit and Wallace 1975, p. 73-75). Young mountajn whitefish over 1 year and older, occur in the Hanford Reach the year around with peak abundance from October through January.

The mountain whitefish is primarily a botton feeder consuming a variety of organisms, especially aquatic insect larvae such as mayflies, stoneflies, caddisflies, and midges, small molluscs and sometime larvae fish (Scott and Crossman 1971, p. 294).

Mountain whitefish prefer coot temperatures. They spawn during winter at temperatures between 1.7 and $7.2^{\circ} \mathrm{C}$ ( 35 and $45^{\circ} \mathrm{F}$ ) (Brown 1971, p. 45). The upper optimum temperature for successful egg development is $6^{\circ} \mathrm{C}\left(42.8^{\circ} \mathrm{F}\right)$; development is disrupted and abnomal fry are produced at $9^{\circ} \mathrm{C}\left(48.2^{\circ} \mathrm{F}\right)$; all eggs die within 2 weeks at $12^{\circ} \mathrm{C}\left(53.6^{\circ} \mathrm{F}\right.$ ) (Rajagopal 1979, p. 155-156). No upper lethal limits have been determined experimentaliy for adult mountain whitefish. 


\subsection{Smallmouth bass. The smallmouth bass was originally}

restricted to fresh waters in east-central North America. Smallmouth bass were introduced to the Yakima River in 1925, and spread into the Columbia and Snake River (Robbins and MacCrimmon 1974). In Washington, smalimouth bass are most numerous in the Columbia and Snake River systems (Wydowski and Whitney 1979 , p. 126).

Smallmouth bass are now abundant in sloughs and slack water areas of the Hanford Reach. Much of the area was closed to public access until recently and fishing pressure on spawning populations of smallmouth bass in various sloughs at Hanford was low. Smallmouth bass were transplanted from the Hanford Reach to the lower Yakima River in the mid-1950s but some of these fish returned to the capture site (Henderson and Foster 1956, p. 116-119). The Hanford Reach of the Columbia River between Vernita RM 363 was opened to the public in 1978.

The Washington State Department of Game recognized the importance of slough areas at Hanford for bass spawning and closed them to fishing in 1979 (Fickeisen et a1. 1980, p. 2-27).

Smallmouth bass usually inhabit cool, clear streams or lakes with some currents. Smallmouth bass in the Snake River are usually found over broken rocky substrate, few over solid rock substrate and none over sand (Munther 1970 , p. 4.4). Smallmouth bass have a definite home range and do not travel long distances. In the Snake River, most of the fish tagged (76\%) remained in the same pool or location where they were originally tagged (loc. cit.). Most of the other fish moved less than three quarters of a mile.

Smallmouth bass prefer water temperatures of 21.1 to $26.7^{\circ} \mathrm{C}\left(70\right.$ to $80^{\circ} \mathrm{F}$ ) (Wydowski and whitney $1979, p .126$ ). In the Snake River they do not occur in shallow water ( $<8$ feet deep) when temperatures drop below $15.6^{\circ} \mathrm{C}\left(60^{\circ} \mathrm{F}\right)$. Distribution in the Snake River changed daily. At night, smallmouth bass remained motionless on broken rock substrate in quiet water; in early morning they were always feeding near the edge of a current (Munther 1970, p. 48-49).

Smallmouth bass usually mature when 3 or 4 years old. Spawning occurs over a period of 6-10 days in late spring and early summer. Nest building and spawning commences over a range of temperatures from 12.8 to $20^{\circ} \mathrm{C}\left(55\right.$ to $68^{\circ} \mathrm{F}$ ) 
but most eggs are deposited at $16.1-18.3^{\circ} \mathrm{C}\left(61\right.$ to $65^{\circ} \mathrm{F}$ ) (Scott and Crossman 1971, p. 730). Smallmouth bass eggs incubated at constant temperatures of 12.8 and $23.9^{\circ} \mathrm{C}$ ( 55 and $75^{\circ} \mathrm{F}$ ) hatched at 9-10 days and 2-3 days, respectiveiy (Webster 1948, p. 46). In the Columbia River, smallmouth bass spawn in sloughs at temperatures of $12.8-15.6^{\circ} \mathrm{C}\left(55\right.$ to $60^{\circ} \mathrm{F}$ ) when the water is warmer than in the main river channel at $7.2-10.0^{\circ} \mathrm{C}\left(45\right.$ to $\left.50^{\circ} \mathrm{F}\right)$ (Henderson and Foster 1976, p. 119). Spawning in April and May was generally unsuccessful if the Columbia River rose in the spring and flooded nest sites in the sloughs with cool water (loc. cit.).

During spawning, the male builds a nest $1-6$ feet $(30.5-183 \mathrm{~cm})$ in diameter on a sandy, gravel, or rocky bottom, usually near the protection of rocks, logs or rarely dense vegetation. Eggs are deposited and fertilized in brief ( $5 \mathrm{sec}$ ) acts that take place repeatedly for about 2 hours. Eggs per female depend on fish size, and range from 5,000 to 14,000. Eggs are demersal and adhesive. The male guards the nest, fans the eggs, and guards the fry after they hatch (Scott and Crossman 1971, p. 730). Often $40 \%$ of the nests fail. About 2000 fry result from most successful nests. Sudden shifts of temperature, changes in water level, and fungal infections kill many eggs. Smallmouth bass fry disperse among rocks and vegetation near the shore when about 1 inch $(2.5 \mathrm{~cm})$ long.

Smallmouth bass in the Columbia River grow at rates equal to or faster than that of bass in other areas of Unjted States (Wydowski and Whitney 1979, p. 127). Mature bass collected at Hanford in 1952 ranged to 8 years of age and 19 inches $(48 \mathrm{~cm}$ ) in length (Henderson and Foster 1956, p. 120-123).

Smallmouth bass fry eat smail crustaceans. When about 1-2 inches (2.5 $5.0 \mathrm{~cm}$ ) long, they change to a diet of insects and small fish. Adult bass feed on insects, crayfish, fish, frogs, and fish eggs.

Studies on reproduction of smallmouth bass in the Hanford Reach confirmed that spawning occurs in at least three large sloughs: Hanford Slough (RM 362), 100-F Slough (RM 368) and White Bluffs Slough (RM 370) (Montgomery et a1. 1980, Figure 2). Fluctuating water levels caused by peaking operations at Priest Rapids Dam appear to impact smallmouth bass spawning by alternately flooding and dewatering nest sites. Cold river water entering warmed slough 
areas can cause temperature changes up to $10^{\circ} \mathrm{C}$ during the spawning period. In addition, changing water levels trap smallmouth bass fry and juveniles in temporary ponds where they are lost from desiccation, thermal stress, malnutrition, and predation (10c. cit., p. 303-34; Becker et a1. 1981, p. 45-46).

Experimental transfer of smallmouth bass eggs from 11.7 to $25.0^{\circ} \mathrm{C}(53$ to $77^{\circ} \mathrm{F}$ ) and from $18.3^{\circ} \mathrm{C}\left(65^{\circ} \mathrm{F}\right)$ to $10.0^{\circ} \mathrm{C}$ and $23.9^{\circ} \mathrm{C}\left(50\right.$ and $\left.75^{\circ} \mathrm{F}\right)$ caused no adverse effects (Webster 1948, p. 43).

Final preferred temperature for smallmouth bass under experimental and field conditions are $28^{\circ} \mathrm{C}\left(82.4^{\circ} \mathrm{F}\right)$ and $20.3-21.3^{\circ} \mathrm{C}\left(68.5\right.$ to $\left.70.3^{\circ} \mathrm{F}\right)$, respectively (Ferguson 1958; p. 612-616). Maximum growth rate of juveniles grown at various constant temperatures occurs at $26^{\circ} \mathrm{C}\left(78.8^{\circ} \mathrm{F}\right)$, while fish held at $35^{\circ} \mathrm{C}\left(95^{\circ} \mathrm{F}\right.$ ) lost weight (Horning and Pearson 1973, p. 1228-1229). Preferred temperatures of smallmouth bass acclimated under rising (spring) thermal regimes range from $20.2^{\circ} \mathrm{C}\left(68.3^{\circ} \mathrm{F}\right)$, at $15^{\circ} \mathrm{C}\left(59^{\circ} \mathrm{F}\right)$ acclimation, to $29.4^{\circ} \mathrm{C}\left(85^{\circ} \mathrm{F}\right)$ at $33^{\circ} \mathrm{C}\left(91.4^{\circ} \mathrm{F}\right)$ acclimation Cherry et a1. 1977, Table 1$)$. Smallmouth bass acclimated to $23.3^{\circ} \mathrm{C}\left(74^{\circ} \mathrm{F}\right)$ and subject to a rapid increase in temperature loose their equilibrium at $38.3^{\circ} \mathrm{C}\left(101^{\circ} \mathrm{F}\right.$ ) (Reutter and Herdendorf 1976. Smallmouth bass fry acclimated to 30 and $35^{\circ} \mathrm{C}$ ( 86 and $95^{\circ} \mathrm{F}$ ) cannot swim at higher temperatures (Larimore and Duever 1968, p. 182).

3.2.4.3.7 Yellow perch. The yellow perch was introduced to washington in 1890, and it subsequentiy became established throughout the state (Wydowski and Whitney 1979, p. 146). Its preferred habitat is cool, clear lakes or slow-moving streams with abundant vegetation. However, the yellow perch is extremely adaptable and reproduces readily under a range of conditions not necessarily favorable to good growth (Brown 1971, p. 173). Yellow perch usually occur in loose schools associated with the bottom. Fingerling yellow perch occur in shallow, inshore waters but move to open and deep water in the fall. Adults are active during daytime in the summer but rest on the bottom at night, and generally do not move great distances (Wydowski and whitney 1979, p. 146).

Yellow perch have been collected by various gear throughout the Hanford Reach. Peak catches of adults near RM 352 occurred from August through 
October (Gray and Dauble 1979b, Figure 5.20). Adult yellow perch are sometimes common in slough areas or large pools adjacent to the main river, particularly at sites containing curled-leaf pondweed.

Yellow-perch are spring spawners. Spawning in Washington State usually occurs in April and May when water temperatures reach 7.2 to $11.1^{\circ} \mathrm{C}$ (45 to $52^{\circ} \mathrm{F}$ ) (Wydowski and Whitney 1979, p. 146). At this time males and females school separately. Spawning takes place over various sand, gravel, or rubble bottom, and on submerged vegetation and brush. Eggs are deposited in a ribbonlike, gelatinous masses. Egg masses are semi-buoyant and undulate with water movement. The number of eggs produced rangs from 10,000 to 40,000 and is related to age of the female. Eggs require 10 to 20 days for incubation. No parental care is given the egg or young (Brown 1971, p. 173; Scott and Crossman 1973, p. 757-758; Ney 1978, p. 3). The egg incubation period depends on water temperature and rate of warming. Hatching will occur 2 to 3 weeks after fertilization at typical spring temperatures of $8-15^{\circ} \mathrm{C}\left(46.4-59^{\circ} \mathrm{F}\right)$ (Ney 1978, p. 3).

In the Hanford Reach near RM 352 (RKM 566), gravid females were collected from mid-November through January and ripe males from September through mid-February (Gray and Dauble 1977a, p. 5.16; 1977b, p. 5.6; 1978, p. 5.13; 1979a, p. 5.12. However, the maturity index for female yellow perch was highest in early April (Gray and Dauble 1979a, p. 5.12). The presence of newly hatched fry near N-Reactor (Page et al. 1977, Table 3) and RM 352 (Gray and Dauble 1978, p. 5.13; 1979b, p. 510) in June and July suggests that some yellow perch at Hanford spawn in spring, but probably later than reported el sewhere.

Yellow perch are about 0.2-0.3 inches (4.5-7.0 mm) total length when hatched. Larvae are initially photopositive and pelagic, becoming demersed at lengths of about $1.0-1.6$ inches (25-40 mon) (Ney 1978, p. 3). Growth is rapid at first; and young yellow perch often form large, compact schools (Scott and Crossman, 1971, p. 758). At Hanford, appearance of young yellow perch is sporadic. No fry were collected near N-Reactor from March 1973 through June 1974 (Gray and Dauble 1976a, Table 5.1), but over 2515 perch fry were collected on traveling screens at HGP water intake over a 3 week period in 
June and JuTy 1977 (Page et a1. 1977a, p. 6, Table 3). Young of the year yellow perch were collected at Hanford Slough in July 1981 (Page et al. 1982, p. 23-24).

The food of adult yellow perch consists of aquatic invertebrates or small fish. Young feed heavily on zooplankton. Feeding occurs all day in deep water and during twilight hours near the surface and in shallow wter near shore (Brown 1971, p. 173). Their high reproductive potential, voracious appetite and effectiveness in feeding can, in some areas, lead to severe competition with more valued species. These characteristics may produce stunted populations where adult yellow perch never exceed 6 inches (152 mm) in length (Scott and Crossman 1973, p. 760).

Adult yellow perch in the Hanford Reach at RM 352 feed primarity on caddisfly larvae and fish (Gray and Dauble 1977b, Table 5.20; 1977b, Table $5.14 ; 1979 a$, p. 5.13). Young of the year show greater dependence on the smaller midge fly larvae, and zooplankton. Most yellow perch collected at Hanford were age 1 to 3 years, but some individuals were 6 years old (Gray and Dauble 1978a, Table 5.45). Some males mature after one year, but most fish mature in about three years.

Yeilow perch in nature are usually found at temperatures of $19-21^{\circ} \mathrm{C}$ $\left(66.2-69.8^{\circ} \mathrm{F}\right)$; young fish show an upper preferred temperature of $24.2^{\circ} \mathrm{C}$ $\left(75.6^{\circ} \mathrm{F}\right)$ and 01 der fish show on upper prefered temperature of $21.0^{\circ} \mathrm{C}\left(69.8^{\circ} \mathrm{F}\right)$ when acclimated to $30^{\circ} \mathrm{C}\left(86.0^{\circ} \mathrm{F}\right.$ ) (Ferguson 1958, p. 607-611). Another study indicates that juvenile yellow perch prefer temperatures between 14.4 and $28.0^{\circ} \mathrm{C}$ (58 and $82.4^{\circ} \mathrm{F}$ ), depending on seasonal environmental temperatures (Barans and Tubb 1973, p. 1699). Peak growth of yellow perch occurs at $28^{\circ} \mathrm{C}$ $\left(82.4^{\circ} \mathrm{C}\right.$ ) (McCormick 1976). Optimum temperatures for hatching of yellow perch are $10.1-18^{\circ} \mathrm{C}\left(50.2-64.4^{\circ} \mathrm{F}\right)$ and for swim-up larvae, $13.1-18 . \mathrm{D}^{\circ} \mathrm{C}(55.6-$ $64.4^{\circ} \mathrm{F}$ ) (Hokanson and Kleiner 1974).

Under experimental conditions, yellow perch acc limated to $22-24^{\circ} \mathrm{C}(71.6$ $75.2^{\circ} \mathrm{F}$ ) and abruptly exposed to elevated temperatures for $24 \mathrm{hr}$ underwent total mortality at $29.1-29.8^{\circ} \mathrm{C}\left(84.4-85.6^{\circ} \mathrm{F}\right), 50 \%$ mortality at $29.2^{\circ} \mathrm{C}$ $\left(84.5^{\circ} \mathrm{F}\right)$ and all survived at $28.9^{\circ} \mathrm{C}\left(84^{\circ} \mathrm{F}\right)(\mathrm{Black} 1953, \mathrm{p} .199)$. Another study showed that upper lethal temperatures (ULT) of yellow perch depended on 
acclimation (A) temperature as follows: $5^{\circ} \mathrm{C}\left(41^{\circ} \mathrm{F}\right) \mathrm{A}, 21.3^{\circ} \mathrm{C}\left(70.3^{\circ} \mathrm{F}\right)$ ULT; $10^{\circ} \mathrm{C}\left(50^{\circ} \mathrm{F}\right) \mathrm{A}, 25^{\circ} \mathrm{C}\left(77^{\circ} \mathrm{F}\right) \mathrm{ULT} ; 15^{\circ} \mathrm{C}\left(59^{\circ} \mathrm{F}\right) \mathrm{A}, 27.7^{\circ} \mathrm{C}\left(81.8^{\circ} \mathrm{F}\right) \mathrm{ULT} ; 25^{\circ} \mathrm{C}$ $\left(77^{\circ} \mathrm{F}\right) \mathrm{A}, 29.7^{\circ} \mathrm{C}\left(85.5^{\circ} \mathrm{F}\right)$ ULT (Brett 1956, p. 77). Yellow perch acclimated to $22^{\circ} \mathrm{C}\left(71.6^{\circ} \mathrm{F}\right)$ and subject to a rapidTy increasing temperature undergo loss of equilibrium at $35^{\circ} \mathrm{C}\left(95^{\circ} \mathrm{F}\right)$ (Reutter and Herdendorf 1976).

\subsubsection{Ichthyoplankton}

Ichthyoplankton are defined herein as small, larvae fish that are present in the downstream drift and are taken by fine-mesh nets during plankton sampling. The occurrence of small, larvae fish as planktonic organisms is indicative of a temporary pelagic life of a particular species. Ichthyoplankton are apt to be exposed to heat and chemicals if they are entrained in power plant cooling systems or in the cooling water discharge plumes.

In studies conducted from June 1973 to June 1974 in the Hanford Reach at RM 380 indicated that ichthyoplankton were neither major or frequent components of the mid-river drift (Page et al. 1976, p. 5-24). Ichthyoplankton were collected only in May and July. In another study, one unidentified ichthyoplankter was collected incidentally in a zooplankton sample near RM 352 in June 1975 (Gray and Dauble 1977a, p. 5.20). Ichthyoplankton tows were subsequently made monthly near RM 350 from September 1978 to March 1980. Only a few yolk-sac and post-yolk sac larvae of the prickly sculpin were collected from May through July 1979; peak densities were 0.14 larvae $/ \mathrm{m}^{3}$ (Beak Consultants Inc. 1980, p. 3.6, Table 3.5).

Additional ichthyoplankton samples were collected twice monthly from April 1981 through Aprit 1982 at RM 361.5. Five species of fish were collected in midstream tows (Puget Power 1982, p. 2.2-32a). Peak abundance $\left(0.17\right.$ larvae $/ \mathrm{m}^{3}$ ) occurred in May and June 1981. About $95 \%$ (211 of 222) of the larvae were prickly scuipin, two were shad, one was a carp, and one was chinook salmon alevin (loc. cit., Table 2.2-2lc). Because of low densities and composition of relatively unimportant species, ichthyoplankton were not thought to be of major importance to the ecology of the Hanford Reach (loc. cit., p. 2.2-32a, 32b). 


\subsubsection{Important Columbia River Habitats. The Hanford Reach, because}

of $i$ ts length, volume, and free-flow characteristics, has aquatic communities that are largely different from those found in the impounded portion of the Columbia River. The Hanford Reach is characterized by cobble and rock substrate and swift currents. A portion of the reach includes the Ringold formation substrate (a conglomerate of gravel and rock). Much of the shoreline is steep and includes a narrow strip of cobble beach next to the water. In some areas, particularly along the left (east) bank near Ringold, bluffs extend into the river. There are 21 islands present from Richland to Priest Rapids Dam, each with cobble and/or sandy shorelines (Fickeisen et al. 1980, p. 2-1).

The rocky substrate and swift to moderate currents provide critical habitats for present populations of chinook salmon, steelhead trout and mountain whitefish. White sturgeon also prefer flowing water for reproduction. Smallmouth bass utilize the waters of the mainstem as adults (loc. cit., p. 2-1).

There are a number of sloughs and backwater areas on both sides of the Hanford Reach. These have largely rocky substrates but may also contain sand, mud and silt substrates. Water in the sloughs warms earlier in the spring than in the mainstem river and summer temperatures often exceed $30^{\circ} \mathrm{C}$ because of insolation. The rocky areas of the sloughs serve as spawning habitats for smallmouth bass and bullhead. Other centrarchids such as largemouth bass, bluegill and pumpkinseed sunfish spawn along shallow shorelines of the quieter waters of the sloughs. The warm water, weak currents and substrate of the sloughs make them important nursery areas for juvenile salmonids. The sloughs are also important nursery areas for centrarchids, bullheads, suckers and cyprinids. Sculpins are abundant in rocky areas of some sloughs.

Some areas in the Hanford Reach of the Columbia River are critical habitats for populations of valued or important fish species. The spawning areas used by adult chinook salmon are critical habitats. Spawning areas used by steelhead trout, although less well known, are also critical habitats. Certain areas in the Hanford Reach have been tentatively identified as spawning sites for white sturgeon (Fickeisen et al. 1980, Figure 10) and 
mountain whitefish (10c. cit., Figure 9). These four species spawn in the main channel where observation of site selection and spawning activity is difficult. The salmonids dig redds and deposit their eggs in the gravel. Hence, chinook salmon and steelhead trout require sites with gravel of suitable composition for digging and for maintaining intergravel water flow after egg deposition.

Certain sloughs and backwater areas in the Hanford Reach are valuable habitats for reproduction of smallmouth bass (Fickeisen et al. 1980, Figure 11). Particularly important areas are the Hanford Slough (RM 362), 100-F Slough (RM 368) and White Bluffs Slough (RM 370). Similar areas are important as feeding and nursery areas for 0 -age chinook saimon prior to spring outmigration and for many species of resident fish (Fickeisen et al. 1980, p. 2-1; PSP\&L 1982, p. 2.2-22). The suitability of these areas for juyenile fish is adversely affected by fluctuating flows from Priest Rapids Dam (Becker et a). 1981, p. 18-37).

\subsection{REFERENCES}

Allen, J. N. 1980. "The Ecology of the Long-Billed Curlew, Numenium americanus parvus, in Southeastern Washington." Wildlife Monograph.

Allen, R. L. 1977. "Status of the Upper Columbia River Salmon and Steelhead Runs," pp. 23-30. In ed. E. Schwiebert, Columbia River Salmon and Steelhead, Spec. Publ. No. 10. Am. Fish. Soc., Bethesda, Maryland.

Bajkov, A. D. 1951. "Migration of White Sturgeon (Accipenser transmontanus) in the Columbia River." Oregon Fish. Comm. Res. Briefs $3(2): \overline{8-21 .}$

Barans, C. A. and R. A. Tubb. 1973. "Temperatures Selected Seasonally by Four Fishes From Western Lake Erie." J. Fish. Res. Board Can. 30:1697-1703.

Beak Consultants Inc. 1977. Operational Ecological Monjtoring Program for the Trojan Nuclear Power Plant, 1976. Annual Report, Vol. 1. Columbia River Aquatic Program: Phytoplankton. Prepared for Portland General Electric Company by Beak Consultants Inc., Portland, Oregon.

Beak Consultants Inc. 1980. Aquatic Ecological Studies Near WNP $-1,2$ and 4. August 1978-March 1980. WPPSS Columbia River Ecology Studies, Volume 7. Prepared for Washington Public Power Supply System by Beak Consultants Inc., Portland, Oregon. 
Beak Consultants Inc. 1980. Preoperational Environmental Monitoring Studies Near WNP 1,2 and 4 August 1978 Through March 1980 . WPPSS Columbia River Ecology Studies Vol. 7, Beak Consultants Inc., Portland, Oregon.

Becker, C. D. 1962. "Estimating Red Salmon Escapements by Sample Counts from Observation Towers." U.S. Fish and Wildlife Service, Fish. Bull. No. 192 $61: 355-369$.

Becker, C. D. 1970. Temperature, Timing and Seaward Migration of Juvenile Chinook Salmon from the Centra] Columbia River. BNWL-1472, Pacific Northwest Laboratory, Richland, Washington.

Becker, C. D. 1973. "Columbia River Thermal Effects Study: Reactor Effluent Problems." J. Water Pollut. Cont. Fed. 45(5):850-869.

Becker, C. D. and M. D. Fujihava. 1978. "The Bacterial Pathogen Flexibacter columnaris and Its Epizootiology among Columbia River Fish." Monograph No. 2, Am. Fish. Soc., Bethesda, Maryland.

Becker, C. D. and R. G. Genoway. 1979. "Evaluation of the Critical Thermal Maximum for Determining Thermal Tolerance of Freshwater Fish." Env. Biol. Fishes 4(3):245-256.

Becker, C.D. 1973. "Food and Growth Parameters of Juvenile Chinook Saimon, Oncorhynchus tshawytscha, in Central Columbia River." Fish.Bull. $71(2): 387-400$.

Becker, C. D., D. H. Fickeisen and J. C. Montgomery. 1981. Assessment of Impacts from Water Level Fluctuations on Fish in the Hanford Reach, Columbia River. PNL-3813, Battelle, Pacific Northwest Laboratory, Richland, Washington.

Be11, M. C. 1973. Fisheries Handbook of Engineering Requirements and Biological Criteria. Fish. Engr. Res. Program, North Pacific Corps of Engineers, Portland, Oregon.

Bilton, H. T., D. F. Alderdice and J. T. Schnute. 1982. "Influence of Time and Size at Release of Juvenile Coho Salmon (Oncorhynchus kisutch) on Returns at Maturity." Can.J.Fish. Aquat. Scj. 39:426-44

Black, E. C. 1953. "Upper Lethal Temperatures of Some British Columbia Freshwater Fishes." J. Fish. Res. Board Can. 10(2):196-210.

Blahm, T. H. and R. J. McConnell. 1970. Mortality of Adult Eulachon, Thaleichthys pacificus, Chinook Saimon and Coho Salmon Subjected to Sudden Increases in Water Temperature (Draft). UnpubTished report, U.S. Bureau Commercial Fisheries, Seattle, Washington. (Cited in EPA 1973, p. 416). 
Bond, C. E. 1963. Distribution and Ecology of Freshwater Sculpines, genus Cottus, in Oregon. Ph.D. Dissertation, University of Michigan, Ann Arbor, Michigan.

Brett, J. R. 1952. "Temperature Tolerance in Young Pacific Salmon, Genus Oncorhynchus." J. Fish. Res. Board Can. 9(5):265-323.

Brett, J. R. 1956. "Some Principles in the Thermal Requirements of Fishes." Quart. Rev. Biol. 31:75-87.

Brett, J. R. 1971. "Energetic Responses of Salmon to Temperature. A Study of Some Thermal Relations in the Physiology and Freshwater Ecology of Sockeye Salmon (Oncorhynchus nerka)." Anr. Zool. 11:99-113.

Brown, C. J. D. 1952. "Spawning Habits and Early Development of the Mountain Whitefish, Prosopium williamsoni, in Montana." Copeia 1952 (2): 109-113.

Brown, R. E. 1970. Interrelationships of Geologic Formations and Processes Affecting Ecology as Exposed at Rattlesnake Springs, Hanford, Project. BNWL-B-29, Pacific Northwest Laboratory, Richland, washington.

Brown, C. J. D. 1971. Fishes of Montana. Agricultural Experiment Station, Montana State University, Bozeman, Montana. 207 pp.

Charlon, N., B. Barbier and L. Bonnet. 1970. "Resistance de la Truite Arc-en-ciel (Salmo gairdneri Richardson) a des Variations Brusques de Temperature." Ann. Hydrobiol. 1(1):73-89.

Cherry, D. S., K. L. Dickson and J. Cairns, Jr. 1975. "Temperatures Selected and Avoided by Fishes at Various Acclimation Temperatures." J. Fish Res. Board Can. 32:485-491.

Cherry, D. S., K. L. Dickson and J. Cairns, Jr. 1977. "Preferred, Avoided, and Lethal Temperatures of Fish During Rising Temperature Conditions." J. Fish. Res. Board Can. 34:239-246.

Clarke, W.C., J. E. Shelbourn and J. R. Brett. 1981. "Effects of Artificial Photoperiod Cycles, Temperature, and Salinity on Growth and Snolting in Underyearling Coho (Oncorhynchus kisutch), Chinook (0. tshawytscha), and Sockeye (‥ nerka) Salmon." Aquaculture 2:105-116.

Cline, J. F., D. W. Uresk, and W. H. Rickard. 1975. Characterization of Plant Communities Adjacent to the B-C Cribs Controlled Area and REDOX Pond Areas on the 200 Area Plateau. BNWL-1916, Pacific Northwest Laboratory, Richland, washington.

Cline, J. F., D. W. Uresk, and W. H. Rickard. 1977. "Plants and Sojl of a Sagebrush Community on the Hanford Reservation." Northwest Sci. $51(1): 60-70$. 
Collins, G. B., W. J. Ebel, G. E. Monan, H. L. Raymond and G. K. Tanonaka. 1975. The Snake River Salmon and Steelhead Crisis. Processed Report, Northwest Fisheries Center, National Marine Fisheries Service, Seattle, Washington.

Coon, J. C., R. R. Ringe and T. C. Bjornn. 1977. Abundance, Growth, Distribution and Movements of White Sturgeon in the Mid-Snake River. Research Technical Completion Report, Project B-026-IDA, Water Resources Research Institute, Univ. of Idaho, Moscow, Idaho.

Coopey, R. W. 1953a. "Radioactive Plankton from the Columbia River." Trans. Am. Microscop. Soc. 72(4):315-327.

Coopey, R. W. 1953b. The Abundance of the Principal Crustacea of the Columbia River and the Radioactivity They Contain. HW 25191, Hariford Atomic Products Operation, Richtand, washington.

Coutant, C. C. 1970. Thermal Resistance of Adult, (Coho Oncornynchus kisutch) and Jack Chinook (0. tshawytscha) Salmon and Adult Stee thead Trout (Salmo gairdneri) from the Columbia River. BNWL-3094, Pacific Northwest Laboratory, Richland, Washington..

Coutant, C. C. 1972. "Biological Aspects of Thermal Pollution II. Scientific Basis for Water Temperature Standards at Power Plants." CRC Crit. Rev. Environ. Contr. 3(1):1-24.

Coutant, C. C. 1973. "Effects of Thermal Shock on Vulnerability of Juvenile Salmonids to Predation." J. Fish. Res. Board Can. 30:965-973.

Coutant, C. C. 1973. Behavior of UTtrasonic Tagged Chinook Salmon and Steelhead Trout Migrating Past Hanford Thermal Discharges (1967). BNWL-1530, Pacific Northwest Laboratory, Richland, Washington.

Craddock, D. R., T. H. Blahm and W. D. Parente. 1976. "Occurrence and Utilization of Zooplankton by Juvenile Chinook Salmon in the Lower Columbia River." Trans. Am. Fish. Soc. 105(1):72-76.

Craigie, D. E. 1963. "An Effect of Water Hardness in the Thermal Resistance of the Rajnbow Trout, Salmo gairdneri Richardson." Can.J. Zool. $41(5): B 25-830$.

Cushing, C. E. and D. G. Watson. 1966. "Accumulation and Transport of Radionuclides by Columbia River Biota," pp. 551-570. In Disposal of Radioactive Waste Into Seas, Oceans and Surface Waters. Internationa 1 Atomic Energy Agency, Vienna.

Cushing, C. E. 1967a. "Concentration and Transport of ${ }^{32} \mathrm{p}$ and ${ }^{65} \mathrm{Zn}$ by Columbia River Plankton." Limnol. Oceanogr. 12(2):330-332. 
Cushing, C. E. 1967b. "Periphyton Productivity and Radionuclide Accumulation in the Columbia River, Washington, U.S.A." Hydrobiologica 29(1-2): 125-139.

Cushing, C. E., and E. G. Wolf. 1971. "Productivity of Rattlesnake Springs." In Pacific Northwest Laboratory Annual Report for 1970 to the USAEC Division of Biology and Medicine, Volume 1 Life Sciences, Part 2 Ecological Sciences. B. E. Vaughan and Staff, BNWL-1550, Pacific Northwest Laboratory, Richland, Washington

Cushing, C. E., and D. G. Watson. 1974. Aquatic Studies of Gable Mountain Pond. BNWL-1884, Pacific Northwest Laboratory, Richland, Washington.

Cushing, C. E., J. M. Gurtisen and A. J. Scott. 1974. "Ecological Studies at Rattlesnake Springs." In Pacific Northwest Laboratory Annual Report for 1974 to the USAEC Division of Biomedical and Environmental Research, Part 2 Ecological Sciences. B.E. Vaughan and Staff. BNWL-1950 Pt. 2, Pacjfic Northiwest Laboratory, Richland, Washongton.

Cushing, C. E., A. J. Scott, J. M. Gurtisen, and W. G. Woodfield, 1976. "Limnological Characteristics of Gable Mountain Pond." In Pacific Northwest Laboratory Annual Report for 1975 to the USERDA Division of Biomedical and Environmental Research Part 2 Ecological Sciences. B.E. Vaughan and Staff, BNWL-2000 pt 2, Pacific Northwest Laboratory, Richland, Washington.

Cushing, C. E., C. 0. McIntire, J. R. Sedell, K. W. Cummins, G. W. Minshall, R. C. Petersen, and R. L. Vannote. 1980. "Comparative Study of Physical-Chemical Variables of Streams Using Multivariate Analyses." Arch. Hydrobiologia 89(3):343-352.

Cushing, C. E., D. G. Watson, A. J. Scott and J. M. Gurtisen. 1981. "Decrease of Radionuclides in Columbia River Biota Following Closure of Hanford Reactors." Health Physics 41:59-67.

Cushing, C. E., and E. G. Wolf. 1982. "Organic Energy Budget of Rattlesnake Springs Washington." The American Midland Naturalist 107(2): 404-407.

Cushing, C. E. and E. G. Wolf. "Primary Production in Rattlesnake Springs, A Cold Desert Spring." To be published in Hydrobiologia, Junk Publishers. The Hague, Netherlands.

Dauble, D. D. 1978. Comparative Ecology of Two Sympatric Catostomids, Catostomus macrochejlus and Catostomus columbianus in the Columbia River. M.S. Thesis, Washington State Univ., PulTman, Washington.

Davis, J. J. and C. L. Cooper. 1951. Effects of Hanford Pile Effluent Upon Aquatic Invertebrates in The Columbia River. HW-20055, U.S. Atomic Energy Commission, Hanford Works, Richland, Washington. 
Dean, J. W. 1973. "The Response of Fish to a Modified Therma? Environment," pp. 33-63. In Responses of Fish to Environmental Changes, ed. W. Chavin, C. C. Thomas, Springfield, Illinois.

Ebe1, W. J., D. L. Park and R. C. Johnson. 1973. "Effects of Transportation on Survival and Homing of Snake River Chinook Salmon and Steelhead Trout." Fish. Bull. 71(2):549-563.

Eberhardt, L. E., J. D. Hedlund, and W. H. Rickard. 1979. Tagging Studies of Mule Deer Fawns on the Hanford Site. PNL-3147, Pacific Northwest Laboratory, Richland, Washington.

Emery, R. M. and M. C. McShane. 1980. "Comparative Ecology of Nuclear Waste Ponds and Streams on the Hanford Site." Health Physics $38: 787-809$.

Environmental Protection Agency (EPA). 1971. Columbia River Thermal Effects Study, Vol. 1: Biological Effects Study. U.S. EPA, Washington, D.C. $95 \mathrm{pp}$.

Environmental Protection Agency (EPA). 1973. Water Qualjty Criteria-1972. EPA/R3/73/033, Report of the Committee on Water Quality Criteria. USEPA, Washington, D.C. $594 \mathrm{pp}$.

Everest, F. H. and D. W. Chapman. 1972. "Habitat Selection and Spatial Interaction by Juvenile Chinook Salmon and Steelhead Trout in Two Idaho Streams." J. Fish. Res. Board Can. 29(1):91-100.

Falter, C. M. and R. R. Ringe. 1974. Pollution Effects on Adult Steelhead Migration in the Snake River. EPA-660/3-73-017. U.S. Environmental Protection Agency, Washington, D.C. 101 pp.

Faurot, D. 1979. The Mid-Columbia Juvenile Salmonid Outmigration, 1977. Report financed jointly by Chelan, Douglas and Grant Co. Public Utility Districts of Washington, and by the Northwest and Alaska Fisheries Center, NMFS, Seattle, Washington. $20 \mathrm{pp}+$ appendices.

Federal Register. 1982. 50 CFR, Part 17. Vol. 47, Nor 251. Endangered and Threatened Wildlife and Plants: Review of Vertebrate Wildijfe for Listing as Endangered or Threatened Species. Department of Interior, fish and Wildlife Service.

Ferguson, R.G. 1958. "The Preferred Temperature of Fish and Their Midsummer 0istribution in Temperate Lakes and Streams". J. Fish. Res. Board Can. 15(4):607-624.

Fessler, J. L. and H. H. Wagner. 1969. "Some Morphological and Biochemical Changes in Steelhead Trout During the Parr-Smolt Transformation." J. Fish. Res. Board Can. 26(11):2823-2841. 
Fickeisen, D. H., D. D. Dauble, D. A. Neitzel, W. H. Rickard, R. L. Skaggs and J. L. Warren. 1980a. Aquatic and Riparian Resource Study of the Hanford Reach, Columbia River, Washington. BattelTe, Pacific Northwest Laboratory, Richland, Washington.

Fickeisen, D. H., R. E. Fitzner, R. H. Sauer and J. L. Warren. 1980b. Wildlife Usage, Threatened and Endangered Species and Habitat Studies of the Hanford Reach, Columbia River, Washington. Battelle, Pacific. Northwest Laboratories, Richland, Washington.

Fish, F. F. and M. G. Hanavan. 1948. "A Report Upon the Grand Coulee Fish Maintenance Projects, 1939-1947." Spec. Sci. Rept. No. 55, U.S. Fish, and Wildlife Service, Washington, D.C.

Fitzner, R. E. and W. C. Hanson. 1979. "A Congregation of Wintering Bald Eagles." Condor 81:311-313.

Fitzner, R. E., K. A. Gano, W. H. Rickard and L. E. Rogers, 1979. Characterization of the Hanford 300 Area Burial Grounds. Task IV Biological Transport. PNL-2774, Pacific Northwest Laboratory, Richiand, Washington.

Fitzner, R. E., W. H. Rickard, L. L. Cadwe1l, and L. E. Rogers. 1980. Raptors of the Hanford Site and Nearby Areas of Southcentral Washington. PNL-3212, Pacific Northwest Laboratory, Richland, Washington.

Fitzner, R. E., D. G. Watson, and W. H. Rickard. 1981. "Bald Eagles of the Hanford NERP." In: Proceedings of the Washington Bald EAgle Symposium, ed. R. L. Knight, G. T. Allen, M. V. Stalmaster, and C. W. Servheen, pp. 2078-218. June 14-15, Seattle, Washington.

Fitzner, R. E. and W. H. Rickard. 1983. "Canada Goose Nesting Performance Along the Hanford Reach of the Columbia River, 1971-1981," Northwest Science (in press).

Foerster, R. E. 1968. The Sockeye Salmon Oncorhynchus nerka. Bu11.162, Fish. Res. Board Can., 0ttawa. 422 pp.

Fulton, L. A. 1968. "Spawning Areas and Abundance of Chinook Salmon (Oncorhynchus tshawytscha) in the Columbia River Basin--Past and Present." Spec. Sci. Rept.--Fish. No. 571, U.S. Fish and Wildiife Service, Washington, D.C. $26 \mathrm{pp}$.

Fulton, L. A. 1970. "Spawning Areas and Abundance of Steelhead Trout and Coho, Sockeye, and Chum Salmon in the Columbia River Basin -- Past and Present." Spec. Sci. Rept.--Fish. No. 618, NatI. Marine Fish. Serv., Washington, DC. $37 \mathrm{pp}$. 
Galbreath, J. 1979. "Columbia River Colossus, the White Sturgeon." Oregon Wildlife March 1979, p. 3-8.

Garside, E. T., and J. S. Tait. 1958. "Preferred Temperature of Rainbow Trout and Its Unusual Relationship to Acclimation Temperature." Can. J. Zool. 36:563-567.

Glad, J. B. 1981. Preoperational Terrestrial Monitoring Studies Near. WNP 1, 2, and 4. Project D2671, Beak Consultants, Inc., Portland, Oregon.

Gortman, A., W. W. Dickhoff, J. L. Mighe11, E. F. Prentice and F. W. Waknitz. 1982. "Morphological Indices of Development Progress in the Parr-Smelt Coho Salmon, Oncorhynchus kisutch." Aquaculture 28:1-9.

Grant County Public Utility District. 1978. Annual Fish Passage Report, Priest Rapids Dam, Columbia River System, Washington. Public Utility District of Grant County, Ephrata, Washington.

Gray, R. H., T. L. Page, E. G. Wolf and M. J. Schneider. 1975. A Study of Screen Impingement and Fish Passage at Hanford Generating ProjectA Progress Report. Battelle, Pacific Northwest Laboratories, Richland, Washington. $47 \mathrm{pp}$.

Gray, R. H. and D. D. Dauble. 1976a. "Synecology of the Fish Community near Hanford Generating Project and Assessment of Plant Operational Impacts." In Final Report on Aquatic Ecological Studies Conducted at the Hanford Generating Project, 1973-1974. WPPSS Columbia River Ecology Studies Vol. 1. Prepared for Washington Public Power Supply System by Battelle, Pacific Northwest Laboratories, under Contract No. 2311201335 with United Engineers and Contractors. Richland, Washington.

Gray, R. H., and D. D. Dauble, 1977. "Checklist and Relative Abundance of Fish Species from the Hanford Reach of the Columbia River." Northwest Sci. 51(3):208-215.

Gray, R. H., R. G. Genoway and S. A. Barraclough. 1977. "Behavior of Juvenile Chinook Salmon (Oncorhynchus tshawytscha) in Relation to Simulated Thermal Effluent. Trans. Am. Fish. Soc. 106(4):366-370.

Gray, R. H., and D. D. Dauble. 1977a. "Synecology of the Fish Community near WNP 1, 2 and 4, and Assessment of Suitability of Plant Area for Salmonid Spawning." In Aquatic Ecological Studies Conducted Niear WNP 1, 2 and 4, September 1974 through September 1975. WPPSS Columbia River Ecology Studies Vol. 2. Prepared for Washington Public Power Supply System Under Contract No. 2311201335 with United Engineers and Constructors by Battelle, Pacific Northwest Laboratories, Richland, WA. 
Gray, R. H., and D. D. Dauble. 1977b. "Fish Community Studies near WNP 1, 2 and 4, October 1975 through December 1976," Section 5 in Aquatic Ecological Studies Near WNP 1,2 and 4, October 1974 thraugh February 1976. WPPSS Columbia River Ecology Studies Vol. 3. Prepared for Washington Public Power Supply System under Contract No. 2311201335 with United Engineers and Constructors by Battelle, Pacific Northwest Laboratories Richland, Washington.

Gray, R. H., and D. D. Dauble. 1978. "Fish Studies Near WNP 1, 2 and 4, March through December 1976," Section 5 in Aquatic Ecological Studies near WNP 1,2 and 4, March through December 1976. WPPSS Columbia River Ecology Studies, Vol. 4. Prepared for Washington Public Power Supply System under Contract No. 2311201335 with United Engineers and Constructors by Battelle, Pacific Northwest Laboratories, Richland, Washington.

Gray, R. H., and D. D. Dauble. 1979b. "Fish Studies near WNP 1, 2 and 4, January through August 1978." In Aquatic Ecological Studies Near WNP 1, 2 and 4, January through August 1978. WPPSS Columbia River Ecology Studies Vol. 6 . Prepared for Washington Public Power Supply System under Contract No. 2311201335 by Battelle, Pacific Northwest Laboratories, Richland, Washington.

Groves, A. B., G. B. Collins and P. S. Trefethen. 1968. "Roles of 01 faction and Vision in the Choice of Spawning Site by Homing Adult Chinook Salmon (Oncorhynchus tshawytscha)." J. Fish. Res. Board Can. 25:867-876.

Hajek, B. F. 1966. Soil Survey-Hanford Project in Benton County, Washington. BNWL-243, Pacific Northwest Laboratory, Richland, Washington.

Haynes, J. M. 1978. Movement and Habitat Studies of Chinook Salmon and White Sturgeon. PNL-2471. Pacific Northwest Laboratory, Richland, Washington. $65 \mathrm{pp}$.

Hedlund, J. D., and L. E. Rogers. 1976. Characterization of Small Mammal Populations Inhabiting the B-C Cribs Environs. BNWL-2181, Pacific Northwest Laboratory, Richland, Washington.

Henderson, H. C., and R. F. Foster. 1956. "Studies of Smallmouth Black Bass (Micropterus dolomieu) in the Columbia River near Richland, Washington." Trans. Am. Fish. Soc. 86:112-127.

Hill, C. W. 1962. "Observations on the Life Histories of Peamouth (Mylocheilus caurinus) and the Northern Squawfish (Ptychocheilus oregonensis) in Montana." Proc. Mont. Acad. Sci. 22:27-44.

Hoar, W. S. 1976. "Smolt Transformation: Evolution, Behavior, and Physiology." J. Fish. Res. Board Can. 33:1233-1252. 
Hokanson, K. E. F., and C. L. F. Kleiner. 1974. "Effects of Constant and Rising Temperatures on Survival and Development Rates of Embryonic and Larval Yellow Perch, Perca flavescens (Mitchell)," pp. 437-448. In The Early Life History of Fish, ed. J. H. S. Blaxter. Springer Verlag, New York, NY.

Holt, R. A., J. E. Sanders, J. L. Zinn, J. L. Freyer and K. S. Pilcher. 1975. "Relation of Water Temperature to Flexibacter columnaris Infection in Steelhead Trout (Salmo gairdneri), Coho (Oncorhynchus kisutch) and Chinook (‥ tshawytscha) Salmon." J. Fish. Res. Board Can. 32:1553-1559.

Honstead, J. F., T. M. BeetTe and J. K. Soldat. 1971. A Statistical Study of the Habits of Local Fishermen and Its Application to Evaluation of Environmental Dose. Battelle, Pacific Northwest Laboratories, Richland, Washington.

Horak, D. L., and H. A. Tanner. 1964. "The Use of Vertical Gill Nets in Studying Fish Depth Distribution, Horsetooth Reservoir, Colorado." Trans. Am. Fish. Soc. 93:137-145.

Horning, W.B., II and R.E. Pearson. 1973. "Growth Requirements and Lower Lethal Temperatures for Juvenile Smallmouth Bass (Micropterus dolomieui)." J. Fish. Res. Board Can. 30(8):1226-1230.

Hovland, G. B., R. S. Kindley, M. T. Rudnicki, M. B. Dell and J. D. Pock. 1982. The Mid-Columbia Juvenile Salmonid Outmigration in 1981 at Priest Rapids Dam. Public Utility District of Grant County, Ephrata, Washington. 27 pp.

Jamison, J. D. 1982. Standardized Input for Hanford Environmental Impact Statements Part II: Site Description. PNL -3509 , Pacjfic Northwest Laboratory, Richland, Washington.

Jeppson, P. W., 1957. "The Control of Squawfish by Use of Dynamite, Spot Treatinent, and Reduction of Lake Levels." Prog. Fish.-Cult. 19: 168-171.

Jeppson, P. W. and W. S. Platts. 1959. "Ecology and Control of the Columbia Squawfish in Northern Idaho Lakes." Trans. Am. Fish. Soc. $88(3): 197-201$.

Keenleyside, M. H. A., and W. S. Hoar. 1954. "Effects of Temperature on the Response of Young Salmon to Water Currents." Behavior 7:77-87.

Kohihorst, D. W. 1976. "Sturgeon Spawning in the Sacramento River in 1973, as Determined by Distribution of Larvae." Calif. Fish. Game $62(1): 32-40$. 
Krejsa, R. J. 1967. "The Systematics of the Prickly Sculpin, Cottus Asper Richardsor, a Polytypic Species. Part II. Studies in the Life History, with Special Reference to Migration." Pac. Sci. 21(3): 414-422.

Larimore, W. R., and M. J. Duever. 1968. "Effects of Temperature Acclimation on the Swimming Ability of Smalimouth Bass Fry." Trans. Am. Fish. Soc. 97:175-184.

Leitritz, E., and R. C. Lewis. 1976. Trout and Salmon Culture (Hatchery Methods). Fish. Bu11. 164, Cali. Dept. Fish. Game, Sacramento, California. 197 pp.

Leonhardt, L. S. 1980. Assessment of the Effects of Existing Major Dams Upon a Radioactive Waste Repository within the Hanford Site. RH0-BW1-LD-26, Rockwell Hanford Operations, Richland, Washington.

Lippert, B. E., and C. E. Cushing. 1973. "Taxonomy of Rattlesnake Springs (ALE) Algae." In Pacific Northwest Laboratory Annual Report for 1972 to the USAEC Division of Biomedical and Environmental Research, Volume 1, Life Sciences, Part 2 Ecological Sciences. B.E. Vaughan and Staff, BNWL-1750 Pt. 2, Pacific Northwest Laboratory, Richland, Washington.

Mains, E. M., and J. M. Smith. 1964. "The Distribution, Size, Time, and Current Preference of Seaward Migrant Chinook Salmon in the Columbia and Snake Rivers." Washington State Dept. of Fisheries, Fish. Res. Papers 2:5-43.

Major, R. L., and J. L. Mighe11. 1967. "Influence of Rocky Reach Dam and the Temperature of the Okanogan River on the Upstream Migration of Sockeye Salmon." U.S. Fish and Wild1. Serv., Fish. Bull. 66:131-147.

Major, R. L., and J. L. Mighel1. 1969. "Egg-to-migrant Survival of Spring Chinook Salmon (Oncorhynchus tshawytscha) in the Yakima River, Washington." Fish. Bu] . 67(2):347-359.

McCauley, R. W., and W. L. Pond. 1971. "Temperature Selection of Rainbow Trout, Salmo gairdneri, Fingerlings in Vertical and Horizontal Gradients." J.Fish. Res. Board Can. 28:1801-1804.

McCormick, J. H. 1976. Temperature Effects on Young Yellow Perch, Perca flavescens (Mitchell). EPA-600/3-76-057, U.S. Environmenta1 Protection Agency, Washington, DC.

Meekin, T. K., and R. L. Allen. 1973. An Evaluation of the Priest Rapids Chinook Spawning Channel, 1963-1971. Tech. Rept. No. 11, Washington Dept. Fisheries, 01ympia, Washington.

Meinhardt, C. C., and J. C. Frostenson. 1979. Current Status of 200 Area Ponds. RH0-CD -798, Rockwell Hanford 0perations, Richland, Washington. 
Monan, G. E., K. L. Liscom and J. K. Smith. 1970. Final Report, Sonic Tracking of Adult Steelhead in Ice Harbor Reservoir, 1969. Biological Laboratory, U.S. Bureau of Commercial Fisheries, Seattle, Washington.

Montgomery, J. C., D. H. Fickejsen and C. Dale Becker. 1980. "Factors Influencing Smallmouth Bass Production in the Hanford Area, Columbia River." Northwest Sci. 54(4):296-305.

Munther, G. L. 1970. "Movement and Distribution of Smallmouth Bass in the Middle Snake River." Trans. Am. Fish. Soc. 99(1):44-53.

Neitze1, D. A., T. L. Page and R. W. Hanf, Jr. 1982a. "Mid-Columbia River Microflora." J. Freshwater Ecol. 1(5):495-505.

Neitze1, D. A., T. L. Page and R. W. Hanf, Jr. 1982b. "Mid-Columbia River Zooplankton." Northwest Sci. 57(2):112-118.

Ney, J. J. 1978. "A Synoptic Review of Yellow Perch and Walley Biology." pp. 1-12. In ed. R. L. Kenda11, Selected Coolwater Fishes of North America. Spec. Publ. No. I1, Am. Fish. Soc., Bethesda, Maryland.

Northcote, T. G. 1954. "Observations on the Comparative Ecology of Two Species of Fish, Cottus asper and Cottus rhotheus, in British Columbia." Copeia (1)

ODFW and WDF. 1983. Status Report, Columbia River Fish Runs and Fisheries 1960-81. Oregon Department of Fish and Wildife (Portland, DR) and Washington Department of Fisheries (OTympia, WA). 83 pp.

O'Farrel1, T. P., R. E. Fitzner, and R. 0. Gilbert. 1973. Distribution of Radioactive Jackrabbit Pellets in the Vicinity of the B-C Cribs, 200 E Area, U.S.A.E.C. Hanford Reservation. BNWL-1794, Pacific Northwest Laboratory, Richland, Washington.

O'Farrel1, T. P., R. J. 01son, and R. 0. Gilbert. 1975. "A Population of Great Basin Pocket Mice (Perognathus parvus) in the Shrub-steppe of Southcentral Washington." Ecol. Monogr. 45:1-28.

01dendorff, R. R. 1973. Raptorial Birds of the U.S.A.E.C. Hanford Reservatio, Southcentral Washington. BNWL-1790, Pacific Northwest Laboratory, Richland, Washington.

01 son, F. W. 1981. The Migration and Behavioral Characteristics of Juvenile Salmonids at Priest Rapids Dam, Spring 1980. Report for Public Utility Districts of Grant, Douglas, and Chelan Counties by $\mathrm{CH}_{2} \mathrm{M} \mathrm{Hill,} \mathrm{Bellevue,} \mathrm{Washington.} 49 \mathrm{pp}$.

Page, T. L., R. H. Gray and E. G. Wolf. 1975. Report on Impingement Studies Conducted at the Hanford Generating Project, March and ApriT 1975. Battelle, Pacific Northwest Laboratories, Richland, Washington. $9 \mathrm{pp}$. 
Page, T. L., and D. A. Neitzel. 1976. "Zooplankton, Seasonal Distribution, Relative Abundance and Entrainment Effects," Section 3. In Final Report on Aquatic Ecological Studies Conducted at the Hanford Generating Project, 1973-1974. WPPSS Columbia River Ecological Studies Vol. 1, Battelle, Pacific Northwest Laboratories, Richland, Washington.

Page, T. L., R. H. Gray and E. G. Wolf. 1976. Final Report on Aquatic Ecological Studies Conducted at the Hanford Generating Project, 1973-1974. Prepared for Washington Public Power Supply System under Contract No. 2311201335 with Unjted Engineers and Contractors, WPPSS Columbia River Ecological Studies, Vol. 1. Battelle, Pacifjc Northwest Laboratories, Richland, Washington.

Page, T. L., R. H. Gray and D. A. Neitzel. 1976a. Fish Impingement Studies at the Hanford Generating Project (HGP) 0ecember 1975 Through ApriT 1976. Battelle, Pacific Northwest Laboratories, Richland, Washington..

Page, T. L., D. A. Neitzel and R. H. Gray. 1977a. Impingement Studies at $100 \mathrm{~N}$ Reactor Water Intake. BNWL -2401 , Pacific Northwest Laboratory, Richland, Washington.

Page, T. L. and D. A. Neitzel. 1978a. "Columbia River Phytoplankton Community Near WNP 1,2 , and 4. Species Composition Relative Abundance and Pigment Concentration January through December 1977," Section 2. In Aquatic Ecological Studies Near WNP 1, 2, and 4, January through December 1977. WPPSS Columbia River Ecology Studies Vol. 5. Battelle, Pacific Northwest Laboratories, Richland, Washington. 154 pp.

Page, T. L. and D. A. Neitzel. 1978b, "Columbia River Benthic Macrofauna and Microfauna Near WNP 1, 2 and 4: January through December 1977," Section 4. In Aquatic Ecological Studies Near WNP 1, 2 and 4, January Through December 1977. WPPSS Columbia River Ecology Studies Vol. 5. BattelTe, Pacific Northwest Laboratories, Richland, Washington. $154 \mathrm{pp}$.

Page, T. L. and D. A. Neitzel. 1978c. "Columbia River Zooplankton Near WNP 1, 2 and 4: Community Composition and Relative Abundance January Through December 1977," Section 3. In Aquatic Ecological Studies Near WNP 1, 2 and 4. January through December 1977. WPPSS Columbia River Ecological Studies Vol. 5, Battelle, Pacific Northwest Laboratories, Richland, Washington.

Page, T. L., D. A. Neitzel and R. W. Hanf. 1979a. "Columbia River Phytoplankton Community near WNP I, 2, and 4. Species Composition, Relative Abundance and Pigment Concentration January through August 1978," Section 2. In Aquatic Ecological Studies near WNP 1, 2, and 4, January Through August 1978. WPPSS Columbia River Ecology Studies Vot. 6. Battelle, Pacific Northwest Laboratories, Richland, Washington. 120 pp. 
Page, T. L., D. A. Neitzel and R. W. Hanf. 1979b. "Columbia River Benthic Macrofauna and Microflora Near WNP 1,2 and 4: January through August 1978," Section 4. In Aquatic Ecological Studies Near WNP 1,2 , and 4, January through August 1978. WPPSS Columbia River Ecology Studies VoT. 6 . Battelle, Pacific Northwest Laboratories, Richland, Washington. $160 \mathrm{pp}$.

Page, †. L., D. A. Nejtzel and R. W. Hanf. 1979c. "Columbia River Zooplankton Near WNP 1, 2 and 4: Community Composition and Relative Abundance January through August 1980," Section 3. In Aquatic Ecological Studies Near WNP 1, 2 and 4 January Through August 1978. WPPSS Columbia River Ecology Studies Vol. 6, Battelle, Pacific Northwest Laboratories, Richland, Washington.

Page, T. L., D. D. Dauble and D. A. Nejtzel. 1982. Columbia River Aquatic Ecological Studies Near the Skagit/Hanford Nuclear Project:Final Report. Battelle, Pacific Northwest Laboratories, Richland, Washington.

Park, D. L. 1969. "Seasonal Changes in Downstream Migration of Age-group Chinook Salmon in the Upper Columbia River." Trans. Am. Fish. Soc. 98(2):315-317.

Park, D. L. and W. Bentley. 1968. A Summary of the 1967 Outmigration of Juvenile Salmonids in the Columbia Basin: Progress Report. U.S. Bureau of Commercial Fisheries, Seattle, Washington.

Patten, B. G. and D. T. Rodmar. 1969. "Reproductive Behavior of the Northern Squawfish, Ptychocheilus oregonenesis." Trans. Am. Fish. Soc. 98(1):108-111.

Pettit, S. W. and R. L. Wallace. 1975, "Age, Growth and Movement of Mountain Whitefish, Prosopium williamsoni (Girard) in the North Fork Clearwater River, Idaho." Trans. Am. Fish. Soc. 104(1):68-75.

Price, K. R., and W. H. Rickard. 1973. Vascular Plants of hiaste Storage Sites in the 200 Areas of the Hanford Reservation. BNwL-1796, Pacific Northwest Laboratory, Richland, Washington.

Puget Sound Power \& Light Company. 1981. Skagit/Hanford Nuclear Project Application for Site Certification/Environmental Report, Vol. 1 . Puget Sound Power \& Light Company, BelTevue, Washington.

Rajagopal, P. K. 1979. "The Embryonic Development and the Thermal Effects on the Development of the Mountain Whitefish, Prosopium williamsoni (Girard)." J. Fish. Biol. 15:153-i58.

Raymond, H. L. 1968. "Migration Rates of Yearling Chinook Salmon in Relation to Flows and Impoundments in the Columbia and Snake Rivers." Trans. Am. Fish. Soc. 97(4):356-359. 
Reutter, J. M. and C. E. Herdendorf. 1974. "Laboratory Estimates of the Seasonal Final Temperature Preferenda of Some Lake Erie Fish." Great Lakes Res. 1974:59-67. (Cited by Spotila et al. 1979).

Reutter, J. F. and C. E. Herdendorf. 1976. "Thermal Discharge From a Nuclear Power Plant: Predicted Effects on Lake Erie Fish." Ohio J. Sci. .76:39-45. (Cited by Spotila et al. 1979).

Rjckard, W. H. 1975. "Vegetation of Knob and Kettle Topography in South-Central Washington." Northwest Science 49(3):147-152.

Rickard, W. H., R. E. Fitzner and C. E. Cushing. 1981. "Biological Colonization of an Industrial Pond: Status after Two Decades." Environmenta1 Conservation $8(3): 241-247$.

Rickard, H. H. and K. A. Gano. 1979. Terrestrial Ecology Studies in the Vicinity of WNP 1 and 4: Progress Report for the Period July 1974 to June 1975. Contract 2311201335. Battelle, Pacific Northwest Laboratories, Richland, Washington.

Rickard, W. H., W. C. Hanson and R. E. Fitzner. 1982. "The Non-Fisheries Biological Resources of the Hanford Reach of the Columbia River." Northwest Science $56(1): 62-76$.

Rickard, W. H., and E. L. Klepper. 1976. Ecological Aspect of Decommissioning and Decontamination of Facjlities on the Hanford Reservation. BNWL-2033, Pacific Northwest Laboratory, RichTand, Washington.

Robbins, W. H. and H. R. MacCrimmon. 1974. The Black Bass in America and Overseas. Biomanagement and Research Enterprises, Ontario.

Roebuck, G. G., C. Henderson and R. C. Palange. 1954. Water Quality Studies on the Columbia River. U.S. Dept. of Health, Education and Welfare, Public Health Service, Washington, D.C.

Rogers, L. E., and W. H. Rickard. 1975. "A Survey of Darkling Beetles in Desert Steppe Vegetation After a Decade." Annals Entomol. Soc. Arier. $68(6): 1069-1070$.

Rogers, L. E., N. E. Woodley, J. K. Sheldon, and V. A. Uresk. 1977. Darkling Beetle Populations (Tenebrionidae) of the Hanford Site in Southcentral Washington. PNL-2465, Pacific Northwest Laboratory, Richland, Washington.

Rogers, L. E., and W. H. Rickard. 1977. Ecology of the 200 Area Plateau Waste Management Environs: A Status Report. PNL-2253, Pacific Northwest Laboratory, Richland, Washington.

Rogers, L. E., and N. E. Woodley. 1978. "Invertebrate Density and Biomass Distribution Patterns in an 01d-Field Community in Southcentral Washington. Northwest Sci. 52(2)100-103. 
Rogers, L. E. 1979. Shrub-Inhabiting Insects of the 200 Area Plateau, Southcentral Washington. PNL-2713, Pacific Northwest Laboratory, Richiand, Wasington.

Rogers, L. E. and R. E. Fitzner. 1980. Characterization of DarkTing Beetles Inhabitaing Radioecology Study Areas at the Hanford Site in Southcentral Washington. Northwest Sci. 54(3):202-206/

Scarola, J. F. 1968. "Cladocera and Copepoda in McNary Reservoir, 1965-66." Northwest Sci. 42(3):112-114.

Schweibert, E., ed. 1977. Columbia River Salmon and Steeihead. Spec. Publ. 10, Amer. Fish. Soc., Washington, DC.

Semakula, S. N. and P. A. Larkin. 1968. "Age, Growth, Food, and Yield of the White Sturgeon (Acipenser transmontanus) of the Frazier River, British Columbia." J. Fish. Res. Board Can. 25(12):2589-2602.

Sims, C. W. and D. R. Mitler. 1976. Migrational Characteristics of Juvenile Salmonids in the Mid-Columbia River During 1976. Report financed jointly by Chelan, Douglas and Grant County Public Utility Districts of Washington, and by the Northwest and Alaska Fisheries Center, National Marine Fisheries Service. Seattle, Washington.

Smith, H. D. 1896. "A Review of the History and Results of the Attempts to Acclimatize Fish and Other Water Animals in the Pacific States." Bul1. U.S. Fish Commission 1895 15:379-472.

Smith, J. R. 1974. "Distribution of Seaward-Migrating Chinook Saimon and Steelhead Trout in the Snake River Above Lower Monumenta? Dam." Mar. Fish. Rev. 36(8):42-45.

Snyder, G. R. and T. H. Blahm. 1970. "Effects of Increased Temperature on Cold-water Organisms." J. Water Pollut. Contr. Fed. 43(5):890-899.

Spigarelli, S. A. 1975. "Behavioral Responses of Lake Michigan Fishes to a Nuclear Power Plant Discharge." In Environmental Effects of Cooling Systems at Nuclear Power Plant Stations. International Atomic Energy Agency (IAEA), Vienna, Austria.

Spotila, J. R., K. M. Terpin, R. R. Koons and R. L. Bonati. 1979. "Temperature Requirements of Fishes from Eastern Lake Erie and the Upper Niagara River: A Review." Env. Biol. Fishes 4(3):281-307.

Springer, J. T. 1977. Movement Patterns of Coyotes in Southcentra1 Washington as Determined by Radiotelemetry. Washington State University, Pullman, Washington. Ph.D. thesis.

Stalnaker, C. B. and R. E. Gresswell. 1974. Early Life History and Feeding of Young Mountain Whitefish. EPA-660/3-73-019, Ecologica? Research Series, Environmental Protection Agency, Washington, D.C. 
Steigers, W. D., Jr. 1978. Mortality of Mule Deer Fawns in Southcentral Washington. Brigham Young University, Provo, Utah. M.S. thesis.

Stockley, C. 1981. Columbia River Sturgeon. Progress Report No. 150, State of Washington Dept. of Fisheries, OTympia, Washington. $28 \mathrm{pp}$.

Stoel, P. F. 1976. Some Coyote Food Habit Patterns in the Shrub-Steppe of Southcentral Washington. M.S. Thesis. Portland State University, Portland, Oregon.

Sula, M. J., J. M. V. Carlile, K. R. Price and W. D. McCormack. 1983. Environmental Surveillance at Hanford for CY1982. PNL-4657. 8attelle, Pacific Northwest Laboratory, Richland, Washington, May 1983.

Sylvester, J. R. 1972. "Effects of Thermal Stress on Predator Avoidance in Sockeye Salmon." J. Fish. Res. Board Can. 29(5):601-603.

Thompson, R. B. 1959. "Food of the Squawfish Ptychocheilus oregonensis (Richardson) of the Lower Columbia River." U.S. Fish Wildl. Ser., Fish. Bull. 60(158):43-58.

Uresk, D. W., J. F. Cline, and W. H. Rickard. 1975. Diets of Black-Tailed Hares on the Hanford Reservation. BNWL-1931, Pacific Northwest Laboratory, Richtand, Washington.

Uresk, D. W., and V. A. Uresk. 1980. Diets and Habitat Analyses of MuTe Deer on the 200 Areas of the Hanford Site in Southcentral Washington. PNL-2471, Pacific Northwest Laboratory, Richland, Washington.

U.S. Army Corps of Engineers. 1982. Annual Fish Passage Report--1981, Columbia River Projects, Snake River Projects, Oregon and Washington. North Pacific Division, COE, Portland, Oregon.

U.S. Department of Energy (DOE). 1982. 316(a) Demonstration for Test of $\mathrm{N}$ Reactor in Plutonium-oniy Mode of Operation. DOE, Richland Operations Office, Richland, Washington.

U.S. Energy Research and Development Administration (USERDA). 1975. Final Environmenta 7 Statement, Waste Management Operations. Hanford Reservation, Richland, Washington. ERDA-1538, USERDA, Washington, D.C., December 1975, 2 vols.

U.S. Nuclear Regulatory Commission (USNRC). 1982. Draft Environmental Statement Related to the Construction of Skagit/Hanford Nuclear Project, Units 1 and 2, Docket NoS. STN 50-522 and STN 50-523. NUREG-0894, USNRC, Washington, D.C.

U.S. Nuclear Regulatory Commission. 1976. Preparation of Environmental Reports for Nuclear Power Stations. NUREG-0999, Regulatory Guide 4.2, Revision 2, Washington, D.C., JuTy 1976. 
USCOE. 1976. Power Pondage Studies. CRT-3Q, U.S. Army Corps of Engineers, North Pacific Division, Portland, Oregon.

Washington Public Power Supply Systen (WPPSS). 1977. WPPSS Nuclear Project No. 2. Environmental Report, Operating License Stage, Docket No. 50-397. WPPSS, Richland, Washington.

Washington State Department of Game. 1971 to 1979. Annual Report: Hatcheries and Semi-natural Rearing Ponds, July 1 - June 30. Mimeo. Annual Reports, WSDG, OTympia, Washington.

Washington Department of Game. 1983. Washington State Special Animal Species. Primary Data Needs Statewide. Olympia, Washington, 23 pp.

Watson, D. G. 1970. Fall Chinook Salmon Spawning in the Hanford Reach of the Columbia River Near Hanford 1947-1969. BNwL-1515, Pacific Northwest Laboratory, Richland, Washington.

Watson, D. G., C. E. Cushing, C. C. Coutant and W. L. Templeton. 1971. "Cycling of Radionuclides in Columbia River Biota," pp. 144-157. In Trace Substance in Environmental Health IV, ed. D. D. Hemphi11, Univ. of Missourj, Columbia.

Watson, D. G. 1973. Estimate of Steelhead Trout Spawning in the Hanford Reach of the Columbia River. Pacific Northwest Laboratory, Richland, Washington.

Watson, D. G. 1976. Temporal and Spatial Fall Chinook Salmon Redd Distribution Near Hanford, 1962-1976. BNWL-2163, Pacific Northwest Laboratory, Richland, Washington.

Webster, D. A. 1945. "Relation of Temperature to Survival and Incubation of the Eggs of Smallmouth Bass (Micropterus dolomieu)." Trans. Am. Fish. Soc. 75:43-47.

Wedemeyer, G. 1973. "Some Physiological Aspects of Sublethal Heat Stress in Juvenile Steelhead Trout (SaImo gairdneri) and Coho Salmon (Oncorhynchus kisutch). J. Fish. Res. Board Can. 30:831-834.

Wedemyer, G. A., R. L. Saunders and W. C. Clarke. 1980. "Environmental Factors Affecting Smoltification and Early Marine Survival of Anadromous Saimonids." Marjne Fish. Rev. 1980:1-14.

Weitkamp, D. E. and D. M. McEntree. 1982. 1982 Gatewell Sampling Wanapaum and Priest Rapids Dams. No. 82-1124-2601, Public Utility District No. 2 of Grant County, Ephrata, Washington. 37 pp.

Wetzel, R. G. 1975. Limnology. W. B. Saunders Co., Philadelphia, Pennsylvania. $743 \mathrm{pp}$. 
Wildung, R. E., R. C. Routson, and R. L. Schmidt. 1972. Seasonal Changes in Particle Size Distribution, Composition, and Strontium Exchange Capacity of Particulate Matter Suspended in The Columbia River. BNWL-1638, Pacjfic Northwest Laboratory, Richland, Washington.

Withler, J. L. 1966. "Variability in Life History Characteristics of Steelhead Trout, Salmo gairdneri, along the Pacific Coast of North America. J. Fish. Res. Board Can. 23(3):365-393.

Wolcott, E. E. 1973. Lakes of Washington, Volume II, Eastern Washington. Washington State Dept. Ecology, Olympia, Washington.

Wolf, E. G. 1976. "Characterization of the Benthic Community," Section 4. In Final Report on Aquatic Ecological Studies Conducted at the Hanford Generating Project, 1973-1974, WPPSS Columbia River Ecology Studies Vol. 1. Battelle, Pacifjc Northwest Laboratories, Richland, Washington.

Wolf, E. G., T. L. Page and D. A. Neitzel. 1976. "Phytoplankton Community: Primary Productivity, Pigment Concentration, Species Composition and Relative Abundance of Phytoplankton and Physiochemical Analysis," Section 2. In Final Report on Aquatic Ecological Studies Conducted at the Hanford Generating Project, 1973-1974. WPPSS Columbia River Ecological Studies, Vol. 1. Battelle, Pacific Northwest Laboratory, Richland, Washington.

Wydowski, R. S., and R. R. Whitney. 1979. Inland Fishes of Washington. University of Washington Press, Seattle, washington. 220 pp. 



\subsection{METEOROLOGY}

This chapter presents a summary of the meteorological characteristics pertinent to the Skagit/Hanford Site. Although no data have been collected at the proposed site itself, meteorological data are collected at a number of locations on the Hanford Site.

Complete climatological data are available for the Hanford Meteorology Station (HMS), located about $15 \mathrm{~km}(9.3 \mathrm{mi})$ northwest of the Skagit/Hanford Site. Data have been collected at the HMS since 1945, and temperature and precipitation data from a nearby location are available for the period from 1912 through 1943. A summary of these data, for the period through 1980, has been compiled by Stone et al. (1983). Sections, Figures, and Tables referred to here without further elaboration are from Stone et a 1 . The summary also contains wind data for several locations on and near the Hanford Site. One location for which supplementary wind data are available is the Wye Barricade, which is about $2.5 \mathrm{~km}(1.6 \mathrm{mi})$ east-southeast of the Skagit/Hanford Site.

The general climatological characteristics of the Skagit/Hanford Site should be adequately described by the HMS summary, although there are some systematic differences where specific climatic elements are concerned. In particular, the HMS summary correctly indicates that the region experiences frequent periods of low wind speeds and has a low annual average wind speed, but comparisons of hourly wind data and wind roses for the HMS and the wye Barricade indicate that the HMS winds are not particularly representative of the proposed site.

The WNP-2 site, approximately $7.2 \mathrm{~km}(4.5 \mathrm{mi})$ east-southeast of the proposed NPR site, is another source of meteorological data that could be used to characterize the climatology of the proposed NPR site. Data from WNP-2 were used in the draft environmental impact statement (U.S. NRC 1982) for the Skagit/Hanford Nuclear Project plants that were considered originally for the site. However, use of these data to characterize the Skagit/Hanford Site climatology is not recommended because 1) the longer period of record for the HMS data provides a better basis for making a statement about the general climatological characteristics of the region, and 2) wind data for WNP-2 and 
the Wye Barricade indicate that the winds at WNP-2 differ significantly from those at the proposed NPR site.

With these considerations, it is recomended that the HMS climatological summary (Stone et al. 1983) be used as the primary source of information for characterizing the atmosphere for general purposes. The narrative on page $i \mathrm{i}$ of the sumary describes the factors that influence the climate at Hanford and gives a synopsis of the normal and extreme meteorological conditions. The description should adequately represent the climate at the proposed site except for winds. Some differences are to be expected in detailed values presented, but the magnitudes of the differences will be inconsequential in the current context.

\subsection{WIND DATA}

The wind data that are most representative of the winds at the proposed site should be those for the Wye Barricade. Measurements at this location are made at a height of $9.1 \mathrm{~m}(30 \mathrm{ft})$ above ground. The data for the period October 19, 1979, through April 25, 1982, are summarized in Table A.IV-1 and Figure A.IV-1 (Station 12). These sumaries, which approximate annual averages, would be appropriate for characterizing the initial transport and diffusion of effluents released at ground level.

Additional Wye Barricade wind data summaries for the data collection periad ending January 31, 1984, are presented in Appendix B. These summaries include both month $1 y$ and annual joint frequency distributions of wind direction, wind speeds, and atmospheric stability.

Comparison of the wind rose for Station 12 (Wye Barricade) with those for the HMS and Station 14 (WNP-2) in Figure A.IV-1 illustrates that the winds at those sites are not fully representative of the winds at the Skagit/Hanford Site. Hour-by-hour comparisons of the winds for a 10-month period show that significant differences $(a)$ exist between the Wye Barricade and HMS winds more

(a) For this purpose, a significant difference is defined as a direction difference of $90^{\circ}$ or more, or a magnitude of the vector difference between two winds that exceeds $80 \%$ of the average of the two wind speeds. 
than 29\% of the time and between the Wye Barricade and WNP-2 winds more than $20 \%$ of the time.

The wind data for the HMS in Tables 41,42 , and 43 indicate the potential variations of the wind joint frequency distributions in the vertical and by months for the Skagit/Hanford Site. However, the strong northwesterly winds shown for the HMS during the summer months are the result of drainage winds that may not extend to the proposed site. The HMS wind data provide the best available estimates of extreme wind events.

The HMS narrative summary table on page iv shows that winds exceeding $50 \mathrm{kts}(25.5 \mathrm{~m} / \mathrm{s}$ or $57 \mathrm{mph})$ occur throughout the year. The direction of the wind during peak gusts (generally from the southwest or south-southwest) indicates that the highest winds are associated with synoptic scale storms. Figure 35 indicates that the expected return internal for a wind of $50 \mathrm{kts}$ or above at the $15.2-\mathrm{m}(50-\mathrm{ft})$ level at the HMS is about 1.4 years. The estimated return periods at the 60 - and $122-m$ (200- and 400-ft) levels are just over 1 year.

Thunderstorms and summertime afternoon drainage winds are also associated with high winds. On average, 10 thunderstorms occur each year. They have occurred in all seasons, but are most frequent during the summer months. The winds during thunderstorms show no directional preference. The strong drainage winds occurring during the summer are generally northwesterly. The period of record of wind data for the Wye Barricade is too short to permit good estimates of the frequency of occurrence of high winds.

Table 40 of the HMS climatological summary lists tornadoes since 1916 within a radius of approximately $161 \mathrm{~km}$ (100 $\mathrm{mi}$ ) of the HMS. An independent list of tornadoes since 1948 occurring within a $161-\mathrm{km}$ radius of the proposed NPR site was obtained in a search of the National Severe Storms Forecast Center (NSSFC) tornado data base.

There are several discrepancies between the lists. The NSSFC list includes a tornado on May 22, 1964, that is not in the HMS data summary; records at National Weather Service offices in the area indicate that the tornado did occur. The HMS list includes a tornado near Colfax, Washington, on August 30 , 1971, and the NSSFC list notes one in about the same location on December 30 , 1971. The date of the tornado in the NSSFC 1ist is incorrect. Similarly, the tornado on August 18, 1978, in the NSSFC list actually occurred on August 15, 
1978, as shown in the HMS list. Finally, the HMS records list the occurrence on August 9, 1982, as a funnel cloud. It was initially reported as a tornado, but no evidence could be found to indicate that the cloud made contact with the ground. Resolving the discrepancies in this manner and treating the 1972 Spokane, Washington, and the 1978 Hatton, Washington, tornadoes as single events because of their proximities in time and space leaves a combined list of 22 tornado events between 1916 and August 1982. Two additional tornadoes have occurred since August 1982. On September 13, 1982, a tornado occurred between Touchet and Lowden, Washington, and on April 23, 1983, one occurred between Connell and Eltopia, Washington.

Given the data in the NSSFC data base and version 2.0 of the NRC computer program TORNADO (Schreck and Sandusky 1982), the tornado recurrence interval at the proposed NPR site is 98,460 years. This is consistent, within the uncertainties of estimating rare events from a 1 imited data base, with the 146,000-year recurrence interval for HMS estimated by Daubek in 1970 (Stone et a]. 1983). The maximum wind speed estimated for a tornado at the skagit/ Hanford Site is $98.3 \mathrm{~m} / \mathrm{s}(220 \mathrm{mph})$. The rotational component of the speed is estimated to be $77.8 \mathrm{~m} / \mathrm{s}(174 \mathrm{mph})$, and the translation component is estimated at $20.6 \mathrm{~m} / \mathrm{d}(46 \mathrm{mph})$. The total pressure drop is estimated to be $12.05 \mathrm{psi}$, with a maximum rate of decrease of $0.47 \mathrm{psi}$.

\subsection{TEMPERATURE, PRECIPITATION AND HUMIDITY}

Diurnal and monthly averages and extremes of temperature, dewpoint, and humidity are contained in the tables in the narrative portion of the HMS summary on pages iv and $v$. They are also discussed in Section VII, and additional detail is provided in Tables $27,28,29$, and 30, and in Figure 24.

Section IV of the climate sumary discusses precipitation. The information presented is specific to the HMS site, but trends and precipitation amounts should be approximately correct for the Skagit/Hanford Site. Table I0 gives monthly precipitation totais for the period from 1912 through 1980 and the monthly averages for the period. The frequency of precipitation and precipitation rates are described in Table 11, 12, 13, and 14, and in Figures 14, 15, and 16. The probability of extreme precipitation is covered in Figures 36,37 , and 18 (snow), and in Table 61 . 
Table 15 compares precipitation averages for the HMS and Richland, Washington, which is about $39 \mathrm{~km}$ (24 mi) to the southeast of the HMS. During the winter months--November through March--Richland receives about $10 \%$ more precipitation than does the HMS. For the remaining months, the monthly averages are about the same for the two locations. This seasonal difference may be attributable to a seasonal variation in the type of precipitation and to a sheltering effect of Rattlesnake Mountain, which lies along the southwest edge of the Hanford Site. The available data are not adequate to determine whether the precipitation pattern at the Skagit/Hanford Site follows HMS or Richland more closely.

Precipitation wind roses have not been prepared for the proposed NPR site. No precipitation data are available for the site. Tables 21 and 22 give the wind direction and speed frequencies, respectively, during periods of precipitation at the HMS.

\subsection{ATMOSPHERIC DIFFUSION}

Wind data for the Wye Barricade contained in the summary are applicable to the Skagit/Hanford Site, but are not sufficient for full evaluation of atmospheric transport and diffusion at the site. Joint frequency distributions of wind and stability for the Wye Barricade using Wye Barricade winds and stability determined at the HMS tower are included in Appendix $B$.

Seasonal variations of the wind direction and speed frequency distributions for the HMS by stability class are contained in Table 50, 51, and 52 . The stability class definitions used in preparing these tables were determined on the basis of numerous atmospheric diffusion tests conducted at Hanford and do not correspond directly to the stability class definitions in Regulatory Guide 1.23 (U.S. NRC 1974).

The probabilities of extended periods with temperature inversions at Hanford are discussed by Stone, Jenne, and Thorp (1972). Given an initial observation of inversion conditions between 1 and $61 \mathrm{~m}$ ( 3 and $200 \mathrm{ft}$ ), the probability of inversion persistence for more than 12 hours varies from a low of about 0.1 from May through August to high of about 0.64 in September and 
October. The probability that an inversion will persist more than 24 hours reaches a maximum of slightly more than 0.02 in January and February.

The depth of the atmospheric mixing layer is monitored continuously at the HMS using an acoustic sounder. The mixing layer depth data summarized for the 22-month period from March 25, 1982, through January 31, 1984, are presented in Appendix $C$.

\subsection{AIR QUALITY}

The discussion of air quality in the S/HNP draft environmental impact statement (U.S. NRC 1982, Section 4.2.10.2) reflects the current conditions in the Columbia Basin, except for the oxides of nitrogen $\left(\mathrm{NO}_{\mathrm{x}}\right)$.

Chemical processing of reactor fuel at Hanford was resumed in November 1983 for the first time since 1972. The fuel processing facilities are located about $11 \mathrm{~km}$ (7 $\mathrm{mi}$ ) northwest of the Skagit/Hanford Site. Releases of ${ }^{N 0}{ }_{x}$ are associated with fuel processing. Ramsdell (1981) reports on the observed $\mathrm{NO}_{x}$ levels in the vicinity of the processing facility during the last period of operation (1968-1969). Recent $\mathrm{NO}_{x}$ measurements made prior to the facility restart indicate a background concentration of less than $0.007 \mathrm{ppm}$ (Sula et al. 1983). Ouring renovation of the facilities prior to resumption

of fuel processing, $\mathrm{NO}_{\mathrm{x}}$ emission control has been upgraded. As a result, even with fuel processing, the ambient $N O_{x}$ concentrations are expected to remain within permissible federal and Washington State limits (U.S. DOE 1982).

\subsection{METEOROLOGICAL INSTRUMENTATION}

The meteorological instrumentation on the tower at the HMS through 1982 is described in Section XII of the climatological sumnary; the instrumentation in the telemetry network is described in Appendix IV. The wind instruments described do not meet the criteria outlined in Regulatory Guide 1.23 (U.S. NRC 1974). The instruments described have been replaced by more sensitive instruments that meet the criteria. Similarly, the temperature sensors on the 
tower have been replaced by platinum resistance sensors. In addition, a Doppler acoustic sounder has been used to estimate mixing depths since the late 1970 s.

The meteorological instrumentation on the Hanford Site is currently being upgraded. The telemetry network is being increased to permit better evaluation of trajectories of effluents after they pass the site boundaries. Three $61-m(200-f t)$ towers and three additional acoustic sounders are being added to the network to permit better definition of the stability and wind structure over the site. The data from all of this instrumentation will be relayed to computers for use in evaluating the consequences of routine and accidental releases to the atmosphere.

\subsection{REFERENCES}

Ramsdel1, J. V. 1981. Hanford 200 East Area Ambient N0 Concentrations February 1968 Through February 1969. PNL-3996, Pacifi $\widehat{C}$ Northwest Laboratory, Richland, Washington.

Schreck, R. I., and W. F. Sandusky. 1982. TORNADO: A Program to Compute Tornado Strike and Intensity Probabilities with Associated Wind Speeds and Pressure Drops at Nuclear Power Stations. PNL-4483, Pacific Northwest Laboratory, Richland, Washington.

Stone, W. A., 0. E. Jenne and J. M. Thorp. 1972. Climatography of the Hanford Area. BNWL-1605, Pacific Northwest Laboratory, Richland, Washington.

Stone, W. A., J. M. Thorp, 0. P. Gifford and D. J. Hoitink. 1983. Climatography Summary of the Hanford Area. PNL-4622, Pacific Northwest Laboratory, Richland, Washington.

Sula, M. J., J. M. V. Carlile, K. R. Price and W. D. McCormack. 1983. Environmental Surveillance at Hanford for CY 1982. PNL-4657, Pacific Northwest Laboratory, Richland, Washington.

U.S. Department of Energy. 1982. Oraft Environmental Impact Statement, Operation of PUREX and Uranium Oxide Plant Facilities. DOE/EIS-00890, Washington, D.C.

U.S. Nuclear Regulatory Commission. 1974. Onsite Meteorological Programs. Regulatory Guide 1.23 (formerly Safety Guide 23), Washington, D.C.

U.S. Nuclear Regulatory Commission. 1982. Draft Environmental Impact Statement Related to the Construction of Skagit/Hanford Nuclear Project, Units 1 and 2. NUREG-0894, Washington, D.C. 



\subsection{HYDROLOGY}

In this chapter, hydrologic characteristics of the Skagit/Hanford and Firehouse sites are provided. Section 5.1 provides a description of surface water hydrology; Section 5.2 characterizes the groundwater hydrology. The descriptions are directed primarily to the Skagit/Hanford Site. However, the more general parts apply to the Firehouse Site as well. Where conditions are different, a description for the Firehouse Site is also given.

\subsection{SURFACE WATER HYDROLOGY}

The main surface water that could be affected or influenced by the plant construction and operation is the Columbia River. Hence, it is discussed in some detail in Section 5.1.1. Watershed characteristics, river water quality, and effluent discharges are then discussed.

\subsubsection{Columbia River Hydrologic and Physical Characteristics}

\subsubsection{Tributaries, Major Dams, and Water Intakes}

The Columbia River and its tributaries, shown in Figure 5.1, drain an area of approximately 259,000 square miles. The river originates at Columbia Lake in British Columbia, flows northwesterly parallelling the Rocky Mountains for about 190 miles, then turns southward flowing 271 miles to the international border. In the United States the river flows southward across the state of Washington to the Washington-Oregon state line. The river then flows westward along the Washington-Oregon state line through the Cascade Coast Ranges to its mouth in the Pacific Ocean near Astoria, Oregon. The Columbia River is about 1200 miles in length.

The stretch of the Columbia River nearest the Skagit/Hanford Site is known as the Hanford Reach. It stretches from Priest Rapids Dam (River Mile 397.1) to the head of Lake Wallula (RM 354). The Hanford Reach is the last free-flowing reach of the Columbia River in the United States (Rickel 1981). The main river channel in this reach is braided around the island reaches, and submerged rock ledges and gravel bars cause repeated pooling and channeling. River bed material is typically sand, gravel and cobbles as large as 8 inches in diameter. The river channel varies from 1200 to 1800 feet wide 


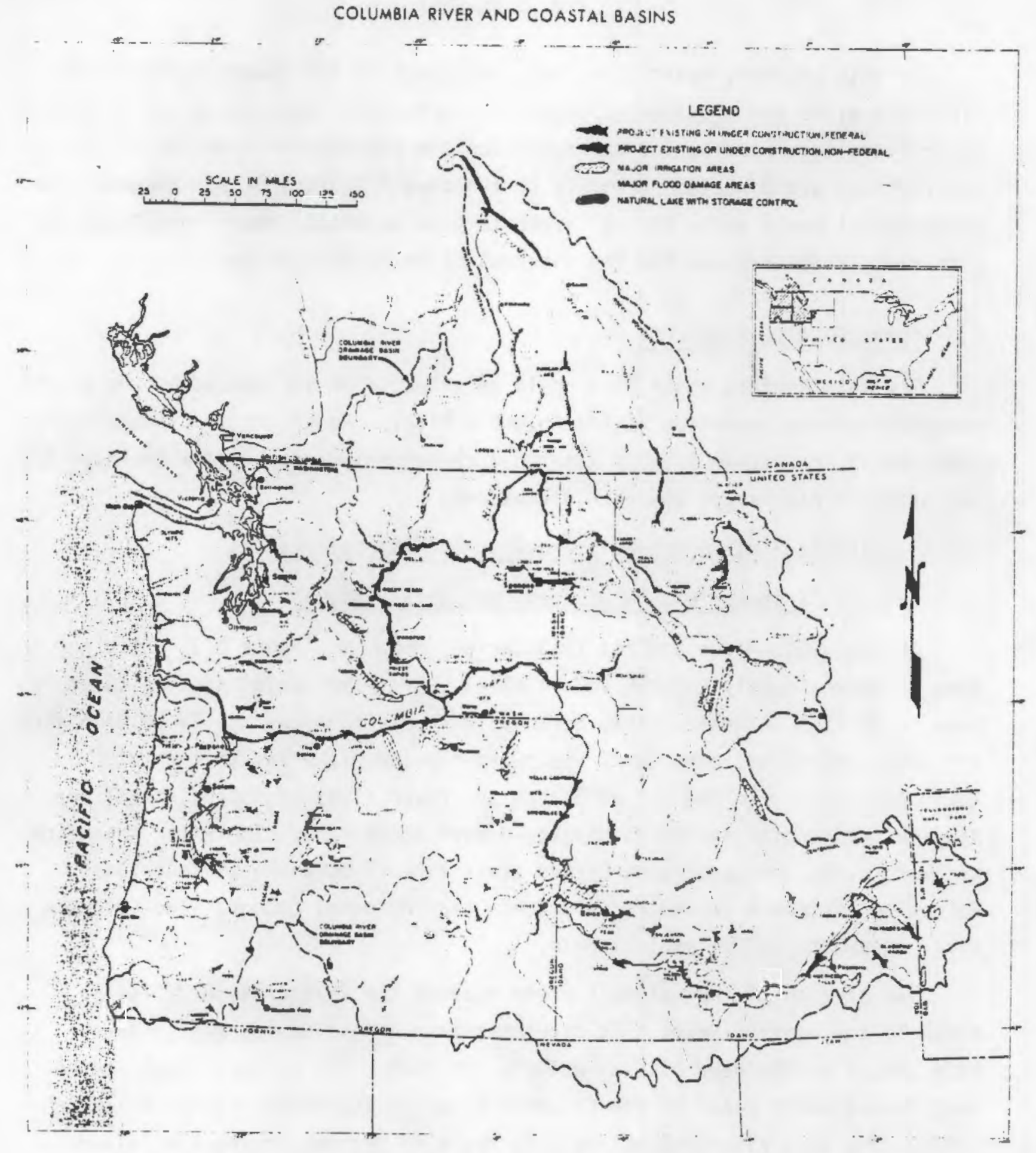

FIGURE 5.1. Columbia River Drainage Basin and Major Dams

Source: PSP\&L (1982) 
during low-water and normal high-water flows. The depth varies from about 23 feet to 45 feet during normal high-water and flood high-water flows, respectively. Flow velocities vary from $3 \mathrm{fps}$ to more than $11 \mathrm{fps}$, depending on flow and location.

Major tributaries of the Columbia River are summarized in Table 5.1. The largest tributary is the Snake River; about 30 river miles downstream of the Hanford Reach. The Snake River has a drainage area of 108,500 square miles and an average annual discharge of $56,380 \mathrm{ft}^{3} / \mathrm{sec}$ (USGS 1979). The Yakima

TABLE 5.1. Location of Significant Structures and Landmarks on Columbia River

\section{Description}

River Mouth

Cowlitz River

Lewis River

Willamette River

Bonneville Dam

The Dalles Dam

Deschutes River

John Day Dam

John Day River

McNary Dam

Walla Walla River

Snake River

Yakima River

WNP-2 Intake and Discharge

Proposed WNP-1 and 4 Intake and Discharge

Skagit/Hanford Nuclear Project Intake and Discharge

(approximate)

Existing Hanford Generating Plant

Priest Rapids Dam

Wanapum Dam

Rock Island Dam

Wenatchee River

Rocky Reach Dam

Chelan River

Wells Dam

Methow River

Okanogan River

Chief Joseph Dam

Grand Coulee Dam

Spokane River

United States-Canadian Boundary
River Mile

0.0

146.1

191.4

215.6

292.0

324.2

335.2

351.75

352.85

361.5

380.0

397.1

415.8

453.4

468.4

473.7

503.3

515.6

545.1

596.6

638.9

745.0

Source: Pacific Northwest River Basin Commission (1962) 
River is the nearest major tributary to the Hanford Reservation. The river mouth is about 19 miles downstream of the Hanford Reach. It has a drainage area of 5,615 square miles.

Eleven multipurpose reservoir projects listed in Table 5.1 have been constructed on the Columbia River within the United States during the past 40 years. The reservoirs provide for electrical power generation, navigation, irrigation, recreation and flood control. Seven dams are located upstream of the Hanford Reach and four dams are located downstream. Figure 5.2 shows these dams in relationship to the Hanford Reach. McNary Dam, the closest downstream dam, is about 62 miles. It began operation in 1953. The maximum pool elevation is 340 feet above mean sea level (MSL) and has a maximum storage volume of 1,350,000 acre-feet. Priest Rapids Dam forms the upstream boundary to the Hanford Reach. It began operation in 1960. The maximum pool elevation is 488 feet above MSL and has a maximum storage capacity of 227,000 acre-feet. Grand Coulee Dam, located 200 miles upstream of the Hanford Reach, is the largest dam. The dam began operation in 1941. The maximum pool elevation is 1288 feet above MSL, and the maximum storage capacity is $9,402,000$ acre-feet.

The Columbia River is regulated on both an hourly and seasonal basis to meet the fluctuating demand for power. The annual variation in power demand is not large, with the winter demand being only about 20 percent greater than the summer demand. The natural streamflow pattern of the Columbia River does not coincide with the demand for electrical power, requiring that the streamflow be regulated by storage reservoirs so it more nearly coincides with the power demand. Water is stored in the high runoff months of April through July for release during the remainder of the year. Daily fluctuation in flow depends on the power demand, the volume of water in the river, and irrigation depletions. Typically, the power demand rises (increase in river flow) from baseload at 0600 hours to the peak demand at 0800 hours, after which the demand stays fairly level until 2000 hours, when it decreases to baseload.

Columbia River surface water users are listed in Tables 5.2 through 5.4 and shown in Figure 5.3. Surface water is withdrawn from the Columbia River primarily for irrigation, livestock, domestic and commercial uses. Within 


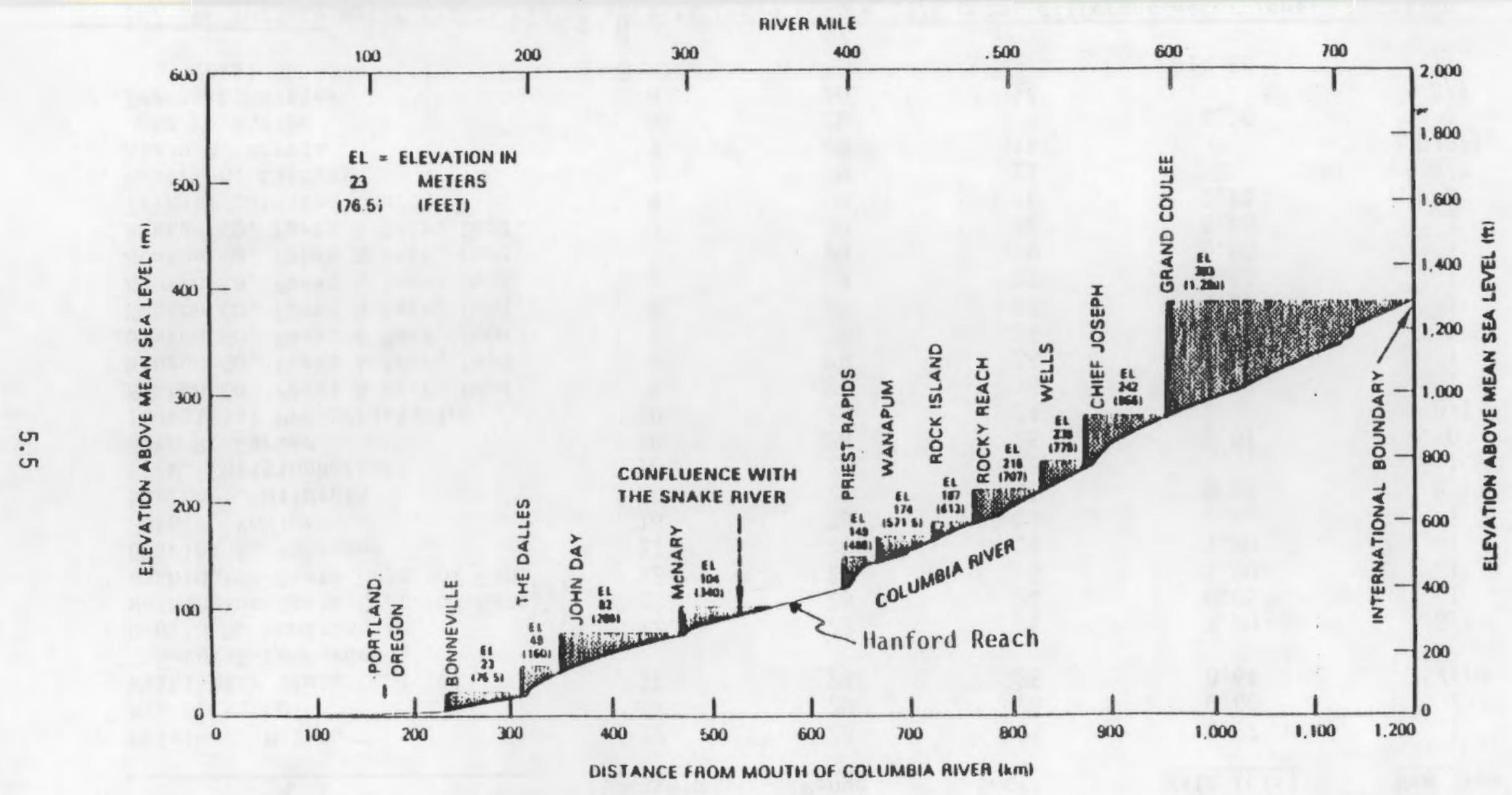

FIGURE 5.2. Schematic Representation of the Hydraulic Regime of the Columbia River Showing Major Dama (U.S. Army Corps of Engineers) 
TABLE 5.2. Surface Water Rights Claims 50 Miles Downstream from Skagit/Hanford Nuclear Project (a) (Washington State DOE 1981a)

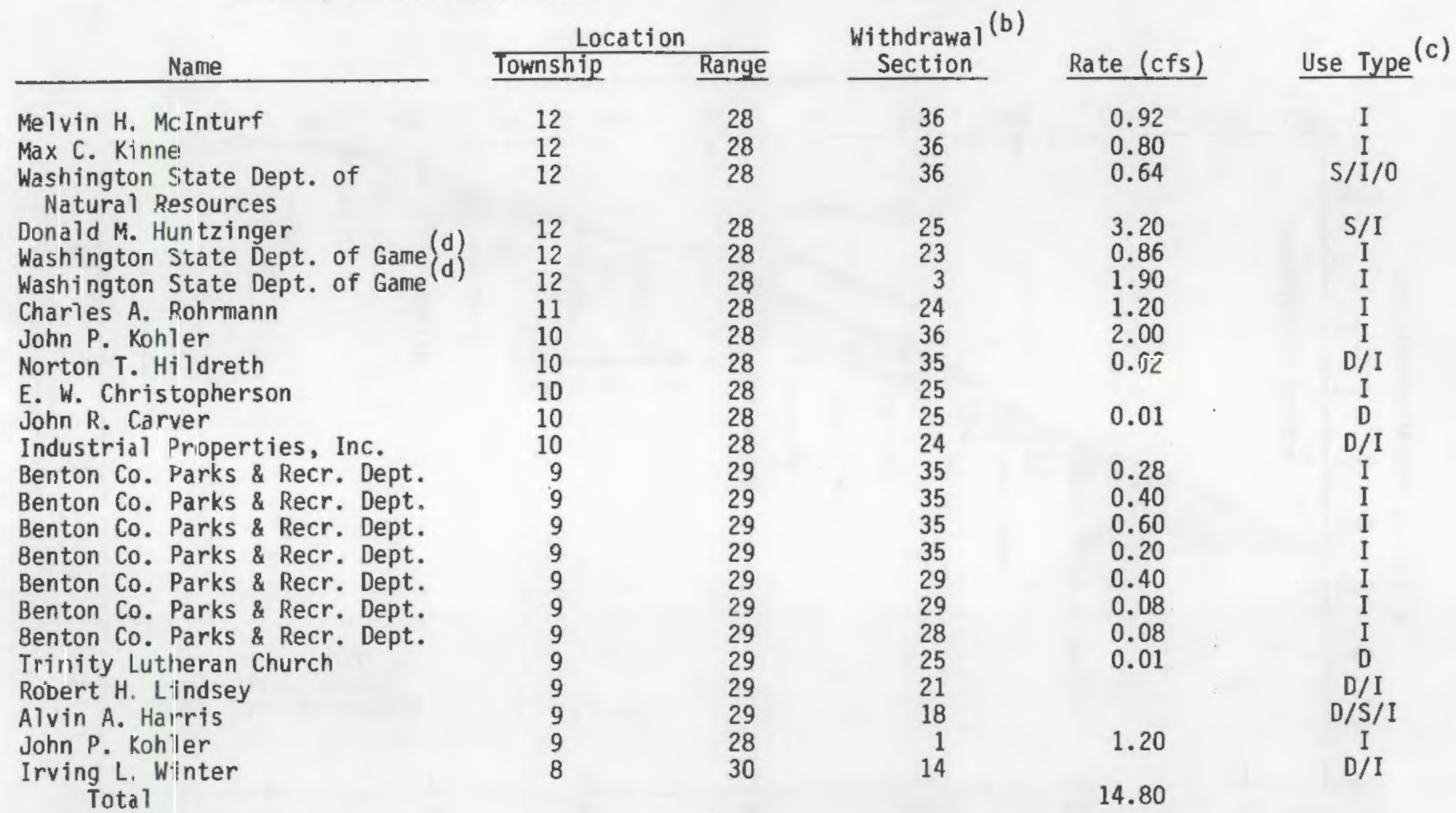

(a) The surface water rights claims were recorded before 1974 under different water laws. Location specified only by township, range, and section. These users are not shown on Figure 2.11.

(b) Minimum permitted withdrawal was calculated using average withdrawal rates assumed by Washington State Dept. of Ecology: $0.01 \mathrm{cfs}$ and $0.02 \mathrm{cfs}$ for domestic use and per acre of irrigation, respectively.

(c) $I=$ irrigation, $S=$ i ivestock, $D=$ domestic, $D=$ other.

(d) Possibly duplicated by a water use permit. 
TABLE 5.3. Surface Water Permits 50 Miles Downstream
From Skagit/Hanford Nuclear Project

No.

(b)

01

02

03

04

05

06

08

09

10

11

12

13

14

15

16

18

20

22

23

24

25

26

27

28

29

30

31

32

33

34

35

37

39

40

41

42

43

44

45

46

47

49
Name

WA State Dept. of Came

WA State Dept. of Game

WA Public Power Supply System

WA Public Power Supply System

L. L. Bailie

H. D. Lloyd

Central Premix Concrete Co.

Battelle Memorial Institute

University of Washington

City of Richland

I van L. Huffman

City of Richl and

City of Richland

City of Richland

R. J. Sloat

City of Richland

City of Richland

City of Kennewick

City of Pasco

Frankl in Co. Irrigation Dist.

Frankl in Co. Bo

Franklin Co. Bo

Frankl in Co. Irrigation Dist.

Benton Co. Parks \& Recr. Dept.

C. C. Walkley

E. C. Watts

E. C. Watts

H. S. Petty

W. H. M. Ketchersid

L. Horrigan

L. Horrigan

Premix Concrete, Inc.

City of Richland

U.S. Bureau of Reclamation

U.S. Bureau of Reclamation

Port of Pasco

Allied Chemical and Dye Co.

F. J. Henckel

Chevron Chemical Co.

Chevron Chemical Co.

Phillips Pacific Chemical Co.

Phillips Pacific Chemical Co.

Gilbert Garn, et al.

Esmieu, Louis P. and Stephen A.

v. L. Layton

Boise Cascade Corp.

Boise Cascade Corp.

Hoyt Stark Berry

U.S. Corps of Engineers

Total

(a) Washington State DOE (19810).

(b) Number keyed to Figure 5.3 .
Location

Township Range Section Rate (cfs)

1.9

0.86

88.0

2.0

0.99

1.78

4.4

1.75

0.67

0.01

31.0

23.25

31.0

0.01

23.25

17.0

55.7

35.0

83.0

0.448

0.672

83.0

0.5

2.32

0.01

0.3

0.48

1.66

2.54

2.54

1.1

2.0

80.0

8.5

14.5

3.55

0.015

3.77

40.0

82.0

20.0

59.4

227.0

1.0

20.68

24.5

179.8

0.24

1266.10
Radial

Distance Miles Cown-

Withdrawal from stream from Use Type Station Discharge

1
1
0
1
1
$C-1$
1

8

8

5

9.5

9.5

12.5

13

13.5

18.5

20

20

20

20.5

20.5

20.5

20.5

21

21

32.5

33

25.5

27

27.5

30

31.5

23

22.5

22.5

23

22.5

24

24.5

25

40.5

40.5

35

38

38

39

39

39.5

39.5

43.5

43.5

43.5

44.5

44.5

45.5

49.5 
TABLE 5.4. Surface Water Applications as of May 18, $1981^{\text {(a) }}$

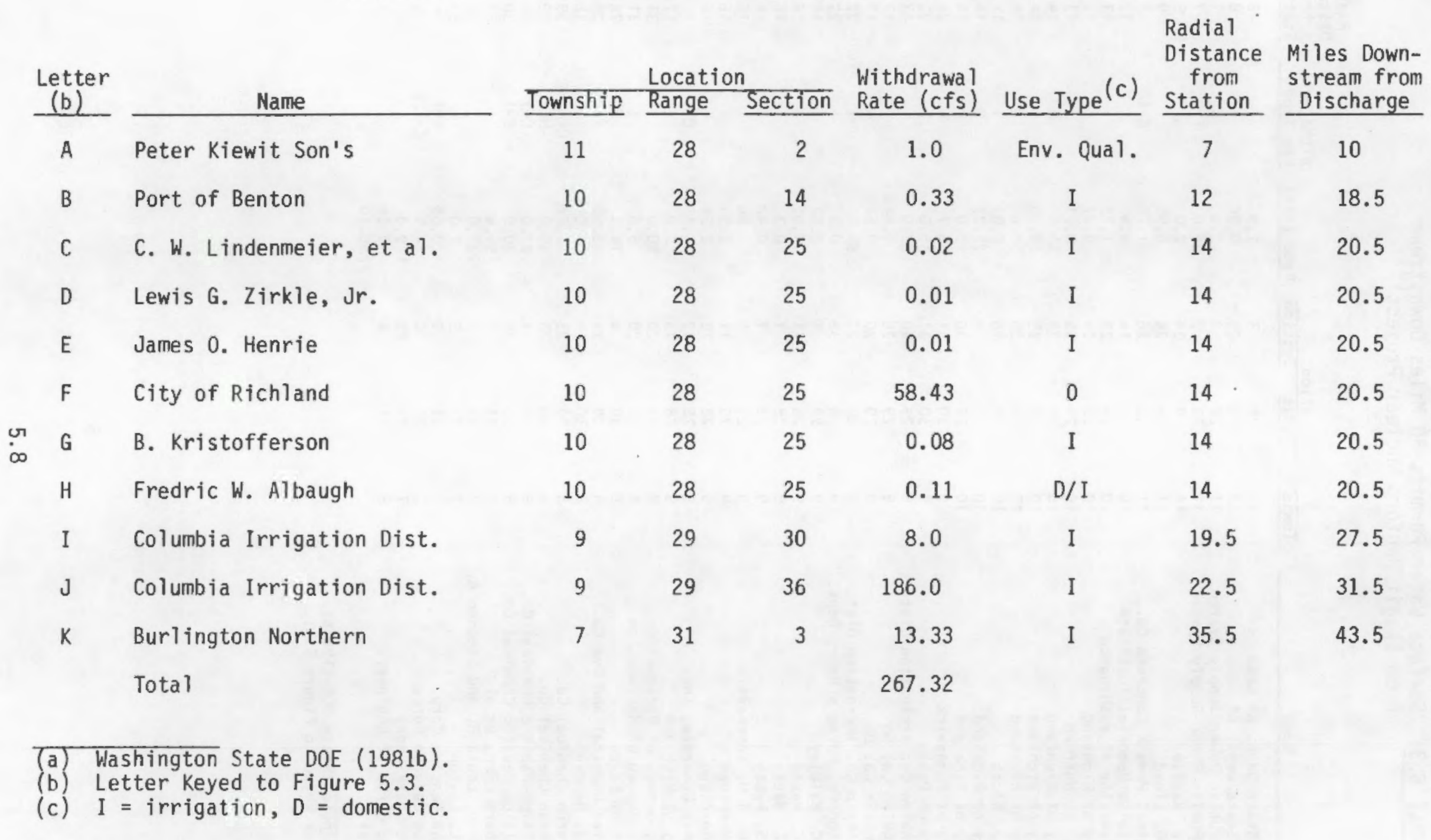




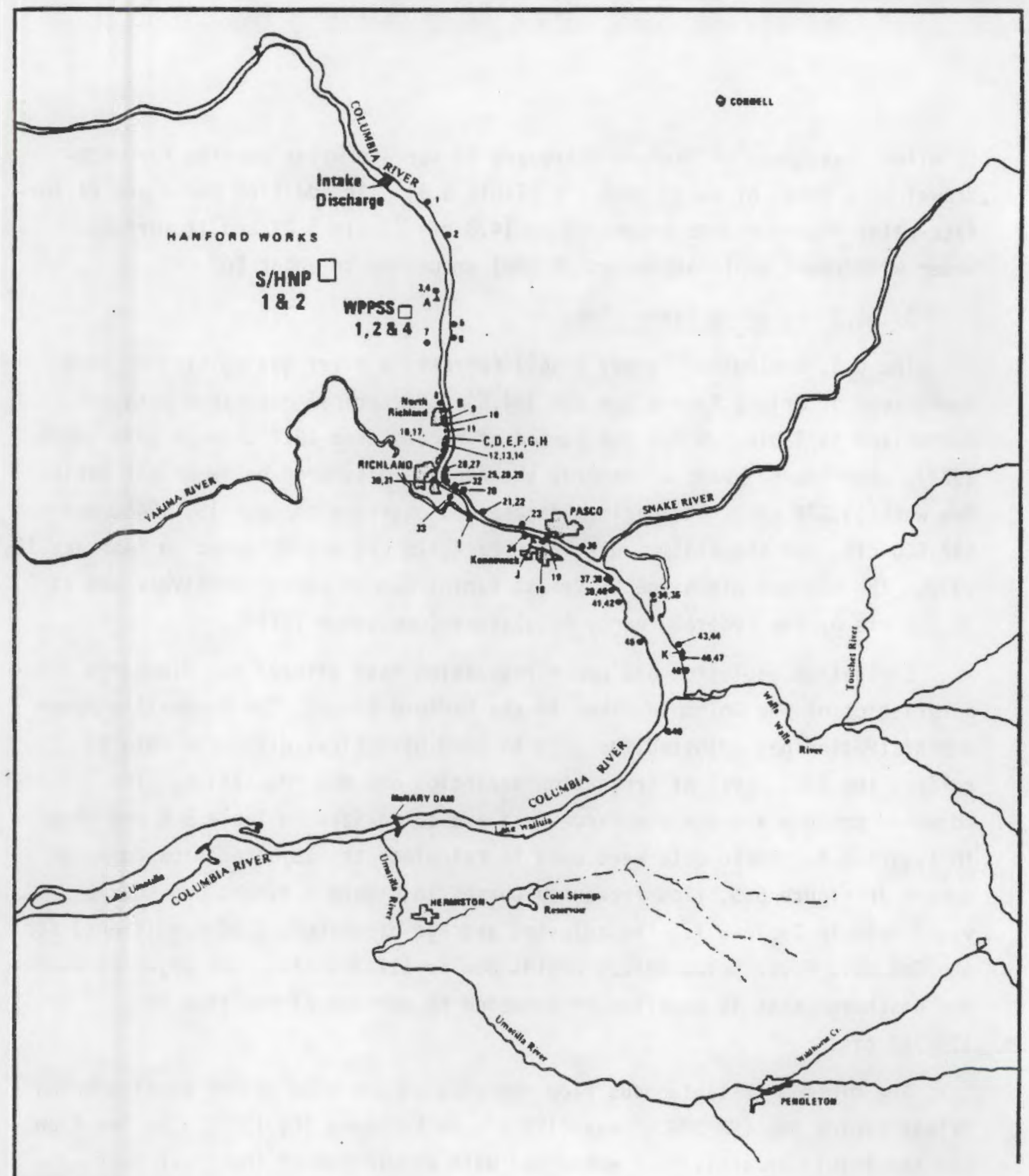

LEGEND:

SUPFACE WATER

- PERMITS (NUMBERS)

$\triangle$ APPLICATIONS (LETTERS)
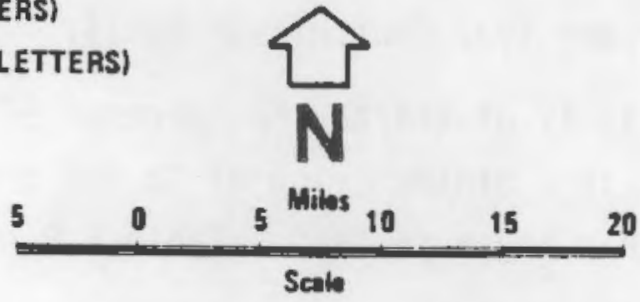

FIGURE 5.3. Location of Surface Water Users

Source: PSP\&L (1981) 
50 miles downstream of Hanford there are 49 surface water permits for withdrawal of a total of about 1266 cfs (Table 5.3). In addition there are 24 surface-water rights claims amounting to $14.8 \mathrm{cfs}$ (Table 5.2) and 11 surfacewater withdrawal applications as of 1981 amounting to about $267 \mathrm{cfs}$.

\subsubsection{Columbia River Flows}

The U.S. Geological Survey (USGS) operates a river gaging station just downstream of Priest Rapids Dam (RM 394.5). Historical discharge data are summarized in Table 5.5 for the period of record from 1917 through 1979 (USGS 1979). For the 62 years of record, the average discharge below Priest Rapids Dam was 119,870 cfs. The maximum discharge, observed on June 12, 1948, was $692,600 \mathrm{cfs}$, and the minimum discharge of 4,120 cfs was observed on February 10 , 1932. The minimum discharge at Priest Rapids Dam is administratively set at 36,000 cfs by the Federal Energy Regulatory Commission (FERC).

Irrigation depletion and power regulation have altered the discharge characteristics of the Columbia River in the Hanford Reach. The Bonneville Power Administration has adjusted the 1929 to 1968 historical discharge data to reflect the 1980 level of irrigation depletion and dam regulation. The adjusted monthly average discharge data are summarized in Table 5.6 and shown in Figure 5.4. These data were used to calculate the adjusted flow duration curves in Figure 5.5, flow frequency curves in Figure 5.6, and dependable yield data in Table 5.7. The adjusted average discharge (1980 conditions) for the Columbia River below Priest Rapids Dam is 117,214 cfs. The adjusted average discharge that is equalled or exceeded 50 percent of the time is 115,752 cfs.

The minimum instantaneous flow recorded at the USGS gaging station below Priest Rapids Dam (RM 394.5) was 4120 cfs on February 10, 1932. The low flow was the result of activities connected with regulation of the river near Wenatchee, washington. The minimum daily average flow of 20,000 cfs occurred on January 31, 1937 (WPPSS 1981). The minimum 30-day average monthly flow of 20,400 cfs occurred during February 1937 (Hutchinson 1981).

The Grant County Public Utility District, the operator of Priest Rapids Dam, has been required to maintain a minimum flow of 36,000 cfs under its FERC license since operation of the dam began in 1960 . Table 5.8 summarizes the 


\section{TABLE 5.5. Historical Discharge Data}

\begin{tabular}{|c|c|}
\hline & $\begin{array}{c}\begin{array}{c}\text { Columbia River } \\
\text { below }\end{array} \\
\text { Priest Rapids Dam }\end{array}$ \\
\hline Gauge number (a) & $12-4728-00$ \\
\hline River mile $e^{(a)}$ & 394.5 \\
\hline Drainage area $\left(m i^{2}\right)^{(a)}$ & 96,000 \\
\hline Period of record (a) & 1917-1979 \\
\hline Average discharge $(\mathrm{cfs})^{(a)}$ & 119,870 \\
\hline \multicolumn{2}{|l|}{ Maximum discharge (cfs) } \\
\hline - Instantaneous & 692,600 \\
\hline - 1-day average & 690,000 \\
\hline - 30-day average & 607,000 \\
\hline - Annual average & 160,000 \\
\hline \multicolumn{2}{|l|}{ Minimum discharge (cfs) } \\
\hline - Instantaneous & 4,120 \\
\hline - 1-day average & 20,000 \\
\hline - 30-day average & 20,400 \\
\hline - Annual average & 78,000 \\
\hline
\end{tabular}

(a) USGS (1979).

(b) Hutchinson (1981). 
TABLE 5.6. Summary of Historical Flow Data (1929-1968) for the Columbia River at Priest Rapids Dam Adjusted to the 1980 Level of Irrigation Depletion and Dam Regulation (in cfs)

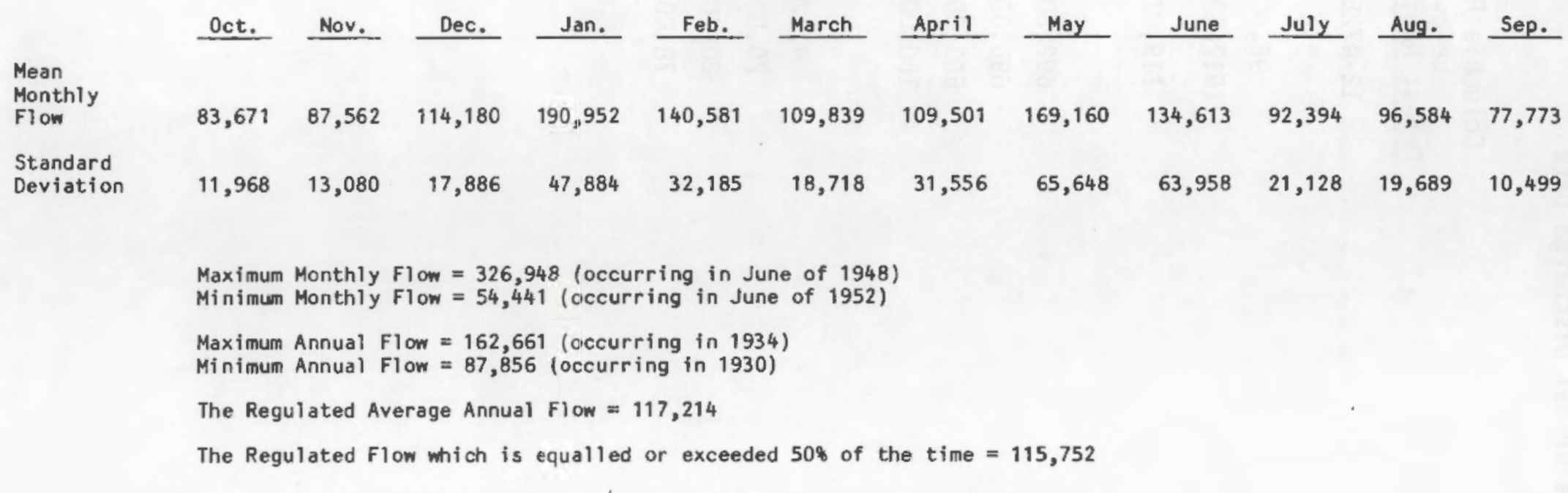

Source: Walters (1981) 


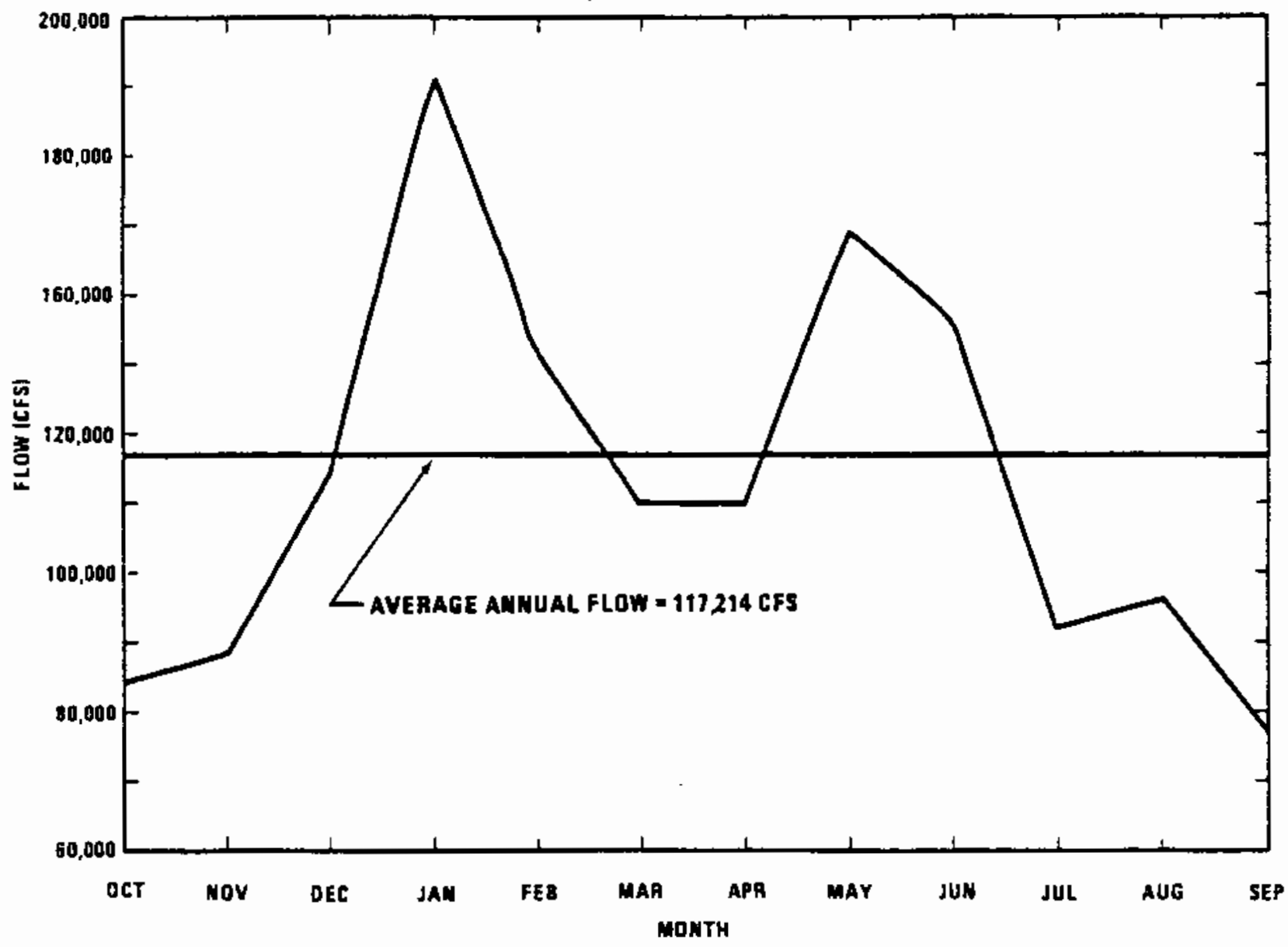

FIGURE 5.4. Adjusted Average Monthly Flow Below Prist Rapids Dam Source: PSP\&L (1982) 


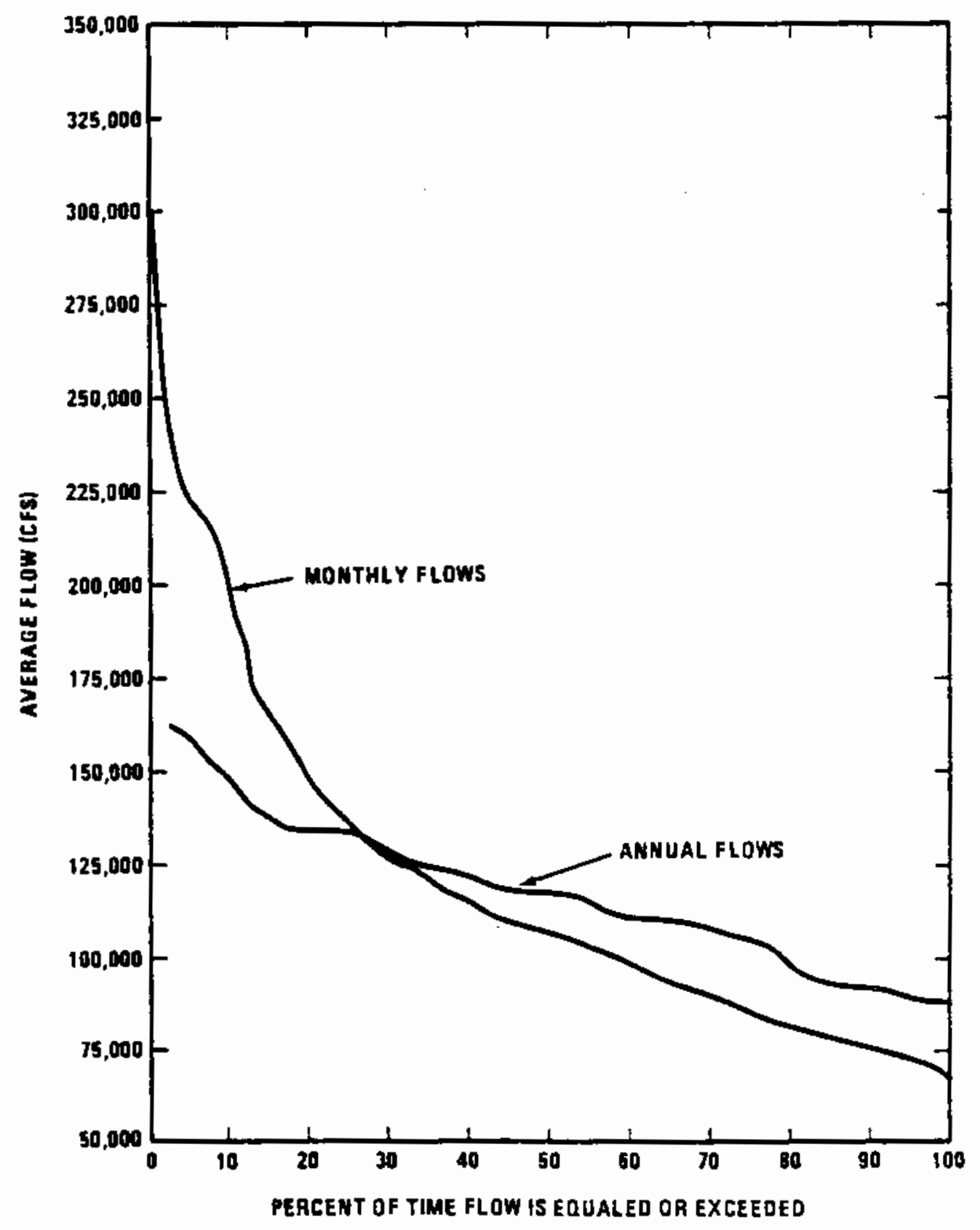

FIGURE 5.5. Adjusted Monthly and Annual Flow Duration Below Priest Rapids Dam 


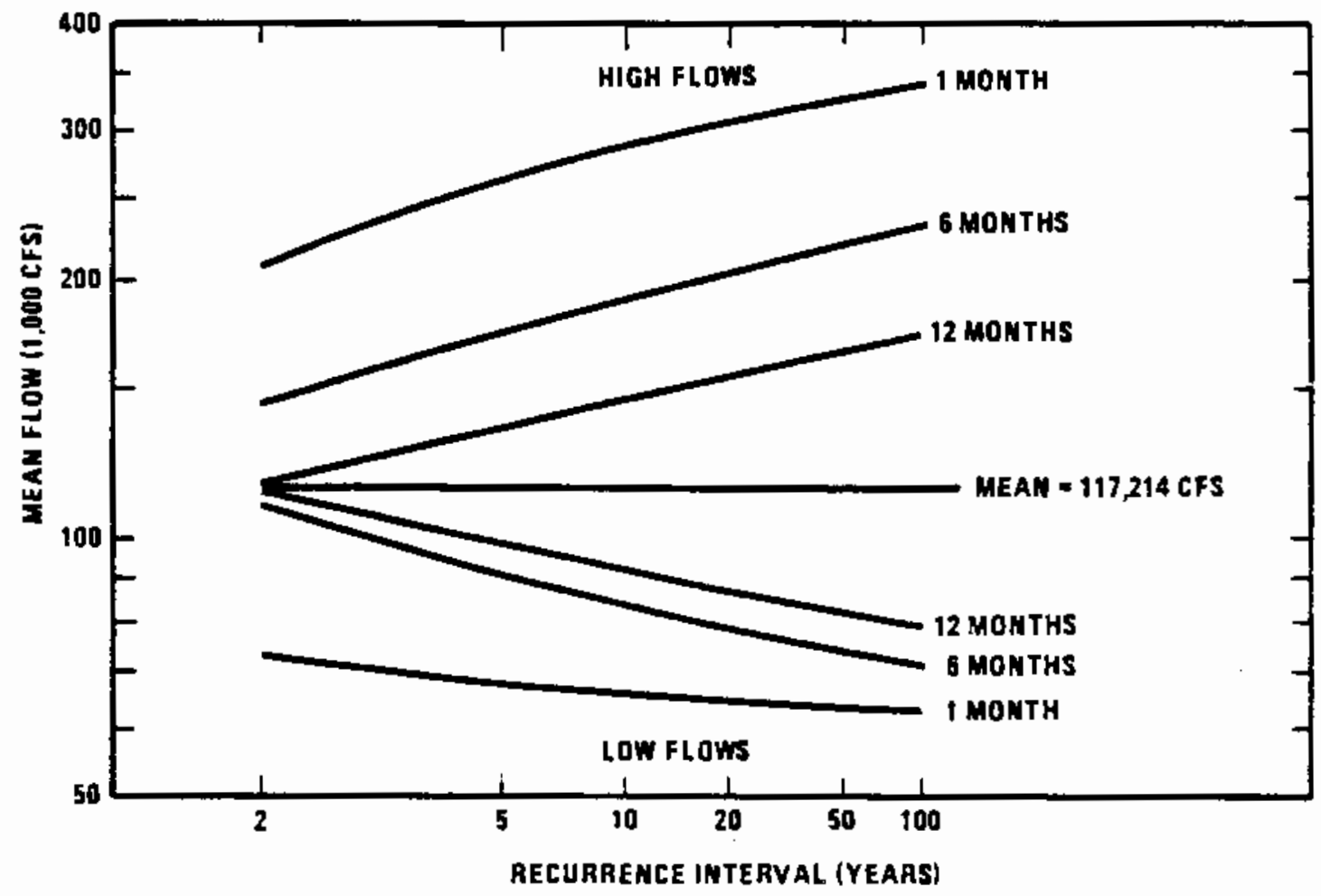

FIGURE 5.6. Flow Frequency Below Priest Rapids Dam 
TABLE 5.7. Dependable Yield for Columbia River Below Priest Rapids Dam (1980 Conditions)

\begin{tabular}{|c|c|c|}
\hline $\begin{array}{c}\text { Consecutive } \\
\text { Years } \\
\end{array}$ & $\begin{array}{c}\text { Lowest } \\
\text { Average Flow } \\
\text { (cfs) }\end{array}$ & $\begin{array}{c}\text { Percent of } \\
1929-1969 \\
\text { Average } \\
\end{array}$ \\
\hline 1 & 87856 & 75.0 \\
\hline 2 & 89647 & 76.5 \\
\hline 3 & 90531 & 77.2 \\
\hline 4 & 94201 & 80.4 \\
\hline 5 & 96018 & 81.9 \\
\hline 6 & 97474 & 83.2 \\
\hline 7 & 98064 & 83.7 \\
\hline 8 & 99361 & 84.8 \\
\hline 9 & 98256 & 83.8 \\
\hline 10 & 99122 & 84.6 \\
\hline 11 & 100052 & 85.4 \\
\hline 12 & 101291 & 86.4 \\
\hline 13 & 102978 & 87.9 \\
\hline 14 & 104512 & 89.2 \\
\hline 15 & 105261 & 89.8 \\
\hline 16 & 104395 & 89.1 \\
\hline 17 & 103684 & 88.5 \\
\hline 18 & 104308 & 89.0 \\
\hline 19 & 105303 & 89.8 \\
\hline 20 & 107464 & 91.7 \\
\hline 21 & 107835 & 92.0 \\
\hline 22 & 108637 & 92.7 \\
\hline 23 & 110537 & 94.3 \\
\hline 24 & 111181 & 94.9 \\
\hline 25 & 111147 & 94.8 \\
\hline 26 & 112038 & 95.6 \\
\hline 27 & 112825 & 96.3 \\
\hline 28 & 114490 & 97.7 \\
\hline 29 & 114851 & 98.0 \\
\hline 30 & 114744 & 97.9 \\
\hline 31 & 115288 & 98.4 \\
\hline 32 & 116010 & 99.0 \\
\hline 33 & 116739 & 99.6 \\
\hline 34 & 116334 & 99.2 \\
\hline 35 & 116182 & 99.1 \\
\hline 36 & 116251 & 99.2 \\
\hline 37 & 116733 & 99.6 \\
\hline 38 & 116709 & 99.6 \\
\hline 39 & 117158 & 100.0 \\
\hline 40 & 117214 & 100.0 \\
\hline
\end{tabular}

Source: Walters (1981) 
TABLE 5.8. Low Flow Data for Columbia River Below Priest Rapids Dam (USGS Station No. 12472800 at River MiTe 394.5)

\begin{tabular}{|c|c|c|}
\hline $\begin{array}{l}\text { Water } \\
\text { Year } \\
\end{array}$ & $\begin{array}{c}\text { Minimum Average } \\
\text { Daily Flow } \\
\text { (cfs) }\end{array}$ & $\begin{array}{c}\text { Minimum } \\
\text { Instantaneous Flow } \\
\text { (cfs) }\end{array}$ \\
\hline 1979 & 50,500 & 34,800 \\
\hline 1978 & 39,000 & 28,300 \\
\hline 1977 & 38,400 & 35,500 \\
\hline 1976 & 39,300 & 32,100 \\
\hline 1975 & 43,500 & 38,300 \\
\hline 1974 & 37,800 & 36,400 \\
\hline 1973 & 38,000 & 35,800 \\
\hline 1972 & 45,900 & 36,100 \\
\hline 1971 & 37,100 & 34,800 \\
\hline 1970 & 38,400 & 36,100 \\
\hline 1969 & 38,500 & 36,100 \\
\hline 1968 & 38,200 & 35,600 \\
\hline 1967 & 38,000 & 36,000 \\
\hline 1966 & 37,600 & 36,300 \\
\hline 1965 & 38,100 & 34,800 \\
\hline 1964 & 38,700 & 36,900 \\
\hline 1963 & 51,100 & 37,300 \\
\hline 1962 & 36,400 & 35,300 \\
\hline 1961 & 44,100 & 37,200 \\
\hline 1960 & 52,100 & 40,100 \\
\hline
\end{tabular}

Source: USGS (1979) 
minimum average daily and minimum instantaneous flows at the USGS gaging station below Priest Rapids Dam from 1960 through 1979 (USGS 1979). The minimum average daily flow has exceeded 36,000 cfs since 1960; however, the minimum instantaneous flow of less than $36,000 \mathrm{cfs}$ has occurred in 9 of the 20 years (1960-1979) (USGS 1979). Low flow recurrence intervals for a 20-year period of record (1960-1979) are given in Table 5.9. The 7-day, 10-year low flow based on data collected since Priest Rapids Dam became operational is $47,899 \mathrm{cfs}$.

TABLE 5.9. Low Flow Recurrence Intervals for the Columbia
River Below Priest Rapids Dam

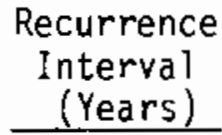

(a) Determined by a Log Pearson Type III Analysis.
Lowest Mean Flow in cfs for the Following Number of Consecutive Days In Year Ending on March 31

\begin{tabular}{lll}
\hline 1-Day & $\underline{7-\text { Day }}$ & $\frac{30-\text { Day }}{70136}$ \\
41993 & 61788 & 60604 \\
38006 & 53012 & 55018 \\
35576 & 47899 & 50144 \\
33392 & 43458 &
\end{tabular}

\subsubsection{Columbia River Floods}

Most major Columbia River floods result from melting of the winter snowpack during late spring and early summer. Localized rainfall can augment the snowmelt runoff but is not the dominant flood factor. Snowmelt floods rise gradually to a peak, and high flows last for a considerable time. Warm winter rainstorms covering a large area can cause flooding at lower elevations. Such floods are relatively rare, but are compounded by snowmelt, frozen ground and ice in streams. Convective storms can also cause floods. These storms are generally Tocalized, but can be accompanied by intense rainfall of short 
duration. Peak discharges from these convective storms may result in extensive local flooding, but have little effect on major streams (PNRBC 1971).

The largest known flood on the Columbia River occurred on June 7, 1894, with an estimated maximum discharge of 740,000 cfs below Priest Rapids Dam (USGS 1979). The flood resulted from the rapid melting of an abnormally large snowpack. The second largest flood occurred on June 12, 1948. It also resulted from snowmelt and produced a peak discharge of 692,600 cfs below Priest Rapids Dam. Other floods include those of June 6, 1956 (533,900 cfs), June 9,1961 (547,400 cfs), and June $24,1924(525,300 \mathrm{cfs})$.

Flood frequency curves for the Columbia River at Trinidad are shown in Figure 5.7. Trinidad is located about 46.5 miles upstream of Priest Rapids Dam, but is considered to be applicable to Priest Rapids Dam because no major tributary inflows occur between these two locations. The curves show unregulated flow conditions and flows regulated by dams as of 1975 with estimated 1985 level of depletion (Merkle 1979). Water surface elevation-discharge curve for the Columbia River at the 0ld Hanford Townsite (RM 361.5) is shown in Figure 5.8 (Walters 1981). The flood of June 7, 1894, would have resulted in a water surface elevation of $388 \mathrm{ft}$ MSL at RM 361.5 .

\subsubsection{Columbia River Erosion and Sedimentation}

The drainage basin of the Columbia River contains a wide variety of igneous, metamorphic and sedimentary rocks, and unconsolidated surficial deposits. Sediment derived from this diverse geologic and physiographic region is transported to the Pacific Ocean (Whetten et al. 1979). Sediments obtained from Grand Coulee, Rocky Reach, Wanapum, and Priest Rapids reservoirs are largely fine-grained nonvolcanic sediments that are carried in suspension. Many of the sediments are probably eroded from surficial deposits, which are primarily of giacial and eolian origin. The sediments in three lower Columbia River reservoirs and from Bonnevilie to the mouth are coarse and of andesitic volcanic origin. Erosion tends to be rapid because, for the most part, the andesitic formations are poorly consolidated and the local reljef is quite high (Whetten et a1. 1979). 


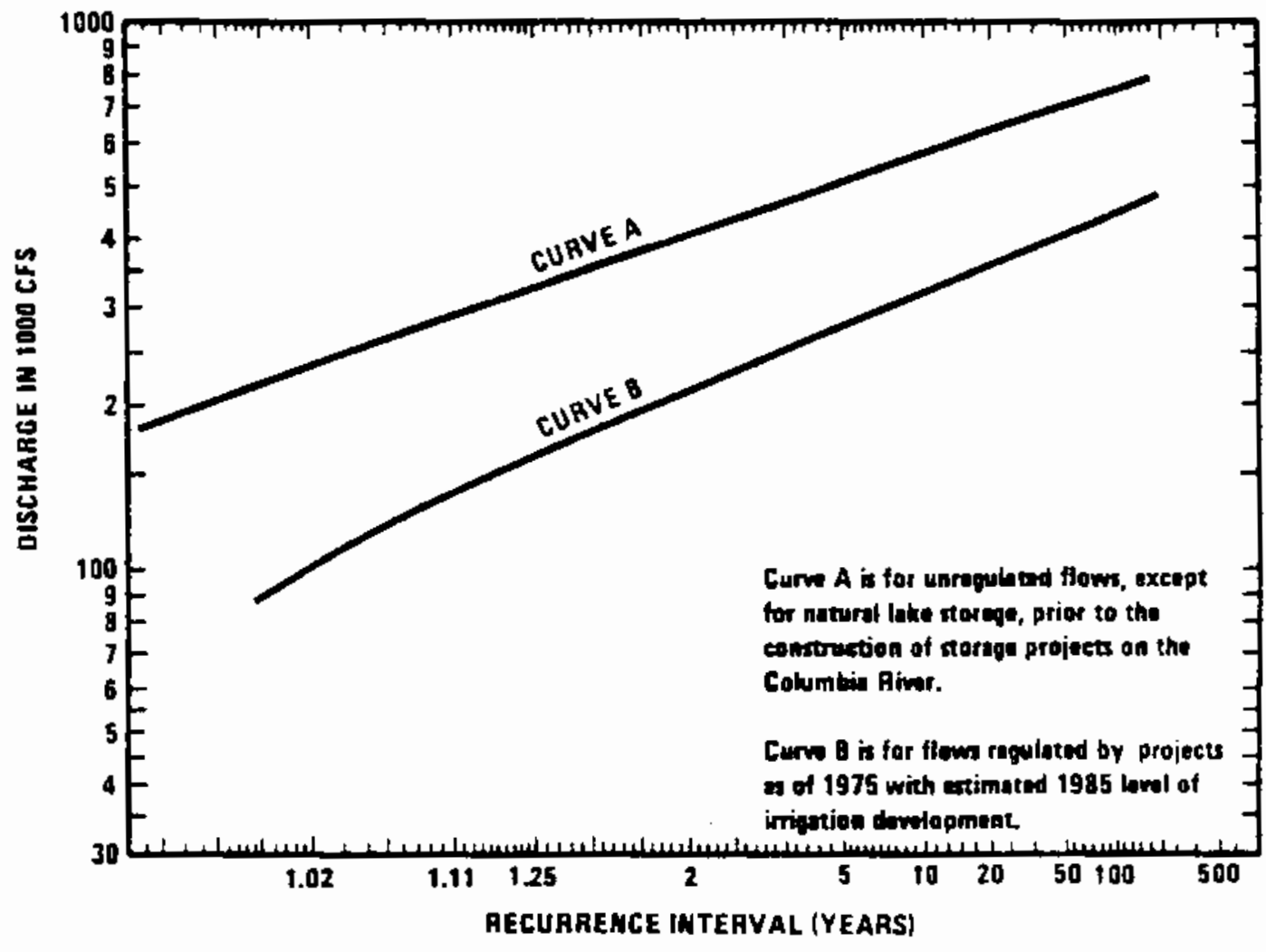

FIGURE 5.7. Flood Frequency Curves for the Columbia River at Irinidad (Annual Peaks)

Source: PSP\&L (1982) 


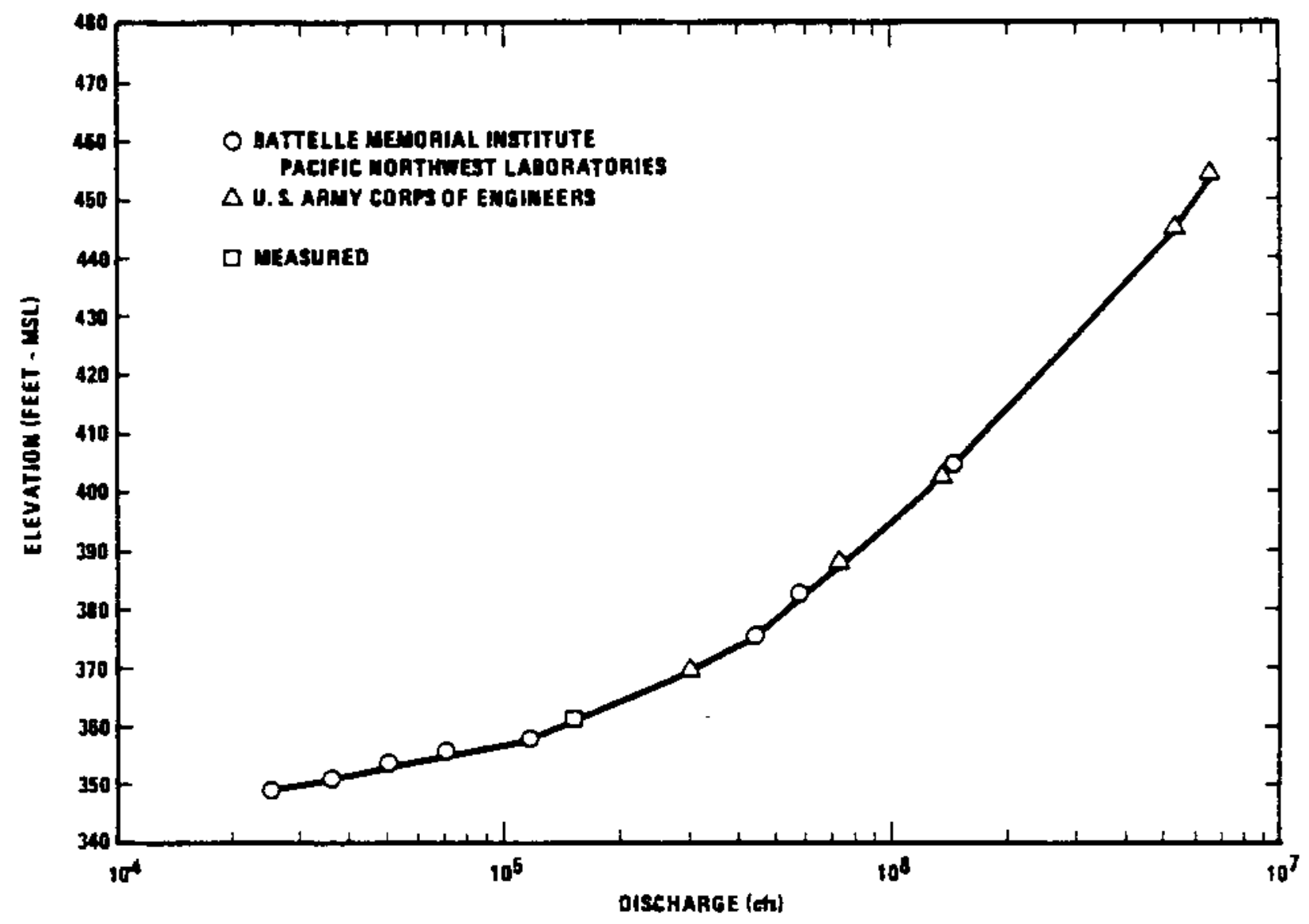

FIGURE 5.8. Water Elevation in Columbia River at River Mile 361.5 Source: PSP\&L (1982) 
Concentrations of suspended sediment carried by the Columbia River vary considerably throughout the year because of the seasonal contribution by tributaries. In a given period, the great bulk of the sediment may be transported during a few days or weeks of unusally high discharge related to flooding. During the floods on the lower Columbia in December 1964, the maximum suspended-sediment concentrations of most rivers in the basin were approximately 10 times higher than peak concentrations of an average year. Sediment discharges for the flood period were generally several times greater than for the entire 1963 water year, the previous year of maximum recorded sediment discharge. Dams along the Columbia and Snake Rivers normally interrupt the transport of suspended sediment as well as the bedload during the slack water. During high water the sediment is resuspended. Thus, most of the suspended sediment is discharged to the Pacific Ocean during the late spring and early summer at the time of maximum water discharge (Whetten et al. 1979).

Except in the lower reaches from Bonneville Dam to the mouth, little sediment has accumulated on the bed of the Columbia River. Some sediment is present in Bonneville and Grand Coulee Reservoirs (and seasonally in other reservoirs), but the bed in most stretches of the river between reservoirs has been either scoured to bedrock or covered with a thin deposit of coarse gravel. In the reservoirs, much of the sand-size and finer sediment deposited during the low- to medium-discharge period from August through April is flushed through the dams during high discharges. Bedload sediment transport is appreciable onty in the lower Columbia, and the amount of sediment transported is probably $5 \mathrm{ma} 11$, perhaps on the order of 10 percent of the total sediment load exclusive of dissolved materials. This estimate is based on the small amount of sediment transported on the bed of Bonneville Reservoir as calculated from rates of sand wave movement. Sediment transported as bedioad is estimated at less than 1 million tons per year. In 1914, Van Winkle estimated that 7 million tons of suspended matter were transported past Cascade Locks (Bonneville) in 1910-1911. In 1966, Hidaka et al. stated that the Columbia River transported 8 million tons of suspended sediment past Vancouver, Washington, near the mouth of the Willamette River in 1962-1963 (Whetten et al. 1979). 
Table 5.10 gives particle-size data for eight of the reservoirs of the Columbia River, based on 152 samples from near the center of the channel. Table 5.1I shows the mineral composition of the sediment while Table 5.12 shows the chemical composition (Stottlemyre 1972).

Results from cation-exchange-capacity (CEC) determinations on sized sediments from the Columbia River and major tributaries are shown in Table 5.13 (Glenn et al. 1973). A comparison of these data with data for streams throughout the continental United States indicates that sediments from the Columbia River and major tributaries have CEC values that generally are comparable to CEC values for other stream sediments in western and midwestern areas (Glenn et al. 1973). The CEC values provide a measure of the capacity of the sediments to adsorb positively charged species in the water, including various radionuclides.

\subsubsection{Local Site Watershed Characteristics}

The Skagit/Hanford Site is located within a small watershed (1200 acres) that lies in a small drainage basin on the Hanford Reservation. The watershed and drainage basin boundaries are shown in figure 5.9. The drainage basin contains the WPPSS Nuclear Projects No. I, 2 and 4 . The upper boundary of the watershed lies on the divide that separates the Yakima River and Columbia River basins. The watershed ranges in elevation from about 516 feet to 530 feet MSL. There are no perennial streams in or near the watershed. The reference site is fairly level with many shallow depressions and low ridges (Figure 5.10).

There are no we11-defined drainage channels within the reference site watershed. General drainage patterns within the watershed and drainage bas in are shown in Figure 5.11.

\subsubsection{Columbia River Water Quality}

Water quality for the Hanford Reach of the Columbia River is very good. The state of Washington has designated the Hanford Reach as Class A, which means the water is suitable for all uses including drinking water, recreation, and wildlife. State water quality standards are given in Table 5.14, and recent measurements of water quality parameters are shown in Table 5.15. 
TABLE 5.10. Particle-Size Distribution of Undispersed and Dispersed Sediments From Columbia River Size Classes

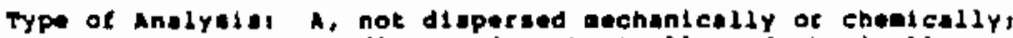

B. dispereed acchanically and cheaically

\{91ze lielte and range in miecons\}

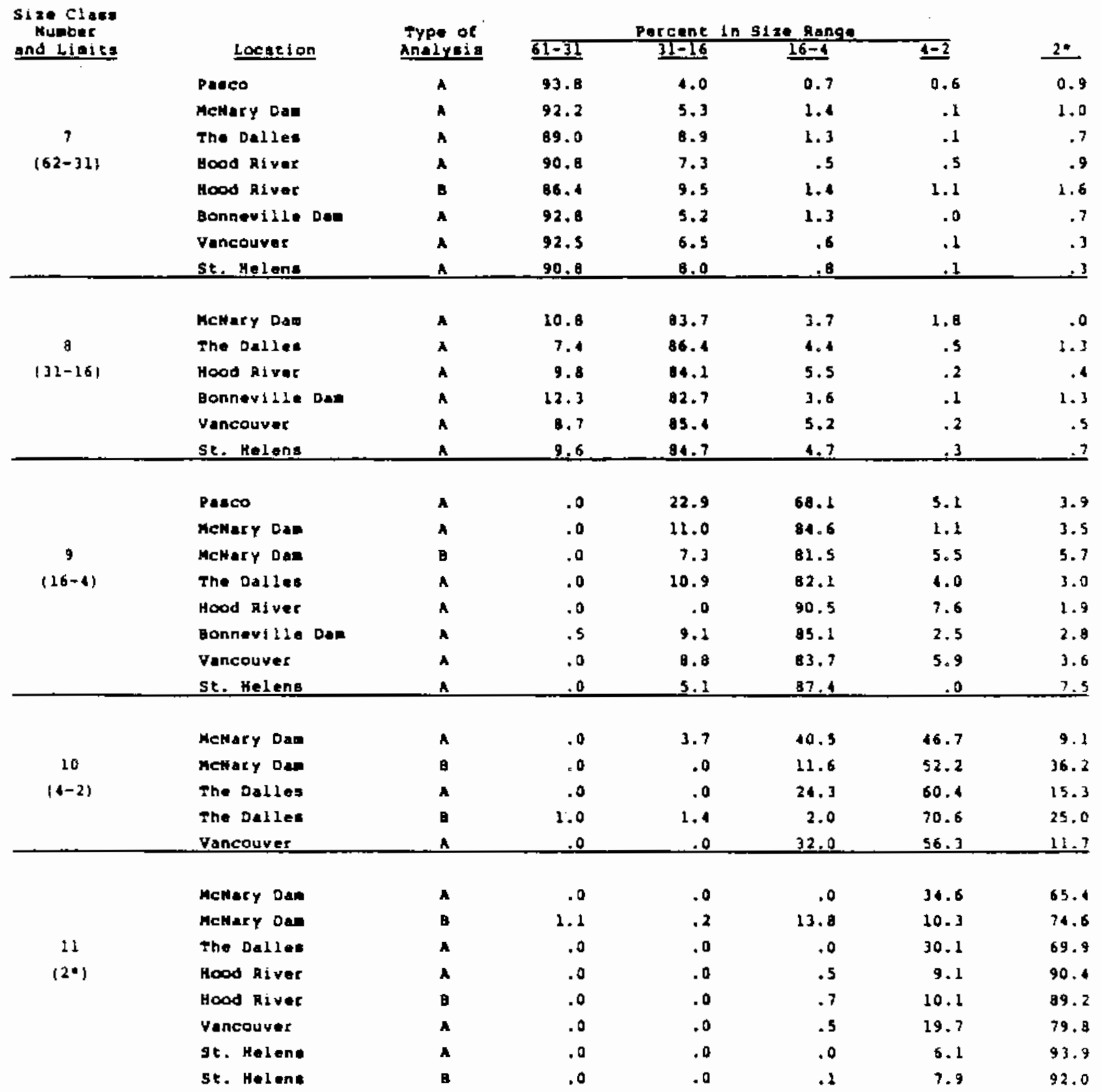

Leas than.

Source: StottTenyre (1972) 
TABLE 5.11 Mineral Composition of Bottom Sediments From Columbia River Reservoirs

Bulk-minesel Composition (in ") ot Botton bediments trom Columbie River Reservoirs

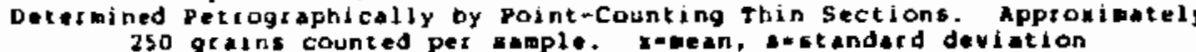

\begin{tabular}{|c|c|c|c|c|c|c|c|c|c|c|c|c|}
\hline \multirow[b]{2}{*}{ Constituent } & \multicolumn{2}{|c|}{ Donneville } & \multicolumn{2}{|c|}{ The Dolles } & \multicolumn{2}{|c|}{ MCNAIY } & \multicolumn{2}{|c|}{$\begin{array}{l}\text { Priest Rapids - } \\
\text { Wanapui - } \\
\text { Rocky Reach }\end{array}$} & \multicolumn{2}{|c|}{$\begin{array}{l}\text { Grand } \\
\text { Coulee }\end{array}$} & \multicolumn{2}{|c|}{ Ice Harthor (c) } \\
\hline & $\underline{x}$ & $\overline{5}$ & $\underline{\underline{\mathbf{x}}}$ & $\underline{E}$ & $\underline{\underline{x}}$ & $\underline{E}$ & $\underline{\underline{\mathbf{I}}}$ & 5 & $\underline{\mathbf{x}}$ & \pm & $\underline{3}$ & 6 \\
\hline $\begin{array}{l}\text { Ouartz } \\
\text { Plagioclace } \\
\text { x-feldspar } \\
\text { Lithic Fragments } \\
\text { Opaque minerals } \\
\text { Matic mineralolal }\end{array}$ & $\begin{array}{l}29 \\
18 \\
10 \\
35 \\
4 \\
5\end{array}$ & $\begin{array}{r}9.0 \\
5.2 \\
4.3 \\
12.5 \\
4.5 \\
3.2\end{array}$ & $\begin{array}{r}29 \\
17 \\
13 \\
32 \\
5 \\
4\end{array}$ & $\begin{array}{r}9.3 \\
5.9 \\
6.6 \\
20.4 \\
2.9 \\
3.1\end{array}$ & $\begin{array}{r}34 \\
15 \\
12 \\
29 \\
4 \\
6\end{array}$ & $\begin{array}{r}9.0 \\
6.0 \\
5.1 \\
11.9 \\
3.2 \\
5.3\end{array}$ & $\begin{array}{l}41 \\
12 \\
11 \\
21 \\
13 \\
2\end{array}$ & $\begin{array}{r}6.5 \\
3.5 \\
2.7 \\
10.9 \\
5.3 \\
1.7\end{array}$ & $\begin{array}{r}37 \\
5 \\
12 \\
28 \\
15 \\
3\end{array}$ & $\begin{array}{r}10.4 \\
0.6 \\
9.9 \\
9.3 \\
2.7 \\
1.7\end{array}$ & $\begin{array}{r}45 \\
8 \\
11 \\
16 \\
3 \\
18\end{array}$ & $\begin{array}{l}5.2 \\
4.1 \\
3.9 \\
2.5 \\
1.5 \\
5.0\end{array}$ \\
\hline MUEEET of nopples & & & & & & & & & & & & \\
\hline
\end{tabular}

(a) Largely ot thopyroxene fhypersthenel, clinopyroxene (augite), hornblende, and biotite.

Heavy-minezal (SG Greater than 3.17) Compotition (in ) of Botton Sediments from Colusbia River Rerervalss Determined Petrographically by Point-Counting Grain Mounts in Hyrax $(n=1.67)$.

\begin{tabular}{|c|c|c|c|c|c|c|c|c|c|c|c|c|}
\hline \multirow[b]{2}{*}{ Constisuent } & \multicolumn{2}{|c|}{ Bonneville } & \multicolumn{2}{|c|}{ The DHIes } & \multicolumn{2}{|c|}{ Mcthary } & \multicolumn{2}{|c|}{$\begin{array}{c}\text { Priest Raplda - } \\
\text { Hanopul - } \\
\text { Rocky Beach }\end{array}$} & \multicolumn{2}{|c|}{$\begin{array}{l}\text { Grand } \\
\text { Coules }\end{array}$} & \multicolumn{2}{|c|}{ Ice Harbor (c) } \\
\hline & $\underline{x}$ & 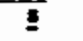 & $\underline{\underline{x}}$ & 3 & $\underline{\underline{x}}$ & $\leqslant$ & I & 3 & I & \pm & $\underline{I}$ & $\underline{\mathbf{s}}$ \\
\hline $\begin{array}{l}\text { Orthopyrorene }(\theta) \\
\text { CJinopyroxene }\{(b) \\
\text { Bornbiende } \\
\text { Epidote } \\
\text { Garnet } \\
\text { sphene } \\
\text { Ifrcon } \\
\text { opatite } \\
\text { other }\end{array}$ & $\begin{array}{r}27 \\
38 \\
22 \\
2 \\
6 \\
1 \\
1 \\
1\end{array}$ & $\begin{array}{r}10.0 \\
9.1 \\
11.9 \\
2.9 \\
5.2 \\
1.0 \\
1.3 \\
0.8\end{array}$ & $\begin{array}{r}10 \\
47 \\
32 \\
1 \\
6 \\
2 \\
1 \\
1 \\
\operatorname{tr}\end{array}$ & $\begin{array}{l}7.3 \\
9.8 \\
9.9 \\
0.8 \\
3.3 \\
1.0 \\
1.0 \\
0.0\end{array}$ & $\begin{array}{r}6 \\
30 \\
41 \\
2 \\
9 \\
3 \\
4 \\
1 \\
t 5\end{array}$ & $\begin{array}{r}3.2 \\
7.7 \\
10.0 \\
1.8 \\
6.8 \\
1.1 \\
4.5 \\
1.0\end{array}$ & $\begin{array}{r}5 \\
30 \\
58 \\
3 \\
7 \\
5 \\
2 \\
1 \\
7\end{array}$ & $\begin{array}{r}2.1 \\
10.1 \\
13.1 \\
3.1 \\
4.5 \\
1.9 \\
1.5 \\
0.7\end{array}$ & $\begin{array}{r}5 \\
14 \\
57 \\
3 \\
9 \\
9 \\
3 \\
0\end{array}$ & $\begin{array}{l}3.5 \\
3.5 \\
3.6 \\
1.7 \\
7.0 \\
3.4 \\
1.3 \\
--\end{array}$ & $\begin{array}{r}2 \\
12 \\
72 \\
1 \\
4 \\
5 \\
3 \\
1\end{array}$ & $\begin{array}{l}1.5 \\
6.0 \\
7.8 \\
1.1 \\
2.0 \\
2.3 \\
1.7 \\
0.3\end{array}$ \\
\hline other & $\mathbf{t r}$ & & tr & & tr & & tr & & tr & & cr & \\
\hline
\end{tabular}

(a) carge hyperothene.

(c) Reservoir on sinate diver.

Source: Stottlemyre (1972) 
TABLE 5.12 Chemical Composition in Bottom Sediments From Columbia River Reservoirs

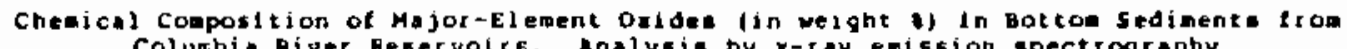

inno and TiOz by optical emission spectrography). xumean, satandard deviation

\begin{tabular}{|c|c|c|c|c|c|c|c|c|c|c|c|c|}
\hline \multirow[b]{2}{*}{ Const i tuent } & \multicolumn{2}{|c|}{ Bonnevilile } & \multicolumn{2}{|c|}{ The Dalles } & \multicolumn{2}{|c|}{ MeNary } & \multicolumn{2}{|c|}{$\begin{array}{l}\text { Priest Rapids - } \\
\text { Uanapus-- } \\
\text { rocky Resch }\end{array}$} & \multicolumn{2}{|c|}{$\begin{array}{l}\text { Grand } \\
\text { Coutes }\end{array}$} & \multicolumn{2}{|c|}{ Ice Baxbat" } \\
\hline & $\underline{\underline{z}}$ & $\underline{E}$ & 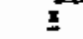 & $\underline{E}$ & 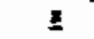 & 5 & $\underline{z}$ & 5 & $\underline{\underline{x}}$ & $E$ & $\underline{x}$ & 5 \\
\hline \multirow{3}{*}{ 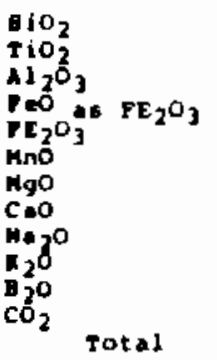 } & $\begin{array}{r}68.5 \\
0.0 \\
13.3\end{array}$ & $\begin{array}{l}4.3 \\
0.2 \\
1.1\end{array}$ & $\begin{array}{r}65.2 \\
0.8 \\
14.1\end{array}$ & $\begin{array}{l}3.1 \\
0.1 \\
1.4\end{array}$ & $\begin{array}{r}67.6 \\
0.8 \\
13.6\end{array}$ & $\begin{array}{l}4.8 \\
0.2 \\
0.8\end{array}$ & $\begin{array}{r}66.2 \\
0.7 \\
14.4\end{array}$ & $\begin{array}{l}3.3 \\
0.2 \\
0.0\end{array}$ & $\begin{array}{r}58.4 \\
0.0 \\
17.0\end{array}$ & $\begin{array}{l}2.9 \\
0.1 \\
1.9\end{array}$ & $\begin{array}{r}62.3 \\
1.1 \\
14.9\end{array}$ & $\begin{array}{l}2.0 \\
0.1 \\
1.1\end{array}$ \\
\hline & 5.1 & 2.3 & 5.7 & 0.9 & 4.0 & 1.3 & 3.3 & 0.0 & 5.1 & 0.6 & 4.6 & 0.7 \\
\hline & $\begin{array}{r}0.1 \\
2.1 \\
3.2 \\
3.0 \\
2.1 \\
\text { nd } \\
\text { nd } \\
98.2\end{array}$ & $\begin{array}{l}0.0 \\
0.5 \\
1.0 \\
0.2 \\
0.3\end{array}$ & $\begin{array}{r}0.1 \\
2.1 \\
3.7 \\
2.7 \\
2.0 \\
\text { nd } \\
\text { nd }\end{array}$ & $\begin{array}{l}0.0 \\
0.2 \\
0.5 \\
0.3 \\
0.2\end{array}$ & $\begin{array}{r}0.1 \\
1.8 \\
3.2 \\
2.0 \\
2.2 \\
\text { nd } \\
96.9\end{array}$ & $\begin{array}{l}0.0 \\
0.1 \\
1.0 \\
0.3 \\
0.2\end{array}$ & $\begin{array}{r}0.1 \\
2.1 \\
3.5 \\
3.5 \\
2.1 \\
\text { nd } \\
\text { nd } \\
95.9\end{array}$ & $\begin{array}{l}0.0 \\
0.1 \\
0.3 \\
0.3 \\
0.1\end{array}$ & $\begin{array}{r}0.2 \\
2.6 \\
2.6 \\
2.5 \\
3.1 \\
\text { nd } \\
\text { nd } \\
82.3\end{array}$ & $\begin{array}{l}0.1 \\
0.5 \\
0.3 \\
0.2 \\
0.3\end{array}$ & $\begin{array}{r}0.3 \\
2.1 \\
3.7 \\
2.9 \\
2.3 \\
\text { nd } \\
\text { nd } \\
94.2\end{array}$ & $\begin{array}{l}0.1 \\
0.2 \\
0.9 \\
0.2 \\
0.3\end{array}$ \\
\hline
\end{tabular}

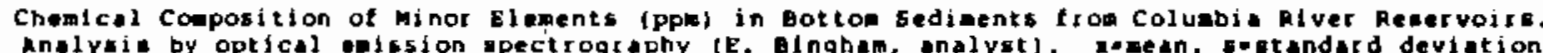

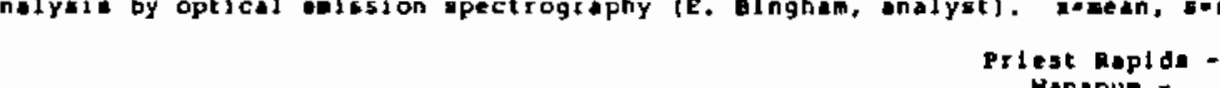

\begin{tabular}{|c|c|c|c|c|c|c|c|c|c|c|c|c|}
\hline \multirow[b]{2}{*}{ Const ituent } & \multicolumn{2}{|c|}{ Bonney 111e } & \multicolumn{2}{|c|}{ The Dalles } & \multicolumn{2}{|c|}{ McHary } & \multicolumn{2}{|c|}{$\begin{array}{l}\text { Manapur - } \\
\text { Rocky React }\end{array}$} & \multicolumn{2}{|c|}{$\begin{array}{l}\text { Grand } \\
\text { Coulce }\end{array}$} & \multicolumn{2}{|c|}{ Ice Herbor ${ }^{\circ}$} \\
\hline & $\underline{\underline{x}}$ & $\underline{5}$ & $\underline{\underline{x}}$ & $\underline{\mathbf{s}}$ & $\underline{I}$ & 5 & $\underline{\underline{z}}$ & $\underline{2}$ & $\underline{\underline{x}}$ & $\underline{1}$ & $\underline{x}$ & 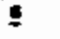 \\
\hline $\begin{array}{l}8 \\
8 . \\
C 0 \\
C r \\
C u \\
\text { Ca } \\
41 \\
\text { Pb } \\
5 c \\
5 r \\
8 \\
8 \\
2 r\end{array}$ & $\begin{array}{r}20 \\
+720 \\
10 \\
50 \\
20 \\
20 \\
30 \\
20 \\
20 \\
430 \\
90 \\
10 \\
150\end{array}$ & $\begin{array}{l}50^{\circ} \\
130 \\
10^{\circ} \\
10 \\
10 \\
10^{\circ} \\
10^{\circ} \\
10^{\circ} \\
10^{\circ} \\
70^{\circ} \\
10^{\circ}\end{array}$ & $\begin{array}{r}20 \\
1600 \\
10 \\
50 \\
10 \\
20 \\
30 \\
40 \\
20 \\
430 \\
120 \\
50 \\
180\end{array}$ & $\begin{array}{c}10^{\circ} \\
270^{\circ} \\
10^{\circ} \\
10^{\circ} \\
10^{\circ} \\
10^{\circ} \\
10^{\circ} \\
20^{\circ} \\
10^{\circ} \\
10^{\circ} \\
10 \\
10^{\circ}\end{array}$ & $\begin{array}{r}30 \\
1410 \\
10 \\
50 \\
10 \\
20 \\
30 \\
10 \\
20 \\
450 \\
60 \\
50 \\
190\end{array}$ & $\begin{array}{c}10 \\
330 \\
10^{\circ} \\
20 \\
10 \\
10^{\circ} \\
10^{\circ} \\
20^{\circ} \\
10^{\circ} \\
110 \\
50 \\
10 \\
50\end{array}$ & $\begin{array}{r}30 \\
860 \\
10 \\
10 \\
10 \\
20 \\
10 \\
70 \\
20 \\
360 \\
100 \\
50 \\
190\end{array}$ & $\begin{array}{l}10^{\circ} \\
60 \\
10^{\circ} \\
10 \\
10 \\
10^{\circ} \\
10 \\
50^{\circ} \\
10^{\circ} \\
110^{\circ} \\
10 \\
10\end{array}$ & $\begin{array}{r}50 \\
970 \\
20 \\
10 \\
90 \\
20 \\
50 \\
570 \\
20 \\
280 \\
90 \\
120 \\
180\end{array}$ & $\begin{array}{c}10^{\circ} \\
190^{\circ} \\
10^{\circ} \\
10 \\
20 \\
10^{\circ} \\
10^{\circ} \\
170^{\circ} \\
10^{\circ} \\
10^{\circ} \\
20 \\
30\end{array}$ & $\begin{array}{r}30 \\
860 \\
20 \\
30 \\
50 \\
20 \\
30 \\
30 \\
30 \\
300 \\
130 \\
60 \\
280\end{array}$ & $\begin{array}{l}10^{\circ} \\
90^{\circ} \\
100^{\circ} \\
10^{\circ} \\
10 \\
10{ }^{\circ} \\
10^{\circ} \\
10 \\
10^{\circ} \\
30^{\circ} \\
30 \\
10^{\circ} \\
90^{\circ}\end{array}$ \\
\hline
\end{tabular}

Less than.

- Reaervoir on snahe hiver

Source: Stottiemyre (1972) 
TABLE 5.13. Cation-Exchange Capacities (in Milliequivalent per 100 Grams) of Sized Sediments From Columbia River and Tributary Locations

Type of ampla:

1. Bulk sapple as recelved tor analysis. CEC computed algebraically by combining the rebulte of CEC anolyses on type of aterial tor each type os veighting factors.

2. Bulk sample after material finer than the lower limit of the bize class has been redoved by decantation.

3. Hatertal tiner than the lower $2101 \mathrm{t}$ of the 1 ise class.

4. Bulk sample ofter treatment with cesiun chloride followed by decantation and removal of material finer than the lowed livit of the bize clats.

5. Haterial troo type teaple is finer than lower jiait of saze
class. If type or 5 basples are not ligted for size classes greater than 62 nicrons at location, or lf a dashed line it ahom, no analyses were necessary, that is, no adoitional fines or floating organic mater vere present. Size init (in parentheses) are given in microns.

\begin{tabular}{|c|c|c|c|c|c|c|c|c|c|c|c|c|c|}
\hline \multirow[b]{2}{*}{ Location } & \multicolumn{13}{|c|}{ Size Class and Limits } \\
\hline & $\begin{array}{c}\text { Type } \\
\text { of } \\
\text { Sample }\end{array}$ & $\begin{array}{c}1 \\
(4000- \\
(2000)\end{array}$ & $\begin{array}{c}2 \\
(2000- \\
(1000)\end{array}$ & $\frac{3}{11000-}(500)$ & $\left\{\begin{array}{c}T \\
(500- \\
(250)\end{array}\right.$ & $\begin{array}{l}(250) \\
(125)\end{array}$ & $\begin{array}{l}6 \\
(125- \\
162\}\end{array}$ & $\begin{array}{l}7 \\
(62- \\
(31)\end{array}$ & $\begin{array}{c}8 \\
(31- \\
16)\end{array}$ & (1) & $\begin{array}{l}10 \\
14-\end{array}$ & $(2 *)$ & Total \\
\hline $\begin{array}{c}\text { Columbia River near: } \\
\text { Pasco }\end{array}$ & $\begin{array}{l}1 \\
2 \\
3 \\
1 \\
5\end{array}$ & $\begin{array}{r}3.0 \\
3.0 \\
6.7 \\
2.9 \\
10.2\end{array}$ & $\begin{array}{r}3.2 \\
3.2 \\
6.7 \\
2.9 \\
10.2\end{array}$ & $\begin{array}{r}9.0 \\
9.5 \\
29.3 \\
8.4 \\
26.4\end{array}$ & $\begin{array}{r}2.9 \\
2.0 \\
18.0 \\
2.7 \\
18.0\end{array}$ & $\begin{array}{r}2.8 \\
2.7 \\
18.2 \\
2.6 \\
19.6\end{array}$ & $\begin{array}{r}3.3 \\
2.8 \\
14.9 \\
2.7 \\
5.9\end{array}$ & $\begin{array}{r}3.5 \\
-- \\
-- \\
--\end{array}$ & $\begin{array}{l}9.2 \\
-- \\
-- \\
--\end{array}$ & $\begin{array}{r}18.7 \\
-- \\
-- \\
--\end{array}$ & $\begin{array}{r}22.3 \\
22.6 \\
20.0 \\
- \\
--\end{array}$ & $\begin{array}{r}35.0 \\
=- \\
=- \\
--\end{array}$ & 113.7 \\
\hline Mchary Da & $\begin{array}{l}1 \\
2 \\
3 \\
4 \\
5\end{array}$ & $\begin{array}{r}12.6 \\
8.4 \\
28.3 \\
8.3 \\
14.0\end{array}$ & $\begin{array}{r}0.5 \\
5.5 \\
53.5 \\
5.8 \\
12.3\end{array}$ & $\begin{array}{r}4.1 \\
3.9 \\
50.6 \\
3.9 \\
3.5\end{array}$ & $\begin{array}{r}2.6 \\
2.2 \\
37.5 \\
- \\
=\end{array}$ & $\begin{array}{r}5.0 \\
4.2 \\
32.3 \\
\ldots \\
\ldots\end{array}$ & $\begin{array}{r}9.5 \\
6.3 \\
30.0 \\
-. \\
--\end{array}$ & $\begin{array}{r}5.2 \\
-- \\
\therefore \\
\therefore\end{array}$ & $\begin{array}{c}8.7 \\
-- \\
-\therefore \\
\therefore\end{array}$ & $\begin{array}{c}16.8 \\
\ldots \\
\ldots \\
-2\end{array}$ & $\begin{array}{r}31.7 \\
32.1 \\
28.7 \\
= \\
=\end{array}$ & $\begin{array}{c}14.8 \\
-- \\
- \\
--\end{array}$ & 149.5 \\
\hline The Dalles & $\begin{array}{l}1 \\
2 \\
3\end{array}$ & $\begin{array}{l}\text { (1) } \\
\text { (1) } \\
\text { (1) }\end{array}$ & $\begin{array}{l}\text { (1) } \\
\text { (1) } \\
\text { (1) }\end{array}$ & $\begin{array}{r}23.1 \\
6.7 \\
48.5\end{array}$ & $\begin{array}{r}4.3 \\
3.8 \\
25.9\end{array}$ & $\begin{array}{r}5.3 \\
4.9 \\
34.3\end{array}$ & $\begin{array}{r}9.9 \\
8.2 \\
10.9\end{array}$ & $\begin{array}{l}6.0 \\
-- \\
--\end{array}$ & $\begin{array}{l}9.3 \\
-- \\
--\end{array}$ & $\begin{array}{r}17.6 \\
-- \\
--\end{array}$ & $\begin{array}{l}34.4 \\
34.7 \\
32.5\end{array}$ & $\begin{array}{c}17.0 \\
-- \\
=\end{array}$ & 157.7 \\
\hline Bood River & $\begin{array}{l}1 \\
2 \\
3 \\
4 \\
5\end{array}$ & $\begin{array}{l}13.3 \\
13.2 \\
11.2 \\
12.5 \\
25.6\end{array}$ & $\begin{array}{r}3.5 \\
3.5 \\
10.3 \\
3.2 \\
107.5\end{array}$ & $\begin{array}{r}2.4 \\
2.3 \\
36.0 \\
=- \\
--\end{array}$ & $\begin{array}{r}2.3 \\
2.1 \\
29.5 \\
:- \\
--\end{array}$ & $\begin{array}{r}3.1 \\
2.8 \\
39.6 \\
-. \\
--\end{array}$ & $\begin{array}{r}10.4 \\
8.1 \\
12.3 \\
-- \\
--\end{array}$ & $\begin{array}{l}5.7 \\
-- \\
=- \\
--\end{array}$ & $\begin{array}{l}8.0 \\
-- \\
=- \\
--\end{array}$ & $\begin{array}{c}14.3 \\
=- \\
=- \\
--\end{array}$ & $\begin{array}{r}32.8 \\
\because- \\
- \\
--\end{array}$ & $\begin{array}{r}11.7 \\
10.8 \\
12.3 \\
-2 \\
--\end{array}$ & 137.7 \\
\hline Bpnneville Dar & $\begin{array}{l}1 \\
2 \\
3\end{array}$ & $\begin{array}{l}18.4 \\
14.4 \\
53.0\end{array}$ & $\begin{array}{r}10.2 \\
9.5 \\
39.5\end{array}$ & $\begin{array}{r}3.4 \\
3.3 \\
32.3\end{array}$ & $\begin{array}{r}2.1 \\
2.1 \\
10.4\end{array}$ & $\begin{array}{r}4.2 \\
3.7 \\
22.3\end{array}$ & $\begin{array}{r}9.1 \\
7.5 \\
25.6\end{array}$ & $\begin{array}{r}5.9 \\
\because-\end{array}$ & $\begin{array}{l}9.5 \\
-- \\
--\end{array}$ & $\begin{array}{r}17.2 \\
\because-\end{array}$ & $\begin{array}{l}31.6 \\
32.1 \\
22.8\end{array}$ & $\begin{array}{r}41.0 \\
- \\
=\end{array}$ & 152.6 \\
\hline Vancouver & $\begin{array}{l}1 \\
2 \\
3 \\
1 \\
5\end{array}$ & $\begin{array}{r}2.0 \\
2.0 \\
10.5 \\
1.9 \\
9.0\end{array}$ & $\begin{array}{r}1.6 \\
1.6 \\
20.2 \\
=- \\
\therefore\end{array}$ & $\begin{array}{r}2.4 \\
2.3 \\
21.2 \\
-. \\
+-\end{array}$ & $\begin{array}{r}3.0 \\
2.9 \\
32.0 \\
=- \\
\ldots\end{array}$ & $\begin{array}{r}4.1 \\
3.0 \\
17.0 \\
-2\end{array}$ & $\begin{array}{r}8.1 \\
6.1 \\
36.2 \\
=- \\
-.-\end{array}$ & $\begin{array}{r}5.1 \\
5.0 \\
1.1 \\
=- \\
=-\end{array}$ & $\begin{array}{l}9.3 \\
=- \\
=- \\
=-\end{array}$ & $\begin{array}{c}18.3 \\
-- \\
-- \\
--\end{array}$ & $\begin{array}{r}29.6 \\
30.0 \\
25.3 \\
-7 \\
-\end{array}$ & $\begin{array}{c}12.0 \\
= \\
=- \\
=\end{array}$ & 125.5 \\
\hline
\end{tabular}


TABLE 5.13, (contd)

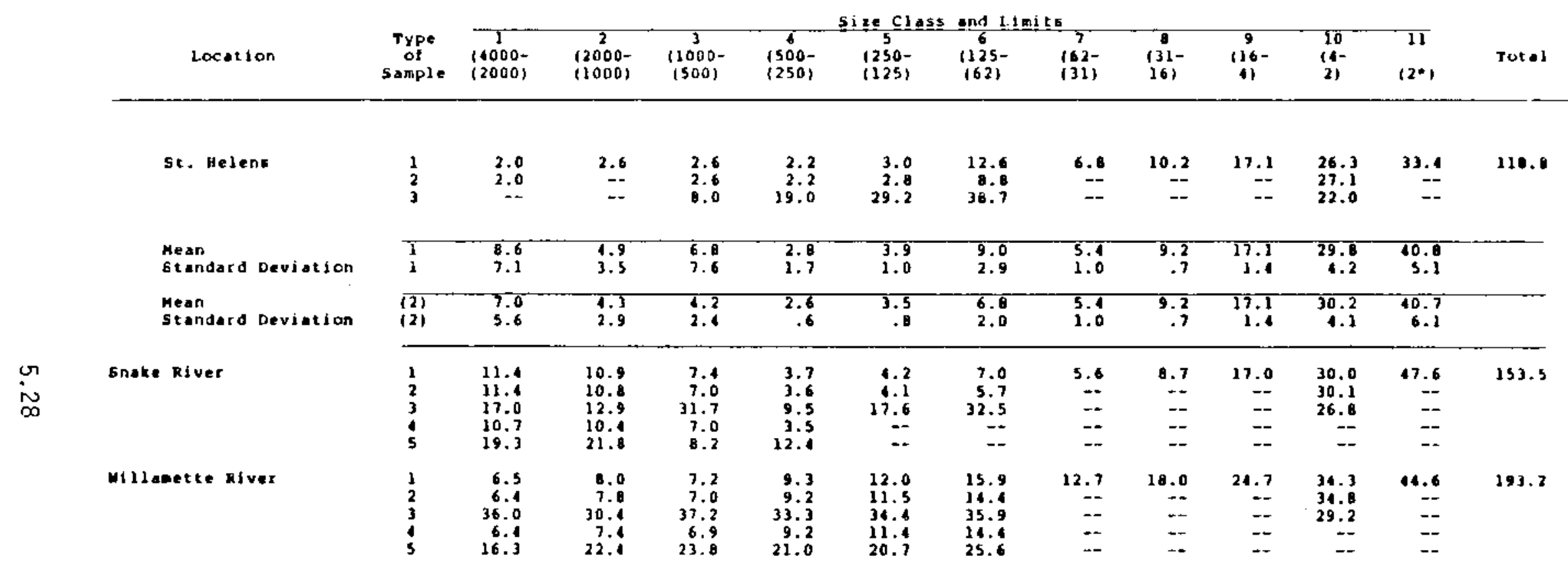

(1) Jnsufficient ateriol for analysia.

(2) Calculated using CRC data tron sample types 1. 2, or 1, In that order of preference.

-Less thart.

Source: Glenn (1973) 

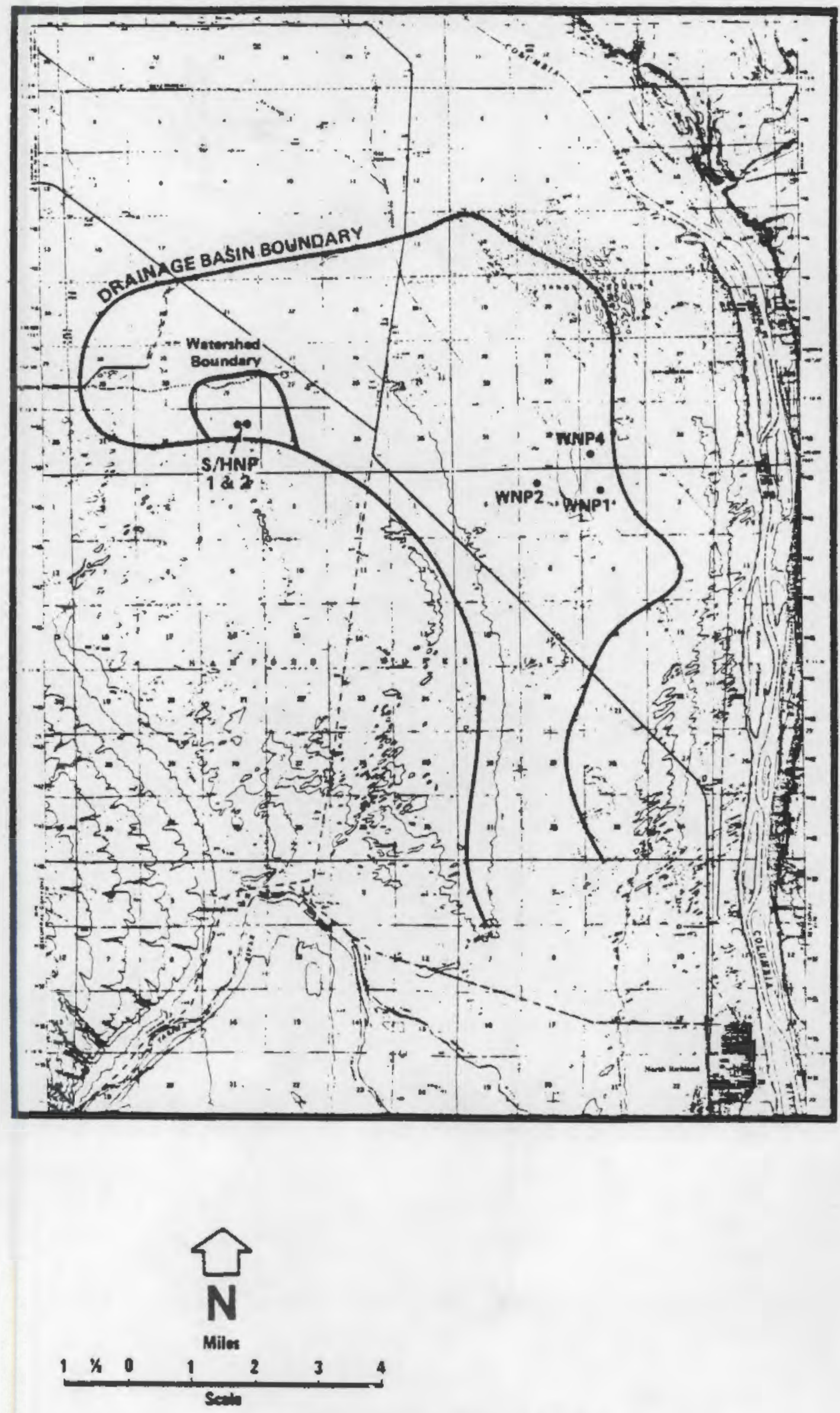

FIGURE 5.9. Local Water Sheds

Source: PSP\&L (1981) 

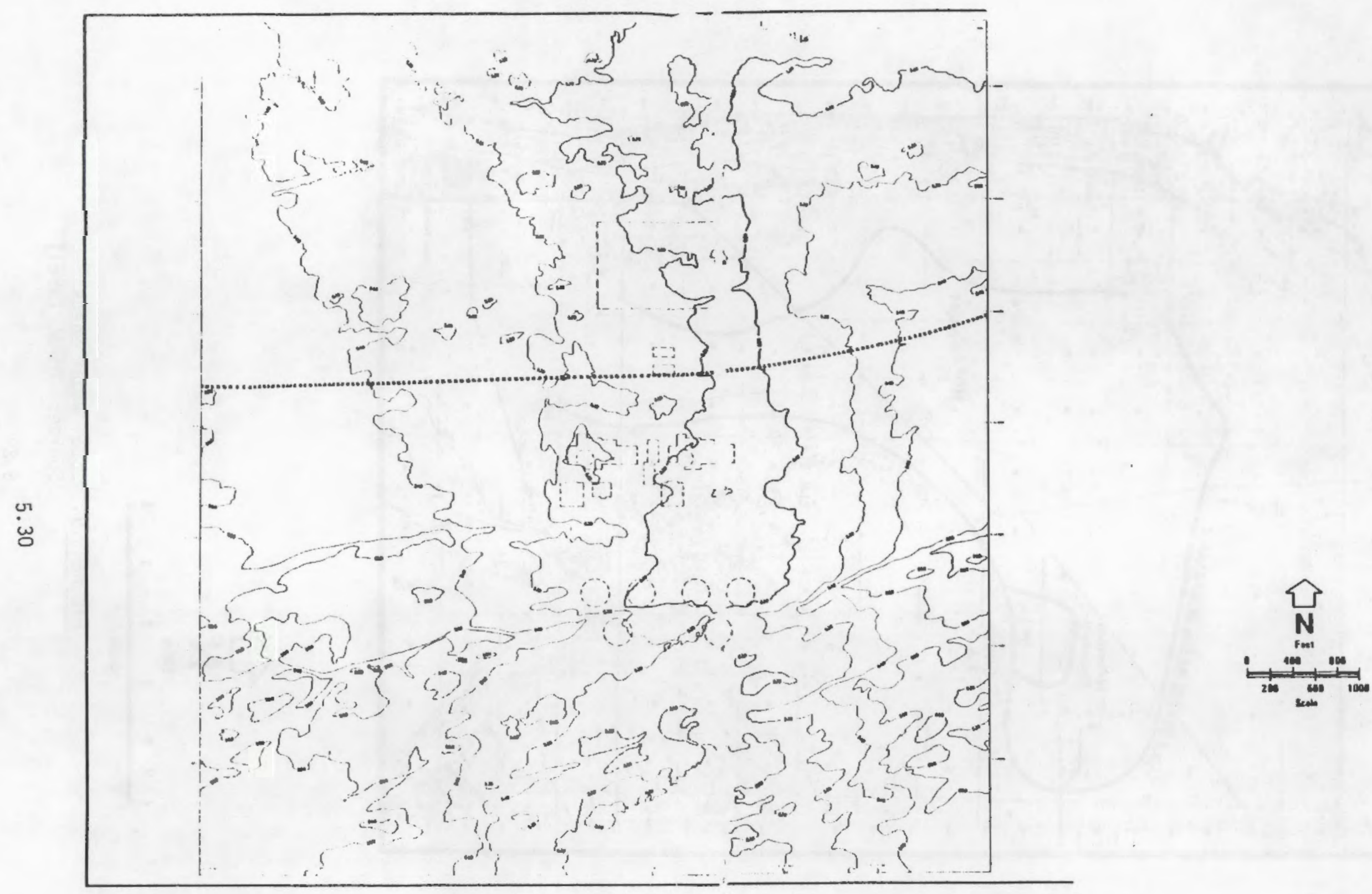

FIGURE 5.10. Natural Site Topography

Source: PSP\&L (1981) 


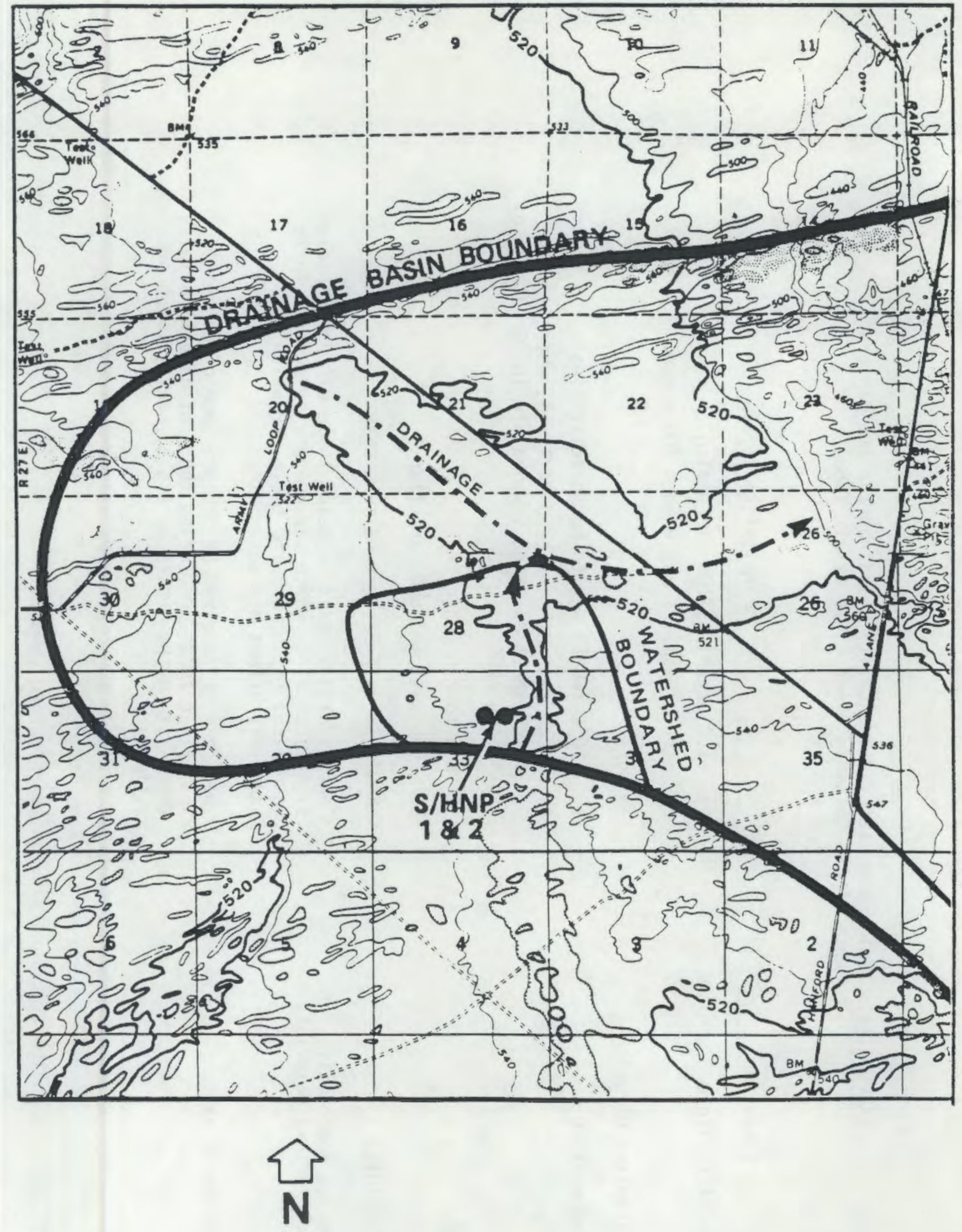

Miles

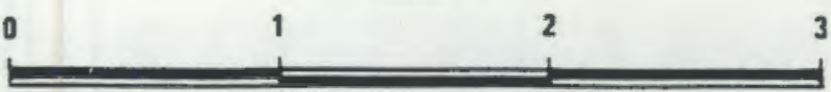

Srale

FIGURE 5.11. Skagit/Hanford Nuclear Project Watershed Source: PSP\&L (1981) 
TABLE 5.14. Washington State Water Quality Standards for the Hanford

Reach of the Columbia River (Sula et al. 1983)

Parameter

Fecal Coliform Organism

Dissolved 0xygen

Temperature

$\mathrm{pH}$

Turbidity

Toxic, Radioactive, or Deleterious Materials

Aesthetic Value

\section{Permissible Levels}

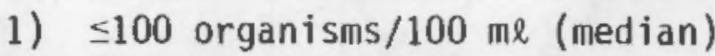

2) $\leq 10 \mu$ of samples may exceed 200 organisms/100 me $>8 \mathrm{mg} / \mathrm{e}$

1) $\leq 20^{\circ} \mathrm{C}\left(68^{\circ} \mathrm{F}\right)$ due to human activities

2) Increases not to exceed $34 / T+9$, where $\mathrm{T}=$ highest existing temperature in ${ }^{\circ} \mathrm{C}$ outside of mixing zone

1) 6.5 to 8.5 range

2) $<0.5$ unit induced variation

$\leq 5 \mathrm{NTU}^{(\mathrm{a})}$ over background turbidity

Concentrations shall be below those of public health significance, or which cause acute or chronic toxic conditions to the aquatic biota, or which may adversely affect any water use.

Shall not be impaired by the presence of materials or their effects, excluding those of natural origin, which offend the senses of sight, smell, touch or taste.

(a) NTU = Nephelometric Turbidity Units--Standard Candle. 
TABLE 5.15. Columbia River Water Quality (Sula et al. 1983)

\begin{tabular}{|c|c|c|c|c|c|c|c|c|c|c|c|}
\hline \multirow{4}{*}{\multicolumn{2}{|c|}{ 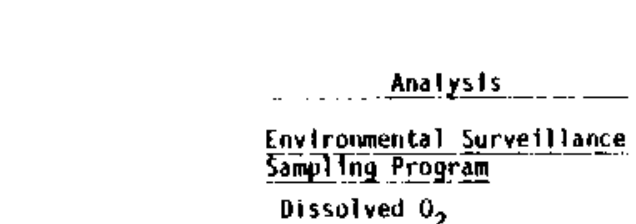 }} & \multirow{3}{*}{ Onits. } & \multirow{3}{*}{$\begin{array}{l}\text { Ho of } \\
\text { samples }\end{array}$} & \multirow{3}{*}{$\begin{array}{c}\text { Vernila } \\
\text { Man. }\end{array}$} & \multicolumn{2}{|c|}{ Br doge (Opstrean) } & \multirow{3}{*}{$\begin{array}{l}\text { No. of } \\
\text { Sampless }\end{array}$} & \multicolumn{3}{|c|}{ flchland (Dowistreain) } & \multirow[b]{2}{*}{$\begin{array}{c}\text { State }(b) \\
\text { Standard }\end{array}$} \\
\hline & & & & & Min. & $\begin{array}{l}\text { Aniual } \\
\text { Average }\end{array}$ & & thax. & Mt!n. & Average (a) & \\
\hline & & & & & & & & & & & \\
\hline & & $\operatorname{mig} / 1$ & 49 & 17 & 6.8 & $12 \div 1.2$ & 48 & 17 & 6.8 & $11: 1.3$ & B (minimue) \\
\hline & Iurbidity & $\mathrm{NTU}^{(\mathrm{c})}$ & 51 & 8.7 & 0.1 & $2.5 \pm 0.8$ & 49 & 7.4 & 1.0 & $2.9 \div 0.9$ & $5 \pm$ background \\
\hline & pli & & 48 & 8.0 & 6.0 & $\mathrm{H} / \mathrm{A}$ & 49 & 7.7 & 5.4 & $M / A$ & $8.5-6.5$ \\
\hline & Fecal Coliform & $1 / 100$ ml & 11 & 110 & 0 & $5.0^{(\mathrm{d})}$ & 10 & 240 & 2 & $7.0^{(\mathrm{d})}$ & 100 \\
\hline & Iotal Colfforil & $/ / 100 \mathrm{ml}$ & 10 & 2400 & 2 & $79^{(d)}$ & 10 & 240 & 4 & $33^{(d)}$ & \\
\hline & $\operatorname{Bov}^{(e)}$ & ang / 1 & 11 & 7.1 & 1.0 & $3.2 \pm 2.2$ & 11 & 7.2 & 0.8 & $3.3 \pm 2.2$ & \\
\hline & Nitrogen (as $\mathrm{NO}_{3}$ ) & $\mathrm{m} y / \mathrm{l}$ & 52 & 0.92 & 0.10 & $0.22 \pm 0.08$ & 52 & 1.6 & 0.10 & $0.58 \div 0.68$ & \\
\hline & uSGS sampling Progran & & & & & & & & & & \\
\hline \multirow{15}{*}{$\begin{array}{l}\omega \\
\omega \\
\omega\end{array}$} & Temperature & ${ }^{\circ} \mathrm{C}$ & 343 & 20.2 & 1.8 & $10.7: 0.6$ & 350 & 21.0 & 2.0 & $10.9 \pm 0.6$ & $20\left(\max x i_{1110100}\right)$ \\
\hline & Ofssolved $\mathrm{O}_{2}$ & $m g / 1$ & 5 & 14.1 & 11.6 & $12 \pm 2$ & 4 & 12 & 10 & $11 \pm 1$ & B (ni ininum) \\
\hline & Jurbidity & $\operatorname{MIU}^{(c)}$ & 6 & 2.6 & 0.6 & $1.4 \div 0.7$ & 3 & 3.5 & 0.6 & $2.4 \div 1.8$ & 5 \& background \\
\hline & pH & & 6 & 9.0 & 1.1 & N/A & 4 & 8.1 & 7.7 & N/A & $8.5-6.5$ \\
\hline & Fecal coliform & $/ / 100 \mathrm{ml}$ & 5 & $B$ & $<1$ & $3^{(d)}$ & 3 & 5 & $<1$ & $2^{(d)}$ & 100 \\
\hline & Suspended Solfds, $105^{\circ} \mathrm{C}$ & $\mathrm{mag} / 1$ & 6 & 7 & $<1$ & $4+1.9$ & 4 & 11 & 3 & $6 \div 3$ & \\
\hline & Dissolved Solids, $180^{\circ} \mathrm{C}$ & $\mathrm{mg} / \mathrm{l}$ & 6 & 93 & 58 & $76 \pm 12.1$ & 4 & 88 & 64 & $78 \pm 12$ & \\
\hline & Specific Conductance & Liminos & 6 & 150 & 113 & $130 \div 11.4$ & 4 & 148 & 122 & $135 \div 189$ & \\
\hline & Harduess, as $\mathrm{CaCO}_{3}$ & $m x / 1$ & 6 & 76 & 55 & $65+7.7$ & 4 & 77 & 55 & $66 \pm 12$ & \\
\hline & Ptrosphorus, total & $\mathrm{mag} / 1$ & 6 & 0.0601 & $\times 0.010$ & $0.03 \div 0.020$ & 4 & 0.050 & 0.020 & $0.032 \pm 0.015$ & \\
\hline & Chloride, dissólved & $m / 1$ & 6 & 1.6 & 0.8 & $1.2 \div 0.2$ & 4 & 1.4 & 0.9 & 1.110 .2 & \\
\hline & Chromiunn total ${ }^{(f)}$ & nเg/1 & 3 & 20 & 20 & $20 \div 0$ & 4 & 10 & $<10$ & $10 \pm 0$ & \\
\hline & Iron, total $(f)$ & $\operatorname{mig} / 1$ & 3 & 360 & 120 & $223 \pm 142$ & 4 & 230 & 60 & $145 \pm 92.6$ & \\
\hline & Nitrugen, Kjeldahl & $\mathrm{Alg} / \mathrm{I}$ & 4 & 0.49 & 0.27 & $0.36 \div 0.12$ & 4 & 0.70 & 0.34 & $0.50 \pm 0.15$ & \\
\hline & $\begin{array}{l}\text { (a) Average }- \text { two standard } \\
\text { (b) See Appendix A. } \\
\text { c) Nepheloutric Iurbidits } \\
\text { (d) Annual median. } \\
\text { (e) Bioloyical Oxygen Dellar } \\
\text { (f) Total - Lotal recoverat } \\
\text { H } / A \text { Not Alplicable. }\end{array}$ & $\begin{array}{l}\text { rror terus } \\
\text { Units. }\end{array}$ & $195 \%$ conf & idence & nettiot. & & & & & & \\
\hline
\end{tabular}


TABLE 5.15. (contd)

300 Ared/Richland

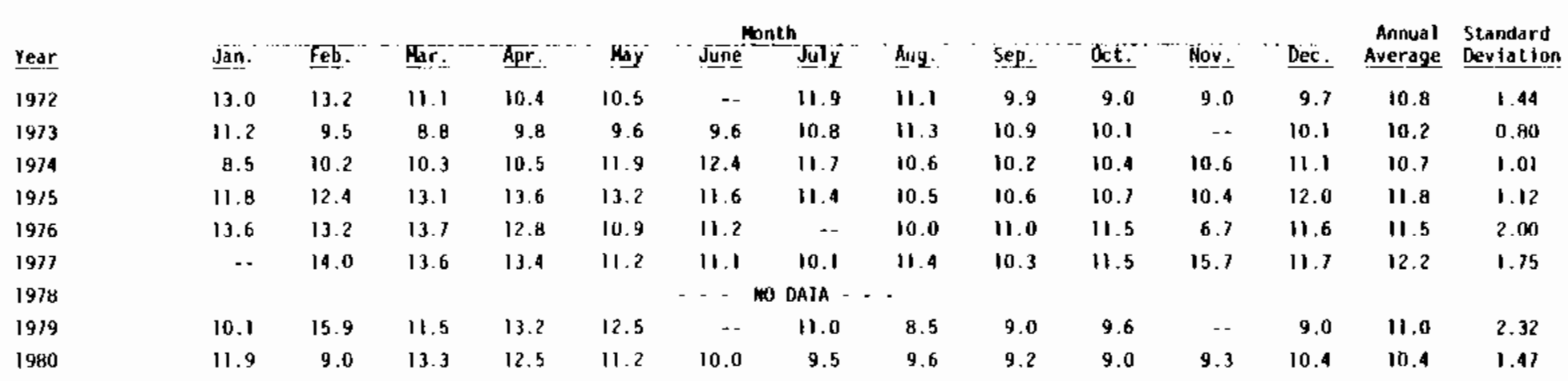

\begin{tabular}{|c|c|c|c|c|c|c|c|c|c|c|c|c|c|c|}
\hline $\begin{array}{l}\text { Average } \\
1972-1977, \\
1979.1980\end{array}$ & 11.4 & 12.2 & 11.9 & 12.0 & 11.4 & 11.0 & 10.9 & 10.4 & 10.1 & 10.2 & 10.3 & 10.7 & 11.1 & \\
\hline Std, Der. & 1.7 & 2.4 & 1.8 & 1.5 & 1.1 & 1.0 & 0.9 & 1.0 & 0.7 & 1.0 & 3.0 & 1.1 & -- & - . \\
\hline $\begin{array}{l}\text { Minimum } \\
\text { oaily } \\
\text { (observed) }\end{array}$ & 6.1 & 5.5 & 1.7 & 8.1 & 8.5 & 9.0 & 0.3 & 3. 0 & 8.5 & 8.1 & 6.7 & 8.7 & $\ldots$ & $\ldots$ \\
\hline $\begin{array}{l}\text { Maxlunen } \\
\text { Daijy } \\
\text { (ubserverd) }\end{array}$ & 14.7 & 16.8 & 19.0 & 14.1 & 14.0 & 13.6 & 14.1 & 13.2 & 12.4 & 14.0 & 11.7 & 12.8 & & \\
\hline
\end{tabular}


Monthly variations in dissolved oxygen, $\mathrm{pH}$, and turbidity are given in Tables 5.16, 5.17, and 5.18, respectively. Metal concentrations are shown in Table 5.19 .

Suspended sediment concentrations in the Hanford Reach vary widely throughout the year because of seasonal differences in the contribution of tributaries (U.S. ERDA 1975, p. II.3.D-8). During low flows the dams along the Columbia intercept much of the suspended sediment; during high flows part of these deposited materials are resuspended and washed out of the dam reservoirs. The concentration of suspended material in river water ranges from about $300 \mathrm{~g} / \mathrm{l}$ in April, or nearly a 100-fold variation during the year (Wildung 1971, p. 7) (Table 5.20). The clay fraction $(<2.0 \mu)$ accounts for a major part of the suspended particle load during the spring flows (Table 5.21) and the concentra-

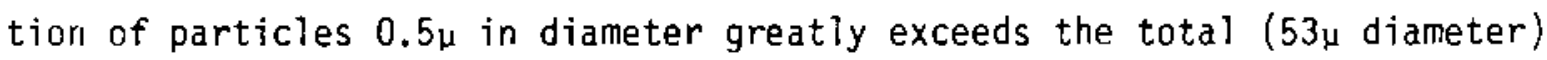
particulate concentrations during other seasons. The total carbon content of the suspended material is greatest in the fall and least in the spring (Table 5.22) and probably reflects the greater fraction of phytoplankton in the suspended load during the fall. The variation in mineral composition of the suspended particulates do not vary greatly seasonally. The relative concentrations of minerals in suspended sediments are shown in Table 5.23. In the fractions $>0.5 \mu$ diameter feldspar, amphibole, mica-illite and chlorite are the most abundant.

Columbia River temperatures have been recorded for a number of years at the Vernita Bridge (RM 391) just upstream from the Hanford Reservation and Richland, washington (RM 339), just downstream of the reservation. The monthiy average temperatures at these locations range from $3.2^{\circ} \mathrm{C}\left(37.8^{\circ} \mathrm{F}\right)$ in February to $19.3^{\circ} \mathrm{C}\left(66.7^{\circ} \mathrm{F}\right.$ ) in August (Tables 5.24 and 5.25). The minimum and maximum daily temperatures are $0.0^{\circ} \mathrm{C}\left(32.0^{\circ} \mathrm{F}\right.$ ) and $21.5^{\circ} \mathrm{C}\left(70.7^{\circ} \mathrm{F}\right.$ ) (PSP\&L 1982 , p. 2.4-6). A diurnal temperature variation of about $1.2^{\circ} \mathrm{C}\left(2.2^{\circ} \mathrm{F}\right)$ in spring and summer, and $0.6^{\circ} \mathrm{C}\left(1.1^{\circ} \mathrm{F}\right)$ in fall and winter can be expected from the diurnal reservoir discharge variations from Priest Rapids Oam (PSP\&L 1982, p. 2.4-6b). The establishment of dams in the Columbia upstream from Hanford delays the annual peak river temperature arrival dates in direct proportion to the increase in trave? time due to the dam (US ERDA 1975, p. II.3-D-5). 
TABLE 5.16. Monthly Average Values of Dissolved Oxygen (mg/I) at Vernita Bridge and at 300 Area/Richland (PSP\&L 1982)

A. Vernite Bridge

\begin{tabular}{|c|c|c|c|c|c|c|c|c|c|c|c|c|c|c|}
\hline & & & & & & & nes & & & & & & Annual & Standard \\
\hline Yeer & Jann & Yeb & niat & ApI & nay & June & July & Aug & sep & oct & Nov & Dec & Aver age & Deviexson \\
\hline 1972 & 22.5 & 13.1 & 10.0 & 10.0 & 10.8 & -- & 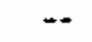 & 12.0 & 10.9 & 19.2 & 9.2 & 6.6 & 11.6 & 3.3 \\
\hline 1973 & 10.3 & 9.0 & 9.2 & 10.5 & 10.2 & 10.5 & 11.3 & 12.6 & 11.0 & 10.4 & - & 10.4 & 10.5 & 1.0 \\
\hline 2974 & 10.0 & 9.8 & 10.5 & 11.0 & 12.5 & 21.7 & 11.3 & 11.1 & 10.7 & 10.6 & 10.7 & 10.8 & 10.9 & 0.0 \\
\hline 1975 & 11.0 & 12.9 & 13.2 & 23.9 & 23.2 & 21.4 & 11.5 & 10.5 & 10.5 & 10.6 & 10.9 & 12.1 & 11.9 & 1.2 \\
\hline 2976 & 13.7 & 14.8 & 14.5 & 12.8 & -- & 10.0 & -- & 11.7 & 10.9 & 10.8 & 5.8 & 11.5 & 11.7 & 2.6 \\
\hline 1977 & 12.6 & 13.5 & 33.6 & 13.6 & 12.0 & 11.0 & 10.6 & 10.2 & 10.1 & 10.5 & 10.4 & $11 . B$ & 11.7 & 2.4 \\
\hline 1978 & 14.1 & 14.3 & 33.3 & 13.5 & 12.0 & 12.9 & 12.0 & 10.9 & $\sim$ & 9.9 & 10.9 & 11.7 & 12.3 & 1.4 \\
\hline 1979 & 13.0 & 15.9 & 13.0 & 13.5 & 12.7 & 0.6 & 10.6 & 10.0 & 10.1 & 9.9 & $\cdots$ & 9.6 & 11.5 & 2.2 \\
\hline $\begin{array}{l}\text { Average } \\
1972-1979\end{array}$ & 12.2 & 13.0 & 12.3 & 12.5 & 11.9 & 10.9 & 11.2 & 11.2 & 10.6 & 11.5 & 9.7 & 10.6 & 11.5 & \\
\hline std. Dev. & 1.5 & 2.4 & 1.8 & 1.4 & 1.1 & 1.1 & 0.5 & 0.9 & 0.1 & 3.1 & 2.0 & 1.0 & - & $m$ \\
\hline $\begin{array}{l}\text { Minieur } \\
\text { Dally } \\
\text { (Observed) }\end{array}$ & 6.3 & 0.4 & 0.6 & 9.5 & 9.3 & 6.0 & 9.0 & 9.2 & 7.4 & 0.0 & 5.8 & 4.0 & -- & $\sim$ \\
\hline $\begin{array}{l}\text { Maxibue } \\
\text { bally } \\
\text { (oberved) }\end{array}$ & 17.0 & 15.9 & 25.0 & 14.4 & 15.0 & 14.1 & 15.2 & 14.1 & 13.0 & 11.7 & 11.5 & 22.6 & -- & 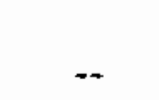 \\
\hline
\end{tabular}


TABLE 5.16. (contd)

B. 300 Area/Richland

\begin{tabular}{|c|c|c|c|c|c|c|c|c|c|c|c|c|c|c|}
\hline$\underline{\text { Year }}$ & $\overline{3 a n}$ & Fet & Mar & $A P S$ & HaY & June & $\frac{\text { nth }}{\text { JuIY }}$ & Aug & $\underline{S \in P}$ & Oct & Nôy & $\overline{D \in C}$ & $\begin{array}{c}\text { Annual } \\
\text { Average }\end{array}$ & $\begin{array}{l}\text { Standard } \\
\text { Devistion }\end{array}$ \\
\hline 1972 & 7.9 & 7.9 & 7.9 & 8. 3 & 8.4 & 0.2 & 0.2 & 8.1 & 0.0 & 0.0 & 7.9 & 7.0 & 8.1 & 0.2 \\
\hline 1973 & 7.9 & 0.1 & 0.1 & 7.9 & a.t & 0.5 & 0.2 & 0.3 & 0.3 & A. 1 & 0.0 & 7.9 & 0.1 & 0.2 \\
\hline 1974 & 0.0 & 7.8 & 7.8 & 7.8 & 7.0 & 3.9 & 7.8 & 7.8 & 0.0 & 7.8 & 7.7 & 7.9 & 7.9 & 0.1 \\
\hline 1975 & 8.0 & 8.1 & 8.0 & 9.2 & 0.1 & 7.9 & 6.0 & 0.0 & a. 1 & 0.2 & 7.8 & 7.7 & 0.0 & 0.2 \\
\hline 1976 & 7.6 & 7.6 & 7.6 & 7.8 & 7.4 & 7.5 & -- & 7.5 & 8.1 & 8. 2 & 7.8 & 7.7 & 7.7 & 0.3 \\
\hline 1977 & 7.4 & 6.1 & 7.7 & 7.9 & 8.1 & 7.0 & 0.1 & 8,4 & 8.2 & 8.4 & 7.7 & - & 8.0 & 0.3 \\
\hline 1978 & & & & & & & 10 DAT & & & & & & & \\
\hline 1979 & 7.4 & 7.5 & 7.6 & 7.5 & 7.9 & -- & 7.3 & 7.7 & 7.7 & 7.6 & 7.9 & 0.1 & 7.7 & 0.2 \\
\hline 1900 & 7.2 & 7.5 & 7.7 & 1.7 & 7.6 & 7.4 & 7.7 & 7.6 & 7.5 & 7.2 & 7.2 & 7.4 & 7.5 & 0.2 \\
\hline
\end{tabular}

$G \quad$ Average

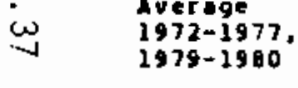

7.71 .0

std. Dev.

$\begin{array}{lll}0.3 & 0.3 & 0.2\end{array}$

7.9

$\bullet$

7.97.

96.9

Minieus

Dally

lobserved

Maninu

lobserved

$7.1 \quad 7.1$

6.77

.27

16.9

9

30.40 .3

7.

7.

$\begin{array}{ll}7.0 & 7.9 \\ 0.2 & -\end{array}$ 
TABLE 5.17. Monthly Numerical Average of pH at Vernita Bridge and at 300 Area/Richland (PSP\&L 1982)

A. Vernita Bridge

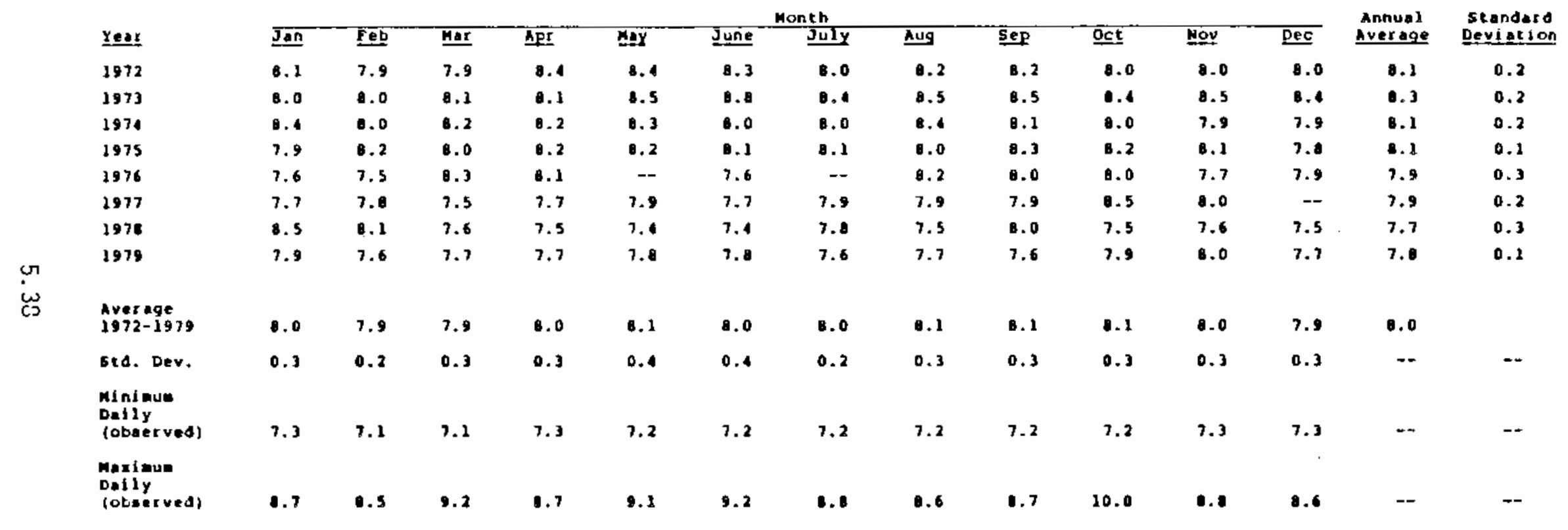


TABLE 5.17. (contd)

B. 300 Area/gichlend

\begin{tabular}{|c|c|c|c|c|c|c|c|c|c|c|c|c|c|c|}
\hline \multirow[b]{2}{*}{ Yeat } & \multicolumn{12}{|c|}{ mont $h$} & \multirow{2}{*}{$\begin{array}{c}\text { Annual } \\
\text { Average }\end{array}$} & \multirow{2}{*}{$\begin{array}{l}\text { Standord } \\
\text { Deviotion }\end{array}$} \\
\hline & J̦An & Feb & Mar & API & MoY & June & July & 스므 & Sep & Oct & Hov & Dec & & \\
\hline 1972 & 1.6 & 2.7 & 6.4 & 6.3 & 6.1 & 16.3 & 5.0 & 1.1 & 2.9 & 1.9 & 1.2 & 1.4 & 4.7 & 4.2 \\
\hline 1973 & 1.6 & 0.9 & 2.6 & 1.7 & 1.7 & 1.9 & 1.6 & 1.3 & 1.0 & 1.4 & 0.9 & 0.9 & 1.5 & 0.5 \\
\hline 1974 & 4.9 & 14.7 & 6.3 & 6.2 & 5.6 & 6.5 & 3.1 & 3.6 & 1.5 & 1.4 & 1.1 & 1.3 & 1.5 & 3.9 \\
\hline 1975 & 1.5 & 1.1 & .9 & 1.8 & 3.6 & - & 2.0 & 2.2 & 1.6 & 1.5 & 1.1 & 1.9 & 1.7 & 0.7 \\
\hline 1976 & 1.5 & 3.3 & 3.10 & 3.6 & 3.9 & 2.8 & -- & 2.2 & 1.6 & 1.4 & 1.4 & 1.5 & 2.5 & 1.0 \\
\hline 1977 & 1.5 & 3.0 & 3.6 & 2.3 & 2.5 & 2.3 & 2.0 & 2.6 & 1.7 & 1.9 & 1.9 & -- & 2.3 & 2.6 \\
\hline 1978 & & & & & & & DAT & & & & & & & \\
\hline 2979 & 1.5 & 1.4 & 1.3 & 2.1 & 1.5 & $\cdots$ & 1.5 & 3.5 & 3.3 & 3.1 & 2.6 & 1.4. & 2.1 & 0.9 \\
\hline 1980 & 1.6 & 1.0 & 2.9 & 1.6 & 6.9 & 2.8 & 1.4 & 1.9 & 1.7 & 1.4 & 1.8 & 2.1 & 2.3 & 1.6 \\
\hline
\end{tabular}

Average
1972-1977

$1979-1980$

$\begin{array}{lllll}2.0 & 3.5 & 3.5 & 3.2\end{array}$

8td. Dev.

$1.2 \quad 4.6 \quad 2.0 \quad 2.0$

2.0

5.42 .4

2.9

1.9

1.7

1.5

$1.5 \quad 2.7$

Minieum

Daily

(observed)

0.10 .6

0.4

0.7

1.2

1.0

0.0

o.

0.

o.

0.6

0.1

Daily

(observed)

9.723.

13.0

.0

10.0

30.0

$\bullet .0$

. 
TABLE 5.18. Monthly Average Values of Turbidity (NTU) at Vernita Bridge and at 300 Area/Richland (PSP\&L)

\section{A. Vernita eridge}

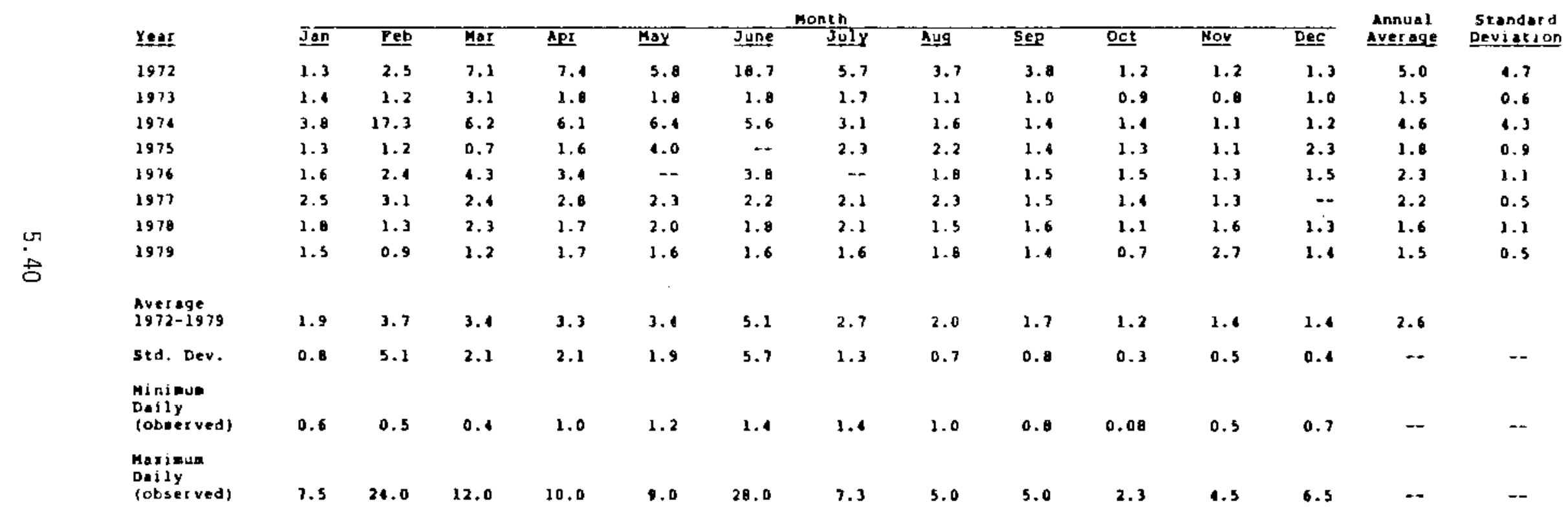


TABLE 5.18. (contd)

B. 300 Area/Richlend

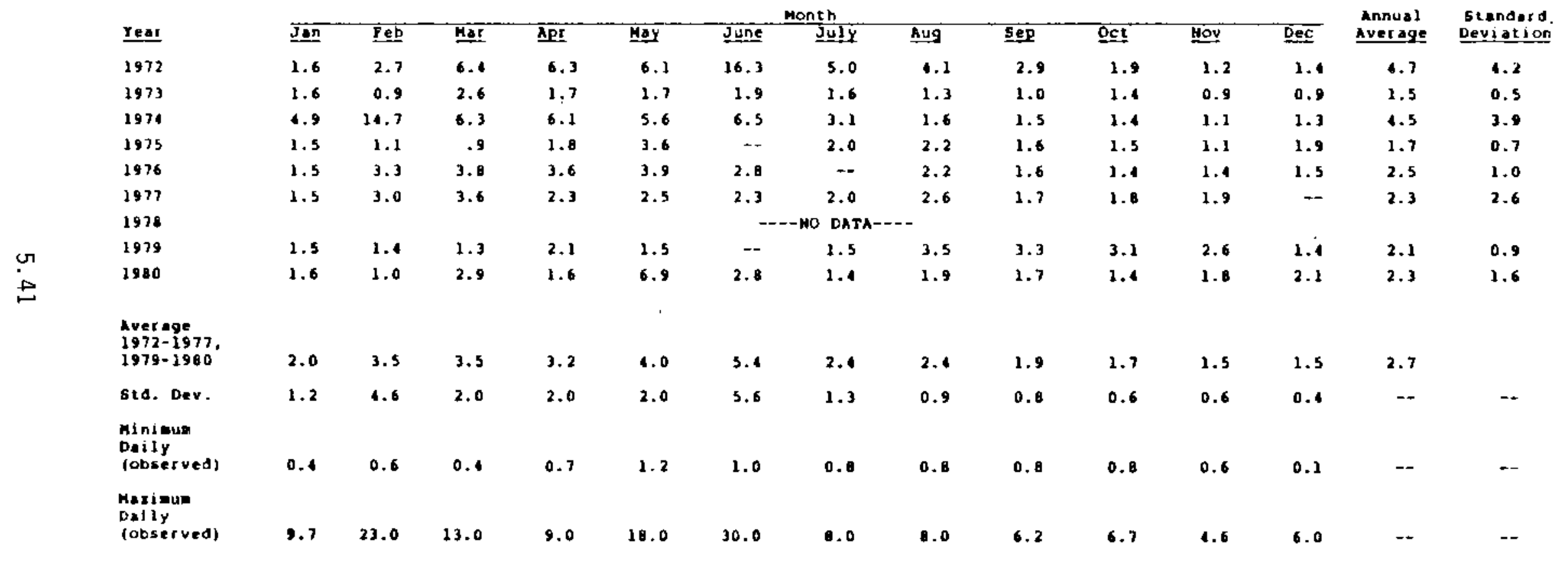


TABLE 5.19. Mean and Extreme Concentrations of Metals and 0ther Water Quality Parameters Measured at Vernita Bridge and Richland During Water Years 1979-1980

(PSP\&L 1982)

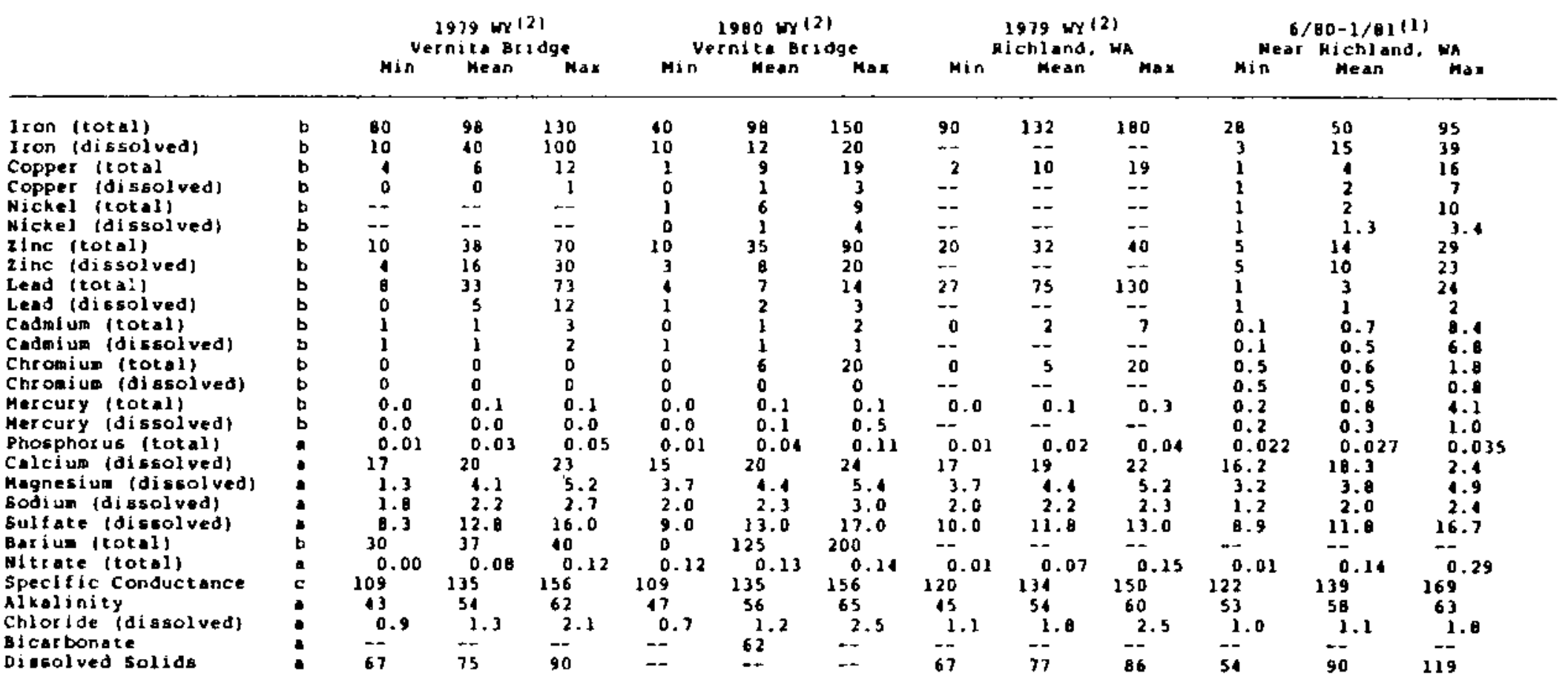

HOTES:

4. Units ore $\operatorname{lol}$.

c. Units are nicromos.

outliers excluded from onalyis.

Sousces: (1) Unpublished chemical onalyses sade by Batlelle Memorial institute, Pacillc Morthuest Laboratories on behalf of the Washington Public Pouer supply system. 
TABLE 5.20. Seasonal Changes in the Concentration of Particulate Matter $(<53 \mu)$ in River Water (Wildung et al. 1972)

Time of Sampling Concentration (a) of Suspended

Particulate Matter

$$
\mathrm{ug} / \mathrm{l}
$$

November

February 2002

April 34680

June 5788

August 3726

(a) Based on oven dry (60C) weight.

TABLE 5.21. Seasonal Changes in the Size Distribution of Particulate Matter Isolated From River Water (Wildung et al. 1972)

\begin{tabular}{|c|c|c|c|c|c|}
\hline \multirow{2}{*}{$\begin{array}{c}\text { Equivalent } \\
\text { Sperical } \\
\text { Diameter } \\
\end{array}$} & \multicolumn{5}{|c|}{ Particle Size Distribution(a) } \\
\hline & November & February & April & June & August \\
\hline$\mu$ & $---\cdot$ & ---- & $-{ }^{\circ} k-$ & $-\cdots$ & -- \\
\hline 53 to 2.0 & 70 & 85 & 37 & 78 & 86 \\
\hline 2.0 to 0.5 & 14 & 8 & 39 & 16 & 7 \\
\hline 0.5 to 0.2 & 9 & 5 & 16 & 4 & 5 \\
\hline$<0.2$ & 7 & 2 & 8 & 2 & 2 \\
\hline
\end{tabular}

(a) Based on oven dry (60C) weight and expressed as a percentage of total recovered particulate matter $(<53 \mathrm{u})$. 
TABLE 5.22. Seasonal Changes in the Carbon Content of Particulate Matter $(<53 \mu)$ Isolated From River Water (Wildung et a1. 1972)

Time of

Sampling

November

February

April

June

August

\begin{tabular}{|c|c|c|}
\hline Ash & $\begin{array}{r}\text { Total } \\
\text { Sample } \\
\end{array}$ & $\begin{array}{l}\text { Ash-Free } \\
\text { Sample }\end{array}$ \\
\hline- & $-\%-$ & -- \\
\hline 65.7 & 14.4 & 42.0 \\
\hline 80.4 & 7.8 & 39.7 \\
\hline 92.1 & 1.5 & 19.4 \\
\hline 86.8 & 2.8 & 20.8 \\
\hline 75.0 & 7.7 & 30.9 \\
\hline
\end{tabular}

(a) Based on oven dry (60C) weight.

Maximum heating of the free-flowing Manford Reach of the Columbia during August and September is about 0.5 to $0.75^{\circ} \mathrm{C}\left(0.9\right.$ to $\left.1.35^{\circ} \mathrm{F}\right)$, due primarily to insolation.

\subsubsection{Effluents Discharged to the Hanford Reach of the Columbia River}

Fifteen liquid effluent lines from Hanford facilities discharge their contents directly to the Columbia River. Pertinent data on quantities and constituents for each discharge are given in Table 5.26, and a summary of annual amounts of the principal chemical discharges is given in TabTe 5.27 (WPPSS 1978).

At present, the only thermal discharges of sufficient magnitude to affect Columbia River temperatures occur either from the 100-N Reactor or from the associated WPPSS Hanford Generating Project (HGP) when the 100-N Reactor is operating (WPPSS 1978).

The largest heated effluent arising from this operation is the cooling water from the HGP (RM 380), which has a thermal capacity of 3780 MW (megawatts) and an eiectrical capacity of $860 \mathrm{MW}$. The cooling water flow rate is 940 to $1260 \mathrm{cfs}$ depending on incoming river temperature, and is discharged at 
TABLE 5.23. Relative Abundance of Minerals in Size Fractions of Suspended Particulate Matter Isolated From River Water Wildung et al. 1972)

\begin{tabular}{|c|c|c|c|c|c|c|c|}
\hline & \multirow{2}{*}{$\begin{array}{l}\text { Equivalent } \\
\text { Spherical } \\
\text { Diameter } \\
\text { (Microns) }\end{array}$} & \multicolumn{6}{|c|}{ Relative Abundance ${ }^{(b)}$ of } \\
\hline & & Quartz & Feldspar & Amphibole & $\begin{array}{l}\text { Mica- } \\
\text { illite }\end{array}$ & Chlorite & Montmorillonite \\
\hline & 53 to 2.0 & 2 & 3 & 3 & 3 & 3 & 1 \\
\hline & 2.0 to 0.5 & 2 & 3 & 3 & 3 & 3 & 1 \\
\hline r & 0.5 to 0.2 & 2 & 1 & 3 & 2 & 2 & 2 \\
\hline E & 0.2 & 1 & 2 & 3 & 2 & 2 & 2 \\
\hline
\end{tabular}

(a) ApriT

(b) Relative mineral abundance designated as: 1) trace $(2-10 \%)$; 2) intermediate (5-25\%); 3) abundant (>25\%) 

IABLE 5.24. Monthly Average Water Temperature in ${ }^{\circ} \mathrm{C}$, at Vernita Bridge, WA ${ }^{(a)}$.
(USGS Station No. 12472900$)(\mathrm{b})$ (PSP\&L 1982)

\begin{tabular}{|c|c|c|c|c|c|c|c|c|c|c|c|c|c|c|}
\hline & & & & & & & th & & & & & & Annual & Standard \\
\hline Year & Jan & Feb & Mar & Apr & hay & June & July & Aūg & Sep & Oct & Nov & Dec & Average & Deviation \\
\hline $1961(\mathrm{c})$ & 5.4 & 4.7 & 4.7 & 7.4 & 10.4 & 13.7 & 17.3 & 18.9 & 17.8 & 14.9 & 10.4 & 6.6 & 11.0 & 5.3 \\
\hline $1962(c)$ & 4.1 & 3.6 & 3.6 & 6.5 & 10.0 & 13.1 & 16.1 & 17.4 & 17.1 & 14.8 & 11.9 & 8.9 & 10.6 & 5.3 \\
\hline $1963(c)$ & 5.3 & 3.8 & 4.6 & 6.5 & 10.4 & 14.0 & 16.6 & 18.4 & 18.3 & 16.3 & 11.9 & 7.7 & 11.2 & 5.5 \\
\hline $1964(\mathrm{c})$ & 5.5 & 4.6 & 4.7 & 7.2 & 9.7 & 12.8 & 15.3 & 17.1 & 16.3 & 14.6 & 10.8 & 6.3 & 10.4 & 4.7 \\
\hline $1965(\mathrm{c})$ & 4.4 & 3.3 & 4.1 & 6.6 & 10.0 & 13.3 & 16.1 & 18.4 & 17.3 & 15.3 & 11.9 & 7.8 & 10.7 & 5.4 \\
\hline $1966(c)$ & 4.8 & 4.1 & 4.5 & 7.8 & 10.6 & 12.4 & 15.3 & 17.5 & 17.5 & 14.6 & 11.6 & 8.4 & 10.8 & 4.9 \\
\hline $1967(c)$ & 5.9 & 5.7 & 5.0 & 6.8 & 10.1 & 13.3 & 16.1 & 18.5 & 18.2 & 15.4 & 11.3 & 7.2 & 11.1 & 5.1 \\
\hline $1968(c)$ & 4.6 & 3.3 & 4.6 & 7.1 & 11.1 & 13.4 & 16.1 & 17.5 & 17.2 & 14.2 & 10.9 & 6.8 & 10.6 & 5.2 \\
\hline $1969(\mathrm{c})$ & 2.4 & 1.5 & 3.4 & 7.2 & 10.8 & 14.6 & 17.1 & 18.2 & 17.7 & 14.8 & 11.5 & 7.6 & 10.6 & 6.1 \\
\hline $1970(c)$ & 4.3 & 4.1 & 4.8 & 6.8 & 10.9 & 14.8 & 18.0 & 19.2 & 17.5 & 15.2 & 10.6 & 6.2 & 11.0 & 5.7 \\
\hline $1971(c)$ & 4.0 & 3.5 & 3.6 & 6.6 & 10.7 & 12.6 & 15.3 & 18.4 & 17.2 & 15.2 & 11.3 & 6.8 & 10.4 & 5.4 \\
\hline $1972(c)$ & 3.6 & 1.9 & 4.0 & 7.2 & 10.6 & 12.9 & 15.2 & 17.3 & 16.8 & 15.4 & 11.3 & 7.3 & 10.3 & 5.4 \\
\hline $1973(c)$ & 2.3 & 2.9 & 4.8 & 7.7 & 12.5 & 15.4 & 17.6 & 18.8 & 17.8 & 15.2 & 10.3 & 7.7 & 11.1 & 6.0 \\
\hline $1974(\mathrm{c})$ & 4.0 & 3.0 & 4.9 & 7.7 & 10.8 & 13.6 & 17.2 & 18.7 & 18.4 & 15.5 & 11.8 & 8.6 & 11.2 & 5.6 \\
\hline $1975(d)$ & 4.4 & 2.3 & 3.3 & 5.9 & 9.8 & 13.7 & 17.2 & 18.0 & 18.6 & 15.7 & 11.6 & 6.7 & 10.6 & 6.0 \\
\hline $1976(d)$ & 3.6 & 3.0 & 3.9 & 6.6 & 10.3 & 12.9 & 15.7 & 17.9 & 17.3 & 14.8 & 11.4 & 7.2 & 10.4 & 5.4 \\
\hline $1977(d)$ & 3.9 & 3.4 & 4.3 & 7.8 & 10.7 & 14.8 & 16.5 & 19.2 & 17.8 & 15.3 & 10.6 & 6.8 & 10.9 & 5.7 \\
\hline $1978(d)$ & 3.9 & 2.4 & 4.0 & 6.6 & 10.4 & -- & 17.1 & 18.7 & 18.0 & 15.5 & 10.0 & -- & -- & -- \\
\hline 1979 (d) & - & 0.9 & 3.0 & 6.3 & 10.7 & 14.5 & 17.5 & 19.4 & 19.4 & 17.1 & 12.7 & 7.8 & - & -- \\
\hline $1980(\mathrm{e})$ & 3.8 & 2.0 & 3.9 & 7.1 & 10.9 & 13.8 & 16.9 & 18.3 & 18.0 & 15.7 & 12.4 & 8.2 & 10.9 & 5.8 \\
\hline $\begin{array}{l}\text { Averayes } \\
1961-1980\end{array}$ & 4.2 & 3.2 & 4.2 & 7.0 & 10.6 & 13.7 & 16.5 & 18.3 & 17.7 & 15.3 & 11.3 & 7.4 & 10.8 & -- \\
\hline Std, Der. & 0.9 & 1.1 & 0.6 & 0.5 & 0.6 & 0.8 & 0.8 & 0.7 & 0.7 & 0.6 & 0.7 & 0.8 & -- & -- \\
\hline $\begin{array}{l}\text { Minilluull } \\
\text { Ddily }(c-f)\end{array}$ & 0.5 & 0.0 & 1.5 & 4.0 & 7.5 & 10.6 & 13.1 & 16.5 & 15.3 & 12.2 & 7.7 & 2.3 & -- & -- \\
\hline $\begin{array}{l}\text { Maximum } \\
\text { Daily(c-t) }\end{array}$ & 7.6 & 6.2 & 6.9 & 10.1 & 14.6 & 17.1 & 19.5 & 20.5 & 20.0 & 18.7 & 14.4 & 10.9 & -- & -- \\
\hline
\end{tabular}

(a) Recolded values adjusted by computer-simulation to compensate for measurement errors and missing data (1961-1974).

(b) Pilot to Octouer 1971 published as 12472800 "at Vernita Ferry". 
TABLE 5.25. Monthly Average Water Temperature in ${ }^{\circ} \mathrm{C}$, at Richland, WA (a)
(USGS Station No. 1247352) (PSP\&L 1982)

\begin{tabular}{|c|c|c|c|c|c|c|c|c|c|c|c|c|c|c|}
\hline & & & & & & & & & & & & & Annual & Standard \\
\hline Year & Jan & Feb & Mar & Apr & May & June & July & Aūg & sep & Oct & Nov & Dec & Average & Deviation \\
\hline $1965(b)$ & 6.1 & 5.4 & 6.3 & 9.1 & 11.0 & 14.2 & 17.3 & 19.8 & 18.5 & 16.4 & 12.6 & 8.4 & 12.1 & 5.1 \\
\hline $1966(b)$ & 5.9 & 6.2 & 6.8 & 10.3 & 12.1 & 13.5 & 16.2 & 18.8 & 19.4 & 15.6 & 12.6 & 9.5 & 12.2 & 4.7 \\
\hline $1967(b)$ & 7.4 & 7.0 & 6.6 & 8.8 & 12.0 & 13.9 & 17.0 & 20.2 & 19.4 & 16.1 & 12.0 & 7.8 & 12.4 & 4.9 \\
\hline $1968(b)$ & 5.7 & 5.0 & 6.0 & 8.8 & 12.8 & 14.3 & 17.0 & 18.7 & 18.3 & 15.0 & 11.4 & 7.4 & 11.7 & 5.0 \\
\hline 1969 (b) & 2.7 & 1.9 & 4.3 & 8.0 & 11.4 & 15.3 & 17.9 & 19.3 & 18.6 & 15.2 & 11.7 & 7.0 & 11.1 & 6.3 \\
\hline 1970 (b) & 5.3 & 4.9 & 5.7 & 7.9 & 11.7 & 15.4 & 19.0 & 19.9 & 17.5 & 14.9 & 10.6 & 5.9 & 11.6 & 5.6 \\
\hline $1971(b)$ & 4.2 & 3.4 & 3.8 & 7.0 & 11.1 & 12.9 & 16.4 & 19.5 & 17.8 & 15.0 & 10.7 & 6.2 & 10.7 & 5.7 \\
\hline $1972(b)$ & 3.3 & 2.2 & 3.7 & 7.0 & 11.0 & 13.3 & 15.5 & 18.1 & 16.9 & 14.0 & 10.5 & 6.1 & 10.1 & 5.6 \\
\hline $1973(b)$ & 3.2 & 3.0 & 4.7 & 7.8 & 12.9 & 15.6 & 18.3 & 19.6 & 18.3 & 15.0 & 9.9 & 7.6 & 11.3 & 6.1 \\
\hline $1974(\mathrm{D})$ & 3.2 & 3.2 & 5.2 & 8.2 & 11.3 & 13.7 & 17.4 & 19.4 & 18.8 & 15.4 & 11.5 & 7.9 & 11.3 & 5.8 \\
\hline $19 \% 5(c)$ & 4.6 & 2.8 & 3.9 & 6.9 & 10.7 & 14.3 & 18.3 & 18.8 & 18.8 & 15.3 & 10.6 & 6.9 & 11.0 & 6.0 \\
\hline $1976(c)$ & 4.0 & 3.4 & 4.5 & 7.2 & 10.9 & 13.5 & 16.3 & 18.3 & 17.5 & 14.7 & 11.0 & 6.8 & 10.7 & 5.4 \\
\hline $1977(\mathrm{c})$ & 3.7 & 3.4 & 4.9 & 8.9 & 11.6 & 15.8 & 17.5 & 19.8 & 17.8 & 15.4 & 10.4 & 6.6 & 11.3 & 5.9 \\
\hline $1978(c)$ & 4.2 & 2.8 & 4.7 & 7.3 & 11.0 & 14.7 & 17.5 & 19.3 & 18.1 & 15.4 & 9.6 & 5.6 & 10.9 & 6.0 \\
\hline $1979(c)$ & 1.5 & 2.0 & 4.1 & 6.5 & 11.4 & 15.3 & 18.4 & 19.9 & 19.6 & 16.9 & -- & 7.0 & -- & -- \\
\hline $1980(d)$ & 3.5 & 2.4 & 4.4 & 8.3 & 11.6 & 14.1 & 17.4 & 18.6 & 17.4 & 15.5 & 9.3 & 7.8 & 10.6 & 5.6 \\
\hline $\begin{array}{l}\text { Averages } \\
1965-1980\end{array}$ & 4.3 & 3.7 & 4.5 & 8.0 & 11.5 & 14.4 & 17.3 & 19.3 & 18.3 & 15.4 & 11.0 & 7.2 & 11.3 &.- \\
\hline Stu. Der. & 1.5 & 1.5 & 1.0 & 1.0 & 0.6 & 0.9 & 0.9 & 0.6 & 0.8 & 0.7 & 1.0 & 1.0 & -- & .. \\
\hline $\begin{array}{l}\text { Minininum } \\
\text { Daily }(b-e)\end{array}$ & 0.2 & 0.5 & 2.4 & 4.0 & 8.0 & 11.0 & 14.0 & 17.0 & 14.6 & 11.1 & 7.0 & 2.4 & -- & -- \\
\hline $\begin{array}{l}\text { Maximumin } \\
\text { Daily (b-e) }\end{array}$ & 8.3 & B.J & 8.6 & 12.8 & 15.0 & 17.7 & 21.0 & 21.5 & 21.1 & 18.5 & 15.9 & 11.3 & -. & -- \\
\hline
\end{tabular}

(4) Recorded values adjusted by couputer-simulation to compensate for measurement errors and inissing data (1961-1974). 
TABLE 5.26. Discharge Lines to Columbia River From Hanford Reservation

\begin{tabular}{|c|c|}
\hline Area -.. & _ \\
\hline $100-B / C$ & 12-1n. steel pipe \\
\hline $100-B / C$ & $42-i n$. steel pipe \\
\hline \multicolumn{2}{|l|}{$\begin{array}{l}100-K e \\
\text { and } \mathrm{KW}\end{array}$} \\
\hline $\begin{array}{l}100-\mathrm{Ke} \\
\text { and } \mathrm{KH}\end{array}$ & Tro $B 4-$ in. steel pipes \\
\hline \multicolumn{2}{|l|}{$100-4$} \\
\hline $100-4$ & 3- by 4 -ft concrete chute \\
\hline $100-\mathrm{H}$ & $42-i n$. steel pipe \\
\hline $100-\mathrm{N}$ & $\begin{array}{l}66-\text { in. pipe to } 12-\mathrm{ft} \text { concrete } \\
\text { flume on riverbank }\end{array}$ \\
\hline $100-\mathrm{N}$ & 102-in. steel pipe \\
\hline LPPSS (HGP) & 132-in. Steel pipe \\
\hline $100-D / 0 R$ & 12-in. steel pipe \\
\hline $100-0 / 0 R$ & Iwo 42-in. steel pipes \\
\hline 300 & $\begin{array}{l}24-\text { in. concrete pipe terininating as a } 30 \text {-in. } \\
\text { balf-round corregated metal pine }\end{array}$ \\
\hline 300 & 36-in. steel pive \\
\hline 300 & 12-in. steel pipe \\
\hline $\begin{array}{l}\text { [HOO-B/C } \\
\text { WPPSS (HIGP) }\end{array}$ & 24-i11. concrete pipe tenuinating as a $30-$ \\
\hline
\end{tabular}

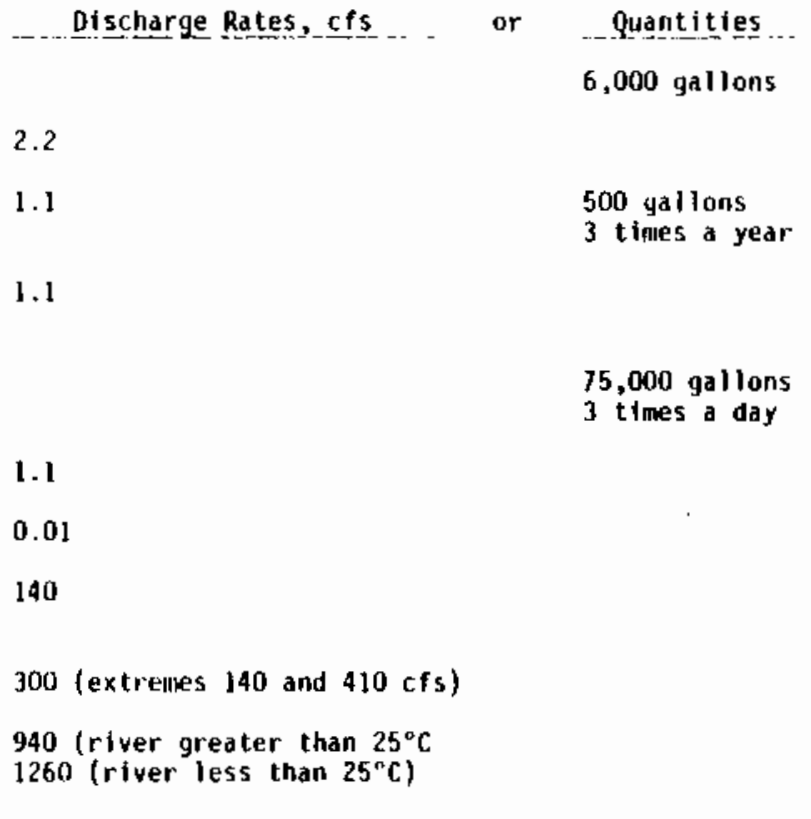
6,000 gallons

$4.4(2.2$ to 22$)$

2.2 (average)

0.01

$1.1(0.04$ to 2.3$)$

940 (rtver greater than $25^{\circ} \mathrm{C}$

\section{6 to $12 /$ day} 12,000 gallons 
TABLE 5.26. (contd)

$$
\text { Ared }
$$

$140-E / C$

$100-B / C$

$100-\mathrm{Ke}$

and $K \mathbf{H}$

$100-\mathrm{Ke}$

and $\mathrm{KW}$

$100-\mathrm{N}$

$100-\mathrm{H}$

$100-\mathrm{N}$

$100-N$

$100-n$

WPHS (HGP)

I00-0/Dit

$100-D / 0 R$

300

300

jư

\section{Oackflush pumin inlet screens}

Orains and filter backwash

Backflush pullp inlet screens

Drains, overfluw and cooling water

for conpressors and pumps

Backflush pump inlet screens

Overflow froul filtered water and

raw water storaye tanks, conden-

sate from medium pressure streall

systein, fitler backwash

Filtered water overflaw, and wasto

froll floor drains

Iurbise condenser cooling water

and graphite beat exchanger

cooling water

Stean cundenser cooling water

\section{Steam condenser cooling water}

Backtlush puap inlet screens ance a worth

the punp inlet screens once

filter backwash and process coolant and wash water, hydrauluic test loop water

filter backwash (from waler treatunent plant)

Air conditiuner couling water and fluor drains

Drainatge from ruof and parking lot, tanks for aquatic origanisms

\section{Teliperdutu!e}

\section{Anbient}

2. $\mathrm{B}^{\circ} \mathrm{C}$, above

anbient

Ambient

2. $0^{\circ} \mathrm{C}$ above

ambient

Anbient

11 to $20^{\circ} \mathrm{C}$

above ambient

6 to $8^{\circ} \mathrm{C}$

alove ambient

$16^{\circ} \mathrm{C}$ above

$5.5^{\circ} \mathrm{C}$ abuve

anbjent

15 to $20^{\circ} \mathrm{C}$

above aubient

Anbient

2. Quc above

aubient

Asibient

$25^{\circ} \mathrm{C}$ abuve

2 to $3^{4} \mathrm{C}$

above aubient
Other Potential Nater Qualily Effects

None - untreated raw river water

Total Solfds, Turbidity, Aluminum, Sulfate

Chloride

None-untreated river water

Total Solids, Turbldity, Alutinum, Sulfate. Chloride, Chiorine $(0.25 \mathrm{mg} / \mathrm{l})$

Hone- untreated river water

Total Solids. Aunonia (as well as radio-

active waste) Clilorine $(0.05 \mathrm{lng} / \mathrm{h})$

Turbidity

Sulfate, Chloride, Chlorine (0.05 $\mathrm{mg} / \mathrm{x})$

Alumilltan, Turbidity

Turbidity, Ammonia, Sulfate, Iron, Sodtum,

(occasionally $0.3 \mathrm{mg} / 2$ ) orthophosphate),

Chlorine - 2 to $40 \mathrm{ppb}$.

(Same as above)

Nune - untreated river water

Total Solids, Turbidity, Aluminum Sultate, Chloride, Chlorine $(0.74 \mathrm{ng} / \ell$ ) (nlaximull

$2.2 \mathrm{mg} / \mathrm{ll})$

Total Solids, Turbidity, Aluminum, Sulfate. "Separan" (a proprietary polyacrylanide filter aid) Chlorine $(0.5 \mathrm{mg} / \mathrm{l})$

Alunisum, Sulfate, Chlarine $(0.5 \mathrm{my} / \mathrm{k})$

Total Solids, Turbidity, Organic Nitrogen 
15 to $20^{\circ} \mathrm{C}$ ( 59 to $68^{\circ} \mathrm{F}$ ) above ambient river temperature (Table 5.26). The calculated temperature increment for complete mixing (about 2.5 miles downstream) at the minimum river flow rate of $36,000 \mathrm{cfs}$ would be $0.6^{\circ} \mathrm{C}\left(1.0^{\circ} \mathrm{F}\right)$ (WPPSS 1978).

During operation, the $N$ Reactor, immediately downstream from HGP, discharges a cooling water stream of about $140 \mathrm{cfs}$, with a temperature up to $16^{\circ} \mathrm{C}\left(28.8^{\circ} \mathrm{F}\right)$ above ambient river temperature, to the river. This discharge increases the river temperature by only $0.06^{\circ} \mathrm{C}\left(0.11^{\circ} \mathrm{F}\right)$ at the minimum river flow rate of $36,000 \mathrm{cfs}$ and $0.02^{\circ} \mathrm{C}\left(0.04^{\circ} \mathrm{F}\right)$ at the approximate average river flow rate of $120,000 \mathrm{cfs}$ (WPPSS 1978).

Chemicals are released to the Columbia River at three locations: 1) the 100-N Area, 2) the 100-K Area, and 3) the 300 Area. The primary source of chemicals released to the river, as shown in Table 5.27, is the 100-N Reactor operation. In addition to these chemicals, impurities removed from the river water by the treatment plants also are returned to the river. The intermittent filter backwash contains suspended solids, principally an aluminum hydroxide floc, plus an accumulation of suspended solids removed from the raw river water during the filtration process. Several of the smaller effluent streams, consisting largely of treated water, may contain free chlorine at concentrations up to a maximum of $1 \mathrm{mg} / \ell$. Other chemical concentrations in treated water are mostly the result of use of alum (aluminum sulfate) and small quantities of polyacrylamide filter aids in the water filtration plant (WPPSS 1978).

A summary of the 1980 NPDES monitoring report data for the $100-\mathrm{N}$ and 100-K area discharges is presented in Table 5.28 (Greger 1981). Chemicat parameters of the low-volume waste sampled from March 1980 through February 1981 at the WPPSS Hanford Generating Project are presented in Table 5.29 (WPPSS 1981b).

The production reactors that were cooled directly with river water have been shut down. Nevertheless, the Hanford Reservation still has several sources of low-level radjoactive effluents. These include cooling water at $100-\mathrm{N}$, animal farm waste at $100-\mathrm{F}$ and 300 Areas, and tritium migrating to the river with groundwater from the 200 Area disposal sites (WPPSS 1978). 
TABLE 5.27. Total Annual Direct Chemical Discharge From Hanford Reservation to Columbia River

Materials

Aluminum Sulfate

Chlorine

Polyacrylamide

Salt (rock)

Sodium Dichromate

Sulfuric Acid

Ammonium Hydroxide

Hydrazine

Morpholine

Sodium Hydroxide

Source: WPPSS (1978)

\begin{tabular}{c}
$\begin{array}{c}\text { Existing } \\
\text { Quantity from } \\
100 \text { and } 300 \text { Areas } \\
\text { (tons) }\end{array}$ \\
\hline 260 \\
20 \\
0.8 \\
22 \\
2 \\
650 \\
60 \\
8 \\
1.5 \\
230
\end{tabular}

Existing 100 and 300 Areas

260 
TABLE 5.28. Sunmary of NPDES Monitoring Report Data for 100-N and 100-K Areas (CY 1980)

\section{Sample \\ Parameter}

Flow

(MGD)

Temp.

$\left({ }^{\circ} \mathrm{F}\right)$

$\mathrm{pH}$

in

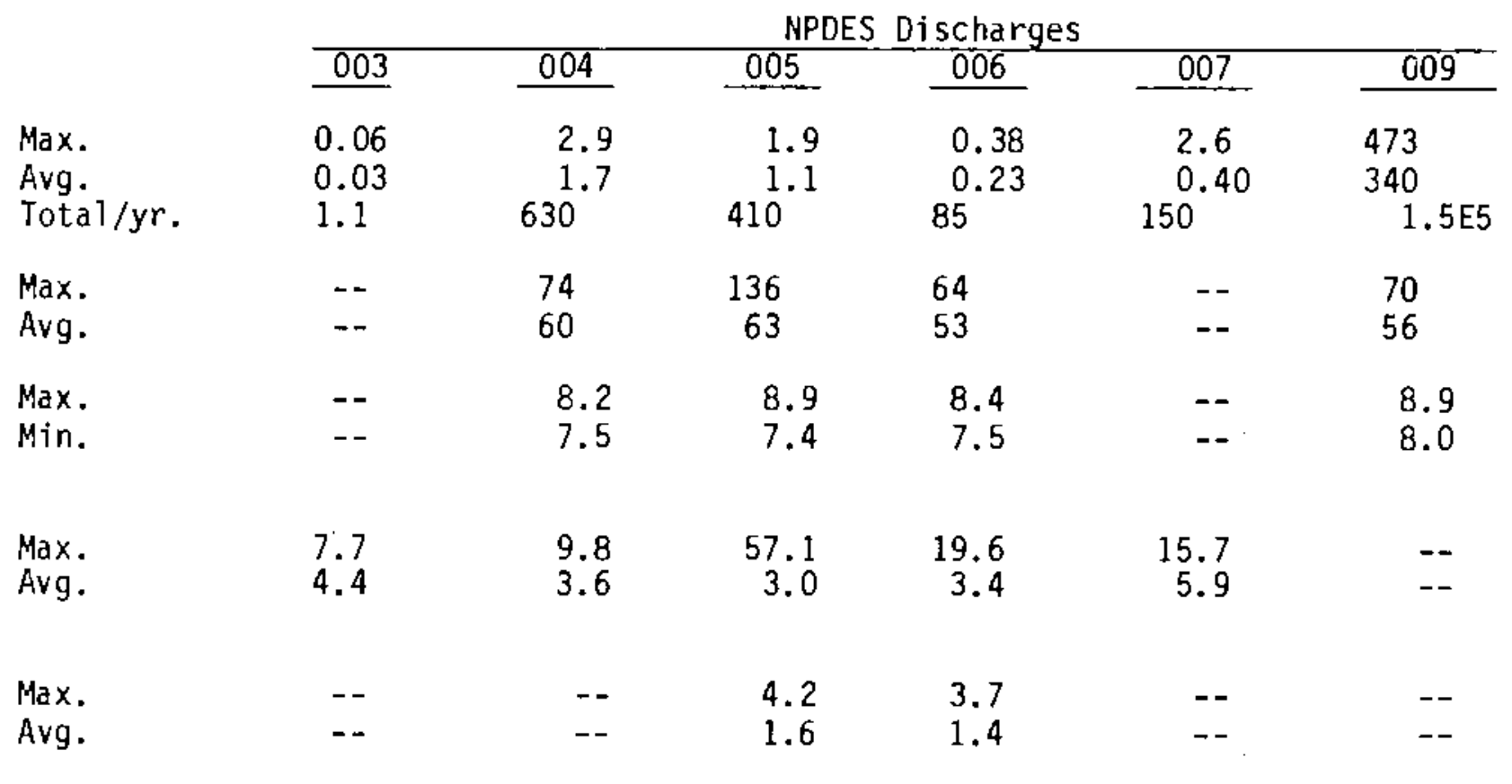

(a) The analytical results for Total Suspended Solids are biased high, especially for Discharge 005, due to the ash fallout from Mt. St. Helens during 1980.

Source: Greger (1981) 
TABLE 5.29. Low-Volume Waste Sampled at the Hanford

Generating Project (March 1980-February 1981)

\begin{tabular}{|c|c|c|c|c|}
\hline $\begin{array}{c}\text { Sample } \\
\text { Parameters }\end{array}$ & & Max. & Avg. & Min. \\
\hline $\mathrm{pH}$ & $\begin{array}{l}-- \\
--\end{array}$ & $8 . \overline{7}$ & -- & 6.2 \\
\hline $\begin{array}{l}\text { Suspended } \\
\text { Solids }\end{array}$ & $\begin{array}{l}\# / \text { day } \\
\mathrm{mg} / \ell\end{array}$ & $\begin{array}{l}4.46 \\
3.1\end{array}$ & $\begin{array}{l}0.43 \\
0.93\end{array}$ & $0 . \overline{5}$ \\
\hline $\begin{array}{l}0 i 1 \text { and } \\
\text { Grease }\end{array}$ & $\begin{array}{l}\text { \#/day } \\
\mathrm{mg} / \ell\end{array}$ & $\begin{array}{l}1.01 \\
1.8\end{array}$ & $\begin{array}{l}0.31 \\
0.59\end{array}$ & 0.5 \\
\hline Total Iron & $\begin{array}{l}\# / \text { day } \\
\mathrm{mg} / \ell\end{array}$ & $\begin{array}{l}0.2 \\
0.25\end{array}$ & $\begin{array}{l}0.041 \\
0.082\end{array}$ & 0.05 \\
\hline Total Copper & $\begin{array}{l}\# / \text { day } \\
\mathrm{mg} / \mathrm{\ell}\end{array}$ & $\begin{array}{l}0.1 \\
0.2\end{array}$ & $\begin{array}{l}0.029 \\
0.058\end{array}$ & $0 . \overline{01}$ \\
\hline
\end{tabular}

Source: WPPSS (1981b)

\subsection{GROUNDWATER}

The Pasco Basin is the appropriate hydrologic boundary to use in assessing the groundwater impact of this project (Figure 5.12). A detailed description of the geohydrologic units that underlie the Hanford Site is found in Gephart (1979). Table 5.30, reproduced from that document, shows the generalized lithologic and hydrologic characteristics of the units. Figure 5.13 is a map showing the locations of the wells on the Hanford Site used to develop this description.

The geological formations at the Skagit/Hanford and Firehouse sites have been divided into seven geohydrologic units according to hydrologic character and properties (Figure 5.14). The vadose zone or unsaturated zone, the unconfined glaciofluvial aquifer, and the upper confining layer are the only geohydrologic units on which the potential NPR facilities could have an impact. 


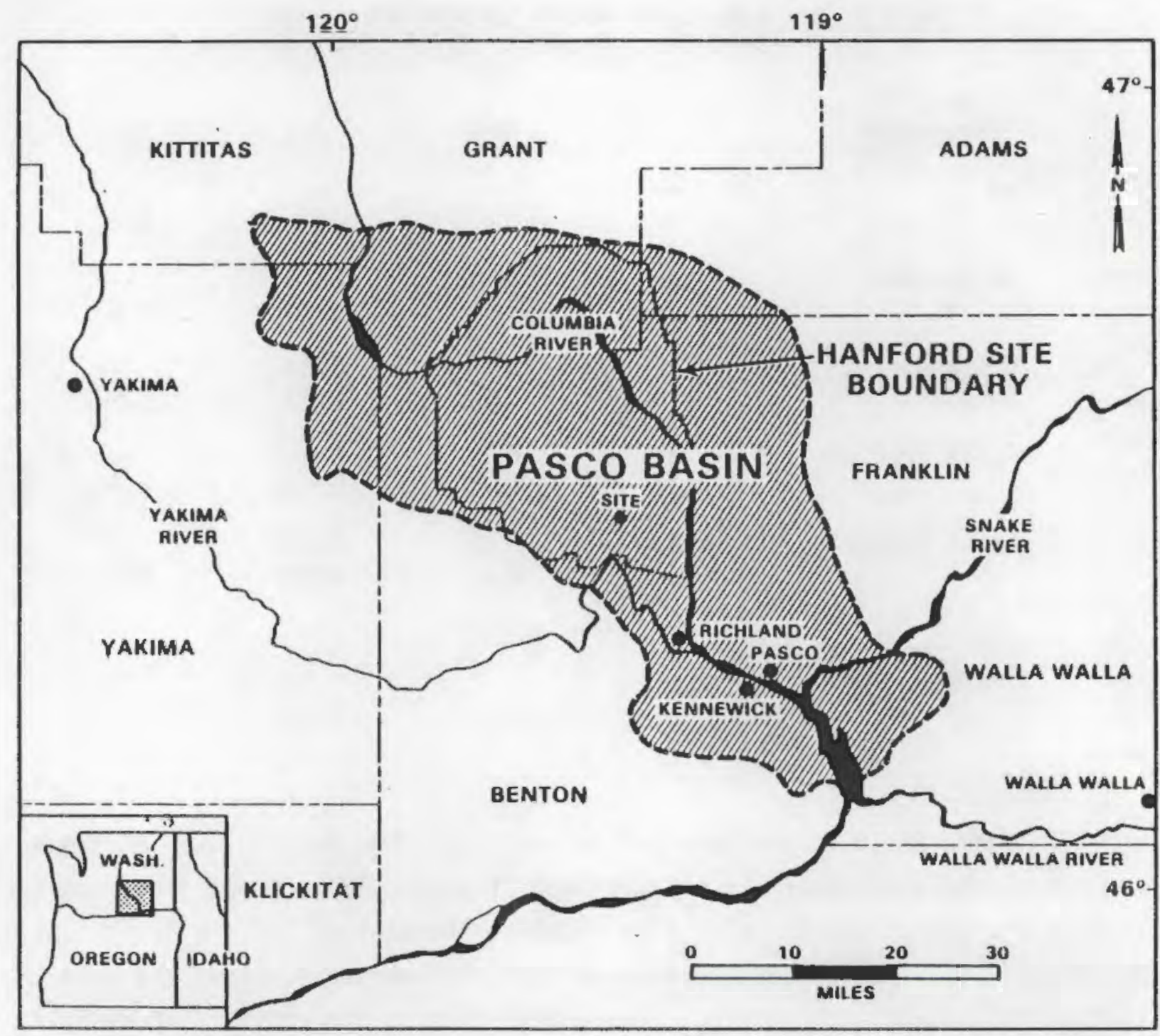

FIGURE 5.12. Pasco Basin Location Map

\subsubsection{Unsaturated Zone}

The unsaturated (vadose) zone lies between the ground surface and the water table. Characteristically, this zone contains liquid water under less than atmospheric pressure, and water vapor and air or other gases usually at atmospheric pressure. In parts of this zone, interstices may be temporarily filled with water. The springs that issue from the flanks of the Rattlesnake Hills are also classified as belonging to the vadose zone. A more detailed 


\section{TABLE 5.30. Major Geologic Units in the Hanford Region and}

Their Hydrologic Character(a)

\section{-. Stratatigraphic}

Alluviun, Colluvium, asid Eoli an Sediments Glaciofluvial Sands Touchet silts
and Gravels (Hanford Formation)

Palouse Soll

Aingold Formation

Upper Ringold

\section{Pasco Gravels \\ Bed or Flow Unit}

Genera! Llthologlc Character

sands, silts, and clays modified by wind erosion

Fine-grained facles of the glaciofluvialdeposits. Bedded in quiet

Predoninantly coarse-grained gravels. Cobbles and sands with cut and fill. 0-400

Calcareous sand and silt eollan

deposit mainly derivel froe pingold formation

Locally capped by callche. Mostly Hell-bedded fluvial silts and sands with some gravels.

Middle Ringold

Sands and gravels well-sorted,

compact, but varlably cemented.

Lower Ringold

sllta and clays with interbedded gravels and sands. Clay is characteristicallyblue, but may be green, brown, or tan.

Saddle Mountains Basalt flows with interflow zones. Several sedimentary interbeds of

Columbia River Ellensburg formation are present.

Wanapum

Grande Ronde

Basalt flows wth interflow zones. Few interbeds of Ellensburg formation are present.

Basalt flows with interflow zones. Interbeds of Ellensburg formation are infrequently and very thin when present.
Average

Thickness

in Feet

Dunes to

50

Hydrologlc Character

Occur everywhere above the water table.

Occur above the water table except between the high terrace plateaus and the Columbia River. Has very high tra.s.
storage.

Above water table when present. Sand and gravel beds have ductivity and storage. Some beds of silty clay or clay are essentially impermeable.

0-400

$0-400$

Flows are dense with lowhydraulic conductivity. Interflows and interbeds have higher hydraulic conductivity and transmissivity.
Aquiclude

Dry

Occasionally an UnconAned Aquifer or Dry

Dry

Unconf ined Aguiter

(a) ditepliart et al. (1979) 


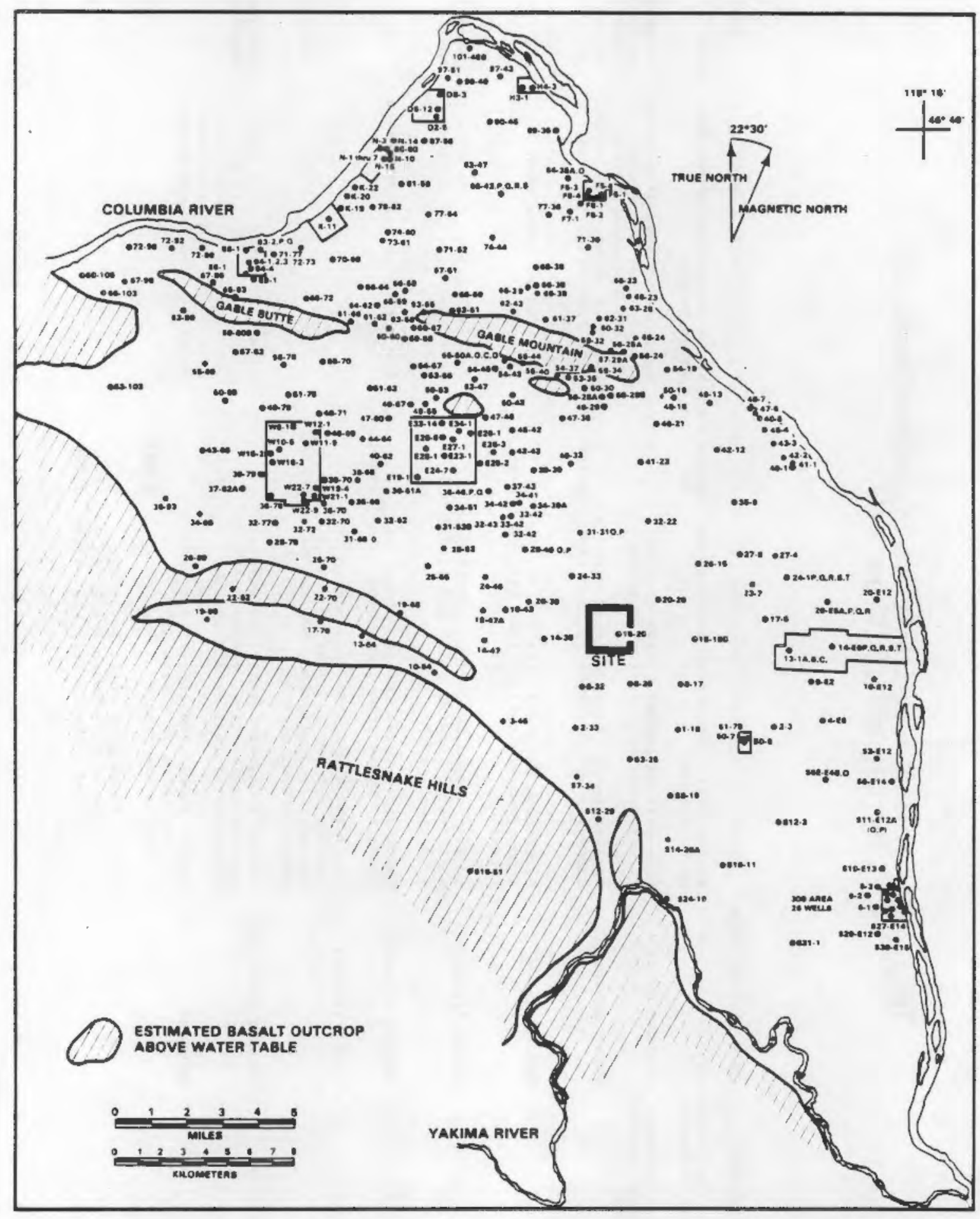

FIGURE 5.13. Selected Hanford Well Locations 


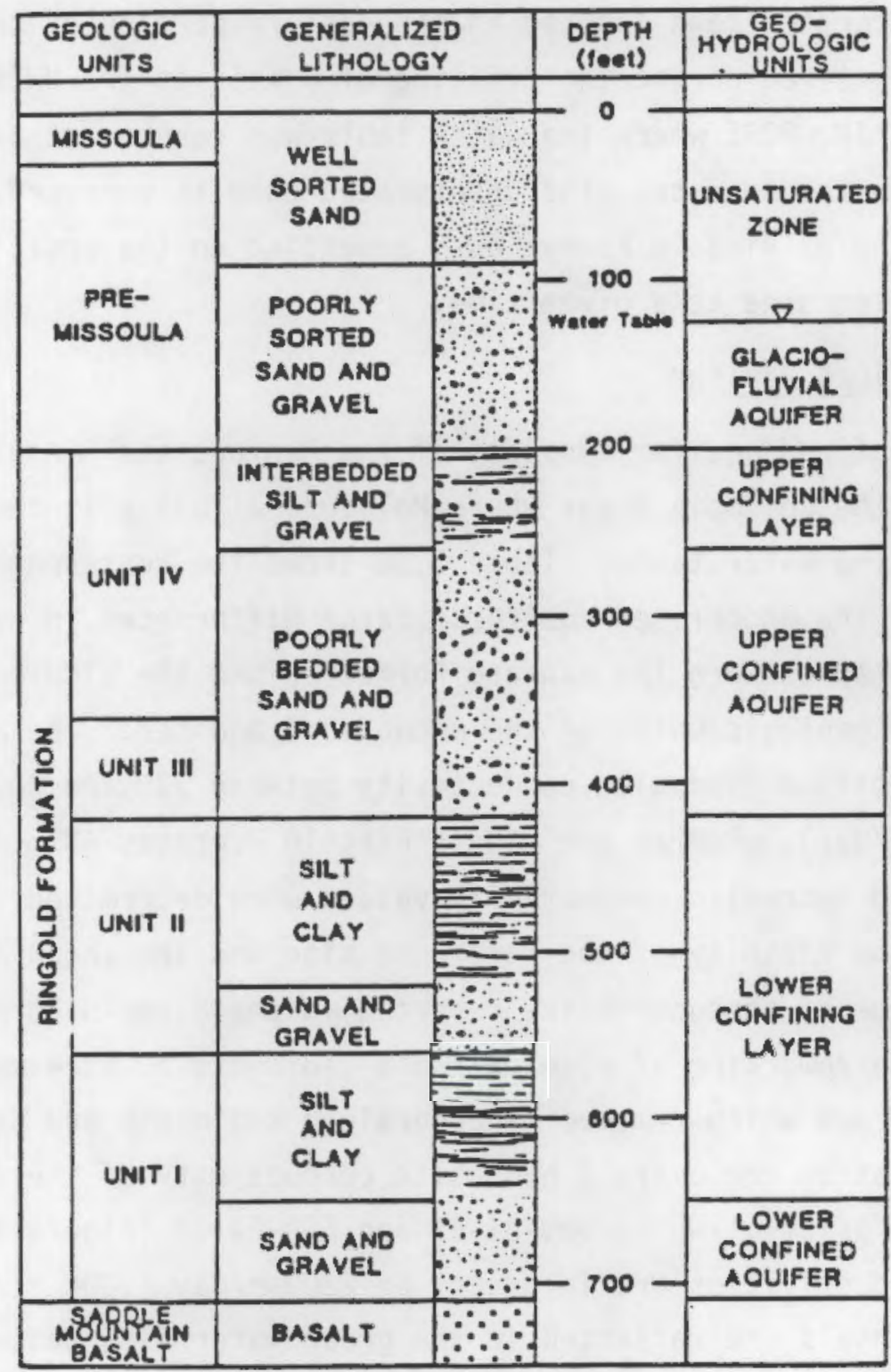

FIGURE 5.14. Generalized Geologic and Geohydrologic Column (PSP\&L 1981) 
discussion of the vadose zone based on work done at the reference site is contained in Appendix D of this report.

Within the Hanford Site, the unsaturated zone ranges in thickness from less than $1 \mathrm{~m}$ near the Columbia River to over $115 \mathrm{~m}$ ( 1 to $350 \mathrm{ft}$ ) beneath the 200 Area plateau and is bounded by the land surface and the water table. The thickest unsaturated zone located in the eastern portion of the Pasco Basin has been encountered during the drilling of a well in the NW1/4, SW1/4, Section 27, T11N, R29E where the water table was reached at a depth of $150 \mathrm{~m}$ (456 ft) below the surface. The unsaturated zone is composed of sediments of the Hanford and/or Ringold Formations, depending on the position of the water table in a given area at a given time.

\subsubsection{Unconfined Aquifer}

The unconfined aquifer consists of the Hanford and Ringold Formations, except along the Columbia River where Holocene alluvium is thick enough to extend below the water table. Table 5.30 shows the representative hydraulic properties of the unconfined aquifer. Large differences in hydraulic conductivity appear between the Hanford Formation and the middle Ringold unit. The two major geologic units of the unconfined aquifer. The Hanford Formation normally exhibits a hydraulic conductivity between 330 and $3300 \mathrm{~m} /$ day $(1000$ and 10,000 ft/day); whereas the middle Ringold averages $43 \mathrm{~m} /$ day (130 ft/day). Field measured hydraulic conductivity values were determined from pump tests on wells in the vicinity of the reference site and are shown in Table 5.31. The great range of conductivities reported in the Ringold Formation may be due in part to the reworking of older Ringold sediments by streams of Hanford or glaciofluvial age which removed finer grained sediments and cementation, thereby increasing the overall hydraulic conductivity of the formation. This situation may exist at Wells 699-31-31 and 699-24-33 (Figure 5.13) where hydraulic conductivities are in excess of $2300 \mathrm{~m} /$ day $(7000 \mathrm{ft} /$ day). These permeable channels are reflected in the groundwater flow pattern of the region.

There are limited data available on storage coefficients and specific yields at the Hanford Site. Those presented in Table 5.32 are extracted from reports and are estimates for the unconfined aquifer. Newcomb et al. (1972) provide an areal estimate of 0.11 for the storage coefficient in the 200 West 
TABLE 5.31. Results of Pumping Tests Completed Within the Unconfined Aquifer

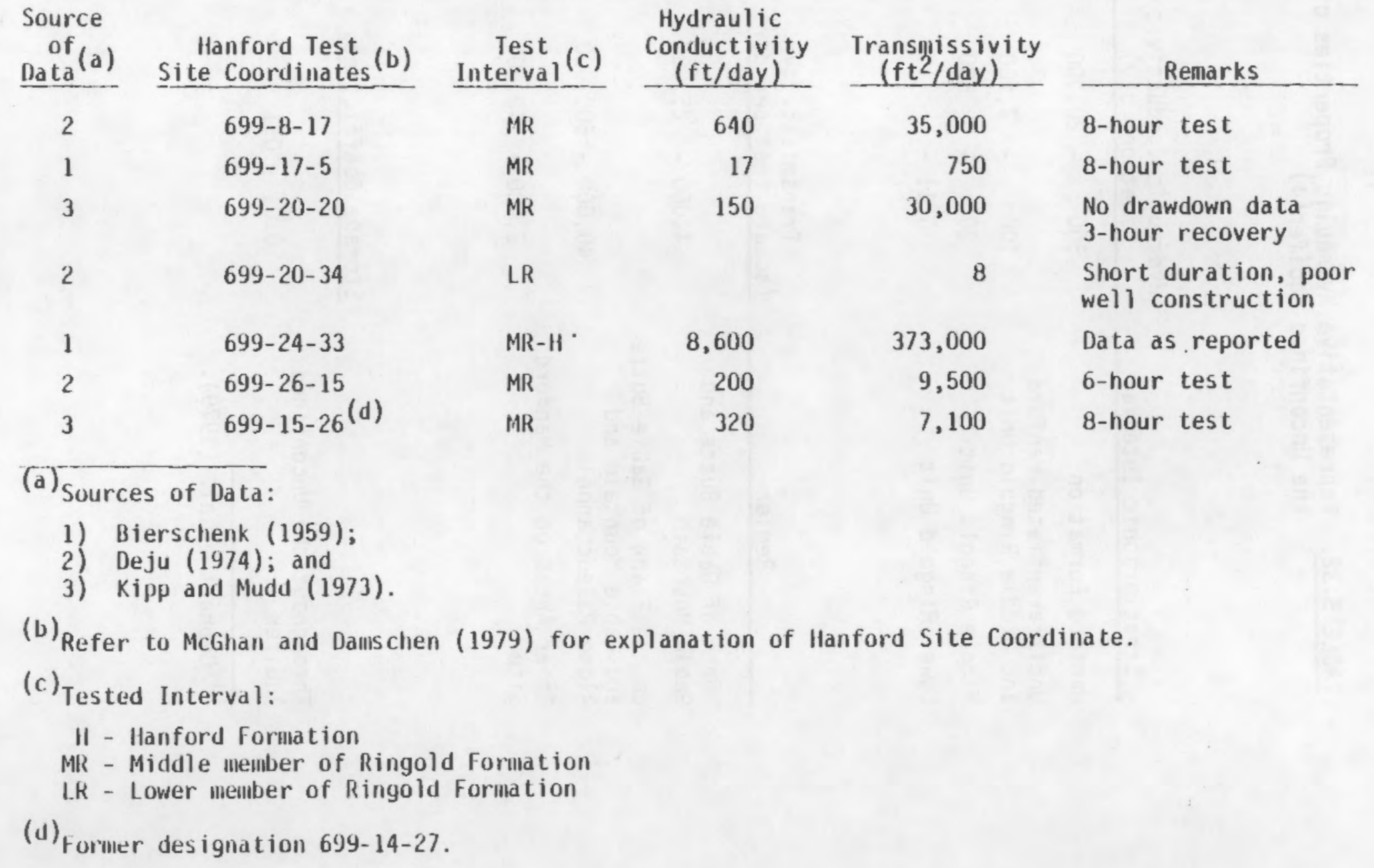


TABLE 5.32. Representative Hydraulic Properties of the Unconfined Aquifer(a)

Stratigraphic Interval

Hanford Formation

Undifferentiated Hanford and Middle Ringold Unit

Middle Ringold Unit

Lower Ringold Unit

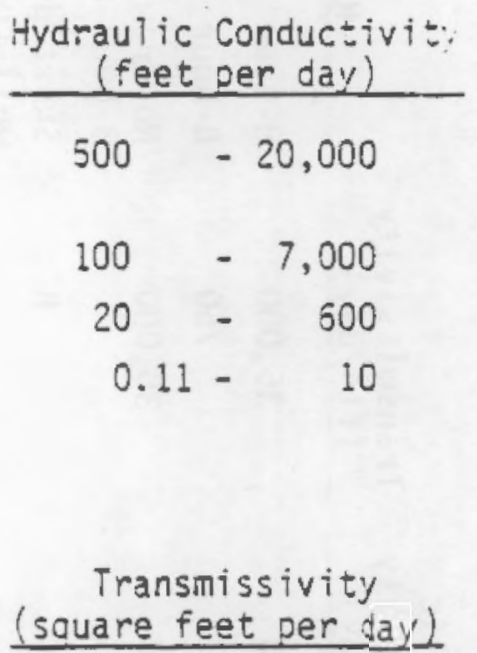

North of Gable Butte and Gable Mountain

On the Flank of Gable Butte and Gable Mountain and

Along Paleochannels

Other Areas on the Haniord Site

$$
\begin{aligned}
& 4,000-25,000 \\
& 40,000-600,000 \\
& 2,000-40,000
\end{aligned}
$$

Storage Coerficients

Throughout the Unconfined Aquifer

(3) Gephart et al. (1979).
$0.01-0.1$ 
area. This estimate is based on the growth of the groundwater mounds between 1948 and 1953 and the water disposal rate during this period. The range of values estimated for the Hanford unconfined aquifer was 0.006 to 0.35 , but the general quality of measurement was poor.

The base of the aquifer is defined by either the silt and clay sediment of the lower Ringold unit or the basalt surface. The thickness of the aquifer ranges from zero to $100 \mathrm{~m}(0$ to $300 \mathrm{ft}$ ). Where the Hanford Formation extends below the water table, it is generally composed of coarse sand, gravel, and cobbles with occasional finer grained sediments. The Ringold Formation is divided into an upper, middle and lower unit, each having different textures as previously noted in Table 5.30. The unconfined aquifer is dominated by the middle Ringold, composed of sorted sands and gravels with a wide range of cementation. The degree of cementing controls the hydraulic properties of this unit; i.e., the less the unit is cemented, the higher its hydraulic conductivity.

The lateral boundaries of the unconfined aquifer are identified by the anticlinal basalt structures which rim the Pasco Basin. These include the Saddle Mountains to the north, Umtanum and Yakima Ridges on the west, Rattlesnake and Horse Heaven Hills on the south, and on the east by a broad monocline. The water table lies within the basalt in areas where the unconfined aquifer thins over bedrock; the most notable of these sites being Gable Mountain and Gable Butte located just south of the alternate site.

\subsubsection{Water Level Chariges}

The groundwater tables for 1944 and 1980 for the Hanford Site reflect the direction of groundwater flow and the effects of natural and artificial recharge and withdrawal. The water level elevations in the glaciofluvial aquifer at the reference site range from $121.63 \mathrm{~m}(400.09 \mathrm{ft}) \mathrm{ms} 1$ at the northeastern edge of the site to $121.11 \mathrm{~m}(399.39 \mathrm{ft}) \mathrm{msl}$ at the southern edge. The water table at the reference site in 1944 had a measured elevation of $115.5 \mathrm{~m}(385 \mathrm{ft}) \mathrm{msl}$, which is $6 \mathrm{~m}(20 \mathrm{ft})$ below the present water table, indicating the impact of artificial recharge on and near the Hanford Site.

Artificial recharge and groundwater withdrawal, that would affect the reference site, occur within the glaciofluvial aquifer from waste injection 
operations in the 200 East and 200 West Areas of the Hanford Site, from irrigation in the Cold Creek Valley, and from withdrawal of water at Hanford Site facilities. The historical sequence of water table maps representing the years 1980, 1978, 1973, 1968, and 1944 (Figures 5.15 through 5.19) illustrates the water table changes which have occurred since Hanford began operations in 1944. Comparison of the 1944 water table map (Figure 5.19) with the 1973 map (Figure 5.17) shows a $10 \mathrm{~m}(30 \mathrm{ft}$ ) increase in water table elevation beneath B pond. Following 1973, the water table elevation gradually declines (compare Figures 5.17 and 5.15) due to the closing of the PUREX plant. Restarting of PUREX in late 1983 is expected to cause water levels to rise again in response to increased discharges of water.

Another groundwater mound is centered below the $U$ Pond where water levels have risen approximately $28 \mathrm{~m}$ (85 ft) over the past 35 years. Decreased disposal to this facility following 1972 has not reduced groundwater elevations significantly (Figure 5.15). This may be due in part to increased irrigation in the Cold Creek Valley west of the Hanford Site boundary which recharges into this area. The combined effects have resulted in a regional increase in groundwater gradient from 0.75 to $0.95 \mathrm{~m} / \mathrm{km}$ ( 4 to $5 \mathrm{ft} / \mathrm{mi}$ ) in 1944 to 1.32 to $1.52 \mathrm{~m} / \mathrm{km}$ (7 to $8 \mathrm{ft} / \mathrm{mi}$ ) in 1980 .

\subsubsection{Confined Aquifers}

The confined aquifers underlying the Hanford Site have been combined into one of three major groups according to the basalt flows in which they 1 ie: Saddle Mountains; Wanapum; or Grand Ronde basalts. The aquifers lying within each basalt sequence tend to have similar hydrologic properties, with groundwater flow occurring primarily horizontally in the interbeds between the individual flows and vertically where fractures or other structures are present. Although understanding the confined aquifer system is essential to understanding the regional hydrology, these aquifers play a minor role in the siting of the proposed facility. Because of this, comments on the confined system are restricted to the uppermost sequence of confined aquifers, those of the Saddle Mountains basalt. 


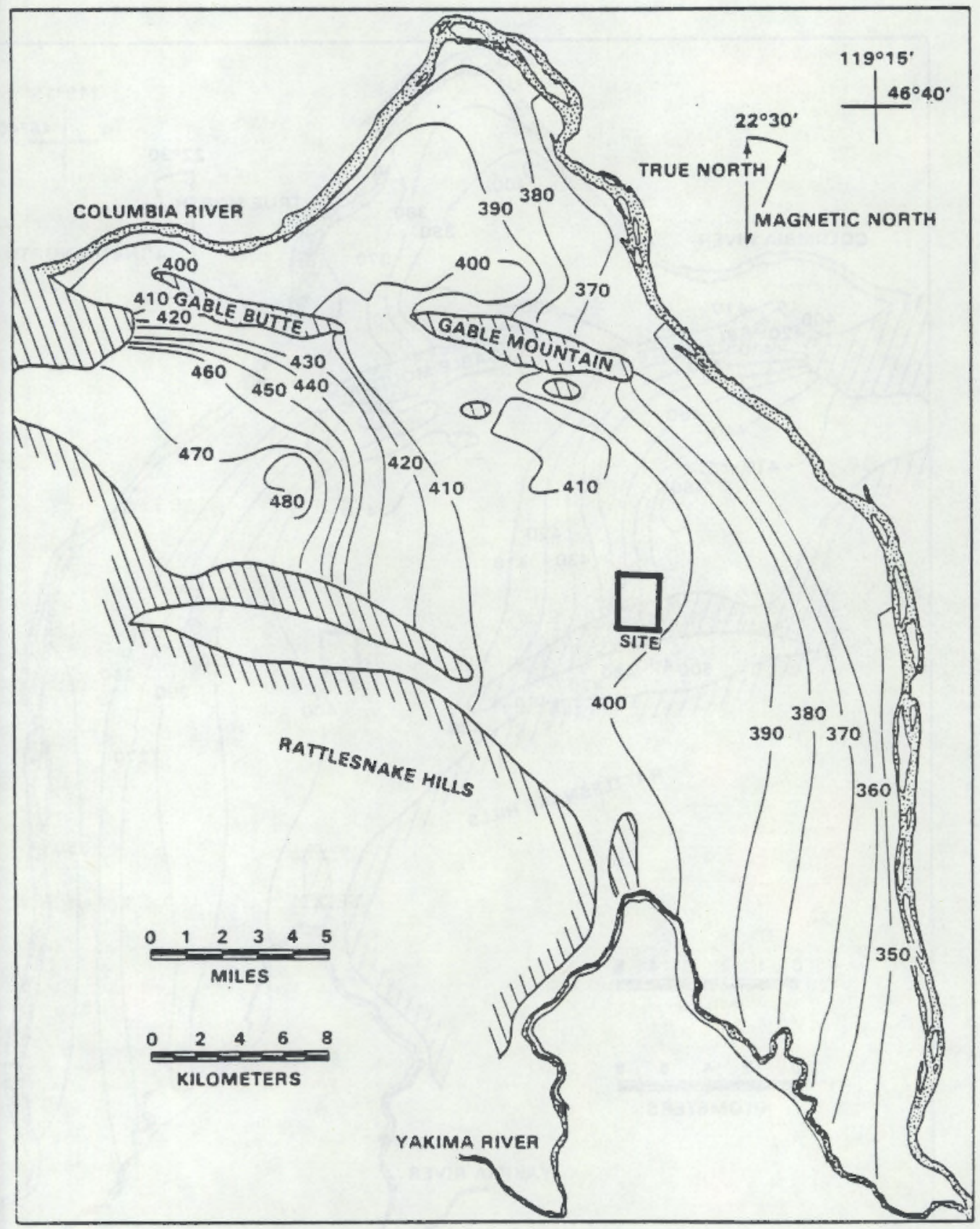

FIGURE 5.15. Water Table Map for the Hanford Reservation for 1980 


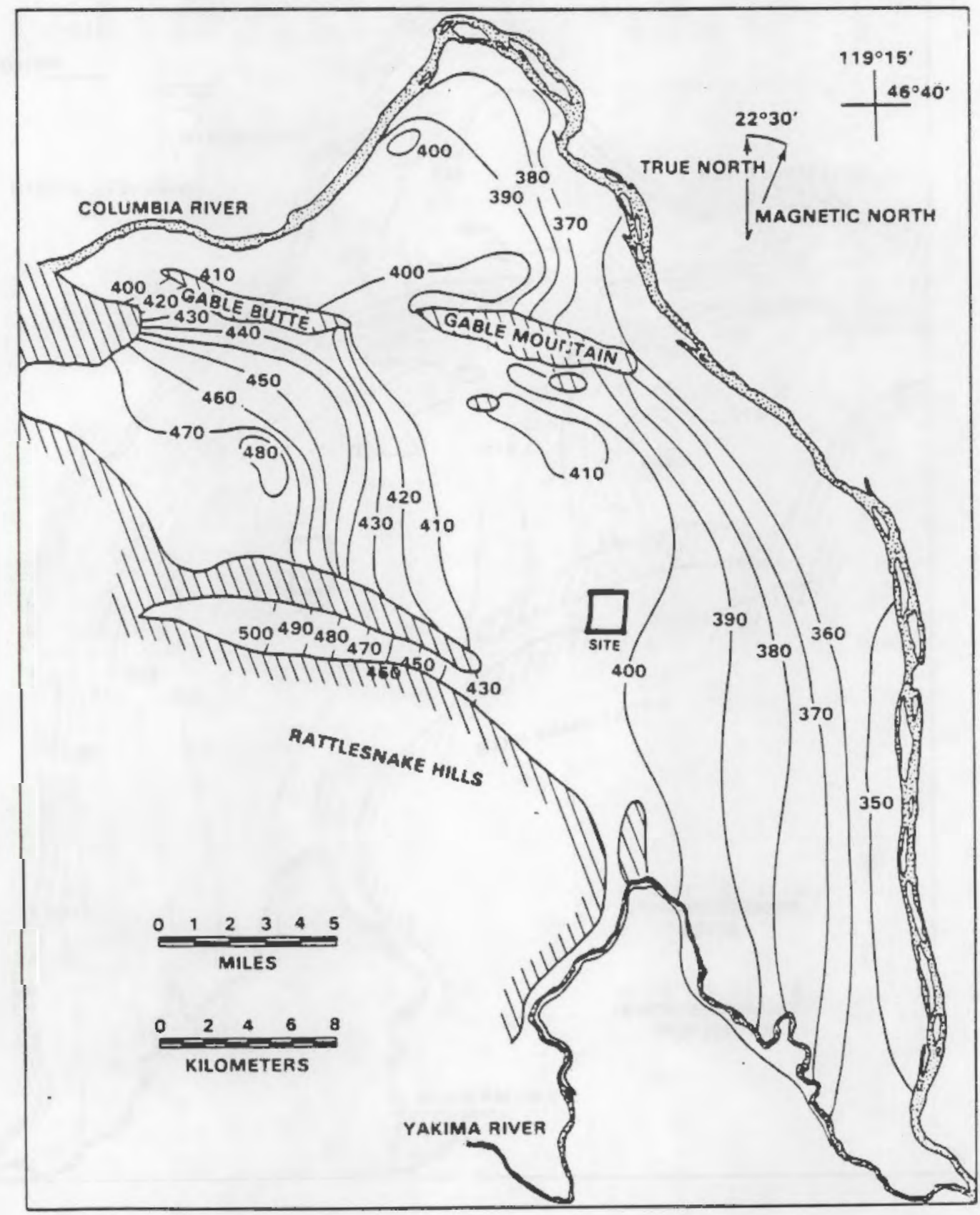

FIGURE 5.16. Water Table Map for the Hanford Reservation for 1978 


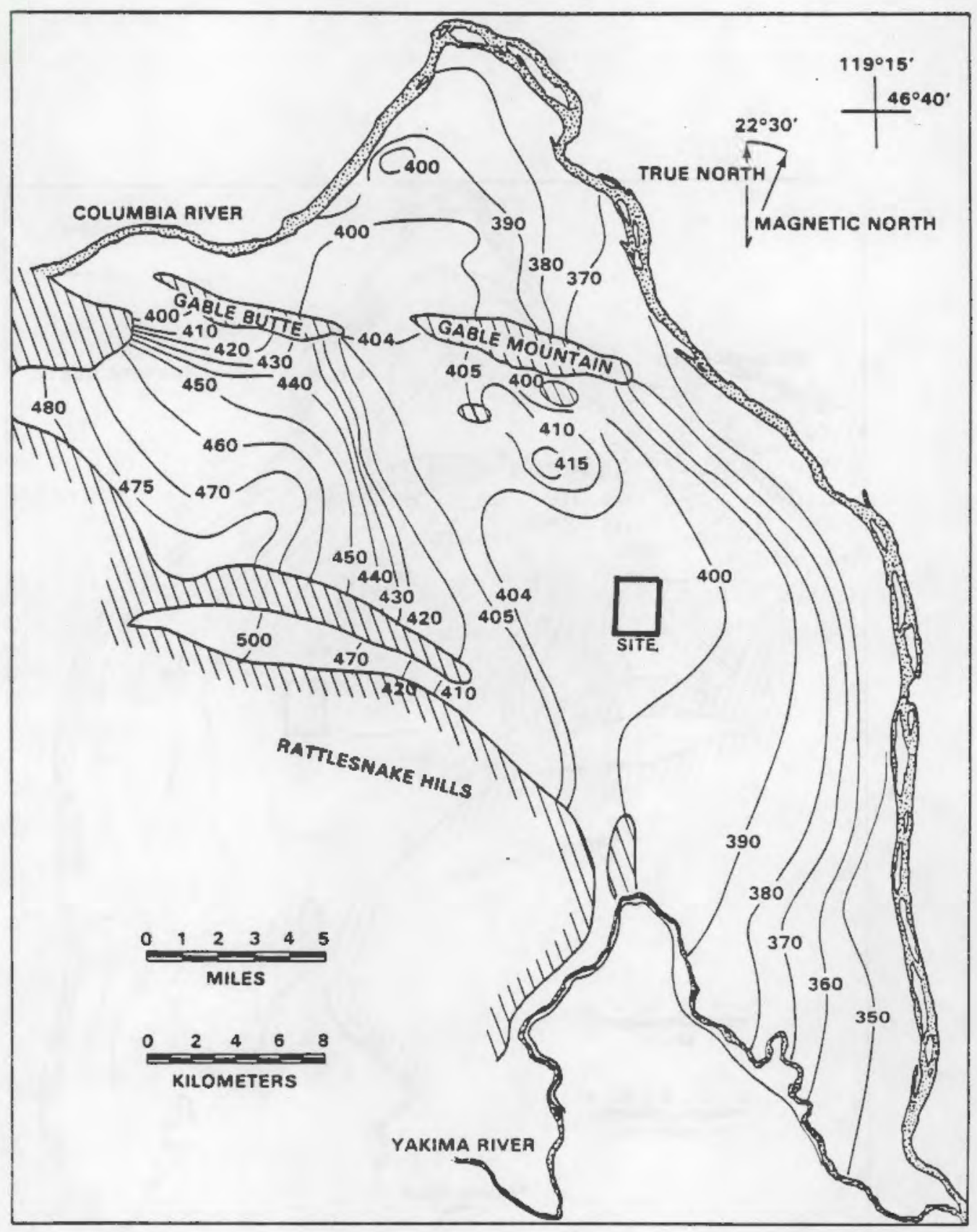

FIGURE 5.17. Water Table Map for the Hanford Reservation for 1973 


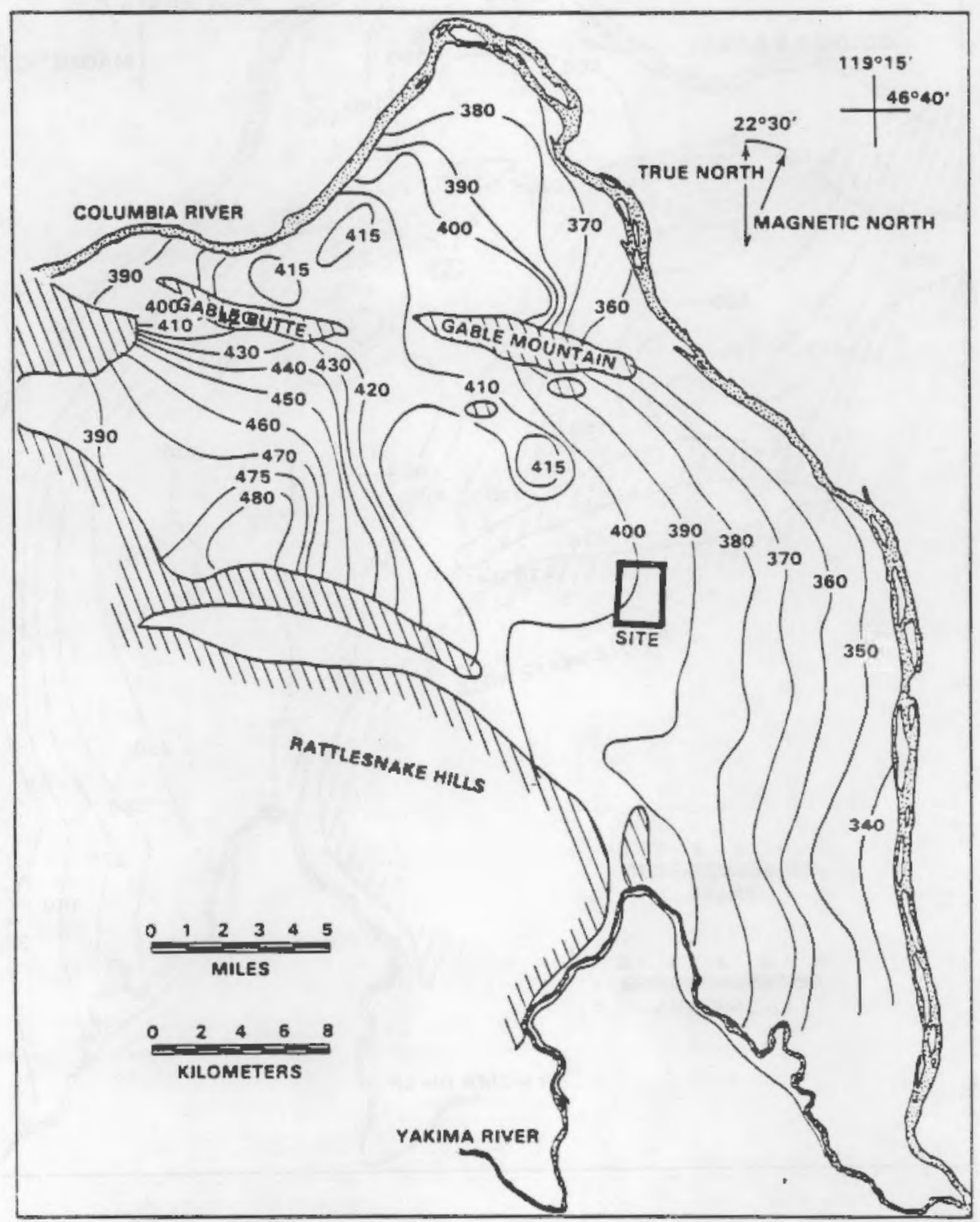

FIGURE 5.18. Water Table Map for the Hanford Reservation for 1968 


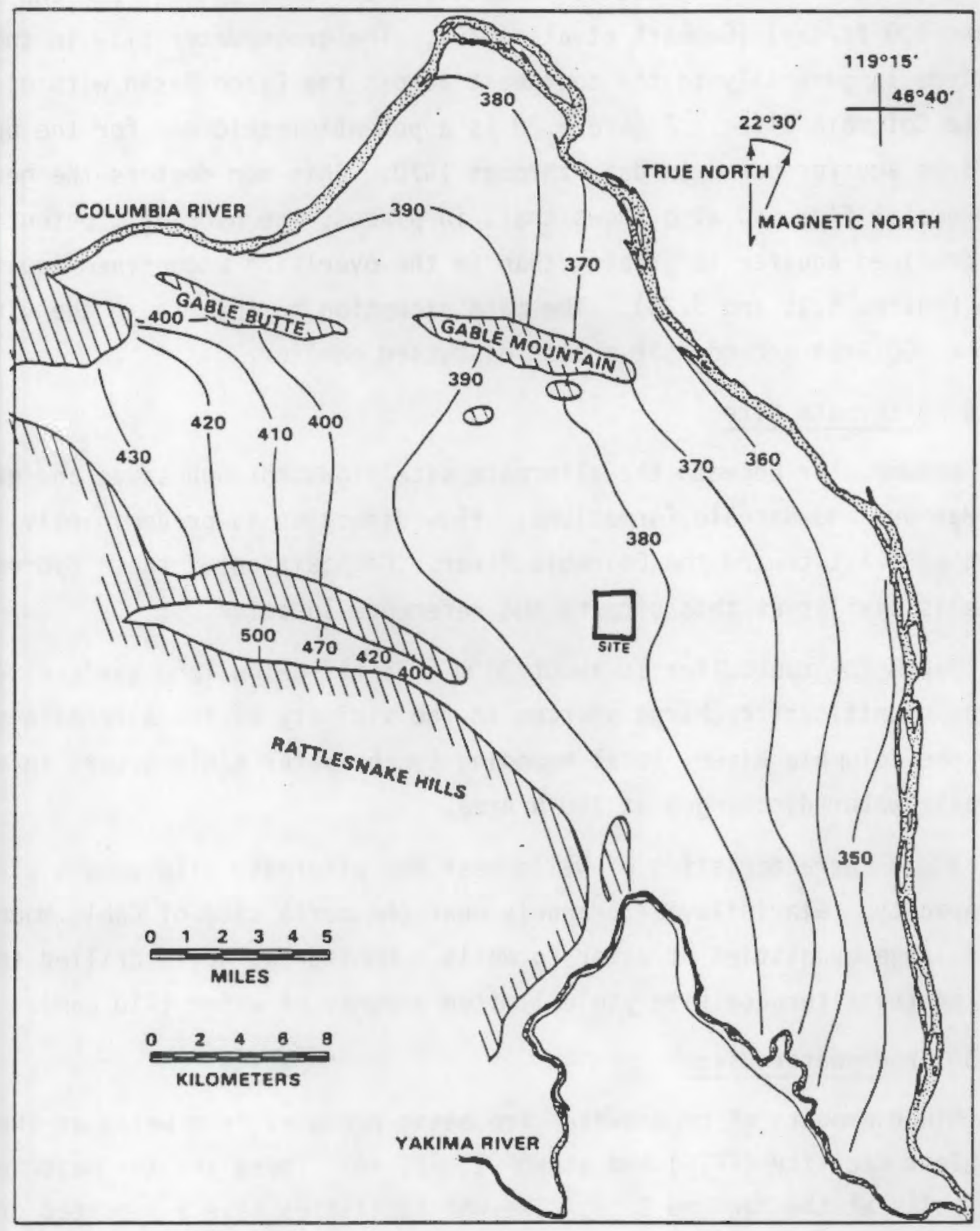

FIGURE 5.19. Water Table Map for the Hanford Reservation for 1944 
Groundwater in the Saddle Mountains confined aquifers occurs principally in the interbeds and interflows separating individual basalt flows. Flow rates are relatively small; hydraulic conductivities range between 0.3 and $33 \mathrm{~m} /$ day (1 and $100 \mathrm{ft} /$ day) (Gephart et a1. 1979). The groundwater flow in these aquifers is generally to the southeast across the Pasco Basin with discharge to the Columbia River. Figure 5.20 is a potentiometric map for the uppermost confined aquifer based on data through 1970. This map depicts the general groundwater flow and also shows that, in places, the hydraulic potential in the confined aquifer is greater than in the overlying unconfined aquifer (compare Figures 5.15 and 5.20 ). The main exception to this is in the vicinity of the 200 Area groundwater mounds discussed earlier.

\subsubsection{Alternate Site}

Groundwater beneath the alternate site flows through sands and gravels of the Hanford and Ringold Formations. Flow direction is predominantly to the north and east toward the Columbia River. Composition of these hydrogeologic units is similar at this site to the reference location.

Depth to groundwater is about $38 \mathrm{~m}(125 \mathrm{ft})$ below land surface. There are no significant recharge sources in the vicinity of the alternate site. Near the Columbia River, local mounding to the water table occurs in response to waste water discharges at $100 \mathrm{~N}$ Area.

Yield characteristics of wells near the alternate site show a wide range of capacity. Glaciofluvial channels near the north side of Gable Mountain yield large quantities of water to wells. Monitoring wells drilled to the west of the alternate site yield limited amounts of water (<10 gpm).

\subsubsection{Groundwater Usage}

Minor amounts of groundwater are being produced from wells at the Fast Flux Test Facility (FFTF) and at WNP-1, -2, -4. These are the major production wells at the Hanford Site. The WNP facilities have a reported groundwater usage of $946 \mathrm{~m}^{3}(9,250,000 \mathrm{gal})$ per month or $22.7 \mathrm{lpm}$ (6 gpm) (WPPSS 1981), most of which comes from aquifer interbeds in the basalts. These amounts of water withdrawal will have little or no impact on the reference and alternate sites. 


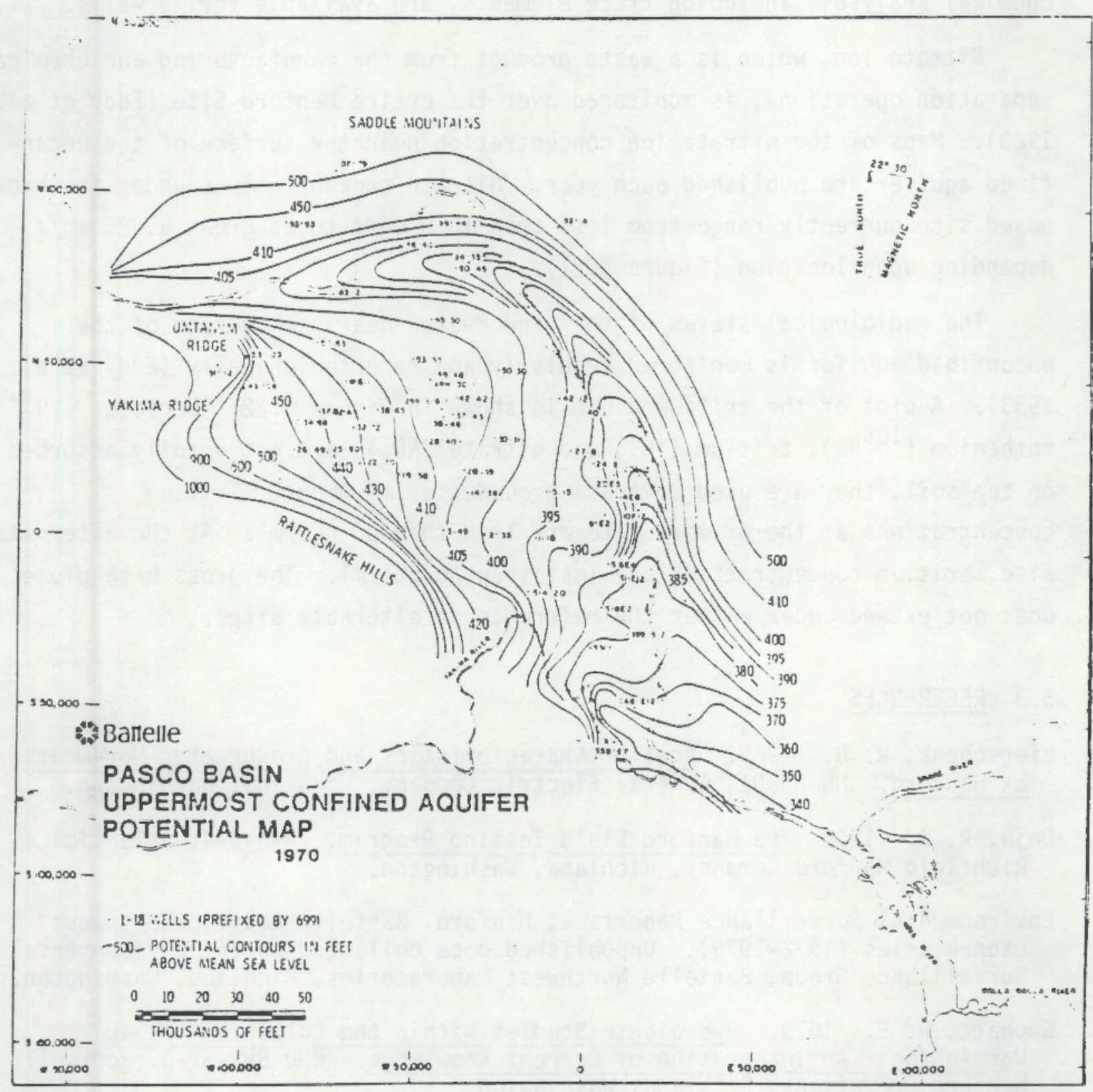

FIGURE 5.20. Uppermost Confined Aquifer Potential Map 


\subsubsection{Groundwater Quality}

The chemical quality of the groundwater in the unconfined aquifer has been determined at numerous locations from 1975 to the present. Complete inorganic chemical analyses, including trace elements, are available for 79 wells.

Nitrate ion, which is a waste product from the manufacturing and chemical separation operations, is monitored over the entire Hanford Site (Eddy et al. 1983). Maps of the nitrate ion concentration near the surface of the unconfined aquifer are published each year. Nitrate concentrations under the proposed site currently range from less than $10.0 \mathrm{mg} / \ell$ to as great as $25 \mathrm{mg} / \ell$ depending upon location (Figure 5.21).

The radiological status of the groundwater near the surface of the unconfined aquifer is monitored regularly and reported annually (Eddy et al. 1983). A plot of the tritium plume is shown in Figure 5.22. Because ruthenium $\left({ }^{106} \mathrm{Ru}\right)$, tritium $\left({ }^{3} \mathrm{H}\right)$, and nitrate $\left(\mathrm{NO}_{3}\right)$, are not readily adsorbed on the soil, they are used to trace groundwater movement. Tritium concentrations at the primary site are less than $60 \mathrm{pCi} / \mathrm{ml}$. At the alternate site, tritium concentrations are less than $30 \mathrm{pCi} / \mathrm{ml}$. The gross beta plume does not extend under either the reference or alternate sites.

\subsection{REFERENCES}

Bierschenk, W. H. 1959. Aquifer Characteristics and Groundwater Movements at Hanford. HW-60601, General Electric Company, Richland, Washington.

Deju, R. A. 1974 The Hanford Field Testing Program. ARH-C-4, Atlantic Richfield Hanford Company, Richland, Washington.

Environmenta1 Surveillance Reports at Hanford, Battelle Pacific Northwest. Laboratories (1972-1979). Unpublished data collected by the Environmental Surveillance Group, Battelle Northwest Laboratories, Richland, Washington.

Gephart, R. E. 1979. Hydrologic Studies Within the Columbia Plateau Washington: An Integration of Current Knowledge. RHO-BWI-ST-5, Rockwe11 Hanford Operations, Richland, Washington.

Glenn, J. L., and R. 0. Van Atta. 1973. Relations Among Radionuclide Content and Physical, Chemical, and Mineral Characteristics of the Columbia River Sediments. USGS Professiona T Paper 433-M, prepared in cooperation with the U.S. Atomic Energy Conmission. 


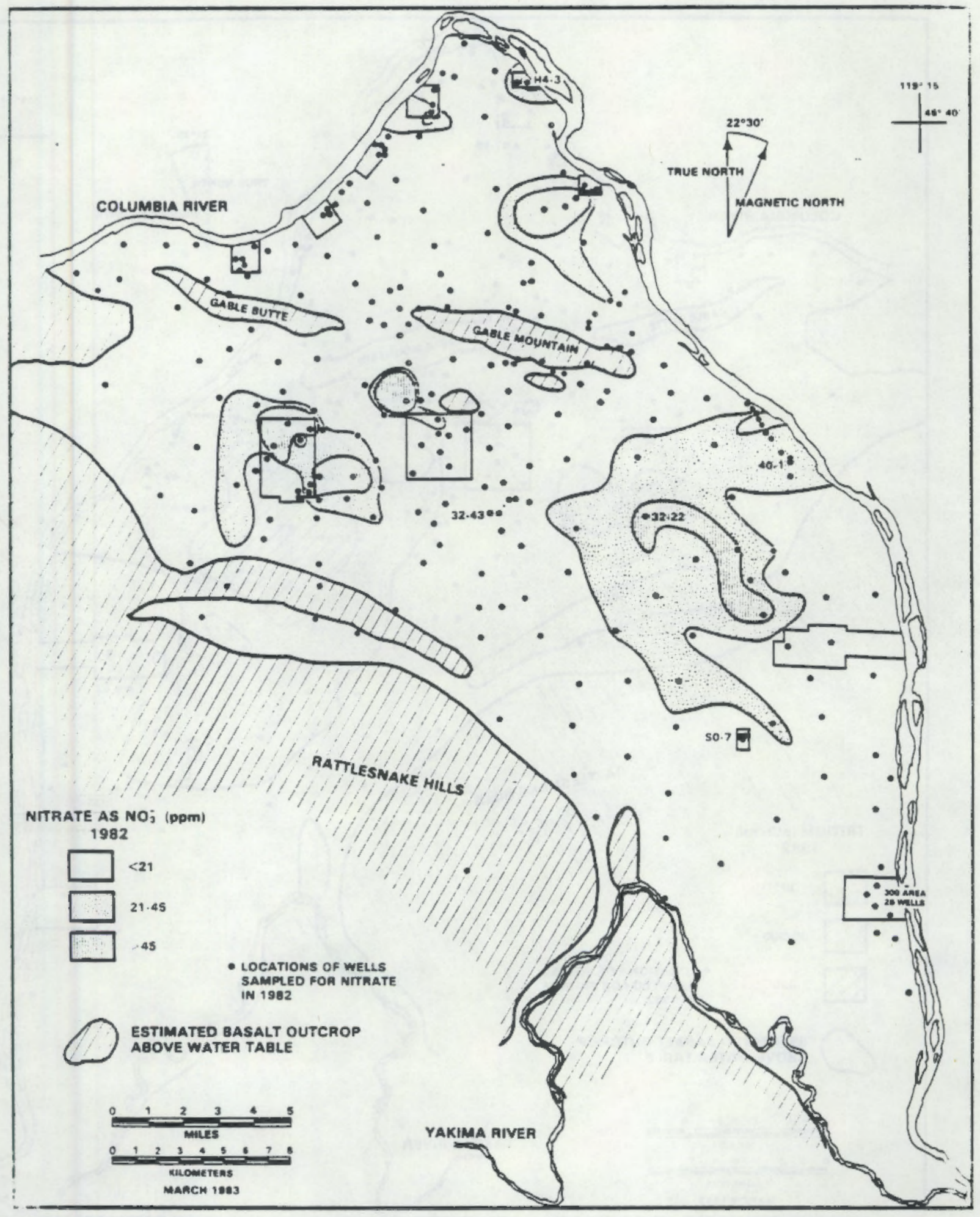

FIGURE 5.21. Nitrate Ion Distribution in Unconfined Ground Water 


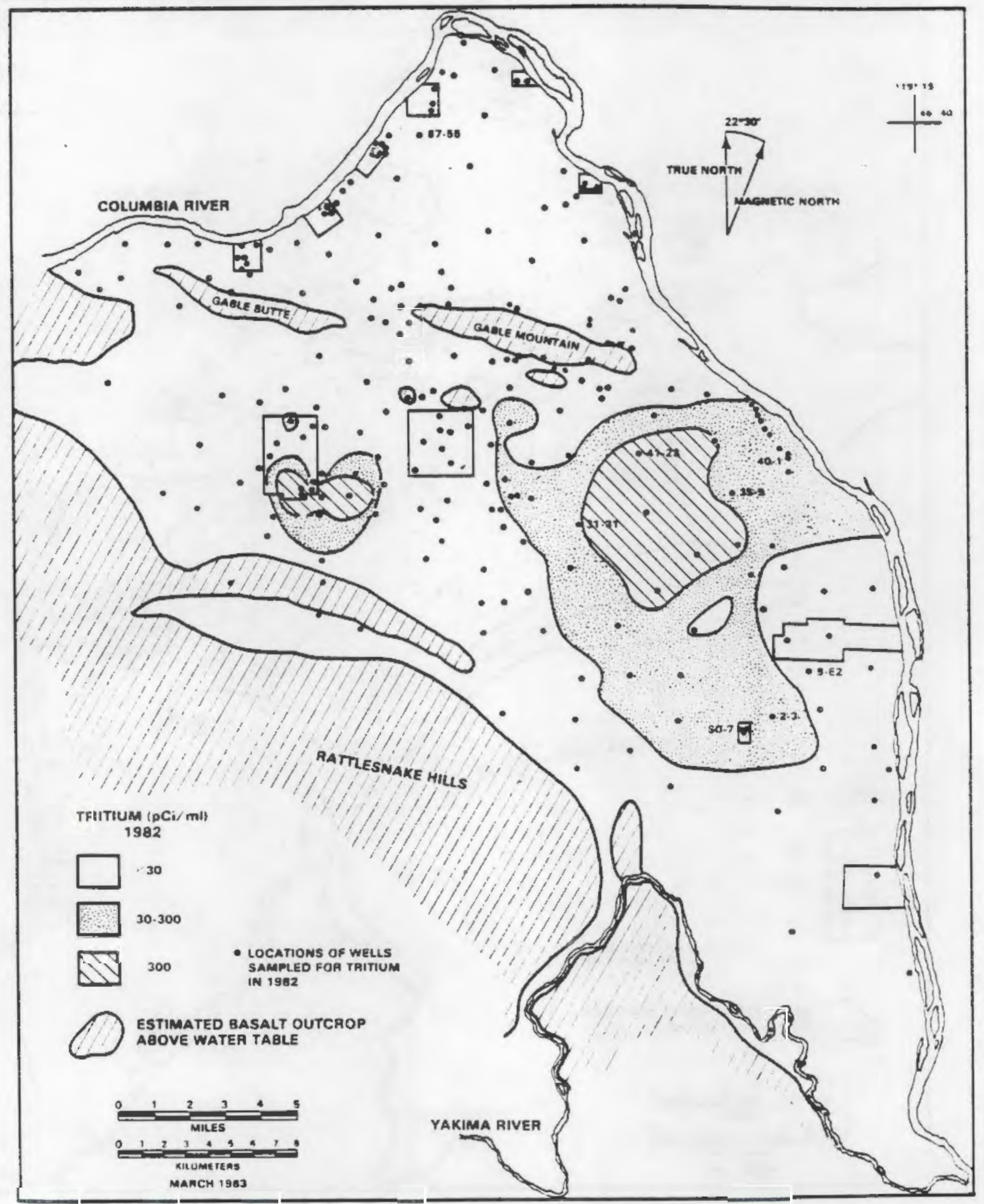

FIGURE 5.22. Tritium Distribution in Unconfined Ground Water 
Greger, E. M. 1981. UNC Nuclear Industries Reactor and Fuels Production Facilities 1980 Effluent Release Report. UNI-1701, United Nuclear Industries, Richland, Washington (March 1981).

Hutchinson, N. E. 1981. "Computer Listing for Peak Flow Tables for USGS Gauging Station 12472800, Columbia River Below Priest Rapids Dam, Washington." Letter to J. 0'Brien, NUS Corporation (May 14, 1981) from U.S. Geological Survey, Water Resources Division.

Kipp, K. L., and R. D. Mudd. 1973. Selected Water Table Contour Maps for the Well Hydrographs on the Hanford Reservation, 1944-1973. BNWL-B-360, Battelle, Pacific Northwest Laboratories, Richland, Washington.

McGhan, V. L., and D. W. Damschen. 1979. Hanford Wells. PNL-2894, Pacific Northwest Laboratory, Richland, Washington.

Merkle, L. 0. 1979. Letter to R. Skaggs, Battelle Memorial Institute, Pacific Northwest Laboratory, Richland, Washington (July 5, 1979), from U.S. Department of the Army, Corps of Engineers, Seattle District, Seattle, Washington.

Newcomb, R. C., J. R. Strand, and F. J. Frank. 1972. Geology and Groundwater Characteristics of the Hanford Reservation of the U.S. Atomic Energy Commission. USGS Geological Survey Professional Paper 717, prepared in cooperation with the U.S. Atomic Energy Commission.

Pacific Northwest River Basins Commission. 1971. Columbia-North Pacific Region Comprehensive Framework Study of Water and Related Lands, Appendix VII, Flood Control. Pacific Northwest River Basins Commission, June 1971 .

Pacific Northwest River Basins Commission. 1962. River Miler Index--Main Stream Columbia River, July 1962. Hydrology and Hydraulic Committee.

Pacific Northwest River Basins Commission. 1971. Water Quality and Pollution Conircl. Comprehensive Framework Study of Water and Related Lands, Appendix XII, Vancouver, Washington (December 1971).

Puget Sound Power \& Light Company. 1981. Skagit/Hanford Nuclear Project, Units 1 and 2, Preliminary Safety Analysis Report with Amendments. Docket Nos. STN 50-522 and STN 50-523, Seattle, Washington.

Puget Sound Power \& Light Company. 1982. Skagit/Hanford Nuclear Project. Application for Site Certification, Environmental Report, Vol. 1. Puget Sound Power \& Light Company, Bellevue, Washington.

Rickel, R. G. 1981. Letter to R. Amish, NUS Corporation, Redmond, Washington (September 24, 1981) from U.S. Department of the Army, Corps of Engineers, Walla Walla District, Walla Walla, Washington. 
Stottlemyre, J. A. 1972. A Summary Report on the Geology and Hydrology of the Hanford Region. BNWL-2406, Battelle, Pacific Northwest Laboratories, Richland, washington.

Sula, M. G., J. M. U. Carlile, K. R. Price, and W. D. McCormack. 1983. Environmental Surveillance at Hanford for CY 1982. PNL -4657, Pacific Nortbwest Laboratory, Richland, Washington.

U.S. Army Corp Engineers. 1976. Power Pondage Studies. CRT-3Q, U.S. Army Corps of Engineers, North Pacific Division, Portland, Oregon.

U.S. ERDA. 1975. Final Environmental Statement, Waste Management Operations, Hanford Reservation, Richland, Washington. ERDA-1538, U.S. Energy Research and Development Administration, Washington, D.C.

U.S. Geological Survey. 1979. Water Resources Data for Washington, Volume 2, Eastern Washington. U.S. Geological Survey Water-Data Report WA-79-2.

Walters, W. H. 1981. Letter to J. D'Brien, NUS Corporation, Rockville, Maryland (July 7, 1981) by Battelle Memorial Institute, Pacific Northwest Laboratory, Richland, Washington.

Washington State Department of Ecology. 198la. "Water Rights (Surface Water Permits and Certificates; Surface Water Applications)." Computer Printout Reports, May 18, 1981.

Washington State Department of Ecology. 1981b. "Recorded Water Rights (Surface Water Permits and Certificates; Surface Water Applications)." Computer Printout Reports, May 18, 1981.

Whetten, J. T., J. C. Kelly, and L. G. Hanson. 1979. "Characteristics of Columbia River Sediment and Sediment Transport." Journal of Sedimentary Petrology, 39(3):1149-1166 (September 1979).

Wildung, R. E., R. C. Rouston, and R. L. Schmidt. 1972. Seasonal Changes in Particle Size Distribution, Composition, and Stontium Exchange Capacity of Particulate Matter Suspended in the Columbia River. BNWL-1638, Battelle, Pacific Northwest Laboratories, Richland, Washington.

WPPSS. 1978. Nuclear Project No. 2, Environmental Report. Operating License Stage, Docket No. 50-397, Washington Public Power Supply System.

WPPSS Nuclear Project No. 2. 1981a. Final Safety Analys is Report, Volume 2, Amendment 13. Washington Public Power Supply System, Richland, Washington.

WPPSS. 1981b. National Pollutant Discharge Elimination System (NPDES) Waste Discharge Permit for the Hanford Generating Project (HGP), Washington Public Power Supply System. Permit No. WA 002487-2, Department of Ecology, State of Washington (March 10, 1981). 


\subsection{GEOLOGY}

This chapter briefly describes the geologic setting and character of the region and area containing the two proposed NPR sites. The regional setting, site topographic expression, structure, stratigraphy, and seismicity are characterized.

The general discussions given apply to both sites, unless noted otherwise, because of their proximity on the Hanford Site. The few local and site-specific differences are described in more detail in the references at the end of the chapter.

Geologic studies of the Pasco Basin are being carried out continually under the Basalt Waste Isolation Project (BWIP). These studies are refining conceptual models of the local geology and seismology. However, much of the information is yet unpublished and therefore not referenceable. In the future, this material will be incorporated into the existing data base as it becomes available.

\subsection{REGIONAL SETTING}

The geologic region containing the reference and alternate sites covers a portion of the Pacific Northwest that includes Washington, Oregon, and adjoining areas of Idaho and British Columbia. The physiographic pattern of the study region, a part of the North American Cordilleran system, is a complex arrangement of mountain ranges, plateaus, and basins (Figure 6.1). These features are the result of extensive Cenozoic (the past 65 million years) volcanic activity and the accumulation of thick sedimentary deposits in the structurally negative areas.

The reference and alternate sites are centrally located in the Pasco Basin, which is near the center of the Columbia Plateau. To the east and north, the plateau is bounded by old, PreCambrian (ended about 570 million years before present (mybp)) and Paleozoic (about 225 to 570 mybp) rocks. To the west and south, almost all deposits are Cenozoic (from 0.01 to 65 mybp). The Columbia Plateau was formed during Miocene time ( 5 to 23 mybp) when vast outpourings of basalt lava blanketed central Washington (U.S. NRC 1982). 


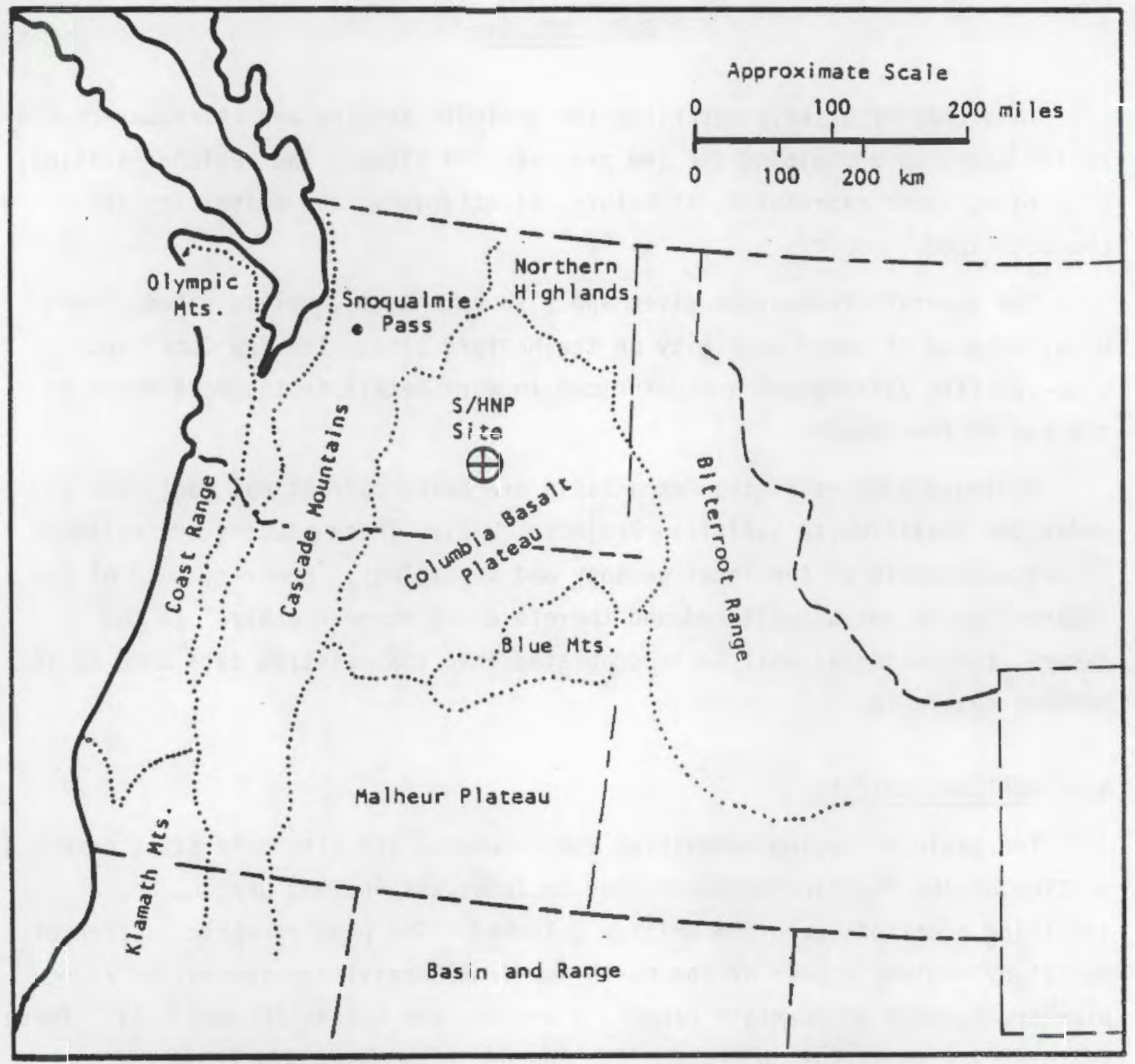

FIGURE 6.1. Principal Physiographic Elements of the Pacific Northwest (Blume and Associates 1970)

Bounding the Columbia Plateau on the west are the Cascade Mountains, the dominant physiographic feature in the region. Topography in the plateau country east of the Cascade Mountains is relatively subdued compared with surrounding mountainous regions. The major topographic features of the plateau are generally east-west trending folds, anticlinal ridges and monoclines, and 
intervening basins. These structures are transected by rivers that locally have cut deep gorges into the layered basalt sequence.

\subsection{SITE TOPOGRAPHY}

The topography of the reference and alternate sites has been created by the geologic structures within the study region and the erosion of surficial geologic materials. The Pasco Basin is a gently undulating plain mantled with Pleistocene glaciofluvial flood deposits and Holocene eolian deposits. This low-relief plain is bounded on three sides by the pronounced topographic/ structural ridges of the Saddle Mountains to the north, Umtanum and Yakima Ridges to the west, and the Rattlesnake and Horse Heaven Hills to the south. The eastern topographic boundary of the basin is indistinct, with major relief being sand dunes and coulees.

The Skagit/Hanford Site has an average elevation of $158 \mathrm{~m}(520 \mathrm{ft})$ above mean sea level (ms 1$)$, and is situated in a slight depression with a local topographic relief of about $6 \mathrm{~m}(20 \mathrm{ft})$. The local topography is further characterized by active sand dunes: a small dune several hundred meters northwest of the site and a larger, east-northeast trending dune east of the site. The dunes are migrating north-eastward, away from the site, and are not expected to change site topography (U.S. NRC 1982).

\subsection{STRUCTURE}

Geologic structures in the region of the Skagit/Hanford Site have been produced by tectonic deformation of the original near-horizontal basalt flows. Deformation began in the upper Miocene prior to cessation of the basaltic lava outpourings. The downwarping of the Pasco Basin and the formation of prominent folds, anticlines, and monoclines was well developed in late Miocene time (10.5 mybp). The basin was filled by Ringold sediments and later by PliocenePleistocene gravels of the Hanford Formation.

The basin is bounded by prominent ridges: the Saddle Mountains to the north, Umtanum and Yakima Ridges to the west, and Rattlesnake Hills and Horse Heaven Hills to the south. To the east, the buried basalt surface slopes gradually upward, forming a gradational boundary. Gable Mountain and Gable 
Butte are asymmetrical anticlines of basalt protruding through the surficial materials. The Umtanum and Yakima Ridges plunge beneath the QuaternaryTertiary sediments of the basin and die out beneath $i t$. Evidence exists that Gable Mountain and Gable Butte are structural extensions of Umtanum Ridge. The Firehouse Site lies within the same regional geologic framework as the Skagit/Hanford Site, but to the north of the Umtanum Ridge/Gable Mountain anticline.

Faults associated with the Gable Mountain anticline include the South and Central faults. Movement has been inferred to have occurred on the south fault in late Pleistocene time on the basis of deformation observed in clastic dikes present along the fault. The Central fault has displaced overlying Missoula Gravels (dated at 13,000 to $17,500 \mathrm{ybp}$ ) a maximum of $0.06 \mathrm{~m}(0.2 \mathrm{ft}$ ) (Myers and Price 1979).

\subsection{STRATIGRAPHY}

The stratigraphy of the Pasco Basin consists of three basic units of highly contrasting lithology and origin. The lowermost identifiable unit in the region is one of basalt flows, which are overlain in the Pasco Basin by the sands, silts, and gravels of the Ringold Formation. Above the Ringold Formation are the uncemented gravels of the Hanford Formation, which are covered within 1.5 to $3 \mathrm{~m}$ ( 5 to $10 \mathrm{ft}$ ) of the ground surface by eolian sand.

The basalt flows of the plateau are generally separated by interbeds of volcanoclastic sediments. Most of the younger flows have been named and agedated, and their areal extent has been mapped. The stratigraphic section illustrating the succession of flows and overlying formations is shown in Figure 6.2. Total thickness of basalt at the Pasco Basin is at least $3,000 \mathrm{~m}$ $(10,000 \mathrm{ft})$ (Blume and Associates 1971a,b); only the upper portion of these flows has been studied in detail. Age determinations of basalt flows range from lower Miocene (16.5 mybp) to upper Miocene (6 mybp) (Myers and Price 1979).

The Ringold Formation consists of fine to coarse sediments containing gravels deposited by a through-flowing stream during the late Miocene and early Pliocene (10.5 to 3.3 mybp). Its thickness over the site area is about $152 \mathrm{~m}$ $(500 \mathrm{ft}$ ) (PSP\&L 1981, Amendment 23). 


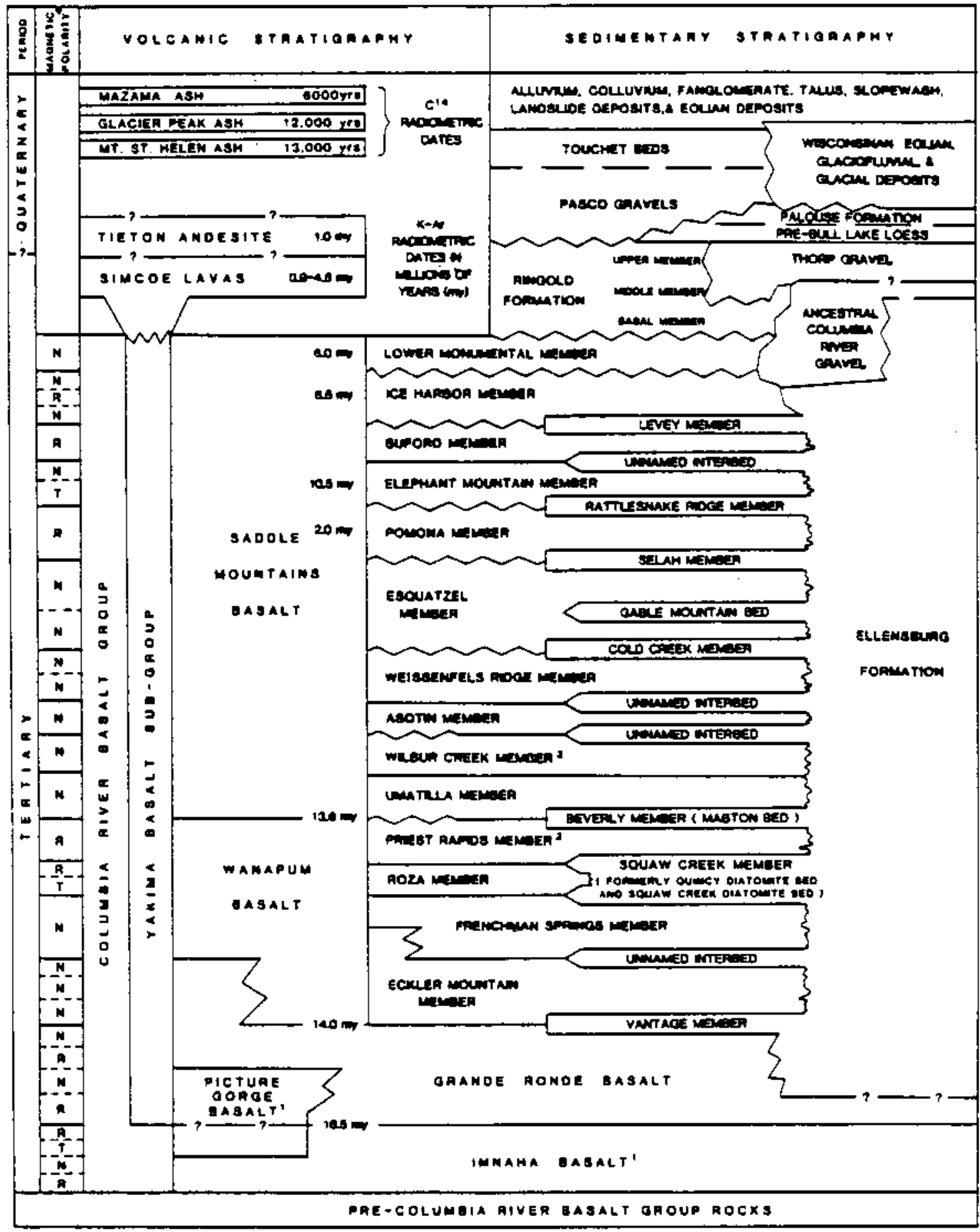

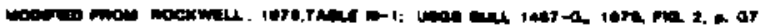

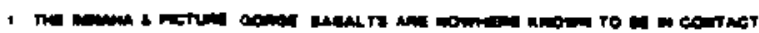

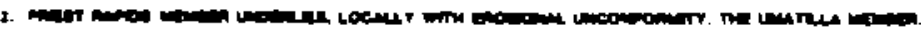

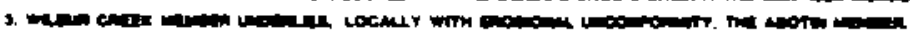

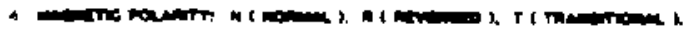

FIGURE 6.2. Late Cenozoic Stratigraphy of the Columbia Plateau (WPPSS 1981) 
The Hanford Formation unconformably overlies the Ringold Formation in the Pasco Basin. The formation consists of uncemented granular material ranging in size from boulders to silt. The uppermost gravels are assigned an age of $13,000 \mathrm{ybp}$, and the age of the lowermost is uncertain but could be as old as 3.3 mybp. The Hanford Formation is about $60 \mathrm{~m}(200 \mathrm{ft})$ thick at the Skagit/ Hanford Site (PSP\&L 1981).

\subsection{SEISMICITY}

Historically, eastern Washington has been a region of low seismicity in comparison with western Washington and many other areas of western North America. The historical record for the Pasco Basin region is probably complete for earthquakes of modified Mercalli intensity (MMI) VII and greater that have occurred since about 1870 (WPPSS 1981). This record indicates that earthquakes with MMI VII or greater (potentially destructive) occur at a rate of about two per century within a circular area with a radius of $110 \mathrm{~km}$ $(68.3 \mathrm{mi})$ centered at the site. The largest historic earthquake in this zone is the Milton-Freewater earthquake of 1936, with MMI VII or ML 6.1 (WPPSS 1979).

Existing faults include the Wallula Fault zone, which coincides with the southern boundary of the basin and aligns with a fault along the north slope of Rattlesnake Mountain. This trend is part of the 0lympic Wallowa Tinement, extending northwest to the 0lympic Peninsula. The existence of the linement as an alignment of topographic features is well established, but its structural and tectonic significance is doubtful (U.S. NRC 1982).

Closest to the sites is a probable fault extending about $6.4 \mathrm{~km}$ ( $4 \mathrm{mi}$ ) along the southwest flank of a buried easterly segment of the Umtanum RidgeGable Mountain structural trend. Other faults are associated with Gable Mountain, Saddle Mountain, Umtanum Ridge, and the northeast margin of the Horse Heaven Hills (Blume and Associates 1971a,b). Only one fault has been designated as capable, although studies are continuing.

Since 1969, abundant swarms of microearthquakes (ML 3.0) in the Hanford (Pasco Basin) region have been thoroughly monitored and analyzed. About 
80 percent of these shocks have had focal depths less than $3 \mathrm{~km}(1.9 \mathrm{mi})$ and may be nontectonic in nature; the remainder have occurred as deep as $25 \mathrm{~km}$ (15 mi) and may be caused by north-south crustal compression.

The only mapped fault in the Pasco Basin deemed to be capable according to NRC criteria is the Central fault, situated on the Gable Mountain-limtanum Ridge structural trend (WPPSS 1979), which is located about $12.9 \mathrm{~km}$ ( $8 \mathrm{mi}$ ) northwest of the site. Other late Pleistocene faults have been mapped along this and other structural trends. Although none of these fauits has a proven tectonic origin or seismogenic potential, the maximum earthquake magnitude that could reasonably be associated with them has been calculated to be approximately ML 5 (WPPSS 1979). The Central fault lies approximately $6.4 \mathrm{~km}$ (4 mi) south of the Firehouse Site and may be a factor determining the suitability of that site.

There is no well-defined correlation between macroseismic activity within the 110-km (68.3-mi) region about the site and geologic structures such as faults, grabens or fold axes. Larger magnitude, deep focus earthquakes in the Pacific Northwest are generally confined to the western side of the Cascade Mountains, where activity is centered in the Puget Sound Lowland and the northern portion of the Willamette Valley of Oregon. These zones are both within the Puget-willamette Trough tectonic province. Activity within the Puget-Willamette province has not significantly affected the proposed sites due to the distance of about $225 \mathrm{~km}$ (140 mi), which separates them at their closest approach (WPPSS 1979).

With two exceptions, the entire region east of the Cascades is characterjzed by low sejsmicity, and by widely scattered epicenters of low intensity. A clustering of epicenters occurs in the Chelan area in the vicinity of the common boundaries of the Northern Cascade, Okanogan Highland, and Columbia Basin tectonic provinces. A second clustering of epicenters occurs in the Walla Walla Basin area, near the boundary of the Columbia Basin and Blue Mountains tectonic provinces. There is no known correlation between these zones and known structures (WPPSS 1979). 
Although there is no well-defined correlation of macroearthquake activity with tectonic structures northwest of the MiTton-Freewater epicentral region, the presence of the Wallula Gap Fault (capable) within the zone of the Rattlesnake-Wallula alignment and associated structures makes this zone the most significant for determining the earthquake potential at the site. No significant faults other than the Wallula Gap Fault are recognized to be associated with this structural zone.

The Wallula Gap Fault has been positively mapped for only 5 miles. Bingham et a1. (1970), on the basis of reconnaissance mapping, have inferred that the fault extends for at least $19 \mathrm{~km}$ (12 mi) southeastward of the Gap, and that it may be related to a youthful 1 inear feature trending southeast beyond that point.

\subsection{REFERENCES}

Bingham, J. W., C. J. Londquist and E. H. Baltz. 1970. Geologic Investigation of Faulting in the Hanford Region: With a Section on the Occurrence of Microearthquakes by A.M. Pitt. U.S. Geological Survey Open FiTe Report, Tacoma, Washington.

Blume, John A., and Assoc. 1970. Seismic and Geologic Siting Evaluation, Fast Flux Test Facility. San Francisco, California.

Blume, John A., and Assoc. 197la. Subsurface Geologic Investigations for Fast Flux Facility Project in Pasco Básin. San Francisco, California.

Blume, John A., and Assoc. 1971b. Supplementary Geologic Investigation for the Fast Flux Test Facility Project in Pasco Basin. San Francisco, California.

Myers, C. W., and S. M. Price. 1979 Geologic Studies of the Columbia Plateau, A Status Report. RHO-BWI-ST-4, Rockwel? Hanford Operations Richland, Washington.

Puget Sound Power \& Light Company. 1981. Skagit/Hanford Nuclear Project, Units 1 and 2, Preliminary Saftey Analysis Report, with Amendments. Docket Nos. STN50-522 and STN50-523, Seattle, Washington.

U.S. Nuclear Regulatory Commission. 1982. Draft Environmental Statement Related to the Construction of Skagit/Hanford Nuclear Project, Nos. I and 2. NUREG-0894, Washington, D.C. 
Washington Public Power Supply System. 1979. Final Safety Analysis Report, Washington Nuclear Power Plant No. 2. Richland, Washington.

Washington Public Power Supply System. 1981. Final Safety Analys is Report, Washington Nuclear Plant No. 2. Amendment 18. Richland, Washington. 



\subsection{CULTURAL RESOURCES ASSESSMENT}

As required by the provisions of the National Environmental Policy Act, Executive Order 11593, and the amended National Historic Preservation Act, an archaeological assessment of both potential NPR sites was performed as part of the environmental characterization effort. This section documents the information obtained, and analyses performed, by Dr. David G. Rice, (a) who determined the archaeological and cultural aspects of the Skagit/Hanford and Firehouse sites.

Between November 22 and December 12, 1983, a 1 iterature search/records check was conducted. In addition to cultural resource reports and records in Dr. Rice's possession, information was obtained from the Washington Archaeological Research Center, the Washington State Office of Archaeology and Historic Preservation, and the U.S. DOE Richland Operations Office. Information on pre-Hanford Reservation history was derived from the Richland Public Library, the University of Washington Library, Seattle District, U.S. Army Corps of Engineers, and the U.S. DOE Richland Operations Office. Other researchers doing work in the area were also consulted. Federal Register listings through June 1983 were checked for additions to the National Register of Historic Places.

An archaeological field survey was carried out between November 25 and November 28,1983 . Because preliminary research disciosed that most of the Skagit/Hanford Site was previously and recently surveyed for cultural resources, the field efforts were focused at the Firehouse site. Field methods employed on-the-ground linear transects (north-south) at 65-yard intervals. Rodent burrows and unvegetated ground surfaces were more intensively examined at transect intervais of 10 yards. Subsurface probes were made with a shove 1 and inmediately backfilled; none of these probes produced evidence of archaeological material. Locational control on the ground was accomplished by use of high-resolution aerial photographs at a scale of 2 inches to a mile. Compass readings were used for maintaining direction while making transects. Archaeological and historical literature were reviewed prior to field studies to

(a) Rice Consulting Service, Seattle, Washington. 
help guide the survey efforts. The type of archaeological survey employed in this study is described by Xing (1978, pp. 36-37) as a "non-exclusive comprehensive survey with background research and subsurface testing." This means that background research including records checks and a literature search were conducted prior to on-the-ground field work; that the survey conducted was comprehensive and did not exclude portions of the study area; and that limited subsurface shovel tests were made. The results of these investigations are summarized by study location in the following subsections.

\subsection{FIREHOUSE SITE}

Within this study area no prehistoric archaeological sites were identified. Lithic material suitable for the production of artifacts was found, but occurred naturally in flood gravel deposits. Even though there is the potential for isolated prehistoric finds, these finds are not apt to be extensive because of the distance from water (minimum of 1.5 miles) in a xerophytic environmental setting.

Historical research indicates that the upland flats of the study area served as grazing lands for Indian horses during the 19th century. An 1880-81 Indian trail (Figure 7.1) was identified as crossing the study area. Field reconnaissance failed to clearly identify the trail on the ground because it appears to coincide with the Hanford No. 1-Ashe Bonneville Power Administration 500-kV power transmission line. The trail also could have been obliterated by herds of grazing livestock late in the 19 th century.

The history of 20th century pre-Hanford Reservation land use identifies grazing as the primary usage (U.S. Army Corps of Engineers 1947). When the Hanford Reservation was established in 1943, the study area was nearly evenly owned by the state and the Milwaukee Railroad, with one small private ownership. The most prominent cultural feature relating to early 20 th century Euroamerican settlement is the Hanford Ditch (45-BN-309H), which cuts across the northwest corner of the study area (Figure 7.2). It was constructed between 1906-08 by the Priest Rapids Irrigation Company, and enlarged by its successor, the Hanford Irrigation and Power Company. This historic site is 


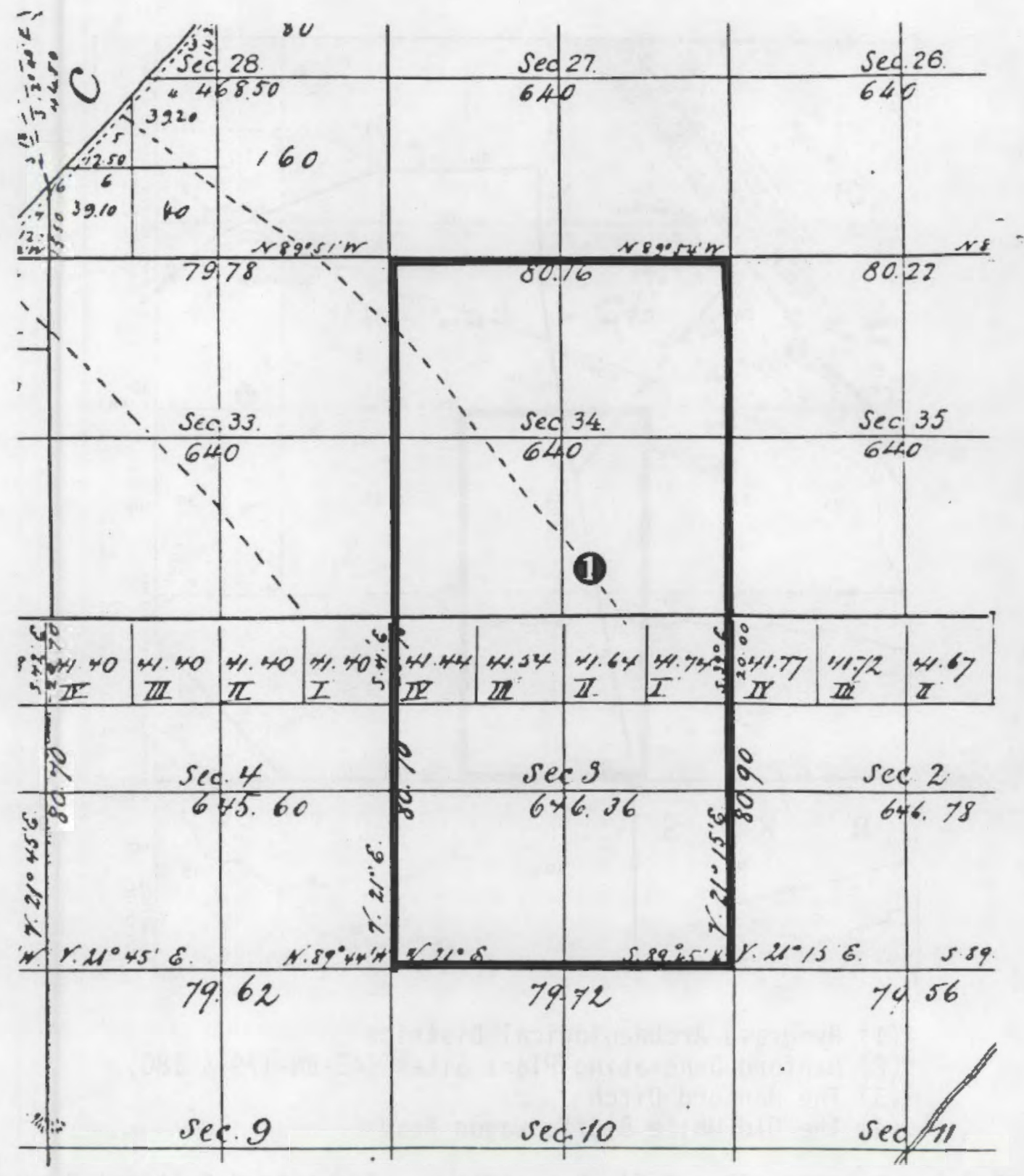

FIGURE 7.1. 01d Indian Trail Passing Through the Firehouse Site [Government Land Office plat map (1880-1881).] 


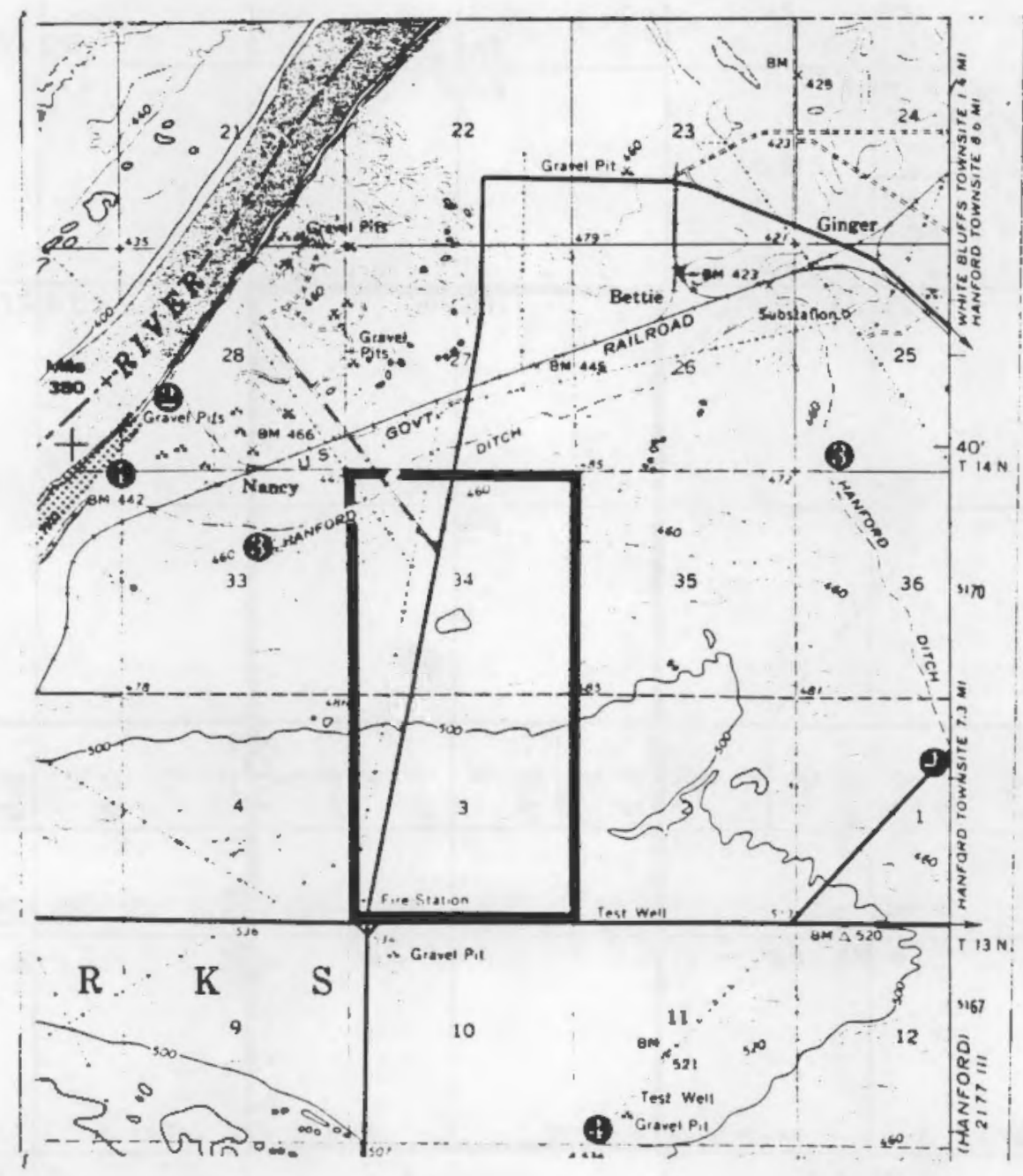

(1) Ryegrass Archaeological District
(2) Hanford Generating Plant Sites (45-BN-179 \& 180)
(3) The Hanford Ditch
(4) The Old White Bluffs Wagon Road

FIGURE 7.2. Relationship of Firehouse Site to Identified Cultural Resources [USGS Coyote Rapids Quadrangle (1965), scale: 1 inch $=1$ mile] 
likely to be eligible for listing on the National Register of Historic Places and appears to meet criteria outlined in 36 CFR Part 60.

Several cultural resource sites were identified in the general vicinity of the study area. They include the Ryegrass Archaeological District (1isted on the National Register) (Rice 1980), archaeological sites at the Hanford Generating Plant (45-BN-179 and 180) (Rice 1980), and the 0ld white Bluffs wagon road to the Yakima River. These are also indicated in Figure 7.2.

\subsection{SKAGIT/HANFORD SITE}

Previous investigations (Rice 1981) identified a prehistoric archaeological site $(45-8 N-266)$ (Figure 7.3$)$ within the study area. The site consisted of a lithic scatter and contained no temporally diagnostic artifacts. The archaeological material was collected, leaving no site to be impacted.

The history of 20th century pre-Hanford Reservation land use indicates that grazing was also the primary usage of this study area (U.S. Army Corps of Engineers 1947). When the Hanford Reservation was established in 1943, the study area was evenly divided between Government and private lands. An historic homestead $(45-\mathrm{BN}-305 \mathrm{H})$ was identified (ERTEC Northwest 1981) at the northeast corner of this study area. There is some evidence that the homestead was a base for livestock grazing and may have served as a sheep ranch. Figure 7.3 shows the site location. No standing structures remain at the site.

Figure 7.4 illustrated the portions of the study area surveyed in 1981 by ERTEC Northwest. Because Section 33 was previously surveyed by Rice (19B1), survey efforts at this study site covered the gaps in the ERTEC survey. No additional archaeological sites or materials were observed.

Significant cultural resources in the vicinity of the study area have been previously identified by Rice (1980) and are illustrated in relation to the study site in Figure 7.5. These include the Hanford North Archaeological District, the Hanford Island Site, the Savage Island Archaeological District, and the Wooded Island Archaeological District. All of these sites are listed on the National Register of Historic Places. 


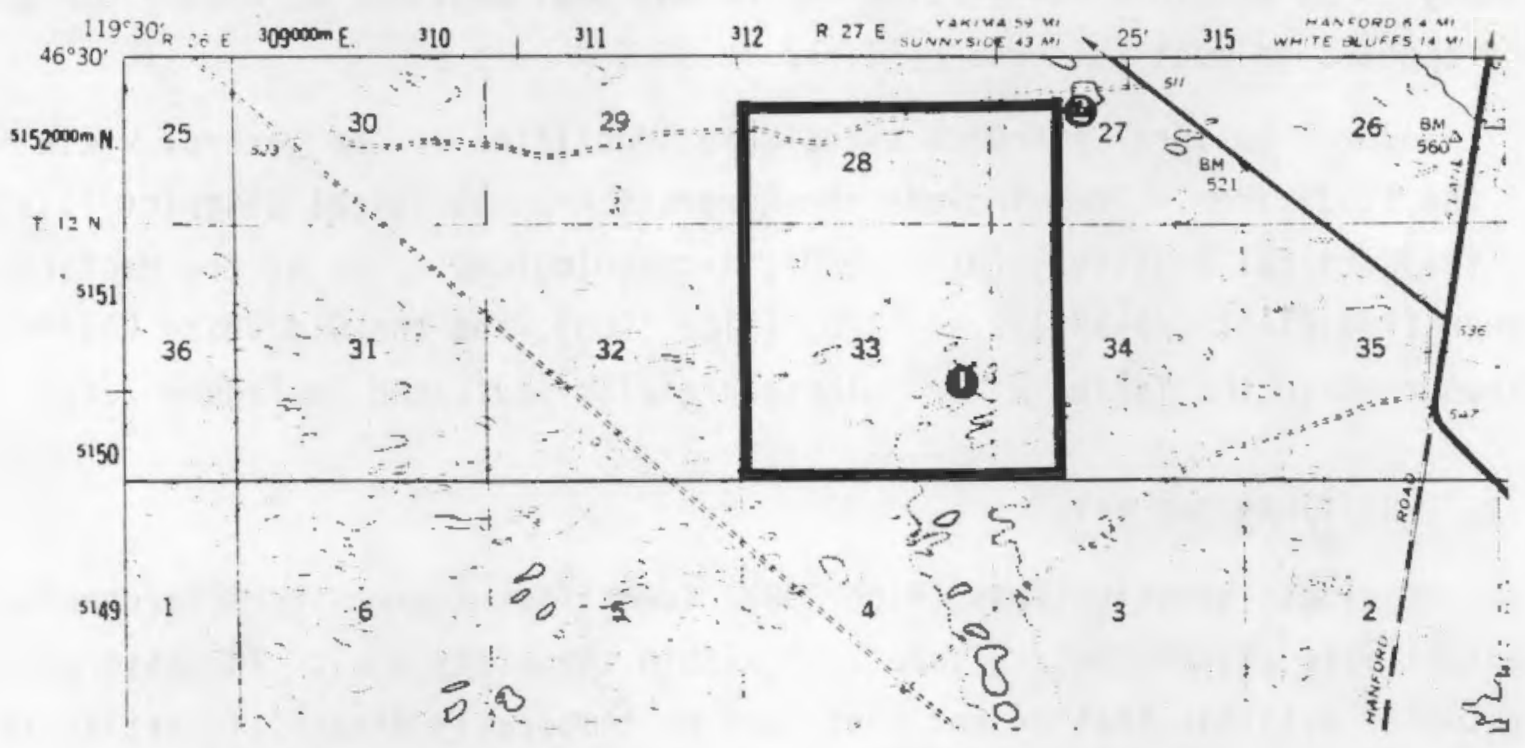

(1) Prehistoric Indian Lithic Scatter (45-BN-266)

(2) Historic pre-Hanford Reservation Homestead (45-BN-305H)

FIGURE 7.3. Relationship of Skagit/Hanford Site to Identified Cultural Resources

[USGS Richland Quadrangle (1951), scale: 1 inch = 1 mile)

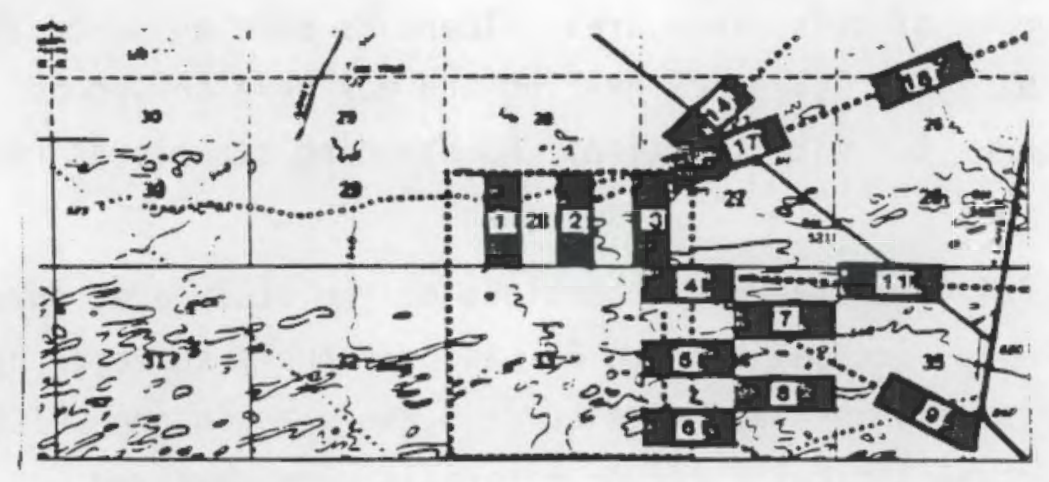

FIGURE 7.4. Survey Units Selected and Walked by ERTEC Northwest in Late 1981 Using 50-Foot Interval Transects (ERTEC Northwest 1981, p. 7) 


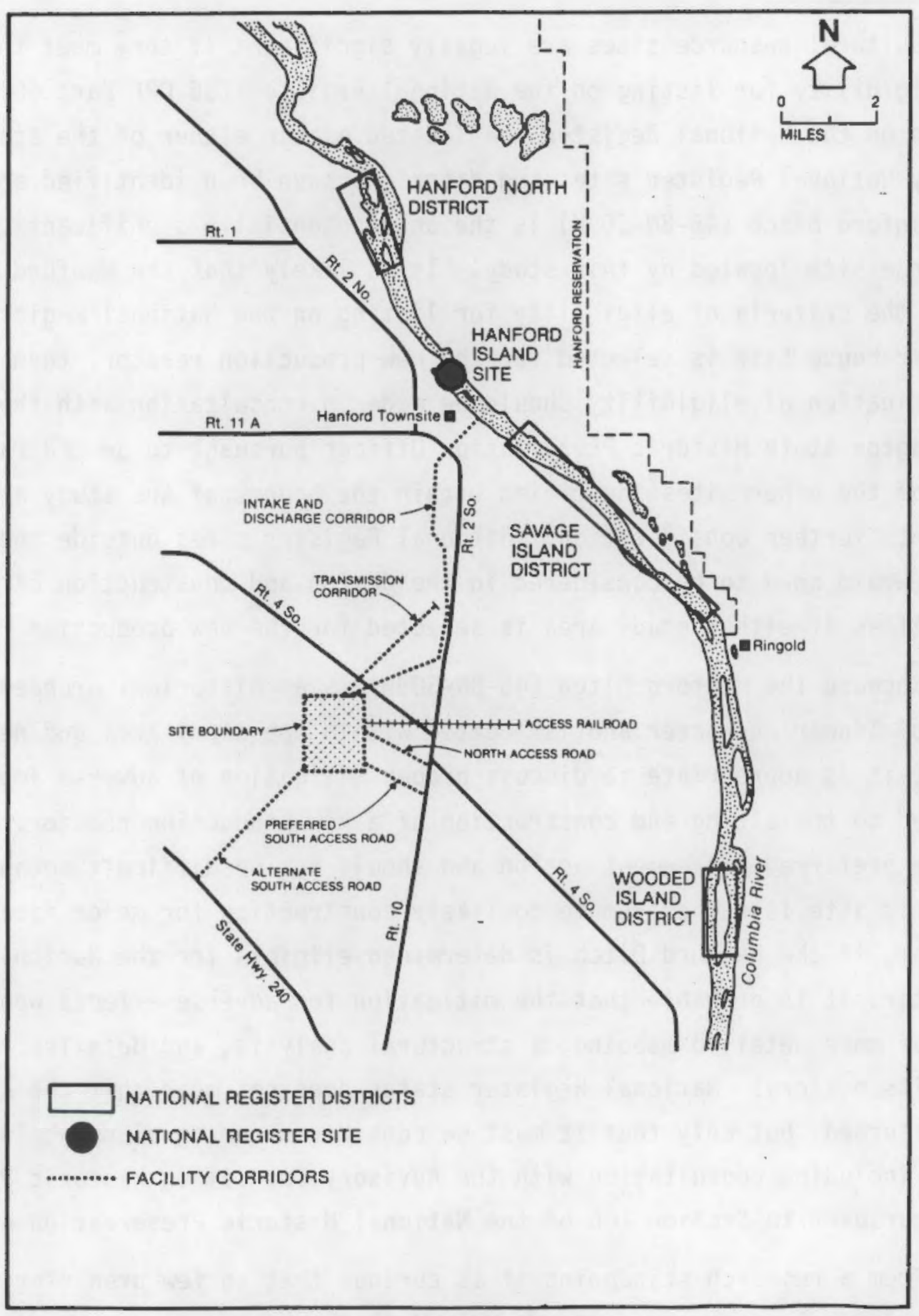

FIGURE 7.5. Significant Cultural Resources in the Skagit/Hanford Site Vicinity (ERTEC Northwest 1981) 


\subsection{CONCLUSIONS}

Cultural resource sites are legally significant if they meet the criteria of eligibility for listing on the National Register ( 36 CRF Part 60). No sites listed on the National Register are located within either of the study areas. Nearby National Register sites and districts have been identified and located. The Hanford Ditch $(45-\mathrm{BN}-309 \mathrm{H})$ is the only potentially significant cultural resource site located by this study. It is likely that the Hanford Ditch meets the criteria of eligibility for listing on the National Register. If the Firehouse Site is selected for the new production reactor, then a formal determination of eligibility should be made in consultation with the Washington State Historic Preservation Officer pursuant to 36 CFR Part 800 . None of the other sites identified within the bounds of the study areas warrants further consideration. National Register sites outside the study areas would need to be considered in the design and construction of associated facilities if either study area is selected for the new production reactor.

Because the Hanford Ditch $(45-\mathrm{BN}-309 \mathrm{H})$ is an historical archaeological site of linear character and is located within one study area and nearby the other, it is appropriate to discuss proper mitigation of adverse impacts related to the siting and construction of a new production reactor. Avoidance is the preferred management action and should not be difficult because the historic site is rather remote to likely construction for major facilities. However, if the Hanford Ditch is determined eligible for the National Register, it is probable that the mitigation for adverse effects would consist only of more detailed mapping, a structural analysis, and detailed research into its history. National Register status does not mean that the site cannot be disturbed, but only that it must be considered during planning for a project, including consultation with the Advisory Council on Historic Preservation pursuant to Section 106 of the National Historic Preservation Act.

From a research standpoint it is curious that so few prehistoric archaeological sites are found on upland flats which include the study areas. The landforms have been available for human use and habitation for 9000 or 10,000 years. Evidently the resources, particularly water, to support significant human activity were lacking. The only type of human activity 
recorded within these areas is transient, including trails and roads. Even in historical times water was the key to development and settlement. The Hanford Ditch takes on specia? significance as a recent adaptation to a longstanding arid environment.

\subsection{REFERENCES}

ERTEC Northwest. 1981. Cultura] Resources Survey and Exploratory Excavations for the Proposed Skagit/Hanford Nuclear Power Project. Report submitted to Northwest Energy Services Company, Bellevue, Washington.

King, T. F. 1978. The Archaeological Survey: Methods and Uses. Heritage Conservation and Recreation Service, U.S. Department of the Interior, Washington, D.C.

Rice, D. G. 1980. Overview of Cultural Resources on the Hanford Reservation in South Central Washington State. Rice Consulting Service, Seattle, Washington.

Rice, D. G. 1981. Archaeological Transects Through Interior Dunes on the Hanford Reservation, Washington. Rice Consulting Service, Seattle, Washington.

Rice, D. G. 1983. Archaeological Investigations at Washington Public Power Supply System Nuclear Plants on the Hanford Reservation, Washington. Rice Consulting Service, Seattie, Washington.

U.S. Army Corps of Engineers. 1947. Manhattan District History, Book IV Pile Project, $X-10$, Vol. 4 - Land Acquisition, Hanford Engineer Works, Appendices. Mss. in possession of U.S. Bepartment of Energy, Richland operations office, Richland, Washington. 



\subsection{BASELINE ECONOMIC AND SOCIAL CONDITIONS FOR THE NPR IMPACT AREA}

This chapter presents the characterization of the baseline economic and social conditions for the NPR impact area of Benton and Franklin Counties. The baseline socioeconomic situation is for the future years corresponding to the NPR construction and operation schedule, and provides the baseline from which impacts from NPR can be projected. This chapter covers only the deveiopment of estimates of the Tri-Cities economy without NPR (baseline condition); the impacts of the NPR are not analyzed.

Because the future cannot be known with certainty, four different scenarios of the baseline socioeconomic conditions are developed in Section 8.2. Each scenario makes different assumptions about future Tri-Cities area employment levels based on historical trends and current information about future trends. In Section 8.1 the current socioeconomic situation in the Tri-Cities is discussed in the context of available historical economic and social data. (Historical population data are given in Section 2.2.) The following analysis applies to both the primary and secondary NPR sites.

\subsection{HISTORICAL SOCIOECONOMIC DATA FOR THE IMPACT AREA}

The primary socioeconomic impact area associated with the construction and operation of the NPR is the Tri-Cities SMSA, composed of Benton and Franklin Counties. This section presents historical data on the economy and social condition of the Tri-Cities area, concentrating on the period from 1970 to 1982. Socioeconomic characteristics covered include employment, labor force characteristics, income, housing, education, public services, recreation, transportation, and public revenues. (Historical population data are presented in Section 2.2.) For some of these categories, such as public services, recreation, and transportation, historical time series are not available; for these categories the most recent available information is used. When available, 1983 data are added to the time series data for 1970 to 1982. 


\subsubsection{Employment}

This section examines employment trends in the Tri-Cities from 1969 to 1982. Major trends are dealt with first, followed by a short section on other employment trends of smaller impact.

Table 8.1 shows Tri-Cities agricultural and manufacturing employment by sector from 1969 to 1981 . Table 8.2 contains calculated average annual growth rates. (a) From 1969 to 1981 wage and salary employment in the Tri-Cities SMSA grew from 33,108 to 72,253 (Table 8.1), for an average annual growth rate of over 6.5 percent, making this area one of the fastest-growing regions in the nation. This growth developed in phases, with different sectors dominating in different years.

1969 to 1973

Total wage and salary employment in the Tri-Cities grew at an annual aver-age rate of 3.3 percent from 1969 to 1973. The largest contributors in this period were the agriculture and Construction sectors, with 11.7 percent and 11.5 percent average annual growth rates, respectively, over the four-year period (Table 8.2). The significant growth in employment in agriculture can be attributed to a continuing increase in productive acreage resulting from irrigation projects sponsored by the Bureau of Reclamation. Irrigated acreage in Benton and Franklin Counties increased at an annual rate of 3.3 percent (Table 8.3 ) over this period, a growth rate large enough to more than offset the lower labor requirements per volume of agricultural output resulting from technological improvements.

\section{3 to 1977}

During the period 1973 to 1977 , the biggest impact on Tri-Cities employment was the beginning of work on the Washington Public Power Supply System (WPPSS) nuclear power plant projects. Local employment at WPPSS falls under two major categories shown in Table 8.2: Construction and Services (for design and engineering). Other jobs directly related to the Supply System are

(a) Actual historical employment figures used in the baseline scenarios are contained in table 8.8. The figures in Table 8.1 are used for historical perspective and not as a starting point for scenario projections. 
TABLE B.1. Ernployment by Type and Broad Industrial Categories for the Tri-Cities SMSA, $1969-1981$

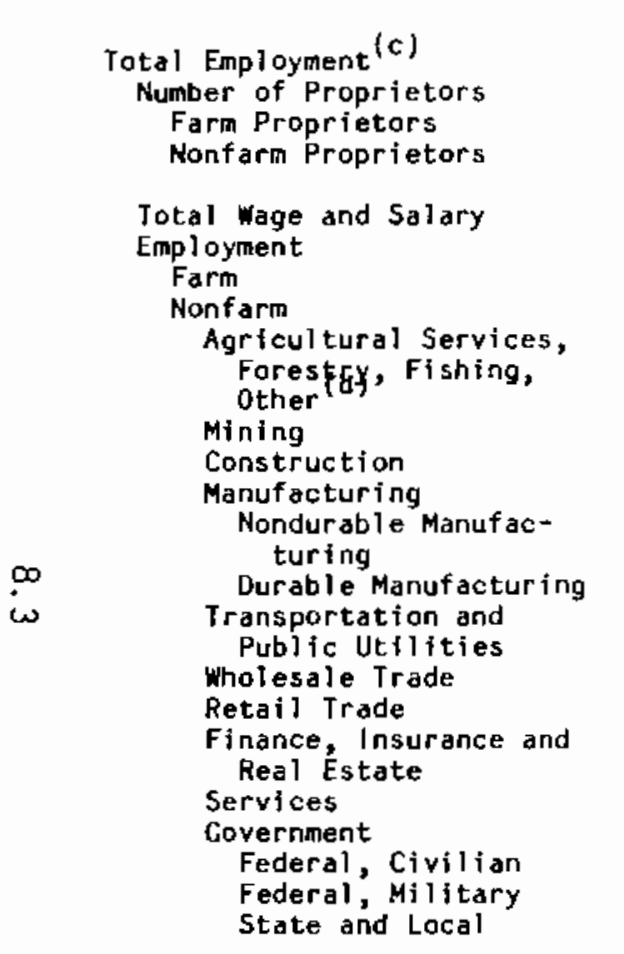

\begin{tabular}{|c|c|c|c|}
\hline $1969^{(a)}$ & $1970^{(a)}$ & $1971^{(a)}$ & $1972^{(a)}$ \\
\hline $\begin{array}{r}37,499 \\
4,391 \\
2,453 \\
1,938\end{array}$ & $\begin{array}{r}38,700 \\
4,354 \\
2,407 \\
1,947\end{array}$ & $\begin{array}{r}38,536 \\
4,479 \\
2,362 \\
2,117\end{array}$ & $\begin{array}{r}39,630 \\
4,500 \\
2,318 \\
2,182\end{array}$ \\
\hline $\begin{array}{r}33,108 \\
2,222 \\
30,886\end{array}$ & $\begin{array}{r}34,346 \\
2,718 \\
31,628\end{array}$ & $\begin{array}{r}34,057 \\
2,869 \\
31,188\end{array}$ & $\begin{array}{r}35,130 \\
2,959 \\
32,171\end{array}$ \\
\hline
\end{tabular}

\section{$\begin{array}{rrrrrr}(D) & (D) & (D) & 368 & 398 & 459 \\ (D) & (D) & (D) & & (L) & (L) \\ 1,976 & 1,758 & 1,695 & 2,376 & 3,124 & 4,004\end{array}$ \\ $\begin{array}{llll}1,976 & 1,758 & 1,695 & 2,376\end{array}$}

$5,514 \quad 5,543$

4,987

527

1,624

4,629

702
9,067

9,067
6,222
813

813
594

4,815
5,078
465

1,655

4,834

700

9,390
6,518

830

595
5,093
5,259

4,788
471

5,334

4,822
512

5,699

$5,043 \quad 5,339$

1,634
, 657

4,947

5,084

$\begin{array}{rr}732 & 868 \\ 9,148 & 8,948\end{array}$

$, 148 \quad 8,948$

6,539
767

$661 \quad 615$

$5,111 \quad 5,190$

\section{$1,808 \quad 1,810$}

$1,120 \quad 1,020$

$5,241 \quad 5,509$

$\begin{array}{rr}899 & 980 \\ 9,132 & 10,012\end{array}$

$\begin{array}{rr}9,132 & 10,012 \\ 7,022 & 7,557\end{array}$

$1975^{(b)}$
51,423
4,960
2,253
2,707

$1976^{(b)}$
55,602
5,195
2,256
2,939
197

$\frac{977^{(b)}}{60,508}$
5,595 2,314 3,281

\section{6,463}

4,638

50,407

5,611
44,796

54,913
4,203

50,710

(D)

5,493

(D)
(D)
5,432

(D)
(D)

7,519

8,024

5,954
949

6,373
930

7,057

1,797

1,392

1,392
5,678

1,878

1,555

2,055

1,630

956
10,900

1,139

1,139
8,321

1,382

8,087
890
612

$\begin{array}{rrr}635 & 625 & 612 \\ 5,610 & 6,097 & 6,585\end{array}$

8,321
929

13,250

8,493
971

$\begin{array}{rr}603 & 536 \\ 6,789 & 6,986\end{array}$

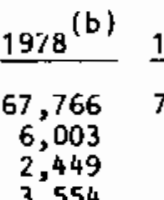

3,554

61,763

4,204

57,559

\section{(D)}

9,374

9,374
8,887

7,874
1,013

2,356

2,356
1,935

8,625

1,531

14,713

9,074
1,012

1,012
568

7,494

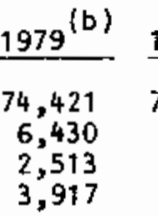

67,991

4,847
63,144

4,850

63,246

1,104
80

11,289

11,289
9,293

(D)

10,063

9,132

8,344
949

8,192
940

2,442

2,130

2,479

1,907

9,426

1,730

15,424

1,733
16,338

1,061

600
8,606

1,117
620

620
9,131 $1981^{(b)}$
78,904
6,651
2,678
3,973

72,253
5,183
67,070

(D)

(D)
13,539

3,539
9,116

8,230
886

2,459

1,917

1,639

1,639

16,380

10,982
1,076

685
9,221

Source: Regional Economic Information System BEA 1982.

(a) Estimates based on 1967 SIC.

c) Consists of wage and salary jobs plus number of propietors.

(d) Includes number of jobs held by U.5. residents working for international arganizations in the U.S. Primary source for private non-farm employment: ES-202 covered wages - Washington Employment Security Department.

(D) Not shown to avoid disclosure of confidential data. Data are included in totals.

(L) Less than 10 mage and salary jobs. 
TABLE 8.2. Calculated Average Annual Growth in Employment: Tri-Cities SMSA (percent)

\begin{tabular}{|c|c|c|c|c|c|}
\hline Employment by Place of Work & $\begin{array}{l}1969- \\
1981 \\
\end{array}$ & $\begin{array}{l}1969- \\
1973 \\
\end{array}$ & $\begin{array}{l}1973- \\
1977 \\
\end{array}$ & $\begin{array}{l}1977- \\
1980 \\
\end{array}$ & $\begin{array}{l}1980- \\
1981\end{array}$ \\
\hline $\begin{array}{l}\text { Total Employment } \\
\text { Number Proprietors } \\
\text { Farm Proprietors } \\
\text { Nonfarm Proprietors }\end{array}$ & $\begin{array}{l}6.2 \\
3.5 \\
0.7 \\
6.0\end{array}$ & $\begin{array}{r}3.1 \\
1.0 \\
-1.6 \\
4.0\end{array}$ & $\begin{array}{l}8.9 \\
5.0 \\
0.1 \\
9.2\end{array}$ & $\begin{array}{l}7.0 \\
5.6 \\
3.6 \\
6.9\end{array}$ & $\begin{array}{r}5.5 \\
0.6 \\
3.8 \\
-1.5\end{array}$ \\
\hline $\begin{array}{l}\text { Total Wage \& Salary Employment } \\
\text { Farm } \\
\text { Nonfarm } \\
\text { Aaricultural, Forestry }\end{array}$ & $\begin{array}{l}6.5 \\
7.1 \\
6.5\end{array}$ & $\begin{array}{r}3.3 \\
11.7 \\
2.6\end{array}$ & $\begin{array}{l}9.3 \\
4.2 \\
9.8\end{array}$ & $\begin{array}{l}7.2 \\
4.8 \\
7.4\end{array}$ & $\begin{array}{l}5.9 \\
6.6 \\
5.9\end{array}$ \\
\hline Services, Fisheries, 0ther & NA & $N A$ & NA & NA & NA \\
\hline Mining & NA & NA & NA & NA & NA \\
\hline Construction & 16.0 & 11.5 & 22.0 & 9.7 & 29.7 \\
\hline Manufacturing & 4.2 & 0.8 & 8.6 & 4.3 & -0.2 \\
\hline $\begin{array}{l}\text { Transportation, Public } \\
\text { Utilities }\end{array}$ & 3.5 & 2.7 & 3.2 & 6.3 & -0.8 \\
\hline Wholesale Trade & 6.9 & 7.4 & 9.4 & 5.2 & 0.5 \\
\hline Retail Trade & 6.3 & 3.1 & 8.9 & 7.7 & 4.0 \\
\hline $\begin{array}{l}\text { Finance, Insurance, and } \\
\text { Real Estate }\end{array}$ & 7.1 & 6.2 & 10.8 & 7.5 & -5.6 \\
\hline Services & 4.9 & 0.2 & 9.3 & 7.0 & 0.3 \\
\hline Government & 4.7 & 3.0 & 4.8 & 8.2 & 1.0 \\
\hline Federal, Civilian & 2.3 & -1.1 & 5.6 & 4.7 & -3.7 \\
\hline Federal, Military & 1.2 & 1.7 & -4.2 & 4.9 & 10.0 \\
\hline State and Local & 5.4 & 3.8 & 5.5 & 8.9 & 1.0 \\
\hline
\end{tabular}

Source: Calculated from Table 8.1.

reflected in the Transportation and Public Utilities category. With the issuance of the construction permit for WNP-2 in March 1973 and the State Site Certifications for WNP-1 and WNP-4 in August 1975, construction employment grew at a rate of 22.0 percent per year during this period. 0verall employment growth in the Tri-Cities increased at an average annual rate of 8.9 percent.

Employment by $00 \mathrm{E}$ and its contractors grew from 7,570 in 1973 to 12,300 in 1977 (Table 8.4), increasing 62 percent over the period, or over 12.1 percent per year. DOE-generated employment falls primarily into the Chemicals and Allied Products, Services, Construction, and Federal Government employment categories. These significant increases fueled demand for housing (real 
TABLE 8.3. Irrigated Acreage in Benton and Franki in Counties, 1969-1982

$\begin{array}{lcccc}\text { Year } & \text { Benton County } & \text { Franklin County } & \text { Benton Franki in Combined } \\ 1969 & 74,184 & 128,899 & 203,083 \\ 1970 & 79,937 & 132,608 & 212,545 \\ 1971 & 85,690 & 135,899 & 221,589 \\ 1972 & 91,443 & 136,743 & 228,186 \\ 1973 & 97,200 & 134,274 & 231,474 \\ 1974 & 107,296 & 140,768 & 248,064 \\ 1975 & 118,441 & 141,787 & 260,228 \\ 1976 & 132,739 & 142,426 & 275,165 \\ 1977 & 143,264 & 144,902 & 288,166 \\ 1978 & 151,911 & 145,984 & 297,895 \\ 1979 & 156,313 & 146,291 & 302,604 \\ 1980 & 159,000 & 148,631 & 307,631 \\ 1981 & 160,991 & 150,335 & 311,326 \\ 1982 & 161,593 & 151,599 & 313,192\end{array}$

Source: Benton County Extension office (1983), Clement et al. (1974).

TABLE 8.4. Tri-Cities DOE and Supply System Employment, 1973-1982 Supply System Corporate Staff

$\begin{array}{ccc}\text { Year } & \text { and Contractors (WNP-1, 2, 4) } & \text { DOE and Contractors } \\ 1973 & 530 & 7,570 \\ 1974 & 1,115 & 8,700 \\ 1975 & 1,946 & 9,800 \\ 1976 & 2,954 & 10,680 \\ 1977 & 3,412 & 12,300 \\ 1978 & 7,097 & 11,750 \\ 1979 & 8,926 & 12,000 \\ 1980 & 7,935 & 12,100 \\ 1981 & 11,728 & 11,880 \\ 1982 & 8,841 & 11,500\end{array}$

Source: McGinnis and Schau (1983). 
estate) and for services, and led to annual growth rates in these sectors of 10.8 percent and 9.3 percent, respectively (Table 8.2). Employment growth rates in virtually all sectors increased during this period, with the exceptions of military and agricultural employment. Despite continuing increases in acreage, technological developments and changes in crop mix slowed growth in farm employment.

\section{7 to 1980}

Tri-Cities employment continued to grow rapidly between 1977 and 1979, then slowed in 1980. The area's annual employment growth rate for wage and salary employment was 7.2 percent, but that figure is based on 11.8 percent growth from 1977 to $1978,9.6$ percent growth from 1978 to 1979 , and 0.2 percent growth from 1979 to 1980 (Table 8.1). Strong growth continued in agriculture, construction, retail trade, real estate, and services, as well as state and local government. Declines were noted in durable manufacturing, and the growth rate in wholesale trade was nearly halved over the 1973 to 1977 period. Dne of the reasons for the stagnant economy in 1980 was the large number of labor disputes that year. The number of employees involved in labor disputes averaged over the total year $(1,040)$ represented 12 percent of construction employment or 13 percent of tota? WPPSS employment for that year (Washington Employment Security 1983). These disputes by construction workers were felt throughout the Tri-Cities economy, particularly affecting the wholesale and retail trade sectors.

\section{0 to 1982}

Employment during the 1980 to 1981 period showed declines in several sectors. Annual average growth in Construction between 1980 and 1981 was 29.7 percent and accounted for the majority of the tota? employment gains that year (Table 8.2). Overall growth in wage and salary employment was 5.9 percent, with Government and Retail Trade posting modest gains; Manufacturing and Utilities modest declines; and employment in Finance, Insurance and Real Estate declines of 5.6 percent.

From 1981 to 1982 , employment in the Tri-Cities began to decline. In the fourth quarter of 1981 , the WNP-4 project (20 percent complete) was mothballed and then terminated (January 1982), a decision based on the Supply System's 
inability to finance the remaining construction and uncertainty regarding the future need for power. Still, moderate increases in payrolls on other WPPSS sites mitigated some of the impact from the halt in construction at WNP-4. In late April 1982, WNP-1 (62 percent complete) was mothballed for at least 5 years. Construction on the WNP-2 project was completed in the second quarter of 1983 and the facility is currently awaiting its fuel load. As a result of these actions, the WPPSS workforce is expected to lose 10,000 of the 13,500 jobs held in June 1981 within 2 years (McGinnis and Schau 1983).

Nearly all non-manufacturing sectors of the Tri-Cities economy experienced a decline from 1981 to 1982. Construction employment fell over 38 percent, while Government, Services, Wholesale and Retail Trade, and Transportation and Public Utilities all experienced declines between 2.9 and 7.8 percent. Finance, Insurance and Real Estate employment, however, increased 4.9 percent, and Manufacturing increased 2.4 percent (McGinnis and Schau 1983).

\section{Other Historical Trends}

Local manufacturing has been a mainstay of the Tri-Cities economy. The Chemicals and Allied Products category provides local support to DOE Hanford contractors and off-Hanford firms that produce agricultural chemicals for local consumption and export. It and the Food and Kindred Products category have provided fairly steady growth between 1971-and 1980. Local manufacturing has maintained its share of employment due to increases in chemicals, food, and other manufacturing categories. Manufacturing jobs in Walla Walla County also add to the Tri-Cities local economy because an estimated 75 percent of workers employed in the Burbank-Wallula area of that county commute daily from the TriCities (Washington State Employment Security 1982).

Between 1980 and 1982, employment in the Food and Kindred Products sector declined; however, opportunities in this area are expected to be increased by the opening of several new wineries in the area. The performance of the Chemicals and Allied Products sector continues to be strong. The increase in Transportation and Public Utilities employment from 1975 to 1982 would have been higher except for pervasive losses in the railroads. Some of the lower 
growth since 1980 can also be attributed to a decline in population growth and the restructuring of local industry.

Federal government budgets represent the single largest source of primary economic activity in the area. The recent changes in emphasis of DOE programs is expected to lead to changes in the mix of employment demands, with relative declines in the Business Services sector, and increases in Chemicals and Allied Products (Washington State Employment Security 1982). The federal budget for Hanford for fiscal year (FY) 1982 was $\$ 756$ million, and $\$ 844$ million for Fy 1983 (Washington State Employment Security 1983).

\subsubsection{Labor Force Characteristics}

The Tabor force of the Tri-Cities has several interesting characteristics. Local occupational studies conducted in 1980 and 1981 examined local employment in the Mining, Construction, Manufacturing, Finance, Insurance and Real Estate, Federal Government, and Services sectors. The studies showed 3,010 engineers, 740 scientists, 2,240 technicians, and 260 computer specialists were employed in these sectors. The ratio of the number of locallyemployed engineers to total non-farm employment is 220 percent of the national average (Washington State Employment Security 1982). This highty technical labor force composition reflects the emphasis on research and development work associated with Hanford activities.

Table 8.5 gives the labor force mix by age, race, and sex for the TriCities and Walla Walla County area for 1970 and projections for 1984. Several changes are shown over this period. The percentage of the total labor force represented by women is expected to grow from 37 percent in 1970 to 45 percent of the projected total work force in 1984. The racial mix is also expected to change, with 98 percent of the 1970 work force composed of whites, compared to a projected 94 percent share of whites in 1984. The largest change will occur in the Other Race category, with a jump from under 1 percent in 1970 to 5 percent in 1984. The fastest growing racial groups within the region during this period have been Hispanics and Asians. Part of this was the result of inmigration to meet seasonal agricultural demands, but the larger part was due to an inflow of workers from Asian countries. Washington State ranked third among the 50 states in Indochinese resettlement during this period, with the TriCities gaining a healthy share of the state total. 
TABLE 8.5. Resident Civilian Labor Force by Age, Sex, and Race for Benton, Franlin, and Walla Walla Counties

\begin{tabular}{|c|c|c|c|c|c|c|c|}
\hline & & & & & & Race & \\
\hline Age & Number & Percent & MaTe & Female & White & Black & other \\
\hline 1984 Projections & 100,240 & 100.0 & 55,100 & 45,140 & 93,970 & 1,230 & 5,040 \\
\hline $16-17$ & 3,540 & 3.5 & 1,900 & 1,640 & 3,110 & 50 & 380 \\
\hline $18-19$ & 3,990 & 4.0 & 1,910 & 2,080 & 3,670 & 50 & 270 \\
\hline $20-24$ & 12,370 & 12.4 & 6,570 & 5,800 & 11,380 & 150 & 850 \\
\hline $25-34$ & 32,180 & 32.1 & 17,820 & 14,360 & 30,650 & 380 & 1,150 \\
\hline $35-44$ & 22,840 & 22.8 & 11,860 & 10,980 & 21,370 & 280 & 1,190 \\
\hline $45-64$ & 22,780 & 22.7 & 13,440 & 9,340 & 21,410 & 260 & 1,100 \\
\hline 65 and older & 2,540 & 2.5 & 1,600 & 940 & 2,380 & 60 & 100 \\
\hline 1970 Census & 54,975 & 100.0 & 34,661 & 20,314 & 53,863 & 703 & 409 \\
\hline $16-17$ & 2,484 & 4.5 & 1,421 & 1,063 & 2,432 & 27 & 25 \\
\hline $18-19$ & 3,031 & 5.5 & 1,632 & 1,399 & 2,979 & 24 & 28 \\
\hline $20-24$ & 5,822 & 10.6 & 3,360 & 2,462 & 5,669 & 92 & 61 \\
\hline $25-34$ & 10,095 & 18.4 & 6,629 & 3,466 & 9,824 & 178 & 93 \\
\hline $35-44$ & 11,497 & 20.9 & 7,237 & 4,260 & 11,297 & 105 & 95 \\
\hline $45-64$ & 20,036 & 36.4 & 13,037 & 6,990 & 19,701 & 237 & 98 \\
\hline 65 and older & 2,010 & 3.7 & 1,345 & 665 & 1,961 & 40 & 9 \\
\hline
\end{tabular}

Source: Washington State Employment Security (1983). 
Finally, the most interesting change in the labor force has been in the age distribution. In 1970, the largest labor force age category for both men and women was the 45 to 64 age range, with 38 percent of all male workers and 34 percent of all female workers within that range. By 1984, a significant shift will occur, with the most workers now in the 25 to 34 age bracket; 32 percent of both the male and female labor force will fall within that range. In 1970, only 19 percent and 17 percent of male and female workers, respectively, were in the younger category. By 1984, the percentage of the labor force aged 45 to 64 will have fallen to 23 percent.

The most significant cause of this shift in the age distribution of the labor force is the dramatic increase in construction employment that accompanied the WPPSS nuclear projects. These projects attracted large ruinbers of mobile, younger, male construction workers to the area throughout the late 1970s and into the early 1980s, altering the age structure of the resident labor force.

\section{Unemployment}

Table 8.6 shows total civilian labor force unemployment rates in the TriCities between 1973 and 1982. Unemployment in the Tri-Cities and surrounding communities has generally averaged higher than the state or nation due to the seasonal variability in the Agricultural and Food Processing sectors. Despite the rapid growth in employment at WPPSS and other industries in the area, unemployment remained a probiem in the region, especialiy for unskilled labor (Washington State Employment Security 1982). It was said that "it seemed for every 10 jobs created, eleven persons would enter the local labor market to compete for these positions" (Washington State Employment Security 1982, p. 10). The labor force grew 7.2 percent between 1978 and 1981 , primarily from in-migration. Although job opportunities grew significantly during the late 1970 s, this in-migration caused the unemployment rate to increase.

Insured unemployment for the Tri-Cities area for 1982 was 4,946 workers. of this total, 32.5 percent were female and 67.5 percent were male (Washington State Employment Security 1983). The increase in the unemployment rate since 1981 reflects the national recession, declining employment in agriculture, and the decisions to mothball and terminate WNP-1 and WNP-4. The recent increase 
TABLE 8.6. Total Tri-Cities Civilian Labor Force Unemployment, 1973-1982 (a)

\begin{tabular}{|c|c|c|c|c|}
\hline Year & $\begin{array}{c}\text { Resident } \\
\text { Civilian } \\
\text { Labor Force } \\
\end{array}$ & Employment & $\begin{array}{c}\text { Total } \\
\text { Unemployment }\end{array}$ & $\begin{array}{c}\text { Annual } \\
\text { Unemployment } \\
\text { Rate } \\
\end{array}$ \\
\hline 1973 & 42,520 & 38,960 & 3,560 & 8.4 \\
\hline 1974 & 45,270 & 42,300 & 2,970 & 6.6 \\
\hline 1975 & 49,190 & 45,550 & 3,640 & 7.4 \\
\hline 1976 & 55,800 & 51,800 & 4,000 & 7.2 \\
\hline 1977 & 60,400 & 55,500 & 4,900 & 8.1 \\
\hline 1978 & 68,670 & 64,340 & 4,330 & 6.3 \\
\hline 1979 & 75,450 & 70,480 & 4,970 & 6.6 \\
\hline 1980 & 79,810 & 72,000 & 7,810 & 9.8 \\
\hline 1981 & 83,000 & 75,600 & 7,400 & 8.9 \\
\hline 1982 & 81,400 & 69,800 & 11,600 & 14.3 \\
\hline
\end{tabular}

(a) These values vary slightly from figures in Table 8.1. The figures from this table are used for scenario development in Section 8.2. Source: McGinnis and Schau (1983).

in unemployment has hit the construction industry hardest, although trade and services have also been significantly affected (Washington State Employment Security 1983). This is reflected in the high unemployment rate of males in the area; nationally the unemployment rate for adult females is higher than that for adult males. Some out-migration of labor has occurred; however, the continuing high level of unemployment indicates that significant numbers of unemployed workers are remaining in the area.

The recent unemployment situation in the Tri-Cities and Walla Walla County is shown in Tabies 8.7 and 8.8, where the number of applicants and the number of nonagricultural job openings by major occupational titie are given for 0ctober 1981 through March 1983. This information gives some indication of the structure of unemployment in the area. The largest numbers of unemployed workers applying for job services occurred in the Construction, Services, Clerical, and Professional categories, with 10 percent or more of total applicants in each of the periods. In 1981 to 1982 , there were roughly twice as many job openings as applicants in the Tri-Cities, while openings 
TABLE 8.7. Applicants and Job Openings for Selected Occupations in the Tri-Cities Job Service Centers

\begin{tabular}{|c|c|c|c|}
\hline $\begin{array}{l}\text { Applicants } \\
\text { Registered: Act ive } \\
\text { (End of Period) }\end{array}$ & $\begin{array}{c}\text { Nonagricultural } \\
\text { Openings Received }\end{array}$ & $\begin{array}{l}\text { Ratio of } \\
\text { Openings to } \\
\text { Applicants } \\
\text { (percent) }\end{array}$ & $\begin{array}{l}\text { Ratio of } \\
\text { Applicants front } \\
\text { Cateyory to Total } \\
\text { Applications } \\
\text { (percent) }\end{array}$ \\
\hline
\end{tabular}

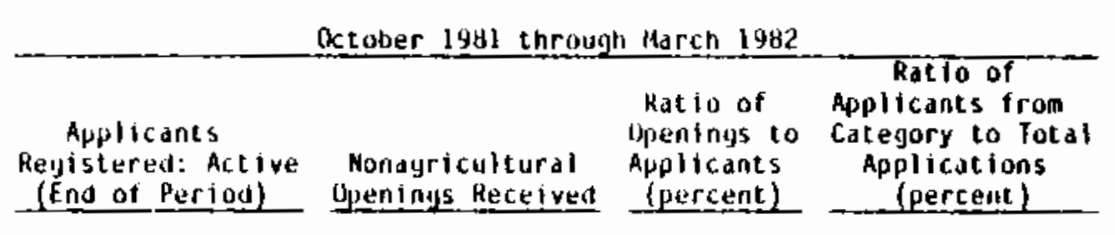

Professiunal, Technical.

Clerical

$\begin{array}{rrr}342 & 60 & 16 \\ 454 & 134 & 29 \\ 116 & 75 & 65 \\ 293 & 206 & 10 \\ & & \\ 91 & 25 & 27 \\ 99 & 124 & 125 \\ 116 & 32 & 28 \\ 29 & 34 & 117 \\ 1,057 & 81 & 8 \\ 274 & 159 & 58 \\ 42 & 37 & 88 \\ 2,957 & 967 & 33\end{array}$

Sales

Services

agriculture, Fishleries,

$\infty$ Forestry

Foud Processiny

Machine Trates

Henchwork

Structure Hork

Miscellaneous

No Decupiational Code

IOIAI

2,957

13
15
4
10
3
3
4
1
36
9
1
100

Source: Hashinigton State Liaployment Security, 1983 (Kaw Data). 
TABLE 8.8. Applicants and Job Openings for Selected Occupations in the Walla Walla Job Service Center

\begin{tabular}{|c|c|c|c|}
\hline $\begin{array}{c}\text { Applicants } \\
\text { Reqtstered: Act 1ve } \\
\text { End of Period) } \\
\end{array}$ & $\begin{array}{c}\text { Nonagricultiral } \\
\text { Dpenings Received }\end{array}$ & $\begin{array}{l}\text { Ratio of } \\
\text { Openings to } \\
\text { Applicants } \\
\text { (percent) } \\
\end{array}$ & $\begin{array}{c}\text { Ratio of } \\
\text { Applicants fron } \\
\text { Category to Iotal } \\
\text { Application } \\
\text { (percent) } \\
\end{array}$ \\
\hline
\end{tabular}

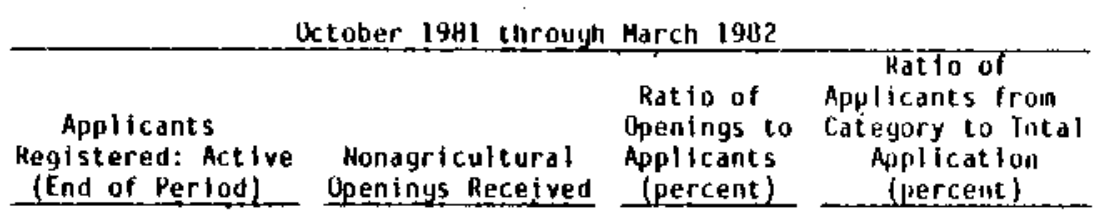

Professional. Technical.

Manayer

Clerical

Sales

Services

$\begin{array}{rrr}73 & 28 & 38 \\ 1111 & 53 & 53 \\ 26 & 32 & 123 \\ 96 & 85 & 89 \\ 36 & 5 & 14 \\ 54 & 61 & 113 \\ 48 & 9 & 19 \\ 9 & 6 & 67 \\ 136 & 17 & 13 \\ 10 & 29 & 14 \\ 9 & 5 & 56 \\ 657 & 330 & 50\end{array}$

11
15
4
15
5
8
7
1
21
11
1
100
(End of Pertod)

Peninys Received

(percent) (jercent)

Agriculture, Fisheries,
Forestry

Food Processing

Machine Trades

Benchwork

Structural Work

Miscellaneous

No Occupational Code

TOIAL

100

$\begin{array}{rr}58 & 26 \\ 68 & 75 \\ 15 & 16 \\ 83 & 73 \\ & \\ 34 & 29 \\ 8 & 125 \\ 42 & 11 \\ 4 & 0 \\ 77 & 38 \\ 58 & 54 \\ 26 & 0 \\ 473 & 447\end{array}$

$\begin{array}{rr}26 & 45 \\ 75 & 110 \\ 16 & 107 \\ 73 & 88 \\ 29 & 85 \\ 125 & 1,563 \\ 11 & 26 \\ 0 & 0 \\ 38 & 49 \\ 54 & 93 \\ 0 & 0 \\ 447 & 95\end{array}$

$88 \quad 18$

Source: Washington State Employment Security, 1983 (Raw lhata). 
were available for 95 percent of Walla Walla County applicants. The Food Processing, Sales, and Clerical categories had the largest number of openings per applicant, while Machine Trades, and Agriculture, Fisheries and Forestry had the lowest ratios.

In the 1982 to 1983 period, the overall ratio of openings to applicant fell dramatically, from 212 percent to 33 percent in the Tri-Cities, and from 95 percent to 50 percent in Walla Walla County. The largest opening-toapplicant ratios for this period in the Tri-Cities were in Food Processing, Benchwork, Services, and Sales. The lowest ratios were in the Professional, Technical and Manager, and Construction categories. The largest ratios in Walla Walla County for the 1982 to 1983 period were in Sales, Food Processing, and Services, and the lowest ratios were in Construction, Agriculture, Fisheries and Forestry, and Machine Trades.

The most dramatic shifts in the ratios of openings to applicants again appeared in the construction sector. In the 1981 to 1982 period, the TriCities figures showed 81 percent as many openings as applicants in construction (structural work) and Walla Walla had 49 percent. In 1982 to 1983, however, the ratios fell to 8 percent and 13 percent, respectively. Of the almost 1200 registered job services applicants in construction, 70 were placed in the 98 job openings received. This category alone accounted for one-third of total applications for the area, more than double the 15 percent of total construction applications in 1981 to 1982.

There are several possible reasons that over 1200 construction workers remained in the area after the decisions to terminate WPPSS construction were made in the fourth quarter of 1981 and second quarter 1982. The most important is probably the depressed nature of the construction industry nationwide. Another is the relatively unskilled nature of construction workers drawn to the Tri-Cities area. A significant number of WPPSS construction workers were young, relatively inexperienced laborers with few specific skilis. The unfavorable employment conditions nationally give construction workers more incentive to remain in the locale of their current union, since "travelers" are generally hired only after local union members are employed. 
Other occupational categories with significant numbers of applicants over available openings in the 1982 to 1983 period were the Professional, Technica] and Manager, Clerical, and Services categories. Between the 1981 to 1982 and 1982 to 1983 periods, the share of total applicants in some of the categories actually fell. For example, during the 1981 to 1982 period 19 percent of all applicants were in the services trade; this share fell to 10 percent in 1982 to 1983. Similarly, clerical applicants fell from 19 percent to 15 percent. However, in every occupational category the total number of job applicants was greater in 1982 to 1983 than in 1981 to 1982.

\section{Seasonality of Employment}

Another major characteristic of unemployment in the Tri-Cities area is the large degree of seasonality in the agricultural sector. Table 8.9 shows monthly employment figures for Benton and Franklin Counties for 1979 to 1982. Covered agricultural employment in June is three times higher than employment in December. The bulk of this seasonal employment is filied by migrant workers, with thousands of positions filled through the issuing of clearance orders from as far away as Texas. Local residents employed in agriculture tend to concentrate in the food processing occupational categories.

The seasonal agricultural work consists of a variety of jobs, each with different requirements throughout the year. The major crops employing migrant workers include asparagus (early spring to-mid-April), hops (early spring to prepare the fields, and then harvesting for $1-1 / 2$ months starting in September), and the orchards (apples and cherries start after the hops, with workers moving up the Yakima Valley picking from September through November). other tasks include thinning of the apple trees in the summer, pruning grapevines in November through February, harvesting field corn and wheat, and the tedious work of moving hoses associated with low technology irrigation. Recently, the demands for labor to prune fruit trees and grapevines have been increasing.

\section{1 .3 Income}

This section examines trends in labor and proprietor income by major sectors. Table 8.10 presents income data for the period 1969 to 1980 , and Table 8.11 shows calculated growth rates in the sectors covered in Table 8.10. 
TABLE 8.9. Seasonality of Employment: Covered Agriculture in Benton and Franklin Counties, 1979-1981

$$
\frac{\text { Ave }}{2,236} \frac{\text { Jan }}{125} \frac{\text { Feb }}{1,057} \frac{\text { Mar }}{1,5649} \frac{\text { Aur }}{1,326} \frac{\text { May }}{1,492} \frac{\text { Jun }}{5,335} \frac{\text { Jul }}{2,790} \frac{\text { Alug }}{2,123} \frac{\text { Sep }}{3,083} \frac{\text { Oct }}{2,224} \frac{\text { Nov }}{1,347} \frac{\text { Dec }}{1,155}
$$

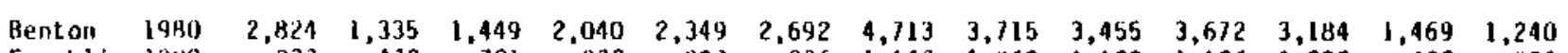

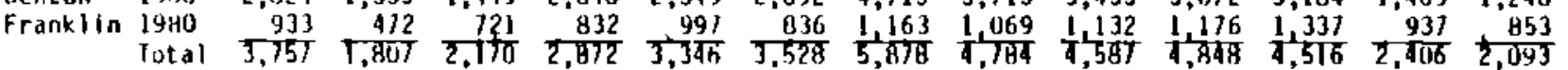

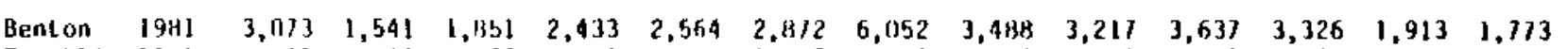

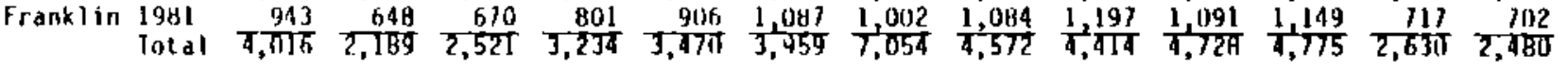

Source: Washington State Employment Security, 1983. 

TABLE 8.10. Total Lapgr and Proprietors Personal Income by Major Sources for the Tri-Cities SMSA (in thousands of

\begin{tabular}{|c|c|c|c|c|c|c|c|c|c|c|c|c|}
\hline & $1969^{(a)}$ & $1970^{(b)}$ & $1971^{\text {(b) }}$ & $1972^{(b)}$ & $1973^{(b)}$ & $1974^{(b)}$ & $1975^{\text {(b) }}$ & $1976^{(b)}$ & $1977^{(b)}$ & $197 \mathrm{e}^{(\mathrm{b})}$ & $1979^{(b)}$ & $1980^{(b)}$ \\
\hline $\begin{array}{l}\text { Wage and 5alary Income } \\
\text { 0ther Labor Incompd) } \\
\text { Proprietor Income } \\
\text { Farm } \\
\text { Non-Farm (d) } \\
\text { By Industry }\end{array}$ & $\begin{array}{r}227.0 \\
9.5 \\
43.7 \\
20.2 \\
23.6\end{array}$ & $\begin{array}{r}244.8 \\
10.9 \\
37.9 \\
14.0 \\
23.9\end{array}$ & $\begin{array}{r}250.8 \\
11.6 \\
41.5 \\
16.8 \\
24.8\end{array}$ & $\begin{array}{r}276.5 \\
13.5 \\
53.2 \\
26.9 \\
26.3\end{array}$ & $\begin{array}{r}319.8 \\
15.6 \\
80.2 \\
51.1 \\
29.1\end{array}$ & $\begin{array}{r}385.9 \\
19.2 \\
94.6 \\
63.6 \\
31.0\end{array}$ & $\begin{array}{r}485.0 \\
26.4 \\
81.4 \\
44.7 \\
36.7\end{array}$ & $\begin{array}{r}554.9 \\
32.6 \\
79.5 \\
32.8 \\
46.7\end{array}$ & $\begin{array}{r}696.5 \\
42.2 \\
57.9 \\
5.2 \\
52.8\end{array}$ & $\begin{array}{r}865.4 \\
52.5 \\
81.3 \\
19.7 \\
61.7\end{array}$ & $\begin{array}{r}1,026.3 \\
64.2 \\
71.7 \\
3.1 \\
68.6\end{array}$ & $\begin{array}{r}1,091.6 \\
72.9 \\
95.6 \\
25.0 \\
70.7\end{array}$ \\
\hline $\begin{array}{l}\text { Farm } \\
\text { Non-Farm } \\
\text { Agricultural Seryices }\end{array}$ & $\begin{array}{r}27.9 \\
252.4\end{array}$ & $\begin{array}{r}24.0 \\
269.6\end{array}$ & $\begin{array}{r}26.8 \\
277.0\end{array}$ & $\begin{array}{r}37.8 \\
305.4\end{array}$ & $\begin{array}{r}.65 .7 \\
349.9\end{array}$ & $\begin{array}{r}82.2 \\
417.6\end{array}$ & $\begin{array}{r}66.9 \\
525.9\end{array}$ & $\begin{array}{r}61.0 \\
606.0\end{array}$ & $\begin{array}{r}31.0 \\
765.5\end{array}$ & $\begin{array}{r}47.1 \\
952.1\end{array}$ & $\begin{array}{r}36.8 \\
1,125.4\end{array}$ & $\begin{array}{r}62.7 \\
1,197.4\end{array}$ \\
\hline $\begin{array}{l}\text { Forestry, Other } \\
\text { Mining } \\
\text { Construction } \\
\text { Manufacturing } \\
\text { Non-Durable Manufacturing } \\
\text { Durable Manufacturing } \\
\text { Transportation } \\
\text { Wholesdle Trade } \\
\text { Retai Trade } \\
\text { Financial, Insurance, }\end{array}$ & $\begin{array}{l}\text { (D) } \\
\text { (D) } \\
25.1 \\
53.9 \\
49.4 \\
4.5 \\
14.5 \\
7.4 \\
26.9\end{array}$ & $\begin{array}{l}\text { (D) } \\
\text { (D) } \\
23.7 \\
55.5 \\
51.3 \\
4.2 \\
16.2 \\
8.0 \\
29.7\end{array}$ & $\begin{array}{l}\text { (D) } \\
\text { (D) } \\
25.0 \\
54.2 \\
49.4 \\
4.8 \\
17.3 \\
8.0 \\
31.4\end{array}$ & $\begin{array}{r}2.3 \\
0.9 \\
35.6 \\
59.3 \\
53.3 \\
6.0 \\
20.0 \\
8.8 \\
34.5\end{array}$ & $\begin{array}{r}2.5 \\
0.2 \\
48.3 \\
65.9 \\
57.3 \\
8.6 \\
23.2 \\
9.7 \\
37.7\end{array}$ & $\begin{array}{r}3.2 \\
0.2 \\
63.5 \\
78.9 \\
68.1 \\
10.8 \\
24.8 \\
21.0 \\
42.8\end{array}$ & $\begin{array}{l}(D) \\
(D) \\
100.8 \\
100.4 \\
82.7 \\
17.7 \\
26.4 \\
17.6 \\
47.0\end{array}$ & $\begin{array}{l}\text { (D) } \\
\text { (D) } \\
106.7 \\
115.1 \\
99.3 \\
15.7 \\
31.5 \\
20.2 \\
56.2\end{array}$ & $\begin{array}{l}\text { (D) } \\
\text { (D) } \\
169.3 \\
137.6 \\
121.2 \\
16.4 \\
38.2 \\
22.6 \\
65.4\end{array}$ & $\begin{array}{l}(D) \\
(D) \\
229.4 \\
165.7 \\
146.9 \\
18.8 \\
46.3 \\
29.7 \\
78.8\end{array}$ & $\begin{array}{r}8.6 \\
1.6 \\
287.6 \\
194.3 \\
174.9 \\
19.4 \\
53.3 \\
36.6 \\
90.7\end{array}$ & $\begin{array}{l}\text { (D) } \\
\text { (D) } \\
252.1 \\
210.4 \\
188.9 \\
21.4 \\
57.3 \\
34.5 \\
97.8\end{array}$ \\
\hline $\begin{array}{l}\text { Real Estate } \\
\text { Services } \\
\text { Covernment } \\
\text { Federal, Civilian } \\
\text { State and Local } \\
\text { Per Capita Personal Income }\end{array}$ & $\begin{array}{r}6.2 \\
77.8 \\
38.6 \\
8.1 \\
29.1 \\
3.6\end{array}$ & $\begin{array}{r}6.0 \\
84.5 \\
44.0 \\
9.5 \\
32.9 \\
3.8\end{array}$ & $\begin{array}{r}6.8 \\
85.4 \\
46.4 \\
.9 .5 \\
35.2 \\
4.0\end{array}$ & $\begin{array}{r}8.0 \\
86.8 \\
49.3 \\
9.9 \\
37.4 \\
4.4\end{array}$ & $\begin{array}{r}8.3 \\
94.7 \\
50.4 \\
11.0 \\
46.2 \\
5.2\end{array}$ & $\begin{array}{r}8.7 \\
113.6 \\
69.7 \\
12.7 \\
54.9 \\
6.0\end{array}$ & $\begin{array}{r}9.5 \\
136.7 \\
83.1 \\
15.1 \\
65.8 \\
6.6\end{array}$ & $\begin{array}{r}12.8 \\
162.7 \\
95.3 \\
17.1 \\
76.8 \\
7.0\end{array}$ & $\begin{array}{r}17.6 \\
200.9 \\
107.2 \\
19.7 \\
86.1 \\
7.8\end{array}$ & $\begin{array}{r}22.9 \\
247.2 \\
123.1 \\
21.8 \\
99.7 \\
8.9\end{array}$ & $\begin{array}{r}27.1 \\
279.0 \\
146.6 \\
23.7 \\
121.2 \\
9.7\end{array}$ & $\begin{array}{r}28.8 \\
332.3 \\
173.4 \\
26.2 \\
145.3 \\
10.3\end{array}$ \\
\hline
\end{tabular}

Source: Regional Economic Information System BEA (1982).

(a) Consists of wage and salary disbursements. Other labor income, and proprietors' income. Primary source for private nonfarm wages: ES-202 covered wages Washington employment security department.

(b) Estimates based on 1967 SIC.

(c) Estimates based on 1972 IIC.

(d) Includes the capital consumption adjustment for non-farm proprietors.

(e) Includes wages and salaries of U.S. residents working for international organizations in the U.5.

(f) The estimates for federal military earnings have been revised for the year 1977-80.

(D) Not shown to avold disclosure of confidential information, data ara included in totals.

(L) Less than $\$ 50,000$ data are included in totals. 
TABLE 8.11. Calculated Growth in Income: Tri-Cities SMSA (percent) ${ }^{(a)}$

\begin{tabular}{lllll}
$1969-$ & $1969-$ & $1973-$ & $1977-$ & $1973-$ \\
1980 & 1973 & 1977 & 1980 & 1980 \\
\hline
\end{tabular}

Total Labor and Proprietors Income

\begin{tabular}{|c|c|c|c|c|c|}
\hline $\begin{array}{l}\text { Wage and Salary Income } \\
\text { Other Labor Income } \\
\text { Proprietor Income } \\
\text { Farm } \\
\text { Non-Farm }\end{array}$ & $\begin{array}{r}14.3 \\
18.5 \\
7.1 \\
1.9 \\
10.0\end{array}$ & $\begin{array}{r}8.6 \\
12.4 \\
15.2 \\
23.2 \\
5.2\end{array}$ & $\begin{array}{r}19.5 \\
24.9 \\
-8.1 \\
-57.1 \\
14.9\end{array}$ & $\begin{array}{r}15.0 \\
18.2 \\
16.7 \\
52.3 \\
9.7\end{array}$ & $\begin{array}{r}17.5 \\
22.0 \\
2.5 \\
-10.2 \\
12.7\end{array}$ \\
\hline \multicolumn{6}{|l|}{ By Industry } \\
\hline $\begin{array}{l}\text { Farm } \\
\text { Non-Farm } \\
\text { Construction } \\
\text { Manufacturing } \\
\text { Non-Durable } \\
\text { Durable } \\
\text { Transportation and Pubtic Utilities } \\
\text { Wholesale Trade } \\
\text { Retai? Trade } \\
\text { Financial, Insurance, Real Estate } \\
\text { Services } \\
\text { Government } \\
\text { Federal, Civilian } \\
\text { State and Local Government } \\
\text { Per Capita Personal Income } \\
\text { Inflation }\end{array}$ & $\begin{array}{r}7.4 \\
14.2 \\
21.0 \\
12.4 \\
12.2 \\
14.2 \\
12.5 \\
14.0 \\
11.7 \\
14.0 \\
13.2 \\
13.7 \\
10.7 \\
14.6 \\
9.6 \\
6.6\end{array}$ & $\begin{array}{r}21.4 \\
8.2 \\
16.4 \\
5.0 \\
3.7 \\
16.2 \\
11.8 \\
6.8 \\
8.4 \\
7.3 \\
4.9 \\
10.8 \\
7.7 \\
11.6 \\
9.2 \\
4.6\end{array}$ & $\begin{array}{r}-18.8 \\
19.6 \\
31.4 \\
18.4 \\
18.7 \\
16.1 \\
12.5 \\
21.1 \\
13.8 \\
18.8 \\
18.8 \\
14.8 \\
14.6 \\
15.6 \\
10.1 \\
7.1\end{array}$ & $\begin{array}{r}23.5 \\
14.9 \\
13.3 \\
14.2 \\
14.8 \\
8.9 \\
13.5 \\
14.1 \\
13.4 \\
16.4 \\
16.8 \\
16.0 \\
9.5 \\
17.4 \\
9.3 \\
8.8\end{array}$ & $\begin{array}{r}-0.7 \\
17.6 \\
23.6 \\
16.6 \\
17.0 \\
13.0 \\
12.9 \\
18.1 \\
13.6 \\
17.8 \\
17.9 \\
15.3 \\
12.4 \\
16.4 \\
9.8 \\
7.8\end{array}$ \\
\hline
\end{tabular}

Source: Calculated from Table 8.10. Inflation rate from Economic Report of the President 1983, Table B-3. Implicit Price Deflators for Gross Nationa] Product, Total Personal Consumption Expenditures Deflator, p. 166.

(a) Data not available for the Agricultural Services, Forestry and 0ther, and Mining categories.

While the overall annual average growth rate in current income over the period was over 14 percent compared to annual growth in inflation of 6.6 percent, the growth has not been steady and has come from a variety of sources. The following discussion details these trends.

\section{9 to 1973}

Over the four-year period from 1969 to 1973, overall wage and salary income in the Tri-Cities SMSA grew at an annual average rate of 8.6 percent, 
compared to a 4.6 percent annual growth in inflation (Table 8.11 ). The sector with the largest average income growth was Agriculture, with annual average growth of 21.4 percent. Construction and Durable Manufacturing had average annual growth rates of 16.4 percent and 16.2 percent, respectively, and Transportation and Public Utilities grew at a rate of 11.8 percent per year. The period showed 8.4 and 10.8 percent growth rates, respectively, in Retail Trade and Government, and 7.3 percent growth in Real Estate. Per capita personal income increased from $\$ 3,600$, to $\$ 5,200$, a total growth of 9.2 percent per year. With inflation growth over this period of 4.6 percent per year, real per capita income grew roughly 4.6 percent per year.

\section{3 to 1977}

Annual income growth over the period 1973 to 1977 was 19.5 percent, a rate which is over twice the rate of the 1969 to 1973 period and over twice the 7.1 percent inflation rate for this period. Construction income showed the greatest increase, growing at an annual growth rate of 31.4 percent. At the Farm income declined 18.8 percent per year over the period, due to a sharp increase in farm income in 1974 and a sharp decline in 1977. Many categories showed annual increases of more than 15 percent, including Manufacturing, Wholesale Trade, Services, and Finance, Insurance and Real Estate. Both Federal Civilian, and State and Local Government income experienced strong growth, while military income declined at an annual average rate of 10.1 percent. Per capita personal income grew 10.I percent per year. Although this annual increase is iarger than during the 1969 to 1973 period, per capita income did not keep pace with total income growth, reflecting the in-migration of workers in excess of available jobs. Real per capita income increased about 3.0 percent per year, which was less than the rate of the 1969 to 1973 period.

1977 to 1980

During the three-year period from 1977 to 1980, wage and salary income increased 15.0 percent. During this period, the annual inflation rate was 8.8 percent. The largest contributing sector was Agriculture, with 23.5 percent annual average growth over the period. Real Estate posted a 16.4 percent gain in income per year, and Manufacturing, Wholesale Trade, Services, and Govern- 
ment each showed 14 percent or greater annual gains. Construction grew at an average annual rate of $\mathbf{1 3 . 3}$ percent over the period. All income categories had growth rates higher than the inflation rate for the 1977 to 1980 period. Per capita income grew 9.3 percent over the period. Inflation during this period.was 8.8 percent, so real per capita income increased roughly 0.5 percent per year.

With reductions in total wage and salary employment, trade sector employment also fell. Adverse impacts were reduced because a portion of the activity within the trade sector is due to consumers outside the immediate Tri-Cities area, and because some of the local whoiesale trade is linked to the export of agricultural food commodities (Washington State Employment Security, 1983).

\subsubsection{Housing}

Following the increases in population and employment that accompanied the WPPSS projects in the mid-1970s, the number of housing units also increased from 1970 to 1982 , a total of 94.3 percent. Table 8.12 gives the historical number of housing units by type for Benton and Franklin Counties. The number of housing units began escalating in 1973, growing at an annual average rate of 7.8 percent through 1981 . Since 1981, the annual average rate of growth has slowed to levels closer to the 1.6 percent rate that occurred prior to 1973 . Ouring the 1970 to 1982 period the number of mobile homes increased at the fastest rate ( 16.1 percent), followed by multi-family units ( 8.4 percent), and single-family homes (6.7 percent).

In 1982, single-family homes accounted for 69 percent of total housing units, multi-family units accounted for 20 percent, and mobile homes accounted for the remaining 11 percent. The single-family share was 76 percent in 1970 , while the multi-family and mobile home shares were 19 and 5 percent, respectively. In periods of rapid growth in population and employment, as occurred in the Trj-Cities area, it is expected that the number of muiti-family and mobile homes would grow more rapidly than the number of single-family homes.

Table 8.13 shows the number of housing units for the cities of Kennewick, Richland, and Pasco for 1975 to 1982. For all the years and types of housing shown, Kennewick had more housing units than the other two cities. Kennewick 
TABLE 8.12. Number of Housing Units for Benton and Frankl in Counties, 1970-1982

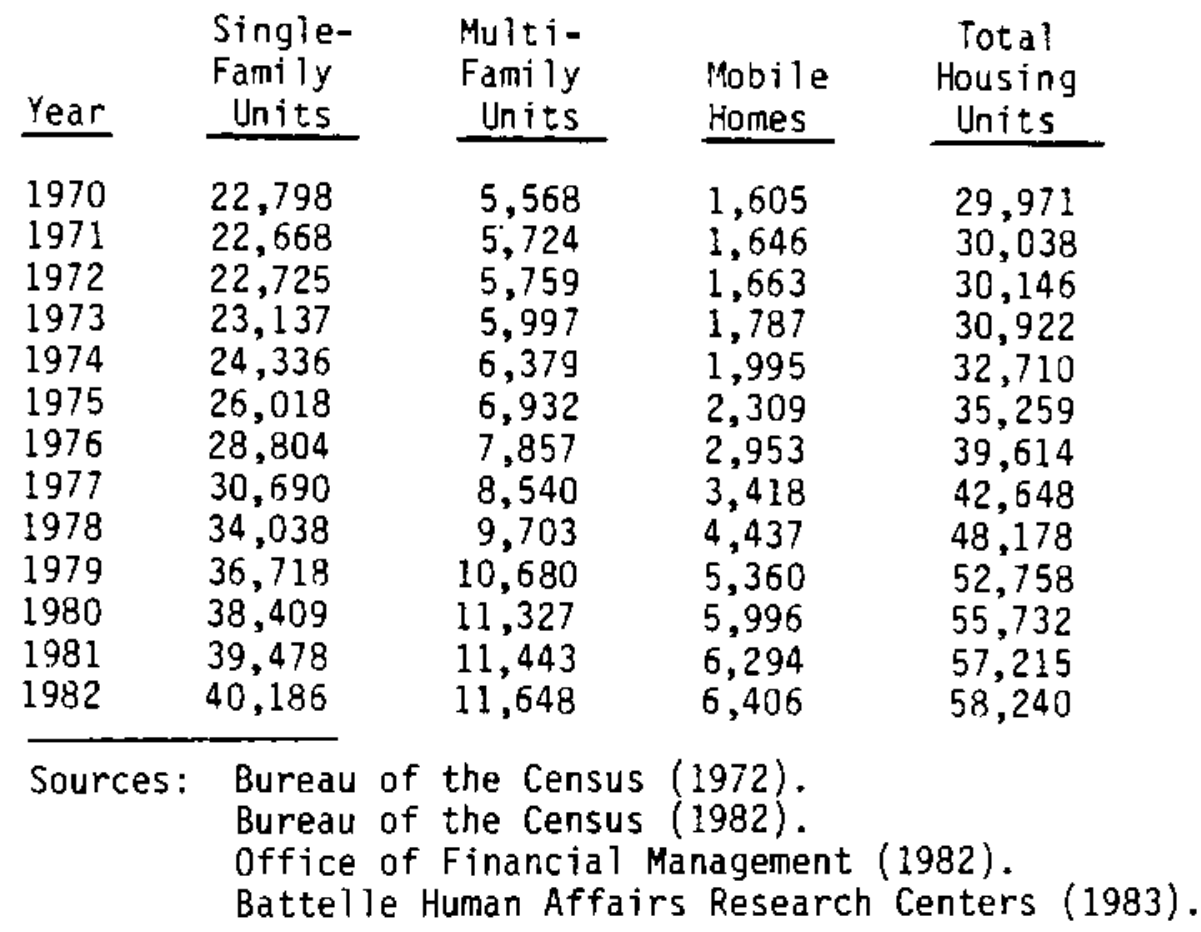

also had a disproportionately large number of housing units compared with its corresponding share of the population. In 1975, Kennewick had 30 percent of the total Tri-Cities population, but 39 percent of the housing; in 1982 the proportions were 40 percent and 45 percent, respectively. Richland had a smaller proportion of housing than population, while Pasco had nearly equal proportions for both population and housing. From 1975 to 1981 , Kennewick's annual average growth rates for each of the three types of housing were higher than the corresponding rates for Richland and Pasco, particularly for singlefamily units. This corresponds with Kennewick's rapid population growth for the same period. Growth in the number of mobile homes was the most similar among the three cities, while Pasco had a lower annual average growth rate in multi-family units than either kennewick or Richland, which were similar. Al1 three cities have experienced sharp declines in housing growth since.1981.

Vacancy rates for the Tri-Cities are presented in Table 8.14. Except for declines in 1978, vacancy rates for all types of housing have generally increased since 1975, with sharp rises after 1980. Multi-family units throughout the area have been hit hardest by increased vacancy rates, 
TABLE 8.13. Number of Housing Units in Richland, Kennewick, and Pasco, 1975-1982

A11 Housing Units

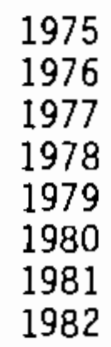

\begin{tabular}{c} 
Richland \\
\hline 10,969 \\
12,339 \\
13,561 \\
14,636 \\
15,139 \\
15,458 \\
15,912 \\
15,887
\end{tabular}

Single-Family Units

1975
1976
1977
1978
1979
1980
1981
1982

Mu?ti-Family Units (a)

1975
1976
1977
1978
1979
1980
1981
1982

Mobile Homes

1975
1976
1977
1978
1979
1980
1981
1982

Mutiofamily units

1975

1977

1978

1979

1981

1982

1,151

1,369

3,795

4,230

4,340

4,369

4,443

4,504

Mobile Hones

1975
1976
1977
1978
1979
1980
1981
1982

$$
\begin{array}{r}
9,301 \\
10,370 \\
9,054 \\
9,523 \\
9,727 \\
10,156 \\
10,312 \\
10,192
\end{array}
$$$$
9,473
$$$$
9,812
$$$$
10,804
$$$$
11,567
$$$$
12,054
$$$$
12,699
$$$$
12,972
$$$$
13.555
$$

11,807

16,663

18,642

20,008

22,247

22,460

$\underline{\text { Pasco }}$

7,689

8,755

9,500

10,108

10,880

11,081

11,876

11,385

$$
\begin{aligned}
& 5,977 \\
& 6,165 \\
& 6,198 \\
& 6,691 \\
& 6,686 \\
& 6,805 \\
& 7,031 \\
& 6,749
\end{aligned}
$$

1,368

2,453

3,658

4,670

5,592

5,624

6,404

6,057

$\begin{array}{rrr}517 & 966 & 788 \\ 600 & 1,398 & 1,191 \\ 712 & 1,805 & 1,303 \\ 883 & 2,405 & 1,605 \\ 1,072 & 2,362 & 1,789 \\ 933 & 2,736 & 2,060 \\ 1,157 & 2,871 & 2,025 \\ 1,191 & 2,848 & 1,410\end{array}$

(a) Includes condominiums.

Source: Tri-Cities Real Estate Research Council (1982). 
TABLE 8.14. Vacancy Rates for the Tri-Cities, 1975-1983 (percent)

\begin{tabular}{|c|c|c|c|}
\hline $\begin{array}{c}i-C i t i e s \\
\text { SiMSA }\end{array}$ & Richland & Kennewick & Pasco \\
\hline $\begin{array}{l}0.6 \\
0.8 \\
1.7 \\
1.3 \\
2.0 \\
2.8 \\
4.3 \\
5.1 \\
8.6\end{array}$ & $\begin{array}{l}0.7 \\
0.7 \\
0.8 \\
1.1 \\
1.7 \\
3.7 \\
3.5 \\
4.9 \\
9.1\end{array}$ & $\begin{array}{l}0.7 \\
0.9 \\
2.1 \\
1.4 \\
2.3 \\
2.5 \\
5.3 \\
5.7 \\
8.7\end{array}$ & $\begin{array}{l}0.3 \\
0.8 \\
2.1 \\
1.5 \\
1.9 \\
1.9 \\
3.4 \\
4.4 \\
7.7\end{array}$ \\
\hline
\end{tabular}

Single-Family Units

$\begin{array}{lllll}1975 & 0.5 & 0.7 & 0.4 & 0.3 \\ 1976 & 0.6 & 0.4 & 1.0 & 0.5 \\ 1977 & 0.9 & 0.3 & 1.2 & 1.1 \\ 1978 & 0.9 & 1.1 & 0.9 & 0.9 \\ 1979 & 1.2 & 1.1 & 1.2 & 1.0 \\ 1980 & 1.2 & 1.4 & 1.2 & 1.1 \\ 1981 & 1.5 & 1.5 & 1.5 & 1.7 \\ 1982 & 2.5 & 2.5 & 2.7 & 1.9 \\ 1983 & 3.6 & 4.2 & 3.7 & 2.5\end{array}$

Multi-Family Units (a)

$\begin{array}{rrrrr}1975 & 1.6 & 1.2 & 2.7 & 0.3 \\ 1976 & 1.8 & 3.2 & 0.9 & 2.1 \\ 1977 & 4.1 & 2.2 & 5.3 & 5.3 \\ 1978 & 2.7 & 1.4 & 3.2 & 4.4 \\ 1979 & 4.4 & .3 .1 & 5.2 & 5.2 \\ 1980 & 7.0 & 9.7 & 5.5 & 5.5 \\ 1981 & 11.4 & 8.4 & 14.4 & 9.2 \\ 1982 & 12.1 & 10.9 & 13.8 & 10.1 \\ 1983 & 19.1 & 19.7 & 19.9 & 16.4\end{array}$

Mobile Homes

$\begin{array}{lllll}1975 & 0.7 & 0.4 & 0.7 & 0.8 \\ 1976 & 0.6 & 0.0 & 0.1 & 1.1 \\ 1977 & 0.9 & 0.0 & 0.8 & 1.6 \\ 1978 & 0.6 & 0.2 & 0.6 & 0.9 \\ 1979 & 0.9 & 1.0 & 0.8 & 0.8 \\ 1980 & 1.6 & 1.5 & 2.2 & 1.0 \\ 1981 & 2.1 & 3.3 & 2.1 & 1.4 \\ 1982 & 3.2 & 2.0 & 2.6 & 4.9 \\ 1983 & 8.8 & 5.7 & 7.3 & 13.0\end{array}$

(a) Includes condominiums.

Source: Federal Home Loan 8ank (1983). 
followed by mobile homes, and lastly, single-family units. In 1983, Richland had the highest vacancy rate for single-family homes (4.2 percent), Kennewick had the highest rate for multi-family homes (19.9 percent), and Pasco had the highest rate for mobile homes ( 13.0 percent). Using the 8.6 percent vacancy estimate for all housing units for the entire Tri-Cities SMSA, there were about 5,000 vacant housing units in 1983. (a)

\subsubsection{Education}

In 1981, the Tri-Cities area was served by 12 public school districts, 9 private schools, 8 vocational schools, a community college, and the Joint Center for Graduate Study, which offers undergraduate and graduate degrees through several Washington and Oregon universities. Public school enrollment for Benton and Franklin Counties is given in Table 8.17 for the years 1970 to 1983 (where available). Total enrollment for Benton and Franklin Counties combined increased 10.2 percent, from 24,579 in 1970 to 27,075 in 1982 . Enrollments in both counties were falling prior to 1974, increasing through 1981, then falling again in 1982 and 1983. Franklin County enrollments varied less than Benton County enrollments. Table 8.15 also gives the enrollments for Richland,

TABLE 8.15. Public School Enrollment in the Tri-Cities SMSA, 1970-1983

\begin{tabular}{|c|c|c|c|c|c|}
\hline Year & $\begin{array}{l}\text { Bent on } \\
\text { County }\end{array}$ & $\begin{array}{c}\text { Franklin } \\
\text { County } \\
\end{array}$ & Richland & Kennewick & Pasco \\
\hline $\begin{array}{l}1970 \\
1971 \\
1972 \\
1973 \\
1974 \\
1975 \\
1976 \\
1977 \\
1978 \\
1979 \\
1980 \\
1981 \\
1982 \\
1983\end{array}$ & $\begin{array}{c}18,002 \\
17,760 \\
17,602 \\
17,475 \\
17,838 \\
18,823 \\
19,832 \\
20,776 \\
21,592 \\
21,840 \\
21,288 \\
21,727 \\
20,552 \\
\quad \text { NA }\end{array}$ & $\begin{array}{l}6,577 \\
6,425 \\
6,234 \\
6,015 \\
5,981 \\
6,302 \\
6,431 \\
6,282 \\
6,383 \\
6,464 \\
6,438 \\
6,590 \\
6,523 \\
\text { NA }\end{array}$ & $\begin{array}{l}7,322 \\
7,224 \\
7,160 \\
7,036 \\
7,206 \\
7,321 \\
7,757 \\
7,993 \\
8,201 \\
8,071 \\
7,833 \\
7,760 \\
7,087 \\
7,050\end{array}$ & $\begin{array}{r}7,598 \\
7,418 \\
7,376 \\
7,401 \\
7,565 \\
8,212 \\
8,576 \\
9,224 \\
9,658 \\
9,927 \\
9,688 \\
10,045 \\
9,578 \\
10,089\end{array}$ & $\begin{array}{l}5,152 \\
5,006 \\
4,869 \\
4,655 \\
4,565 \\
4,816 \\
4,946 \\
4,907 \\
4,991 \\
5,058 \\
5,096 \\
5,249 \\
5,114 \\
5,330\end{array}$ \\
\hline
\end{tabular}

Sources: Pacific Northwest Laboratory.

Educational Service District 123 (1983).

(a) Estimated using the 1982 total for housing units $(58,240$ units) from Table 8.12 . 
Kennewick, and Pasco. Kennewick had both the most students and experienced the most growth during the 1970 to 1983 period. The teacher-to-student ratio in elementary through high school classes is approximately 1 to 23 in Pasco, 1 to 21 in Kennewick, and 1 to 22 in Richland.

Table 8.16 gives the 1981 estimates of public school capacity and enrol1ment. All the districts except Kennewick had significant amounts of unused capacity and even Kennewick had some unused capacity. Because enrollment has declined since 1981, additional unused capacity is available in 1983. The districts are experiencing fewer facility strains than in the mid-1970s, aithough some have used portable classrooms to accommodate temporary expansion needs. In the past 3 years, the area has seen the construction of two new high schools, four new elementary schools, and the expansion of existing buildings to add classrooms (U.S. Department of Energy 1982).

Public school expenditures are presented in Table 8.17 for 1970 to 1981. Both total expenditures and expenditures per student feil from 1970 to 1972 , increased steadily through 1980, then fell again in 1981. Broken down by county, expenditures increased at an annual average rate of 4.9 percent in Benton County and 2.6 percent in Franklin County between 1972 and 1980. Part of the increase was due to increased enroliment and part was due to increased expenditures per student. Expenditures per student grew at an average annual rate of 2.2 percent in Benton County and 1.4 percent in Franklin County from 1970 to 1981. Expenditures for education generally kept up with the changing enrollment patterns that followed the changing population growth patterns in the Tri-Cities area during the 1970 to 1982 period.

\subsubsection{Public Services}

Public services discussed in this section include public utilities, public safety, health care and human services, and libraries, historical and cultural resources. Because historical data are not readily available for these categories, only the most recent data will be presented here. Information on government expenditures for public services is covered in Section 8.1.9. 
TABLE 8.16. Enrollments and Capacities of School Districts in the Immediate Tri-Cities Area, 1981

$\begin{array}{lcccc}\text { School District } & \text { Enrollment } & & \text { Capacity } & \begin{array}{c}\text { Non-Utilized } \\ \text { Capacity }\end{array} \\ \text { Columbia (No. 400) } & 886 & & 1,129 & 243 \\ \text { Finley (No. 503) } & 902 & & 1,163 & 261 \\ \text { Kennewick (No. 017) } & 10,604 & 11,290 & 686 \\ \text { Kiona-Benton (No. 052) } & 1,163 & 1,625 & 462 \\ \text { Pasco (No. 001) } & 5,535 & 7,016 & 1,481 \\ \text { Richland (No. 400) } & 8,308 & 10,103 & 1,795\end{array}$

Source: Puget Sound Power \& Light (1981).

TABLE 8.17. School District Expenditures in Benton and Franklin Counties, 1970 to 1981 (doTlars)

\begin{tabular}{ccc} 
Year & $\begin{array}{c}\text { Benton-Franklin } \\
\text { Total Expenditures }\end{array}$ & $\begin{array}{c}\text { Expenditure } \\
\text { per Student }\end{array}$ \\
\cline { 2 - 3 } 1970 & $44,572,169$ & 1,813 \\
1971 & $41,946,001$ & 1,734 \\
1972 & $39,359,327$ & 1,651 \\
1973 & $41,550,143$ & 1,769 \\
1974 & $43,003,553$ & 1,805 \\
1975 & $46,182,910$ & 1,838 \\
1976 & $51,307,339$ & 1,954 \\
1977 & $55,825,772$ & 2,063 \\
1978 & $59,433,278$ & 2,125 \\
1979 & $62,643,395$ & 2,213 \\
1980 & $62,885,528$ & 2,268 \\
1981 & $58,499,186$ & 2,066 \\
\end{tabular}

Source: Battelle, Human Affairs Research Centers (1983). 


\section{Public Utilities}

The water systems of Benton City, Kennewick, Prosser, Richland, West Richland, and Pasco were operating at less than capacity in 1981. The City of Richland has the largest water supply system capacity in the area with an ability to supply 178.8 million liters per day (mld) while experiencing a maximum daily usage of $140.0 \mathrm{mld}$; it was operating at 84 percent of capacity in 1981. Pasco has a water supply capacity of $73.8 \mathrm{mld}$ and treatment capacity of $70.0 \mathrm{mld}$, while experiencing a maximum daily use of $56.0 \mathrm{mld}$ in 1980 . Kennewick's water treatment facility is designed for 113.6 mid and was operating at $28.4 \mathrm{mld}$, with wells producing $54.9 \mathrm{mld}$, for a total system capacity of $83.3 \mathrm{mld}$. Maximum daily use in Kennewick in 1981 was $64.3 \mathrm{mld}$. The three smaller cities in the study area have municipal water systems that supply water in excess of 22.7 mld while experiencing a maximum daily usage total somewhat larger than 15.1 mld in 1981 (PSP\&L 1982).

The major incorporated areas of Benton and Franklin Counties are served by municipal waste-water treatment systems, whereas the unincorporated areas are served by onsite septic systems. The kennewick system is running at about 73 percent of capacity and the Pasco system is running at about 26 percent of capacity. Richland's waste-water treatment plant is running near capacity and a new treatment plant is currently under construction, which should be on Tine in 1987 with capacjty to serve 65,000 people. Both West Richland and Benton City are operating waste-water disposal systems at capacity and are moving to improve the situation. Prosser is operating well within system capacity limits, but has been violating Federal clean water standards (PSP\&L 1982).

Solid waste disposal is currentiy supplied largely by the local governments through contractual agreements with private disposal companies; the City of Richland is the only jurisdiction to operate its own solid waste disposal service. Wastes collected in Richland are disposed in a sanitary landfill operated by the city in the Horn Rapids area. Wastes from Kennewick, Benton City, West Richland, and Pasco are disposed in the sanitary landfill-operated by the city of Pasco. Current capacity in these landfills is adequate to meet existing and future needs through 1990 (PSP\&L 1982). 


\section{Public Safety}

Police protection in the Tri-Cities SMSA is provided by the Benton and Franklin County sheriff departments, local municipal police departments, and the Washington State Patrol division headquartered in Kennewick. Table 8.18 gives the number of staff and patrol cars for the major jurisdictions. The larger cities of Richland, Kennewick, and Pasco maintain the largest police personnel staffs with 55,56 , and 37 people, respectively. Of the incorporated areas, West Richland maintains the largest staff per thousand population (2.4 per 1000), whereas Kennewick and Richland have the lowest (1.6 per 1000). A ratio of 2.0 per 1000 is generally considered an appropriate level of service. Nearly all of the other municipal staffing levels are near the 2.0 per 1000 residents ratio, while the Benton County sheriffs are understaffed with a 0.7 per 1000 residents ratio (PSP\&L 1982 ).

The police staffs in the Tri-Cities area have increased over recent years with population growth, as have the number of police calls. When the rate of crime per hundred thousand residents is compared for SMSAs in washington State, the Tri-Cities has substantially lower rates than either Yakima or Spokane or the state as a whole. Table 8.19 gives the type and number of crimes in the Tri-Cities SMSA for 1980 (PSP\&L 1982).

Jail facilities in the study area include county jails in both Benton and Franklin Counties, and city jails in Richland, Kennewick, and Pasco. In 1981, available jail facilities were inadequate; state-mandated improvements in

TABLE 8.18. Police Personnel in the Tri-Cities Area, 1981

\begin{tabular}{|c|c|c|}
\hline Type & Staff & Patrol Cars \\
\hline Benton City Municipal & 5 & 2 \\
\hline Kennewick Municipal & 56 & 17 \\
\hline Pasco Municipal & 37 & 8 \\
\hline Richland Municipal & 55 & 9 \\
\hline West Richland Municipal & 9 & 3 \\
\hline County Sheriff, Benton County & 25 & 16 \\
\hline County Sheriff, Franklin County & 32 & $N / A$ \\
\hline
\end{tabular}


TABLE 8.19. Type and Number of Crimes in the Tri-Cities SMSA, 1980

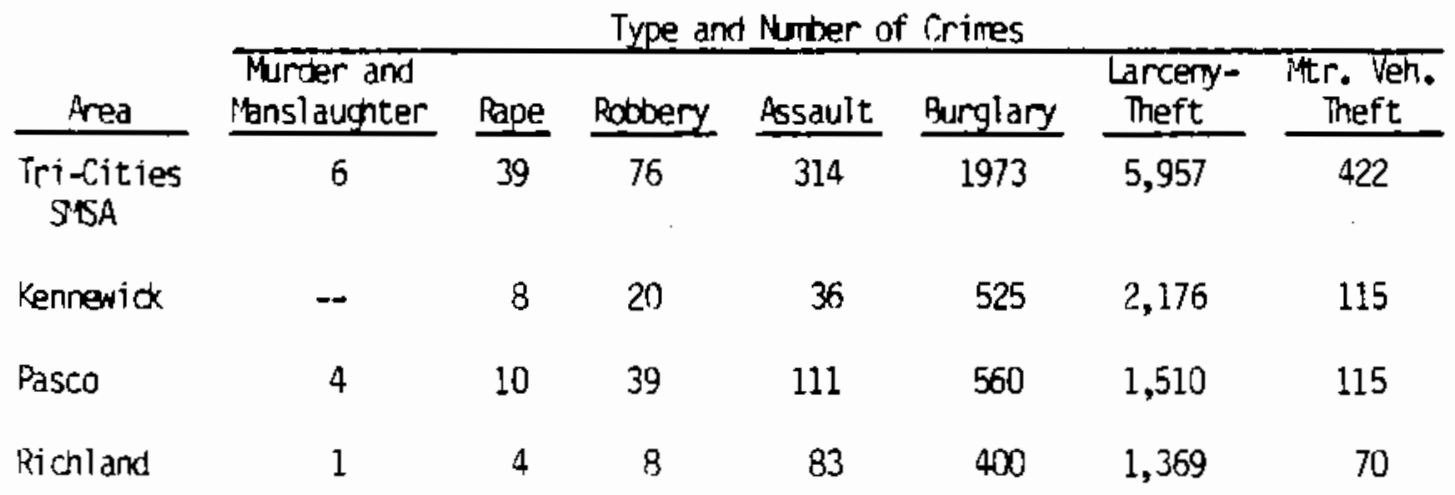

Source: PSP\&L (1981).

Benton County resulted in construction of a new 109-bed county jail scheduled to replace the existing 33-bed jail in 1983. Completion of this facility will alleviate prisoner overloads at the Benton County, Franklin County, Richland, and Kennewick jails. A juvenile justice center run jointly by Benton and Franklin County is located in Kennewick and has a capacity of 28 live-in juveniles.

Fire protection in the area is provided by municipal fire departments, and by fire protection units for specific service areas in Benton and Franklin Counties. The departments serving the area are listed in Table 8.20 along with data on staff size, and the service area covered. Only Pasco and Richland maintain exclusively full-time non-volunteer fire departments (PSP\&L 1981). Mutual aid agreements have been established among the five incorporated areas in Benton County, Pasco, and rural areas of Benton and Franklin Counties to supply fire protection service. The mutual aid agreements allow jurisdictions to reinforce each other during emergency situations. Each specific fire protection unit is capable of offering better fire protection service because of the availability of backup personnel and equipment from the neighboring fire protection units.

Health Care and Human Services

Numerous health care facilities and services are offered within the Tri-Cities area. Four general hospitals, located in Richland, Kennewick, Pasco, and Prosser offer a total of 351 beds. Other facilities include a bi- 
IABLE 8.20. Fire Protection Personnel Within the Tri-Cities Area, 1981

Fire Protection Unit

Kennewick

Pasco.

Richland

BCRFD No. 1

BCRFD No. 2

BCRFD No. 3

BCRFD No. 4

BCRFD No. 5

FCRFD No. 3
Staff

\begin{tabular}{|c|c|c|c|}
\hline Full Time & Volunteers & Total & Service Area \\
\hline 33 & 15 & 48 & City \\
\hline 26 & 0 & 26 & City \\
\hline 42 & 0 & 42 & City \\
\hline 1 & 126 & 127 & Kennewick Area \\
\hline 1 & 17 & 18 & Benton City \\
\hline 1 & 11 & 12 & Prosser Area \\
\hline 1 & 17 & 18 & West Richland \\
\hline 1 & 68 & 69 & Southeast of Prosser \\
\hline 3 & 65 & 68 & Surrounds City of $\mathrm{Pas}$ \\
\hline
\end{tabular}

Note: There are mutual aid agreements among all fire districts in the area. The "Tri-Cities Mutual Aid Agreement" (September 15, 1980) includes the cities of Pasco, Kennewick, Richland, BCRFDs Nos. 1, 2, 3, FCRFD No. 3, Walla Walla County, and the Rockwell Hanford Fire Protection Department.

Source: PSP\&L (1981).

county medical health facility operated by the Benton-Franklin District Health Department, a medical clinic in Benton City, the Hanford Environmental Health Facility in Richland, and 4 minor emergency clinics. There is a large range of medical specialties among the approximately 125 physicians and 50 dentists in the Tri-Cities area. Seven nursing homes serve the area with a total of 411 beds. The Mid-Columbia Mental Health Center is the primary source of mental health services and currently provides direct service to 3 percent of the population, with approximately one practicing psychiatrist or psychologist for each 10,000 residents. Services include treatment for drugs, crisis intervention, family-planning programs, and some services for the developmentally disabled. Maximum inpatient capacity for the center will be reached with a population of 140,000 in the immediate Tri-Cities area, but outpatient services are more flexible and are influenced primarily by revenue availability and demand for services.

A broad range of social services is offered in the Tri-Cities area. Benton and Franklin Counties cooperatively provide extension programs, health services, and emergency services. State human service offices in the Tri-Cities 
include the job services offices of the Employment Security Department, Food Stamp offices, the Division of Developmental Disabilities, financial and Medical Assistance, the Child Protective Service, emergency medical service, a senior companion program, vocational rehabilitation and various farm workers programs. The federal government maintains local Social Security offices.

In addition to these public human services programs, the area is also served by a Targe number of private agencies and voluntary human service organizations. Various organizations provide counseling programs on family problems, family planning, alcohol abuse, legal aid, behavioral difficulties, child placement, and aid to persons affected by various physical, emotional, and learning disabilities (PSP\&L 1981). Table 8.21 lists several specific programs available in these areas.

\section{Libraries and Historical and Cultural Sites}

The Mid-Columbia Library District serves Benton and Franklin Counties from a main library located in Kennewick and maintains branch libraries in Benton City, West Richland, and Pasco. A bookmobile maintains a scheduled route throughout the rural areas of the Tibrary district, offering service to residents outside the incorporated areas. The cities of Richland and Prosser have their own library systems. Increased usage of library services has created a need for better facilities in West Richland and Benton City. Although population served by the Mid-Columbia District increased by more than 28,000 persons between 1977 and I980, library material increased by only 2500 volumes (PSP\&L 1982). Total Mid-Columbia volumes were 218,086 in 1980.

The Columbia River was one of the most densely inhabited regions of aboriginal North America. Sites along the Hanford reach of the Columbia are the only remaining archaeological evidence of the early cultures. Nine archaeological properties on the Hanford Reservation are listed in the National Register of Historic Places. Controlled access to the Hanford Site provides protection to the remaining sites. The known archaeological sites nearest the primary NPR site are some of the Rattlesnake Springs sites. Table 8.22 lists the historic places in counties adjacent to the Hanford Reservation.

\subsubsection{Recreation}

Many opportunities for both indoor and outdoor recreation are available in the Tri-Cities area as shown in Table 8.23. The Tri-City Court Club in 
TABLE 8.21. Examples of Human Services Facilities and Organizations in the Tri-city SMSA

Facility or Organization

911 Emergency Dispatch Center

Benton-Franklin Association for Retarded Citizens

Benton-Franklin Developmental Center

Catholic Family Services

Lutheran Social Services of Washington

Children's Home Society of Washington

Columbia Industries

Benton-Franklin Council on Aging

Evergreen Legal Services

Good Shepherd Home

A Woman's Place

Planned Parenthood of BentonFranklin Counties

Tri-Cities Chaplaincy

Tri-Cities Food Bank

\section{Descriptive Comments}

Provides immediate referral to emergency information and dispatch of ambulance, fire, police, etc., services.

Counseling, recreation, transportation and referral services for learning-disabled individuals.

Provides services and programs for developmentally disadvantaged children.

Provides foster care programs, family and individual counseling programs and adoptive services.

Residential treatment facilities and programs for emotionally disturbed children.

Assists the physically and mentally disabled towards meaningful employment through vocational evaluation, work training, job placement and sheltered employment.

Program to provide meals, household assistance, health care and information and transportation services.

Free legal aid program for civil cases involving low-income persons.

A residential treatment program for adolescent girls with behavior problems.

Crisis phone and temporary residence for women and their children who are victims of doinestic violence.

Family planning education, information and assistance prograns.

Chap!aincy service to those with life-threatening $i 11$ nesses and their families, including a hospice program.

Provides food for those in need.

Source: United Way (1983). 
TABLE 8.22. Washington State Register of Historic PIaces in Counties Adjacent to the Hanford Site (State of Washington 1981c)

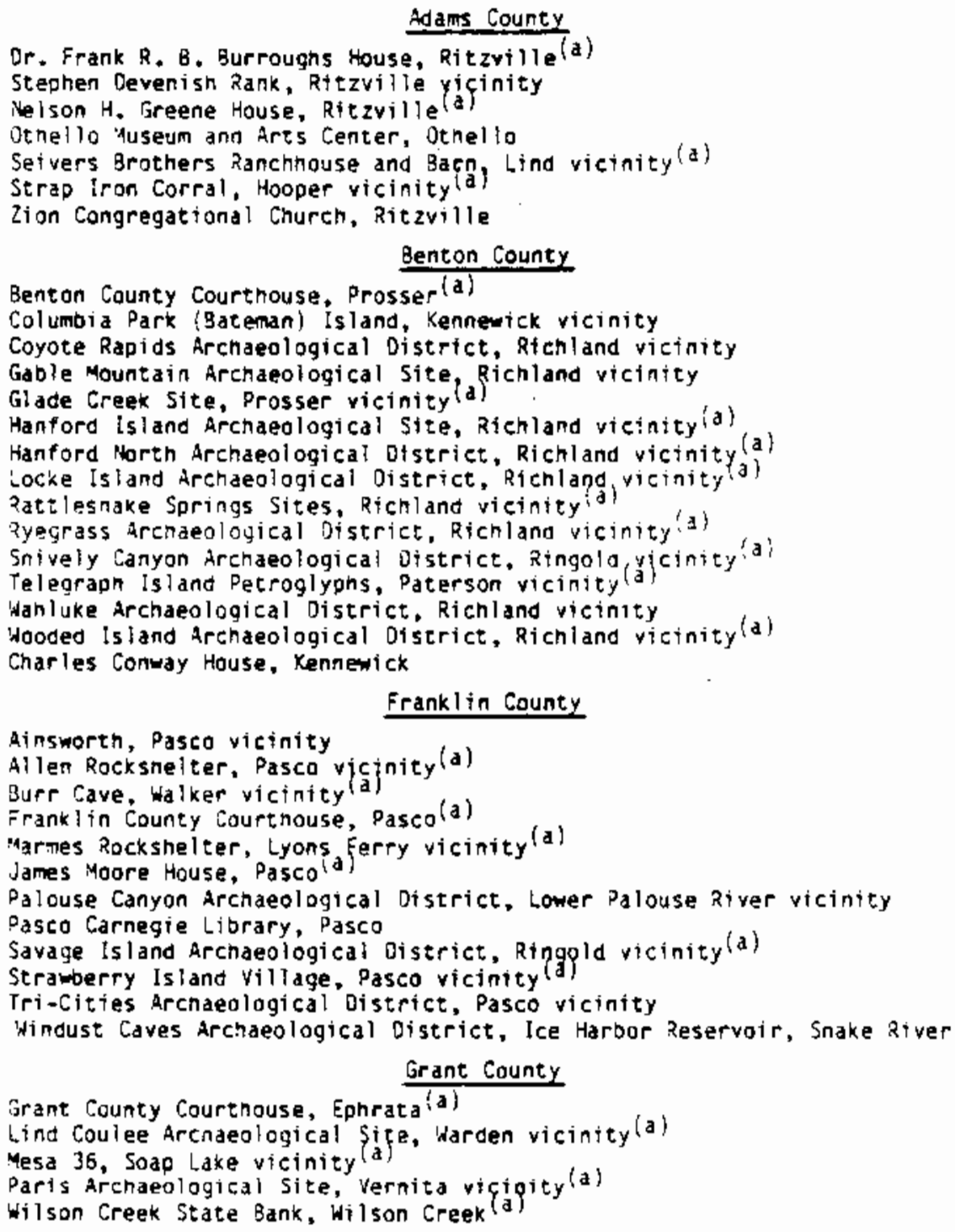

(a) Also listed in the National Register of Historic Places (State of Washingtion ! g8:c).

Source: IJ.S. Jepartinent of Energy 1982. 
TABLE 8.23. Examples of Physical Recreational Facilities

Avaitable in the Tri-Cities Area

Physical Activity

Tennis

Golf

Bowling

Swiming

Ball

Skating

Camping

Fishing

Hunting
Descriptive Comments

62 outdoor courts (e.g., Sylvester Park, Howard Amon Park, Pasco High School). Indoor courts at Tri-City Court Club and the Columbia Basin Racquet Club.

Six courses including Tri-City Country Club, Canyon Lakes and West Richland Municipal Golf Course. Several driving ranges and pro shops are also available.

Lanes in each city including Atomic Bowling Center, Clover Leaf Lanes and Columbia Lanes.

Private (e.g., Ranchette Estates) and public (e.g., Kennewick) swimming pools in the area. Boating, waterskiing and swimming on the Columbia River in the TriCities area.

Baseball fields and basketball courts are located throughout the Tri-Cities including such places as Badger Canyon, Craighill Playgrounds, Stevens Playground and Lewis and Clark School. Soccer and football fields are also located in various areas.

Roller-skating, ice-skating and skateboard facilities.

Several hundred campsites within driving distance from the Tri-Cities area including Levy Park, Fishook Park and Sun Lakes.

Steelhead, sturgeon, trout, and crappie fishing in the lakes and rivers near the Tri-Cities area.

Duck, geese, pheasant and quail hunting. Deer and elk hunting in the Blue Mountains and the Cascade Range.

Source: PSP\&L (1981).

Kennewick and the Columbia Basin Racquet Club in Richland have indoor tennis and racquetball courts, pools, and exercise equipment. Several exercise clubs are also in business. Bowling lanes are available in each of the cities. Private and public swimming pools and ice-skating and roller-skating rinks are 
also available. More than 15 movie theaters are found in the Tri-Cities, as well as several playhouses, a light opera company, the Mid-Columbia Symphony, and several art galleries.

Numerous tennis courts, ball fields, and six golf courses offer outdoor recreation to area residents and tourists. Camping sites and fishing areas are abundant within short driving distances of the Tri-Cities. The Columbia River Basin is also a popular area for migratory waterfowl and upland game bird hunting, and the Blue Mountains to the east and Cascades to the west offer opportunities for big game hunting, as well as hiking and skiing. Boating, auto racing, and hydroplane racing are also popular in the area. There are 134 outdoor recreation sites under local jurisdiction, 18 state sites, and 7 federal sites in Benton and Franklin Counties (PSP\&L 1982).

\subsubsection{Transportation}

The Tri-Cities serves as a regional transportation and distribution center with major air, land, and river connections. The Tri-Cities Regional Airport, located in Pasco, provides passenger and freight service to other major cities. The Richland Airport has facilities for commuter and private air traffic, while the Kennewick Airport is limited to serving small private aircraft. Commercial rail service is based in Pasco and includes a passenger station and a major switching yard for freight traffic. Rail service within the Hanford Site is controlled and maintained by DOE. Port facilities for barge traffic on the Columbia River are available at each of the three cities. All three cities are also served by Greyhound bus service.

Primary roads in the area include Routes $12,395,260$, and 17, and Interstate-82 currently under construction. Routes 240 and 24 , which traverse the Hanford Reservation, are maintained by the State of Washington while other secondary roads within the Reservation are maintained by DOE. Bridges across the Columbia River currently exist at Vernita in the northwest corner of the Hanford Site and at two locations connecting Kennewick and Pasco. Currently, a new bridge is being constructed across the Columbia; it will connect Richland to West Pasco as part of the I-182 project. This bridge will reduce traffic congestion over the Yakima River bridge connecting Richland and Kennewick and should increase population growth in Pasco (U.S. Department of 
Energy 1982). Major transportation facilities near and within the Hanford Reservation are shown in Figure 8.1.

Existing travel patterns and characteristics in the Tri-Cities area are heavily influenced by commuter travel generated on or near the Hanford Reservation. The recent history of traffic volumes on streets in the impact area has been one of growth since the mid-1970s, and has generally been parallel with the pattern of employment associated with Hanford. Traffic growth on the Yakima River Bridge (the "causeway"), for example, mirrors the year-by-year trend of combined DOE and WPPSS employment even to the 1980 "notch" in traffic volume (a sharp decrease) that occurred during the labor strikes. Traffic volumes on Stevens Drive and the Bypass Highway are similar. Traffic volumes peaked in 1981 .

Most of the arterials serving the Tri-Cities area are two lanes wide; exceptions are Route 4, George Washington Way, Stevens Drive, and the Bypass Highway. Traffic along the routes serving Hanford exhibit some unusual and extreme characteristics. Peak hour traffic near the Hanford Reservation forms a much larger portion of daily traffic (15 to 20 percent) than the portion of peak hour traffic to daily traffic found in other urban areas. Average vehicle occupancy in the area varies from 1.5 to 1.7 persons per car, well above the more usual 1.2 found in other areas. The southbound peak hour traffic volumes on the Route 240 bridge across the Yakima River (the "causeway") approached 2,000 cars per lane per hour in 1981, which is near or at maximum capacity (PSP\&L 1982).

Traffic congestion is heaviest during the evening peak hours. The most serious street capacity deficiencies in 1981, which was the peak traffic year, were observed at the intersection of the Bypass Highway with Van Giesen Street, and just north of the Yakima River Bridge where traffic from the Bypass Highway and George Washington Way merges. Current transit service is provided by crew buses serving the Hanford Reservation (but not including construction workers) and a local charter bus operation that also serves the Reservation (PSP\&L 1982). The Ben Franklin Transit System, a publicly-owned urban transit operation established in 1981, provides general daytime transportation service throughout the Tri-Cities and also runs an express service for contractors on the outskirts of the Reservation. 


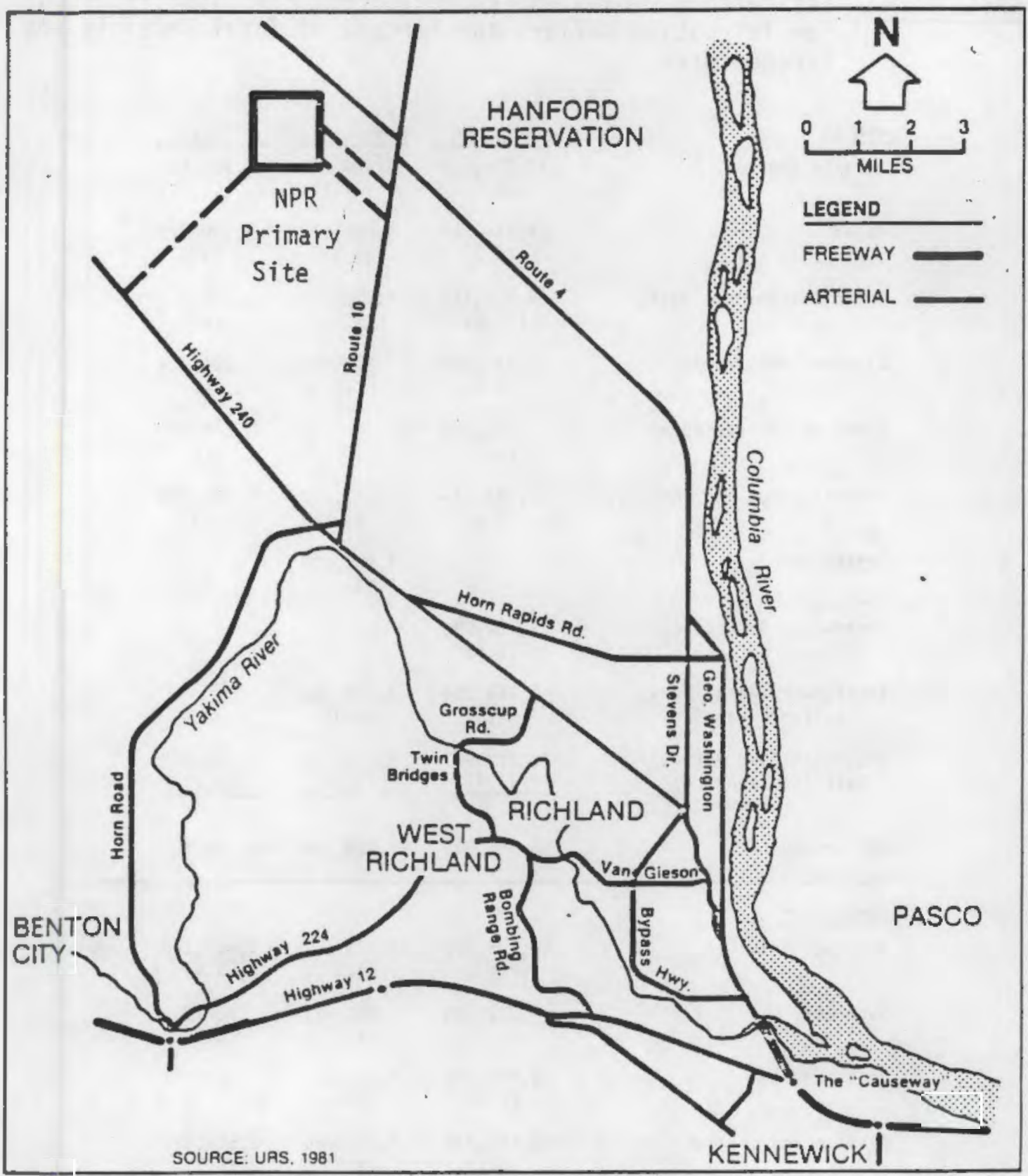

FIGURE 8.1. Major Transportation Routes in the Tri-Cities Area Serving the Hanford Reservation

\subsubsection{Public Revenues}

Table 8.24 compares the 1983 budget revenues and expenditures for all funds for the cities of Richland, Kennewick, and Pasco. An examination of 
TABLE 8.24. Estimated Revenues and Expenditures, All Funds 1983 Budget for Tri-Cities Dollars and Percent of Total Receipts and Expenditures

$\frac{\text { Revenues }}{\text { Service Charges }}$
Taxes
Intergovernmental Revs.
Licenses and Permits
Fines and Forefeitures
Mtscellaneous and Interest
Litilities
Nonrevenue Receipts
Intergovernmental Servs (R)/
Interfund Transfers (K)
Beginning Fund Bal ( $R$ )/
Cask ( $K$ )/Resources
Forward ( $P$ )

\begin{tabular}{|c|c|c|}
\hline Richland & Kennewick & Pasco \\
\hline $\begin{array}{c}24,039,102 \\
(36.4)\end{array}$ & $\begin{array}{c}1,984,795 \\
(7.1)^{-19}\end{array}$ & $\begin{array}{r}3,968,617 \\
(32:)\end{array}$ \\
\hline $\begin{array}{c}5,744,315 \\
(8.7)\end{array}$ & $\begin{array}{c}5,800,550 \\
(20.8)\end{array}$ & $\begin{array}{c}4,340,675 \\
(35)\end{array}$ \\
\hline $\begin{array}{c}9,821,412 \\
(14.8)\end{array}$ & $\begin{array}{c}4,710,420 \\
(16.8)\end{array}$ & $\begin{array}{c}1,736,270 \\
(14)\end{array}$ \\
\hline $\begin{array}{l}342,500 \\
(0.5)\end{array}$ & $\begin{array}{l}279,000 \\
(1.0)\end{array}$ & $\begin{array}{c}124,019 \\
\text { (1) }\end{array}$ \\
\hline $\begin{array}{l}322.500 \\
(0.5)\end{array}$ & & $\begin{array}{c}248,039 \\
(2)\end{array}$ \\
\hline \multirow[t]{2}{*}{$\begin{array}{c}2,368,644 \\
(3.6)\end{array}$} & $\begin{array}{c}2,203,519 \\
(7.9)\end{array}$ & $\begin{array}{c}520,096 \\
(5)\end{array}$ \\
\hline & $\begin{array}{l}4,305,000 \\
(15.4)\end{array}$ & \\
\hline \multicolumn{3}{|l|}{$\begin{array}{c}1,097,080 \\
(1.6)\end{array}$} \\
\hline $\begin{array}{c}1,549,356 \\
(2.5)\end{array}$ & $\begin{array}{c}2,220,942 \\
(8.0)\end{array}$ & \\
\hline $\begin{array}{c}20,729,907 \\
(31.4) \\
\end{array}$ & $\begin{array}{c}6,424,136 \\
(23.0) \\
\end{array}$ & $\begin{array}{c}1,364,212 \\
(11)^{2} \\
\end{array}$ \\
\hline $66,155,316$ & $27,928,362$ & $13,401,929$ \\
\hline
\end{tabular}

Total Revenue

$0.155,316$

Expenditures

\begin{tabular}{|c|c|c|c|}
\hline Personal Services & $\begin{array}{c}13,196,812 \\
920.01\end{array}$ & $\begin{array}{l}7,971,141 \\
(28.5)\end{array}$ & $\begin{array}{l}4,417,144 \\
(35.6)\end{array}$ \\
\hline Supplies & $\begin{array}{l}113,025 \\
(1.7)\end{array}$ & $\begin{array}{l}854,521 \\
(3.1)\end{array}$ & $\begin{array}{l}357.236 \\
(2.9)\end{array}$ \\
\hline Debt Service & $\begin{array}{l}2,926,485 \\
(4.4)\end{array}$ & $\begin{array}{l}2,222,991 \\
(8.0)\end{array}$ & $\begin{array}{l}487,081 \\
(3.9)\end{array}$ \\
\hline Service and charges & $\begin{array}{c}28,513,036 \\
(43.1)\end{array}$ & $\begin{array}{l}4,005,380 \\
(14.3)\end{array}$ & $\begin{array}{l}2,556,820 \\
(20.6)\end{array}$ \\
\hline Capital Outlays & $\begin{array}{l}3,524,356 \\
(5.3)\end{array}$ & $\begin{array}{l}6,877,250 \\
(24.6)\end{array}$ & $\begin{array}{l}1,654,4 ! 7 \\
(13.3)\end{array}$ \\
\hline $\begin{array}{c}\text { Council \& Admin. Conting. (R)/ } \\
\text { Ending Fund Balance (X) } P \text { ) }\end{array}$ & $\begin{array}{c}15,504,403 \\
(23.5)\end{array}$ & $\begin{array}{l}3,775,637 \\
(13.5)\end{array}$ & $\begin{array}{c}2,578,989 \\
(20.8)\end{array}$ \\
\hline $\begin{array}{l}\text { Transfers }(R, K) / \text { Gov't } \\
\text { Services }(P)\end{array}$ & $\begin{array}{l}1,319,999 \\
(2.0) \\
\end{array}$ & $\begin{array}{l}2,220,942 \\
(8.0) \\
\end{array}$ & $\begin{array}{l}350,243 \\
(2.8) \\
\end{array}$ \\
\hline tal Expenditures & $66,115,316$ & $27,928,362$ & $12,401,929$ \\
\hline
\end{tabular}


these shows several interesting differences in methods of raising and dispersing funds, and the overall size of the budgets for the cities.

Richland's total 1983 budget is $\$ 66,155,316$ while Kennewick's is $\$ 27,928,352$, or 42 percent of Richland's, despite similarly sized populations between the two cities. Pasco's budget is $\$ 12,401,929$. The major source of the disparity in budget size is the fact that Richland owns and operates four utilities: water, sewer, garbage, and electric. Kennewick and Pasco, on the other hand, operate only two: water and sewer. Further, Richland's electric utility fund alone for 1983 is $\$ 32$ million, overshadowing Kennewick's total utility fund of $\$ 4$ million. This amount accounts for virtualiy all of the difference in total budgets between the cities.

Other interesting differences occur in the manner in which the cities raise funds. Taxes account for 21 percent of Kennewick revenues and 35 percent of Pasco revenues, but oniy 9 percent of Richland revenues are attributable to taxes. However, service charges represent 36 percent of Richland revenues and only 7 percent of Kennewick's. Intergovernmental revenues, largely state and federal revenue sharing and grants distributed by a formula based on population, represent 14.8 percent of Richland's revenues, 18.8 percent of Kennewick's revenues, and 14 percent in Pasco. Funds raised from licenses and permits and miscellaneous sources are also roughly comparabie. The funds marked "Beginning Fund Balance" in Richland, "Cash" in Kennewick, and "Resources Forward" in Pasco represent roughly comparable funds. These funds enable certain revenues to equal expenditures, a requirement set out by state law. The use of such funds also allows city disbursements to proceed smoothly throughout the year despite the "chunkiness" in certain revenues.

Revenue sources particularly vulnerable to shifts in population, employment, and the business sector inciude some tax revenues (sales tax and business license tax), building permit revenues, and some state-shared revenues. The special revenues derived from the WPPSS construction were used by Richland's government mainly for special projects, so basic services and revenues were not greatly affected by the shift in wPPSS fortunes.

Expenditures in major cjty budget categories were roughly comparable among the three cities with the major exception of services and charges, where 
43 percent of Richland's budget fund services; Kennewick's service charges account for only 14 percent of outlays. Again, Richland's electric utility accounts for most of the difference.

Few of these expenditure categories vary greatly with economic conditions or population. Funding for police and fire protection (Table 8.25) increased rapidly from 1978 to 1981, but increased gradualiy (or fell slightly for fire) between 1981 and 1983 , even though the population fell.

Tables $8.26,8.27$, and 8.28 show local government revenues and expenditures for the current or general funds for the three cities (Richland, Kennewick, and Pasco, respectively) for 1981 to 1983. (a) These funds represent operational revenues and expenditures. They are a suitable basis for analysis because they tend not to fiuctuate based on one-time events and, therefore, better portray the underlying fiscal structure of the area.

TABLE 8.25. Tri-Cities Police and Fire Protection, 1978 and 1983

\begin{tabular}{|c|c|c|c|c|c|c|c|c|c|c|}
\hline \multirow[b]{2}{*}{ City } & & \multicolumn{3}{|c|}{ Personnel } & \multicolumn{3}{|c|}{$\begin{array}{l}\text { Officers per } \\
1000 \text { Residents }\end{array}$} & \multicolumn{2}{|c|}{$\begin{array}{r}\text { Budget } \\
\text { (mi)ion }\end{array}$} & \multirow{2}{*}{ \$) } \\
\hline & & 1978 & 1981 & 1983 & 1978 & 1981 & 1983 & 1978 & 1981 & \\
\hline Richland & $\begin{array}{l}\text { Police } \\
\text { Fire }\end{array}$ & $\begin{array}{l}51 \\
38\end{array}$ & $\begin{array}{l}55 \\
42\end{array}$ & $\begin{array}{l}55 \\
42.5\end{array}$ & $\begin{array}{l}1.6 \\
1.2\end{array}$ & $\begin{array}{l}1.6 \\
1.2\end{array}$ & $\begin{array}{l}1.7 \\
1.3\end{array}$ & $\begin{array}{l}1.25 \\
1.1\end{array}$ & $\begin{array}{l}2.0 \\
1.6\end{array}$ & $\begin{array}{l}2.5 \\
1.65\end{array}$ \\
\hline Kennewick & $\begin{array}{l}\text { Police } \\
\text { Fire }\end{array}$ & $\begin{array}{l}35 \\
30 \mathrm{ft}^{(\mathrm{a})} \\
14 \mathrm{Vol}\end{array}$ & $\begin{array}{l}56 \\
33 \mathrm{ft} \\
15 \mathrm{Vol}\end{array}$ & $\begin{array}{l}58 \\
37\end{array}$ & $1.3(b)$ & $\begin{array}{l}1.6 \\
0.95^{(b)}\end{array}$ & $\begin{array}{l}1.6 \\
1.0\end{array}$ & $\begin{array}{l}1.2 \\
0.84\end{array}$ & $\begin{array}{l}2.1 \\
1.2\end{array}$ & $\begin{array}{l}2.5 \\
1.4\end{array}$ \\
\hline Pasco & $\begin{array}{l}\text { Police } \\
\text { Fire }\end{array}$ & $\begin{array}{l}38 \\
26\end{array}$ & $\begin{array}{l}37 \\
26\end{array}$ & $\begin{array}{l}39 \\
27\end{array}$ & $\begin{array}{l}2.4 \\
1.6\end{array}$ & $\begin{array}{l}2.0 \\
1.4\end{array}$ & $\begin{array}{l}2.0 \\
1.4\end{array}$ & $\begin{array}{l}0.90 \\
0.66\end{array}$ & $\begin{array}{l}1.36 \\
0.84\end{array}$ & $\begin{array}{l}1.55 \\
1.02\end{array}$ \\
\hline
\end{tabular}

(a) FT denotes full-time personnel.

(b) Based on number of full-time personnel.

Source: Richland, Pasco, Kennewick City Budgets $(1978,1981,1983)$.

(a) The term "actual" budget refers to actual receipts and expenditures tallied after the end of the financial year. "Preliminary" budgets are proposed, but not yeat approved by the Council. "Adopted" (or "final") budgets have been approved by the city Council, and "revised" budgets are revised midway through the financial year with adjustments and corrections made for known contracts, outlays, etc. 
TABLE 8.26. City of Richland General Fund Revenues and Expenditures (dollars)

Revenues

General Property Tax

Retail Sales and Use Tax

Other Taxes

Licenses and Permits

Charges for Services

Fines and Forfeitures

Intergovernmental Revenues

Miscellaneous Revenue

Nonrevenue Receipts

Total Current Revenue

Beginning Fund Balance

Total Available Revenue

Expenditures

Personal Services

Supplies

Charges and Services

Capital Outlay

Debt Service and Reserves

Transfer from General Fund

Admin. and Council Contingency

Total Requirements

Ending Fund Balance
1981 Actua

$1,492,079$

751,046

$1,745,830$

342,434

627,140

238,015

$3,118,129$

763,002

$\frac{4,617}{9,082,292}$

$\frac{1,915,844}{10,998,136}$

$$
\begin{array}{r}
6,028,174 \\
236,761 \\
1,916,557 \\
95,303 \\
-17,006 \\
692,403 \\
0 \\
\hline 8,986,204
\end{array}
$$

$2,011,932$
1982 Revised

$$
1,665,915
$$

847,000

$1,885,117$

286,833

450,579

300,000

$3,187,742$

406,804

$\frac{35,660}{9,065,650}$

$2,011,932$

$11,077,582$

$1983 \mathrm{Fina} 1$

$1,851,729$

.906,000

$2,226,908$

342,500

501,850

320,000

$3,321,409$

301,346

$\frac{39,000}{9,810,742}$

$1,312,482$

$11,123,224$

\begin{tabular}{rr}
$6,377,903$ & $7,235,993$ \\
259,072 & 273,994 \\
$1,893,871$ & $1,863,108$ \\
242,657 & 148,814 \\
17,337 & 171,503 \\
948,407 & 865,542 \\
25,853 & 56,527 \\
\hline $9,765,100$ & $11,123,224$ \\
$1,312,482$ & 0
\end{tabular}

Source: City of Richland Budget (1983). 
TABLE 8.27. City of Kennewick, Current Fund Revenues and Expenditures

\begin{tabular}{|c|c|c|c|}
\hline Revenues & 1981 Actual & 1982 Budgeted & 1983 Adopted \\
\hline Property Taxes & $1,709,905$ & $1,976,000$ & $2,216,000$ \\
\hline Retail Sales and Use Taxes & $1,507,467$ & $1,750,000$ & $1,450,000$ \\
\hline Business and Utility Taxes & $1,258,842$ & $1,388,000$ & $1,575,000$ \\
\hline Other Taxes & 347,614 & 350,000 & 355,000 \\
\hline Licenses and permits & 355,061 & 331,300 & 279,000 \\
\hline Intergovernmental Revenue & 946,165 & $1,132,125$ & $1,054,531$ \\
\hline Charges for Services & 717,391 & 872,025 & 909,200 \\
\hline Fines and Forfeitures & 318,360 & 300,000 & 310,000 \\
\hline Miscellaneous Revenue & 481,428 & 404,200 & 352,500 \\
\hline Nonrevenue Receipts & 0 & 17,515 & 16,500 \\
\hline Other Financing Sources & 439,223 & 749,401 & 561,415 \\
\hline Total Current Expense Revenue & $8,081,556$ & $9,270,566$ & $9,079,146$ \\
\hline Cash on hand and Begin. Fund Bal. & 732,359 & 850,570 & 865,000 \\
\hline Total Current Expense Fund & $8,813,915$ & $10,121,136$ & $9,944,146$ \\
\hline \multicolumn{4}{|l|}{ Expenditures } \\
\hline Personal Services and Benefits & $4,825,171$ & $5,600,777$ & $5,806,101$ \\
\hline Capital Outlay & 201,023 & 349,870 & 130,250 \\
\hline Debt Service & 260,868 & 380,393 & 398,400 \\
\hline Supplies & 164,111 & 215,080 & 228,821 \\
\hline Other Services and Charges & $1,762,594$ & $2,196,258$ & $2,099,326$ \\
\hline Interfund Transfers & 746,000 & 989,100 & 972,277 \\
\hline Ending Fund Balance & 0 & 390,658 & 308,971 \\
\hline Total Current Expense & $, 959,767$ & $10,121,136$ & $9,944,146$ \\
\hline
\end{tabular}

Source: City of Kennewick Budget (1983). 
IABLE 8.28. City of Pasco, General Fund Revenues and Expenditures

\begin{tabular}{|c|c|c|c|}
\hline Revenues & 1981 Actual & 1982 Revised & 1983 Final \\
\hline Real and Personal Property Taxes & 715,036 & 764,000 & 950,000 \\
\hline Retail Sales and Use Taxes & 709,188 & 650,000 & 654,000 \\
\hline Other Taxes & 882,491 & $1,148,800$ & $1,344,900$ \\
\hline Licenses and Permits & 124,334 & 142,000 & 107,000 \\
\hline - Intergovernmental Revenue & 917,649 & 781,900 & 640,625 \\
\hline Charges for Services & 121,656 & 137,755 & 135,900 \\
\hline Fines and Forfeitures & 162,319 & 165,000 & 150,000 \\
\hline Miscellaneous Revenue & 730,045 & 621,201 & 561,550 \\
\hline Intragovernmental Services & 0 & 0 & 257,692 \\
\hline Total Current Revenues for Fund & $4,362,718$ & $4,410,656$ & $4,801,667$ \\
\hline Est. Cash Plus Begin. Balance & 0 & 295,247 & 175,249 \\
\hline Total for Fund & $4,362,718$ & $4,705,903$ & $4,976,916$ \\
\hline Expenditures & & $\begin{array}{c}1982 \text { Revised } \\
\text { Budget } \\
\end{array}$ & $\begin{array}{l}1983 \text { Prelim. } \\
\text { Budget } \\
\end{array}$ \\
\hline City Council & & 39,580 & 35,954 \\
\hline Muricipal Court & & 118,971 & 132,164 \\
\hline City Manager & & 89,454 & 89,818 \\
\hline City Attorney & & 76,860 & 80,494 \\
\hline Police & - & $1,467,477$ & $1,547,913$ \\
\hline Fire & & 943,780 & $1,022,116$ \\
\hline Parks/Recreation & & 466,011 & 499,324 \\
\hline Community Qevelopment & & 187,328 & 192,240 \\
\hline Engineering & & 194,042 & 196,072 \\
\hline Administration Services & & 609,643 & 584,400 \\
\hline Miscellaneous Nondepartmental & & 505,188 & 405,113 \\
\hline Library & & 177,990 & 191,308 \\
\hline Total General Fund & & $4,876,324$ & $4,976,916$ \\
\hline
\end{tabular}

Source: City of Pasco Budget (1983). 
Within Richland's general fund (Table 8.26), the most volatile revenue categories over the period 1981 to 1983 have been Licenses and Permits, Charges for Services, and Miscellaneous Revenue, all of which fell in 1982 and rose again in 1983. The largest of component changes included declines in the demand.for engineering services, in zoning and subdivision fees, in interest in loans, in leases and rentals, and a substantial decline in bujlding permit revenues. Revenue categories experiencing growth over the period included all tax categories, Fines and Forfeitures, Intergovernmental Revenues, and Nonrevenue Receipts.

Kennewick's current fund revenues and expenditures are detailed in Table 8.27. Categories showing variable or declining revenues for the 1981 to 1983 period, include Retail Sales and Use Taxes, Licenses and Permits, Miscellaneous Revenues, and the category "Other Financing Sources". Sources of these variations include changes in sales tax laws on food, and declines in building permits, construction engineering revenues, and interest on investments. Categories experiencing growth in revenues include Property Taxes, Business and Utility Taxes, Other Taxes, and Charges for Services.

Pasco's general fund revenues and expenditures for 1981 to 1983 are shown in Table 8.28. Major revenue categories with variable or declining trends include Retail Sales and Use Taxes, Licenses and Permits, Intergovernmenta] Revenues, and Miscellaneous Revenues. Sources for these variations include changes in the sales tax laws and collections, variation in building permits, large declines in federal grants, variations in liquor board profits, and declines in interest on investments, rents and surplus sales. Growth sectors included Real and Personal Property Taxes, Other Taxes, and Intragovernmental Services.

Table 8.29 shows a time series of total revenues and tax revenues for current operating funds for Richland, Kennewick, and Pasco for the period 1975 to 1981 , and per capita revenues by source. (a) Average annual growth rates

(a) Figures on city budget revenues from Table 8.29 are not strictly comparable with the figures in TabTes $8.24,8.26,8.27$ and 8.28 . The figures for Tables 8.24 and 8.26 to 8.28 are derived directly from the 1983 city budgets. Table 8.29 is based on a time series from the Auditor of the State of Hashington. There are no checks provided between the two sources to ensure compatibility, so the reader should avoid comparisons. Similar problems occur with Tables 8.31 and 8.32 . are also given. 
TABLE 8.29. Per Capita Revenue for the Tri-Cities, 1975-1981 (in 1981 dollars)

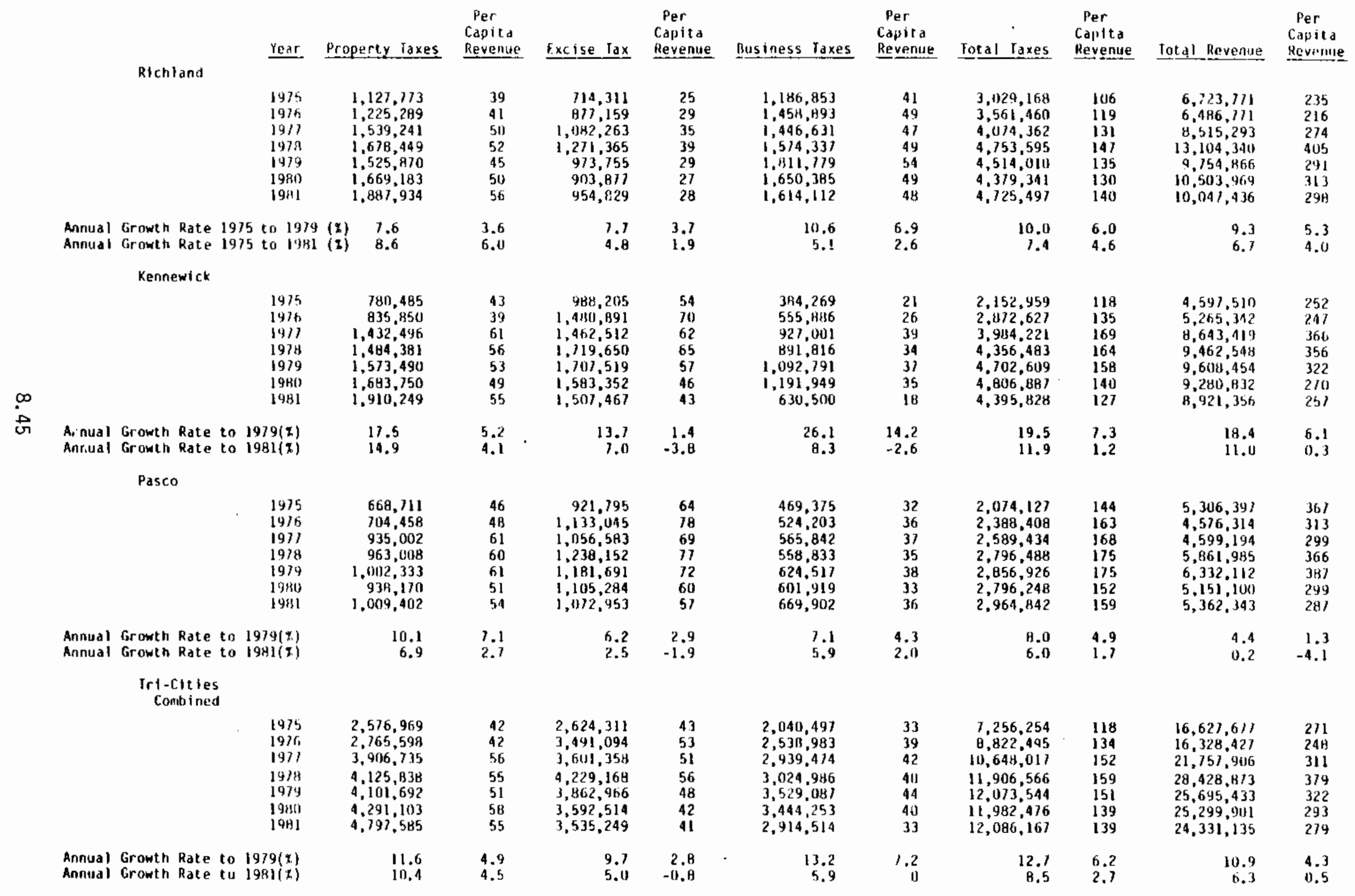

Source: Washinitun State 0f fice of the State Awtitor, $14 / 5-1781$. 
Although these data come from the same publications, some fairly wide variations between years occur. Some possible causes include effects on property, retail sales, and excise tax revenues due to city annexations of county property, changes in interest rates, changes in taxing rates (food tax, property tax, etc.) and special project levies.

Table 8.29 shows that real per capita revenues in the Tri-Cities fell initially, and then rose dramatically for two periods, and then felf again. Between 1975 and 1981, per capjta total revenues grew at an average annual rate of 4 percent in Richland, 0.3 percent in Kennewick, fell 4.1 percent in Pasco, for an overall Tri-Cities growth of 0.5 percent. Analys is of total rea? revenues shows a 6.7 percent per annum growth in total revenues in Richland, 11.0 percent growth in Kennewick, 0.2 percent growth in Pasco, and 6.3 percent over the combined Tri-cities. In each case, total revenues grew more rapidly than did per capita revenue. This holds true for each tax revenue source for each of the three cities.

Breaking revenues down by tax source shows fairly substantial rises in property tax revenues over the period. Property tax revenues rose at average annual rates equal to 8.6 percent in Richland, 14.9 percent in Kennewick, and 6.9 percent in Pasco. Per capita property taxes in each city rose, but at a slower rate. Similar patterns exist for the other tax revenues. The largest growth occurred in Kennewick's property, business, and excise taxes, Richland's property taxes, and Pasco's property taxes. In ali cities per capita growth was greatest in the Property Taxes revenue category.

Examining the growth rates calculated for the sub-period 1975 to 1979 shows that growth in revenues (and in per capita revenues) from most sources was greater in the early part of the period, and slowed or declined thereafter. (The only exception is property tax revenues in Richland.) Some declines were particularly dramatic, including business taxes in Kennewick and Richland. Kennewick had 29.9 percent growth through 1979, declining to 8.6 percent over the entire period. Richland had 11.1 percent in the early period and 5.3 percent growth overa]1. Property taxes in Pasco grew 11 percent in the early period and 7.0 percent overa 11. Excise taxes showed considerable variation between the periods throughout the area. Growth rates through 1979 were 
roughily twice what they were from 1975 to 1981, and per capita revenues from this source actually declined in Kennewick and Pasco as well as in the combined Tri-Cities as a whole.

Examining the tax revenues from these cities shows that a higher proportion of Richland's revenues derive from business taxes, and that revenues from this source became an increased share of total revenues for Kennewick over this period. Also, although per capita revenues were highest in Pasco at the beginning of the period, by 1981 the more rapid and consistent growth in per capita revenues for Richland and Kennewick left all three cities at approximately the same level.

The high growth in revenues in Richland and Kennewick reflects the rapid expansion of activities at the Hanford site over this period. Prior to this, population and employment were growing more rapidly in Franklin County than in Benton County. However, with the imminent completion (1985-1986) of the bridge connecting Pasco with Richland, Pasco stands to share more equaliy in Hanfordrelated activities in the future.

Tabie 8.30 shows the percentage each tax revenue source contributes to total top revenues, and the share that taxes contribute toward current operating revenues for Richland, Kennewick, and Pasco, 1975-1981. The data in Table 8.30 demonstrate that contributions from property taxes remained fairly stable over the period in all cities, and that roughly one-third of total tax collections derive from property taxes. Richland consistently receives a smaller share of total tax revenues from excise taxes, with the difference made up in business tax collections (which are higher than those in Kennewick and Pasco). Table 8.30 also shows that excise taxes as a share of total taxes have been decreasing over time in each of the three cities. Business taxes have shown much more variation as a share of total taxes in Richland and Kennewick than they have in Pasco. This may be related to the more direct involvement of these cities in the secondary effects related to the WPPSS activities. Tax contributions as a share of total operating revenues have averaged 45 percent in Richland, and in Kennewick around 49 percent. Disregarding the 1975 figure, taxes have contributed an average of 51 percent of total operating revenues in Pasco. 
TABLE 8.30. Revenue Source Shares: 1975-1981. Richland, Pasco, Kennewick (as a share of operating revenues)

\begin{tabular}{|c|c|c|c|c|}
\hline & $\begin{array}{l}\text { Property Taxes } \\
\text { snare of total } \\
\text { iaxes (a) } \\
\end{array}$ & $\begin{array}{l}\text { Excise Taxes } \\
\text { Share of Tatal } \\
\text { Taxes } \\
\end{array}$ & $\begin{array}{l}\text { Business Taxes } \\
\text { Share of tatal } \\
\text { Taxes (:) } \\
\end{array}$ & $\begin{array}{c}\text { Taxes a5 snare } \\
\text { of total ooerating } \\
\text { rayeniges i:? }\end{array}$ \\
\hline \multicolumn{5}{|c|}{ Richland } \\
\hline $\begin{array}{l}1975 \\
1975 \\
1977 \\
1978 \\
1979 \\
1980 \\
1981\end{array}$ & $\begin{array}{l}37 \\
34 \\
38 \\
35 \\
34 \\
38 \\
40\end{array}$ & $\begin{array}{l}24 \\
25 \\
27 \\
27 \\
22 \\
21 \\
20\end{array}$ & $\begin{array}{l}39 \\
41 \\
36 \\
33 \\
40 \\
39 \\
34\end{array}$ & $\begin{array}{l}45 \\
55 \\
40 \\
36 \\
46 \\
42 \\
47\end{array}$ \\
\hline \multicolumn{5}{|c|}{ Xennewick } \\
\hline $\begin{array}{l}1975 \\
1976 \\
1977 \\
1978 \\
1979 \\
1980 \\
1981\end{array}$ & $\begin{array}{l}35 \\
29 \\
36 \\
34 \\
33 \\
35 \\
43\end{array}$ & $\begin{array}{l}46 \\
52 \\
37 \\
39 \\
36 \\
33 \\
34\end{array}$ & $\begin{array}{l}18 \\
19 \\
23 \\
20 \\
23 \\
25 \\
14\end{array}$ & $\begin{array}{l}47 \\
55 \\
45 \\
45 \\
49 \\
52 \\
49\end{array}$ \\
\hline \multicolumn{5}{|l|}{ Pasco } \\
\hline $\begin{array}{l}1975 \\
1976 \\
1977 \\
1978 \\
1977 \\
1940 \\
1941\end{array}$ & $\begin{array}{l}32 \\
24 \\
36 \\
34 \\
35 \\
34 \\
34\end{array}$ & $\begin{array}{l}34 \\
47 \\
41 \\
44 \\
41 \\
40 \\
36\end{array}$ & $\begin{array}{l}23 \\
22 \\
22 \\
20 \\
22 \\
22 \\
23\end{array}$ & $\begin{array}{l}39 \\
52 \\
56 \\
43 \\
45 \\
51 \\
55\end{array}$ \\
\hline
\end{tabular}

Sonrce: Calculated from Table B.29

\section{County Revenues}

Table 8.31 shows current expense revenues for Benton and Franklin County for 1983. The major source of revenues for both counties is taxes. Over 61 percent of total current expense revenues in Benton County and 47 percent in Franklin County derive from taxes. Benton County relies more heavily upon tax revenues, with the major sources being property taxes (33 percent) and retail sales and use taxes (23 percent). As a share of total tax revenues, property taxes account for 53 percent, retail sales for 38 percent, and penalties for 8 percent in Benton County. Franklin County's most important contributors are property taxes at 64 percent of total taxes collected, retail sales taxes (17 percent) and penaities (19 percent).

Table 8.32 shows a time series of real and per capita county tax revenues by source; these categories represent major stable county revenue sources. Table 8.33 calculates the share each of the various sources contributes to total operating revenues. These figures show that since 1975 property taxes have been contributing decreasing shares of total taxes in Benton County, while the share deriving from excise taxes has been increasing. Further, total 
TABLE 8.31. County Budgets: Benton and Franklin Counties, Current Expense Revenues, 1983

\begin{tabular}{|c|c|c|}
\hline Benton & $\begin{array}{r}\text { Source as } \\
\text { Share of Total } \\
\text { Taxes (I) } \\
\end{array}$ & $\begin{array}{c}\text { Source as } \\
\text { Share of Total } \\
\text { Operatigg Revenue (g) }\end{array}$ \\
\hline $\begin{array}{r}3,000,000 \\
2,150,000 \\
60,000\end{array}$ & $\begin{array}{r}53 \\
38 \\
1\end{array}$ & $\begin{array}{r}32.7 \\
23.4 \\
0.7\end{array}$ \\
\hline $\begin{array}{r}428,000 \\
10 \\
\end{array}$ & 8 & 4.7 \\
\hline $5,638,010$ & & 61.4 \\
\hline 94.650 & & 1.0 \\
\hline 905,881 & & 9.9 \\
\hline $\begin{array}{r}1,200,300 \\
1,342,005 \\
\end{array}$ & & $\begin{array}{l}13.1 \\
14.6\end{array}$ \\
\hline
\end{tabular}

\begin{tabular}{|c|c|c|}
\hline Franklin & $\begin{array}{l}\text { Source as } \\
\text { Share of Total } \\
\text { Taxes (1) }\end{array}$ & $\begin{array}{c}\text { Source as } \\
\text { Share of Total } \\
\text { Operating Revenue (x) }\end{array}$ \\
\hline $\begin{array}{r}1,390,809 \\
360,000 \\
7,000\end{array}$ & $\begin{array}{r}64 \\
17 \\
0\end{array}$ & $\begin{array}{r}30.1 \\
7.8 \\
0.1\end{array}$ \\
\hline $\begin{array}{r}400,000 \\
5,000 \\
\end{array}$ & 19 & 8.7 \\
\hline $2.162,809$ & & 46.8 \\
\hline 75,000 & & 1.6 \\
\hline 710,687 & & 15.4 \\
\hline $\begin{array}{r}384,666 \\
1,288,619 \\
\end{array}$ & & $\begin{array}{r}8.3 \\
27.9\end{array}$ \\
\hline$\$ 4,618,708$ & & \\
\hline
\end{tabular}

(a) figures in parentheses are percentages of total operating revenue.

Source: Benton County Budget, 1983

Franklin County Budget, 1983 
TABLE 8.32. Per Capita Revenue for Benton/Franklin Counties, 1975-1981 (in 1981 dollars)

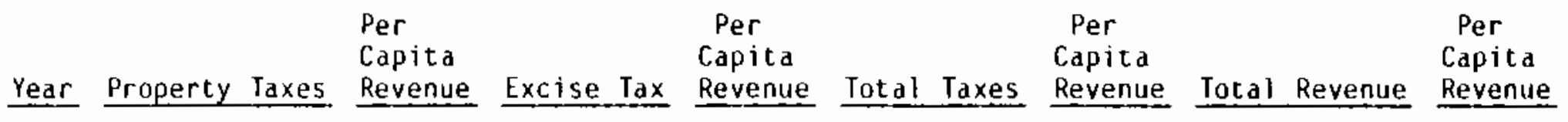

Benton County

$\begin{array}{ll}1975 & 2,586,822 \\ 1976 & 2,650,098 \\ 1977 & 3,144,684 \\ 1978 & 3,330,944 \\ 1979 & 3,372,405 \\ 1980 & 3,627,004 \\ 1981 & 3,694,838\end{array}$

$1,657,056$
$1,810,452$
$1,673,816$
$3,332,423$
$4,509,694$
$3,590,590$
$3,561,368$

$$
\begin{aligned}
& 4,370,750 \\
& 4,581,187 \\
& 4,955,697 \\
& 6,839,207 \\
& 8,036,075 \\
& 7,413,348 \\
& 7,561,793
\end{aligned}
$$

57
54
55
70
77
68
68

$$
\begin{array}{rr}
8,736,543 & 113 \\
11,604,481 & 138 \\
10,613,215 & 117 \\
13,134,110 & 134 \\
14,660,784 & 140 \\
14,819,489 & 135 \\
15,117,687 & 136
\end{array}
$$

Franklin County

$\begin{array}{lllllllll}1975 & 2,003,983 & 72 & 347,271 & 12 & 2,453,191 & 88 & 5,616,338 & 202 \\ 1976 & 1,914,246 & 64 & 373,498 & 13 & 2,401,937 & 81 & 6,201,233 & 209 \\ 1977 & 2,101,432 & 71 & 430,907 & 14 & 2,636,728 & 88 & 6,947,018 & 233 \\ 1978 & 2,126,489 & 65 & 486,524 & 15 & 2,722,830 & 84 & 7,388,057 & 227 \\ 1979 & 2,199,683 & 64 & 450,949 & 13 & 2,805,665 & 82 & 6,713,179 & 196 \\ 1980 & 2,127,074 & 61 & 374,298 & 11 & 2,662,547 & 76 & 7,215,452 & 206 \\ 1981 & 2,232,681 & 62 & 376,154 & 10 & 2,950,322 & 81 & 6,701,836 & 185\end{array}$

Source: Vashingt on State Office of the State Auditor, 1975-1981. 
taxes as a share of total revenues collected grew significantly between 1976 and 1979, and returned to 1975 levels in 1980 and 1981 .

Franklin County figures in Table 8.33 show that property taxes are the major contributor of total tax revenues, but that the share declined between 1975 and 1981. The share of total taxes contributed by excise taxes grew between 1975 and 1978, but has fallen since then. The share of taxes represented by other sources has increased from 4 percent in 1975 to 11 percent in 1981. As a proportion of total revenues collected, taxes fell from 1975 to 1977 , but have generaily risen since that time.

TABLE 8.33. Benton/Franklin County Revenue Source Shares, 1975-1981 (Operating Revenues)

\begin{tabular}{|c|c|c|c|c|}
\hline & $\begin{array}{l}\text { Property Taxes } \\
\text { share of total } \\
\text { Taxes (s) } \\
\end{array}$ & $\begin{array}{l}\text { Excise Taxes } \\
\text { Share of Total } \\
\text { Taxes }(\%) \\
\end{array}$ & $\begin{array}{l}\text { Dther Taxes } \\
\text { Share of Total } \\
\text { Taxes }(\%) \\
\end{array}$ & $\begin{array}{c}\text { Taxes as share } \\
\text { of total operating } \\
\text { revenues }(q) \\
\end{array}$ \\
\hline \multicolumn{5}{|c|}{ Benton County } \\
\hline $\begin{array}{l}1975 \\
1976 \\
1977 \\
1978 \\
1979 \\
1980 \\
1981\end{array}$ & $\begin{array}{l}60 \\
58 \\
63 \\
49 \\
42 \\
48 \\
49\end{array}$ & $\begin{array}{l}38 \\
40 \\
34 \\
49 \\
56 \\
48 \\
47\end{array}$ & $\begin{array}{l}2 \\
2 \\
3 \\
2 \\
2 \\
4 \\
4\end{array}$ & $\begin{array}{l}50 \\
39 \\
47 \\
52 \\
55 \\
50 \\
50\end{array}$ \\
\hline \multicolumn{5}{|c|}{ Franklin County } \\
\hline $\begin{array}{l}1975 \\
1976 \\
1977 \\
1978 \\
1979 \\
1980 \\
1981\end{array}$ & $\begin{array}{l}82 \\
80 \\
80 \\
78 \\
78 \\
80 \\
76\end{array}$ & $\begin{array}{l}14 \\
16 \\
16 \\
18 \\
16 \\
14 \\
13\end{array}$ & $\begin{array}{l}4 \\
4 \\
4 \\
4 \\
6 \\
6 \\
11\end{array}$ & $\begin{array}{l}44 \\
39 \\
38 \\
37 \\
42 \\
37 \\
44\end{array}$ \\
\hline
\end{tabular}

Source: Calculated from Table 8.32 .

Comparing Benton and Franklin County revenue sources shows that .Franklin County has traditionally garnered a larger share of total tax revenues from property taxes than has Benton County, although the reliance on this revenue source in both counties has fallen since 1975. Excise taxes have been a more important contributor in Benton County (roughly 40 to 50 percent of tax 
revenues) than in Franklin County (13 to 18 percent). In each year, Benton County's tax receipts made up a larger portion of the total operating reverue than in Franklin County.

In general, operating revenues grew more rapidly in Benton than in Frankijn County between 1975 and 1981--9.1 percent compared to 2.9 percent (Table 8.32). Per capita revenues also increased rapidly in Benton County, while decreasing in Franklin County. Benton County received about 85 percent of the total revenue increase over the period (and about 80 percent of the twocounty population increase) suggesting that Benton County residents received a larger share of revenue benefits over the period 1975 to 1981 . With the opening of the $1-182$ bridge to Pasco it is possible that Franklin County will share revenue benefits from Hanford projects to a larger extent.

\subsection{ALTERNATIVE BASELINE SCENARIOS}

To measure the socioeconomic impacts of construction and operation of the NPR, a baseline for comparison is necessary. Because the future socioeconomic condition of the Hanford area cannot be known with certainty for the years coinciding with the NPR construction and operating schedules, four different baseline socioeconomic scenarios are developed. The scenarios are based on different assumptions about the level of primary employment in Benton and Franklin counties, projected without potential NPR employment. From the projected primary employment for each of the scenarios, estimates of secondary employment, population, and other socioeconomic impacts are made.

\subsubsection{Methodology and Assumptions}

Although assumptions about primary employment differ for each baseline scenario, some assumptions and methodological approaches are common to al? four. All of the scenarios divide primary employment into three major categories, based on historical trends: WPPSS and its contractors, DOE and its contractors, and agriculture. Each of the four scenarios will be developed from estimates of employment for these three categories; then, using common multipliers, secondary employment effects and socioeconomic impacts will be estimated. All of the scenarios concentrate on the 1983 to 2010 period. 
Because there is little chance of replacing, in the short run, the approximately 10,000 WPPSS jobs that have been lost between 1981 and 1984, and because this means there is somewhat less uncertainty about what will happen in the Tri-Cities economy during that time, all four baseline scenarios will rely on the same employment projections through 1984, and two of the scenarios share 1985 fjgures. The estimated primary and secondary employment impacts for these years are shown in Table 8.34. Primary sector jobs are projected to decrease untit 1985, when a modest increase is estimated. A deciline of 3,219 primary sector jobs between 1981 and 1982 was accompanied by an actual reduction in total employment of 5,800 jobs. This suggests that for every 10 jobs lost in the primary sector, an additional 8 jobs were lost in the secondary sector. From this observation a primary sector-based total employment muttiplier of 1.8 was used to estimate the total employment figures for 1982 to 1985 shown in Table 8.34.

The population estimates in Table 8.34 are based on the assumptions that, during periods of declining employment, 25 percent of the workers losing their jobs leave the area, and that the average family size of the workers leaving the area is three. Population multipliers based on historical trends are not used because population multipliers observed during periods of increasing employment are not likely to be relevant during periods of declining employment, because population decreases more slowly during downturns than it increases during periods of increasing employment. Because most of the workers losing WPPSS jobs are construction workers who are relatively more mobile than other workers, a 25 percent out-migration rate is used. An average family size of three is used instead of the average construction worker household size of 3.4 (suggested by the socioeconomic 1iterature), because single workers and workers with small families are more likely to migrate than workers with large families.

The loss in economic activity from 1981 to 1985 in the Benton and Franklin County area is significant, and will leave the area with excess capacity in housing and public services. Considerable growth would have to take place after 1985 before the area could begin to feel the pressures of growth experienced in the mid-1970s. All four baseline scenarios assume that the Supply System, DOE, and agriculture will continue to be the main economic 
TABLE 8.34. Projected Primary and Secondary Employment in Benton and Frankling Counties: 1981-1985

1981 1982 Number of Workers 1985

Primary Sector

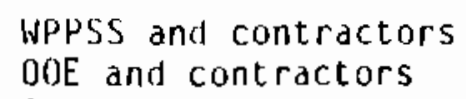

TOTAL

Difference between years

Secondary Sector

Total Enployment

Total Population

\begin{tabular}{|c|c|c|c|c|}
\hline $\begin{array}{r}11,728 \\
11,880 \\
4,850 \\
\end{array}$ & $\begin{array}{r}8,841 \\
11,500 \\
4,898 \\
\end{array}$ & $\begin{array}{r}4,376 \\
12,485 \\
4,947 \\
\end{array}$ & $\begin{array}{r}920 \\
12,485 \\
4,997 \\
\end{array}$ & $\begin{array}{r}920 \\
12,485 \\
5,047 \\
\end{array}$ \\
\hline \multirow[t]{2}{*}{28,458} & 25,239 & 21,808 & 18,402 & 18,452 \\
\hline & $-3,219$ & $-3,431$ & $-3,406$ & +50 \\
\hline
\end{tabular}

$\begin{array}{rrrrr}47,142 & 44,561 & 41,816 & 39,091 & 39,131 \\ 75,600 & 69,800 & 63,624 & 57,493 & 57,583 \\ 148,260 & 143,910 & 139,278 & 134,680 & 134,950\end{array}$

Annual

Rate of Change

$$
\begin{array}{r}
-63.6 \% \\
1.2 \% \\
1.0 \% \\
-10.8 \% \\
-4.9 \% \\
-6.8 \% \\
-2.4 \%
\end{array}
$$

Source: Battelle, Muman Affairs Research Centers (1983). 
drivers, but each scenario makes different assumptions about the future growth of these three sectors. The scenarios will be referred to in the remajnder of this discussion as Scenarios A through D.

\subsubsection{Scenario A}

Baseline Scenario A predicts a low growth rate for all three primary employment sectors for the period 1985 to 208. The key assumptions that determine primary sector employment under this scenario are as follows:

1. The expected level of employment at WPPSS for 1985 (920 workers) will remain constant until 208. This implies that no further work is done on either WNP-1 or WNP-4.

2. Agricultural employment continues to grow at the moderate 1.0 percent per year rate assumed for the 1981 to 1985 period.

3. DOE and its contractor employment continues to grow at the moderate 1.2 percent per year rate assumed for the 1981 to 1985 period.

The projected total primary employment for each year from 1985 to 2010 for Scenario $A$ is given in Tabie 8.35. The assumptions listed above result in about a 1.1 percent per year increase in primary employment over the forecast period.

The primary sector employment growth shown in Table 8.35 is used to project growth in total employment for the $1985^{\circ}$ to 2010 period. 8ecause even the 2010 total primary employment figure of 24,253 workers generated by Scenario A does not exceed the 28,500 workers employed in 1981, a muitiplier of 1.8 is assumed to apply throughout the forecast period. This total employment multiplier is based on the ratio of the expected decrease in total employment between 1981 and 1985 of 18,017 persons to the expected decrease in primary employment between 1981 and 1985 of 10,006 jobs (Table 8.34). That is, for every 10 jobs added in the primary sector, it is expected that 8 secondary sector jobs would also be added to the Tri-Cities area economy. This is a conservative assumption, as 12 secondary jobs for every 10 primary jobs were added from 1973 to 1981. The secondary employment, total employment, and population projections under Scenario $A$ are also shown in Table 8.35. 
TABLE 8.35. Baseline Employment and Population Using Scenario A, 1985-2010

\begin{tabular}{|c|c|c|c|c|c|c|c|}
\hline Year & $\begin{array}{c}\text { WPPSS and its } \\
\text { Contractors } \\
\end{array}$ & $\begin{array}{l}\text { DOE and its } \\
\text { Contractors } \\
\end{array}$ & Agriculture & Total & $\begin{array}{c}\text { Secondary Sector } \\
\text { Empl loyment } \\
\end{array}$ & $\begin{array}{c}\text { Total } \\
\text { Employment } \\
\end{array}$ & Population \\
\hline $\begin{array}{l}1985 \\
1986 \\
1987 \\
1988 \\
1989 \\
1990 \\
1991 \\
1992 \\
1993 \\
1994 \\
1995 \\
1996 \\
1997 \\
1998 \\
1999 \\
2000 \\
2001 \\
2002 \\
2003 \\
2004 \\
2005 \\
2006 \\
2007 \\
2008 \\
2009 \\
2010\end{array}$ & $\begin{array}{l}920 \\
920 \\
920 \\
920 \\
920 \\
920 \\
920 \\
920 \\
920 \\
920 \\
920 \\
920 \\
920 \\
920 \\
920 \\
920 \\
920 \\
920 \\
920 \\
920 \\
920 \\
920 \\
920 \\
920 \\
920 \\
920\end{array}$ & $\begin{array}{l}12,485 \\
12,638 \\
12,788 \\
12,943 \\
13,099 \\
13,257 \\
13,417 \\
13,579 \\
13,743 \\
13,909 \\
14,077 \\
14,247 \\
14,419 \\
14,593 \\
14,769 \\
14,947 \\
15,128 \\
15,310 \\
15,495 \\
15,682 \\
15,872 \\
16,063 \\
16,257 \\
16,453 \\
16,652 \\
16,853\end{array}$ & $\begin{array}{l}5,047 \\
5,098 \\
5,149 \\
5,201 \\
5,253 \\
5,306 \\
5,359 \\
5,413 \\
5,467 \\
5,522 \\
5,578 \\
5,634 \\
5,690 \\
5,748 \\
5,805 \\
5,864 \\
5,923 \\
5,982 \\
6,042 \\
6,103 \\
6,164 \\
6,226 \\
6,289 \\
6,352 \\
6,416 \\
6,480\end{array}$ & $\begin{array}{l}18,452 \\
18,653 \\
18,857 \\
19,063 \\
19,272 \\
19,483 \\
19,696 \\
19,912 \\
20,130 \\
20,351 \\
20,575 \\
20,801 \\
21,029 \\
21,260 \\
21,494 \\
21,731 \\
21,970 \\
22,213 \\
22,458 \\
22,705 \\
22,956 \\
23,210 \\
23,466 \\
23,725 \\
23,988 \\
24,253\end{array}$ & $\begin{array}{l}39,131 \\
39,293 \\
39,455 \\
39,620 \\
39,787 \\
39,955 \\
40,126 \\
40,299 \\
40,474 \\
40,651 \\
40,829 \\
41,009 \\
41,193 \\
41,378 \\
41,565 \\
41,754 \\
41,946 \\
42,139 \\
42,335 \\
42,534 \\
42,734 \\
42,937 \\
43,142 \\
43,350 \\
43,560 \\
43,773\end{array}$ & $\begin{array}{l}57,583 \\
57,946 \\
58,312 \\
58,683 \\
59,059 \\
59,438 \\
59,822 \\
60,211 \\
60,604 \\
61,002 \\
61,404 \\
61,810 \\
62,222 \\
62,638 \\
63,059 \\
63,485 \\
63,916 \\
64,352 \\
64,793 \\
65,239 \\
65,690 \\
66,147 \\
66,608 \\
67,075 \\
67,548 \\
68,026\end{array}$ & $\begin{array}{l}134,945 \\
135,226 \\
135,501 \\
135,779 \\
136,061 \\
136,346 \\
136,634 \\
136,925 \\
137,220 \\
137,518 \\
137,820 \\
138,125 \\
138,433 \\
138,745 \\
139,061 \\
139,381 \\
139,704 \\
140,031 \\
140,361 \\
140,696 \\
141,034 \\
141,377 \\
141,723 \\
142,073 \\
142,428 \\
142,786\end{array}$ \\
\hline
\end{tabular}

Source: Battelle, Human Affairs Research Center (1983). 
Under Scenario $A$, the Tri-Cities baseline economy is projected to grow slowly during the 1981 to 2010 period. Total employment in the Tri-cities SMSA will grow at an average annual rate of 0.7 percent, the lowest rate for any of the four baseline scenarios. The population multiplier of 0.75 is based on the observed relationship between total employment and population in 1981 to 1982; that is, the ratio of the decrease in population from 1981 to 1982 and the decrease in total employment during that year is 0.75 . This conservative multiplier is used because employment does not reach 1981 levels throughout the forecast period in this scenario. These assumptions yield an annual rate of population increase between 1985 and 2010 of about 0.2 percent.

The low baseline economic growth predicted with the Scenario A assumptions will probabiy result in continued excess capacity in Tri-Cities area housing and schools. The persistence of low population growth into the 1990s could create fiscal problems for local governments accustomed to the revenue levels associated with the higher employment and population levels of 1981. Public revenues may not be sufficient for the maintenance of public service capacity, such as roads, water, and sewage systems, built during the WPPSS construction period. Revenue shortages could lead to higher local taxes, special levies, and long-term borrowing.

\subsubsection{Scenario B}

Scenario B projects a higher level of-economic activity than Scenario $A$ and is defined by the following assumptions about primary sector employment:

1. WNP-1 will be restarted in 1986 to 1987 and completed by 1991.

2. Agricultural employment will grow at an average annual rate of 6 percent until 1991, and at 3 percent thereafter until 2008.

3. DOE-related employment will grow at an average annual rate of 5 percent until 1991, and at 2 percent thereafter until 2008.

The assumption regarding the WNP-1 restart is based on internal studies conducted by the Supply System, and on publicity indicating that the restart costs may be too high in the l990s for serious consideration. The 6 percent growth rate in the agricultural sector is based on the possibility of the development of another half million acres of irrigated farmland as a result of 
the proposed second phase of the Columbia Basin project. This rate falls between the 8.7 percent average annual agricultural growth rate for 1967 to 1973 and the 4.2 percent rate for 1973 to 1981 (Battelle, Human Affairs Research Centers 1983). The DOE-related growth rate is based on DOE estimates of increased use of DOE facilities and contractors at Hanford for defense research. DOE employment growth was approximately 5 percent from 1970 to 1981.

Primary, secondary, and total employment for Scenario $B$ are shown in Table 8.36. Rapid growth in WPPSS employment due to the restart in WNP-1 construction, plus strong steady growth in the DOE and agriculture sectors brings primary employment up to the 1981 peak of 28,500 workers in 1995. Under the Scenario B assumptions, primary employment will exceed 39,000 workers by 2010, a 39.4 percent increase over the 1981 peak level.

Recognizing the slack in the regional economy in 1985 caused by the reduction in primary sector employment from 28,500 in 1981 to 18,500 in 1985 , it is assumed that, from 1985 onward, increases in the primary sector employment of up to 28,500 jobs would use the 1.8 total employment multiplier (explained under Scenario A). Increases beyond 28,500 jobs are assumed to have a 2.2 multiplier effect on total employment. The 2.2 multiplier used for the period 1996 to 2010 is derived from the experience of the WPPSS construction period, 1973 to 1981. Under these assumptions, growth in primary sector employment after 1995 has a higher rate of associated secondary sector growth compared with the period from 1985 to 1995.

For similar reasons it is assumed that the smaller population multiplier of 0.75 applies during the period when primary sector employment is returning to the former high level of 1981, and a larger population multiplier of 1.2 applies after that level is reached in 1995. The 1.2 multiplier is based on pre-WPPSS experience from 1965 to 1973 (Battelie, Human Affairs Research Centers, 1983). During that period, total population increased by 7,830 persons while total employment increased by 6,790. The level of moderate growth assumed under Scenario $B$ is likely to more closely match the growth prior to the WPPSS construction period than the rapid growth that accompanied construction. 
TABLE 8.36. Baseline Employment and Population Using Scenario B, 1985-2010

\begin{tabular}{|c|c|c|}
\hline Year & $\begin{array}{l}\text { WPPSS and its } \\
\text { Contractors }\end{array}$ & $\begin{array}{l}\text { DOE and its } \\
\text { Contractors }\end{array}$ \\
\hline 1985 & 920 & 12,485 \\
\hline 1986 & 1,450 & 13,125 \\
\hline 1987 & 5,800 & 13,798 \\
\hline 1988 & 7,000 & 14,506 \\
\hline 1989 & 5,600 & 15,249 \\
\hline 1990 & 4,700 & 16,031 \\
\hline 1991 & 1,600 & 16,853 \\
\hline 1992 & 1,600 & 17,193 \\
\hline 1993 & 1,600 & 17,541 \\
\hline 1994 & 1,600 & 17,895 \\
\hline 1995 & 1,600 & 18,257 \\
\hline 1996 & 1,600 & 18,625 \\
\hline 1997 & 1,600 & 19,002 \\
\hline 1998 & 1,600 & 19,386 \\
\hline 1999 & 1,600 & 19,777 \\
\hline 2000 & 1,600 & 20,177 \\
\hline 2001 & 1,600 & 20,584 \\
\hline 2002 & 1,600 & 21,000 \\
\hline 2003 & 1,600 & 21,424 \\
\hline 2004 & 1,600 & 21,857 \\
\hline 2005 & 1,600 & 22,299 \\
\hline 2006 & 1,600 & 22,749 \\
\hline 2007 & 1,600 & 23,209 \\
\hline 2008 & 1,600 & 23,678 \\
\hline 2009 & 1,600 & 24,156 \\
\hline 2010 & 1,600 & 24,644 \\
\hline
\end{tabular}

\begin{tabular}{|c|c|}
\hline Agriculture & Total \\
\hline 5,047 & 18,452 \\
\hline 5,359 & 19,934 \\
\hline 5,690 & 25,289 \\
\hline 6,042 & 27,548 \\
\hline 6,416 & 27,265 \\
\hline 6,813 & 27,544 \\
\hline 7,234 & 25,687 \\
\hline 7.454 & 26,248 \\
\hline 7,681 & 26,822 \\
\hline 7,915 & 27,410 \\
\hline 8,156 & 28,013 \\
\hline 8,405 & 28,630 \\
\hline 8,661 & 29,262 \\
\hline 8,924 & 29,910 \\
\hline 9,196 & 30,573 \\
\hline 9,476 & 31,253 \\
\hline 9,765 & 31,949 \\
\hline 10,062 & 32,662 \\
\hline 10,369 & 33,393 \\
\hline 10,684 & 34,142 \\
\hline 11,010 & 34,909 \\
\hline 11,345 & 35,694 \\
\hline 11,691 & 36,499 \\
\hline 12,047 & 37,324 \\
\hline 12,414 & 38,169 \\
\hline $12,79 ?$ & 39,036 \\
\hline
\end{tabular}

Secondary Sector Employment

39,131

40,317

44,600

46,408

46,182

46,404

44,919

45,367

45,827

46,298

46,780

47,521

48,279

49,056

49,853

50,668

51,503

52,359

53,236

54,134

55,054

55,998

56,964

57,954

58,968

60,006
Total

57,583

60,251

69,889

73,956

73,447

73,948

70,606

71,615

72,649

73,708

74,793

76,151

77,541

78,966

80,426

81,921

83,452

85,021

86,629

88,276

89,963

91,692

93,463

95,278

97,137

99,042
Population

134,954

136,955

144,183

147,233

147,233

147,233

144,726

145,483

146,259

147,053

147,866

149,496

151,165

152,875

154,626

165,420

158,258

160,141

162,070

164,046

166,071

168,145

170,271

172,448

174,680

176,966

Source: Batteile, Human Affairs Research Centers (1983). 
The projections shown in Table 8.36 imply that the excess capacity in housing, school, and public services developed from 1981 to 1985 would disappear in the 1990s. Increased public revenues that would accompany the restart of WNP-i, as well as the expansion of the DOE and agricultural sectors, should allow local government to expand public services as needed to keep pace with the economic expansion between 1995 and 2008. The rapid employment and popula- tion growth of the WNP-1 restart should not cause an exhaustion of current capacity, because it will peak in 1990 and then decrease in 1991 . The steady growth of the other primary employment sectors will not match the 1981 peak until 1995, after which the moderate pace of growth should allow for a smooth increase in the capacity of the Tri-Cities infrastructure.

\subsubsection{Scenario C}

Scenarios $C$ and $D$ are calculated using a slightly different method than the one used for Scenarios $A$ and $B$. The same assumptions about agricultural and WPPSS employment used in Scenario B are used for $C$ and $D$, but instead of calculating future growth rates for total DOE employment based on general estimated DOE employment, the employment growth rate is calculated based on the estimated future employment generated by specific DOE projects. To do this, DOE employment is divided into employment growth for existing DOE projects and employment growth for new DOE projects. The key assumptions defining Scenario $C$ are as follows:

1. WNP-1 will be restarted in 1986 to 1987 and conpleted in 1991.

2. Agricultural employment will grow at an average annual rate of 6 percent until 1991, and at a 3 percent rate from 1992 to 2008 .

3. Existing DOE employment will grow at an average annual rate of 1.2 percent, while employment in new DOE projects will grow an average of 4 percent per year.

Primary, secondary, and total employment for Scenario $\mathrm{C}$ are shown in Table 8.37. The restart of WNP-1 again causes a primary employment bulge in the late 1980s; then steady growth to 2010 leads to a primary employment total of over 34,000 workers. The same total employment and population multipliers of 2.2 and 1.2 , respectively, used in the later years of Scenario $B$ are used. 
TABLE 8.37. Baseline Employment and Population Using Scenario C, 1985-2010

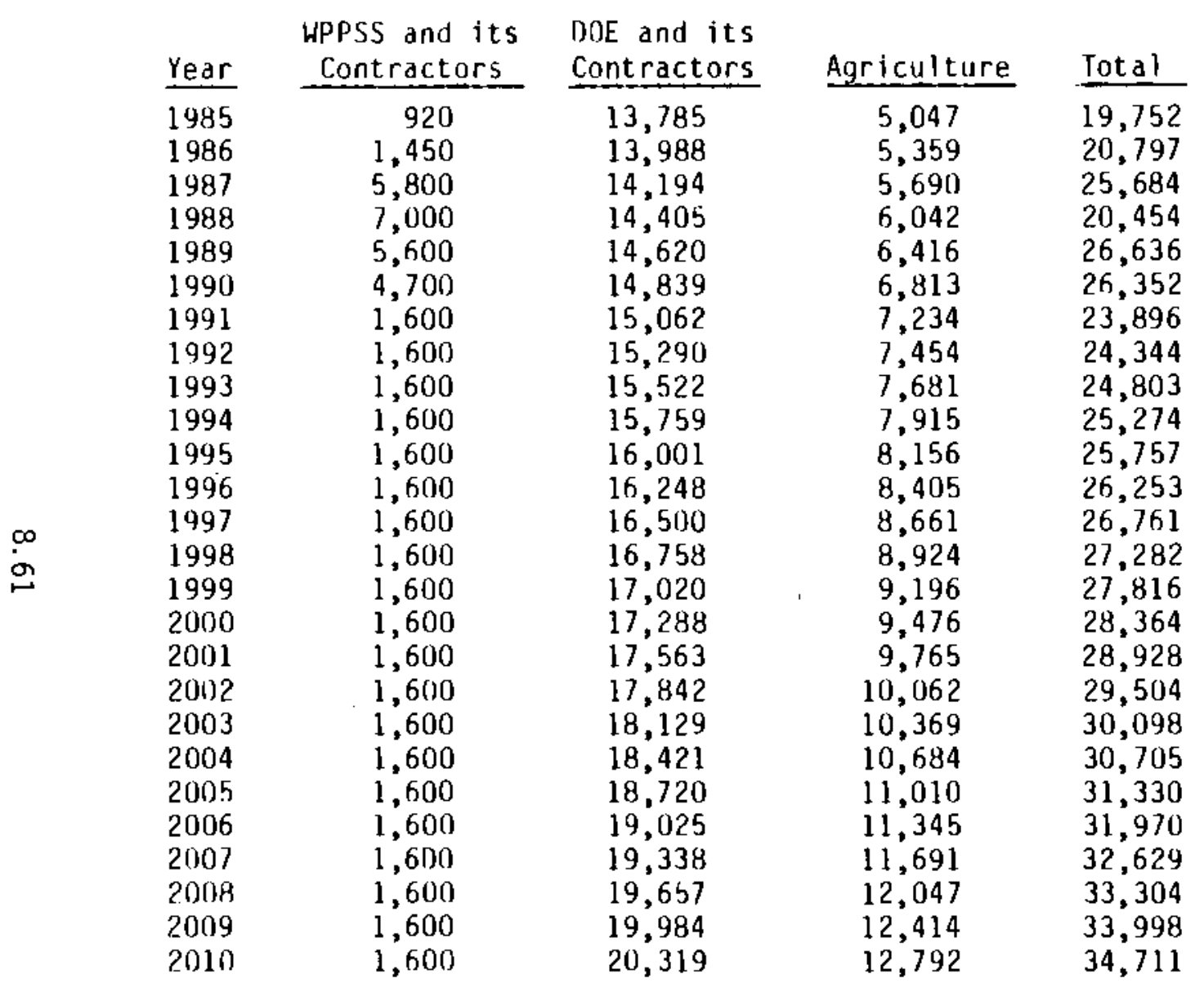

\begin{tabular}{c}
$\begin{array}{c}\text { Secondary Sect or } \\
\text { Employment }\end{array}$ \\
\hline 37,831 \\
39,085 \\
44,949 \\
40,765 \\
48,183 \\
47,956 \\
45,991 \\
46,529 \\
47,080 \\
47,645 \\
48,225 \\
48,820 \\
49,429 \\
50,054 \\
50,694 \\
50,694 \\
51,370 \\
52,061 \\
52,774 \\
53,502 \\
54,252 \\
55,020 \\
55,811 \\
56,621 \\
57,454 \\
58,310
\end{tabular}

Total

Employment Population

$\begin{array}{ll}57,583 & 134,954 \\ 59,882 & 137,713 \\ 70,633 & 150,614 \\ 61,219 & 143,554 \\ 74,819 & 159,874 \\ 74,308 & 159,491 \\ 69,887 & 156,175 \\ 70,873 & 157,161 \\ 71,883 & 158,373 \\ 72,919 & 159,616 \\ 73,982 & 160,892 \\ 75,073 & 162,201 \\ 76,190 & 163,541 \\ 77,336 & 164,916 \\ 78,510 & 166,325 \\ 79,058 & 166,983 \\ 80,298 & 168,471 \\ 81,565 & 169,991 \\ 82,872 & 171,559 \\ 84,207 & 173,161 \\ 85,582 & 174,811 \\ 86,990 & 176,219 \\ 88,440 & 177,959 \\ 89,925 & 179,741 \\ 91,452 & 181,573 \\ 93,021 & 183,456\end{array}$

Source: Pacific Northwest Laboratory 
The out-migration rate remains at 25 percent for the years in which population decreases after completion of the WNP-1 plant (Section 8.2.1). The projections for Scenario $C$ are fairly close to those for Scenario $B$.

Table 8.38 shows the steps used to derive the DOE primary employment figures contained in Table 8.37. Existing DOE programs and contractor employment was assumed to grow 1.2 percent per year, the rate of DOE employment

TABLE 8.38. DOE Employment for Scenario C, 1985-2010

\begin{tabular}{cccc} 
Year & $\begin{array}{c}\text { Employment in } \\
\text { Existing DoE Pro- } \\
\text { jects and Contracts }\end{array}$ & $\begin{array}{c}\text { Employment in } \\
\text { New DoE Projects }\end{array}$ & $\begin{array}{c}\text { Total DOE } \\
\text { Employment }\end{array}$ \\
\cline { 2 - 4 } 1985 & 12,485 & 1,300 & 13,785 \\
1986 & 12,636 & 1,352 & 13,988 \\
1987 & 12,788 & 1,406 & 14,194 \\
1988 & 12,943 & 1,462 & 14,405 \\
1989 & 13,099 & 1,521 & 14,620 \\
1990 & 13,257 & 1,582 & 14,839 \\
1991 & 13,417 & 1,645 & 15,062 \\
1992 & 13,579 & 1,711 & 15,290 \\
1993 & 13,743 & 1,779 & 15,522 \\
1994 & 13,909 & 1,850 & 15,759 \\
1995 & 14,077 & 1,924 & 16,001 \\
1996 & 14,247 & 2,001 & 16,248 \\
1997 & 14,419 & 2,081 & 16,500 \\
1998 & 14,593 & 2,165 & 16,758 \\
1999 & 14,769 & 2,251 & 17,020 \\
2000 & 14,947 & 2,341 & 17,288 \\
2001 & 15,128 & 2,435 & 17,563 \\
2002 & 15,310 & 2,532 & 17,842 \\
2003 & 15,495 & 2,634 & 18,129 \\
2004 & 15,682 & 2,739 & 18,421 \\
2005 & 15,872 & 2,848 & 18,720 \\
2006 & 16,063 & 2,962 & 19,025 \\
2007 & 16,257 & 3,081 & 19,338 \\
2008 & 15,453 & 3,204 & 19,657 \\
2009 & 16,652 & 3,332 & 19,984 \\
2010 & 16,853 & 2,466 & 20,319 \\
& & &
\end{tabular}

Source: Pacific Northwest Laboratory 
growth assumed for the 1981 to 1985 period when few DOE projects were under construction. From 1973 to 1977 DOE employment grew at a rapid 9.7 percent annual average rate, but since 1977 growth has been much slower, even declining in some years (see Table 8.4). Because most of the rapid DOE growth will occur in the construction of new projects, the growth rate of existing programs was assigned the lower 1.2 percent rate. Future employment growth in new DOE projects of 4 percent is based on an analysis of the construction and operation employment requirements and time schedules of the presently pianned DOE projects that are most likely to be implemented: B-Plant Immobilization Pilot Plant (BIPP); 100 Area Decommissioning (100 D\&D); Fuels and Materials Examination Facility (FMEF); Breeder Reprocessing Engineering Test Facility (BREI); Secure Automated Fabrication (SAF); Fusion Materials Irradiation Test Facility (FMIT); Process Facility Modification (PFM, to the Plutonium and Uranium Extraction Plant; PUREX); Waste Receiving and Processing Facility (WRAP); and the Special Isotope Separation Facility (SIS). Since many of the projects are only in the development stages, employment estimates used are preliminary. Because the scheduling of these projects tended to complement each other, employment growth was reasonably steady from 1985 to 1998.

Under the assumptions for Scenario $C$, the 1981 peak primary employment level of 28,500 will be reached in 1995. Once again, growth after this point is steady and Tri-Cities area government should be able to adjust its level of public services gradually. Primary employment is over 34,000 in 2010, and total employment reaches 93,000. Population between 1985 and 2010 is projected to increase 35.9 percent. The information currently available on the timing of the more likely new DOE projects shows a good dispersion of mainly medium and smaller projects, so that there is no year when construction of several projects combines to form a single employment impact equal to that of the WNP-1 restart.

\section{2 .5 Scenario D}

Scenario $D$ depicts the largest socioeconomic baseline condition for the Iri-Cities SMSA with the following key assumptions:

1. WNP-1 will be restarted in 1986-87 and completed in 1991 . 
2. Agriculture employment will grow at an average annual rate of 6 percent until 1991, and at 3 percent thereafter.

3. Existing DOE employment will grow at an average annual rate of 1.2 percent until 1990 and 2.2 percent thereafter. Employment from new DOE projects will grow at an average annual rate of 8 percent.

As show in Table 8.39, the WPPSS and agricultural primary employment sectors are the same as those assumed in Scenarios $B$ and $C$, and the approach for calculating the DOE sector is the same as that used under Scenario $C$. In Scenario D, however, all of the currently planned DOE construction projects are assumed to be implemented instead of only the most likely ones covered in Scenario C. In addition to the facilities listed in Section 8.2.4, the Basalt Waste Isolation Project (BWIP), and the Hanford Defense Waste Project are assumed to be constructed. Available information about the timing of these projects and their employment levels suggest an average annual employment growth rate of 8 percent through 1998 .

Because there is generally a 5 - to 8 -year lag time between the conception of a project idea and implementation, it is not unreasonable to assume that projects that would begin construction after 1998 have not even been proposed. The projects planned for 1985 to 1998 represent an assortment of different sized projects, although no single project is as large as WNP-1 in terms of construction employment. It is assumed that a similar assortment of projects will occur from 1998 to 2010 and the 8 percent is assumed to carry through the 1985 to 2010 period. The calculation of total DOE employment is shown in Table 8.40 .

According to Scenario D, the 1981 peak employment level will not be regained until 1995. The economy, however, will be operating close to this peak from 1987 to 1995, and it is likely that public services, education and housing in the Tri-Cities will be triggered into growth. Total primary employment will reach a high of 45,763 in 2010 , with corresponding tota? employment and population levels of 115,417 and 204,565 , respectively. 
TABLE 8.39. Baseline Employment and Population Using Scenario D, 1985-2010

\begin{tabular}{|c|c|c|c|c|c|c|c|}
\hline Year & $\begin{array}{l}\text { WPPSS and its } \\
\text { Contractors }\end{array}$ & $\begin{array}{l}\text { DoE and its } \\
\text { Contractors }\end{array}$ & Agriculture & Total & $\begin{array}{c}\text { Secondary Sector } \\
\text { Employment }\end{array}$ & $\begin{array}{c}\text { Total } \\
\text { Employment } \\
\end{array}$ & Population \\
\hline $\begin{array}{l}1985 \\
1986 \\
1987 \\
1988 \\
1989 \\
1990 \\
1991 \\
1992 \\
1993 \\
1994 \\
1995 \\
1996 \\
1997 \\
1998 \\
1999 \\
2000 \\
2001 \\
2002 \\
2003 \\
2004 \\
2005 \\
2006 \\
2007 \\
2008 \\
2009 \\
2010\end{array}$ & $\begin{array}{r}920 \\
1,450 \\
5,800 \\
7,000 \\
5,600 \\
4,700 \\
1,600 \\
1,600 \\
1,600 \\
1,600 \\
1,600 \\
1,600 \\
1,600 \\
1,600 \\
1,600 \\
1,600 \\
1,600 \\
1,600 \\
1,600 \\
1,600 \\
1,600 \\
1,600 \\
1,600 \\
1,600 \\
1,600 \\
1,600\end{array}$ & $\begin{array}{l}14,045 \\
14,321 \\
14,608 \\
14,908 \\
15,221 \\
15,679 \\
16,158 \\
16,657 \\
17,177 \\
17,723 \\
18,294 \\
18,891 \\
19,518 \\
20,176 \\
20,865 \\
21,591 \\
22,352 \\
23,154 \\
23,998 \\
24,887 \\
25,826 \\
26,816 \\
27,861 \\
28,965 \\
30,134 \\
31,371\end{array}$ & $\begin{array}{r}5,047 \\
5,359 \\
5,690 \\
6,042 \\
6,416 \\
6,813 \\
7,234 \\
7,454 \\
7,681 \\
7,915 \\
8,156 \\
8,405 \\
8,661 \\
8,924 \\
9,196 \\
9,476 \\
9,765 \\
10,062 \\
10,369 \\
10,684 \\
11,010 \\
11,345 \\
11,691 \\
12,047 \\
12,414 \\
12,792\end{array}$ & $\begin{array}{l}20,012 \\
21,130 \\
26,098 \\
27,950 \\
27,237 \\
27,192 \\
24,992 \\
25,711 \\
26,458 \\
27,238 \\
28,050 \\
28,896 \\
29,779 \\
30,700 \\
31,661 \\
32,667 \\
33,952 \\
34,816 \\
35,967 \\
37,171 \\
38,436 \\
39,761 \\
41,152 \\
42,612 \\
44,148 \\
45,763\end{array}$ & $\begin{array}{l}37,571 \\
38,912 \\
44,874 \\
47,096 \\
46,526 \\
46,490 \\
44,730 \\
45,593 \\
46,489 \\
47,425 \\
48,399 \\
49,414 \\
50,474 \\
51,579 \\
52,732 \\
53,939 \\
55,481 \\
56,518 \\
57,899 \\
59,344 \\
60,862 \\
62,452 \\
64,121 \\
65,873 \\
67,716 \\
69,654\end{array}$ & $\begin{array}{r}57,583 \\
60,042 \\
70,972 \\
75,046 \\
73,763 \\
73,682 \\
69,722 \\
71,304 \\
72,947 \\
74,663 \\
76,449 \\
78,310 \\
80,253 \\
82,279 \\
84,393 \\
86,606 \\
89,433 \\
91,334 \\
93,866 \\
96,515 \\
99,298 \\
102,213 \\
105,273 \\
108,485 \\
111,864 \\
115,417\end{array}$ & $\begin{array}{l}134,954 \\
137,905 \\
148,835 \\
153,724 \\
152,762 \\
152,701 \\
149,731 \\
151,629 \\
153,601 \\
155,660 \\
157,803 \\
160,036 \\
162,368 \\
164,799 \\
167,336 \\
169,992 \\
173,384 \\
175,665 \\
178,703 \\
181,882 \\
185,222 \\
188,720 \\
192,392 \\
196,246 \\
200,301 \\
204,565\end{array}$ \\
\hline
\end{tabular}

Source: Pacific Northwest Lahoratory 
TABLE 8.40. DOE Employment for Scenario D, 1985-2010

\begin{tabular}{cccc} 
Year & $\begin{array}{c}\text { Employment in } \\
\text { Existing DOE Pro- } \\
\text { jects and Contracts }\end{array}$ & $\begin{array}{c}\text { Employment in } \\
\text { New DoE Projects }\end{array}$ & $\begin{array}{c}\text { Total ooE } \\
\text { Employment }\end{array}$ \\
\cline { 2 - 3 } 1985 & 12,485 & 1,560 & 14,045 \\
1986 & 12,636 & 1,685 & 14,321 \\
1987 & 12,788 & 1,820 & 14,608 \\
1988 & 12,943 & 1,965 & 14,908 \\
1989 & 13,099 & 2,122 & 15,221 \\
1990 & 13,387 & 2,292 & 15,679 \\
1991 & 13,682 & 2,476 & 16,158 \\
1992 & 13,983 & 2,674 & 16,657 \\
1993 & 14,290 & 2,887 & 17,177 \\
1994 & 14,605 & 3,118 & 17,723 \\
1995 & 14,926 & 3,368 & 18,294 \\
1996 & 15,254 & 3,637 & 18,891 \\
1997 & 15,590 & 3,929 & 19,518 \\
1998 & 15,933 & 4,243 & 20,176 \\
1999 & 16,283 & 4,582 & 20,865 \\
2000 & 16,624 & 4,949 & 21,591 \\
2001 & 17,008 & 5,344 & 22,352 \\
2002 & 17,382 & 5,772 & 23,154 \\
2003 & 17,764 & 6,234 & 23,998 \\
2004 & 18,155 & 6,732 & 24,887 \\
2005 & 18,555 & 7,271 & 25,826 \\
2006 & 18,963 & 7,853 & 26,816 \\
2007 & 19,380 & 8,481 & 27,861 \\
2008 & 19,806 & 9,169 & 28,965 \\
2009 & 20,242 & 9,892 & 30,134 \\
2010 & 20,687 & 10,684 & 31,371
\end{tabular}

Source: Pacific Northwest Laboratory 


\subsection{REFERENCES}

Battelle, Human Affairs Research Centers. 1983. Unpublished data. Seattle, Washington.

Benton County Extension 0ffice. 1983. Summary of Irrigated Land. Kennewick, Washịngton.

Benton County. 1983. 1983 Benton County Budget. Benton County, Prosser, washington.

Bureau of Economic Analysis, U.S. Department of Commerce. 1982. Regional Economic Information System (Microfiche tabulations by county, Washington State). Table 25, "Employment by Type and Broad Industrial Sources," and Table 5, "Personal Income by Major Sources and Broad Industrial Sources," Washington, D.C.

Bureau of the Census, U.S. Department of Commerce. 1972. 1970 Census of Housing: Housing Characteristics for States, Cities, and Couniries. Vol. 1, Part 49 , Washington, D.C.

Bureaus of the Census, U.S. Department of Commerce. 1982. 1980 Census of Housing: General Housing Characteristics. HC80-1-A49, washington, D.C.

City of Kennewick. 1978. Kennewick, Washington 1978 Budget. Kennewick, washington.

City of Kennewick. 1983. Kennewick, Washington 1983 Budget. Kennewick, Washington.

City of Pasco. 1978. 1978 City of Pasco Budget. Pasco, Washington.

City of Pasco. 1983. 1983 City of Pasco Budget. Pasco, Washington.

City of Richland. 1978. 1978 Annual Operating Budget. Richland, Washington.

City of Richland. 1983. 1983 Annual Operating Budget. Richland, Washington.

Clement, M. et al. 1974. Study and Forecast of Tri-City Economic Activity and its Related Impact on Gasoline Needs and Housing. Battelle Pacific Northwest Laboratories, Richland, Washington.

Economic Report of the President 1983. Table B-3, p. 166. U.S. Government Printing Office, washington D.C.

Educational Service District 123. 1983. School Directory. Pasco, Washington.

Federal Home Loan Bank of Seattie. 1983. Housing Vacancy Survey: Tri-Cities, Washington. Seattle, Washington. 
Franklin County. 1983. 1983 Frankl in County Budget. Franklin County, Pasco, Washington.

McGinnis, Karen and Dean Schau. 1983. "The Downside of Nuclear Plant Construction." Paper presented at the Northwest Regional Economics Conference, May 5-7 1983, Bellingham, Washington.

Office of Financial Management, State of Washington. 1982. Population Irends for Washington State. 0FM/F\&S/P-141, 0lympia, Washington.

Puget Sound Power and Light Company. 1981. Skagit/Hanford Nuclear Projecte, Application for Site Certification/Environmental Report, Richland, Washington.

Puget Sound Power and Light Company. 1982. Draft Environmenta] Statement Related to the Construction of Skagit/Hanford Nuc Tear Project, Unjits I and 2. RichTand, Washington.

Tri-Cities Real Estate Research Committee. 1982. Tri-Cities Real Estate Research Report. Vol. 5, No. 2, Kennewick, Washington.

Tri-Cities Real Estate Research Committee. 1983. Tri-Cities Real Estate Research Report. Vol. 6, No. 1, Kennewick, Washington.

United Way. 1983 "People Who Need People," (brochure). Kennewick, Washington.

U.S. Bureau of Economic Analysis. 1982. Regional Economic Information System. U.S. Department of Commerce, Table 5, Table 25, Washington, D.C.

U.S. Department of Energy. 1982. Site Characterization Report for the Basalt Waste Isolation Project. Richland, Washington.

Washington State Employment Security Department. 1982. Annual Planning Report 1982. Richiand-Kennewick-Pasco SMSA. 01ympia, Washington

Washington State Employment Security Department. 1983. Annual Planning Report 1983. Service Delivery Area IX. 0lympia, Washington.

Washington State, Office of State Auditor, Division of Systems Development and Research. Annual Report. 1975. Local Government Comparative Statistics. OTympia, Washington.

Washington State, Office of State Auditor, Division of Systems Development and Research. Annual Report. 1976. Local Government Comparative Statistics. 0lympia, Washington.

Washington State, Office of State Auditor, Division of Systems Development and Research. Annual Report. 1977. Local Government Comparative Statistics. 01 ympia, Washington. 
Washington State, Office of State Auditor, Division of Systems Development and Research. Annual Report. 1978. Local Government Comparative Statistics. 01 ympia, Washington.

Washington State, Office of State Auditor, Division of Systems Development and Research. Annual Report. 1979. Local Government Comparative Statistics. Olympia, Washington.

Washington State, Office of State Auditor, Division of Systems Development and Research. Annual Report. 1980. Local Government Comparative Statistics. 01 ympia, Washington.

Washington State, Office of State Auditor, Division of Systems Development and Research. Annual Report. 1981. Local Government Comparative Statistics. Olympia, Washington. 



\subsection{EFFLUENT AND ENVIRONMENTAL MEASUREMENTS}

ANO MONITORING PROGRAMS

This chapter describes the methods used to obtain baseline environmental data for the Skagit/Hanford Nuclear Plant (S/HNP) and describes programs that were proposed for monitoring the environmental impacts of site preparation and S/HNP construction and operation. The material in this chapter is taken directly from the environmental report on the S/HNP (PSP\&L 1981a). It is believed that information on measurement and monitoring programs for the $S / H N P$ is applicable to the NPR, because the reference location for the NPR is the same area PSP\&L had proposed for locating the S/HNP.

As a result, the term "site" used in this chapter refers not only to that area on the Hanford Reservation proposed for the S/HNP, but also to the Skagit/ Hanford Site for the NPR. In addition, although the term "facility" (in the context of PSP\&L's environmental report) refers strictly to the S/HNP, it also refers to the NPR in this chapter.

Section 9.1 of this chapter discusses the proposed preoperational environmental programs, Section 9.2 discusses the proposed operational environmental monitoring programs, and Section 9.3 discusses related environmental measurement and monitoring programs. Appendix E provides a generic description of exposure pathways for reference.

\subsection{PREOPERATIONAL ENVIRONMENTAL PROGRAMS}

Preoperational environmental monitoring programs have been developed to assess the characteristics of the site and the surrounding region prior to facility operation. Portions of these programs will continue through facility operation. However, as data are collected and evaluated, the scope of these programs may change. The purpose of these programs is to establish a reference framework for assessing subsequent effects attributable to site preparation, facility construction, and station operation. Reports that present data and appropriate conclusions of monitoring efforts witl be made available to federal and state agencies at the conclusion of each program. Technical descriptions of procedures, techniques, and instrumentation used in the preoperational studies are discussed in this subsection. 


\subsubsection{Surface Water}

No surface water exists in the vicinity of the site. The Columbia River, $11 \mathrm{~km}(7 \mathrm{mi})$ to the northeast, will serve as the source for cooling water makeup, as well as the receiving body for wastewater discharges. The Yakima kiver, approximately $11 \mathrm{~km}$ (7 $\mathrm{mi}$ ) south of the site, will not be affected by facility construction or operation. Sampling programs to determine preconstruction and preoperational baseline water conditions and the related ecology of the Columbia River are described in the subsequent sections.

\subsubsection{Physical and Chemical Parameters}

This section describes the monitoring programs developed to determine physical and chemical characteristics of the Columbia River in the vicinity of the facility intake and discharge structures (River Mile [RM] 361.5).

9.1.1.1.1 Preapplication Monitoring. The purpose of the preapplication monitoring program is to assess site acceptability with regard to thermal and chemical impacts that could result from operation of the facility. The following factors were considered in developing the preapplication monitoring programs for physical and chemical characteristics:

- existing environmental baseline data

- location and number of monitoring stations as required to consider the following factors

- bathymetric characteristics in the vicinity of the intake and discharge structures

- type of cooling system employed and its probable operating modes

- transient hydrological parameters in the vicinity of the intake and discharge structures

- vertical and horizontal temperature and salinity structure in the vicinity of the intake and discharge structures

- sampling frequency and times to ensure that important terporal variations were adequately monitored

- duration of monitoring programs

- data analysis procedures. 
The Columbia River in the vicinity of the site has been studied for the last 36 years. These studies have included both general observations and detailed analyses of the impacts upon the river from plutonium reactor effluents. Study reports have been reviewed and summarized by Becker and Waddel (1972), and by Neitzel (1979), and they provide a comprehensive historical picture of water quality conditions in the river. Major information sources include publications by the U.S. Geological Survey (1981); the Washington Public Power Supply System (Supply System) ${ }^{(a)}$; Puget Sound Power \& Light Company (1981a, Tables 2.14-2.17); U.S. Environmental Protection Agency (U.S. EPA 1979); and the Washington State Department of Ecology (1980). A summary of these data is included in Section 2.4 of Puget Sound Power \& Light Company (1981a).

Two ongoing water quality monitoring programs in the Hanford Reach (see Section 9.3) are of particular interest. The U.S. Geological Survey (USGS 1981) has collected monthiy water quality data since 1974 at a monitoring station located upstream of the facility at Vernita Bridge (RM 388.1). Parameters analyzed include an extensive list of general chemical, thermal, inorganic and organic constituents, as well as a full complement of nutrients, trace metals, and solid residues. Prior to 1974, samples were collected at Vernita Ferry (RM 394.5); however, this record is incomplete. Downstream of the site, the Supply System is conducting a one-year water chemistry study at RM 352.1. Their objective is to collect site-specific data and expand the preoperational data base for WNP 1, 2, and 4. Samples are collected weekly or monthly and analyzed for a full complement of parameters.

Because a comprehensive history of surface water data exists and because water quality sampling programs that bracket the area in the vicinity of the intake and discharge structures are in progress, a specific preapplication water quality monitoring program was unnecessary.

An instream data collection program for bathymetric survey and current velocity measurements was conducted from May 8 through May 11, 1981, along a 4-km (2.5-mi) portion (66 cross-sections) of the Columbia RM 361.5 where the

(a) Letter from R. A. Chitwood to 3. Mecca, Washington Public Power Supply System, Columbia River Water Chemistry, February 26, 1981. 
facility intake and discharge structures will be located (PSP\&L 1981a, Appendix B). This program provides field-surveyed input data to various environmentaT analyses presented in this report, including the thermal plume modeling, the radionuclide dispersion calculations, the intake and discharge structures location, and the aquatic ecology studies.

The river discharge as measured below Priest Rapids Dam (RM 394.5) during the instream data collection program was 144,500 cfs. The discharge at RM 361.5, computed from the cross section area and depth profiles, was about 143,000 cfs. The maximum recorded velocity at RM 361.5 was about $2 \mathrm{~m} / \mathrm{sec}$ $(7.0 \mathrm{ft} / \mathrm{sec})$ and was found in midstream. The intake and discharge structures will be located in a channel crossing where the transverse-channel profile is uniform. The main flow channel upstream of RM 361.5 is located along the east bank of the river and crosses to the west bank downstream of RM 361.5. The minimum bed elevation (maximum depth) in the vicinity of the intake and discharge structures is about $101 \mathrm{~m}$ (335 ft) above National Geodetic Vertical Datum (NGVD).

A continuous recording fathometer was used to obtain the hydrographic data. Horizontal positioning was accomplished with a navigation system and data processor. A $7-m(23-\mathrm{ft})$ survey vessel was used to collect the instream data. The vertical velocity profiles at RM 361.5 were obtained using a current meter. A complete description of the field work, station locations, equipment and procedures used, and results and discussion are presented in the instream data collection program report (PSP\&L 1981a, Appendix B).

The stage-discharge relationship for the Columbia River at RM 361.5 was developed using the U.S. Corps of Engineers HEC-2 waste surface profiles computer program (1981) with input data obtained from the instream data collection program. The general procedures for applying HEC-2 to the Columbia River, as described in Appendix B of Puget Sound Power \& Light Company (1981a), inciude Columbia River model development, model calibrations, and computation of water surface profiles. The results of the calculations are presented in Section 2.4 of that document. 
The thermal plume (dilution) analysis was conducted using a state-of-theart mathematical model implemented on a high speed digital computer. The computer code, designated HOTSUB3, was adapted from the work of Koh and Fan (1970) and the U.S. Nuclear Regulatory Commission's (NRC's) Regulatory Guide 1.113 (1977). With an input of discharge design, discharge flow parameters, and receiving water characteristics, the code generates excess temperature (concentration) profiles in the ambient receiving water. The format of the output is such that isotherms (isopleths) may be plotted for horizontal planes at selected depths. In addition, by using the data from the isotherm (isopleth) contours, the program calculates corresponding surface areas and volumes. A complete description of the thermal plume modeling is presented in Appendix C of Puget Sound Power \& Light Company (1981a).

9.1.1.1.2 Site Preparation and Construction Monjtoring Program. A water quality monitoring program will be established to detect possible direct or indirect effects of site preparation and facility construction on surface waters, and to evaluate potential impacts on the Columbia River ecology. This program will also serve as part of the construction impact control program to ensure that construction activities will be performed in a manner to minimize scouring, erosion, runoff, turbidity, and toxicity.

A monitoring program will be initiated during excavation and backfilling activities for the intake and discharge structures. The basic program of water quality monitoring during construction wilt include measurements of total suspended solids (TSS), turbidity, light penetration, pH, oil and grease, temperature, and dissolved oxygen at stations iocated both upstream and downstream from the excavation site. Duplicate water samples will be collected at five locations (Table 9.1 and Figure 9.1).

Water samples will consist of a 1-liter (0.3 gal) aliquot taken from a composite of three subsurface grab samples per station. Samples will be returned to the laboratory for determination of tota? suspended solids (nonfilterabie residue) and for various calibration purposes. Water quality measurement from temperature, dissolved oxygen, $\mathrm{pH}$, and turbidity will be conducted. The proposed analytical methods and levels of detection are presented in Table 9.2 . 
TABLE 9.1. Water Quality Sampling Stations for Site Preparation and Construction Monitoring Program

\begin{tabular}{|c|c|c|}
\hline Station & Location & Description \\
\hline WQ-1 & $\mathrm{RM} 361.5+91 \mathrm{~m}(300 \mathrm{ft})$ & $\begin{array}{l}\text { Control Station; } 0.10 \mathrm{~km}(0.06 \mathrm{mi}) \\
\text { upstream of the NPR intake }\end{array}$ \\
\hline$W Q-2$ & RM 361.4 & $\begin{array}{l}\text { D. } 16 \mathrm{~km}(0.1 \mathrm{mi}) \text { downstream of the NPR } \\
\text { discharge }\end{array}$ \\
\hline$W Q-3$ & RM 361.3 & $\begin{array}{l}0.32 \mathrm{~km}(0.2 \mathrm{mi}) \text { downstream of the NPR } \\
\text { discharge }\end{array}$ \\
\hline$W Q-4$ & RM 359.5 & $\begin{array}{l}3.2 \mathrm{~km}(2.0 \mathrm{mi}) \text { downstream of the NPR } \\
\text { discharge }\end{array}$ \\
\hline$W Q-5$ & RM 351.9 & $\begin{array}{l}\text { WNP } 1 \text { and } 4 \text { intake; } 15 \mathrm{~km}(9.6 \mathrm{mi}) \\
\text { downstream of the NPR discharge. }\end{array}$ \\
\hline
\end{tabular}

Note: See Figure 9.1 for station locations.

In addition, samples of material to be dredged shali be collected and standard bulk sediment and elutriate testing performed (U.S. EPA 1979). Such tests delineate the type and amount of trace substances and the organic content of the material in question. Should results indicate high levels of contaminating substances, the basic monitoring program can be expanded to incorporate these parameters.

9.1.1.1.3 Preoperational Monitoring Program. The objective of the preoperational water quality monitoring program is to provide the data base necessary for identifying and assessing any changes in water quality resulting from plant operation. The monitoring program, to be initiated one year prior to fuel load, is designed to be compatible with the operational monitoring program (see Section 9.2). 


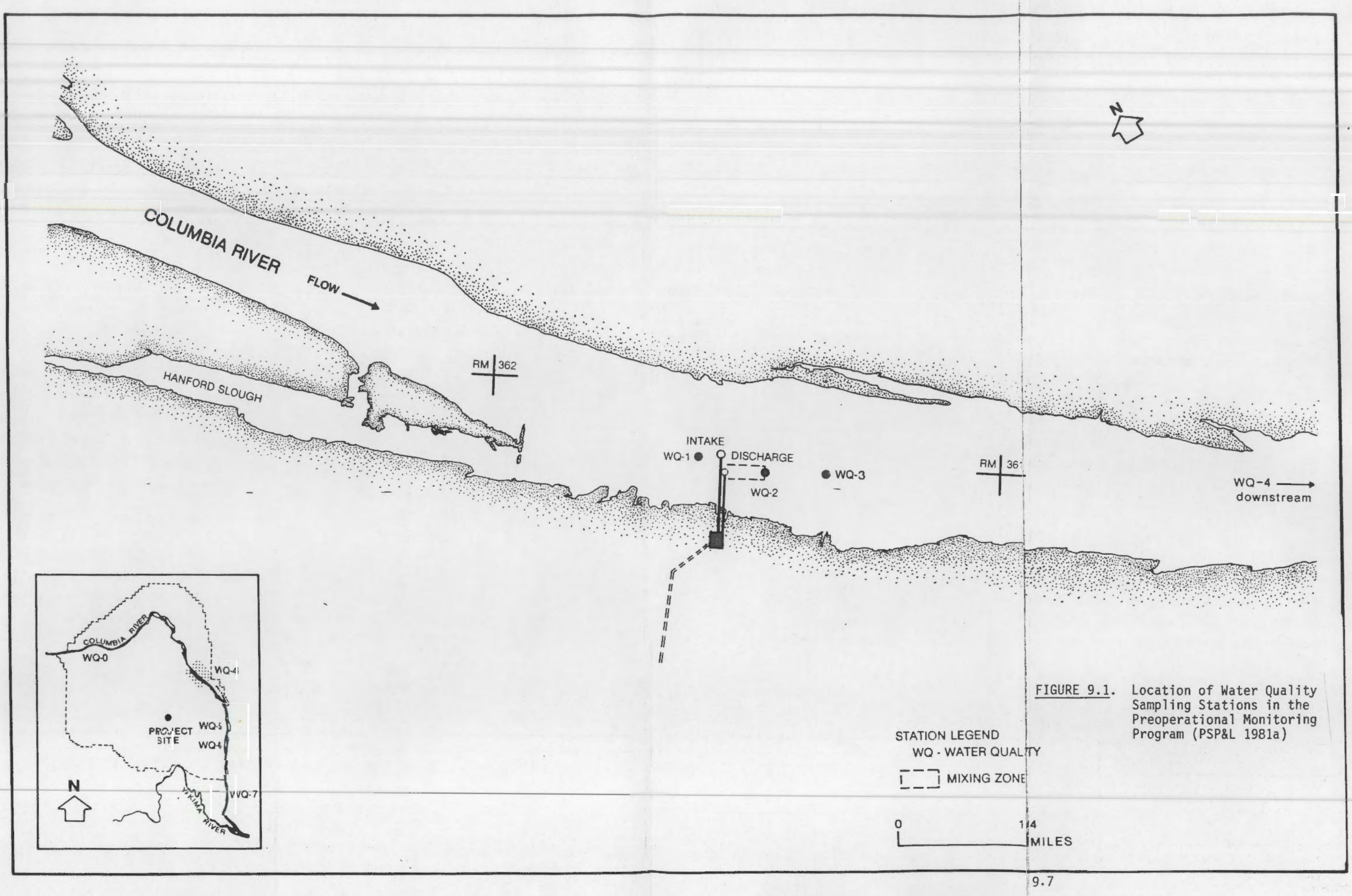



TABLE 9.2. Analytical Methods and Levels of Detection for Water Characteristics to be Measured During the Construction Monitoring Program (PSP\&L 1981a)

Detection

Characteristic

1. Temperature

2. Dissoived axygen

3. $\mathrm{ph}$

4. Turbidity

5. Suspended Solids

6. Light Penetration

7. 0 il and Grease

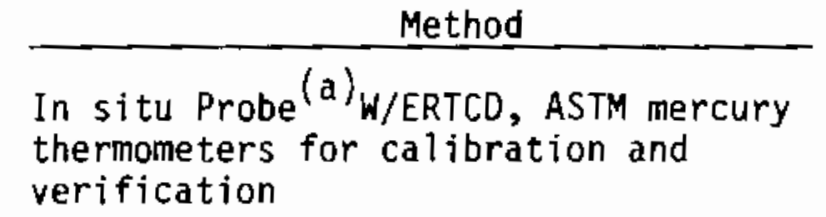

In situ Probe ${ }^{(a)}$ W/Azid modification

of Winkler Iodometric $\left\langle\right.$ f ${ }^{2}$ calibration and verification

In situ Probe ${ }^{(a, b)}$ W/Potentiometric (Corning 610A) for calibration and verification

In situ Turbidimgter (c)

W/Nephelometric formazin standards for calibration

Glass Fiber filtration ${ }^{(b)}$ and gravimetric at $105^{\circ} \mathrm{C}$ (mettler balance) Preservation: cool to

$4^{\circ} \mathrm{C} ; 2$ days maximum

$20 \mathrm{~cm}$ black and white Secchi Disk

Solvent extraction, partition
Limit

$1.0^{\circ} \mathrm{C}$

0.10 $\mathrm{mg} / 1$ iter

0.1 $\mathrm{pH}$ units

$0.01 \mathrm{NTU}$ 1.0 $\mathrm{mg} / 1$ iter

1.0 $\mathrm{mg} / 1$ iter

(a) Hydrolab Corporation (1978)

(b) American Public Health Association, American Water Works Association, Water Pollution Control Federation (1980)

(c) Research Technology, Inc. (1979)

(d) U.S. EPA (1979) 
The following factors were considered in developing the preoperational monjtoring program for physical and chemical characteristics:

- the average and extreme extent and enclosed surface area of the limiting excess temperature isotherms as established by the state, by comparison with background and baseline data

- temperatures at positions appropriate to define the extent of the mixing zones.

- time-temperature relationships at biological monitoring stations.

Water quality characteristics, frequency of sampling, and the methods to be used in sample preservation and analysis are provided in Table 9.3. The study includes all of the physical and chemical parameters considered essential to characterize the water quality in the vicinity of the intake and discharge structures. Seven sampling Tocations, described in Table 9.4 and shown in Figure 9.1, have been established.

Three stations unique to the site will be sampled on a weekly or monthly basis depending on the parameter (Table 9.3). The stations include the facility intake $(W Q-1)$, the downstream boundary of a legaliy defined mixing zone (WQ-2), and a station approximately $3.2 \mathrm{~km}(2 \mathrm{mi})$ downstream of the facility discharge in the major axis of the discharge plume (wQ-4). The remaining four stations $(W O-0,5,6$, and 7$)$ correspond to sampling locations for related monitoring programs (Section 9.3). These stations will be sampled quarterly to ensure that preoperational results can be correlated with other studies in progress. This objective will be accomplished by performing side-by-side sample collection and sample splitting with the various agencies or analytical laboratories involved.

The water quality parameters to be monitored were chosen to detect any possible direct effects of facility operation on the thermal regime or water quality characteristics of the Columbia River, and to detect possible synergistic effects that may affect the ecology of the Columbia River. Genera? sampling and analytical procedures are discussed below.

Duplicate grab samples will be collected in the main river current approximateiy $30 \mathrm{~cm}(1 \mathrm{ft})$ below the water surface at each station. Samples collected 
TABLE 9.3. Analytical Methods, Detection Limits and Preservation Techniques Proposed for the Water Quality Parameters to be Surveyed in the Preoperational Monitoring Program (PSP\&L 1981a)

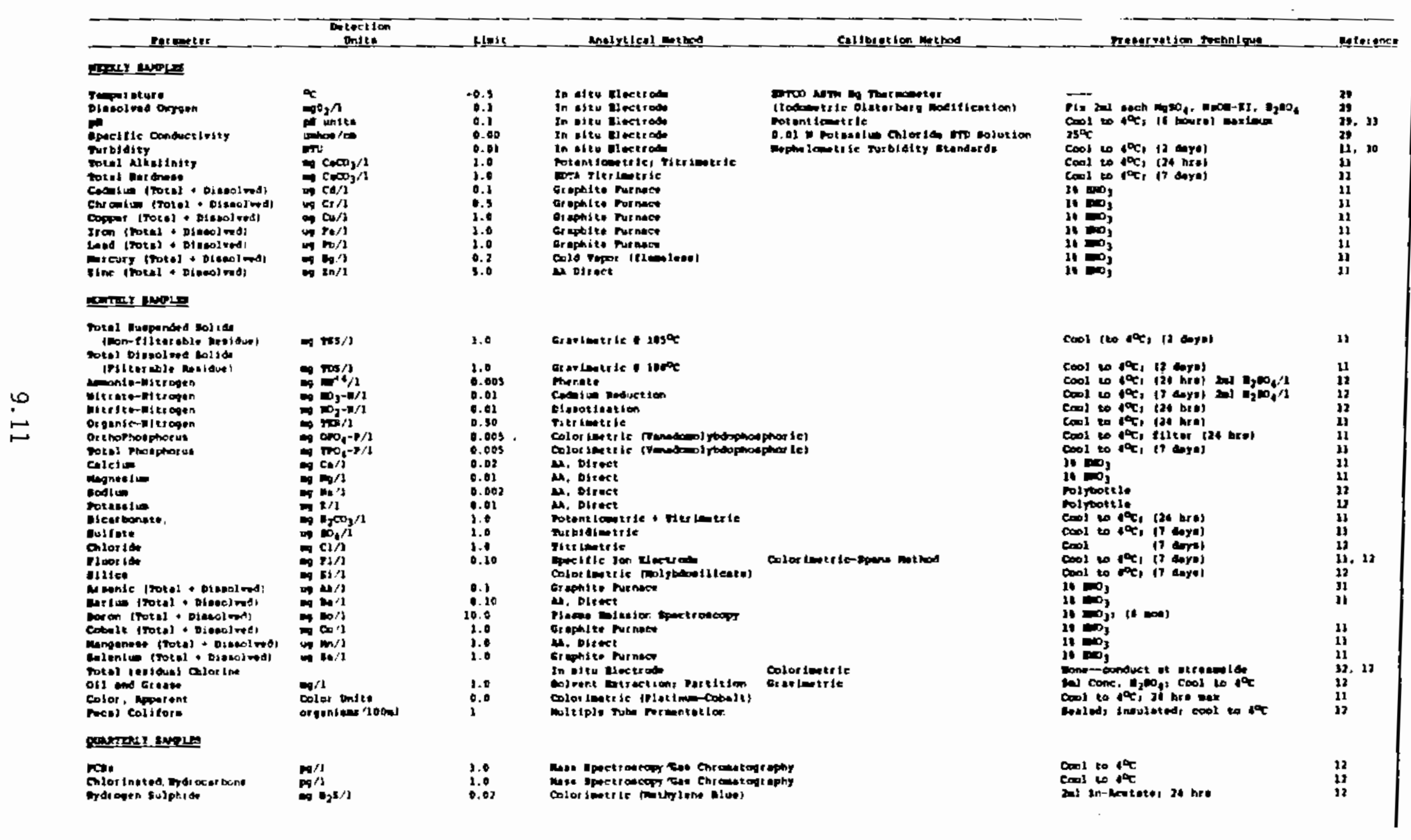


TABLE 9.4. Water Quality Sampling Stations for the Preoperational Monitoring Program (PSP\&L I981a)

\begin{tabular}{|c|c|c|}
\hline Station & Location & Description \\
\hline $\mathrm{HG}-0$ & RM 388.1 & $\begin{array}{l}\text { Control station. Vernita Bridge (Hwy \#24) } \\
\text { (42.5 km or } 26.5 \mathrm{mi} \text { upstream of NPR intake) }\end{array}$ \\
\hline WQ-1 & $\mathrm{RM} 361.5$ & NPR intake \\
\hline$W Q-2$ & RM 361.4 & $\begin{array}{l}\text { Downstream boundary of mixing zone. (0.16 km } \\
\text { or } 0.1 \mathrm{mi} \text { downstream of NPR discharge) }\end{array}$ \\
\hline$W Q-4$ & RM 359.5 & $\begin{array}{l}3.2 \mathrm{~km}(2.0 \mathrm{mi}) \text { downstream of facility } \\
\text { discharge }\end{array}$ \\
\hline$W Q-5$ & RM 351.9 & $\begin{array}{l}\text { WNP } 1 \text { and } 4 \text { intake }(15.4 \mathrm{~km} \text { or } 9.6 \mathrm{mi} \text { down- } \\
\text { stream of NPR intake) }\end{array}$ \\
\hline WQ-6 & RM 345.0 & $\begin{array}{l}300 \text { area intake. }(26.4 \mathrm{~km} \text { or } 16.5 \mathrm{mi} \text { down- } \\
\text { stream of NPR discharge) }\end{array}$ \\
\hline $\mathrm{HQ}-7$ & $\mathrm{RM} 33 \mathrm{~B} .0$ & $\begin{array}{l}\text { City of Richland municipal intake }(37.6 \mathrm{~km} \text { or } \\
23.5 \mathrm{mi} \text { downstream of NPR discharge })\end{array}$ \\
\hline
\end{tabular}

Note: See Figure 9.1 for station locations.

will be filtered onsite where necessary and stored in ice-filled coolers prior to shipment. Samples will be shipped promptiy to a certified analytical laboratory.

In situ instrumentation wilt be calibrated per manufacturer's instruction immediately prior to and following field sampling. Dual calibration will provide information regarding drift in calibration due to sensor fouling. In addition, a small number of discrete water samples will be returned to the laboratory for analysis and further verification of in situ instrumentation.

Sampling and analytical methodology will be performed in accordance with the latest guidelines set forth by the U.S. EPA (1979), the American Public Health Association (APHA 1980), and/or the American Society for Testing and Materials (ASTM 1980). In the event of a conflict, the U.S. EPA (1979) will be used as the principal reference document. 
For quality control purposes, standard solutions will be run prior to each sampling effort to ensure accuracy of results. Blind duplicates will be submitted to ensure reproducibility and accuracy. Satisfactory completion of the U.S. EPA's sample audit program (1972) will also be accomplished. All work related to this program will be stringently recorded in bound field notebooks, bound laboratory notebooks, including worksheets and copies of standard curves, and final data reports.

\section{1 .1 .2 Ecological Parameters}

This section describes the monitoring programs to determine aquatic ecological characteristics of the Columbia River in the vicinity of the facility intake and discharge structures (RM 361.5).

9.1.1.2.1 Preapplication Program. Studies at the Hanford Site over a 36-year period have provided substantial qualitative and quantitative information useful for impact assessment. In addition, the supply system has conducted literature reviews (Neitzel 1979; Becker 1973) and field studies on the Columbia River since 1973 (Battelle 1976a,b; 1977; 1978; 1979a,b; Beak Consultants 1980). These studies provide comprehensive baseline information on the composition, structure and function of the aquatic ecosystem of the Hanford Reach of the Columbia River. The information was used to describe the existing ecological conditions (PSP\&L 1981a, Section 2.2.2) in the vicinity of the facility intake and discharge locations at RM 361.5 .

Predictions of nonlethal physiological and behavioral responses as described in Sections 4.1.2, 5.1.3 and 5.3.1 of Puget Sound Power \& Light Company (1981a) are based upon:

- knowledge of local aquatic ecosystems

- a thorough review of literature on tolerance levels and nonlethal physiological and behavioral responses of local aquatic organisms to thermal, physical, and chemical stresses

- predicted stresses of construction and operation activities.

\subsection{Site Preparation and Construction Program. A potential} ecological concern may arise during facility construction as a result of the excavation and backfilling activities associated with construction of river intake and discharge structures. Increases in suspended and settleable 
materials may affect aquatic biota in several ways. An increase in suspended particles may decrease light penetration and reduce photosynthetic activities of macrophytes, phytoplankton, and periphyton. A reduction of plant growth may be reflected in all food-web levels. Additions of suspended and settleable materials may mechanically abrade and clog gitls of fish and sessile organisms, as well as interfere with the feeding processes of filter feeding organisms (Shark 1973; Warren 1971). Settling and shifting of solid materials on the river bottom may fill substrate interstices, eliminating micro- and macro-invertebrate habitats and thus altering the benthic community structure (Hynes 1966).

The Supply System evaluated these possibilities during installation of WNP-2 makeup and circulating water blowdown lines (Page 1976). Results indicated that, after backfilling was completed, settled material covered approximately 2.8 ha (6.9 acres) (or 13 percent of the river cross section), to a point approximately $300 \mathrm{~m}(1000 \mathrm{ft})$ downstream from the WNP construction activities. Periphyton growth and macro-invertebrate numbers were markedly reduced in the affected area. The river, however, continued to wash the area, dissipating the deposits within a few weeks. Other researchers have noted that the recolorization of bottom substrates is usually rapid and can occur in as little as a few days (Rosenberg and Snow 1975). It was concluded that the impacts from the installation of the intake and discharge structures are inconsequential to the aquatic community (Page 1976).

The Supply System study provided sufficient data to address the biological impacts to the river from facility construction activities. Therefore, no aquatic monitoring is proposed during the site preparation and construction program.

9.1.1.2.3 Preoperational Program. The objective of the preoperational aquatic ecology monitoring program will be to augment the historical and confirmatory data used for identifying and assessing potential ecological changes resulting from facility operation. Accordingly, preoperational monitoring will be concentrated on that portion of the river immediately adjacent to the plant intake/discharge facilities, and will emphasize organisms most ijkely to be affected by facility operation (i.e., benthic biota and fish). 
The following factors were considered in developing the preoperational monitoring program for aquatic ecology:

- alteration of habitat - The composition of bottom substrates, movement of material, and the size of affected areas in relation to intake and discharge velocities and ambient environmental conditions were considered.

- entrainment, impingement, entrapment - The distribution and abundance of important species and their various life stages susceptible to entrainment, impingement, and entrapment were considered so that estimates of potential losses and predictions of the effects of these losses could be made.

- thermal and chemical stress - The distribution and abundance by 1 ife stage of important species in the cooling water body to be influenced by thermal and chemical discharges were considered so that estimates of potential losses and predictions of the effects of these discharges could be made. Water quality monitoring pertinent to determining the impact of NPR operation was considered.

The seasonal cycles found in ecosystems may require long-term studies to detect perturbations. Therefore, the preoperational program will collect field data for two years prior to fuel load to provide additional information on natural variations in the seasonal occurrences and abundance of important aquatic species near the facility intake and discharge location. A knowledge of the extent of natural variations will permit evaluation of changes in the abundance of important aquatic species in the intake and discharge vicinity before and during operation. A comparison of changes in species abundance in the vicinity of the intake and discharge, and in control areas outside the influence of the facility will also be made before and during operation. The following monitoring program was designed to be consistent and compatible with data collected in the preapplication program as well as with data from other locations in the Hanford Reach.

Benthic Organisms: Alterations of Columbia River aquatic biota due to the influence of lant effluent should be most readily indicated by changes in the structure of the benthic community in the immediate vicinity of the discharge. The preoperational benthic program will focus on characteriz ing the benthic flora and fauna in the area of expected impact. 
Sampling locations for preoperational benthic studies are shown in Figure 9.2 and described in Table 9.5. Stations will be sampled four times per year (in March, June, September, and December) to establish baseline information on community composition and abundance. To sample benthic fauna, rock-filled baskets will be incubated on the bottom for a threemonth period. Upon recovery, species composition, biomass and community dominance will be determined. Benthic flora will be sampled using glass microscope slides incubated at the same sites as the rock-filled baskets and samples at the same frequency. Qualitative species analysis, chlorophyll-a and biomass measurements witl be made. Replicate benthic fiora and fauna samples will be taken to allow for statistical analysis of community changes. Representatives of ail taxa present will be preserved in a species reference collection, complete with voucher specimens.

Special benthic programs may occur on an intermittent basis in response to regional concerns. A survey of asiatic clam (Corbjcula sp.) distribution in the vicinity of the plant intake and the upriver shoreline and backwater slough areas $\mathbf{w} \hat{1} \mathbf{l}$ be initiated in accordance with guidance provided in U.S. NRC (1981).

Fish: Identification of fish species in the Hanford Reach is essentially complete. The Supply System's preliminary Program (Battelle 1976a,b; 1977; 1978; 1979a,b; Beak Consultants 1980) has examined the spatial and temporal distribution, relative species abundance, age structure and feeding habits of fish found near the WNP-1/4 and 2 intake and discharge locations. In the preoperational program, emphasis will be placed on fish fcund in the immediate vicinity of the facility intake and discharge structures.

Species and numbers of fish residing seasonally near the structures wii? be examined with particular attention given to anadromous outmigrants and juvenile smallmouth bass. Samples will be obtained using one or more of the following sampling methods: hoop-nets, electroshocking, or beach seining. Sampling locations for each of these methods are shown in Figure 9.2. A tag and release program will be used in an attempt to determine population size and residence time within the study area. 


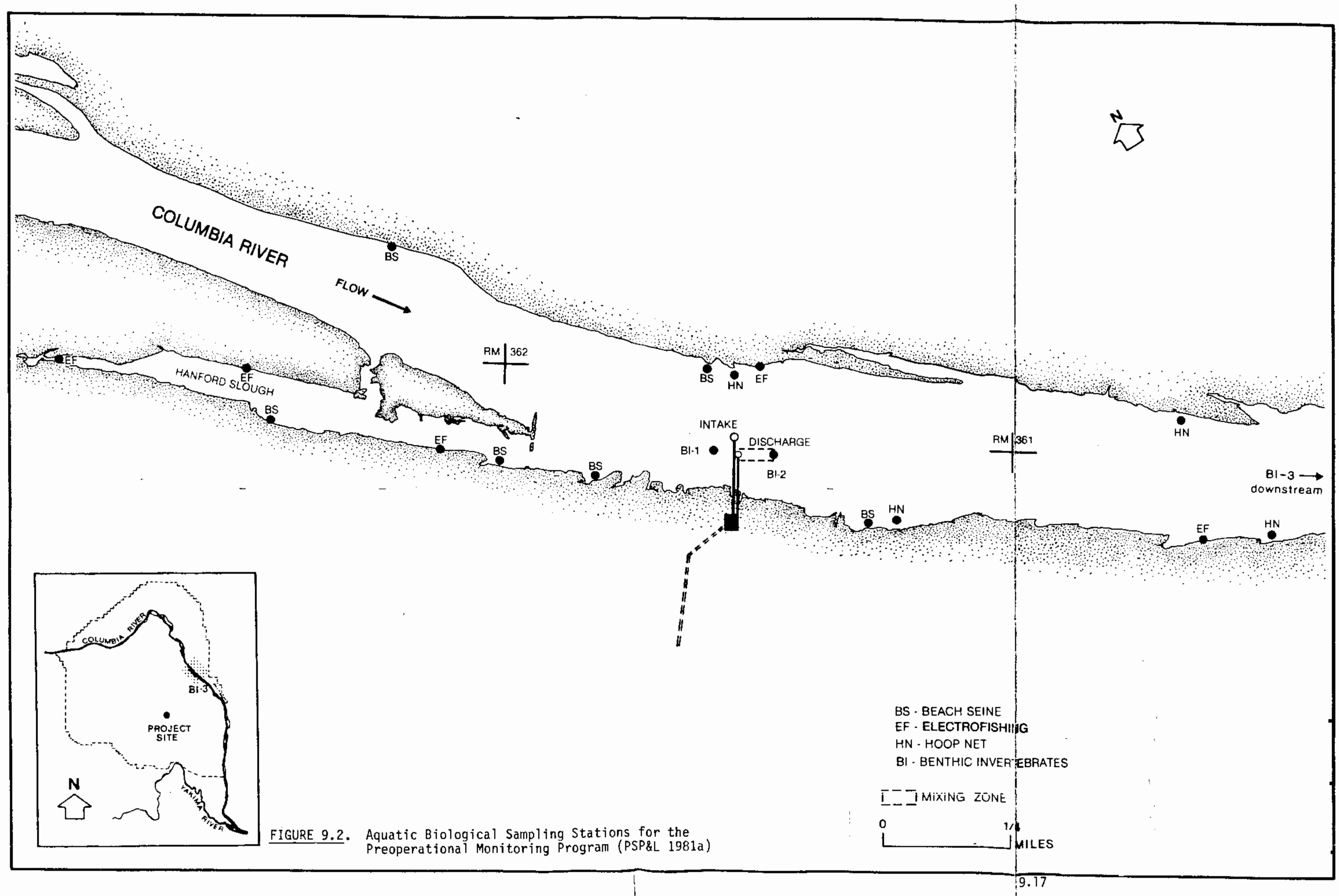



TABLE 9.5. Benthic Invertebrate Sampling Stations for the Preoperational Monitoring Program (PSP\&L 1981a)

\begin{tabular}{|c|c|c|}
\hline Station & Location & Description \\
\hline $8 I-1$ & $R M 361.5+300 \mathrm{ft}$ & $\begin{array}{l}\text { Control station } 0.10 \mathrm{~km} \text { or } 0.06 \mathrm{mi} \\
\text { upstream of facility intake) }\end{array}$ \\
\hline$B !-2$ & RM 361.4 & $\begin{array}{l}\text { Downstream boundary of mixing zone } \\
\text { ( } 0.16 \mathrm{~km} \text { or } 0.1 \mathrm{mi} \text { downstream of } \\
\text { facility discharge) }\end{array}$ \\
\hline$B I-3$ & RM 359.5 & $\begin{array}{l}3.2 \mathrm{~km} \text { or } 2.0 \mathrm{mi} \text { downstream of } \\
\text { facility discharge }\end{array}$ \\
\hline
\end{tabular}

Fish sampling will be conducted at least monthly. The planned sampling frequency by method is provided in Table 9.6. The program will be statistically designed to estimate the standard error of all calculations.

Special fish sampling programs may occur intermittently in response to regional concerns. The Columbia River upstream of the intake and discharge location is currently receiving considerable attention from federal and state fisheries agencies and the mid-Columbia PuDs to determine the impacts of hydroelectric development on fisheries resources. Studies regarding fish passage and migrations, spawning and rearing success, and turbine and system mortality either are in progress or have been planned (see Section 9.3). Periodic studies in the vicinity of the facility intake are planned to capture marked fish released at upstream locations. Such studies will provide improved information on distribution and residence time of anadromous species near the intake and discharge location. 0ther short-term studies may be initiated as the need arises. Plankton: Some fraction of the river's plankton will be drawn into the plant with cooling water and another fraction will be exposed to the effects of entrainment in the discharge plume. The numbers affected represent an extremeiy small fraction of the population passing the plant. Studies conducted by the Supply System on the Columbia River indicate that 
TABLE 9.6. Proposed Fish Sampling Frequency, by Station and Method, for the Preoperational Monitoring Program (PSP\&L 1981a)

$\begin{array}{lccc}\text { Month } & \begin{array}{c}\text { Beach } \\ \text { Seine } \\ \text { Six Statjoris) }\end{array} & \begin{array}{c}\text { Hoop Net } \\ \text { (four Stations) }\end{array} & \begin{array}{c}\text { Electro- } \\ \text { Fishing } \\ \text { (five statjons) }\end{array} \\ \text { January } & 1 & 0 & 0 \\ \text { March } & 1 & 0 & 0 \\ \text { April } & 2 & 1 & 2 \\ \text { May } & 4 & 2 & 4 \\ \text { June } & 4 & 2 & 4 \\ \text { July } & 4 & 2 & 4 \\ \text { August } & 2 & 1 & 2 \\ \text { September } & 2 & 1 & 2 \\ \text { October } & 2 & 1 & 0 \\ \text { November } & 1 & 0 & 0 \\ \text { December } & 1 & 0 & 0\end{array}$

Note: See Figure 9.2 for station Tocations.

planktonic algae and microcrustaceans in the aquatic system near WNP-1/4 and 2 do not have a major role in energy transfer pathways (Battelle $1976 a, b ; 1977 ; 1978 ; 1979 a, b ;$ Beak Consultants 1980). The small volume of water to be withdrawn by the facility and the small volume to be discharged is inconsequential in comparison to the total river flow. No significant impact on the plankton community is expected. Therefore, no plankton sampling is proposed during the preoperational monitoring program.

\section{1 .2 Groundwater}

McGhan and Damschen (1979) provides the most complete catalog of monitoring wells located on the Hanford Site. There are over 2,200 wells on the Hanford Site, more than 45 of which are located within $8 \mathrm{~km}(5 \mathrm{mi})$ of the site (see Section 2.4.1 of PSP\&L 1981a). Extensive environmental monitoring programs concerning the physical, chemical and radiological characteristics of 
groundwater on the Hanford Reservation have been conducted for DOE (Myers, Fix and Raymond 1977). These programs and investigations continue to accumulate comprehensive information on groundwater characteristics and are expected to be continued routinely as part of the DOE program. Eight additional monitoring wells were recently installed in the inmediate vicinity of the site. There are no plaris to monitor nonradiological groundwater quality parameters during the preoperational phase.

There will be no release of radioactive liquid to the ground during normal operations. There are no realistic accidental releases of radioactive liquids to the ground. Puget Sound Power \& Light Company (1981b) describes the models used for transport of radionuclides to groundwater.

\section{1 .3 Air}

\section{1 .3 .1 Meteorology}

Meteorological data were collected at the WNP-2 site from April 1, 1974 through March 30, 1976. The data collection system is shown in Appendix $D$ of Puget Sound Power \& Light Company (1981a).

Two options exist for the preoperational and operational meteorological monitoring programs. The first option is to initiate an onsite monitoring program after issuance of the construction permit. This program will satisfy requirements of regulatory guidelines regarding operational meteorological monitoring programs. The second option recognizes the unique characteristics of the Hanford Site in terms of existing meteorological monitoring programs and that there may be some form of joint monitoring program in the future. Under this option, onsite meteorological measurements and routine and accidental dose assessments would be performed for the entire Hanford Site through a common headquarters. The selection of the specific option will depend on regulatory requirements in effect following issuance of the construction permit (CP) and on the administrative feasibility of conducting cooperative meteorological monitoring programs for the Hanford Site and vicinity (see Section 9.3.3). 


\subsubsection{Mode]s}

9.1.3.2.1 Short-Jerm Atmospheric Dispersion Model. The dispersion factors $(x / Q)$ for ground-level releases were determined using the methodology presented in Regulatory Guide 1.145 (U.S. NRC 1979).

The $x / Q$ values applicable for releases of less than or equal to 2 hours duration were calculated at the distances of interest, using the joint frequency distributions of wind speed and wind direction by atmospheric stability class.

During neutral (D) or stable (E, $F$, or $G$ ) atmospheric stability conditions when the $10-\mathrm{m}(33-\mathrm{ft})$ wind speed is less than $6 \mathrm{~m} / \mathrm{s},(20 \mathrm{ft} / \mathrm{s})$ the 2-hour $X / Q$ value was calculated from the following set of equations:

$$
\begin{aligned}
& x / Q=\frac{1}{\bar{u}\left(\pi \sigma_{y} \sigma_{z}+A / 2\right)} \\
& X / Q=\frac{1}{\bar{u}\left(3 \pi \sigma_{y} \sigma_{z}\right)} \\
& x / Q=\frac{1}{\bar{u} \Sigma_{y} \sigma_{z}}
\end{aligned}
$$

where $x / Q=$ the relative concentration at ground level $\left(\mathrm{sec} / \mathrm{m}^{3}\right)$

$$
\begin{aligned}
\pi= & 3.14159 \\
\vec{u}= & \text { the mean wind speed at } 10 \mathrm{~m}(33 \mathrm{ft})(\mathrm{m} / \mathrm{s}) \\
\sigma_{y}= & \text { the Pasquill-Gifford lateral plume spread, a function of } \\
& \text { atmospheric stability and distance }(\mathrm{m}) \\
\sigma_{z}= & \text { the Pasquill-Gifford vertical plume spread, a function of } \\
& \text { atmospheric stability and distance }(\mathrm{m}) \\
A= & 2,200 \mathrm{~m}^{2},\left(1.4 \mathrm{mi}^{2}\right) \text { the smallest vertical plane cross-sectional } \\
& \text { area of the building from which the effluent is released } \\
\Sigma_{y}= & \text { the lateral piume spread with meander and building wake effects } \\
& (\mathrm{m}) . \quad \Sigma_{y} \text { is a function of atmospheric stability, windspeed, and }
\end{aligned}
$$


distance. For distances of $800 \mathrm{~m}(2,600 \mathrm{ft})$ or less, $\Sigma_{y}=M \sigma_{y}$ where $M$ is based on Figure 3 of Becker and Wadde? (1972). For distances greater than $800 \mathrm{~m}, \Sigma_{y}=\{M-1\} \sigma_{y} 800 m+\sigma_{y}$.

$x / Q$ values were calculated using Equations (9.1), (9.2), and (9.3). The higher value calculated from Equations (9.1) and (9.2) was compared to the value computed from Equation (9.3) and the lower was chosen as the appropriate $x / Q$ vaiue.

For all other meteorological conditions (i.e., unstable - A, B, or C atmospheric stability and/or $10-\mathrm{m}(33-\mathrm{ft})$ wind speeds of $6 \mathrm{~m} / \mathrm{s}(20 \mathrm{ft} / \mathrm{s})$ or greater), plume meander was not considered. The appropriate $x / Q$ value was chosen as the higher value calculated from Equation (9.1) or (9.2).

The realistic $x / Q$ values from the standard population distances were calculated using a direction-dependent (sector-dependent) methodology. Cumulative probability distributions of $x / Q$ values were detemined for each of the 16 wind direction sectors relative to the total hours in all sectors. For realistic estimates at the population distances, $x / Q$ values at the 3.125 percentile (relative to all sectors, or approximately 50 percent for a given sector) were selected from these probability distributions. These selected values represented periods of 2 hours or less. The annual-average value was calculated in accordance with the methodology described in Regulatory Guide 1.111, Rev. 1 (U.S. NRC 1977). Values for periods of $8,16,72$, and 624 hours were obtained by logarithmic interpolation between the 2-hour value and the annual-average value in the same sector.

To select representative atmospheric dispersion value at the Exclusion Area Boundary and Low Population Zone (LPZ) Boundary, $x / Q$ values were determined using direction-independent methodology per Regulatory Guide 1.111 (U.S. NRC 1977). This methodology, although sector-independent, gives realistic estimates for the site as a whole. The 2 -hour $x / Q$ values were ranked without regard to sector and an overall cumulative probability distribution determined. From this distribution, the value that was exceeded no more than 50 percent of the total time was selected for the realistic estimate. Values for longer time periods (i.e., 8 and 16 hours, and 3 and 26 days) were determined by a logarithmic interpolation between the overa 1150 th percentile two-hour value and the maximum annual average $x / Q$ value over the 16 sectors. 
Input meteorological data consisted of joint frequency distributions (JFOs) of hourly averages of wind speed and wind direction by stability class. For computer modeling purposes, 12 wind speed groups were used to give good resolution at lower wind speeds (NUS 1981). The annual JFD with the standard seven wind speed groups is shown in Table 9.7. The JFOs were based on two years of data collected at WNP-2 as described in Section 9.1.3. Occurrences of caims and variable wind directions were distributed by direction and stability class to the lowest wind speed group of the JFOs. Calms were assigned a speed one-half of the threshold speed of the wind vane. Winds were based on observations at $10 \mathrm{~m}(33 \mathrm{ft})$ and stability class on observations of delta $T$ $74-10 \mathrm{~m}$ (245-33 ft) in accordance with Regulatory Guide 1.23 (U.S. NRC 1972).

9.1.3.2.2 Short-Term Dispersion Estimates. The realistic $x / Q$ estimates at the Exclusion Area Boundary and LPZ Boundary for a hypothetical accident are presented in Table 9.8. The maximum zero to two-hour value at the Exclusion Area Boundary is $2.8 \times 10^{-5} \mathrm{sec} / \mathrm{m}^{3}$, and at the $L P Z$ is $4.7 \times 10^{-6} \mathrm{sec} / \mathrm{m}^{3}$.

The realistic $x / Q$ estimates as a function of distance are presented in Table 9.9. These are sector-dependent values. The higher values are to the south/southeast (SSE) of the facility and the lower values are to the west (W).

9.1.3.2.3 Long-Term Atmospheric Dispersion Model. This section describes the model for atmospheric dispersion estimates applicable for long-term dose assessment. Dispersion factors $(x / Q)$ were determined using the methodology presented in Regulatory Guide 1.111, Rev. 1 (U.S. NRC 1977) and the NRC computer code X0QDOQ (Sagendorf and Goll 1977).

The calculations were made for the site boundary and at the standard distances out to $80 \mathrm{~km}(50 \mathrm{mi})$. All releases were assumed to be at ground jevel.

$X / Q$ values were detemined by:

$$
(x / 0)_{0}=\frac{2.032}{x} \quad i j \frac{n_{i j}}{N \Sigma_{z j} \bar{u}_{j j}}
$$

where $(x / Q)_{0}=$ the average effluent concentration, $x$, normalized by source strength, $Q$, at a downwind distance, $x$, for a given direction, $0\left(\mathrm{sec} / \mathrm{m}^{3}\right)$ 
TABLE 9.7. Annual Distribution of Variable Winds (PSP\&L 1981a)

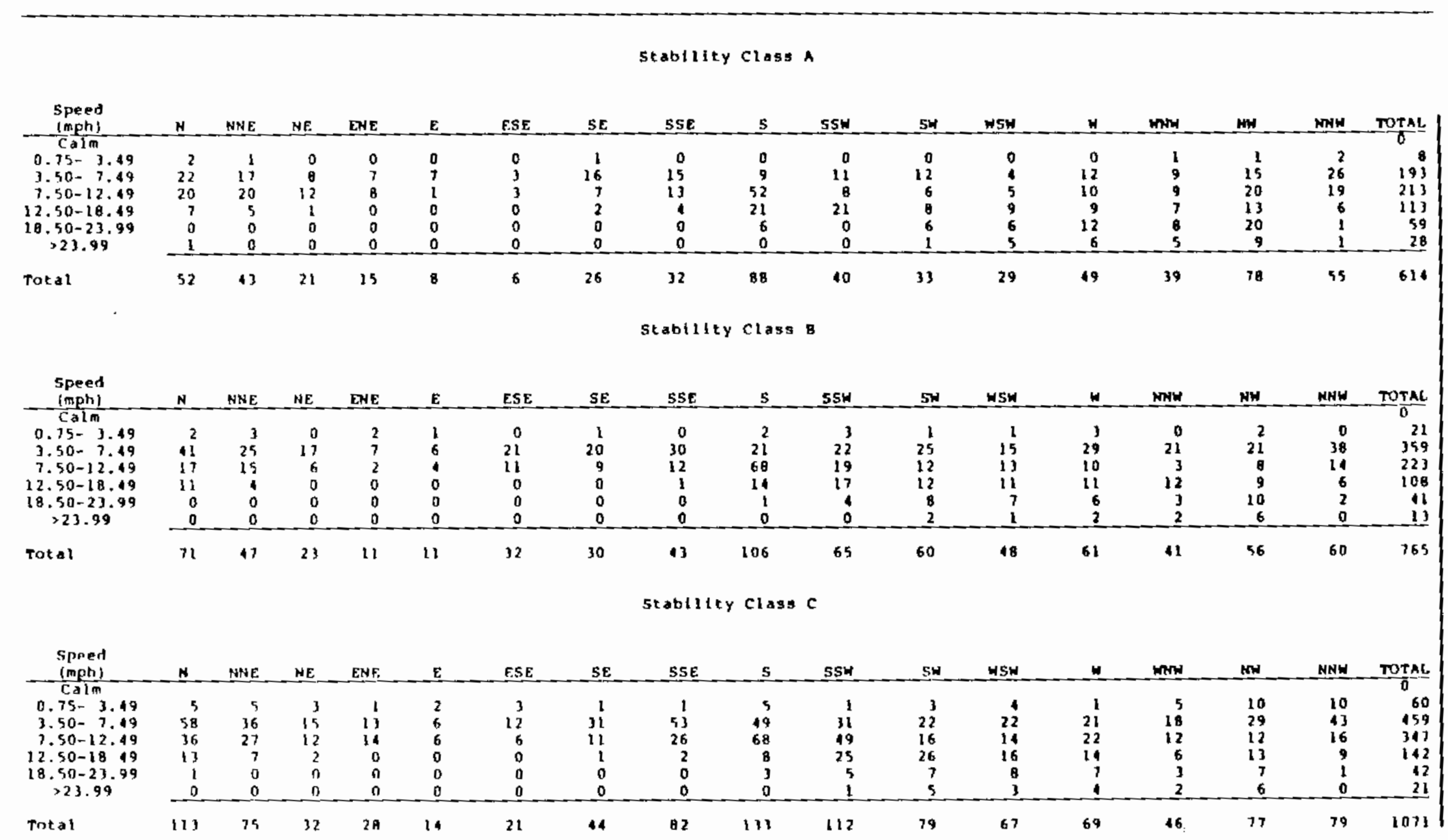


TABLE 9.7. (contd)

stability class

\begin{tabular}{|c|c|c|c|c|c|c|c|c|c|c|c|c|c|c|c|c|c|c|}
\hline Speed & & & & & & & & & & & & & & & & & & \\
\hline$\frac{(m p h]}{c a \mid m}$ & 프. & HNE & NE & Nㅡ & $\underline{\mathbf{E}}$ & ESE & $\underline{S E}$ & $\underline{S} \underline{S} \underline{E}$ & -5 & SSW & SH & HSH & 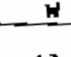 & NNW & $\mathrm{NH}$ & NWW & ToTAL & 4 \\
\hline $\begin{array}{c}0.75-3.19 \\
3.50-7.49 \\
7.50-12.19 \\
12.50-18.19 \\
16.50-23.99 \\
>23.99\end{array}$ & $\begin{array}{r}62 \\
99 \\
71 \\
23 \\
0 \\
0 \\
\end{array}$ & $\begin{array}{r}37 \\
97 \\
18 \\
12 \\
1 \\
8 \\
-9\end{array}$ & $\begin{array}{r}32 \\
16 \\
19 \\
1 \\
2 \\
0 \\
\end{array}$ & $\begin{array}{r}29 \\
65 \\
22 \\
0 \\
0 \\
0 \\
\end{array}$ & $\begin{array}{r}32 \\
50 \\
15 \\
0 \\
0 \\
0\end{array}$ & $\begin{array}{r}52 \\
59 \\
8 \\
0 \\
0 \\
0 \\
\end{array}$ & $\begin{array}{r}53 \\
122 \\
27 \\
6 \\
1 \\
0 \\
\end{array}$ & $\begin{array}{r}56 \\
169 \\
75 \\
15 \\
0 \\
0 \\
\end{array}$ & $\begin{array}{r}39 \\
148 \\
165 \\
70 \\
6 \\
0 \\
\end{array}$ & $\begin{array}{r}55 \\
119 \\
183 \\
151 \\
39 \\
18 \\
\end{array}$ & $\begin{array}{r}58 \\
31 \\
71 \\
103 \\
17 \\
10\end{array}$ & $\begin{array}{r}11 \\
50 \\
56 \\
50 \\
25 \\
-9\end{array}$ & $\begin{array}{r}13 \\
82 \\
53 \\
46 \\
13 \\
-8 \\
\end{array}$ & $\begin{array}{l}66 \\
91 \\
78 \\
75 \\
50 \\
11 \\
\end{array}$ & $\begin{array}{r}68 \\
161 \\
106 \\
81 \\
47 \\
25 \\
\end{array}$ & $\begin{array}{r}28 \\
159 \\
82 \\
24 \\
1 \\
0\end{array}$ & $\begin{array}{r}803 \\
1576 \\
1085 \\
667 \\
235 \\
109 \\
\end{array}$ & 5 \\
\hline Total & 258 & 201 & 103 & 116 & 97 & 119 & 211 & 317 & 128 & $\$ 68$ & 363 & 239 & 227 & 371 & 488 & 347 & 1479 & \\
\hline \multicolumn{18}{|c|}{ stabillty Class E } & \\
\hline $\begin{array}{l}\text { speed } \\
\text { (mph) }\end{array}$ & $\mathrm{N}$ & NNE & $N \underline{n}$ & DNE & $\underline{E}$ & ESE & $\mathrm{SE}$ & SSE & $s$ & SSH & SH & HSH & $N$ & HNH & NH & NHH & TOTAL & \\
\hline $\begin{array}{l}\text { Calm } \\
0.75-3.49 \\
3.50-7.49 \\
1.50-12.49 \\
12.50-19.49 \\
18.50-23.99 \\
223.99\end{array}$ & $\begin{array}{r}67 \\
68 \\
25 \\
1 \\
0 \\
0 \\
\end{array}$ & $\begin{array}{r}15 \\
32 \\
13 \\
17 \\
13 \\
\end{array}$ & $\begin{array}{r}35 \\
53 \\
9 \\
1 \\
0 \\
0 \\
\end{array}$ & $\begin{array}{r}28 \\
52 \\
10 \\
1 \\
0 \\
0 \\
\end{array}$ & $\begin{array}{r}37 \\
37 \\
1 \\
0 \\
0 \\
0\end{array}$ & $\begin{array}{r}18 \\
36 \\
0 \\
0 \\
0 \\
0 \\
\end{array}$ & $\begin{array}{r}56 \\
93 \\
45 \\
11 \\
1 \\
0 \\
\end{array}$ & $\begin{array}{r}53 \\
156 \\
117 \\
33 \\
3 \\
0\end{array}$ & $\begin{array}{r}66 \\
141 \\
140 \\
71 \\
7 \\
1 \\
\end{array}$ & $\begin{array}{r}50 \\
108 \\
102 \\
127 \\
52 \\
26 \\
\end{array}$ & $\begin{array}{r}50 \\
100 \\
66 \\
82 \\
28 \\
14 \\
\end{array}$ & $\begin{array}{r}55 \\
98 \\
69 \\
26 \\
11 \\
\\
\end{array}$ & $\begin{array}{r}17 \\
100 \\
77 \\
26 \\
0 \\
2 \\
\end{array}$ & $\begin{array}{r}90 \\
169 \\
216 \\
126 \\
25 \\
-2 \\
\end{array}$ & $\begin{array}{r}80 \\
238 \\
220 \\
86 \\
12 \\
0 \\
\end{array}$ & $\begin{array}{r}78 \\
156 \\
96 \\
13 \\
0 \\
0 \\
\end{array}$ & $\begin{array}{r}12 \\
893 \\
1621 \\
1237 \\
608 \\
154 \\
64 \\
\end{array}$ & 5 \\
\hline Total & 161 & 114 & 98 & 91 & 78 & 92 & 196 & 392 & 426 & 165 & 340 & 269 & 260 & 628 & 644 & 333 & 1595 & \\
\hline \multicolumn{19}{|c|}{ Stability class $\mathrm{f}$} \\
\hline $\begin{array}{l}\text { Speed } \\
\text { imphy }\end{array}$ & H & NNEE & $\mathrm{NE}$ & ENE & $\underline{E}$ & $E S E$ & $\underline{\mathbf{S E}}$ & SSE & $\underline{\mathbf{s}}$ & SSE & sw & HSK & $\underline{H}$ & wrin & NH & NNW & TOTAL & 4 \\
\hline $\begin{array}{c}\text { Calm } \\
0.75-3.49 \\
3.50-7.49 \\
7.50-12.49 \\
12.50-18.19 \\
18.50-23.99 \\
723.99\end{array}$ & $\begin{array}{r}68 \\
65 \\
7 \\
0 \\
0 \\
0 \\
\end{array}$ & $\begin{array}{r}56 \\
64 \\
8 \\
0 \\
0 \\
0 \\
\end{array}$ & $\begin{array}{r}35 \\
55 \\
3 \\
3 \\
0 \\
0\end{array}$ & $\begin{array}{r}37 \\
31 \\
10 \\
0 \\
0 \\
0\end{array}$ & $\begin{array}{r}32 \\
14 \\
1 \\
0 \\
0 \\
0 \\
\end{array}$ & $\begin{array}{r}31 \\
24 \\
0 \\
0 \\
0 \\
0 \\
\end{array}$ & $\begin{array}{r}32 \\
71 \\
17 \\
0 \\
0 \\
0 \\
\end{array}$ & $\begin{array}{r}30 \\
153 \\
98 \\
7 \\
0 \\
0\end{array}$ & $\begin{array}{r}11 \\
14 \\
96 \\
14 \\
0 \\
0\end{array}$ & $\begin{array}{r}54 \\
113 \\
64 \\
19 \\
0 \\
0 \\
\end{array}$ & $\begin{array}{r}39 \\
61 \\
20 \\
6 \\
0 \\
0 \\
\end{array}$ & $\begin{array}{r}51 \\
54 \\
16 \\
0 \\
0 \\
0\end{array}$ & $\begin{array}{r}34 \\
54 \\
43 \\
2 \\
0 \\
0 \\
\end{array}$ & $\begin{array}{r}66 \\
86 \\
00 \\
1 \\
0 \\
0 \\
\end{array}$ & $\begin{array}{r}62 \\
136 \\
66 \\
2 \\
0 \\
0\end{array}$ & $\begin{array}{r}72 \\
127 \\
16 \\
0 \\
0 \\
0 \\
\end{array}$ & $\begin{array}{r}5 \\
712 \\
1259 \\
545 \\
54 \\
0 \\
0 \\
\end{array}$ & \\
\hline Total & 140 & 128 & 96 & 78 & 17 & 55 & 120 & 292 & 295 & 250 & 129 & 123 & 133 & 233 & 266 & 215 & 2605 & \\
\hline
\end{tabular}




\section{TABLE 9.7. (contd)}

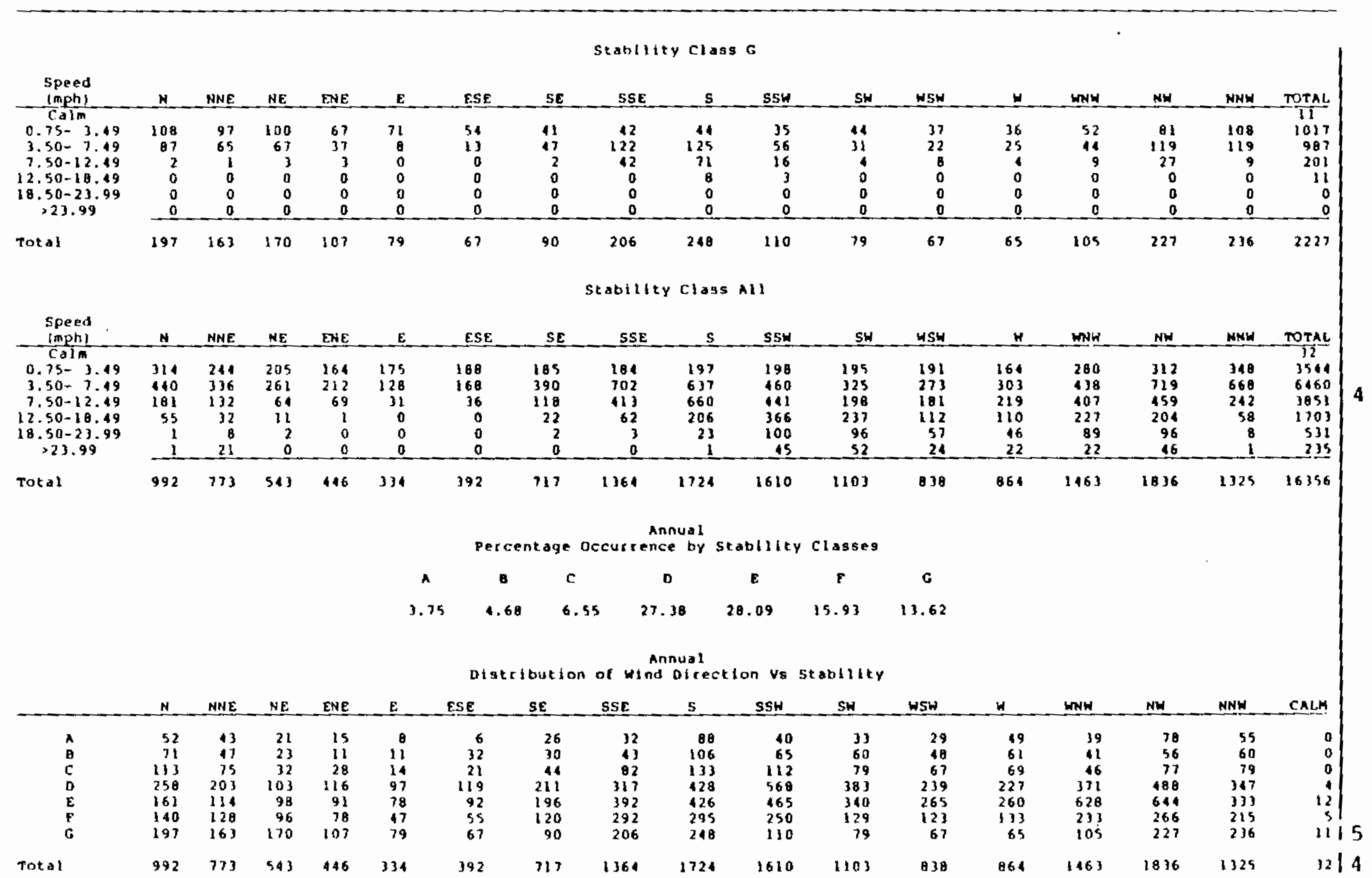


TABLE 9.7. (contd)

\begin{tabular}{|c|c|c|c|c|c|c|c|c|}
\hline $\begin{array}{c}\text { Speed } \\
\text { (mph) }\end{array}$ & A & $\mathrm{B}$ & C & D & $\mathrm{E}$ & F & G & TOTAL \\
\hline calm & 0 & 0 & 0 & 0 & 0 & 0 & 0 & 0 \\
\hline $0.75-3.49$ & 1 & 5 & 15 & 48 & 30 & 41 & 43 & 103 \\
\hline $3.50-7.49$ & 22 & 31 & 32 & 42 & 19 & 11 & 8 & 165 \\
\hline $7.50-12.49$ & 3 & 1 & 3 & 3 & 3 & 0 & 0 & 13 \\
\hline $12: 50-18.49$ & 0 & 0 & 0 & 0 & 1 & 0 & 0 & 1 \\
\hline $18.50-23.99$ & 0 & 0 & 0 & 0 & 0 & 0 & 0 & 0 \\
\hline$>23.99$ & $\underline{0}$ & 0 & 0 & 0 & 0 & 0 & 0 & 0 \\
\hline & 26 & 37 & 50 & 93 & 53 & 52 & 51. & 362 \\
\hline
\end{tabular}

*Based on WNP-2 data with the 33-ft wind and delta $T(245-33 \mathrm{ft})$ stability.

Total Number of Observations: 17544

Total Number of Valid Observations: 16356

Total Number of Missing Observations: 1188

Percent Data Recovery for this Period: 93.28

Mean Wind Speed for this Period: $7.5 \mathrm{mph}$

Total Number of Observations with Backup Data: 0

Wind Measured At: 33.0 Feet

Wind Threshold at: $0.75 \mathrm{mph}$ 
IABLE 9.8. Realistic Short-Term Chi/Qs by Sector for the Facility at the Exclusion Area Boundary and the Low Population Zone Boundary (PSP\&L 1981a)

\begin{tabular}{|c|c|c|c|}
\hline \multirow{2}{*}{\multicolumn{2}{|c|}{$\begin{array}{c}\text { Accident } \\
\text { Period (hr) }\end{array}$}} & \multicolumn{2}{|c|}{ Location } \\
\hline & & $\begin{array}{l}\text { Exclusion } \\
\text { Area } \\
\text { Boundary }\end{array}$ & $\begin{array}{l}\text { Low Population Zone } \\
\text { Boundary (4 mi) }\end{array}$ \\
\hline \multicolumn{2}{|l|}{2} & $2.8 E-5$ & $4.7 E-6$ \\
\hline \multicolumn{2}{|l|}{8} & $2.0 E-5$ & $3.0 E-6$ \\
\hline \multicolumn{2}{|l|}{16} & $1.7 E-5$ & $2.4 E-6$ \\
\hline \multicolumn{2}{|c|}{72 (3 days) } & $1.2 E-5$ & $1.5 E-6$ \\
\hline \multicolumn{2}{|c|}{624 (26 days) } & $7.2 E-6$ & $7.8 E-7$ \\
\hline \multicolumn{4}{|c|}{$\begin{array}{l}\text { Note: } \\
\text { 1. These realistic chi/Q values }\left(\mathrm{sec} / \mathrm{m}^{3}\right) \text { are applicable for a ground- } \\
\text { level release to a ground-level receptor, based on delta } T \text { stability } \\
\text { class category and include plume meander and building wake effects. } \\
\text { The values are sector-independent } 50 \text { th percentile chi } / Q \text { values. } \\
\text { 2. Based on wNP-2 meteorological data for the period Apri } 11,1974 \text {, (a) } \\
\text { to March } 31,1976 \text { : (33-ft) wind and delta } T 74-10 \mathrm{~m}(245-33 \mathrm{ft}) \text {. (a) }\end{array}$} \\
\hline \multirow[t]{3}{*}{ (a) } & \multicolumn{3}{|c|}{$\begin{array}{l}\text { Unpublished data transmitted to } B \mathrm{r} \\
\text { New York, by PNL, Richland, Washir }\end{array}$} \\
\hline & \multicolumn{3}{|c|}{$x=$ downwind distance $(m)$} \\
\hline & $n_{i j}$ & $\begin{array}{l}\text { ime in hours } \\
D \text {, wind spee } \\
\text { ber of hours }\end{array}$ & $\begin{array}{l}\text { a given wind } \\
\text { mospheric stability, } j\end{array}$ \\
\hline
\end{tabular}

An effective vertical stability parameter, $\Sigma_{z j}$, is calculated to account for building wake effects as follows (U.S. NRC 1977):

$$
\Sigma_{z j}=\sigma_{z j}^{2}+{\frac{H^{2}}{2 \pi}}^{1 / 2}
$$


TABLE 9.9. Realjstic Short-Term Accident Chi/Os by Sector for Facility at Standard Distances (PSP\&L 1981a)

\begin{tabular}{|c|c|c|c|c|}
\hline \multirow{2}{*}{$\begin{array}{l}\text { Receptor (a) } \\
\text { Director }\end{array}$} & \multicolumn{4}{|c|}{ Accident Period (hr) } \\
\hline & 8 & 16 & 72 & 624 \\
\hline & & Distan & $m(2,650$ & \\
\hline N & $7.4 E-5^{(b)}$ & $6.5 E-5$ & $4.8 E-5$ & $3.1 E-5$ \\
\hline NNE & $5.3 E-5$ & $4.7 E-5$ & $3.6 E-5$ & $2.5 E-5$ \\
\hline NE & $4.0 E-5$ & $3.5 E-5$ & $2.7 E-5$ & $1.9 E-5$ \\
\hline ENE & $3.8 E-5$ & $3.4 E-5$ & $2.6 E-5$ & $1.8 \mathrm{E}-5$ \\
\hline$E$ & $3.5 E-5$ & $3.1 E-5$ & $2.4 E-5$ & $1.7 E-5$ \\
\hline ESE & $6.2 E-5$ & $5.5 E-5$ & $4.2 E-5$ & $2.9 E-5$ \\
\hline SE & $7.8 E-5$ & $6.9 E-5$ & $5.3 E-5$ & $3.7 E-5$ \\
\hline SSE & $7.8 E-5$ & $6.9 E-5$ & $5.2 E-5$ & $3.6 E-5$ \\
\hline 5 & $5.8 E-5$ & $5.1 E-5$ & $4.0 E-5$ & $2.8 \mathrm{E}-5$ \\
\hline SSW & $3.7 E-5$ & $3.4 E-5$ & $2.7 E-5$ & $2.0 E-5$ \\
\hline SW & $1.2 E-5$ & $1.2 E-5$ & $1.2 E-5$ & $1.2 E-5$ \\
\hline WSW & $9.4 E-6$ & $9.4 E-6$ & $9.4 E-6$ & $9.4 E-6$ \\
\hline W & $7.6 E-6$ & $7.6 E-6$ & $7.6 E-6$ & $7.6 E-6$ \\
\hline WNW & $8.7 E-6$ & $8.7 E-6$ & $8.7 E-6$ & $8.7 E-6$ \\
\hline $\mathrm{NW}$ & $3.6 E-5$ & $3.2 E-5$ & $2.5 E-5$ & $1.8 E-5$ \\
\hline NNW & $7.1 E-5$ & $6.2 E-5$ & $4.5 E-5$ & $2.9 E-5$ \\
\hline
\end{tabular}

(a) N-north, E-east, 5-south, W-west

(b) Can also be written $7.4 \times 10^{-5}$

Notes:

1. These realistic chi/Q values $\left(\mathrm{sec} / \mathrm{m}^{3}\right.$ ) are for a ground-level release to a ground-level receptor, based on delta $T$ stability class category and include plume meander and building wake effects. The values are sector-dependent 50 th percentile values.

2. Based on WNP-2 meteorological data for the period April 1, 1974 to March 31, 1976: 33-ft wind and delta $T(245-33 \mathrm{ft})$.

3. Standard distances based on Regulatory Guide 1.111 (U.S. NRC 1977). 
TABLE 9.9. (contd)

Receptor
Director

N

NNE

NE

ENE

E

ESE

SE

SSE

$\mathrm{S}$

SSW

SW

WSW

$W$

WNW

NW

NNW

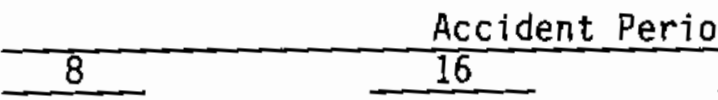

72
624

Bistance: $2,414 \mathrm{~m}(734 \mathrm{ft})$

$1.8 \mathrm{E}-5$

1. $3 E-5$

1. $5 E-5$

9. $1 E-6$

$4.6 E-6$

1. $0 \mathrm{E}-5$

6. $7 E-6$

$3.6 \mathrm{E}-6$

8. $3 E-6$

$6.9 E-6$

$4.6 \varepsilon-6$

$2.6 \mathrm{E}-6$

7. $7 \mathrm{E}-6$

$6.5 E-6$

4. $4 E-6$

2. $5 E-6$

7. $0 \mathrm{E}-6$

$5.8 E-6$

$3.9 E-6$

2. $2 E-6$

1. $4 E-5$

1. $2 E-5$

$7.7 E-6$

4. $2 E-6$

2. $0 \mathrm{E}-5$

1. $7 \mathrm{E}-5$

1. $1 \mathrm{E}-5$

$5.5 E-6$

2. $0 E-5$

1. $6 \mathrm{E}-5$

1. $1 \mathrm{E}-5$

$6.2 E-6$

1. $4 \mathrm{E}-6$

1. $1 E-6$

8.7E-7

9. 9E-7

$6.4 E-6$

1. $4 \mathrm{E}-5$
1. $0 E-5$

7. IE-6

4. $5 \mathrm{E}-6$

1. $4 E-6$

1. $1 E-6$

8.7E-6

9. $8 \mathrm{E}-7$

4. $3 E-6$

8. $6 E-6$
5. $4 \mathrm{E}-6$

4. $0 E-6$

2. $8 \mathrm{E}-6$

1. $4 \mathrm{E}-6$

1. $1 E-6$

8. $6 E-7$

9. $6 \mathrm{E}-7$

$2.5 E-6$

4. $3 E-6$ 
TABLE 9.9. (contd)

Receptor

Director

N

NNE

NE

ENE

E

ESE

SE

SSE

$S$

SSW

SW

WSW

$W$

WNW

$N$

NNW

\begin{tabular}{|c|c|c|c|}
\hline \multicolumn{4}{|c|}{ Accident Period (hr) } \\
\hline 8 & 16 & $7 ?$ & 624 \\
\hline \multicolumn{4}{|c|}{ Distance: $4.023 \mathrm{~m}(2.5 \mathrm{mi})$} \\
\hline $9.5 E-6$ & $7.3 E-6$ & $4.2 E-6$ & $1.9 E-6$ \\
\hline $6.2 E-6$ & 4. $9 E-6$ & $2.9 E-6$ & 1. $4 \mathrm{E}-6$ \\
\hline $3.8 E-6$ & 3. $1 E-6$ & 2. $.0 E-6$ & 1. $0 E-6$ \\
\hline $3.8 E-6$ & $3.1 E-6$ & $2.0 E-6$ & $1.0 E-6$ \\
\hline $3.4 E-6$ & $2.8 E-6$ & $1.7 E-6$ & $8.9 E-7$ \\
\hline $7.5 E-6$ & $5.9 E-6$ & $3.5 E-6$ & 1. $7 E-6$ \\
\hline $1.0 \mathrm{E}-5$ & $8.1 E-6$ & $4.8 E-6$ & $2.2 E-6$ \\
\hline $1.0 E-5$ & $8.1 E-6$ & $4.7 E-6$ & $2.2 E-6$ \\
\hline $6.3 E-6$ & $5.0 E-6$ & $3.1 E-6$ & $2.6 \mathrm{E}-6$ \\
\hline $3.4 \mathrm{E}-6$ & $2.8 E-6$ & $1.9 E-6$ & $1.1 E-6$ \\
\hline $5.0 \mathrm{E}-7$ & $4.9 \mathrm{E}-7$ & $4.9 E-7$ & $4.8 \mathrm{E}-7$ \\
\hline $3.9 E-7$ & $3.8 E-7$ & $3.8 E-7$ & $3.7 E-7$ \\
\hline $3.2 E-7$ & $3.1 E-7$ & 3. $1 \mathrm{E}-7$ & $3.0 E-7$ \\
\hline $3.5 \mathrm{E}-7$ & $3.5 \mathrm{E}-7$ & $3.5 E-7$ & $3.4 \mathrm{E}-7$ \\
\hline $3.7 E-6$ & $3.0 \mathrm{E}-6$ & 1. $9 \mathrm{E}-6$ & $9.6 \mathrm{E}-7$ \\
\hline $8.9 E-6$ & $6.8 E-6$ & $3.9 E-6$ & $1.7 \mathrm{E}-6$ \\
\hline
\end{tabular}


TABLE 2.9. (contd)

Receptor
Director

N

NNE

NE

ENE

E

ESE

SE

SSE

5

SSW

SW

WSW

W

WNW

NW

NNW

\begin{tabular}{c} 
Accident Period (hr) \\
\hline 16 \\
$-72 \quad-624$
\end{tabular}

Distance: $5,633 \mathrm{~m}(3.5 \mathrm{mi})$

\begin{tabular}{llll}
\hline $6.3 E-6$ & $4.7 E-6$ & $2.6 E-6$ & $1.1 E-6$ \\
$3.9 E-6$ & $3.0 E-6$ & $1.7 E-6$ & $7.8 E-7$ \\
$2.4 E-6$ & $1.9 E-6$ & $1.1 E-6$ & $5.6 E-7$ \\
$2.4 E-6$ & $1.9 E-6$ & $1.1 E-6$ & $5.6 E-7$ \\
$2.1 E-6$ & $1.7 E-6$ & $1.0 E-6$ & $4.9 E-7$ \\
$4.6 E-6$ & $3.6 E-6$ & $2.1 E-6$ & $9.4 E-7$ \\
$7.0 E-6$ & $5.3 E-6$ & $3.0 E-6$ & $1.3 E-6$ \\
$7.0 E-6$ & $5.3 E-6$ & $2.9 E-6$ & $1.3 E-6$ \\
$4.0 E-6$ & $3.1 E-6$ & $1.9 E-6$ & $8.8 E-7$ \\
$2.0 E-6$ & $1.6 E-6$ & $1.1 E-6$ & $6.0 E-7$ \\
$2.5 E-7$ & $2.5 E-7$ & $2.5 E-7$ & $2.5 E-7$ \\
$2.0 E-7$ & $2.0 E-7$ & $2.0 E-7$ & $2.0 E-7$ \\
$1.6 E-7$ & $1.6 E-7$ & $1.6 E-7$ & $1.6 E-7$ \\
$1.8 E-7$ & $1.8 E-7$ & $1.8 E-7$ & $1.7 E-7$ \\
$1.3 E-6$ & $1.8 E-6$ & $1.1 E-6$ & $5.3 E-7$ \\
$5.7 E-6$ & $4.3 E-6$ & $2.3 E-6$ & $9.7 E-7$
\end{tabular}


TABLE 9.9. (contd)

Receptor
Director

N

NNE

NE

ENE

E

ESE

SE

SSE

$S$

SSW

SW

WSW

W

WNW

NW

NNW

\begin{tabular}{|c|c|c|c|}
\hline \multicolumn{4}{|c|}{ Accident Period (hr) } \\
\hline 8 & 16 & 72 & 624 \\
\hline \multicolumn{4}{|c|}{ Distance: $7,242 \mathrm{~m}(4.5 \mathrm{mi})$} \\
\hline 4. $4 E-6$ & $3.3 E-6$ & $1.8 E-6$ & $7.0 E-7$ \\
\hline $2.8 E-6$ & $2.1 E-6$ & $1.2 E-6$ & $5.2 E-7$ \\
\hline $1.7 E-6$ & $1.3 E-6$ & $7.8 E-7$ & $3.7 E-7$ \\
\hline $1.7 E-6$ & 1. $3 E-6$ & $7.8 E-7$ & $3.7 E-7$ \\
\hline $1.5 E-6$ & $1.2 E-6$ & $6.9 E-7$ & $3.2 E-7$ \\
\hline $3.4 E-6$ & $2.6 E-6$ & $1.4 E-6$ & $6.3 E-7$ \\
\hline $5.2 E-6$ & $3.9 E-6$ & 2. IE-6 & $8.5 E-7$ \\
\hline $5.1 E-6$ & $3.8 E-6$ & $2.1 E-6$ & $8.4 E-7$ \\
\hline $2.8 E-6$ & $2.2 E-6$ & 1. $3 E-6$ & $5.9 E-7$ \\
\hline $1.4 E-6$ & $1.1 E-6$ & $7.4 E-6$ & $4.0 E-7$ \\
\hline $1.6 E-7$ & $1.6 E-7$ & $1.6 E-7$ & $1.6 E-7$ \\
\hline $1.2 E-7$ & $1.2 E-7$ & $1.2 E-7$ & 1. $2 E-7$ \\
\hline $1.0 E-7$ & $1.0 E-7$ & $1.0 E-7$ & $1.0 E-7$ \\
\hline $1.1 E-7$ & $1.1 E-7$ & $1.1 E-7$ & 1. $1 E-7$ \\
\hline $1.7 E-6$ & $1.3 E-6$ & $7.6 \mathrm{E}-7$ & $3.6 \mathrm{E}-7$ \\
\hline $4.1 E-6$ & $3 \cdot 1 E-6$ & 1. $6 \mathrm{E}-6$ & $6.5 E-7$ \\
\hline
\end{tabular}


TABLE 9.9. (contd)

Receptor

Director

N

NNE

NE

ENE

E

ESE

SE

SSE

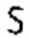

SSW

SW

WSW

$W$

WNW

NW

NNW

\begin{tabular}{|c|c|c|c|}
\hline \multicolumn{4}{|c|}{16 Accident P } \\
\hline \multicolumn{4}{|c|}{ Distance: $12,070 \mathrm{~m}(7.5 \mathrm{mi})$} \\
\hline $2.6 E-6$ & $1.9 E-6$ & $9.4 E-7$ & $3.4 E-7$ \\
\hline $1.6 \mathrm{E}-6$ & $1.2 \mathrm{E}-6$ & $6.4 \mathrm{E}-7$ & $2.5 E-7$ \\
\hline $9.9 E-7$ & $7.5 E-7$ & $4.2 E-7$ & $1.8 \mathrm{E}-7$ \\
\hline $9.9 E-7$ & $7.5 E-7$ & $4.2 E-7$ & $1.8 \mathrm{E}-7$ \\
\hline $9.2 E-7$ & $7.0 \mathrm{E}-7$ & $3.8 \mathrm{E}-7$ & $1.6 \mathrm{E}-7$ \\
\hline $2.0 \mathrm{E}-6$ & $1.5 E-6$ & $7.8 \mathrm{E}-7$ & 3. IE-7 \\
\hline $3.0 E-6$ & $2.2 \mathrm{E}-6$ & $1.1 E-6$ & 4. $1 E-7$ \\
\hline $3.0 E-6$ & $2.2 \mathrm{E}-6$ & $1.1 E-6$ & 4. $I E-7$ \\
\hline $1.8 E-6$ & $1.3 E-6$ & $7.1 E-7$ & $3.0 \mathrm{E}-7$ \\
\hline $8.8 E-7$ & $6.9 \mathrm{E}-7$ & $4.2 E-7$ & $2.0 E-7$ \\
\hline $1.2 \mathrm{E}-7$ & $1.1 \mathrm{E}-7$ & $1.0 \mathrm{E}-7$ & $8.7 E-8$ \\
\hline $5.9 E-8$ & $5.9 E-8$ & $5.8 E-8$ & $5.7 E-8$ \\
\hline $4.8 E-8$ & $4.8 E-8$ & $4.7 E-8$ & $4.6 E-8$ \\
\hline $5.4 E-8$ & $5.3 E-8$ & $5.2 \mathrm{E}-8$ & $5.0 E-8$ \\
\hline $9.8 E-7$ & $7.4 \mathrm{E}-7$ & $4.2 E-7$ & 1.7E-7 \\
\hline $2.4 E-6$ & $1.7 \mathrm{E}-6$ & $8.5 E-7$ & $3.1 E-7$ \\
\hline
\end{tabular}


TABLE 9.9. (contd)

Receptor
Director

N

NNE

NE

ENE

E

ESE

SE

SSE

$S$

SSH

SW

WSW

W

WNW

NW

NNW

\begin{tabular}{|c|c|c|c|}
\hline \multirow{3}{*}{8} & \multicolumn{2}{|c|}{ Accident Period (hr } & \multirow[b]{2}{*}{624} \\
\hline & 16 & 72 & \\
\hline & \multicolumn{2}{|c|}{ Distance: $24,140 \mathrm{~m}(15 \mathrm{mi})$} & \\
\hline $1.3 E-6$ & $9.2 \mathrm{E}-7$ & $4.3 E-7$ & $1.5 E-7$ \\
\hline $8.3 E-7$ & $6.0 \mathrm{E}-7$ & $2.9 E-7$ & $1.1 E-7$ \\
\hline $5.0 \mathrm{E}-7$ & $3.7 E-7$ & $1.9 E-7$ & $7.6 E-8$ \\
\hline $4.8 \mathrm{E}-7$ & $3.6 \mathrm{E}-7$ & $1.9 \mathrm{E}-7$ & $7.5 \mathrm{E}-8$ \\
\hline $4.9 \mathrm{E}-7$ & $3.6 \mathrm{E}-7$ & $1.8 E-7$ & $7.0 \mathrm{E}-8$ \\
\hline $1.1 \mathrm{E}-6$ & $7.7 E-7$ & $3.8 \mathrm{E}-7$ & $1.3 E-7$ \\
\hline $1.5 \mathrm{E}-6$ & $1.1 E-6$ & $5.1 E-7$ & $1.8 \mathrm{E}-7$ \\
\hline $1.5 E-6$ & $1.1 \mathrm{E}-6$ & $5.2 \mathrm{E}-7$ & $1.8 \mathrm{E}-7$ \\
\hline $9.1 E-7$ & $6.7 E-7$ & $3.4 \mathrm{E}-7$ & $1.3 \mathrm{E}-7$ \\
\hline $5.1 E-7$ & $3.9 E-7$ & $1.2 \mathrm{E}-7$ & $9.2 E-8$ \\
\hline $8.0 E-8$ & $7.2 E-8$ & $5.8 \mathrm{E}-8$ & $4.2 \mathrm{E}-8$ \\
\hline $2.4 E-8$ & $2.3 \mathrm{E}-8$ & 2. $3 E-8$ & $2.2 \mathrm{E}-8$ \\
\hline $1.9 E-8$ & $1.9 \mathrm{E}-8$ & $1.8 \mathrm{E}-8$ & $1.8 \mathrm{E}-8$ \\
\hline $2.1 E-8$ & $2.0 \mathrm{E}-8$ & $2.0 \mathrm{E}-8$ & $1.9 E-8$ \\
\hline $5.1 E-7$ & $3.7 \mathrm{E}-7$ & $1.9 E-7$ & $7.5 \mathrm{E}-8$ \\
\hline $1.2 E-6$ & $8.4 \mathrm{E}-7$ & $4.0 \mathrm{E}-7$ & $1.3 \mathrm{E}-7$ \\
\hline
\end{tabular}


IABLE 9.9. (contd)

Receptor

Director

N

NNE

NE

ENE

E

ESE

SE

SSE

$S$

SSW

SW

WSW

$W$

WNW

NW

NNW

\begin{tabular}{|c|c|c|c|}
\hline \multicolumn{4}{|c|}{ Accident Period (hr) } \\
\hline \multirow[t]{2}{*}{8} & 16 & 72 & 624 \\
\hline & \multicolumn{3}{|c|}{ Distance: $40,234 \mathrm{~m}(25 \mathrm{mi})$} \\
\hline $8.1 E-7$ & $5.6 \mathrm{E}-7$ & $2.5 \mathrm{E}-7$ & 8.1E-8 \\
\hline $5.0 \mathrm{E}-7$ & $3.6 \mathrm{E}-7$ & $1.7 \mathrm{E}-7$ & $5.8 \mathrm{E}-8$ \\
\hline $3.1 E-7$ & $2.2 E-7$ & $1.1 \mathrm{E}-7$ & 4. $2 \mathrm{E}-8$ \\
\hline $2.9 \mathrm{E}-7$ & $2.1 E-7$ & $1.1 \mathrm{E}-7$ & 4. $1 \mathrm{E}-8$ \\
\hline $3.1 E-7$ & $2.2 \mathrm{E}-7$ & 1. $1 \mathrm{E}-7$ & $3.9 \mathrm{E}-8$ \\
\hline $6.5 \mathrm{E}-7$ & $4.6 \mathrm{E}-7$ & $2.1 \mathrm{E}-7$ & $7.2 \mathrm{E}-8$ \\
\hline $9.3 \mathrm{E}-7$ & $6.5 \mathrm{E}-7$ & $3.0 \mathrm{E}-7$ & $9.7 \mathrm{E}-8$ \\
\hline $9.3 \mathrm{E}-7$ & $6.5 \mathrm{E}-7$ & $3.0 \mathrm{E}-7$ & $9.9 \mathrm{E}-8$ \\
\hline $6.1 E-7$ & $4.4 \mathrm{E}-7$ & 2. $1 \mathrm{E}-7$ & $7.4 \mathrm{E}-8$ \\
\hline $3.3 \mathrm{E}-7$ & $2.5 E-7$ & 1. $3 E-7$ & $5.3 E-8$ \\
\hline $6.1 E-8$ & $5.3 E-8$ & $3.9 E-8$ & $2.6 \mathrm{E}-8$ \\
\hline $1.2 \mathrm{E}-8$ & $1.2 E-8$ & $1.2 E-8$ & $1.2 \mathrm{E}-8$ \\
\hline $9.5 E-9$ & $9.5 \mathrm{E}-9$ & $9.4 \mathrm{E}-9$ & $9.4 \mathrm{E}-9$ \\
\hline $9.9 E-9$ & $9.9 \mathrm{E}-9$ & $9.9 E-9$ & $9.8 \mathrm{E}-9$ \\
\hline $3.1 E-7$ & 2. $3 \mathrm{E}-7$ & $1.1 \mathrm{E}-7$ & $4.1 E-8$ \\
\hline $7.2 E-7$ & $5.0 \mathrm{E}-7$ & $2.3 E-7$ & $7.3 \mathrm{E}-8$ \\
\hline
\end{tabular}


TABLE 9.9. (contd)

Receptor

Director

N

NNE

NE

ENE

E

ESE

SE

SSE

$\mathrm{S}$

SSW

SW

WSW

W

WNW

NW

NNW

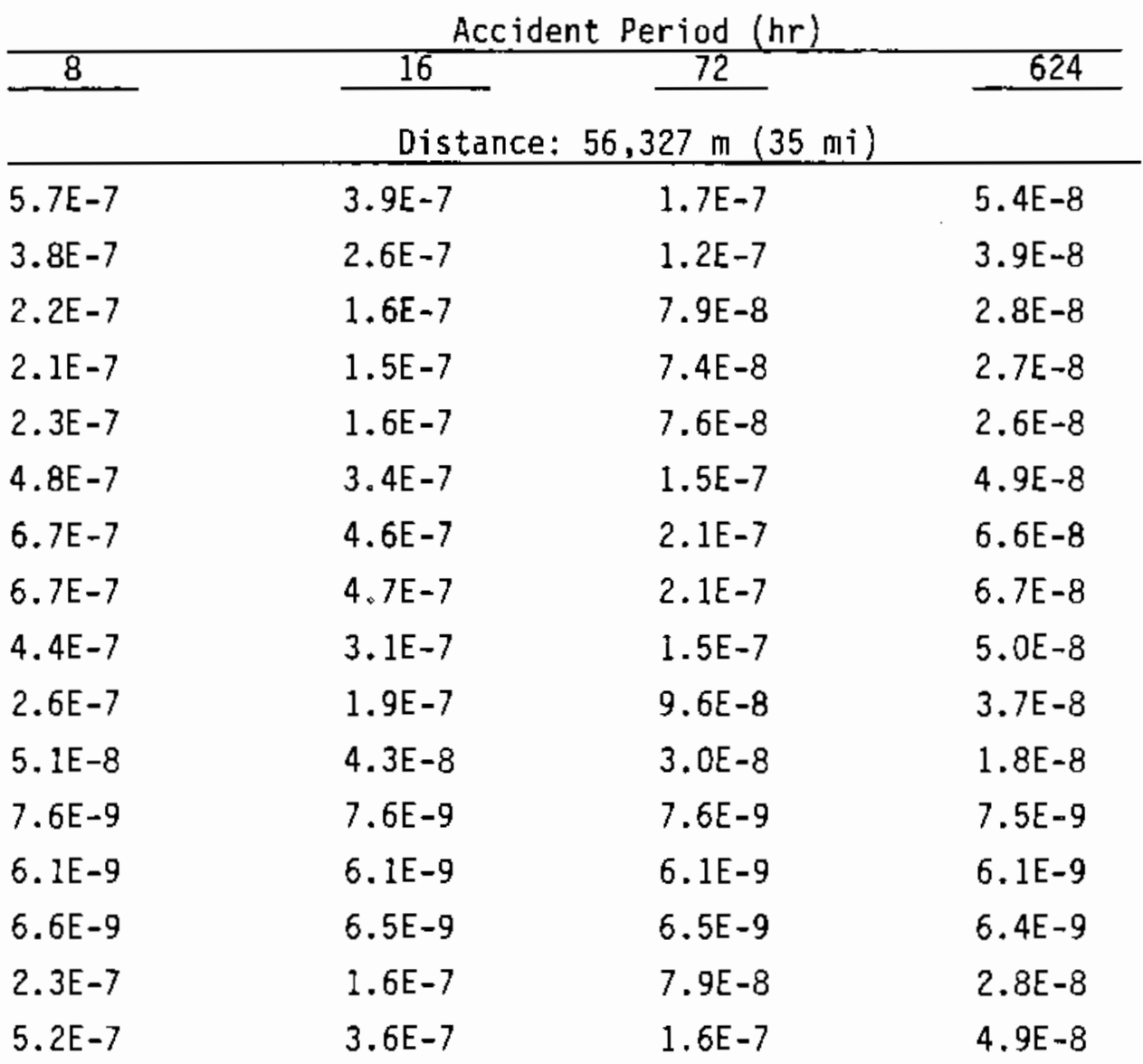


TABLE 9.9. (contd)

Receptor

Director

N

NNE

NE

ENE

E

ESE

SE

SSE

$S$

SSW

SW

WSW

W

WNW

$\mathrm{NW}$

NNW

\begin{tabular}{cccc}
\multicolumn{4}{c}{ Accident Period (hr) } \\
\hline \multicolumn{1}{c}{ Distance: } & 72, $420 \mathrm{~m}(45 \mathrm{mi})$ & \\
\hline $4.6 \mathrm{E}-7$ & $3.1 \mathrm{E}-7$ & $1.4 \mathrm{E}-7$ & $4.1 \mathrm{E}-8$ \\
$3.0 \mathrm{E}-7$ & $2.1 \mathrm{E}-7$ & $9.3 \mathrm{E}-8$ & $3.0 \mathrm{E}-8$ \\
$1.7 \mathrm{E}-7$ & $1.2 \mathrm{E}-7$ & $6.0 \mathrm{E}-8$ & $2.1 \mathrm{E}-8$ \\
$1.7 \mathrm{E}-7$ & $1.2 \mathrm{E}-7$ & $5.8 \mathrm{E}-8$ & $2.1 \mathrm{E}-8$ \\
$1.8 \mathrm{E}-7$ & $1.3 \mathrm{E}-7$ & $5.9 \mathrm{E}-8$ & $2.0 \mathrm{E}-8$ \\
$3.9 \mathrm{E}-7$ & $2.7 \mathrm{E}-7$ & $1.2 \mathrm{E}-7$ & $3.7 \mathrm{E}-8$ \\
$5.2 \mathrm{E}-7$ & $3.6 \mathrm{E}-7$ & $1.6 \mathrm{E}-7$ & $4.9 \mathrm{E}-8$ \\
$5.2 \mathrm{E}-7$ & $3.6 \mathrm{E}-7$ & $1.6 \mathrm{E}-7$ & $5.0 \mathrm{E}-8$ \\
$3.6 \mathrm{E}-7$ & $2.5 \mathrm{E}-7$ & $1.2 \mathrm{E}-7$ & $3.8 \mathrm{E}-8$ \\
$2.1 \mathrm{E}-7$ & $1.5 \mathrm{E}-7$ & $7.6 \mathrm{E}-8$ & $2.8 \mathrm{E}-8$ \\
$4.5 \mathrm{E}-8$ & $3.7 \mathrm{E}-8$ & $2.5 \mathrm{E}-8$ & $1.4 \mathrm{E}-8$ \\
$5.5 \mathrm{E}-9$ & $5.5 \mathrm{E}-9$ & $5.5 \mathrm{E}-9$ & $5.5 \mathrm{E}-9$ \\
$4.4 \mathrm{E}-9$ & $4.4 \mathrm{E}-9$ & $4.4 \mathrm{E}-9$ & $4.4 \mathrm{E}-9$ \\
$4.6 \mathrm{E}-9$ & $4.6 \mathrm{E}-9$ & $4.6 \mathrm{E}-9$ & $4.6 \mathrm{E}-9$ \\
$1.8 \mathrm{E}-7$ & $1.3 \mathrm{E}-7$ & $6.0 \mathrm{E}-8$ & $2.1 \mathrm{E}-8$ \\
$4.0 \mathrm{E}-7$ & $2.7 \mathrm{E}-7$ & $1.2 \mathrm{E}-7$ & $3.7 \mathrm{E}-8$ \\
& & &
\end{tabular}


with the constraint

$$
\Sigma_{z j} \leq \sigma_{z j} \sqrt{3}
$$

where $\sigma_{z j}=$ Pasquill-Gifford vertical plume spread $(m)$, a function of atmospheric stability, $j$, and distance, $x$

$H=$ maximum adjacent building height $(m)$.

The value used for the term $H$ was $34 \mathrm{~m}$ (112 ft). This approximates the average height of the buildings adjacent to which routine releases are expected: Containment, Turbine, Auxiliary, Fuel, and Radwaste Buildings. Open terrain correction factors were used as described in Regulatory Guide 1.111, Rev. 1 (U.S. NRC 1977).

9.1.3.2.4 Long-Term Dispersion Estimates. The annual average relative concentrations $\left(_{\chi} / Q s\right)$ at the site boundary are presented in Figure 9.3 for S/HNP Units 1 and 2 separately. The same information is listed in Table 9.10. The highest estimate for releases from Unit 1 is $1.5 \times 10^{-5} \mathrm{sec} / \mathrm{m}^{3}$ in the east/southeast (ESE) sector and from Unit 2 is $2.6 \times 10^{-5} \mathrm{sec} / \mathrm{m}^{3}$, in the ESE sector.

The annual average relative concentrations at the Hanford Site and at selected locations are given in Tables 9.11 and 9.12 . The annual average relative concentrations as a function of distance are presented in Table 9.13. From this table, the relative concentrations at a distance of $3.2 \mathrm{~km}$ (2 mi) are plotted in Figure 9.4. The higher values at each distance are to the SSE. Values of 2.26 day decay and undepleted $x / Q$, eight-day depleted and decayed relative concentration $\left({ }_{\chi} / Q\right)$ and for deposition $(0 / Q)$ are also presented in Table 9.13 as provided by Computer Code XOQDOQ (Sagendorf and Goll 1977).

\subsubsection{Cooling Tower Effects Models}

The environmental impacts of the operation of an evaporation cooling system include the formation of fog, ice, and elevated visible plumes, as well as the airborne concentration and ground deposition of dissolved solids contained in drift droplets released from the cooling system.

The occurrence of icing, ground-level fog, elevated visible plumes, and the airborne concentration and ground deposition rates of dissolved solids in 


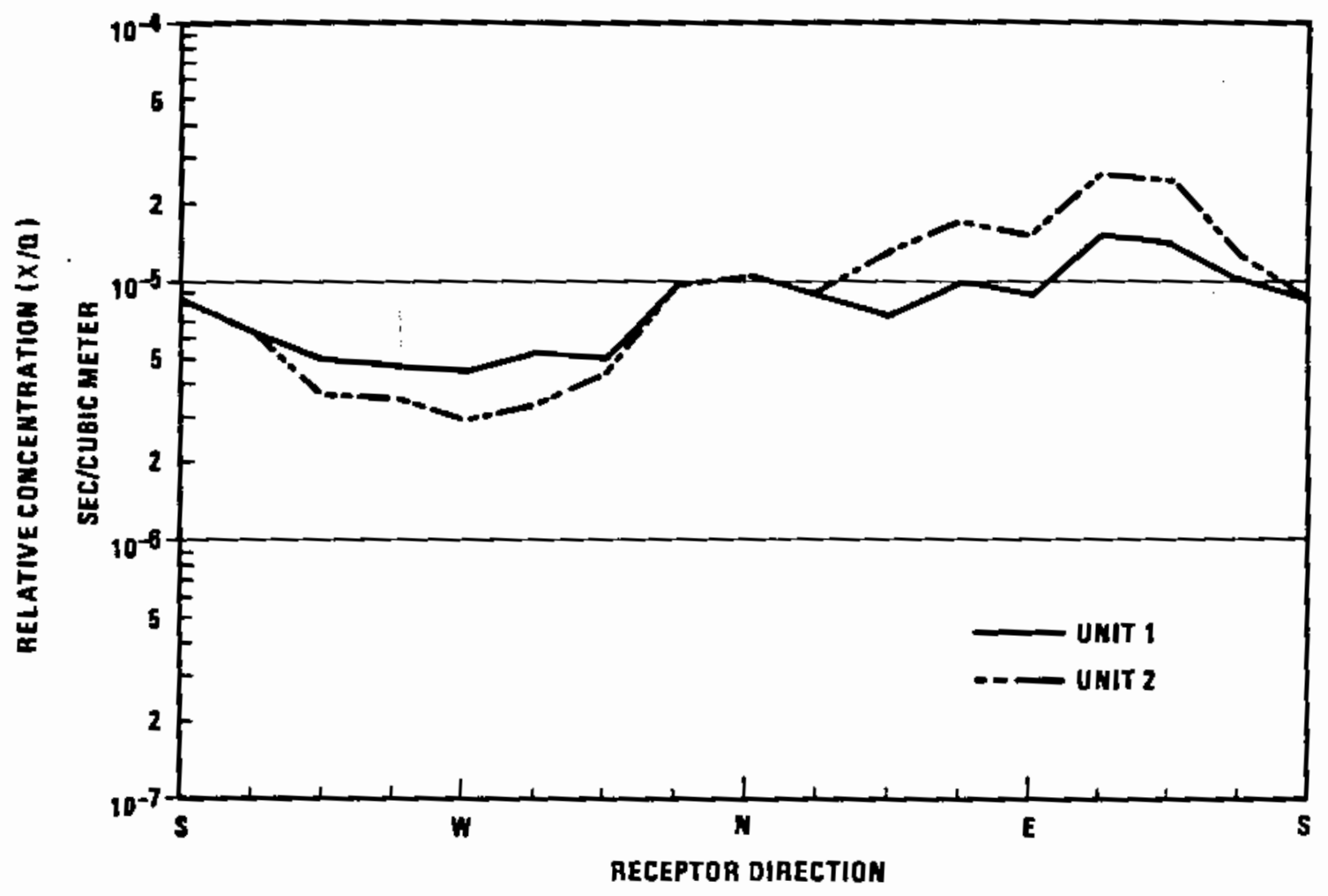

FIGURE 9.3. Annual Chi/Q at Site Boundary

drift, were calculated using the computer model FOG (Fisher 1974; 1981). The FOG model provides predictions of these environmental impacts over the area surrounding the site. This model uses the entire set of hourly meteorological measurements collected at the meteorological tower at WNP-2.

A second limited dispersion modeling analysis was conducted with the Langrangian Vapor Plume Model (LVPM) (Lee 1974). This model was used to represent expected plume rise and plume moisture content during typical summer morning and winter morning periods. Input to the LVPM model are average morning meteorological conditions as obtained from the WNP-2 meteorological data base.

9.1.3.3.1 FOG Model. The FOG model simulates the dispersion of the plume from evaporative cooling systems using sequential hourly meteorological data. 


\section{TABLE 9.10. Annual Average Atmospheric Dispersion and}

Deposition Parameters for NPR

Site Boundary: Unit 1

\begin{tabular}{|c|c|c|c|c|c|}
\hline Direction $(a)$ & $\begin{array}{c}\text { Distance } \\
\text { (m) } \\
\end{array}$ & $\begin{array}{c}\mathrm{Chi} / \mathrm{Q} \\
\left(\mathrm{sec} / \mathrm{m}^{3}\right) \\
\end{array}$ & $\begin{array}{c}\text { Chi } / Q \\
\text { Decayed } \\
\left(\mathrm{sec} / \mathrm{m}^{3}\right) \\
\end{array}$ & $\begin{array}{c}\text { Chi } / Q \\
\text { Decayed, } \\
\text { Depleted } \\
\left(\mathrm{sec} / \mathrm{m}^{3}\right) \\
\end{array}$ & $\begin{array}{c}D / 0 \\
\left\langle\mathrm{~m}^{-2}\right\rangle \\
\end{array}$ \\
\hline N & 1150. & $1.043 \mathrm{E}-05^{(b)}$ & $1.040 E-D 5$ & $9.308 E-06$ & $4.571 E-08$ \\
\hline NNE & 1175. & $8.661 E-06$ & $8.632 E-06$ & $7.722 \mathrm{E}-06$ & $4.112 E-08$ \\
\hline NE & 1095. & $7.276 \mathrm{E}-06$ & $7.252 E-06$ & $6.513 E-06$ & $3.177 E-08$ \\
\hline ENE & 930. & $9.820 \mathrm{E}-06$ & $9.780 E-06$ & $8.876 E-06$ & $3.185 \mathrm{E}-08$ \\
\hline$E$ & 910. & $8.727 E-06$ & $8.699 \mathrm{E}-06$ & $7.900 E-06$ & $3.383 E-08$ \\
\hline ESE & 930. & $1.504 \mathrm{E}-05$ & $1.499 E-05$ & $1.360 E-05$ & $5.545 E-08$ \\
\hline SE & 1095. & $1.400 E-05$ & $1.396 \mathrm{E}-05$ & $1.253 E-05$ & $5.311 E-08$ \\
\hline SSE & 1290. & $1.012 E-05$ & $1.007 E-05$ & $8.970 E-06$ & $2.780 E-08$ \\
\hline$S$ & 1265. & $8.321 E-06$ & $8.281 E-06$ & $7.385 E-06$ & $2.202 \mathrm{E}-08$ \\
\hline SSW & 1290. & $6.341 \varepsilon-06$ & $6.310 \mathrm{E}-06$ & $5.621 \mathrm{E}-06$ & $1.626 E-08$ \\
\hline $5 W$ & 1325. & $4.94 I E-06$ & $4.918 E-06$ & $4.373 E-06$ & $1.061 E-08$ \\
\hline WSW & 1125. & $5.499 E-06$ & $5.474 \mathrm{E}-06$ & $4.913 E-06$ & $1.242 \mathrm{E}-08$ \\
\hline W & 1100. & $4.439 E-06$ & $4.423 E-06$ & $3.972 E-06$ & $9.598 E-09$ \\
\hline WNW & 1120. & $5.175 E-06$ & $5.148 \mathrm{E}-06$ & $4.624 E-06$ & $1.106 \mathrm{E}-08$ \\
\hline NW & 1325. & $4.921 E-06$ & $4.896 E-06$ & $4.355 E-06$ & $1.397 \mathrm{E}-08$ \\
\hline NNW & 1175 . & $9.362 E-06$ & $9.334 E-06$ & $8.348 E-06$ & $3.502 E-08$ \\
\hline
\end{tabular}

(a) N-north, E-east, S-south, W-west

(b) Can also be written $1.043 \times 10^{-05}$.

Notes:

1. Relative concentrations are for a ground-level release are undepleted and undecayed, and incorporate Pasquill-Gifford dispersion coefficients, building height wake, and open terrain correction factors.

2. Based on WNP-2 meteorological data for the period April 1, 1974 to March 31, 1976: 33-ft wind and deita T (245-33 ft).

3. Distances are from the center of each containment. 
TABLE 9.10. (contd)

Site Boundary: Unit 2

\begin{tabular}{|c|c|c|c|c|c|}
\hline Oirection $(a)$ & $\begin{array}{c}\text { Distance } \\
\quad \text { (II) } \\
\end{array}$ & $\begin{array}{c}\text { Chi } / Q \\
\left\langle\mathrm{sec} / \mathrm{m}^{3}\right\rangle \\
\end{array}$ & $\begin{array}{c}\text { Chi/Q } \\
\text { Decayed } \\
\left(\text { sec/m } / \mathrm{m}^{3}\right) \\
\end{array}$ & $\begin{array}{c}\text { Chi/Q } \\
\text { Decayed, } \\
\text { Depleted } \\
\left\langle\mathrm{sec} / \mathrm{m}^{3}\right\rangle \\
\end{array}$ & $\begin{array}{c}D / Q \\
\left(m^{-2}\right)\end{array}$ \\
\hline N & 1150. & $1.043 E-05$ & $1.040 E-05$ & $9.308 \mathrm{E}-06$ & $4.571 E-08$ \\
\hline NNE & 1145. & $9.001 E-06$ & $8.972 E-06$ & $8.037 E-06$ & $4.295 E-08$ \\
\hline NE & 765. & $1.288 \mathrm{E}-05$ & $1.286 \mathrm{E}-05$ & $1.179 \mathrm{E}-05$ & $5.699 \mathrm{E}-08$ \\
\hline ENE & 650. & $1.707 E-05$ & $1.702 \mathrm{E}-05$ & $1.577 E-05$ & $5.677 E-08$ \\
\hline$E$ & 635. & $1.528 \mathrm{E}-05$ & $1.524 \mathrm{E}-05$ & $1.413 E-05$ & $6.037 E-08$ \\
\hline ESE & 650. & $2.616 \mathrm{E}-05$ & $2.610 E-05$ & $2.417 \mathrm{E}-05$ & $9.884 E-08$ \\
\hline SE & 765. & $2.473 E-05$ & $2.468 E-05$ & $2.264 E-05$ & $9.528 E-08$ \\
\hline SSE & 1145. & $1.270 E-05$ & $1.264 E-05$ & $1.134 E-05$ & $3.594 E-08$ \\
\hline s & 1265. & $8.321 E-06$ & $8.281 E-06$ & $7.385 E-06$ & $2.202 E-08$ \\
\hline SSW & 1290. & $6.341 E-06$ & $6.310 E-06$ & $5.621 E-06$ & $1.626 \mathrm{E}-08$ \\
\hline SW & 1520. & $3.601 E-06$ & $3.582 E-06$ & $3.160 E-06$ & $7.416 E-09$ \\
\hline WSW & 1400 . & $3.542 \mathrm{E}-06$ & $3.522 E-06$ & $3.123 E-06$ & $7.525 E-09$ \\
\hline$w$ & 1375. & $2.887 E-06$ & $2.873 E-06$ & $2.550 E-06$ & $5.871 E-09$ \\
\hline WSW & 1400. & $3.282 E-06$ & $3.261 E-06$ & $2.894 E-06$ & $6.653 E-09$ \\
\hline $\mathrm{NW}$ & 1385. & $4.428 \mathrm{E}-06$ & $4.404 E-06$ & $3.908 E-06$ & $1.244 E-08$ \\
\hline NNW & 1175. & $9.362 E-06$ & $9.334 E-06$ & $8.348 E-06$ & $3.501 E-08$ \\
\hline
\end{tabular}

A bent-over plume treatment is used by incorporating Briggs plume rise equations (Briggs 1969) to the downwind distance where the plume rise stops. Gaussian dispersion equations are then used for calculations beyond this distance. The plume buoyancy employed in the plume rise calculations is computed from the effluent temperature and air flow rate at the exit of the cooling tower and from the ambient dry bulb temperature and relative humidity. For the round mechanical-draft multifan cooling towers, plume merging is considered using equations developed by Briggs (1974) for a "cluster" of cells. No enhanced plume rise due to the merging of plumes from neighboring towers is considered; this conservative assumption leads to lower plume rises and greater ground-level effects. 
TABLE 9.11. Annua1 Average Atmospheric Dispersion and Deposition Parameters for the Facility (PSP\&L 1981a)

Hanford Site Boundary

\begin{tabular}{|c|c|c|c|c|c|}
\hline Direction $(a)$ & $\begin{array}{c}\begin{array}{c}\text { Distance } \\
(\mathrm{m})\end{array} \\
\end{array}$ & $\begin{array}{c}\text { Chi/Q } \\
\left(\mathrm{sec} / \mathrm{m}^{3}\right) \\
\end{array}$ & $\begin{array}{c}\text { Chi/Q } \\
\text { Decayed } \\
\left(\mathrm{sec} / \mathrm{m}^{3}\right) \\
\end{array}$ & $\begin{array}{c}\text { Chi/Q } \\
\text { Decayed, } \\
\text { Depleted } \\
\left(\mathrm{sec} / \mathrm{m}^{3}\right) \\
\end{array}$ & $\begin{array}{c}0 / Q \\
\left(m^{-2}\right)\end{array}$ \\
\hline N & 30000 . & $2.899 E-08^{(b)}$ & $2.687 E-08$ & $1.683 E-08$ & $4.094 E-11$ \\
\hline NNE & 15100 . & $5.747 E-08$ & $5.501 E-08$ & $3.855 E-08$ & $1.233 \mathrm{E}-10$ \\
\hline $\mathrm{NE}$ & 13000 . & $5.610 E-08$ & $5.379 E-08$ & $3.861 E-08$ & $1.099 \mathrm{E}-10$ \\
\hline ENE & 12600. & $6.184 E-08$ & $5.831 E-08$ & $4.257 E-08$ & $8.905 E-11$ \\
\hline E & 12600. & $5.243 E-08$ & $5.009 E-08$ & $3.623 E-08$ & $9.127 E-11$ \\
\hline ESE & 13100. & $8.867 E-08$ & $8.434 E-08$ & $6.080 \mathrm{E}-08$ & $1.450 E-10$ \\
\hline SE & 15000. & $8.996 E-08$ & $8.609 E-08$ & $6.041 E-08$ & $1.431 \mathrm{E}-10$ \\
\hline SSE & 13200 . & $1.100 E-07$ & $1.047 \mathrm{E}-07$ & $7.536 \mathrm{E}-08$ & 1. $305 E-10$ \\
\hline$S$ & 11800. & $1.026 E-07$ & $9.808 E-08$ & $7.163 E-08$ & $1.191 \mathrm{E}-10$ \\
\hline SSW & 13700 & $6.822 E-08$ & $6.471 E-08$ & $4.640 E-08$ & $7.155 E-11$ \\
\hline SW & 15600. & $4.899 \mathrm{E}-08$ & $4.639 E-08$ & $3.258 E-08$ & $3.990 E-11$ \\
\hline WSW & 1699). & $3.463 E-08$ & $3.230 E-08$ & $2.261 E-08$ & $2.854 E-11$ \\
\hline$W$ & 26600. & $1.508 E-08$ & 1. $369 \mathrm{E}-08$ & $8.936 E-09$ & $9.842 E-12$ \\
\hline WNW & 27800 . & $1.554 \mathrm{E}-08$ & $1.375 E-08$ & $9.052 E-09$ & $1.083 \mathrm{E}-11$ \\
\hline NW & 30700 . & $1.758 \mathrm{E}-08$ & $1.557 \mathrm{E}-08$ & $1.001 E-08$ & $1.654 \mathrm{E}-11$ \\
\hline NNW & 31200. & $2.515 E-08$ & $2.332 \mathrm{E}-08$ & $1.447 \mathrm{E}-08$ & $3.035 \mathrm{E}-11$ \\
\hline
\end{tabular}

(a) N-north, E-east, S-south, W-west

(b) Can also be written $2.899 \times 10^{-08}$.

The FOG model makes calculations over a polar grid centered on the cooling system. This grid consists of up to 20 downwind distances. After a17 calculations have been made, the resuits are further processed and summarized on a Cartesian grid. The plume is assumed to propagate rectilinearly, and any meandering effects due to wind shifts are neglected. Required Pasquill stability classes are determined from the measured difference between the dry bulb temperatures at the two levels of the onsite meteorological tower. The dispersion parameters used (sigma $y$ and sigma $z$ ) were those of Pasquili-Gifford 
TA8LE 9.12. Annual Average Atmospheric Dispersion Parameters and Deposition Estimates at Selected Locations (PSP\&L 1981a)

\begin{tabular}{|c|c|c|c|c|c|c|}
\hline Item & Direction $(a)$ & $\begin{array}{c}\text { Distance } \\
\quad(m) \\
\end{array}$ & $\begin{array}{c}\operatorname{Chi} / Q \\
\left(\mathrm{sec} / \mathrm{m}^{3}\right) \\
\end{array}$ & $\begin{array}{c}\text { Chi/Q } \\
\text { Decayed } \\
\left(\text { sec } / \mathrm{m}^{3}\right) \\
\end{array}$ & $\begin{array}{c}\text { Chi } / Q \\
\text { Decayed } \\
\text { Depleted } \\
\left(\mathrm{sec} / \mathrm{m}^{3}\right) \\
\end{array}$ & $\begin{array}{c}D / Q \\
\left(m^{-2}\right)\end{array}$ \\
\hline Residence & $S$ & 12125 & $9.862 E-08(b)$ & $9.420 E-08$ & $6.856 E-08$ & $1.137 \mathrm{E}-10$ \\
\hline Residence & $\mathrm{NE}$ & 13485 & $5.317 \mathrm{E}-08$ & $5.089 E-08$ & $3.636 \mathrm{E}-08$ & $1.031 \mathrm{E}-10$ \\
\hline Residence & ENE & 13765 & $5.433 E-08$ & $5.095 \mathrm{E}-08$ & $3.680 E-08$ & $7.640 \mathrm{E}-11$ \\
\hline Residence & $E$ & 13750 & $4.612 E-08$ & $4.388 \mathrm{E}-08$ & $3.138 E-08$ & $7.845 \mathrm{E}-11$ \\
\hline Residence & ESE & 14840 & 7. $385 E-08$ & $6.978 \mathrm{E}-08$ & 4. $949 \mathrm{E}-08$ & 1. $166 \mathrm{E}-10$ \\
\hline Residerice & SSE & 15640 & $8.621 \mathrm{E}-08$ & $8.128 E-08$ & $5.723 E-08$ & $9.701 E-11$ \\
\hline WYE Barricade & E & 3500 & 5. $180 E-07$ & $5.116 \mathrm{E}-07$ & 4.240E-07 & $1.471 \mathrm{E}-09$ \\
\hline
\end{tabular}

(a) S-south, N-north, E-east.

(b) Can also be written $9.862 \times 10^{-08}$. 
TABLE 9.13. Annua] Average Dispersion Parameters and Deposition Estimates at Standard Distances for the Facility (PSP\&L 1981a)

No Decay, Undepleted

Corrected for open Ierrain Recirculation

Arnual Aversge $x / 0\left(s e c / a^{3}\right)$

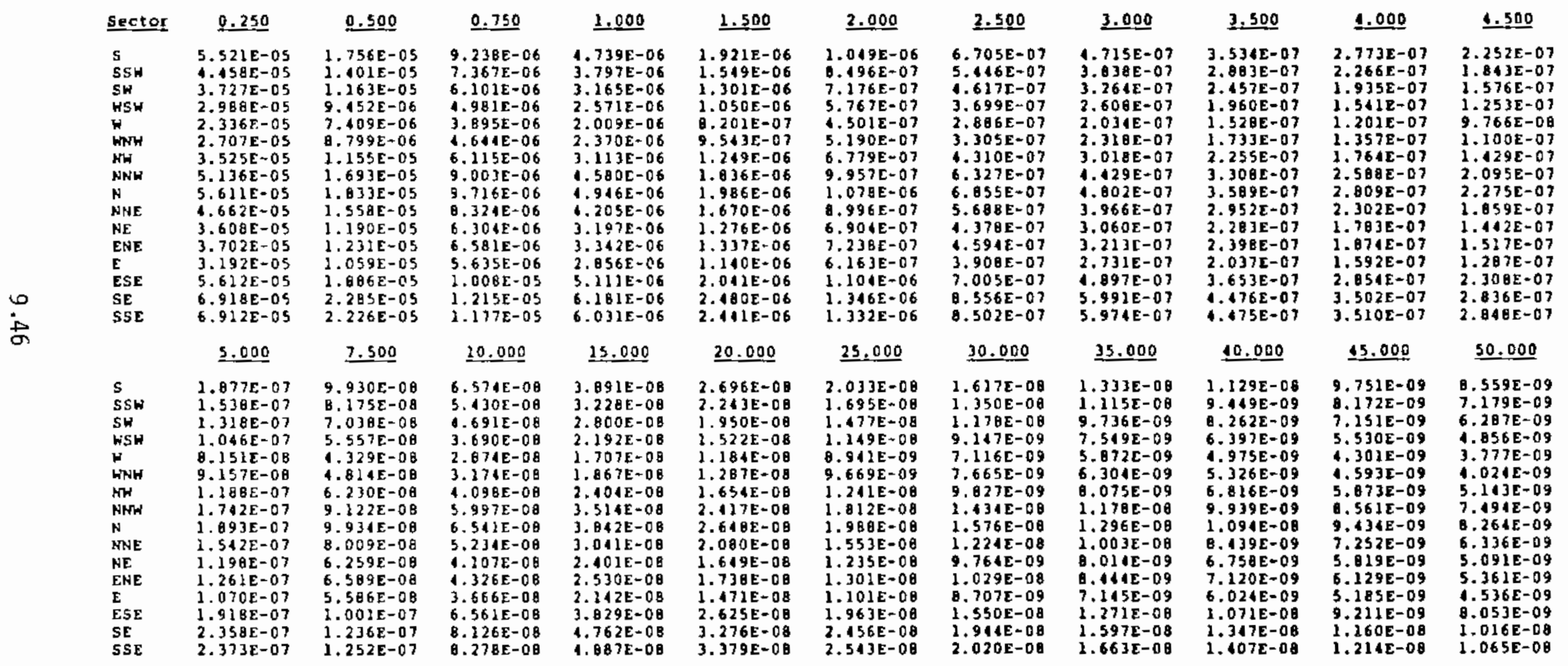


TABLE 9.13. (contd)

2.260 Day Decol, Undepleted

corrected for Open Terratn Reclsculation

\begin{tabular}{|c|c|c|c|c|c|c|c|c|c|c|c|}
\hline \multicolumn{12}{|c|}{ Diotance In wldee } \\
\hline Sector & 0.250 & 0.500 & $\underline{0.750}$ & 2.000 & 1.500 & 2.000 & 2.500 & 3.900 & 3.500 & 4,000 & 4.500 \\
\hline $\begin{array}{l}\text { S } \\
\text { SSH } \\
S H \\
\text { KSH } \\
H \\
\text { WNH } \\
N H \\
\text { NHW } \\
N \\
\text { HNE } \\
\text { NE } \\
\text { ENE } \\
\text { E } \\
\text { ESE } \\
\text { SE } \\
\text { SSE }\end{array}$ & $\begin{array}{l}5.313 E-05 \\
4.451 E-05 \\
3.722 E-05 \\
2.9 B 3 E-05 \\
2.333 E-05 \\
2.702 E-05 \\
3.519 E-E S \\
5.131 E-05 \\
5.606 E-05 \\
4.657 E-05 \\
3.603 E-05 \\
3.695 E-05 \\
3.167 E-05 \\
5.604 E-05 \\
6.910 E-05 \\
6.901 E-05\end{array}$ & $\begin{array}{l}2.750 E-05 \\
1.397 E-05 \\
1.260 E-05 \\
9.121 E-06 \\
7.380 E-06 \\
8.767 E-06 \\
1.152 E-05 \\
1.699 E-05 \\
1.629 E-05 \\
1.356 E-05 \\
1.187 E-05 \\
1.226 E-05 \\
1.056 E-05 \\
1.080 E-05 \\
2.280 E-05 \\
2.219 E-05\end{array}$ & $\begin{array}{l}9.396 E-06 \\
7.334 E-06 \\
6.075 E-06 \\
4.957 E-06 \\
3.879 E-06 \\
1.616 E-06 \\
6.017 E-06 \\
8.916 E-06 \\
9.667 E-06 \\
8.296 E-06 \\
6.201 E-06 \\
6.546 E-06 \\
5.612 E-06 \\
1.003 E-05 \\
1.210 E-05 \\
1.172 E-05\end{array}$ & $\begin{array}{l}1.710 E-06 \\
3.771 E-06 \\
3.117 E-06 \\
2.551 E-06 \\
1.998 E-06 \\
2.353 E-06 \\
3.093 E-06 \\
1.561 E-06 \\
1.926 E-06 \\
1.186 E-06 \\
3.181 E-06 \\
3.318 E-06 \\
2.060 E-06 \\
5.080 E-06 \\
6.153 E-66 \\
5.995 E-06\end{array}$ & $\begin{array}{l}1.903 E-06 \\
1.335 \mathrm{E}-06 \\
1.290 \mathrm{0}-06 \\
1.040 \mathrm{E}-06 \\
0.131 \mathrm{E}-07 \\
9.438 \mathrm{E}-07 \\
1.237 \mathrm{E}-06 \\
1.825 \mathrm{E}-06 \\
3.973 \mathrm{E}-06 \\
1.556 \mathrm{E}-06 \\
1.267 \mathrm{E}-06 \\
1.322 \mathrm{E}-06 \\
1.130 \mathrm{E}-06 \\
2.023 \mathrm{E}-06 \\
2.463 \mathrm{E}-06 \\
2.419 \mathrm{E}-06\end{array}$ & $\begin{array}{l}1.037 E-06 \\
8.392 E-07 \\
3.0958-07 \\
5.691 E-07 \\
1.150 E-07 \\
5.111 E-07 \\
6.694 E-07 \\
9.876 E-07 \\
1.069 E-06 \\
8.9115-07 \\
6.835 E-07 \\
7.131 E-07 \\
6.093 E-07 \\
1.091 E-06 \\
1.333 E-06 \\
1.316 E-06\end{array}$ & $\begin{array}{l}6.603 E-07 \\
5.362 E-07 \\
6.552 E-07 \\
3.637 E-07 \\
2.011 E-07 \\
3.245 E-07 \\
1.212 E-07 \\
6.263 E-07 \\
6.785 E-07 \\
5.623 E-07 \\
6.324 E-07 \\
4.309 E-07 \\
3.652 E-07 \\
6.699 E-07 \\
8.456 E-07 \\
0.372 E-07\end{array}$ & $\begin{array}{l}4.629 E-07 \\
3.768 E-07 \\
3.209 E-07 \\
2.556 E-07 \\
1.999 E-07 \\
2.267 E-07 \\
2.961 E-07 \\
1.375 E-07 \\
1.713 E-07 \\
3.911 E-07 \\
3.0148-07 \\
3.142 E-07 \\
2.604 E-07 \\
1.807 E-07 \\
5.907 E-07 \\
5.866 E-07\end{array}$ & $\begin{array}{l}3.459 E-07 \\
2.021 \mathrm{E}-07 \\
2.109 E-07 \\
1.911 E-07 \\
1.4978-07 \\
1.689 E-07 \\
2.205 E-07 \\
3.261 E-07 \\
3.537 E-07 \\
2.901 E-07 \\
2.242 E-07 \\
2.336 E-07 \\
1.996 E-07 \\
3.575 E-07 \\
1.403 E-07 \\
1.381 E-07\end{array}$ & $\begin{array}{l}2.706 E-07 \\
2.211 E-07 \\
1.692 E-07 \\
1.500 E-07 \\
1.172 E-07 \\
1.310 E-07 \\
1.720 E-07 \\
2.546 E-07 \\
2.762 E-07 \\
2.2602-07 \\
1.747 E-07 \\
1.019 E-07 \\
1.555 E-07 \\
2.785 E-07 \\
3.135 E-07 \\
3.625 E-07\end{array}$ & $\begin{array}{l}2.191 E-07 \\
1.992 E-07 \\
2.537 E-07 \\
1.216 E-07 \\
9.5116-08 \\
1.061 E-07 \\
1.380-07 \\
2.057 E-07 \\
2.233 E-07 \\
1.2112-07 \\
1.410 E-07 \\
1.166 E-07 \\
1.254 E-07 \\
2.215 E-07 \\
2.776 E-07 \\
2.771 E-07\end{array}$ \\
\hline & 5.000 & 500 & 10.000 & 15.000 & 20.000 & 23.000 & 30.000 & 35.000 & 10.000 & 15.000 & 50.000 \\
\hline $\begin{array}{l}\text { S } \\
\text { SSH } \\
S W \\
H S H \\
H \\
\text { HNH } \\
\text { NH } \\
\text { NNH } \\
\text { N } \\
\text { NHE } \\
\text { HE } \\
\text { ENE } \\
\text { E } \\
\text { ESE } \\
\text { SE } \\
\text { SSE }\end{array}$ & $\begin{array}{l}1.821 E-07 \\
1.491 E-07 \\
1.281 E-07 \\
1.011 E-07 \\
7.918 E-00 \\
8.828 E-00 \\
1.151 E-07 \\
1.707 E-07 \\
1.054 E-07 \\
1.507 E-07 \\
1.160 E-07 \\
1.211 E-07 \\
1.039 E-07 \\
1.060 E-07 \\
2.303 E-07 \\
2.302 E-07\end{array}$ & $\begin{array}{l}9.185 E-08 \\
7.803 E-08 \\
6.717 E-08 \\
5.286 E-08 \\
6.111 E-00 \\
1.559 E-08 \\
5.935 E-000 \\
9.850 E-08 \\
9.630 E-08 \\
7.734 E-00 \\
6.020 E-00 \\
6.228 E-08 \\
5.348 E-08 \\
9.555 E-08 \\
1.193 E-09 \\
1.197 E-07\end{array}$ & $\begin{array}{l}6.18 \theta E-0 \theta \\
5.106 E-0 B \\
4.435 E-08 \\
3.453 E-0 \theta \\
2.711 E-0 \theta \\
2.953 E-08 \\
3.812 E-0 B \\
5.762 E-0 \theta \\
6.277 E-0 \theta \\
4.996 E-08 \\
3.098 E-08 \\
4.014 E-08 \\
3.459 E-08 \\
6.171 E-0 \theta \\
7.751 E-08 \\
7.792 E-0 B\end{array}$ & $\begin{array}{l}3.556 E-08 \\
2.941 E-0 B \\
2.576 E-0 B \\
1.966 E-08 \\
1.364 E-08 \\
1.678 E-0 B \\
2.183 E-08 \\
3.311 E-08 \\
3.613 E-08 \\
2.837 E-08 \\
2.219 E-0 \theta \\
2.263 E-0 B \\
1.965 E-08 \\
3.195 E-08 \\
4.438 E-0 B \\
1.467 E-0 B\end{array}$ & $\begin{array}{l}2.395 E-08 \\
1.906 E-08 \\
1.766 E-08 \\
1.336 E-08 \\
1.051 E-08 \\
1.216 E-08 \\
1.457 E-08 \\
2.235 E-08 \\
2.411 E-08 \\
1.898 E-08 \\
1.181 E-08 \\
1.500 E-0 B \\
1.312 E-08 \\
2.328 E-0 B \\
2.906 E-08 \\
3.001 E-0 B\end{array}$ & 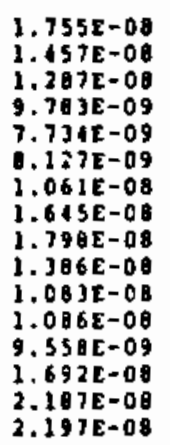 & $\begin{array}{l}1.358 E-08 \\
1.228 E-08 \\
9.996 E-09 \\
7.555 E-09 \\
5.9 B 3 E-09 \\
6.236 E-09 \\
9.159 E-09 \\
1.278 E-08 \\
1.397 E-08 \\
1.069 E-00 \\
9.319 E-09 \\
9.302 E-09 \\
7.357 E-09 \\
1.300 E-00 \\
1.693 E-08 \\
1.697 E-00\end{array}$ & $\begin{array}{l}1.009 \mathrm{E}-08 \\
9.056 \mathrm{E}-09 \\
8.053 \mathrm{E}-09 \\
6.053 \mathrm{E}-09 \\
1.000 \mathrm{C}-09 \\
.96 \mathrm{BE}-09 \\
6.316 \mathrm{E}-09 \\
1.031 \mathrm{E}-08 \\
1.228 \mathrm{E}-0 \mathrm{0} \\
8.53 \mathrm{E}-09 \\
6.681 \mathrm{E}-09 \\
6.395 \mathrm{E}-09 \\
5.801 \mathrm{E}-09 \\
1.038 \mathrm{E}-08 \\
1.361 \mathrm{E}-00 \\
1.361 \mathrm{E}-00\end{array}$ & 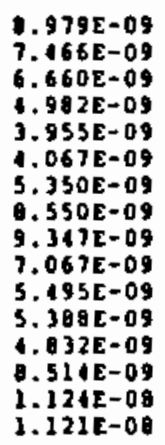 & $\begin{array}{l}7.554 E-09 \\
6.282 E-09 \\
5.619 E-09 \\
1.183 E-09 \\
3.325 E-09 \\
3.100 E-09 \\
4.186 E-09 \\
7.236 E-09 \\
3.911 E-09 \\
3.950 E-09 \\
4615 E-09 \\
1.196 E-09 \\
1.055 E-09 \\
7.137 E-09 \\
9.476 E-09 \\
9.127 E-09\end{array}$ & $\begin{array}{l}6.459 E-09 \\
5.372 E-09 \\
4.817 E-09 \\
3.572 E-09 \\
2.011 E-09 \\
2.090 E-09 \\
3.025 E-09 \\
6.226 E-09 \\
6.805 E-09 \\
5.094 E-09 \\
3.9602-09 \\
3.816 E-09 \\
3.1612-09 \\
6.085 E-09 \\
8.123 E-09 \\
8.060 E-09\end{array}$ \\
\hline
\end{tabular}


TABLE 9.13. (contd)

0.000 Day Decoy, Depleted

Corrected for Open territin Reclrculation

$\begin{array}{lc}\text { Sector } & 0.250 \\ \text { S } & 5.223 E-05 \\ \text { SSH } & 1.217 E-05 \\ \text { SH } & 3.526 E-05 \\ \text { HSH } & 2.026 E-05 \\ \text { H } & 2.210 E-05 \\ \text { HWH } & 2.561 E-05 \\ \text { NH } & 3.335 E-05 \\ \text { NHH } & 1.059 E-05 \\ \text { N } & 5.309 E-05 \\ \text { NHE } & 1.111 E-05 \\ \text { HE } & 3.413 E-05 \\ \text { ENE } & 1.502 E-05 \\ \text { E } & 3.020 E-05 \\ \text { ESE } & 5.309 E-05 \\ \text { SE } & 6.545 E-05 \\ \text { SSE } & 6.539 E-05\end{array}$

0.300
$.602 E-05$
$.278 E-05$
$.062 E-05$
$.623 E-06$
$.760 E-06$
$.027 E-06$
$.051 E-05$
$1.545 E-05$
$1.673 E-05$
$1.422 E-05$
$.006 E-05$
$1.123 E-05$
$.661 E-05$
$1.723 E-05$
$2.086 E-05$
$2.031 E-05$

0.350

$8.222 \mathrm{E}-06$

$6.557-06$

$3.93 E-06$

$3.567-06$

1. $132 \mathrm{E}-06$

$5.112 \mathrm{E}-06$

$0.016 \mathrm{E}-06$

A. $631 E-06$

$7.110 E-06$

5. $612 \mathrm{E}-06$

$5.856 E-06$

$5.016 E-08$

0. $96 \mathrm{gE-O}$

1. $081 E-05$

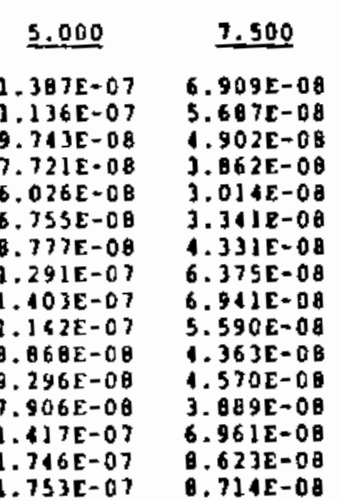

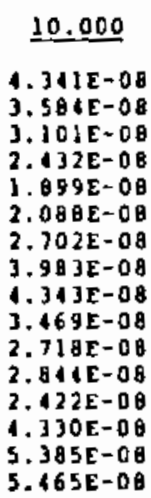

1.000
$4.141 E-06$
$3.318 E-06$
$2.766 E-06$
$2.247 E-06$
$1.756 E-06$
$2.070 E-06$
$2.720 E-06$
$1.004 E-06$
$1.325 E-06$
$3.676 E-06$
$2.791 E-06$
$2.919 E-06$
$2.196 F-06$
$1.166 E-06$
$5.104 E-06$
$5.271 E-06$

Dlatance in wiles

$\begin{array}{cc}1.500 & 2.000 \\ 1.627 E-06 & 8.658 E-07 \\ 1.312 E-06 & 7.011 E-07 \\ 1.203 E-06 & 5.923 E-07 \\ 8.095 E-07 & 1.758 E-07 \\ 6.948 E-07 & 3.715 E-07 \\ 8.079 E-07 & 4.280 E-07 \\ 1.058 E-06 & 5.593 E-07 \\ 1.557 E-06 & 0.226 E-07 \\ 1.601 E-06 & 0.900 E-07 \\ 1.115 E-06 & 7.030 E-07 \\ 1.002 E-06 & 5.701 E-07 \\ 1.132 E-06 & 3.968 E-07 \\ 9.856 E-07 & 5.087 E-07 \\ 1.729 E-06 & 9.313 E-07 \\ 2.102 E-06 & 1.111 E-06 \\ 2.067 E-06 & 1.099 E-06\end{array}$

3.500

3.000

3.500

1.000

1.500

S. 108E-07
$4.392 E-07$

$3.725 E-07$
$3.033 E-07$

2.7415-07

$2.2145-07$

$1.727 x-07$
$3.676 E-0)$

$3.723 E=07$
$3.925-07$

$2.328 E-0$ ?

$3.060 E-07$
$1.600 E-07$

$1.9076-07$

$1.5198-07$
$1.2068-07$

$2.663 E=07$

1. $029 E-07$

$3.376 \varepsilon-07$

2. 3 BSE-0?

$1.343 \mathrm{E}=0$

$1.174 E=07$

$9.160 \mathrm{E}-08$

$1,345 E-0$

2.57E-0?

5. $5378-07$

3. $0018-07$

3. $593 E-07$
$3.534 E-07$

3. $702 E-07$

J.J38E- O)

$2.120 E-07$
$2.536 E-07$

2.159E-07

3. $869 E-07$

2.7995-07

2. $293 \mathrm{E}-07$

1. $7735-07$

1. $0538-07$
1. $5008-07$

3. $9338-07$

6. $907 \mathrm{E}-07$

$1.720 E-07$
4.7205

3.4712-01

$.977 E-07$

$2.165-07$

I. $758 E-07$

1. $4276-07$

1.211E-07

2.17SE-O

$2.6795-07$
$3.6758-07$

$1.689 E-07$

1.183E-07

9.39:15-0日

$9.3295-0 B$

8.205-08

1. $5765-87$

1. 11 IE-01

1. $397 E-07$

1. $003 \varepsilon=07$

$1.1365-07$

$9.660 \varepsilon=08$

$2.2\} 1 E-07$

$2.131 \varepsilon-0$

15.000
$2.357 E-00$
$1.954 E-00$
$1.900 E-08$
$1.325 E-00$
$1.035 E-08$
$1.125 E-08$
$1.153 E-08$
$2.148 E-00$
$1.3470-08$
$1.053 E-08$
$1.159 E-08$
$1.522 E-08$
$1.299 E-08$
$2.318 E-08$
$2.902 E-08$
$2.960 E-00$

20.000

25.000

30.000

35.000

10.000

13. 000

50.000

$1.521 \mathrm{E}-0 \mathrm{~g}$

$1.0785-00$

8. $098 \mathrm{E}-09$

$6.339 E-09$

3.112E-09

1. $218 \mathrm{E}=09$

3. $326 \varepsilon-09$

3.1 $372 \mathrm{E}-09$

8.555E-09

$6.0635-09$
$1.362-09$

1. $711 E-09$
$5.083 E-09$

6. $\$ 51 E-09$

$5.921 E-09$

$.557 E-09$
$3.569 E-09$

3. BO3E- 09

3. $991 E-09$
i. $312 E-09$

9. $304 \mathrm{E}-09$

2. $300 \mathrm{E}-08$

$9.717 \varepsilon-09$

$3.567 E-08$

$2.965 E-09$

3.811E-09

5.710E-09

3.760E-09

2. $876 \mathrm{E}-09$

$2.3562-09$

2. $302 E-09$

$4.6095-0$

$1.0625-09$

2.521E-09

3.802E-09

8.022E-09 6.278E-09

$5.0635-09$

4.179E-c9

$3.879 E-09$

$3.082 E-09$

$6.576 E-09$ C.

$1.193 E-08$
$9.339 E-09$

9.71TE-09

3.083E -09

$3.951 E-09$

$1.366 E-09$

3. $101 E-09$

$3.166 E-09$

2.732E-09

1.03e

$9.013 E-09$

$6.0252-09$

7. $904 E=09$

6.) $199 E-09$

2.535E-09

2.597E-09

$2.216 \varepsilon-09$

3.911E-09

5. $099 \mathrm{E}-09$

$3.513 E-09$

$2.9645-09$

$2.618 E-09$
$1.992 E-09$

1. $365 E-09$

$1.6408-09$

$3.195 \mathrm{E}-09$

$3.51 \mathrm{JE}-09$

$2.671 E-09$

$2.1218-09$

2.1695-09

$1.8805-09$
3. $322 \mathrm{E}-09$

3. $322 \mathrm{E}-09$

$479 \mathrm{E}-09$
$+405 \mathrm{E}-09$

105E- 0 
TABLE 9.13. (contd)

Corrected for Open Terrala Recliculation

Distance in mlies

\begin{tabular}{|c|c|c|c|c|}
\hline ector & 0.250 & 0.500 & 0.750 & 1.000 \\
\hline s & $.1255-07$ & $.819 E-0 \theta$ & $2.474 E-08$ & 1. $176 E-08$ \\
\hline ss & $.108 E-07$ & TATE-08 & $1,924 E-08$ & $\therefore 116 E-09$ \\
\hline & $56 E-08$ & $62] \mathrm{E}-09$ & $1.347 E-08$ & $6.0036-09$ \\
\hline WSW & $6.354 E-08$ & $119 E-00$ & $1.10] \mathrm{C}-00$ & $5.245 E-09$ \\
\hline 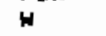 & $1.730 E-08$ & $1.599 E-08$ & $8,212 E-09$ & $1.900 E-09$ \\
\hline WHAS & $5.618 E-0 B$ & $900 E-08$ & $9.75+2-09$ & $1.6375-09$ \\
\hline $\mathrm{HW}$ & $02\} E-0\}$ & $1.4578-08$ & I.TJJE-OB & $0.430 E-09$ \\
\hline Nin & $1.92 \mathrm{~B} E-07$ & $6,520 E-08$ & $3.3 \angle \theta E-O B$ & 1. $592 \mathrm{E}-00$ \\
\hline N & $2.12 \mathrm{BE}-07$ & $209 E-108$ & $1.215 E-0 B$ & $2.001 E-00$ \\
\hline HHE & $2.26(E-0)$ & $7.657 \mathrm{E}-09$ & $3,9\} \mid E-O B$ & $1.069 \mathrm{E}-00$ \\
\hline NE. & $.554 E-0]$ & $5.2548-09$ & $2.098 \mathrm{E}-0 \mathrm{~B}$ & $1.282 E-08$ \\
\hline ENE: & $1.191 E-07$ & $\triangle O A \& E-O O$ & $3.0716-08$ & $9, \theta+6 E-09$ \\
\hline E & $1.223 \mathrm{E}-07$ & $4.133 E-00$ & $2.123 \mathrm{E}-0 \mathrm{~B}$ & $1.009 \mathrm{E}-00$ \\
\hline ESE & $2.0776,07$ & $7.023 E-0 B$ & $3.606 F-08$ & $1.724 E-0 B$ \\
\hline SE & $2.597 E-07$ & $. P B A E-D B$ & 1. $310 E-00$ & 2. $114 E-0 B$ \\
\hline ss & I. 095 E-07 & $6.101 E-08$ & J. $2 B 9 E \times 0 \theta$ & $1.564 E-00$ \\
\hline
\end{tabular}

$1.500 \quad 2.000$

1.226E-09 2.096E-09

$3.285 E-09 \quad 1.629 E-09$

$\begin{array}{ll}3.100 E-09 & 1.2+1 E-09 \\ 1.08+2-09 & 9.313 E-10\end{array}$

$1.1028-09$

$3.028 \mathrm{E}-09$

$6.250 E-10$
., $502 E-09$

?.290E-09 $3.570 E-09$

$6.7168-09$ 3. $329 E-09$

1.607E-09

3.5 $37 E-09$

3.625E-09

$7,102 E-09$

S. $617 E-09$

$2.329 E-09$

I. 35 SE- DO

$1.790 E-09$

. $054 E-09$

\subsection{0 \\ 20.000 \\ 25.0므믄}

5.000

$\begin{array}{ll}S & 2.579 E-10 \\ \text { SSH } & 2.005 E-10\end{array}$

SH $1.100 \mathrm{E}-10$

7.500

10.000

$3.508 E-11$

2. $328 E-11$

1.909E-1!

1. $16+2-11$

Q. $560 \mathrm{E}-11$

3. $095 \mathrm{E}-11$

$3.304 \mathrm{E}-1$

1. $30 \mathrm{IE}-\mathrm{B}$

2.SIAE- II

$5.976 \mathrm{E}-11$

5.574E-11

3. $925 E-11$

$3.010 \mathrm{E}-11$

5. $113 \mathrm{E}-1$

$6.394 E-11$
$1.66+E-11$

$2.1235-11$

$1.651 E-11$

1. $424 E-11$

1. $107 \mathrm{~T}-11$

$.160 E-12$

.

1. $522 \mathrm{E}-1$

2.

3. $617 \mathrm{ZE}-11$

$3.170 E-11$

2. $3 \mid 5 E-11$

$2.822 \mathrm{E}-11$

$3.095 E-11$

3. B $70 \mathrm{E}-11$
$2.82 \mathrm{JE}-11$

6. $318 E-12$

5. $613 \mathrm{E}-12$

$1.020 E-11$

1. $926 E-11$

$2.25 E-11$

$2.262 \mathrm{E}-11$

$1.552 \mathrm{E}-11$

$1.1918-11$

EE $\quad 2.213 E-10$ 9.8JIE-11 5.95

1.7O1E-10 2.088E-10 1.265E-10 1. $523 E-10$

$9.227 E-11$

$2.075 \mathrm{E}-1$

$2.595 E-11$
$1.093 E-11$
3. $7865-09$

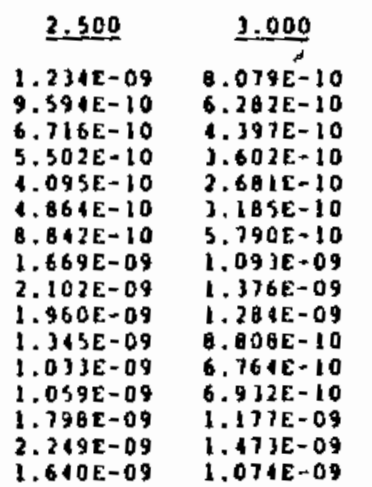

3.500

$5.685 E-10$
$4.20 E-10$

$1.40 E-10$
$.09+E-10$

$2.535 E-10$

1. BB JE- 10

$2.121 E-10$

7.692E-10

$6.69+2-10$

$9.01) E-10$

$6.198 E-10$

4. $759 \mathrm{E}-10$

1. OTE 10

9.205E-10

1.036E-09

$7.558 E-10$

\subsection{0 \\ 35.000}

$1.020 \mathrm{E}-11$
$7.9 \mathrm{~J} 2 \mathrm{E}-12$

$5.552 E-12$

1. $549 \mathrm{E}-1$

3. $021 E-1$

7. $310 \mathrm{E}-12$

i. $380 \mathrm{E}-11$

1. 7$\} \theta E-1$

1.62โz-11

1. $112 \mathrm{E}-11$

8. $540 \mathrm{E}-12$

$0.7528-12$
$1.487 E-11$

1. $187 E-11$

I. $859 \mathrm{E}-1$

I. $156 \mathrm{E}-1 \mathrm{I}$
$3.660 E-12$

$5.956 \mathrm{E}-12$
f. $169 \mathrm{E}-12$

$3.115 E-12$

$2.542 \mathrm{E}-1$

$5.489 C-12$

$1.036 \mathrm{E}-11$

t. $305 E-11$

B. JSIE+1

$6.163 \mathrm{E}-12$
$6.572 \mathrm{E}-1$

1. $116 \mathrm{E}-1$

1. $018 \mathrm{E}-11$

\subsection{0}

$3.950 \mathrm{E}-12$

4. $6318-12$

$3.242 E-12$

I? $\mathrm{E}-1$

3. $36 \mathrm{E}-12$

C. $268 E-12$

9.059E-12

$9.461 E-12$

B. $93 \mathrm{E}-1$

$4986 E-12$

$5.110 E-12$

B. $600 \mathrm{E}-\mathrm{I}$

$3.086 \mathrm{E}-11$
$7.918 \mathrm{E}-12$
$1.000 \quad 1.500$

4. $213 \mathrm{E}-10$

$3.2765-10$

$1.079 \mathrm{E}-10$

$.198 E-10$

3.019E- 10

$7005-10$

$.177 E-10$

$6.691 E-10$

$3.527 E-10$

3. $615 E-10$

$6.110 \mathrm{E}-10$

$7.679 E-10$
$5.601 E-10$

15.000

1.758E-12

$3.699 E-12$

2.

$1.579 \mathrm{E}-12$

$1.075 E-12$

$3.109 E-12$
$6 .+17 E-12$

6. $103 \mathrm{E}-12$

$7.359 E-12$

S.107E-12

J.98]E- 12

1. $0 B 2 \mathrm{E}-12$

$6.934 E-12$

$.672 \mathrm{E}-12$

6. $325 \mathrm{E}-12$
$3.267 \mathrm{E}-10$

$2.52+E-10$

1.3678 .

$1.0785-10$

2. $327 \mathrm{E}-10$

2. 39 ic- 10

$5.531 E-10$

$5.159 E-10$

$3.540 E-10$

2. $118 E-10$

2. $786 E-10$

4.7) $2 E-10$

3. $913 E-10$
$4.316 E-10$

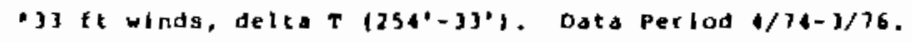

\section{0. 으으}

$3.083 E-12$ 3. $019 E-12$

1. $311 E-12$

1. $209 \mathrm{E}-12$

$1.531 E-12$

$2.783 E-12$

$6.615 E-12$

6.1 JOE- 12

4.2)6.

3. $251 \mathrm{E}-12$

5. $660 \mathrm{E}-12$

$7,07 \mathrm{AE}-12$ 


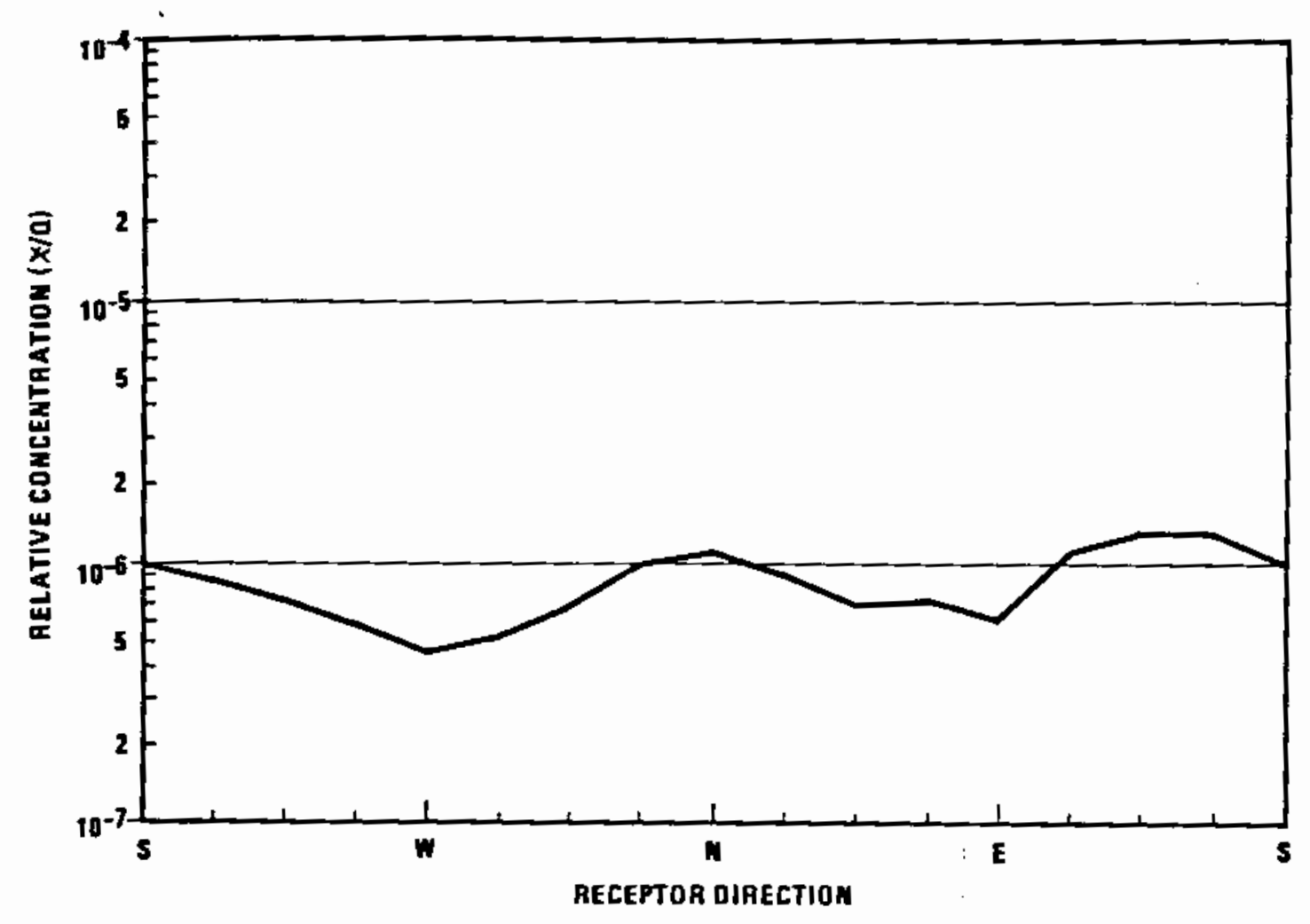

FIGURE 9.4. Site Annual Chi/Q at $3.2 \mathrm{~km}(2 \mathrm{mi})$

(U.S. NRC 1979). Formulations for critical wind speed relative to the aerodynamic downwash of the exhaust plumes are also included in the FOG moder.

Induced ground level fogging. Induced ground-level fog is defined as a reduction in ground-level visibility to $1,000 \mathrm{~m}(5 / 8 \mathrm{mi})$ or less as a result of the operation of the cooling systems. According to the international definition, $1,000 \mathrm{~m}(5 / 8 \mathrm{mi})$ is the limit on visibility above which fog is not considered to occur (Huschke 1959). The fogging calculations were based on a criterion that $2.1 \times 10^{-5}$ lbs of liquid water per $1 b$ of dry air $\left(0.015 \mathrm{~g}\right.$ of water $\left./ \mathrm{m}^{3}\right)$ would result in a visibility of $1,000 \mathrm{~m}$ $(5 / 8 \mathrm{mi})$ or less (Pettersen 1956). The water content of the plumes at ground level is calcuiated by means of the dispersion analysis. All moisture in excess of that required to saturate the ambient air is assumed to form condensed water droplets. An empirical equation presented by Petterrsen (1956) is then used to relate the atmospheric water content to horizontal visibility. 
Induced ground level icing. The frequencies of occurrence of various ice thicknesses resulting from the operation of the cooling towers were calculated by the FOG model, which includes subroutines to simulate the formation and accumulation of ice and to calculate the frequencies of ice occurrence.

The ice-formation routines predict accumulations of ice around a cooling system from the impingement of condensed water and drift droplets. Calculations of ice buildup are made for both vertical and horizontal flat surfaces. The rate of ice buildup can be limited either by the liquid water delivery rate to the collecting surface or by the heat balance necessary to sustain freezing conditions.

In the case of ice formation on elevated flat vertical surfaces, ice buildup can result from the impingement of both condensed water and drift droplets. The liquid water delivery rate is computed as the liquid mass flux times the intercepted surface area. This value is then multiplied by a collection efficiency of 0.8 for the condensed water droplets. The dispersion of the relatively small condensed water droplets is treated the same as that of the vapor plume, while the transport of the drift droplets is the same as that employed for the salt deposition calculations. The FOG model performs an energy balance on the surface or volume of interest. Ice formation is assumed to occur only when the ambient temperature is less than $0^{\circ} \mathrm{C}$. Under certain conditions, the ice buildup rate can be limited by heat transfer considerations. This occurs when the latent heat of fusion released during freezing results in a surface temperature equal to $0^{\circ} \mathrm{C}$. Since any additional ice buildup would increase the surface temperature above $0^{\circ} \mathrm{C}$, such ice formation would not be possible.

In the case of ice formation on horizontal ground-level surfaces, ice buildup is assumed to result only from the fallout of the drift droplets. Since the much smaller condensed water droplets have negligibly small settling velocities, the condensed water droplets are assumed not to impinge on flat horizontal surfaces. The heat transfer limitations on ice formation on flat horizontal surfaces are basicaliy the same as those discussed above for flat vertical surfaces, with the exception of melting due to solar radiation, which 
is not included because unshielded flat horizontai surfaces are always exposed to solar radiation, whereas vertical surfaces are not.

Elevated visible plumes. The FOG model was used to calculate the frequencies of occurrence of elevated visible plumes over each grid point. The total flux of air through a cross-section of the plume normal to the plume axis is calculated at successive downwind distances. This calculation is made whether the plume is in the rising stage or has reached its maximum height and leveled off. The amount of entrained air is computed as the difference between the total air flow and the air flow leaving the cooling system. The entrained air and the effluent air from the cooling system are assumed to be thoroughiy mixed isobarically, and the thermodynamic properties of the resulting mixture are calculated. A visible plume is predicted to occur if calculations show that the mixed plume is supersaturated.

Drift analysis. The FOG model was used to calculate the transport and ground deposition rate of dissolved solids contained in the entrained drift droplets released from the cooling systems.

Orift deposition analysis by the FOG model involves the following three calculations: the sequential release of the entrained drift droplets from the effluent plume, the subsequent horizontal transport of the drift droplets, and the airborne concentrations and deposition rates at prespecified downwind distances for each wind direction.

It is assumed in the FOG model that the excess water vapor, the temperature excess, the vertical velocity, and the initial concentration of drift droplets follow a Gaussian distribution normal to the plume axis. The plume is assumed to extend two standard deviations (i.e., two sigma $y$ and two sigma z) away from the plume axis. The release of the entrained droplets at any point within the plume depends on the relative magnitudes of the terminai fall velocity of the droplets and the vertical velocity of the air in the plume. At each downwind distance under consideration, these two velocities are compared for the various size categories of plume droplets, and a fraction of the droplets is released. This process is repeated until all droplets are released from the plume. When the plume 
reaches its maximum height, the vertical velocity throughout the plume is zero. Droplets released from the plume fall first through the plume air, and then through the ambient air beneath the plume. This drift is carried downstream by the ambient wind until it is deposited on the ground. The rate of fall of the drift droplets is proportional to their terminal velocity, which in turn is dependent on the droplet size. The droplet size can change by evaporative processes, which depend on the physical and transport properties of both the liquid droplets and the surrounding air. For relative humidities below 50 percent, complete evaporation of the drift droplets to dry particles is possible. A stepwise procedure is employed in the FOG model to compute the trajectory of the droplets by considering the above effects.

Drift deposition rates and airborne concentrations of dry drift particles are calculated for each of the sequential meteorological records included in the two-year meteorological data set. These are then summarized to obtain the deposition ( $16 / a c r e-y r)$ and airborne concentrations of dry particles (micrograms $/ \mathrm{m}^{3}$ ) over the entire grid. The calculation of airborne concentration is made at a height of $2 \mathrm{~m}(6.5 \mathrm{ft})$ above the ground surface.

9.1.3.3.2 LVPM Model. Cooling tower plume rise and moisture content were calculated with the LVPM (USGS 1981), a one-dimensional numerical model capable of predicting the detailed behavior of plumes for a given meteorological condition. The numerical technique utilized in the LVPM model is described by equations for the motion of a quasi-incompressible fluid. Based on the assumption of steady-state plume, the model simulates a continuous efflux into a horizontally homogeneous atmosphere. This assumption simplifies the numerical computation and leads to practical and economical application.

The LVPM model was used to calculate plume rise and plume moisture content, i.e., vertical profiles of temperature, vertical velocity, and moisture through the plume at selected downwind distances for average summer and winter conditions. In addition, variations of plume rise as a function of ambient atmospheric stability are calculated. 


\subsubsection{Air Quality}

Nonradiological air quality measurements in Benton County, where the site is located, are the responsibility of the Tri-County Air Pollution Control Authority (TCAPCA). As a result of the sma11 quantities of nonradiological air pollutants to be released to the atmosphere, the Applicant will not conduct a preoperational air quality monitoring program.

The primary air quality nuisance at the Hanford site area is fugitive dust. Thus, only total suspended particulates (TSP) are monitored by the TCAPCA at the Hanford Site. During the 1980's, the annual mean average of TSP at the Hanford Site was below the federal standard of $60 \mathrm{micrograms} / \mathrm{m}^{3}$. The highest 24-hour measurement at the Hanford Site was 279 micrograms $/ \mathrm{m}^{3}$ on July 9, 1980 (TCAPCA 1981). The sample mainly consisted of volcanic ash from the Mt. St. Helen's eruption that was being resuspended as windblown dust into the atmosphere. During the day of the eruption (May 18, 1980), however, Sehme) (1981) reported an average concentration for respirable particles (less than 5.5 micrograms diameter) of $1430 \mathrm{micrograms} / \mathrm{m}^{3}$.

\subsubsection{Land}

\subsubsection{Geology and Soils}

No geological or soil studies have been made specifically to determine the environmental impact on these factors of construction and operation of the facility. Detailed analyses of soil engineering properties at the site have been carried out for the purpose of determining safety-related design parameters. These analyses and the results are reported in Section 2.5.4 of Puget Sound Power and light Company (1981b). Detailed geological studies have also been carried out in the Site Area and are reported in Section 2.5 .1 of the same document. There are no indications from any of the geological or soils studies that construction or operation of the plant would have an adverse environmental impact on these factors.

\subsubsection{Land Use and Demographic Surveys}

Land use information and data presented in Section 2.1 of Puget Sound Power $\&$ Light Company (1981a) were obtained by such means as onsite visits, personat communications with cognizant persons and organizations (e.g., agricultural extension agents and relevant county and state agencies), publications, 
maps, and aerial photographs. The list of numbered references in Section 2.1 of the same document indicates the specific sources of information and data contained in the text, tables, and figures.

Demographic analyses were conducted using traditional scientific demographic methods. The list of numbered references for Section 2.1 of Puget Sound Power \& Light Company (1981a) indicates specific sources of demographic information and data.

Population estimates are based on the latest available data. All population estimates and projections were calculated with the approximate centroid of the facility reference site as the geographic reference. For the analys is of the popuiation within $16 \mathrm{~km}(10 \mathrm{mi})$, a house count was conducted in 0ctober, 1981. For the estimate of the population between 16 and $80 \mathrm{~km}$ (10 and $50 \mathrm{mi}$ ), data from the 1980 U.S. Census were analyzed for blocks, tracts ard enumeraticn districts.

Population projections from 1990 through 2030 were based on county forecasts for the states of Washington and Oregon. For the census years 1990 and 2000, existing projections were directly employed. For the years 2010 , 2020 and 2030 , projections were made following a logic similar to that of the U.S. Census projections through 2030 for the nation as a whoie. It was assumed that after the year 2000, stabilization of population growth will gradually occur within a $80 \mathrm{~km}(50-\mathrm{mi})$ radius of the site. For each of the census years, from 2010 through 2030, it was estimated that the rate of population increase in each county would decline by one-half of the rate prevalent in the previous decade. For each county within $80 \mathrm{~km}(50 \mathrm{mi})$, this procedure results in a stabilized population by the year 2030 .

Distribution of population growth was assumed to be equal throughout each county, with the major exceptions of the Benton and Franklin metropolitan counties, which are nearest to the site. Based on interviews with local planners and city officials, and review of land use and annexation plans, a number of areas within the Tri-Cities were identified as having high growth potential. Those areas include the Horn Rapids Triangle in Richland, the Horn-Williamette area in West Richland and northwest Pasco near the new I-182 bridge. Accordingly, for the period 1980-2000, appropriate enumeration 
districts and census blocks were projected to grow at approximately twice the rate of the remainder of the metropolitan area. Several of these areas were projected to sustain growth from 2000-2010, but after 2010 ali areas were projected to stabilize and generally parallel the overall metropolitan area growth rates.

\subsubsection{Preoperational Ecological Programs}

This section describes the preoperational program designed to assess the terrestrial ecological characteristics of the site, with primary reference to important terrestrial species. A species was considered important as defined in Regulatory Guide 4.2, Rev. 2 (U.S. NRC 1978). Species listed as endangered, threatened, or sensitive, and species of special interest as defined by the Washington Natural Heritage Program were considered important species.

The monitoring program was designed to identify preoperational ecological conditions so that specific environmental changes induced by the facility coutd be recognized and assessed. The program was divided into three stages: preapplication, site preparation and construction, and preoperational. Preappication studies were designed with these specific objectives:

- describe the terrestrial biota from a regional and site-specific perspective

- determine which important species might occur within the study area, and verify occurrence whenever possible

- identify important species or areas of special concern that may be affected by the facility.

Site preparation and construction monitoring will expand upon the important conclusions of preapplication monitoring, and will continue until piant construction is completed. The objectives of this monitoring effort are:

- determine the actual distribution of important species within the site and associated areas

- monitor abundance and/or habitat usage of species indicated above

- estimate the impact of site preparation and construction upon plant or wildlife species and/or habitats 
- describe potential mitigation measures, if necessary, to ameliorate and/or compensate for adverse terrestrial impacts.

Preoperational monitoring is the final stage before operation and is designed to provide the data necessary for evaluating any changes to the terrestrial environment arising from facility operation. In many instances, the previous monitoring programs will provide the necessary data base.

9.1.4.3.1 Preapplication Monitoring. The vegetation and wildife of the Hanford Site has been thoroughly studied in connection with the activities of the DOE (and its predecessor agencies), the Supply System and the U.S. Army Corps of Engineers (riparian zone only). The preapplication monitoring program was designed to confirm that the area likely to be affected by the facility is similar to areas already described in the literature, and therefore, impacts will be predictable based primarily on data from previous studies. Field surveys also were conducted to check for the occurrence of important species, as defined in NRC Regulatory Guide 4.2 (U.S. NRC 1978).

Relevant 1 iterature is listed in Section 2.2 Puget Sound Power \& Light Company (1981a). The area studied was the site and associated areas, which encompassed the site and the railroad, transmission line, pipeline, and access road corridors. To assure proper coverage, the corridor width was assumed to be $300 \mathrm{~m}(1,000 \mathrm{ft})$.

Qualitative field surveys of vegetation were conducted in April-0ctober, 1981. Each area was searched on foot by a plant taxonomist/ecologist to identify any threatened, endangered, or other sensitive plant species or habitats and to document their presence, local and regional abundance, sensitivity, and relationships to the site.

A qualitative field investigation of wildije was conducted to: assure applicability of existing information to the site and associated areas, locate specific areas used by important wildlife species, and search for unique wildife features within the area to be directly impacted by site preparation and station construction. This field investigation was conducted in May, June, and July 1981. The site and associated areas were traversed in a systematic manner to record all signs of wildlife and observations. 
The facility intake/discharge location and the old Hanford townsite were studied in detaj]. The townsite is unique within the Hanford Site because of the trees planted decades ago by early settiers for shade and fruit production. Since the pipeline corridor transects the townsite, a reconnaissance of the entire area was conducted.

Most of the trees within the townsite were checked for signs of wildiffe use. Trees with significant signs of wildlife use (e.g., raptor nests) were mapped for future identification. An attempt was made to ascertain if nests were active and which species were using them. If possible, nest success was determined. In addition to trees, all other remaining features of the townsite (i.e., the old schoolhouse, pumphouse, and miscellaneous remnants from the town) were checked for signs of wildlife use.

The remaining important feature of the townsite was the riparian habitat along the Columbia River. This area was also checked for signs of wiidlife use, especially breeding and feeding activity of hydrophilic species. The extent and qualjty of riparian habitat available to wildlife was noted on aerial photographs.

Sections 4.1, 4.2, and 4.5 of Puget Sound Power \& Light Company (1981a) describe mitigation measures to be utilized to minimize environmental impact. The construction impact control program described in Section 4.5 of the same document is divided into three categories: construction control, environmentai monitoring, and restoration. As indicated in Section 4.5, a detailed description of the elements of the construction impact control program will be submitted to EFSEC for its review and approval prior to commencement of site construction activities.

\subsection{Site Preparation and Construction Monitoring. As previously} mentioned, the site preparation and construction monitoring effort will determine the distribution of important species within the site and associated areas and monitor the abundance of these important species or areas of special concern: bald eagles, long-billed curlews, and the old Hanford townsite. This monjtoring effort will begin sufficiently in advance of the start of construction activities to provide the preconstruction data base necessary for assessing the extent of construction impacts. Studies will continue until construction effects have subsided or the extent of impact has been satisfactorily 
appraised. The following describes the methodologies for each facet of the monitoring program.

Important plant species. The iisting status of persistant sepal yellow cress, Rorippa calycina, var. Columbiae, will be monitored in case of a change from its present status as a candidate for listing as threatened or endangered on the federal list, and threatened on the Washington State 1ist. The area occupied by the population along the riparian zone will be determined during the time of low water levels in the spring. The percentage of the population which will be disturbed by construction will be estimated. An additional check of the population during the low water period in late summer or fall will be conducted to help determine the ability of the species to resist disturbance.

Important Wildlife Species. A reconnaissance of the site and associated areas will occur twice each spring and winter to map the distribution of important species. Occurrence data will be recorded and no effort will be made to estimate population levels. The objective of this investigation is to determine if the distribution of important species changes during construction activities.

Bald eagles. Bald eagles primarily are found during the winter at the old Hanford townsite. This area will be surveyed monthly during the winter to detenmine the number of eagles present. An attempt will be made to determine habitat usage within the site and associated areas. Observation regarding prey selection, preferred roosting sites and sensitivity to disturbance will be recorded.

Long-billed curlews. Curiews are found during the breeding period (March-june) and at least two pairs have been found within the site and associated areas. Potential nesting habitat within or adjacent to the site and associated areas will be surveyed monthiy (during the breeding period) for signs of breeding activity. Territories actively defended will be mapped and nesting success will be determined whenever possible. In addition, the breeding chronology will be monitored to assist in scheduling construction activities. 
oid Hanford townsite. The townsite is an area of special concern for wildiife. The objective of this portion of the monitoring program is to deveiop a data base on wildijfe occurrence and monitor the impacts of construction activities upon wildije at the townsite. Raptors, landbirds, and deer will be monitored.

Wildijfe abundance will be monitored in the spring and fall/winter to sample breeding adults and winter residents, respectively. Spring sampling will occur in April and May; fall/winter sampling will occur from November through lanuary. The procedures for this monitoring effort are outlined in Table 9.14 .

\section{TABLE 9.14. Summary of Procedures for Monitoring Wild] ife Occurrence at the 01d Hanford Townsite (PSP\&L 1981a)}

Sampling Period

Species/Group

Raptors

Landbirds

Deer

Spring
Method: Biweekly counts of
nesting raptors.
Data: Breeding population,
breeding chronology, nest
location, clutch size and
number fledged.

Method: Biweekly direct counts along predetermined strip transects. Data: Relative abundance and species diversity

Method: BiweekTy spotlight surveys and dawn counts. Oata: Number of deer using townsite for breeding and fawn production (if possible).
Fall/winter

Method: Monthiy direct counts of winter residents Oata: Occurrence.
Method: Monthly reconnaissance. Data: Species diversity of winter population.
No surveys planned, but deer observations incidental to other surveys will be recorded.

9.1.4.3.3 Preoperational Monitoring. Site preparation and construction monitoring will supply an adequate data base for monitoring the effects of plant operation on Rorippa calycina, var. Columbiae, bald eagles, long-billed curlews, and wildlife at the old Hanford townsite. Monitoring other wildlife species or wildife use areas is not deemed necessary at this time. 
Data regarding the land area altered or rendered unsuitable for biological productivity will be measured near the end of construction. A map showing all areas of disturbance will be developed.

The Supply System is studying the effects of drift on vegetation and wildife. The drift effects associated with the facility do not require monitoring and will be less than those found at the Supply System units because of a much reduced particulate ratio. Therefore, the Supply System study will serve as a conservative estimate of the drift effects which might result from the facility.

\subsubsection{Radiological Monitoring}

The NPR preoperational radiological environmental monitoring program (REMP) is designed to provide measurements of radiation and radioactive materials in those exposure pathways and for those radionuclides that are expected to lead to the highest radiation exposures to individuals from the operation of the NPR. The preoperational program objectives are to measure background levels and their variations in exposure pathways surrounding the site, to train personnel, and to evaluate procedures, equipment, and techniques.

The facility preoperation REMP is based on a combination of airborne, terrestrial, and aquatic monitoring stations. Airborne sample stations have been chosen based on the projected population distribution around the site, adjacent land use, and meteorological data presented in Chapter 2 of Puget Sound Power \& Light Company (1981a). The area within a 16-km (10-mi) radius of the site is of primary interest in the terrestrial monitoring part of the program. Attention is given to the area of Franklin County that uses Columbia River water for irrigation and is in the prevailing downwind direction.

Aquatic sampiing locations have been chosen based on the need to determine the facility's impact on the aquatic environs separately from other facilities on the Hanford Site.

Table 9.15 describes the sample type, approximate location, sample collection, and analyses to be performed on each sample. Analytical techniques will be used such that the detection capabilities in Table 9.16 are achieved. Figure 9.5 and 9.6 show the approximate location of the stations. 

JABLE 9.15. Radiological Environmental Monitoring Program
(PSP\&L 1981a)

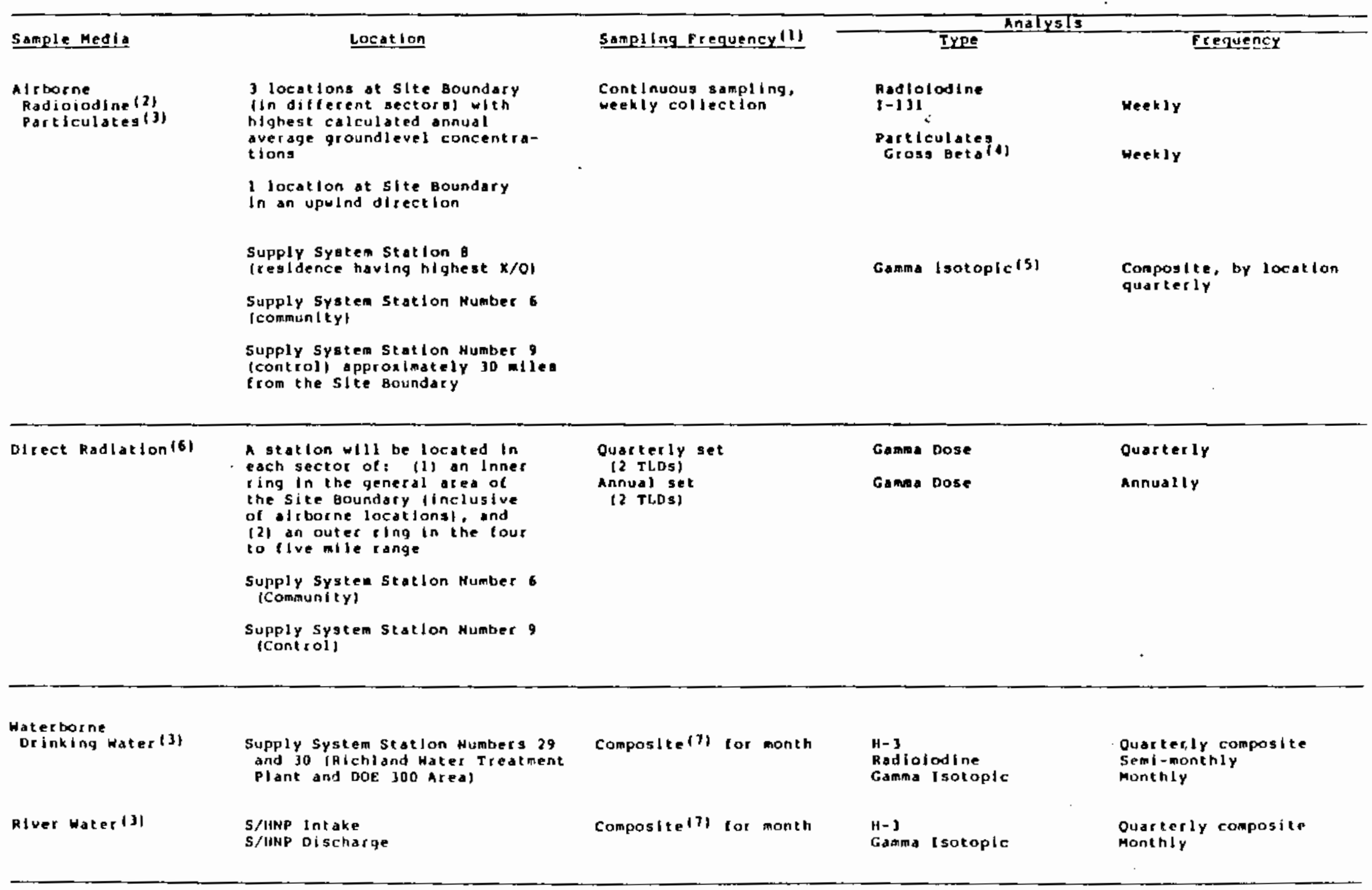


TABLE 9.15. (contd)

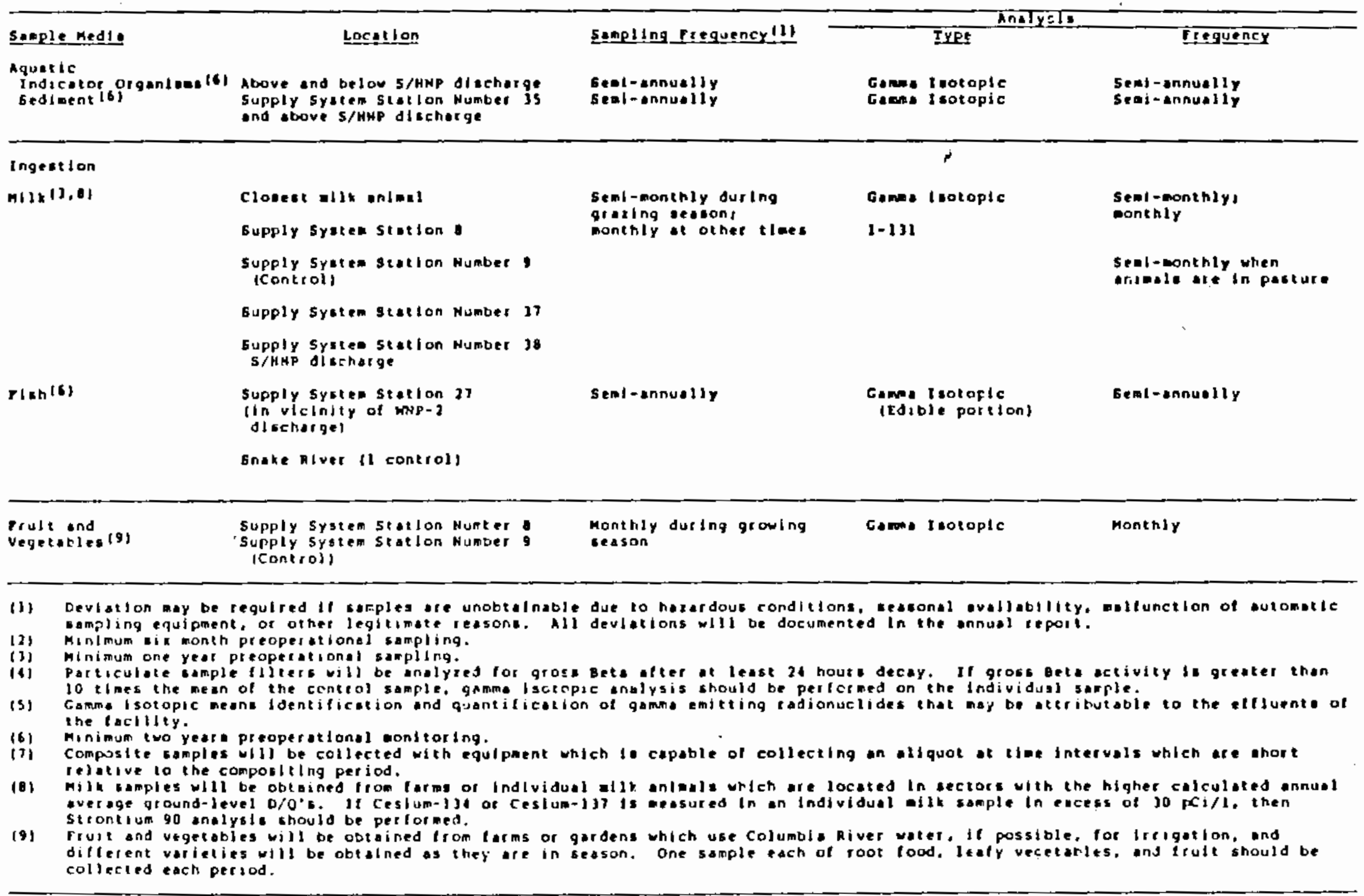


TABLE 9.16. Maximum Value for the Lower Limit of Detection (LLD) (a)

(PSP\&L 1981a)

\begin{tabular}{|c|c|c|c|c|c|c|}
\hline Analygis & $\begin{array}{c}\text { Macer } \\
|x|_{1 / 1}\end{array}$ & $\begin{array}{c}\text { Atrborne } \\
\text { partlcul bete } \\
\text { or Gat } \\
\text { IRCL/al }\end{array}$ & $\begin{array}{c}\text { Pish } \\
\text { (pci/kg wet) }\end{array}$ & $\begin{array}{c}\text { Midd } \\
(0 \times 1 / 1\}\end{array}$ & $\begin{array}{c}\text { Vegetation } \\
\text { (pCl/kg, =et) }\end{array}$ & $\begin{array}{c}\text { Sedigent } \\
(\mathrm{xe} 1 / \mathrm{kg} \text { d dry) }\end{array}$ \\
\hline 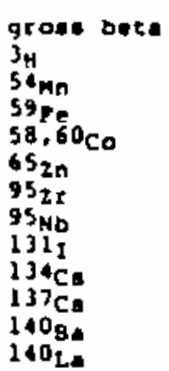 & $\begin{array}{r}4 \\
2,000 \\
15 \\
30 \\
15 \\
30 \\
30 \\
15 \\
25 \\
15 \\
16 \\
60 \\
15\end{array}$ & $\begin{array}{l}7 \times 10^{-2} \\
5 \times 10^{-2} \\
6 \times 10^{-2}\end{array}$ & $\begin{array}{l}130 \\
260 \\
130 \\
260\end{array}$ & $\begin{array}{l}1 \\
15 \\
18 \\
60 \\
15\end{array}$ & $\begin{array}{l}60 \\
60 \\
60\end{array}$ & $\begin{array}{l}150 \\
200\end{array}$ \\
\hline
\end{tabular}

Note: This 1 ist doet not mean that these nuclides are to be detected and seported. Other peaks whlih are teasursble and ldentiflable, together with the above nuclides, shall alao be identified and reported.

athese detection capabilities are tabulated in teras of the lower linita of detection (LLDa). The LLD is defined, far purposes of this qulde, a the sallest concentration of radioactive asterbal in a ample that will yield net count (above oysten background) that wil be detected uleh $95 \mathrm{l}$ probability with only 50 probability of falgely concluding that a blank obatrution represente a real- agnal.

Por a particular aeasurement aygtea (which asy Include radiochenical aeparation),

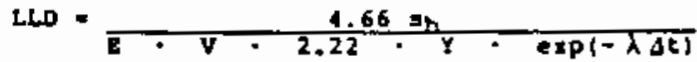

where

LLD 1a the lower limit of detection as defined above las pci per unit wase or volune)

sb 1: the standard deviation of the backqround counting $r a t e$ or of tha counting rate of a blank anple as appropriate fav counts per winutel.

E 1a the counting effletency (as counta per disintegration).

$V$ ta the anple atze (in units of masa or volume)

2.22 is the number of digintegrations per winute per picocurte.

Y I. the fractional radtochemical yteld (when applicable).

$\lambda$ la the radiaactive decay conetant for the particular tadionuclide.

$\Delta t$ is the elapeed tiae between sample collection and counting.

The value of so uaed in the calculation of the Lid for a particulat measurement aystem ghould be based on the actual obaerved yariance of the background counting tate of of the counting cate of the blank sarples ias appropriatel rather than on an unverified theoretically predicted variance. In calculating the clo toc a radionuclide determined by gama-tay spectronetry, the background ahould include the typleal contributione of other cadionuclides normally present in the asmpies te.g. potalsiug-40 vilk mapl*El.

bled for delinking vater. 


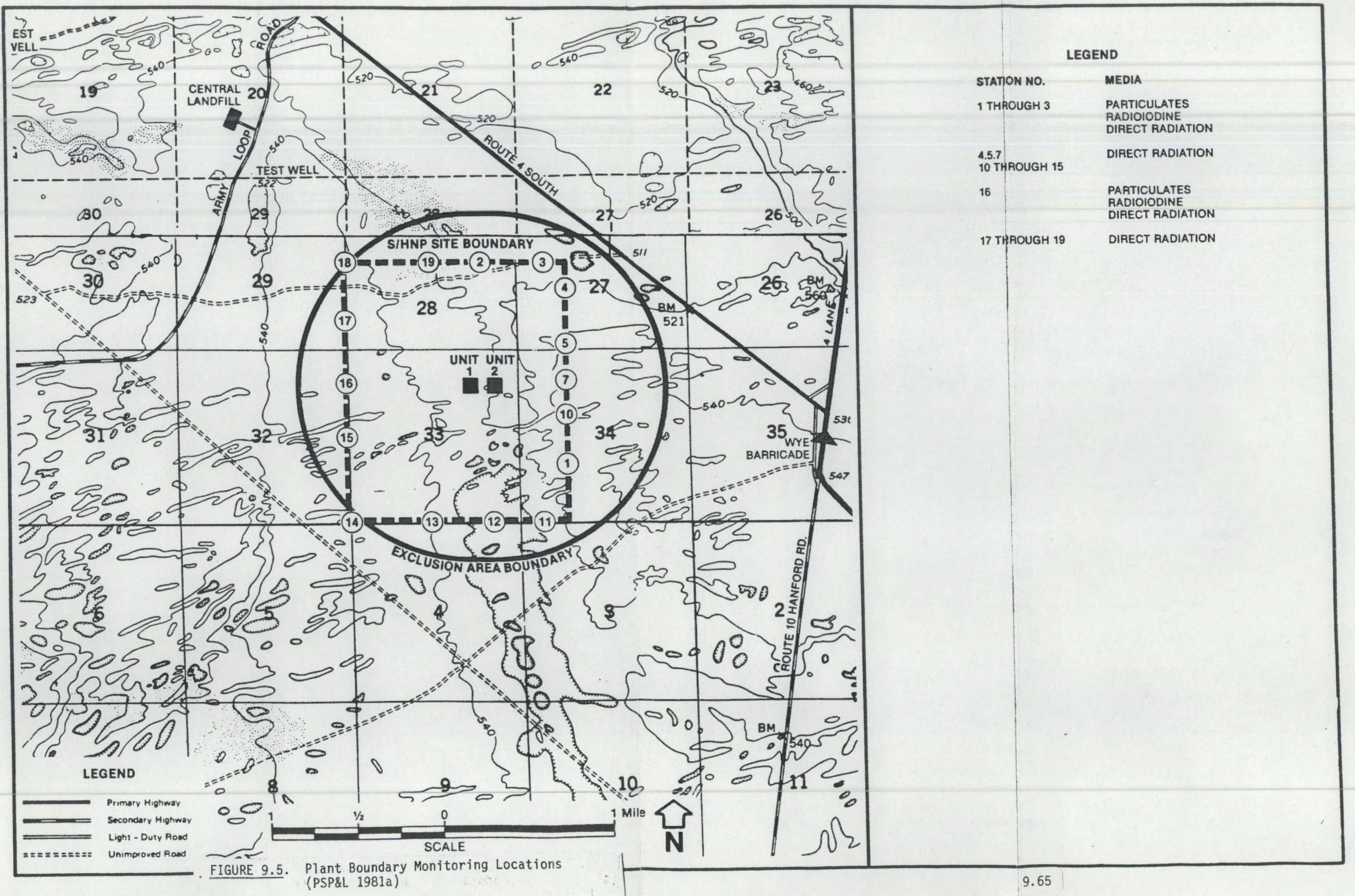





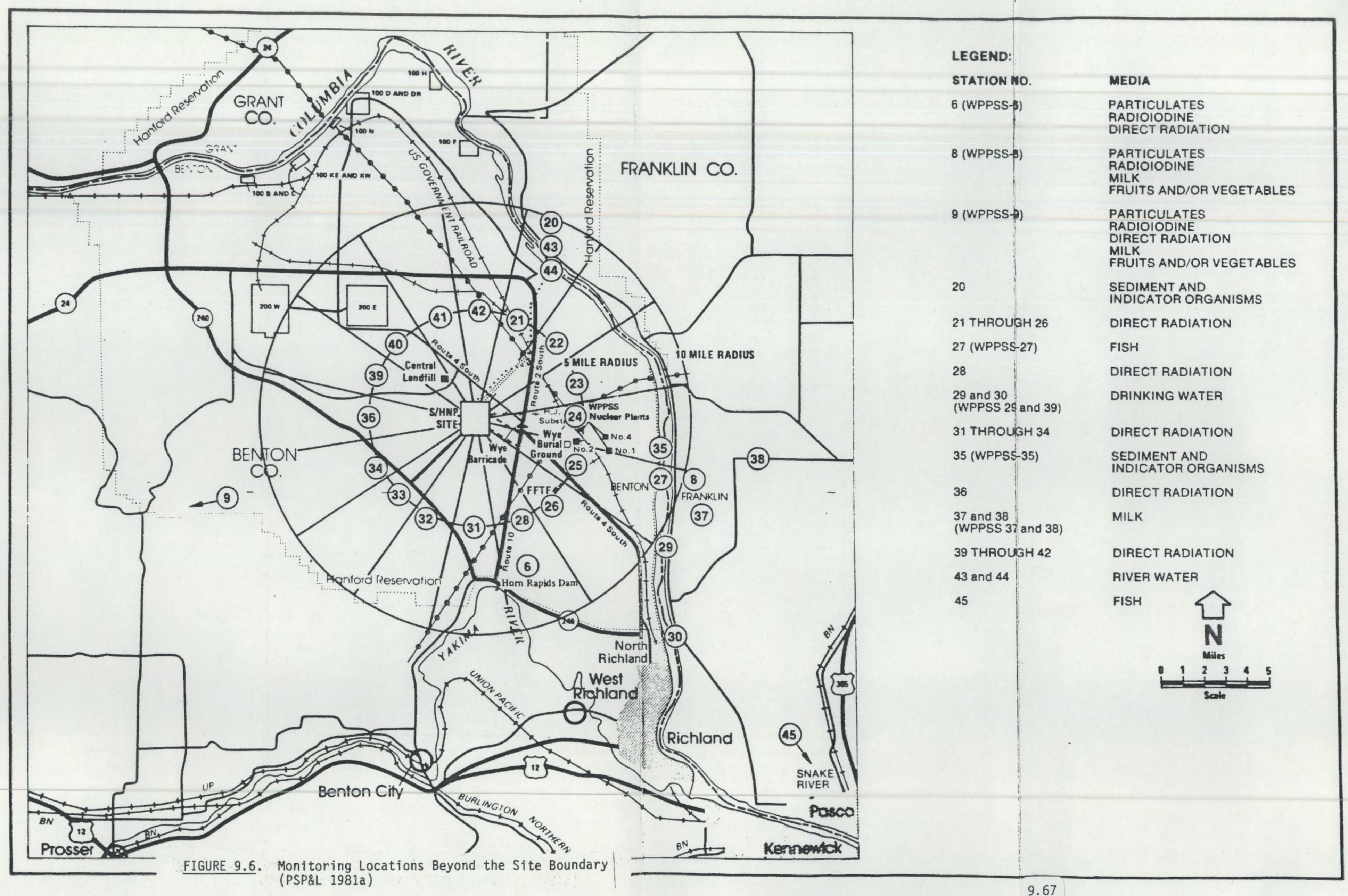



A more detailed discussion of the facility REMP is discussed below:

Radioiodine and particulates. The air sampling network will consist of seven stations. Three of the stations will be located in the vicinity of the site boundary in three different downwind directions. One additional site boundary station will be situated in an upwind direction to monitor potential impact from the Hanford Site 200 Area. Three stations from the Supply System program will be used to complete the air monitoring network. The Supply System Station 6, located approximateily $14 \mathrm{~km}$ (9 mi) SSE from the facility, is situated in the vicinity of a proposed residential community. Supply System Station 8 is in the general vicinity of the nearest farm approximately $18 \mathrm{~km}$ (11 mi) ESE from the facility. The control station for this monitoring program will be Supply System Station 9 located about $40 \mathrm{~km}(25 \mathrm{mi})$ west/southwest (WSW) from the facility.

Airborne iodine and particulates will be sampled by continuous low volume air samplers with a flow rate of approximately $1 \mathrm{ft}^{3} / \mathrm{min}$. Radioiodine will be collected via charcoal canisters fitted in-line with the glass fiber filter for particulate collection.

The particulate filters will be changed weekly and analyzed for gross beta (beta analysis will occur no sooner than 24 hours from the time of collection to allow for radon and thoron daughter decay). Quarterly composited filters, by location, will be analyzed for gama-emitting nuclides. Individual weekly filters will have gamma isotopic analysis performed only if gross beta results are ten times the mean of the control location. Charcoal canisters will be analyzed weekly for iodine-13I.

Direct radiation. Direct radiation levels will be measured by a thermoluminescent dosimeter (TLD) system consisting tentatively of 34 stations. The exact number and location of stations will depend upon data on prevailing wind directions, station accessibility and the existing TLD stations maintained by the Supply System and PNL for DOE.

A TLO station will be located in each sector on an inner ring in the general area of the site boundary (inclusive of airborne locations) and an outer emergency assessment ring in the 6 to $8 \mathrm{~km}$ (4 to $5 \mathrm{mi}$ ) range. Data from the Supply System Stations 6 (community) and 9 (control) will be used to complete the sampling network. 
Duplicate TLD sets will be placed at each location. One set will be exchanged on a quarterly basis, the other set of dosimeters will be collected annually.

Groundwater. Groundwater will not be used for drinking or construction activities at the facility. Groundwater on the Hanford Site is extensively monitored by PNL; during 1982, 324 wells were sampled at various times for radionuclide and chemical contaminants (Eddy, Prater and Rieger 1983). As a result of continual groundwater monitoring in the Hanford Site, and the fact that the facility will not utilize groundwater, the facility preoperational REMP will not include this medium as part of its program.

Columbia River water. River water will be sampled at the facility intake and discharge facilities. The intake water will be sampled to identify the isotopes and concentrations present prior to use by the facility. The water from the discharge line will be sampled prior to dilution by the Columbia River, and analysis will identify the isotopes and their concentrations which may be due to the facility operation. Similar samples will be taken immediately downstream from the facility discharge. The Columbia River will be sampled at the first downstream user. The water will be sampled, prior to any treatment or mixing, in the vicinity of the river water intake.

Drinking water. Drinking water will be monitored utilizing the data from the Supply System's stations at the DOE 300-Area and at the Municipal Water Treatment Plant for the City of Richland.

Sediment. Sediment samples will be collected above and below the facility discharge structure. Due to the velocity of the Columbia River in the vicinity of the discharge, sedimentary deposits are minimal. Data from the Supply System Sediment Station 35 will be used to evaluate potential radionuclide adsorption to sediments below the facility discharge.

Indicator organisms. Periphyton, moss, or rooted macrophytes will be sampled where available near the sediment station location. These indicator organisms will be analyzed to determine if radioactive effluents released from upstream users and potentially from the facility discharge are accumulated by the biota. 
Fish. Fish will be collected from locations near the facility discharge utilizing, in part, available data from the Supply System. The species selected will include resident fish and/or those fish which are seasonally available. A station at the lower Granite Dam on the Srake River, utilized by the Supply System REMP, will be used as a control station. Milk. Milk samples will be obtained from farms or individual milk animals which are located in sectors with the higher calculated annual average atinospheric dilution factors. The facility REMP will utilize data from the Supply System Stations 8, 9, 37, and 38. Milk Station 9 is the control location.

Food products. Data from the Supply system food product sampling network (Suppiy System Stations 8 and 9) witl be used by the facility REMP.

The type of analysis to be performed for the various media was chosen to provide measurements of radionuclides from which the population doses may be estimated or verified to be below that specifjed in Appendix I of 10 CFR 50. In some cases, the analysis provides a trend indicator and will signal the need to perform additional specific analyses of individual samples. The frequencies selected are those expected to minimize the effect of day-to-day variations and provide an adequate quantity of samples to meet minimum sensitivity requirements of Table 9.16. The samples will provide statistically valid data which will be compared to subsequent results in order to detect variation from expected values.

The facility REMP will employ quality control procedures to ensure that samples are collected and prepared for measurement in a thorough, concise manner. Instrumentation to measure radioactivity will be state-of-the-art technology at the time the program begins. The analytical laboratory wili be required to meet internal quality control standards and to participate in an inter-laboratory quality control prograin. The internal quality control analyses will include spikes (samples to which known activity is added), duplicate samples and blanks (samples free of activity). The results of all quality control analyses will be included in each progress and/or semi-annual report. 
The facility preoperational REMP will be instituted two years prior to plant operation. The duration of the facility preoperational REMP for specific media will be as follows:

Two Years

Direct radiation

Fish

Vegetation

Sediment
One Year

Airborne particulate

Milk (except iodine)

River water

Drinking water

\subsection{OPERATIONAL MONITORING PROGRAMS}

\subsubsection{Radiological Monitoring}

The REMP is designed to meet federal and state requirements.

The facility's operational REMP will be an extension of the preoperational REMP described in Section 9.1.5. A comprehensive radiological monitoring program will be conducted for the first 3 years of facility operation (or the period corresponding to the maximum fuel burnup in the initial core cycle). The scope of monitoring in subsequent years will be determined based upon the results of the 2-year preoperational program and the initial 3 years of facility operation. If it can be demonstrated that the concentrations of radionuclides and doses to organisms associated with a particular pathway are sufficientiy smali, the number of samples and sample types may be reduced. An adequate program for measuring radiation levels and radioactivity in the facility environs will be maintained on a continuing basis to assist in verifying anticipated radioactivity concentrations and related public exposure.

To the extent possible, the facility's REMP will be interfaced with the monitoring program established for the Supply System nuclear projects 1, 2, and 4. The operational monitoring program will also utilize data from the DOE and Washington State radiological surveillance programs. The PML has conducted a comprehensive annual radiological monitoring program of the Hanford Generating Plant and surrounding environs for more than 20 years. The Washington State Division of Social and Health Services collects and analyzes samples of Columbia River water, air, milk, and shellfish at a number of locations 
relevant to the facility (Section 9.3.4). Together with the facility monitoring program, this extensive data base will be used to monitor:

- important pathways for the anticipated types and quantities of radionuclides released from the plant

- potential buildup of long-lived radionuclides in the environment, and the physical and biological sites of accumulation that may contribute to human exposure

- potential radiation exposure to important plants and animals

- correlations between levels of radiation and radioactivity releases from plant operation.

\subsubsection{Chemical Effluent Monitoring}

The water quality monitoring program will ensure that the quality of the receiving waters, the Columbia River, is maintained at the level specified by state and federal standards during construction and operation. Sampling will be done on effluents from the various waste streams entering the facility's discharge line. The effluent plume will also be sampled. The operational monitoring program frequency and methods of analysis will be basically those of the preoperational monitoring program described in Section 9.1. Detailed descriptions of sampling locations, frequencies and analytical techniques are included in that section.

Additional sampling locations in the facility discharge and in the major axis of the discharge plume will be established as part of the operational sampling program as necessary. Effluent in the discharge pipeline will be sampled weekly during the first few months of operation until a satisfactory balance of chemical additions is established. It is expected that during the initial year of operation, sufficient data will be gathered to characterize the effluent so that the sampling frequency may be adjusted appropriately. The sampling frequency then will be reduced to biweekly or monthly for a period of one year. Each sample taken for analysis will consist of a 24-hour composite to ensure a representative sample. Expected chemical waste characteristics of the discharge are given in Table 3.6-5 of Puget Sound Power \& Light Company (1981a). Analysis will be for parameters which: 
- the preoperational program has shown to exist in the intake water

- are expected to be part of the discharge (see Section 3.6 of Puget Sound Power \& Light Company 1981a);

- are required by current state or federal regulations.

A detailed chemical study to define the extent and nature of the effiuent plume will be performed during the first few months of operation. The sampling scheme will be a three-dimensional grid blanketing the region of the plume, with control locations sampled directly upstream from the facility's discharge point. The samples collected will be analyzed for the parameters identified above. This study will monitor changes in plume structure and water quality. From the results, positions for monthly and biweekly sampling locations in the major axis of the plume will be determined as part of the overall operational water quality monjtoring program. Knowledge and experience gained during the first year's sampling program will be the basis for the ongoing water quality and chemical discharge monitoring studies.

The operational program will be coordinated with the existing water quality monitoring conducted upstream at Vernita Bridge (RM 388.1) by the USGS, and similar discharge monitoring conducted for WNP 1, 2, and 4 downstream of the facility, as well as with the USGS program at Richland (RM 338.9).

\subsubsection{Thermal Effluent Monitoring}

The operational program for thermal effluent monitoring is part of an integrated chemical and hydrological study of the discharge and receiving waters. Many of the samping locations are the same as have been identified in the preoperational program in Section 9.1 and the additional three-dimensional plume monitoring stations required for water quality monitoring in Section 9.2.2. The thermal monitoring program consists of instantaneous and continuous monitoring studies. The instantaneous temperature monitoring program functions in conjunction with the operational water quality program to provide biweekly to monthly measurements. Seasonal studies of the temperature profiles in the Columbia River near the facility's discharge point will monitor the extent of the thermal plume. 


\subsubsection{Continuous Thermal Monitoring}

Continuous thermographs will be placed in the facility's intake and discharge points. Temperature measurements will be made at seven locations. This monitoring grid will tie into two existing continuous thermographs maintained by USGS at Vernita Bridge and the City of Richland water supply intake as well as with proposed continuous thermograph at the intake of WNP 1/4.

\subsubsection{Instantaneous Thermal Monitoring}

The thermal and water quality monitoring programs undertaken during facility operations will be integrated. Instantaneous temperature measurements will be routinely made at all water quality sampling locations. During initial facility operation, thermal plume definition will be made in conjunction with the chemical water quality studies outlined in Section 9.2.2 over a three-dimensional grid.

\subsubsection{Meteorological Monitoring}

The operational meteorological monitoring program will be a continuation of the preoperational program discussed in Section 9.1.3.1.

\subsubsection{Ecologicai Monitoring}

The ecology of the Hanford Site has been under continuous study since 1943 by state and federal agencies (Section 9.3). The operational and preoperational program will supplement the accumulation of scientific data by acquiring additional biological information.

The operational monitoring program for the facility will be a continuation of the preoperational program (discussed in Section 9.1.1). The operational program will be conducted for one year, after which an evaiuation will determine the necessity of continuation or alteration.

Additional monitoring programs will be conducted during the first year of operation to evaluate the incidence of impingement and entrainment in the plant intake and cooling water supply system. 


\subsection{RELATED ENVIRONMENTAL MEASUREMENT AND MONITORING PROGRAMS}

A number of environmental measurement and monitoring programs may be related to programs that would be conducted if the facility were sited at Hanford. These are listed in the following subsections.

\subsubsection{Hydrological and Water Quality Studies in Progress}

Agency

U.S. Geological Survey, Tacoma District office

U.S. Geological Survey, Tacoma District OFfice

U.S. Geologica] Survey, Tacoma District Office

U.S. Department of Energy, Richland Operations Office

U.S. Department of Energy, Richland Operations Office
Program

Continuous water stage and discharge measurements of the Columbia River below Priest Rapids Dam (RM 394.5) (USGS 1974).

Continuous water temperature measurements of the Columbia River at the City of Richland water supply treatment plant $(R M 338$ ) and at Vernita Bridge (RM 388.1) ${ }^{(a, b)}$.

Monthly to quarterly monitoring of National Stream Quality Accounting Network Stations at Vernita Bridge and City of Richland pumping plant intake. Parameters measured are: conductance, $\mathrm{pH}$, turbidity, dissolved oxygen, fecal coljform, hardness, major cations and anjons, alkalinity, dissolved and suspended solids, dissolved silica, total and dissolved nutrients, metais (total recoverable, suspended recoverable, and dissolved). In addition, at the Vernita Bridge Station, periphyton biomass, chlorophyll a and b and phytoplankton cell counts are conducted.

Weekly $\mathrm{pH}$, turbidity, dissolved oxygen, biochemical oxygen demand, and coliform sampling of the Columbia River at the City of Richland water supply treatment plant (RM 338), 300 Area (RM 345), and Vernita Bridge (RM 388.1), by PNL (Bramson and Corley 1973).

Weekly coliform, fluoride and nitrate sampling of Columbia River at the City of Richland water supply treatment plant (RM 338), 300 Area (RM 345), and 100 Areas (to RM 384), by Hanford Environmental Health Foundation (Schultz 1972).

(a) E. L. Hilty and J. P. Corley, personal communication, Pacific Northwest Laboratory, Richland, Washington, 1975.

(b) Letter from Y. Onishi, Pacific Northwest Laboratory to P. G. Holsted, U.S. Atomic Energy Commission, Columbia River Quality Radionuclide and Sediment Transport, December 11, 1974. 
Agency

U.S. Department of Energy, Richland Operations office

U.S. Department of Energy, Division of Biomedica! and Environmental Research

U.S. Department of Energy, Richland Operations Office

\section{U.S. Army Corps of Engineers} North Pacific Division

Kashington State Department of Ecology

U.S. Envi ronmenta 1

Protection Agency
Program

Monthly to annual groundwater depth and water quality measurements for observation wells on Hanford Site, by PNL and Rockwell. Hanford Operations (Bramson and Corley 1973; Kipp 1973).

Studies by PNL on sediment and radionuclide transport in the Columbia River below Priest Rapids.

Environmental surveitlance of the levels of radionuclide concentrations in Columbia River water, foodstuffs, wildlife, soils and vegetation, and direct radiation on the Hanford Site, by PNL (Sula et al. 1983).

Review of Columbia River and tributaries water resources (U.S. Army Corps of Engineers 1972).

Water temperature, dissolved oxygen, conductivity, color, $\mathrm{pH}$, turbidity, total coliform bacteria and fecal coliform bacteria sampling in the Columbia River at Highway 24 Bridge near Vernita (RM 388.1) (semimonthly during water year 1972, quarterly during water year 1975), and at the Port of Pasco public dock (RM 328.4 (semimonthly December 1971 - September 1972), and occasional biochemical oxygen demand and streamflow determinations at both sites. Sampling of additional 21 parameters at Vernita Bridge during water year $1972^{(d)}$. Data also available through STORET (U.S. EPA 1976).

Miscellaneous water quality measurements in STORET data systern for period 1957 to present at following Columbia River locations between McNary and Priest Rapids Dams:

RM 292.0 (McNary Dam), 292.4, 292.5, 293.0, 324.9 (above mouth of Snake River), 326.3, 328.0 (Kennewick-Pasco State Highway 12 bridge), 328.0, 329.0,330.0, 334.7 (below mouth of Yakima River), 388.1 (Vernita Bridge, State Highway 24), 388.5, 395.6, 397.1 (Priest Rapids Dam) (U.S. EPA 1976).

(a) Letter from R. Cunningham, Water Quality Monitoring Section, Washington State Department of Ecology, 0lympia, Washington to A. Brandstetter, Pacific Northwest Laboratory, Rjchland, Washington, May 26, 1976. 


\subsubsection{Ecological Parameters}

\subsubsection{Aquatic Studies in Progress}

\section{Agency}

U.S. Department of Energy, Division of Biomedical and Environmental Research

U.S. Department of Energy, Division of Biomedical and Environmenta! Research

U.S. Department of Energy, Division of Biomedical and Environmenta] Research

\section{U.S. Army Corps of Engineers, Grant County PUD, Chelan County PUD}

Mid-Columbia Studies Comnittee

Grant County PUD

Ephrata, Washington

Grant County PUD Ephrata, hashington

Grant County PUD Ephrata, Washington

\section{Program}

Annual (since 1947) census of the fall chinook salmon spawning population in the Columbia River between Richland and Priest Rapids Dam, by PNL. Weekly aerial observations have provided data to evaluate the fluctuations in spawning populations in this section of the river and examine the relationships between numbers of fish and perturbations in the river (Watson 1970)

Studies on fish behavior in waters whose quality has been altered by various perturbations. Emphasis in this work is on the effects of water level fluctuation on the use of shoreline and shallow water habitats by resident and anadromous fish (PNL 1976).

Studies by PNL on the impact of flow manipulation due to hydroelectric power generation on important fish species.

Studies of upstream adult migrant fish passage over Columbia River dams. These fish counts are generally made from April to October each year.

Studies on Priest Rapids Dam and the Hanford Reach to increase salmon production by assessing mortalities accurately, assessing fish condition and improving survivability past Priest Rapids Dam (Whitney 1981).

Ongoing survey of fall chinook salmon spawning areas on Vernita Bar, downstream of Priest Rapids Dam, from 1978 to 1980 (Weitcamp, Chapman and Welsh 1979, 1981).

Studies of the contribution of Priest Rapids Hatchery fall chinook to the artificial and natural spawning populations near Priest Rapids Dam during 1979 (Young and Arthur 1980).

Studies at Priest Rapids Dam in 1981 to assess fry movements downstream through the forebay and dam (Mid-Columbia Studies Committee). 
Agency

Grant, Douglas and

Chelan Counties PUD's

Grant, Douglas and Chelan Counties PUO's

Washington State Departinent of Fisheries

Washington State Department of Game

U.S. Fish and Wildlife

National Marine Fisheries Service

National Marine Fisheries Service
Program

An assessment of the down-stream migration of juvenile salmonids in the mid-Columbia River (CH2M-Hill 1980).

Evaluation of the effectiveness of water spilling at Wanapum Dam for the passage of juvenile salmon (CH2M-Hill and Washington Department of Fisheries 1980).

Aerial spawning surveys in the Hanford Reach and vicinity. Surveys to determine chinook spawning are conducted from October through November. Carcass recovery of spawning fall chinook salmon occurs on an irregular basis.

Year-round creel census of anglers in the Ringold area, and in the upper Hanford Reach from July to October. Periodic fish sampling and slough surveys are conducted to determine relative abundance of fish species and production of resident fish spawning area.

Studies to determine impact of resident fish populations on salmonid smolt rearing in McNary pool.

Research on timing and abundance of juvenile downstream migrant salmonids at Priest Rapids Dam.

Research on the enhancement of downstream passage of juvenile salmonids at Priest Rapids Dam and other PUD dams on the Columbia River.

\subsubsection{Related Terrestrial Ecology Monitoring Programs} Agency

Grant County PUD
Program

Grant County PUD is conducting a short-term study of the effects of fluctuating water levels on island habitats in the Hanford Reach of the Columbia River. This study will supply little relevant information for the facility; nonetheless, the final report will be

(a) Personal communication of A.D. Every, NUS Corporation, August 1981. 
Agency

Washington Public Power

Supply System

U.S. Army Corps of Engineers

U.S. Department of Energy
Program

Vegetation. Studies in the vicinity of WNP 1,2 , and 4 have been conducted under contract to PNL and Beak Consultants, Inc. These studies are continuing and include vegetation transects and soil and plant chemistry. These studies will provide baseline data for monitoring the effects of drift on the soil and vegetation. These data will be used to determine if drift impacts might potentially occur at the facility (Rickard and Gano 1979 a,b; Glad 1981).

Wildijfe. Studies in the vincity of WNP 1 , $\overline{2 \text {, and } 4}$ have been conducted by Supply System personnel and PNL. These studies documented relative abundance of pocket mice, deer, rabbits, and landbirds. These data will assess the impact of drift on resident wildlife. Studies of deer, rabbits, and landbirds are continuing. These data also will be used to determine if drift impacts might potentially occur at the facility (Rickard and Gano 1979a,b; Nudge 1981).

Studies of the riparian biota were conducted in 1980 under contract to PNL. The issued report is titled "Wildlife Usage, Threatened and Endangered Species and Habitat Studies of the Hanford Reach, Columbia River, Washington." This study evaluated potential impacts of the potential Ben Franklin Oam. Oata presented in this report is directly related to the facility and is cited frequently in Section 2.2.1 of Puget Sound Power and Light Company (1981a) (Fickeisen et a1. 1980).

ALE Reserve. The objective of the Arid Lands Ecology (ALE) Reserve is to quantitatively assess the role of environmental stresses on the structure and function of shrub steppe ecosystems in the northwestern United States. Natural and man-induced stresses have been evaluated for a 10-year period on the ALE Reserve. Widespread stresses studied include drought, fire, cattle grazing, and plowing. Oata regarding habitat stress is relevant to the facility (see Section 2.2.1.6 of Puget Sound Power and Light Company, 1981a). Oata regarding vegetation and wildije provides valuable regional data on the shrub steppe 
that is summarjzed in Section 2.2.1 of the same document.

Vegetation. PNL has conducted vegetation studies on the Hanford Site for several years, including ecological characterization and studies of productivity, succession, fire effects, revegetation, drought response, and uptake of transuranic elements by plants. Some of these were close enough to the facility to provide valuable background information (Section 2.2.1 and footnotes of Puget Sound Power and Light Company, 1981a).

Rockwell Hanford Operations is conducting radionuclide accumulation studies of plant samples, but not ecological vegetation studies. These data are not particularly relevant to the facility.

Wildlife. PNL has conducted many studies on the wild ife of the Hanford Site including habitat requirements, food habits, population ecology, breeding ecology, and radionuclide transport. In general, these studies provide relevant data on the area and often will help monitor wildliff $\hat{f}_{c}$ )mpacts
which may result from the facility.

In addition to the continuing studies at the ALE Reserve, long-term monitoring of certain wildlife populations are being conducted throughout the Hanford Site.

\section{a. Canada Goose Nesting Surveys}

Since 1953, routine yearly surveys of goose nesting on islands in the Columbia River directly across from the Hanford Site have been conducted. Productivity of individual nests on each of 20 islands has been documented and related to natural (qnd man-caused environmental changes.

(a) Personal Communication of R. E. Fitzner, PNL, May 1981.

(b) Personal communication of A. D. Every, NUS Corporation, August 1981.

(c) Personal communication of R. E. Fitzner, PNL, May 1981. 
b. Great Blue Heron Studies

Radionuclide and heavy metal analyses

of excreta collected under a colony

at the islands across from the Hanford

Site have been compared to several other

colonies in the Northwest. This

study enables researchers to examine

the trends in chemical composition

of excreta as they relate to know (b)
contamination in the environment.

c. Bald Eagle Wintering Surveys

Yearly wintering surveys of bald eagles are conducted on the Hanford Reach of the Columbia River. A careful watch is being made to determine if Hanford operations are having any impact on this threatened species activities.

d. Gutls and Terns

Two colonies of ring-billed and California gulls, and three colonies of Forster's terns nest on islands in the Hanford Reach. Periodic nesting surveys relate nesting success to various environmental perturbations ${ }^{(a)}$.

e. Deer

Over 20 mule cieer have been radiotracked to determine movement patterns in relation to Hanford

(a) Personal communication of R. E. Fitzner, PNL, May 1981.

\subsubsection{Meteorological Monitoring Programs in Progress}

Washington Public Power

Supply System
The meteorological data collection program at the WNP-2 site (about $8 \mathrm{~km}$ (5 mi) from the site) was operational from April 1974 to June 1976 and was resumed in the fall of 1979. System measurements include wind speed and wind direction at the 10- and 74-m (33- and 
Agency

U.S. Department of Energy

\section{Program}

245-ft) levels. Temperature difference measurements are made between the two levels. Dewpoint temperature is measured at the $10 \mathrm{~m}$ (33-ft) leve1; precipitation is measured at ground level.

The Hanford Meteorological Station $18 \mathrm{~km}$ (11 $\mathrm{mi})$ west/northwest of the site) is operated for DOE by PNL. This station is manned by an observer-forecaster $24 \mathrm{hr} /$ day. Complete surface weather observations are made hourly. Wind and temperature profiles from the surface to $122 \mathrm{~m}(400 \mathrm{ft})$ are monitored continuously (Stone 1964). In addition, a network of eighteen telemetered wind and temperature stations, including those near the WNP-2 site and the facility site, is operated on the Hanford Site to assist in defining airflow patterns. Micrometeorological and climatological records dating

(a) Personal communication of A. D. Every, NUS Corporation, August 1981.

\subsubsection{Radiological Studies in Progress}

Agency

U.S. Department of Energy

Richland Operations Office

U.S. Department of Energy
Program

from 1944 to 1980 are available from the Hanford Meteorological Station (Stone, Thorp, Gifford, and Hoitink 1983).

Climatological measurements of maximum and minimum temperature, humidity, and temperature, humidity, and precipitation are currently being made on DOE's ALE Reserve by PNL (Thorp 1973). The ALE Reserve lies to the west of the site.

A comprehensive radiological monitoring program for the Hanford Plant and surrounding environs is carried out by PNL to evaluate the disposition and translocation of Hanford plantreleased radionuclides (continuous since before 1960). Table 9.19 provides a summary of the program, taken from (BTumer et al. 1982) and Figures 9.7 and 9.8 show sampling locations. Annual reports provide surveillance program details (Blumer, et al 1982) and results (Sula et al. 1983; Eddy et al. 1983). 
Agency

Washington State, Division of Social and Health

Services

Washington Public Power Supply System
Program

A state-wide radiological program is carried out by the Radiological Control Units (Mooney 1975). Samples of Columbia River water, air, milk, and shellfish are obtained at a number of locations relevant to WNP-2 and WNP-1/4 which are shown in Table 9.20 and Figure 9.9. Results are reported to the EPA and published annually.

Preoperational radiological environmenta] program prior to the start-up of WNP-2. Table 9.21 provides a summary of the program taken from (WPPSS). Figure 9.10 and its key, Table 9.22, show the sampling locations. Table 9.23 lists representation results of samples collected between March 1978 through June 1980.

The results of the U.S. DOE and Washington State programs are published arinualiy and are available publicly. Their procedures and methodologies are discussed in their annual reports (B1umer et a1. 1982; Sula et al. 1983; Eddy et al. 1983; Mooney 1983, and later reports).

The Supply System program is discussed in WPPSS.

The results of all three programs are readily available to the facility.

\subsection{REFERENCES}

Amierican Public Health Association, American Water Works Association, and Water Pollution Control Federation. 1980. Standard Methods for the Analysis of Water and Waste Water. 15th edition, Washington, D.C.

American Society for Testing and Materials. 1980. 1980 Annual Book of ASTM Standards, Part 31: Water. Philadelphia, Pennsylvania.

Atomic Absorption Newsletter, "Determination of Trace Metals in Power Plant Effluents," 14:29.

Battelle, Pacific Northwest Laboratories, 1976a. Final Report on Aquatic

Ecological Studies Conducted at the Hanford Generating Project, 1973-1974. WPPSS Columbia River Ecology Studies Volume 1, United Engineers and Constructors for the Washington Public Power Supply System, Richland, Washington. 
Battelle Pacific Northwest Laboratories. 1976b. Aquatic Ecological Studies Conducted Near WNP 1, 2, and 4 September 1974 to September 1975. WPPSS Columbia River Ecology Studies Volume 2, United Engineers and Constructors for the Washington PUblic Power Supply System, Richland, Washington.

Battelle, Pacific Northwest Laboratories. 1977. Aquatic Ecological Studies Near WNP 1, 2 and 4, October 1974 through February 1976. WPPSS Columbia River Ecology Studies Volume 3, United Engineers and Constructors for the Washington Public Power Supply System, Richland, Washington.

Battelle, Pacific Northwest Laboratories. 1978. Aquatic Ecological Studies Near WNP 1, 2 and 4 March through December 1976, WPPSS Columbia River Ecology Studies Volume 4 . Richland, Washington.

Battelie, Pacific Northwest Laboratories. 1979a. Aquatic Ecological Studies Near WNP 1, 2, and 4 January through December 1977. WPPSS Columbia River Ecology Studies Volume 5 , Richland, washington.

Battelle, Pacific Northwest Laboratories. 1979b. Aquatic Ecological Studies Near WNP 1, 2 and 4 January through August 1978. WPPSS Columbia River Ecology Studies Volume 6 , Richland, Washington.

Beak Consultants, Inc. 1980. Preoperational Environmental Monitoring Studies Near WNP 1, 2 and 4 August 1978 through March 1980. WPPSS Columbia River Ecology Studies Volume 7, Portland, Oregon.

Becker, C. D. 1973. Aquatic Bioenvironmental Studies in the Columbia River at Hanford 1945-1971. A Bibliography with Abstracts. BNWL-1734, Pacific Northwest Laboratory, Richland, Washington.

Becker, C. D. and W. W. Waddel. 1972. A Summary of Environmental Effects Studies on the Columbia River. Pacific Northwest Laboratory, Richland, wiashington.

Blumer, P. J., M. U. Sula, P. A. Eddy, and R. L. Dirkes. 1982. Master Schedule for $\mathrm{CY}-1983$, Hanford Environmental Surveillance Routine Sampling Program. PNL-4575, Pacific Northwest Laboratory, Richland, Washington.

Brainson, P. E. and J. P. Corley. 1973. Environmental Surveillance at Hanford for CY-1972. BNWL-1727, Richland, Washington.

Briggs, G. A. 1969. Plume Rise. TID-25075, U.S. Atomic Energy Commission Critical Review Series, Washington, D.C.

Briggs, G. A. 1974. Plume Rise from Multiple Sources, Cooling Tower

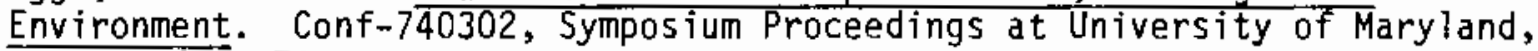
March 4-6, 1974.

CH2M-Hill. 1980. The Downstream Migration of Juvenile Salmonids in the Mid-Columbia River, Spring 1979. Report for the Public Utility Districts of Grant, Douglas, and CheTan Counties. 
CH2M-Hill and Washington Department of Fisheries. 1980. An Evaluation of the Effectiveness of Water Spilling for Passage of Juvenile Salmon at Wanapum Dam. Report for the Public Utility Districts of Grant, Douglas, and Che Tan Counties.

Chiortec, Inc. 1980. Operating Instruction Manual for the EPCO Portable Chlorine Probe.

Corning Scientific Instruments. 1972. Instruction Manual for Corning $610 \mathrm{~A}$ Potentiometer. Medfield, Maine.

Eddy, P. A., L. S. Prater and Rieger, J. T. 1983. Groundwater Surveillance of the Hanford Site for $\mathrm{CY}-1982$. PNL -4659 , Pacific Northwest Laboratory, Richland, Washington.

Fickeisen, D. H., R. E. Fjtzner, R. H. Sauer and J. L. Warren. 1980. Wildlife Usage, Threatened and Endangered Species and Habitat Studies of the Hanford Reach, Columbia River, Washington. Contract 2311104244, Battelle, Pacific Northwest Laboratorjes, Richland, Washington.

Fisher, G. E. 1974. FOG Model Description. NUS-TM-S-185, NUS Corporation, Rockville, Maryland.

Fisher, G. E. 1981. FOG Model - A Dispersion and Droplet Trajectory Model for Cooling Towers. NUS Corporation, Rockville, Maryland.

Glad, J. B. 1981. Preoperational Terrestrial Monitoring Studies Near WNP 1, 2, and 4, Project 02671. Beak ConsuTtants, Inc., Portland, Oregon.

Huschke, R. E. 1959. Glossary of Meteorology. American Meteorological Society, Boston, Mass Tachusetts.

hydrolab Corporation. 1978. Dperating Instruction for Hydrolab System 8000. Austin, Texas.

Hynes, H. B. N. 1966. The Biology of Polluted Waters, Liverpool University Press, Liverpool, England.

Kipp, K. L., Jr. 1973. Radiological Status of the Groundwater Beneath the Hanford Project, July-December 1972. BNwL-1752, Pacific Northwest Laboratory, Richland, Washington.

Koh, R.C.Y. and L. N. Fan. 1970. Mathematical Models for the Prediction of Temperature Distribution Resulting from the Discharge of Heated Water into Large Bodies of Water. 161300W010/70, Water Pollution Control Research Series, U.S. Environmental Protection Agency, Washington, D.C.

Lee, J. 1974. The Lagrangian Vapor Plume Model - Version 3. NUS-TM-S-184, NUS Corporation, Rockville, Maryland.

McGhan, V. L. and D. W. Damschen. 1979. Hanford Hells. PNL-2894, Pacific Northwest Laboratory, Richland, Washington. 
Mid-Columbia Studies Committee. 1981. Reports on 1981 Studies Conducted Under the Auspices of the Mid-Columbia Studies Committee - Draft.

Mudge, J. E. 1981. Summary of Hanford Anjmal Studies (unpublished). Washington Public Power Supply System, Richland, Washington.

Mooney, R. R. 1983. Environmental Radiation Program 20th Annual Report July 1980-June 1981. Envïronmental Health Surveillance Office, Department of Social and Health Services, State of Washington, Olympia, Washington.

Myers, D. A., J. J. Fix and J. R. Raymond. 1977. Environmental Monitoring Report on the Status of Groundwater Beneath the Hanford Site January December 1976. BNWL-2199, Pacific Northwest Laboratory, Richland, washington.

Neitze1, D. A. 1979. A Summary of Environmental Effects Studies on the Columbia River 1972 Through 1978. Pacific Northwest Laboratory, Richland, Washington.

NUS Corporation. 1981. Joint Frequency Distributions of Atmospheric Stability and Wind for the Skagit/Hanford Nuclear Project. NUS-3855, Rockville, Maryland.

Pacific Northwest Laboratory. 1976. Pacific Northwest Laboratories Annual Report for 1975 to the U.S. Energy Research and Development Administration, Division of Biomedical and Environmental Research, Part 2 - Ecological Sciences. BNWL-2000, Part 2, Richland, Washington.

Page, T. L. 1976. Sedimentation and Turbidity Effects from Excavation in the Columbia River at WiNP-2, August through October 1975. Battelle, Pacific Northwest Laboratories, Richland, Washington.

Petterssen, S. 1956. Weather Analysis and Forecasting. Volumes I and II, McGraw-Hill, New York.

Puget Sound Power \& Light Company. 1981a. Puget Sound Power and Light Company, Skagit/Hanford Nuclear Project, Units 1 and 2, Application for Site Certification/Environmental Report. With amendments, Docket Nos. 50-522 and STN 50-523, Seattle, Washington.

Puget Sound Power \& Light Company. 1981b. Puget Sound Power and Light Company, Skagit/hanford Nuclear Project, Units 1 and 2 , Preliminary Safety Analysis Report. With amendments, Docket Nos. STN 50-522 and STN 50-523, Seattle, Washington.

Research Technology, Inc. 1979. Operating Instructions for the Portable Turbidineter PN-80. Gainesville, Florida.

Rickard, W. H. and K. A. Gano. 1979a. Terrestrial Ecology Studies in the Vicinity of WNP 1 and 4: Progress Report for 1978. Contract 2311203104, Battelle, Pacific Northwest Laboratories, Richland, washington. 
Rickard, W. H. and K. A. Gano. 1979b. Terrestrial Ecology Studies in the Vicinity of WNP 1 and 4: Progress Report for the Period July 1974 to June 1975. Contract 231120335, Battelle, Pacific Northwest Laboratories, Richland, Washington.

Rosenberg, D. M. and N. B. Snow. 1975. Ecological Studies of Aquatic Organisms in the Mackensie and Porcupine River Orainages in Relation to Sedimentation. Fisheries and Marine Service Technical Report No. 547, Environment, Canada.

Sagendorf, J. F. and J. T. Goll. 1977. X0QD0Q Program for the Meteorological Evaluation of Routine Effluent Releases at Nuclear Power Stations. NUREG-0324 (Draft), U.S. NucTear Regulatory Commission, Washington, 0.C.

Schultz, M. J. 1972. Chemical and Biological Pollution Surveillance of the Hanford Environs, Quarterly Report, Hanford Environmental Hearth Foundation. Richiand, Washington.

Sehme 1, G. A. 1981. Ambient Airborne Solid Concentrations Inciuding Volcanic Ash at Hanford, Washington, Sampling Sites Subsequent to the Mount St. Helens Eruption. PNL-SA-9347, Pacific Northwest Laboratory, Richland, Washington.

Sherk, J. A., Jr. 1973. The Effects of Suspended and Deposited Elements on Estuarianal Organisms; Literature Sumbary and Research Needs. Contribution No. 443, Natural Resources Institute, University of Maryland, Maryland.

Stone, W. A. 1964. MeteorologicaT Instrumentation of the Hanford Area $H W-62445, U . S$. Atomic Energy Commission, National Technical Information Service, Springfield, Virginia.

Stone, W. A., D. E. Jenne and J. M. Thorp. 1972. Climatography of the Hanford Area. BNWL-I605, Pacific Northwest Laboratory, Richland, Washington.

Sula, M. J., J. M. Carlile, K. R. Price and W. D. McCormack. 1983. Environmental Surveillance of Hanford for CY-1982. PNL-4657, Pacific Northwest Laboratory, Richland, Washington.

Sula, M. J. and P. J. Blumer. 1981. Environmental Surveillance at Hanford for CY-1980. Pacific Northwest Laboratory, Richland, Washington.

Thorp, 3. M. 1973. 1972 Microclimatological Measurements on the Arid Lands Ecological Reserve. Pacific Northwest Laboratory Annual Report for $197 \hat{c}$ to the USAEC Division of Biomedical and Environmental Research, Vol. II: Physical Sciences, Atmospheric Sciences, PT 1, BNWL-1751, Part 1, Pacific Northwest Laboratory, Richland, Washington.

Tri-County Air Pollution Control Authority. 1981. 1980 Annual Data Report. RichTand, Washington.

U.S. Army Corps of Engineers, North Pacific Division, 1972. The Columbia River and Its Tributaries. 
U.S. Army Corps of Engineers. 1981. HEC-2 Water Surface Profiles. 1981. User Manua], Hydrologic Engineering Center.

U.S. Code of Federal Regulations. Title 10, Part 50, "Domestic Licensing of Production and Utilization Facilities."

U.S. Environmental Protection Agency. 1972. Handbook for Analytical Quality Control in Water and Wastewater Laboratories. National Environmental Research Center, Analytical Quality Control Laboratory, Cincinnati, Ohio.

U.S. Environmental Protection Agency. 1976. Storet Data. Washington, D.C.

U.S. Environmental Protection Agency. 1979. Methods for Chemical Analysis of Water and Wastes. Office of Research and DeveTopment, Cincinnati, Ohio.

U.S. Environmental Protection Agency. 1979. STORET Computer File. Open file material, Region $x$, Seattle, Washington.

U.S. Geological Survey. 1974. Water Data Report. WA-79-2.

U.S. Geological Survey. 1981. Water Resources Data for Washington, Part 1, Surface Water Records. Data from Columbia River at Vernita Bridge Near Priest Rapids Dam, Washington, National Stream Water Quality Accounting Network Station 12472900.

U.S. Nuclear Regulatory Comassion. 1972. Onsite Meteorological Programs. Regulatory Guide 1.23, Washington, D.C.

U.S. Nuclear Regulatory Commission. 1977. Estimating Aquatic Uispersion of Effluents from Accidental and Routine Reactor Releases for the Purpose of Implementing Appendix I. Regulatory Guide 1.113, Revision I, Washington, D.C.

U.S. Nuclear Regulatory Commission. 1977. Methods for Estimating Atmospheric Transport and Dispersion of Gaseous Effluents in Routine Releases from Light-Water-Cooled-Reactors. Regulatory Guide 1.111, Rev. 1, washington, D.C.

U.S. Nuclear Regulatory Commission. 1978. Preparation of Environmenta] Reports for Nuclear Power Stations. NUREG-0099, Regulatory Guide 4.2, Revision 2, Washington, D.C.

U.S. Nuclear Regulatory Commission. 1979. Atmospheric Dispersion Models for Potential Accident Consequence Assessments at Nuclear Power PTants. Regulatory Guide 1.145, Washington, 0.C.

U.S. Nuclear Regulatory Commission. 1981. Flow Blockage of Cooling Water to Safety System Components by Corbicula sp. (Asiatic Clam) and Mytilus sp. (Musse1). IE Bulletin 81-03; Office of Inspection and Enforcement, Washington, D.C.

Warren, C. D. 1971. Biology and Water Pollution Control. W. B. Saunders Company, Philadlphia, Pennsylvania. 
Washington State Department of Ecology. 1980. Water Resource Inventory Area (WRIA \#40); open computer file material, 0lympia, washington.

Washington Public Power Supply System. WPPSS Nuclear Project No. 2

Environmental Report Operating License Stage, Docket No. S0-397.

Richland, Washington.

Watson, 0. G. 1970. Fall Chinook Salmon Spawning in the Columbia River Near Hanford, 1947-1969. BNWL-1515, Pacific Northwest Laboratory, Richland, Washington.

Weitkamp, D., D. Chapman and T. Welsh. 1979. Vernita Bar Spawning Survey 1978-79. Parametrix, Inc., to Grant County PUD.

Weitkamp, D., D. Chapman and T. Welsh. 1981. Vernita Bar Spawning Survey 1979-1980. Parametrix, Inc., to Grant County PUD.

Whitney, R. R. 1981. Annual Review of Studies Conducted Under the Auspices of the Mid-Columbia Studies Committee. Mid-Columbia Studies Committee.

Young, W., and R. Arthur. 1980. Contribution of Priest Rapids Hatchery Fall Chinook to Artifical and Natural Spawning Populations Near Priest Rapids Dam During 1979. Washington Department of Fisheries Funded by Grant County PUD. 
APPENDIX A

OETAILED ECOLOGICAL DATA 
TABLE A.1. Terrestrial Plants Expected in the Environs of the Primary Site (U.S. NRC 1982)

PLANTS

Shrubs

Big sagebrush

Artemesia tridentata

Bitterbrush

Green rabbitbrush

Gray rabbitbrush

Spiny hopsage

Snow eriogonum

Purshia tridentata

Chrysothanmus viscidiflorus

C. nauseosus

Grayia spinosa

Eriogonum niveum

Forbs

Longleaf phlox

Phlox Tongifolia

Bal ismaroot

Balsamorhiza careyana

Sand dock

Scurf-pea

Lupine

Pale evening primrose

Desert mallow

Cluster lily

Sego lily

Tansy mustard

Tumble mustard

Cryptantha

Russian thistle (tumbleweed)

Rumex venosus

Psoralea Tanceolata

Lupinus Taxiflorus

Oenothera pullida

Sphaeralcea munroana

Brodiaea douglasii

Calochortus macrocarpus

Descurainia pinnata

Sisymbrium altissimum

Cryptantha circumscissa

Salsola kali

Fieabane

Wild parsley

Spring draba

Bur sage

Littlebells polemonium

Longhorn plectritis

Erigeron filifolius

Cymopterus terebinthum

Draba verna

Franseria acanthicarpa

Polemonium micranthum

Plectritis macrocera

Grasses

Sandberg bluegrass

Poa sandbergii

Cheatgrass

Bromus tectorum

Indian ricegrass

Squirrel tail

Six-week fescue

Thickspike wheatgrass

Sand dropseed

Oryzopsis hymenoides

Sitanion hystrix

Festuca octofiora

Agropyron dasystachyum

Sporobolus cryptandrus

Riparian Vegetation

Willow

Salix exigua and others

Cottonwood

Sedges

Rushes

Horsetail

Cock lebur

wild onion

Populus trichocarpa

Carex spp.

Juncus $\mathrm{sp}$.

Equisetum sp.

Xanthium sp.

A)lium $\mathrm{sp}$. 
IABLE A.3. Average Chemical and Physical Properties of Soil from Sagebrush/Cheatgrass Plant Communities on the Hanford Reservation

\begin{tabular}{|c|c|c|c|c|c|c|c|}
\hline \multicolumn{8}{|c|}{ Soil Depth (dnı) } \\
\hline & $0-1$ & $1-2$ & $2-3$ & $3-4$ & $4-5$ & $5-6$ & Avg \\
\hline \multicolumn{8}{|l|}{ Texture } \\
\hline$\%$ Sand & 59 & 62 & 67 & 63 & 57 & 57 & 61 \\
\hline$\% \operatorname{Silt}$ & 40 & 37 & 32 & 36 & 42 & 42 & 38 \\
\hline$\%$ clay & 1 & 1 & 1 & 1 & 1 & 1 & 1 \\
\hline
\end{tabular}

Organic Matter

$\begin{array}{llllllll}\text { i } & 0.68 & 0.45 & 0.35 & 0.43 & 0.43 & 0.50 & 0.47\end{array}$

Elec. Cond.

\begin{tabular}{llllllll} 
mmhos $/ \mathrm{cm}$ & 0.25 & 0.20 & 0.24 & 0.29 & 0.21 & 0.30 & 0.25 \\
$\mathrm{pH}$ & 7.5 & 7.6 & 7.7 & 7.9 & 7.9 & 8.1 & 7.8 \\
\hline
\end{tabular}

Source: Cline, J. F., O. W. Uresk, and W. H. Rickard. 1977. "PIants and SoiT of a Sagebrush Community of the Hanford Reservation." Northwest Sci. $51(1): 60-70$. 
IABLE A.4. Summayy of Soil Chemistry Data from Nine Sites Near WNP 1,2 and $4^{4}$ ) Located Within 5-8 km of the Primary Site (Soit Type was Predominantly Rupert Sand)

\begin{tabular}{|c|c|c|}
\hline Parameter & Mean (b) & Standard Deviation \\
\hline $\begin{array}{l}\mathrm{pH} \\
(1: 2 \text { soil to water })\end{array}$ & 7.19 & .304 \\
\hline $\begin{array}{l}\text { Bicarbonate } \\
\left.\text { (mea. of } \mathrm{HCO}_{3} / \mathrm{gm}\right)\end{array}$ & 2.67 & 1.715 \\
\hline $\begin{array}{l}\text { Conductivity } \\
\left.\text { (umhos/cm } 025^{\circ} \mathrm{C}\right) \\
(1: 2 \text { soil to water) }\end{array}$ & 23.10 & 7.123 \\
\hline Sulfate $(u g / g)$ & 63.67 & 50.022 \\
\hline Chloride (ug/g) & 13.14 & 3.265 \\
\hline Copper (ug/g) & 12.22 & 1.302 \\
\hline Lead (ug/g) & 4.41 & 0.701 \\
\hline Cadmium (ug/g) & 0.67 & 0.701 \\
\hline Nicke] $(u g / g)$ & 17.11 & 1.324 \\
\hline $\operatorname{Zinc}(u g / g)$ & 60.61 & 12.503 \\
\hline Sodium $(\%)$ & 0.12 & 0.043 \\
\hline Potassium ( $(\%)$ & 0.28 & 0.044 \\
\hline Calcium $\left(\begin{array}{l}\% \\
b\end{array}\right)$ & 0.64 & 0.075 \\
\hline Mercury (ug/g) & .04 & - \\
\hline Floride (ug/g) & 267.44 & 40.570 \\
\hline
\end{tabular}

(a) Source: (Glad 1981)

(b) Caiculated from raw data presented by Glad (PSP\&L 1981). 
TABLE A.5. A Comparison of Beetle Abundance on the 200 Area Plateau With a Control Area on the Arid Lands Ecology (ALE) Reserve (Rogers and Rickard 1977)

Species $(a)$
ANCA
CONE
COSE
ELHI
ELHU
ELNI
ELNO
ELOB
EUMU
PHDE

Tota ]
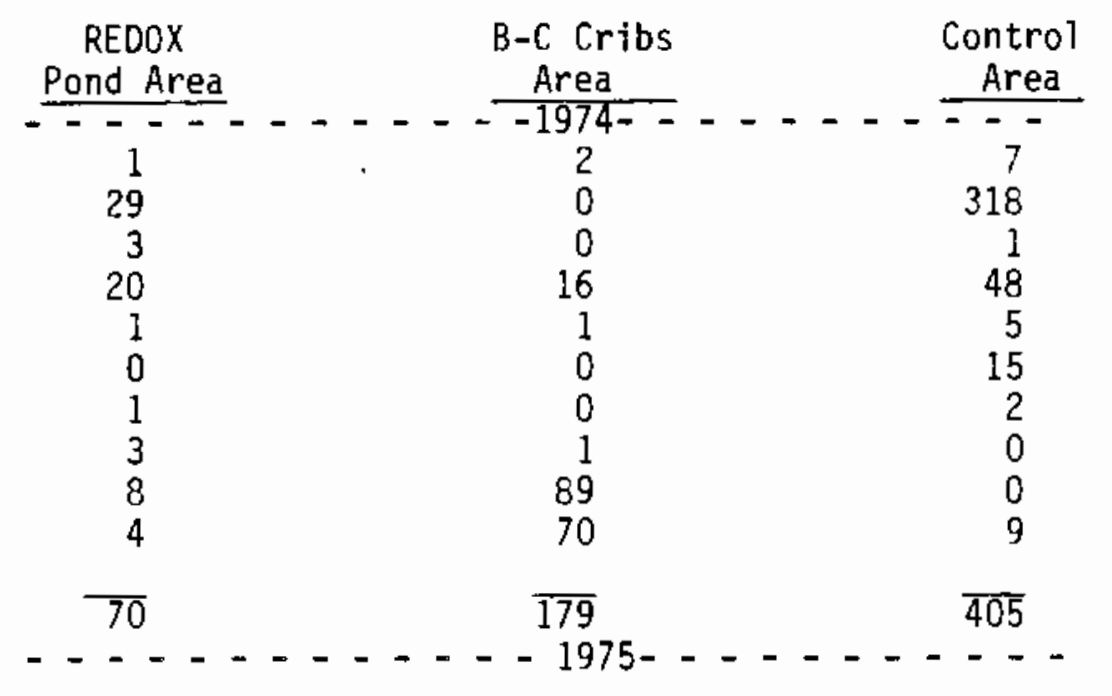

$\begin{array}{lr}\text { ANCA } & 0 \\ \text { CONE } & 1 \\ \text { COSE } & 5 \\ \text { ELHI } & 3 \\ \text { ELHU } & 0 \\ \text { ELNI } & 0 \\ \text { ELNO } & 0 \\ \text { ELOB } & 0 \\ \text { EUMU } & 19 \\ \text { PHDE } & 11\end{array}$

Total $\overrightarrow{39}$

\section{SCIENTIFIC NAME}

Anemia californica

Blapstinus spp.

Coniontis lane $i$

Coniontis ovalis

Coniontis setosa

Conisattus nelsoni

Eleodes granulata

ETeodes hispilabris

Eleodes humeralis

Eleodes nigrina

Eleodes novoverrucula

Eleodes obscura

Eusattus muricatus

Oxygonodera hispidula

Philolithus densicoll is

Stenomorpha Puncticolitis

17

(a) Abbreviations derived from first two letters of genus \& species names, respectively. 
TABLE A.6. Darkling Beetle Abundance on the 200 Area Plateau, Hanford Reservation (Rogers et al. 1978)

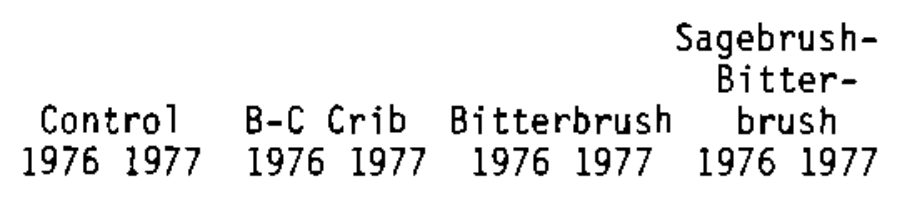

\begin{tabular}{|c|c|c|c|c|c|c|c|c|}
\hline Eleodes hispilabris Say & 404 & 278 & 344 & 219 & 193 & 280 & 358 & 429 \\
\hline Eleodes novoverucula Bod. & 153 & 40 & 90 & 38 & 191 & 166 & 198 & 178 \\
\hline Eleodes humeralis LeC & 56 & 93 & 81 & 83 & 56 & 62 & 10 & 29 \\
\hline Eleodes nigrina LeC & 55 & 47 & 5 & 6 & 5 & 11 & 5 & 29 \\
\hline Eleodes granulata LeC & 18 & 4 & 12 & 10 & 10 & 2 & 14 & 1 \\
\hline Eleodes obscura Say & 0 & 1 & 0 & 0 & 24 & 24 & 0 & 5 \\
\hline Eusatus muricatus LeC & 20 & 38 & 310 & 3 & 5 & 54 & 0 & 18 \\
\hline Coniontis setosa Csy。 & 55 & 35 & 131 & 16 & 17 & 959 & 41 & 1323 \\
\hline Conisattus nelsoni Bod. & 0 & 0 & 0 & 0 & 0 & 3 & 0 & 0 \\
\hline Oxygonodera hispidula Horn & 0 & 0 & 0 & 0 & 0 & 1 & 0 & 0 \\
\hline Philolitbus densicollis (Horn) & 37 & 21 & 180 & 39 & 1 & 0 & 135 & 72 \\
\hline Tota & 798 & 557 & 1153 & 414 & 502 & 1562 & 761 & 2084 \\
\hline
\end{tabular}


TABLE A.7. Grasshopper Species Collected at B-C Crib and REDOX Pond Areas (Sheldon and Rogers 1976)

$B-C$ Crib

Species:

Agoneotettix deorum (Scudder)

Apote notabilis (Scudder)

Aulocara elliotti (Thomas)

Conozoa wallula (Scudder)

Hesperotettix viridis (Thomas)

Melanoplus cinereus (Scudder)

Melanoplus sanguinipes ( $F$. )

Mealanoplus yarrowit (Thomas)

Oedaleonotus enjgma (Scudder)

Steiroxys sp.

Trimerotropis bilobata (Rehn and Bebard)

Trimerotropis caeruleippennis (Brunner)

Trimerotropis pallidipennis (Burmeister)

Zanthippus lateritus (Saussure)

TOTAL: 14
REDOX Pond

Ageneotettix deorum (Scudder)

*Amphitornus coloradus (Thomás)

Apote notabilis Scudder

Arphia pseudonietana (Thomas)

Aulocara elliotti (Thomas)

Conozoa wallula (Scudder)

Hesperotettix virjdis (Thomas)

Melanoplus cinereus Scudder

Melanoplus sanguinipes ( $F$. )

Mealanoplus yarrowij (Thomas)

Dedaleonotus enigma (Scudder)

Paropomala pallida Brumer

Stejroxys sp.

Trimerotropis caeruleippennis

(Brunner)

Trimerotropis pallidipennis

(Burmeister)

Zanthippus lateritus

(Saussure)

TOTAL: 16

* Collected during the summer of 1975. 
TABLE A.8. Species List of Birds Associated Either Directly or Peripheraliy with the Pacific Northwest Steppe. Habitat Preferences Are Shown, Along with Crude Estimates of Abundance (Rogers and Rickard 1977)

\begin{tabular}{|c|c|c|c|}
\hline Status & Species & Steppe & Shrub-Steppe \\
\hline Permanent Residents & $\begin{array}{l}\text { Marsh Hawk } \\
\text { Red-tailed Hawk } \\
\text { Sharp-tailed Grouse } \\
\text { Sage Grouse } \\
\text { Chukar } \\
\text { Ring-necked Pheasant } \\
\text { Gray Partridge } \\
\text { Short-eared Owl } \\
\text { Horned Lark } \\
\text { Black-billed Magpie } \\
\text { Common Raven } \\
\text { Common Crow } \\
\text { Western Meadowlark } \\
\text { California Quail }\end{array}$ & $\begin{array}{l}+ \\
+ \\
- \\
- \\
+ \\
- \\
- \\
- \\
++ \\
+ \\
+ \\
- \\
+ \\
+\end{array}$ & $\begin{array}{l}+ \\
+ \\
- \\
- \\
+ \\
- \\
- \\
- \\
+ \\
++ \\
+ \\
+ \\
++ \\
+\end{array}$ \\
\hline Surmer Residents & $\begin{array}{l}\text { Prairie Falcon } \\
\text { Long-billed Curlew } \\
\text { Mourning Dove } \\
\text { Burrowing Owl } \\
\text { Swainson's Hawk } \\
\text { Common Nighthawk } \\
\text { Barn Swallow } \\
\text { Sage Thrasher } \\
\text { Loggerhead Shrike } \\
\text { Grasshopper Sparrow } \\
\text { Vesper Sparrow } \\
\text { Lark Sparrow } \\
\text { Black-throated Sparrow } \\
\text { Sage Sparrow } \\
\text { Brewer's Sparrow }\end{array}$ & $\begin{array}{l}- \\
+ \\
+ \\
+ \\
+ \\
+ \\
- \\
- \\
- \\
+ \\
-\end{array}$ & $\begin{array}{l}- \\
+ \\
+ \\
+ \\
+ \\
+ \\
+\end{array}$ \\
\hline Winter Residents & $\begin{array}{l}\text { Rough-legged Hawk } \\
\text { Northern Shrike } \\
\text { Bald Eagle }\end{array}$ & $\begin{array}{l}+ \\
- \\
-\end{array}$ & $\begin{array}{l}+ \\
- \\
-\end{array}$ \\
\hline
\end{tabular}


TABLE A.9. Vascular Plants of Waste Storage Sites in the 200 Areas of the Hanford Reservation (Price and Rickard 1973)

\begin{tabular}{|c|c|c|}
\hline Common Name & Scientific Name & General Occurrence \\
\hline Annual fescue & Festuca pacifica & Dry areas \\
\hline Asparagus & Asparagus officinalis & Ditch banks and moist areas \\
\hline Aster & Aster canescens & Disturbed dry areas \\
\hline Barnyard grass & Echinochloa crusgallii & Ditch banks and moist areas \\
\hline Bassia & Bassia hyssopifolia & Disturbed dry areas \\
\hline Bastard toad-flax & Comandra pal11jda & Dry areas \\
\hline Beggar-tick & Bidens faronosa & Ditch banks and moist areas \\
\hline Big bluegrass & Poa ampla & Dry àreas \\
\hline Big sagebrush & Artemisia tridentata & Undisturbed dry areas \\
\hline Blazing Star & Mentzelia albicaulis & Dry areas \\
\hline Bluebunch wheatgrass & Agropyron spicatum & Dry areas \\
\hline Bluegrass & Poa canbyi & Dry areas \\
\hline Bracken fern & Pteriduim aquilinum & Dry areas \\
\hline Bristlegrass & Setaria viridis & Ditch banks and moist areas \\
\hline Brodiaea & Brodiaea douglasij & Dry areas \\
\hline Brodiaea & Brodiaea howeliij & Dry areas \\
\hline Buckwheat & Eriogonum sp. & Dry areas \\
\hline Bulrush & Scirpus maritimus & $\begin{array}{l}\text { Ditches and ponds aquatic } \\
\text { emergent }\end{array}$ \\
\hline Bulrush & Scirous validus & $\begin{array}{l}\text { Ditches and ponds aquatic } \\
\text { emergent }\end{array}$ \\
\hline Bur Sage & Franseria acanthicarpa & \\
\hline Cattail & Typha latifolia & $\begin{array}{l}\text { Ditches and ponds aquatic } \\
\text { emergent }\end{array}$ \\
\hline Chaenactis & Chaenactis douglasij & Dry areas \\
\hline
\end{tabular}


TABLE A.9. (contd)

\begin{tabular}{|c|c|c|}
\hline Commion Name & Scientific Name & General Occurence \\
\hline Cheatgrass & Bromus tectorum & $\begin{array}{l}\text { Solid waste burial grounds } \\
\text { Disturbed dry areas }\end{array}$ \\
\hline Comandra & Comandra pallida & \\
\hline Common mullen & Verbascum thapsus & Ditch banks and moist areas \\
\hline Cottonwood & Populus deltoides & $\begin{array}{l}\text { Ditch banks and moist areas } \\
\text { around ponds }\end{array}$ \\
\hline Cryptantha & Cryptantha circumscissa & Dry areas \\
\hline Cryptantha & Cryptantha pterocarya & Dry areas \\
\hline Cudweed & Gnaphalium chilensis & Disturbed moist areas \\
\hline Daisy & Townsendia florifer & Dry areas \\
\hline Dandelion & Taraxacim officinale & Ditch banks and moist areas \\
\hline Desert mallow & Spharalcea munroana & Dry areas \\
\hline Desert parsley & Lomatium grayi & Dry areas \\
\hline Desert parsiey & Lomatium spp. & Dry areas \\
\hline Dock & Rumex spp. & $\begin{array}{l}\text { 01d pond bottom, disturbed } \\
\text { moist areas }\end{array}$ \\
\hline Dogbane & Apocynum sibiricum & Ditch banks and moist areas \\
\hline Dogbane & $\frac{\text { Apocynum }}{\text { androsoemi fol ium }}$ & 01d pond bottom, moist areas \\
\hline Douglas Brodiaea & Brodiaea douglasii & \\
\hline Draba & Draba verna & Dry areas \\
\hline Erigeron species & Erigeron spp. & Dry areas \\
\hline Evening primrose & Oenothera andina & Dry areas \\
\hline Evening primrose & Oenothera pallida & Dry areas \\
\hline Fiddleneck & Amsinckia tesselata & Disturbed dry areas \\
\hline Fleabane & Erigeron filifolius & Dry areas \\
\hline
\end{tabular}


TABLE A.9. (contd)

\begin{tabular}{|c|c|c|}
\hline Common Name & Scientific Name & General Occurrence \\
\hline Fleabane & Erigeron pumilus & Dry areas \\
\hline Gilia & Gilia leptomeria & Dry areas \\
\hline Goldenrod & Salidago spp. & $\begin{array}{l}\text { 0ld pond bottom and moist } \\
\text { areas }\end{array}$ \\
\hline Green rabbitbrush & $\begin{array}{l}\text { Chrysothammus } \\
\text { nauseosus }\end{array}$ & $\begin{array}{l}\text { Solid waste burial grounds, } \\
\text { disturbed dry areas }\end{array}$ \\
\hline Grey rabbitbrush & $\frac{\text { Chrysothammus }}{\text { viscidiflorus }}$ & $\begin{array}{l}\text { Solid waste burial grounds, } \\
\text { disturbed dry areas }\end{array}$ \\
\hline Mardstem bulrush & Scirpus acutus & $\begin{array}{l}\text { Ditches and ponds, aquatic } \\
\text { emergent }\end{array}$ \\
\hline Hawksbeard & Crepis atrabarba & Dry areas \\
\hline Hopsage & Grayia Spinosa & \\
\hline Horsetail & Equisetum laevigatum & Shoreline, wet areas \\
\hline Horsetail & Equisetum hyemale & Ditch banks and moist areas \\
\hline Horseweed & Conyze canadensis & Disturbed dry areas \\
\hline Indian ricegrass & Oryzopsis hymenoides & Dry, sandy areas \\
\hline Jim Kill mustard & Sisymbrium altissimum & $\begin{array}{l}\text { Solid waste burial grounds, } \\
\text { disturbed dry areas }\end{array}$ \\
\hline Larkspur & Delphinium nelsonii & Dry areas \\
\hline Layia & Layia glandulosa & Dry areas \\
\hline Locoweed & Astragalus purshii & Dry areas \\
\hline Locoweed & Astragulus spp. & Dry areas \\
\hline Matted Cryptantha & Cryptantha circumscissa & \\
\hline Microsteris & Microsteris gracillis & Dry areas \\
\hline Muhlenbergia & $\frac{\text { Muhlenbergia }}{\text { asperifolia }}$ & Ditch banks and moist areas \\
\hline Mustard & The lypodium laciniatum & Dry areas \\
\hline Needle and thread & Stipa comata & Sandy, dry areas \\
\hline
\end{tabular}


TABLE A.9. (contd)

\begin{tabular}{|c|c|c|}
\hline Common Name & Scientific Name & General Occurrence \\
\hline Nettle & Urtica dioica & Ditch banks and moist areas \\
\hline Panic grass & Panicum capiliare & Ditch banks \\
\hline Peachleaf willow & $\underline{\text { Salix amygdaloides }}$ & Ditch banks, pond shoreline \\
\hline Pens temon & Penstemon accuminatus & Dry areas \\
\hline Phacelia & Phacelia linearis & $\begin{array}{l}\text { Solid waste burial grounds, } \\
\text { dry areas }\end{array}$ \\
\hline Phlox & Phlox longifolia & Dry areas \\
\hline Pigweed & $\begin{array}{l}\text { Chenopodium } \\
\text { lepthophyl]um }\end{array}$ & Dry areas \\
\hline Plantain & $\underline{\text { Plantago patagonica }}$ & Moist areas \\
\hline Plectritis & Plectritis macrocera & Moist areas \\
\hline Reed Canary grass & Phalaris arundinacea & Moist areas \\
\hline Rabbit brush & Chrysothamnus nauseosus & \\
\hline Rabbit brush & $\frac{\text { Chrysothamnus }}{\text { viscidiflorus }}$ & \\
\hline Russian Napweed & Centaurea repens & Disturbed moist areas \\
\hline Russian thistle & $\underline{\text { Salsola kali }}$ & $\begin{array}{l}\text { Solid waste burial grounds, } \\
\text { tank farms, dry areas }\end{array}$ \\
\hline Sand dropseed & Sporoblus cryptandrus & Ditch banks and disturbed areas \\
\hline Sandbar willow & Salix exiqua & Ditch banks, pond shoreline \\
\hline Sandbur & Franseria acanthicarpa & $\begin{array}{l}\text { Solid waste burial grounds, } \\
\text { disturbed dry areas }\end{array}$ \\
\hline Sandberg bluegrass & Poa sandbergii & Undisturbed dry areas \\
\hline Sand verbena & $\underline{\text { Abronia mellifera }}$ & Dry areas \\
\hline Scurf-pea & Psoralea lanceolata & \\
\hline $\begin{array}{l}\text { Sharp-leaved } \\
\text { Penstemon }\end{array}$ & Penstemon acuminatus & \\
\hline
\end{tabular}


JABLE A.9. (contd)

Common Name

Sixweek Fescue

Smartweed

Speedwe 11

Spiny hopsage

Spiny hopsage

Spurred lupine

Squirrel tajl

Star tulip

Stickseed

Storks-bil1

Sunflower

Swainsona

Sweet bullclover

Tansy mustard

Thick-spike

wheatgrass

Thistle

Three-square

bulrush

Tumbleweed

Turpentine

cymopterus

Wallflower
Scientific Name

Festuca octoflora

Polygonum persicaria

Veronica anagallisaquatica

Grayia spinosa

Grayia spinosa

Lupinus sp.

Sitanion hystrix

Calochortus macrocarpus

Lappula redowski

Erodium circutarium

Baisamorhiza careyana

Swainsona salsula

Melilotus alba

Descurainea pinnata

Agropyron dasytachyum

Cirsium brevifolium

Scipus americanus

(see Russian thistle)

Cymopterus terebinthinus

Erysimum asperum
General Occurrence

Ditch banks and pond shoreline

Ditch banks, pond shoreline,

Solid waste burial sites, dry areas

Solid waste burial sites, dry areas

Dry areas

Disturbed dry areas

Cry areas

Ditch banks, moist areas

Ditch banks, disturbed moist areas

Solid waste burial grounds, disturbed dry areas

Moist areas

Ditches and ponds, aquatic emergent

Ory areas 
TABLE A.9. (contd)

\begin{tabular}{|c|c|c|}
\hline Common Name & Scientific Name & General Occurrence \\
\hline Watercress & $\begin{array}{l}\text { Rorippa nasturtium- } \\
\text { aquaticum }\end{array}$ & Ditches, running water \\
\hline $\begin{array}{l}\text { White-stem } \\
\text { mentzelia }\end{array}$ & Mentzelia albicaulis & \\
\hline Willow herb & $\begin{array}{l}\text { Epilobium } \\
\text { suffruticosum }\end{array}$ & Disturbed dry areas \\
\hline Wing-nut Cryptantha & Cryptantha pterocarya & \\
\hline Wild lettuce & Lactuca serriola & $\begin{array}{l}\text { Ditch bank, disturbed moist } \\
\text { areas }\end{array}$ \\
\hline Yarrow & Achillea millifolium & Disturbed dry areas \\
\hline Yarrow & Achillea lanulosa & \\
\hline
\end{tabular}


TABLE A.10. Algae in the Phytoplankton and Periphyton Communities of the Hanford Reach of the Columbia River (PSP\&L 1982; Neitze)

et al. 1982)

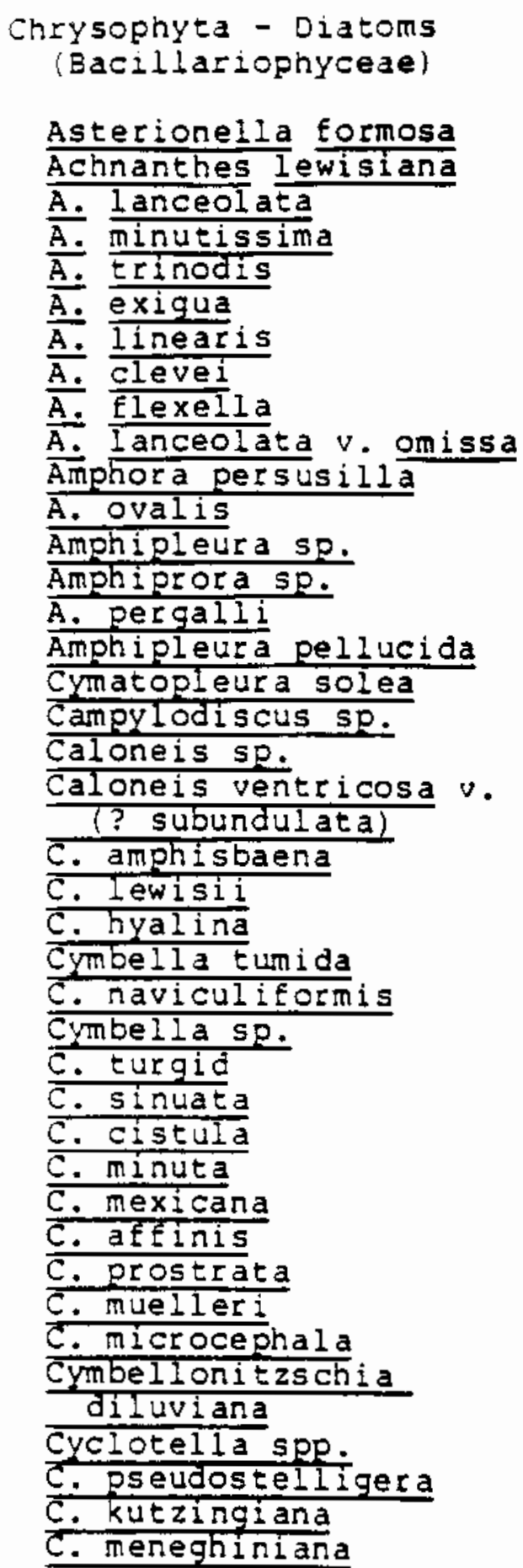

C. glomerata

C. comta

C. comensis

C. bodanica

C. steligera

C. atomas

C. Ocellata

Dinobryon divergens

Denticula sp.

Diatoma sp.

D. vulgare

$\overrightarrow{D .}$ tenue $v$, tenue

D. hiemale $v$ (? mesodon)

Diploneis elliptica

D. puelia

D. smithil $v$. dilatata

D. oculata

Epithemia spo.

E. tuzgida

E. Sorex

Eunotia sp.

E. pectinalis

Erugilaria leptostauron v. dubia

F. vaucheriae

v. vaucheriae

E. leptostauron

v. leptostauron

$E$. construens v. venter

F. Crotonensis

F. construens

F. capucina

F. Leprostauron

F. virescens

Frustulia sp.

F. thomboides

F. vulgaris

Gomphonema sp.

G. parvulum

G. Subclavtum

G. Olivacedides

G. truncaturn

G. ventricosum

G. Olivaceum

G. olivaceum v. calcurea 
TABLE A.10. (contd)

\section{Chrysophyta \\ (Bacillar iophyceae) \\ (continued)}

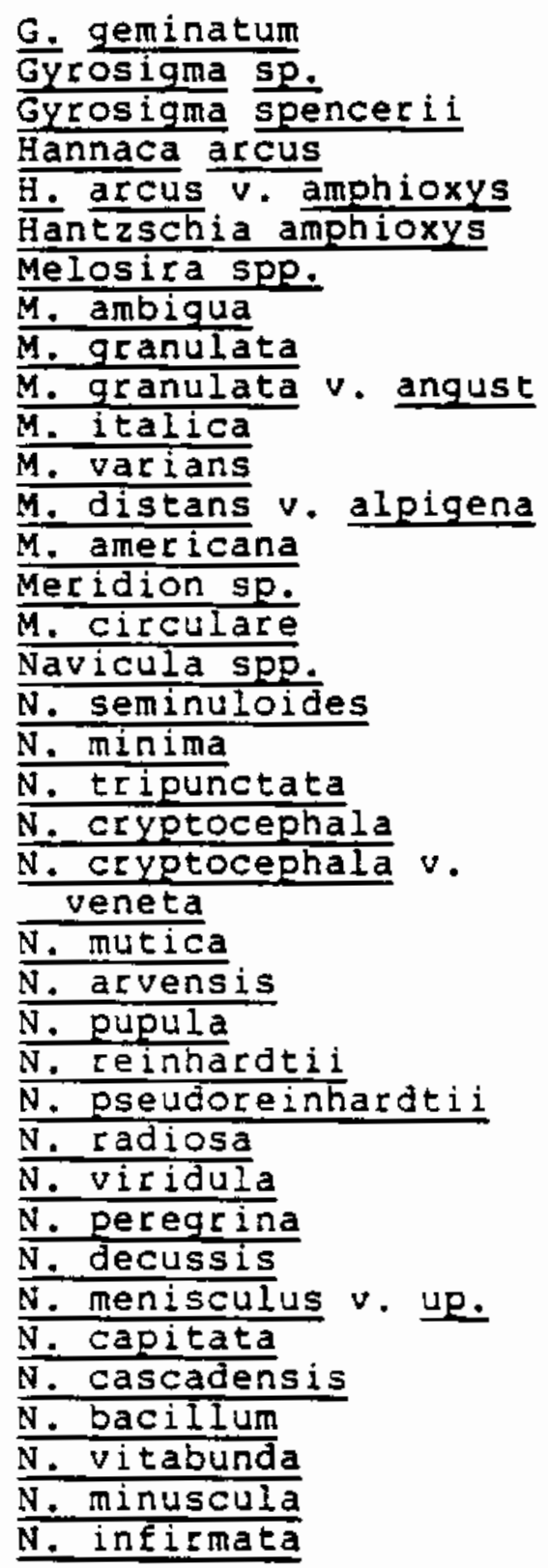

N. circumtexta

N. bacillum Ehr. v. bacillum

N. cincta

N. latens

N. mutica v. cohnii

N. mutica $v$. Eropica

Nedium dubium

N. spp.

N. affine $v$, humerus

Nitzschia latens

N. paleacea

N. Silica

N. palea

N. dissipata

N. innominata

N. perminuta

N. allansoni

N. Erustulum

N. osmophila

N. obsoleta

N. linearis

N. intermissa

N. acicularis

N. amphibia

N. oregona

N. fonticola

N. bacota E. Lin.

N. recta

N. angustata

N. holsatica

N. gracilis

N. stagnorum

N. lavenbergiana

N. amphioxides

N. sigmoidea

N. subacicularis

N. accomodata

N. demota

N. hungarica

N. Subpunctata

N. vermicularis

N. serpenticula 
TABLE A.10. (contd)

\section{Chrysophyta \\ (Bacillariophyceae) (continued)}

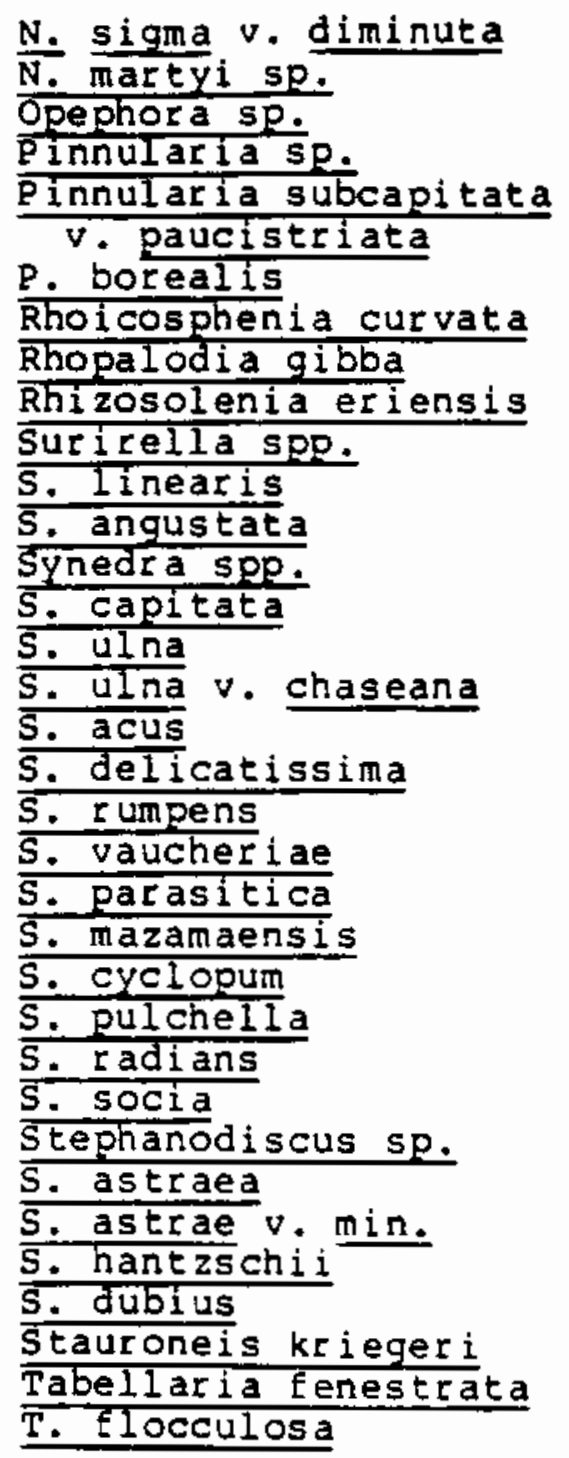

Chrysophyta - Golden or Yellow-Brown Alga. (Chrysophyceae)

Chrysococcus refescens

Codosiga

Kephyrion spirale

K. asper

K. Ovale

K. gracilis

Mallomonas alpina

Mallomonas tonsurata

Ochromonas-iike

Rhizochrisis

Chlorophyta - Green Algae

Ankistrodesmus falcatus

Actinastrum sp.

Asterococcus sp.

Botryococcus sp.

Crucigenia guadrata

Cosmarium sp.

Cladophor a sp.

Characlum ambiguum

C. so.

Closterium acutum

C. sp.

C. gracile

Dictyosphaterium ehrenbergianum

Eudorina sp.

E. elegans

Golenkinia sp.

Kicchnerielia obesa

Lagerheimia sp.

Mougeotia

Odcystis pusilla

o. lacustria

Pandorina morum

pediastrum boryanum

p. tetras

P. duplex 
TABLE A. 10. (coritd)

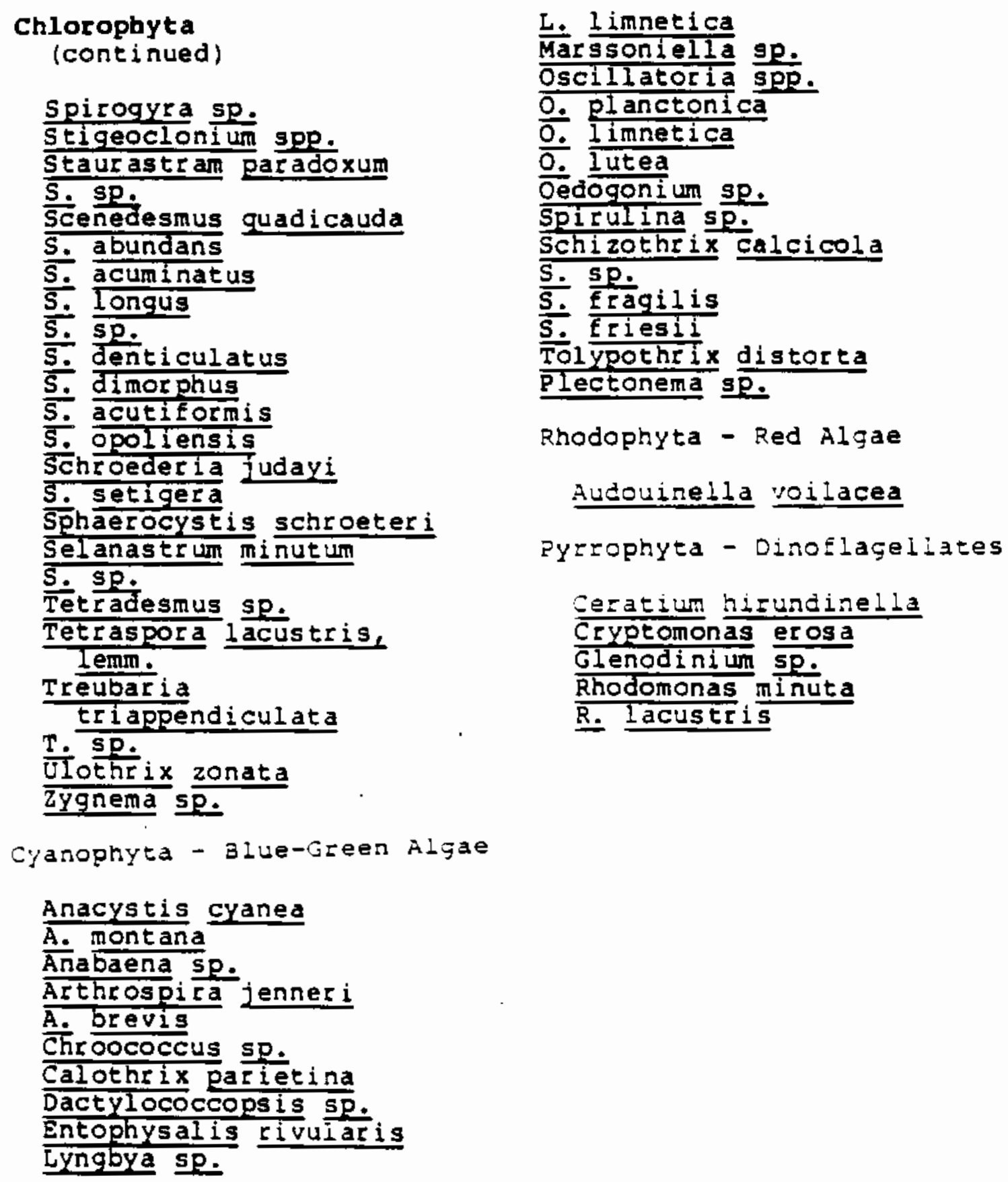


TABLE A.11. Total Number of Phytoplankton Species (S) Within Major Algal Division and the Percent of Mean Monthly Phytoplankton Density Comprised by Algal Division (\%) at RM352 (RKM566), September 1978 - March 1980 (Beak

Consultants Inc. 1980)

Algol Diviston
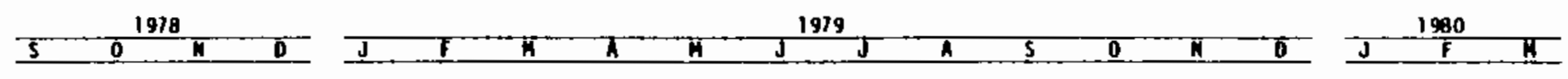

$5 \quad 49 \quad 44 \quad 46 \quad 52$

$2 B$

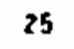

$22 \quad 21 \quad 31 \quad 37$

$42 \quad 33$

35

1) $48 \quad 53$

$31 \quad 14 \quad 20$

CHRYSOPHYIA

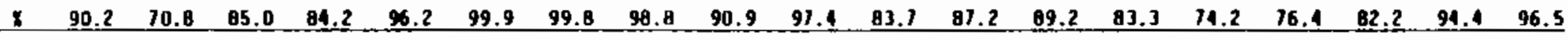

CHLOROPHY IA

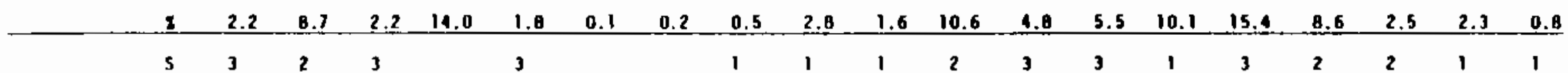

PYRROPHYIA

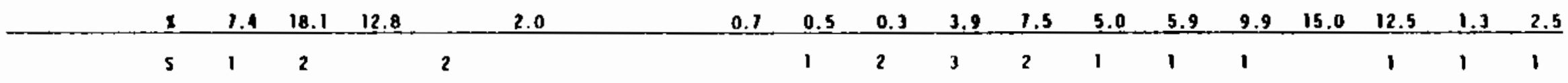

CYAMPFYYA

\begin{tabular}{lllllllllllllllllllll} 
& 2 & 0.2 & 2.4 & & 1.8 & & & & & 5.8 & 0.1 & 1.0 & 0.5 & 0.3 & 0.7 & 0.5 & & 2.8 & 2.0 & 0.2 \\
\hline totel 10xa & 1 & 57 & 56 & 51 & 61 & 33 & 26 & 23 & 23 & 34 & 43 & 54 & 13 & 51 & 54 & 56 & 60 & 36 & 18 & 23 \\
\hline
\end{tabular}


TABLE A.12. Zooplankton Taxa Collected in the Hanford Reach, Columbia River (PSP\&L 1982; Neitzel et a!, 1982b)

\section{Coelenterata}

Hydra. spp.

\section{Ectoprocta}

Bryozoa

Paludicellidae

Paludicella articulata

Nematoda

\section{Rotifera}

Brachionidae

Kellicottia longispina

Keratella cochlearis

Kerratella (? quadrata)

Brachionus spp.

Euchlanis spp.

Kellicottia spp.

lecani iae

lecane spp.

Synchaet i iae

Synchaeta spp.

Polyarthra sp.

Testudinelidae

Testudinella spp.

\section{Tardigrada}

\section{Annelida}

Oligochaeta

Hirudinea

\section{Arthropoda}

Cladocera

Leptodor i dae

Leptodora kindtii

Sididae

Sida crystallina

Latona spp.

Diaphanosoma spp.

Daphni dae

Daphnia spp.

Daphnia pulex

Daphnia middendorf $i$ ana

Ceriodaphnia spp.

Bosminidae

Bosmina longirostris

Macrothricidae

Macrothrix spp.

Dyocryptus spp.

chydoridae

Pleuroxus spp.

Pieuroxus denticulatus

Alona costata

Alona guadrangalar is

Alona gut lata

Alona rectangula 
TABLE A.12. (contd)

Arthropoda $\left(\operatorname{con}^{\prime} t\right)$

Chydorus spp.

Eurycercinae

Eurycercus lamellatus

Ostr acoda

Copepoda

Calanoida

Temoridae

Epischura spp.

Temoridae copepodid

Di aptomi dae

Diaptomus spp.

Diaptomus ashiandi

Cyclopoida

Cyclopidae

Copepoda naupli i

Cyclops spp.

Cyclopoid copepodid

Cyclops bicuspidatus thomasi

Harpacticoida

\section{Apphi poda}

Acari

\section{Insecta}

Collembola

Ephemeropter a

Tri chopter a

Rhyacophilidae

Hydropsychidae

Diptera

Chi ronomi dae

Simuli idae

simulium sp.

Platybelninthes

Turbellaria

Dugesia sp.

Protozoa

Vorticella sp. 
TA8LE A.13. Benthic Macrofauna of the Hanford Reach, Columbia River (PSP\&L 1982)

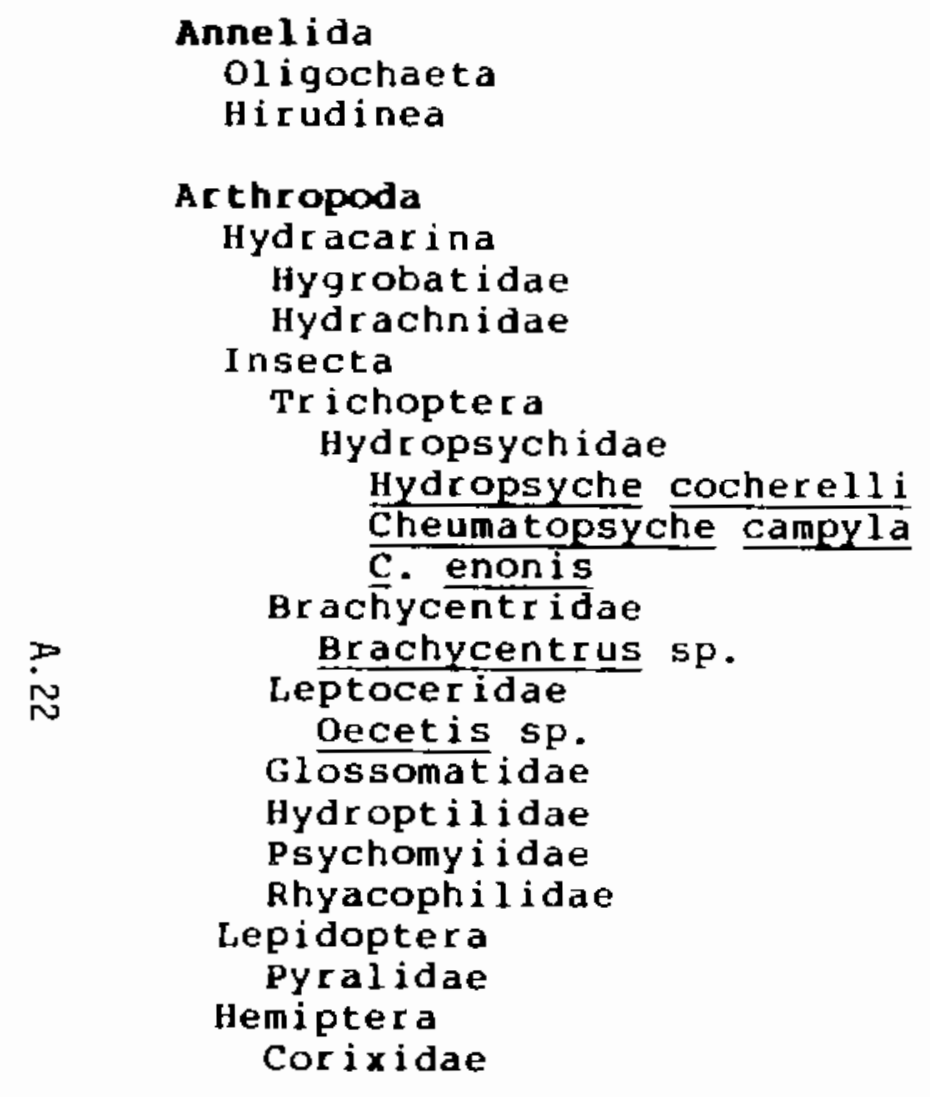

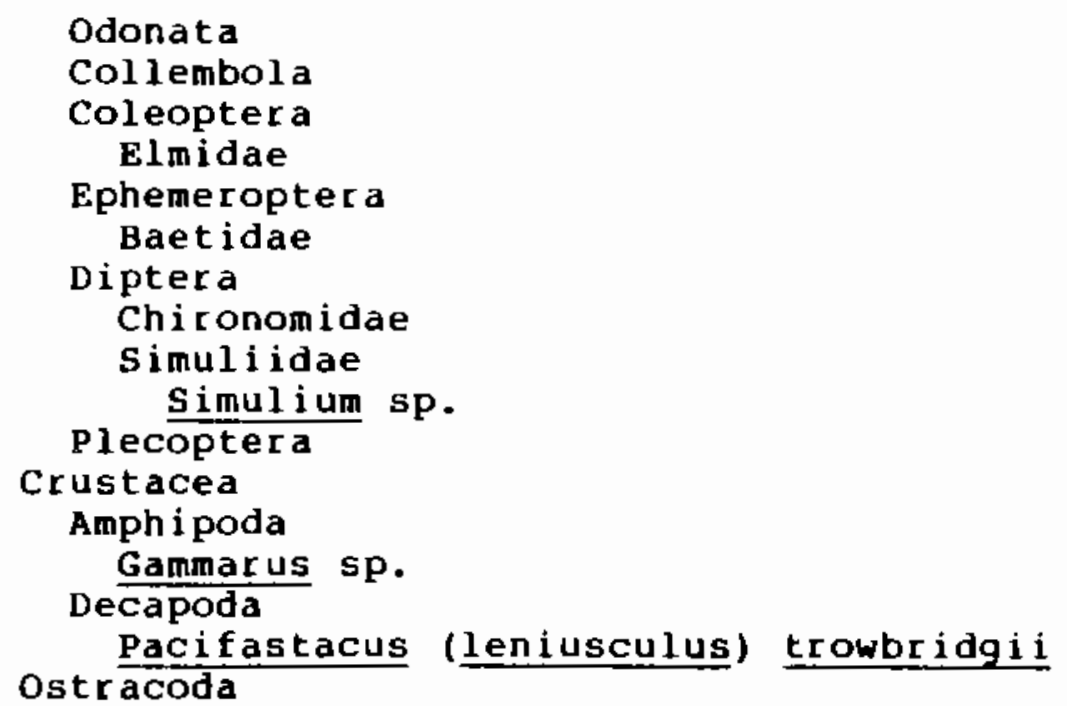

Paludicella sp. 
TABLE A.13. (contd)

Mollusca

Gastropoda

Physa sp.

Fisherola nuttalli

Lymnaea sp.

parapholyx sp.

Lithogiyphus sp.

Nematoda

Tardigrada

Coelenterata

Hydra sp.

Porifera

Spongilla lacustris
Platyhelninthes

Turbellaria

Dugesia sp.

Cura sp.

Chordata

Agnatha

Lampetra tridentatus 
TABLE A.14. Appearance of Algae in Ponds and Streams on the Hanford Site

\begin{tabular}{|c|c|c|c|c|c|c|c|c|c|}
\hline $\begin{array}{c}\text { Oivision } \\
\text { (Common Plame) }\end{array}$ & Family & $\begin{array}{l}\text { ble } \\
\text { ond }\end{array}$ & $\begin{array}{c}\text { B- } \\
\text { Pond }\end{array}$ & $\begin{array}{l}\text { U- } \\
\text { Pond }\end{array}$ & $\begin{array}{l}\text { West } \\
\text { Pond }\end{array}$ & $\begin{array}{r}A-29 \\
\text { Ditch } \\
\end{array}$ & $\begin{array}{r}B-3 \\
\text { Ditch } \\
\end{array}$ & $\begin{array}{r}2-19 \\
\text { sitch } \\
\end{array}$ & $\begin{array}{l}100-i i \\
\text { Trench }\end{array}$ \\
\hline $\begin{array}{l}\text { Cyanophyta } \\
\text { (Blue-green } \\
\text { Algae) }\end{array}$ & $\begin{array}{l}\text { Oscillatoriaceae } \\
\text { Chroococcacede } \\
\text { lios tocaceae }\end{array}$ & $\begin{array}{l}+ \\
+ \\
+\end{array}$ & $\begin{array}{l}+ \\
+ \\
+\end{array}$ & $\begin{array}{l}+ \\
+ \\
+\end{array}$ & $\begin{array}{l}+ \\
+ \\
+\end{array}$ & $\begin{array}{l}+ \\
+ \\
+\end{array}$ & $\begin{array}{l}+ \\
+ \\
+\end{array}$ & $\begin{array}{l}+ \\
+\end{array}$ & + \\
\hline $\begin{array}{l}\text { Cnlorophyta } \\
\text { (Green Aljoe) }\end{array}$ & $\begin{array}{l}\text { Desmidiaceae } \\
\text { Palmellacede } \\
\text { Volvocacede } \\
\text { Characiaceae } \\
\text { Phacotaceae } \\
\text { Oocys taceae } \\
\text { Scenedesmaceae } \\
\text { Tetrasporaceae } \\
\text { Nicractiniaceae } \\
\text { Coccomyxacede } \\
\text { Zygnemataceae } \\
\text { Cladophoraceae } \\
\text { Hydrodictyaceae } \\
\text { Characede }\end{array}$ & $\begin{array}{l}+ \\
+ \\
+ \\
+ \\
+\end{array}$ & $\begin{array}{l}+ \\
+ \\
+ \\
+ \\
+ \\
+\end{array}$ & $\begin{array}{l}+ \\
+ \\
+ \\
+ \\
+ \\
++\end{array}$ & $\begin{array}{l}+ \\
+ \\
+\end{array}$ & $\begin{array}{l}+ \\
+ \\
+\end{array}$ & $\begin{array}{l}+ \\
+ \\
+ \\
+ \\
+ \\
+ \\
+\end{array}$ & $\begin{array}{c}+ \\
+ \\
+\end{array}$ & $\begin{array}{c}-1 \\
+ \\
+ \\
+\end{array}$ \\
\hline $\begin{array}{l}\text { Euglenopnyta } \\
\text { (Euglenoid Algae }\end{array}$ & Euglenaceas & & & * & + & & & & \\
\hline $\begin{array}{l}\text { Cnrysophyta } \\
\text { (Golden-Drown } \\
\text { Algae } 8 \\
\text { Didtoms) }\end{array}$ & $\begin{array}{l}\text { Mallomonadaceae } \\
\text { Ocnromonadaceae } \\
\text { Coscinodiscacede } \\
\text { Rni zosolentacede } \\
\text { Tabellariaceae } \\
\text { Diatomacede } \\
\text { Acnnanthaceae } \\
\text { Iaviculaceae } \\
\text { Gomphoneriataceae } \\
\text { Cy'loeliaceae } \\
\text { idizscniacede } \\
\text { Surirellaceae } \\
\text { Fracilariaceae } \\
\text { Synuraceae }\end{array}$ & $\begin{array}{c}++ \\
+ \\
+ \\
+ \\
+ \\
+ \\
+ \\
+ \\
+ \\
+ \\
+\end{array}$ & $\begin{array}{r}+ \\
+ \\
+ \\
+ \\
+ \\
+ \\
+\end{array}$ & $\begin{array}{l}+ \\
+ \\
+ \\
+ \\
+ \\
+ \\
+\end{array}$ & $\begin{array}{c}+ \\
+ \\
+ \\
+ \\
++ \\
+ \\
+ \\
+ \\
+ \\
+\end{array}$ & $\begin{array}{c}+ \\
+ \\
+ \\
+ \\
+ \\
+\end{array}$ & $\begin{array}{c}+ \\
++ \\
+ \\
+ \\
+ \\
+ \\
+ \\
+ \\
+ \\
+ \\
+ \\
+\end{array}$ & $\begin{array}{l}+ \\
+ \\
+ \\
+\end{array}$ & . \\
\hline $\begin{array}{l}\text { Pyrrophyta } \\
\text { (Dinoflagel lates) }\end{array}$ & $\begin{array}{l}\text { Gymnodiniacede } \\
\text { iGlerodiniacede }\end{array}$ & & & + & + & & & & \\
\hline $\begin{array}{l}\text { Cryotoonyceae } \\
\text { (Cryptomonads) }\end{array}$ & Cryptomonadaceae & & + & + & + & + & + & & \\
\hline
\end{tabular}

Note: The presence of a taxon is indicated by a "+", notabiy large abundance by a "++", and no symbol indicates an absence

Source: Emery and McShane (1980). 
TABLE A.15. Dominant Macrophytes 0bserved in Ponds and Streams on the Hanford Site

\begin{tabular}{|c|c|c|c|c|c|c|c|c|c|}
\hline ignon varye & Genus & $\begin{array}{l}\text { Gable } \\
\text { Pond }\end{array}$ & $\begin{array}{c}3- \\
\text { Pond } \\
\end{array}$ & $\begin{array}{c}\text { U- } \\
\text { Pond }\end{array}$ & $\begin{array}{l}\text { west } \\
\text { Pond }\end{array}$ & $\begin{array}{r}i-29 \\
0 i t c h \\
\end{array}$ & $\begin{array}{r}8-3 \\
\text { Ditch } \\
\end{array}$ & $\begin{array}{r}2-19 \\
\text { Ditch }\end{array}$ & $\begin{array}{l}100-1 ; \\
\text { irench }\end{array}$ \\
\hline -orsecall & Eguisetur & • & & + & & & & & \\
\hline zondweec & Dotamogeton & + & + & + & & & & ++ & \\
\hline tornwort & Ceratochyl : & + & & & & & & & \\
\hline 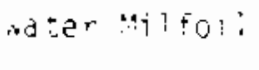 & Myriogn, in & $\cdots$ & & & & & & & \\
\hline ischees & Lemna & & & + & & & & & \\
\hline attcail & jona & - & + & $\cdots$ & * & * & + & ++ & \\
\hline $3 \mu i n+5 n$ & Sc:rpis & - & * & * & - & + & + & + & - \\
\hline silar tweed & Po:yconsm & & & + & & & & & \\
\hline Sceetwe: i & veronica & & & & & + & + & - & - \\
\hline matersaess & Roripga & & & - & & & & - & \\
\hline$n^{\prime} Z$ - & Lactuca & & & - & & & & - & \\
\hline nitis... & $\underline{j a l i x}$ & - & & - & & & & & \\
\hline $0: 20^{\prime}, \ldots 00 \mathrm{i}$ & Doulus & + & & - & & + & & + & \\
\hline
\end{tabular}

Note: The presence of a taxon is indicated by a "+", notably large abundance by a "++", and no symbol indicates an absence.

Source: Emery and McShane (1980). 
TABLE A.16. Appearance of Aquatic Fauna in Ponds and Streams on the Hanford Site

\begin{tabular}{|c|c|c|c|c|c|c|c|c|c|}
\hline Common & Taxon & $\begin{array}{l}\text { Gable } \\
\text { Pand }\end{array}$ & $\begin{array}{l}\text { B- } \\
\text { Pond }\end{array}$ & $\begin{array}{l}\text { U- } \\
\text { Pond }\end{array}$ & $\begin{array}{l}\text { 'iest } \\
\text { Pond }\end{array}$ & $\begin{array}{r}A-29 \\
\text { Ditch }\end{array}$ & $\begin{array}{c}8-3 \\
\text { Ditch }\end{array}$ & $\begin{array}{r}2-19 \\
0 i t c n \\
\end{array}$ & $\begin{array}{l}: 20-: 1 \\
\text { Trench }\end{array}$ \\
\hline Fla tworm & Ougesia & + & + & + & & + & + & & \\
\hline Leech & Girundinea & & + & + & & & & & \\
\hline Segmented worm & 01 igochaeta & + & + & + & ++ & + & + & + & + \\
\hline $\begin{array}{l}\text { Wa terflea } \\
\text { Seed Shrimp }\end{array}$ & $\frac{\text { Daphnia }}{\text { Ostracoda }}$ & ++ & + & + & & & & & \\
\hline scud & Hyaletla & + & ++ & + & & & + & & \\
\hline $\begin{array}{l}\text { Watermi te } \\
\text { Mayfly }\end{array}$ & $\begin{array}{l}\text { Hydrocarina } \\
\text { Baetidae }\end{array}$ & + & + & + & & & & & \\
\hline Draganfly & Aeschna & ++ & + & ++ & & & + & & - \\
\hline Oragon & Libellúla & + & + & + & & & & & \\
\hline Oragonfly & ramea & & & + & & & & & \\
\hline $\begin{array}{l}\text { Oragonfiy } \\
\text { Oragonfly }\end{array}$ & $\frac{\text { Erythem is }}{\text { Anax }}$ & + & + & + & & & & & \\
\hline Damselfly & $\frac{\operatorname{mon}}{\operatorname{sch} n u r a}$ & + & + & + & + & & + & - & . \\
\hline Naterstrider & Gerridae & + & + & + & & + & + & - & \\
\hline $\begin{array}{l}\text { Backswimer } \\
\text { Creeping }\end{array}$ & $\begin{array}{l}\text { Notonectidae } \\
\text { Naucoridae }\end{array}$ & + & + & $*$ & + & & & + & - \\
\hline inater Bug & & & & & & & & & \\
\hline water Scorpion & Nepidae & + & & $*$ & & & & & \\
\hline Giant water Buc & Gelostomatidae & + & & + & & & & & \\
\hline Water Boatrian & Corixidae & + & + & + & + & & & + & \\
\hline Eaddisfly & Tricoptera & - & + & - & + & & + & & \\
\hline $\begin{array}{l}\text { Predaceous } \\
\text { Diving Beetle }\end{array}$ & Dytiscidae & + & + & - & & & - & * & \\
\hline $\begin{array}{l}\text { Hater Scavenger } \\
\text { Beetle }\end{array}$ & Hydrophilidae & + & + & & & & & & \\
\hline $\begin{array}{l}\text { Erawling } \\
\text { Water Beecle }\end{array}$ & Halipidae & + & & & & & & & \\
\hline Beetle & Amphizoidae & & & - & & & & & \\
\hline Beetle & Noteridae & & & - & & & & & \\
\hline Beetle & Helodidae & & & - & & & & & \\
\hline Midge & Chironomidde & - & - & - & . & $\cdots$ & $\cdots$ & - & - \\
\hline $\begin{array}{l}\text { Black Fly } \\
\text { Shore Fly }\end{array}$ & Simulitidae & & & & & + & & & \\
\hline $\begin{array}{l}\text { Shore Fly } \\
\text { Aqua tic }\end{array}$ & Ephydridae & & & & + & & & & \\
\hline $\begin{array}{l}\text { Aquatis } \\
\text { Caterpilier }\end{array}$ & Nymphulidae & & + & & & & + & & \\
\hline Snail & Physd & + & * & + & & & & & \\
\hline 5nail & Lymnaea & + & & + & & & & & $\ldots$ \\
\hline Snajl & Planorbidae & + & + & & & & & & \\
\hline Goldfish & Carassius & + & . & $\cdots$ & & & + & & \\
\hline
\end{tabular}

Note: Presence of a taxon is indicated by a " + ", notably large abundance of a taxon by a "++", and no symbol indicates an absence.

Source: Emery and McShane (1980). 
TABLE A.17. Fish 0bserved in the Hanford Reach, Columbia River (Gray and Dauble 1977, p. 211-212; U.S. DOE 1982, p. 4.6)

\begin{tabular}{|c|c|c|}
\hline $\begin{array}{l}\text { Acipenseridae } \\
\text { (sturgeons) }\end{array}$ & Acipenser transmontanus & white sturgeon \\
\hline $\begin{array}{l}\text { Catostomidae } \\
\text { (sucker) }\end{array}$ & $\begin{array}{l}\text { Catostomus columbianus } \\
\frac{\text { C. }}{\underline{c}} \cdot \frac{\text { macroche }}{\text { platyrhynchus }}\end{array}$ & $\begin{array}{l}\text { bridgelip sucker } \\
\text { largescale sucker } \\
\text { mountain sucker }\end{array}$ \\
\hline $\begin{array}{l}\text { Centrarchidae } \\
\text { (bass and sunfish) }\end{array}$ & $\begin{array}{l}\text { Lepomis gibbosus } \\
\text { M: macrochirus } \\
\text { Micropterus dolomieui } \\
\text { M. salmoides } \\
\text { Pomoxis annularis } \\
\text { P. nigromaculatus }\end{array}$ & $\begin{array}{l}\text { pumpkinseed* } \\
\text { bluegil]* } \\
\text { smallmouth bass* } \\
\text { largemouth bass* } \\
\text { white crappie } \\
\text { black crappie* }\end{array}$ \\
\hline $\begin{array}{l}\text { Clupeidae } \\
\text { (herrings) }\end{array}$ & Alosa sapidissima & American shad* \\
\hline $\begin{array}{l}\text { Cottidae } \\
\text { (sculpins) }\end{array}$ & 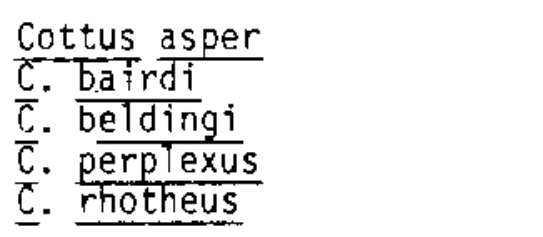 & $\begin{array}{l}\text { prickly sculpin } \\
\text { mottied sculpin } \\
\text { piute sculpin } \\
\text { reticulate sculpin } \\
\text { torrent sculpin }\end{array}$ \\
\hline $\begin{array}{l}\text { Cyprinidae } \\
\text { (minnows and } \\
\text { carp) }\end{array}$ & $\begin{array}{l}\text { Acrocheilus alutaceus } \\
\text { Cyprinus carpio } \\
\text { Mylocheilus caurinus } \\
\overline{\text { PtychocheiTus }} \\
\text { Rhinichthys cataractae } \\
\bar{R} \text {. falcatus } \\
\bar{R} \text {. } \frac{\text { osculus }}{\text { oratis }} \\
\bar{R} \text { ichardsonius balteatus } \\
\text { Tinca tinca }\end{array}$ & $\begin{array}{l}\text { chiselmouth } \\
\text { carp* } \\
\text { peamouth } \\
\text { northern squawfish } \\
\text { longnose dace } \\
\text { leopard dace } \\
\text { speckled dace } \\
\text { redside shiner } \\
\text { tench* }\end{array}$ \\
\hline $\begin{array}{l}\text { Gadidae } \\
\text { (codfishes) }\end{array}$ & Lota lota & burbot \\
\hline $\begin{array}{l}\text { Gasterosteidae } \\
\text { (sticklebacks) }\end{array}$ & Gasterosteus aculeatus & $\begin{array}{l}\text { threespine } \\
\text { stickleback }\end{array}$ \\
\hline $\begin{array}{l}\text { Ictaluridae } \\
\text { (freshwater } \\
\text { catfishes) }\end{array}$ & $\begin{array}{l}\text { IctaTurus melas } \\
\frac{\text { I. }}{I} \cdot \frac{\text { natalis }}{\text { nebulosus }} \\
\frac{\bar{I}}{\text { punctatus }}\end{array}$ & $\begin{array}{l}\text { black bulthead* } \\
\text { yellow bulthead* } \\
\text { brown bullhead* } \\
\text { channel catfish* }\end{array}$ \\
\hline
\end{tabular}


TABLE A.17. (contd)

\begin{tabular}{|c|c|c|}
\hline $\begin{array}{l}\text { Percidae } \\
\text { (perches) }\end{array}$ & $\frac{\frac{\text { Perca }}{\text { Stizostedion vitreum }}}{\text { vitreum }}$ & $\begin{array}{l}\text { yellow perch* } \\
\text { walleye }\end{array}$ \\
\hline $\begin{array}{l}\text { Percopsidae } \\
\text { (troutperches) }\end{array}$ & Percopsis transmontanus & sand roller \\
\hline $\begin{array}{l}\text { Petromyzontidae } \\
\text { (1ampreys) }\end{array}$ & $\frac{\text { Entosphenus }}{\text { Lampetra ayresi }}$ & $\begin{array}{l}\text { Pacific lamprey } \\
\text { river lamprey }\end{array}$ \\
\hline $\begin{array}{l}\text { Salmonidae } \\
\text { (salmon, trout, } \\
\text { and whitefish) }\end{array}$ & $\begin{array}{l}\text { Oncorhynchus kisutch } \\
\text { 0. nerka } \\
\overline{0} \cdot \frac{\text { tshawytscha }}{\text { Salmo clarki }} \\
\text { S. gairdneri } \\
\text { Salvelinus malma } \\
\frac{\text { Coregonus }}{\text { Prosopium williamsoni }}\end{array}$ & $\begin{array}{l}\text { coho salmon } \\
\text { sockeye saimon } \\
\text { chinook salmon } \\
\text { cutthroat trout } \\
\text { rainbow (steelhead } \\
\text { trout } \\
\text { Dolly Varden } \\
\text { lake whitefish } \\
\text { mountain whitefish }\end{array}$ \\
\hline
\end{tabular}

ऋ Introduced species 
TABLE A.18. Summary of Fall Chinook Salmon Production at the Priest Rapids Spawning Channel and Rearing Facility, 1963 Through 1978 (from Meekin and Allen, 1973, and Washington State Department of Fisheries, unpublished annual reports)

\begin{tabular}{|c|c|c|c|c|c|c|c|}
\hline \multirow[b]{2}{*}{$\begin{array}{l}\text { Brood } \\
\text { Year }\end{array}$} & \multicolumn{3}{|c|}{ Spawning Channel } & \multicolumn{4}{|c|}{ Rearing Facility } \\
\hline & $\begin{array}{l}\text { Adults } \\
\text { Spawned }\end{array}$ & $\begin{array}{c}\text { Egg } \\
\text { Deposition }\end{array}$ & $\begin{array}{l}\text { Juvenile } \\
\text { Release }\end{array}$ & $\begin{array}{l}\text { Adults } \\
\text { Spawned }\end{array}$ & $\begin{array}{l}\text { Eggs } \\
\text { Taken }\end{array}$ & $\begin{array}{l}\text { Juvenile } \\
\text { Release }\end{array}$ & $\begin{array}{c}\text { Total } \\
\text { Release }\end{array}$ \\
\hline & & $\left(\times 10^{6}\right)$ & $\left(\times 10^{6}\right)$ & & $\left(x 10^{6}\right.$ & $\left(\times 10^{6}\right)$ & $\left(\times 10^{6}\right)$ \\
\hline 1963 & 1237 & 2.95 & 1.10 & - & - & - & 1.10 \\
\hline 1964 & 4440 & 7.07 & 0.35 & - & - & - & 0.35 \\
\hline 1965 & 5589 & 10.91 & 1.22 & - & - & - & 1.22 \\
\hline 1966 & 5410 & 11.29 & 1.96 & - & - & - & 1.96 \\
\hline 1967 & 3355 & 9.20 & 7.19 & - & - & - & 7.19 \\
\hline 1968 & 1820 & 4.99 & 3.02 & - & - & - & 3.02 \\
\hline 1969 & 3130 & 7.02 & 3.61 & - & - & - & 3.61 \\
\hline 1970 & 2814 & 5.97 & 1.83 & - & - & - & 1.83 \\
\hline 1971 & 2973 & 7.13 & 2.80 & - & - & - & 2.80 \\
\hline 1972 & 716 & 1.57 & 0.41 & 927 & 1.95 & 0.25 & 0.66 \\
\hline 1973 & 1973 & 4.56 & 0.54 & 857 & 3.20 & 2.37 & 2.91 \\
\hline 1974 & 1063 & 2.50 & 0.72 & 223 & 0.85 & 0.57 & 1.29 \\
\hline 1975 & 608 & 1.41 & 0.54 & 813 & 2.99 & 1.34 & 1.88 \\
\hline 1976 & 593 & ND & ND & 451 & 1.19 & ND & NO \\
\hline 1977 & 529 & 0.75 & ND & 816 & 1.98 & ND & IID \\
\hline 15 & ND & ND & ND & ND & ND & ND & iin \\
\hline
\end{tabular}




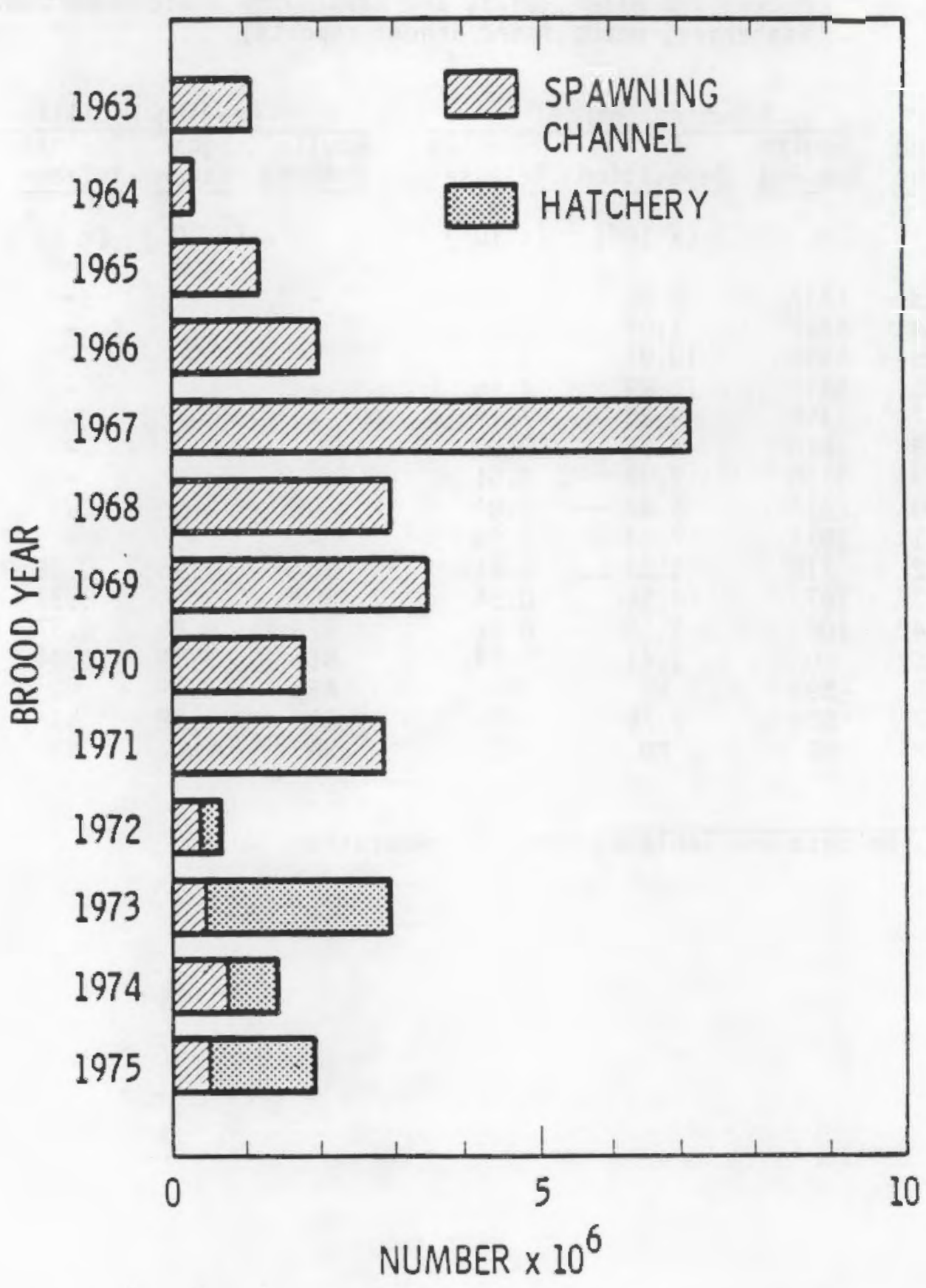

FIGURE A.1. Fall Chinook Salmon Released From Priest Rapids Spawning Channel and Rearing Facility, 1963 Through 1978 (from Meekin and Allen, 1973, and Washington State Department of Fisheries, 1973, 1974, 1975, 1976, 1977, 1978) 


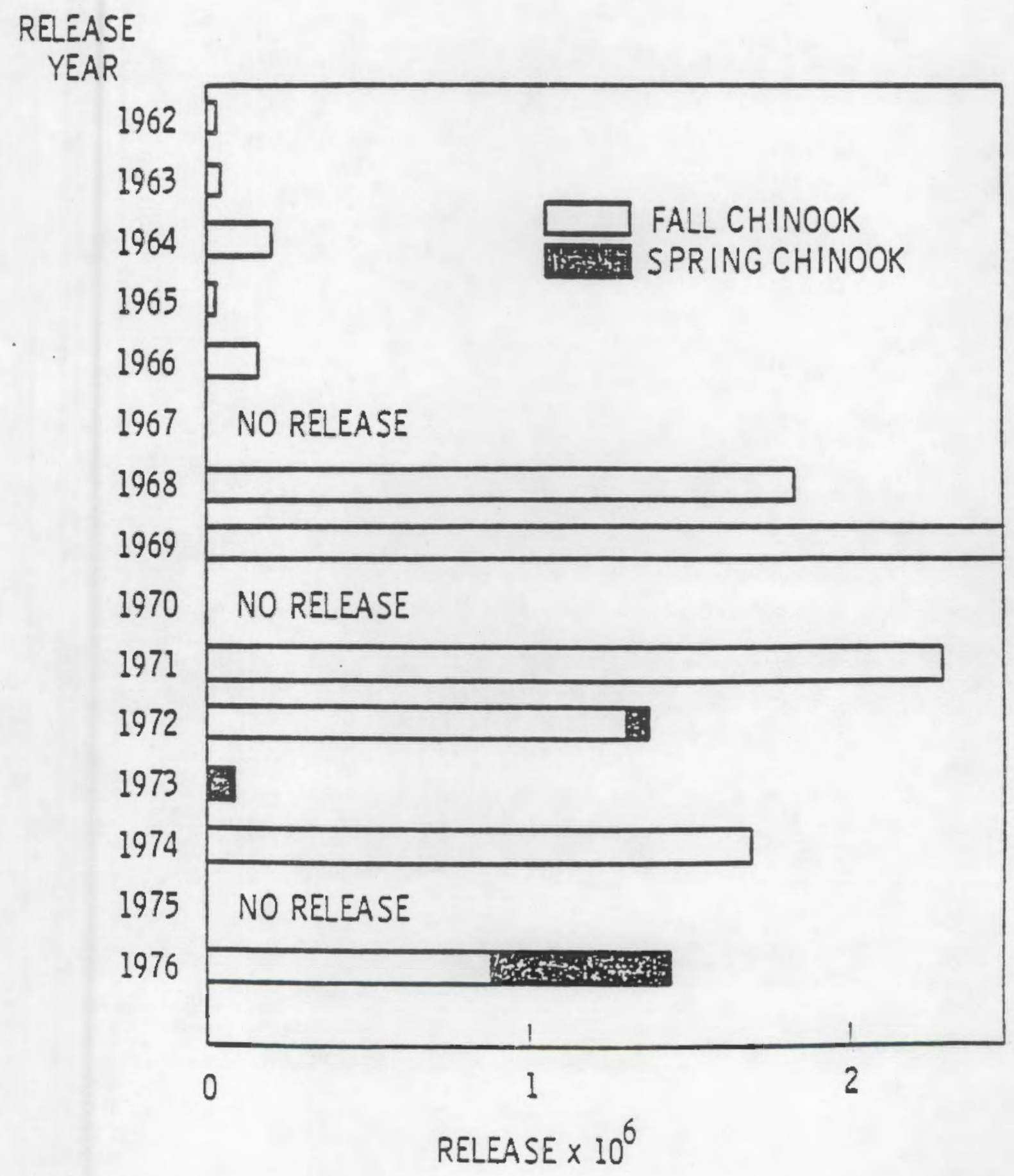

FIGURE A.2. Chinook Salmon Released from Ringold Rearing Ponds 1962 Through 1976 (from K. Bauersfeld, Washington State Department of Fisheries, personal communication) 

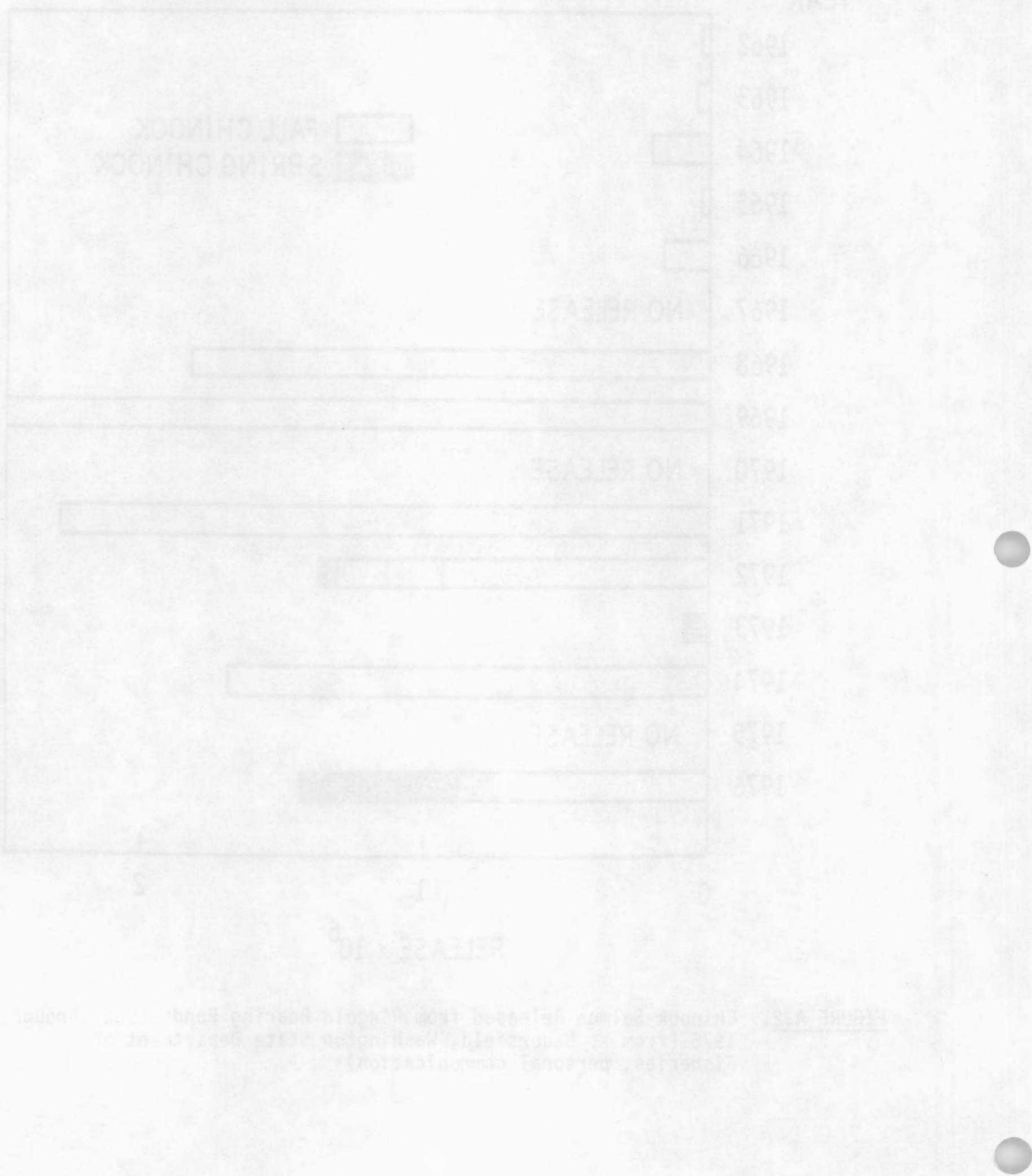
APPENDIX B

WIND DATA SUMMARIES FOR THE SKAGIT/HANFORD SITE 
APPENDIX B

\section{WIND DATA SUMMARIES FOR THE SKAGIT/HANFORD SITE}

Wind data summaries for the Skagit/Hanford Site are presented in Tables B.I and B.2 The summaries are based on data collected at the Wye Barricade from late March 1982 through the end of January 1984, a period of approximately 22 months. Monthly and annual summaries are provided for use with ground-level and elevated $(89 \mathrm{~m})$ release points.

In the summaries, the frequencies of occurrence of wind speeds and directions are given as functions of atmospheric stability class. Stability Class 1 corresponds to extremely stable (Pasquill A) conditions and Class 7 corresponds to extremely unstable (Pasquill G) conditions. Prior to March 1983 atmospheric stabilities were determined at the Hanford Meteorology Station using the Pasquill-Gifford-Turner approach based on sky cover/wind speed (see Gifford 1968, p. 10I, or Turner 1969, p. 6). Since then they have been determined using the NRC temperature gradient (Regulatory Guide 1.23) method.

The wind speed classes used are: $W 1=0$ to $4 \mathrm{mph} ; W_{2}=4$ to $8 \mathrm{mph} ; W_{3}=$ 8 to $13 \mathrm{mph}$; $W 4=13$ to $19 \mathrm{mph}$; $W 5=19$ to $25 \mathrm{mph} ; W 6=25$ to $32 \mathrm{mph} ; W 7=32$ to $39 \mathrm{mph}$, and $w 8=39 \mathrm{mph}$ or greater. Class $w 9$ includes a 11 winds less than $4 \mathrm{mph}$. This class differs from Class $\mathrm{Wl}$ because calm and variable winds have been distributed according to the frequency of occurrence of wind directions in Class Wi.

The joint frequency distributions for elevated release points were developed using the HMS atmospheric stability, the Wye Barricade wind direction, and a wind speed estimated from the Wye Barricade wind speed and a correction factor determined from the vertical profile of the winds on the tower at the HMS. The wind speed correction is based on the assumption that the wind speed shears at the HMS and the Wye Barricade are the same. In a climatological sense this assumption may be reasonably good. However, for individual hours the assumption may be seriously in error. 


\section{REFERENCES}

Gifford, F. A. 1968. "An Outline of Theories of Diffusion in the Lower Layers of the Atmosphere." In Meteorology and Atomic Energy - 1969, TID-24190, U.S. Atomic Energy Commission, Washington, D.C.

Turner, D. B. 1969. Workbook of Atmospheric Dispersion Estimate. 999-AP-26, U.S. Department of Heath, Education and WeTfare, Washington, D.C.

U.S. Nuclear Regulatory Commission. 1974. Onsjte Meteorological Programs. Regulatory Guide 1.23 (formerly Safety Guide 23), Washington, D.C. 
RELEASE HEIGHT: ๆ M

BTARTING DATE I 325 BZ

ENU DATE: 13184

TOTAL OF HOURS: 15674

WIND SPEED CLASS

$\begin{array}{ccccc}* \text { DF LON SPEED CLASSONE HINDS } & 1938 \\ 1 & 2 & 3 & 4 & \\ 1938 & 6071 & 5067 & 1928\end{array}$

1930

5

146

75

0

HIND DIRECTION (10 SECIUKS + CALH + VARIABLE)

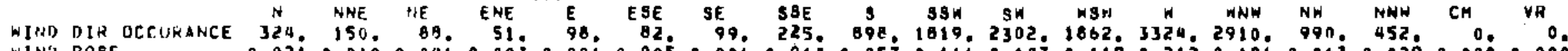

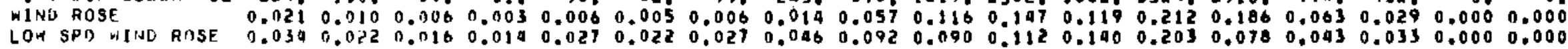

FRESIJENCY OISTRIBUTION OF THE HIND AS FUNCTION OF HIND GPEED AMO MIND DIRECTION

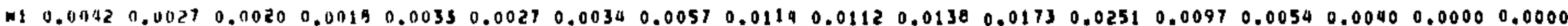

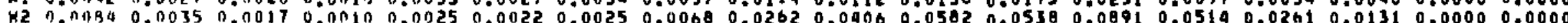

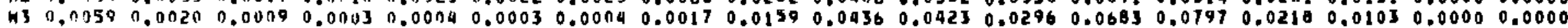

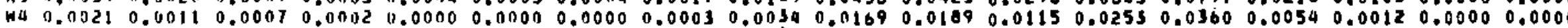

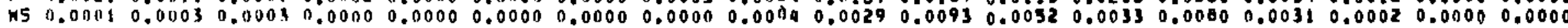

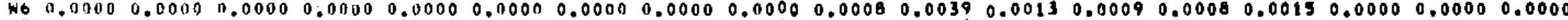

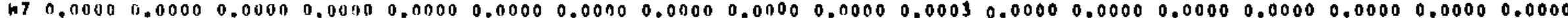

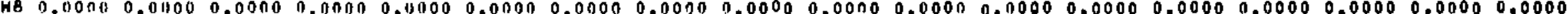

FREUUENCY OIQTRIBUTION OF THE HIND AS FUNCTION OF WIND SPEED, WIND DIRECTION AND GTAEILITY

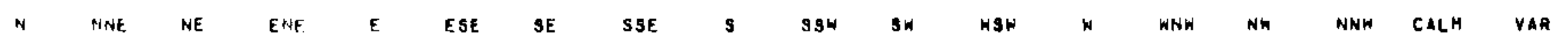

STAUILITY CLASS 1

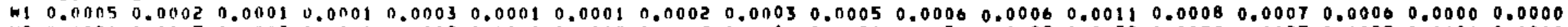

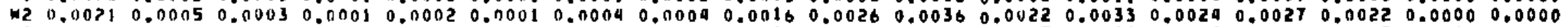

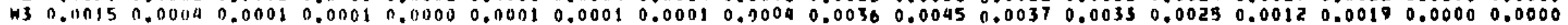

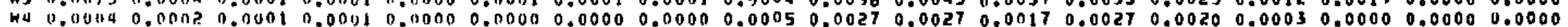

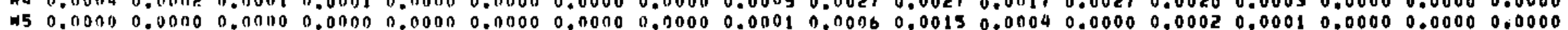

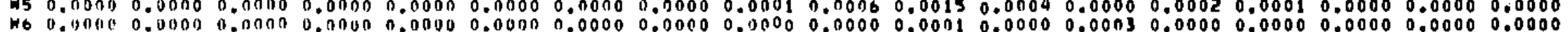

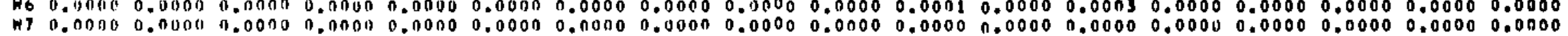

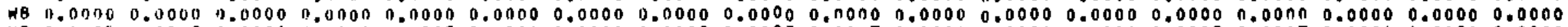

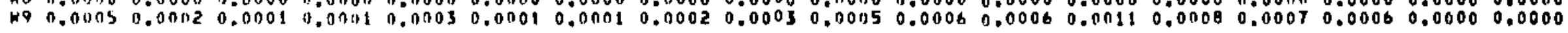

STaBility CLASS ?

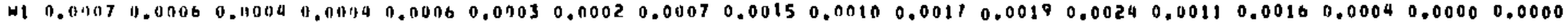

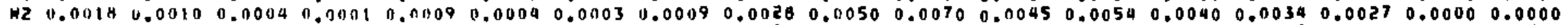

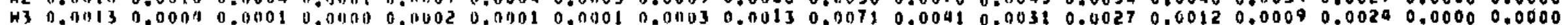

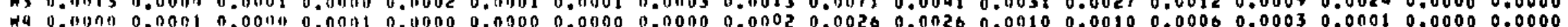

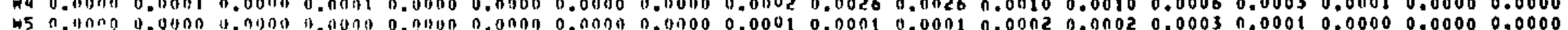

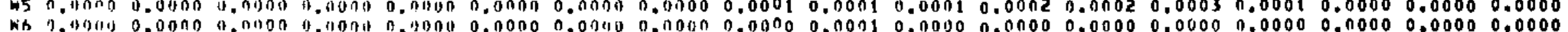

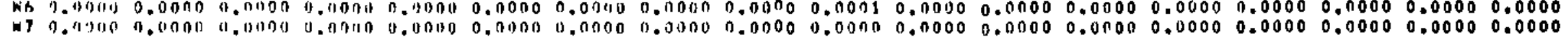

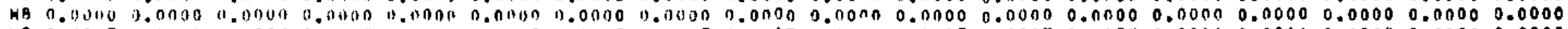

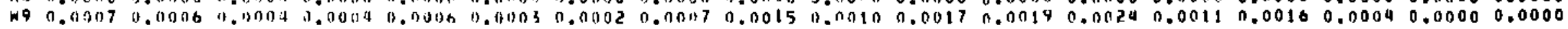




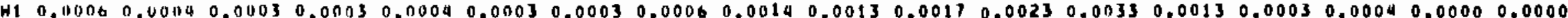

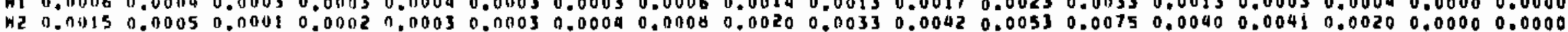

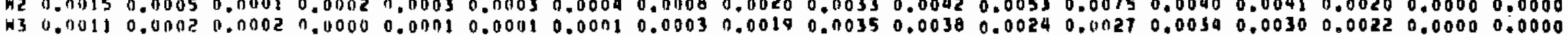

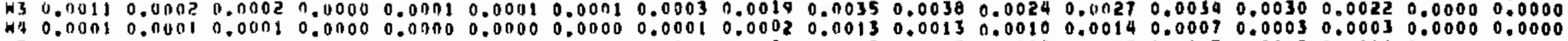

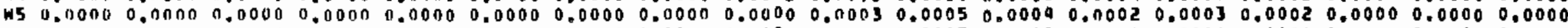

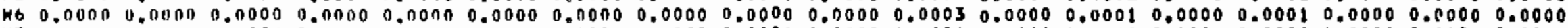

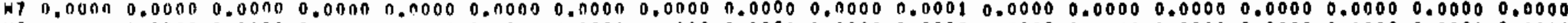

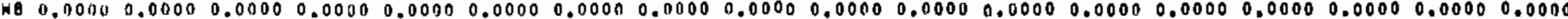

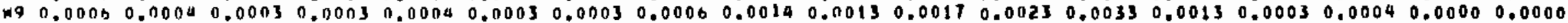

STAEILITR CLASS 4

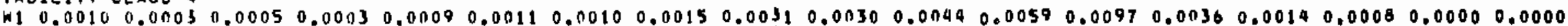

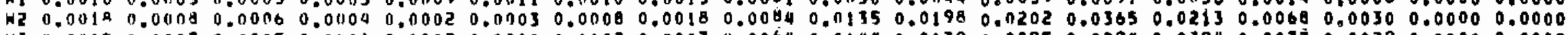

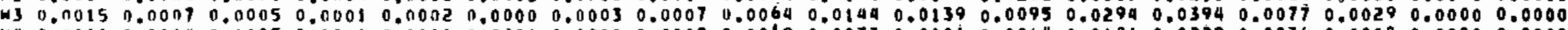

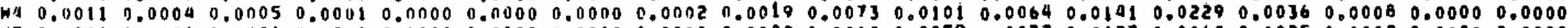

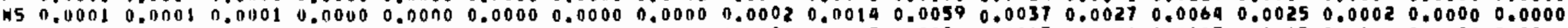

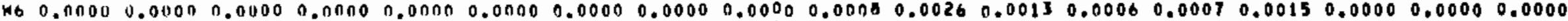

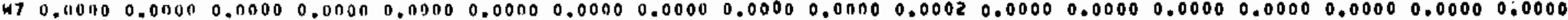

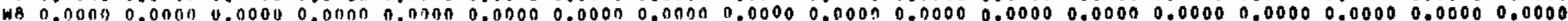

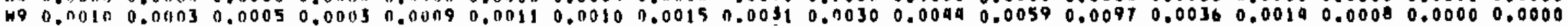

STAAILITY CLASS 5

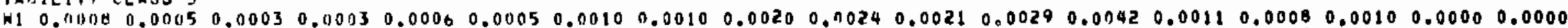

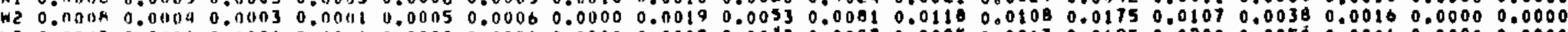

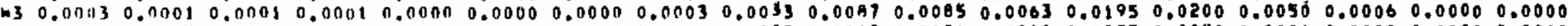

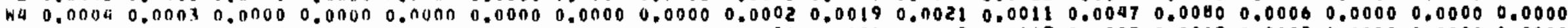

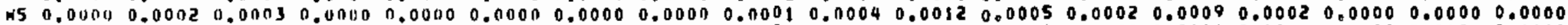

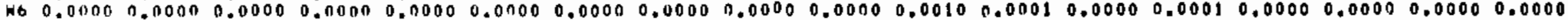

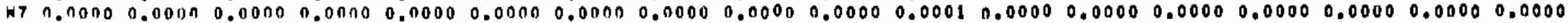

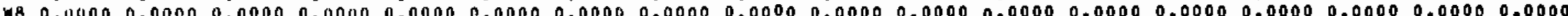

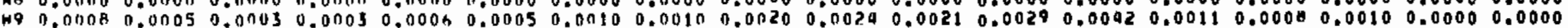

GTAEILITY CLASS 6

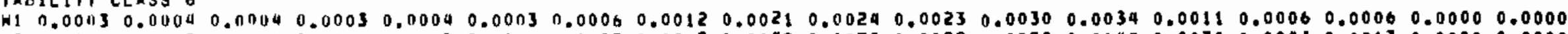

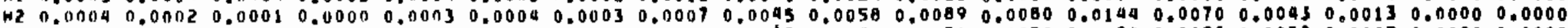

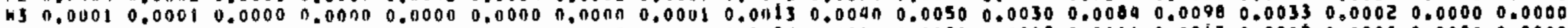

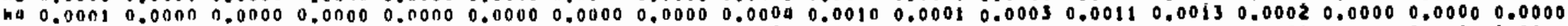

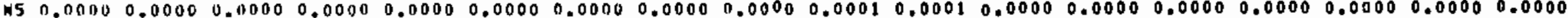

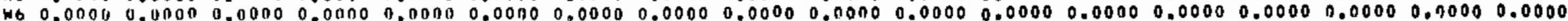

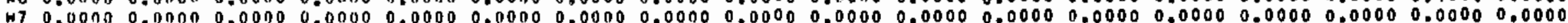

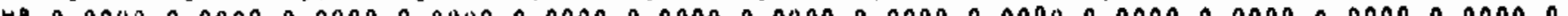

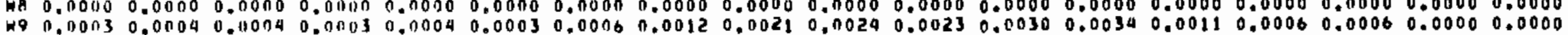

STABILITY CLASS 7

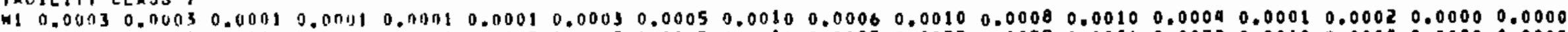

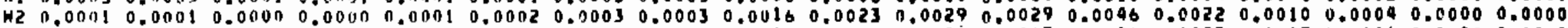

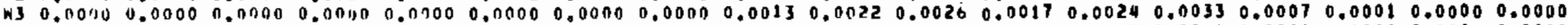

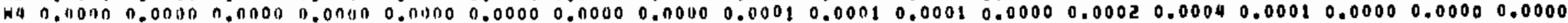

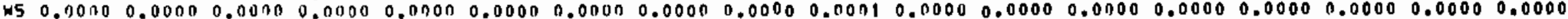

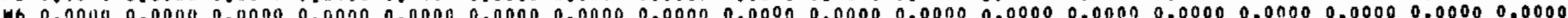

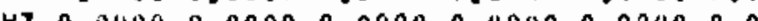

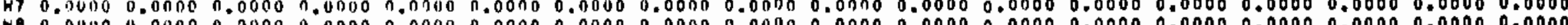

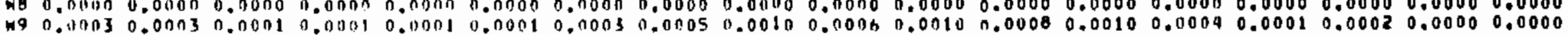


- IIF LOW SPEED CLASG ONE WINASI 232 HINO SPEEO CLASS

WIND UIRECTION (16 SECTURS + CALM + VARIABLE)

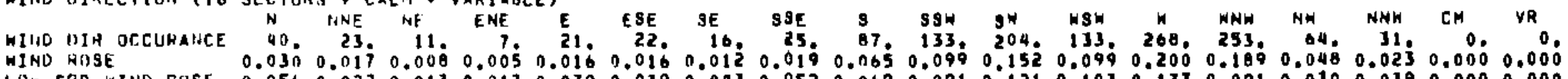

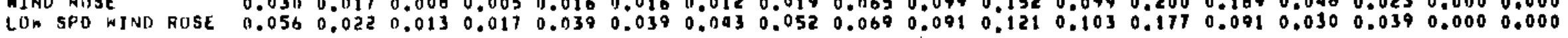

FRETUENCY DISTRIBUTIDH OF THE MIND AS FUHCTION OF NIND GPEED AND WINO DIRECTION

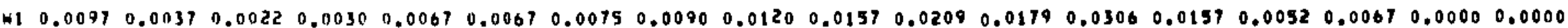

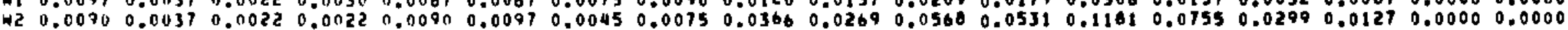

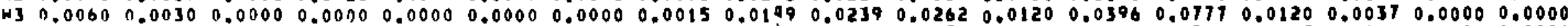

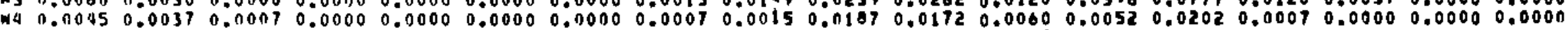

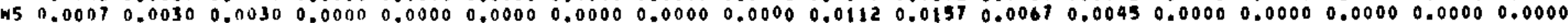

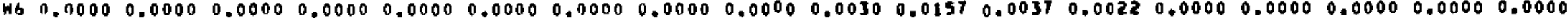

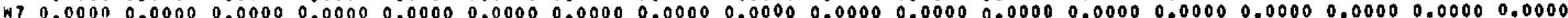

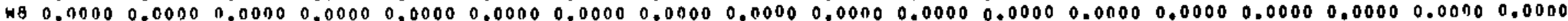

FHEDUENCY OISTPIQUTION OF THE HIND AS A FUNTION OF WIND SPEED, WIND DIRECTION AND STABILITY

NiIE

NE

ENE

F.

ESE

SE

GSE

$\checkmark$

s5i

sw

เ9

H

WN

NH

HNH CALH

VAR

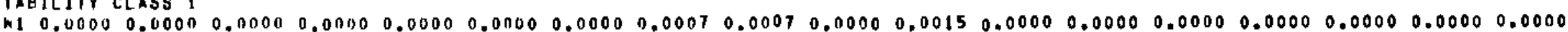

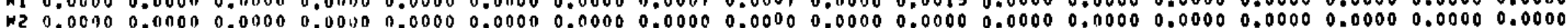

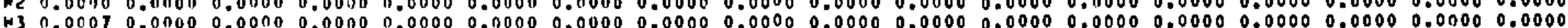

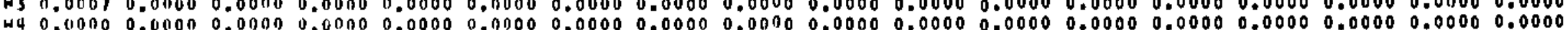

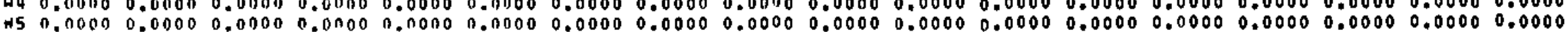

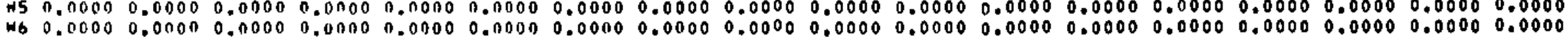

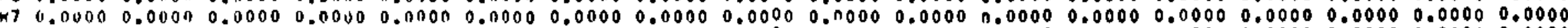

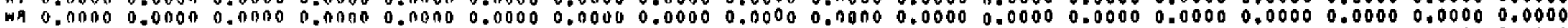

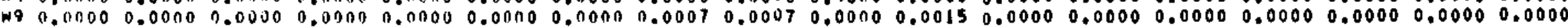

STABILITY CLASS 2

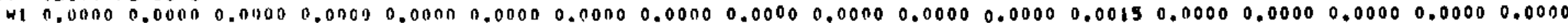

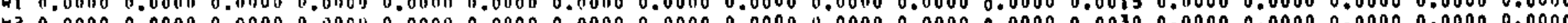
T.

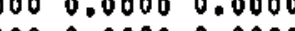
0.00000 .00000 .00000 .00000 .0000

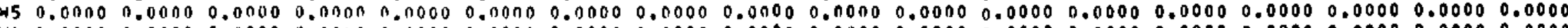

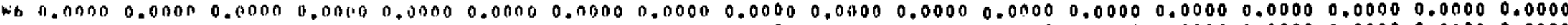

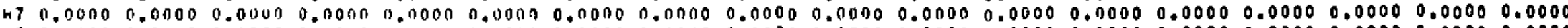

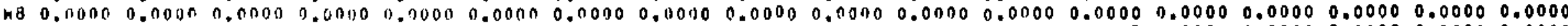

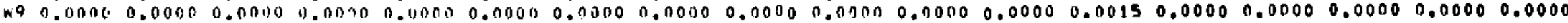

STAEIL ITY CLASS

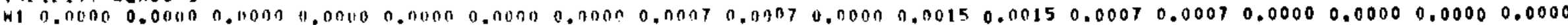

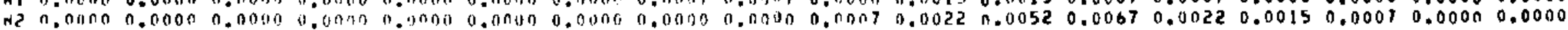


D IIF LOW SPEEP CLASS ONE WINIS: WIND SPEED CLASS * of occiJrances
232
2
3
106
5
33
7

\section{.}

WINO OINECTIOH (16 SECTORS + CALH + VARIABLE)

WIHO HIT OC,CUhaHCE N HNE AE ENE

HIND RUSE 0.0300 .0170 .006 7.005 $\begin{array}{lcl}21 . & E S E & \\ 016 & 0.016 & 0\end{array}$ 0.0050 .016

\section{$\cos$}

(2) (1)

\section{FREAUENCY DISTRIOUTIOH OF THE WIND AS A FUNCTION OF WINO gPEEO ANO WIND DIRECTION}

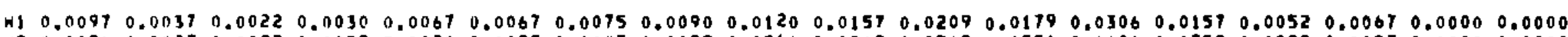

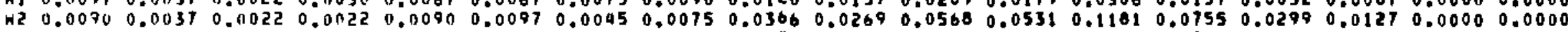

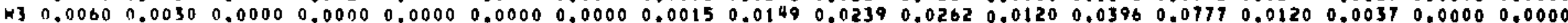

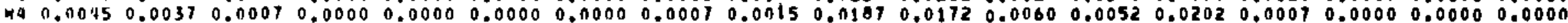

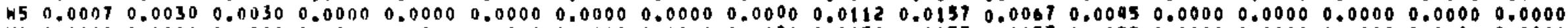

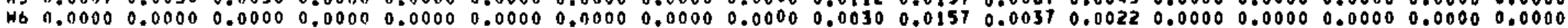

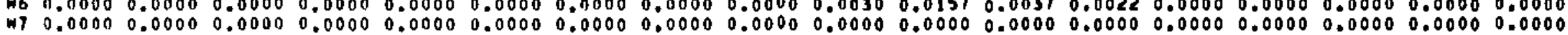

FHEGUFACY OISTRIPUTION OF THE WIND AS FUACTION OF WIND SPEED, WINO DIAECTION ANU STABILITY

$\uparrow$

NIE NE

ENE

f.

ESE SE

GSE

s

ssm

sit

WW

$w$

WNW NW

HNH CALM

VAR

STABILITY CLASS 1

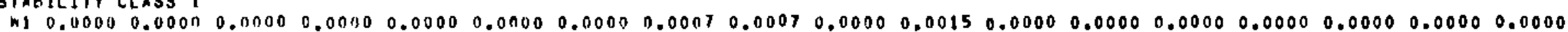

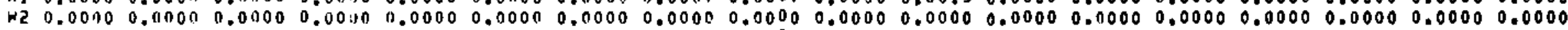

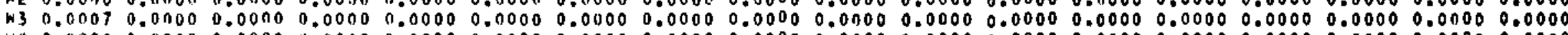

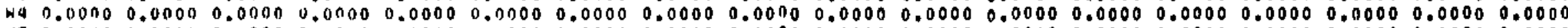

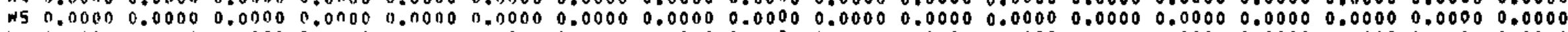

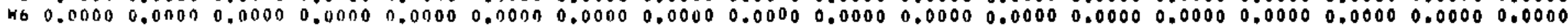

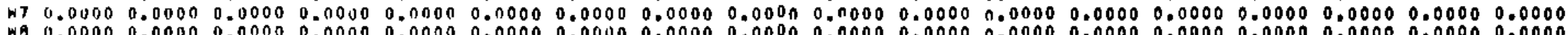

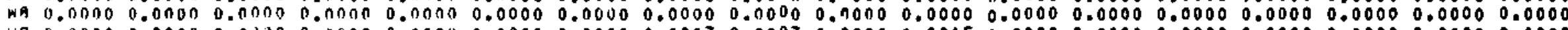

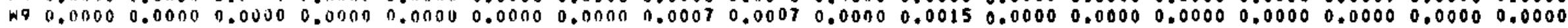

\section{SThith ITY CLASS}

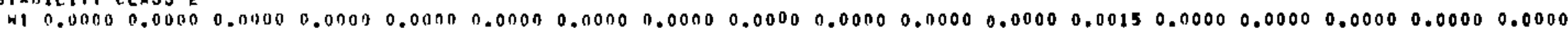

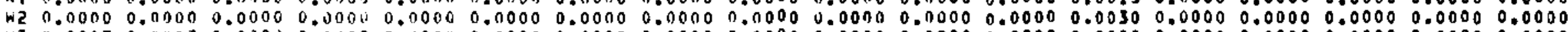

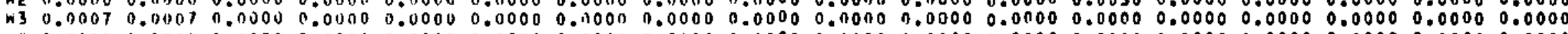

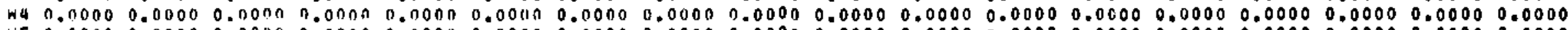

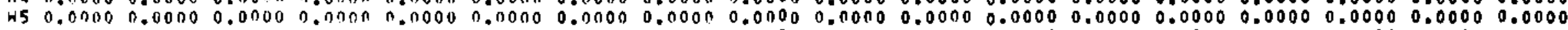

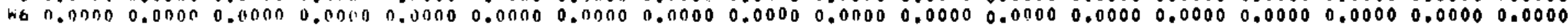

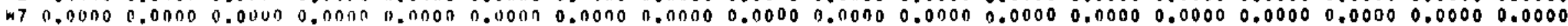

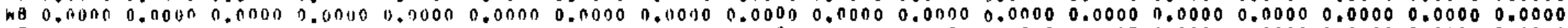

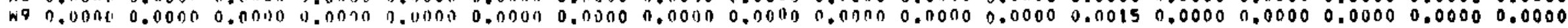

- staetilitrclass

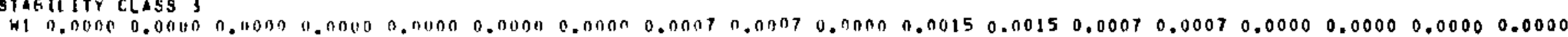

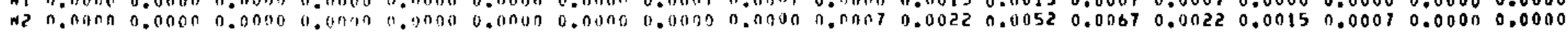




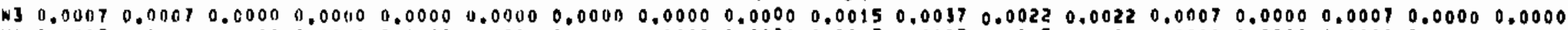

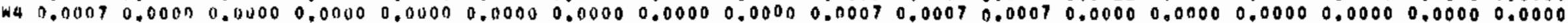

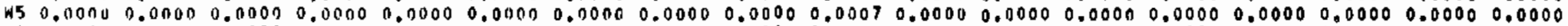

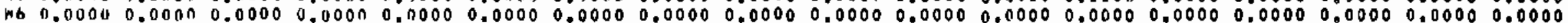

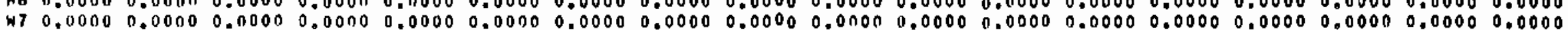

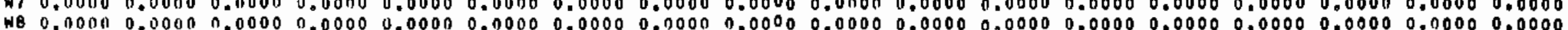

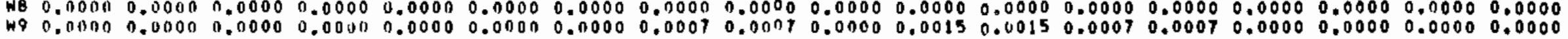

STABILITY CLASS a

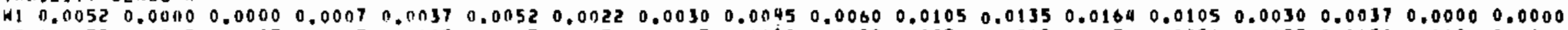

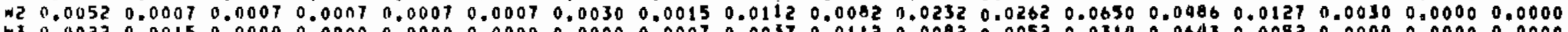

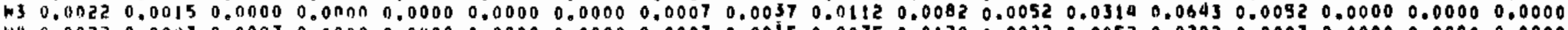

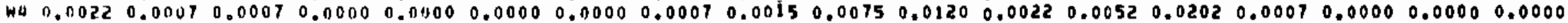

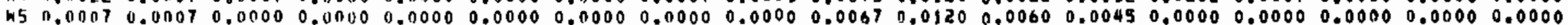

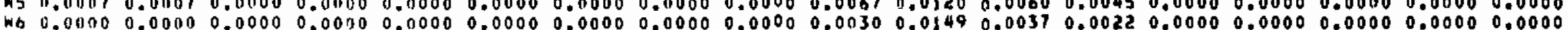

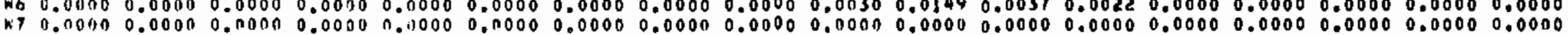

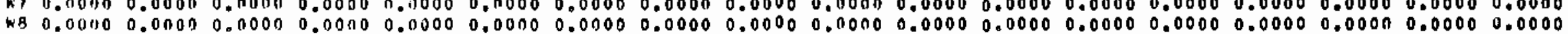

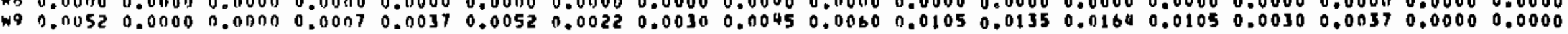

otAbILITR CLASS 5

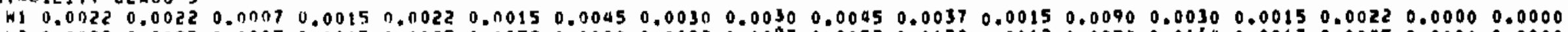

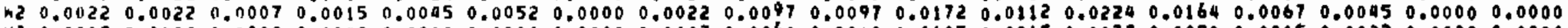

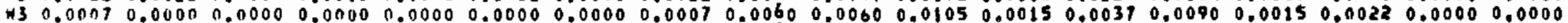

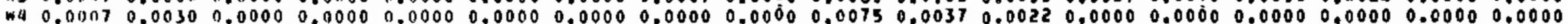

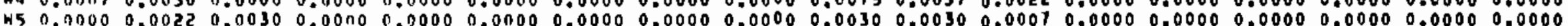

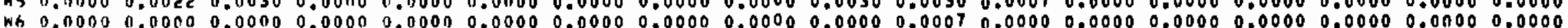

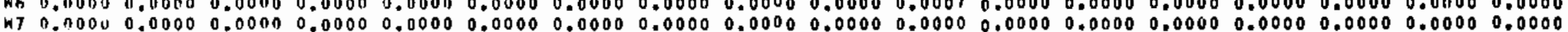

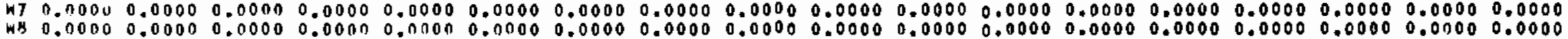

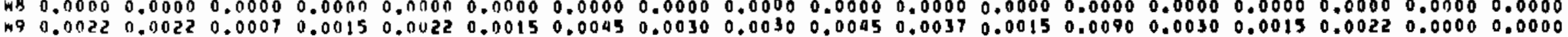

\section{gTABJLITY CLASS 6}

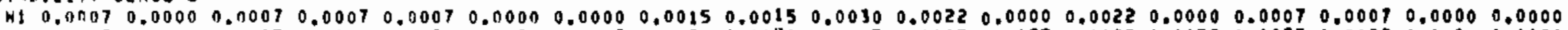

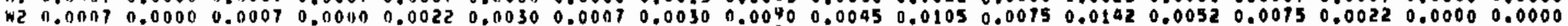

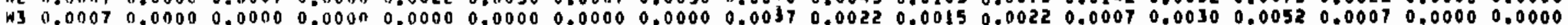

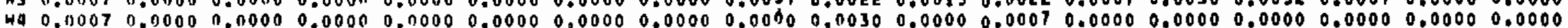

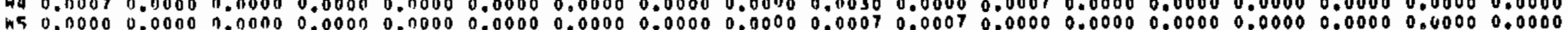

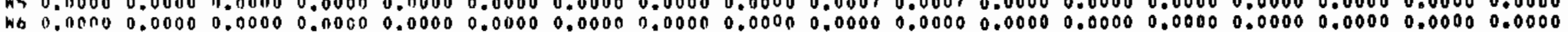

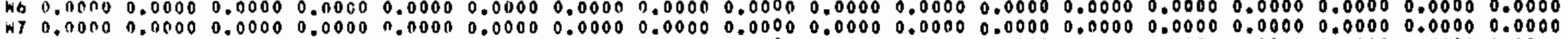

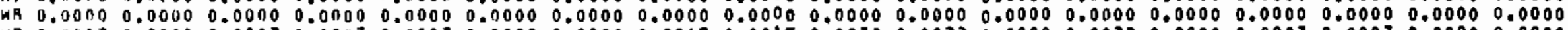

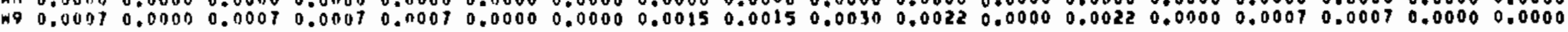

\section{STABILITY CLASS T}

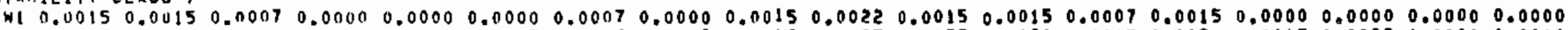

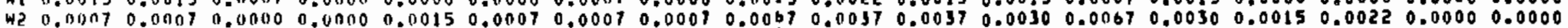

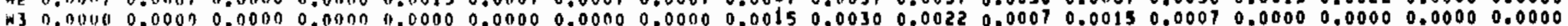

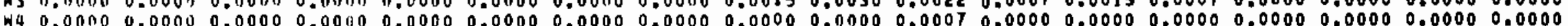

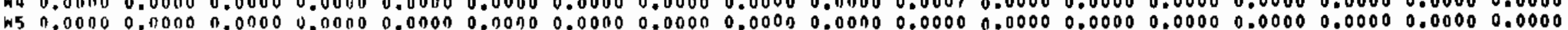

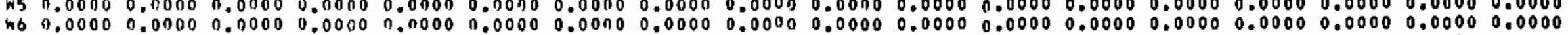

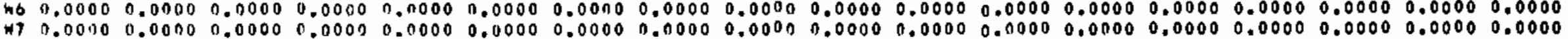

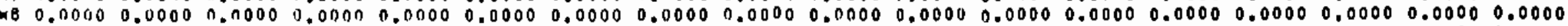

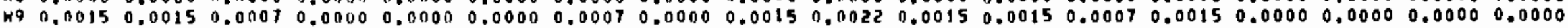


WOF LOW SPEEN CLASS UNE WINIS:
THD SPEED TLASS

- OF OCCURAMCES

WINU OIHECTIOH (16 SECTOR3 + CALM + VARIAELE)

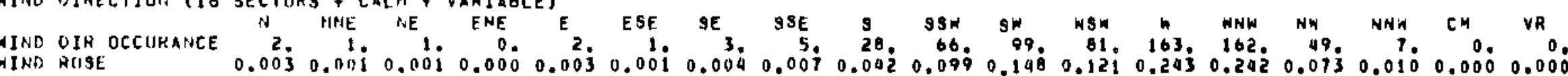
LOW SFL WIHI ROSE 0.0190 .0000 .1190 .0000 .0370 .0190 .0190 .0370 .0370 .1110 .1300 .0930 .2960 .1110 .0190 .0560 .0000 .000

FREIJIECY DISTPIBUTIOH OF THE WINI AS AUNCTION OF WINO SPEEO AND HIND DIAECTIOH

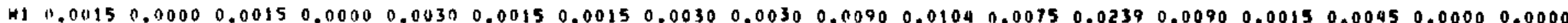

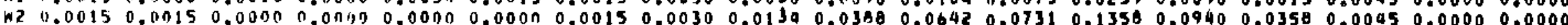

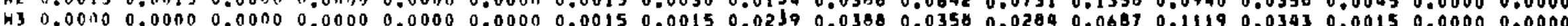

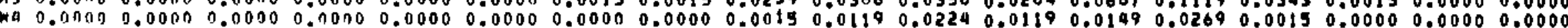

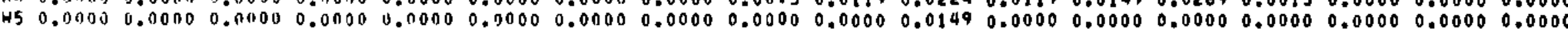

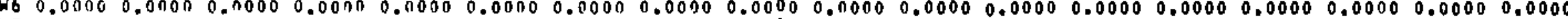

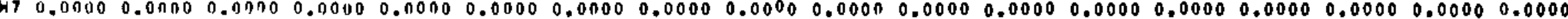

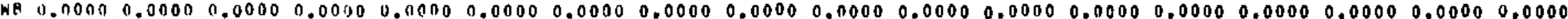

FREDUEHCY DISTRIBUTIOH OF THE WINO AS FUNCTIOY OF MIND SPEED, HIND DIRECTION AMO BTABILITY

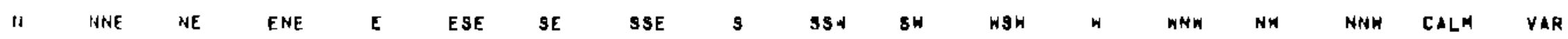

\section{STAFILITY CLASS}

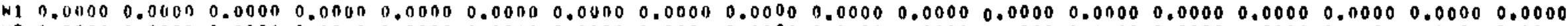

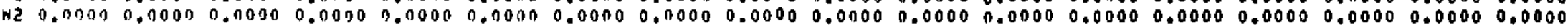

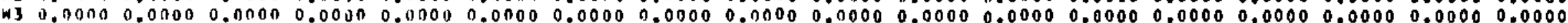

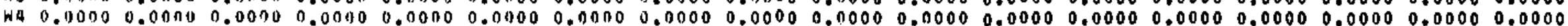

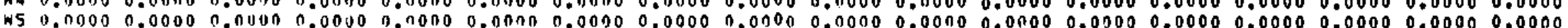

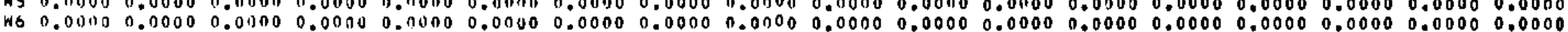

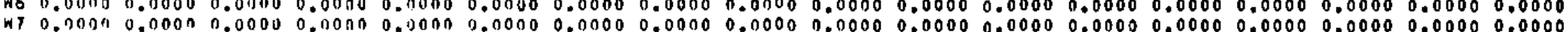

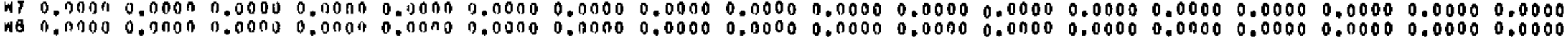

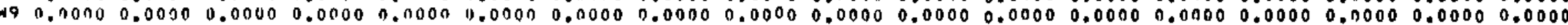

STABILITY CLASS 2

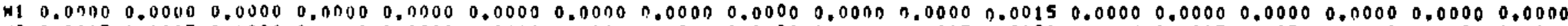

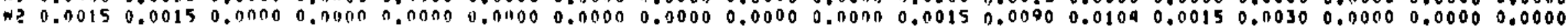

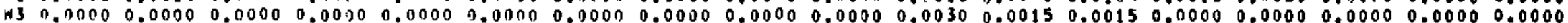

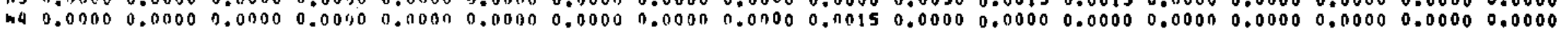

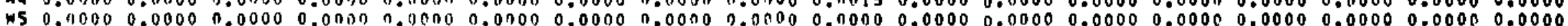

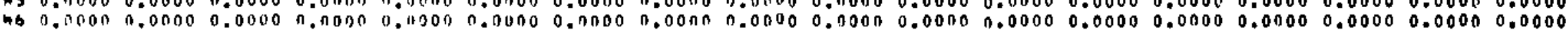

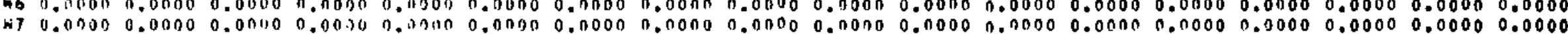

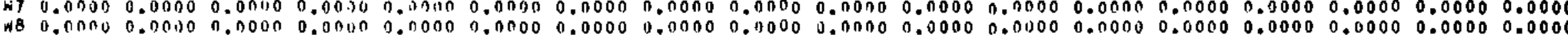

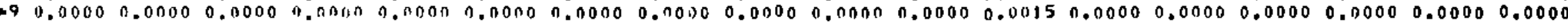

STÁtilitit CLASS 3

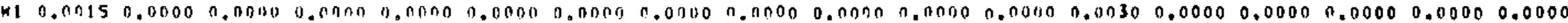

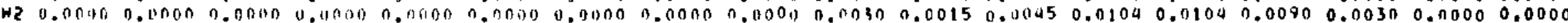




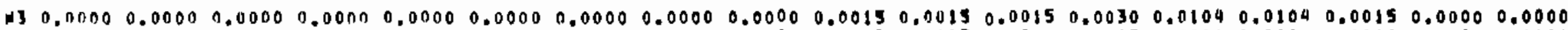

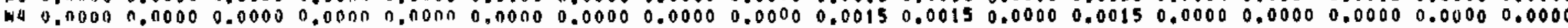

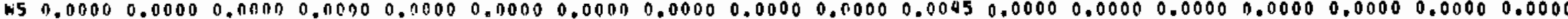

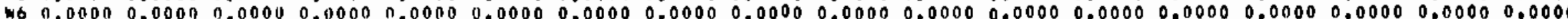

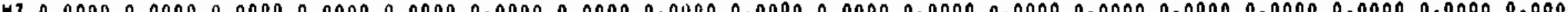

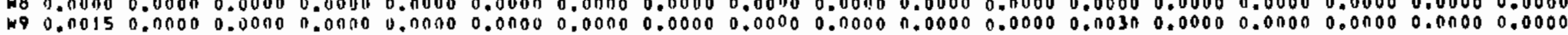

STABILITY CLASS A

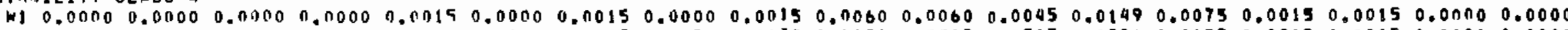

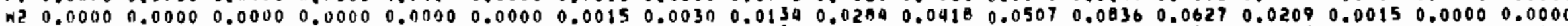

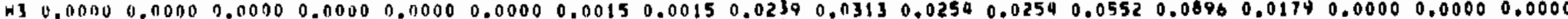

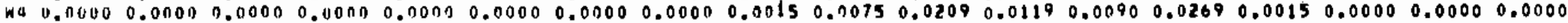

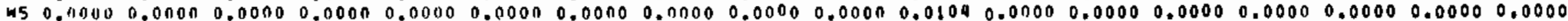

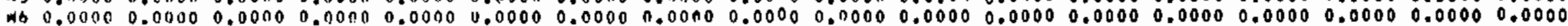

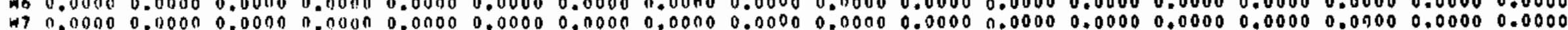

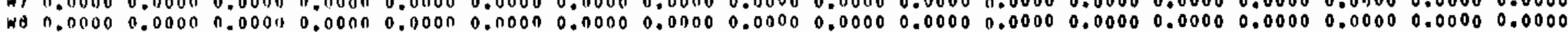

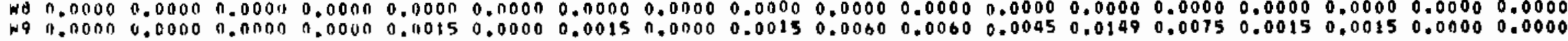

stahilitr Class 5

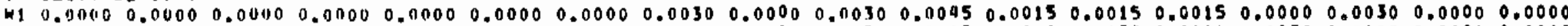

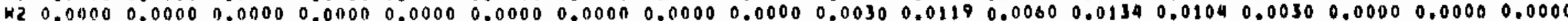

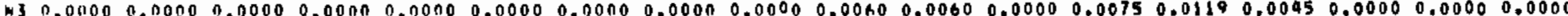

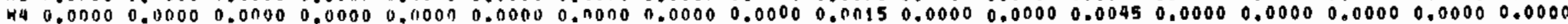

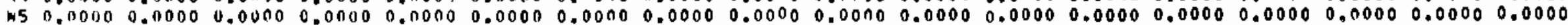

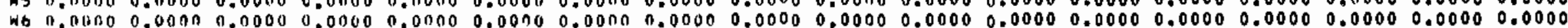

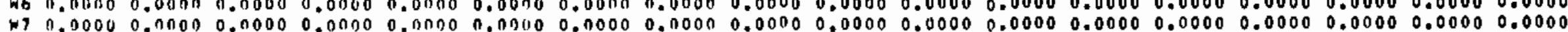

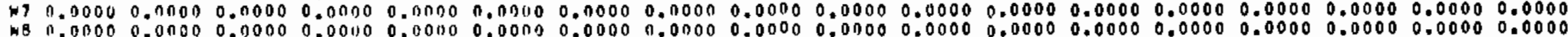

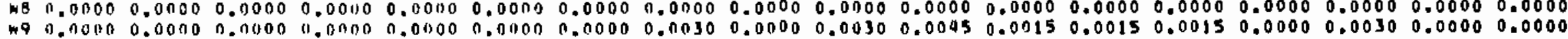

STAHILITY CLASS B

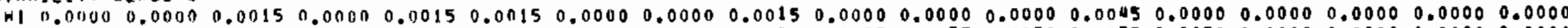

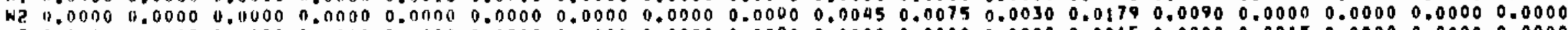

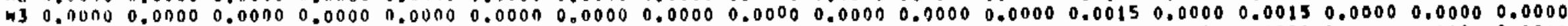

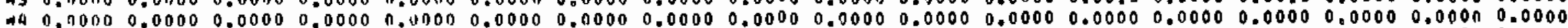

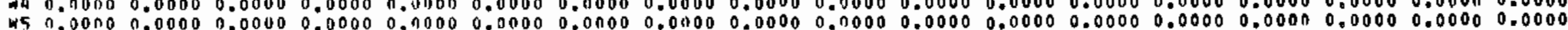

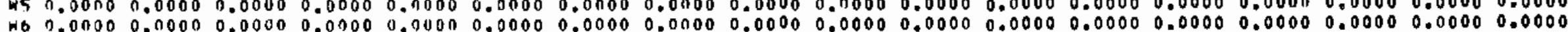

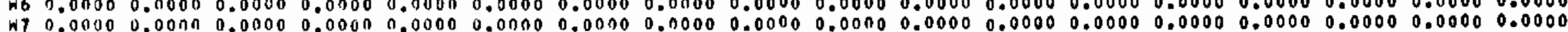

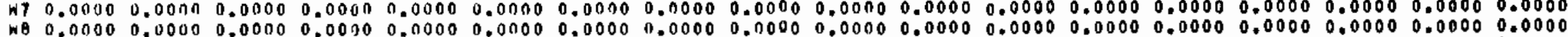

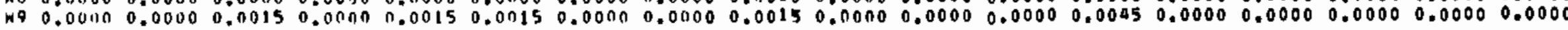

STASILITY CLASS ?

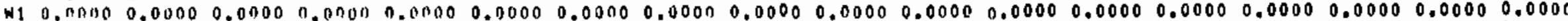

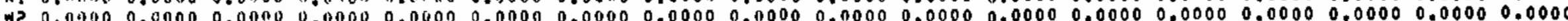
w 3 . 0.00000 .0000 .

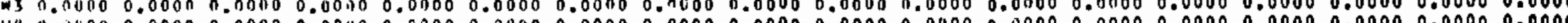
(1)

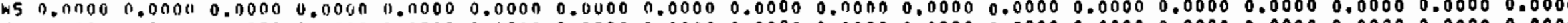

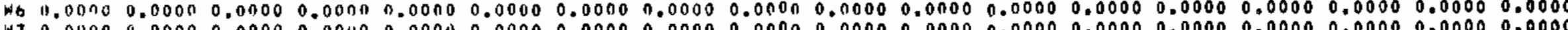

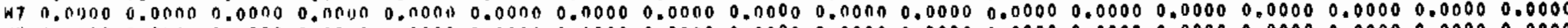

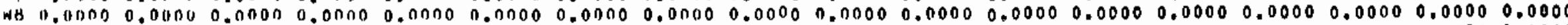

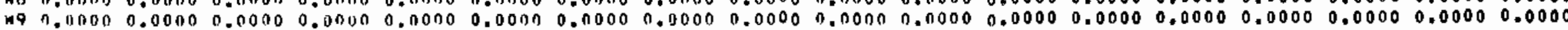


* if lob speeu class orje ninog: WIND SPELU CLASS

- of JCCURANCES

WIHO DIHECTION (JO SECIORS + CALM + VARIABLE)

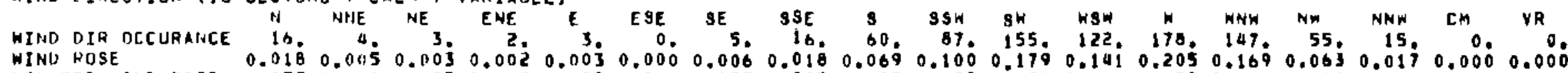

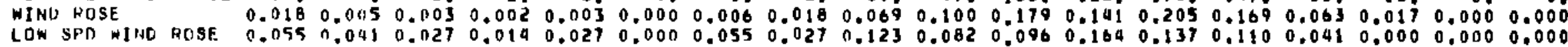

\section{FREUUENCY DISTHIBUTION OF THE WIND AS FUNCTION OF WIND SPEED ANO WIMD OIRECTION}

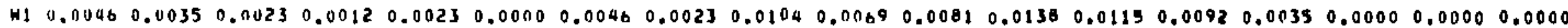

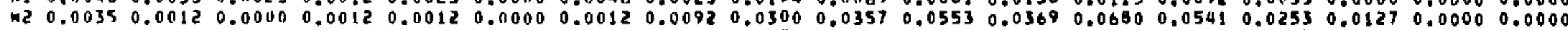

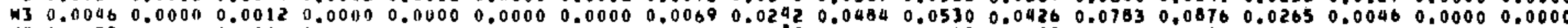

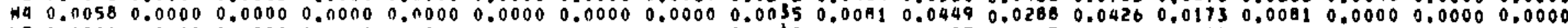

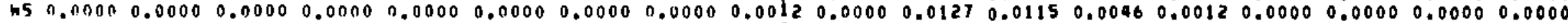

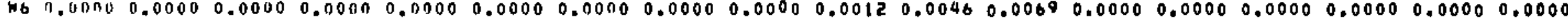

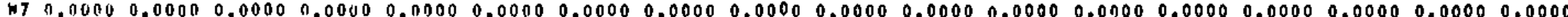

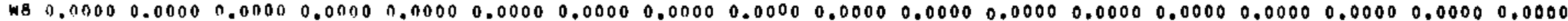

FHERUENCY DISTRIBUTIOH OF THE HINU AS FUNCTION OF MIND SPEED, KIND DIRECTION AND STABILITY

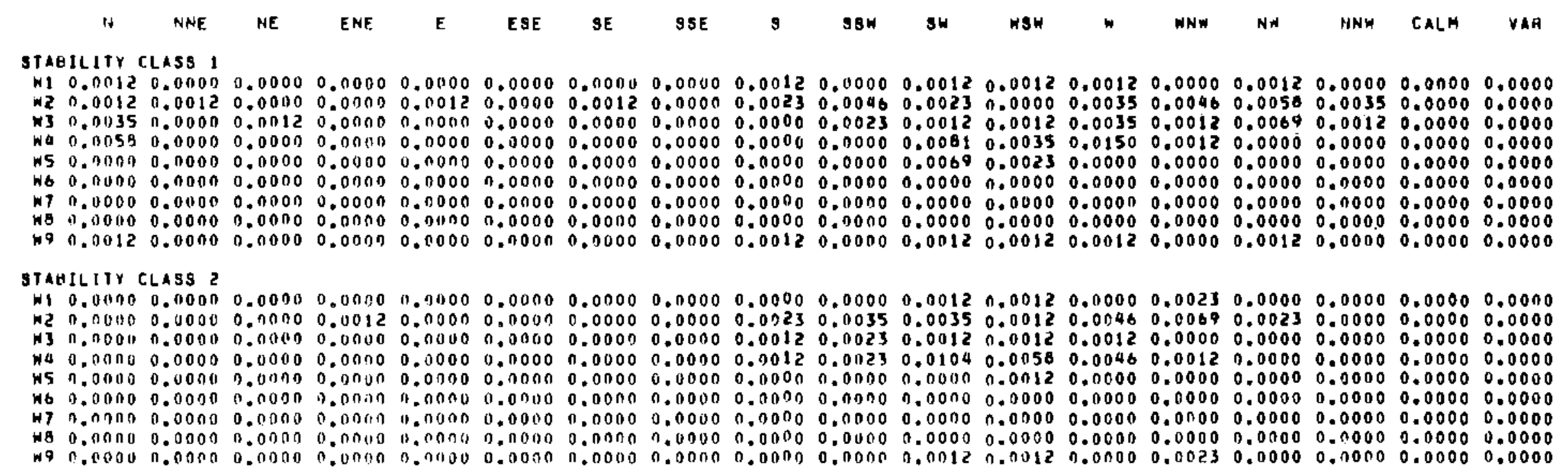

SIAD̈LLIITLLLASS

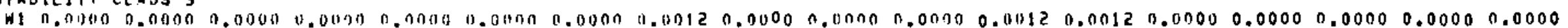

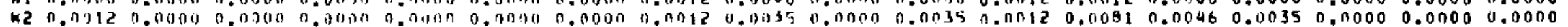




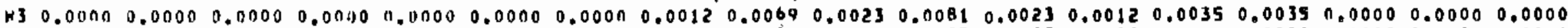

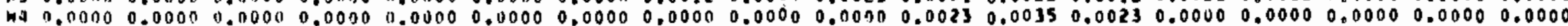

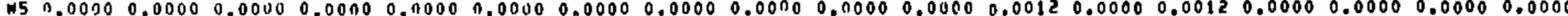

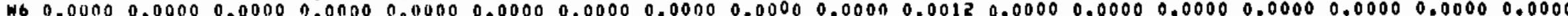

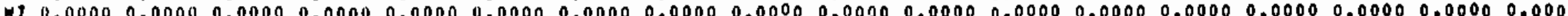

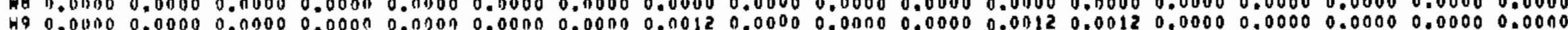

\section{STABILITY CLASS}

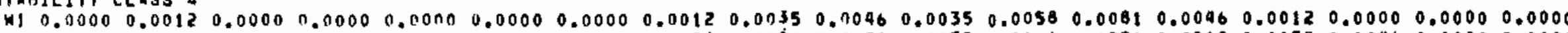

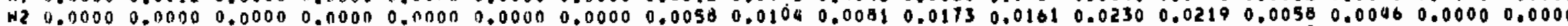

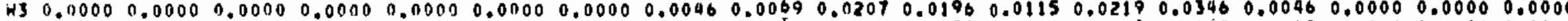

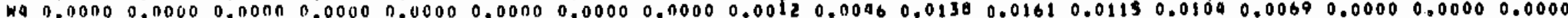

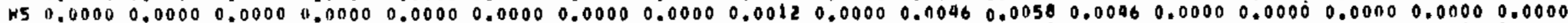

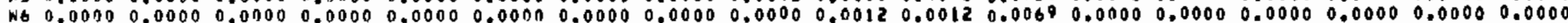

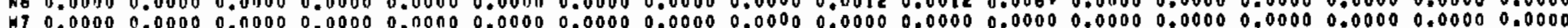

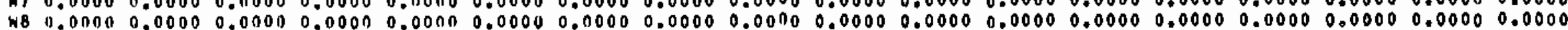

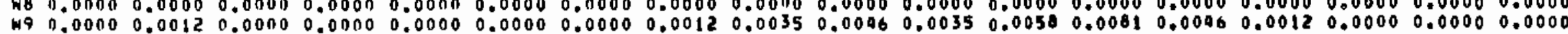

STABILITY CLASS 5

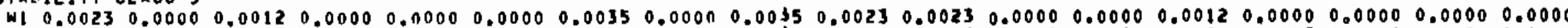

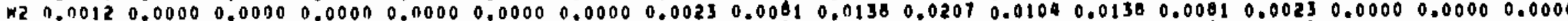

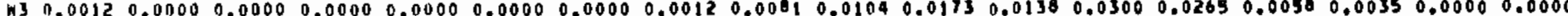

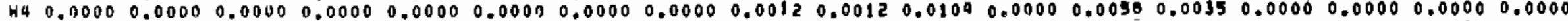

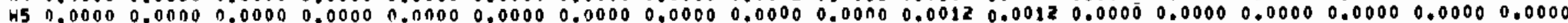

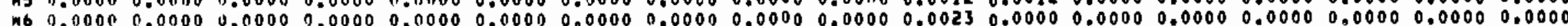

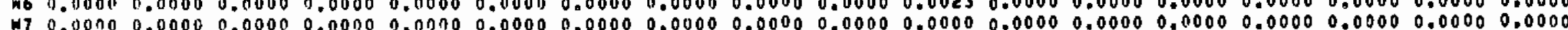

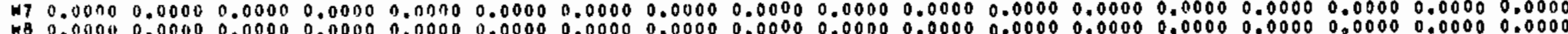

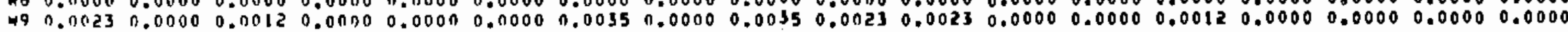

8TAgILITY CLASS 6

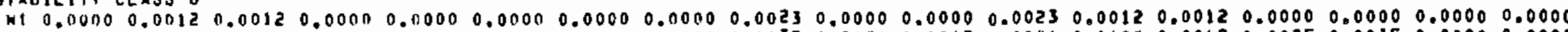

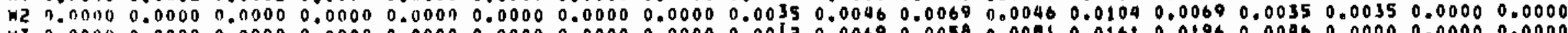

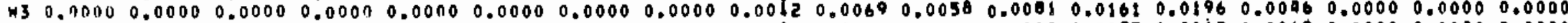

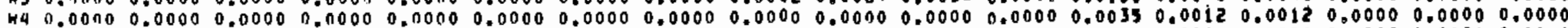

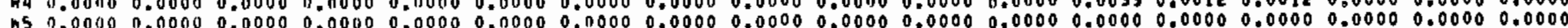

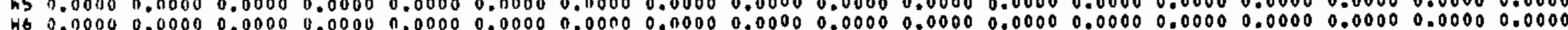

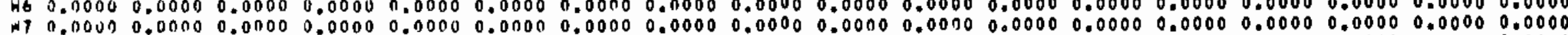

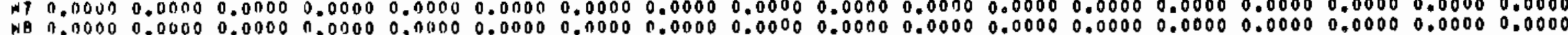

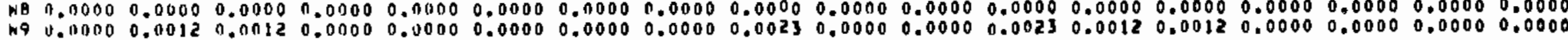

BTARILITY CLASS T

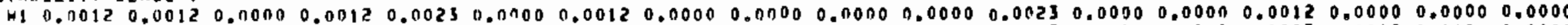

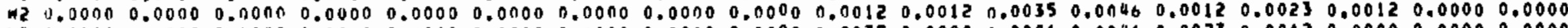

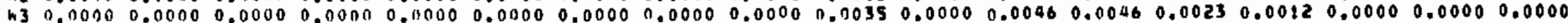

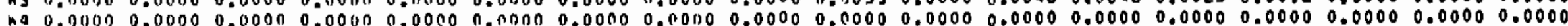

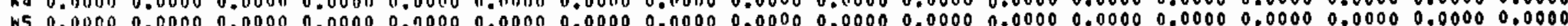

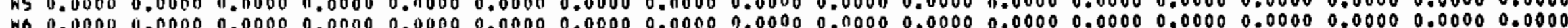

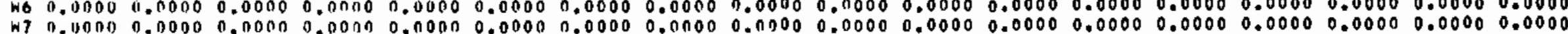

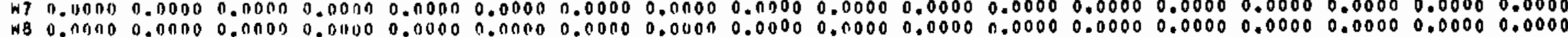

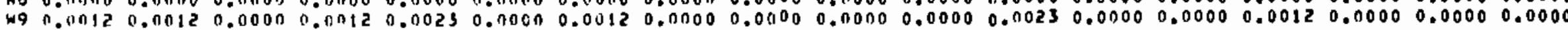


- DF LaW SPEED CLASS DNE WINIS: 174 WHD SPEED CLASS
OF OCCURANCES

WIND DIRECIION (16 SECIOKS + CALH + VARIABLE)

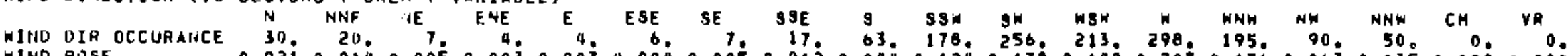
WIND RISE $\quad 0.021 \quad 0.0140 .0050 .0030 .0030 .0040 .0050 .0120 .0440 .1240 .1700 .1400 .2070 .1360 .0630 .0350 .0000 .000$ LOW SPD IUD RISE 0.0290 .0230 .0110 .0110 .0230 .0290 .0230 .0400 .0980 .1210 .1150 .1670 .1210 .0920 .0520 .0460 .0000 .000

FHEQUENCY DISTAIBUTION OF THE WIHD AS A FUNCTION OF HINO SPEED AND WINO DIAECTION

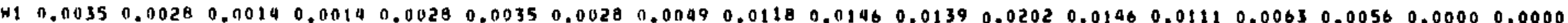

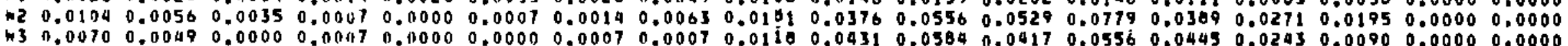

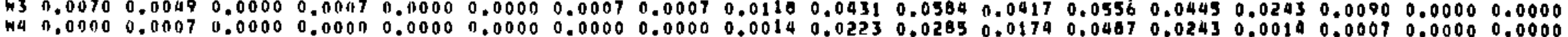

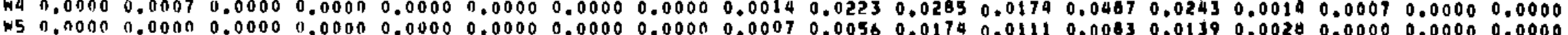

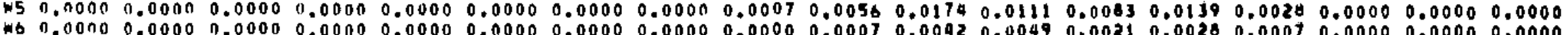

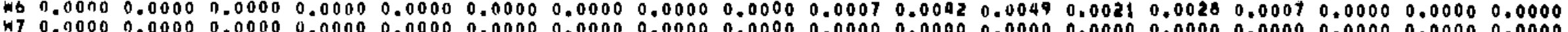

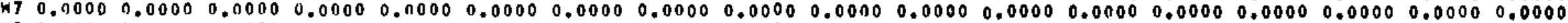

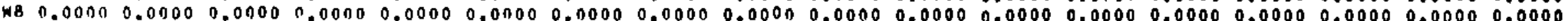

FREDUENCY DISTRIBUIION OF THE WIND AS FUNCTION OF WINO GPEED, WIND DIRECIION AND BTABILJTY

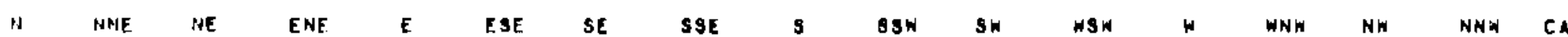

BTABILITY CLASS 1

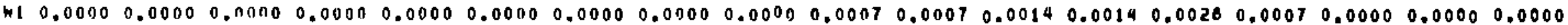

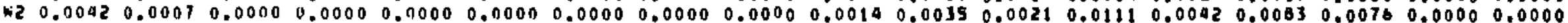

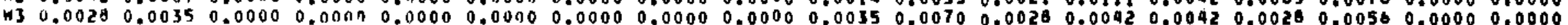

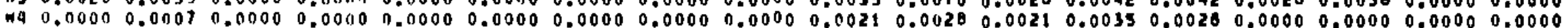

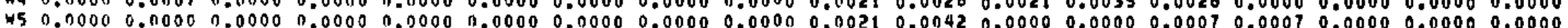

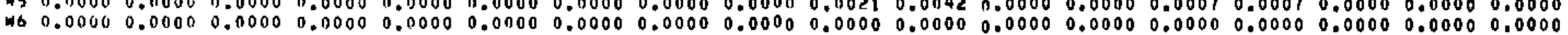

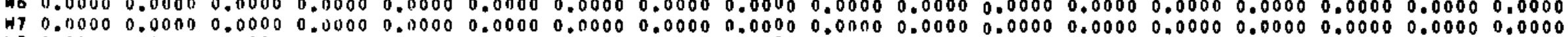

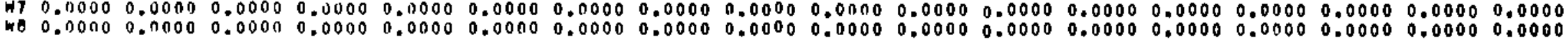

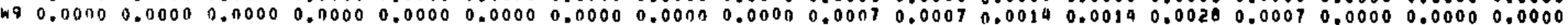

stheilitr Class 2

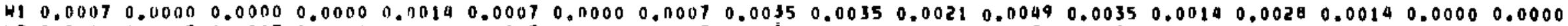

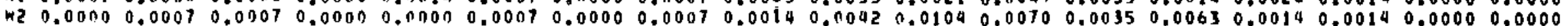

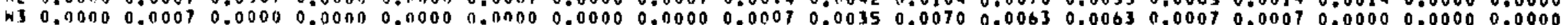

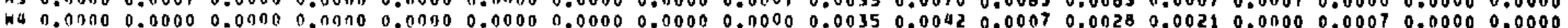

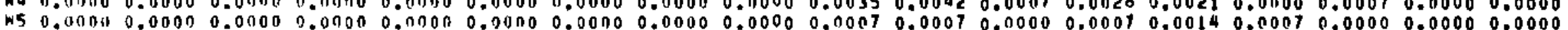

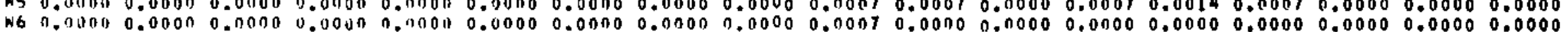

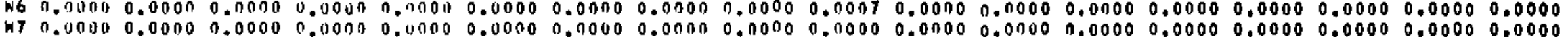

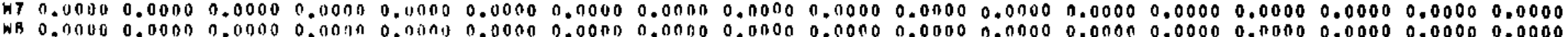

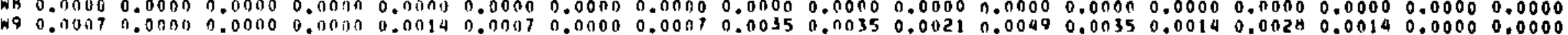

gtabizitr ́́lass 3

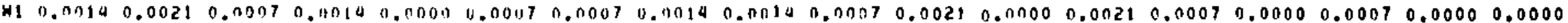

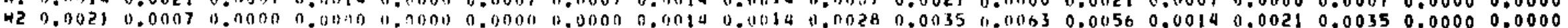




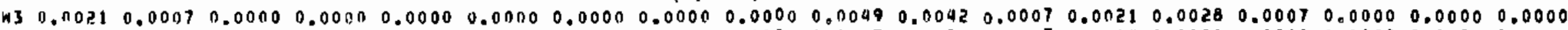

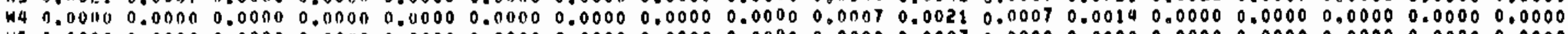

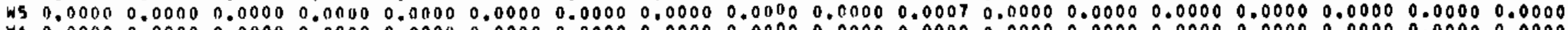

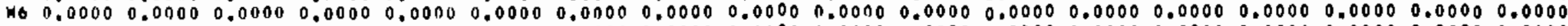

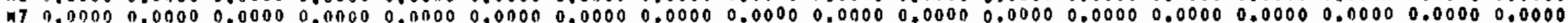

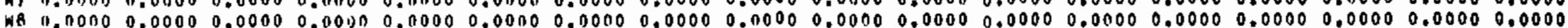

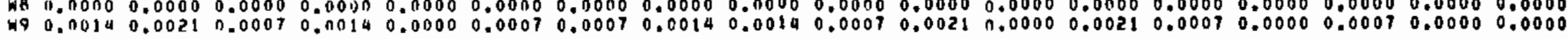

STABILITY CLASS 4

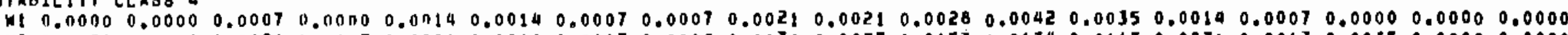

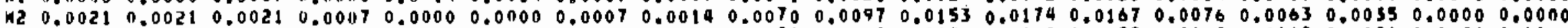

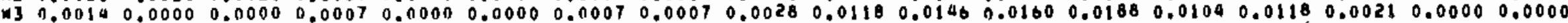

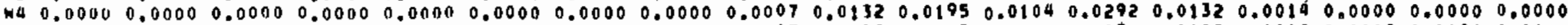

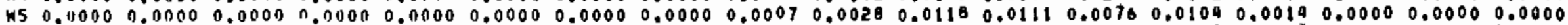

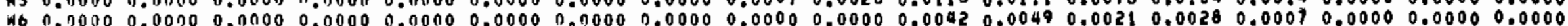

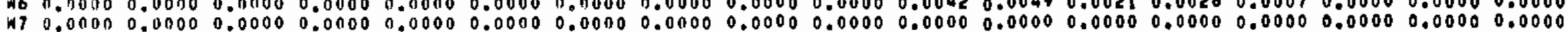

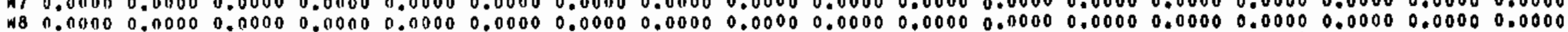

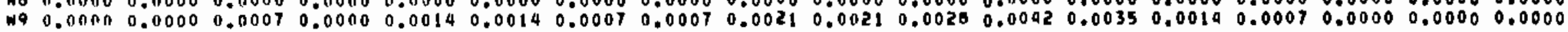

STABILITY CLASS 5

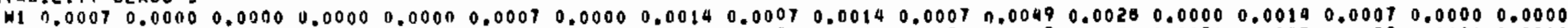

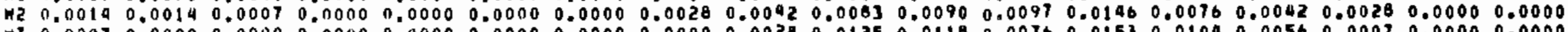

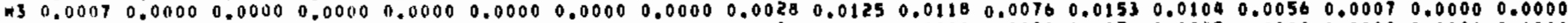

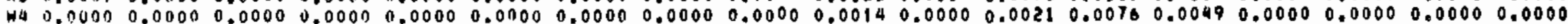

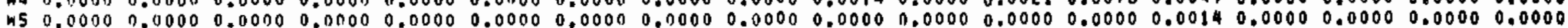

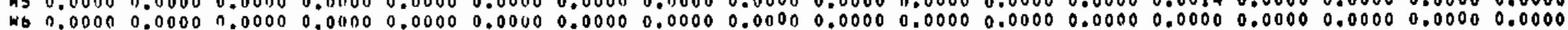

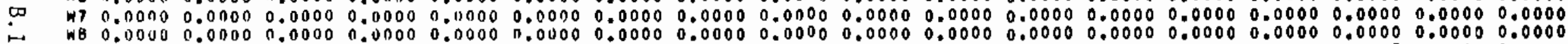

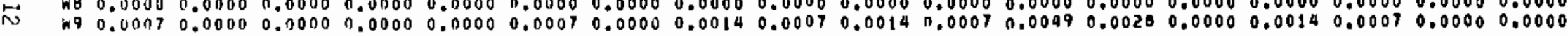

STAAILITY CLASS 6

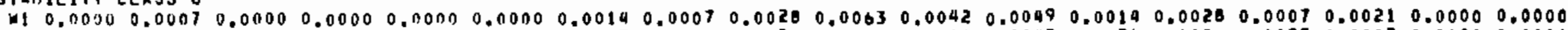

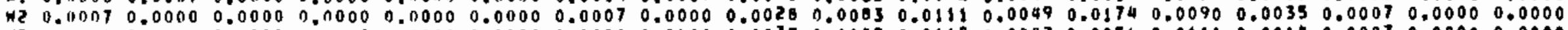

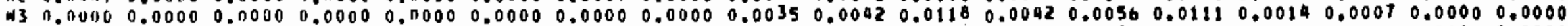

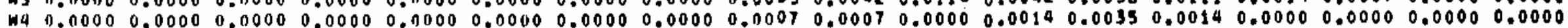

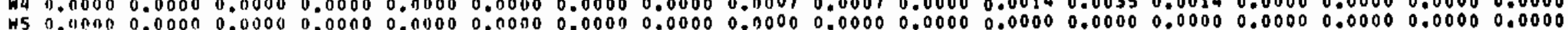

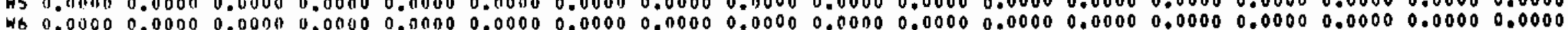

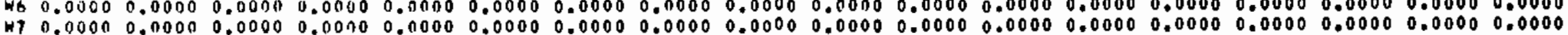

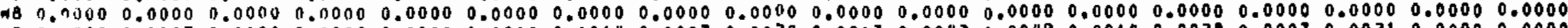

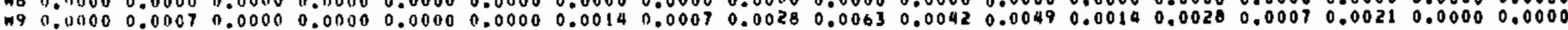

8tahILITY CLASS 7

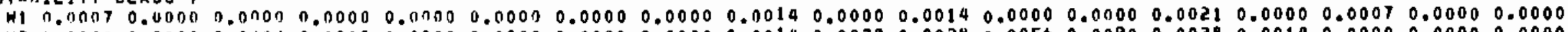

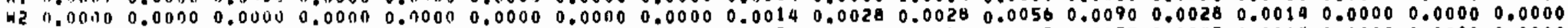

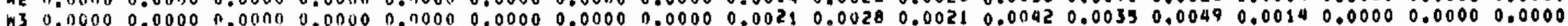

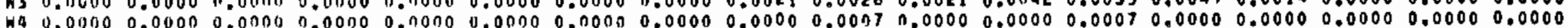

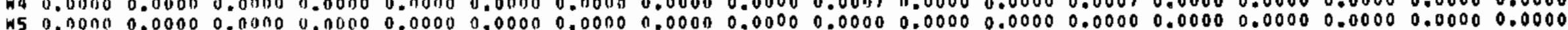

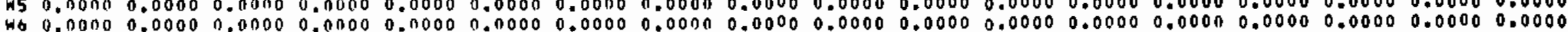

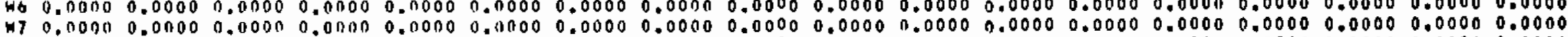

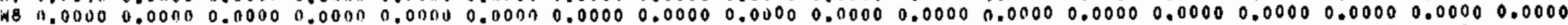

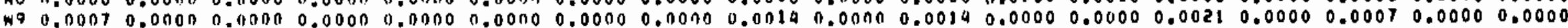


- IJF LOW SPEEU CLASS IITE miHOSi WIND SPEED CLASS 1 1 - UF DCCURAMCES $160 \quad 529$ 338
43
230
5
6
0
0

WIND DPAECTION (16 SECITRS + CALM + VARIABLE)

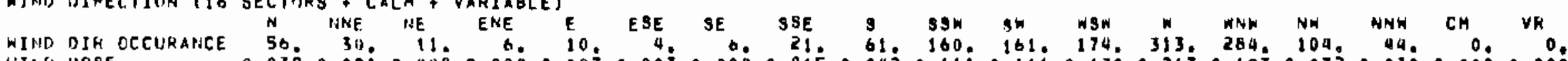

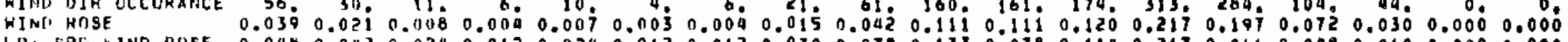

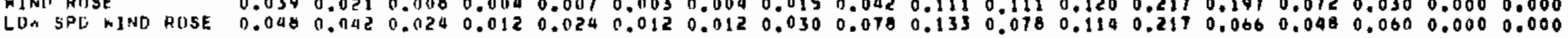

FHETUENCY OISTRIBUTIOH OF THE WINO AS A FUNCTION OF WIND SPEED AND WIND DIRECTION

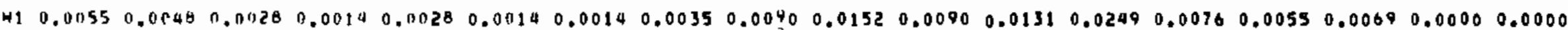

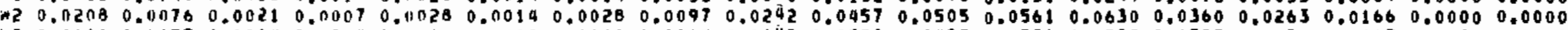

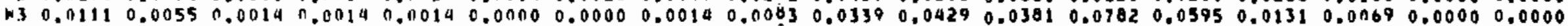

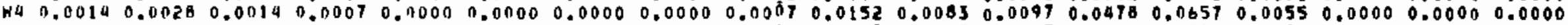

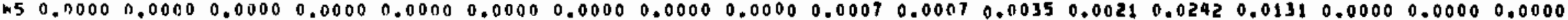

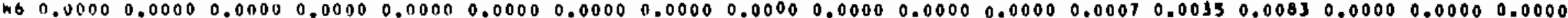

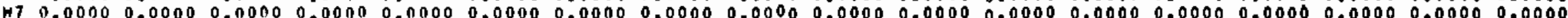

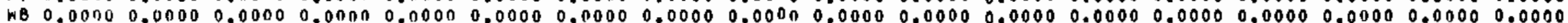

FREDUERCY DISTRIBUTION OF THE WINO AO A FUNCTION OF HINO SPEED, WIND DIRECTION AND STABILITY

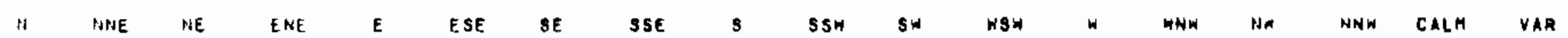

STAHILITY CLASS I

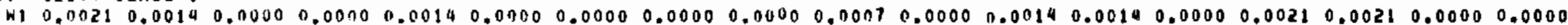

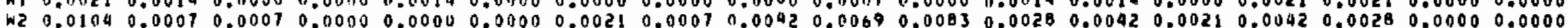

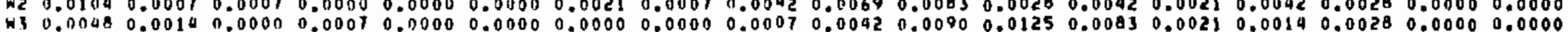

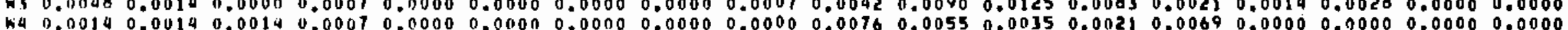

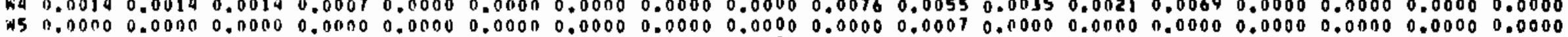

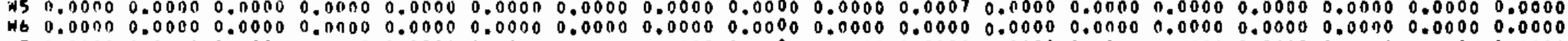

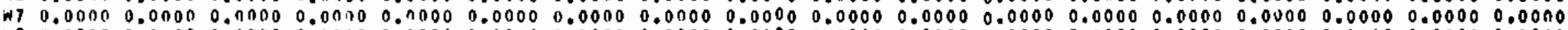

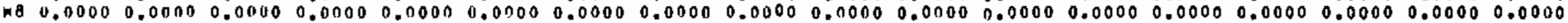

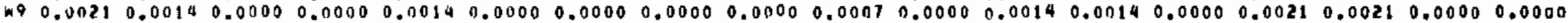

\section{STAEILITY CLASS Z}

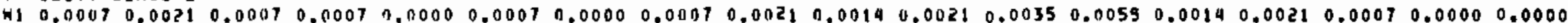

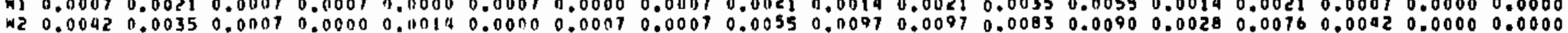

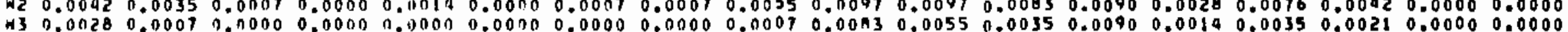

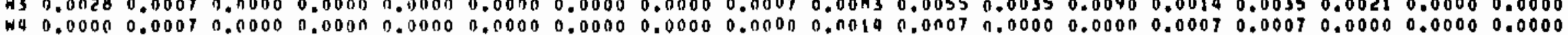

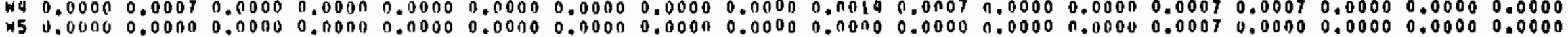

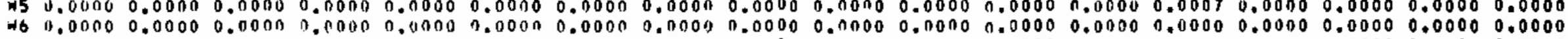

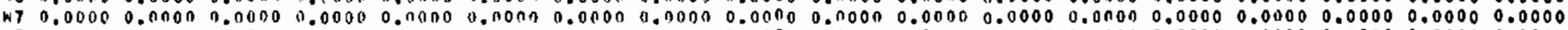

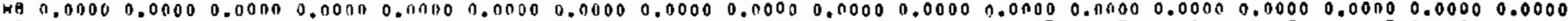

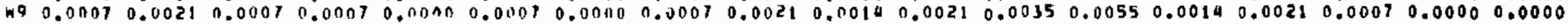

STABILITY CLASS 3

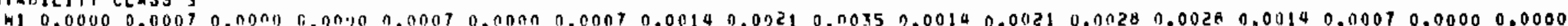

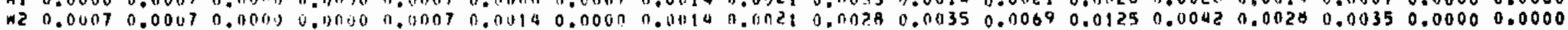




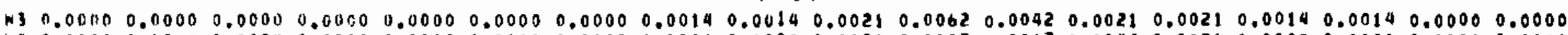

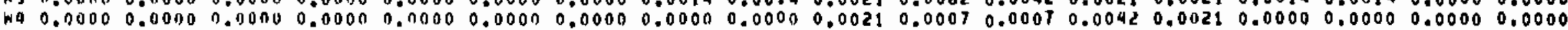

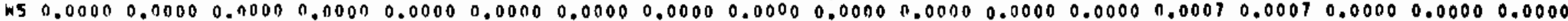

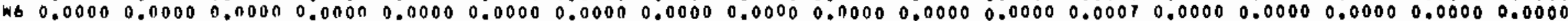

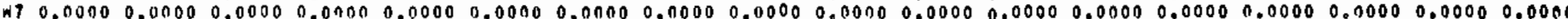

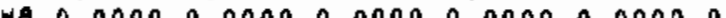

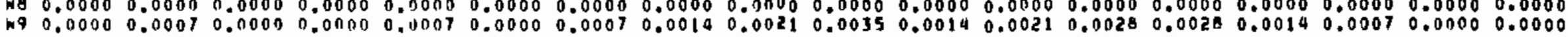

STABILITY CLASS 4

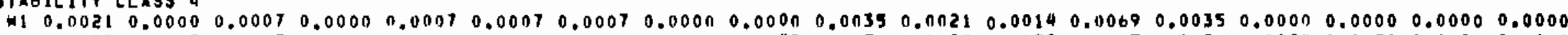

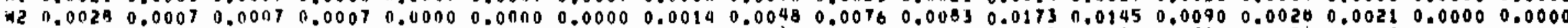

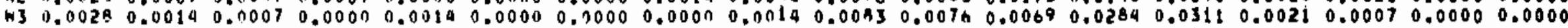

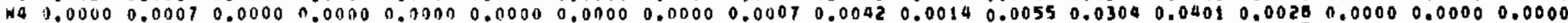

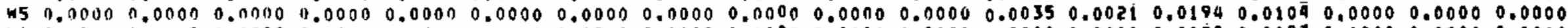

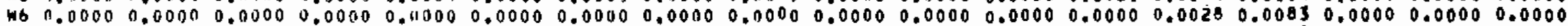

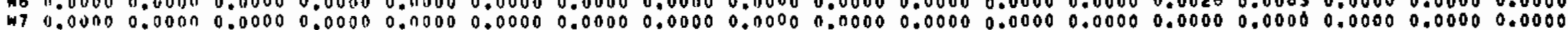

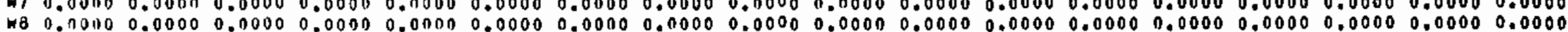

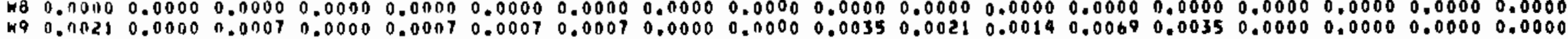

\section{OTABILITY CLASS 5}

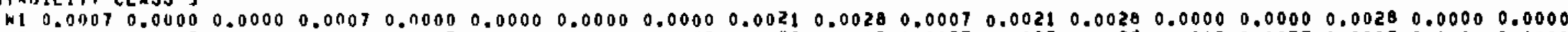

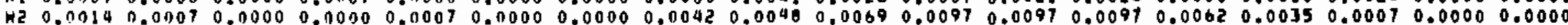

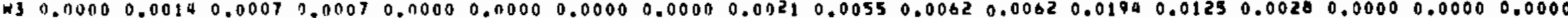

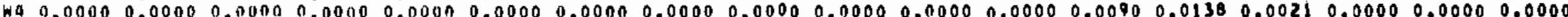

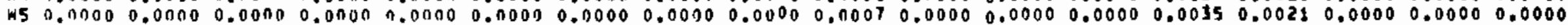

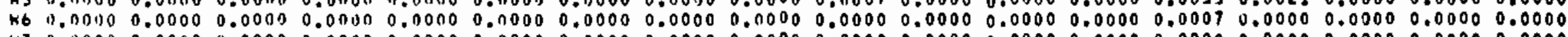

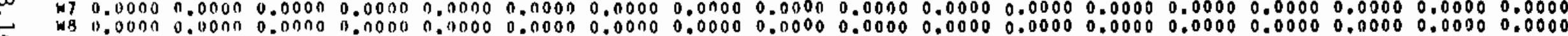

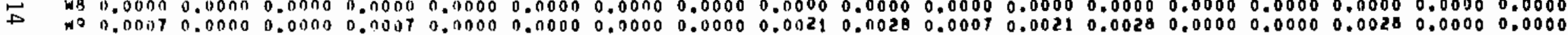

STAIILITY CLASS O

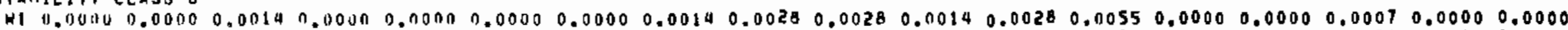

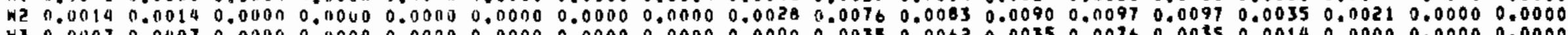

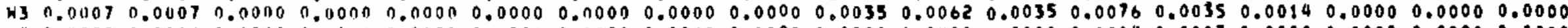

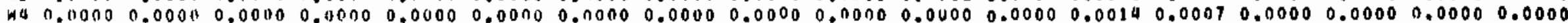

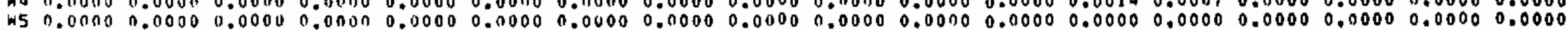

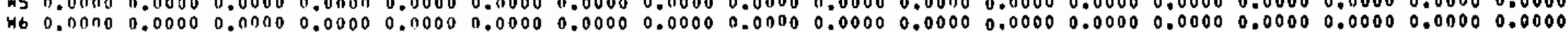

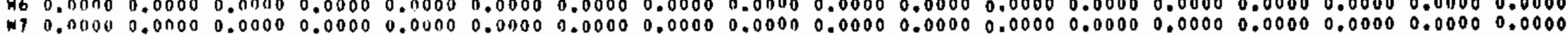

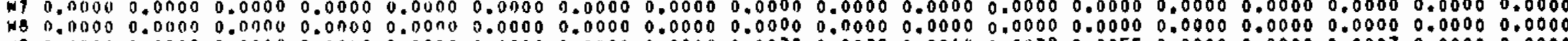

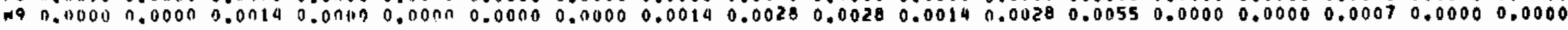

STARILITY CLASS 7

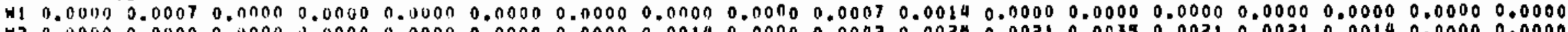

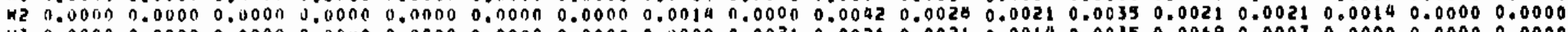

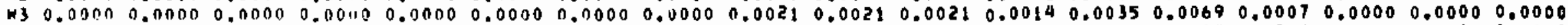

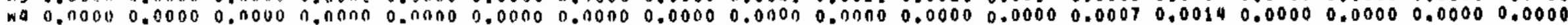

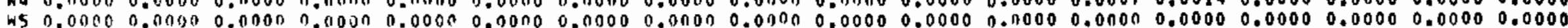

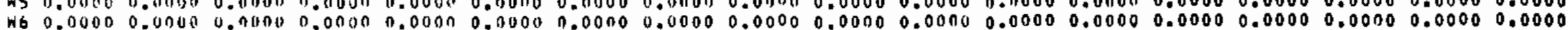

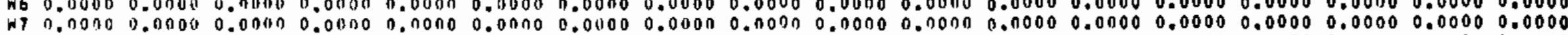

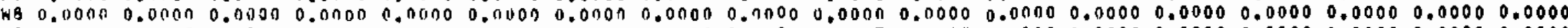

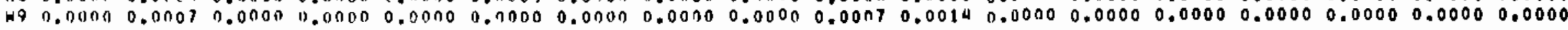


* UF LUW SPEEO CLASS DNE WJNDS: WINI) SPEED CLASS 155
155

491
472
221
5
6
7
(3)

HIND DIHECTION (16 SECTRRS CALH Y VARIAALE)

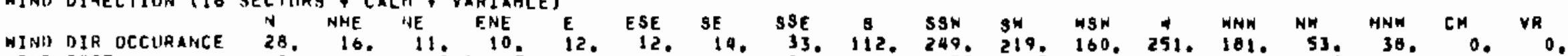

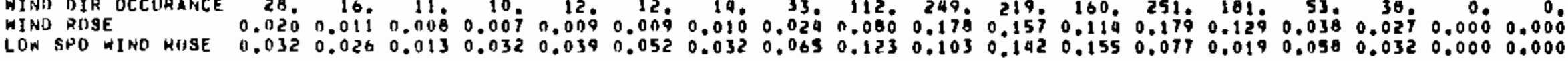

\section{FREQUENCY OISTRIBUTION OF THE HINO AS AUNCTION OF WINO SPEED ANO WINO DIRECTION}

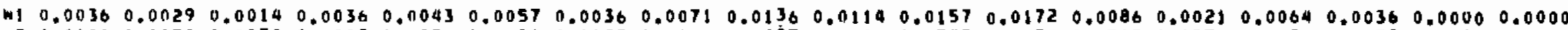

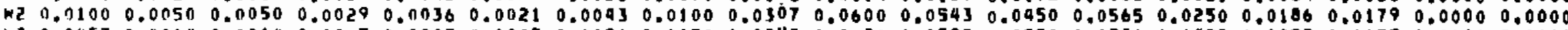

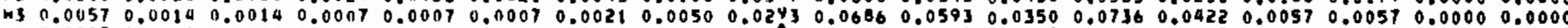

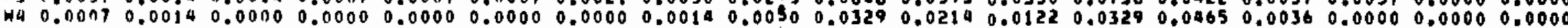

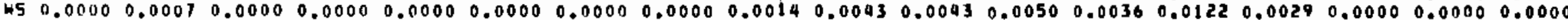

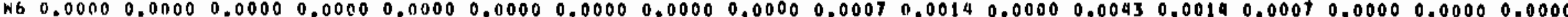

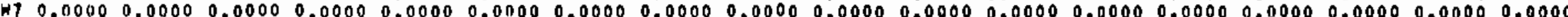

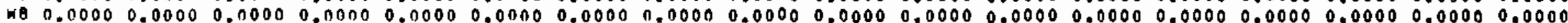

$\infty$

FREQUENCY OISTRIGUTION OF THE HIND AS EUNCTION OF WINO SPEEO, WIND DIAECTION ANO STABILITY

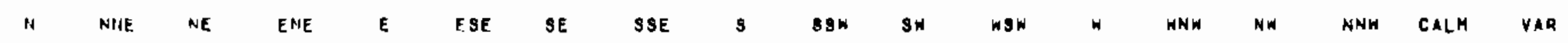

STABILITY CLASS I

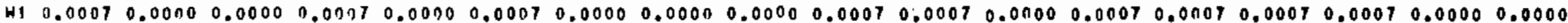

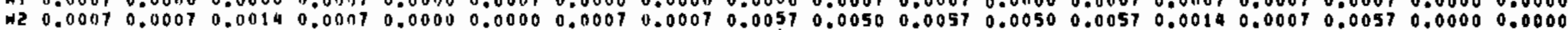

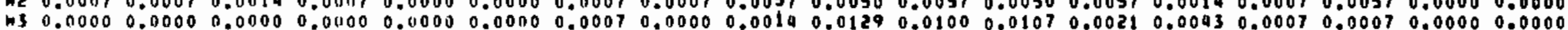

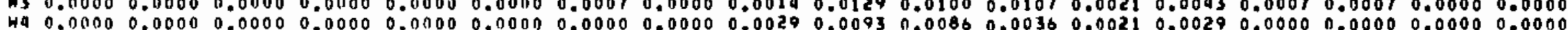

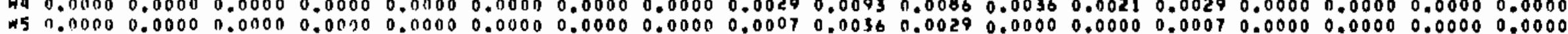

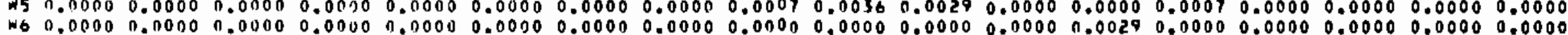

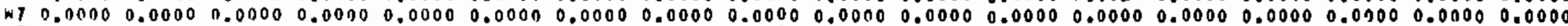

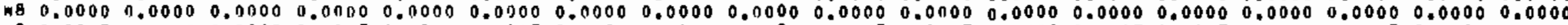

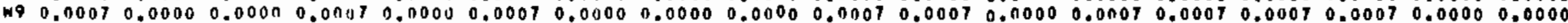

STABILITY CLASS 2

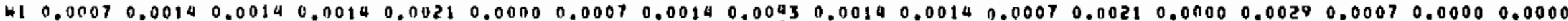

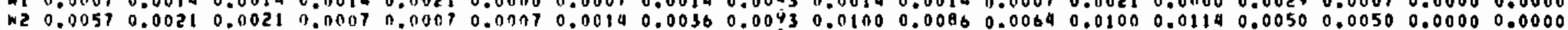

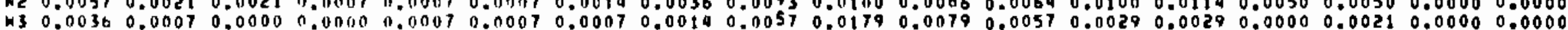

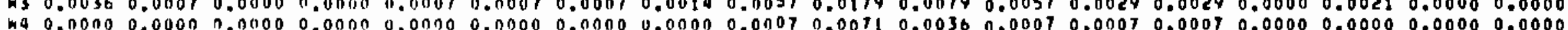

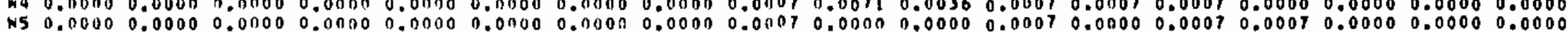

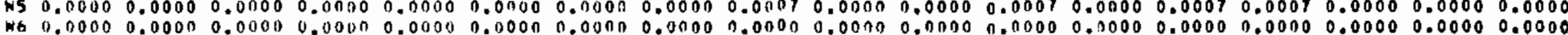

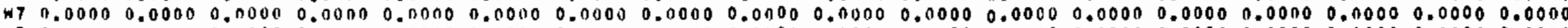

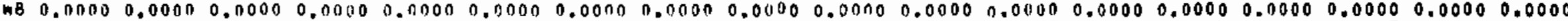

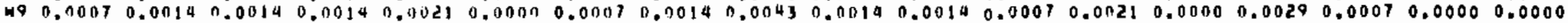

- STABILtTE CLASS 3

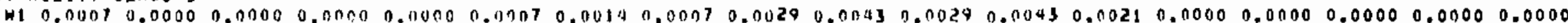

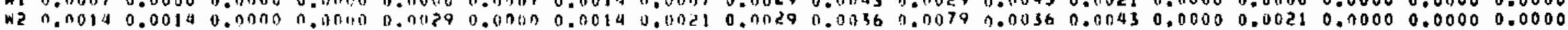




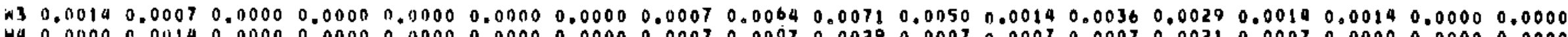

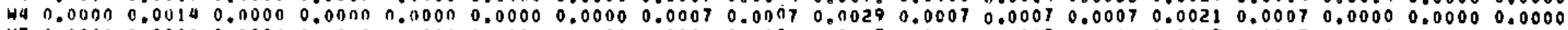

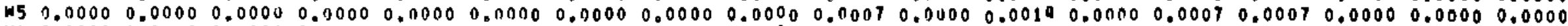

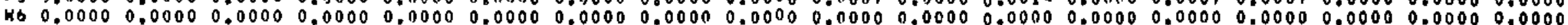

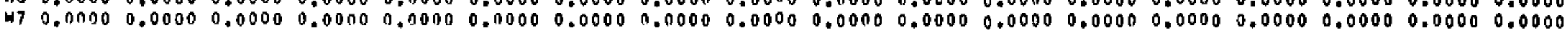

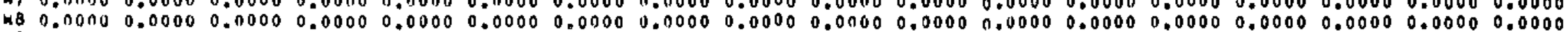

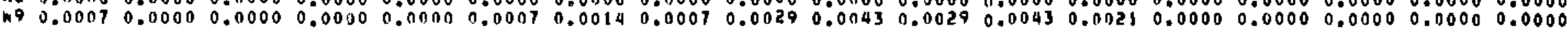

oTABILITY CLASS 4

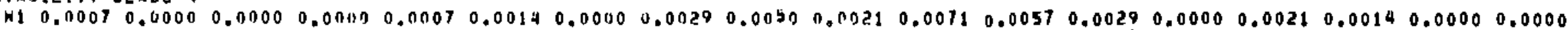

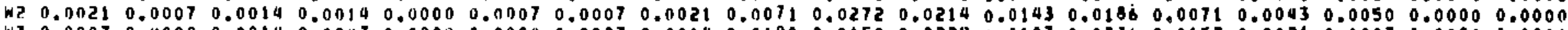

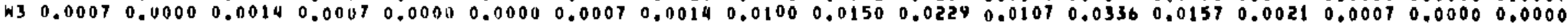

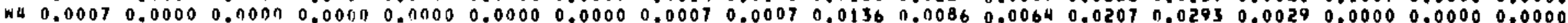

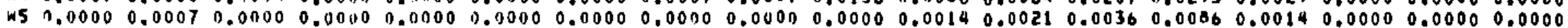

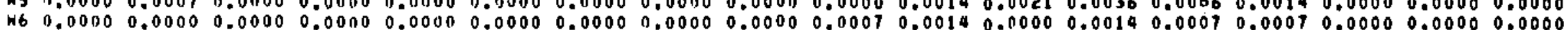

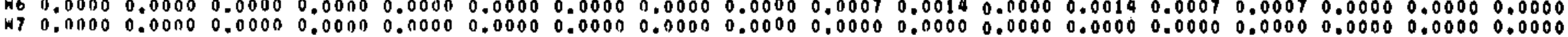

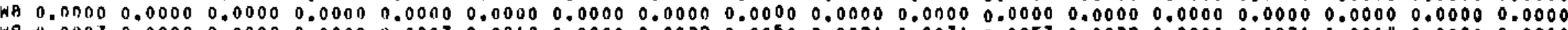

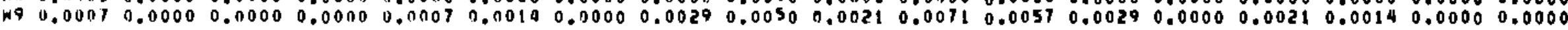

STABILITY CLASS 5

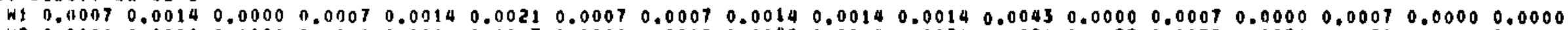

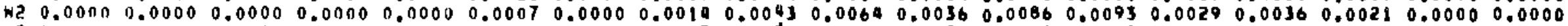

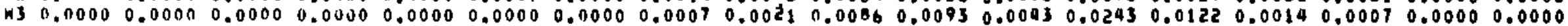

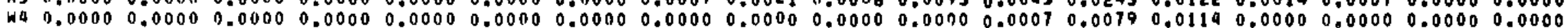

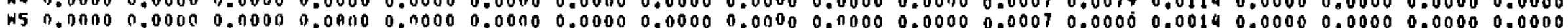

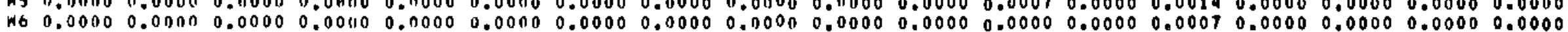

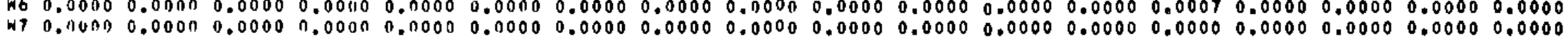

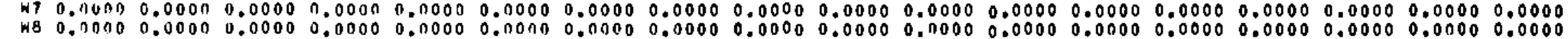

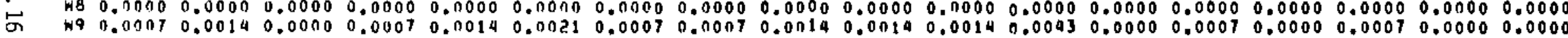

STABILITY CLASS b

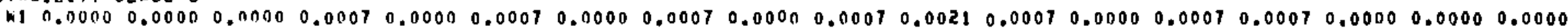

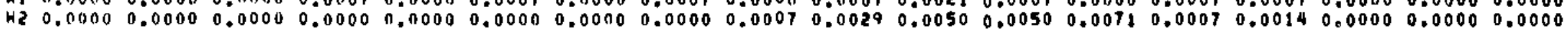

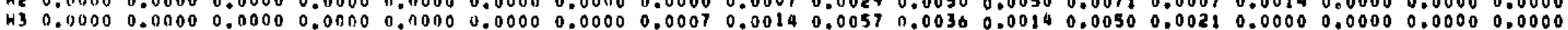

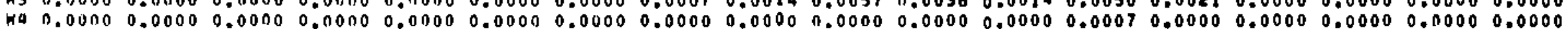

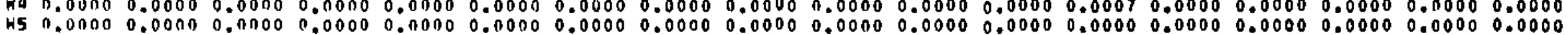

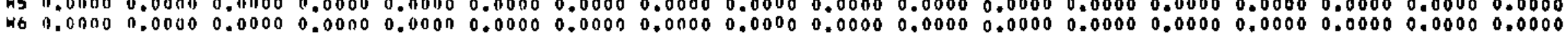

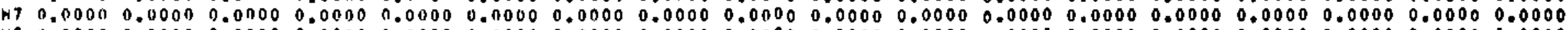

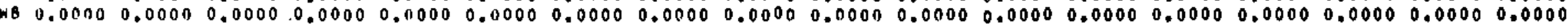

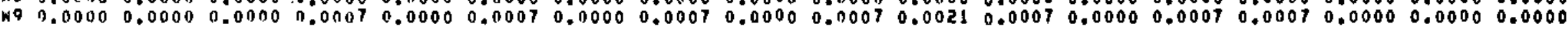

STABILITY CLASST

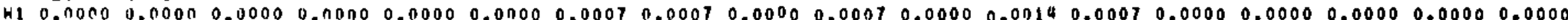

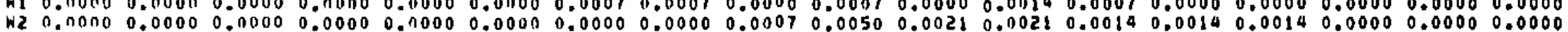

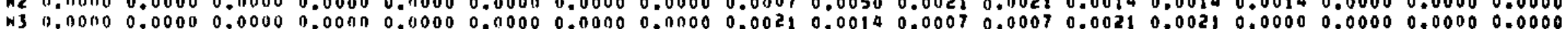

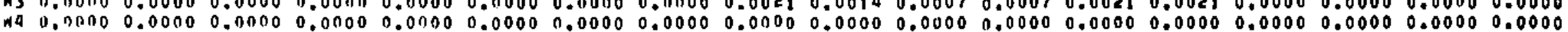

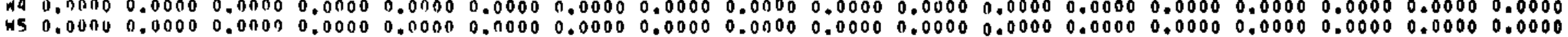

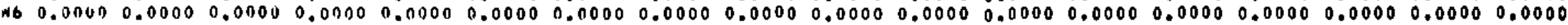

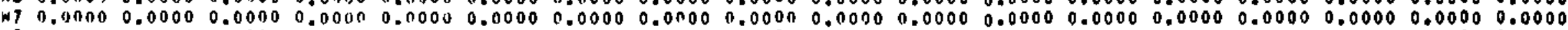

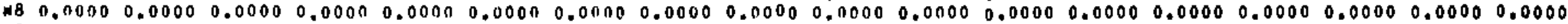

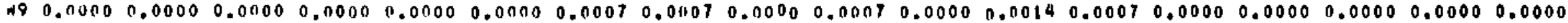



* OF LOW SPEED CLASS OHE INOS
WIND SPEED CLASS
*F OCCURANCES

WITO DIRECTION (16 SECTORS + CALM + VARIABLE)

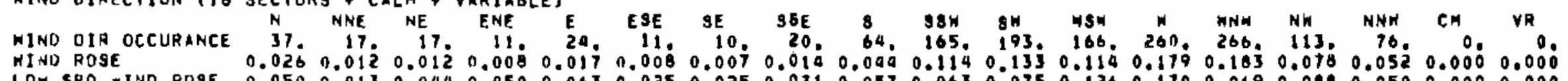

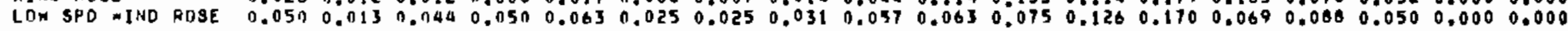

FRE UUENCY DISTRIBUTION OF THE WIND AS FUNCTION OF HIND GPEEO ANO WIND DIAECTIDN

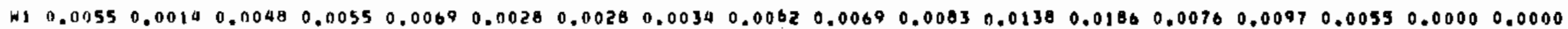

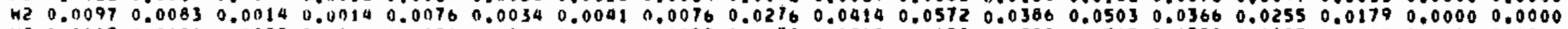

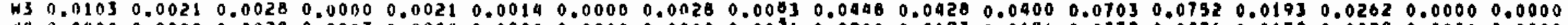

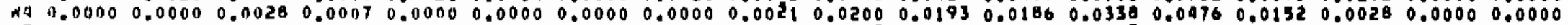

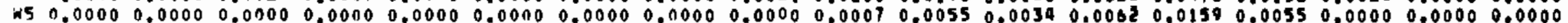

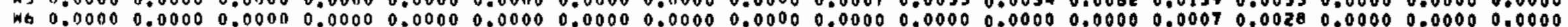

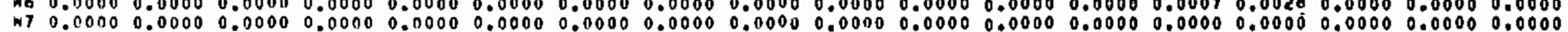

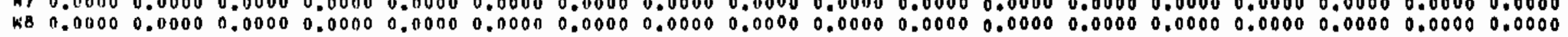

CD

FRE UIJEHCY DISTRIBUTION OF THE WINO AS FUNCTION OF NINO GPEED, WIND DIAECTION AHO ATABILITY

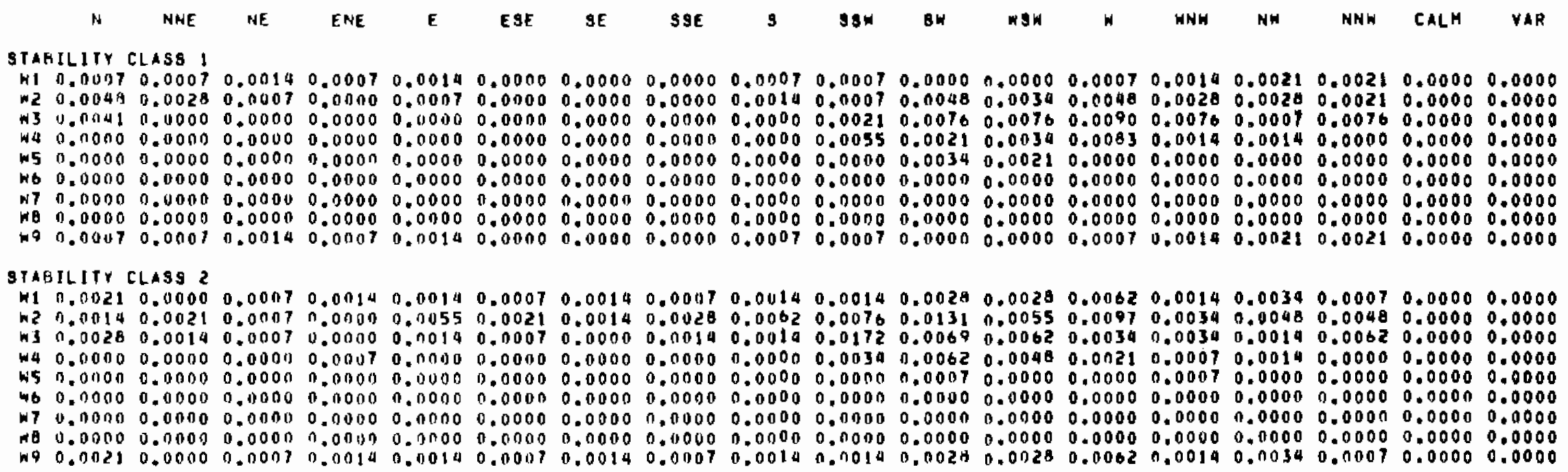

siabllitr CLASS 3

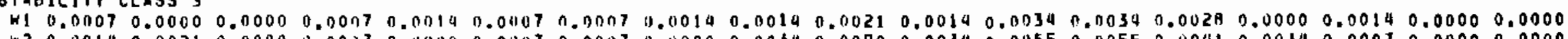

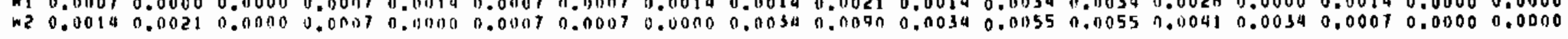




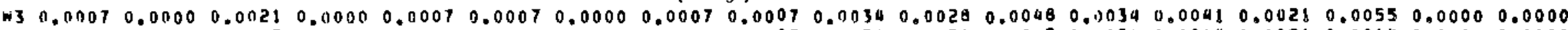

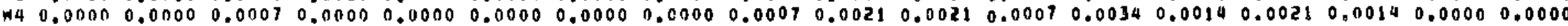

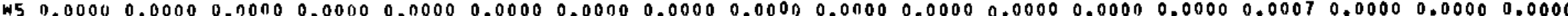

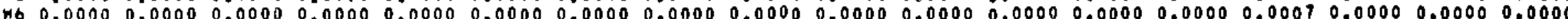

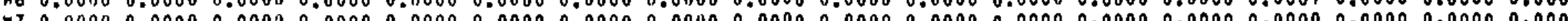

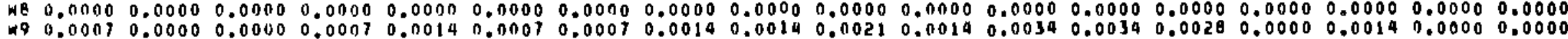

stabllitr CLASS a

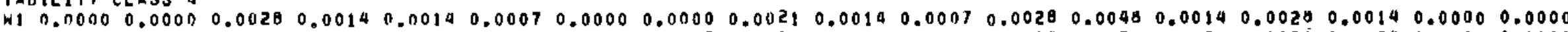

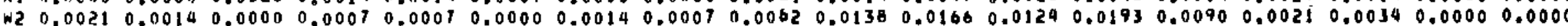

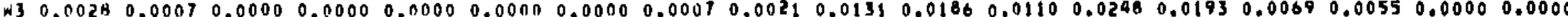

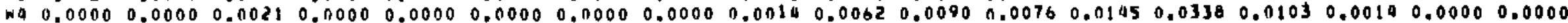

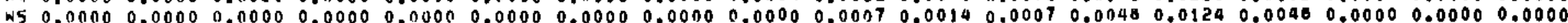

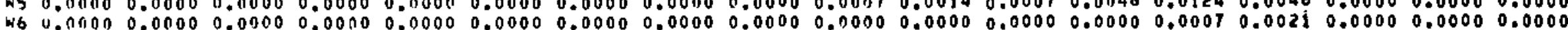

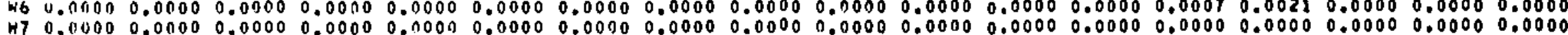

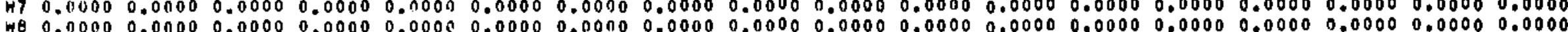

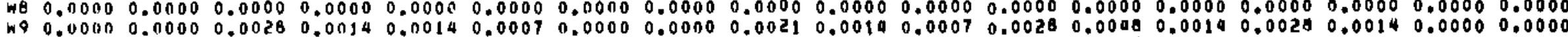

tabilite class 5

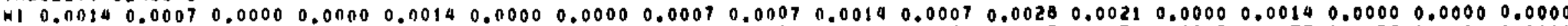

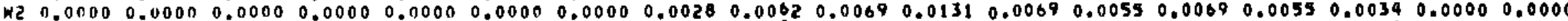

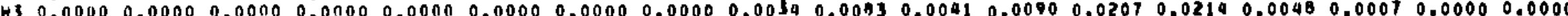

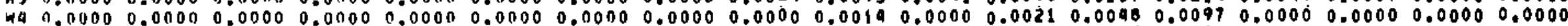

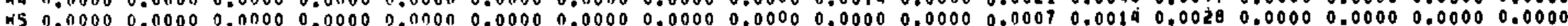

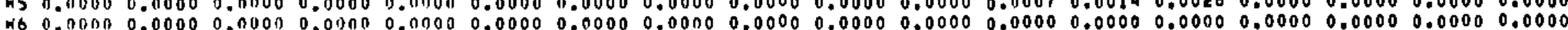

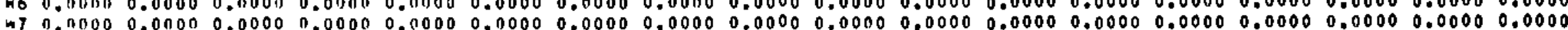

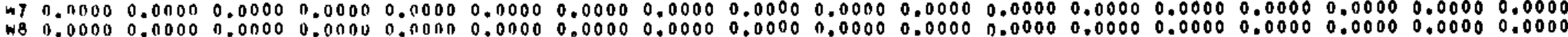

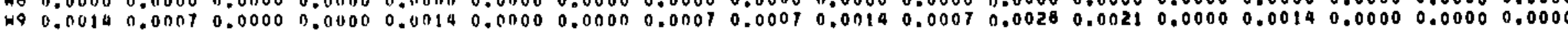

- STAGILITY CLASS

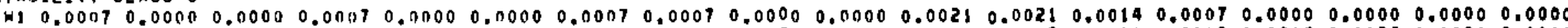

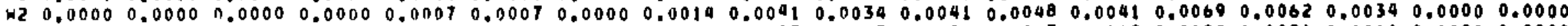

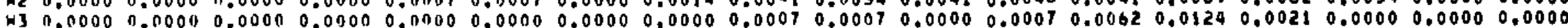

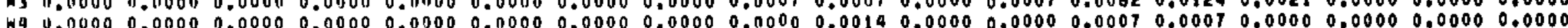

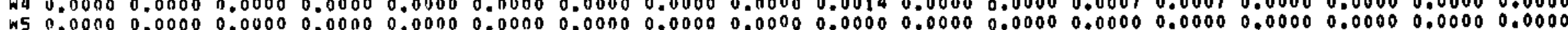

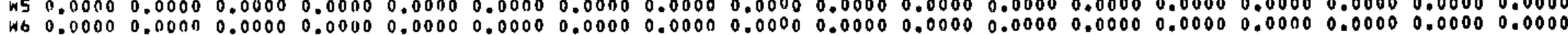

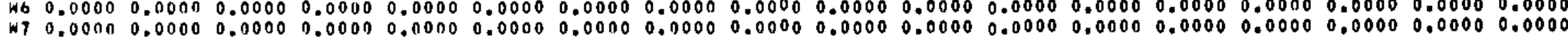

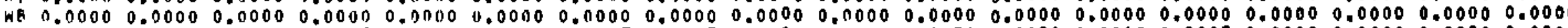

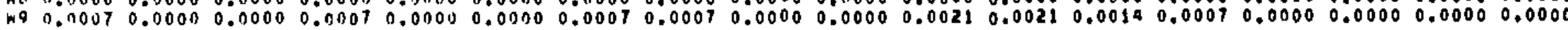

\section{STAHILITY CLASS Y}

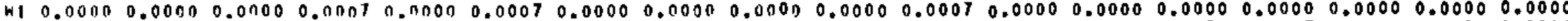

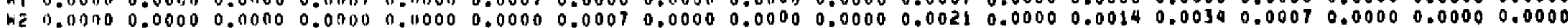

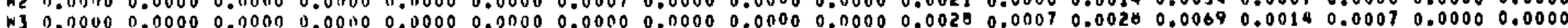

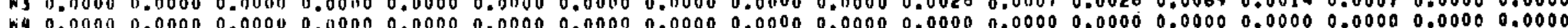

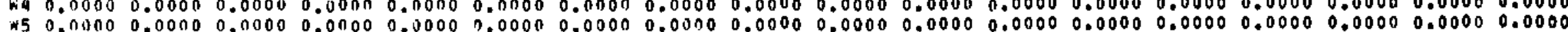

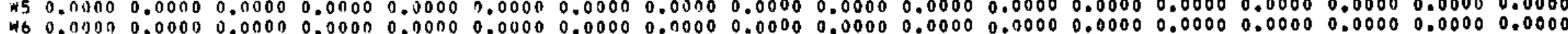

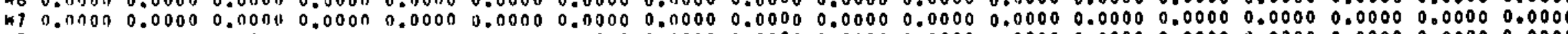

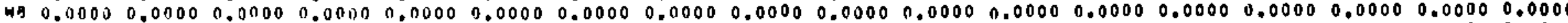

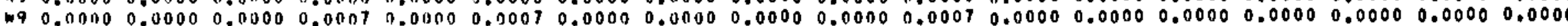


* of loH SPEED CLASS ONE WIHOS: 180 HITH SPEEO CLASS 607 $\stackrel{3}{472}$ $4_{162}^{4}$ 52 6 7

WINO DIRECTION (16 SECTORS + CAL.H + VARIABLE)

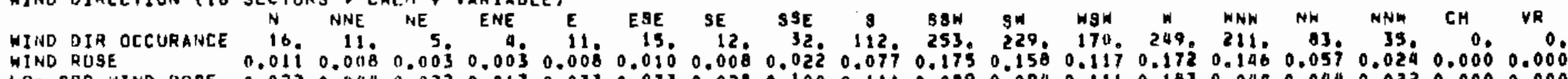

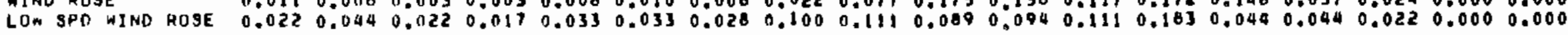

\section{FREDUENCY DISTRIBUTIOH OF THE HIND AS A FUNCTION OF HIND SPEEO AND WINO OIRECTION}

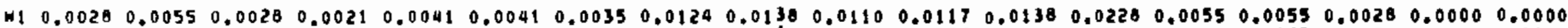

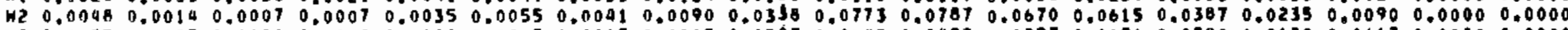

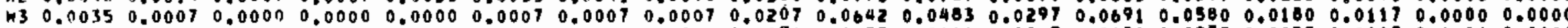

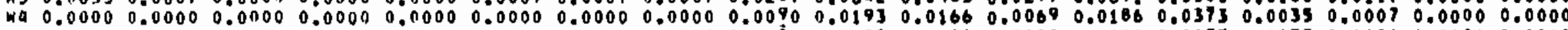

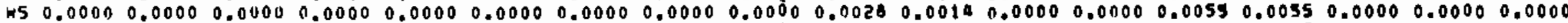

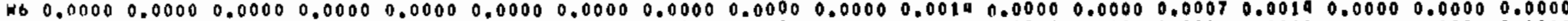

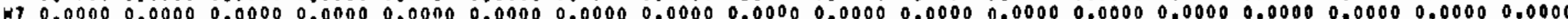

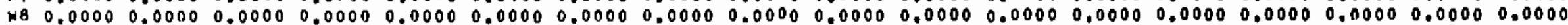

\section{TABILITY CLASS}

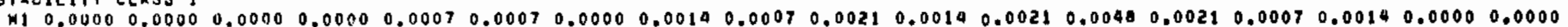

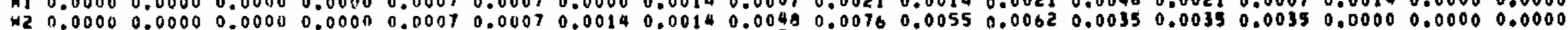

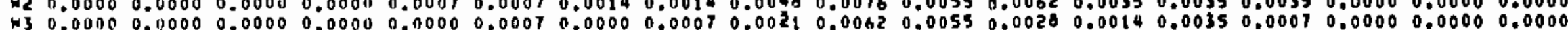

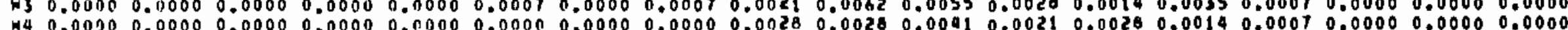

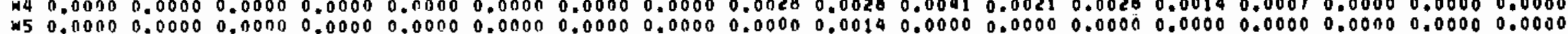

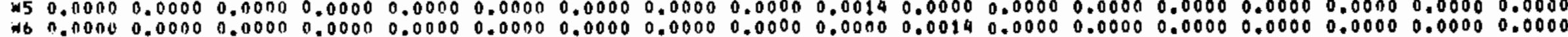

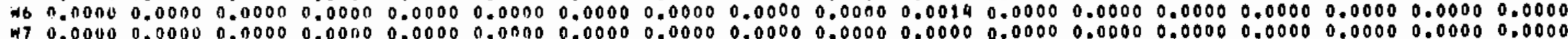

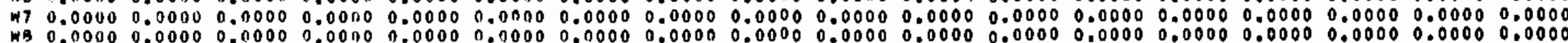

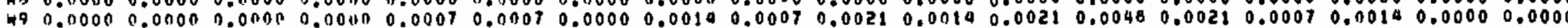

\section{STAAILITY CLASS 2}

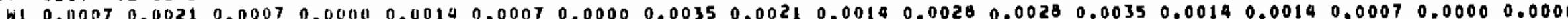

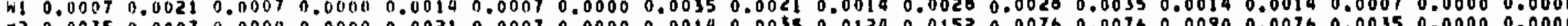

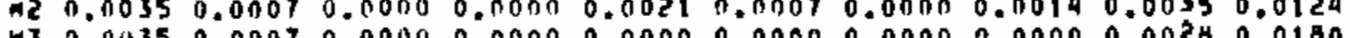

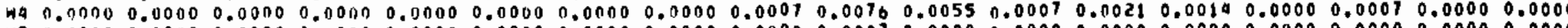

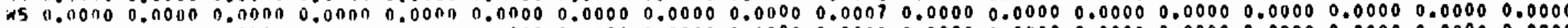

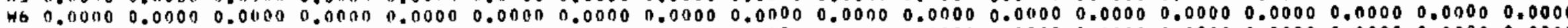

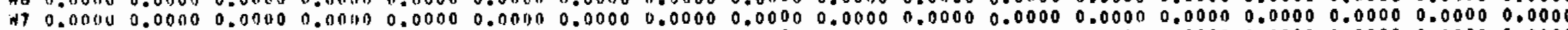

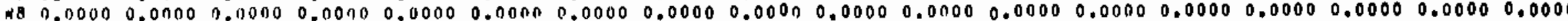

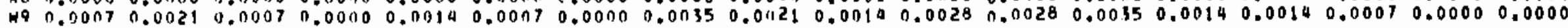

STAUILITY CLASS 3

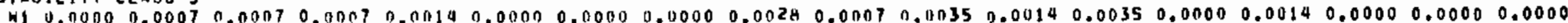

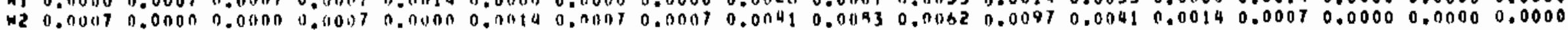




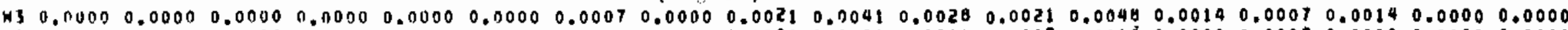

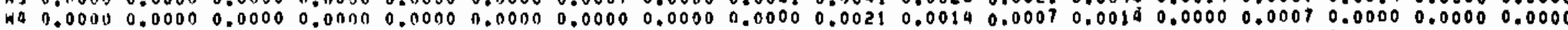

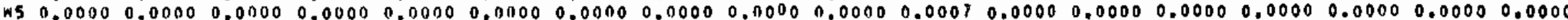

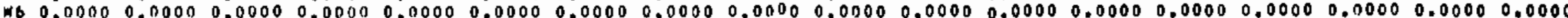

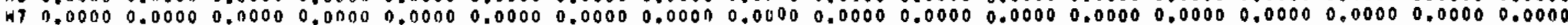

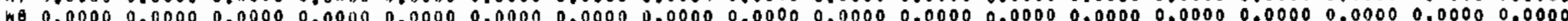

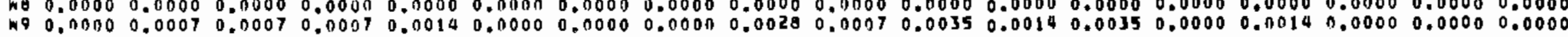

STABILITY CLASS a

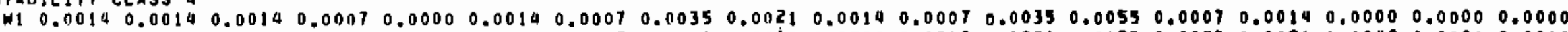

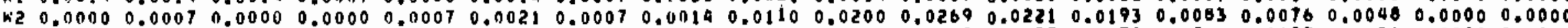

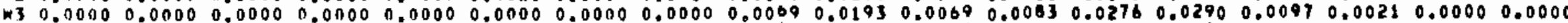

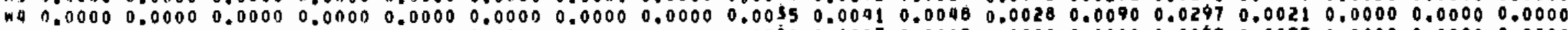

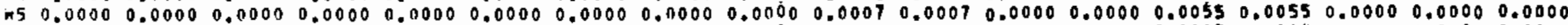

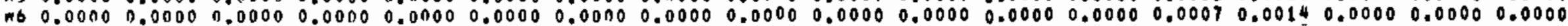

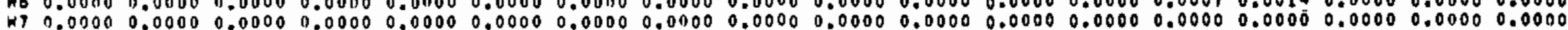

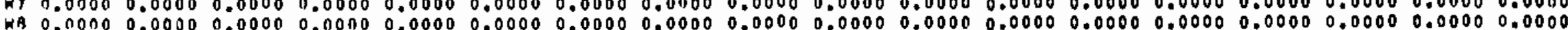

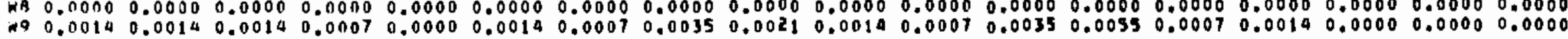

STABILITY CLASS 5

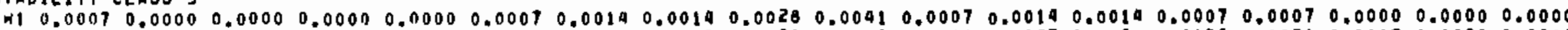

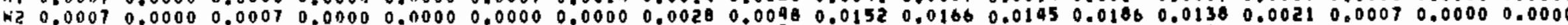

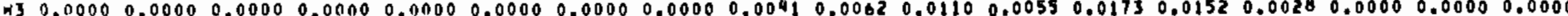

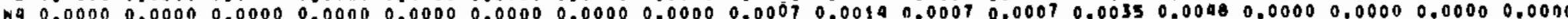

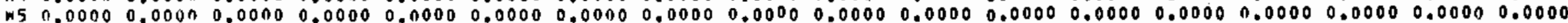

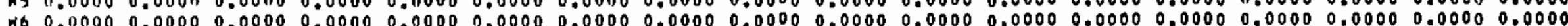

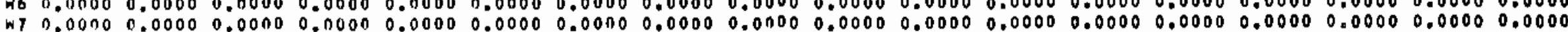

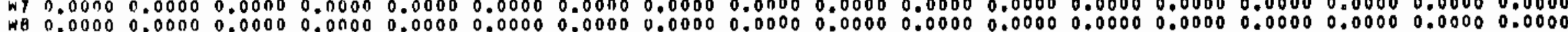

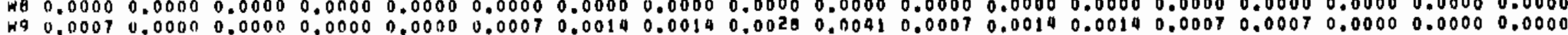

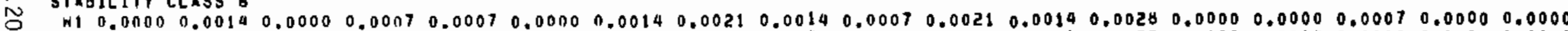

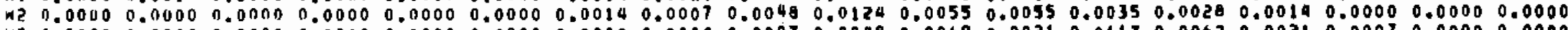

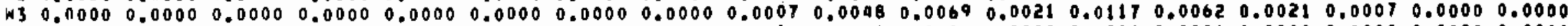

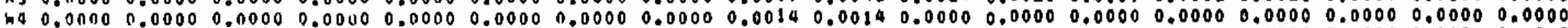

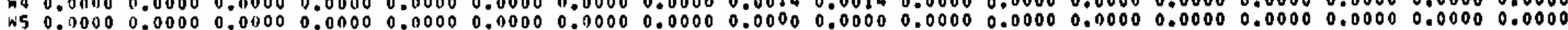

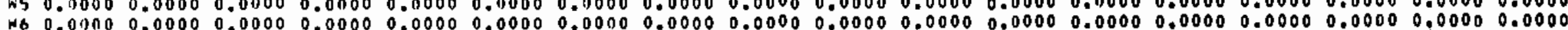

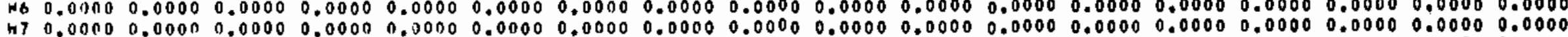

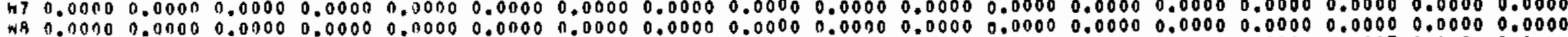

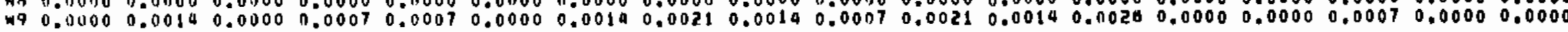

\section{STABILITY CLASS ?}

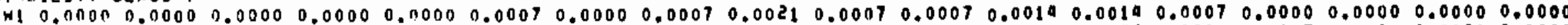

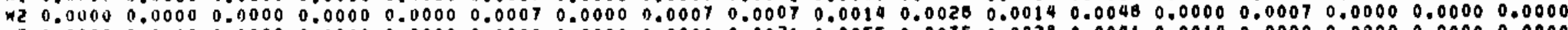

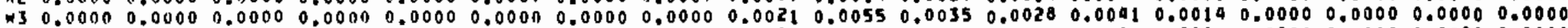

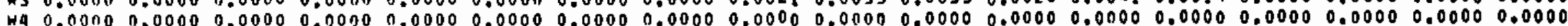

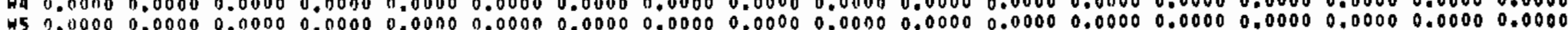

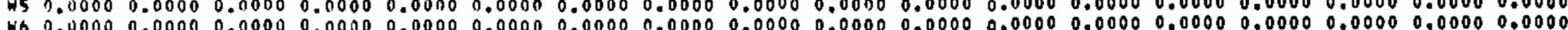

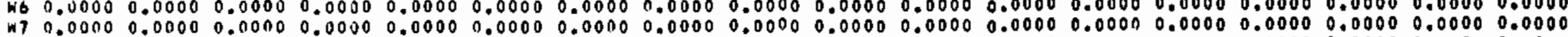

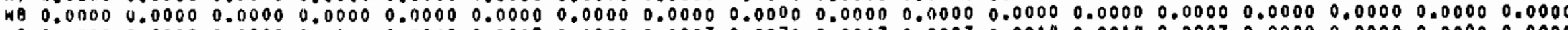

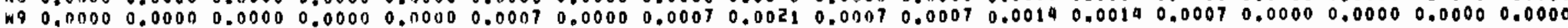


(September)

RELEASE HEIGHT, O H TOTAL OF HOURS 1400

* of LoH speed elass one hinUgt 160

HIND SPEED CLASS

- OF DCCURANEES

1

160

3

159

37

6

7

(3)

HINO DIAECTIDN (16 SECTORS + CALM + VARIABLE)

HIND DIR DCCURANCE

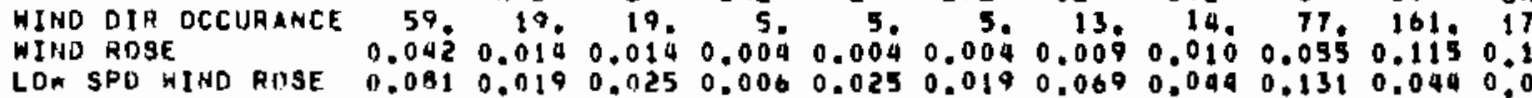

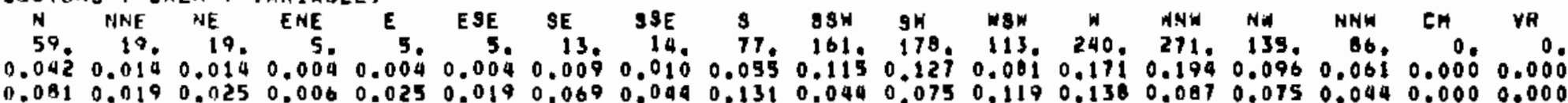

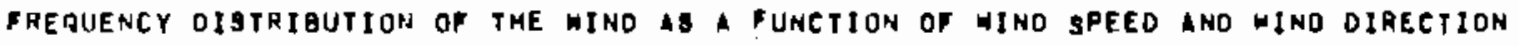

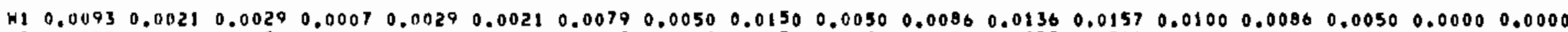

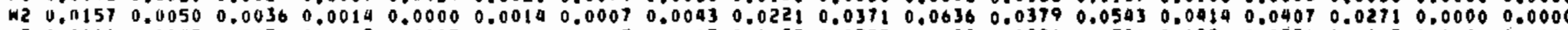

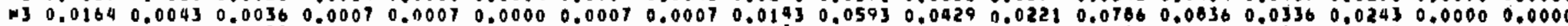

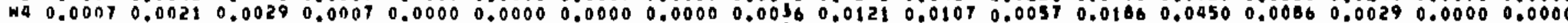

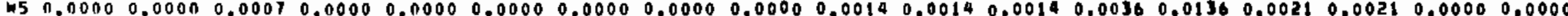

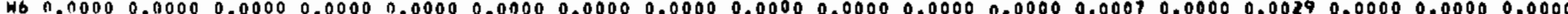

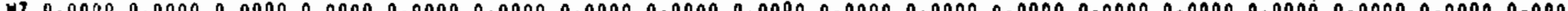

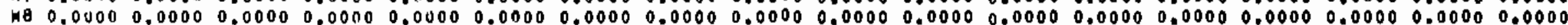

FAEOUENCY DISTAIBUTION OF THE WIND AS A PUNCTION OF WINO SPEED, HIND DIRECTION AND BTABILITY
N
NNE
NE
ENE
E ESE
SE
SBE
8
saw s
wo
w
WNA NM
NWH CALH
VAR

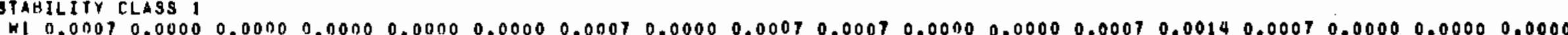

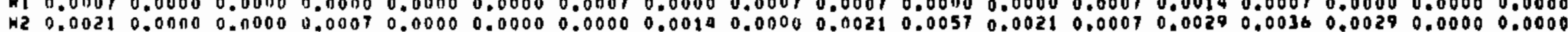

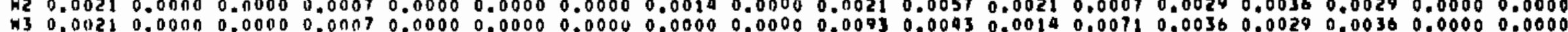

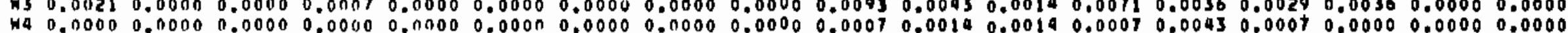

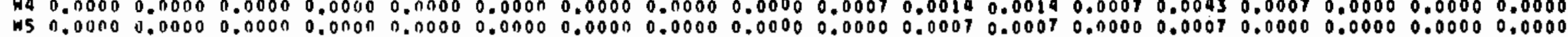

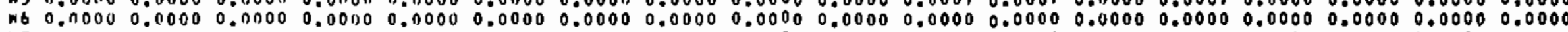

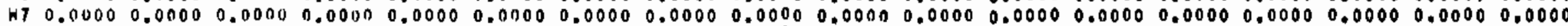

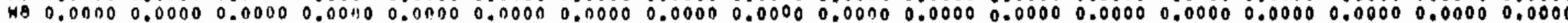

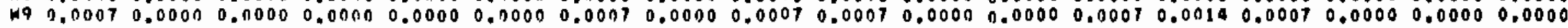

\section{STABILITY CLASS}

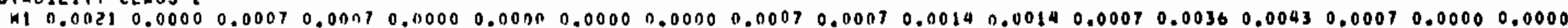

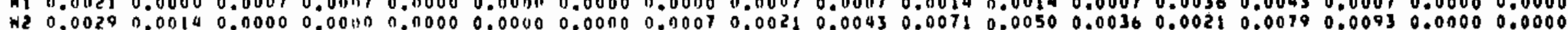

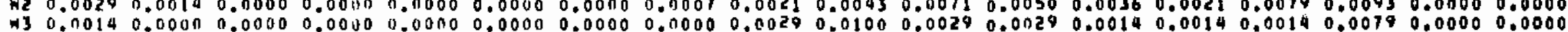

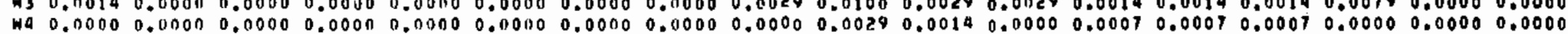

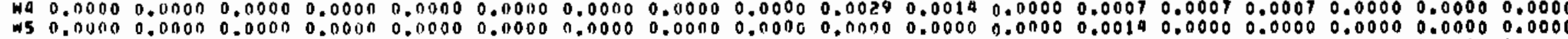

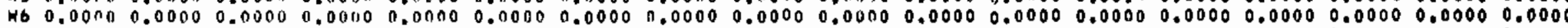

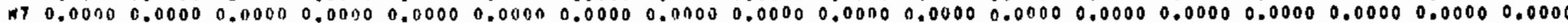

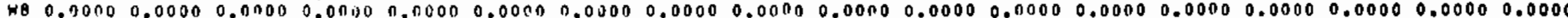

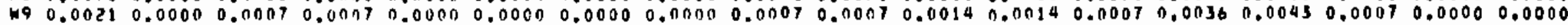

STABILITY CLASS 3

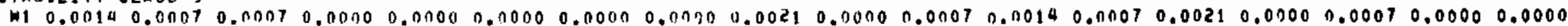

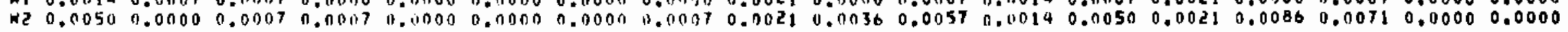




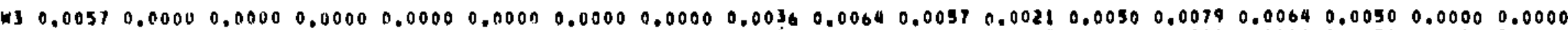

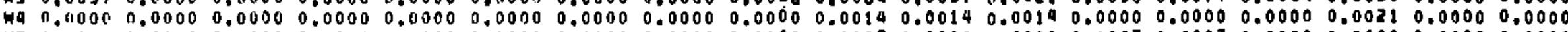

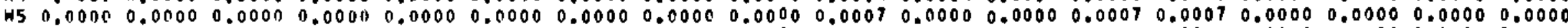

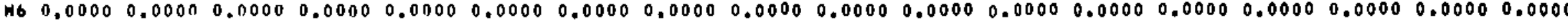

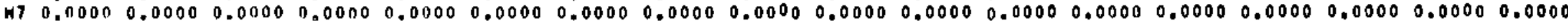

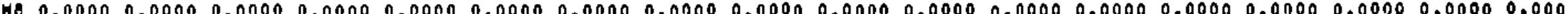

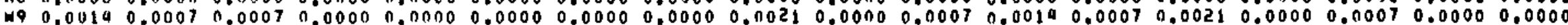

STABILITY CLASS 4

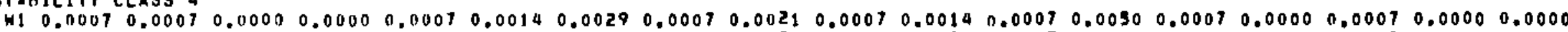

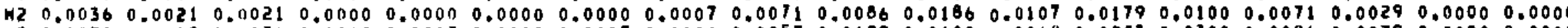

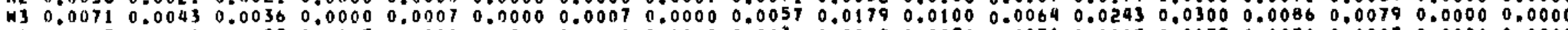

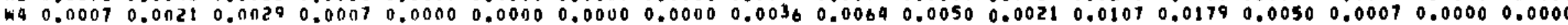

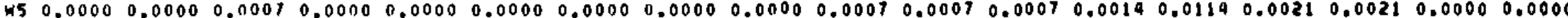

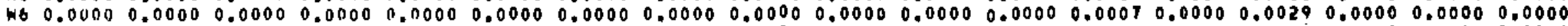

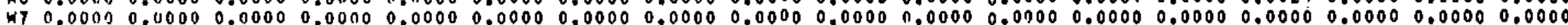

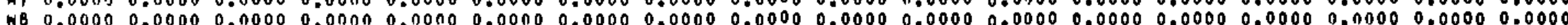

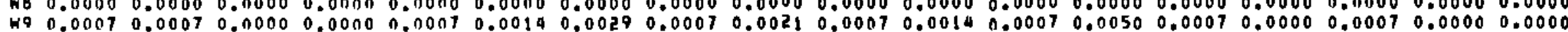

STABILITY CLASS 5

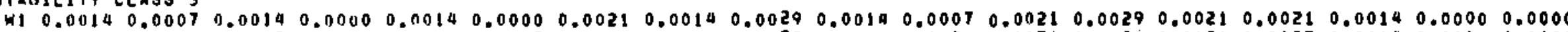

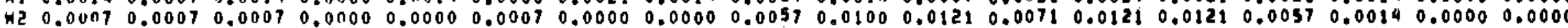

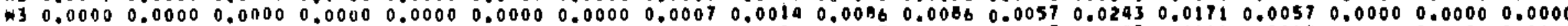

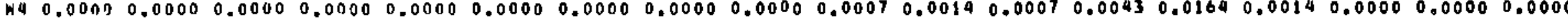

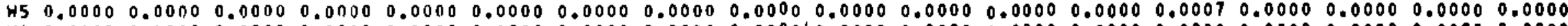

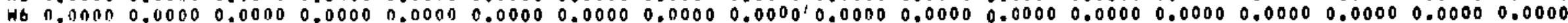

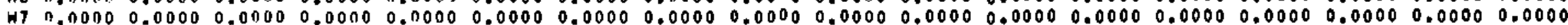

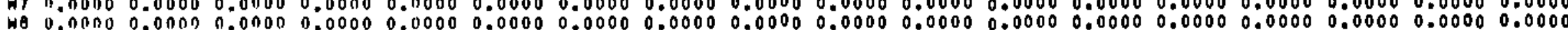

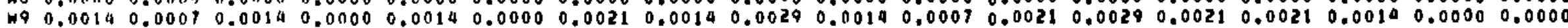

N STABILITY CLASS

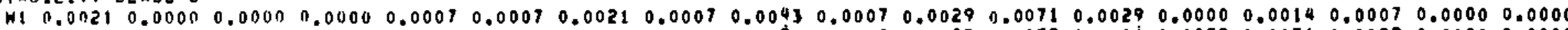

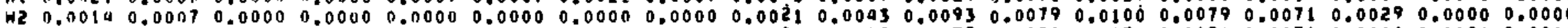

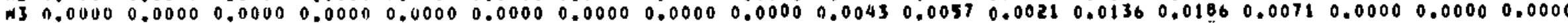

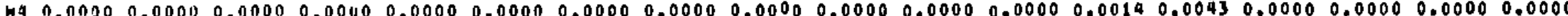

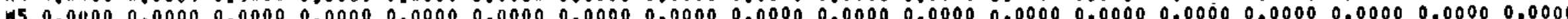

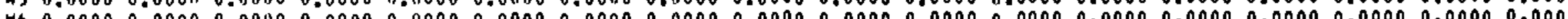

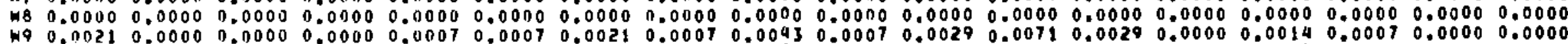

STABILITY CLASS T

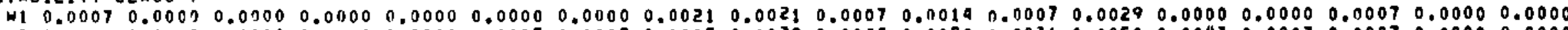

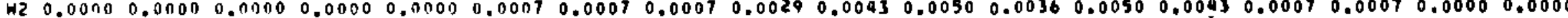

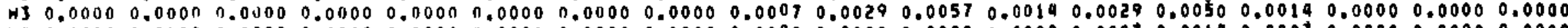

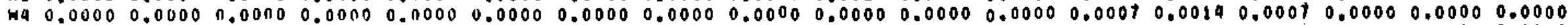

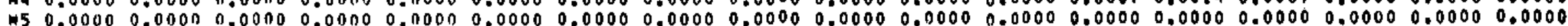

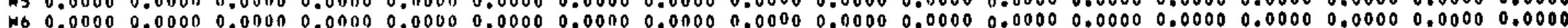

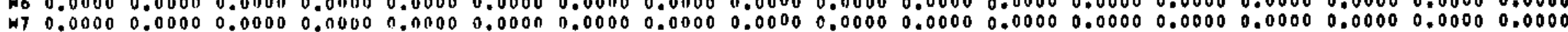

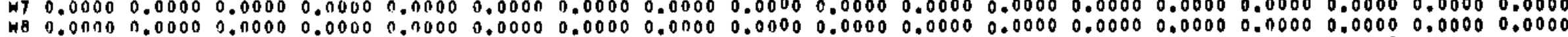

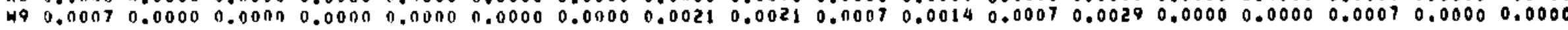


(October)

RELEASE HEIGHT: OH TOTAL OF MDURS, 1428

OF LOW SPEED CLASS OHE WINDS,
WIND SPEED CLLSS
OF OCCURANCES

* OF OCCURANCES

274

$\underset{2}{274}$

3

91

22

3

7

6

WINO DIRECTION (16 SECTOKS + CALH + VARIABLE)

WINO DIR OCCURANCE

HIND ROSE

h NNE NE ENE

LOW SPO WINE ROSE

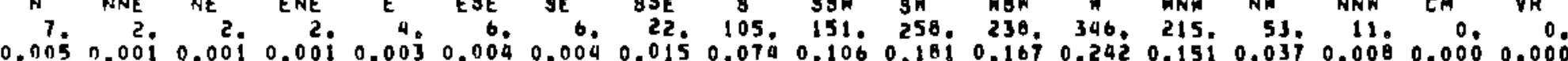
$0.0070 .007 \quad 0.0040 .0070 .0150 .0180 .0180 .040 \quad 0.1130 .0880 .1610 .2010 .2260 .0690 .0150 .0110 .000 \quad 0.000$

FREQUENCY DISTRIQUTIDN OF THE MINO AS AUNCTION OF HIND SPEED IND WIND DIRECTION

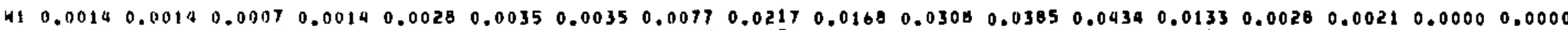

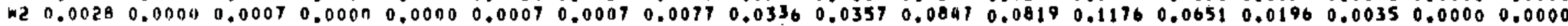

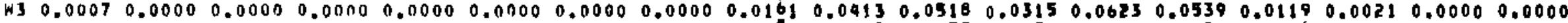

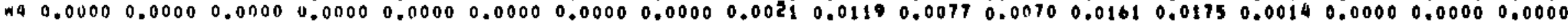

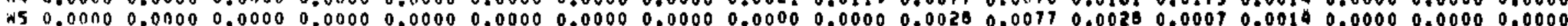

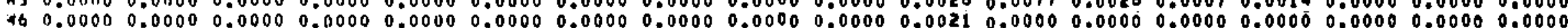

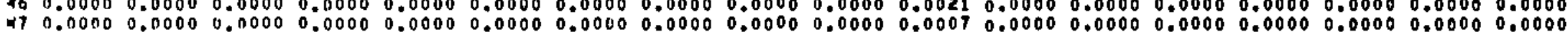

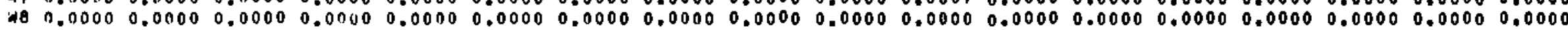

FREUUENCY DISTRIOIJIION OF THE MINO AS PUNCTION OF MIND GPEED, WIND DIRECTION AHD OTABILITY

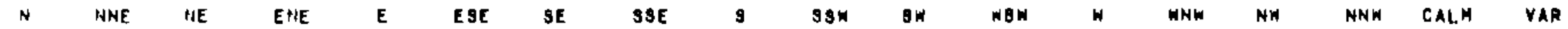

BTABILITY CLASS 1

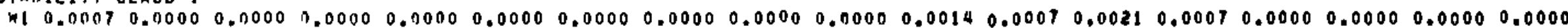

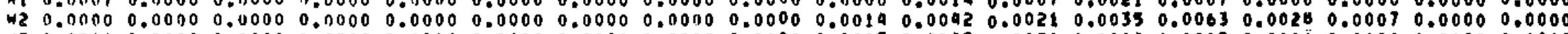

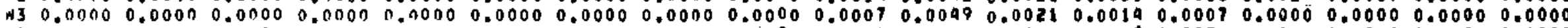

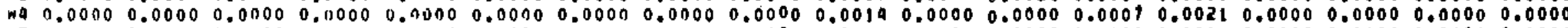

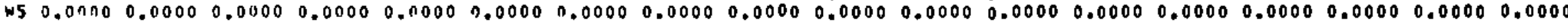

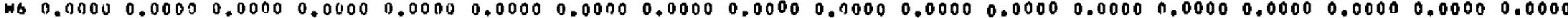

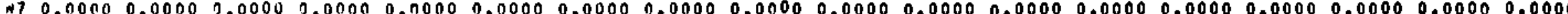

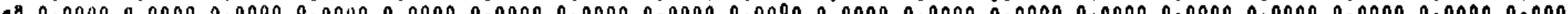

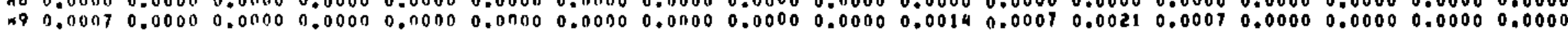

STAGILITY CLASS 2

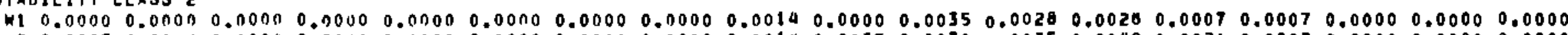

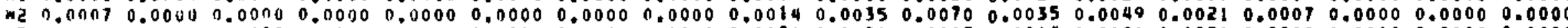

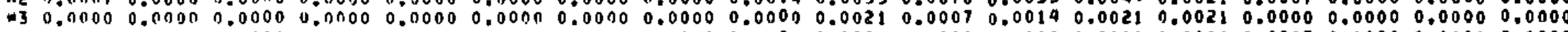

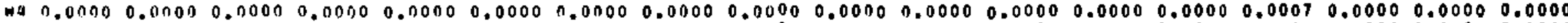

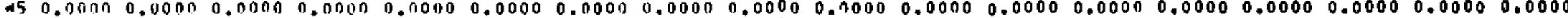

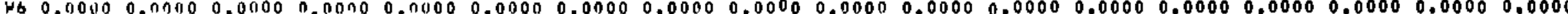

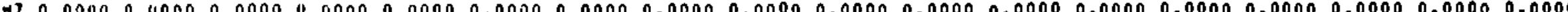

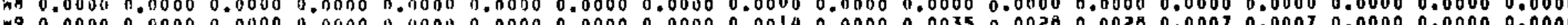

- stabilitir class 3

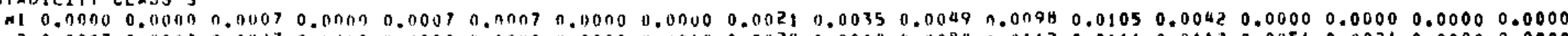

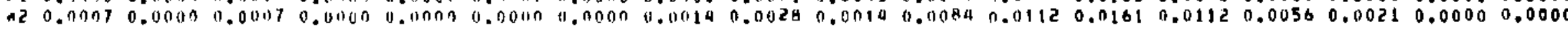




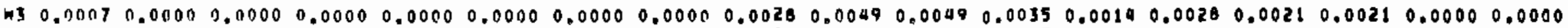

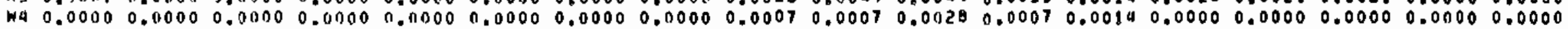

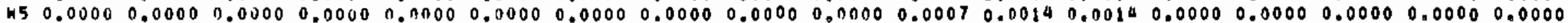

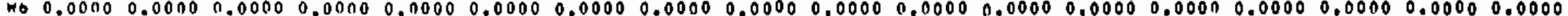

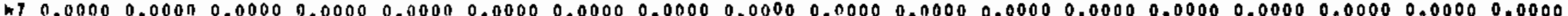

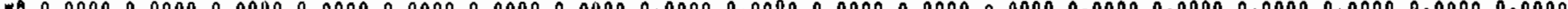

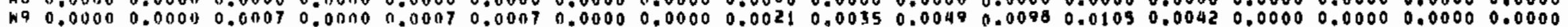

STAAILITY CLASS 4

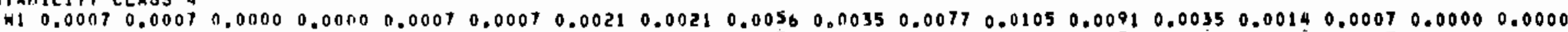

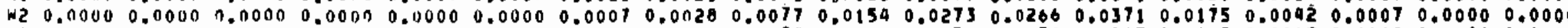

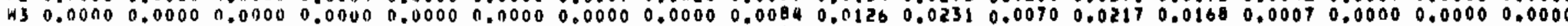

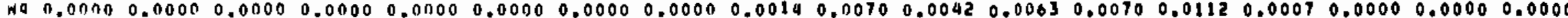

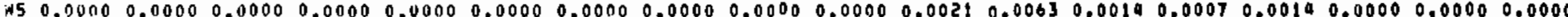

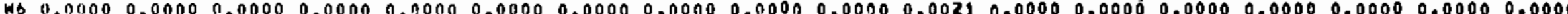

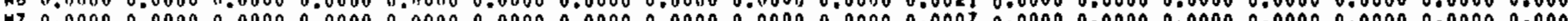

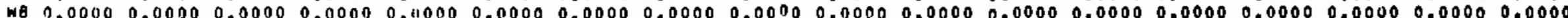

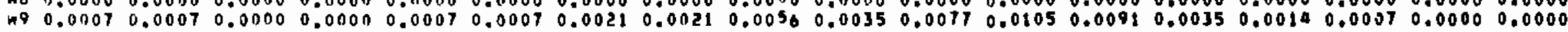

STAAILITY CLASS 5

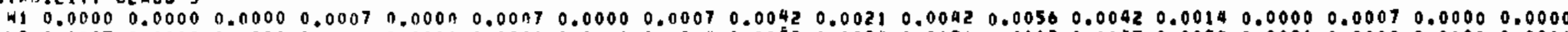

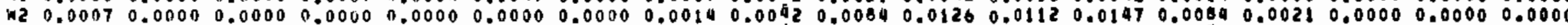

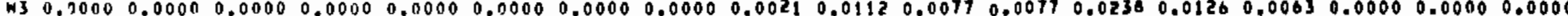

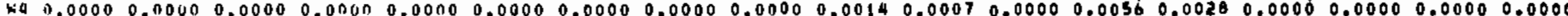

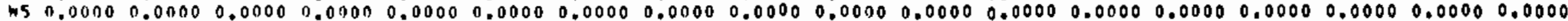

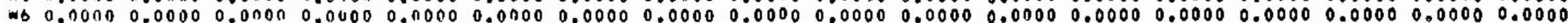

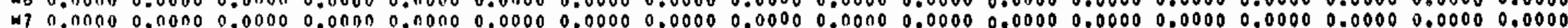

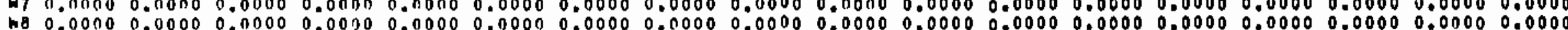

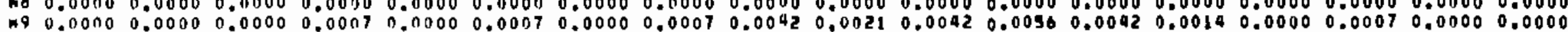

STAEILITY CLASS 6

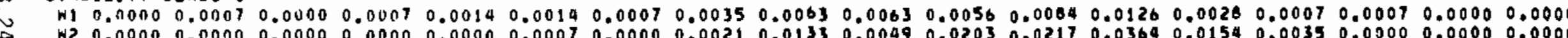

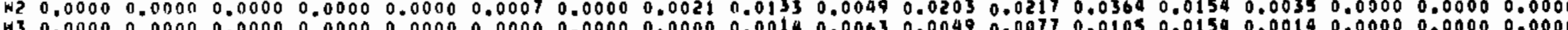

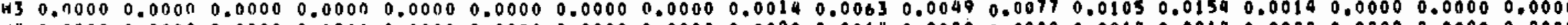

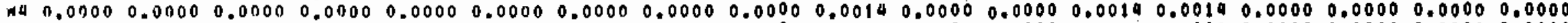

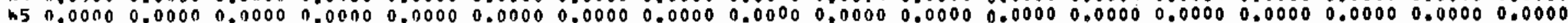

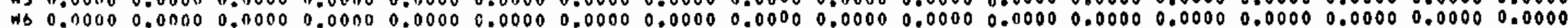

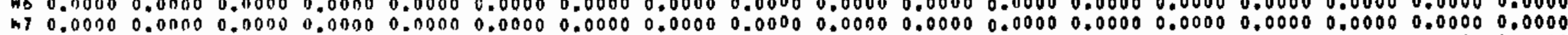

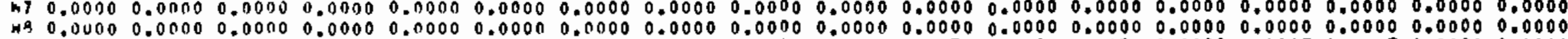

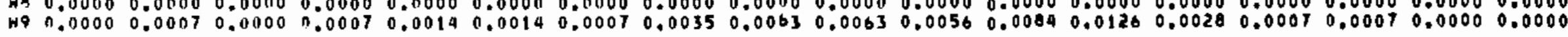

STABILITY CLASS 7

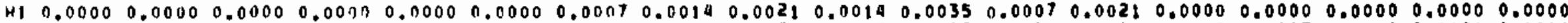

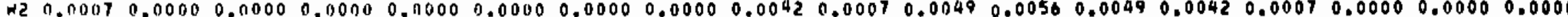

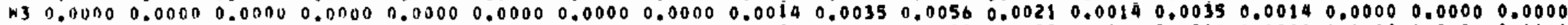

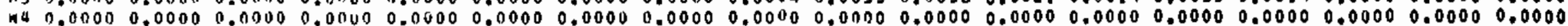

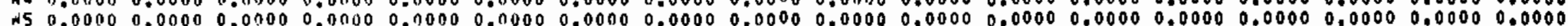

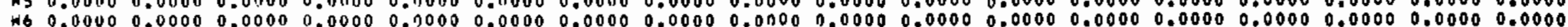

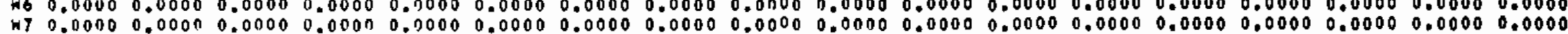

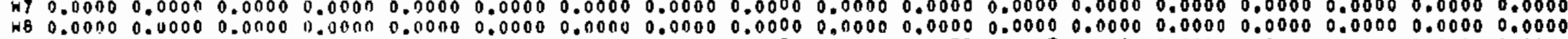

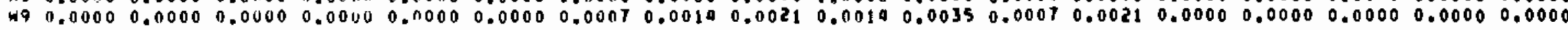


" OF LOW SPEEU CLASS THE WINISS HIMO SPEED CLASS 145

2

531
497
163
50
19
7
0

WINU OIAECTION (16 SECTOHS + CALM + VARIABLE)

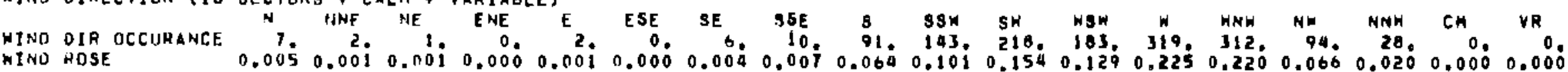

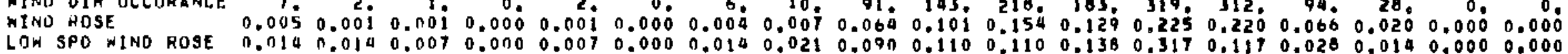

\title{
FRECUENCY DISTRIBUTION DF THE WIND AB A FUNCTION OF HINU SPEED ANO RIND DIRECIION
}

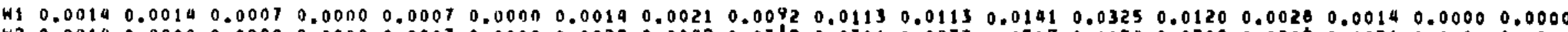

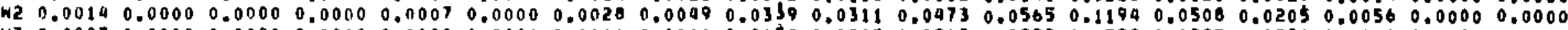

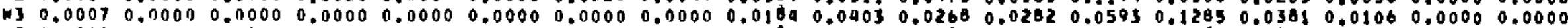

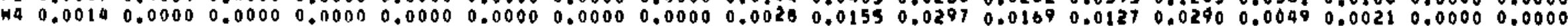

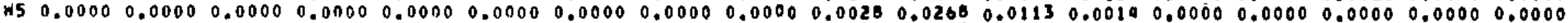

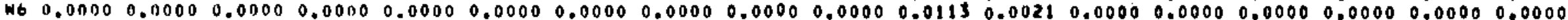

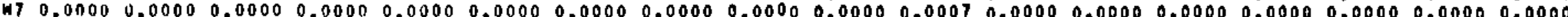

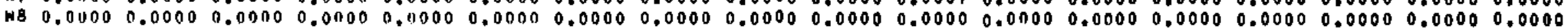

\section{STABILITY CLASS I}

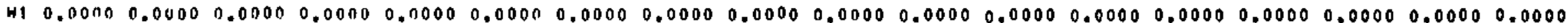

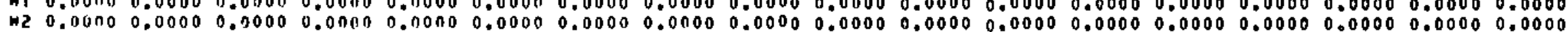

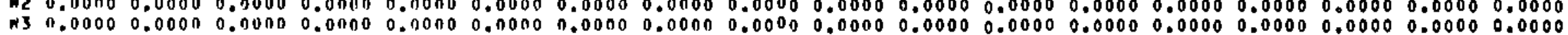

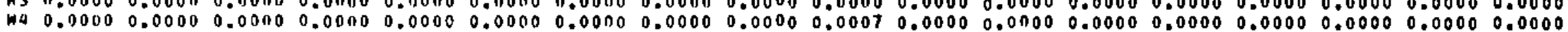

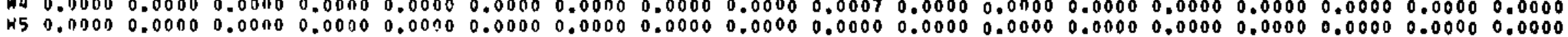

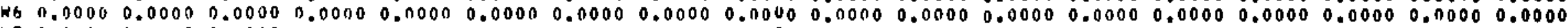

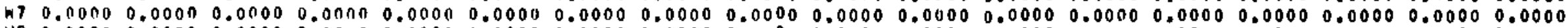

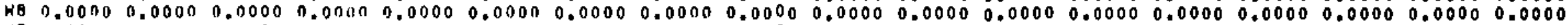

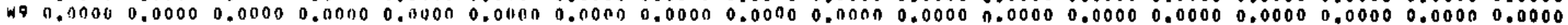

STARILTTY CLASS 2

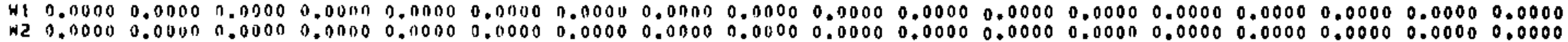

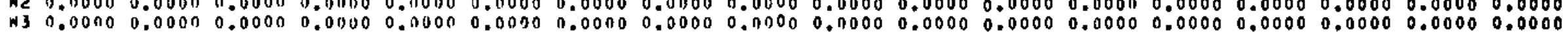

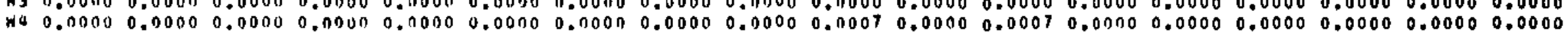

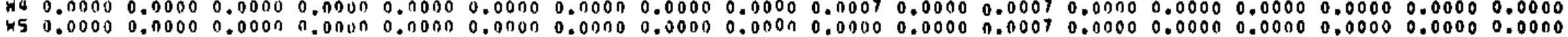

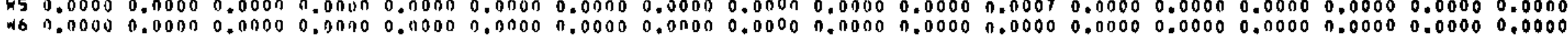

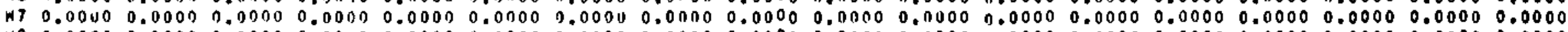

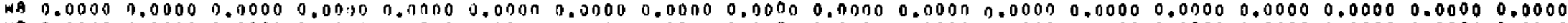

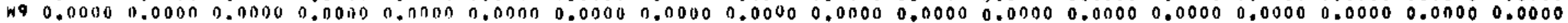

- stanilitr cl.ass 3

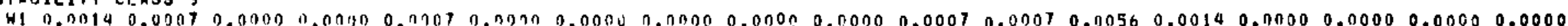

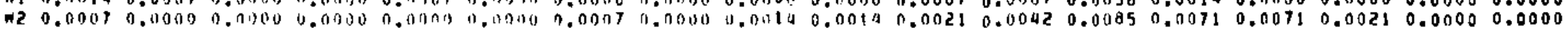




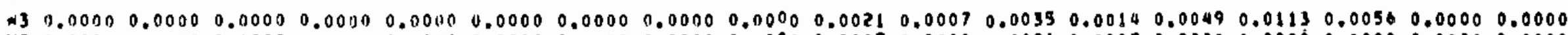

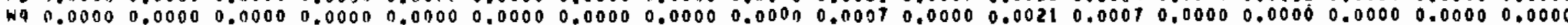

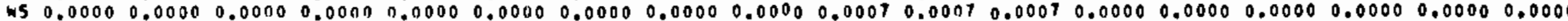

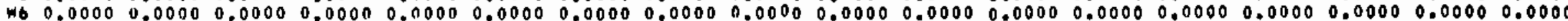

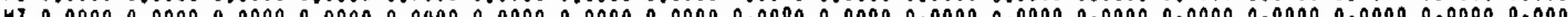

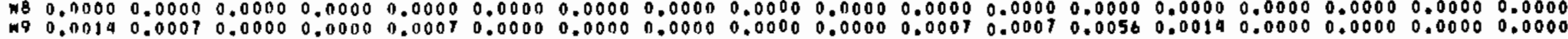
STARILITY CLASS

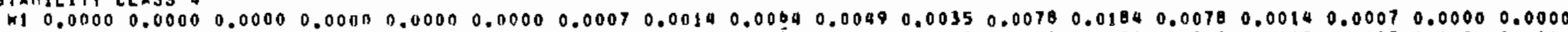

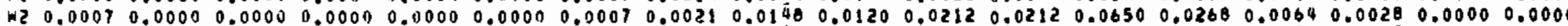

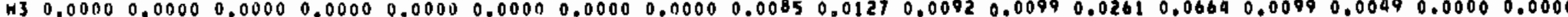

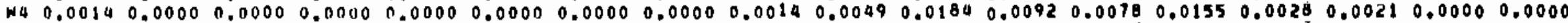

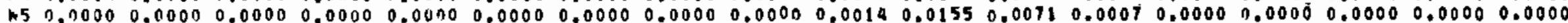

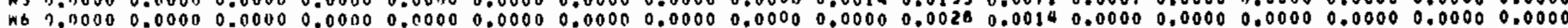

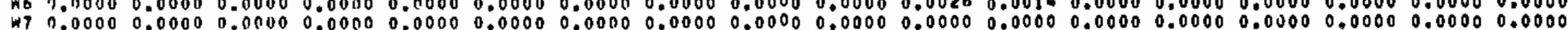

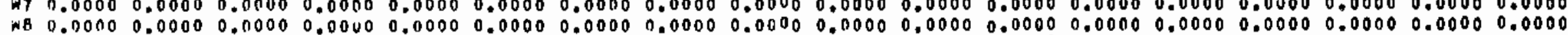

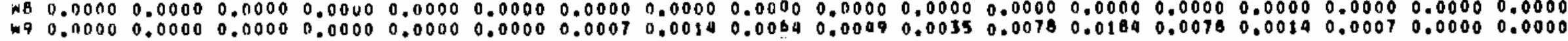

sThulliter CLABS 5

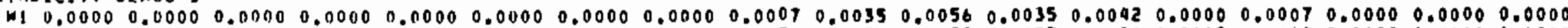

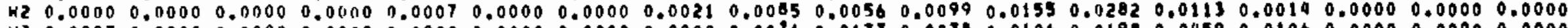

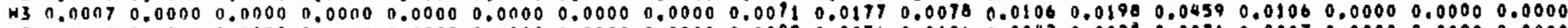

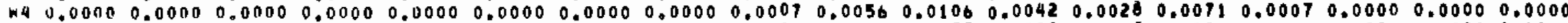

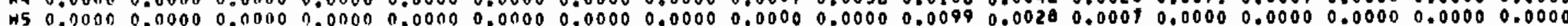

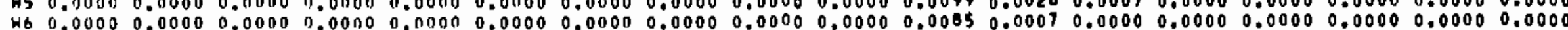

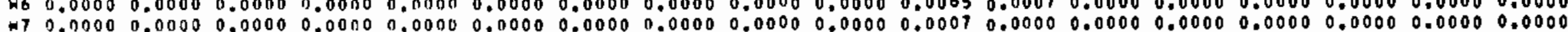

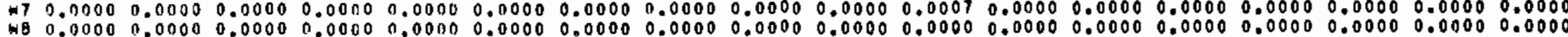

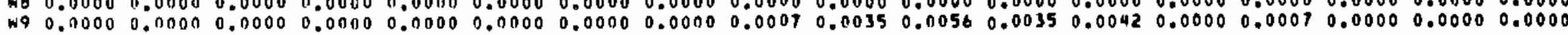

- TABILITY CLASB

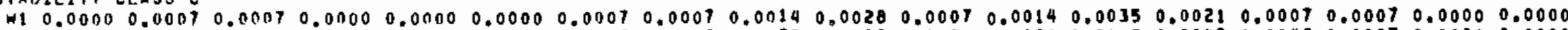

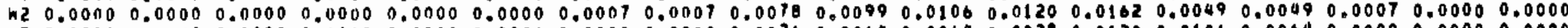

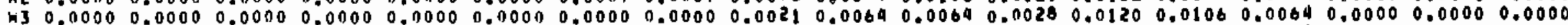

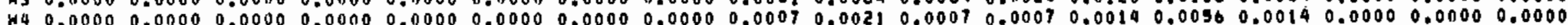

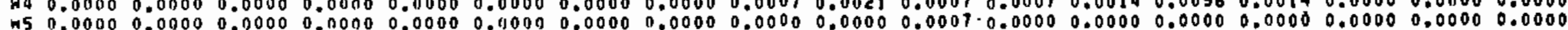

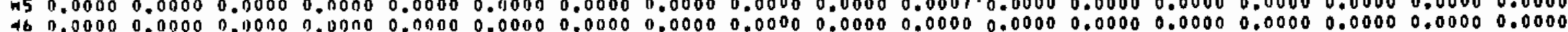

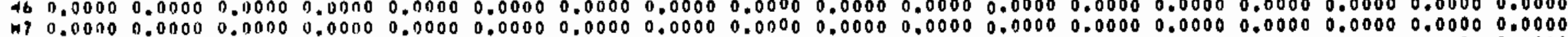

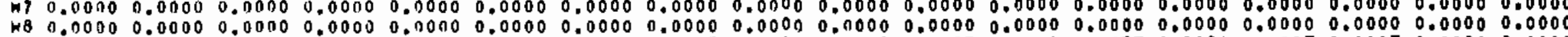

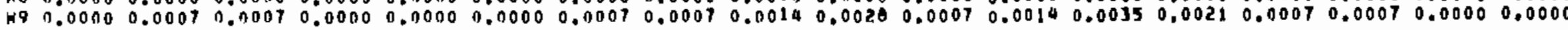

\section{SIAEILITY CLASS 7}

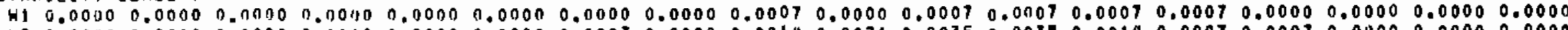

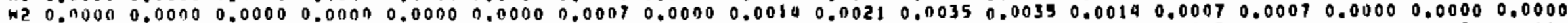

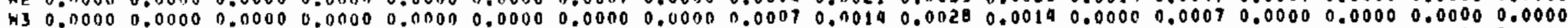

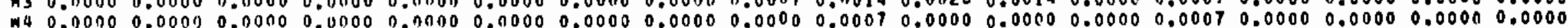

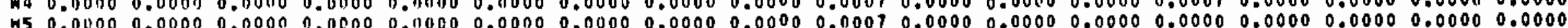

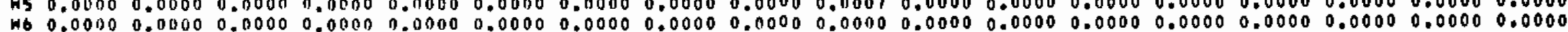

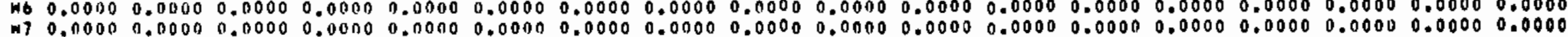

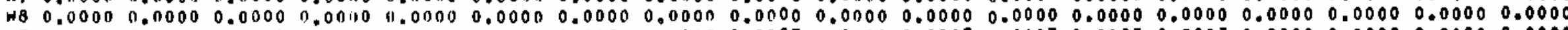

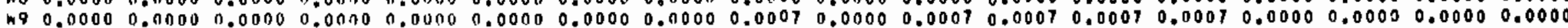


* OF LOW SPEED CLASS ONE hINDSI

WOF LOW SPEED CLASS OHE MINDSI
WNO GPEEO CLASS
OF OCCURANCES

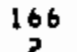
2

3
46

465

152

5

13

${ }^{7}$

8

HIND DIRECTION (16 SECTOHS + CALH + VARIABLE)

HINU DIR OCCURATCE HINO RUSE No NNE HE ENE ESE SE SSE (3)

FREDLENCY DISTRIBITION OF THE WIND AS AUNCTION OF WINO SPEEO ANO HIND DIAECTION

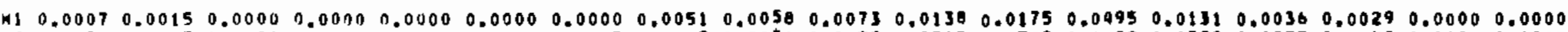

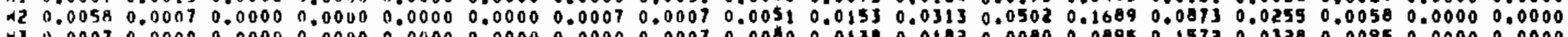

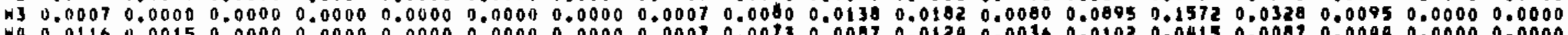

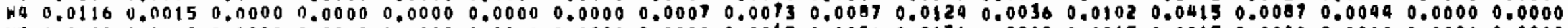

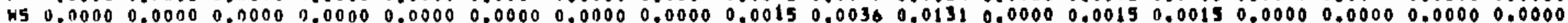

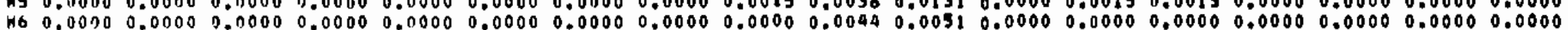

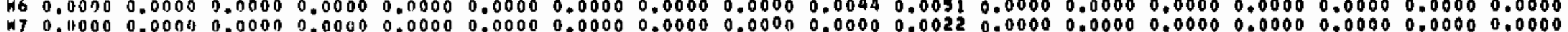

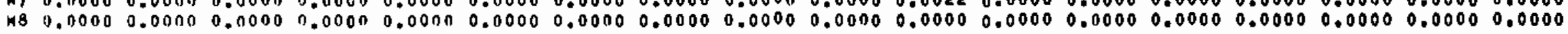

FREQIJENCY BISTRIBUIION OF THE WIND AB FUNCTION OF HINO GPEED, HIND DIRECTION AND BTABILITY

\section{STAEILIIY CLASS I}

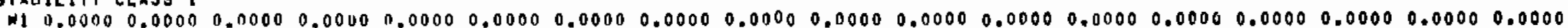

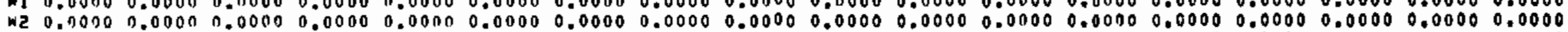

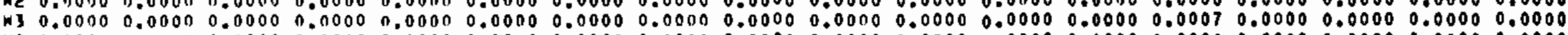

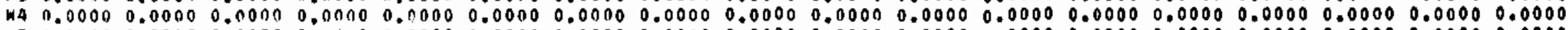

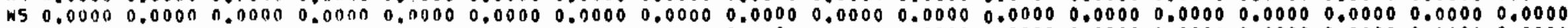

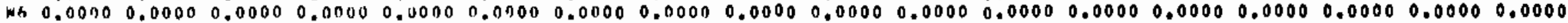

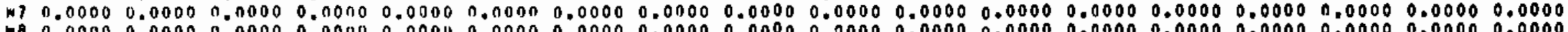

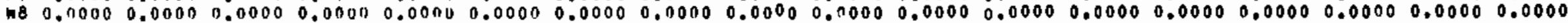

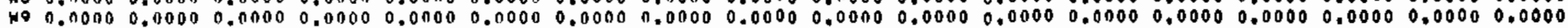

STABILITY CLAS9 $z$

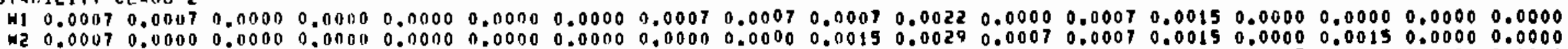

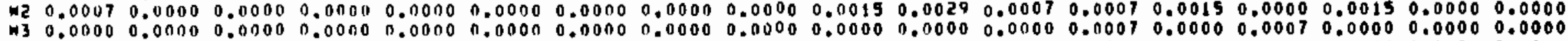

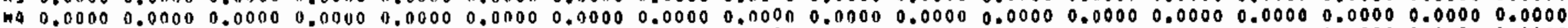

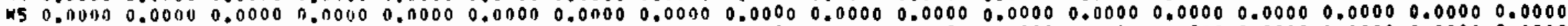

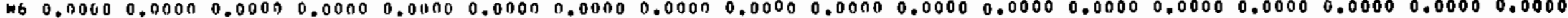

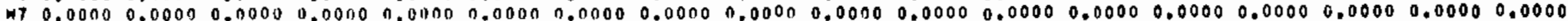

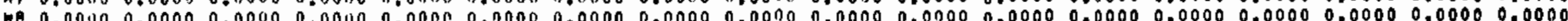

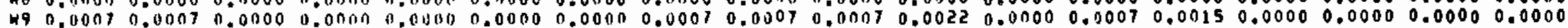

- ataullitr class 3

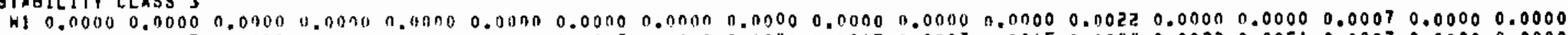

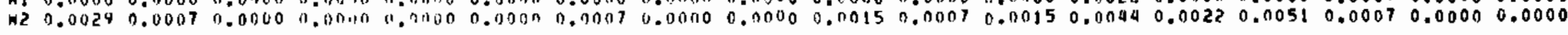




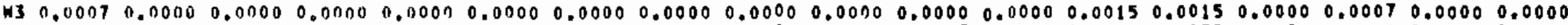

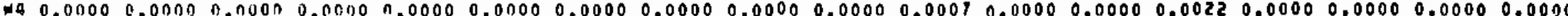

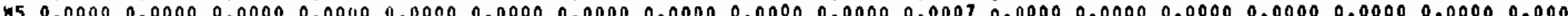

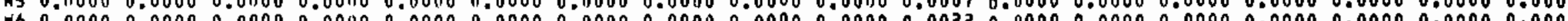

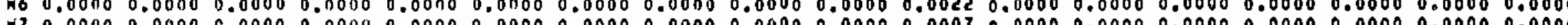

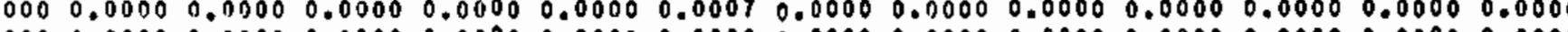

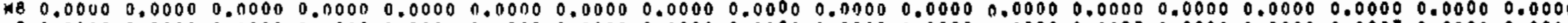

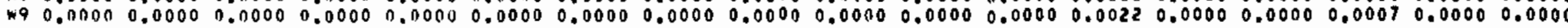

\section{STAEILITY CLASS}

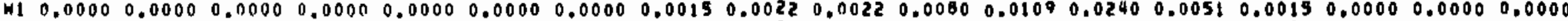

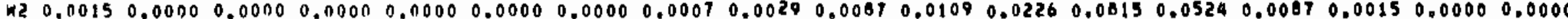

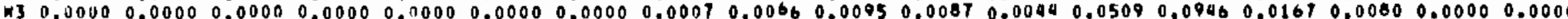

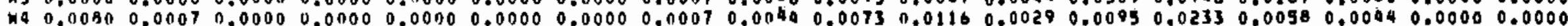

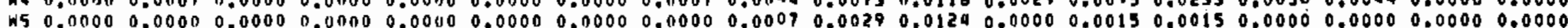

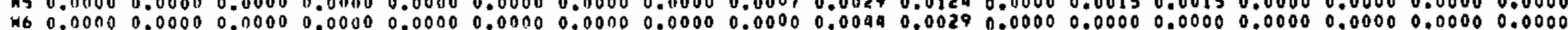

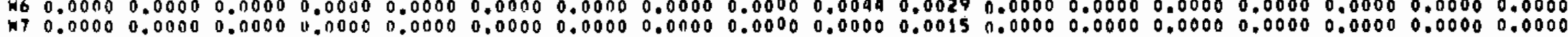

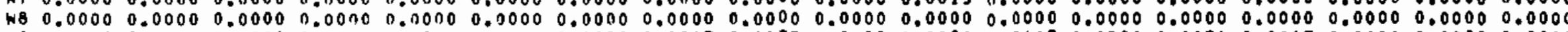

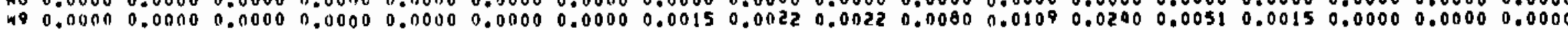

STABILITY CLASS 5

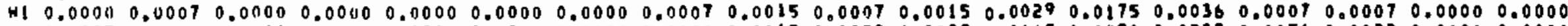

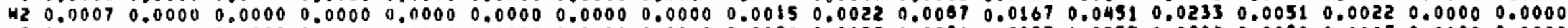

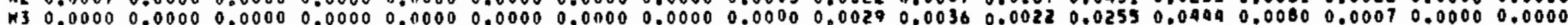

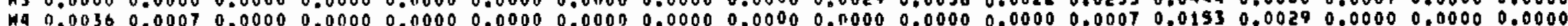

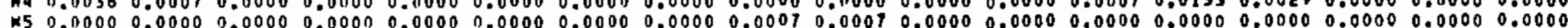

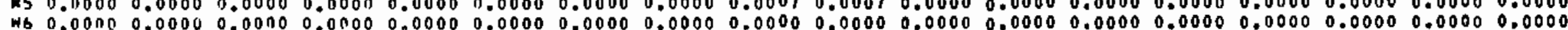

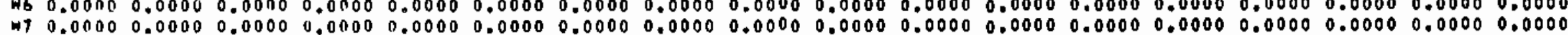

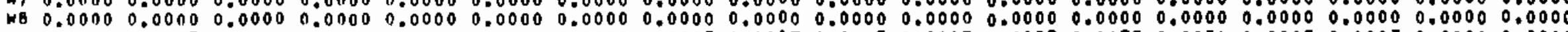

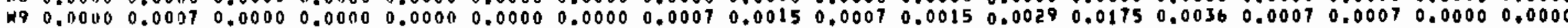

9TAGILITY CLASS B

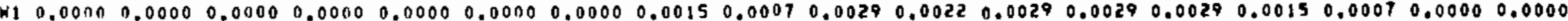

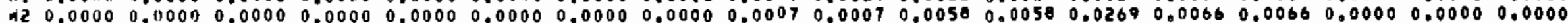

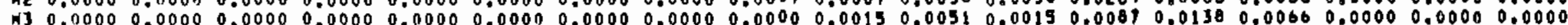

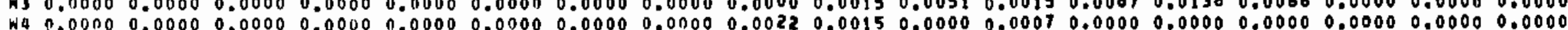

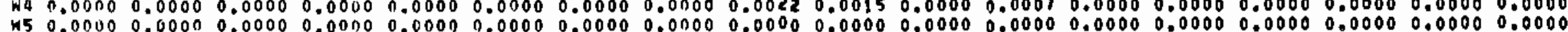

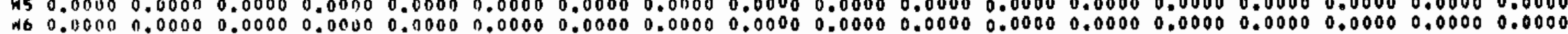

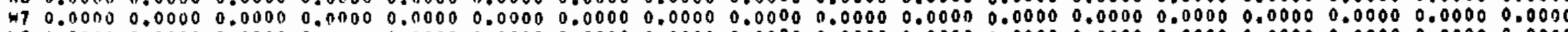

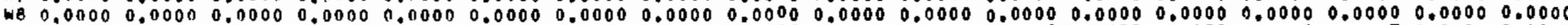

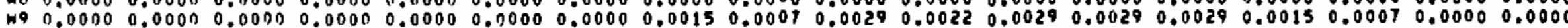

\section{oTAHILITY CLA8S7}

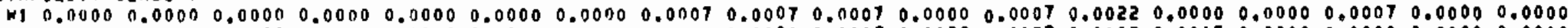

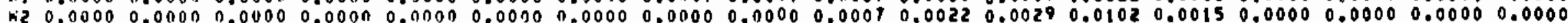

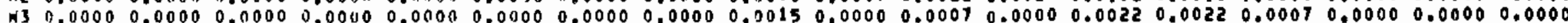

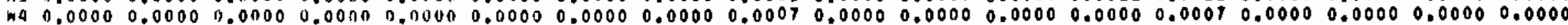

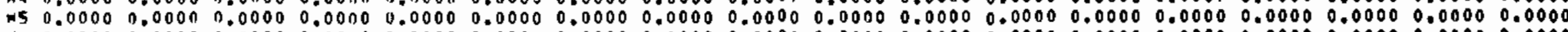

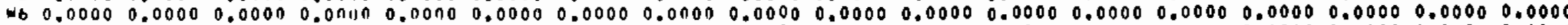

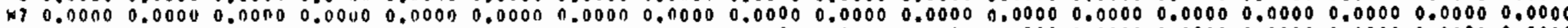

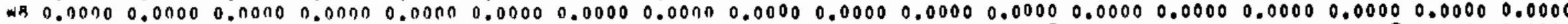

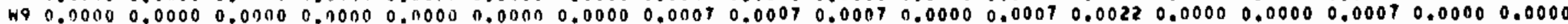


RELEASE HEIGHT: BQ H

STARTIAG DATE : 325 A2 ENH DATE, 131 AG

TOTLL \# DF HOURS, 15674 *OF LOW SPEEO CLASSONE WINDSI 2304

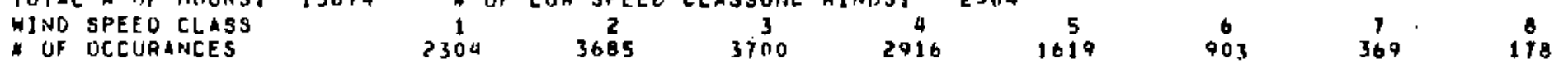

WIHD CIRECTION (10 SECTURS C CALH + VARIABLE) NE ESE SE SSE

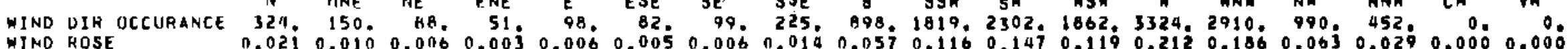

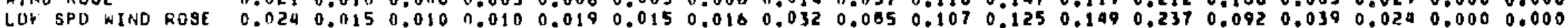

FREAUEHCY OISTRIBUTION OF THE HINO AS A FUNCTION OF MINO gPEED AND WJND DIRECTION

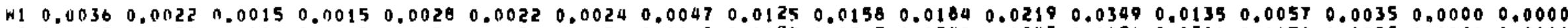

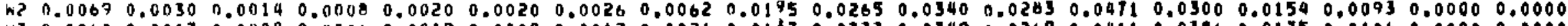

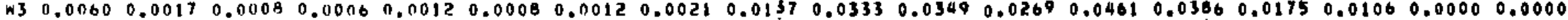

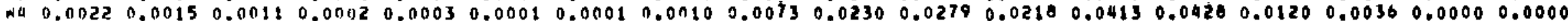

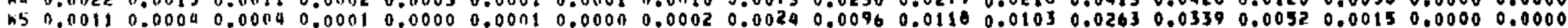

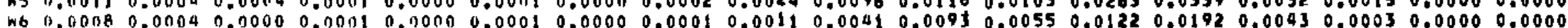

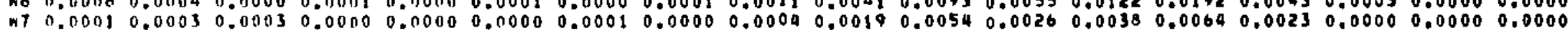

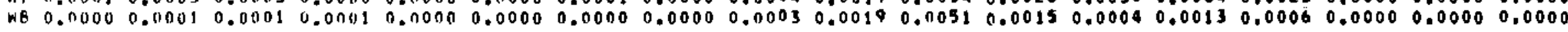

FPEDLENCY DISTRIGUTION OF THE HINO AS AUNCTION OF WIND SPEED, WIND OIRECTION AND BTABILITY

\begin{tabular}{|c|c|c|c|c|c|c|c|c|c|c|c|c|c|c|c|c|c|c|}
\hline & :" & IIME. & HE & EHE & E & ESE & $S E$ & SSE & s & ssw & sw & w sw & $w$ & WNN & NW & NNW & CALH & VAR \\
\hline \multicolumn{19}{|c|}{ HAHILITY CLASS 1} \\
\hline n1 & 0.0006 & $0.0010 ?$ & $n$. & $\ln 3$ & $0.0 \cap 03$ & 1 & 0 & 3 & 0.0098 & 0 & 0 & 0.0010 & 0.0022 & & 2 & 0,0008 & 0 & \\
\hline $\begin{array}{l}152 \\
\text { in } 3\end{array}$ & 0.0019 & 0.0 & $\begin{array}{l}0.0002 \\
0.0001\end{array}$ & & $\begin{array}{l}0.0002 \\
0.0000\end{array}$ & & & & 3 & & & & & & & & & \\
\hline na & 0.00116 & 0.0001 & 0.0000 & 0.0001 & 0.0000 & 0.0 & 0.0000 & 0.0000 & 0.0004 & 0.0 & 0 & 0.1 & 0.0025 & & 3 & & & \\
\hline 105 & 0.0001 & $0 . n$ & 0.01101 & in & .0000 & 0. & 00 & 0. & .0001 & & & & & & & & & \\
\hline$\times 6$ & $\because, 0000$ & 0.0000 & 0.0000 & 0.0 & 0.0000 & & 0 & & 0.00 & & & & & & & & & \\
\hline$W 7$ & 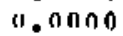 & 0.01000 & 0.0000 & 0.01140 & 0.0000 & & 0. & 0 & 0.0 & & & & 1 & & & & & \\
\hline $\begin{array}{l}n A \\
40\end{array}$ & $\begin{array}{l}0.11000 \\
11.0106\end{array}$ & $\begin{array}{l}0.0000 \\
0.0002\end{array}$ & $\begin{array}{l}0.0 \\
0.0\end{array}$ & 0.0 & $\begin{array}{l}0.0000 \\
0.0003\end{array}$ & 0. & 0 & 0.0 & 0.00 & & & & & & & & & \\
\hline \multicolumn{19}{|c|}{ STAEILITY CLASS 2} \\
\hline WI & 1.0 & 0.0 & 0.0003 & 3 & 0.11004 & 3 & 0. & 0.0007 & $0,0 \cap 11$ & & & & & & & & & \\
\hline w? & 0.0015 & 0.0 & 0 . & & & & & & & & & & & & & & & \\
\hline w3 & 10.0013 & 0.0 & 0.0 & 0.0 & .00134 & 0.0 & 0. & 0. & 0.0 & & & n & 0. & & & & & \\
\hline wa & $0,0 \cap \cap 3$ & 0.00 & 0.0 & 0.0 & 001 & 0. & & & & & & & & & & & & \\
\hline ins & 0.0000 & 0.0000 & 0.0000 & & $00 n$ & 0. & & & & & & 0 & 0 & 4 & & & & \\
\hline W6 & 0.0000 & 0.01 & 0.1 & () & 0.0000 & 0.0 & 0. & & 0. & $n$, & & $n$ & 0.1 & 0. & & & & 00 \\
\hline & $0.1)$ & 9.0 & & & $n \pi$ & & & & & & & & & & & & & \\
\hline his & $n .0000$ & $n .0$ ก & 0.00100 & 0 & 0 & $n$ & סח ממו & חוו & & & & 0 & 0 & & & & & \\
\hline$\omega$ & & & 11.8005 & $n(3,13$ & 11 ता & a 1 & nat & 4007 & 017 & 015 & 26 & 028 & 1031 & 012 & 015 & 1004 & 2000 & 0 \\
\hline
\end{tabular}




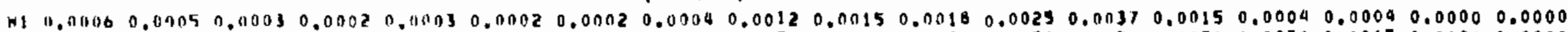

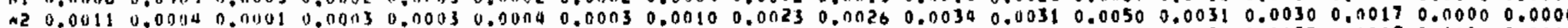

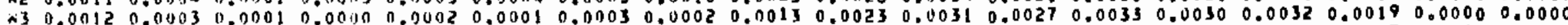

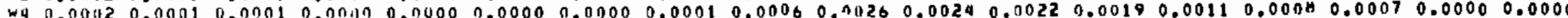

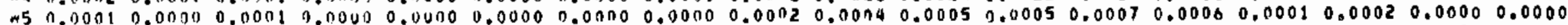

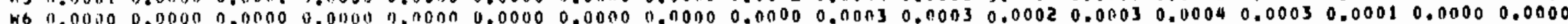

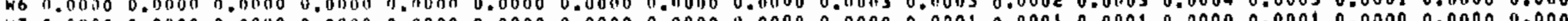

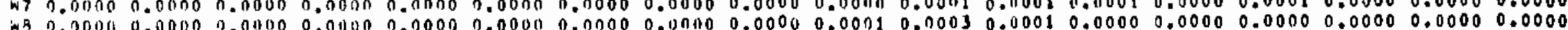

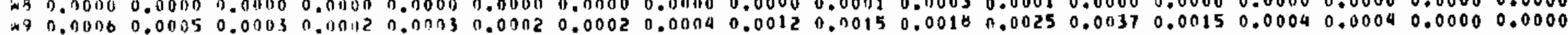

STAKILITY CLASS a

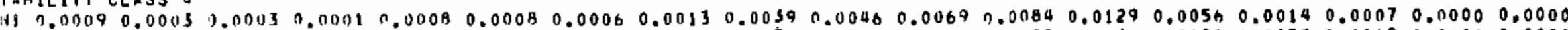

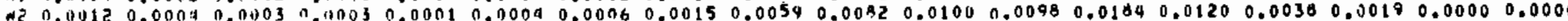

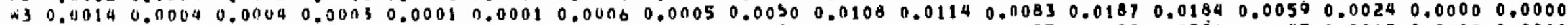

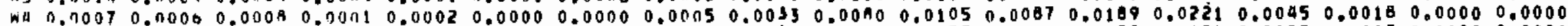

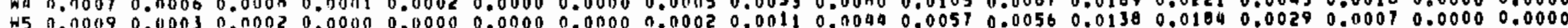

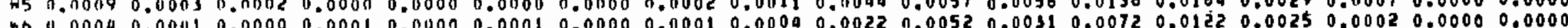

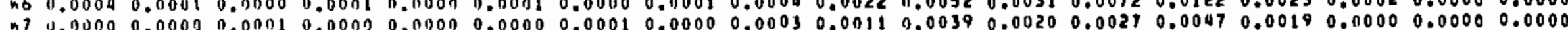

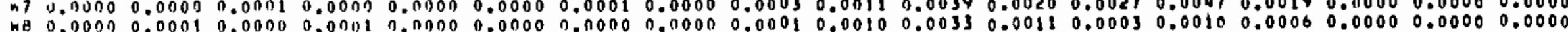

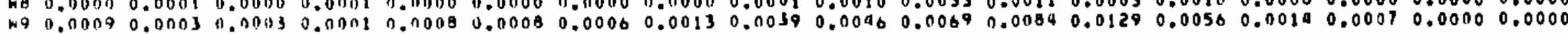

STABILITY CLASS

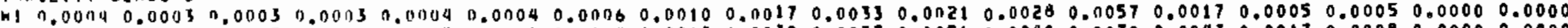

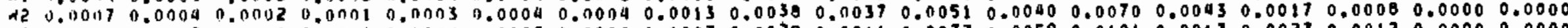

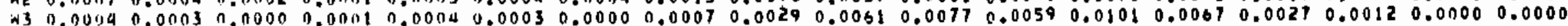

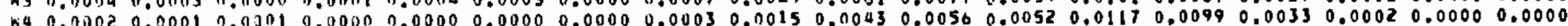

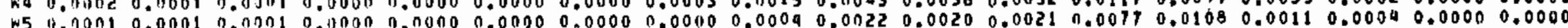

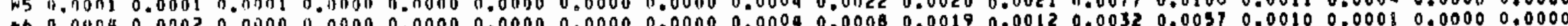

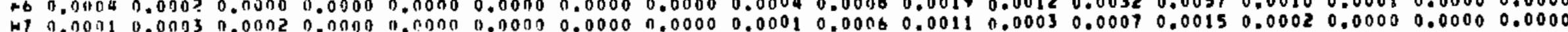

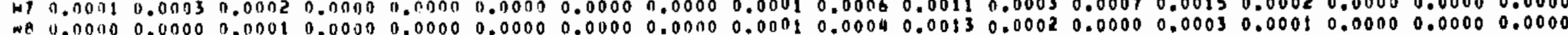

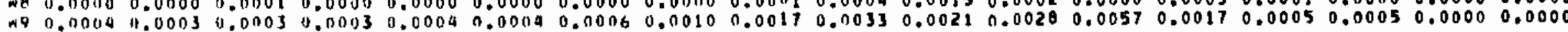

STAAILITY CLASS

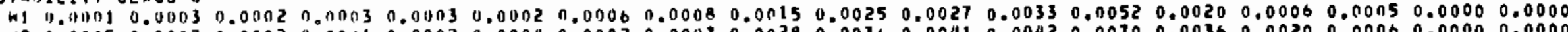

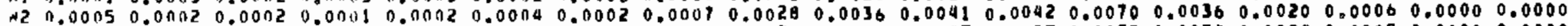

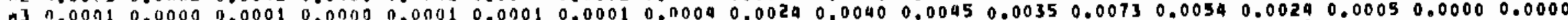

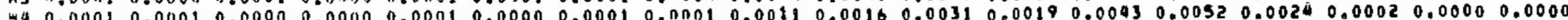

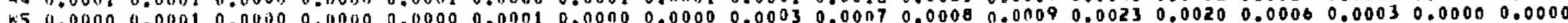

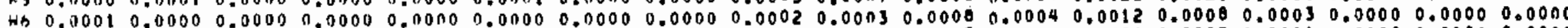

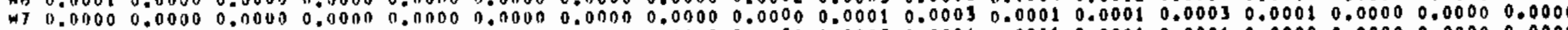

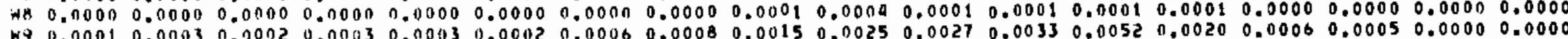

SIAHILITY CLASS 1

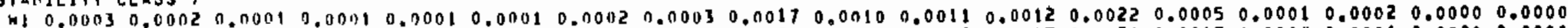

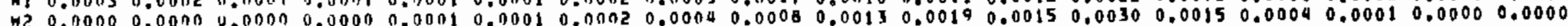

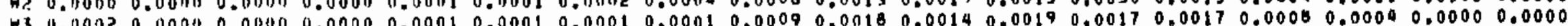

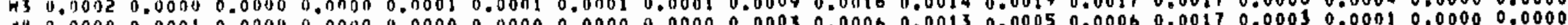

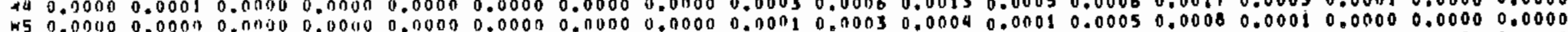

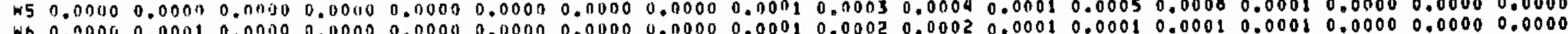

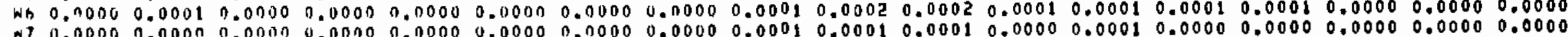

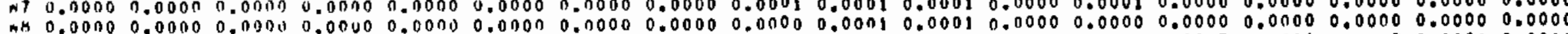

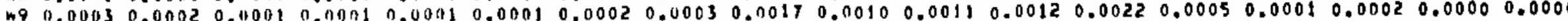




\section{STABILITY CLASS I}

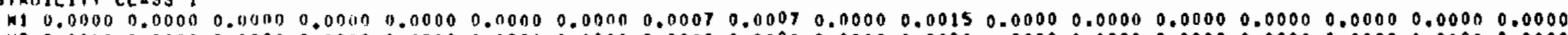

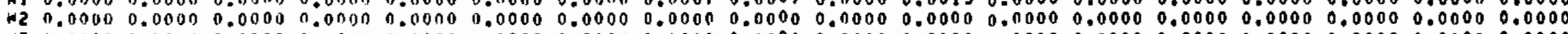

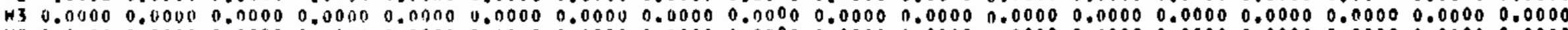

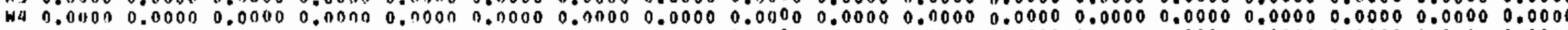

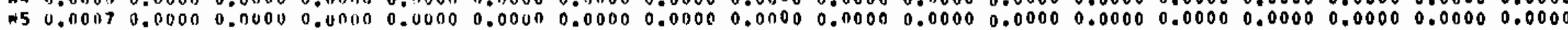

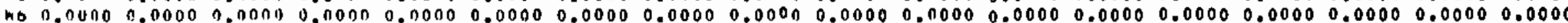

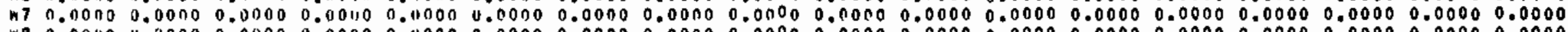

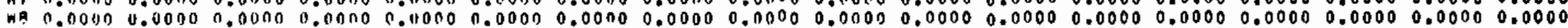

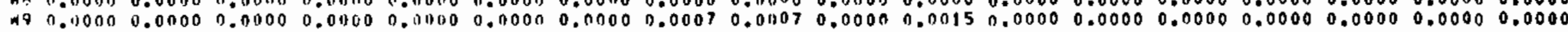

aThHLITY CLASS 2

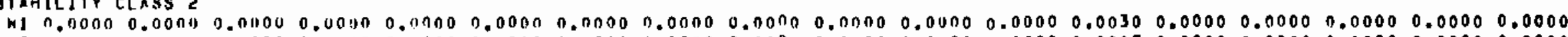

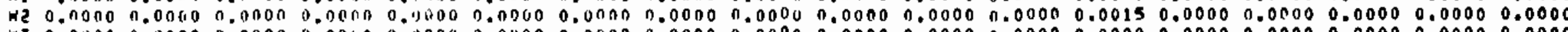

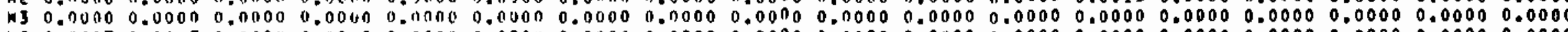

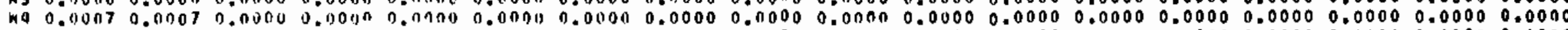

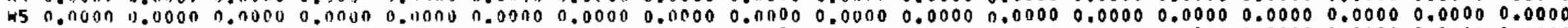

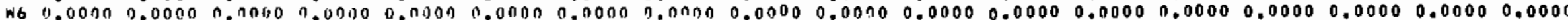

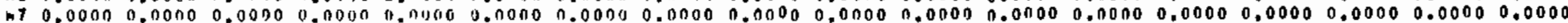

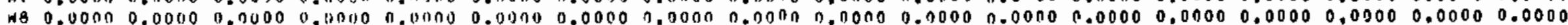

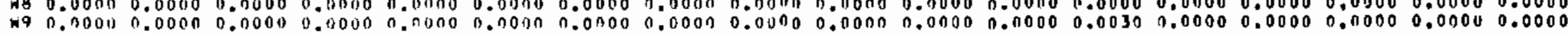




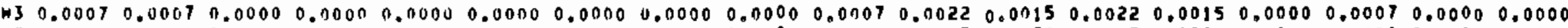

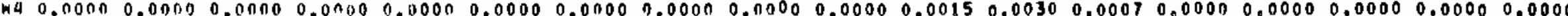

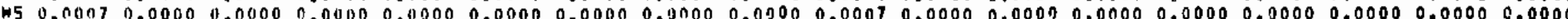

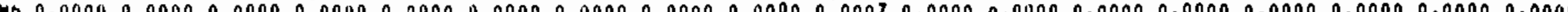

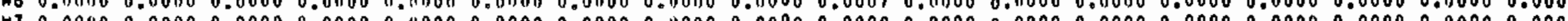

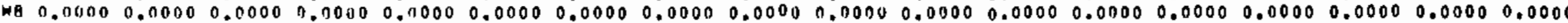

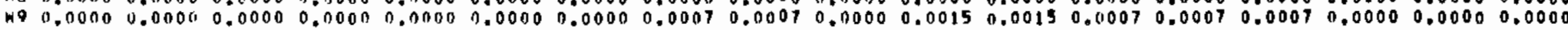

tabilitr class a

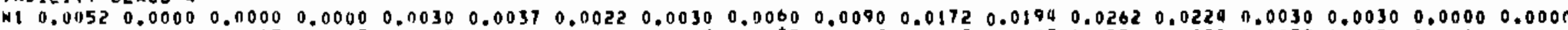

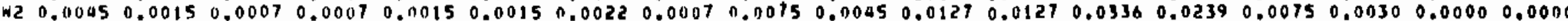

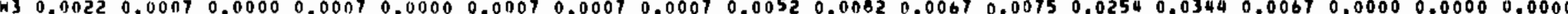

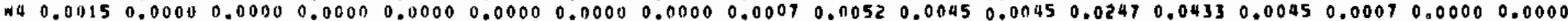

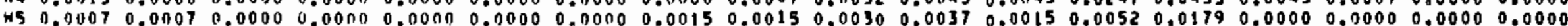

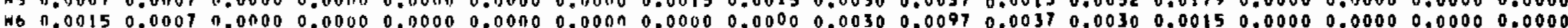

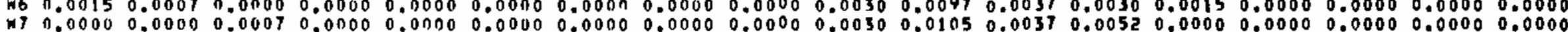

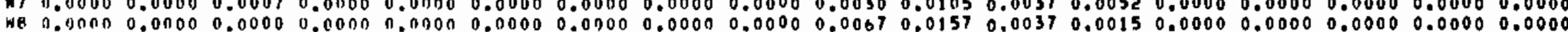

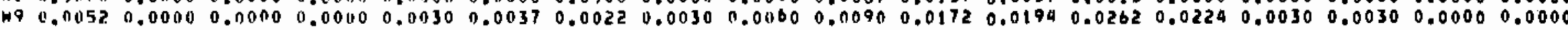

\section{STABILITY CLASS S}

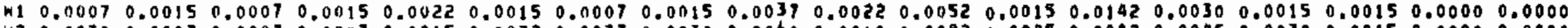

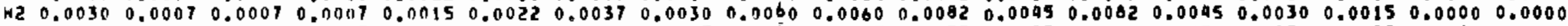

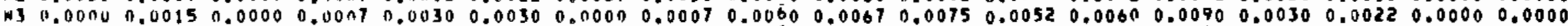

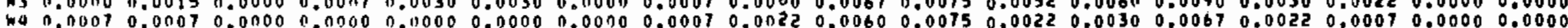

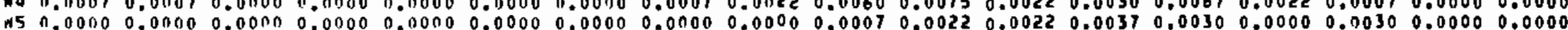

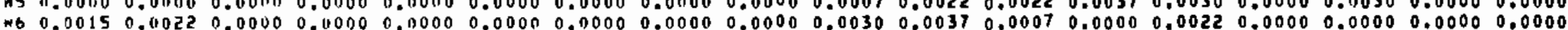

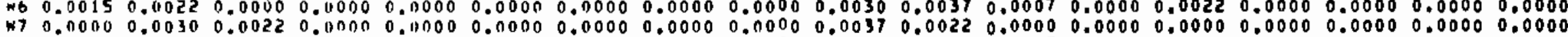

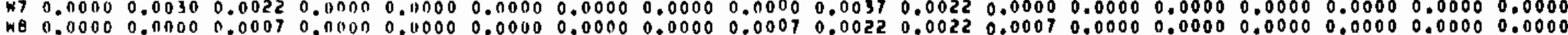

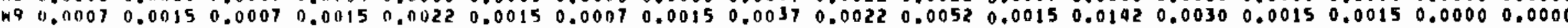

D STAAILITY CLASS 6

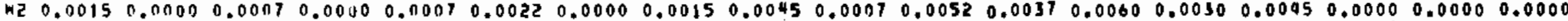

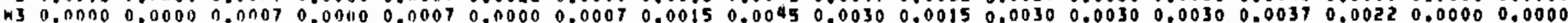

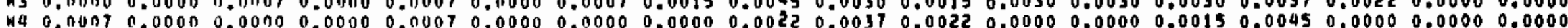

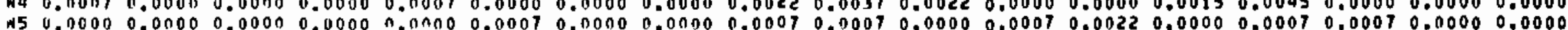

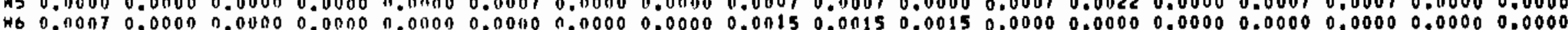

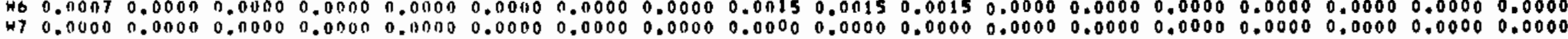

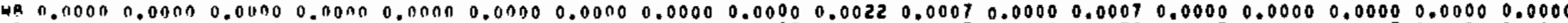

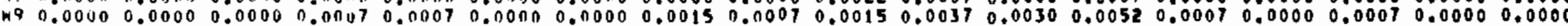

\section{STAEILITY CLASS 7}

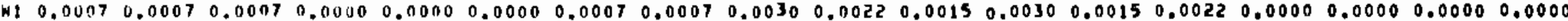

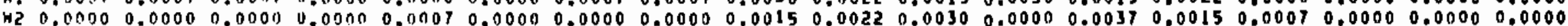

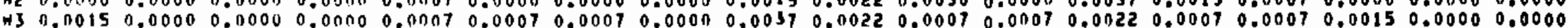

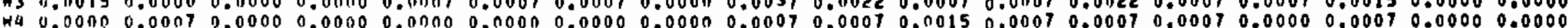

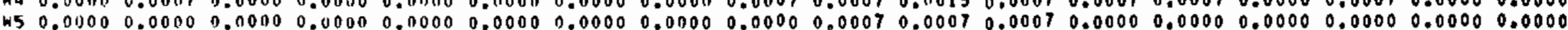

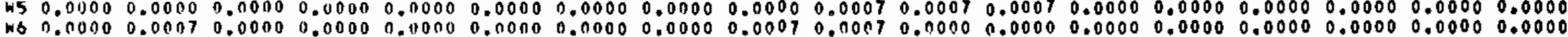

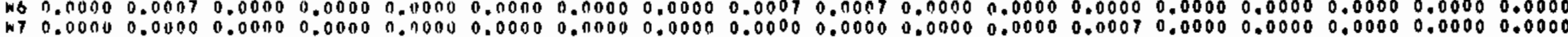

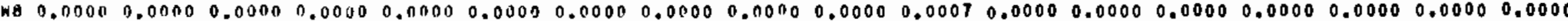

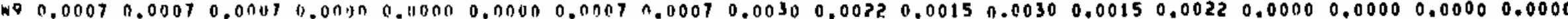


* if lon speeu class one winis WIND SPEED CLISS - uF occuratices
166
164
117
5
11
7
8

WINO DIRECTION (16 SECTIRG + CALH + VARIAQLE)

WINT DIA OCCURANCE WIND ROSE

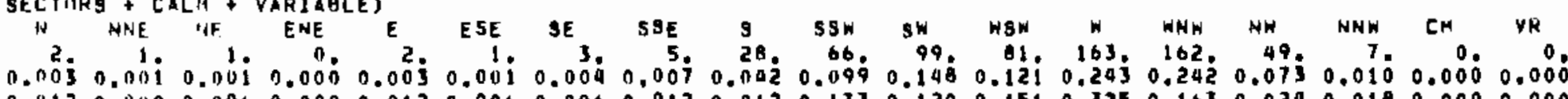
LDN SPO WINO ROSE $0.0120,000 \quad 0.0060 .000 \quad 0.0120 .0060 .0060 .0120 .0120 .1330 .1200 .151 \quad 0.3250 .1630 .0240 .0180 .0000 .000$

FREQUENCY OISTRIHUTION OF THE HIND AB FUNCTION OF NIND SPEEO ANU NIMO DIRECTIUN

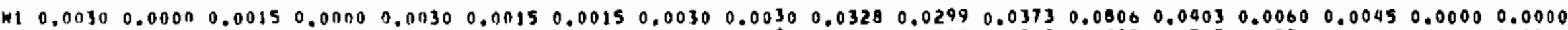

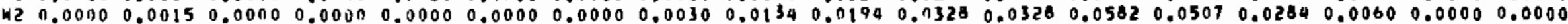

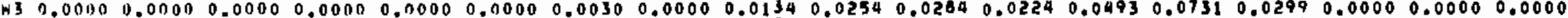

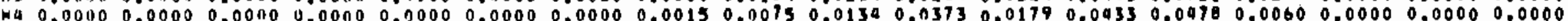

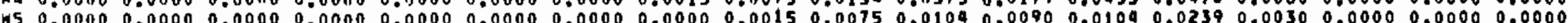

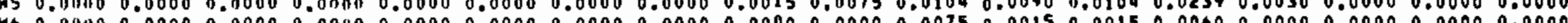
0.0060 0.0000 0.0000 0.0000 0.0000

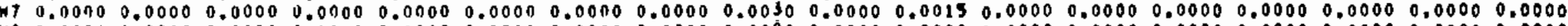

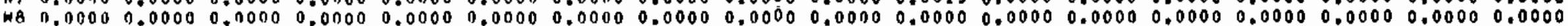

\section{STABILITY CLASS 1}

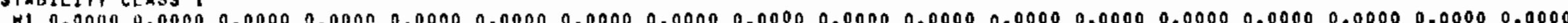

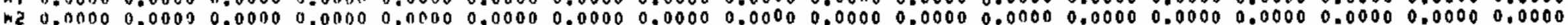

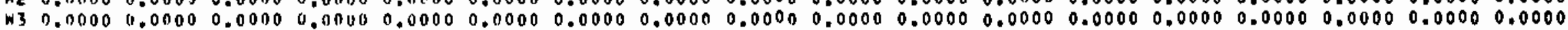

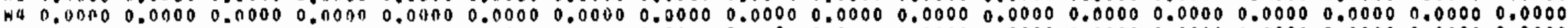

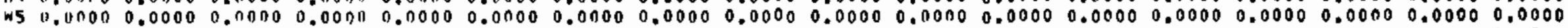

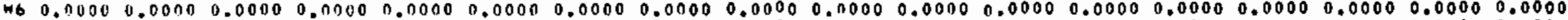

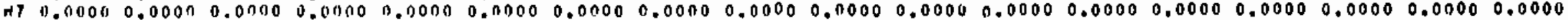

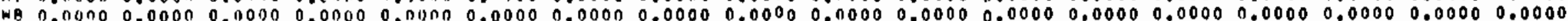

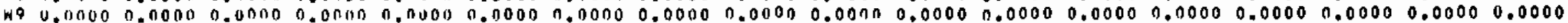

STAUILITY CLASS $z$

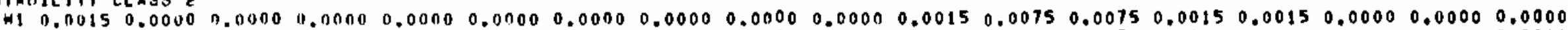

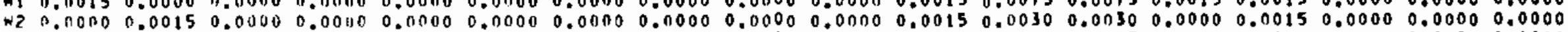

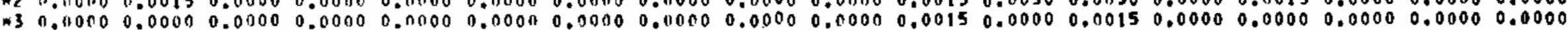

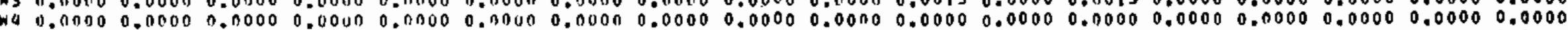

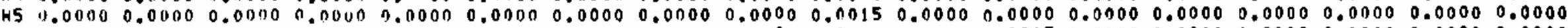

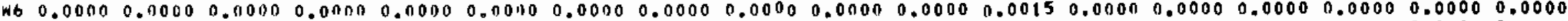

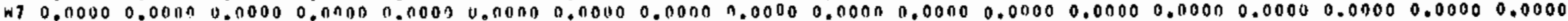

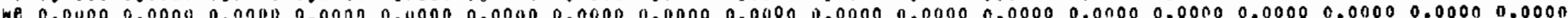

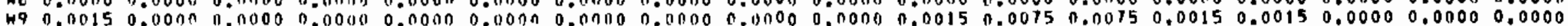

TAHILITY CLASS 3

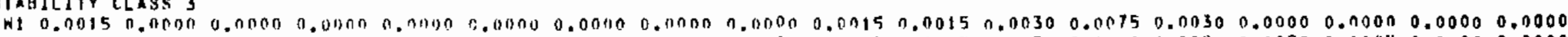

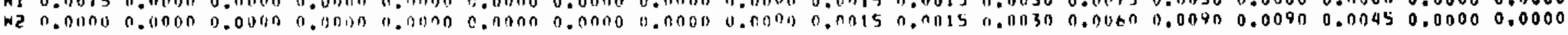




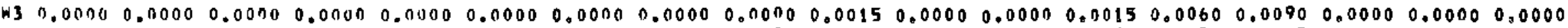

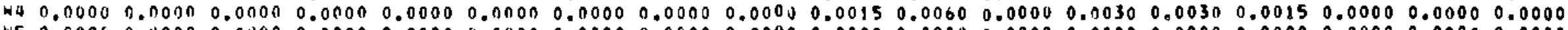

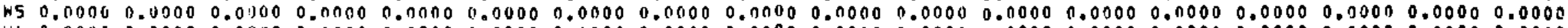

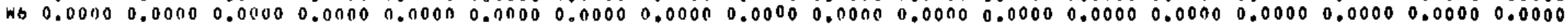

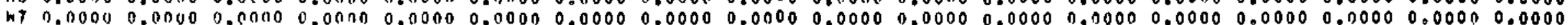

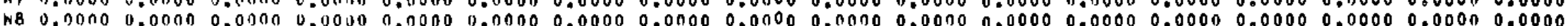

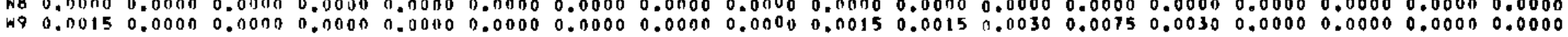

STABILITY CLASS 4

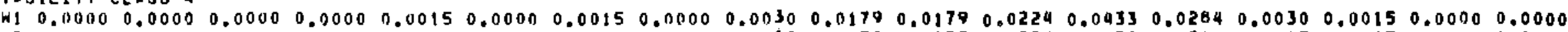

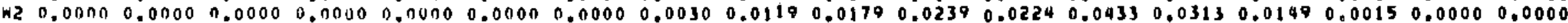

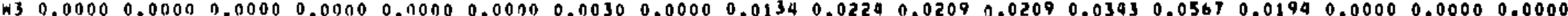

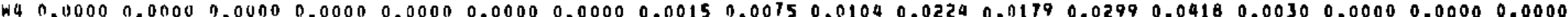

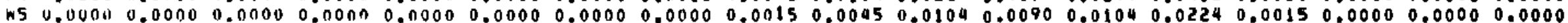

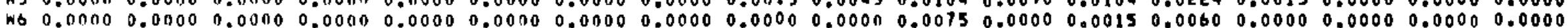

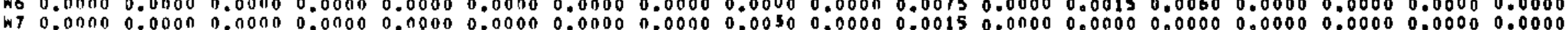

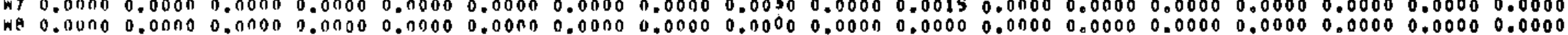

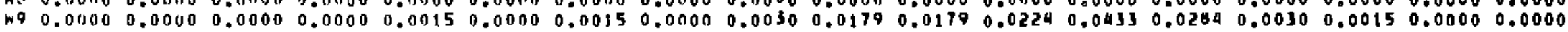

STABILITY CLASS 5

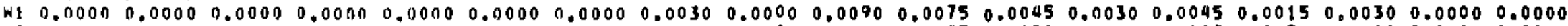

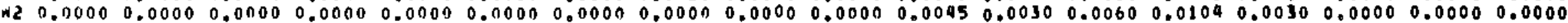

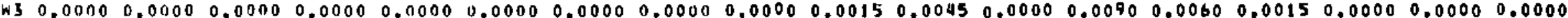

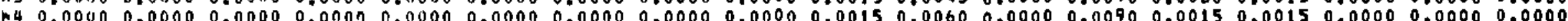

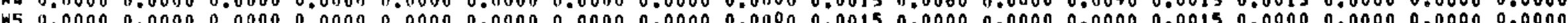

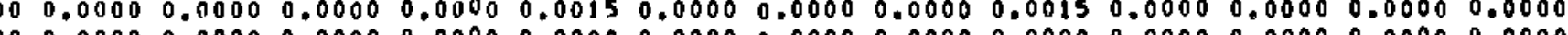
(1)

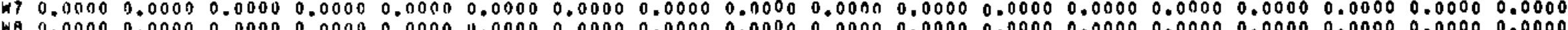

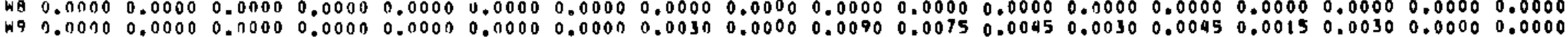

G SIABILITY CLASS b

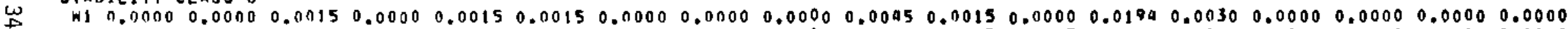

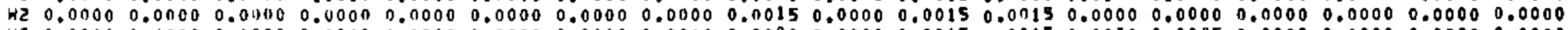

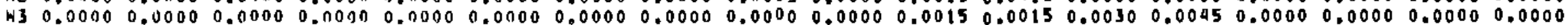

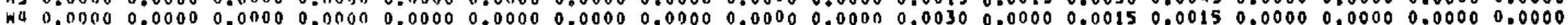

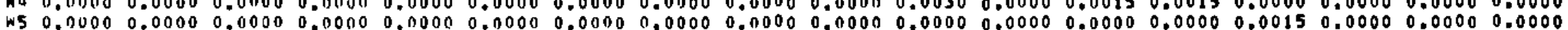

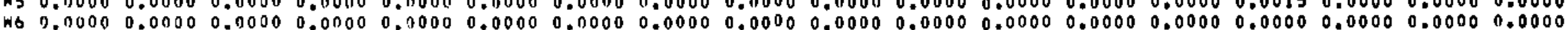

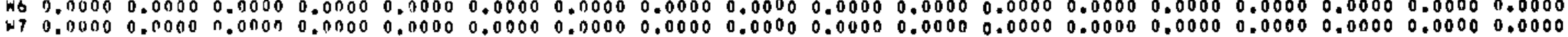

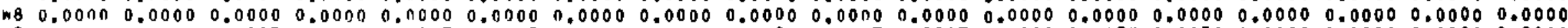

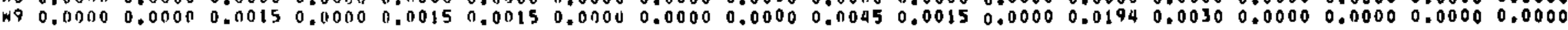

STAHILITY CLASS I

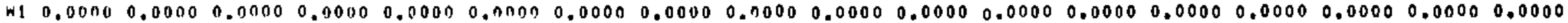

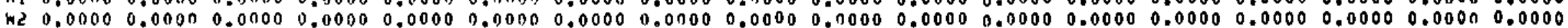

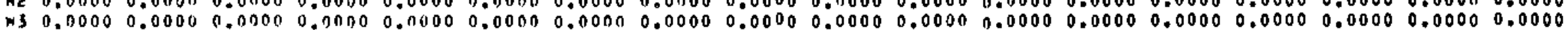

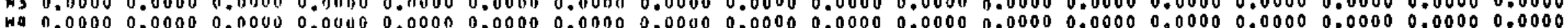

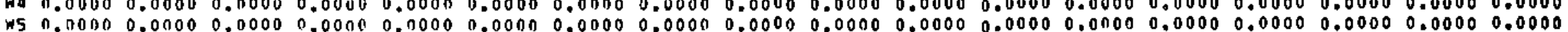

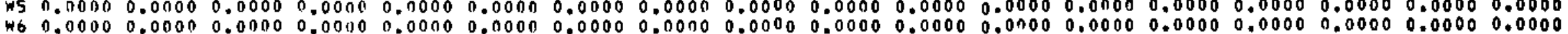

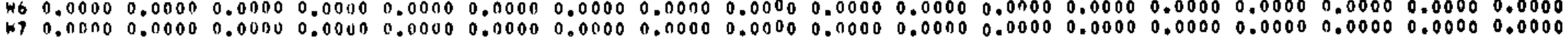

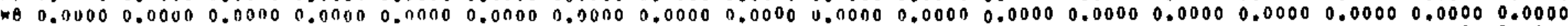

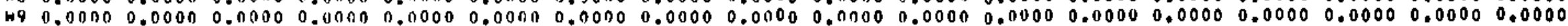


* of low gPEed Class dite witJPaj WINIS SPEEO CLASS

* of OCCURANCES

132

152

WINH DIRECTIUN (16 SECTORS + CALH + VARIABLE)

HINI) OIR DCCURANCE WIMO ROSE NNF NE ENE E LOK' SPO WIND ROSE 0.0180 .0050 .003 $2,0020,003$ 3 49 108 6 T 8

w NW. NNW CA VA

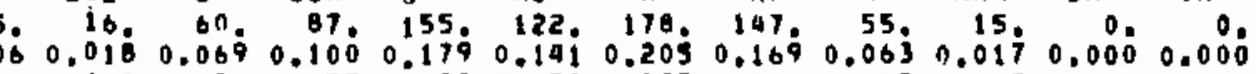

\section{FAE UUENCY DISTRIBUTION OF THE HIND AS A FUNCTION OF HIND SPEEO ANO WINO DIRECTION}

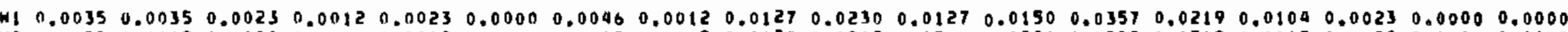

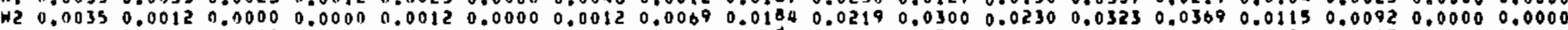

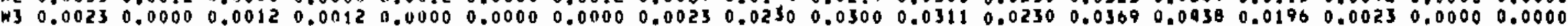

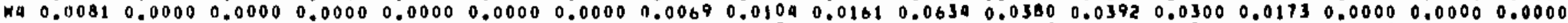

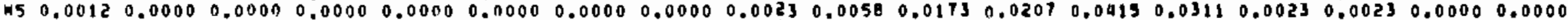

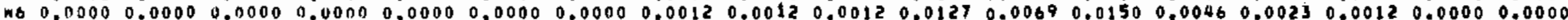

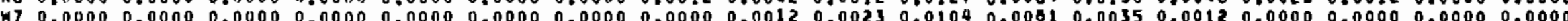

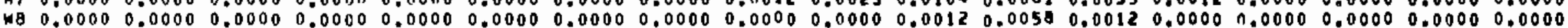

$\infty$

FREUUENCY DISTRIBUTION OF THE HINO AS A FUNCTION OF WINO GPEED, WIHO DIRECTION AND STAGILITY

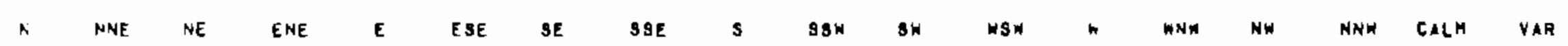

\section{STABILITY CLASS I}

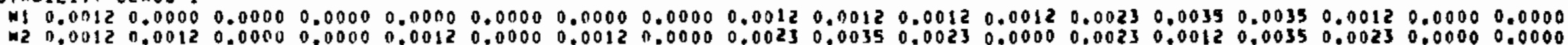

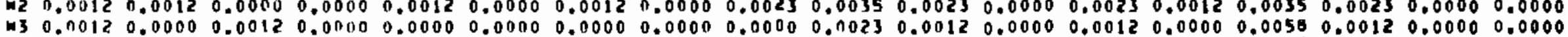

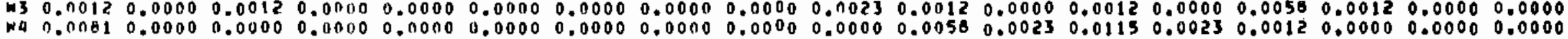

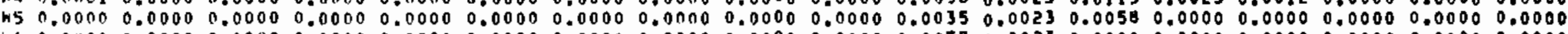

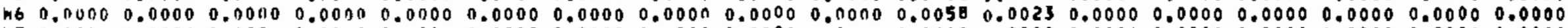

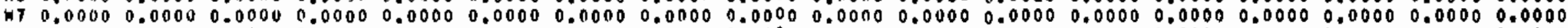

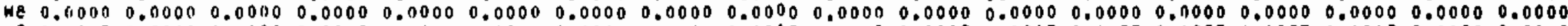

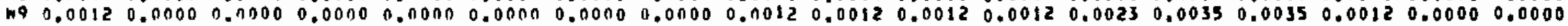

\section{STABILITY CLASS 2}

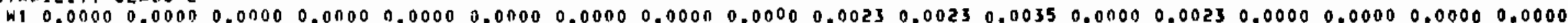

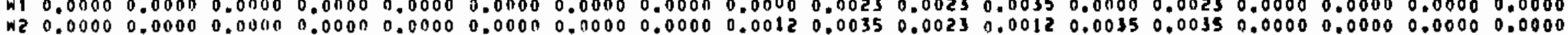

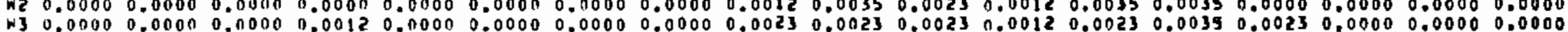

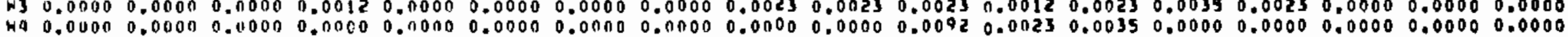

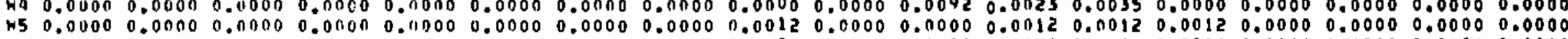

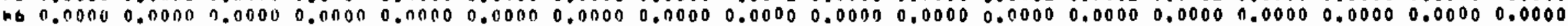

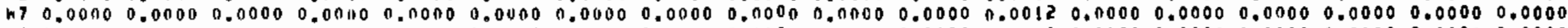

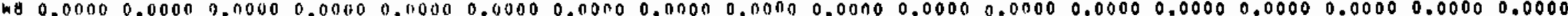

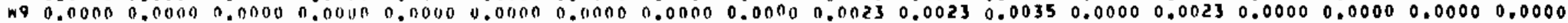

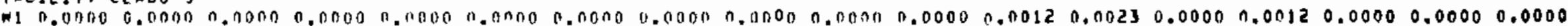

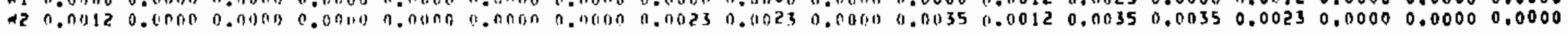




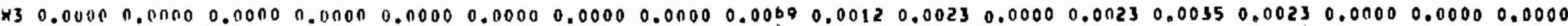

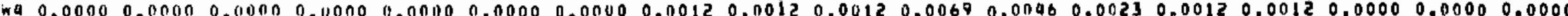

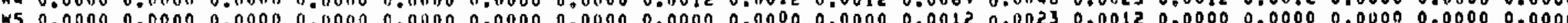

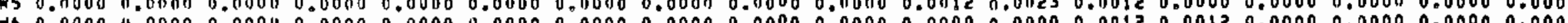

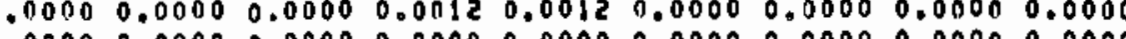

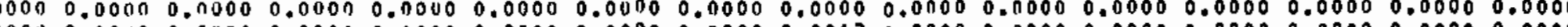

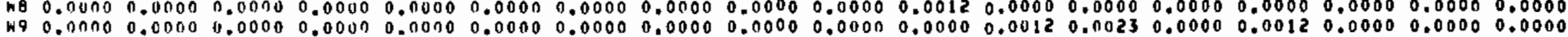

STAALITY CLASS 4

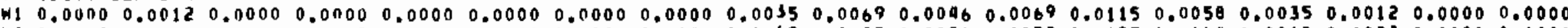

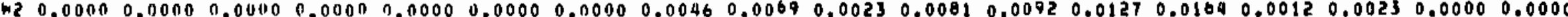

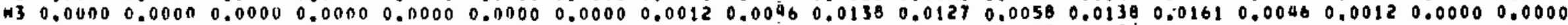

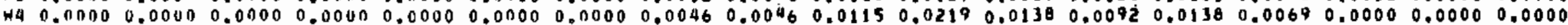

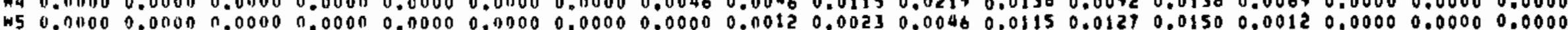

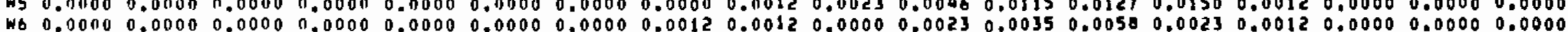

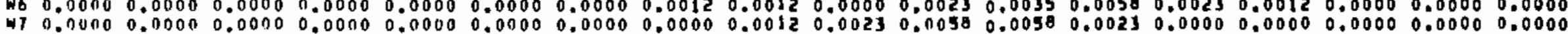

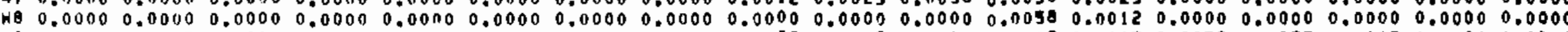

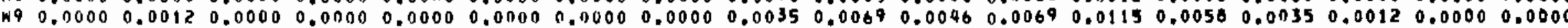

1- TTABILITY CLASS 5

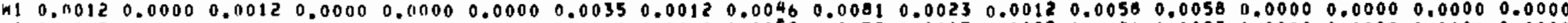

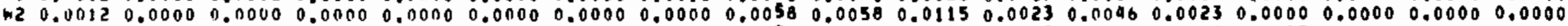

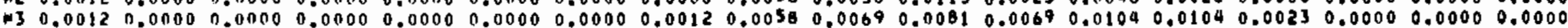

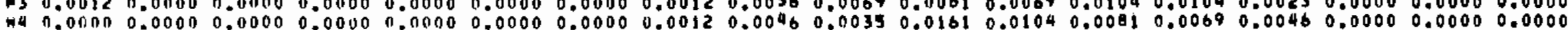

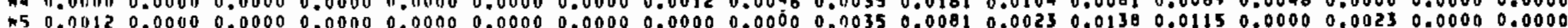

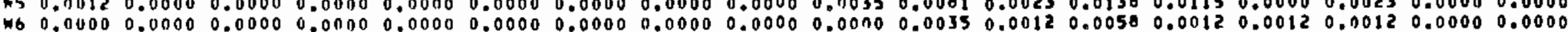

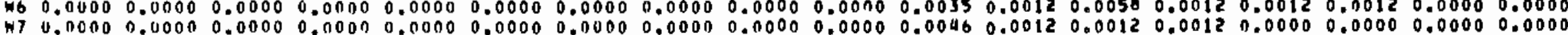

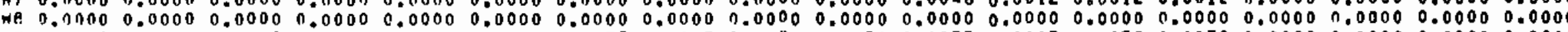

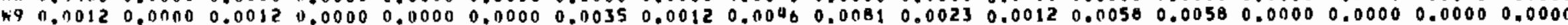

STARILITY CLASS 6

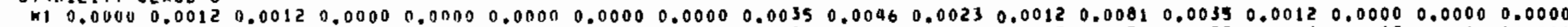

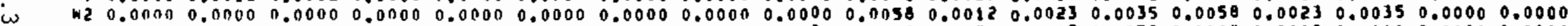

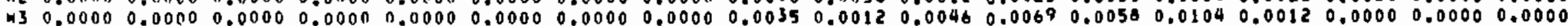

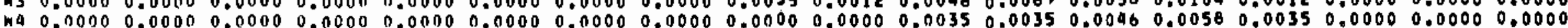

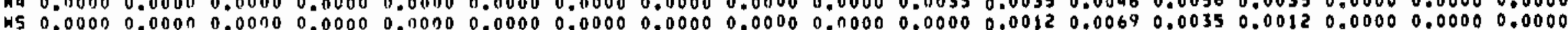

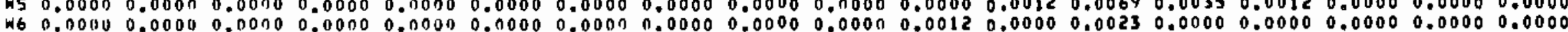

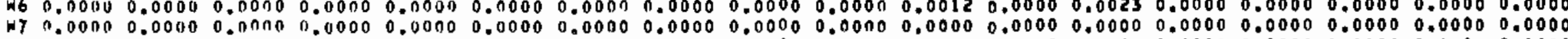

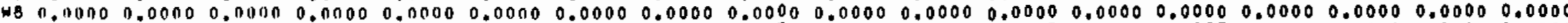

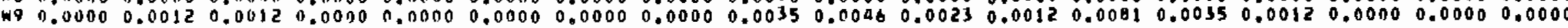

STAHILITY CLASS ?

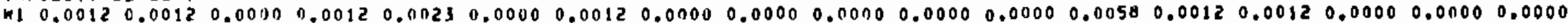

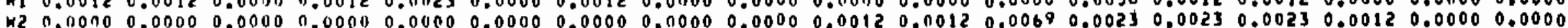

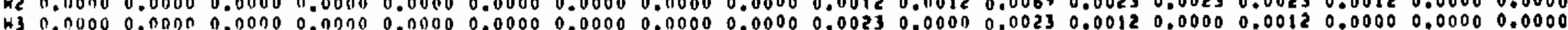

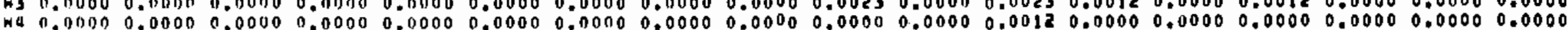

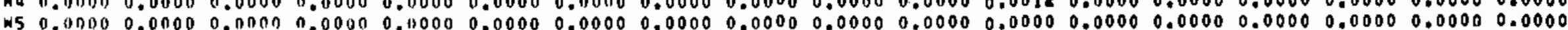

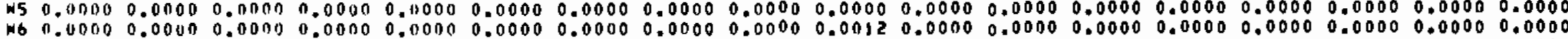

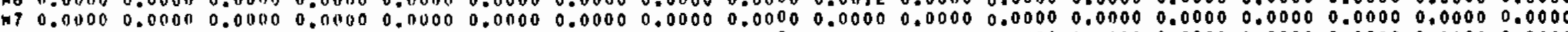

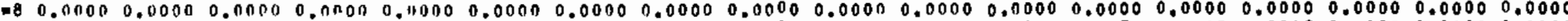

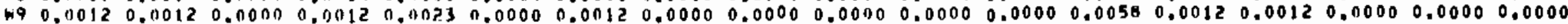


(April)

RELEASE HEIGHT, BQ H TOTAL " DF HOJRSI 1938

" OF LOH SPEEI CLASS DHE WINDSA 230

$\begin{array}{lcc}\text { "INO SPEED CLASS } & 230 \\ \text { "IF OCCURANCES } & 1 & 2 \\ & 230 & 315\end{array}$

WIND DIRECTION (IS SECTURS + CALH + VARIAGLE)

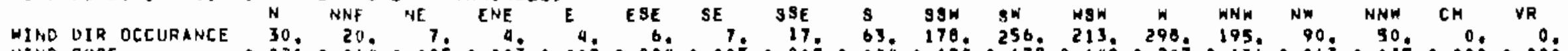

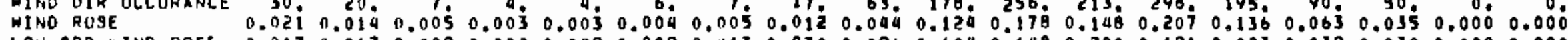

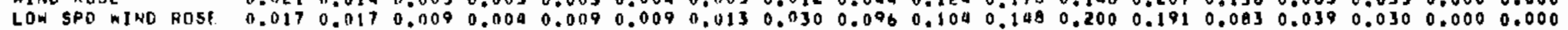

FREGLIENCY DISTRIBUTION OF THE WIND AS FUNCTION OF HIND SPEEO ANO HIND DIREGTION

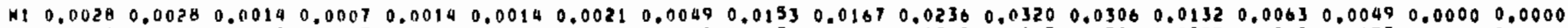

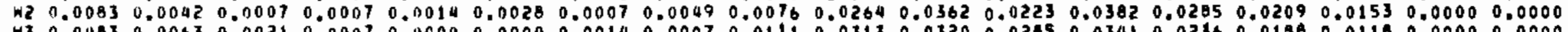

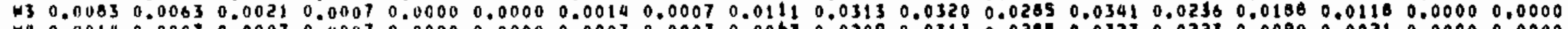

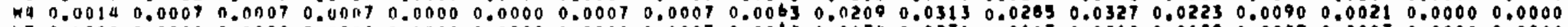

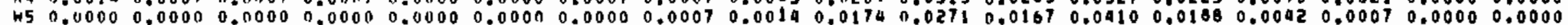

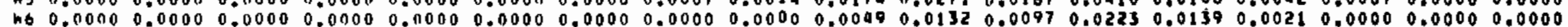

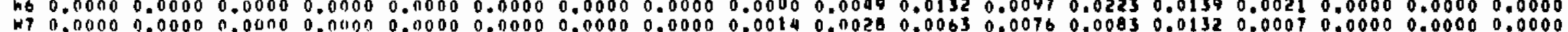

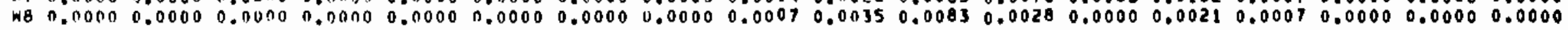

\section{STABILITY CLASS 1}

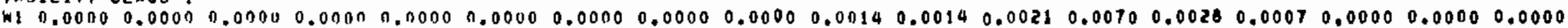

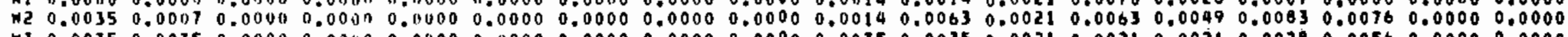

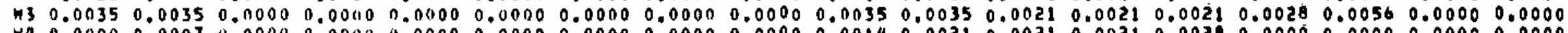

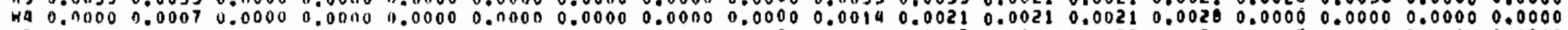

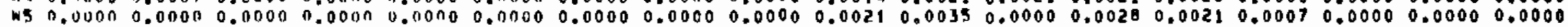

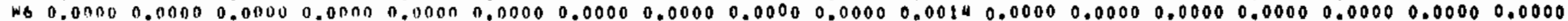

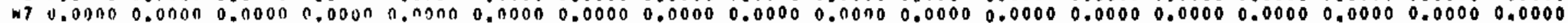

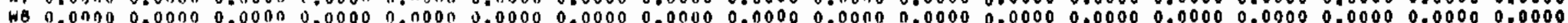

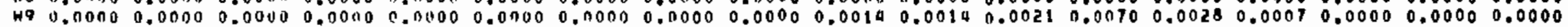

STAAILITY CLASS

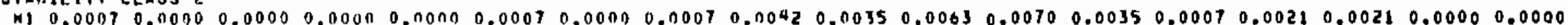

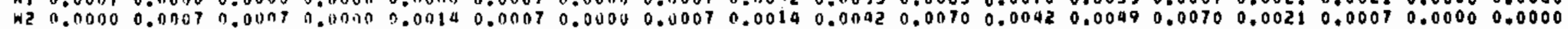

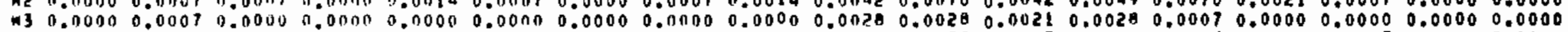

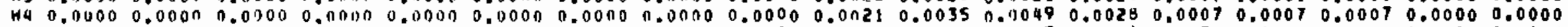

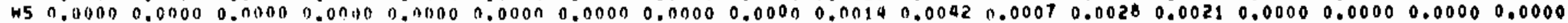

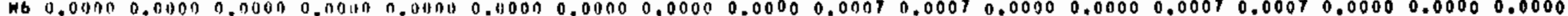

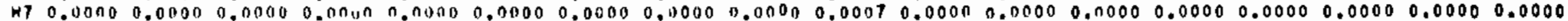

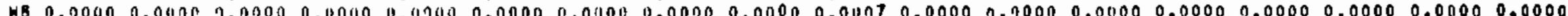

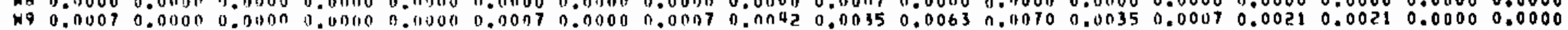

SIAHILIIY LLASS

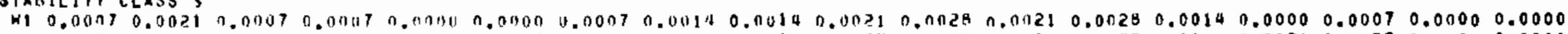

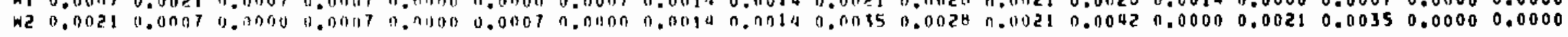




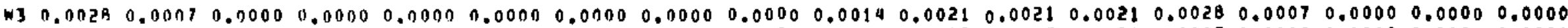

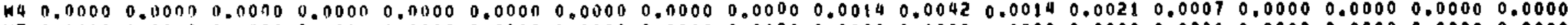

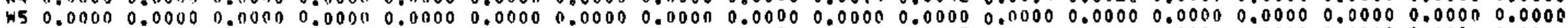

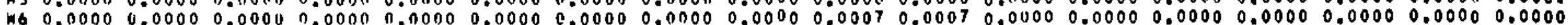

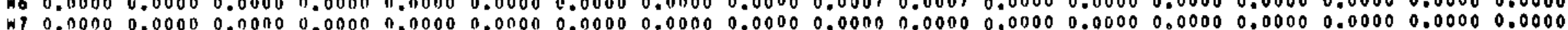

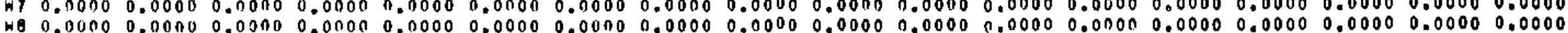

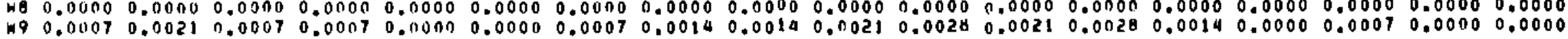

STAEILITY CLASS A

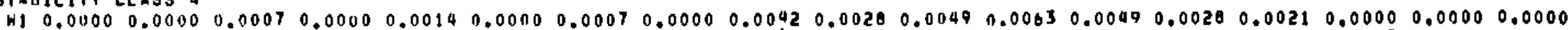

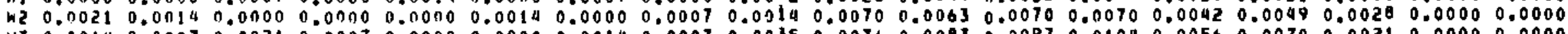

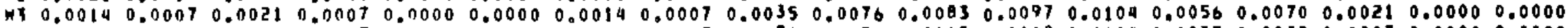

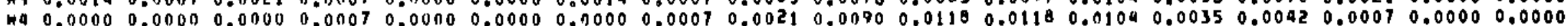

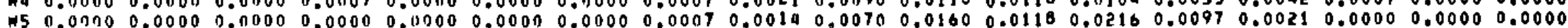

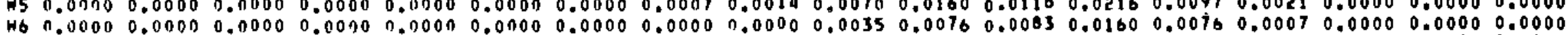

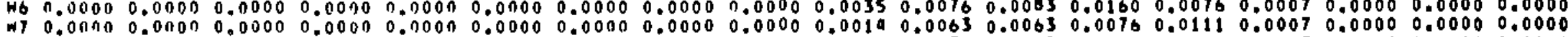

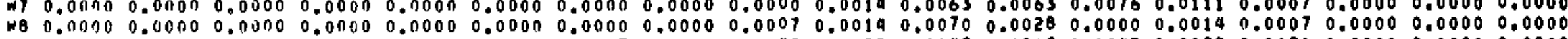

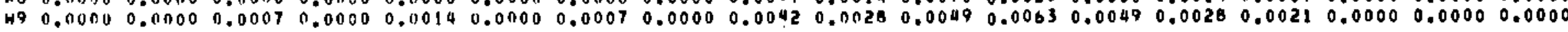

STAHILITY CLASS S

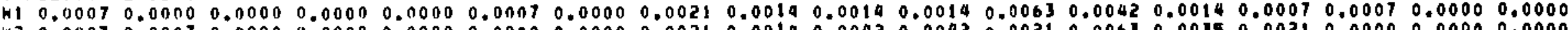

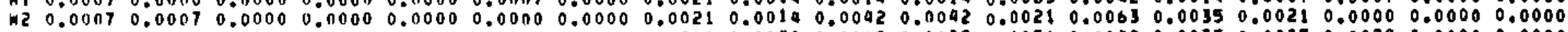

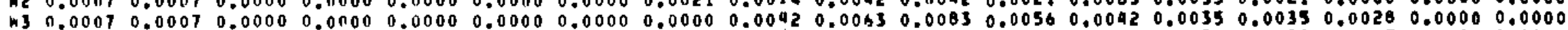

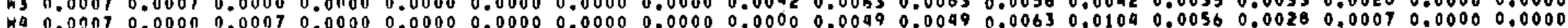

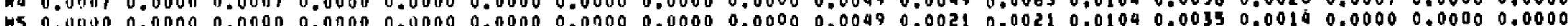

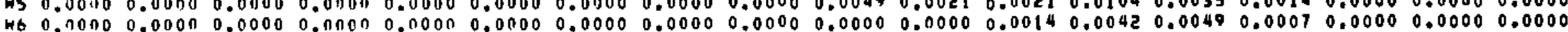

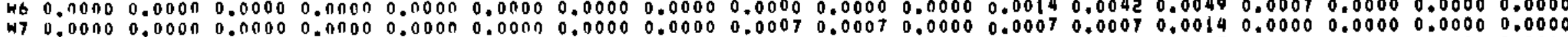

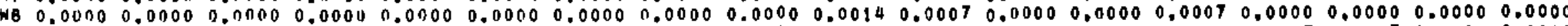

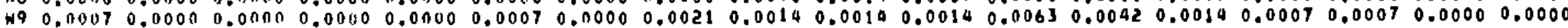

STABILIIY CLASS

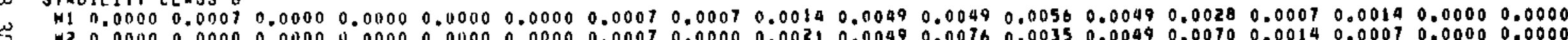
$0000 \quad 0.0000 \quad 0.0000 \quad 0.0000 \quad 0.0000 \quad 0.0000 \quad 0.0007 \quad 0.0000 \quad 0.00210 .00490 .00760 .00350 .00490 .00700 .00140 .00070 .00000 .0000$

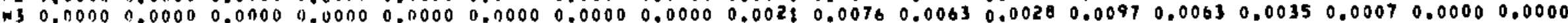

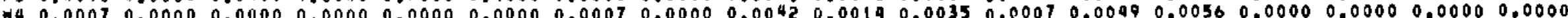

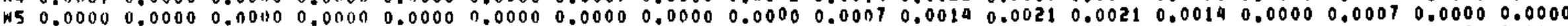

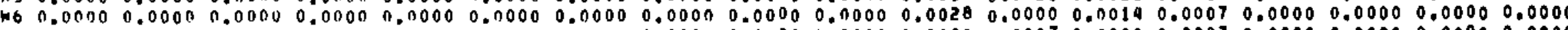

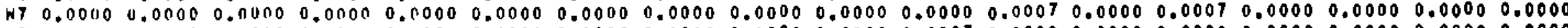

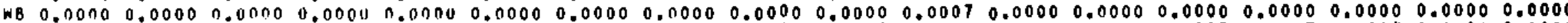

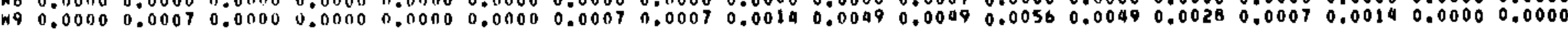

\section{STARILITY CLASS T}

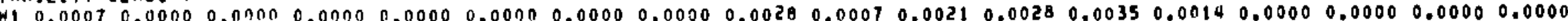

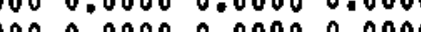

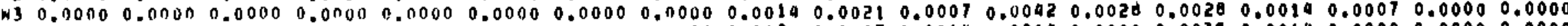

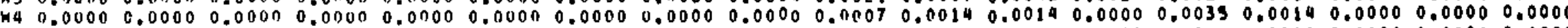

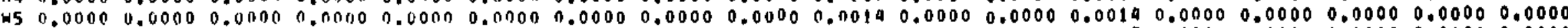

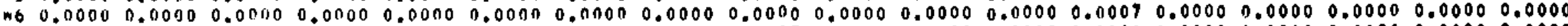

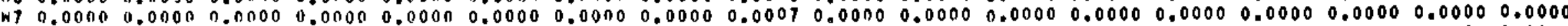

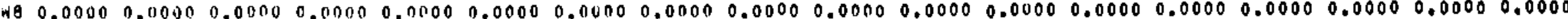

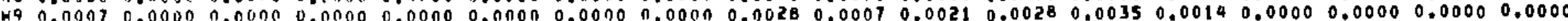


* of low speed class une hinos! WINO SPEED CLASS
WOF OCCURANCES

HIND DIRECIION (16 SECIORS + CALH + VARIABLE)

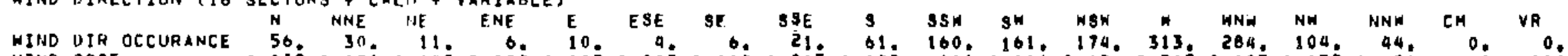

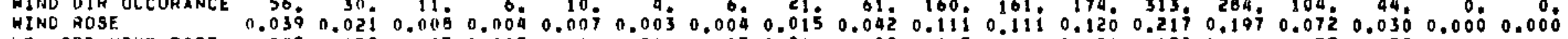

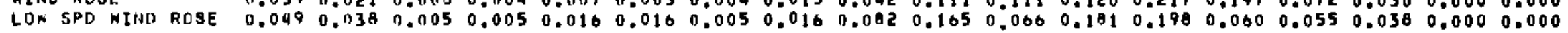

\section{FREAHENCY DISTRIBUTION DF THE INO AS A FUNCTION OF WINO SPEED AND WIND DIAECTION}

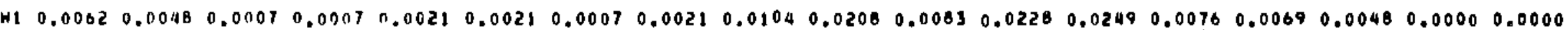

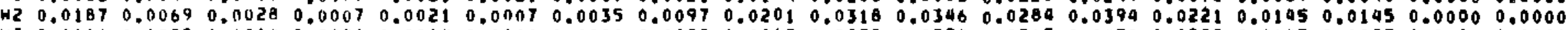

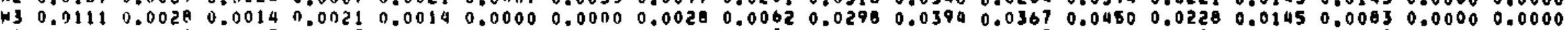

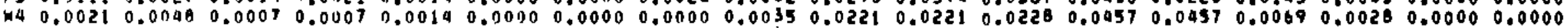

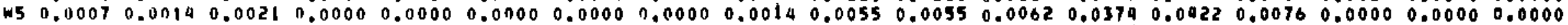

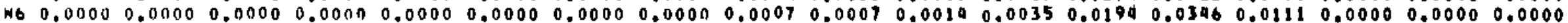

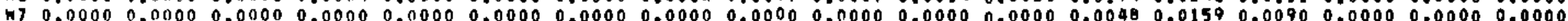

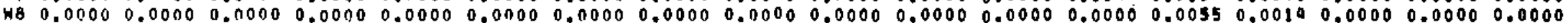

FREUUENCY DISTRIQUTION OF THE WINO AS FUNCTION OF HIMO SPEEO, HIND DIAECTION AND BTABILITY

STABILITY CLASS

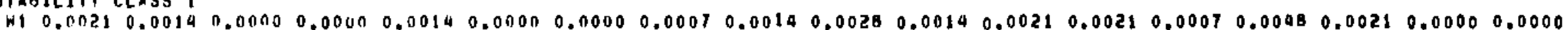

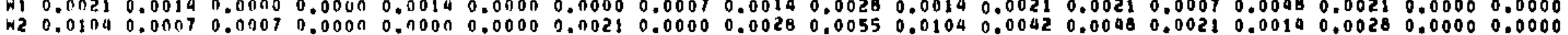

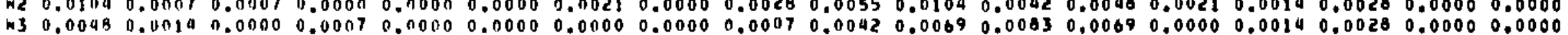

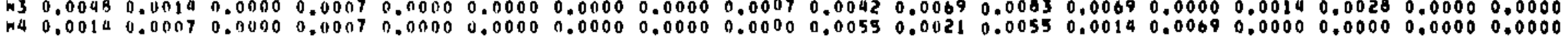

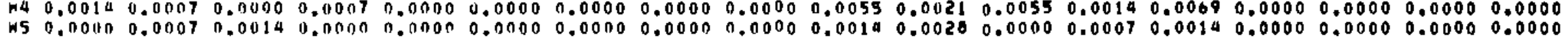

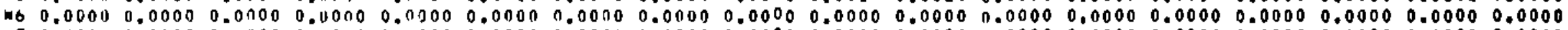

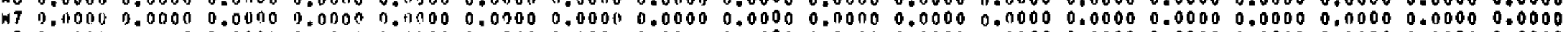

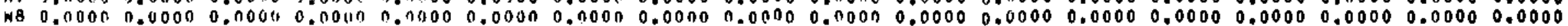

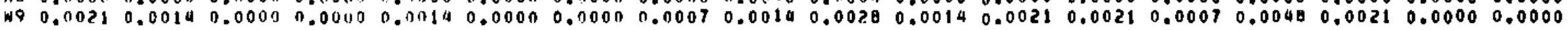

\section{STABILITY CLASS 2}

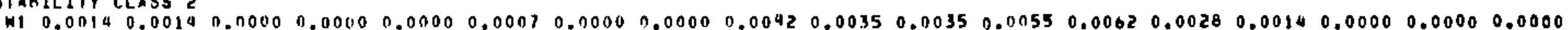

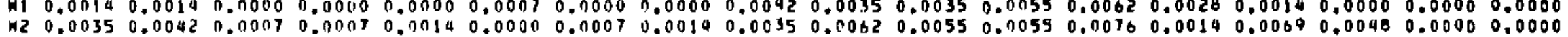

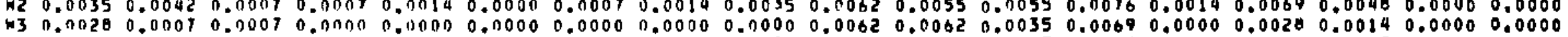

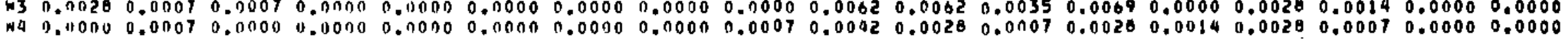

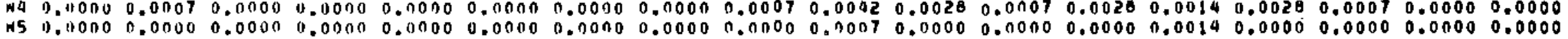

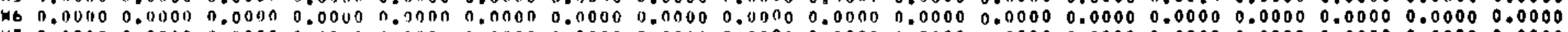

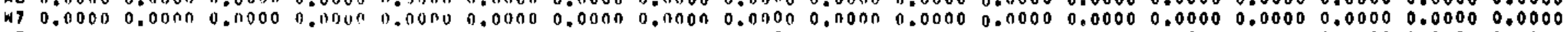

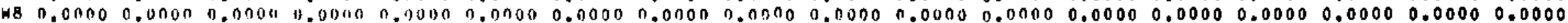

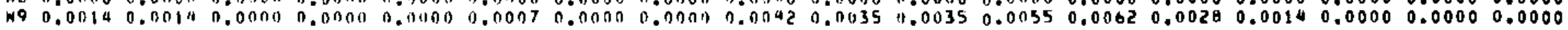

stanILIIr CLASS 3

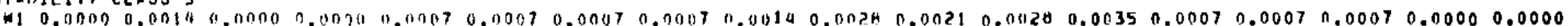

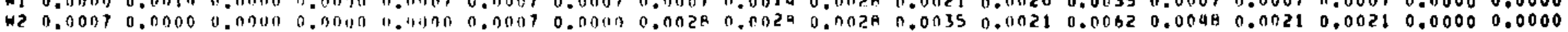




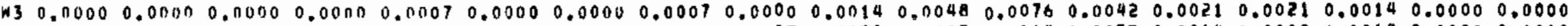

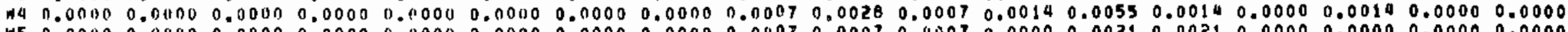

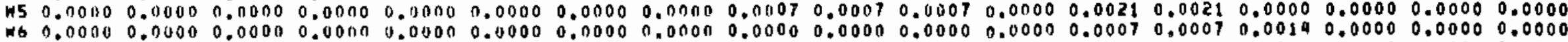

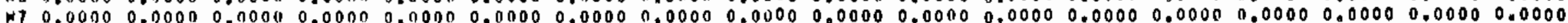

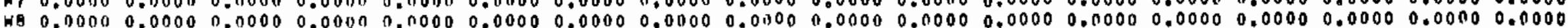

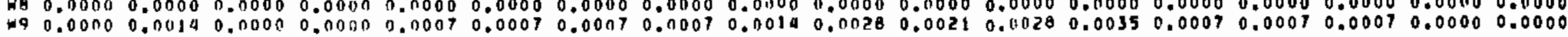

STARILITY CLASS"

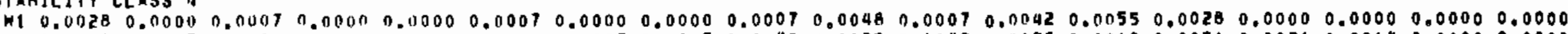

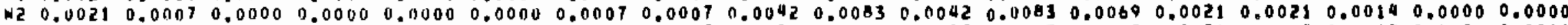

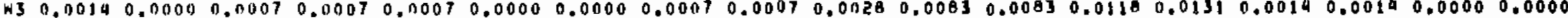

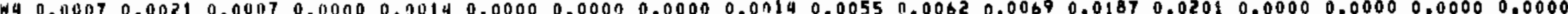

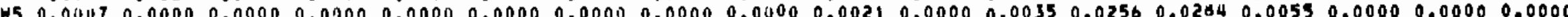

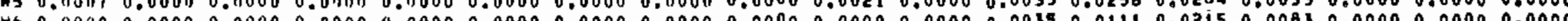

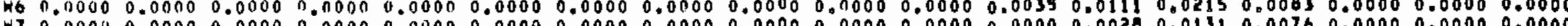

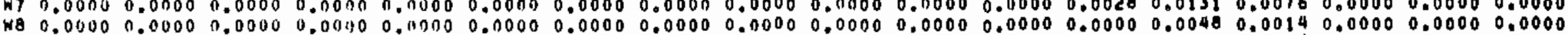

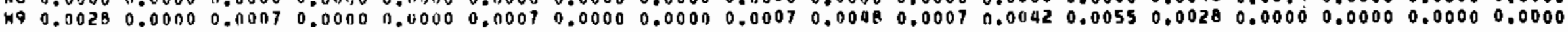

STABILITY CLASS 5

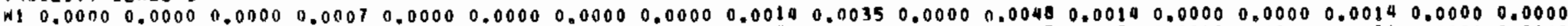

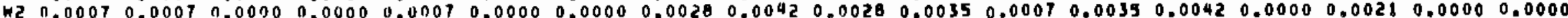

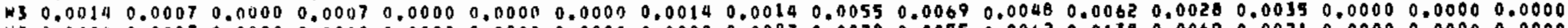

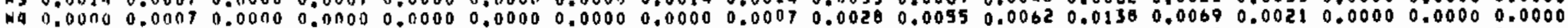

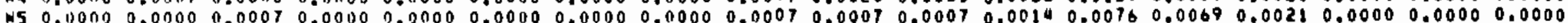

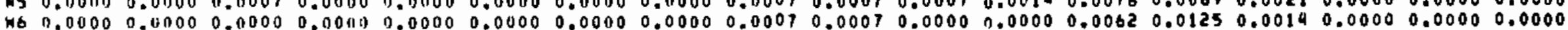

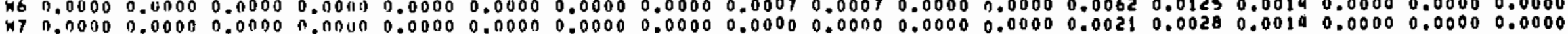

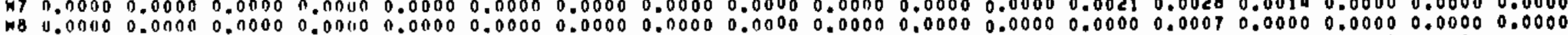

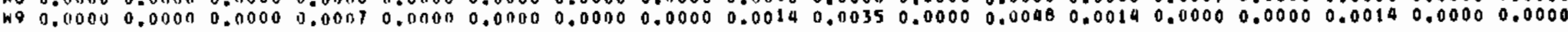

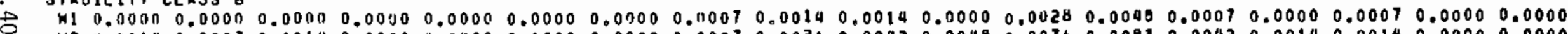

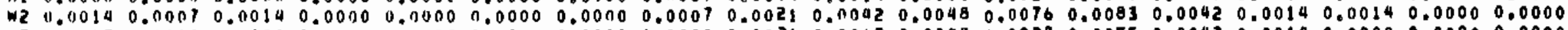

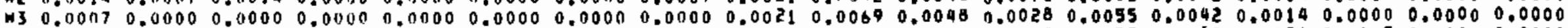

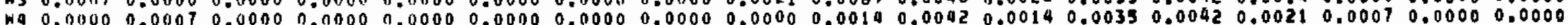

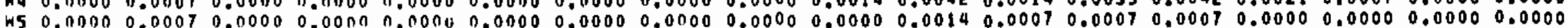

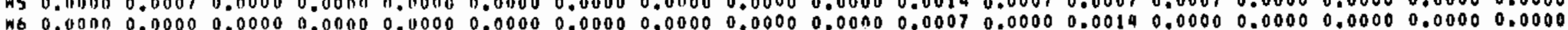

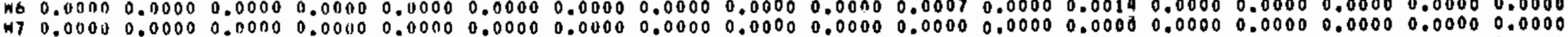

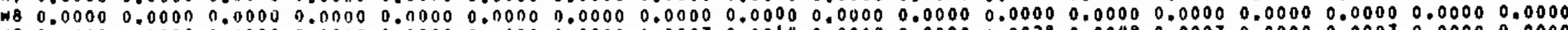

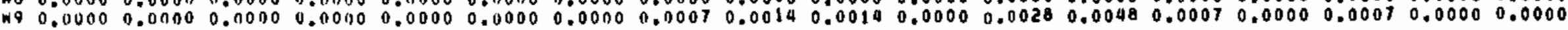

STAGILITY CLASS?

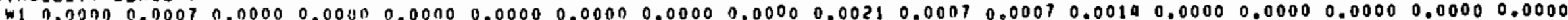

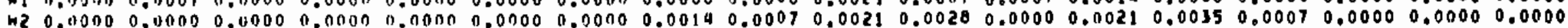

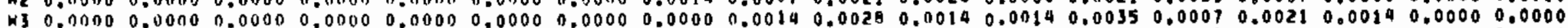

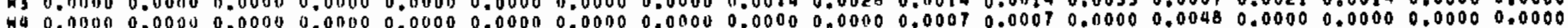

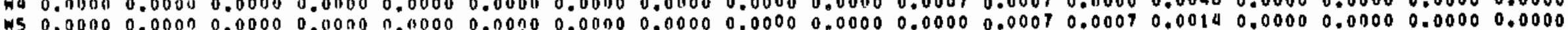

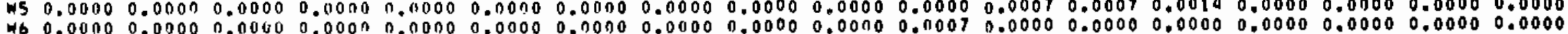

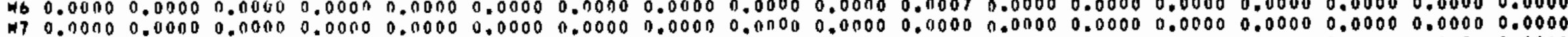

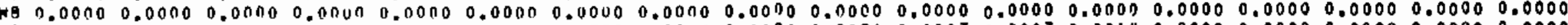

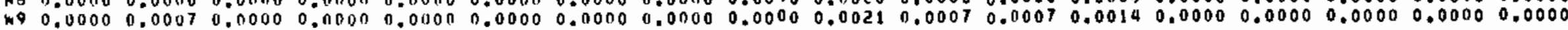



"OF LOW SPEED CLASS UHE WINOSI
HIND SPEED CLASS
OF OCEURAHCES
OF - of nccurapies 199 49 WIND DIRECIION (16 SECTIRSS + CALM + VARIABLE) 337 301 $\stackrel{5}{149}$ 63 7
20 8

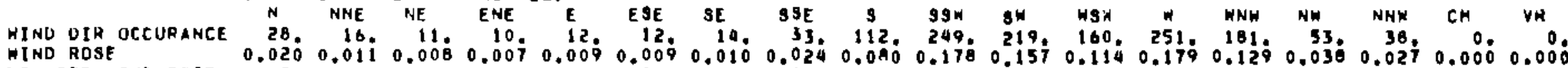

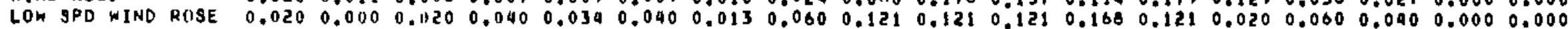

FREQUENCY DISTRIQUTION OF THE WIND AS FUNCTION OF MIND SPEED ANO HIND DIRECTIDN

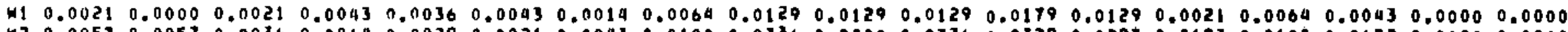

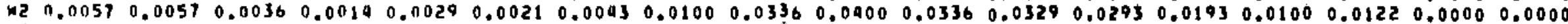

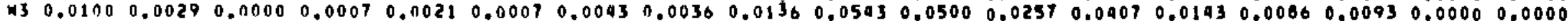

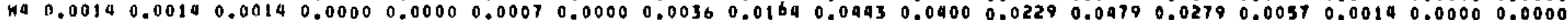

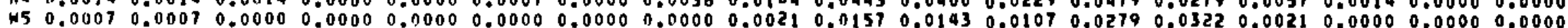

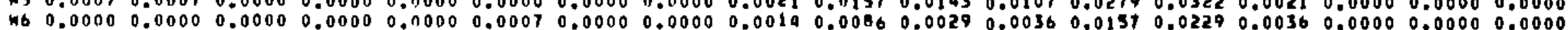

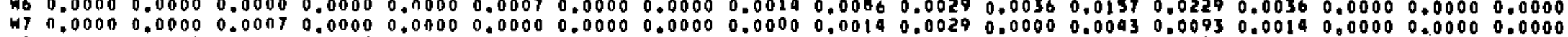

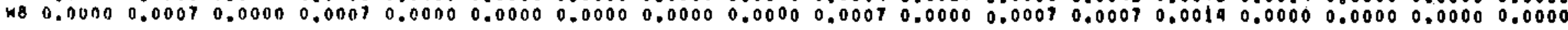

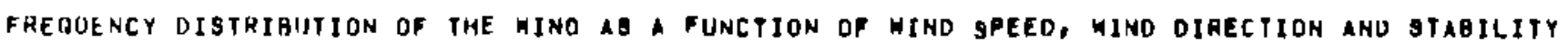

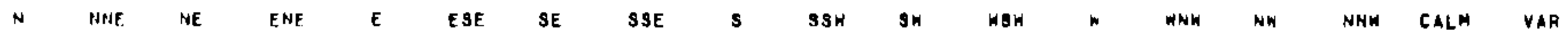

STABILITY CLASS 1

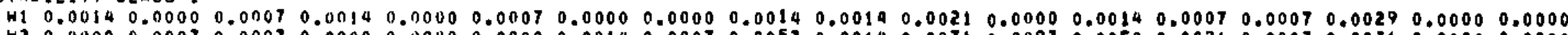

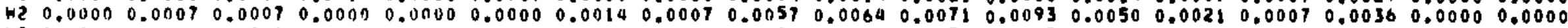

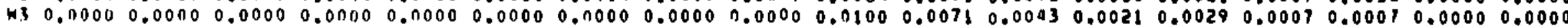

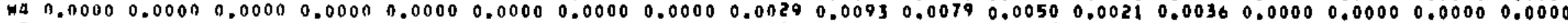

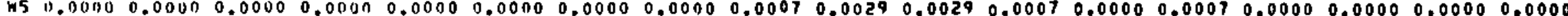

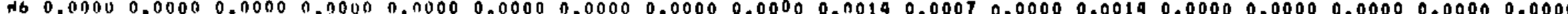
W 70.00000 .0000 0.0000

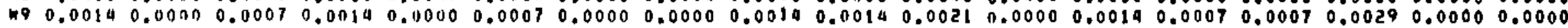
BTABILITY CLASS 2

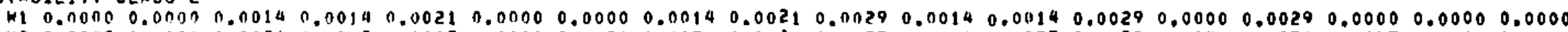

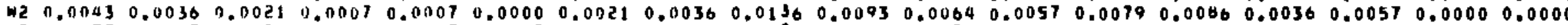

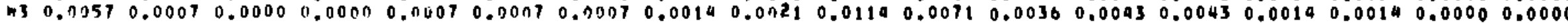

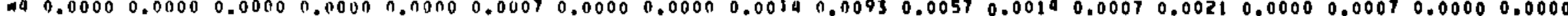

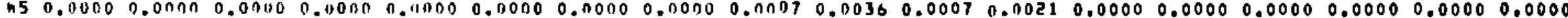

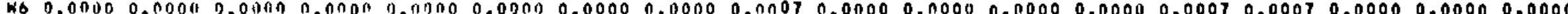
.

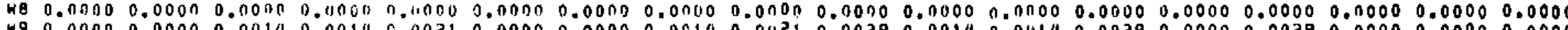
STABLITY CLASS 3

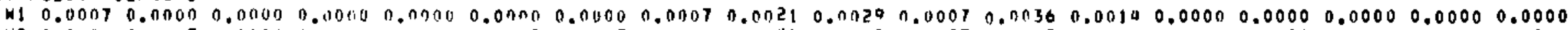

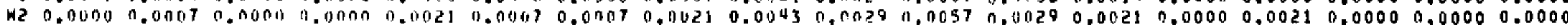




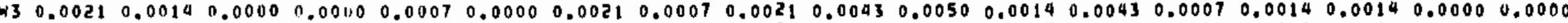

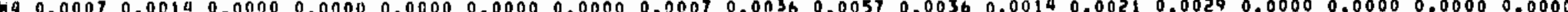

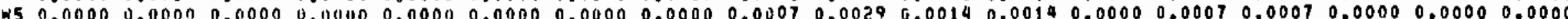

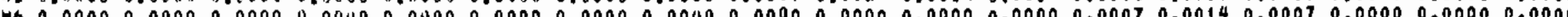

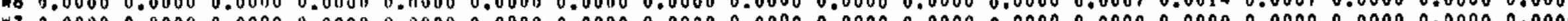
.

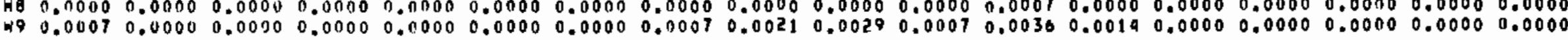

STAILITY CLASS A

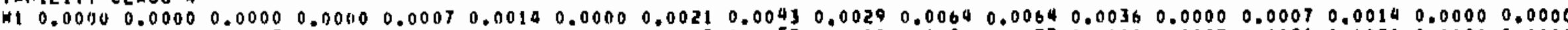

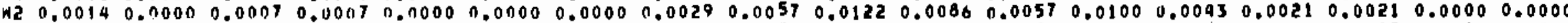

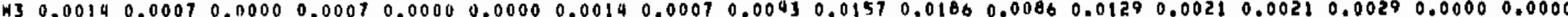

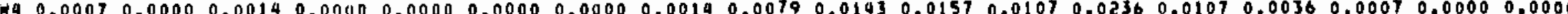

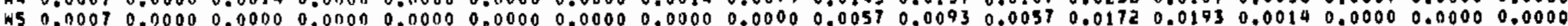

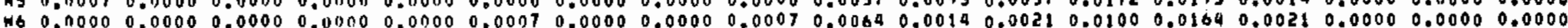

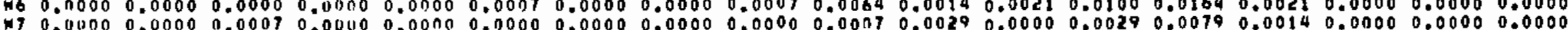

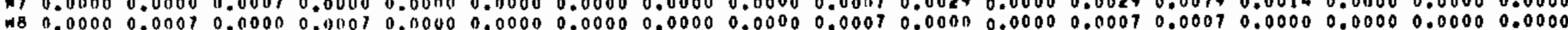

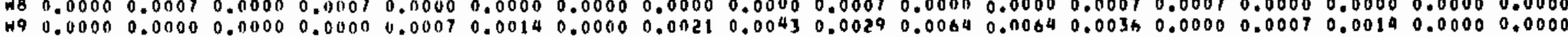

STABILITY CLASS 5

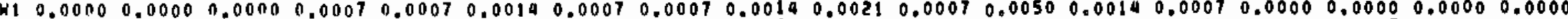

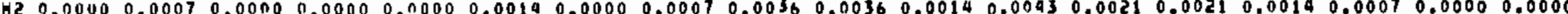

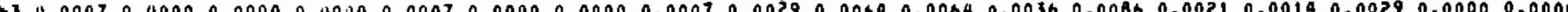

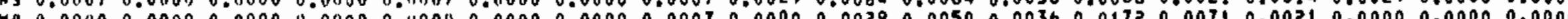

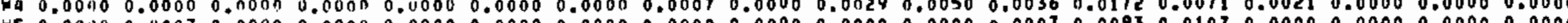
(1)

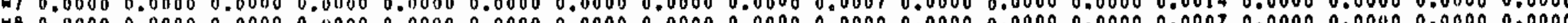

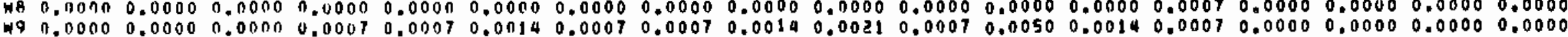

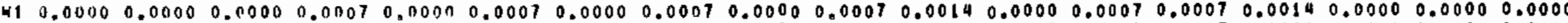

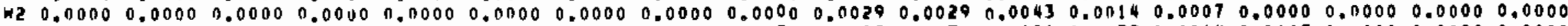

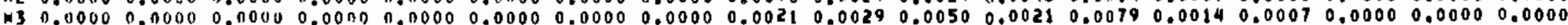

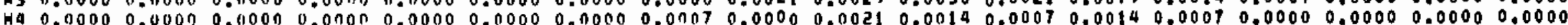

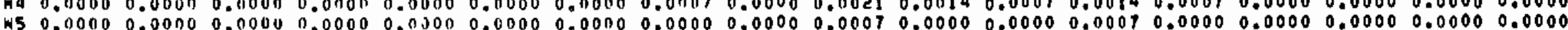

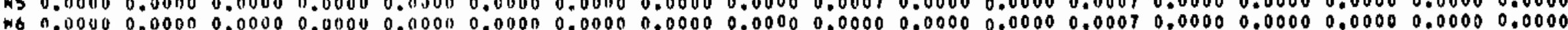

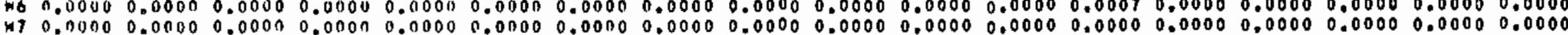

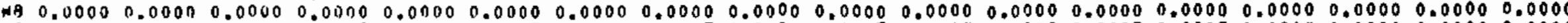

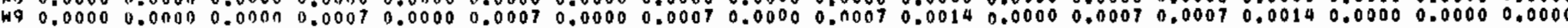

STABILJTY CLASS ?

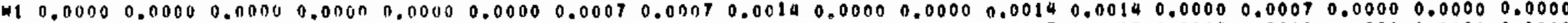

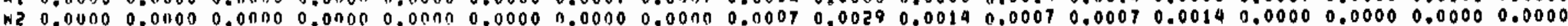

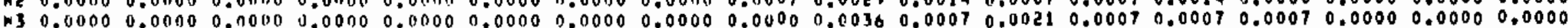

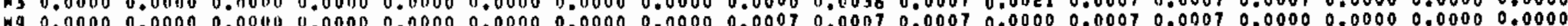

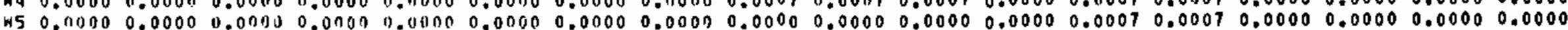

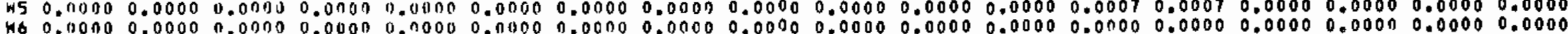

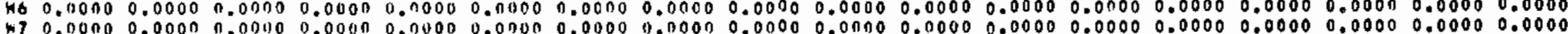

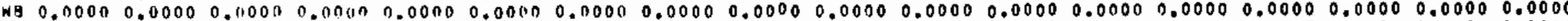

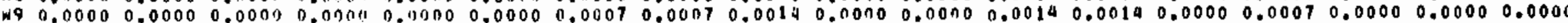


- OF LOM BPEed CLASS DHe WinUS: 160 $\begin{array}{lcc}\text { WIND SPEED CLASS } & 1 & 2 \\ \text { W OF DCCURANCES } & 160 & 330\end{array}$
$330 \quad 391$
273
170
93
74
8

IIND DIRECTION (16 SECTOHS + CALH + VARIAQLE)

WINU DIR OCCURAHCE WINO ROSE

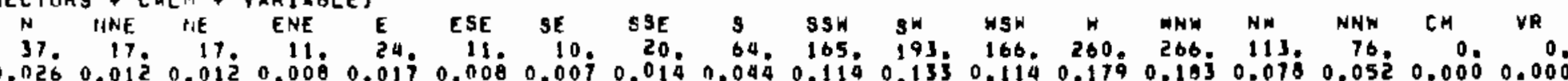
LUW SPD WINO HOSE 0.0310 .0060 .0250 .0310 .0500 .0250 .0250 .0100 .0810 .1060 .1060 .1060 .1810 .0750 .0870 .0440 .0000 .000

FREIUENCY OISTRIBUTION OF THE HINO AS FUHCTION OF WINO SPEED ANO WIND DIRECTION

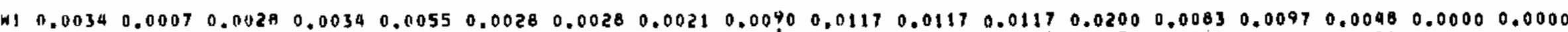

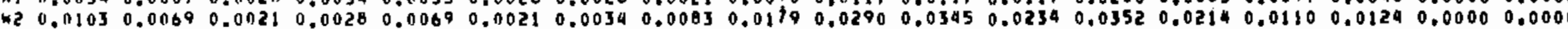

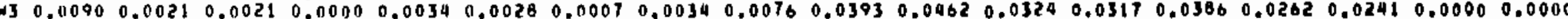

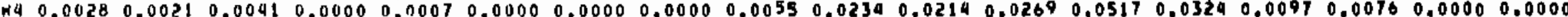

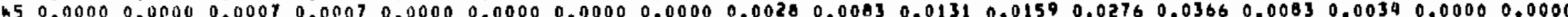

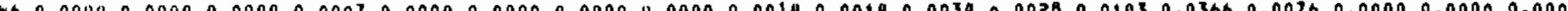

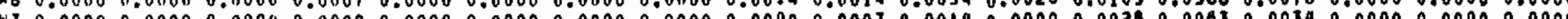

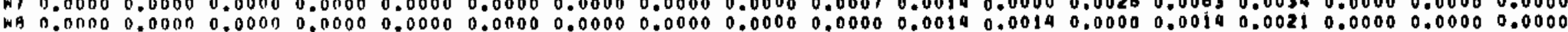

W

FREUIENCY DISTRIBUTION TF THE WINO $A 8$ A FUNCTION OF WINO GPEED, HIND DIRECTION AND BTABILITY

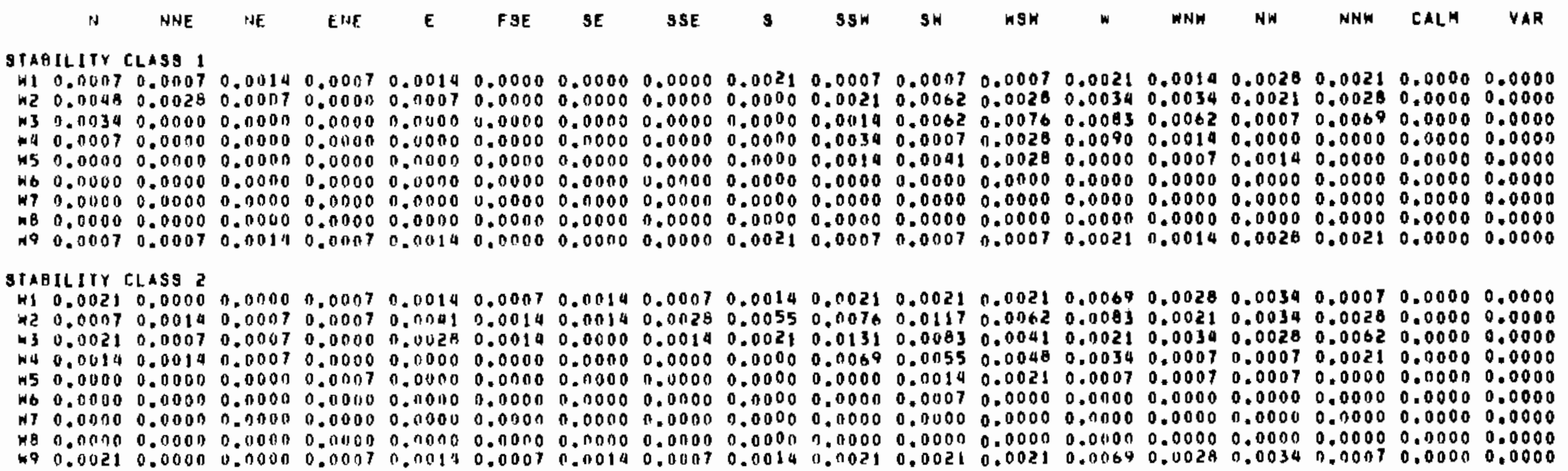

SIABILITY CIASS

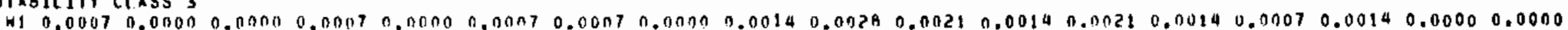

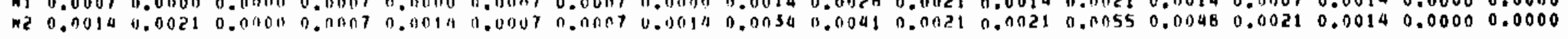




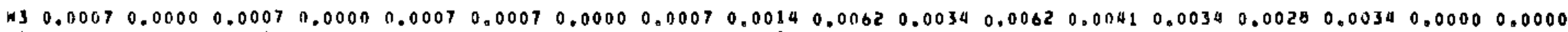

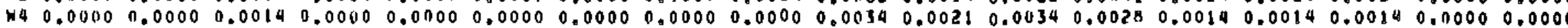

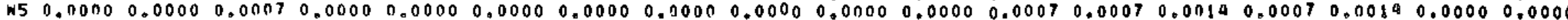

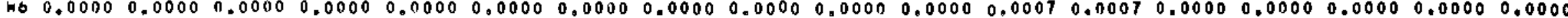

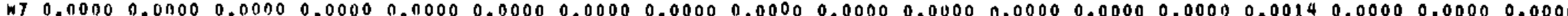

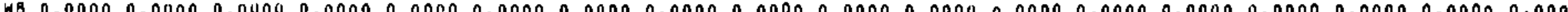

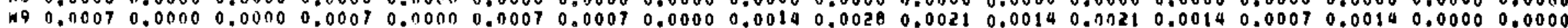

\section{STAEILITY CLASS}

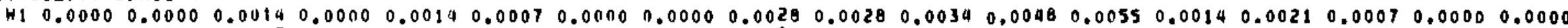

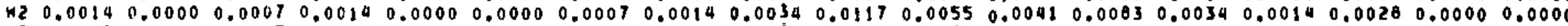

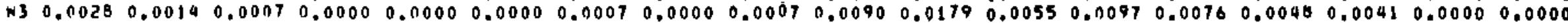

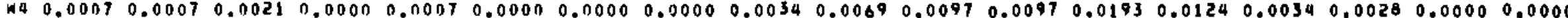

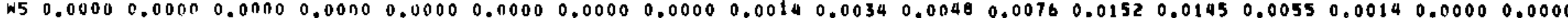

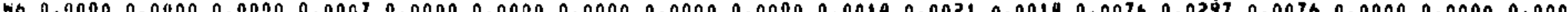

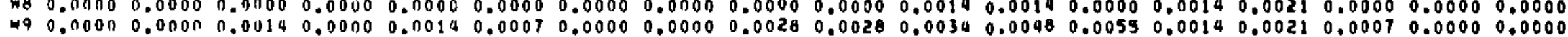
STARILITY CLASS 5

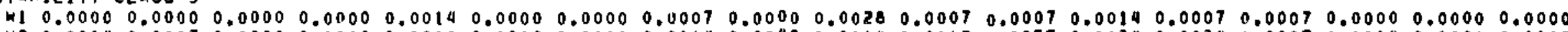

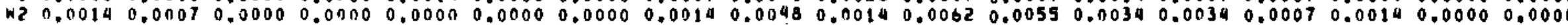

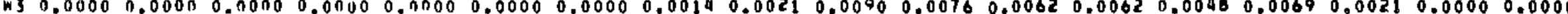

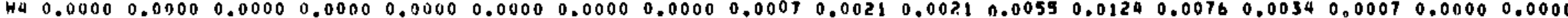

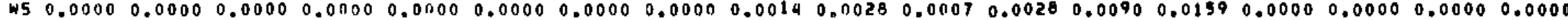

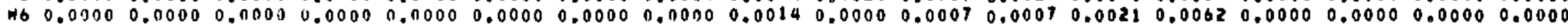

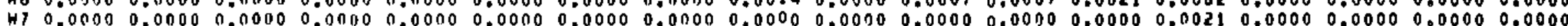

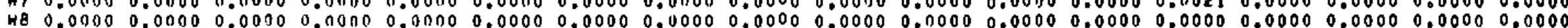

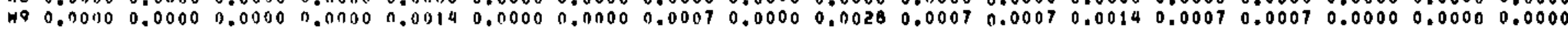

\section{P STABILITY CLASS}

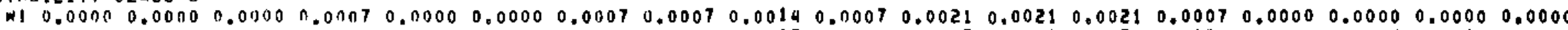

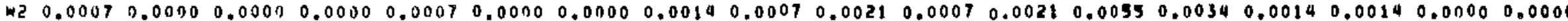

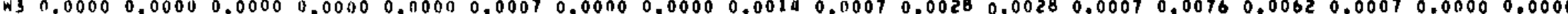

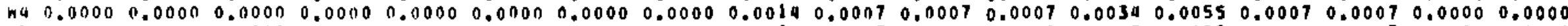

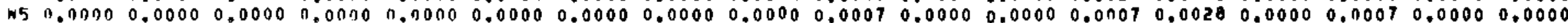

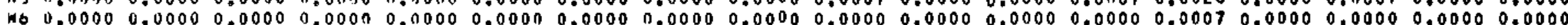

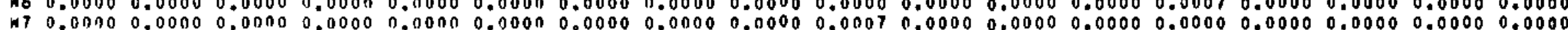

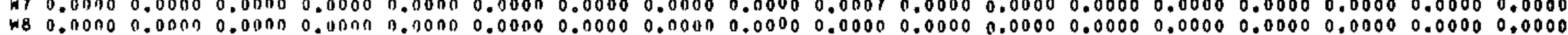

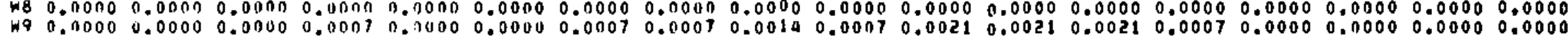

STABILITY CLASS 7

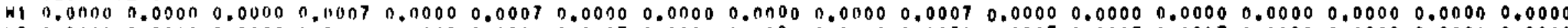

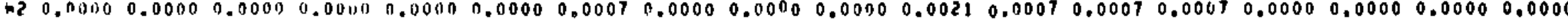

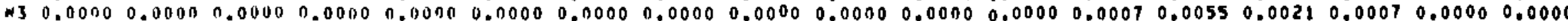

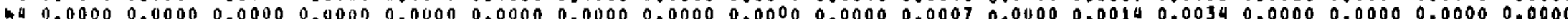

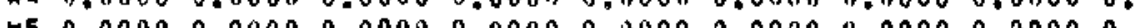

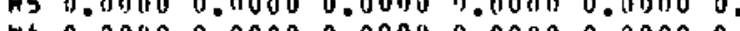

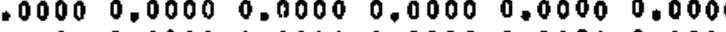

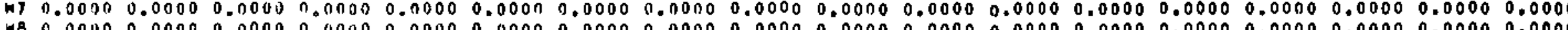

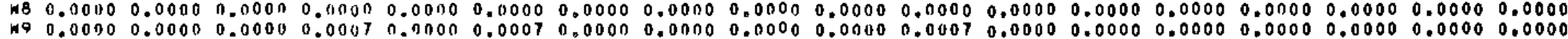


- DF LON SPEED CLASS ONE WINI>S: 221

HIHO SPEED CLASS

HINO DIRECTIOH (10 SECTHRG + CALH + VARIABLE)

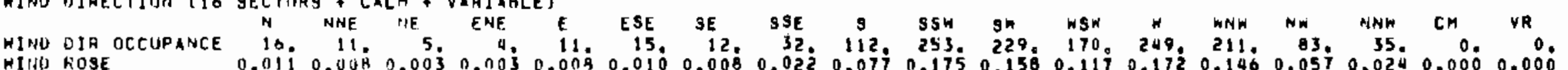

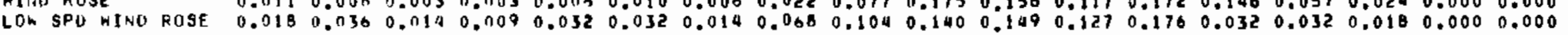

FHEQTERCY OISTAIEUIION DF THE WIND AS FUNCTION OF WIND SPEED AND WIND DIRECTION

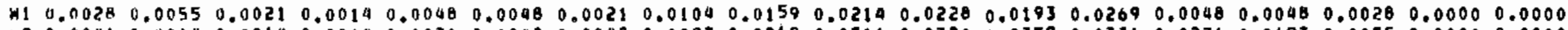

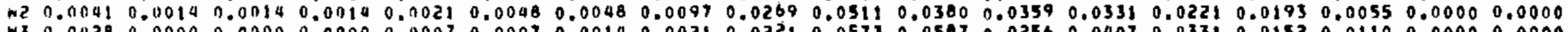

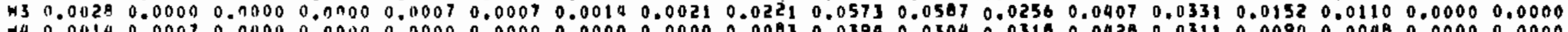

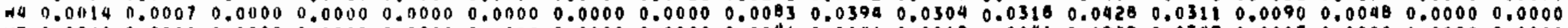

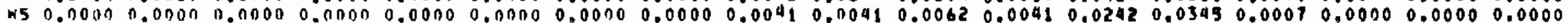

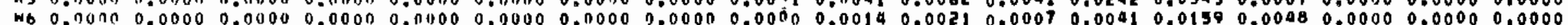

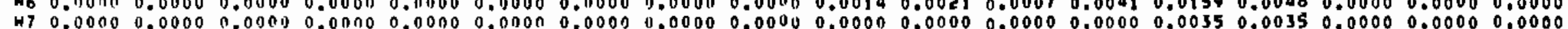

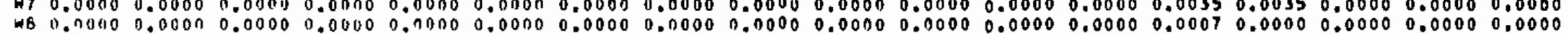

\section{STABILITY CLASS 1}

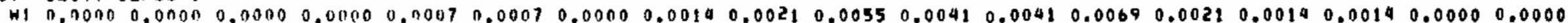

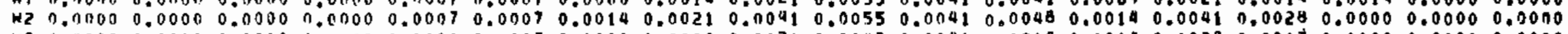

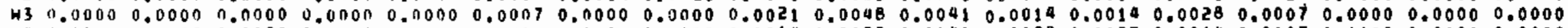

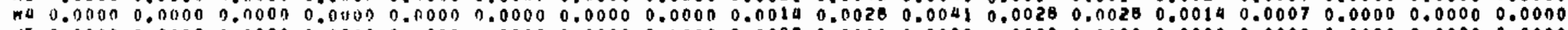

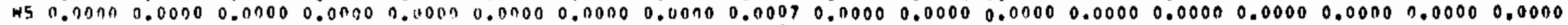

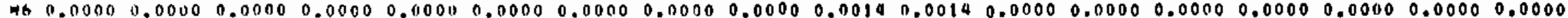

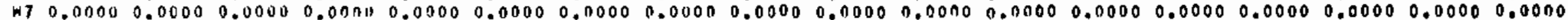

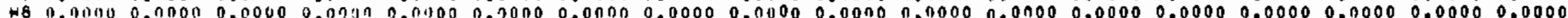

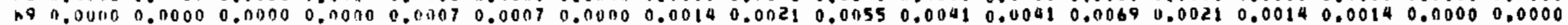

\section{STABILITr CLASS}

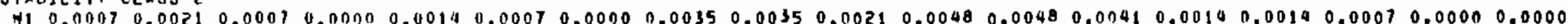

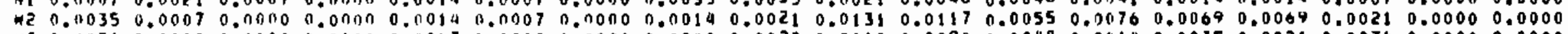

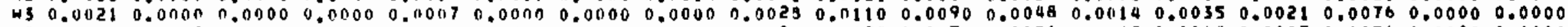

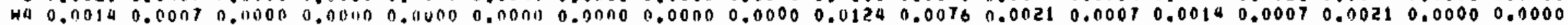

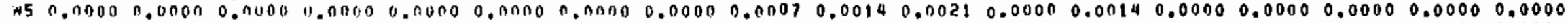

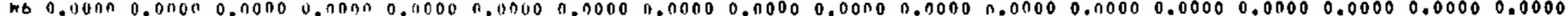

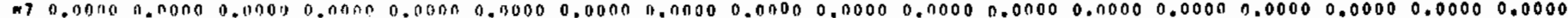

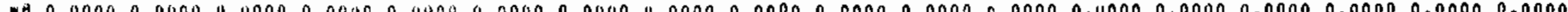

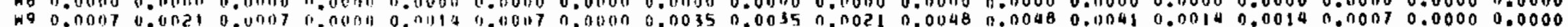

STAHILITY CLASS 3

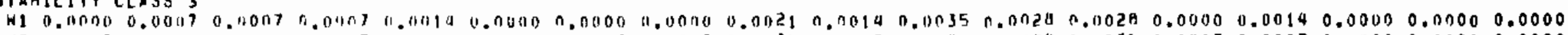

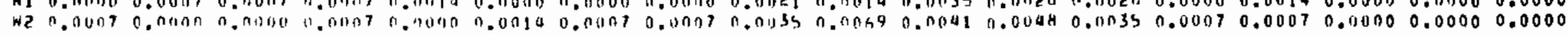




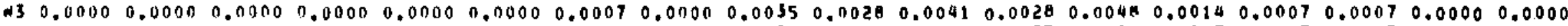

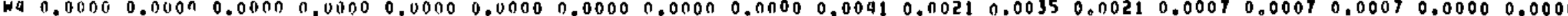

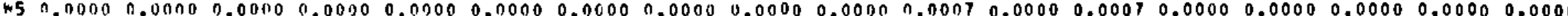

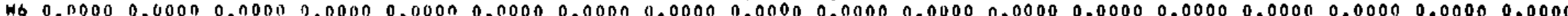

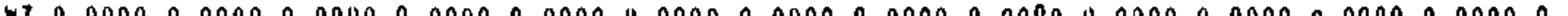

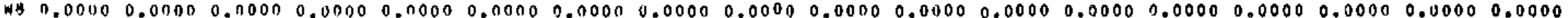

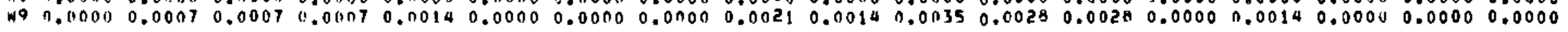

STABILITY CLASS 4

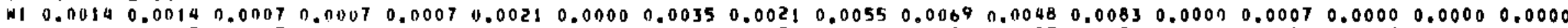

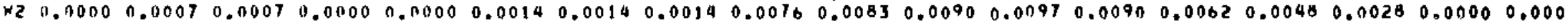

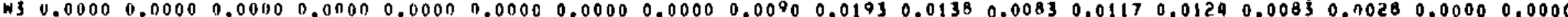

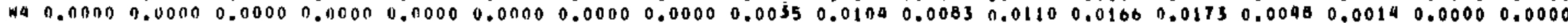

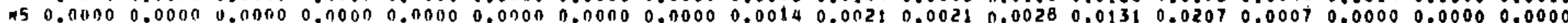

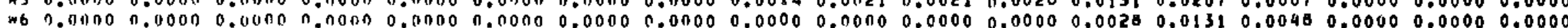

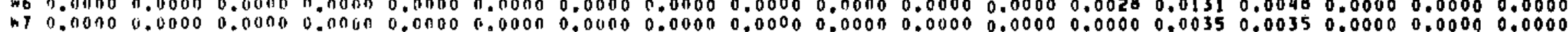

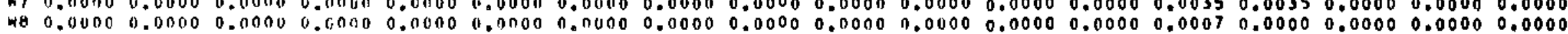

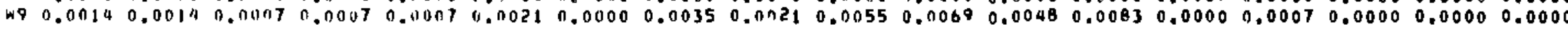

STAHILITY CLASS 5

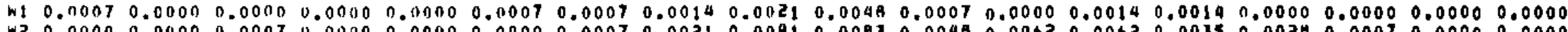

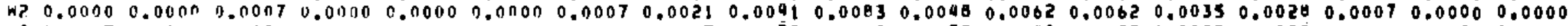

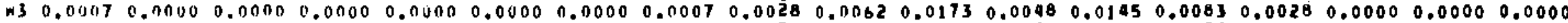

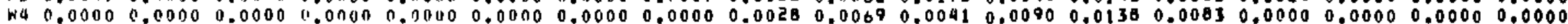

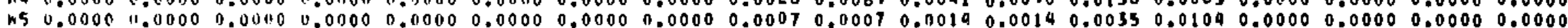

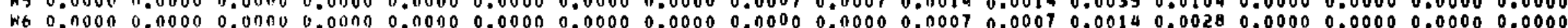

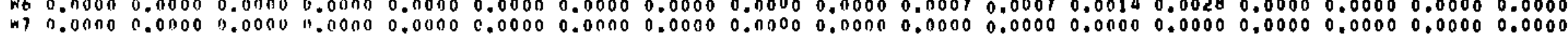

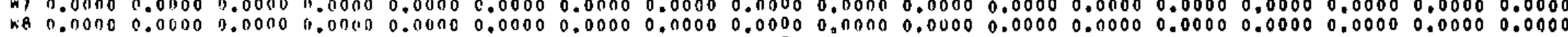

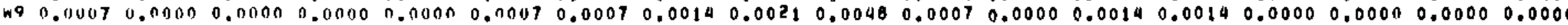

of STAFILITY CLASS

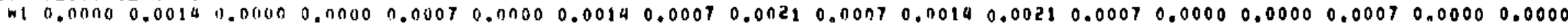

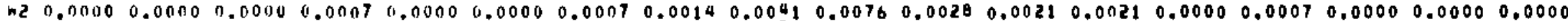

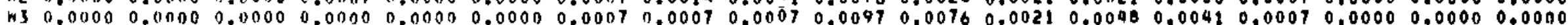

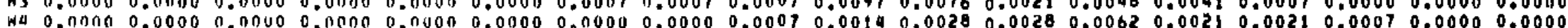

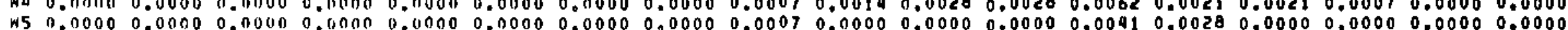

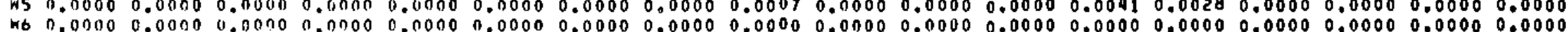

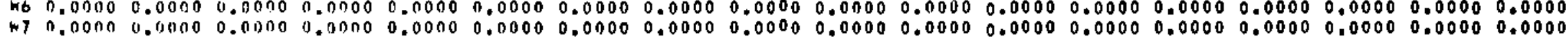

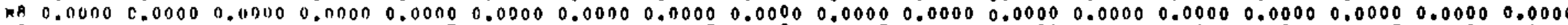

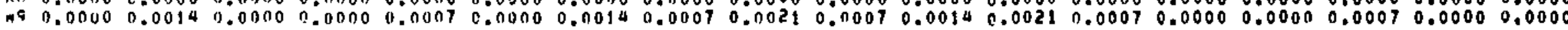

STAHILITY CLASS T

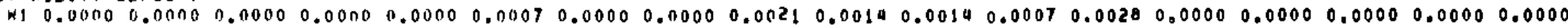

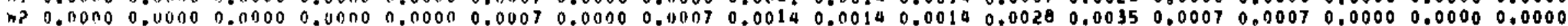

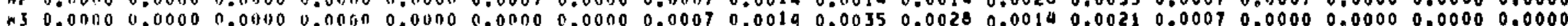

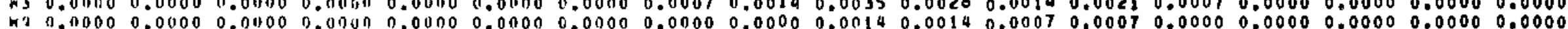

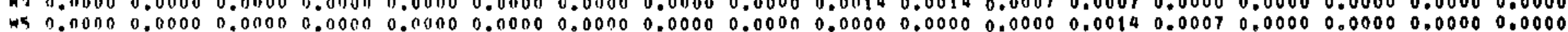

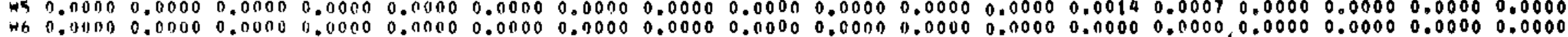

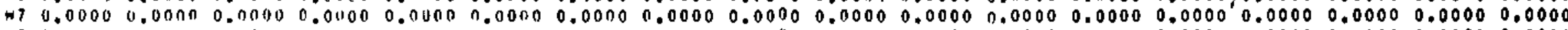

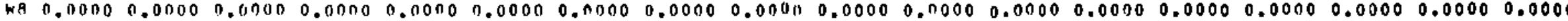

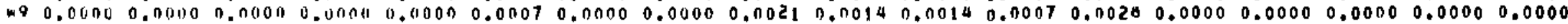


" DF LUA SPEED CLASS DHE WINAgi

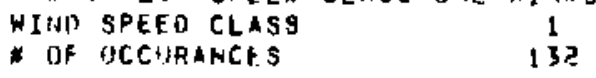

152
2
319

3
407

4
295

5

i6

7

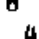

WIND OIRECIIOH (16 SECYURS + CALF + VARIAELE)

HIHD TIR DCCURANCE 50 NHF NE ENE E

WINI) HDSE

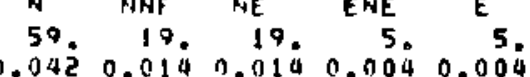

ESE SE SSE

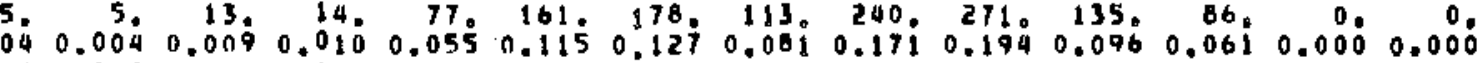

\section{FREIJUENCY DISTRIBUTION OF THE MINO AS A FUNCTION DF HIND BPEEN ANO WIND DIRECTION}

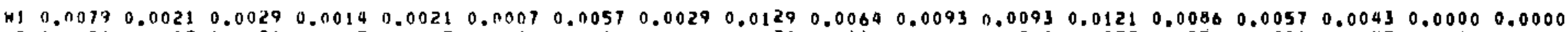

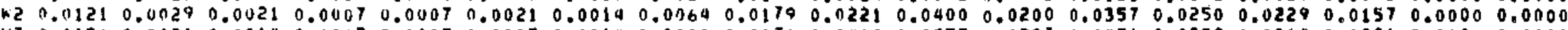

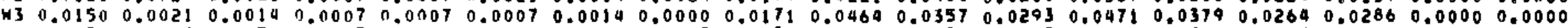

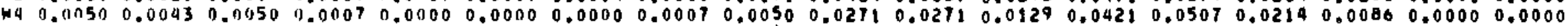

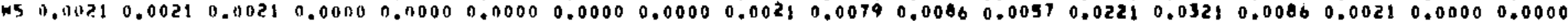

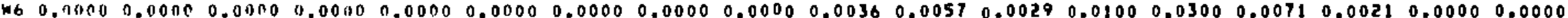

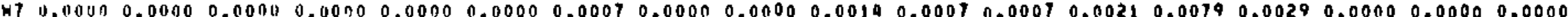

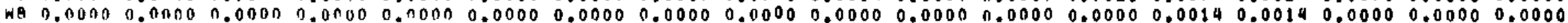

FHEQUENCY DISTRIBUTION GF THE MINO AS AUHCTION OF WIND SPEED, WIND DIRECTION AND STABILITY

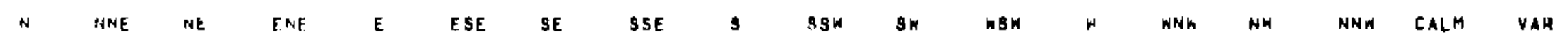

STAHILITY CLASS I

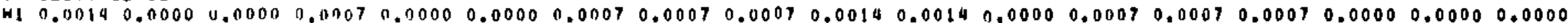

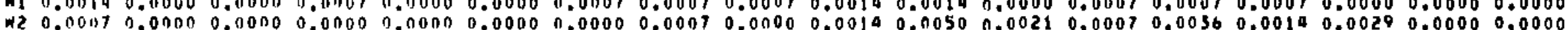

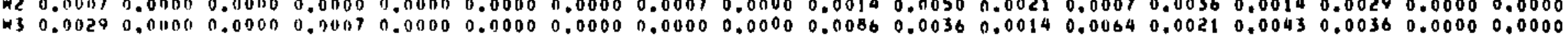

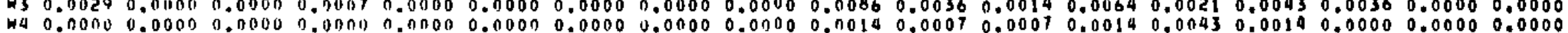

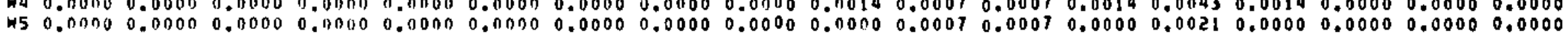

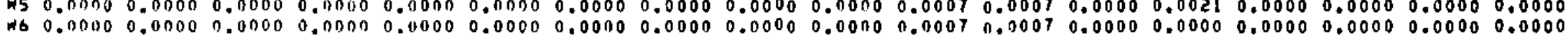

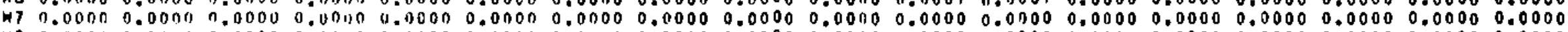

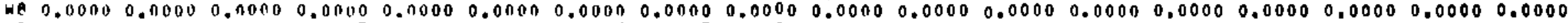

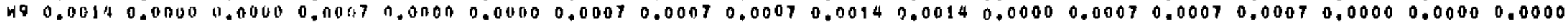

STABILITY CLASS?

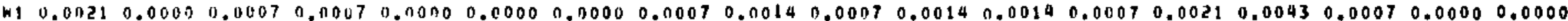

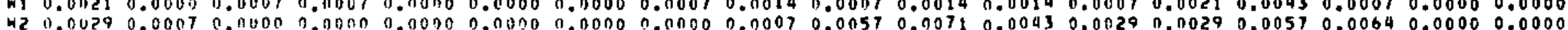

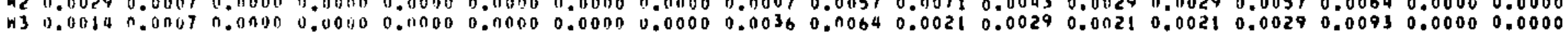

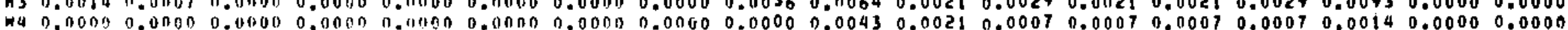

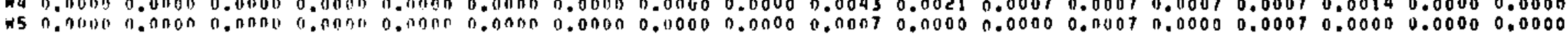

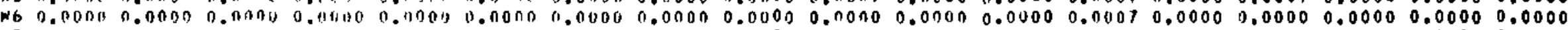

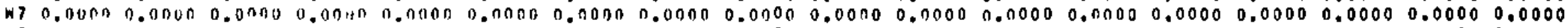

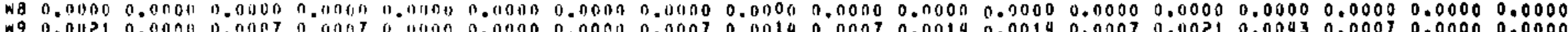

sabilitir classis

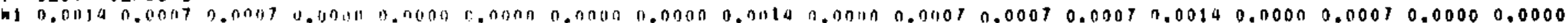

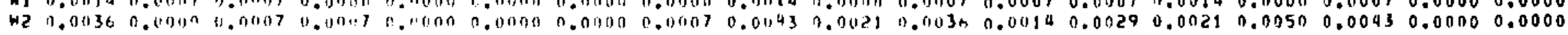




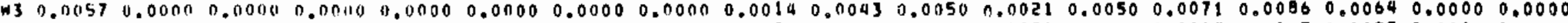

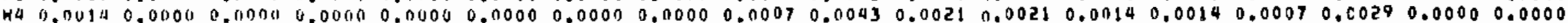

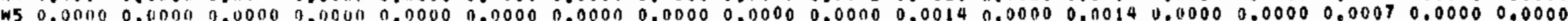

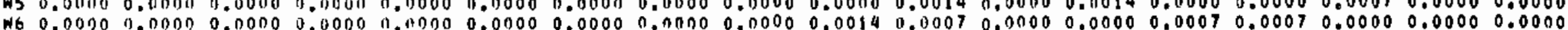

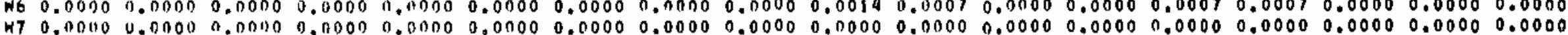

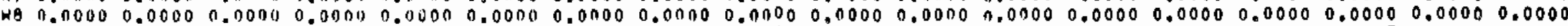

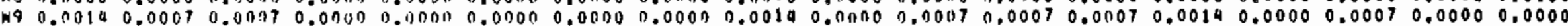

BTABILITY CLASS A

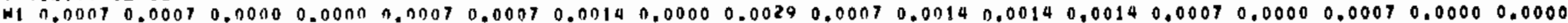

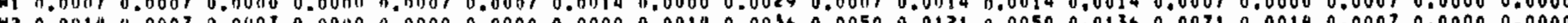

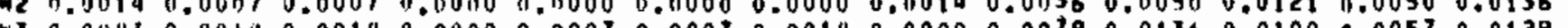

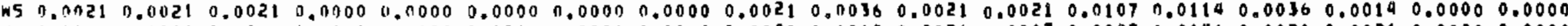

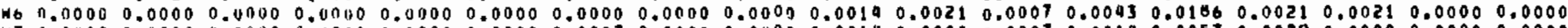

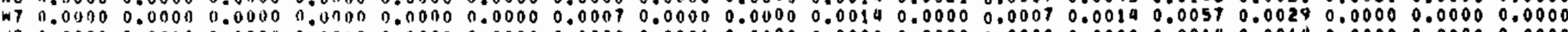

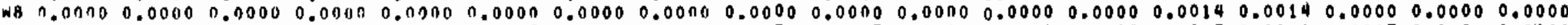

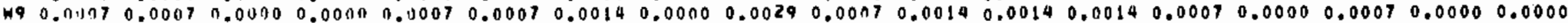

STABILITY CLASS 5

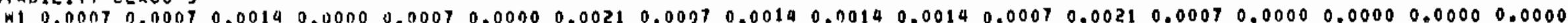

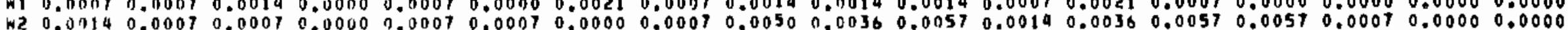

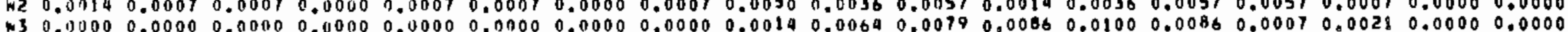

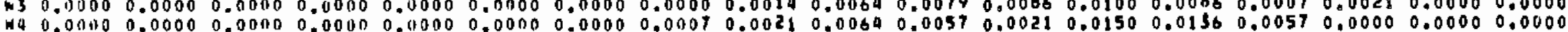

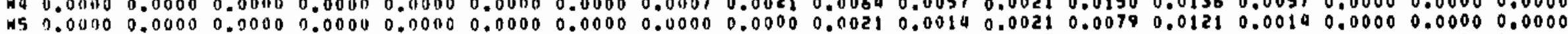

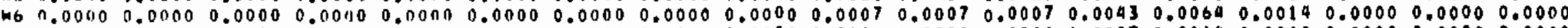

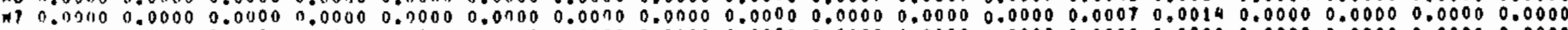

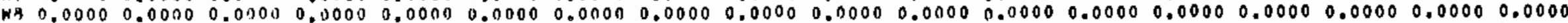

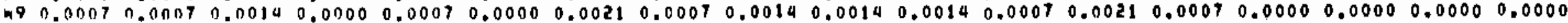

STABILITY CLASS -

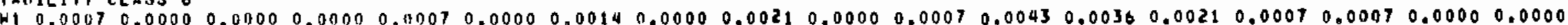

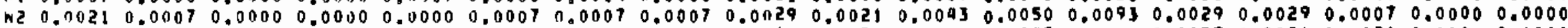

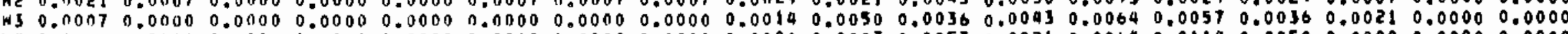

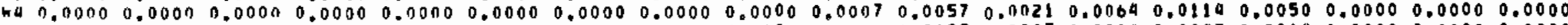

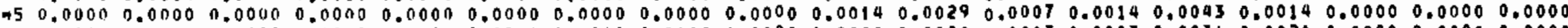

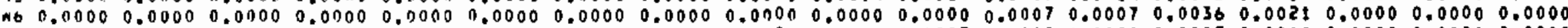

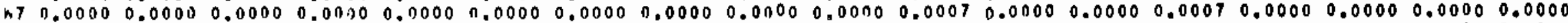

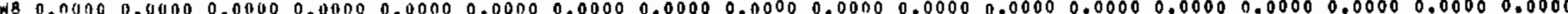

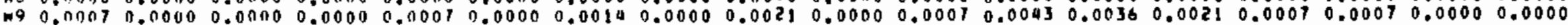

STABILITY CLASST

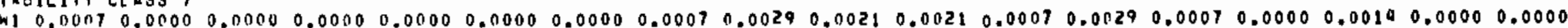

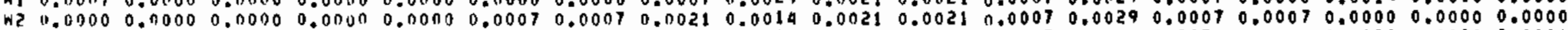

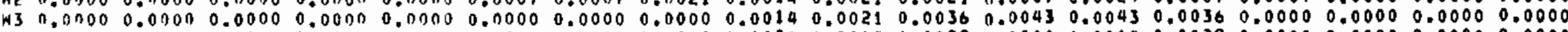

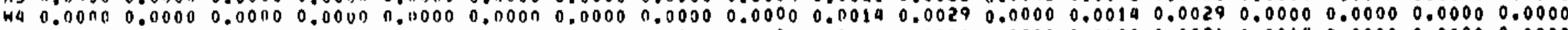

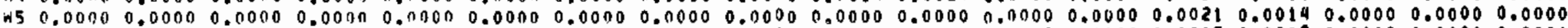

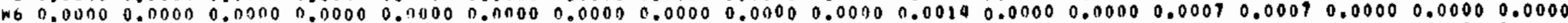

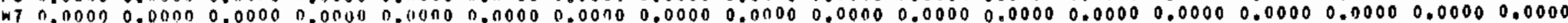

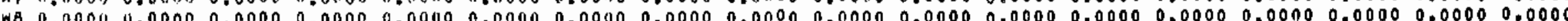

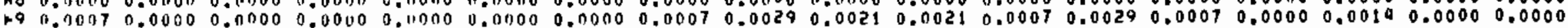


* DF LOW SPEED CLASS DI:E MINUS: WIND SPEED CLASS

- of jucculasanes

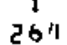

264
2
415
3
225
5
129
6 A
22 s,

HIND DIRECTIOH (16 SECTORS + CALH + VARIABLE)

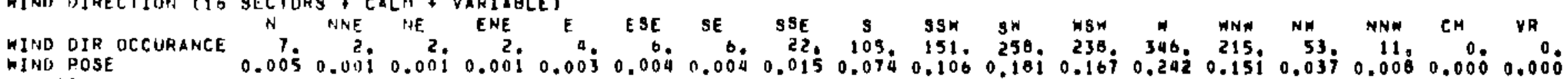

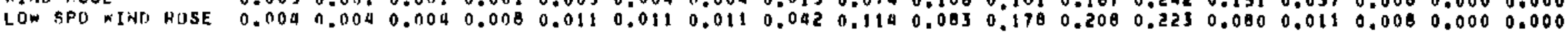

FREMUENCY TISTRIBUTION OF THE IINO AS FIJNCTION OF WIND SHEED AND HIND DIRECTION

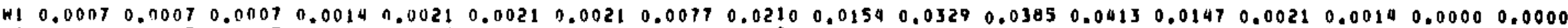

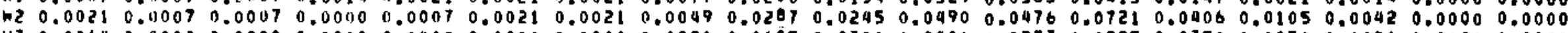

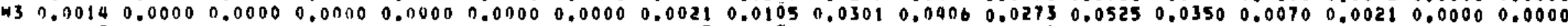

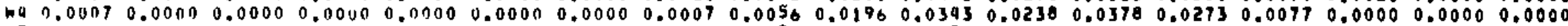

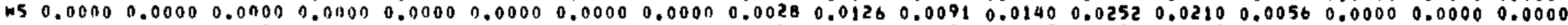

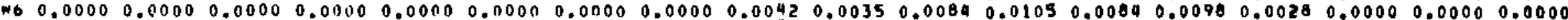

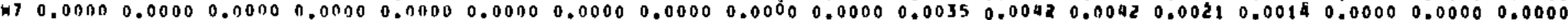

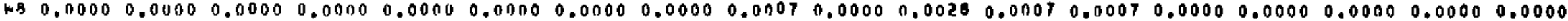

FREIJUECY DISTRIBUTION OF THE WINO AS FUNCTION OF WIND SPEEO, WIND OIAECTIDN AND BTABILIFY

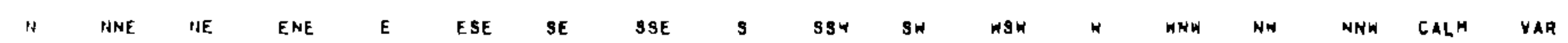

STABILITY CLASS I

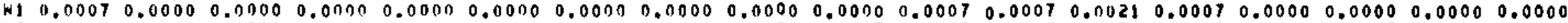

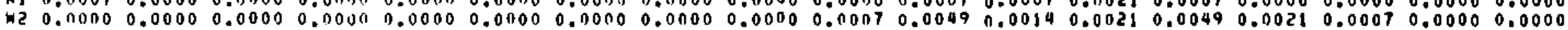

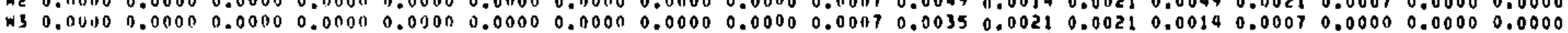

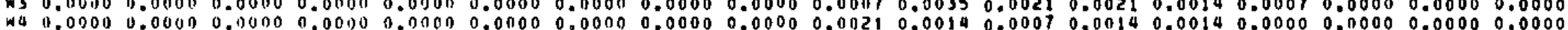

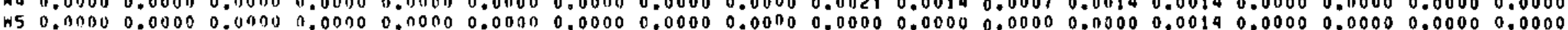

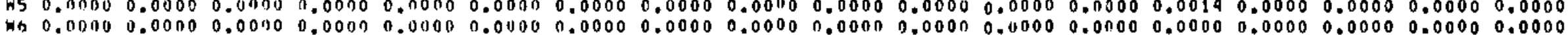

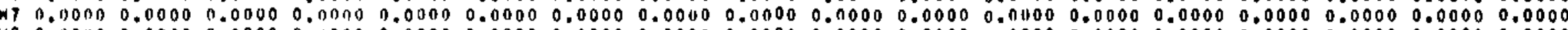

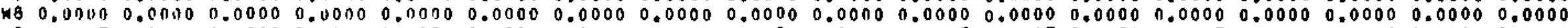

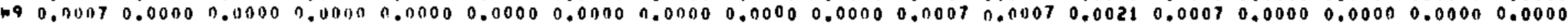

STAEILITY CLASS 2

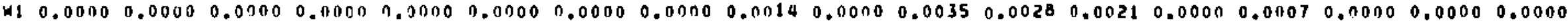

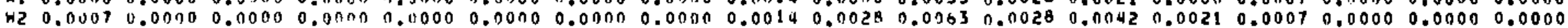

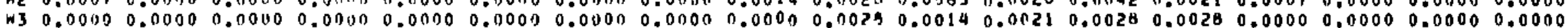

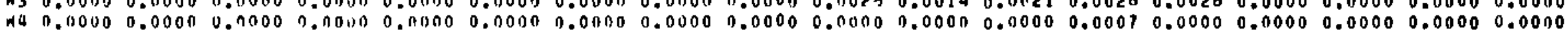

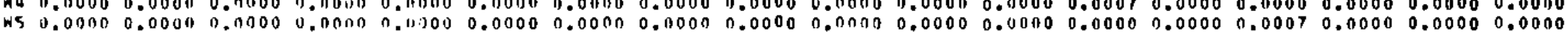

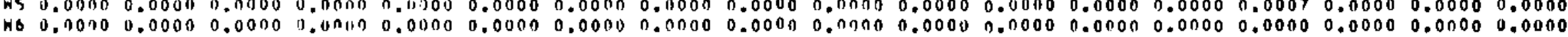

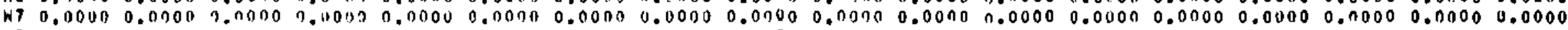

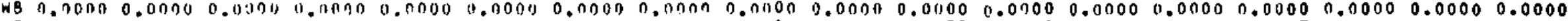

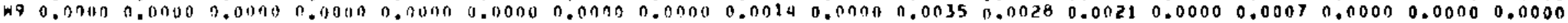

SIAHILETY CLASS B

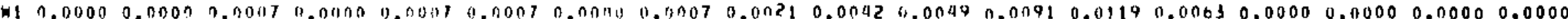

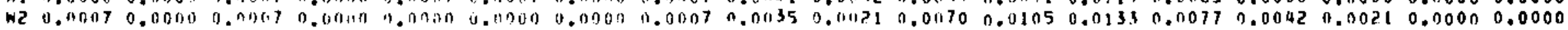




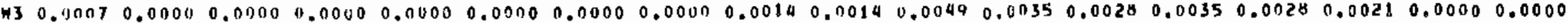

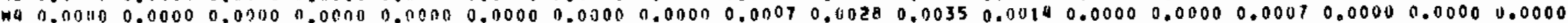

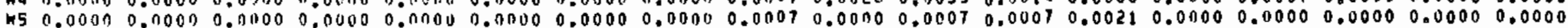

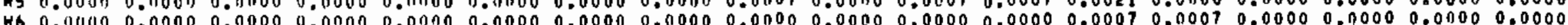

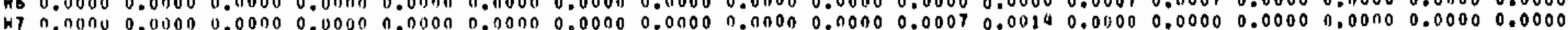

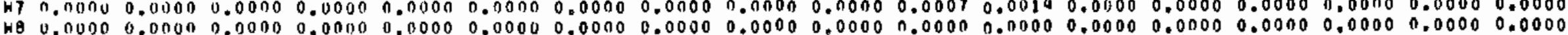

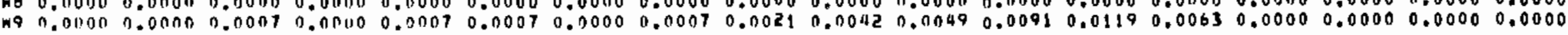

vaeilitr Class a

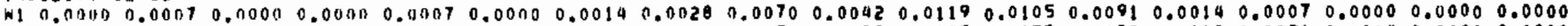

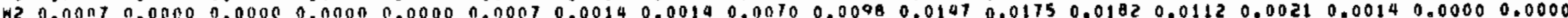

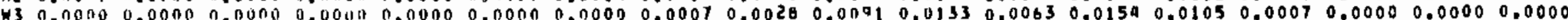

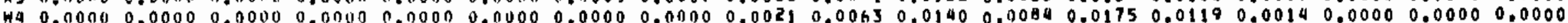

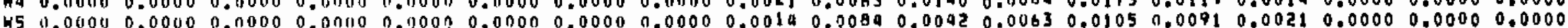

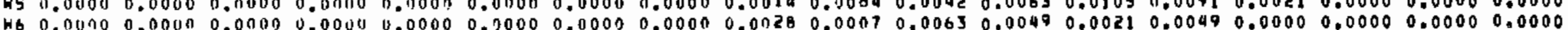

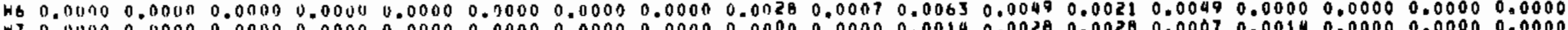

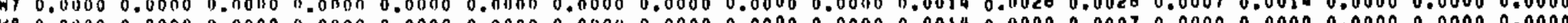

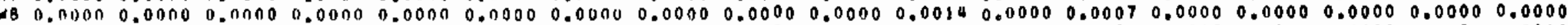

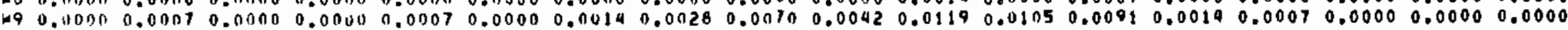

STAPILITY CLASS 5

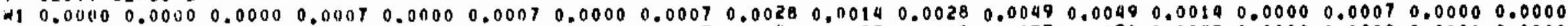

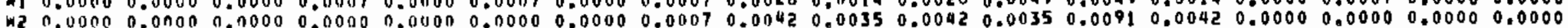

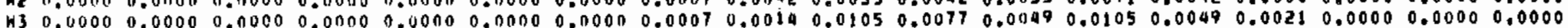

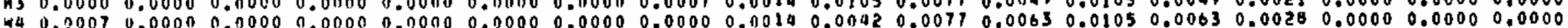

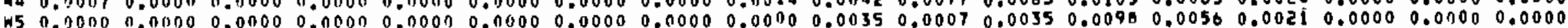

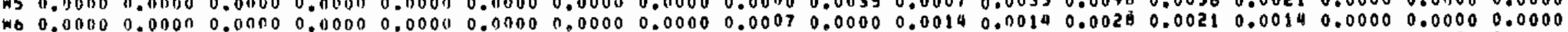

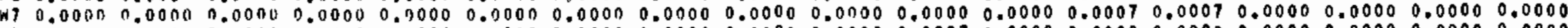

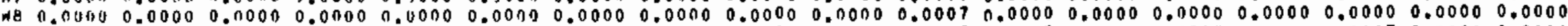

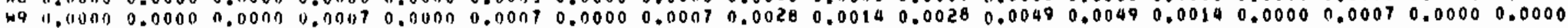

\section{G STABILITY CLASS o}

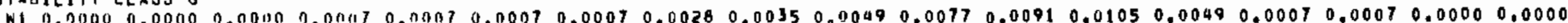

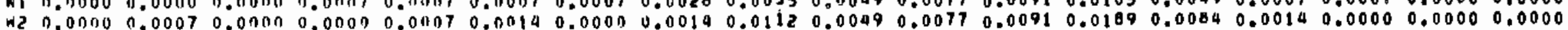

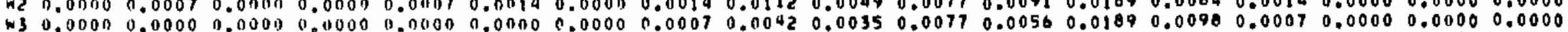

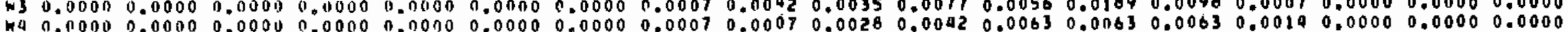

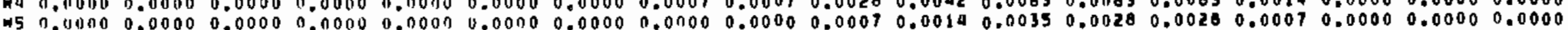

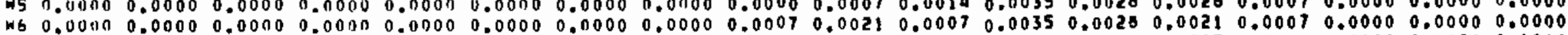

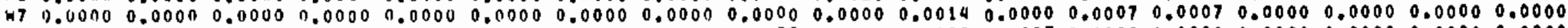

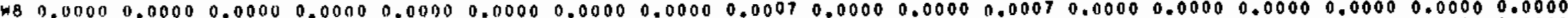

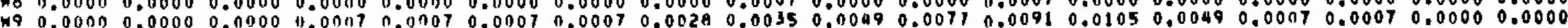

\section{jabilitr Class 1}

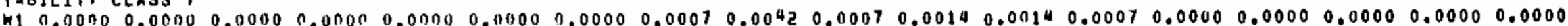

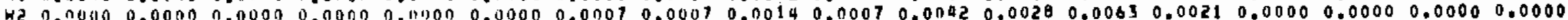

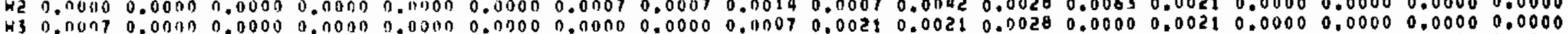

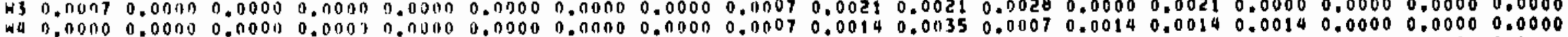

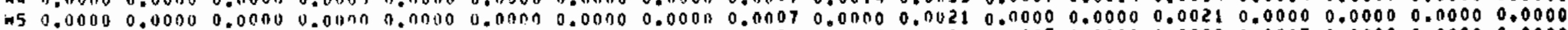

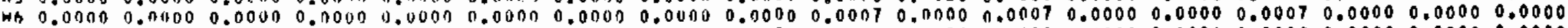

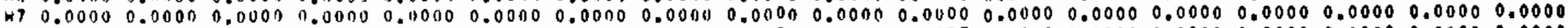

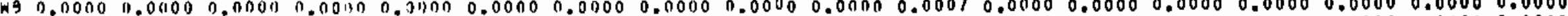

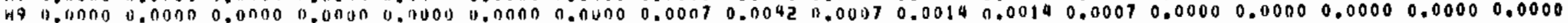




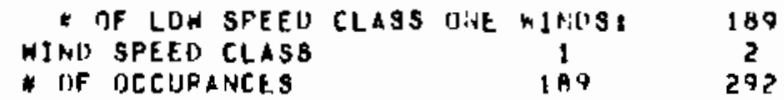
89 $\begin{array}{cccccc}3 & 4 & 5 & 6 & 7 & 0 \\ 305 & 250 & 175 & 117 & 50 & 20\end{array}$

WINO OIRECIION (16 SECTIRS + CALH + VARIABLE)

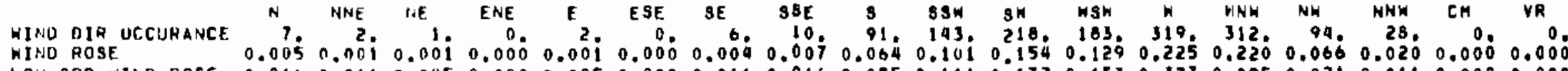

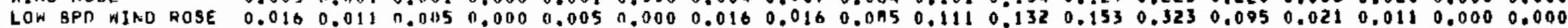

FHEULFNCY OISTRIBUTION OF THE HIND AS FUNCTIOH OF HINO gPEED ANO WIND DIRECTION

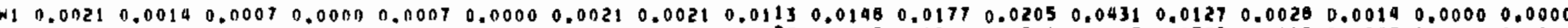

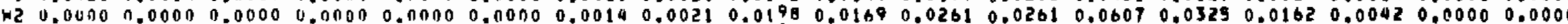

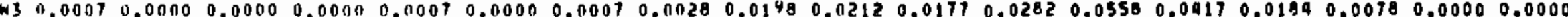

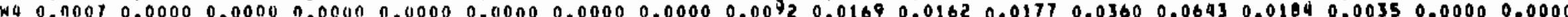

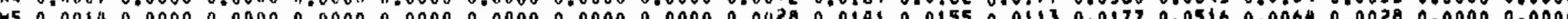

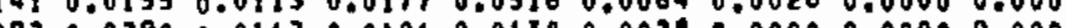
0000.0000 .0000 .00140 .00920 .0290 .01620 .01060 .01340 .0020 .00000 .00000 .0000

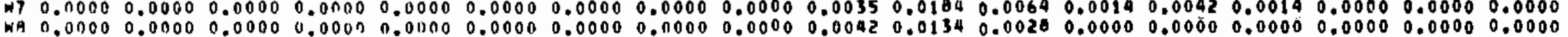

$\infty$

FRERUENCY DISTAIGUTION UF THE WIND AS A FUNCTIOH OF WINO BPEEO, HINO DIRECTION AND STABILITY

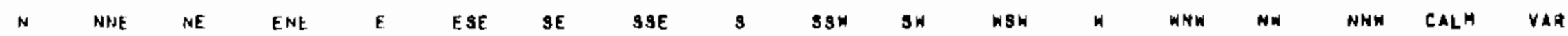

STABILITY CLASg

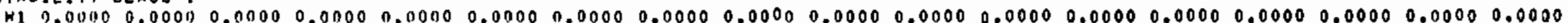

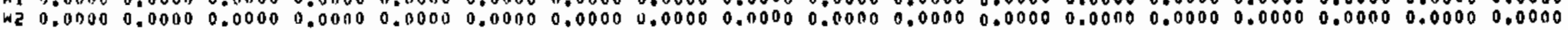

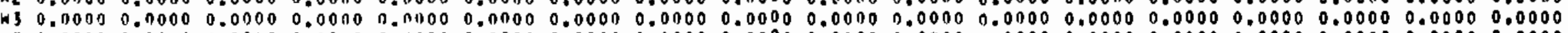

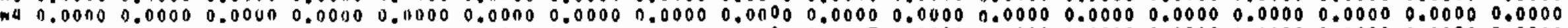

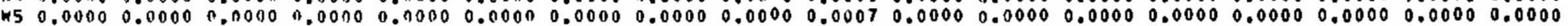

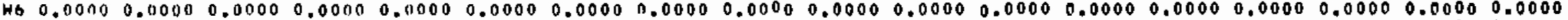

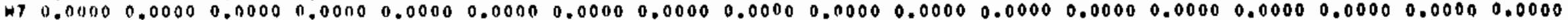

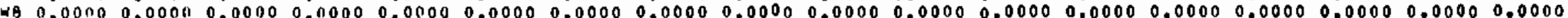

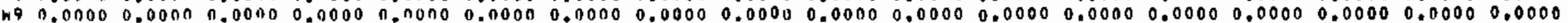

\section{STAGILITY CLASS}

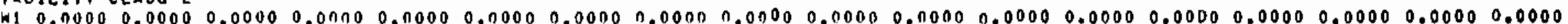

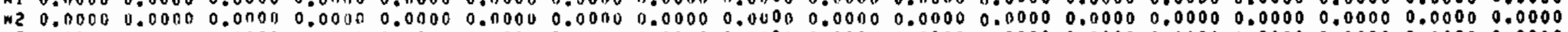

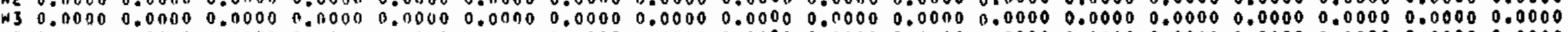

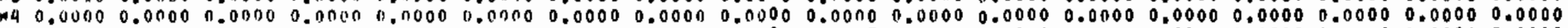

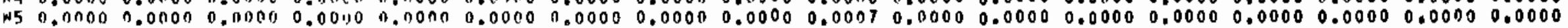

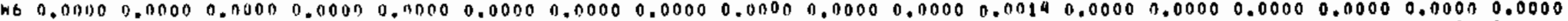

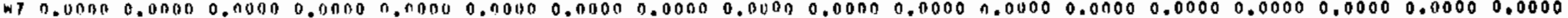

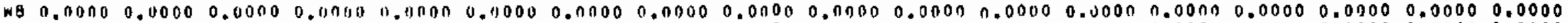

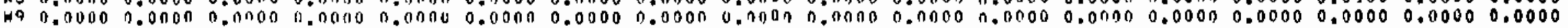

giabilitr lilass 3

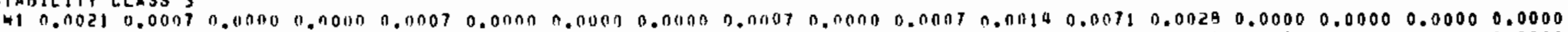

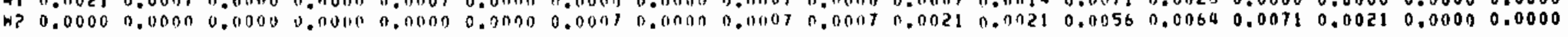




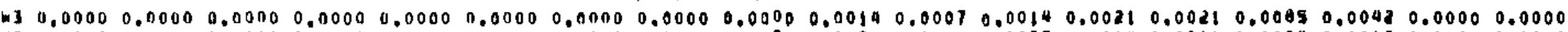

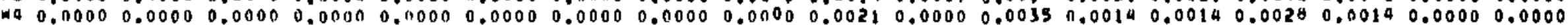

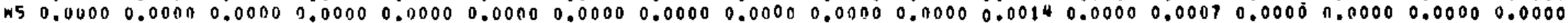

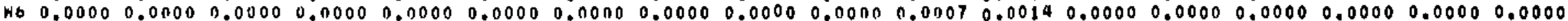

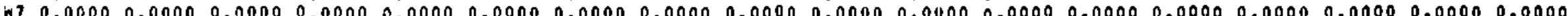

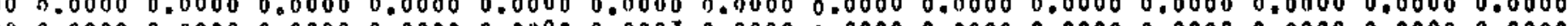

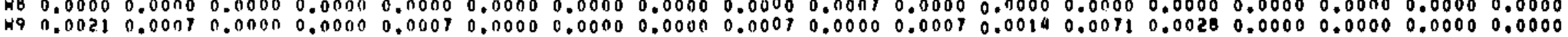
STAEILITY CLASS 4

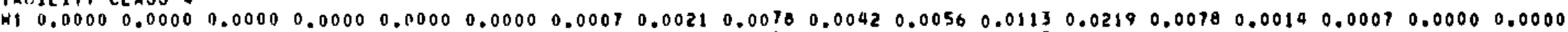

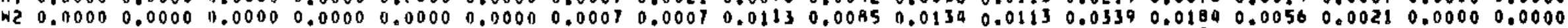

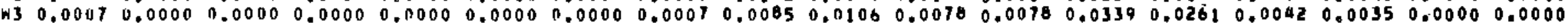

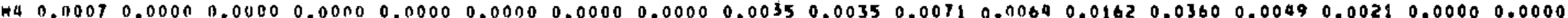

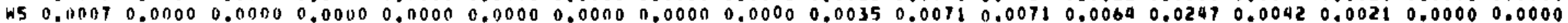

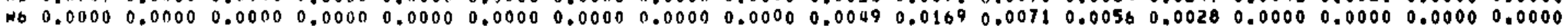

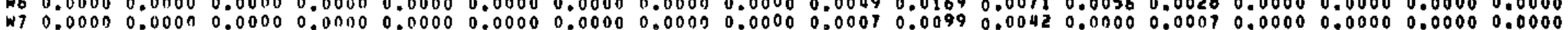

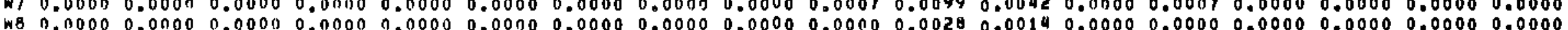

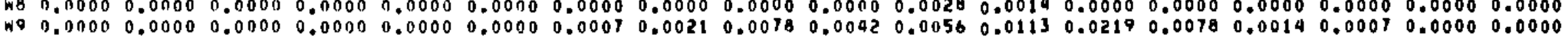

STAEILITY CLASE 5

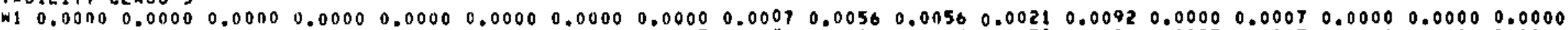

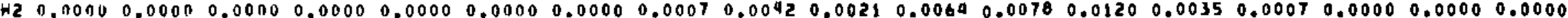

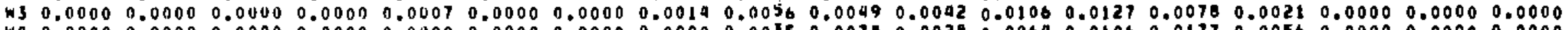

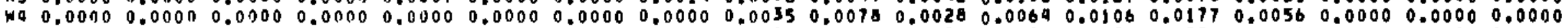

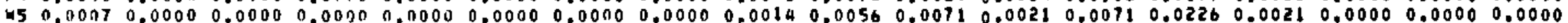

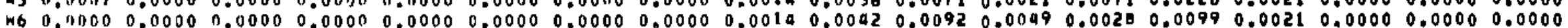

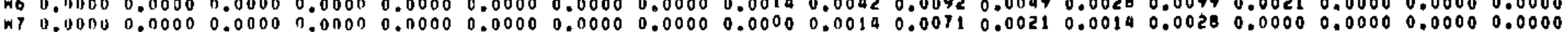

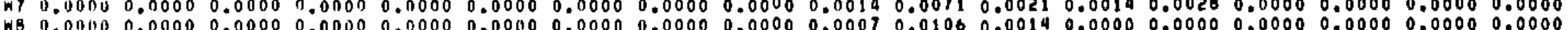

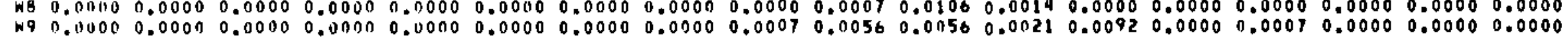

in BTAHLITY CLAS3 B

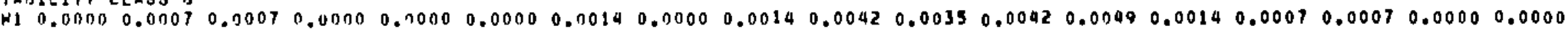

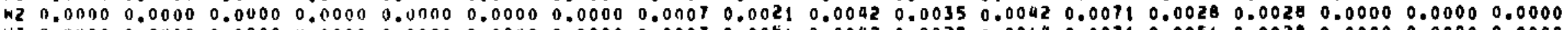

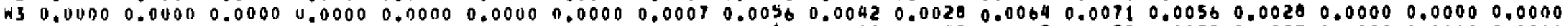

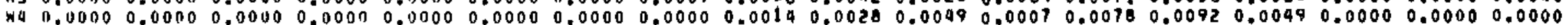

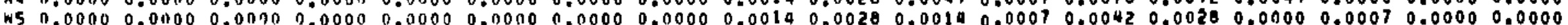

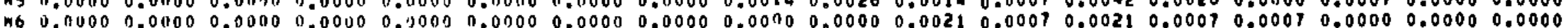

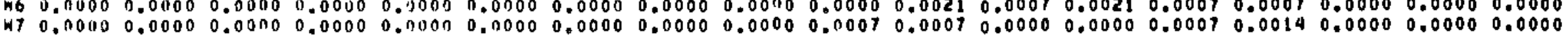

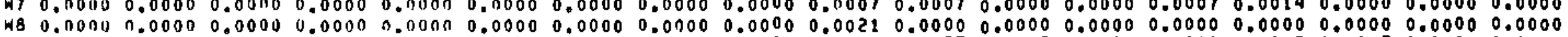

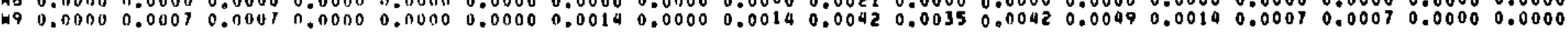

\section{STAFILITY CLASST}

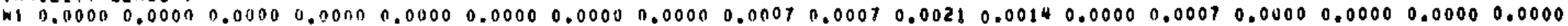

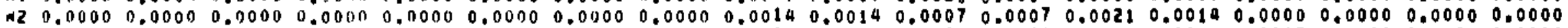

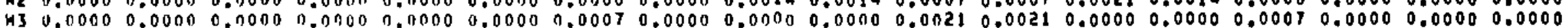

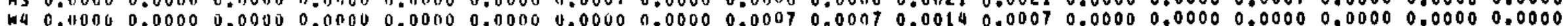

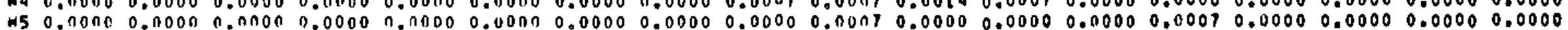

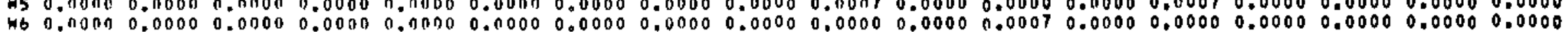

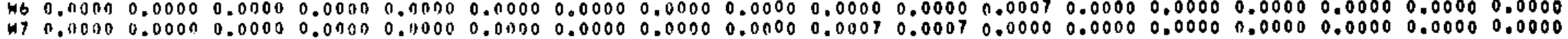

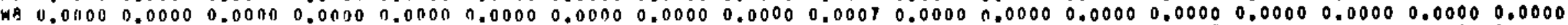

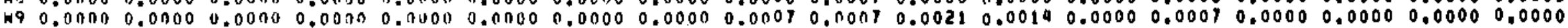




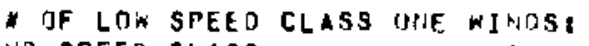
HINO SPEED CLASS

191

- UF OCCUHANICES

19

2
267

3

4

171

105

7

8

WINO OIRECIION (16 SECTOQS + CALH + VAGIASLE)

WINO OIR UCCIJHANCE

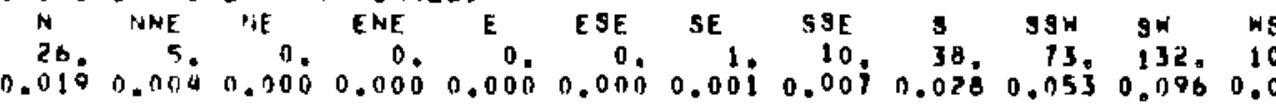

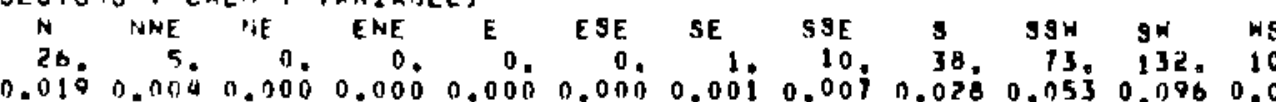

HIVU ROSE LOA SPD FINU ROSE

\section{FHEQUE.URY UISTRIBUTIDN OF THE WIND AS FUNCTION OF HIND SPEED AND KIND DIRECTION}

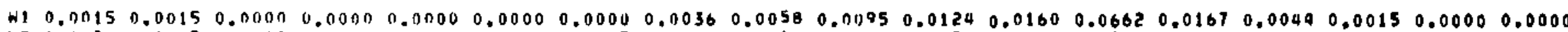

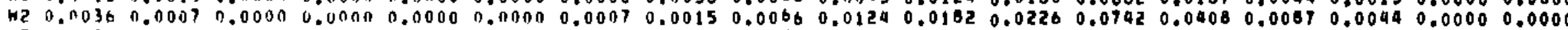

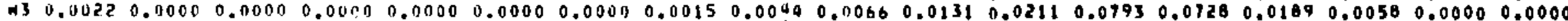

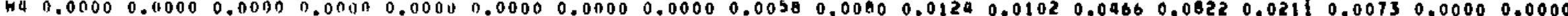

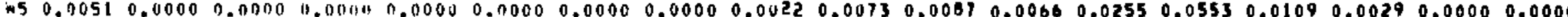

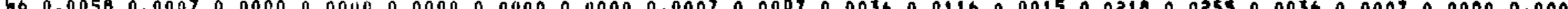

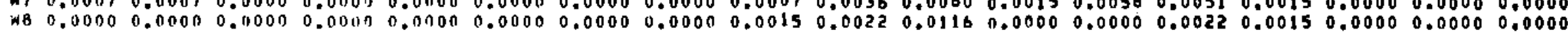

\section{STABILITY CLASS}

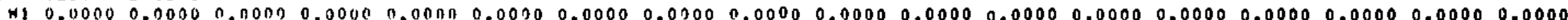

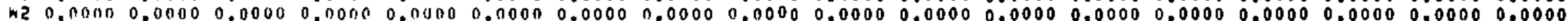

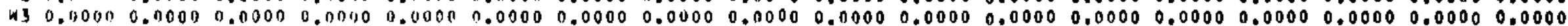

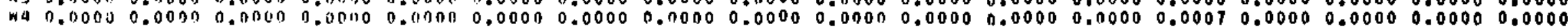

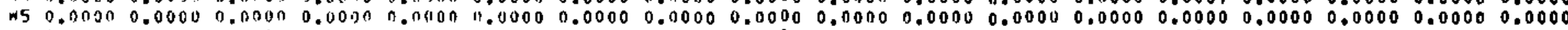

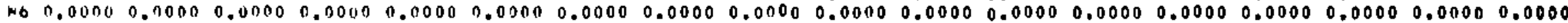

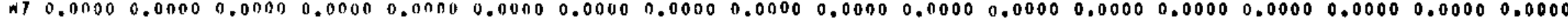

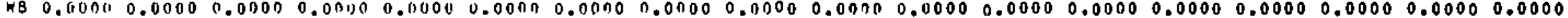

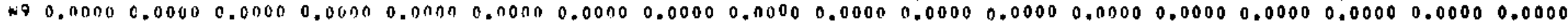

STAFILITY CLASS ?

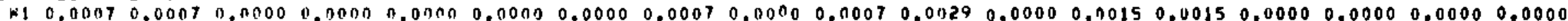

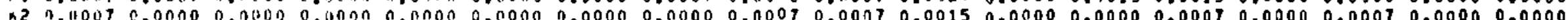

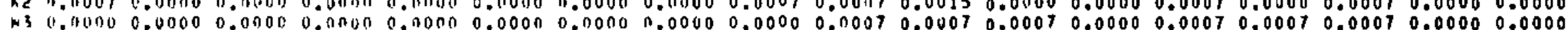

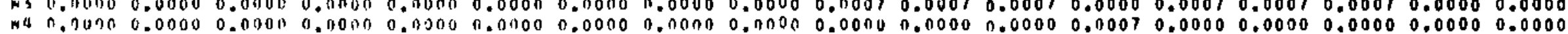

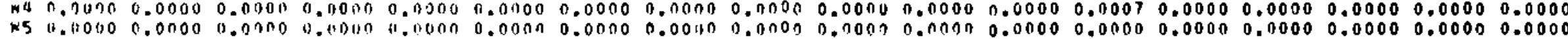

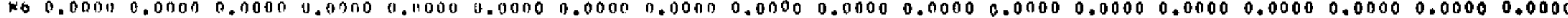

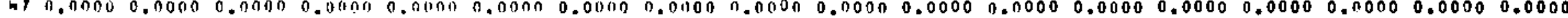

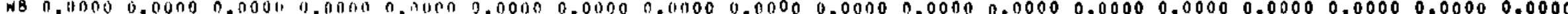

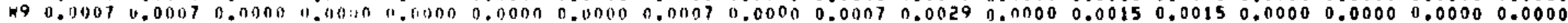

STABILITY CIASS

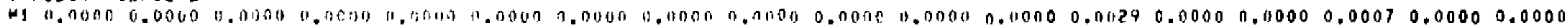

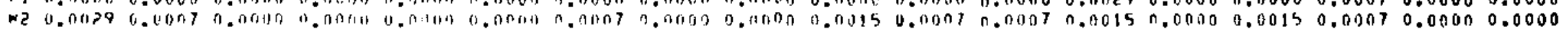




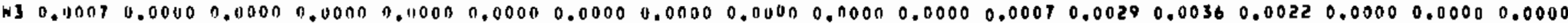

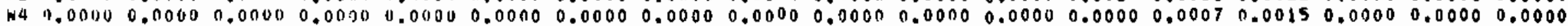

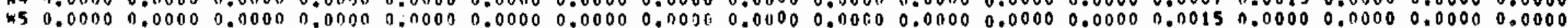

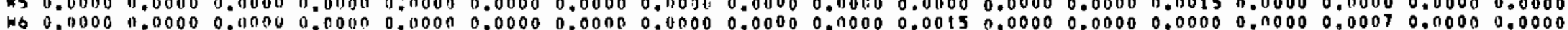

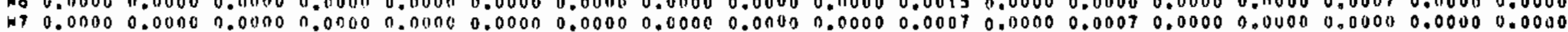

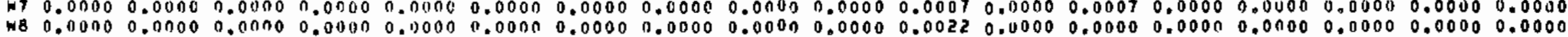

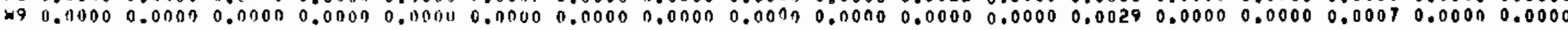

STABILITY CLASS 4

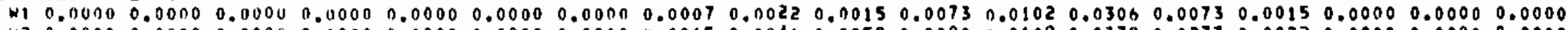

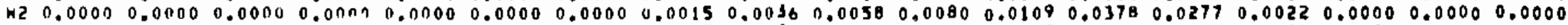

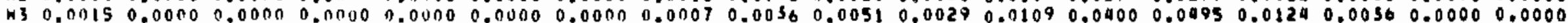

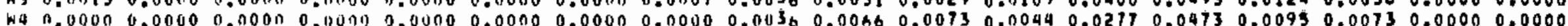

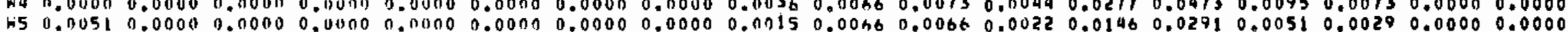

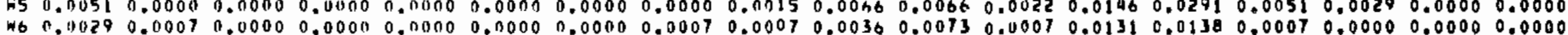

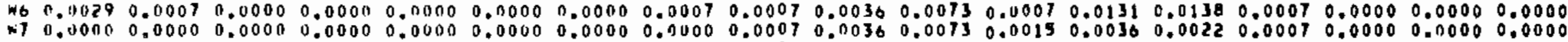

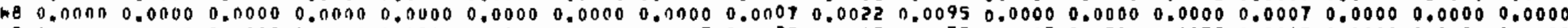

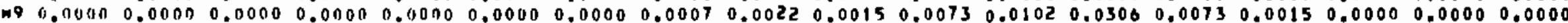

TABILITY CLASS 5

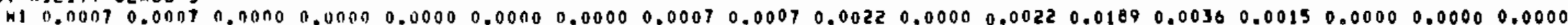

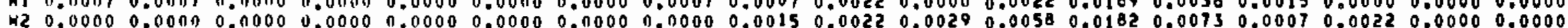

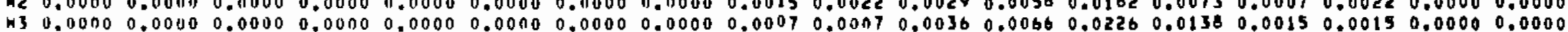

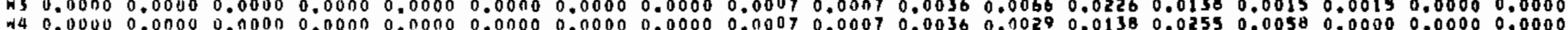

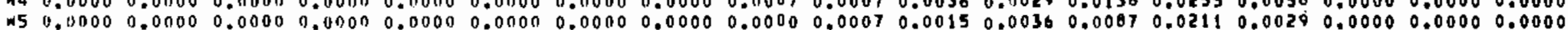

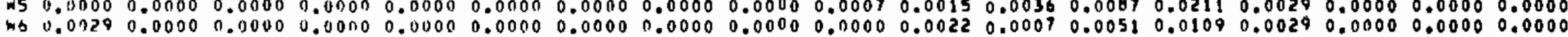

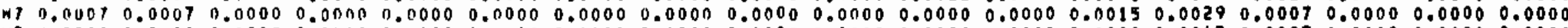

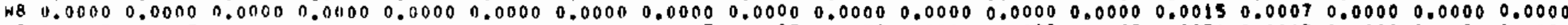

in STAHILITI CLASS b

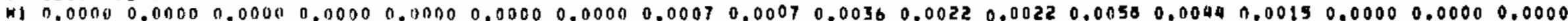

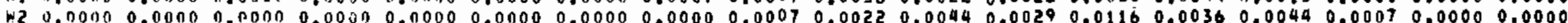

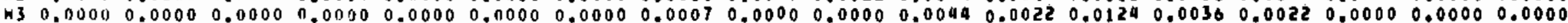

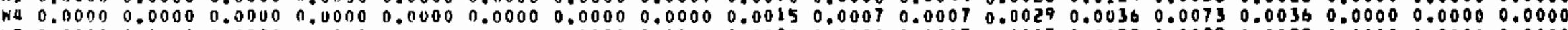

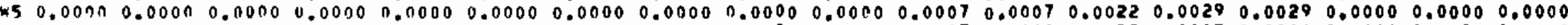

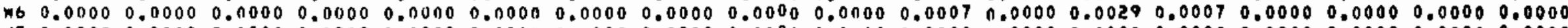

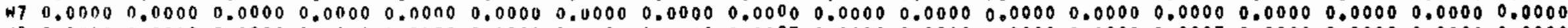

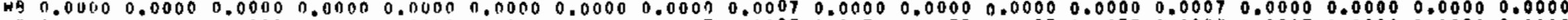

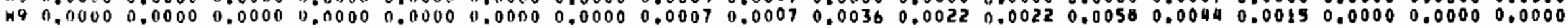

\section{SIAUILITY CLASS7}

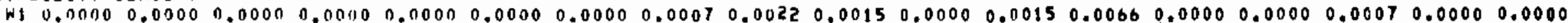

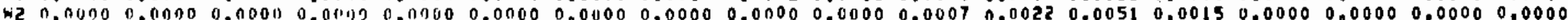

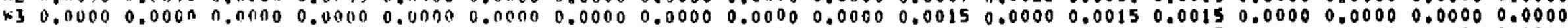

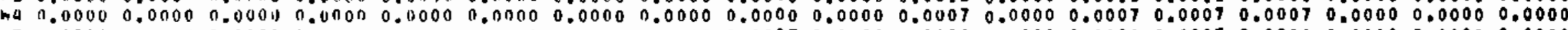

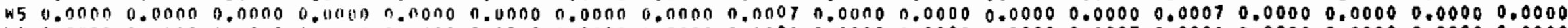

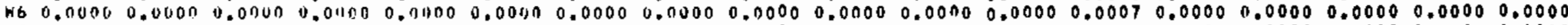

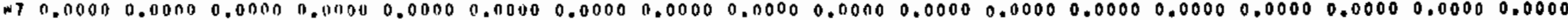

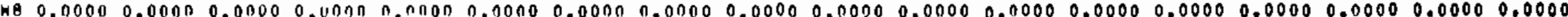

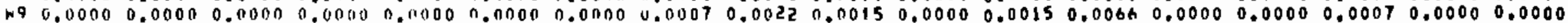




\section{APPENDIX C}

\section{MIXING LAYER THICKNESS CLIMATOLOGY FOR THE HANFORD SITE}




\section{APPENDIX 6 \\ MIXING LAYER THICKNESS CLIMATOLOGY FOR THE HANFORO SITE}

Climatological summaries of the mixing layer thickness at Hanford for the 22-month period from March 25, 1982, through January 31, 1984, are shown in Table C.1. The mixing layer thickness is a measure of the vertical extent to which material released near the nearth's surface will mix as a result of turbulence in the wind. The first four summaries give frequencies of occurrence of mixing layer thicknesses as a function of season and time-of-day. The fifth summary gives the frequencies by time-of-day, and the last summary gives seasonal and annual frequencies. These summarizes should be appropriate for use in dispersion estimates for the Skagit/Hanford Site.

The mixing layer thicknesses are estimated using: 1) temperature profiles on the 125-m Hanford Meteorological Station tower, 2) a Doppler acoustic sounder, and 3) the temperature at the top of Rattlesnake Ridge. The acoustic sounder is the primary method of determining the thickness. However, it is not reliable during heavy precipitation or high winds. Ouring heavy precipitation, the mixing layer thickness is assumed to be small $(<100 \mathrm{~m})$, and during high winds it is assumed to be large $(>1,000 \mathrm{~m})$. The assumption of a small thickness during precipitation is conservative because material is not allowed to mix upward, which tends to increase estimates of ground-level $x / Q$. The assumption of a large mixing layer thickness under high wind conditions is not conservative, but it has $1 i$ ttie effect on the overail $x / Q$ estimates becasue high winds are associted wsith good dispersion. The effects of the assumptions are also minimal because of infrequency of heavy precipitation and high winds.

\section{1}


TABLE C.1. Halltord Mixing Layer Thickness Climatology $(a)$

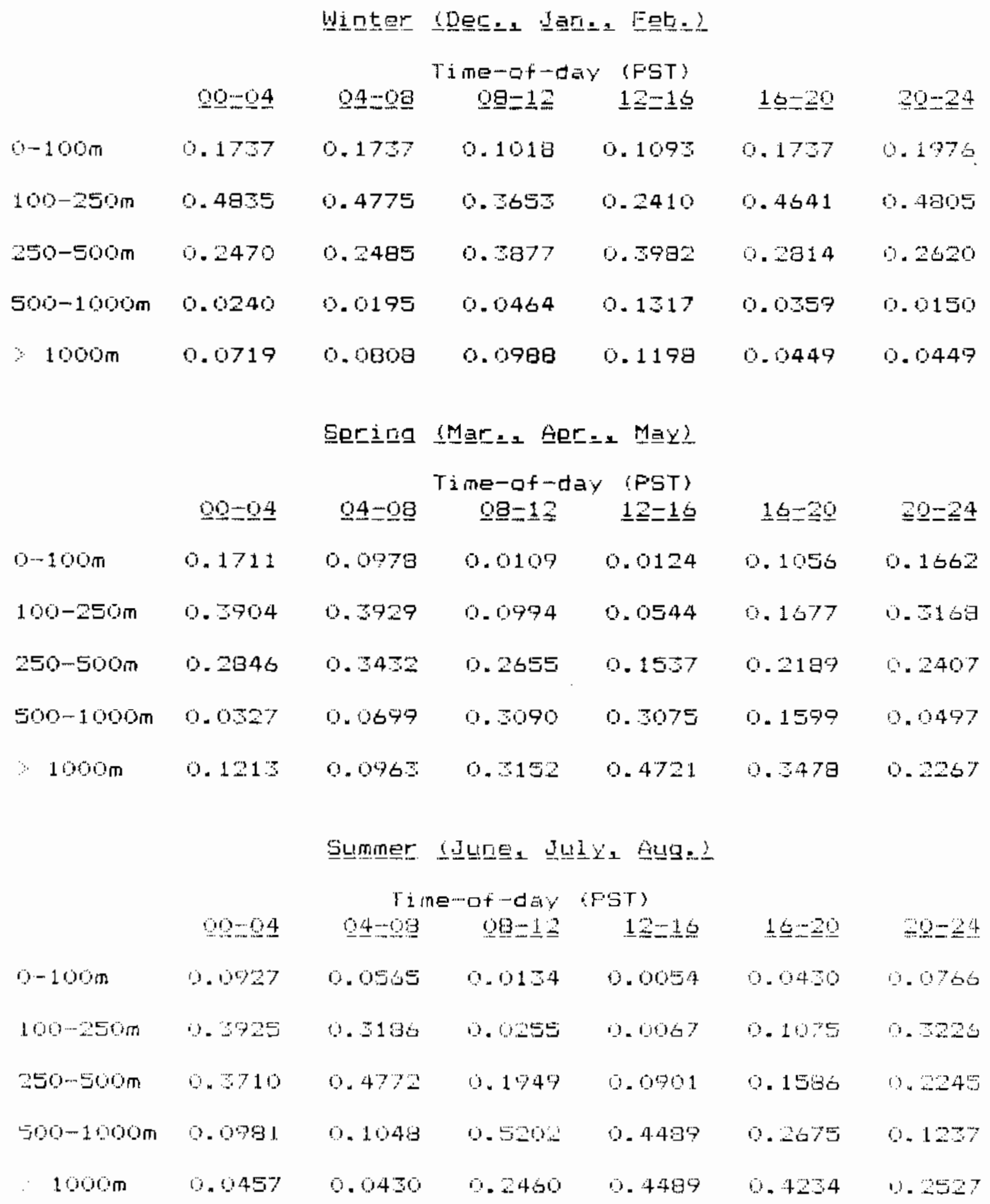

(a) Based on temperature records and acoustic sounder data $3 / 25 / 82$ through
$1 / 31 / 84$. 
TABLE C.1. (contd)

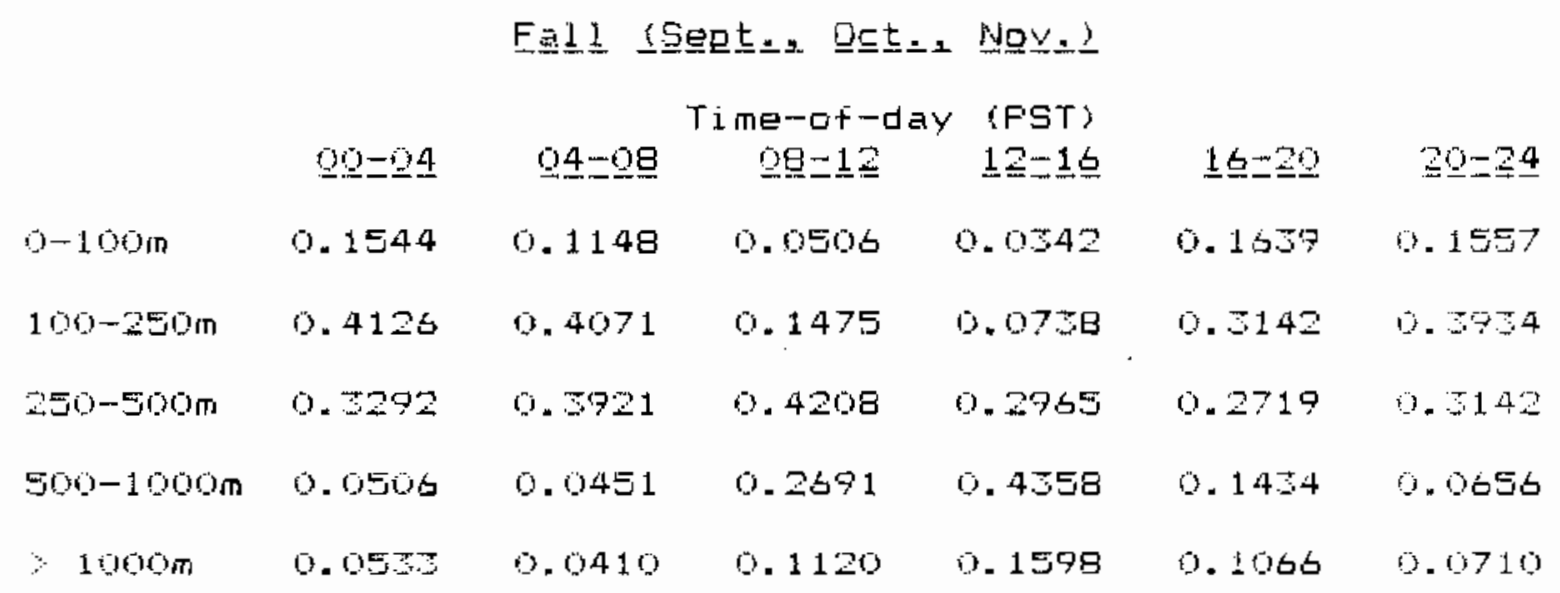

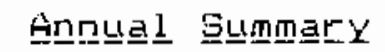

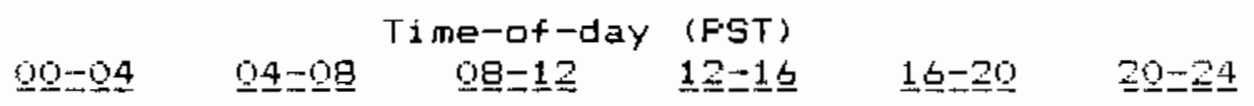

$\begin{array}{lllllll}0.100 \mathrm{~m} & 0.1464 & 0.1094 & 0.0438 & 0.0594 & 0.1205 & 0.1471\end{array}$

$\begin{array}{lllllll}100-250 m & 0.4191 & 0.3771 & 0.1560 & 0.0915 & 0.2611 & 0.577\end{array}$

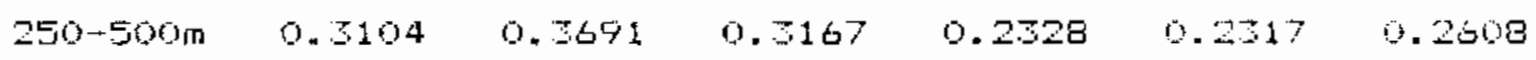

$\begin{array}{lllllll}500-1000 m & 0.0527 & 0.0606 & 0.2920 & 0.358 & 0.1546 & 0.0653\end{array}$

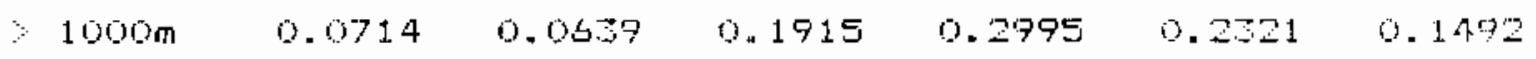

\begin{tabular}{|c|c|c|c|c|c|}
\hline & winteㄹ & Sering & Stummer & $E \equiv 1$ & Anrius \\
\hline $0-100 m$ & 0.1549 & 0.0940 & 0.0479 & 0.1125 & 0.1011 \\
\hline $100-250$ & 0.4197 & 0.2369 & 0. & 0.2914 & $0.285 \%$ \\
\hline 250 - $500 \pi$ & 0.3041 & 0.2511 & 0.2527 & 0. .74 & 9.2969 \\
\hline $500-1000 \mathrm{~m}$ & 0.0494 & $0,154 B$ & 0.2605 & 0.1505 & $\therefore 1505$ \\
\hline$\therefore \quad 1000 \mathrm{~m}$ & 0.0767 & 0.2630 & 0,24 & . & $0.16 \%$ \\
\hline
\end{tabular}

C. 3 
APPENDIX D

GEOTECHNICAL PROPERTIES: PARTIALLY SATURATED ZONE CHARACTERISTICS OF THE SKAGIT/HANFORD SITE 
APPENDIX 0

GEOTECHNICAL PROPERTIES: PARTIALLY SATURATED ZONE

CHARACTERISTICS OF THE SKAGIT/HANFORD

INTRODUCTION

The hydrology of the partially saturated (vadose) zone $e^{(a)}$ at the Department of Energy Hanford Site has been of considerable interest for the past 15 to 20 years (Reisenauer 1963; Brownell et al. 1975; Isaacson and Brown 1978; Jones 1978; Jones and Gee 1984). Hydrologic interest has centered on the use of the vadose zone at Hanford as a long-term radioactive waste storage area. The vadose zone can also be considered a buffer or delay zone that can extend the travel time of contaminants that might potentially seep to groundwater from waste processing operations or power-production facilities. The safety of buried radioactive wastes depends in part upon the hydrologic isolation of the radionuclides from the relatively deep ground-water table at Hanford (Galley 1966; National Academy of Sciences 1957, 1976, 1978).

Past work at the Hanford site indicated that the vadose zone sediments remain fairly dry under the existing arid climate conditions (Enfield, Hsieh and Warrick 1973; Jones 1978; Jones and Gee 1984). However, the soils and sediments at the Hanford site, although highly variable, are generally coarse in texture and drain readily (Newcomb, Strand and Frank 1972; Routson and Fecht 1979). When excess water (from irrigation, liquid waste disposal, or increased precipitation) is applied at the surface, these soils and sediments can readily transmit water downward below the root zone such that further additions of water can be a source for deep drainage to the water table. Recent studies indicate that, when above-normal precipitation occurs,

(a) The partially saturated (vadose) zone can be defined as the zone of geologic material (e.g., soils, sediments, and rocks) that lies between the land surface and the deepest water table. Generally, water in this zone is under pressure that is less than atmospheric (sometimes called negative pressure). At least some of the soil voids contain air or other gases at or near atmospheric pressure. At the Hanford site, this zone ranges from $15 \mathrm{~m}(45 \mathrm{ft})$ to over $100 \mathrm{~m}(300 \mathrm{ft})$. 
significant amounts of water can be transmitted below the root zone on coarse-textured soils at the Hanford site (Jones and Gee 1984; Kirkham and Gee 1984). Unfortunately, only limited hydrologic characterization has been completed on the Hanford site sediments; hence, the analys is of vadose zone water flow remains incomplete.

This report documents a recent effort to hydrologically characterize vadose zone sediments at the Hanford site. The report details measurements of field water contents for samples collected from five boreholes drilled in the vicinity of the Skagit Hanford site Nuclear Project, a few kilometers west of the Wye barricade and about $15 \mathrm{~km}$ north of Richland, Washington. Capiliary pressure (matric water potential) laboratory analysis data were taken on samples from three of the five holes. Laboratory analyses were performed to determine field moisture content, water potential, water retention characteris tics, hydraulic conductivity, particle size analysis, calcium carbonate content, $\mathrm{pH}$, and electrical conductivity. Results are tabulated by hole and depth, and a general discussion concerning the use of this information for hydrologic modeling is provided.

\section{METHOD}

\section{SAMPLING}

Samples from four of the five boreholes were taken in approximately $1.5-m$ segments. From each core segment, a $0.5-\mathrm{m}$ section was saved for laboratory analysis in sealed airtight plastic buckets. From borehole \#5, each core segment was saved in $0.75-m$ sections for a complete field water content analysis over the entire profile. All other analyses for borehole $\$ 5$ were performed on only the odd-numbered samples, to be consistent with the other boreholes; that is, a $0.5-m$ section of every odd-numbered $1.5-m$ segment was used for analysis.

Samples were collected from the depth of the water table or from the depth where further drilling became impossible, whichever was deeper. For boreholes $\# 2$ through $\# 5$, water was added to a drilling lubricant at about 25 to $28 \mathrm{~m}$; therefore, no water contents were obtained for the samples taken at this level. 
Forty samples, eight from each borehole, were chosen for detailed analy sis, based on visual texture changes down through the profile. One sample was selected to represent each of the visually distinct layers in the profile.

\section{SOIL PROPERTIES PROCEDURES}

\section{Field Moisture Content}

Field moisture content was determined on all samples. Samples were taken at the depths indicated in the previous section, by core borehole techniques and placed immediately in vapor-tight containers in the field. The samples were first logged into the laboratory using the field log information recorded on the buckets. Before the seal was broken on the lid, the samples were mixed by rolling the bucket to evenly distribute the water and to readsorb the condensation on the lid. Subsamples for moisture content were taken quickly to ensure minimum water loss caused by evaporation. These subsamples were weighed and oven-dried $\left(16 \mathrm{~h}\right.$ or more at $\left.110^{\circ} \mathrm{C}\right)$ to determine moisture content according to ASTM procedure D 2216 (ASTM 1980).

Water Potential

When subsamples were taken from boreholes \#3 through \#5 for the field moisture content analysis, a second set of subsamples was collected to determine the water potential at the field moisture content. A comercial psychrometer sample changer(a) was used to determine the water potential. The samples were packed into small cups $1.4 \mathrm{~cm} \times 1.2 \mathrm{~cm}$ (diameter $\times$ height). The cups were put into vapor-tight chambers in the psychrometer sample changer. After approximately $1 \mathrm{~h}$, the relative humidity was measured with a miniature thermocouple psychrometer. The psychrometer measures the wet bulb depression (humidity) in a closed chamber directly above the sample using a miniature thermocouple connected to a microvolt sensing unit. The equilibrium vapor pressure, or relative humidity, can be related directly to the water potential of the water in the sample (Campbell 1977). The relationship between the water potential and the relative humidity can be written as:

$$
\psi=-R T / M \ln (R H / 100)
$$


where

$$
\begin{aligned}
\psi & =\text { total water potential } \\
\mathrm{R} & =\text { universal gas constant } \\
\mathrm{T} & =\text { Kelvin temperature } M=\text { molecular weight of water } \\
\mathrm{RH} & =\text { relative humidity. }
\end{aligned}
$$

\section{Particle Size}

Particle size was determined on two separate bases. The particles larger than 2 man were determined by dry sieve analysis using sieve sizes of 3 in., 2 in., 1 in., $3 / 4$ in., $1 / 2$ in., No. 4 and No. 10 mesh (Tyler numbers). Size distribution was done in accordance with ASTM procedure D 422 (ASTM 1972). For all samples, sand, silt and clay distribution was determined based on only the less than 2-rmm sized particles from each large sample. The 40 predetermined samples were analyzed for a complete distribution curve, except for dispersion of the sample, of the particle sizes by ASTM procedure D 422 . Sample dispersion was done using an ultrasonic homogenizer for more complete dispersion of the particles.

\section{Water Retention}

Water retention characteristics were measured at $0.1,1.0$, and 15.0 bars applied pressure for each sample using a pressure plate extractor obtained from Soilsmoisture Equipment Corp., Santa Barbara, California. Equilibrium water contents were obtained by packing samples in containing rings on a porous ceramic plate where they were saturated and pressure-drained in the extractor.

Both the samples and porous plate were brought to saturation by allowing an excess of water to stand on the surface of the plate for $24 \mathrm{~h}$. On complete saturation, the plate was placed in the extractor vessel and the internal air pressure rajsed to the desired test level. Equilibrium was reached when the drajnage ceased. At the end of the run, the samples were weighed and ovendried to determine the moisture contents. Water content data are tabulated in terms of the associated matric water potential expressed in -bars. At equili brium, the applied pressure is equal to the matric water potential (Richards 1965). 


\section{Hydraulic Conductivity}

Hydraulic conductivity of each of the 40 predetermined samples was deter mined using a falling water head method of analysis (Klute 1965). In this method, the sample is placed in a container and enclosed with lids having an inflow valve at one end and an outflow valve at the other end. The inflow valve is connected to a standpipe of a known cross-sectional area and height. The sample is saturated before any test runs are done. An initial head in the standpipe is recorded, and water is allowed to flow from the standpipe through the sample for a given length of time. The ending head level in the standpipe is recorded. The hydraulic conductivity is determined using the following equation:

$$
K=(a L / A t) \ln (H 1 / H 2)
$$

where

$$
\begin{aligned}
a= & \text { cross-sectional area of the standpipe } \\
L= & \text { length of the sample } \\
A= & \text { cross-sectional area of the sample } \\
t= & \text { time for the hydraulic head difference } \\
& \text { to decrease from } H 1 \text { to } H 2 .
\end{aligned}
$$

The hydraulic conductivity values were determined on an average of five falling head runs over a period of several minutes or several hours, depending on the flow rate, and at room temperature $\left(22 \pm 2^{\circ} \mathrm{C}\right)$.

\section{Chemistry}

The cation exchange capacity (CEC) for each of the 40 samples tested was done by sodium saturation and sodium determination by atomic adsorption (Chapman 1965). The CaCO3 content was determined using a volumetric calcimeter method (Allison and Moodie 1965). The pH and electrical conductivity were determined on a $1: 1$ soil extract (Bower and Wilcox 1965). 


\section{RESULTS AND DISCUSSION}

SOILS AND WELL DESCRIPTION

Field Operations

Collection of field samples for testing of the unsaturated zone at the in this was initiated in November 1983 and completed in late December of the same year. Five sites were selected for collection of samples. These sites were located at the approximate corners of the primary site and near the center of the proposed reactor location. The four corner holes were drilled and then backfilled with clean materials. The centrally iocated test hole was cased to its entire depth and preserved as a site for repeatable soil moisture analyses using radioactive logging techniques. Samples were collected using a percussion drilling machine and drive-barrel tools. The drive barrel inside diameter was $12.7 \mathrm{~cm}$ (5 in.); its length changed over the course of operations because of reforming and refurbishing. The operating procedure was as follows:

1. Set up drilling machine over selected hole location.

2. Drive sampler tube to maximum capacity.

3. Measure depth of hole and record.

4. Empty sample tube into sample container.

5. Lower drive sampler back into hole; remeasure depth and record.

6. Repeat steps 2 through 5 .

The onsite geologist then marked the sample container and its lid according to well location and sample number. Sample containers were filled to as near capacity as feasible and then sealed to prevent moisture gain or loss during handling. Samples were transported to the laboratory at the end of each drilling day, or as soon as possible. The containers were covered during each intervening sample run to minimize soil moisture changes caused by atmospheric contact. At the four corner locations, a $0.5 \mathrm{~m}$ sample was collected from each $1.5-\mathrm{m}(5-\mathrm{ft})$ intervals. Continuous sampling was carried out at the central location. Sample volume was a nominal $19 \mathrm{~L}$ (5 gal). The target depth for each 6 of the holes was to the regional water table. The method selected was such that, except under extremely adverse conditions, no 
drilling fluid would be needed. This assured that the samples obtained were representative of the actual conditions at depth. Heavy gravels were encountered in each of the holes near the water table. It became necessary to change over from drive- barrel methods to hard tools in four of the five holes. This changeover resulted in the lowermost samples being inappropriate for water-content analysis and biased the particle-size analysis toward the smaller size range.

\section{PHYSICAL CHARACTERIZATION}

Heterogeneity

Tables 0.1 and 0.2 list the results of the physical characterization completed for all samples from the five boreholes. Sieve analysis results confirm that, at this site, the soils are typically coarse-textured, with clay contents of all samples generally $\$ 5 \%$ and sand contents ranging from 60 to $90 \%$ or more. Silt contents varied considerably, ranging from $\$ 10$ to $\$ 60 \%$. The gravel and stone content of the material was also highly variable, ranging from 0 to over $60 \%$ by weight. The particle-size distributions for these materials reflect an extremely heterogeneous profile indicative of the glacial-fluvial processes that were responsible for the formation of the sediment layers (Routson and Fecht 1979).

Moisture

Previous reports (McHenry 1957; Benson, Nelson and Alkine 1963; Routson and Fecht 1979) have documented soil properties. However, none clearly documents the field moisture status of the sediment profiles sampled. The Routson and Fecht (1979) study of 12 wells located south of the 200 East Area reported moisture contents, but indicated that the values (ranging from 0.2 to $3.2 \mathrm{wt} \%$ ) represented a "minimum moisture;" the authors suggested that most samples had dried during storage, prior to analysis.

As indicated in the description of sampling and methods, we designed the study primarily to assess the moisture content of the sediment profile. The field moisture content values reported in Table 0.1 are generally higher than those reported by Routson and Fecht (1979). The values that we measured 
TABLE D.1. Moisture Analys is

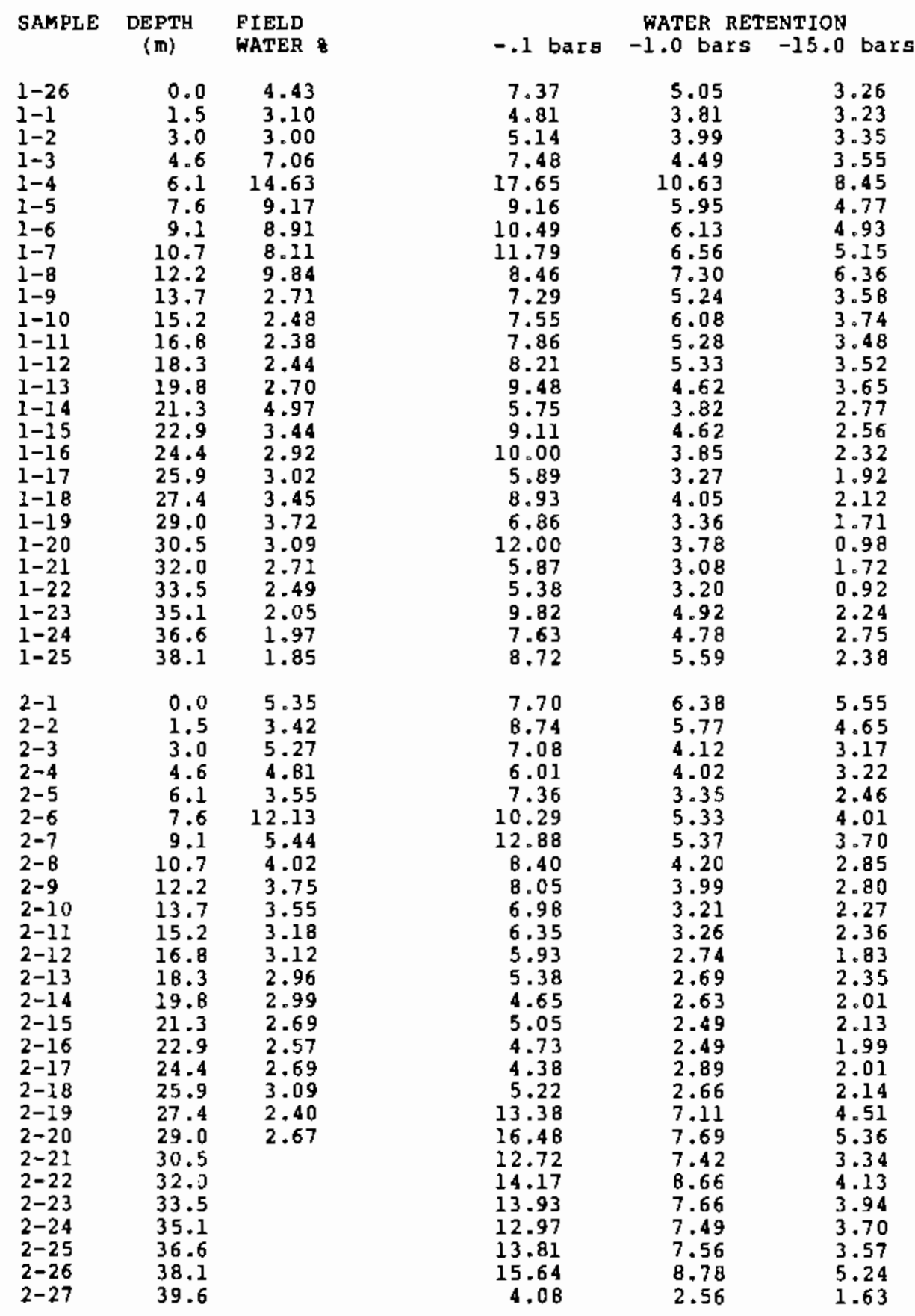

D. 8 
TABLE D.1. (contd)

\begin{tabular}{|c|c|c|c|c|c|}
\hline \multirow[t]{2}{*}{ SAMPLE } & \multirow{2}{*}{$\begin{array}{l}\text { DEPTH } \\
(\mathrm{m})\end{array}$} & \multirow{2}{*}{$\begin{array}{l}\text { FIELD } \\
\text { WATER }\end{array}$} & \multicolumn{3}{|c|}{ WATER RETENTION } \\
\hline & & & -.1 bars & -1.0 bars & -15.0 bars \\
\hline $\begin{array}{l}3-1 \\
3-2 \\
3-3 \\
3-4 \\
3-5 \\
3-6 \\
3-7 \\
3-8 \\
3-9 \\
3-10 \\
3-11 \\
3-12 \\
3-13 \\
3-14 \\
3-15 \\
3-16 \\
3-17 \\
3-18 \\
3-19 \\
3-20 \\
3-21 \\
3-22 \\
3-23 \\
3-24 \\
3-25 \\
3-26\end{array}$ & $\begin{array}{l}0.0 \\
3.0 \\
4.6 \\
6.1 \\
7.6 \\
9.1 \\
10.7 \\
12.2 \\
13.7 \\
15.2 \\
16.8 \\
18.3 \\
19.8 \\
21.3 \\
22.9 \\
24.4 \\
25.9 \\
27.4 \\
29.0 \\
30.5 \\
32.0 \\
33.5 \\
35.1 \\
36.6 \\
38.1 \\
39.6\end{array}$ & $\begin{array}{l}5.87 \\
6.67 \\
8.74 \\
4.80 \\
4.23 \\
4.55 \\
4.89 \\
5.53 \\
6.16 \\
5.32 \\
6.78 \\
5.50 \\
6.47 \\
5.02 \\
4.07 \\
4.00 \\
3.54\end{array}$ & $\begin{array}{r}4.57 \\
7.72 \\
8.14 \\
5.59 \\
5.60 \\
5.78 \\
4.89 \\
5.77 \\
5.65 \\
5.92 \\
5.59 \\
5.67 \\
7.69 \\
5.05 \\
4.59 \\
2.52 \\
4.08 \\
13.83 \\
12.56 \\
14.18 \\
12.88 \\
14.30 \\
12.12 \\
12.77 \\
13.26 \\
11.84\end{array}$ & $\begin{array}{l}2.55 \\
3.74 \\
4.50 \\
3.53 \\
3.91 \\
4.62 \\
3.87 \\
4.07 \\
4.48 \\
3.91 \\
4.00 \\
3.92 \\
2.22 \\
2.62 \\
3.11 \\
2.30 \\
3.71 \\
7.00 \\
8.46 \\
8.64 \\
7.37 \\
7.79 \\
6.50 \\
7.47 \\
7.83 \\
6.86\end{array}$ & $\begin{array}{l}2.35 \\
3.38 \\
3.43 \\
2.77 \\
2.68 \\
3.35 \\
3.19 \\
3.21 \\
2.95 \\
2.68 \\
2.89 \\
2.90 \\
2.70 \\
1.64 \\
2.54 \\
2.12 \\
3.10 \\
3.51 \\
4.52 \\
4.14 \\
3.96 \\
3.79 \\
3.46 \\
3.81 \\
4.03 \\
3.41\end{array}$ \\
\hline $\begin{array}{l}4-1 \\
4-2 \\
4-3 \\
4-4 \\
4-5 \\
4-6 \\
4-7 \\
4-8 \\
4-9 \\
4-10 \\
4-11 \\
4-12 \\
4-13 \\
4-14 \\
4-15 \\
4-16 \\
4-17 \\
4-18 \\
4-19 \\
4-20 \\
4-21 \\
4-22 \\
4-23 \\
4-24 \\
4-25\end{array}$ & $\begin{array}{r}0.0 \\
3.0 \\
4.6 \\
6.1 \\
7.6 \\
9.1 \\
10.7 \\
12.2 \\
13.7 \\
15.2 \\
16.8 \\
18.3 \\
19.8 \\
21.3 \\
22.9 \\
24.4 \\
25.9 \\
27.4 \\
29.0 \\
30.5 \\
32.0 \\
33.5 \\
35.1 \\
36.6 \\
38.1\end{array}$ & $\begin{array}{r}5.63 \\
4.36 \\
4.68 \\
10.86 \\
3.68 \\
3.17 \\
3.52 \\
3.82 \\
3.97 \\
4.14 \\
2.79 \\
2.27 \\
2.35 \\
2.46 \\
2.49 \\
2.25\end{array}$ & $\begin{array}{r}3.09 \\
4.75 \\
6.03 \\
9.51 \\
4.60 \\
4.09 \\
4.78 \\
4.41 \\
4.28 \\
5.58 \\
6.31 \\
10.00 \\
8.43 \\
5.78 \\
7.41 \\
6.47 \\
15.71 \\
14.09 \\
12.00 \\
14.29 \\
16.28 \\
19.32 \\
18.49 \\
11.17 \\
17.67\end{array}$ & $\begin{array}{l}2.93 \\
4.30 \\
5.82 \\
8.81 \\
4.43 \\
3.95 \\
3.70 \\
3.66 \\
3.78 \\
4.24 \\
3.79 \\
5.55 \\
4.62 \\
3.42 \\
4.17 \\
3.70 \\
8.82 \\
8.05 \\
8.54 \\
8.21 \\
7.88 \\
8.20 \\
9.68 \\
4.34 \\
8.85\end{array}$ & $\begin{array}{l}2.79 \\
3.77 \\
5.32 \\
6.50 \\
3.70 \\
3.19 \\
3.62 \\
3.61 \\
3.69 \\
3.51 \\
3.19 \\
3.40 \\
3.11 \\
2.50 \\
2.38 \\
2.86 \\
4.42 \\
4.20 \\
3.56 \\
3.80 \\
3.60 \\
3.81 \\
3.99 \\
2.06 \\
3.31\end{array}$ \\
\hline
\end{tabular}


TABLE D.1. (contd)

\begin{tabular}{|c|c|c|}
\hline SAMPLE & $\begin{array}{c}\text { DE PTH } \\
(m)\end{array}$ & $\begin{array}{l}\text { EIELD } \\
\text { HATER }\end{array}$ \\
\hline $\begin{array}{l}5-1 \\
5-2 \\
5-3 \\
5-4 \\
5-5 \\
5-6 \\
5-7 \\
5-8 \\
5-9 \\
5-10 \\
5-11 \\
5-12 \\
5-13 \\
5-14 \\
5-15 \\
5-16 \\
5-17 \\
5-18 \\
5-19 \\
5-20 \\
5-21 \\
5-22 \\
5-23 \\
5-24 \\
5-25 \\
5-26 \\
5-27 \\
5-28 \\
5-29 \\
5-30 \\
5-31 \\
5-32 \\
5-33 \\
5-34 \\
5-35 \\
5-36 \\
5-37 \\
5-38 \\
5-39 \\
5-40 \\
5-41 \\
5-42 \\
5-43 \\
5-44 \\
5-45 \\
5-46 \\
5-47 \\
5-48 \\
5-49 \\
5-50 \\
5-51 \\
5-52 \\
5-53 \\
5-54 \\
5-55 \\
5-56\end{array}$ & $\begin{array}{r}0.0 \\
1.5 \\
2.1 \\
3.0 \\
3.7 \\
4.0 \\
4.6 \\
5.2 \\
6.1 \\
6.7 \\
7.6 \\
7.9 \\
8.8 \\
9.4 \\
10.1 \\
10.2 \\
11.3 \\
11.9 \\
12.8 \\
13.4 \\
14.3 \\
14.9 \\
15.2 \\
16.2 \\
16.8 \\
17.4 \\
17.7 \\
18.6 \\
19.2 \\
19.8 \\
20.1 \\
20.7 \\
21.3 \\
22.3 \\
22.9 \\
23.5 \\
23.8 \\
24.4 \\
25.0 \\
25.3 \\
25.9 \\
26.5 \\
27.1 \\
27.4 \\
28.0 \\
28.3 \\
29.0 \\
30.2 \\
31.1 \\
31.7 \\
32.9 \\
33.8 \\
34.4 \\
35.4 \\
36.0 \\
36.9\end{array}$ & $\begin{array}{l}5.41 \\
5.47 \\
3.24 \\
3.98 \\
4.01 \\
4.51 \\
4.93 \\
4.51 \\
4.68 \\
4.53 \\
4.82 \\
4.24 \\
4.42 \\
5.48 \\
5.59 \\
4.79 \\
7.00 \\
8.02 \\
9.64 \\
5.57 \\
4.41 \\
3.66 \\
4.08 \\
3.86 \\
3.70 \\
3.54 \\
3.29 \\
3.37 \\
3.86 \\
3.42 \\
3.96 \\
3.86 \\
4.11 \\
3.76 \\
3.72 \\
3.38 \\
3.08 \\
3.15 \\
2.87 \\
2.97 \\
2.93 \\
2.59 \\
2.71 \\
2.54 \\
2.30 \\
3.48 \\
3.93\end{array}$ \\
\hline
\end{tabular}

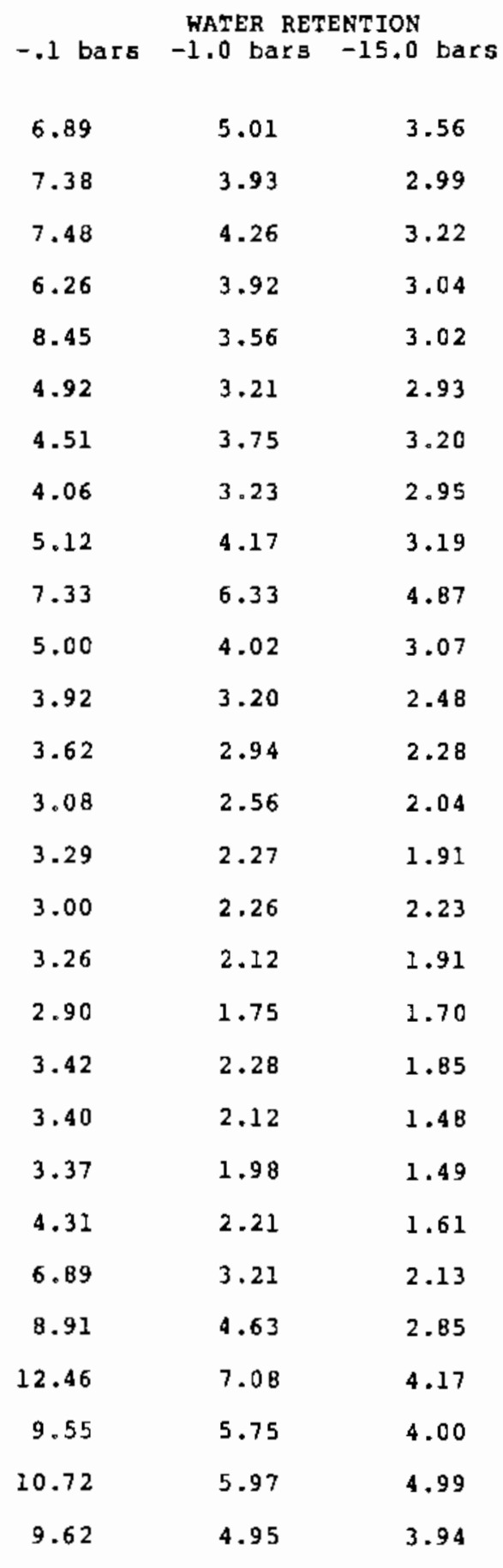


TABLE D.2. Mechanical Analys is

\begin{tabular}{|c|c|c|c|c|c|}
\hline SAMPLE & $\begin{array}{c}\text { DEPTH } \\
\text { (m) }\end{array}$ & $1>2 \mathrm{MM}$ & ISAND & $\$$ SILT & $\$$ CLAY \\
\hline $\begin{array}{l}1-26 \\
1-1 \\
1-2 \\
1-3 \\
i-4 \\
1-5 \\
1-6 \\
1-7 \\
1-8 \\
i-9 \\
1-10 \\
1-11 \\
1-12 \\
1-13 \\
1-14 \\
1-15 \\
1-16 \\
1-17 \\
1-18 \\
1-19 \\
1-20 \\
i-21 \\
1-22 \\
i-23 \\
i-24 \\
1-25\end{array}$ & $\begin{array}{l}0.0 \\
1.5 \\
3.0 \\
4.6 \\
6.1 \\
7.6 \\
9.1 \\
10.7 \\
12.2 \\
13.7 \\
15.2 \\
16.8 \\
18.3 \\
19.8 \\
21.3 \\
22.9 \\
24.4 \\
25.9 \\
27.4 \\
29.0 \\
30.5 \\
32.0 \\
33.5 \\
35.1 \\
36.6 \\
38.1\end{array}$ & $\begin{array}{r}22.00 \\
13.38 \\
19.77 \\
4.62 \\
0.00 \\
0.00 \\
0.00 \\
0.00 \\
0.00 \\
62.89 \\
47.80 \\
55.70 \\
53.30 \\
48.06 \\
31.96 \\
20.38 \\
30.01 \\
23.81 \\
2.20 \\
8.21 \\
16.29 \\
1.34 \\
11.71 \\
54.87 \\
47.54 \\
40.35\end{array}$ & $\begin{array}{l}63.77 \\
80.03 \\
70.77 \\
82.26 \\
72.19 \\
84.93 \\
80.62 \\
79.01 \\
80.49 \\
30.08 \\
35.93 \\
32.31 \\
29.10 \\
32.68 \\
56.62 \\
65.88 \\
60.89 \\
67.23 \\
86.99 \\
83.14 \\
73.13 \\
88.53 \\
78.90 \\
36.49 \\
42.83 \\
46.46\end{array}$ & $\begin{array}{r}31.69 \\
17.94 \\
26.33 \\
15.07 \\
22.72 \\
12.36 \\
16.23 \\
17.81 \\
15.40 \\
65.47 \\
58.47 \\
63.64 \\
63.93 \\
62.75 \\
39.37 \\
30.72 \\
36.50 \\
30.50 \\
10.78 \\
14.41 \\
24.34 \\
9.16 \\
18.51 \\
59.25 \\
53.43 \\
49.21\end{array}$ & $\begin{array}{l}4.54 \\
2.03 \\
2.90 \\
2.67 \\
5.06 \\
2.71 \\
3.15 \\
3.18 \\
4.12 \\
3.45 \\
5.60 \\
4.15 \\
6.97 \\
4.57 \\
4.01 \\
3.40 \\
2.61 \\
2.27 \\
2.23 \\
2.45 \\
2.53 \\
2.31 \\
2.59 \\
4.26 \\
3.74 \\
4.33\end{array}$ \\
\hline $\begin{array}{l}2-1 \\
2-2 \\
2-3 \\
2-4 \\
2-5 \\
2-6 \\
2-7 \\
2-8 \\
2-9 \\
2-10 \\
2-11 \\
2-12 \\
2-13 \\
2-14 \\
2-15 \\
2-16 \\
2-17 \\
2-18 \\
2-19 \\
2-20 \\
2-21 \\
2-22 \\
2-23 \\
2-24 \\
2-25 \\
2-26 \\
2-27\end{array}$ & $\begin{array}{r}0.0 \\
1.5 \\
3.0 \\
4.6 \\
6.1 \\
7.6 \\
9.1 \\
10.7 \\
12.2 \\
13.7 \\
15.2 \\
16.8 \\
18.3 \\
19.8 \\
21.3 \\
22.9 \\
24.4 \\
25.9 \\
27.4 \\
29.0 \\
30.5 \\
32.0 \\
33.5 \\
35.1 \\
36.6 \\
38.1 \\
39.6\end{array}$ & $\begin{array}{r}37.21 \\
40.11 \\
14.74 \\
27.41 \\
27.06 \\
2.67 \\
0.50 \\
0.86 \\
1.58 \\
12.30 \\
11.57 \\
4.69 \\
5.08 \\
3.26 \\
2.56 \\
3.37 \\
1.73 \\
1.36 \\
55.81 \\
45.59 \\
36.68 \\
24.76 \\
15.19 \\
26.55 \\
13.53 \\
0.45 \\
14.45\end{array}$ & $\begin{array}{l}83.12 \\
81.40 \\
88.66 \\
86.90 \\
88.67 \\
78.47 \\
81.94 \\
85.66 \\
91.15 \\
90.45 \\
92.41 \\
89.89 \\
93.11 \\
90.28 \\
91.76 \\
91.33 \\
94.44 \\
93.76 \\
68.01 \\
66.23 \\
69.65 \\
60.55 \\
69.75 \\
66.49 \\
66.78 \\
32.42 \\
90.69\end{array}$ & $\begin{array}{r}12.96 \\
13.83 \\
9.35 \\
11.82 \\
8.67 \\
17.00 \\
14.30 \\
11.64 \\
6.92 \\
9.22 \\
6.11 \\
8.54 \\
5.97 \\
7.55 \\
6.15 \\
7.05 \\
3.64 \\
4.83 \\
27.95 \\
28.69 \\
23.03 \\
28.97 \\
22.30 \\
24.64 \\
24.71 \\
50.06 \\
5.53\end{array}$ & $\begin{array}{r}3.92 \\
4.77 \\
1.99 \\
1.28 \\
2.56 \\
4.53 \\
3.76 \\
2.70 \\
1.53 \\
0.33 \\
1.48 \\
1.57 \\
0.92 \\
2.97 \\
2.09 \\
1.62 \\
1.92 \\
1.41 \\
4.04 \\
5.08 \\
7.32 \\
10.48 \\
7.95 \\
8.87 \\
8.51 \\
17.52 \\
3.78\end{array}$ \\
\hline
\end{tabular}

D. 11 
TABLE D.2. (contd)

\begin{tabular}{|c|c|c|c|c|c|}
\hline SAMPLE & $\begin{array}{c}\text { OEPTH } \\
(\mathrm{m})\end{array}$ & $x>2 \mathrm{MH}$ & $\$$ SAND & $\$ S I L T$ & \&LAY \\
\hline $\begin{array}{l}3-1 \\
3-2 \\
3-3 \\
3-4 \\
3-5 \\
3-6 \\
3-7 \\
3-8 \\
3-9 \\
3-10 \\
3-11 \\
3-12 \\
3-13 \\
3-14 \\
3-15 \\
3-16 \\
3-97 \\
3-98 \\
3-19 \\
3-20 \\
3-21 \\
3-22 \\
3-23 \\
3-24 \\
3-25 \\
3-26\end{array}$ & $\begin{array}{l}0.0 \\
3.0 \\
4.6 \\
6.1 \\
7.6 \\
9.1 \\
10.7 \\
12.2 \\
13.7 \\
15.2 \\
16.8 \\
18.3 \\
19.8 \\
21.3 \\
22.9 \\
24.4 \\
25.9 \\
27.4 \\
29.0 \\
30.5 \\
32.0 \\
33.5 \\
35.1 \\
36.6 \\
38.1 \\
39.6\end{array}$ & $\begin{array}{r}0.10 \\
0.00 \\
0.00 \\
4.00 \\
9.19 \\
14.37 \\
8.36 \\
1.98 \\
6.96 \\
13.41 \\
4.09 \\
11.22 \\
0.07 \\
0.39 \\
4.89 \\
5.50 \\
39.53 \\
30.11 \\
21.59 \\
25.51 \\
30.11 \\
27.76 \\
40.14 \\
33.81 \\
37.25 \\
18.66\end{array}$ & $\begin{array}{l}88.58 \\
84.81 \\
86.98 \\
86.94 \\
88.44 \\
88.21 \\
89.04 \\
88.29 \\
90.61 \\
91.62 \\
89.81 \\
91.36 \\
86.66 \\
88.57 \\
90.62 \\
89.59 \\
88.16 \\
69.15 \\
69.58 \\
66.93 \\
88.38 \\
74.22 \\
52.36 \\
62.87 \\
67.68 \\
70.63\end{array}$ & $\begin{array}{r}9.54 \\
12.70 \\
10.44 \\
10.84 \\
8.48 \\
8.26 \\
7.88 \\
9.86 \\
7.07 \\
6.06 \\
7.74 \\
6.39 \\
10.48 \\
8.94 \\
6.59 \\
7.83 \\
8.73 \\
24.47 \\
22.49 \\
26.68 \\
6.29 \\
19.26 \\
49.23 \\
30.99 \\
24.89 \\
23.49\end{array}$ & $\begin{array}{l}1.88 \\
2.49 \\
2.58 \\
2.23 \\
3.08 \\
3.53 \\
3.08 \\
2.05 \\
2.32 \\
2.32 \\
2.45 \\
2.25 \\
2.86 \\
3.29 \\
2.79 \\
2.58 \\
3.11 \\
6.38 \\
7.93 \\
6.39 \\
5.33 \\
6.52 \\
6.41 \\
6.22 \\
7.43 \\
5.88\end{array}$ \\
\hline $\begin{array}{l}4-1 \\
4-2 \\
4-3 \\
4-4 \\
4-5 \\
4-6 \\
4-7 \\
4-8 \\
4-9 \\
4-10 \\
4-11 \\
4-12 \\
4-13 \\
4-14 \\
4-15 \\
4-16 \\
4-17 \\
4-18 \\
4-19 \\
4-20 \\
4-21 \\
4-22 \\
4-23 \\
4-24 \\
4-25\end{array}$ & $\begin{array}{l}0.0 \\
3.0 \\
4.6 \\
6.1 \\
7.6 \\
9.1 \\
10.7 \\
12.2 \\
13.7 \\
15.2 \\
16.8 \\
18.3 \\
19.8 \\
21.3 \\
22.9 \\
24.4 \\
25.9 \\
27.4 \\
29.0 \\
30.5 \\
32.0 \\
33.5 \\
35.1 \\
36.6 \\
38.1\end{array}$ & $\begin{array}{r}0.61 \\
9.73 \\
39.27 \\
0.00 \\
1.36 \\
5.90 \\
1.67 \\
6.41 \\
9.54 \\
1.11 \\
39.24 \\
45.71 \\
58.76 \\
46.78 \\
41.52 \\
27.51 \\
27.72 \\
26.29 \\
23.09 \\
22.34 \\
32.91 \\
18.46 \\
1.38 \\
16.73 \\
2.93\end{array}$ & $\begin{array}{l}95.37 \\
90.01 \\
85.10 \\
81.02 \\
92.78 \\
89.13 \\
88.79 \\
90.84 \\
90.63 \\
90.19 \\
77.63 \\
67.54 \\
70.97 \\
80.07 \\
73.26 \\
78.39 \\
62.03 \\
64.83 \\
65.19 \\
66.28 \\
67.76 \\
62.83 \\
64.82 \\
82.23 \\
63.01\end{array}$ & $\begin{array}{r}2.34 \\
7.34 \\
11.63 \\
14.18 \\
5.14 \\
10.14 \\
8.99 \\
7.09 \\
7.21 \\
7.72 \\
19.19 \\
27.17 \\
24.64 \\
17.17 \\
22.08 \\
18.16 \\
34.88 \\
29.21 \\
28.77 \\
27.56 \\
26.48 \\
31.80 \\
30.08 \\
14.88 \\
28.67\end{array}$ & $\begin{array}{l}2.29 \\
2.65 \\
3.27 \\
4.80 \\
2.08 \\
0.73 \\
2.22 \\
2.07 \\
2.16 \\
2.09 \\
3.18 \\
5.29 \\
4.39 \\
2.78 \\
4.66 \\
3.45 \\
3.09 \\
5.96 \\
6.04 \\
6.16 \\
5.76 \\
5.37 \\
5.10 \\
2.89 \\
8.32\end{array}$ \\
\hline
\end{tabular}


TABLE D.2. (contd)

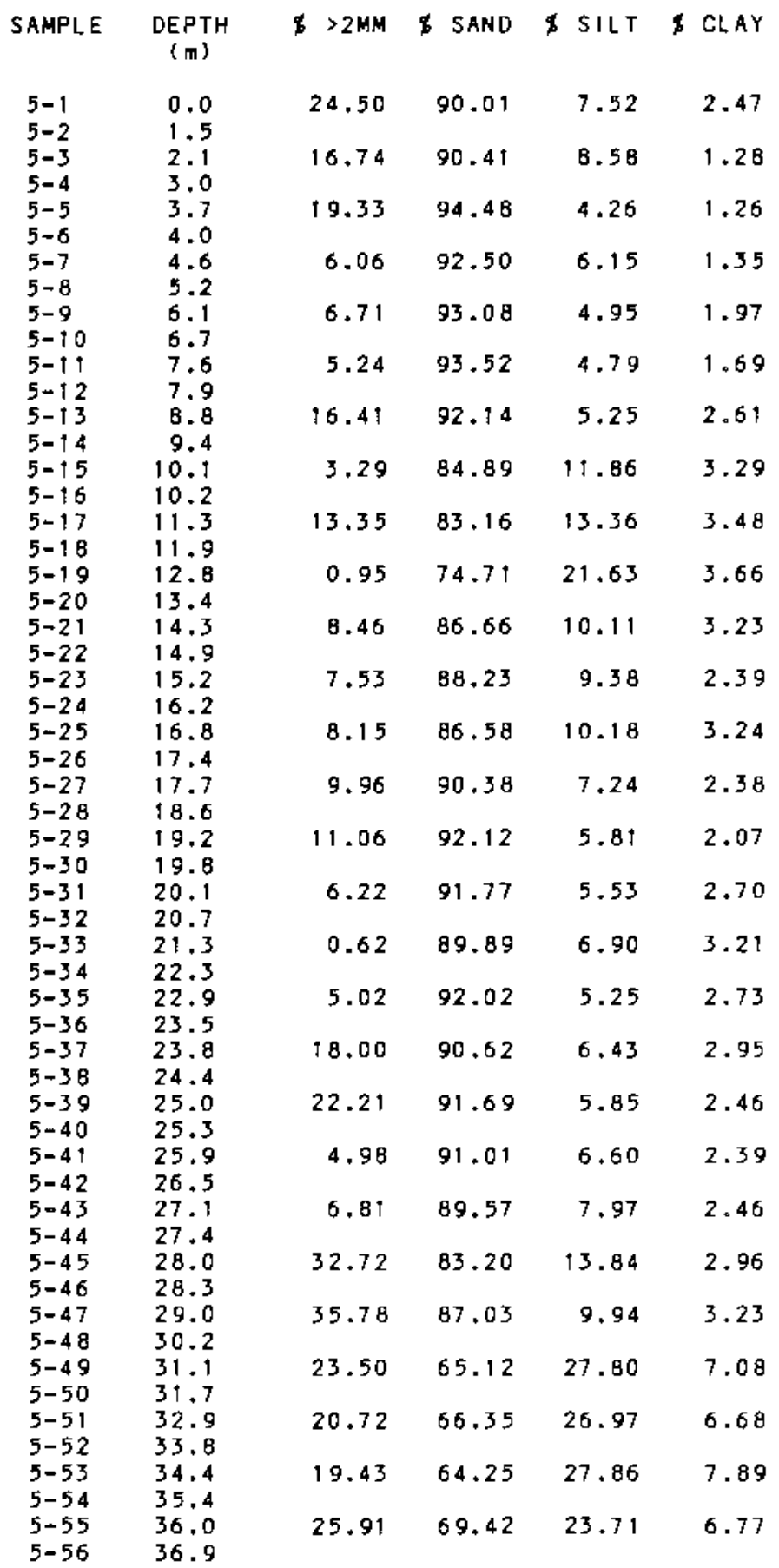

ก. 13 
ranged from 2 to $15 \mathrm{wt} \%$. The higher field moisture contents (those above 10\%) appear to be associated with fine-textured sediments containing fairly high water- retention values at metric potential at -0.1 bar. Based on the measured water- retention values, the bulk of the data indicate wetness values that are consistent with moisture contents associated with a draining profile (0- to -1-bar capillary pressure), particularly in the region from 5 to $20 \mathrm{~m}$ deep. The moisture data at depths below 25 to 30 m are unavailable in all but hole $\# 1$ because of difficulties in obtaining core material from the very coarse gravel/soil layers at this site. The data from hole \#I indicate some desicca tion at depth, but this is very difficult to interpret. In general, the lowest water contents were found at the lowest depths, but the lower depths (i.e., below f20 m) also tended to be associated with the coarsest soils (i.e., 2-mm fragments exceeding 60\%). Hole \#3 yielded the most uniformly wet profile, indicating that moisture redistribution and drainage had extended to depths below $25 \mathrm{~m}$. All field moistures at this hole were consistently wetter than the measured -1-bar capillary pressure, suggesting that drainage was occurring and that evaporation was likely not occurring at depth.

\section{Water Potential}

The measured total water potential was reported to be wetter than -1 bar for all but samples measured in hole \#4. These data confirm that, in general, the soil remained wet at depth at this site. The data meausred from hole \#4 remain to be explained. A water potential at -5 bars (Sample 4-14) adjacent to a sample at -1 bars (Sample 4-15) is not consistent with the concepts of equilibrium (e.g., the samples at depth should indicated equal to slowly varying water potential. Silt content of the soil solution, sample desiccation, or measurement error are possible explanations for the observed water potential. Careful and detailed measure ment of 17 samples from hole \#3 and 47 samples from hole \#5 indicated that no samples to depths of $29 \mathrm{~m}$ had water potentials drier than -1 bars. The resolu tion of the water potential sensing unit is 1 bar. However, we also deter mined from pressure plate tests that, in general, all samples with total water potential was $\S 1$ bar also had metric potentiat wetter than -1 bar. These data support the concept of a draining profile at this site. 
Hydraulic Conductivity

A1i measurements were made on disturbed samples. The course sediments made it impossible to sample without noticeable segregation of material. Tables D.3 and D.4 give detailed characterization for the sand ( $<2-\mathrm{mm}$ size) frac tion for eight samples from each of the five boreholes tested. Included in Table $D .3$ are measured hydrautic conductivity values. The measured conduc tivities vary from $10-3$ to $10-5 \mathrm{~cm} / \mathrm{s}$ and under the compaction conditions, reflect moderately high permeabilities indicative of samples with a wide range of particle sizes. Because of large fragments present in many of the samples, an attempt was made to estimate the effect of coarse fragments on the packing. The conductivity was calculated using a method described by Bouwer and Rice (1984) for stony soils. The relationship is:

$$
k=k_{s}\left(e_{t} / e_{s}\right)
$$

where

$k=$ the overall hydraulic conductivity

$\mathrm{ks}=$ the conductivity of the sand fraction ( $<2 \mathrm{~mm})$

et $=$ the void ratio of the total sample

es $=$ the sand fraction.

The data indicate that the overall conductivity is not significantly affected by the presence of the larger fragments. Thus, for general calcula tions, the sand fraction permeability could be used. The reported values are considered representative of vertical permeabilities of the sediments.

Because of the disturbed nature of the samples no attempt was made to measure differences between vertical and horizontal permeabilities for these materials.

Chemical Properties

No unusual chemical properties were noted in these sediments. They are alkaline with low cation exchange capacities and generally low carbonates. These findings are very similar to those reported by Routson and Fecht (1979) for 200 East Area sediments. 
TABLE D.3. Detailed Moisture Analysis

\begin{tabular}{lllll} 
SAMPLE & HYDRAULIC & \multicolumn{2}{c}{ Water Retention } \\
OEPTH & $\begin{array}{c}\text { CONDUCTIVITY } \\
\text { (Cm/sec) }\end{array}$ & $\begin{array}{c}\text { WATER } \\
(\$)\end{array}$ & -.1 BAR -1 BAR -15 BAR
\end{tabular}

HOLE 1

SURFACE

$3.0 \mathrm{~m}$

$12.2 \mathrm{~m}$

$18.3 \mathrm{~m}$

$24.4 \mathrm{~m}$

$29.0 \mathrm{~m}$

$33.5 \mathrm{~m}$

$36.6 \mathrm{~m}$

HOLE 2

SURFACE

$4.6 \mathrm{~m}$

$7.6 \mathrm{~m}$

$13.7 \mathrm{~m}$

$22.9 \mathrm{~m}$

$27.4 \mathrm{~m}$

$32.0 \mathrm{~m}$

$36.6 \mathrm{~m}$

HOLE 3

SURFACE

$4.6 \mathrm{~m}$

$9.1 \mathrm{~m}$

$18.3 \mathrm{~m}$

$21.3 \mathrm{~m}$

$25 \mathrm{~g}$

$32.2 \mathrm{~m}$

$38.1 \mathrm{~m}$

HOLE 4

SURFACE

$4.6 \mathrm{~m}$

$6.1 \mathrm{~m}$

$12.2 \mathrm{~m}$

$19.8 \mathrm{~m}$

$27.4 \mathrm{~m}$

$35.1 \mathrm{~m}$

$38.1 \mathrm{~m}$

HOLE 5

SURFACE

$10.1 \mathrm{~m}$

$11.3 \mathrm{~m}$

$15.2 \mathrm{~m}$

$21.3 \mathrm{~m}$

$28.0 \mathrm{~m}$

$32.9 \mathrm{~m}$

$36.0 \mathrm{~m}$

$4.65 e-04$
$7.48 e-04$
$3.71 e-04$
$3.30 e-04$
$2.49 e-03$
$1.46 e-03$
$4.64 e-04$
$8.36 e-05$
$2.25 e-03$
$2.38 e-03$
$4.37 e-05$
$1.43 e-03$
$6.11 e-04$
$2.84 e-03$
$6.19 e-05$
$4.10 e-05$
$1.63 e-03$
$7.78 e-04$
$5.00 e-03$
$2.28 e-03$
$2.08 e-03$
$1.84 e-03$
$1.47 e-04$
$2.61 e-04$
$1.33 e-03$
$4.25 e-04$
$2.81 e-04$
$1.84 e-03$
$2.35 e-03$
$2.42 e-04$
$2.37 e-03$
$2.71 \theta-03$
$2.24 e-03$
$2.63 e-03$
$7.95 e-04$
$2.43 e-03$
$2.72 e-03$
$3.67 e-03$
$2.65 e-03$
$2.68 e-03$

\subsection{3}

3.70

9.84

2.44

2.92

3.72

2.49

i. 97

5.05

3.26

8.46

8.21

3.99

3.35

5.33

10.00

6.86

3.85

3.52

$3.36 \quad 1.79$

$\begin{array}{lll}5.38 & 3.20 & 0.92\end{array}$

$\begin{array}{llll}5.35 & 7.70 & 6.38 & 5.55\end{array}$

$\begin{array}{llll}4.81 & 6.01 & 4.02 & 3.22\end{array}$

12.13

10.29

0.29
6.98

4.73

5.33

4. 01

3.55

2.57

13.38

8.66

2.49

2.27

7.56

7.11

1.99

$7.56 \quad 3.57$

$\begin{array}{llll}5.87 & 4.57 & 2.55 & 2.35\end{array}$

$\begin{array}{llll}8.74 & 8.14 & 4.50 & 3.43\end{array}$

$\begin{array}{llll}4.55 & 5.78 & 4.62 & 3.35\end{array}$

$\begin{array}{llll}5.50 & 5.67 & 3.92 & 2.90\end{array}$

$\begin{array}{llll}5.02 & 5.05 & 2.62 & 1.64\end{array}$

$\begin{array}{llll}3.54 & 4.08 & 3.71 & 3.10\end{array}$

$\begin{array}{lll}12.88 & 7.37 & 3.96\end{array}$

$\begin{array}{lll}13.26 & 7.83 & 4.03\end{array}$

5.63

4.68

3.09

2.93

2.79

10.86

6.03

5.82

8.81

5.32

3.82

$4.4 \uparrow$

8. 43

12.00

3.06

6.50

2.35

18.49

4.62

.61

17.67

9.68

3.11

3.56

3.99

5. 4

5.59

6.89

8.85

3.31

7.00

4.06

5.01

3.56

4.08

5.12

3. 23

2. 95

4.11

3.92

4.17

3.19

2.30

3.26

3.20

2.48

6.89

2.12

9.55

3.21

2.13

9.62

4.95

3.94

D. 16 
TABLE D.4. Chemistry

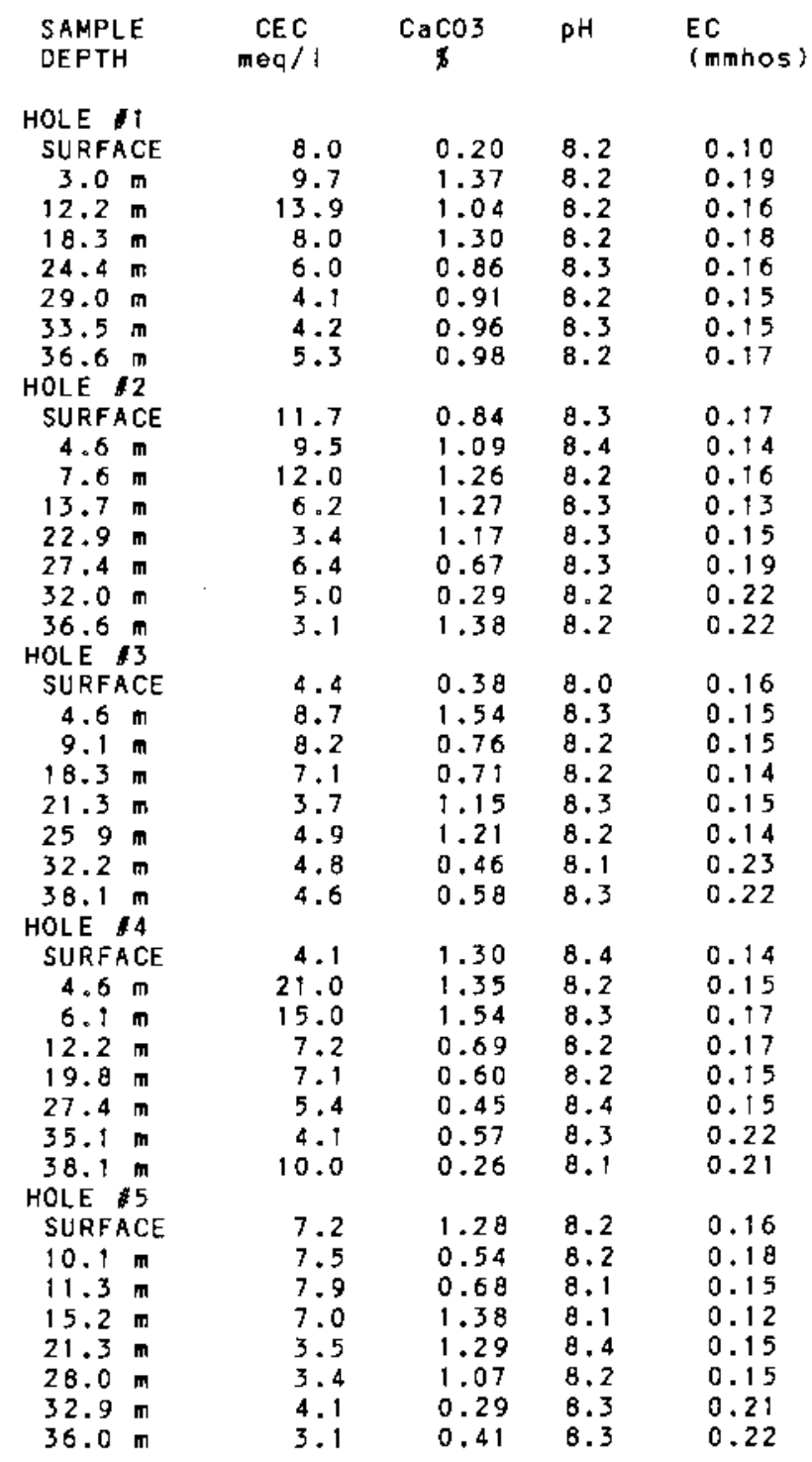


Travel Time Estimates

Travel time in the vadose zone can be defined as the time necessary for water to move from the soil surface to the water table. Travel time is a key parameter needed to estimate consequences for siting facilities where radio active waste can be potentially leached to ground water. For radioactive species (e.g., tritium, ruthenium, iodine, or organically complexed species that are sorbed little on soil or sediments), the major mode of concentration reduction is through decay; hence, long travel times are desirable. Travel times can be estimated using the hydrologic properties that have been measured at the test site. For unsaturated flow considerations, the major uncertainty is the annual seepage (recharge) rate that occurs at depth, below the zone of evaporation (top 2 to $3 \mathrm{~m}$ ). From recent lysimeter studies at the Hanford site (Jones and Gee 1984), we estimate that the annual recharge rate can range from 0.5 to $5.0 \mathrm{~cm} / \mathrm{yr}$. Much uncertainty still exists as to the actual recharge rate but, for our calculations, we made travel time estimates assuming 0.5 and $5.0 \mathrm{~cm} / \mathrm{yr}$ as steady-state recharge values.

Travel times were analyzed in two ways. The first method assumed that the soit properties could be averaged over the entire depth $[37.6 \mathrm{~m}(\mathrm{ft})]$. The second method separated the sediments into two zones, based on textural differences, and computed the travel times by summing the travel time in the individual zones. Table 0.5 tabulates the estimated travel times based on the properties reported for hole $\# 3$, using annual recharge rates of 0.5 and 5.0 $\mathrm{cm} / \mathrm{yr}$.

TABLE D.5. Estimated Times for Hole \#3 Soil Characteristics

\begin{tabular}{|c|c|c|}
\hline \multirow[b]{2}{*}{ Method } & \multicolumn{2}{|c|}{ Recharge Rate } \\
\hline & $0.5 \mathrm{~cm} / \mathrm{yr}$ & $5.0 \mathrm{~cm} / \mathrm{yr}$ \\
\hline Method 1 - Averaged Soil Values & $677 \mathrm{yr}$ & $86 \mathrm{yr}$ \\
\hline Method 2 - Two Layer System & $677 \mathrm{yr}$ & $88 \mathrm{yr}$ \\
\hline
\end{tabular}

The results presented in Table 0.5 show that travel times depend on both the estimated recharge rates and the method of calculation. Essentially no difference occurred in calculating travel times assuming average soil 
characteristics (method 1) and computing travel times in individual layers (method 2). However, more detajled analysis may show added importance for including the individual Tayer characteristics of the soil in the calcula tion. In addition to the uncertainty in the recharge rate, the nonuniformity (spatial variability) present at this site makes it impossible to estimate a single travel time for water flow to the water table. A complete analysis of travel times in the vadose zone awaits more definite measurements of recharge rates and a detailed uncertainty analysis of the hydrologic properties of the Tayered unsaturated sediments. It is anticipated that over the next few years, ongoing research at the Hanford site will provide detailed measurements and analysis that will complement this initial characterization study.

\section{SUMMARY}

The following key observations can be made:

1. The sediment profiles at this site are extremely heterogeneous but, in general, the soils are coarse-textured and drain relatively quickly.

2. The sediment profiles were wet to extended depth $(25 \mathrm{~m})$, suggesting that drainage is occurring at this site. Rates of drainage were estimated, but can be determined using the measured soil hydraulic properties and more detailed measurements of climatic variables (rainfall, radiation, wind speed, temperature) and plant cover (evapotranspiration).

3. Estimated travel times for water to move through the unsaturated zone to the water table at this site range from less than $100 \mathrm{yr}$ to over $600 \mathrm{yr}$ for annual water influx rates ranging from 0.5 to $5 \mathrm{~cm} / \mathrm{yr}$.

4. The soil properties determined here will be useful in modeling the transport of water and chemicals (e.g., radionuclides) to the ground water at this site.

\section{REFERENCES}

Allison, L. E., and C. D. Moodie, 1965. "Carbonate." In Methods of Soil Analysis, Part 2, ed. C. A. Black, pp. 1389-1392. American Society of Agronomy, Madison, Wisconsin. 
ASTM. 1972. "Particle Size Analysis of Soils." ASTM D 422, in Annual Book of ASTM Standards, Part 19. American Standard Testing Materials,

Philadelphia, Pennsylvania.

ASTM. 1980. "Laboratory Determination of Water (Moisture) Content of Soil, Rock, and Soil-Aggregate Mixtures." ASTM D 2216 in Annual Book of ASTM Standards, Part 19, American Standard Testing Materials, PhiTadelphia, Pennsylvania.

Benson, D. W., J. L. Nelson and G. J. Alkine. 1963. Chemical and Physical Properties of 100 Area Soils. General Electric Co., Richland, Washington.

8ouwer, H., and R. C. Rice. 1984. "Effects of Stones on Hydraulic Properties of Vadose Zones." Proceedings of the National Water Well Association Conference on Characterization and Monitoring of the Vadose Zone, Las Vegas, Nevada.

Bower, C. A., and L. V. Wilcox 1965. "Soluble Salts." Methods of Soil Analysis, Part 2, ed. C. A. Black, pp. 935-940. American Society of Agronomy, Madison, Wisconsin.

Brownell, L. E., J. G. Backer, R. E. Isaacson and D. J. Brown. 1975. Soil Moisture Transport in Arid Site Vadose Zones ARH-ST-123, Atlantic Richfield Hanford, Richland, Washington.

Campbel1, G. S. 1974. "A Simple Method for Determining Unsaturated Conductivity from Moisture Retention Data." Soil Sci. 117:311-314.

Campbe11, G. S. 1977. An Introduction to Environmental Biophysics. Springer-Verlag, New York.

Chapman, H. D. 1965. "Cation Exchange Capacity." Methods of Soil Analysis, Part 2. ed. C. A. Black, pp. B91-900. American Society of Agronomy, Madison, Wisconsin.

Enfield, C. G., J. J. C. Hsieh and A. W. Warrick. 1973. "Evaluation of Water Flux Above a Deep Water Table Using Thermocouple Psychrometers." Soil Sci. Soc. Am. Proc., 37:968-970.

Galley, J. E. 1966. Report of the Committee on Geologic Aspects of Radioactive Waste Disposal. National Academy of Sciences, National Research Council, Washington, D.C.

Isaacson, R. E., and D. J. Brown. 1978. Environmental Assessment Related to

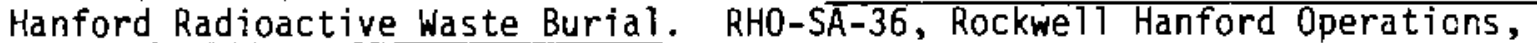
Richland, Washington.

Jones, T. L. 1978. Sediment Moisture Relations: Lysimeter Project 1976-1977 Water Year. RHO-ST-15, Rockwe'] Hanford Operations, Richland, Washington. 
Jones, T. L., and G. W. Gee. 1978. Assessment of Unsaturated Zone Transport for Shallow Land Burial of Radioactive Waste. PNL-4747, Pacific Northwest Laboratory, Richland, washington.

Kirkham, R. R., and G. W. Gee. 1984. "Measurement of Unsaturated Flow Below the Root-Zone at an Arid Site." Proceedings of the Nationa? Water Well Association Conference on Characterization and Monitoring of the Vadose Zone. National Water Well Association, Las Vegas, Nevada.

Klute, A. 1965. "Laboratory Measurement of Hydraulic Conductivity of Saturated Soil." Methods of Soil Analysis, Part 1. ed. C. A. Black, pp. 2ID-222. American Society of Agronomy, Inc., Madison, Wisconsin.

McHenry, J. R. 1957. Properties of Soils of the Hanford Project. HW-53218, General Electric Company, Richland, Washington.

National Academy of Sciences. 1957. "The Disposal of Radioactive Waste on Land." National Research Counci1, Washington, D.C.

National Academy of Sciences. 1976. The Shallow Land Burial of Low-Level Radioactively Contaminated Solid Waste. National Research Council, Washington, D.C.

National Academy of Sciences. 1978. Committee on Radioactive Waste Management, "Radioactive Wastes at the Hanford Reservation: A Technical Review." National Research Council, Washington, D.C.

Newcomb, R. C., J. R. Strand, and F. J. Frank. 1972. "Geology and Groundwater Characteristics of the Hanford Reservation of the U.S. Atomic Energy Commission." Professional Paper 717, U.S. Geological Survey, Washington, D.C.

Reisenauer, A. E. 1963. "Methods of Solving Problems of Multidimensional Partially Saturated Steady Flow in Soils." J. Geophys. Res. $68(20): 5725-5733$.

Richards, L. A. 1965. Physical Conditions of Water in Soil. Methods of Soil Analysis, Part 1, ed. C. A. Black, PP. 128-137. American Society of Agronomy, Inc., Madison, Wisconsin.

Routson, R. C., and K. R. Fecht. 1979. Soil (Sediment) Properties of Twelve Hanford Wells with Geological Interpretation. RHO-CD-82, Rockwell Hanford Operations, Richland, Wasington. 



\section{APPENDIX E}

EXPOSURE PATHWAYS 
The potential environmental pathways through which persons may be exposed to radiation originating in a nuclear reactor or related fuel cycie facilities are shown in Figure E.1. When an individual is exposed through one of these pathways, the dose is determined in part by the amount of time he/she is in the vicinity of the source, or the amount of time the radioactivity inhaled or ingested is retained in his/her body. The actual effect of the radiation or radioactivity is determined by calculating the dose comitment. The annual dose commitment is calculated to be the total dose that would be received over a 50-year period following the intake of radioactivity for 1 year under the conditions expected to exist at the midpoint of facility operation. This would represent an average exposure over the life of the facility. However, with few exceptions, most of the internal dose commitment for each nuclide is given during the first few years after exposure because of the turnover of the nuclide by physiological processes and radioactive decay.

There are a number of possible exposure pathways to man that are appropriate for study to determine the impact of routine releases from the NPR or other fuel cycle facilities on members of the general public living and working outside of the site boundaries, and whether the releases projected at this point in the licensing process wili in fact meet regulatory requirements. A detailed listing of these exposure pathways would include external radiation exposure from the gaseous effluents, inhalation of iodines and particulate contaminants in the air, drinking milk from a cow or eating meat from an animal that feeds on open pasture near the site on which iodines or particulates may have been deposited, eating vegetables from a garden near the site that may be contaminated by similar deposits, and drinking water or eating fish caught near the point of discharge of liquid effluents.

(a) This information is taken from U.S. NRC and Washington State Energy Facility Site Evaluation Council (1982). It is recognized that site-specific identification of exposure pathways requires definition of those facilities generating emissions. As a result, the presentation of exposure pathways will be modified and updated as more information becomes available on the NPR and other fuel cycle facilities. 


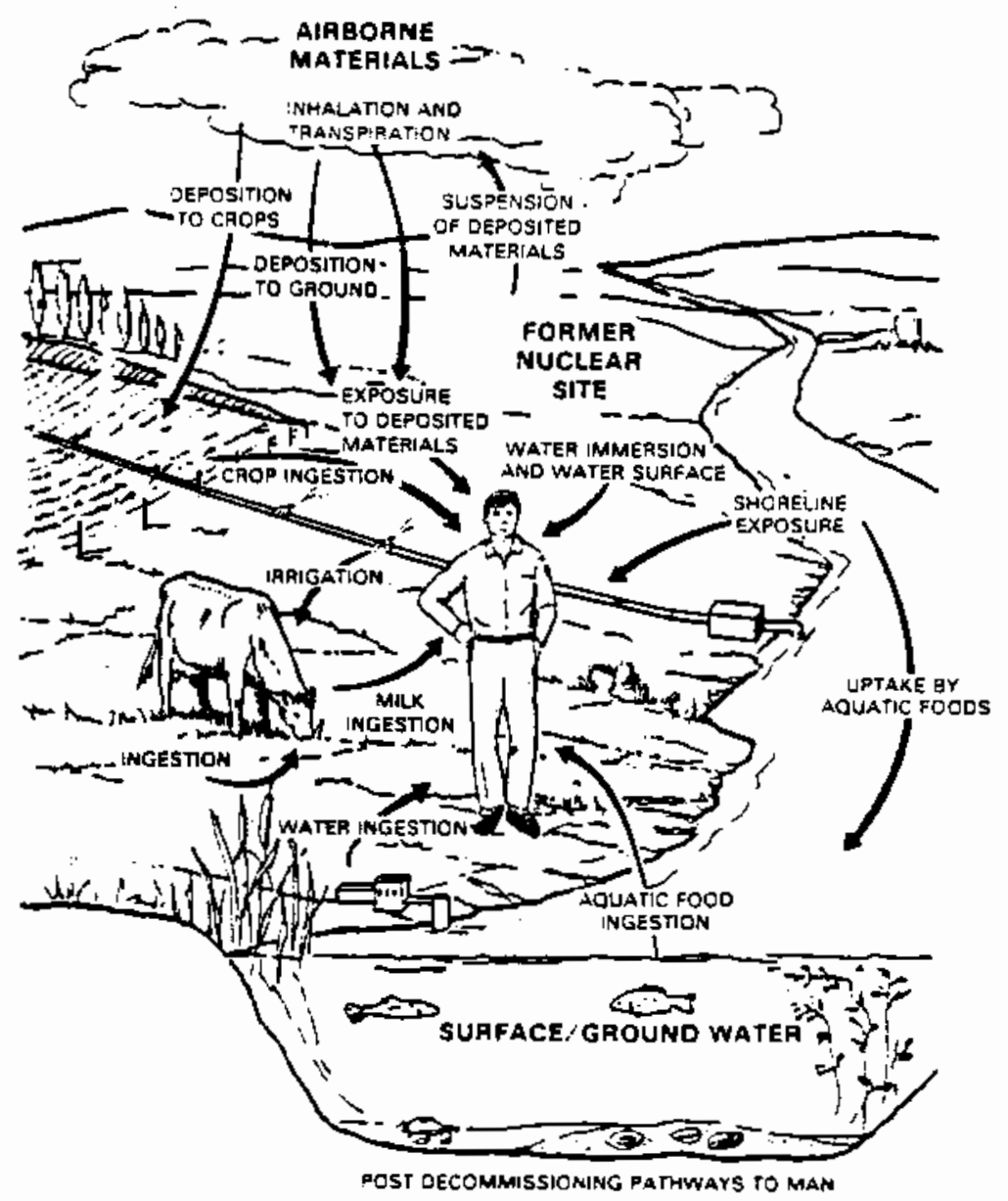

\section{FIGURE E.1. Potentially Meaningful Exposure Pathways to Individuals}

Other less important pathways include: external irradiation from radionuclides deposited on the ground surface; eating animals and food crops raised near the site using irrigation water that may contain liquid effluents; shoreline, boating, and swimming activities near lakes or streams that may be contaminated by effluents; drinking potentially contaminated water; and direct radiation from within the facility itself.

Calculations of the effects for most pathways are limited to a radius of $80 \mathrm{~km}$ (50 mi). This limitation is based on several facts. Experience, as demonstrated by calculations, has shown that all individual dose commitments do not exceed $0.1 \mathrm{mrem} / \mathrm{yr}$ beyond a radius of $80 \mathrm{~km}$ from the plant. Beyond $80 \mathrm{~km}$, the doses to individuals are smaller than $0.1 \mathrm{mrem} / \mathrm{yr}$, which is far below natural-background doses, and the doses are subject to substantial uncertainty because of limitations of predictive mathematical models. 


\section{REFERENCE}

U.S. NRC and Washington State Energy Facility Site Evaluation Council. 1982. Draft Environmental Statement Related to the Construction of Skagit/Hanford Nuclear Project, Units I and 2. NUREG-0894, Washington, D.C. 
APPENDIX $F$

ENVIRONMENTAL PERMITS 


\section{ENVIRONMENTAL PERMITS}

A preliminary list of environmental permits which will likely have to be obtained assuming construction and operation of an NPR are shown in Table F.1.

The responsible federal, state, or local agency is shown in Column 2 of the table. To date no application has been made for any of the permits listed in Table F.I. 


\section{Permit}

Federal

$\stackrel{\pi}{\mathrm{n}}$
Section 10 or 404 of the Clean Water Act

Prevention of Significant Deterioration (PSD)

Permit to Appropriate Public Waters (water right)

Water Quality Certification

National Pollutant Discharge ETimination System (NPDES) or State Waste Discharge

Sewage and Industrial Waste Treatment Facilities Approval

Public Water Supply Approva]

Loca ]

New Source Construction Approva I

Shoreline Substantial

Development
Agency

Army Corps of Engineers. Seattle District Office

EPA (Environmental Protection Agency), Region $X$

Department of Ecology

Department of Ecology

Department of Ecology

Department of Ecology

Department of Social and Health Services

Local or State Air Pollution Control Authority

County or City Planning Department
Comrnents

Required for any activity in navigable waters.

Required to determine compliance with federal air quality standards.

For use or diversion of surface or ground water or change of use.

Required by federal law for discharges to water.

Needed if pollutants will be discharged into state's waters (surface or ground).

Required if improvements or extensions are needed to a new sewage treatment or disposal system.

If a public drinking water supply is needed or altered.

Requiation insures proper controls are included in plant design. Authorizing agency depends upon project location.

Required if project is located within local shoreline jurisdiction. 


\section{DISTRIBUTION}

No. of

Copies

OFFSITE

J. A. Ford

U.S. Oepartment of Energy NPR Project Office

Suite 101

20010 Century Boulevard

Germantown, MD 20874

T. F. Burns

U.S. Department of Energy

NPR Project Office

Suite 101

20010 Century Boulevard

Germantown, MD 20874

H. J. Zeile

U.S. Department of Energy

NPR Project Office

Suite 101

20010 Century Boulevard

Germantown, MD 20874

2 DOE Technical Information Center

J. H. Sako, Director

U.S Department of Energy

Reactor Operations Program

Division

Idaho Operations Office

550 Second Street

Idaho Falls, ID 83401

K. R. Thompson

EG\&G/I daho

P.0. Box 1625

Idaho Falls, ID 83415

J. Tseng

U.S. Department of Energy

Savannah River Operations Office

P.0. Box A

Aiken, SC 29801
No. of

Copies

ONSITE

3 DOE Richland Operations Office

0. J. Elgert

G. J. Mishko

H. E. Ransom

24 Pacific Northwest Laboratory

J. B. Burnham

J. V. Robinson

E. C. Watson (15)

Technical Information (5)

Publishing Coordination (2) 
